
THE UNIVERSITY

OF ILLINOIS

\section{LIBRARY}

$$
\begin{gathered}
590.5 \\
F I \\
V .9 \\
\text { cop. } 2
\end{gathered}
$$


NOTICE: Raturn or renew all Library Materialsi The Minimum Fee for each Lost Book is $\$ 50.00$.

The person charging this material is responsible for its return to the library from which it was withdrawn on or before the Latest Date stamped below.

Thaft, mutilation, and underlining of books are reasons for disciplinary action and may result in dismissel from the University.

To renew call Telephone Center, 333-8400

UNIVERSITY OF IHINOIS HBRARY AT URBANA-CHAMPAIGN

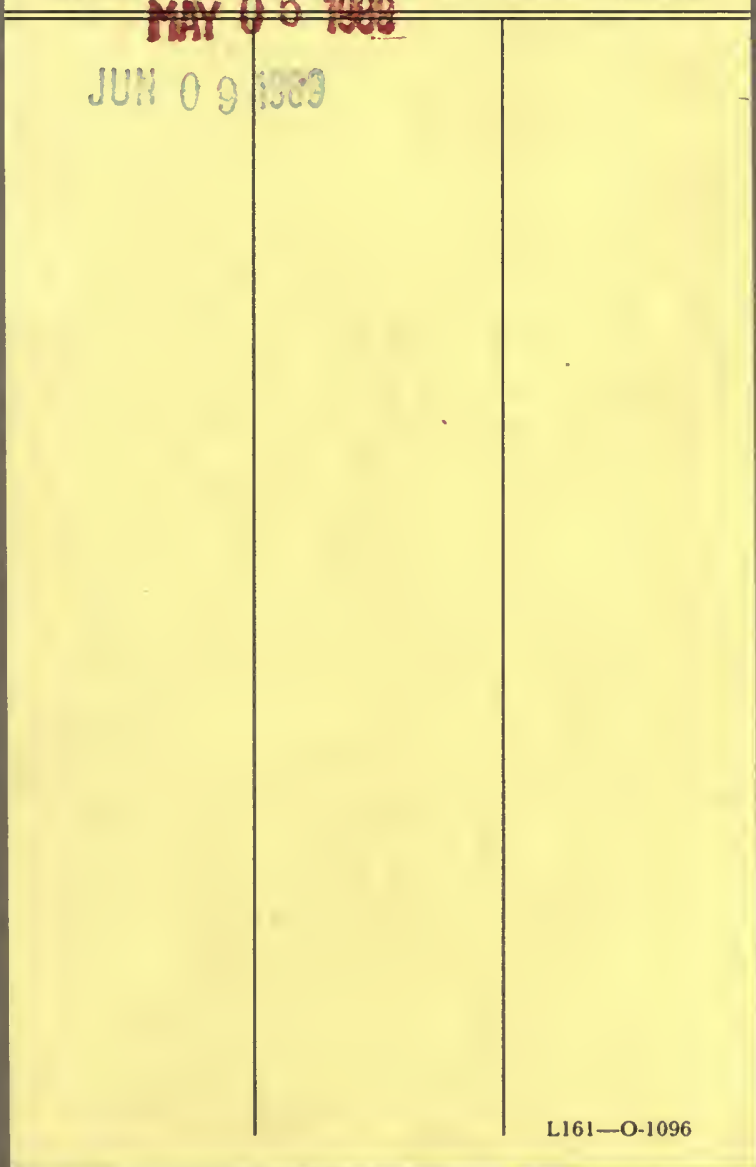



crp. 2 Field Museum of Natural History.

Publicátion $\mathrm{I} 3 \mathrm{I}$.

Zoölogical Series.

VoL. IX.

\section{THE BIRDS OF ILLINOIS AND WISCONSIN}

Charles B. Cory

Curator of Department of Zoölogy.

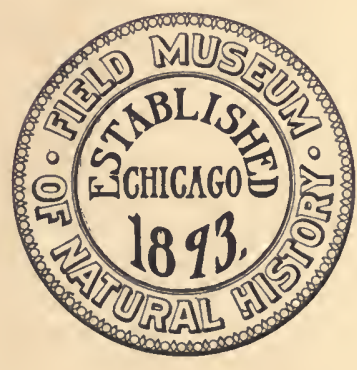

Chicago, U. S. A.

I 909 



\section{PREFACE.}

The present work includes, as far as known, all species and subspecies of birds which occur in Illinois and Wisconsin, the total number being 398, with descriptions of their various plumages, nests and eggs, and geographical distribution, together with more or less brief biographical notes concerning them.

The keys to families and species are practically the same as those which first appeared in the author's Birds of Eastern North America, revised to meet their present needs. These should enable the student to readily identify a bird, the species belonging to the different families being arranged according to the length of the wing (measured from carpus to tip). A key to the eggs of our more common species is also included.

Careful comparison of large series of specimens has shown that while adult birds of the same species differ considerably in length, the wing measure is very constant, the variation in a large number of specimens being so small that, allowing for possible extremes, we may safely arrange our birds in groups, using the length of the wing as a basis. The identification of any species then becomes a comparatively simple matter, as usually the birds contained in each group are so few in number that characteristic differences are easily indicated.

Let us, for example, assume we have a bird before us which we wish to identify; we should first learn to which family it belongs. Turning to the Key to Families, we find this a simple matter (as the families are few and the illustrated differences in the bills and feet very characteristic), we discover our bird to be a duck. Having ascertained the family to which the bird belongs, we turn to the Key to Species. We have, of course, measured the wing and found it to be 5.90 inches long, measured from the carpus (bend of wing) to tip. (See illustration, "How to Measure a Bird," on page 20.)

We now turn to the Ducks, and discover they are divided into subfamilies, the Bay and Sea Ducks having a flap or lobe on the hind toe, and the fresh-water ducks, or River and Pond Ducks having no large flap on the hind toe. Our bird has a flap on its hind toe, and is evidently a salt-water duck, belonging to the subfamily Fuliguline. 
This subfamily, we find, contains two sections: Section I, having the tail feathers not stiff and pointed, and Section 2, tail feathers stiff and pointed. Our duck has stiff, pointed tail feathers, and therefore belongs in Section 2. Section 2 contains two species, one having whole front of head and cheeks black, 'the other, with sides of head more or less white. As our duck has a patch of white on the side of the head, it must therefore be the Ruddy Duck, Erismatura jamaicensis, No. 66, the number indicating its location in the main body of the work, where the different species and subspecies are treated in their proper order and more amplified descriptions of the various plumages are given.

All measurements of birds are given in inches and fractions of an inch. The diagrams on page 20 will illustrate how a bird should be measured, and the chart (page I2) will be useful to the student of ornithology who may not be familiar with the technical terms used in describing birds. Such terms as primaries, axillars, carpus, etc., should be learned at once. It is customary to indicate the sexes by the signs of Mars and Venus; the male, of course, being given that of Mars, $\sigma^{7}$, and the female, Venus, o .

In preparing the present work I have made free use of previous publications by various authors, due credit being given in such cases, and I wish to express my acknowledgments and thanks to Mr. Isaac E. Hess, Mr. Ruthven Deane, Mr. Frank M. Woodruff, Mr. R. Magoon Barnes, Mr. Girard A. Abbott, Mr. H. K. Coale, Mr. J. Grafton Parker, Mr. B. T. Gault, Mr. H. S. Swarth and Mr. John F. Ferry, for many notes, and records, and to Mr. Wm. J. Gerhard, Assistant Curator of Entomology, for valuable assistance in reading and correcting the proofs.

C. B. C. 


\section{CONTENTS.}

TItLE-PAgE

PAGE

PREFACE . . . . . . . . . . . . . . . . . . . 5

CONTENTS

Glossary

TOPOGRAPHY OF A BiRD

INTRODUCTION .

What a bird is . . . . . . . . . I

The wing . . . . . . . . . . . . . . .

The tail . . . . . . . . . . . . . . .

The leg and foot . . . . . . . . . . . . .

The bill . . . . . . . . . . . . . . I7

How to Measure a Bird. . . . . . . 20, 2 I

Index to Key to Families. Water Birds . . . . 22

Key to Families. Water Birds . . . . . . . 23

Group I. Toes, four, with lobate webs, or webs on sides of toes . . . . . . . . . 23

Group 2. Toes, four; front toes, palmate (full webbed); hind toe not connected with front ones by web

Group 3. Toes, four, full webbed; hind toe connected with front ones by web

Group 4. Toes, four, not full webbed; small webs, between toes at base, or toes entirely without web

Section I. Hind toe, raised above level of front toes

Section 2. Hind toe, on level with front toes . . 30

Group 5. Toes, three, full webbed; no hind toe. . . 32

Group 6. Toes, three; a small web between toes, or entirely without web . . . . . . . . .

Key to the Species of Water Birds of Illinois and

Wisconsin

Family Colymbide. Grebes.

Family Gavinde. Loons . . . . . . . . 37, 382

Family Alcide. Auks, Murres, etc. . . . . . 39, 279

Family Stercoraridde. SkUas and Jegers . . ' 4 4,286

Index to Key to Family Laride . . . . . . . 42 
Family Laride. Gulls and Terns . . . . . 43, 288

Subfamily Larine. Gulls . . . . . . . . . 43, 289

Subfamily Sternine. Terns . . . . . . . . 47, 297

Family Anhingide. Darters, Snake Birds . . . 50, 307

Family Phalacrocoracide. Cormorants . . . . 5I, 308

Family Pelecanide. Pelicans . . . . . . 52, 3 I I

Family Fregatide. Man-of-War Birds . . . . 53, 3 I 4

Index to Key to Family Anatide . . . . . . . 54

Family Anatide. Ducks, Geese, and Swans : . 56, 3 i6

Subfamily Mergine. Mergansers, Sheldrakes . . 56,3i6

Subfamily Anatine. River and Pond Ducks • 58, 3 I 9

Subfamily Fuliguline. Bay and Sea Ducks . . 62,33 I

Subfamily Anserine. Geese . . . . . . 7 I, 347

Subfamily Cygnine. Swans . . . . . . . . 73,354

Family Plataleide. Spoonbills . . . . . . 75,357

Family Ibidide. Ibises . . . . . . . . . . 76,358

Family Ciconidie. Storks and Wood Ibises . . . 77, 360

Family Ardeide. Herons, Egrets, and Bitterns . 78, 362

Family Gruide. Cranes . . . . . . . . 84, 375

Family Aramide. Courlans, Limpkins . . . . 85, 379

Family Rallide. Rails, Galinules, and Coots . . 86, 380

Subfamily Ralline. Rails . . . . . . . 87, 381

Subfamily Gallinuline. Gallinules . . . . 89,386

Subfamily Fulicine. Coots . . . . . . . . 89,387

Family Phalaropodide. Phalaropes . . . . . 9 93, 389

Family Recurivirostride. Avocets and Stilts . . 95, 392

Index to Key to Family Scolopacide . . . . . . 9 I

Family Scolopacide. Snipes, Sandpipers, Curlews, etc. 96, 395

Family Charadride. Plovers . . . . . . . ili, 425

Family Aphrizide. Turnstones . . . . . . . II $4,43^{\circ}$

Index to Key to Families. Land Birds . . . . I 5

Key to Families of Land Birds . . . . . . . II

Group I. Birds having wings less than 1.75 inches long; measured bend of wing (carpus) to tip of longest feather

Group 2. Birds having wings 1.75 to 2.75 inches long .

Section I. First primary, less than half as long as third

Part I. Tip of upper mandible with small but distinct hook or notch

Part 2. Upper mandible without notch or hook at tip 
Section 2. First primary more than half as long as third . . . . . . . . . . . .

Part I. Tip of upper mandible with small but distinct hook or notch . . . . . . .

Part 2. Tip of upper mandible not notched or hooked .

Group 3. Birds having wings measuring from 2.75 to 3.25 inches long

Section I. First primary, less than half as long as third

Part I. A small but distinct hook or notch at tip of upper mandible . . . . . . .

Part 2. Tip of upper mandible not notched or hooked

Section 2. First primary, not short, always more than half as long as third

Part I. Tip of upper mandible with small but distinct hook or notch

Part 2. Tip of upper mandible not notched

Group 4. Birds having wings 3.25 to 9.50 inches long .

Section r. Bill with strong hook claws armed with talons

Section 2. Upper mandible with distinct hook or notch at tip, but feet not armed with talons . .

Section 3. Upper mandible not notched or hooked at tip . First primary less than half as long as third

Part 2. First primary more than half as long as third

Group 5. Birds having wings over 9.50 inches long . Key to the Species of Land Birds of Illinois and Wis-

Family Tetraonide. Grouse, Quail, etc. . . . I36, 432

Subfamily Perdicine. Quall and Partridges . . I 36,432

Subfamily Tetraonine. Grouse and Ptarmigan. I 36,435

Family Phasianide. Pheasants, Turkeys, etc. . . I39, 442

Subfamily Meleagrine. Turkeys . . . . . . I39, 442

Family Columbide. Pigeons and Doves . . . . I39, 444

Family Cathartide. American Vultures. . . . i4i, 448

Index to Key to Family Falconid . . . . . . I 43

Family Falconide. Hawks, Falcons, Eagles, etc. - I45, 45 I 
Family Aluconide. Barn Owls . . . . . 157,484

Family Strigide. Horned Owls, Hoot Owls. . I55, 486

Family Psittacide. Parrots . . . . . . I60, 50 I

Family Cuculide. Cuckoos... . . . . . . i6 i, 504

Family Alcedinide. Kingfishers . . . . . . i62, 506

Family Picide. Woodpeckers . . . . . . i6 6,508

Family Caprimulgide. Night-hawks, Whip-poor-Wills i68, 52 I

Family Micropodide. Swifts . . . . . . i69, 525

Family Trochilide. Humming-birds. . . . . . 169,527

Family Tyrannide. Flycatchers . . . . . I I 70,529

Family Alaudide. Larks . . . . . . . . . I75,540

Family Corvide. Crows, Jays, etc. . . . . I I 76,542

Subfamily Garruline. Jays and Magpies . . i76,543

Subfamily Corvine. Crows and Ravens . . . I 78,546

Family Icteride. Blackbirds, Orioles, Meadowlarks. I79,550 Index to Key to Family Fringillide . . . . . 190

Family Fringillide. Sparrows, Finches, Crossbills,

Buntings, etc. . . . . . . . . . . . 192,565

Family Tangaride. Tanagers . . . . . . . 220,614

Family Hirundinide. Swallows . . . . . 222,618

Family Bombycillide. Waxwings. And Cedar Birds . 225,624

Family Lanitde. Shrikes . . . . . . . . 226,627

Family Vireonide. Vireos . . . . . . . $227,63 \mathrm{I}$

Index to Key to Family Mniotiltide . . . . . 23 I

Family Mniotiltide. Warblers . . . . . . 233,638

Family Motacillide. Pipits and Wagtails . . . 261,678

Family Troglodytide. Wrens . . . . . . 262,684

Family Mimide. Thrashers, Catbirds, Mockingbirds . 265,680

Family Certhide. Creepers . . . . . . . 266,693

Family Sittide. Nuthatches . . . . . . . 267,694

Family Paride. Titmice and Chickadees . . . 268,697

Family Sylvilde. Kinglets and Gnatcatchers . 269,702

Family Turdide. Thrushes, Blue-birds, etc. . . 27I, 705

The Birds of Illinois and Wisconsin Systematically

Arranged . . . . . . . . . . . . . 275

Index to Key to EgGs . . . . . . . . . . 7 . 76

Key to the Eggs of the more Common Birds Known to

Breed in northern Illinois and southern Wisconsin

Bibliography . . . . . . . . . . . . . . 740

INDEX . . . . . . . . . . . . . . . . $75^{\mathrm{I}}$

Map of Illinois and Wisconsin . . . . . . 767 


\section{GLOSSARY.}

Nearly all the terms used in describing a bird may be more easily and clearly understood by examining the illustrations of "bird topography," on page I 2, than from a written description; a few, however, may require a word of explanation.

Culmen. - The ridge of the upper mandible.

Cere. - A hard skin-like covering on the base of the upper mandible (Parrots, Hawks, etc.).

Mandibles. - Some authors use the word maxilla for the upper half of the bill, and mandible for the lower. I prefer, however, to describe the two halves of the bill as upper and lower mandible.

Gonys. - Bend of under mandible, usually used to include the outline of under mandible from angle to the tip.

Unguis. - The nail on the end of the upper mandible; very pronounced in several families of water birds (Ducks, Pelicans, and Petrels).

Axillars or Axillary Plumes. - Several elongated feathers at the junction of the wing and body. (Lat. axilla, the arm-pit.)

Carpus or Carpal Joint. - Bend of the wing. The third segment of the wing, corresponding to the wrist (see illustration).

Speculum. - A wing band or patch (usually of a different color from the rest of the wing), formed by the terminal portion of the secondaries; very noticeable in the Ducks.

Tarsus. - Extends from the root of the toes to the end of the tibia (what appears to be the bend of the leg or knee; but which is, in reality, the heel joint). See illustration.

Toes Syndactyle. - Outer and middle toes more or less joined together (Kingfisher, etc.).

Toes Zygodactyle. - Arranged in pairs, two in front, two behind (Cuckoos, etc.').

Tarsus Reticulate. - Covered with numerous small, uneven scales, usually more or less rounded (Plovers, Geese, etc.).

Tarsus Scutellate. - Comparatively large, somewhat square-cut scales, one above the other, covering the front of the tarsus. 
Booted Tarsus. - Scales fused together on greater portion of tarsus so as to be indistinct or invisible except on lower part (Robins, etc.).

Superciliary Stripe. - Stripe over the eye.

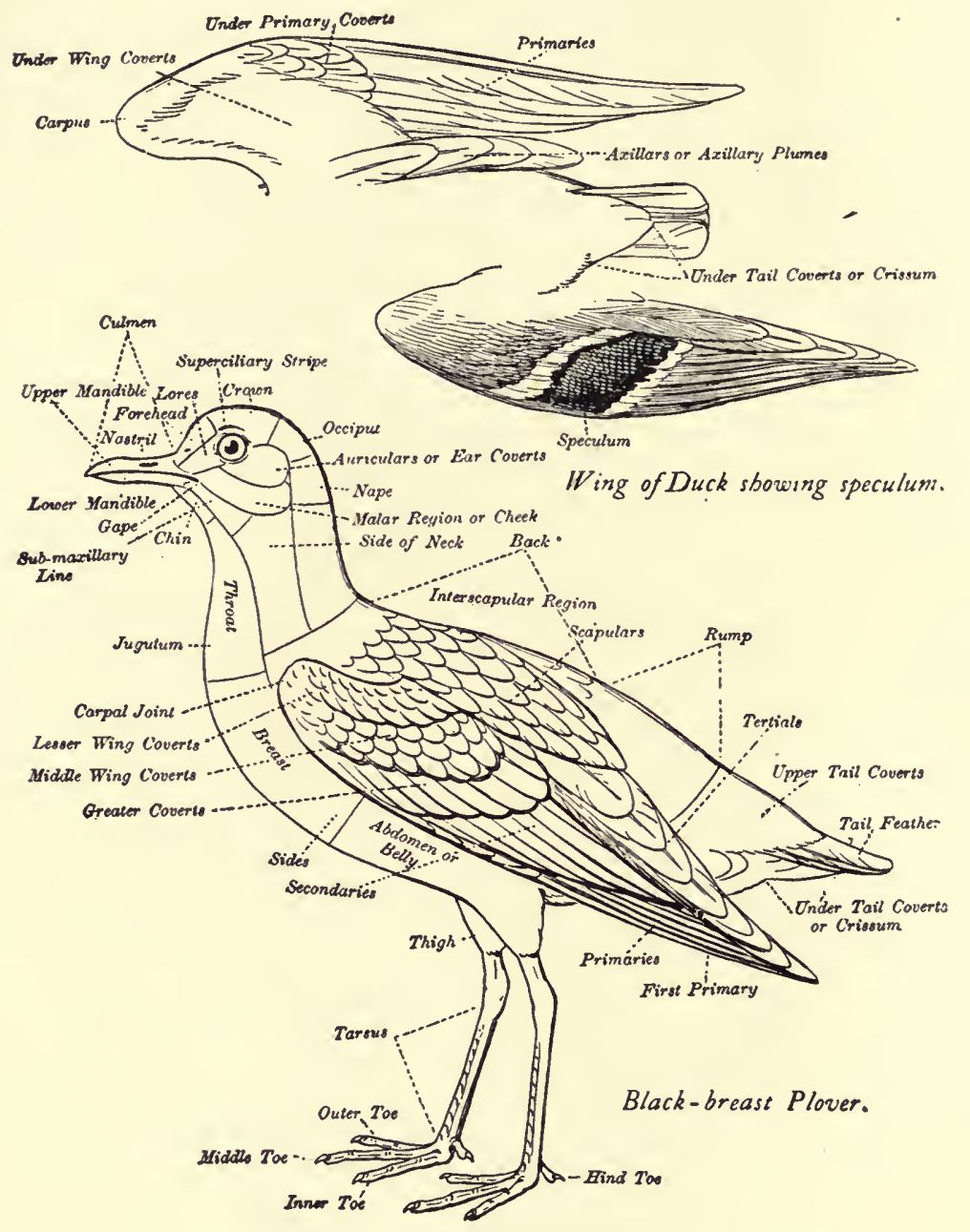




\section{INTRODUCTION.}

A bird is a feathered vertebrate animal; or, to describe it more fully, it is an air-breathing, warm-blooded, feathered, oviparous (egglaying), vertebrate animal, having a four-chambered heart, and a complete double circulation. Birds occupy a place in nature intermediate between the mammals and the reptiles, and many naturalists consider a bird to be merely a modified reptile.

These feathered vertebrates are recognized by zoölogists as belonging to a Class named Aves to distinguish them from other animals, and the Class is separated into subclasses, which in turn are again subdivided into orders, suborders, families, subfamilies, genera and subgenera and finally into species and subspecies.

Birds belonging to the same family, but which show decided and constant differences, are recognized as species, whereas if the differences in color or size are not very great and intermediate forms occur showing an intergradation from one to the other, they are called races or subspecies. Races or subspecies are really species in process of development, and are caused by difference in climate, food, etc.

It should be borne in mind, however, that the line of demarkation between a species and a subspecies is a purely arbitrary one, and is largely a matter of individual opinion. Subspecies are distinguished by a third name; for example, Dendroica palmarum hypochrysea is a race or subspecies of Dendroica palmarum.

Having learned something as to what a bird is, let us take up in order the more important external parts, such as the wing, tail, bill, and feet.

\section{THE WING.}

As an aid to identification, the wing characters are most important. The terms primaries, secondaries, axillars, wing coverts, etc., are constantly used in describing birds, and the student should learn to recognize them at a glance. 


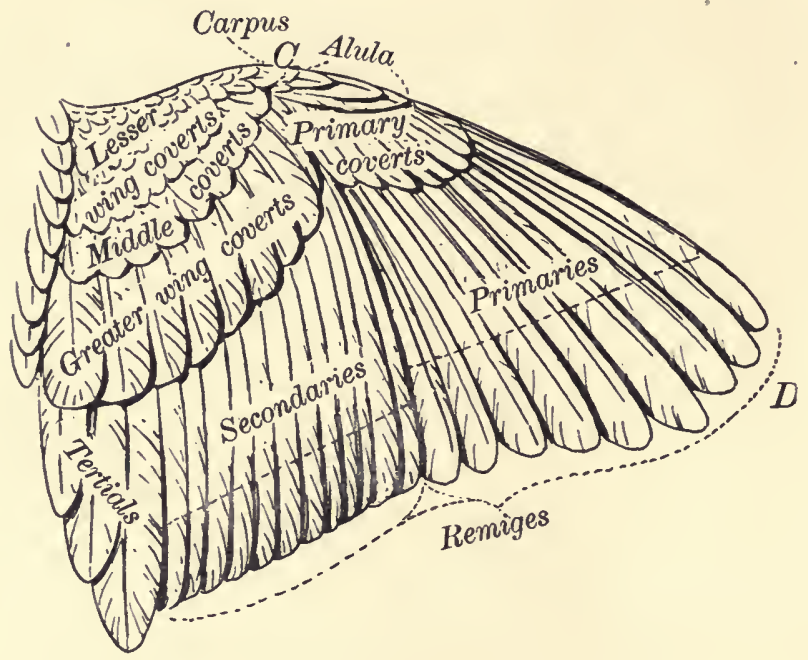

The Remiges are the flight feathers of the wing, and the Tectrices are the small feathers covering the upper part of the wing or shoulder (see illustration), and are usually called coverts. The remiges are divided into primaries, secondaries, and tertials, according to the location in the wing.

The Primaries are the feathers growing from the outer section of the wing; that is to say, from the outer bend of the wing (carpus) to tip, $\mathrm{C}$ to $\mathrm{D}$, the number ranging from 9 to ro (and rarely $\mathrm{II}$ ) in various families. At first, it is not always easy to distinguish the last primary from the first secondary; but experience is the best teacher, and the point can always be settled by examining the roots of the feathers.

The Secondaries are the remiges attached to the ulna or forearm, B to C (see illustration); they number from 6 to 40 in the various families, the Humming-bird having the smallest number, and the Albatross more than 40.

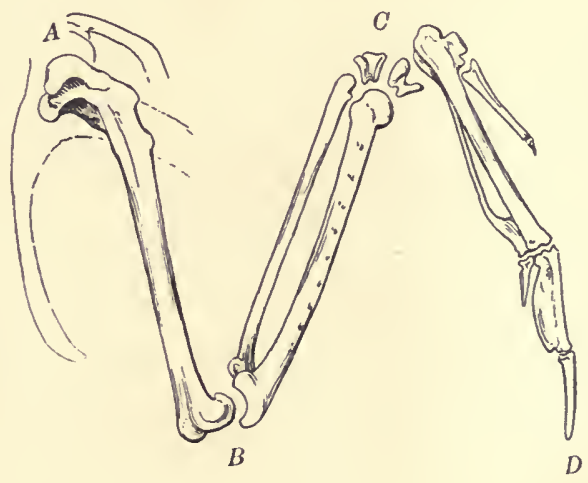

The Tertials are the few remaining remiges which grow from the humerus, A to $\mathrm{B}$.

The Tectrices, or Wing Coverts, are small feathers covering the larger wing feathers; the feathers lining the edge of the under surface of the wing are called under wing coverts. The outer wing coverts are divided and described as greater wing coverts, middle wing coverts, and lesser wing coverts, respectively. (See illustration.) 


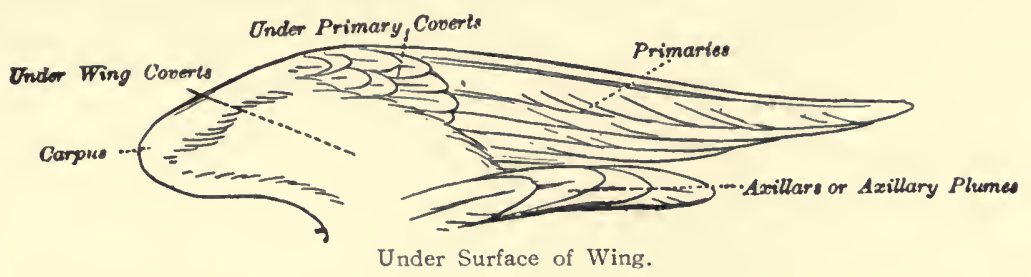

The Speculum. A term used to indicate a patch or band on the wing (usually of different color from the rest of the feathers), formed by the terminal portion of the secondaries, very noticeable in the Ducks. (See illustration, page r 2.)

The Axillary Plumes, or Axillars, are an important aid in the identification of many species; these are several rather elongated feathers growing from the armpit (axilla), at the junction of the wing and body.

\section{THE TAIL.}

The Rectices, or Tail Feathers, proper, number from 8 to 24 , and in some very few cases even more. By far the greater number of birds, however, have $\mathrm{I} 2$ rectices. The small feathers overlapping the rectices are called upper tail coverts, while those below are the under tail coverts or crissum, although the latter term is often used to include the region immediately about the vent.

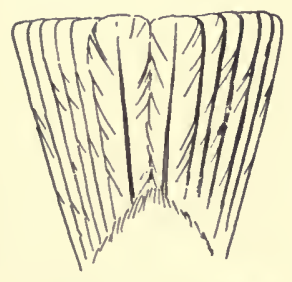

Truncate or square tail

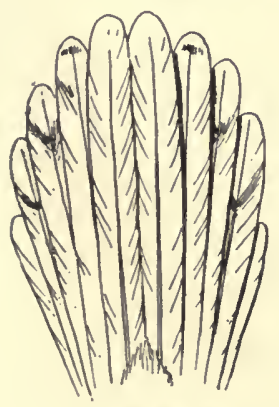

Graduated tail
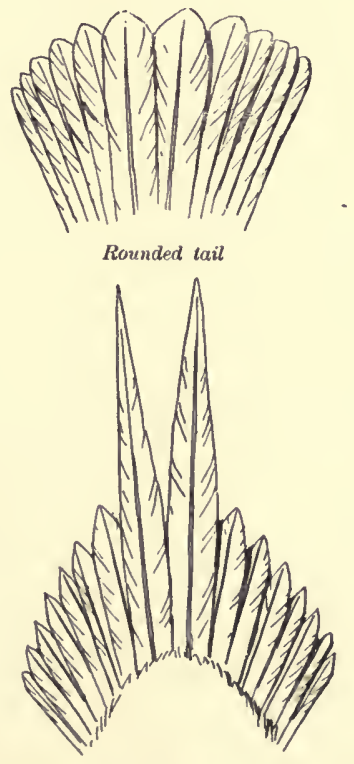

Pointed or cuneale tail

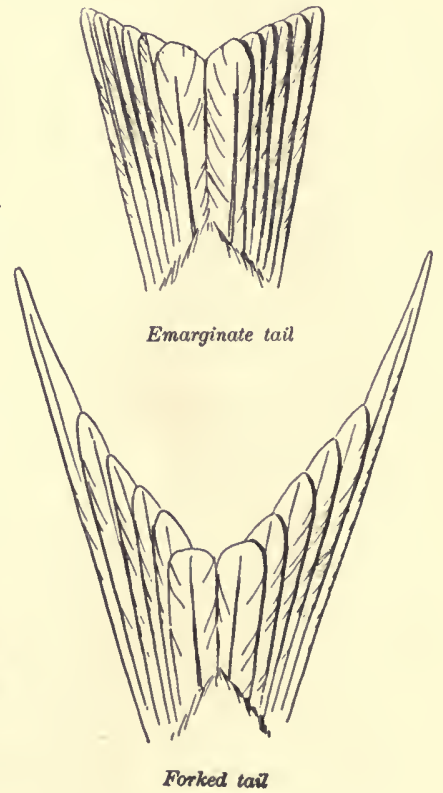

Forked tail 


\section{THE LEG AND FOOT.}

A bird's leg may be briefly described as having only the knee downward exposed; the true thigh is concealed, but may be felt under the skin on the side of the body. The true knee is close to the

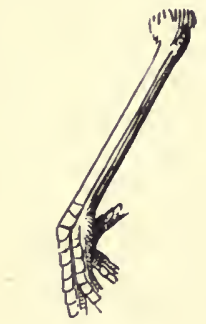

Booted Tarsus

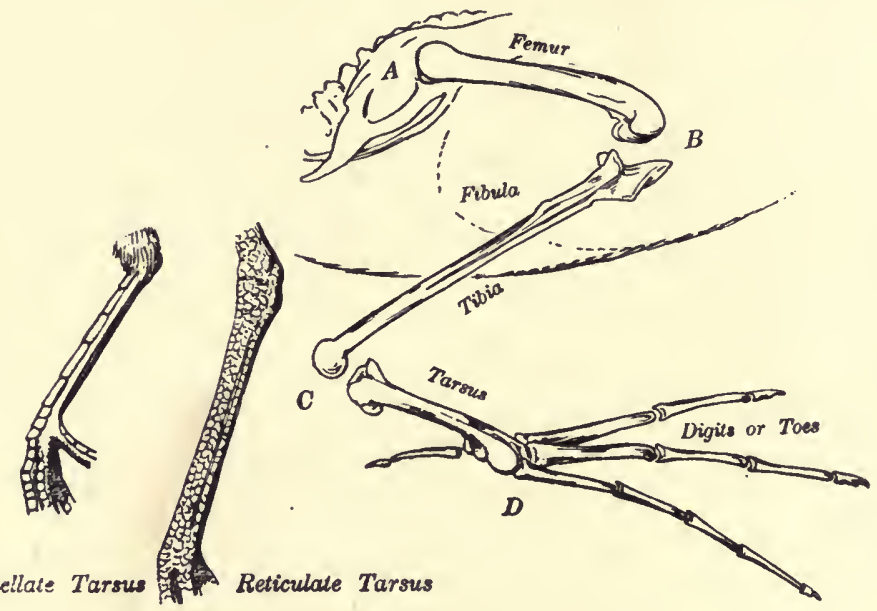

body just under the skin. The first exposed joint, which is apparently the knee, is really the heel. (See illustration.) The bird does not walk on the foot (from the heel downward), but merely walks on its toes.
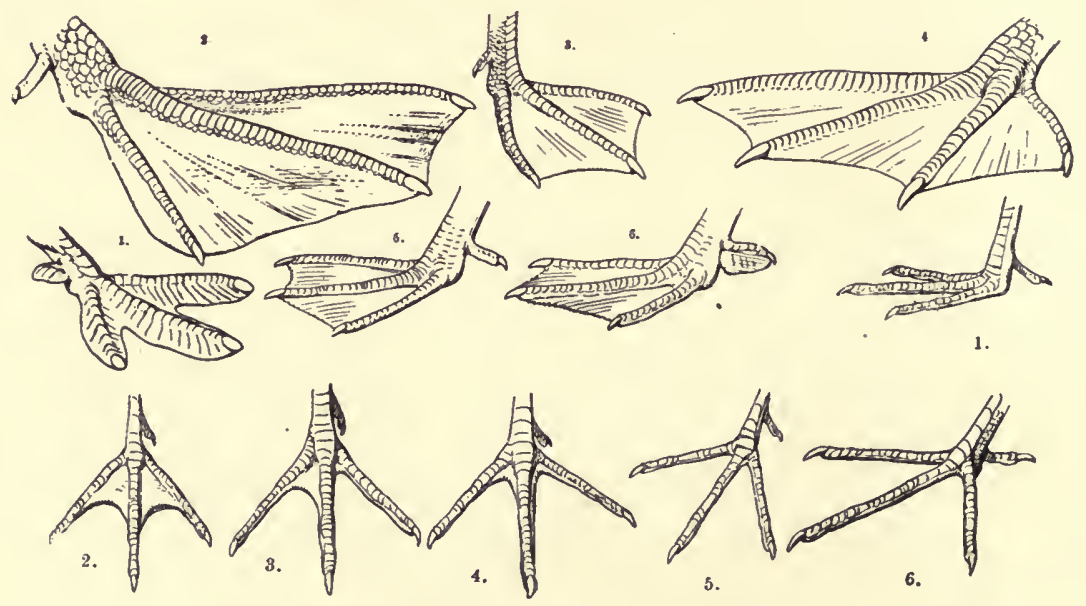

Types of Feet. - Water Birds. 
is Field Museum of Natural History-Zoölogy, Vol. IX.

2. Hypognathous. Lower mandible longer than upper mandible. (Example: Black Skimmers, Rhynchops.)

3. Paragnathous. Both mandibles of about equal length.

4. Metagnathous. Mandibles crossed. (Example: Crossbill, Loxia.)

The shape and size of the bill vary greatly, as will be seen by the following illustrations representing fifteen of the principal types among our birds:-

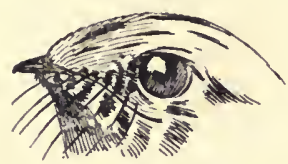

Fissirostral bill of Whippooroull

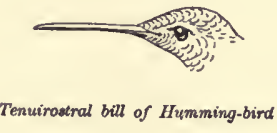

Tenuirostral bill of Humming-bird

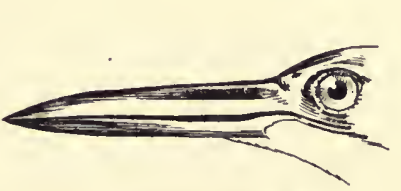

Cultrirostral bull of Least Bittern

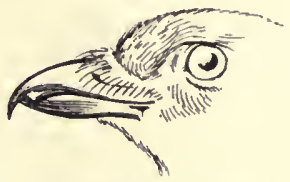

Dentirostral Bill of Shrike

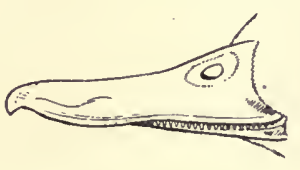

Lamellirostral bill of Duck

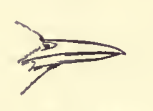

Bill of Warbler

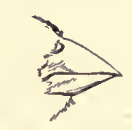

Bill of Sparrovo

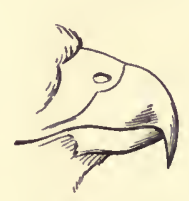

Bill of Hawk

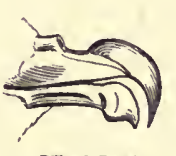

Bin of Petrel

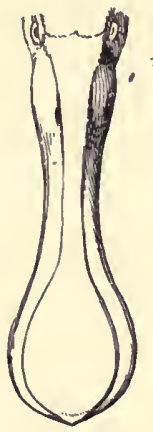

Bill of Spoonbill

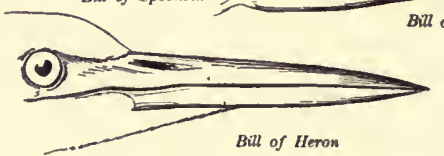

Cere. A membrane (usually hard), which covers the base of the upper mandible. (Hawks, Parrots, Jægers.)

Nasal Fossa, or Nasal Groove. Groove in which the nostrils open.

Gonys. Bend of lower mandible; usually used to include the outline of the under mandible, from the angle to the tip.

Culmen. The ridge of the upper mandible. 
Jan., i909. Birds of Illinois and Wisconsin-Cory.

Unguis. The nail on the end of the upper mandible. Very pronounced in some families of Water Birds. (Ducks, Pelicans, and Petrels.)

Mandibles. - Some authors use the word maxilla for the upper half of the bill, and mandible, for the lower. I prefer, however, to describe the two halves of the bill as upper and lower mandible. 
HOW TO MEASURE A BIRD.

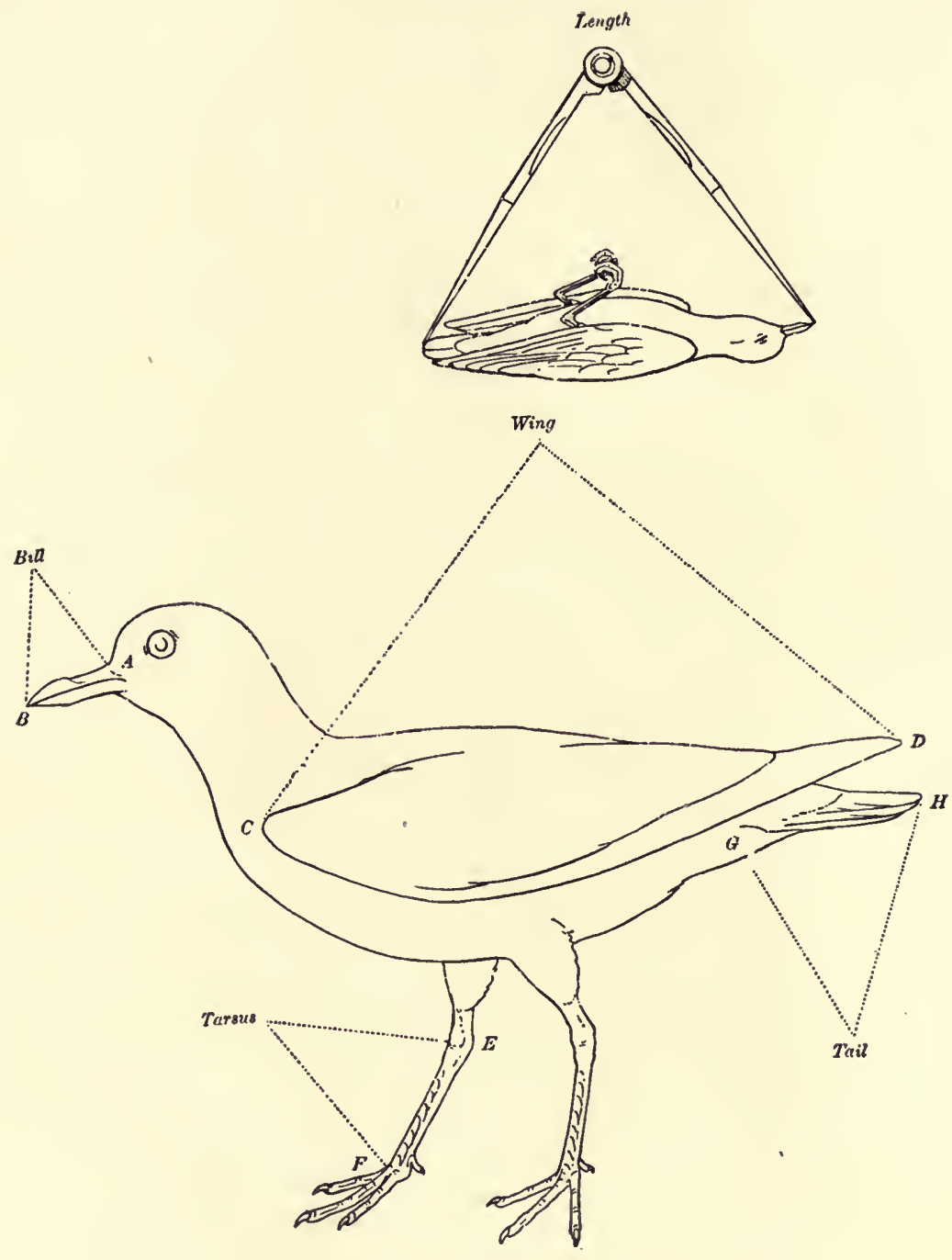

For description, see page $2 \mathrm{I}$. 


\section{HOW TO MEASURE A BIRD.}

See illustration, page 20 .

Wing. - Distance from carpal joint $\mathrm{C}$ (bend of wing) to the tip of the longest primary D. See cut on page 20.

Length. - Distance in a straight line from the end of the bill to the tip of the longest tail feather. (Occasionally the middle feathers are much elongated, as in the Old Squaw and Pintail Duck, and in other families of birds, such as Phethon and Stercorarius. In such cases it is well to give the length from bill to longest tail feather, and also to end of outer tail feather.)

Tail. - Distance from the tip of the longest tail feather to its base (the point where it enters the body).

Bill. - The distance in a straight line from where the bill (upper mandible) joins the skin of the forehead (A) to the tip (B). (There are a few exceptions to this rule, in some families, such as birds with frontal plate, etc. Some curved bills are measured along the curve of the culmen, and at times it is advisable to measure from the nostril to the tip of the bill, but in such cases it should always be so stated.)

Tarsus. - Distance in front of the leg from what appears to be the knee joint (end of tibia) to the root of the middle toe.

All measurements are given in inches and fractions of an inch. 


\section{INDEX TO KEY TO FAMILIES. WATER BIRDS.}

Group I. Toes, four, with lobate web or web on sides of toes. See page 23.
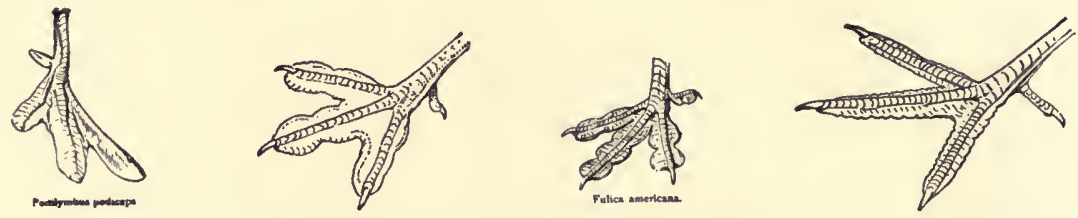

Group 2. Toes, four; front toes, palmate (full webbed); hind toe, not connected with front ones by web. See page 24 .
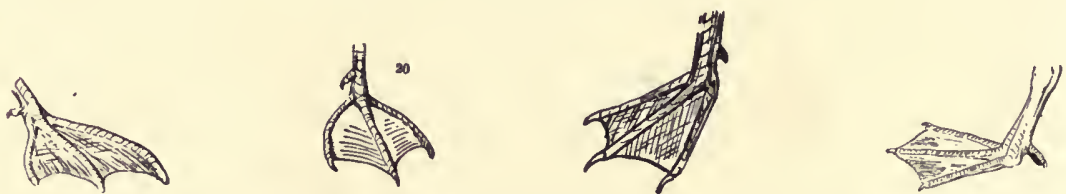

Group 3. Toes, four; totipalmate (all toes full webbed); hind toe, connected with front ones by web. See page 27 .
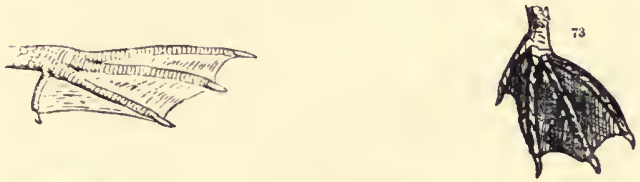

Group 4. Toes, four, not full webbed; small web between toes at base, or toes entirely without web; hind toe, sometimes very small. See page 28 .
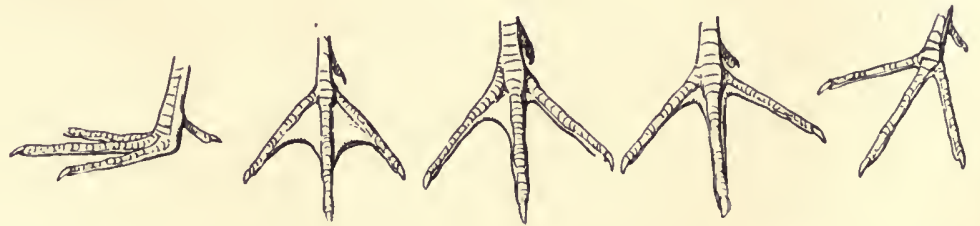

Section I. Hind toe, raised above level of front toes. See page 28 .

Section 2. Hind toe, on same level with front toes. See page 30.

Group 5. Toes, three, full webbed; no hind toe. See page 32.

Group 6. Toes, three, not full webbed; a small web between toes at base, or toes entirely without web. See page 33 . 


\title{
WATER BIRDS.
}

\author{
KEY TO FAMILIES.
}

GROUP 1. Toes, four; with lobate webs, or webs on sides of toes.
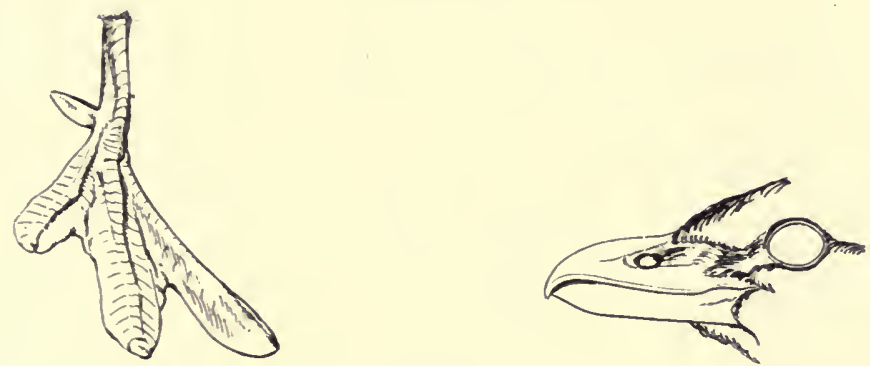

Bill, pointed; feet, placed far back, near tail; underparts, silvery white: tail, very short.

Family COLYMBID $Æ$. Grebes.

See page 35 .
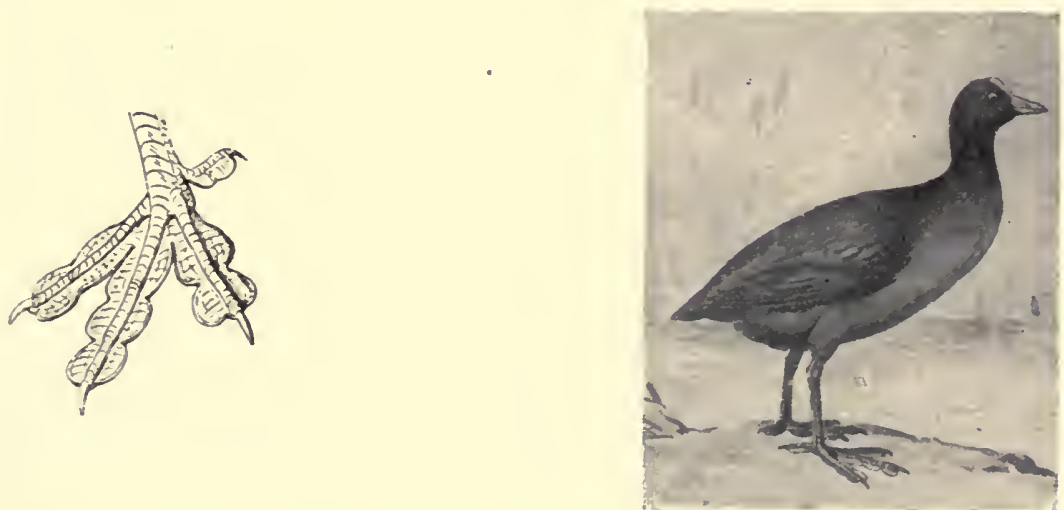

Forehead, with bare shield; bill, rather short; general color, slaty gray; toes, with lobate webs.

Family RALLID $Æ$. Subfamily FULICINÆ. Coots.

See page 89 . 
24 Field Museum of Natural History-Zoölogy, Vol. IX.

Hind toe, elevated above the level of the others; bill, slender; nostrils, opening through slits; sides of toes, webbed.

Family PHALAROPODID AE. Phalaropes.

See pages 9r, 93 .
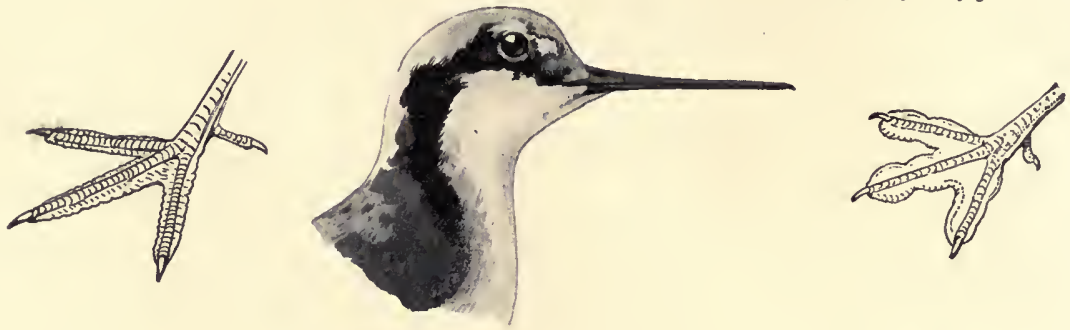

GROUP 2. Toes, four; front toes, palmate (full webbed); hind toe, not connected with front ones by web.

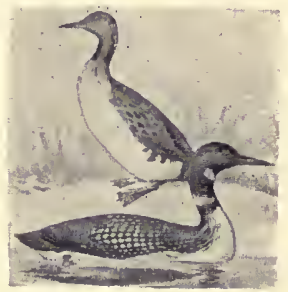

Bill, straight and pointed; tarsus, flattened; hind toe, with flap or lobe; feet, placed far back near the tail; tail, very short.

Family GAVIID $Æ$. Loons.

See page 37.

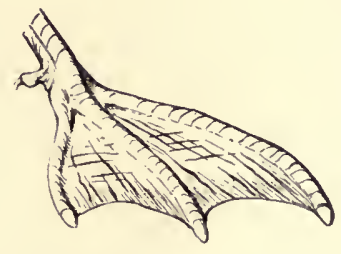

Nostrils, separate, not tubular; bill, with cere (a horny or skinlike covering on base of upper mandible); hind toe, sometimes very small; end of upper mandible (unguis), swollen and somewhat rounded; back and wings, always dark, sometimes sooty, sometimes barred with brown; tail, never white or gray, usually very dark;
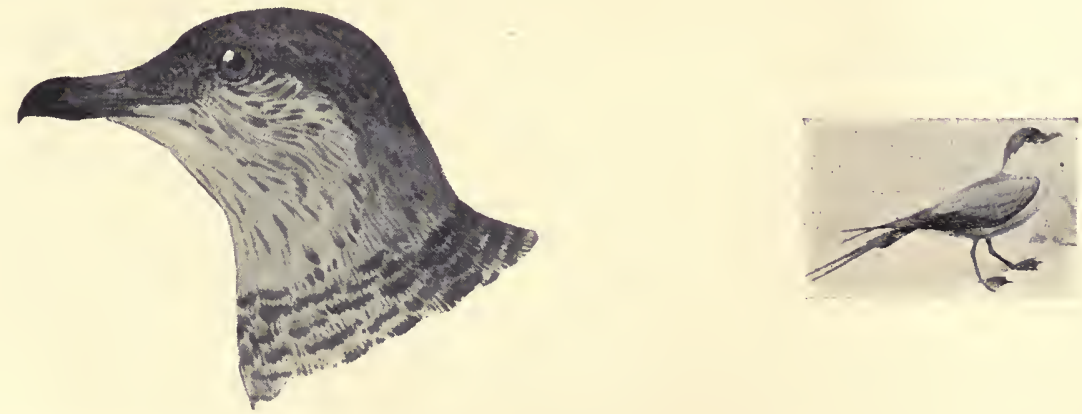

middle tail feathers, longest, but only very long in adult birds, sometimes only slightly longer than rest of tail feathers in immature birds. 
In brown plumages, the axillars (feathers extending from armpit) are heavily barred, brown and white; in other plumages, the axillars and under wing coverts are sooty brown or dark slaty brown.

Family STERCORARIIDÆ. Skuas and Jægers. See page $4 \mathrm{I}$.
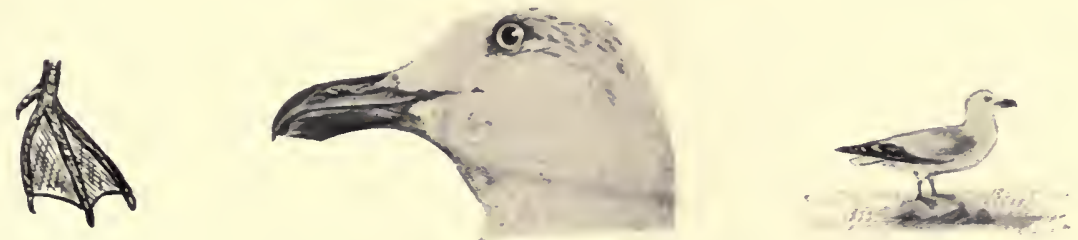

Nostrils, separate, not tubular; bill, without cere; hind toe, sometimes very small; upper mandible, curved; unguis (end of bill), not swollen; middle tail feathers, about equal in length to the others; tail, rarely dark, although sometimes tipped with black or brown; axillars and under wing coverts, white or gray, sometimes with narrow gray lines or faint wavy bars.

Family LARIDÆ. Subfamily LARINÆ. Gulls. See page 42 .
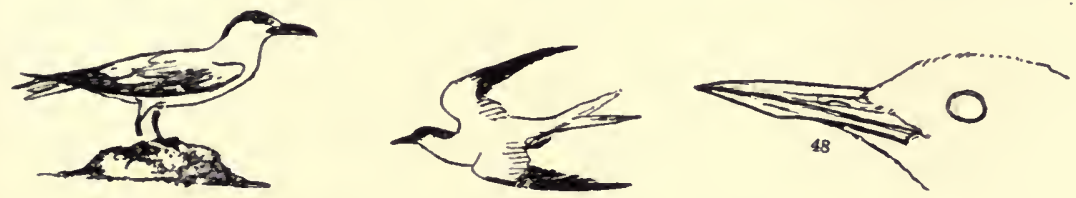

Nostrils, separate, not tubular; hind toe, sometimes very small; upper mandible, nearly straight, not hooked or decidedly rounded near tip; outer tail feathers, usually longer than middle feathers.

Family LARIDE. Subfamily STERNINAE. Terns. See page 42 .

Bill, long and narrow, having tooth-like serrations on edges; toes, four, the front ones, full webbed; hind toe, with flap.

Family ANATIDE. Subfamily MERGINÆ. Mergansers. See pages 54,56 .

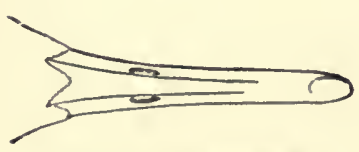

Top of bill of Merganser.

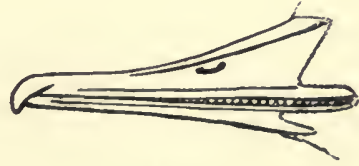

Side of biil.

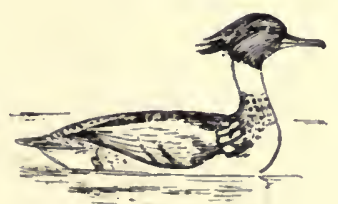

$-=$ 
26 Field Museum of Natural History-Zoölogy, Vol. IX.

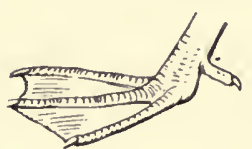

webbed; hind toes, without decided flap or lobe. Family ANATIDAE. Subfamily ANATINA. River and Pond Ducks. See pages 54,58 .

Ducks.

Bill, not narrow; tarsus, scutellate in front (transverse scales); toes, four, the front ones, full

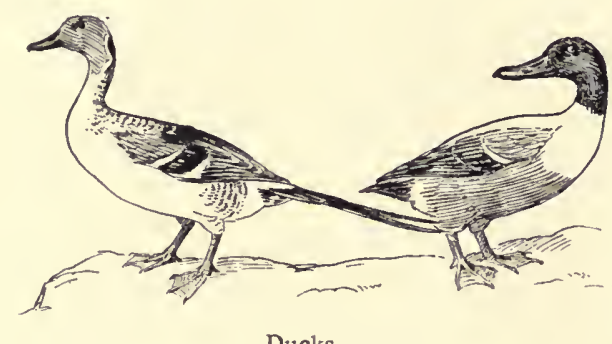

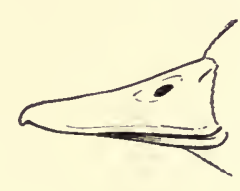

Bill of Duck.

Bill, not narrow; tarsus, scutellate in front (transverse scales); toes, four, the front ones, full webbed; hind toe, with flap or lobe.

Family ANATIDE. Subfamily FULIGULINE.

Sea Ducks.

See pages 54, 62 .

Lores, feathered; tarsus, reticulate (scales rounded); wing, more than thirteen inches long; toes, four, the front ones full webbed:

Family ANATIDÆ. Subfamily ANSERINÆ. Geese and Brant. See pages $55,7 \mathrm{I}$.

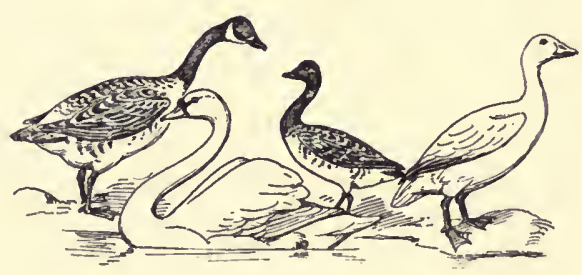

Geese and Swan.

Lores, partly bare; tarsus, recticulate (scales rounded); size, large; neck, long; wing, over eighteen inches-long; plumage, white or gray.

Family ANATIDE. Subfamily CYGNINÆ. Swans. 
GROUP 3. Toes, four, totipalmate (front toes, full webbed); hind toe, connected with front ones by web.

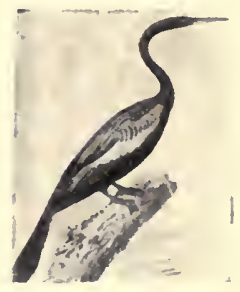

Bill, sharp-pointed and slender; chin, bare; neck, long and slender; toes, four, all connected by webs; middle tail feathers, corrugated or fluted.

Family ANHINGIDÆ. Darters, Snake Birds. See page 50 .

Bill, hooked at tip, over twelve inches long and having a large pouch; lores, bare; toes, four, all connected by webs.

Family PELECANID Æ. Pelicans. See page $5^{2}$.
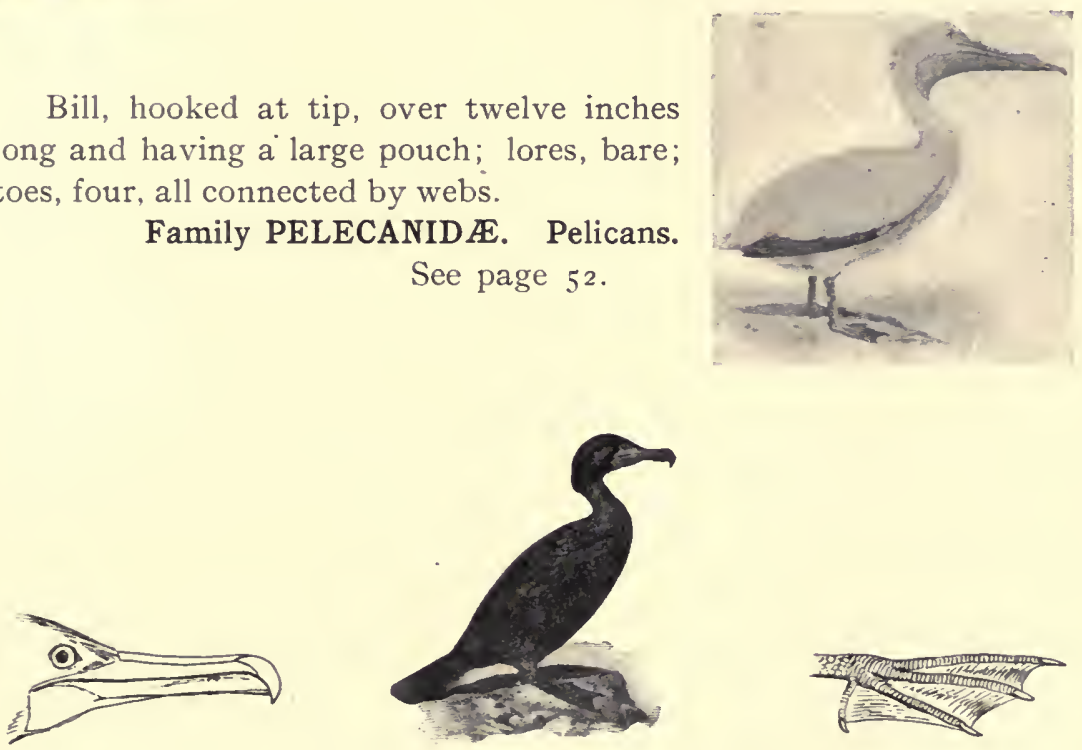

Bill, hooked at tip, and less than twelve inches long; bare skin at base of bill and chin; lores, kare; toes, four, all connected by webs. Family PHALACROCORACID $Æ$. Cormorants. See page $5 \mathrm{I}$.

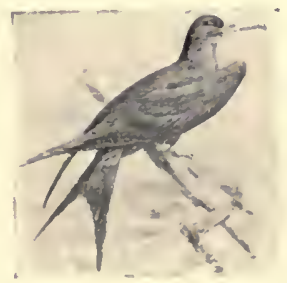

Bill, hooked at tip; lores, feathered; upper plumage, entirely black; toes, four, all connected by webs; tail, forked; wings, very long.

Family FREGATID $Æ$. Man-of-war Birds, Frigate Birds.

See page $5^{2}$. 
28 Field Museum of Natural History-Zoölogy, Vol. iX.

GROUP 4. Toes, four, not full webbed; small webs between toes at base, or toes entirely without webs; hind toe, sometimes very small.

SECTION 1. Hind toe, raised above level of front toes.

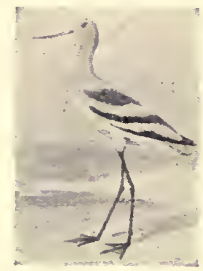

Avocet.

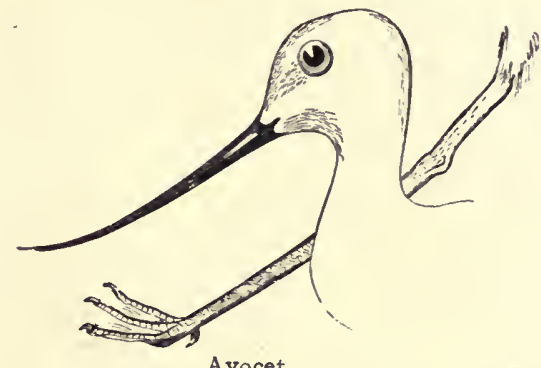

Avocet.

Tarsus, over 3.50 inches long; bill, curved upward or straight. Family RECURVIROSTRID $Æ$. Avocets. See pages 9I, 95 .

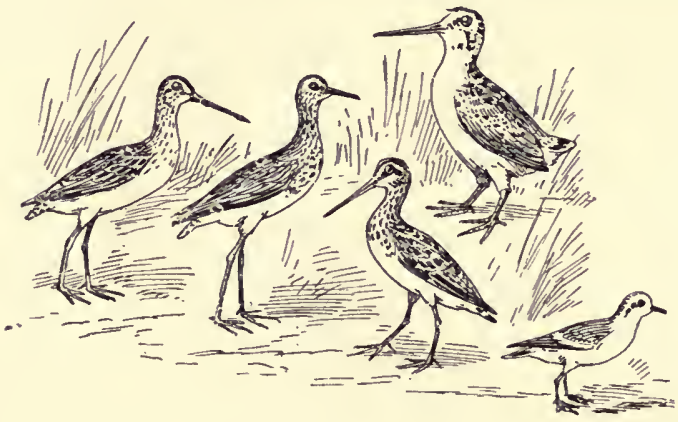

Tarsus less than 3.50 inches long, with transverse scales in front; middle toe and claw together shorter than bill, except a few of the small species, which have middle toe and claw equal to or longer than bill; but all such have the belly and under tail coverts pure white in most plumages.

Family SCOLOPACID $Æ$. Snipe, Curlews, Sandpipers, etc.

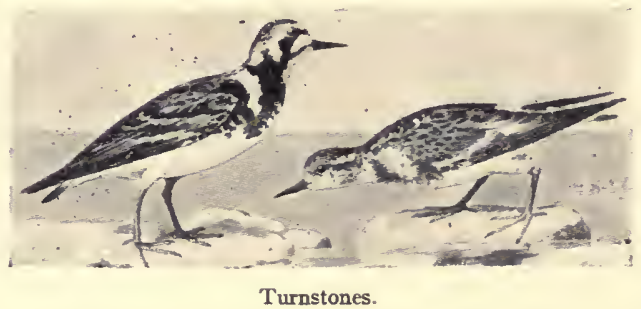

See pages 9I, 96.

Turnstones.

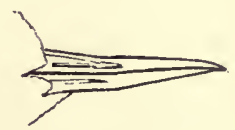

Turnstone (bill). 
Jan., rgog. Birds of Illinois and Wisconsin-Cory.

Hind toe, higher than front ones; lower back and rump; white, with black band across rump. Family APHRIZIDE. Turnstones.

See pages 92, I 14 .

Hind toe, higher than front ones; hind toe, very small, hardly noticeable; bill, black, rather short and stout; all other species belonging to this family (in North America) have but three toes.

Family CHARADRIIDA. Black-bellied Plover. (Squaterola squaterola.)

See page II 3 .

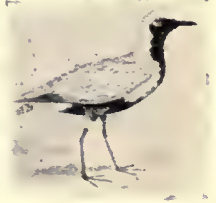

Plover.

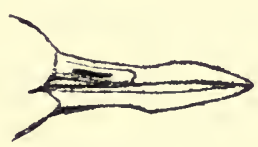

Plover.

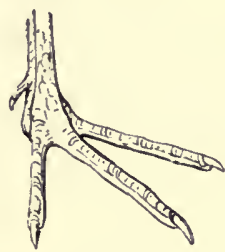

Black-bellied Plover.

Hind toe, above level of front toes; bill, less than 3

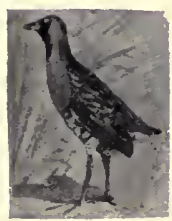

Sora Rail.

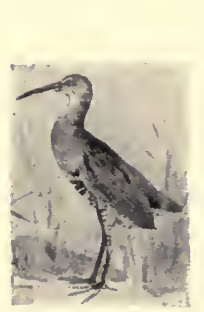

King Rail. inches long; toes, four, no comb-like edge on inner side of middle toe nail; middle toe and claw together not shorter than bill, usually decidedly longer; under tail coverts, not white.

Family RALLIDÆ. Rails, etc. See pages 86,87 .

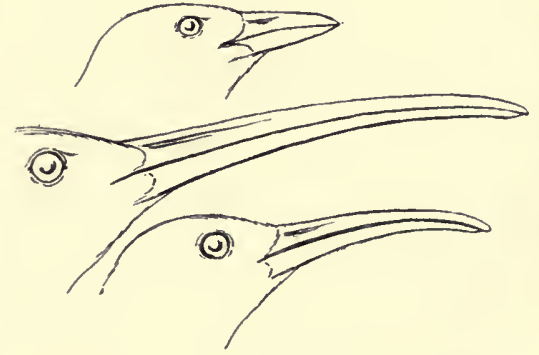

Rails.

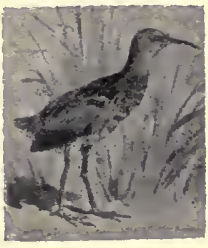

Virginia Rail.

Hind toe, above level of front toes; bill, over 3 inches long; wing, over 16 inches; tarsus, over 7 inches; toes, four, no comb-like edge on inner side of middle toe nail; lores, with hair-like bristles. Family GRUID $Æ$. Cranes.

See page 84 . 
30 Field Museum of Natural History-Zoölogy, Vol. iX.

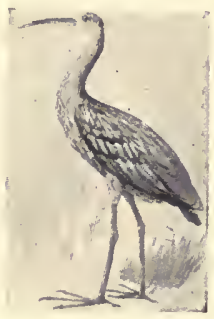

Hind toe, above level of front toes; bill, over 3 inches long; tarsus, under 7; wing, under 16 ; toes, four, no comb-like edge on inner side of middle toe nail; under mandible, often slightly twisted near tip; plumage, dark brown with white streaks.

\section{Family ARAMID $Æ$. Courlans.}

See page 85 .

SECTION 2, Hind toe, on level with front toes.
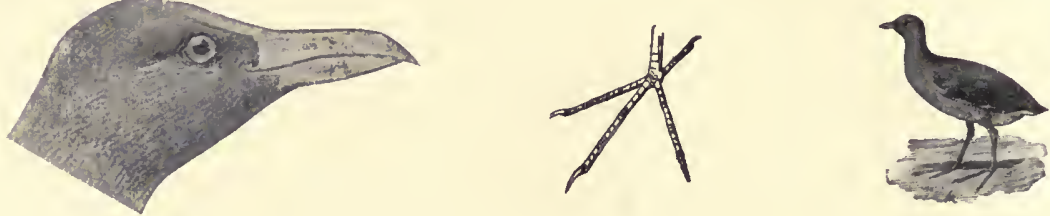

Toes, long and slender; bill, short and pointed; a bare shield or plate on forehead; wing, about 7 inches long, carpus (bend of wing) to tip; under tail coverts, white.

Family RALLID E. Subfamily GALLINULINA. Purple Gallinule, or Florida Gallinule.

See page 89.
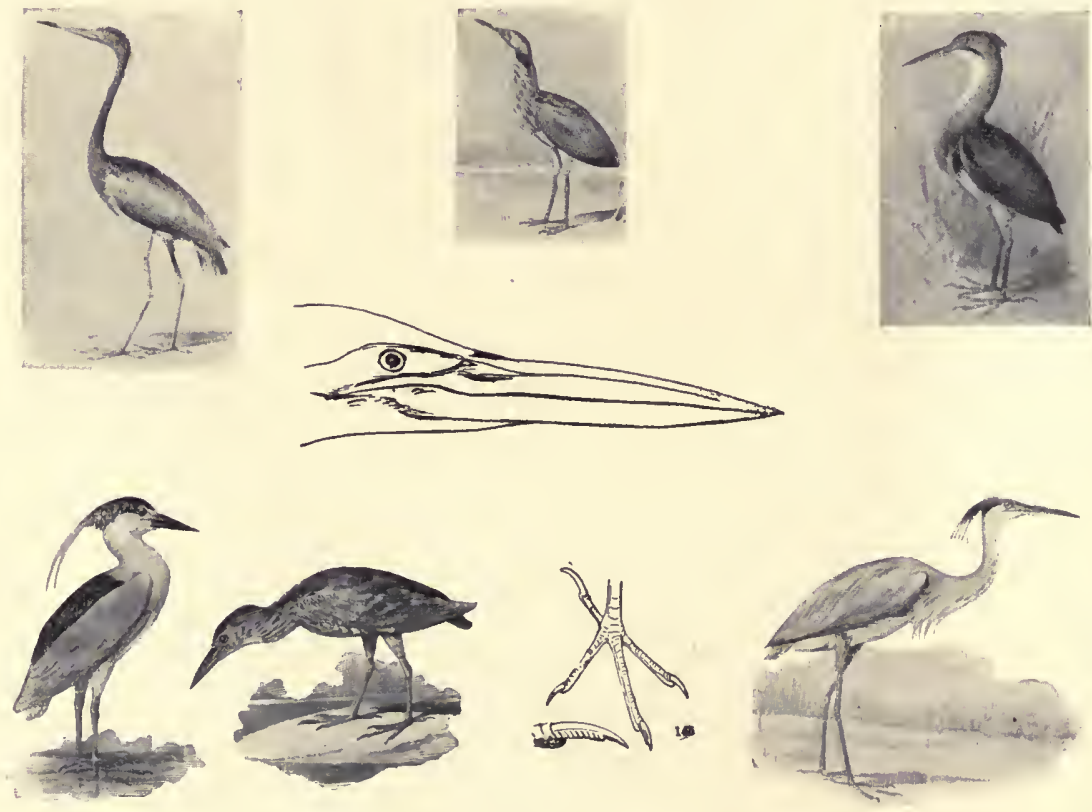

Herons and Bitterns. 
Jan., 1909. Birds of Illinois and Wisconsin-Cory.

Bill, nearly straight and sharply pointed; inner side of middle toe nail, with distinct comb-like edge; toes, four, all on same level. Bitterns, tail with ten feathers. Herons, tail with twelve feathers.

Family ARDEIDÆE. Herons, Egrets, and Bitterns. See page 78 .

Greater part of plumage, white; bill, very large and stout, rounded and somewhat curved; tarsus, always over five inches long; toes, four, all on same level; no comb-like edge on inner side of middle toe nail; wing, over 16 inches long.

Family CICONIIDE. Storks and Wood Ibises. See page 77 .
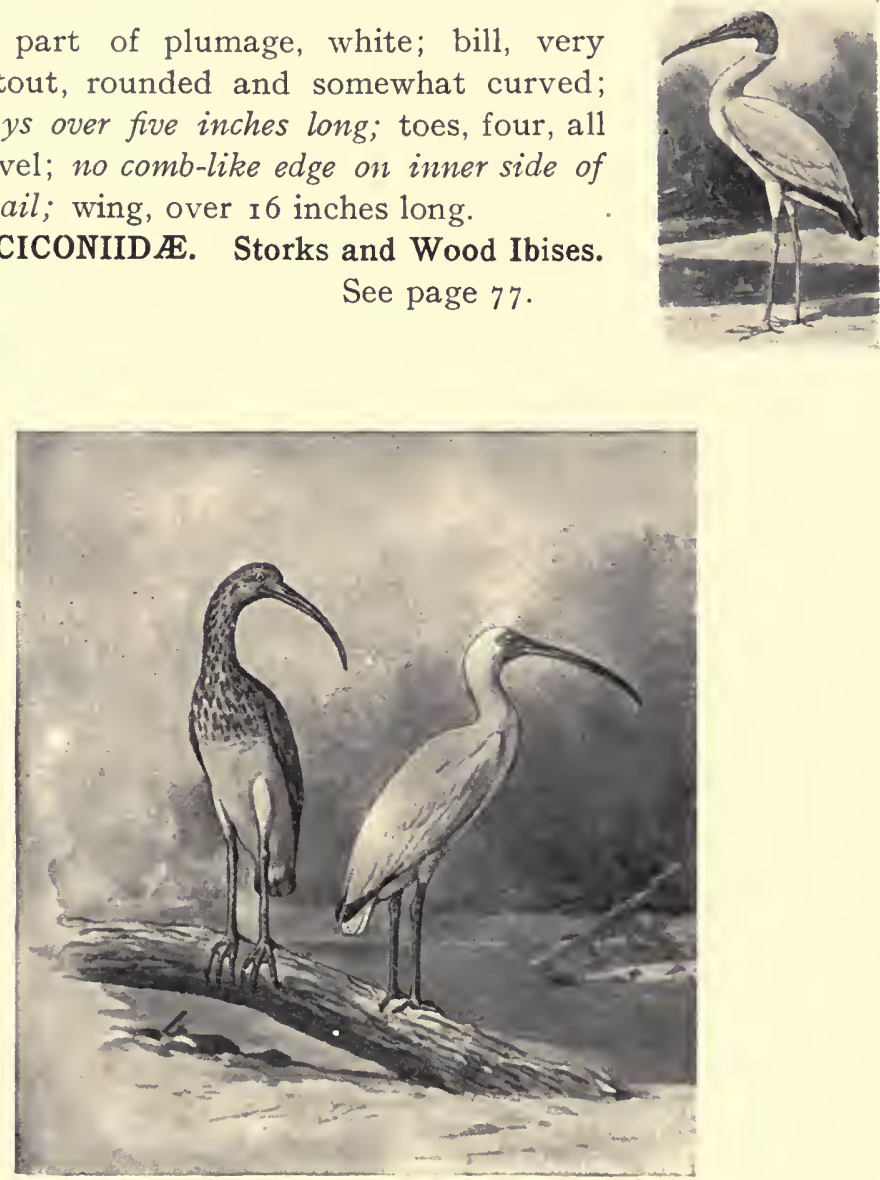

Bill, long, rather slender, and decidedly curved downward; tarsus, always less than five inches long; toes, four, all on the same level; no comblike edge on side of middle toe nail.

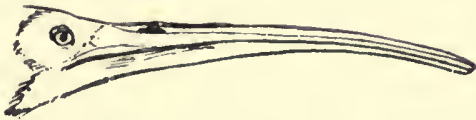

Family IBIDID Æ. Ibises. See page 76 . 
32 Field Museum of Natural History-Zoölogy, Vol. iX.
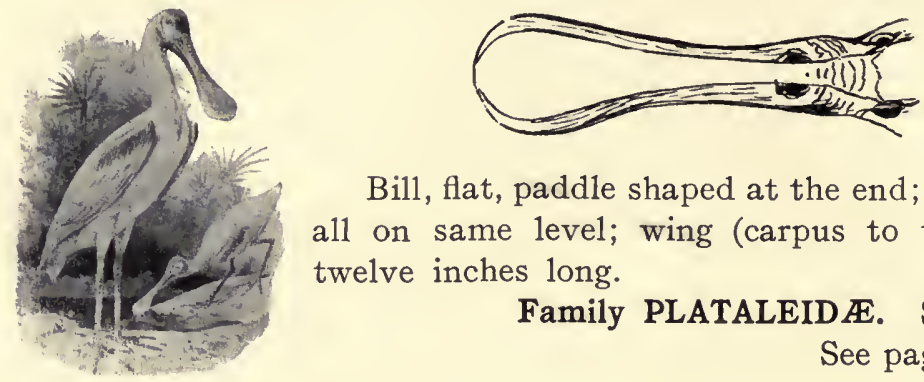

Bill, flat, paddle shaped at the end; toes, four, all on same level; wing (carpus to tip), over twelve inches long.

Family PLATALEIDÆ. Spoonbills. See page 75 .

GROUP 5. Toes, three, full webbed; no hind toe.

Nostrils, separate, not opening into one double-barrelled tube; upper mandible, curved near tip; bill, yellowish, or greenish yellow; an indication of a hind toe, in the form of a small knob without nail; tail, entirely white, or white with black band near tip. This is the only North American gull lacking a hind toe.

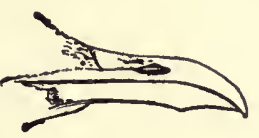

Family LARIDAE. Rissa tridactyla. Kittiwake Gull. See page 44 .
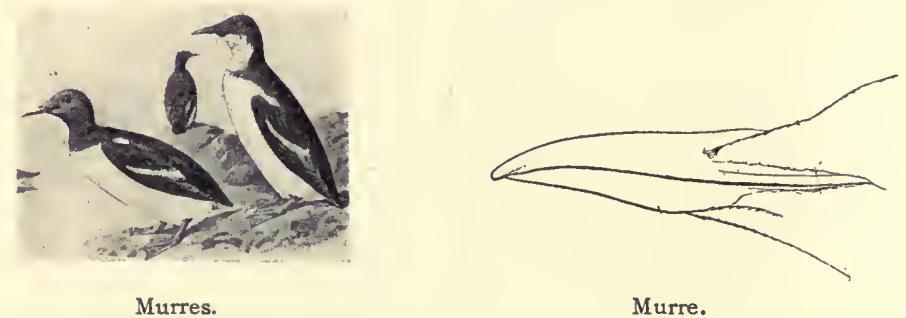

Murre.

Legs placed far back near the tail; bill, black or brownish; wing, over 6.50 inches long, carpus (bend of wing) to tip.

Family ALCID Æ. Auks and Murres. See page 39 .

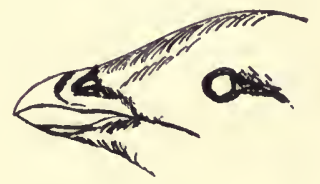

-Size, small; tail, very short; bill, black or brownish; wing, less than 6.50 inches long.

Family ALCIDÆ. Murrelet, Dovekies, etc. See page 39 . 
GROUP 6. Toes, three; a small web between toes, or, entirely without web.
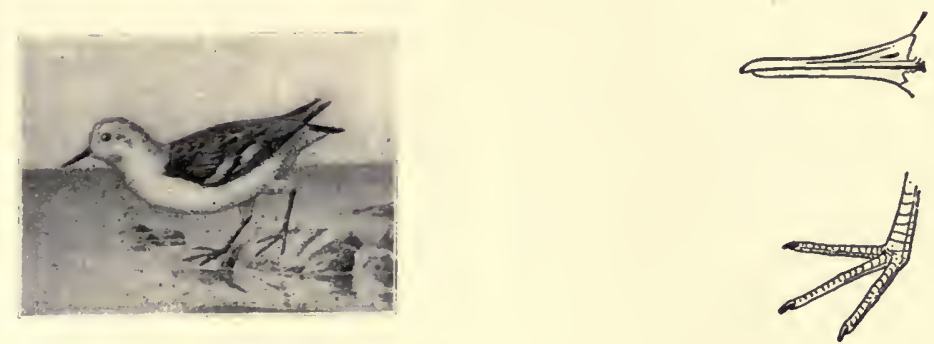

Toes, three; bill, slender; wing, about 5 inches; bill, about one inch; this is the only representative of this family with three toes, all others have four; tarsus, less than $\mathrm{r} .50$ inches long.

Family SCOLOPACIDE. Calidris leucophaa. Sanderling Sandpiper. See page I03.
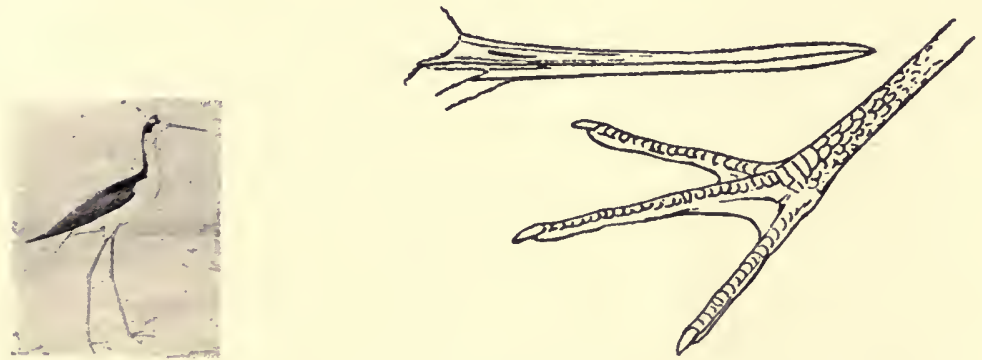

Toes, three, partly webbed; tarsus, over 3 inches long; general plumage, black and white; legs, pink red in life.

Family RECURVIROSTRIDÆ. Stilts.

See pages 9I, 95. 
34 Field Museum of Natural History-Zoölogy, Vol. IX.

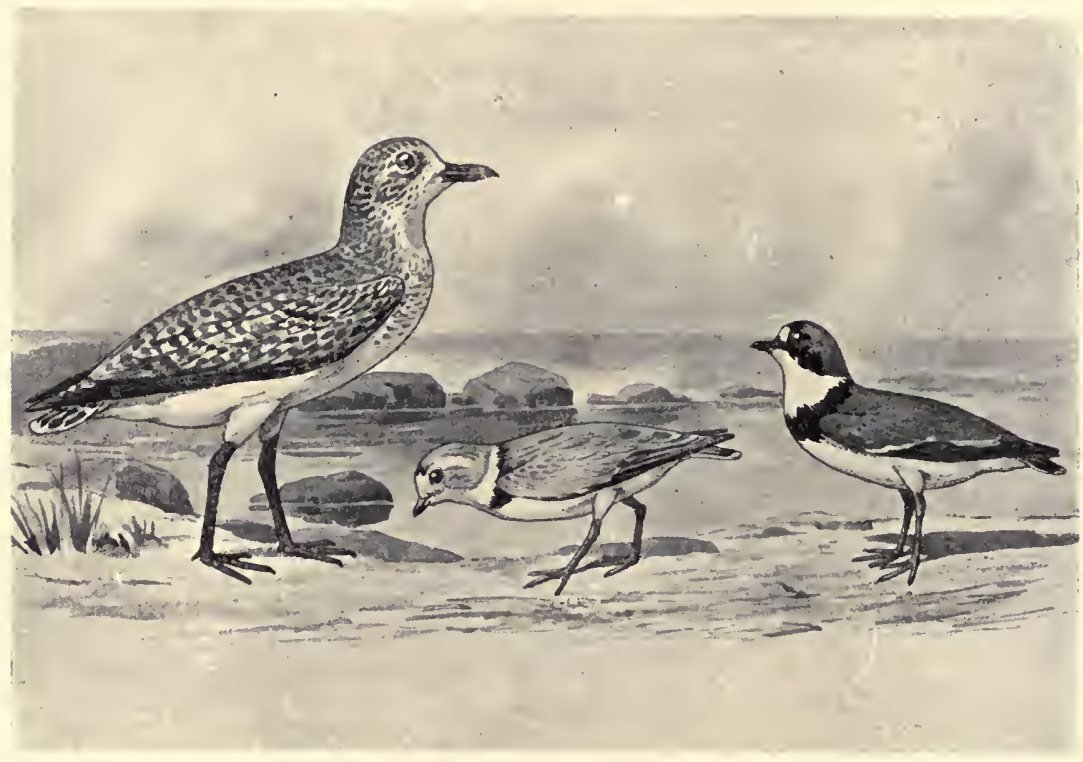

Plovers.

Toes, three; front of tarsus with small rounded scales; bill, short; some species have bill less than three-quarters inch long; none have bill over two inches long.

Family CHARADRIIDÆ. Plovers. See pages 92 , III. 


\section{WATER BIRDS. \\ KEY TO THE SPECIES.}

\section{Family COLYMBIDÆ. The Grebes.}

Special Characters: Bill, straight and pointed; toes, four, with lobate webs; hind toe elevated above the rest; tail feathers apparently wanting; legs placed far back.

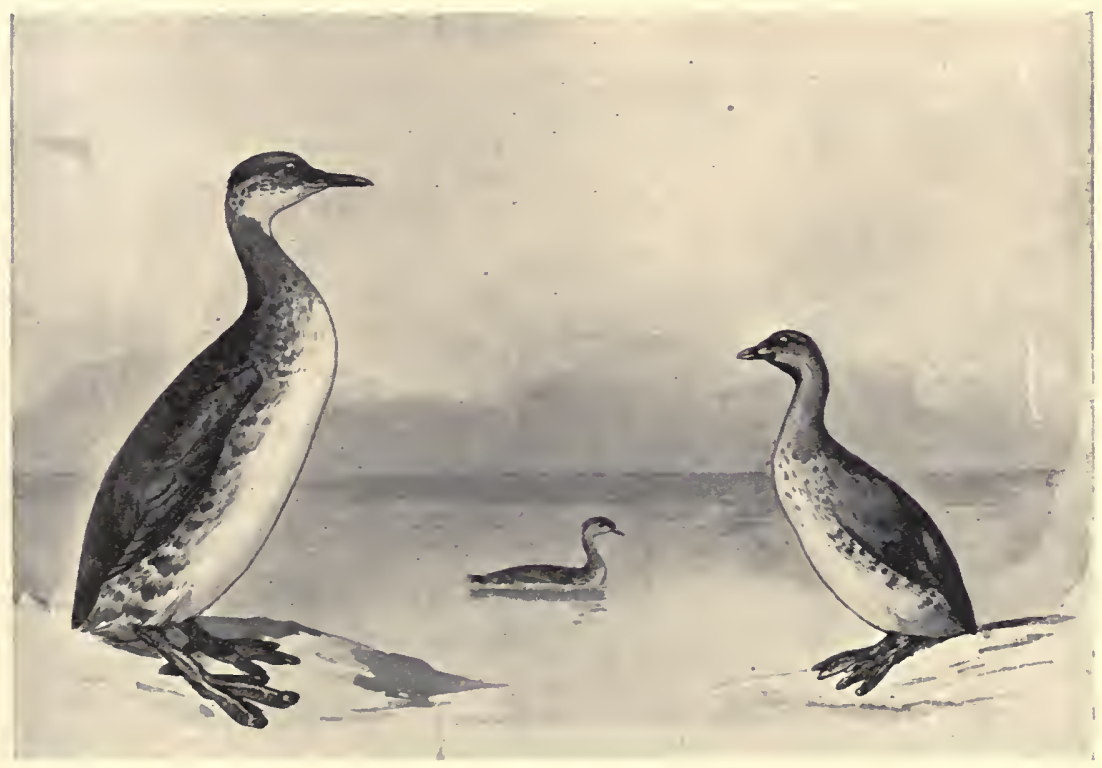

Grebes.

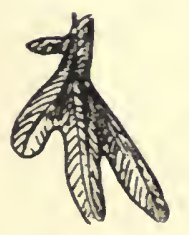

Toes, four; three in front, one behind, with lobate webs. 
*GROUP 1. Wing, less than 6.50 inches long.

Depth of bill at base of culmen, over .40. Upper parts, glossy brownish black; sides of body and neck, tinged with brown, belly white.

In summer: Bill, with black band; throat, black. In winter: Bill, without black band; throat, white. Podilymbus podiceps.

Pied-billed Grebe. Hell Diver.

See No. 5 .

Depth of bill at base of culmen, less than .40; upper mandible, nearly straight and decidedly flattened at nostril; under mandible, straight for about three-fourths of its length and then sharply ascending.

Colymbus nigricollis californicus.

American Eared Grebe.

See No. 4 .

Depth of bill at base of culmen, less than .40; top of upper mandible (culmen), curved and not flattened at nostrils; under mandible, not as sharply ascending near the tip. While the summer plumages of

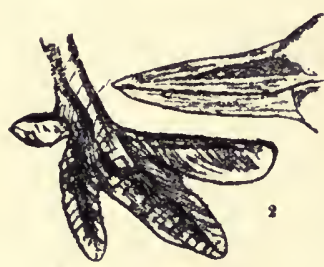
californicus.and auritus are very different, the winter plumages are similar.

In summer: Two small tufts of grayishbrown or buff-colored feathers, behind the eye; crown, nape, and throat, black.

In winter: Plain colored, without black or buff on head; upper plumage, grayish black; under parts, silvery white, often tinged with ash gray on throat and sides; no developed plumes behind the eye.

Colymbus auritus.

Horned Grebe.

See No. 3 .

* GROUP 2. Wing, over 6.50 inches long.

Nostril to tip of bill, less than 2 inches; tarsus with middle toe and claw together, less than $\mathbf{5 . 5 0}$.

In summer: Crown, black; upper throat, gray; lower throat and breast, chestnut rufous; rest of underparts, silvery grayish white.

* For directions for measurement, see page $2 \mathbf{r}$. 
Jan., ig09. Birds of Illinois and Wisconsin-Cory.

In winter: No rufous brown on throat or breast.

Colymbus holballii. Holbœll's Grebe. See No. 2.

Nostril to tip of bill, over 2 inches; tarsus and middle toe with claw together, over 5.50 inches.

In winter: Ends of primaries brown, shading into white at base; upper plumage, dark; under parts, silvery white.

Echmophorus occidentalis.

Western Grebe. See No. I.

\section{Family GAVIID艮. Loons.}

Special Characters: Bill, straight and pointed; tail, short; toes, four; front toes, palmate (full webbed); tarsus, flattened; hind toe, with flap or small lobe; legs placed far back near the tail.

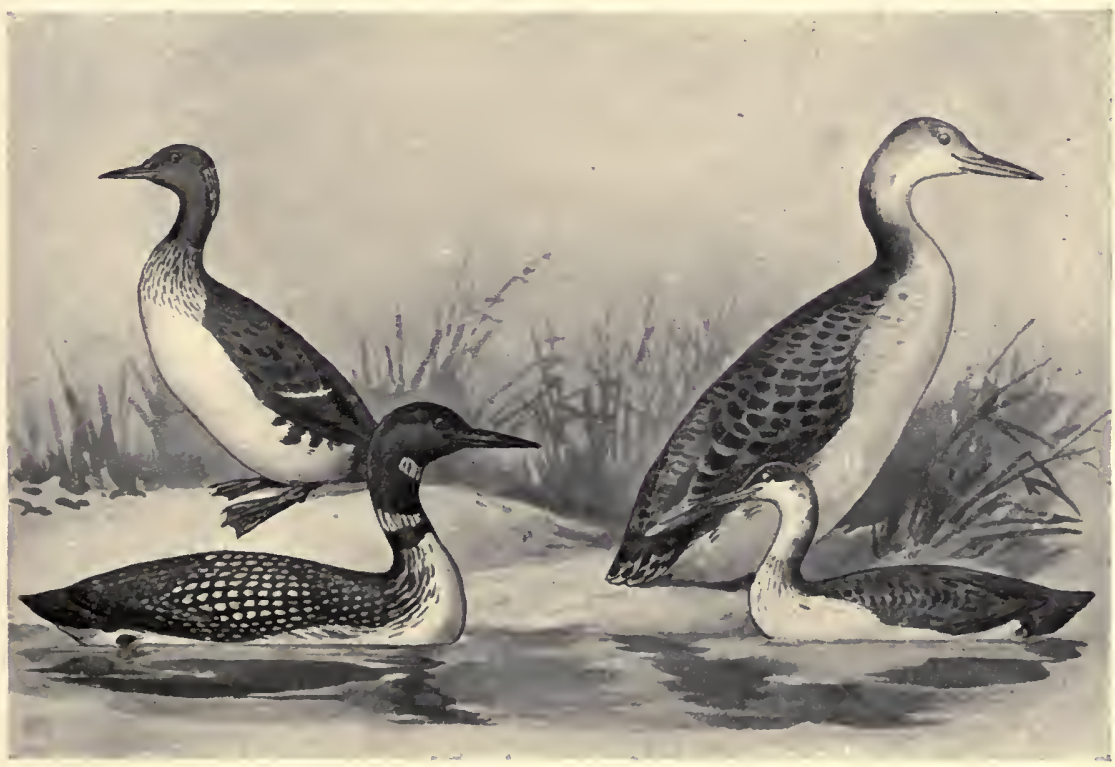


38 Field Museum of Natural History-Zoölogy, Vol. IX.

*GROUP 1. Wing, 9.50 to I I inches long.

Back, with white spots; throat, white or whitish (immature or winter). Gavia stellata.

Red-throated Loon. See No. 9 .

Back, without distinct white spots; the feathers, edged with ashy; throat, white or dusky (immature or winter).

Gavia arctica.

Black-throated Loon. See No. 8 .

Head, ashy gray; throat, black (adult).

Gavia arctica. Black-throated Loon. See No. 8.

Throat, gray; front of neck, chestnut brown (adult).

Gavia stellata. Red-throated Loon. See No. 9 .

*GROUP 2. Wing, I I to I 5 inches long.

SECTION 1. Depth of bill. at base, more than .85 .

Head, black (adult).

Gavia immer. See No. 7 .

Loon.

Top of head, grayish; throat, white (immature or winter plumage).

Gavia immer.

Loon.

See No. 7 .

SECTION 2. Depth of bill at base, less than .85 .

Head, ash gray; throat, black (adult).

Gavia arctica. Black-throated Loon. See No. 8.

Throat, gray; front of neck, chestnut brown (adult).

Gavia stellata.

Red-throated Loon.

See No. 9.

* For directions for measurement, see page 2 I. 
JAN., 1909. Birds OF Illinois and Wisconsin - Cory.

Back. with white spots; throat, white or whitish (immature or winter).

Gavia stellata.

Red-throated Loon.

See No. 9 .

Back, without distinct white spots; the feathers, edged with ashy; throat, white or dusky (immature or winter).

Gavia arctica.

Black-throated Loon.

See No. 8.

*GROUP 3. Wing, over I 5 inches long.

Feet, webbed; head, black, in adult; head, gray; throat, whitish. in immature.

Gavia immer.

Loon.

See No. 7 .

\section{Family ALCIDÆ. Auks, Murres, etc., etc.}

Toes, three; no hind toe (hallux); toes, palmate (full webbed); nostrils, separate, and not tubular.

*GROUP 1. Wing, less than 6 inches long.

Summer plumage: Sides of neck and stripe on side of occiput and through the eye, white; rest of head, black; back, plumbeous, with lateral streaks of white; under parts, white.

Winter plumage: Head, dusky; back, plumbeous; throat and under parts, white. Length, about Io inches; wing, 5.40; bill, .65.

Synthliboramphus antiquus.

Ancient Murrelet.

See No. 6.

* For directions for measurement, see page 21 . 


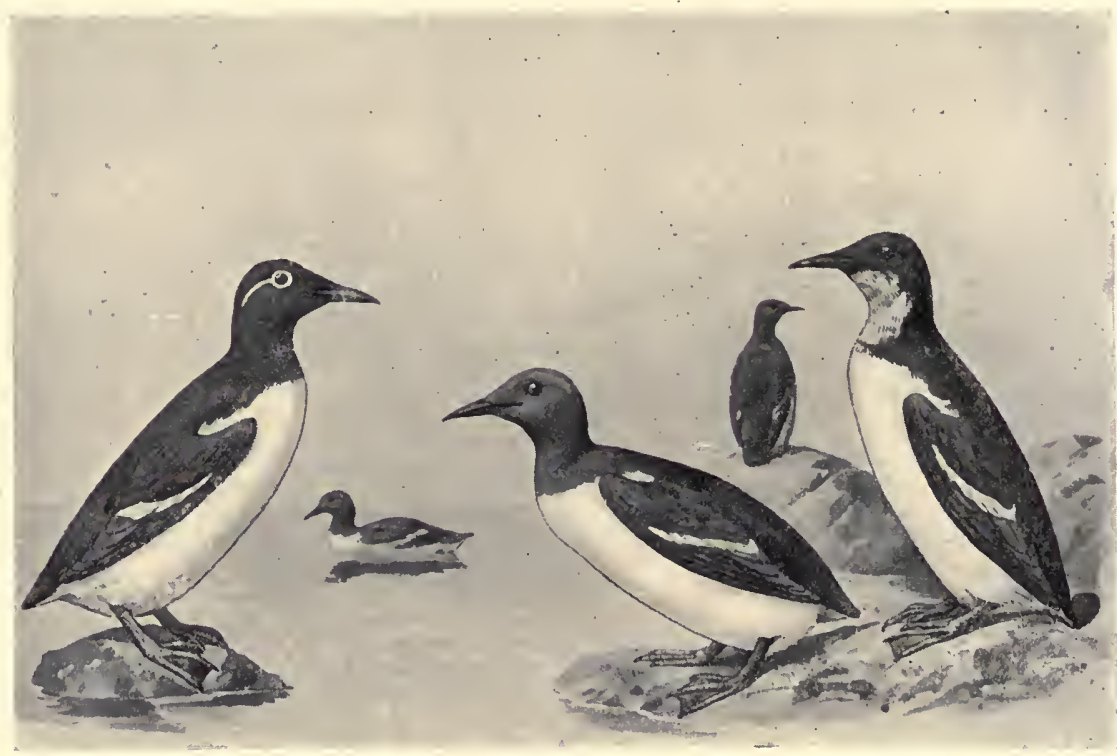

Murres.

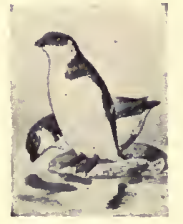

Winter plumage: Upper parts, black, or blackish; under parts, white; length, about 8 inches; wing, about 4.50 ; bill, .50 .

Alle alle.

Dovekie, or Little Auk. See No. 6r.

\section{*GROUP 2. Wing, over 6.50 inches long.}

Summer plumage: Length, about $\mathrm{x} 6$; wing, about 8 ; head, back, wings, and tail, dark sooty brown; under parts and tips of secondaries, white. Winter plumage: Under parts, white, more or less marked with sooty brown or blackish about the throat, belly, and flanks; bill, usually over x.60. Maritime species - not recorded from Illinois or Wisconsin.

Uria troile.

Murre.

Similar to Uria troile, but has the head darker than the throat; size slightly larger; length, about 16.50 ; wing, about 8.20 ; bill, usually under 1.60. No record for Illinois or Wisconsin, but has been taken in Indiana, Michigan, etc.

Uria lomvia. Brünnich's Murre.

* For directions for measurement, see page $2 \mathbf{r}$. See page 28 I. 


\section{ORDER LONGIPENNES.}

LONG-WINGED SWIMMERS. JÆGERS, GULLS, TERNS, ETC.

\section{Family STERCORARIIDÆ. The Skuas \\ and Jægers.}

Special Characters: Nostrils, separate and not tubular; bill, with cere; front toes, palmate (full webbed); hind toe, small, but always present and without web; end of upper mandible (unguis), swollen and somewhat rounded; plumage, always dark, sometimes sooty, sometimes barred with brown; tail, never white or gray; middle tail feathers, longest. The cere, a hard skin-like covering on base of upper mandible, well distinguishes them from the Gulls.
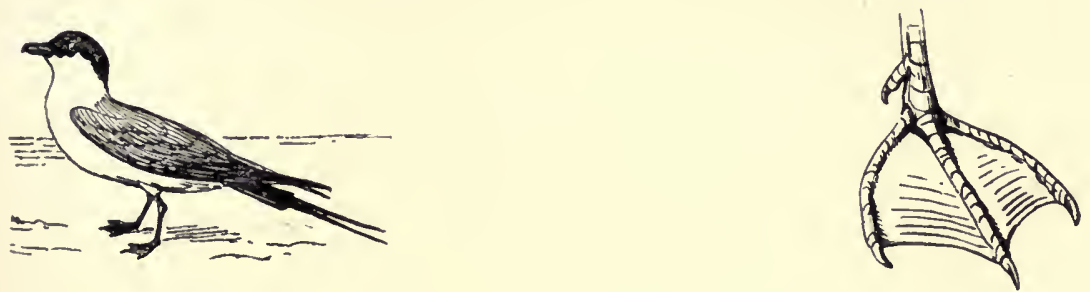

*GROUP 1. Wing, 1 I to 15 inches long.

Under parts, not entirely pure white; bill, over I.35; tarsus, over I.80; middle tail feathers, not pointed; plumage, sometimes dark brown; sometimes mixed gray, brown, and white.

Stercorarius pomarinus. Pomarine Jæger. See No. ro.

Bill, under I.35; tarsus, under I.80; middle tail feathers, pointed; base of unguis to frontal feathers, less than length of unguis; shafts of primaries, yellowish white.

Stercorarius longicaudus. Long-tailed Jæger. See No. II.

Bill, under I.35; tarsus, under I.80; middle tail feathers, pointed; base of unguis to frontal feathers, greater than length of unguis; shafts of primaries, yellowish white.

Stercorarius parasiticus. Parasitic Jæger. See page 288 .

* For directions for measurement, see page 21 . 


\section{INDEX TO KEY.}

\section{Family LARIDÆ. Gulls and Terns. Subfamily LARIN Æ. Gulls.}

Tail, usually nearly square.

Group 1. Wing, 9.50 to I i inches long Group 2. Wing, I I to I 3 inches long. GROUP 3. Wing, I 3 to 15 inches long . GROUP 4. Wing, 15 to 17 inches long .
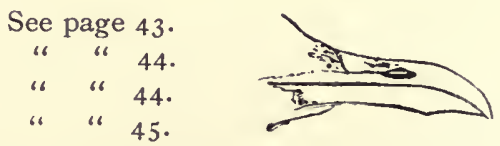

Section 1. Length, over $2 \mathrm{I}$; bill, over 2 ; under parts, white See page 45.

Section 2. Length, over $2 \mathrm{I}$; bill, over 2 ; under parts, not white " 45 .

Section 3. Length, over 21 ; bill, under 2 ; under parts, white . " 46.

Section 4 . Length, over $2 I$; bill, under 2 ; under parts, not white. " 46.

Section 5. Length, under 21 . . . . . . . " 46. Grou P 5. Wing, over I 7 inches long . . . . . . " “ 47 .

\section{Subfamily STERNINÆ. Terns.}

Tail, usually forked.

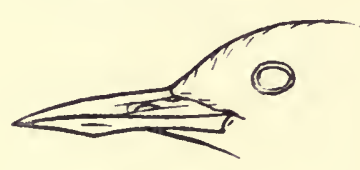

Group 1. Wing, 5.50 to 7.50 inches long See p. 47 . GROUP 2. Wing, 7.50 to 8.50 inches long " 48 . GROUP 3. Wing, 8.50 to 9.50 inches long “ 48 . Group 4. Wing, 9.50 to I I inches long. " 48 . Grou P 5. Wing, I I to 13 inches long . " 48 .

Group 6. Wing, I3 to $I_{7}$ inches long . . . . . . " 49 . GRoup 7. Wing, over 17 inches long . . . . . . " " 49 . 


\section{Family LARIDÆ. Gulls and Terns.}

$$
\text { Subfamily LARINÆ. Gulls. }
$$

Upper mandible, curved; unguis (end of bill), not swollen; nostrils, near middle of upper mandible; middle tail feathers, about equal in length to the others; tail, rarely dark, although

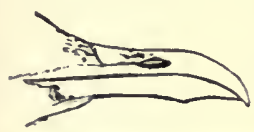
sometimes tipped with black or brown; hind toe, small, but always present except in one genus; bill, without cere.

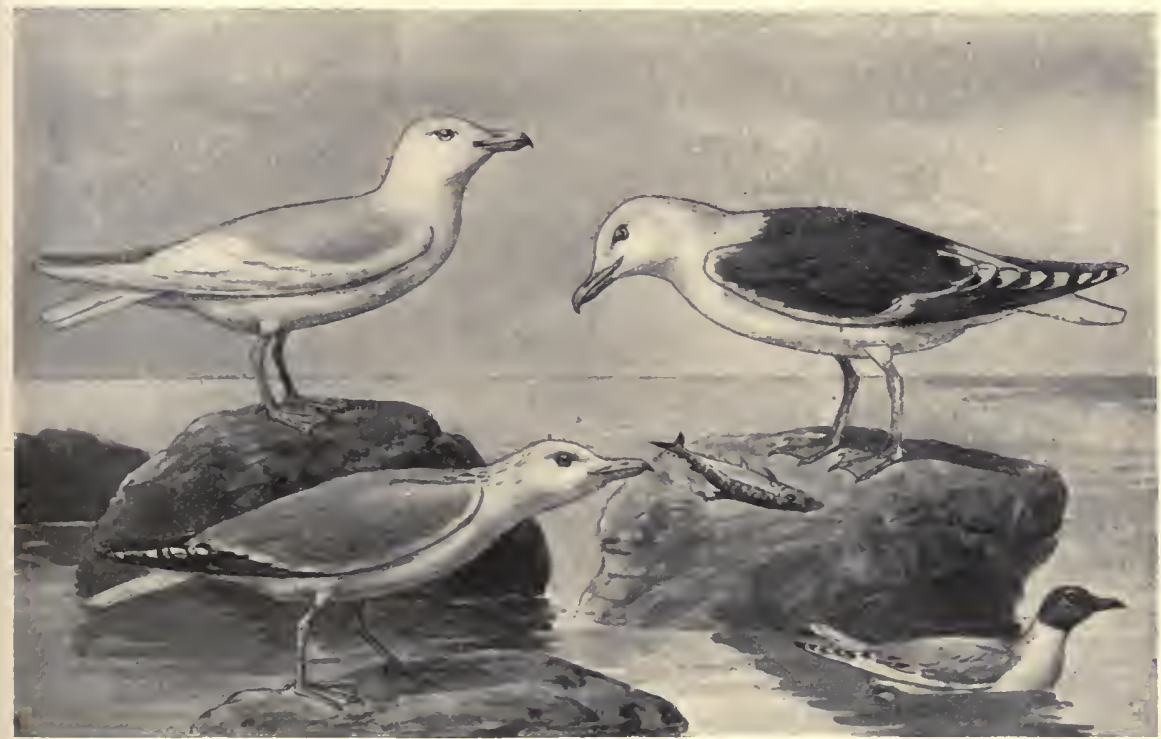

Glaucous Gull.
Herring Gull.

Great Black-backed Gull.

Bonaparte's Gull.

*GROUP 1. Wing, 9.50 to I I inches long.

Under parts, white; inner web of first primary, white, with black spot near the end; the tip, white; shaft of feather, white; adult birds have the bill dark red; in immature birds it is brownish.

Larus franklinii. Franklin's Gull. See No. 19.

* For directions for measurement, see page 21 . 
44 Field Museum of Natural History-Zoölogy, Vol. IX.

Under parts, white; inner web of first primary, white; the tip, black; bill, black; shaft of feather, white.

Larus philadelphia.

Bonaparte's Gull.

See No. 20.

Under parts, white; inner web of first primary, about half white; shaft of feather, dark brown on upper surface. In the adult the bill is black, tipped with yellow.

Yema sabinii.

Sabine's Gull. See No. 2 r.

\section{*GROUP 2. Wing, I 1 to I 3 inches long.}

Shafts of primaries, black or dark brown; under parts, not pure white (immature).

Larus atricilla.

Laughing Gull.

See No. i 8 .

Under parts, pure white; inner web of first primary, white, with black spot near the end, the tip, white; shaft of feathers, white. Adult birds have bill dark red; in immature birds it is brownish.

Larus franklinii.

Franklin's Gull.

See No. Ig.

Under parts, white; first primary, entirely black or dark brown (adult).

Larus atricilla.

Laughing Gull.

See No. 18.

Back, pearl gray; inner web of primary, white, broadly tipped with black; a small rudimentary hind toe, without nail.

Rissa tridactyla. Kittiwake Gull.

See No. I 2.

*GROUP 3. Wing, I 3 to I 5 inches long.

Under parts, white; first primary entirely black, or dark brown.

Larus atricilla.

Laughing Gull.

See No. 18.

*For directions for measurement, see page $2 \mathrm{r}$. 
Jan., igog. Birds of Illinois and Wisconsin-Cory.

Under parts, white; inner web of primary, white, broadly tipped with black; a small rudimentary hind toe, without nail.

Rissa tridactyla. Kittiwake Gull. See No. I 2 .

Under parts, white; terminal portion of first primary, black, with white spot near tip.

Larus delawarensis. Ring-billed Gull. See No. I7.

Primaries, pale pearl gray, becoming white at tip; bill, over $1.5^{\circ}$; wing, over 14.

Larus leucopterus. Iceland Gull. See No. I 4 .

*GROUP 4. Wing, I 5 to $\mathrm{I} 7$ inches long. SECTION 1. Length, over 2 I; bill, over 2; under parts, white. No black on primaries (adult).

Larus hyperboreus.

Glaucous Gull. See No. I3.

Back, slaty black; primaries, black with more or less white. (adult).

Larus marinus Great Black-backed Gull. See No. I 5 .

Back, pale bluish, gray, or pearl gray; primaries, dull black or brownish black, more or less marked with white.

Larus argentatus. American Herring Gull. See No. 16.

SECTION 2. Length, over 2I; bill, over 2; under parts, not white. Outer webs of primaries, ash color (immature).

Larus hyperboreus.

Glaucous Gull.

* For directions for measurement, see page $2 \mathrm{I}$.

See No. I3. 
46 Field Museum of Natural History-Zoölogy, Vol. IX.

Outer webs of primaries, dark brown; wing, over I7.50; depth of bill at angle, over .90 (immature).

Larus marinus.

Great Black-backed Gull.

See No. I 5 .

Outer webs of primaries, dark brown; depth of bill at angle, under .90 ; wing, under I 7.50 (immature).

Larus argentatus.

American Herring Gull.

See No. 16.

SECTION 3. Length, over 2I; bill, under 2; under parts, white.

Back, grayish blue, more or less black on primaries.

Larus argentatus. American Herring Gull.

See No. 16.

Back, pale pearl color; primaries, whitish or pearl color, shading to white at the tips.

Larus leucopterus. Iceland Gull. See No. I 4 .

SECTION 4. Length, over $2 \mathrm{I}$; bill, under 2; under parts, not white. Outer webs of primaries, dark brown; bill, over r.90 (immature). Larus argentatus. American Herring Gull. See No. I6.

Outer webs of primaries, ash color (immature).

Larus leucopterus. Iceland Gull. See No. I 4 .

SECTION 5. Length, under $2 \mathrm{I}$.

A band of black on the bill (adult); bill, dull yellow, tipped with black (immature).

Larus delawarensis.

Ring-billed Gull.

See No. 77. 
*GROUP 5. Wing, over I 7 inches long.

Primaries, marked with more or less black.

Larus marinus.

Great Black-backed Gull. See No. 15.

No black on primaries.

Larus hyperboreus. Glaucous Gull. See No. I3.

\section{Subfamily STERNINÆ. Terns.}

Upper mandible, nearly straight, not hooked or decidedly rounded near tip; nostrils, in basal half of bill; outer tail feathers, usually longer than middle feathers; toes, four; front toes, webbed; hind toe, small, but well developed.

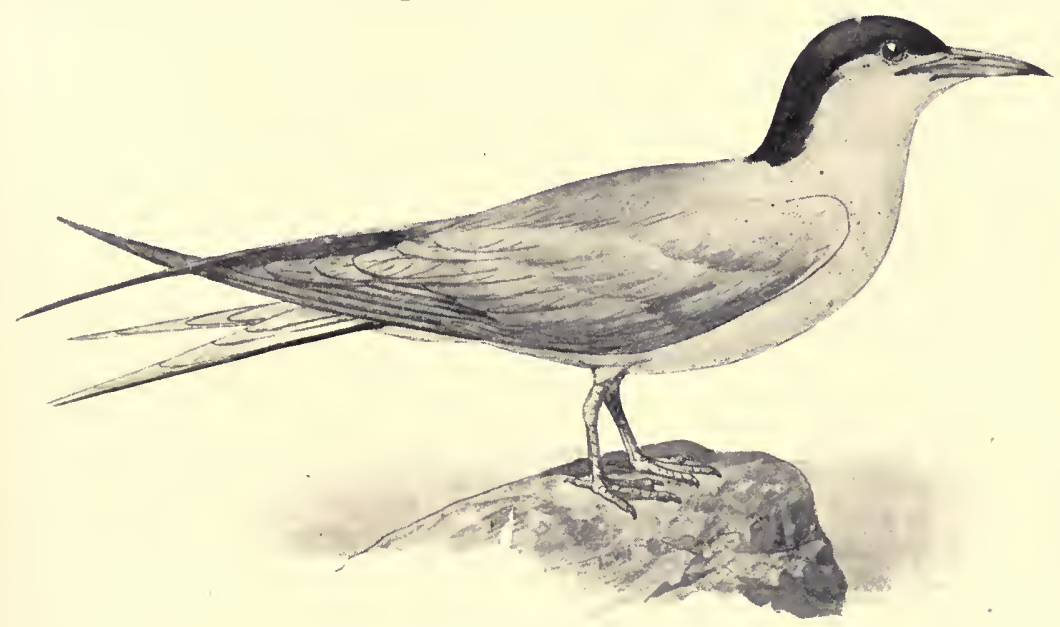

Common Tern.

*GROUP 1. Wing, 5.50 to 7.50 inches long.

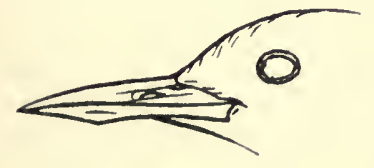

Forehead, white; bill, black; under parts, white; back, pearl gray; crown, black (adult in summer); back and crown, mottled (immature).

Sterna antillarum.

Least Tern.

See No. 28. 
48 Field Museum of Natural History-Zoölogy, Vol. IX.

*GROUP 2. Wing, 7.50 to 8.50 inches long.

Head and under parts, black (adult). A patch of black behind the eye; back of head, dusky; rest of head, white (immature).

Hydrochelidon nigra surinamensis.

Black Tern.

See No. 29.

*GROUP 3. Wing, 8.50 to 9.50 inches long.

Inner web of outer tail feather, gray; entire under parts, white.

Sterna forsteri.

Forster's Tern.

See No. 25 .

*GROUP 4. Wing, 9.50 to I I inches long.

Outer web of outer tail feather, darker than inner web; back, pearl gray; breast, washed with pearl gray; bill in adults, red, tipped with black; tarsus, usually over .70.

Sterna hirundo.

Common Tern. Wilson's Tern. See No. 26.

Inner web of outer tail feather, darker than outer web; back, pearl gray; bill in adults, black, slightly yellowish at tip; entire under parts, white.

Sterna forsteri.

Forster's Tern.

See No. 25.

Outer web of outer tail feather, darker than inner web; back, pearl gray; breast and under parts, pearl gray; bill, in adults, entirely red; tarsus, usually less than .70 .

Sterna paradisca. Arctic Tern.

See No. 27.

* GROUP 5. Wing, I I to I 3 inches long.

Bill, black, not tipped with yellow; feet, blackish; back, pearl gray; bill, comparatively short and stout. Gelochelidon nilotica.

Gull-billed Tern.

See No. 22. 
JAN., igog. Birds of Illinois and Wisconsin-Cory.

Bill, red, tipped with black; feet, orange red; back, pearl gray or gray and buff.

Sterna hirundo.

Common Tern. Wilson's Tern.

See No. 26.

* GROUP 6. Wing, I 3 to I 7 inches long.

Bill, orange or yellowish; tarsus, less than $1.5^{\circ}$; inner web of outer primary, usually with more or less white.

Sterna maxima.

Royal Tern.

See No. 24.

Bill, red or reddish; tarsus, over 1.50 ; inner web of outer primary, usually without white.

Sterna caspia.

Caspian Tern.

See No. 23.

$\because$ GROUP 7 . Wing, over 17 inches long.

Bill, red or reddish.

Sterna caspia.

Caspian Tern.

See No. 23.

* For directions for measurement, see page 21 . 


\section{ORDER STEGANOPODES.}

TOTIPALMATE SWIMMERS. ANHINGAS, CORMORANTS, PELICANS, ETC.

\section{Family ANHINGIDÆ. Darters, Snake Birds.}

Bill, sharp-pointed and slender; chin, bare; neck, long and slender; toes, four, all connected by webs; middle tail feathers, corrugated or fluted.

* GROUP 1. Wing, I 2.50 to 15.50 inches long.

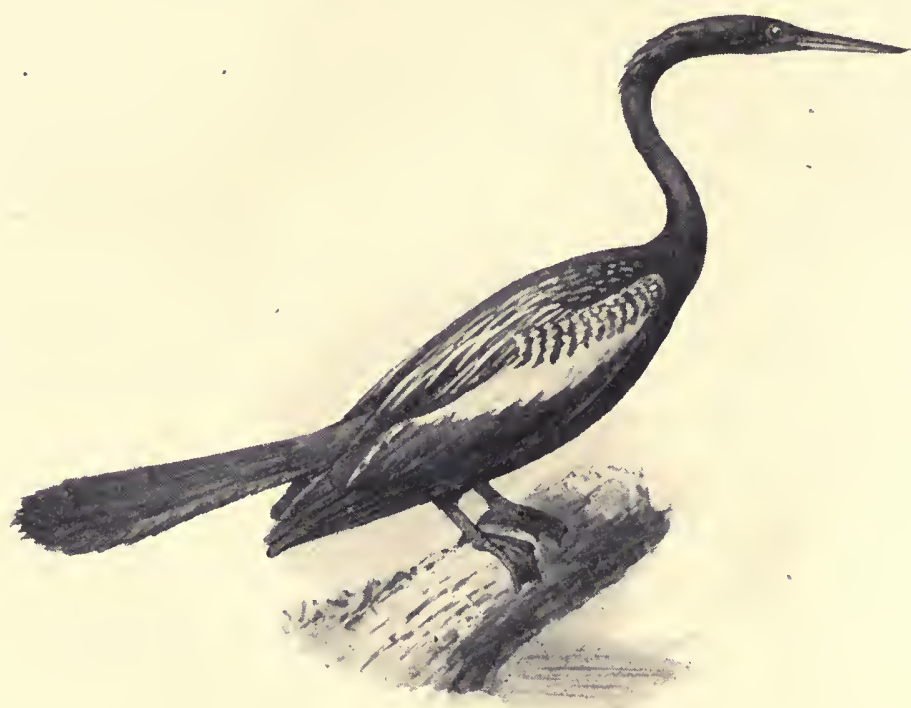

Neck, long, snake-like; head and neck, black in male, brown in female; outer webs of two middle tail feathers, "fluted."

Anhinga anhinga.

Anhinga. Water Turkey. See No. $3 \mathrm{~J}$.

* For directions for measurement, see page $2 \mathrm{I}$. 


\section{Family PHALACROCORACIDÆ. Cormorants.}

Bill, hooked at tip, and less than twelve inches

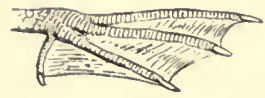
long; bare skin at base of bill and chin; lores, bare; toes, four, all connected by webs; tail feathers, stiff.

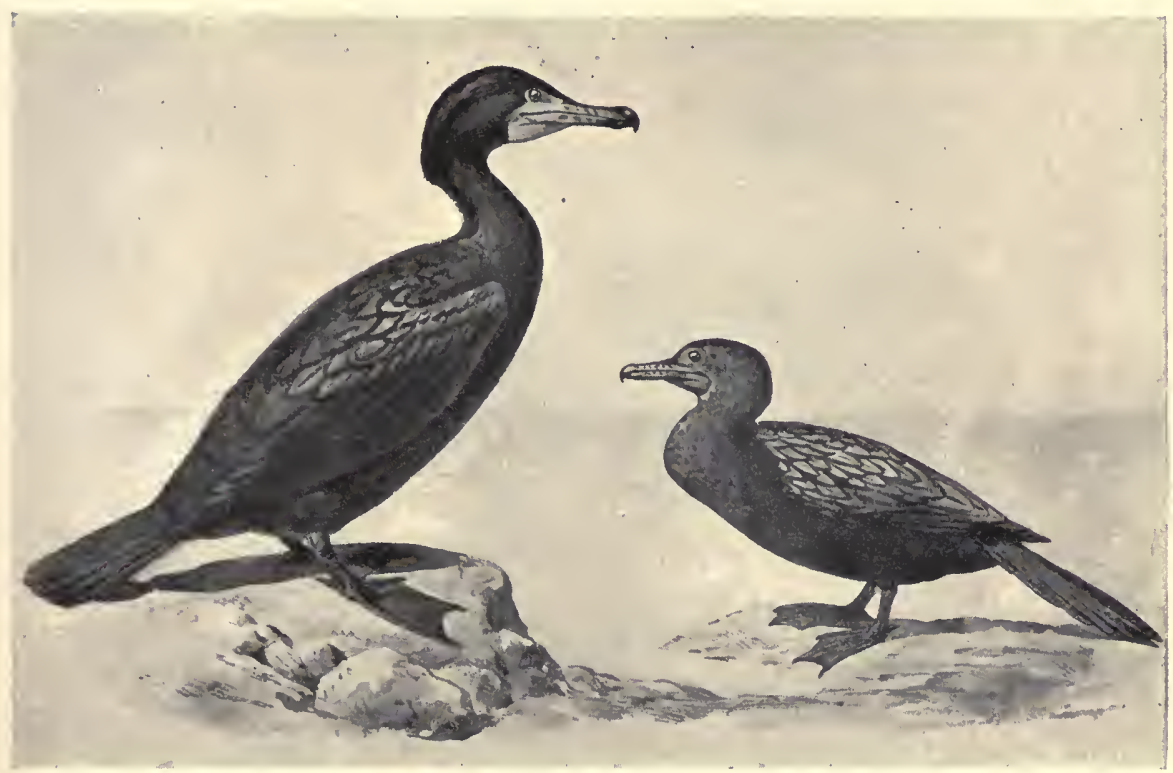

Double-crested Cormorant.

Mexican Cormorant.

* GROUP 1. Wing, I I to I 5 inches long.

Plumage, variable at different seasons; but wing, always over I I inches long.

Phalacrocorax auritus, and races. Double-crested Cormorant and Florida Cormorant. See Nos. 32 and 32 a.

* GROUP 2. Wing, less than 10.50 inches long.

Adult: With white line bordering the bare skin on throat; immature: showing throat pale, but white line not clearly defined.

Phalacrocorax vigua mexicanus.

Mexican Cormorant. See No. 3.3 .

* For directions for measurement, see page $2 \mathrm{I}$. 


\section{Family PELECANIDÆ. Pelicans.}

Bill, hooked at tip, over twelve inches long and having a large pouch attached to the under mandible; lores, bare; toes, four, all connected by webs.

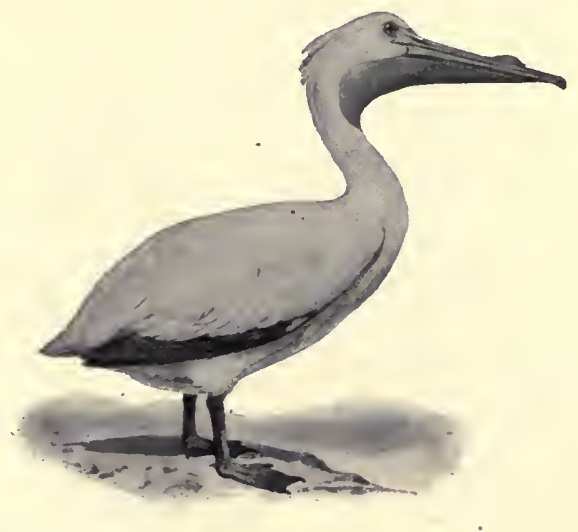

American White Pelican.

* GROUP 1. Wing, over 17 inches long.

Géneral plumage, white.

Pelecanus erythrorhynchos. American White Pelican. See No. 34 .

General plumage, not white (coloration very variable according to age and season, but never white).

Pelecanus occidentalis.

Brown Pelican.

See No. 35 .

\section{Family FREGA'TIDÆ. Man-of-war Birds. Frigate Birds.}

Bill, hooked at tip; lores, feathered; upper plumage, entirely black; toes, four, all connected by webs; tail, forked; wings, very long.

* For directions for measurement, see page $2 \mathbf{r}$. 
* GROUP 1. Wing, over 21 inches long.

Size, large; length, 3 feet or more; wing, over 20 inches; entire plumage, black or brownish black (adult, male); general plumage, black; belly, white (female); head and neck, whitish; belly, white; rest of plumage, black (immature).

Fregata aquila. Man-of-war Bird. See No. 36.

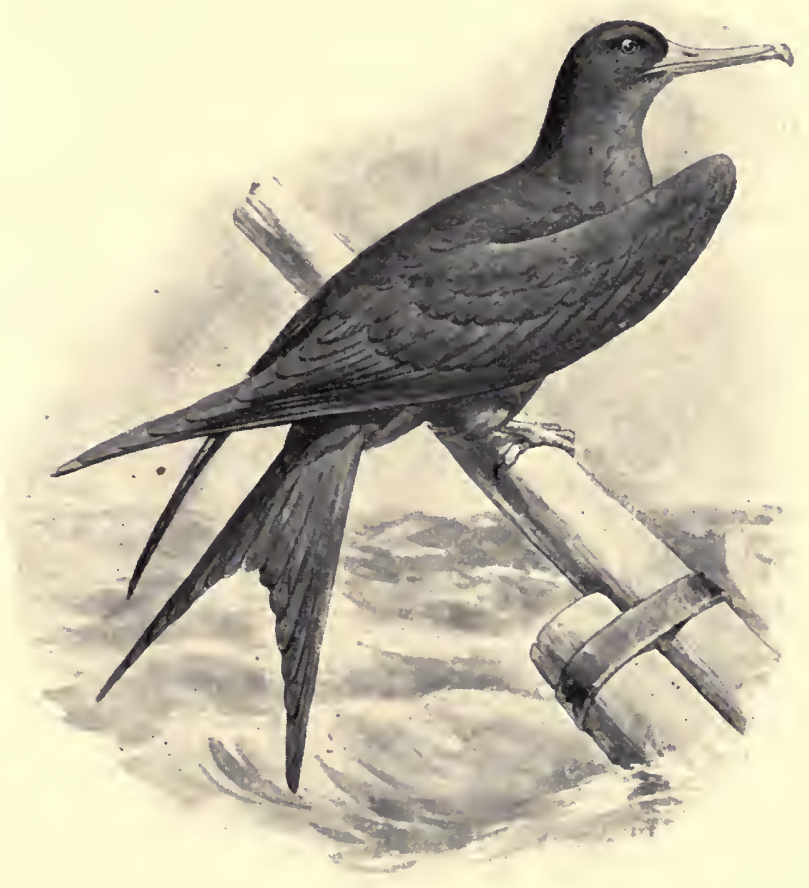

Man-of-war Bird. 


\section{INDEX TO KEY.}

\section{Family ANATIDÆ. Ducks, Geese, and Swans.}

\section{Subfamily MERGINÆ. Mergansers.}

Fish-eating Ducks having narrow bills with tooth-like serrations on edges; tarsus, scutellate (transverse scales) in front.

Group 1. Wing, 6.50 to 8.50 inches long . . . . See page $5^{6}$. Group 2. Wing, 8.50 to 12 inches long . . . . . " " 57 .

\section{Subfamily ANATINÆ. River and Pond Ducks.}

Ducks having hind toe without well developed membraneous lobe or flap; tarsus, scutellate (transverse scales) in front.

Group 1. Wing, 5 to 7.50 inches long . . . . . See page 58 . Group 2. Wing, 8 to ro inches long . . . . " " 59.

Section 1. Belly, white . . . . . . . “ " 59 .

Section 2. Belly, not white . . . . . . " " 59 .

Group 3. Wing, ro to $\mathrm{I}_{4}$ inches long . . . . . " " 60.

Section 1. Belly, white, or tinged with dusky or gray on lower part

" " 6 " 60

\section{Subfamily FULIGULINÆ. Bay and Sea Ducks.}

Ducks having a flap or membraneous lobe on hind toe; tarsus, scutellate (transverse scales) in front.

Group 1. Wing, 5 to $6.5^{\circ}$ inches long

Tail feathers, not stiff and pointed

Section 2. Tail feathers, stiff and pointed . . . " “ $66_{2}$.

Group 2. Wing, 6.50 to 7.50 inches long . . . . " " " 63 .

Section 1. Belly, white. . . . . . . " " " 63 .

Section 2. Belly, not white . . . . . . " " 64 .

Group 3. Wing, 7.50 to 8.50 inches long . . . . " " 64 .

Section 1. Head, with more or less white or brownish white; belly, white, sometimes tinged with dusky or gray on lower part . See page 64 .

Section 2. No white or grayish white on head; belly, white, sometimes tinged with grayish white on head . . . See page $65_{5}$.

Section 3. Belly, not white . . . . . " “ 65 . 
Group 4. Wing, 8.50 to ro inches long. See page 66.

Section 1. Hind toe, with flap or lobe; belly, white, sometimes tinged on lower part with dusky or gray; hcad, marked with more or less white, or brownish white. See page 66 .

Section 2. Belly, white, sometimes tinged on lower part with gray or dusky; no white or grayish white on head. See page 66.

Section 3. Belly, not white; head, marked with more or less white, or grayish white. See page 67.

Section 4. Belly, not white; no white on head. See page 68.

Group 5. Wing, ro to 14 inches long. See page 68 .

Section 1. Head, with more or less white, or grayish white; belly, black. See page 68.

Section 2. No white on head; belly, black. See page 69 .

Section 3. Head, with more or less white, or grayish white; belly, mottled brown, or grayish brown, or slaty. See page 69.

Section 4. No white on head; belly, mottled brown, or grayish brown. See page 70 .

\section{Subfamily ANSERINÆ. Geese.}

Lores, feathered; tarsus, reticulate (scales rounded).

Group 1. Wing, 12 to 14 inches long. See page $7 \mathrm{r}$.

Group 2. Wing, I4 to 20 inches long. See page $7 \mathrm{I}$.

Section 1. Head and neck, black or blackish, marked with more or less white; bill and feet, black. See page $i$ r.

Section 2. Head, white, sometimes tinged with brownish orange; bill and feet, pink or flesh color in life, yellowish or pale brownish in dried skin. See page 72 .

Section 3. Head, brownish or grayish, sometimes marked with white; bill, pinkish; feet, yellow or pink. See page 72 .

\section{Subfamily CYGNINÆ. Swans.}

Bare skin between the bill and eye; tarsus, reticulate (scales rounded); neck, very long; wing, over Ig inches long. See page 73 . 


\section{ORDER ANSERES.}

LAMELLIROSTRAL SWIMMERS.

\section{Family ANATIDÆ. Ducks, Geese, and Swans.}

Subfamily MERGINÆ. Mergansers.

Fish-eating Ducks having narrow bills with tooth-like serrations on edges, and the tarsus, scutellate in front.

*GROUP 1. Wing, from 6.50 to 8.50 inches long; bill, narrow, with tooth-like serrations.

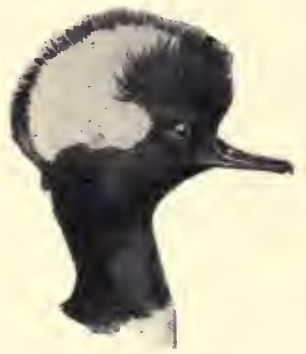

Lophodytes cucullatus (male).

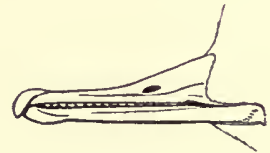

Lophodytes cucullatus.

Head, brownish or grayish; breast and belly, white; sides, rufous brown, narrowly barred with black; tarsus, less than 1.50; crest, small (female and immature).

Lophodytes cucullatus.

Hooded Merganser.

See No. 39 .

Head, with black and white crest; lower breast and belly, white; sides, grayish brown; tarsus, less than r.50 (male).

Lophodytes cucullatus.

Hooded Merganser.

See No. 39 .

* For directions for measurement, see page $2 \mathrm{r}$. 
* GROUP 2. Wing, from 8.50 to 12 inches long; bill, narrow, with tooth-like serrations.

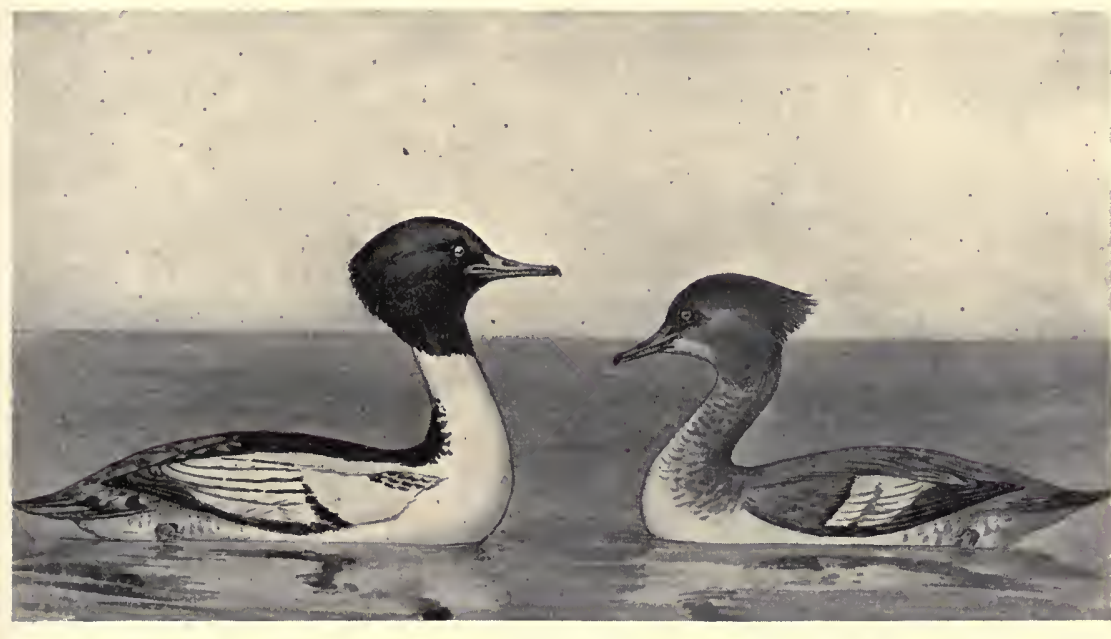

Male.

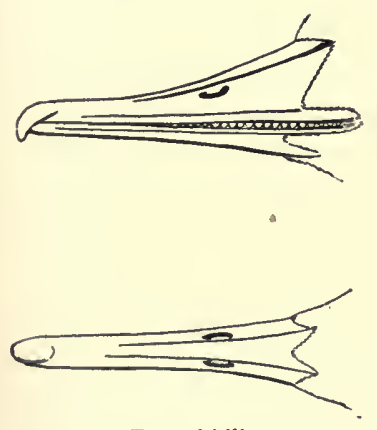

Top of bill.

Mergus americanus.
American Mergancer.

Female.

Distance from nostril to tip of bill, less than I.50; head and neck, greenish black; under parts, creamy white, tinged with salmon color; feet, red (male).

Mergus americanus.

American Merganser. Sheldrake.

See No. 37 .

Distance from nostril to tip of bill, less than I.5o; head, rufous brown; upper throat, white; feet, orange red (female).

Mergus americanus.

American Merganser. Sheldrake.

See No. 37 .

Distance from nostril to tip of bill, more than I.50; head, black, tinged with green; breast, rufous, streaked with black (male).

Mergus serrator.

Red-breasted Merganser.

See No. 38 .

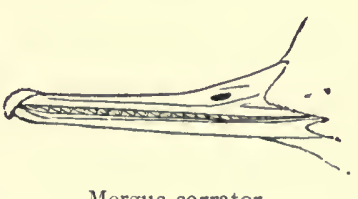

Mergus serrator.

* For directions for measurement, see page $2 \mathrm{r}$. 
58 Field Museum of Natural History-Zoölogy, Vol. iX.

Distance from nostril to tip of bill, more than I.50; head, brownish, palest on the throat; speculum, white (female). Mergus serrator.

Red-breasted Merganser.

See No. 38 .

Subfamily ANATINÆ. River and Pond Ducks.

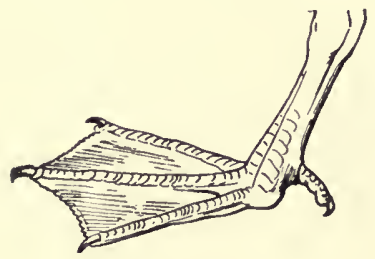

Ducks having hind toe without membraneous lobe or flap; tarsus, scutellate in front.

* GROUP 1. Wing, 5 to 7.50 inches long; hind toe, without flap or lobe.

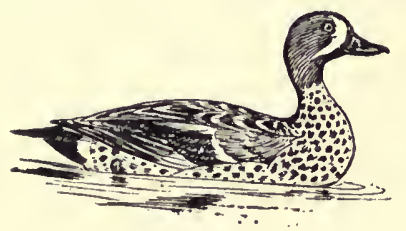

Querquedula discors.

Large patch pale blue on wing (coverts); white crescent on face (male); no white crescent, face speckled; chin whitish (female).

Common in Eastern United States.

Querquedula discors.

Blue-winged Teal.

See No. 46.

Large patch of pale blue on wing (coverts); head and breast, rufous brown; crown, blackish (male); sides of head, speckled (dull white, dotted with black); chin and throat, dusky, tinted with rufous (female). Western species, rare east of the Mississippi River.

Querquedula cyanoptera.

Cinnamon Teal.

See No. 47.

No blue patch on wing; head, rufous brown, with large patch of green through eye to nape; speculum, black and green (male); head, speckled. No blue patch on wing (female). Nettion carolinensis. 
* GROUP 2. Wing, from 8 to ro inches long.

SECTION 1. Belly, white; no flap or lobe on hind toe.
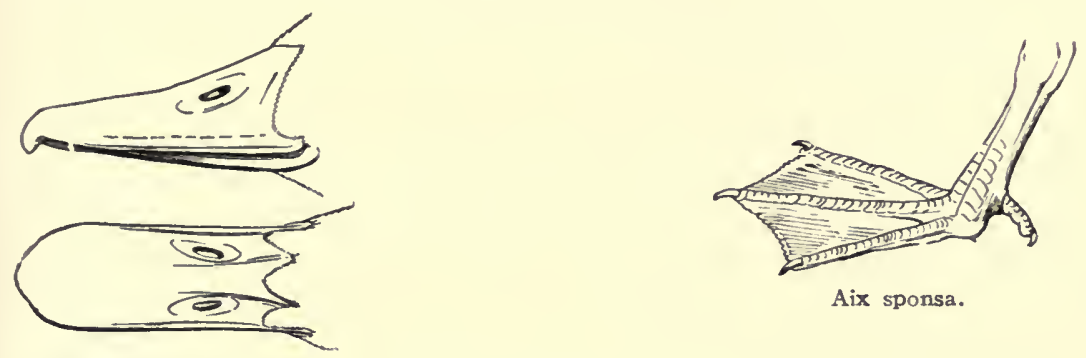

Aix sponsa.

Head, green, purple, black, and white; chin and upper throat, white; feet, yellow in life (male).

Aix sponsa.

Wood Duck. Summer Duck. See No. 50.

Head, grayish brown, with white stripe through the eye; chin and upper throat, white; toes, dull yellow in life (female). Aix sponsa.

Wood Duck. Summer Duck. See No. 50.

Head, brown; chin, not white; a white stripe on sides of the neck; tail, pointed (male).

Dafila acuta. Pintail Duck. See No. 49.

SECTION 2. Belly, not white; hind toe, without membraneous lobe or flap.

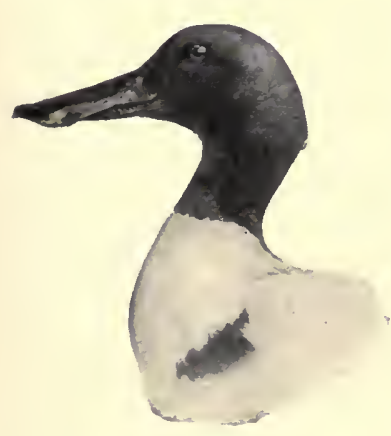

Spatula clypeata.

Bill, more than one inch wide near tip; head, green or greenish; speculum, metallic green; axillars, white; feet, orange red in life (male).

Spatula clypeata.

Shoveller Duck. Broad-bill. See No. 48.

Bill, more than one inch wide near tip; head, narrowly streaked and speckled with brown and dull white; speculum, metallic green; feet, orange red in life; axillars, white (female). Spatula clypeata.

Shoveller Duck. Broad-bill. See No. 48.

\footnotetext{
* For directions for measurement. see page 21 .
} 
60 Field Museum of Natural History-Zoölogy, Vol. IX.

Bill, less than one inch wide near tip; head, lined and speckled with brown and brownish white; speculum, not metallic green; axillars, white, barred with brown; rump and tail coverts, brown, narrowly

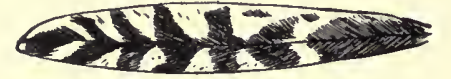

Axillar. Dafila acuta. edged and banded with white; feet, dusky (female).

Dafila acuta. Pintail Duck. See No. 49.

Belly, white, with more or less brown spots; axillars, white; bill, less than .90 wide at widest part (female).

Chaulelasmus streperus.

Gadwall.

See No. 42 .

Belly, more or less spotted; throat, white; rump, olive brown; secondaries, metallic green, tipped with white; axillars and under wing coverts, heavily barred; toes, yellowish in life (female).

Aix sponsa.

Wood Duck. Summer Duck. See No. 50.

* GROUP 3. Wing, from ro to 14 inches long.

SECTION 1. Hind toe, without membraneous lobe or flap; belly, white, sometimes faintly tinged with dusky or gray on lower part.

Axillars, white; the shafts, white; exposed speculum, black and white; head, tawny brown; cheeks and throat, tawny, speckled with brown (male).

Chaulelasmus streperus.

Gadwall. Creek Duck. See No. 42.

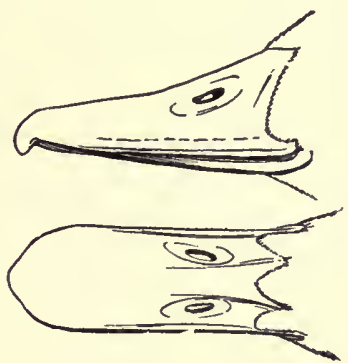

Axillars, white; the shafts, white; head,

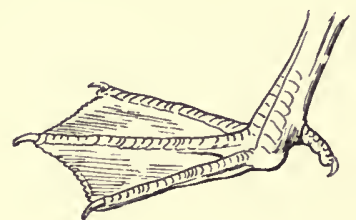
speckled; exposed speculum, black and white (female).

Chaulelasmus streperus. Gadwall. Creek Duck. See No. 42.

* For directions for measurement, see page $2 \mathbf{r}$. 
JAN., I909. BiRds of IllinoIs ANd Wisconsin-Cory.

Axillars, white, with shafts dark near the tips; speculum, green and black; white patch on shoulder; top of head, white, more or less green behind the eye (male).

Mareca americana. American Widgeon. Baldpate. See No. 44 .

Axillars, white, with shafts dark near the tips; no white shoulder patch; head, speckled (female).

Mareca americana.

American Widgeon. Baldpate. See No. 44.

Axillars, thickly speckled and faintly barred with gray; head, speckled (female); head and upper neck, brown; top of head, white or whitish.

Mareca penelope.

European Widgeon.

See No. 43 .

Axillars, grayish white; head, brown, not speckled; stripe of white on sides of neck; tail, pointed; middle feathers, long (male).

Dafila acuta.

Pintail Duck.

See No. 49.

SECTION 2. Hind toe, without membraneous lobe or flap; belly, not white.

Speculum, bluish purple, edged with white; head, green; a white ring around neck; breast, chestnut; belly, grayish white; feet, orange red; axillars, white (male).

Anas platyrhynchos.

Mallard Duck.

See No. 40.

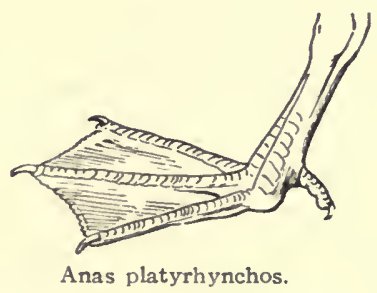

Belly, white, showing more or less brown spots; axillars, white; bill, less than .90 wide at widest part; speculum, black and white (female).

Chaulelasmus streperus.

Gadwall.

See No. 42. 
62 Field Museum of Natural. History-Zoölogy, Vol. iX.

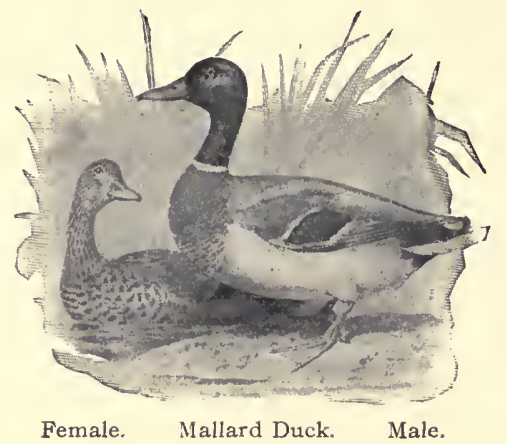

Speculum, bluish purple, edged with white and black; greater wing coverts, with broad band of white; head, tawny brown, streaked with dark brown; belly, pale buff, mottled with brown; feet, orange red; axillars, white (female).

Anas platyrhynchos. Mallard Duck. See No. 40.

Speculum, purplish blue; no white band on greater wing coverts; head and throat, streaked; throat, not buff; no black spot at base of bill; feet, olive (sometimes red); axillars, white; Eastern North America.

Anas rubripes.

Black Duck. Dusky Duck. See No. 4I.

Subfamily FULIGULINÆ. Bay and Sea Ducks.

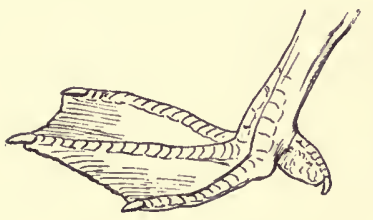

Ducks having flap or membraneous lobe on hind toe; tarsus, scutellate (transverse scales) in front.

* GROUP 1. Wing, from 5 to 6.50 inches long.

SECTION 1. Tail feathers, not stiff and pointed.

Head, greenish purple, with white patch (male); head, grayish brown, with white patch (female or immature); no dark stripes on cheek; bill, less than three-fourths inch wide. Charitonetta albeola.

Buffle-head Duck. Dipper Duck. See No. 58.

SECTION 2. Tail feathers, stiff and pointed.

No greenish or purple on head; throat, whitish; cheeks, white or whitish; bill, broad, three-quarters inch or more wide.

Erismatura jamaicensis. Ruddy Duck. See No. 66.

* For directions for measurement, see page $2 \mathrm{I}$. 
Jan., 1909. Birds of Illinois and Wisconsin-Cory.

Front of head, including cheeks, black (adult); head with black stripes on side (female or immature). Tropical species, accidental in the United States.

Nomonyx dominicus.

Masked Duck.

See No. 67 .

* GROUP 2. Wing, from 6.50 to 7.50 inches long. SECTION 1. Belly, white.

Head, greenish purple, no white on head; back, barred black and white; speculum, white (male).

Marila affinis.

Lesser Scaup Duck. Blue-bill. See No. 54 .

Head, brownish, a patch of dull white at base of bill; no white on ear coverts; speculum, white (female).

Marila affinis.

Lesser Scaup Duck. Blue-bill.

See No. 54 .

Head, greenish purple, no white on head; back, dull black; speculum, gray (male).

Marila collaris. Ring-necked Duck. See No. 55 .

Head, dull brown, brownish white at base of bill and below eye; speculum, gray (female).

Marila collaris.

Ring-necked Duck.

See No. 55 .

Head, greenish purple, a large patch of white on back of head (male).

Charitonetta albeola.

Buffle-headed Duck.

See No. 58 .

Head, dark brown or dusky, a patch of white behind the eye (on ear coverts); no white or brownish white at base of bill; speculum, white (female).

Charitonetta albeola. Buffle-headed Duck.

See No. $5^{8}$.

* For directions for measurement, see page $\mathbf{2 1 .}$ 
64 Field Museum of Natural History-Zoölogy, Vol. IX.

\section{SECTION 2. Belly, not white.}

Plumage, variously marked with white, slate-color, and chestnut (male).

Histrionicus histrionicus.

Harlequin Duck.

See No. 60.

General plumage, dull brown, mottled on the under parts (female).

Histrionicus histrionicus.

Harlequin Duck.

See No. 60.

* GROUP 3. Wing, from 7.50 to 8.50 inches long.

SECTION 1. Head, marked with more or less white or brownish white; belly, white, sometimes tinged with dusky or gray on lower part.

Head, brownish; a patch of dull white on face at base of bill; speculum, white (female). Marila marila.

Scaup Duck. Bluebill. See No. 53 .

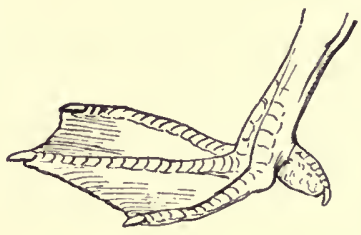

Speculum, white, similar to preceding but somewhat smaller (female). More common in the South than the Greater Scaup Duck.

Marila affinis.

Lesser Scaup Duck.

See No. 54 .

Speculum, gray; head and neck, brownish; chin and anterior portion of lores, brownish white or whitish (female); resembles female Red-head, but is smaller.

Marila collaris.

Ring-necked Duck.

See No. 55 .

A patch of white or grayish white on the head, including the eye; no speculum; under tail coverts, white; adult males have the tail feathers long and pointed.

Harelda hyemalis.

Old-squaw. Long-tailed Duck.

See No. 59.

* For directions for measurement, see page 21 . 
SECTION 2. Belly, white, sometimes tinged on lower part with dusky or gray; no white or grayish white on head.

Head, brown; a distinct wing band of white (female).

Clangula clangula americana.

American Golden-eye. See No. 56.

Head, black, glossed with green; speculum, white; back, grayish white, finely lined with black (male).

Marila marila.

Scaup Duck. Bluebill or Blackhead.

See No. 53 .

Head, black, glossed with purple, finely lined with black; speculum, white; back, grayish white; smaller than the preceding species, but resembles it closely (male).

Marila affinis.

Lesser Scaup Duck. Bluebill or Blackhead.

See No. 54 .

Head, black, with violet or bluish gloss, a spot of white on the chin; speculum, gray; back, dull black (male).

Marila collaris. Ring-necked Duck.

See No. 55 .

SECTION 3. Belly, not white.

Plumage, variously marked with white, slate-color, and chestnut; speculum, bluish; top of head and wing coverts, not white (male).

Histrionicus histrionicus.

Harlequin Duck.

See No. 60.

Top of head and wing coverts, not white; plumage, dull brown, mottled on the under parts (female).

Histrionicus histrionicus. Harlequin Duck.

See No. 60. 
* GROUP 4. Wing, 8.50 to 10 inches long.

SECTION 1. Hind toes, with well defined membraneous lobe or flap; belly, white, sometimes tinged on lower part with dusky or gray;

head, marked with more or less white, or brownish white

Head, brownish; a patch of dull white on face at base of bill; speculum, white (fe. male).

Marila marila.

Scaup Duck. Bluebill. Blackhead. See No. 53 .

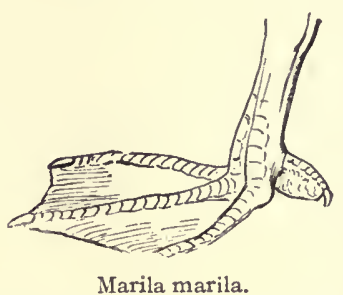

Head and neck, dark glossy green; a nearly round patch of white on check at base of bill; back, black; speculum, white (male). Clangula clangula americana. American Golden-eye. Whistler. See No. 56.

Head, bluish black, or purplish blue; an irregular white patch on cheek at base of bill (male).

Clangula islandica.

Barrow's Golden-eye.

See No. 57 .

Top of head, brown; sides of head, brownish white; speculum, gray; bill, more than one and a quarter inches long (female).

Marila americana.

Redhead Duck.

See No. 5 I.

Bill, not over 1.25 long; a patch of white, or grayish white, on the head, including the eye; no speculum; under tail covert, white; adult males have the tail feathers long and pointed. Harelda hyemalis.

Old-squaw. Long-tailed Duck.

See No. 59.

SECTION 2. Hind toe, with well defined membraneous lobe or flap; belly, white, sometimes tinged on lower part with dusky or gray; no white, or grayish white, on head.

Head, black, glossed with green; back, grayish white, finely lined with black; speculum, white (male).

Marila marila.

Scaup Duck. Bluebill. Blackhead.

See No. 53 .

* For directions for measurement, see page $2 \mathrm{I}$. 
Jan., ig09. Birds of Illinols and Wisconsin-Cory.

Head, cinnamon brown; upper breast and back. ashy gray, not barred; speculum, white (female); very similar to female Barrow's Golden-eye, but slightly smaller. Much more common than the next species.

Clangula clangula americana. American Golden-eye. Whistler. See No. 56.

Head, cinnamon brown; upper breast and back, ashy gray, not barred; speculum, white (female); very similar to preceding species, but slightly larger.

Clangula islandica.

\section{Barrow's Golden-eye.}

See No. 57 .

Head, rufous brown; crown, blackish; breast, black; lower back, ashy white, finely lined with black (male); bill, very different from that of Red-head. (See cut.)

Marila vallisneria.

Canvas-back Duck.

See No. $5^{2}$.

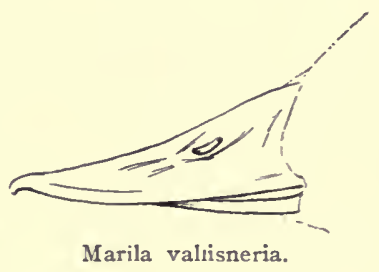

Head, neck, and upper breast, dull cinnamon brown, palest on throat; lower back, dull brown, barred with fine, wavy, white lines (female); easily distinguished by shape of bill. (See cut.)

Marila vallisneria.

Canvas-back Duck.

See No. $5^{2}$.

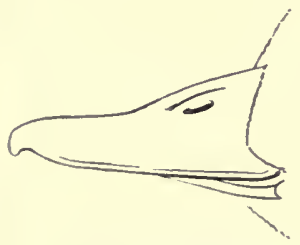

Marila americana.

Head, reddish brown; crown, not blackish; breast, black; lower back, grayish, finely lined with black (male); bill, very different from that of Canvas-back. (See cut.)

Marila americana.

Red-headed Duck.

See No. 5 I.

SECTION 3. Hind toe, with well defined membraneous lobe or flap; belly, not white; more or less white, or grayish white, on head.

General plumage, black; a patch of white on front of crown and nape; bill, large, marked with orange, red, black, and white; no white on wings (male).

Oidemia perspicillata.

Surf Scoter. Skunk-head Coot. See No. 65 .

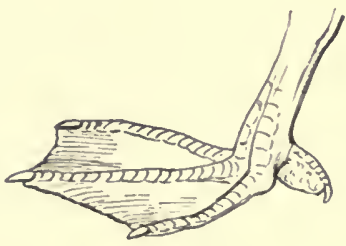


Field Museum of Natural History-Zoölogy, Vol. IX.

General plumage, brown; top of head and wings, dark; a spot of dull white at base of bill and behind eye; no white on wings (female).

Oidemia perspicillata. Surf Scoter. Skunk-head Coot. See No. 65 .

SECTION 4. Hind toe, with well defined membraneous lobe or flap; belly, not white; no white on head.

Axillars, brown; secondaries, white, forming a white wing patch; upper parts dark brown; under parts, sometimes brown, sometimes grayish (female).

Oidemia deglandi.

White-winged Scoter. White-winged coot.

See No. 64.

* GROUP 5. Wing, Io to I 4 inches long.

SECTION 1. Hind toe, with well defined membraneous lobe or flap; head, with more or less white, or grayish white; belly, black.

General plumage, black; speculum, white; spot under eye, white; axillars, black; bill, orange at base (male).

Oidemia deglandi. White-winged Scoter. White-winged Coot. See No. 64 .

General plumage, black; head, black, with patch of white on crown and nape; no white on wing; axillars, black; bill, orange, black, and white (male).

Oidemia perspicillata. Surf Scoter. Skunk-head Coot. See No. 65 .

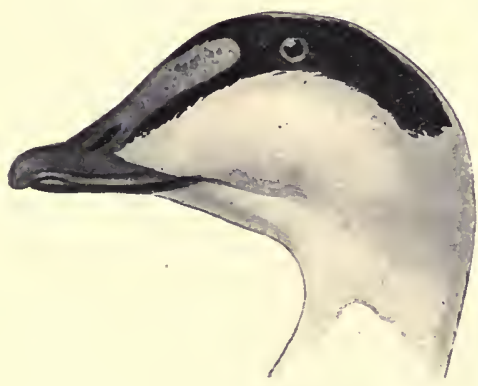

American Eider Duck. Somateria dresseri.

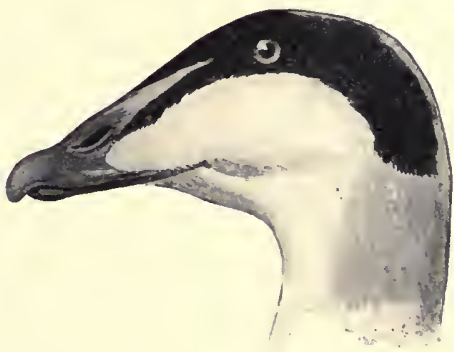

Northern Eider Duck. Somateria mollissima borealis.

* For directions for measurement, see page 21 . 
Top of head, black, divided on crown; more or less green on head; throat, white; axillars, white; bill (culmen), divided and rounded at base (male). (See cut of bill.)

Somateria dresseri. American Eider Duck. See No. 6r.

Top of head, black, divided on crown; more or less green on head; throat, white; axillars, white; culmen, divided and pointed at base (male). (See cut of bill.) Arctic species; not recorded from Lake Michigan region.

Somateria mollissima borealis.

Northern Eider Duck.

Top of head, slate color; cheeks, greenish; throat, white, with large, black, V-shaped mark (male).

Somateria spectabilis.

King Eider Duck.

See No. 62.

SECTION 2. Hind toe, with well defined membraneous lobe or flap; no white on head; belly, black.

General plumage, black; axillars, black; no white on wing; bill, orange at base; feathers
on bill, more than one-half inch from nostril
(male).
American Scoter. Black Coot. Butter-bill
Coot.

SECTION 3. Hind toe, with well defined membraneous lobe or flap; head, marked with more or less white, or grayish white; belly, mottled brown, or grayish brown, or slaty.

General plumage, brownish; no white on wing; feathers on bill, more than one-half inch from nostril (female and immature).

Oidemia americana.

American Scoter. Butter-bill Coot.

See No. 63 .

General plumage, grayish brown; speculum, white; feathers on bill, less than one-half inch from nostril (female and immature).

Oidemia deglandi.

White-winged Scoter. White-winged Coot.

See No. 64. 
70 Field Museum of Natural History-Zoölogy, Vol. IX.

General plumage, grayish brown; feathers extending on upper part of bill more than on the sides; no white on wing; feathers on bill, less than one-half inch from nostril (female).

Oidemia perspicillata.

Surf Scoter. Skunk-head Coot.

See No. 65 .

SECTION 4. Hind toe, with well defined membraneous lobe or flap; no white on head; belly, mottled brown, or grayish brown.

General plumage, brownish; no white on wings; axillars, black; feathers on the bill, more than one-half inch from nostril (female).

Oidemia americana.

American Scoter. Butter-bill Coot. Gray Coot.

See No. 63 .

Head, dark brown or black; feathers on bill, less than one-half inch from nostril; axillars, black; no white on wings (immature male).

Oidemia perspicillata.

Surf Scoter. Skunk-head Coot. See No. 65.

A patch of white on the wings; back and upper parts, dark brown; feathers on the base of bill, extending to within one-half inch of nostril (female).

Oidemia deglandi. White-winged Scoter. See No. 64 .

Head, tawny, streaked with brown; axillars, white, or grayish white; throat, streaked; feathers on bill, within one-fourth inch from nostril; decided difference in bill from next species (female). (See cut.) Eastern North America.

Somateria dresseri. American Eider Duck.

See No. 6r.

Head, tawny, streaked with brown; axillars, white, or grayish white; throat, streaked; feathers on bill, within one-fourth inch from nostril; decided difference in bill from preceding species (female). (See cut.) Eastern North America. This is given for comparison; the species has not yet been recorded from the Lake Michigan region.

Somateria mollissima borealis. Northern Eider Duck. 
Head, tawny, streaked with brown; axillars, white, or grayish white; throat, not streaked; feathers on bill, more than one-fourth inch from nostril (female).

Somateria spectabilis. King Eider Duck.

See No. 62 .

\section{Subfamily ANSERINÆ. Geese.}

Special Characters: Size, large; lores, feathered; tarsus, reticulate (scales rounded); hind toe, without flap.

* GROUP 1. Wing, 12 to 14 inches long.

Bill and feet black; head and neck, black; sides of neck (not front, mottled with white; no speculum; lower breast, grayish; no white on head.

Branta bernicla glaucogastra.

Brant.

See No. 72.

A patch of white on side of head, extending to throat; rest of head and neck, black.

Branta canadensis minima.

Cackling Goose.

See No. $7 \mathrm{Ib}$.

* GROUP 2. Wing, from I 4 to 22 inches long.

SECTION 1. Head and neck, black or blackish, marked with more or less white; bill and feet, black.

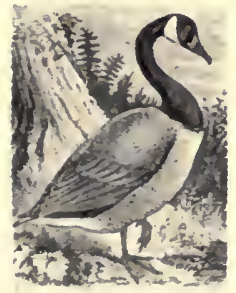

Head and neck, black; a patch of white on each cheek, extending to upper throat; no white on neck. Branta canadensis, and races.

Canada Goose.

See Nos. 7 r, 7 Ia, 7 Ib.

Head and neck, black; side (not front) of neck, speckled with white; upper belly, whitish. Common on Atlantic coast.

Branta bernicla glaucogastra.

Brant.

See No. 72 .

* Por directions for measurement. see page 21 . 
72 Field Museum of Natural. History-Zoölogy, Vol. IX.

SECTION 2. Bill and feet, pink or flesh color in life; head, white, sometimes tinged with brownish orange.

Entire plumage, white; primaries, black; smaller than $C . h$. nivalis; bill, over I.90; tarsus, over 2.80; middle toe, over 2.ro (adult). Chiefly Pacific coast to Mississippi Valley, rare on Atlantic coast.

Chen hyperborea.

Lesser Snow Goose.

See No. 68.

Entire plumage, white; primaries, black; resembles preceding species but is larger (adult). Eastern North America, south in winter on Atlantic coast to Florida and Cuba.

Chen hyperborea nivalis. Greater Snow Goose. See No. 68a.

Back, slaty brown; belly and rump, gray; the feathers, not barred; terminal half of tail, not white (adult).

Chen ccerulescens.

Blue Goose.

See No. 69.

SECTION 3. Bill, pinkish; feet, yellow or pink; head, brownish or grayish, sometimes marked with white.

Forehead and feathers at base of bill, white; nail of bill (unguis), whitish; bill, yellowish in dried skin; breast, grayish, more or less marked or spotted with black (adult).

Anser albifrons gambeli.

American White-fronted Goose.

See No. 70.

No white on forehead or base of bill; bill, yellowish in dried skin; nail of bill (unguis), dusky; rump, slaty brown; wing coverts, edged with white (immature).

Anser albifrons gambeli.

American White-fronted Goose.

See No. 70.

General plumage, grayish; rump, white; smaller than $C . h$. nivalis; bill, over I.90; tarsus, over 2.80; middle toe, over 2.Io (immature). Chiefly Pacific coast to Mississippi Valley; rare on Atlantic coast.

Chen hyperborea.

Lesser Snow Goose.

See No. 68 . 
General plumage, grayish; rump, white; larger than C. hyperborea (immature). Eastern North America, south in winter to Florida and Cuba.

Chen hyperborea nivalis. Greater Snow Goose. See No. 68a.

Head, brownish gray; chin, white; rump, gray; unguis (nail of bill), yellow; wing coverts, grayish, showing very little white on the edge of the feathers (immature).

Chen carulescens. Blue Goose. See No. 69 .

\section{Subfamily CYGNINÆ. Swans.}

Size, very large; bare skin, between the bill and eye; tarsus, reticulate (scales rounded); neck, very long; wing, over 19 inches long; hind toe, without flap.

General plumage, white; bill, black, with yellow spot (adult); distance from tip of bill to nostril, less than distance from nostril to eye (immature birds are gray or brownish gray). Olor columbianus.

Whistling Swan. See No. 73 .

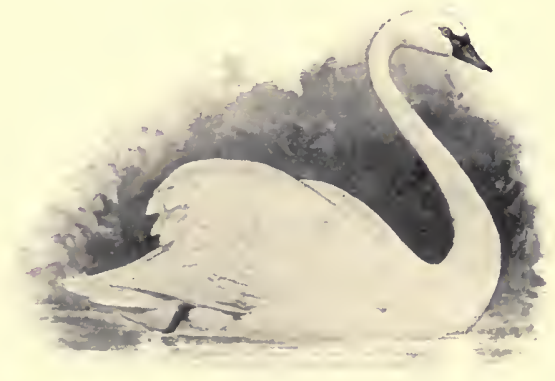

Whistling Swan.

General plumage, white; bill, black, showing no yellow; distance from tip of bill to nostril, more than distance from nostril to eye. Chiefly found in the interior of North America; (immature birds are gray or brownish gray).

Olor buccinator. Trumpeter Swan. See No. 74 . 
74 Field Museum of Natural History-Zoölogx, Vol. IX.

General plumage, gray, or brownish gray; distance from tip of bill to nostril, less than distance from nostril to eye (immature).

Olor columbianus.

Whistling Swan.

See No. 73 .

General plumage, gray or brownish gray; distance from tip of bill to nostril, more than distance from nostril to eye (immature).

Olor buccinator. Trumpeter Swan. See No. 74. 


\section{ORDER HERODIONES.}

HERONS, IBISES, SPOONBILLS, ETC.

Suborder IBIDES.

IBISES AND SPOONBILLS.

Family PLATALEIDÆ. Spoonbills.

Bill, wide, flat, and rounded at the end; toes, four, all on same level.

Wing, I 3 to 17 inches long.

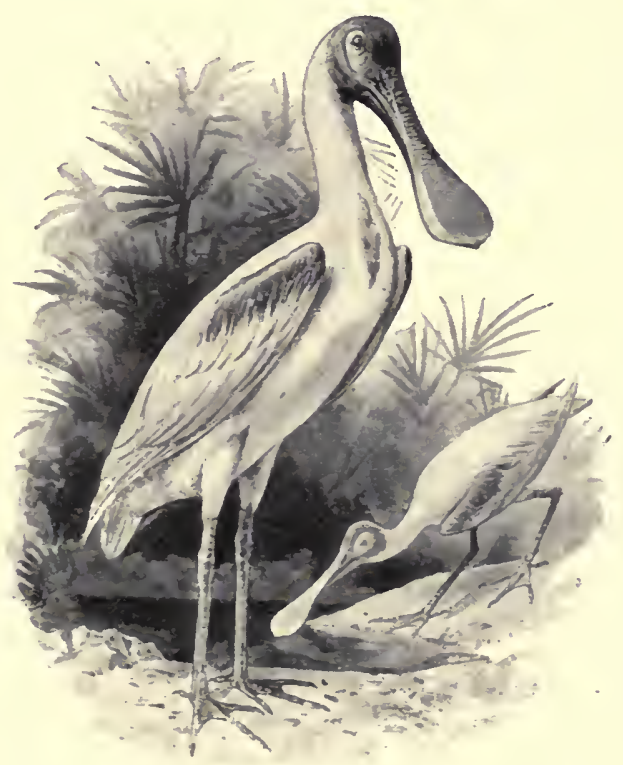

Bill, flat, widened and rounded at end; general plumage, pink and white in the adult. 


\section{Family IBIDIDÆ. Ibises.}

Bill, long, rather slender, and decidedly curved downward; tarsus, always less than five inches long; toes, four, all on the same level, no comb-like edge on side of middle toe nail; wing, from 8.50 to 13 inches long.

Wing, less than 10.50 inches long. white.

General plumage, dark chestnut; feathers, at base of bill, not

Plegadis autumnalis. Glossy Ibis.

See No. 77 .

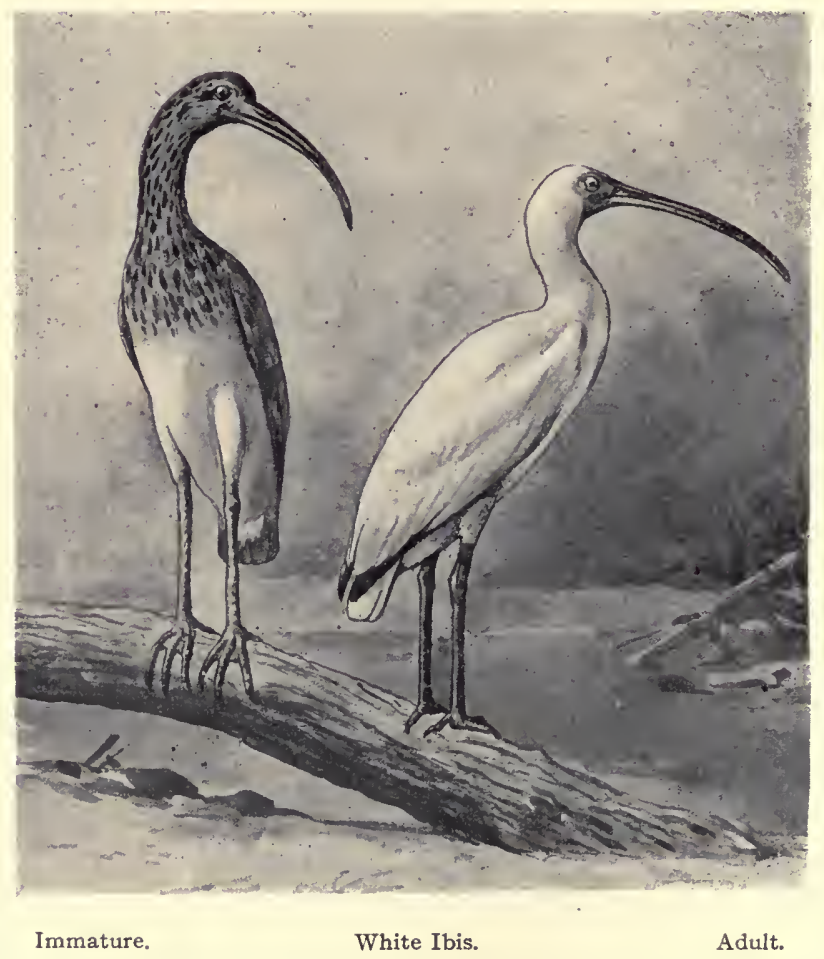

General plumage, white; primaries, blackish (adult). Guara alba. White Ibis.

See No. 76.

General plumage, brownish or grayish, often more or less mixed brown, gray, and white; rump, white (immature). Guara alba. 
Suborder CICONIÆ.

STORKS, ETC.

Family CICONIIDÆ. Storks and Wood lbises.

Subfamily MYCTERIINÆ. Wood Ibises.

Greater part of plumage, white; bill, rounded and somewhat curved, very thick and strong; tarsus, always over 5 inches long; toes, four, all on same level; no comb-like edge on inner side of middle toe nail; front toes, with small webs at base; wing, 17 to 19 inches long.

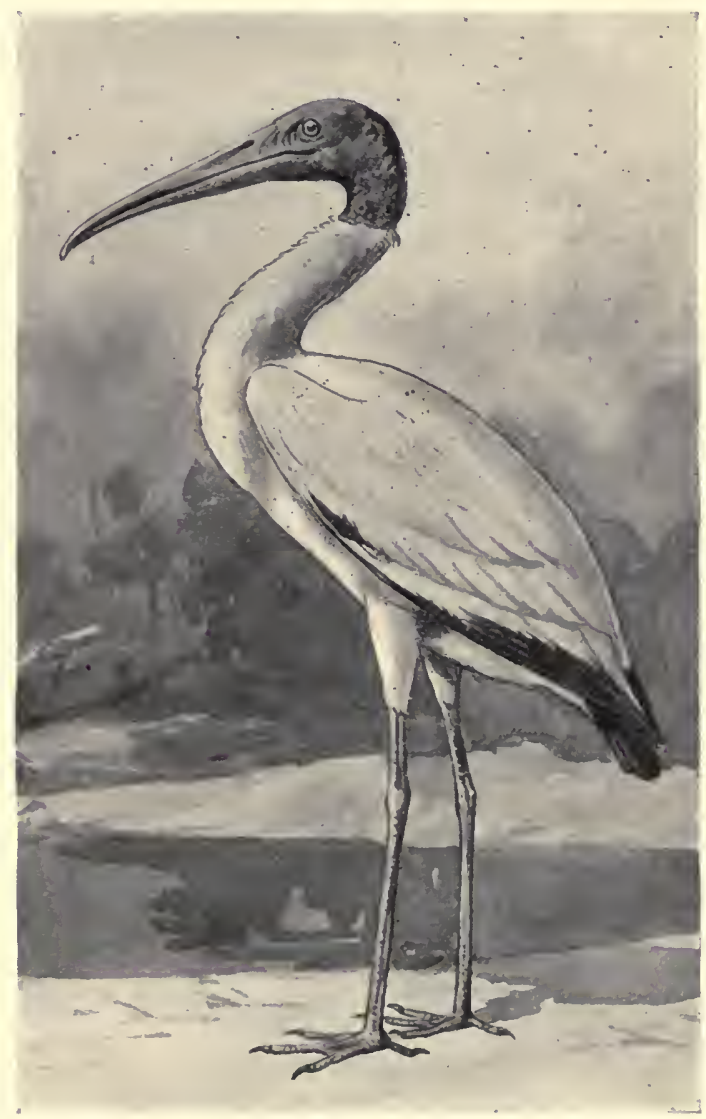

Wood Ibis. 
78 Field Museum of Natural History-Zoölogy, Vol. IX.

General plumage, white; the wings and tail, more or less black; head and upper neck, bare in adult, feathered in immature birds.

Mycteria americana.

Wood Ibis.

See No. 78.

\section{Suborder HERODII.} HERONS, EGRETS, BITTERNS, ETC.

\section{Family ARDEIDÆ. Herons and Bitterns.}

Special Characters: In the true Herons there are three pairs of thick tracts of concealed feathers known as powder down tracts, one on the lower back, one on the belly, and one on the breast. The Bitterns lack the down patch on the breast, having only two. Bill, straight, stout, and sharp pointed, having a groove on the side of the upper mandible; lores, with bare space variable in size; tail, short, usually 12 feathers in the Herons and 10 in the Bitterns; hind toe, on level with the front ones; inner side of middle toe nail, with distinct comb-like edge.

Tail feathers, Io; two pairs of powder down tracts (concealed feathers I.

Subfamily Botaurince. Bitterns.

Tail feathers (usually), I 2 ; three pairs of powder down tracts. Subfamily Ardeince. Herons.

* GROUP 1. Wing, less than 6 inches long.

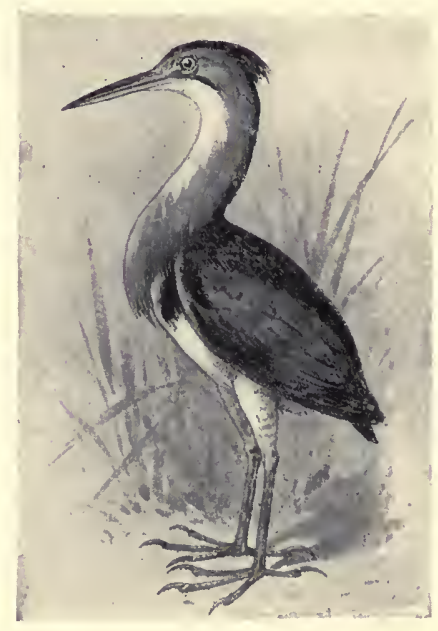

Least Bittern. 
Jan., ig09. Birds of Illinois and Wisconsin-Cory.

Under parts and sides of the head and throat, buff white; a black patch on sides of the breast.

Ixobrychus exilis.

Least Bittern. See No. 80.

Under parts and sides of the head and throat, rufous chestnut; under tail coverts, dull black.

Ixobrychus neoxenus.

Cory's Least Bittern.

See No. 8I.

* GROUP 2. Wing, 6 to 7.50 inches long.

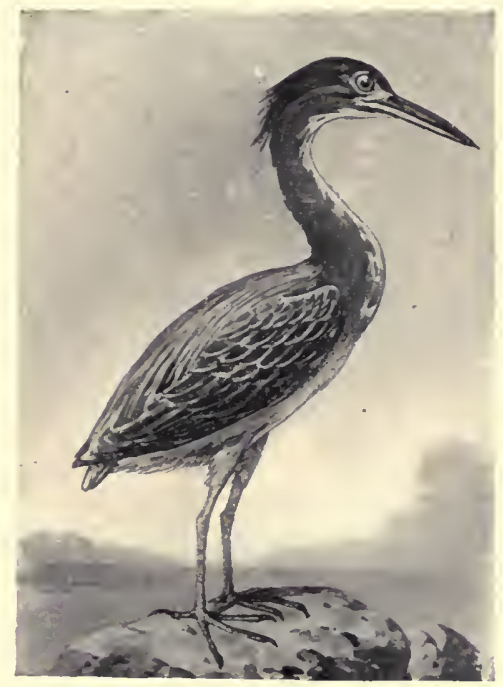

Green Heron.

Crown, greenish or greenish black; legs, orange yellow in life.

Butorides virescens.

Green Heron.

See No. 87 .

* GROUP 3. Wing, 8.50 to I I inches long.

Greater part of plumage, slaty blue; belly, slaty blue; head, tinged with purplish brown (adult).

Florida carulea.

Little Blue Heron.

See No. 86.

* For directions for measurement, see page 21 . 
80 Field Museum of Natural History--Zoölogy, Vol. iX.

General plumage, white; tips of primaries, tinged with slaty blue; legs, yellowish olive (immature).

Florida carulea.

Little Blue Heron.

See No. 86.

General plumage, white; ends of primaries, not tinged with slaty blue; legs, black; feet, yellow.

Egretta candidissima.

Snowy Heron. Snowy Egret. See No. 84 .

General plumage, tawny brown, mottled and streaked with dark brown; upper surface of primaries, blackish.

Botaurus lentiginosus.

American Bittern.

See No. 79 .

Bill, large; top of head, black; back, green (adult); culmen, about as long as tarsus.

Nycticorax nycticorax nevius.

Black-crowned Night Heron.

See No. 88.

Bill, large; top of head, white or whitish; back, not green (adult); culmen, much shorter than tarsus.

Nyctanassa violacea.

Yellow-crowned Night Heron.

See No. 89 .

Bill, large; general plumage, mottled, and streaked brown and white; outer edge of primaries, reddish brown (immature); culmen, about as long as tarsus.

Nycticorax nycticorax nevius.

Black-crowned Night Heron.

See No. 88.

Bill, large; general plumage, mottled and streaked brown and white; primaries, slaty brown (immature); culmen, much shorter than tarsus.

Nyctanassa violacea. Yellow-crowned Night Heron. See No. 89 . 
Jan., 1909. Birds of Illinois and Wisconsin-Cory.
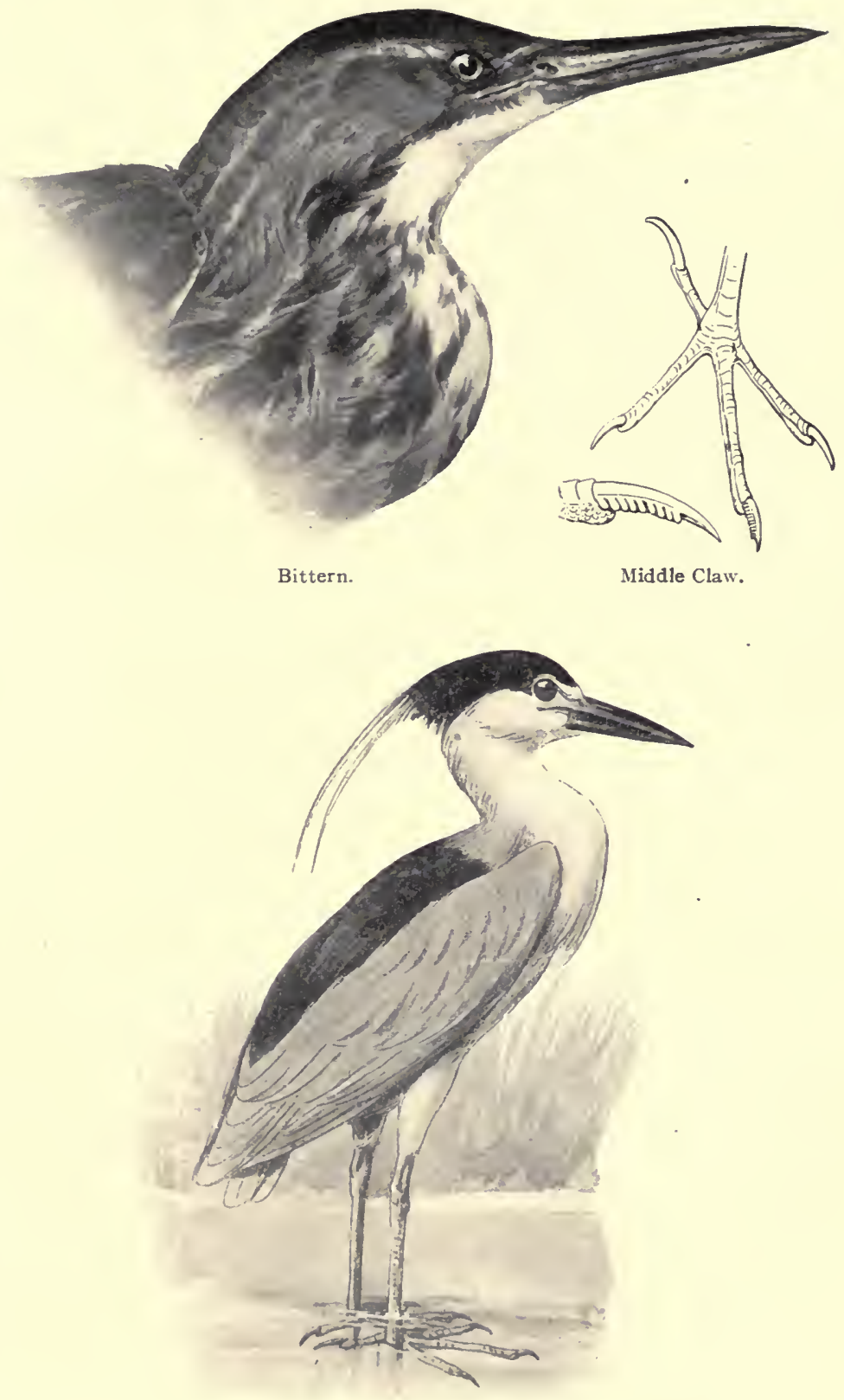

Black-crowned Night Heron. 
82 Field Museum of Natural History-Zoölogy, Vol. IX.

* GROUP 4. Wing, I I to I 5 inches long.

Bill, stout; top of the head, black; back, dark green; culmen, about as long as tarsus (adult).

Nycticorax nycticorax nevius. Black-crowned Night Heron. See No. 88.

Bill, stout; top of head, white or whitish; back, not green; culmen, much shorter than tarsus (adult).

Nyctanassa violacea. Yellow-crowned Night Heron. See No. 89 .

Bill, stout; general plumage, mottled and streaked brown and white; outer edge of primaries, reddish brown; culmen, about as long as tarsus (immature).

Nycticorax nycticorax nevius. Black-crowned Night Heron.

See No. 88.

Bill, stout; general plumage, mottled and streaked grayish brown and white; primaries, slaty brown ; culmen, much shorter than tarsus (immature).

Nyctanassa violacea. Yellow-crowned Night Heron.

See No. 89 .

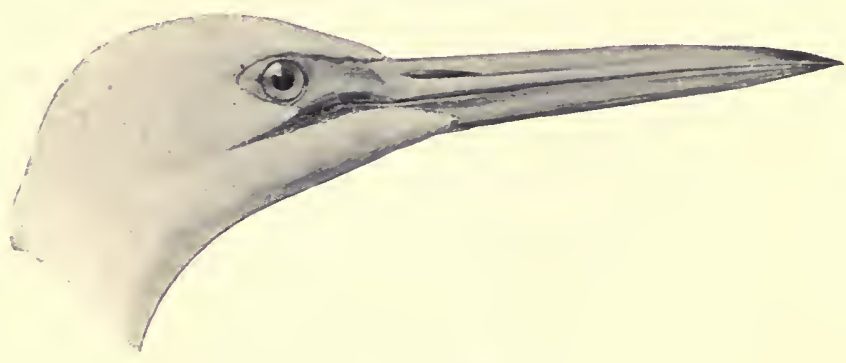

American Egret.

General plumage, white; bill, yellow; legs, black.

Herodias egretta. American Egret. See No. 83 .

* For directions for measurement, see page $2 \mathbf{1}$. 
Jan., 1909. Birds of Illinois and Wisconsin-Cory.

General plumage, white; legs, dark olive; terminal half of bill, black; basal half, flesh color (white phase).

Dichromanassa rufescens.

Reddish Egret.

See No. 85 .

Head and neck, rufous chestnut; rest of plumage, slate color, or slaty gray.

Dichromanassa rufescens.

Reddish Egret.

See No. 85 .

General plumage, yellow brown, mottled and streaked with dark brown; upper surface of primaries, blackish.

Botaurus lentiginosus.

American Bittern.

See No. 79.

* GROUP 5. Wing, over I 5 inches long.

Plumage, entirely white; wing, less than I 7 inches long; bill, under $5.5^{\circ}$; tarsus, under 7.25 .

Herodias egretta. American Egret. See No. 83 .

Greater part of upper plumage, bluish gray or slaty gray; adults in breeding have middle of crown and throat, white; bill, less than 6.25; immature birds have the top of the head, black.

Ardea herodias. Great Blue Heron. See No. 82 .

\footnotetext{
* For directions for measurement, see page 21 .
} 


\section{ORDER PALUDICOLAE.}

CRANES, RAILS, LIMPKINS.

Suborder GRUES. CRANES.

Family GRUID床. Granes.

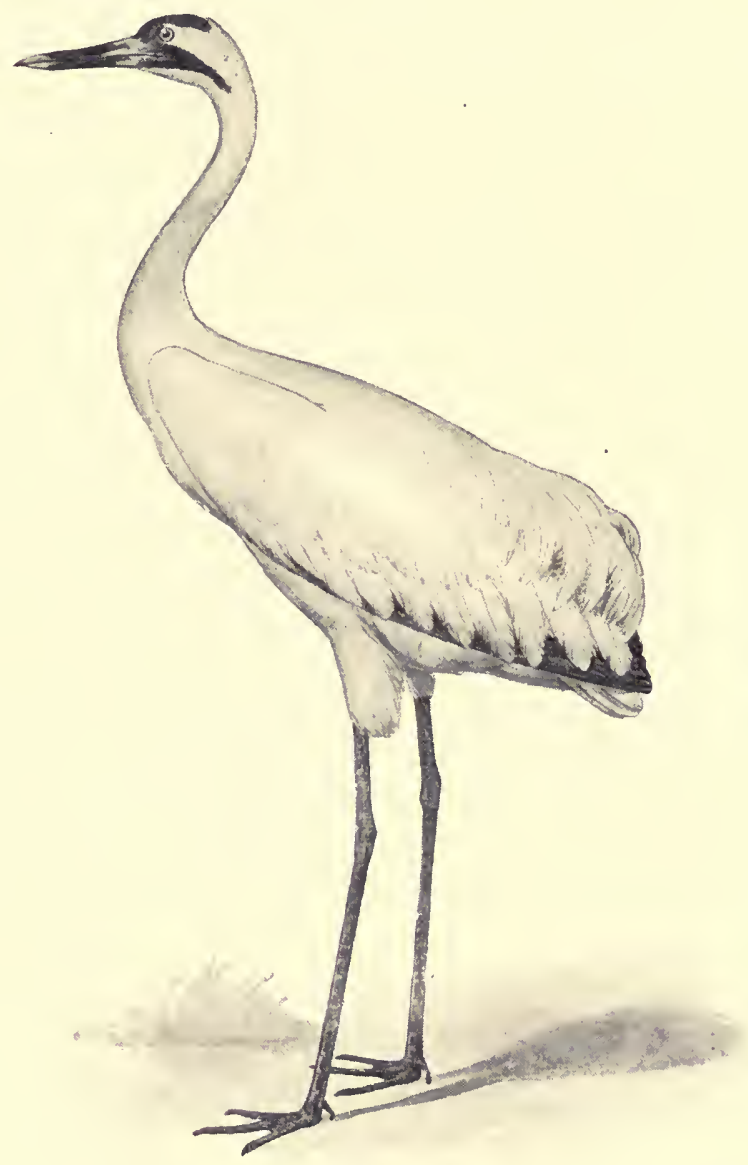

Whooping Crane.

Special Characters: Size, large; lores, with hair-like bristles; bill, over 3 inches long; wing, over 16 inches; tarsus, over 7 inches; toes, 
four, no comb-like edge on inner side of middle toe nail; hind toe, elevated above level of front toes; tarsus, broadly scutellate (transverse scales) in front.

Adult: General plumage, white; wing, over 22 inches long; bill, 5.20 to 6 ; tarsus, II inches or over. Immature birds are whitish; often washed with pale rusty; head, entirely feathered.

Grus americana. Whooping Crane. See No. 90.

General plumage, slaty gray; bare skin on head of adult, red (in life); immature birds are brownish; distinguished from the next by its size. Wing over 20 (2I to 22.50 ); bill, 5 to 6 ; tarsus, ro to 10.75 inches.

Grus mexicana. Sandhill Crane. See No. 92.

General plumage, slaty gray; resembles $G$. mexicana but smaller; wing, less than 20 inches ( 17 to 19.75 ); tarsus, always less than 9.00 (6.60 to 8.75); bill, 3 to 4.50 inches. Northwestern species; accidental straggler in Wisconsin.

Grus canadensis. Little Brown Crane. See No. 9 I.

\section{Suborder RALLI.}

LIMPKINS, RAILS, GALLINULES, COOTS, ETC.

\section{Family ARAMIDÆ. Courlans, Limpkins.}

Bill, over 3 inches long; tarsus, under 7 ; wing, under 16 ; toes, four, no comb-like edge on inner side of middle toe nail; hind toe, raised above level of front toes.

General plumage, dark olive brown, streaked and marked with pure white; tail, purplish brown, showing metallic gloss when held in the light; feathers of the back, breast, and wing coverts, brown, with stripe in middle of each feather; tip of lower mandible slightly 
86 Field Museum of Natural History-Zoölogy, Vol. IX.

twisted. Occurs in Atlantic States only in Florida; accidental in Illinois.

Aramus vociferus.

Limpkin.

See No. 93 .

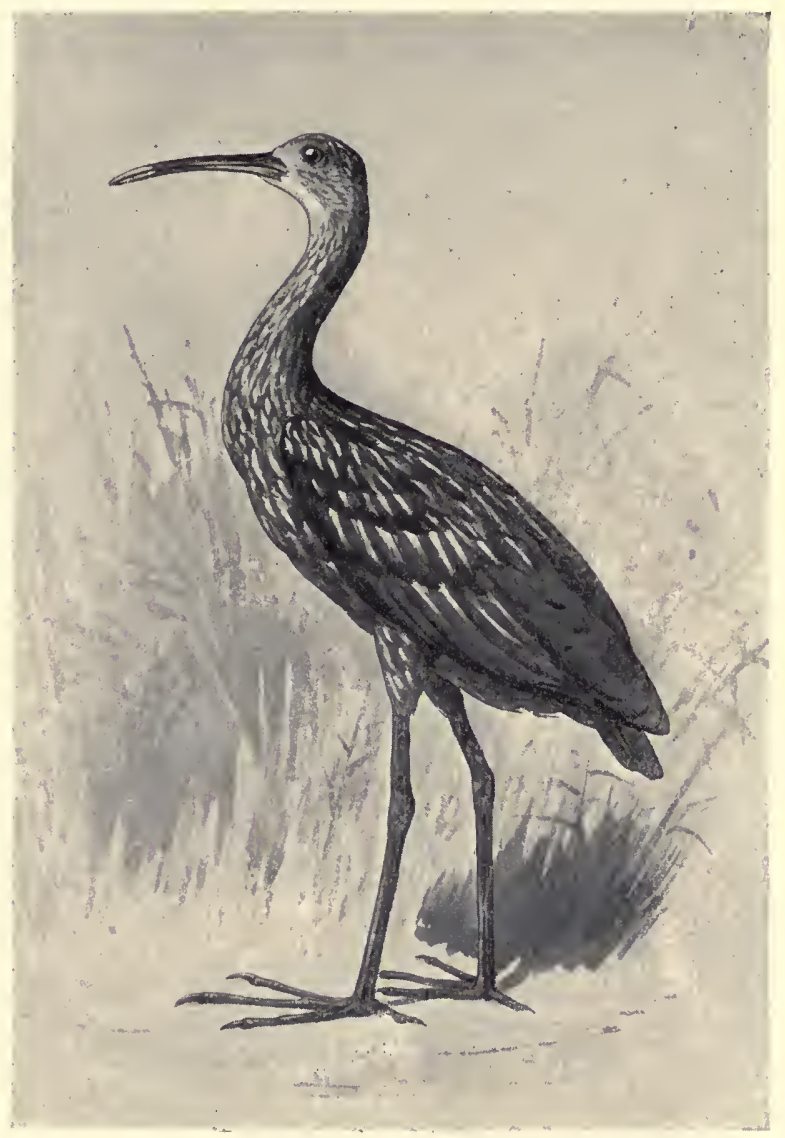

Limpkin.

Family RALLIDÆ. Rails, Gallinules, and Coots.

In North America the Rallidæ are subdivided into three wellmarked groups, which may be characterized as follows:

Key to subfamilies and genera.

I. No frontal shield; toes, long; tail, short; wings, short and rounded.

Subfamily RALLINE. Rails. 
Jan., I909. Bikds of Illinois and Wisconsin--Coky.

A. Bill, slender, longer than head.

RALLUS.

B. Bill, comparatively stout, shorter than head.

PORZANA.

2. A horny frontal plate or shield; toes, without large lobate webs. Subfamily GALLINULINAE. Gallinules.

A. Toes, without narrow lateral margin. IONORNIS.

B. Toes, with narrow lateral margin.

GALLINULA.

3. A horny frontal shield; toes, with large lobate webs.

Subfamily FULICINA. Coots.

A. General plumage, slate color; pale on under parts.

FULICA.

Subfamily RALLINÆ. Rails.

Birds which frequent marshy places. Toes, long; wings, short and rounded; bill, shorter than middle toe and claw together.

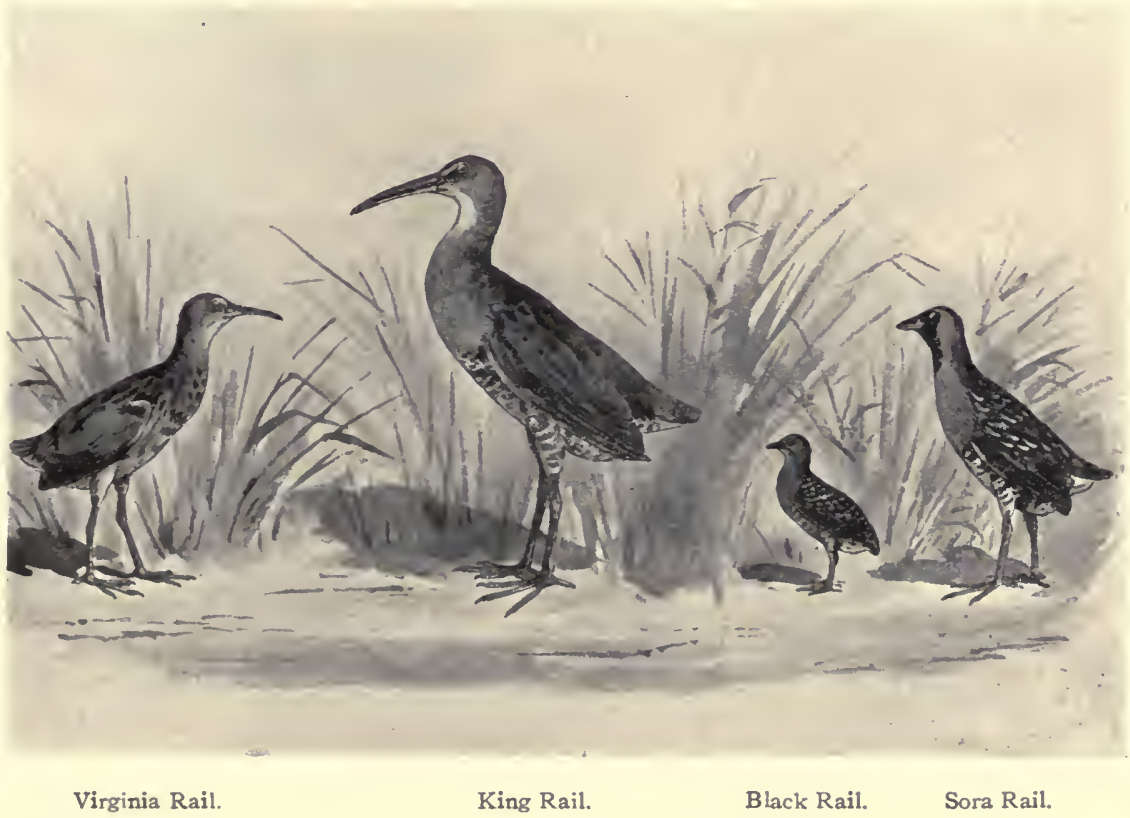


88 Field Museum of Natural History-Zoölogy, Vol. IX.

GROUP 1. Wing, less than 3.75 inches long.

Throat, breast, and sides of head, slaty gray; primaries, with more or less white spots. Frequents marshes. Creciscus jamaicensis.

Black Rail. See No. 98 .

Throat, breast, and sides of the head, tawny brown, no white spots on primaries.

Coturnicops noveboracensis.

Yellow Rail. See No. 97.

* GROUP 2. Wing, from 3.75 to 4.75 inches long.

Back, black or fuscous, the feathers edged with brownish or grayish olive; under parts, cinnamon rufous, whitish on the throat; bill, slightly curved.

Rallus virginianus.

Virginia Rail. See No. 95 .

Back, with more or less white streaks; breast, gray or tawny, according to age; lower belly, dull white.

Porzana carolina.

Carolina Rail or Sora.

See No. 96.

* GROUP 3. Wing, over 4.75 inches long.

Breast tinged with rufous; feathers on back, dark olive, edged with gray; cheeks and ear coverts, pale cinnamon rufous, sometimes blackish in young birds; bill, over I.25 inches long. Found in fresh water marshes.

Rallus elegans.

King Rail.

See No. 94.

* For directions for measurement, see page 21 . 


\section{Subfamily FULICIN Æ. Coots.}
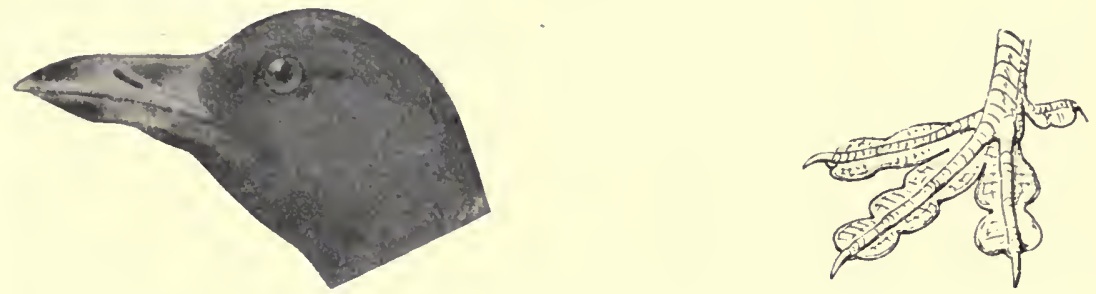

Bill, short and pointed; forehead, with more or less of a shield; toes, with large lobate webs; head, blackish; back, dark slaty gray; under parts, dark ash gray, whitish on abdomen.

Fulica americana.

American Coot. Mud Hen. Blue Peter.

See No. Ior.

Subfamily GALLINULINÆ. Gallinules.
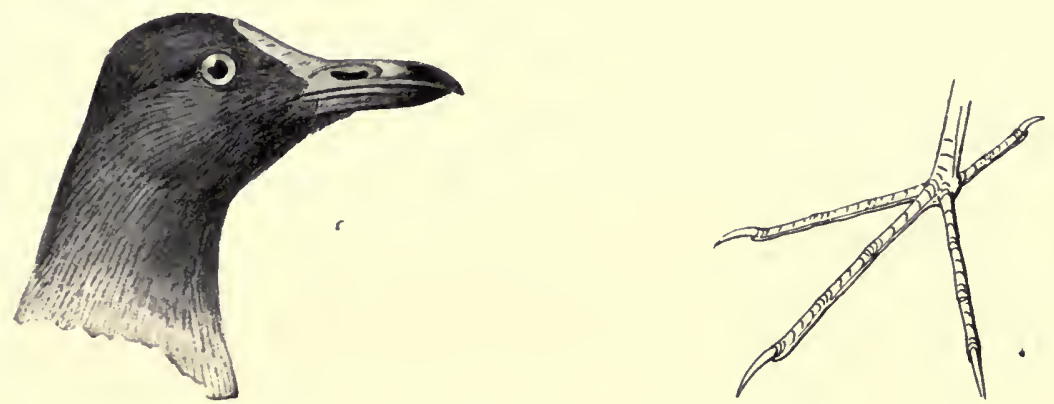

Toes, not webbed; no white on sides of body; head and breast, purplish blue; back, greenish.

Ionornis martinica.

Purple Gallinule.

See No. 99. 
90 Field Museum of Natural History-Zoölogy, Vol. IX.

Head, smoky black; breast, dark gray; toes not webbed; more or less white on sides of body.

Gallinula galeata. Florida Gallinule.

See No. roo.
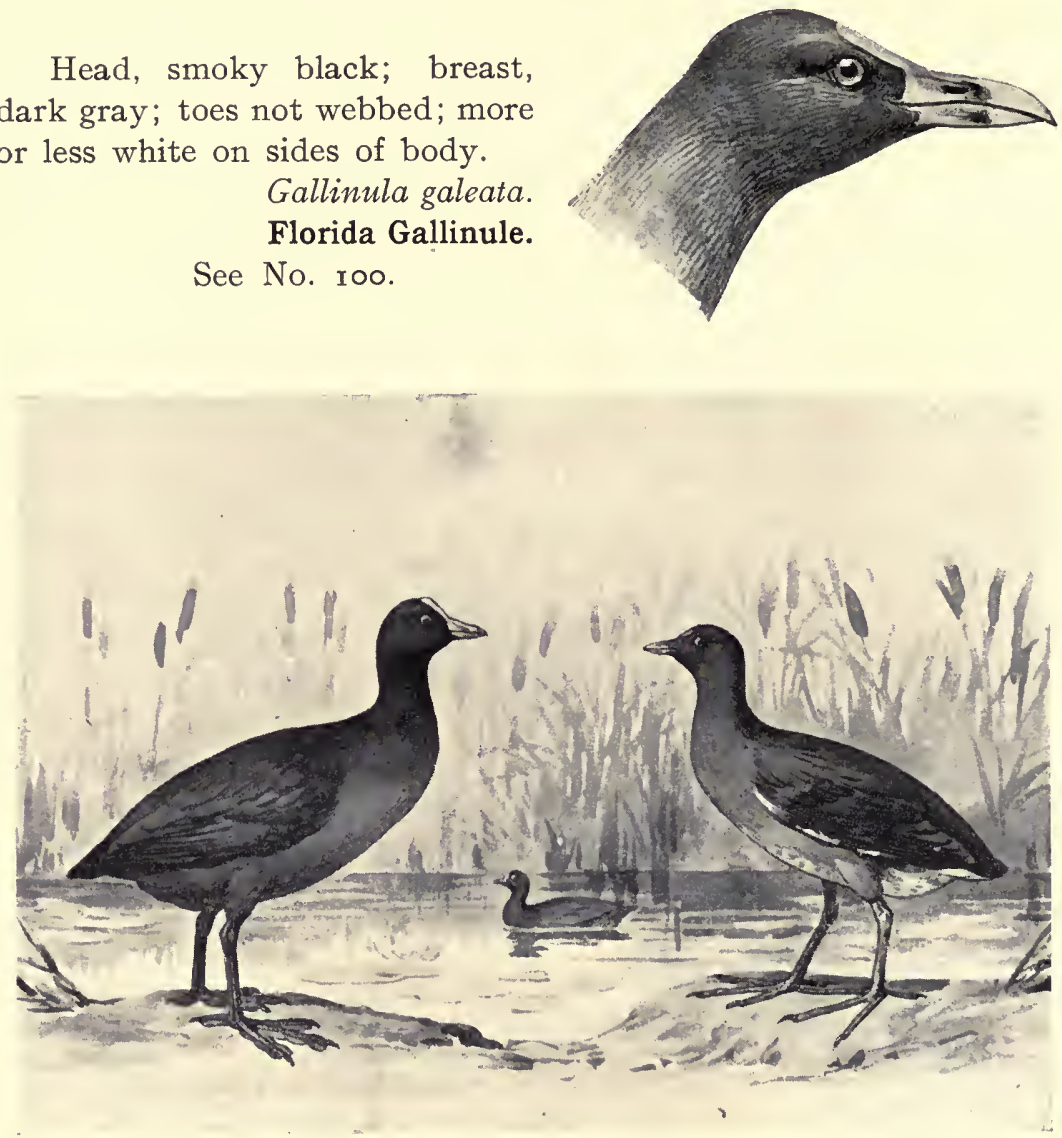

Coot.

Gallinule. 


\section{INDEX TO KEY. \\ ORDER LIMICOOLE.}

SHORE BIRDS.

Hind toe, when present, always elevated above level of front toes.

\section{Family PHALAROPODIDÆ. Phalaropes.}

Sides of toes with rounded lobes or narrow webs. See page 93.

\section{Family RECURVIROSTRIDÆ. Avocets and Stilts.}

Toes, more or less webbed (not lobate); tarsus, over $3.5^{\circ}$; bill curved upward or straight. See page 95 .

\section{Family SCOLOPACIDÆ.}

SNIPE, SANDPIPERS, CURLEWS, WOODCOCK, GODWITS, WILLETS, ETC.

Tarsus, less than 3.50 inches long; sides of toes, without lobate webs; toes, four (one exception, the Sanderling); front of tarsus, with transverse scales.

Group I. Birds having wings from 3.25 to 3.75 inches long

Group 2. Birds having wings from 3.75 to 4.50 inches long

Section r. Toes, four, with small web (not lobate at base).

Section 2. Toes, four, without web .

Section 3. Toes, three; bill, over . 75

Group 3. Birds having wings from 4.50 to $5 \cdot 50$ inches long

Section 1. Toes, four, a small web between toes; bill, less than .75

Section 2. Toes, four, a small web between outer and middle toes; bill, over 1.75

Section 3. Toes, four, without web; bill, over 2 inches long

Section 4. Toes, four, without web; bill, over I. ro and less than I. 90

Section 5. Toes, four, without web; bill, under r. ro .

Section 6. Toes, three; bill, over .60 inch long

See page 96 .

“" $" 97$.

“ “ $“ 97$.

“ “ 98.

“ “ 98 .

“ " $" 99$.

“ “ 99 .

“" 100 .

" " 100.

" "IOI.

“" $" 102$.

“ “ 103 . 
Group 4. Birds having wings from 5.50 to 6.75 inches long . See page ro3.

Section I. Toes, four, a small web between outer and middle toes; bill over 1.80 . . . . .

Section 2. Toes, four, a small web between outer and

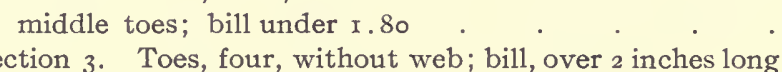

Section 3. Toes, four, without web; bill, over 2 inches long
Section 4 . Toes, four, without web; bill, under 2. Group 5. Birds having wings from 6.75 to 9 inches long

Section I. Toes, four, with more or less web; bill, curved upwards or straight; bill, over 2.60 inches

Section 2. Toes, four, with small web; bill, slightly curved upward or straight: bill, under 2.60 and over I. 50 inches long

Section 3. Toes, four, with small web; bill, nearly straight; bill, less than I. 50 inches long

Section 4. Toes, four, with small web; bill, curved downward; bill, over 2 inches long.

Group 6. Birds having wings from 9 to $\mathrm{I} 2$ inches long .

Section I. Toes, four; bill, curved downward .

Section 2. Toes, four; bill, curved upward or nearly straight

\begin{tabular}{|c|c|}
\hline 6" & ، \\
\hline " & " \\
\hline ، & 16 \\
\hline " & " \\
\hline " & " \\
\hline “، & " \\
\hline "6 & "، \\
\hline “، & "، \\
\hline “" & ") \\
\hline 16 & "4 \\
\hline " & "व \\
\hline " & " \\
\hline
\end{tabular}

\section{Family CHARADRIIDÆ. Plovers.}

Toes, three (one exception, Black-bellied Plover); bill, comparatively short and thick; front of tarsus, with small rounded scales . . See page IIr.

Group 1. Wing, 3.75 to 4.50 inches long; toes, three, no

hind toe

Section r. Bill, under .60 inch long - . . . “ " “ II2.

Group 2. Wing, $4 \cdot 50$ to $5 \cdot 50$ inches long; toes, three, no hind toe " " Ir2.

Section r. Bill, under.60 inch long . . . . " " Ir2.

Group 3. Wing, 5.50 to 6.75 inches long; toes, three, no hind toe “ " I 2 .

Group 4. Wing, over 6.75 inches long . . . . " "II3.

Section $r$. Toes, three, no hind toe . . . . " " II3.

Section 2. Toes, four . . . . . . . " " Ir3.

\section{Family APHRIZIDÆ. Turnstones, etc.}

Bill, shorter than head and horny at tip; toes, four; lower back and rump, white, with black band . . . . See page ri4. 


\section{ORDER LIMICOL $Æ$.}

SNIPES, PLOVERS, SANDPIPERS, CURLEWS, PHALAROPES, ETC.

Hind toe, when present, always elevated above level of front toes.

\section{Family PHALAROPODIDÆ. \\ PHALAROPES.}

Sides of toes, with lobes or narrow marginal webs; tarsus, compressed; nostrils, near base of bill.

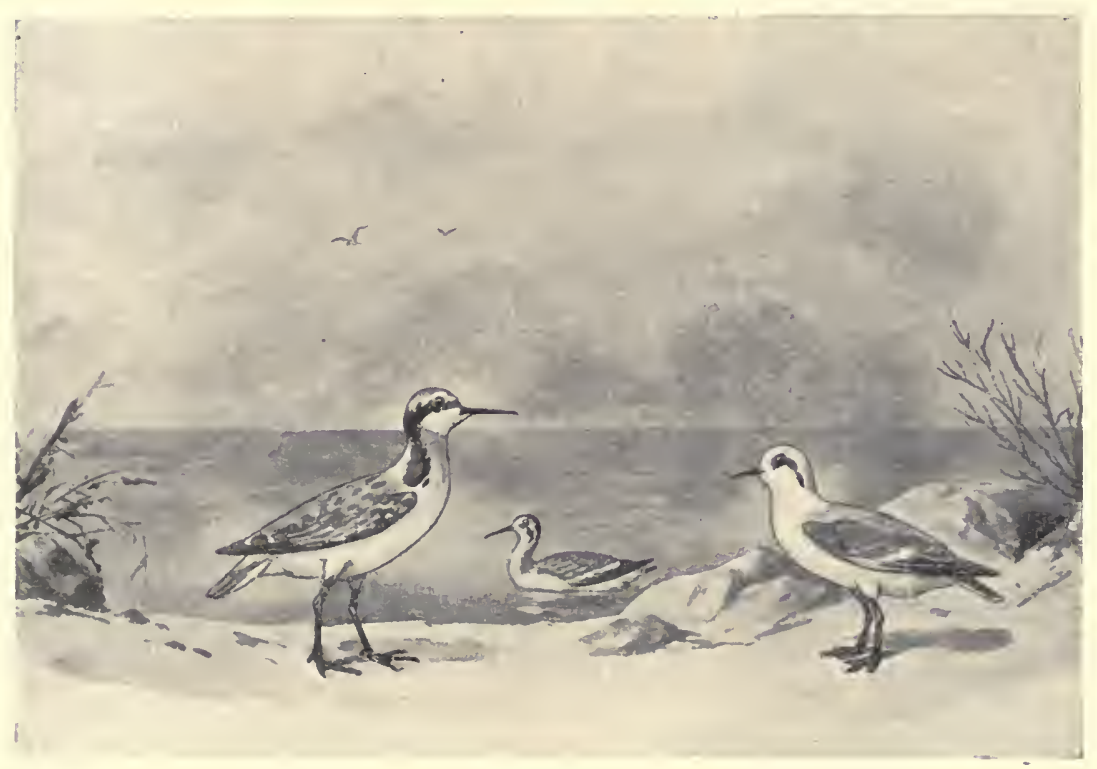

Wilson's Phalarope.

Red Phalarope. Winter plumage. 
94 Field Museum of Natural History-Zoölogy. Vol. IX.

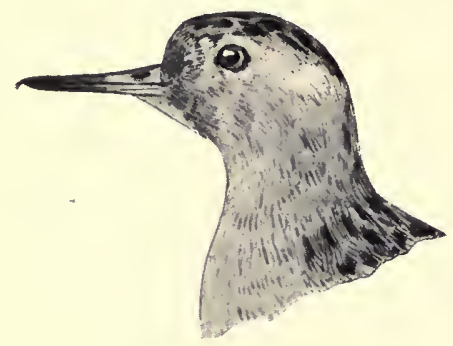

Red Phalarope.

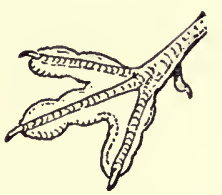

Phalaropus fulicarius.

Back, heavily streaked with black and tawny; belly, reddish brown, showing more or less white; toes, with small lobate web; wing, 5.20 to 5.50 .

Phalaropus fulicarius.

Red Phalarope.

See No. I02.

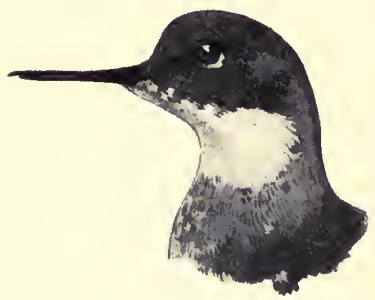

Northern Phalarope.

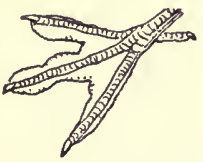

Lobipes lobatus

Back, grayish, streaked with tawny; belly, white; toes, partly webbed; bill, under I.05; tarsus, under I; wing, 4 to 4.50 .

Lobipes lobatus. Northern Phalarope.

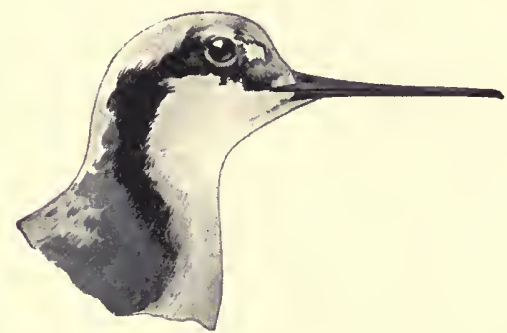

Wilson's Phalarope.
See No. Iо3.

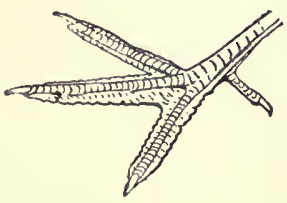

Steganopus tricolor.

Back, grayish, marked with chestnut brown; belly, white; bill, over I.05; tarsus, over I ; toes, with narrow web on sides; wing, 5.10 to 5.40 (female).

Steganopus tricolor. Wilson's Phalarope.

See No. I04. 
Jan., 1909. Birds of Illinois and Wisconsin - Cory.

Back, grayish, mottled with dusky or whitish; bill, over I.05; tarsus, over I inch; toes, with narrow web on sides; wing, 4.75 to 4.95 (male).

Steganopus tricolor. Wilson's Phalarope.

See No. 104.

\section{Family RECURVIROSTRIDÆ.}

\section{AVOCETS AND STILTS.}

Legs, long; tarsus over 3.50 inches; bill, curved upward or straight.

Bill, curved upward; head and neck, pale rufous (summer), white or grayish (winter); back and tail, white; axillars, white; belly, white; first primary, dark with dark shaft; toes, four; toes, webbed.

Recurvirostra americana.

American Avocet.

See No. ro5.

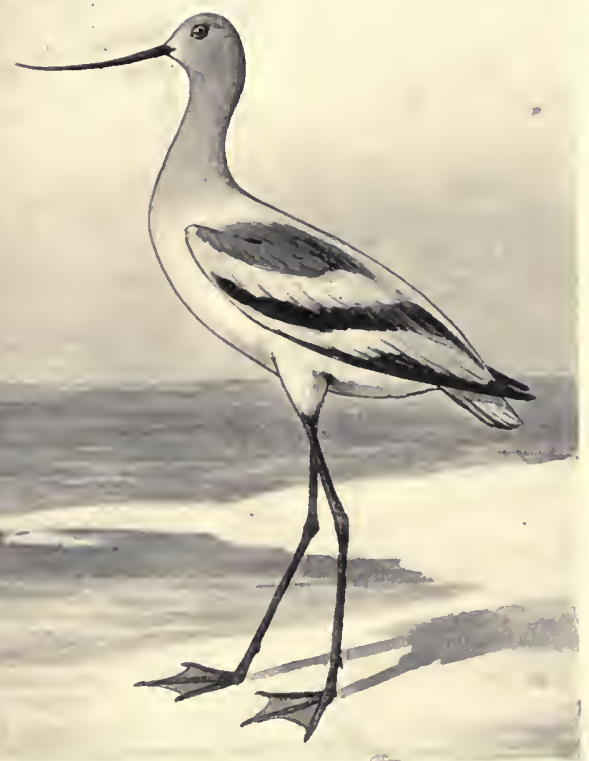

A vocet.

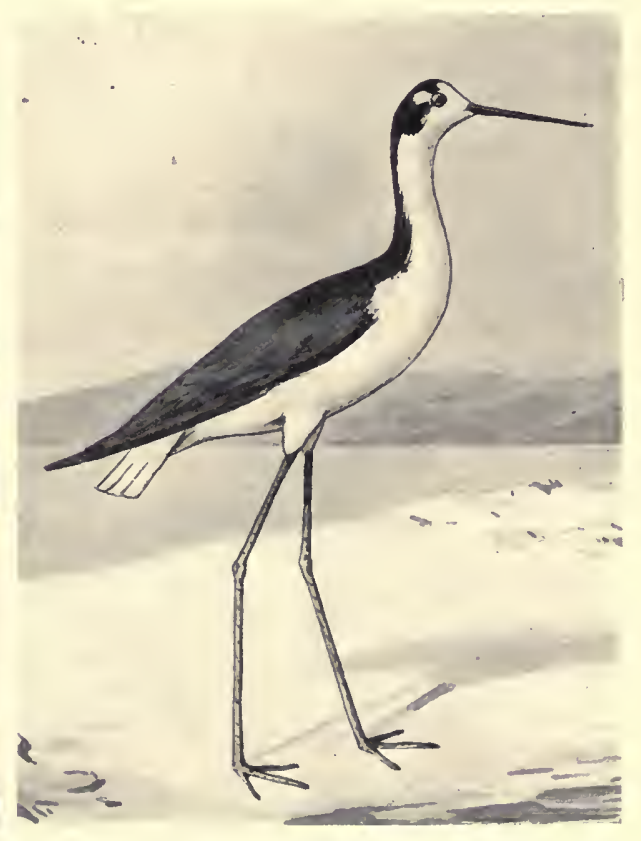

Stilt. 
96 Field Museum of Natural History-Zoölogx, Vol. IX.

Bill, nearly straight; top of head and nape, black; general upper plumage, glossy black; front of head and front of neck, rump, and under parts, white; axillars, white; first primary, dark, with dark shaft; legs, very long, rose pink in life; toes, three.

Himantopus mexicanus. Black-necked Stilt. See No. Io6.

\section{Family SCOLOPACIDÆ.}

\section{SNIPES, SANDPIPERS, CURLEWS, E'TC.}

Toes, four (one exception, the Sanderling Sandpiper); bill, comparatively slender and soft skinned; nasal grooves, narrow and long (from one-half to two-thirds the length of the bill); nostrils, narrow slits; tail, short; wing (in most species), long and pointed; hind toe (when present), always elevated above the level of the front toes; tarsus, with transverse scales.

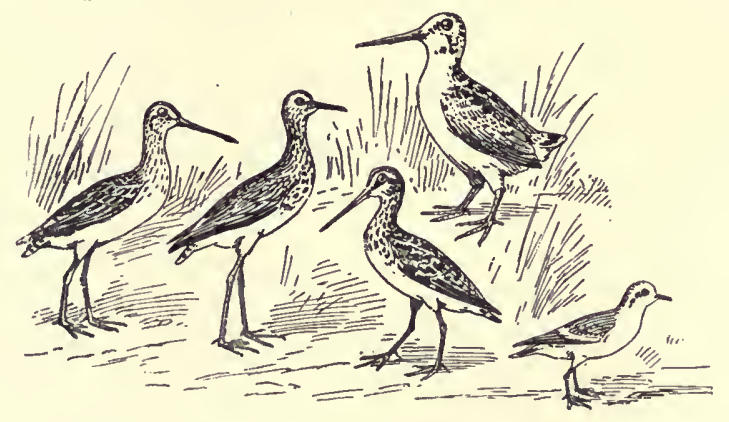

* GROUP 1. Wing, from 3.25 to 3.75 inches long.

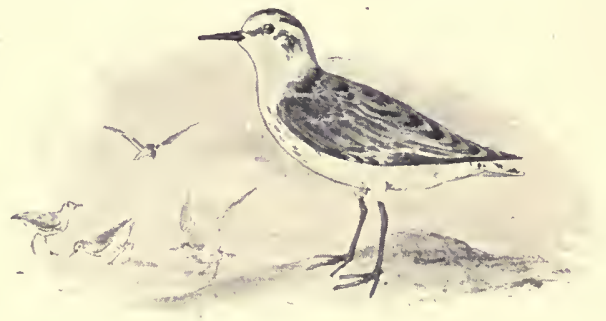

No web between toes; belly, white.

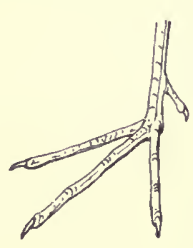

Pisobia minutilla.

Pisobia minutilla.

Least Sandpiper.

See No. II 7 .

* For directions for measurement, see page $\mathbf{2}$. 
Jan., I909. Birds of Illinois and Wisconsin-Cory.

Toes, with small web;. bill, usually under .85 .

Ereunetes pusillus. Semipalmated Sandpiper. See No. iाg.
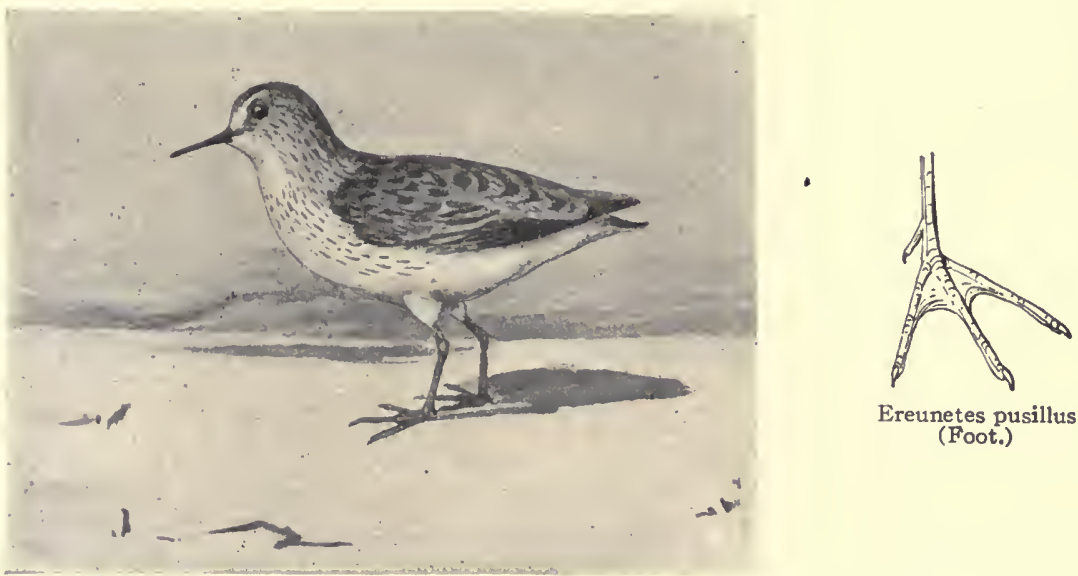

Ereunetes pusillus (Foot.)

Toes, with small web; bill, usually over .85 .

Ereunetes mauri. Western Sandpiper. See No. I 20.

*GROUP 2. Wing, 3.75 to 4.50 inches long.

SECTION 1. Toes, four, with small web at base.

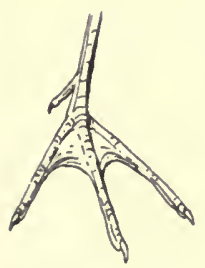

Bill, under .85; back, not greenish olive; bill, entirely black.

Ereunetes pusillus.

Semipalmated Sandpiper.

See No. II 9 .

Ereunetes pusillus.

Bill, over .85; back, not greenish olive; bill, black; no white patch on inner web of third primary. Ereunetes mauri. Western Sandpiper.

See No. I 20.

* For directions for measurement, see page 21 . 
98 Field Museum of Natural History-Zoölogy, Vol. iX.

Small web between outer and middle toe; bill, over .85 ; back, greenish olive, sometimes banded; under mandible, pale yellow (in life); third primary and inner primaries with patch of white on inner web.

Actitis macularia.

Spotted Sandpiper.

See No. I30.

SECTION 2. Toes, four, without web.

Belly, white; bill, black.

$$
\begin{aligned}
& \text { Pisobia minutilla. } \\
& \text { Least Sandpiper. } \\
& \text { See No. } 117 .
\end{aligned}
$$

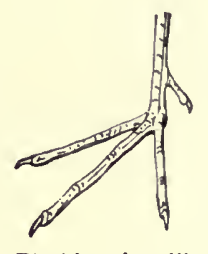

Pisobia minutilla.

SECTION 3. Toes, three; bill, over .75 inches long.

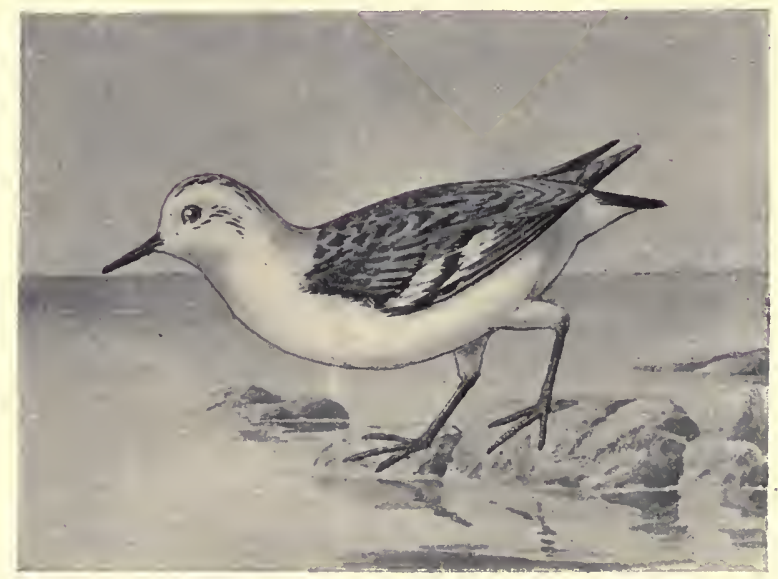

Sanderling Sandpiper.

Belly, white; basal half of outer webs of inner primaries, white; back, mixed rufous, black and white, or grayish brown, or entirely black (breeding), according to season; bill, about one inch long.

Calidris leucophcea. Sanderling Sandpiper. See No. I 2 I. 
* GROUP 3. Wing, 4.50 to 5.50 inches long. SECTION 1. Toes, four, a small web between toes; bill, under I.75.

Bill, under 1.75; tarsus, over 1.30. All other species in this section have the tarsus less than I.3O.

Micropalama himantopus. Stilt Sandpiper. See No. II I.

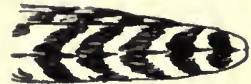

Axillars, Helodromus solitarius.

Tarsus, under I.30; back, dark olive spotted with white, or brownish gray spotted with dull white according to season. Axillars, heavily barred; a small web between the outer and middle toe.

Helodromas solitarius. Solitary Sandpiper. See No. 26.

Back, greenish olive, sometimes barred with black; axillars, white; without bars. At some seasons under parts with round black spots, a small web between the outer and middle toe.

Actitis macularia. Spotted Sandpiper. See No. I 30.

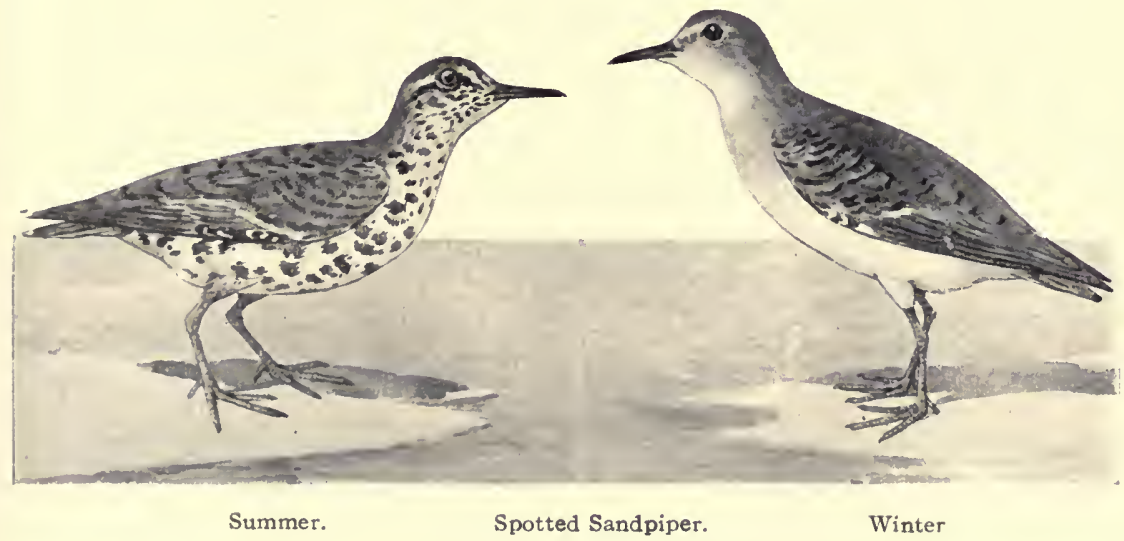

* For directions for measurement, see page 21 
ioo Field Museum of Natural History-Zoölogy, Vol. IX.

SECTION 2. Toes, four, a small web between outer and middle toes; bill, over 1.75 .

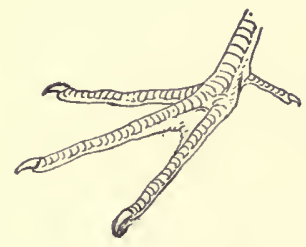

Macrorhamphus griseus.

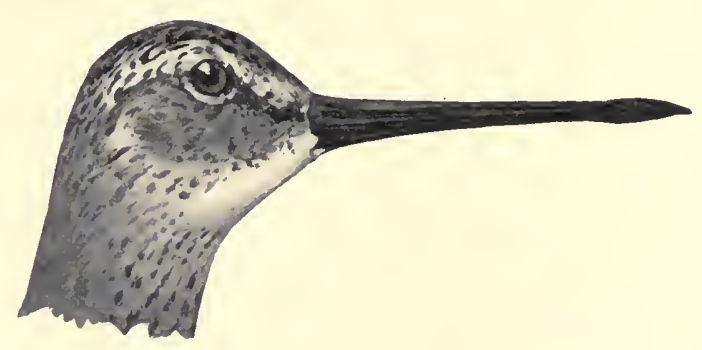

Macrorhamphus griseus.

Bill, over 1.75; axillars, white, barred with dark brown; rump and tail, 'white, spotted and banded with black; a small web between outer and middle toes.

Macrorhamphus griseus. Dowitcher. Red-breasted Snipe. Macrorhamphus scolopaceus. Long-billed Dowitcher. See Nos. rog and i ro.

SECTION 3. Toes, four, without web; bill, over 2 inches long. Axillars, rufous brown, without bars; belly, buff color.

Philohela minor. Woodcock. See No. 107 .

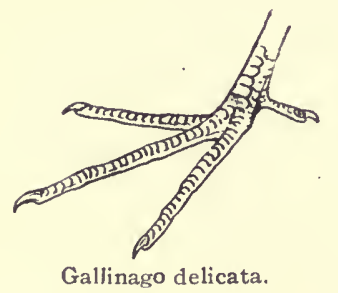

Axillars, barred black and white; belly, white; upper tail coverts and tail, tawny, more or less marked with black; no web between toes.

Gallinago delicata. Wilson's Snipe. Jack Snipe. See No. 108. 
SECTION 4. Toes, four, without web; bill, over I.IO; and less than $\mathbf{1} .90$.

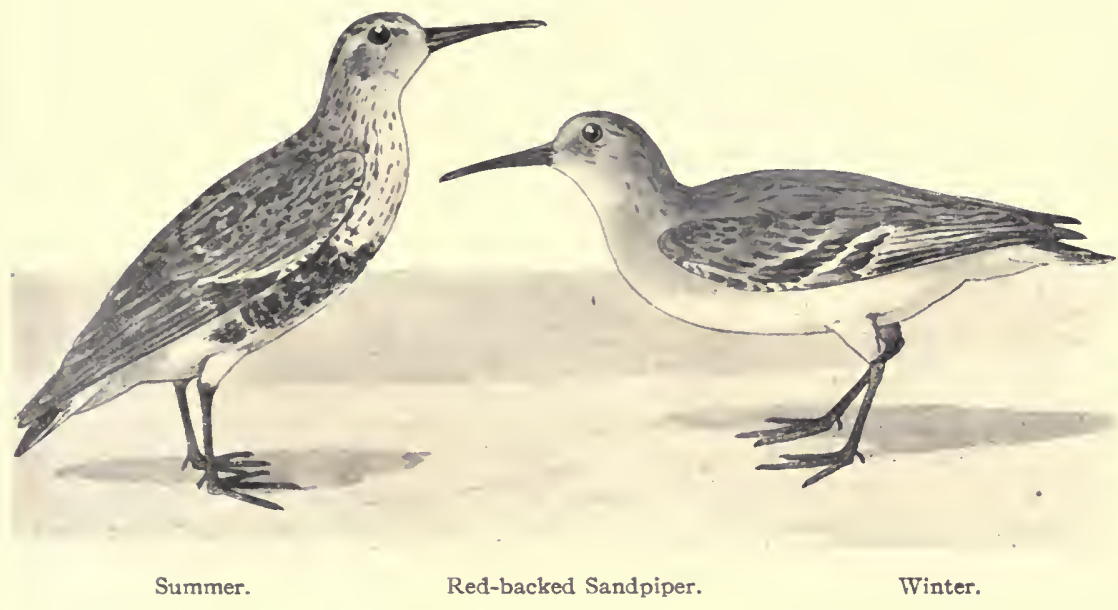

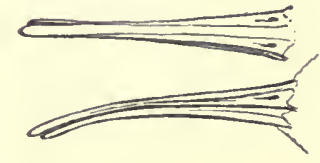

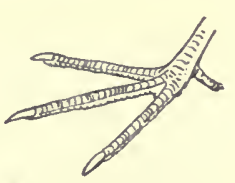

Pelidna alpina sakhalina

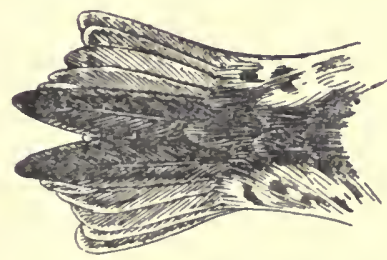

Tail and upper tail coverts. Pisobia maculata.
Bill, decurved near tip; one or more of inner secondaries, almost entirely white; upper tail coverts, not white, barred with black; legs and feet, black. Spring birds have black on the belly, and back, rufous brown and black. Fall birds have the belly white and back gray. Pelidna alpina sakhalina. Red-backed Sandpiper. American Dunlin. See No. I 8 .

Bill, nearly straight; back, marked with tawny and black; breast with numerous narrow, brown streaks; none of inner secondaries almost. entirely white; lower rump and upper tail coverts, black, the feathers more or less tipped with buff; two middle tail feathers, longer than the others. Pisobia maculata. Pectoral Sandpiper. Grass Bird. See No. II4. 
io2 Field Museum of Natural History-Zoölogy, Vol. IX.

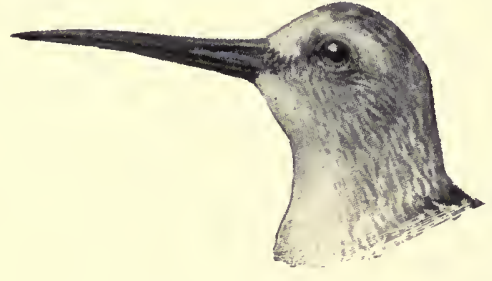

Purple Sandpiper.

Bill, nearly straight; back, dark; feathers, edged with ashy or buff; breast, grayish, without brown streaks; one or more of inner secondaries almost entirely white; legs and feet, yellow in life, pale brown in dried skin.

Arquatella maritima. Purple Sandpiper. See No. Ir 3 .

SECTION 5. Toes, four, without web; bill, under r.ı.

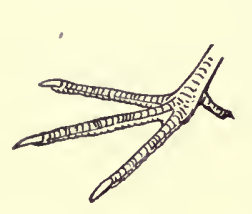

Upper tail coverts, white; inner webs of primaries, not speckled.

Pisobia fuscicollis.

White-rumped Sandpiper.

See No. I 5 .

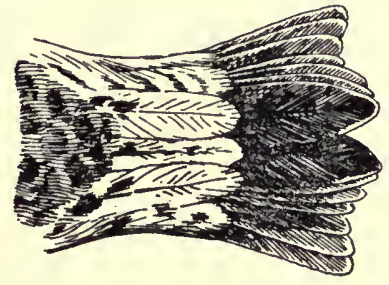

Pisobia fuscicollis.

Middle upper tail coverts, smoky or dusky, often tipped with buff; inner webs of primaries not speckled; sides, white; middle toe and claw, less than .95; legs and bill, blackish.

Pisobia bairdii.

Baird's Sandpiper.

See No. rí.

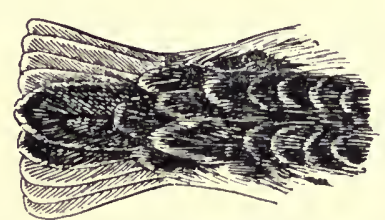

Pisobia bairdii.

Tail and upper tail coverts.

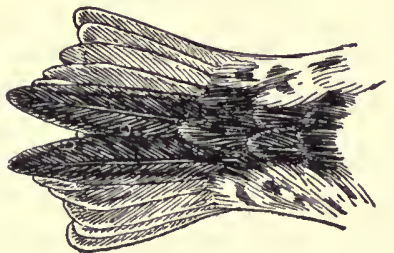

Pisobia maculata. Tail and upper tail coverts.

Middle upper tail coverts, black, often narrowly tipped with brownish buff; inner webs of primaries, not speckled; middle toe and claw, over .95; middle tail feathers decidedly longer than the rest; legs, yellowish olive; base of bill, dull olive; tip, black.

Pisobia maculata.

Pectoral Sandpiper. Grass Bird. See No. II 4 . 
Inner web of primaries speckled.

Tryngites subruficollis.

Buff-breasted Sandpiper.

See No. I 29.

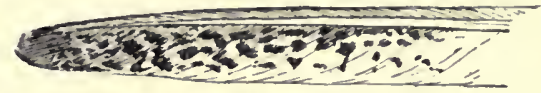

Tryngites subruficollis. First primary.

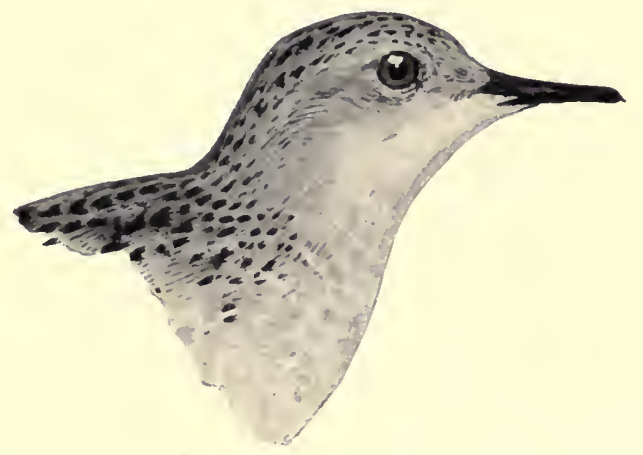

Buff-breasted Sandpiper.

SECTION 6. Toes, three; bill, over .60 inch.

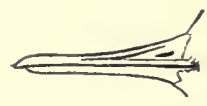

Bill, black; shoulder (lesser and middle wing coverts), brown; no web between toes; legs,

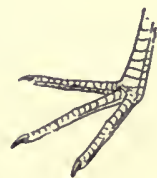
black; no hind toe.

Calidris leucophcea. Sanderling Sandpiper. See No. I 2 I.

Calidris leucophæa.

* GROUP 4. Wing, 5.50 to 6.75 inches long.

SECTION 1. Toes, four, a small web between outer and middle toe; bill, over 1.80.

Upper tail coverts and axillars, white,

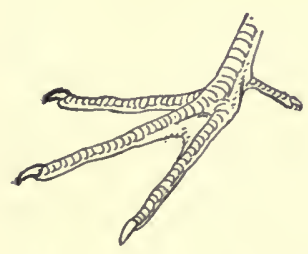

Macrorhamphus griseus. spotted or barred with dusky; bill, nearly straight.

Macrorhamphus griseus. Dowitcher. Red-breasted Snipe.

See No. rog.

Macrorhamphus scolopaceus.

Long-billed Dowitcher. Western Red-breasted Snipe.

See No. I Io.

* For directions for measurement, see page $2 \mathrm{I}$. 
io4 Field Museum of Natural History-Zoölogy, Vol. IX.

SECTION 2. Toes, four, a small web between outer and middle toe; bill, under 1.80 .

Tarsus and middle toe together, more than 2.60 inches long; outer primary, slate brown, without bars; rump and upper tail coverts, white, more or less barred with brown; legs, yellow. Totanus flavipes.

Summer Yellow-legs. See No. 125 .
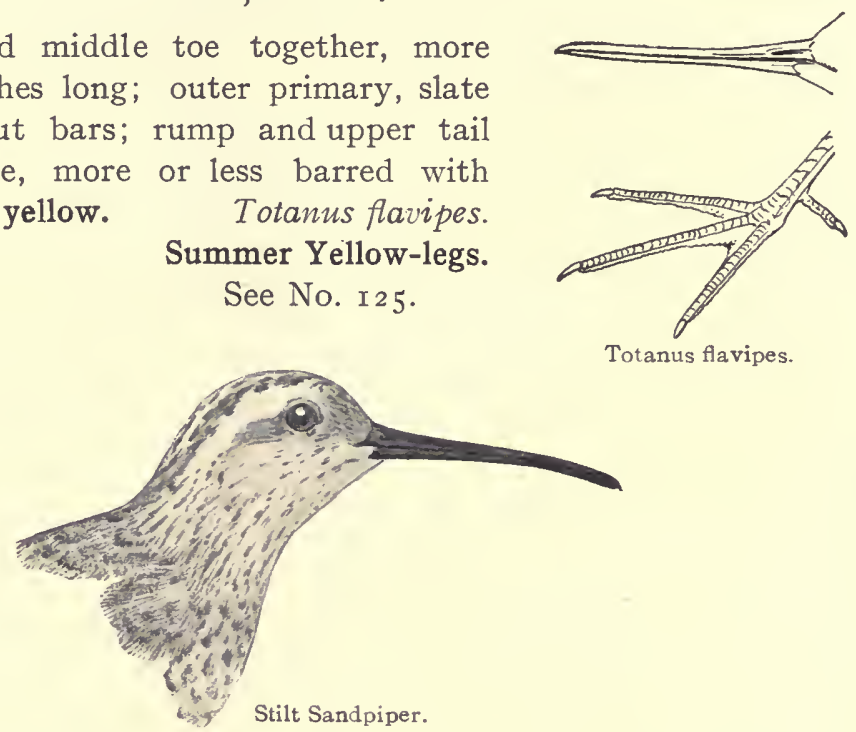

Tarsus and middle toe together, less than 2.60; upper tail coverts, white, or white barred with black; outer primary, slate brown, without bars.

Micropalama himantopus.

Stilt Sandpiper. See No. III.

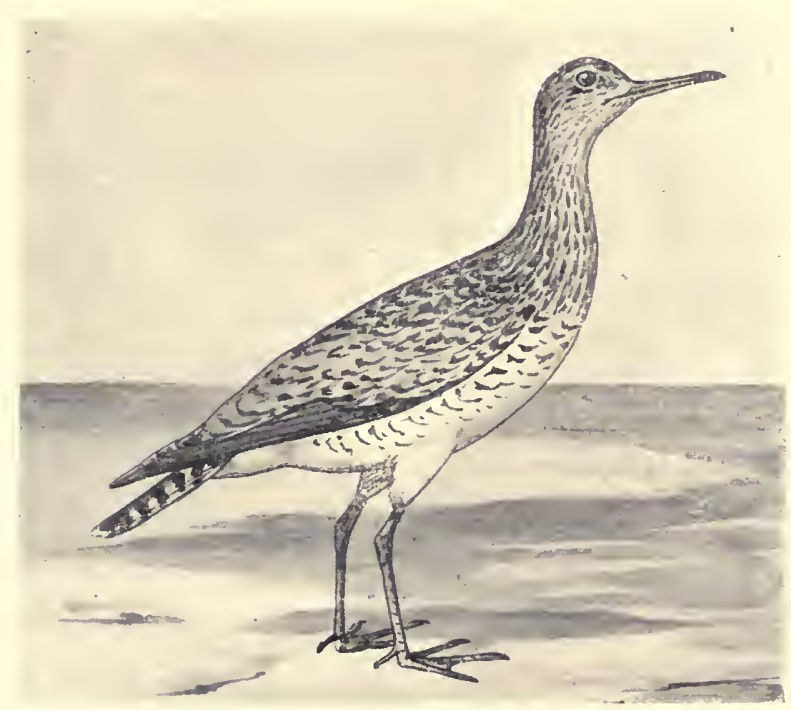

Bartramian Sandpiper. 
Jan., rgo9. Birds of Illinoís and Wisconsin-Cory.

Outer primary, whitish, barred with dark brown.

Bartramia longicauda. Bartramian Sandpiper. Upland Plover. See No. I 28.

SECTION 3. Toes, four, without web; bill, over 2 inches long.

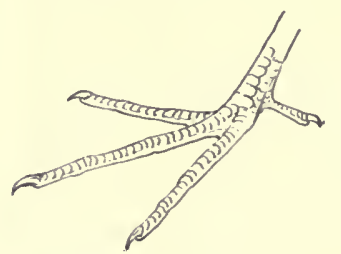

Lower belly, whitish or white; axillars, barred black and white. Gallinago delicata. Wilson's Snipe. Jack Snipe. See No. 108.

Gallinago delicata

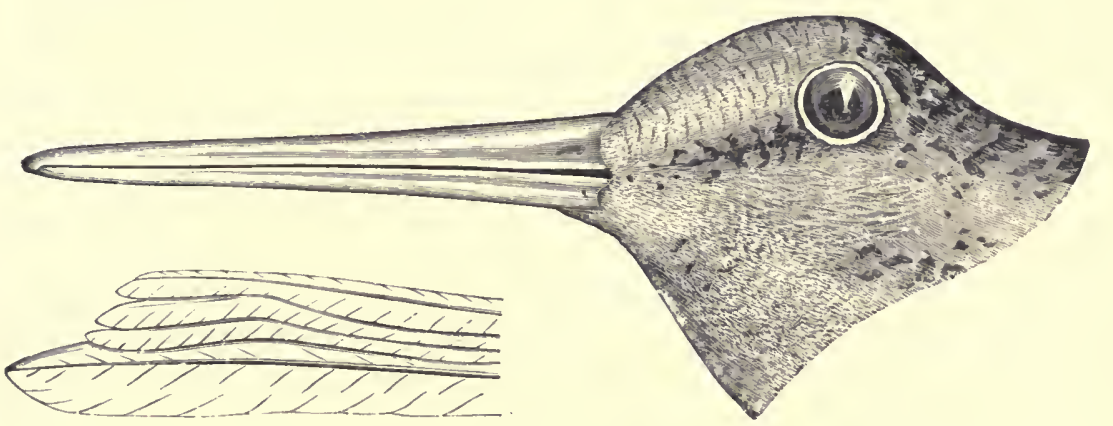

Belly, buff color; axillars, rufous brown.

Philohela minor. Woodcock.

See No. ro7.

SECTION 4. Toes, four, without web; bill, under 2 inches long.

Rump, gray; upper tail coverts, whitish, banded or marked with black; inner webs or primaries, not speckled.
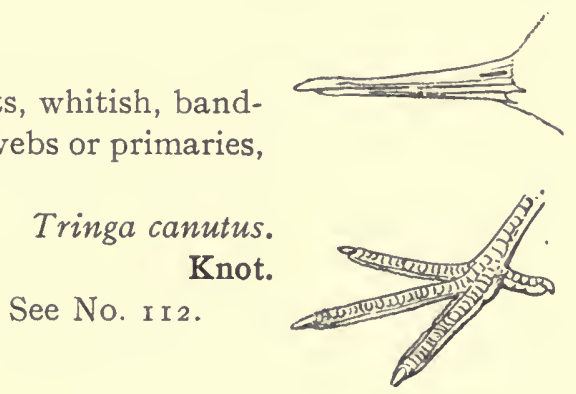

Tringa canutus. 
io6 Field Museum of Natural History-Zoölogy, Vol. IX.

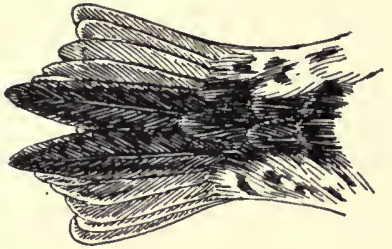

Pisobia maculata.

Rump, blackish; middle upper tail coverts, black (not banded); inner web of primaries, not speckled.

Pisobia maculata.

Pectoral Sandpiper. Grass Bird. See No. I 14.

Inner webs of primaries, speckled.

Tryngites subruficollis. Buff-breasted Sandpiper. See No. I 29.

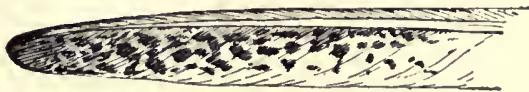

Tryngties subruficollis.

* GROUP 5. Wing, 6.75 to 9 inches long.

SECTION 1. Toes, four, with more or less web; bill, curved up wards or straight; bill, over 2.60 .

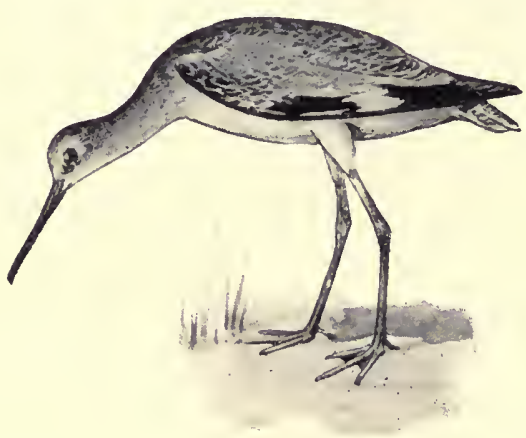

Willet.

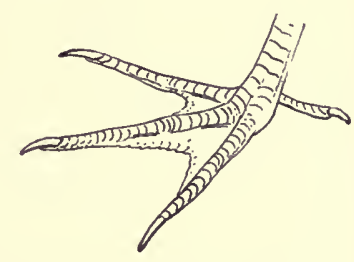

Catoptrophorus semipalmatus.

Axillars, smoky black; belly, white; terminal third of outer primary, black; the rest, white; bill, nearly straight.

Catoptrophorus semipalmatus.

Willet.

Catoptrophorus semipalmatus inornatus.

Western Willet.

See Nos. 127 and I 27 a.

* For directions for measurement, see page 2 I. 


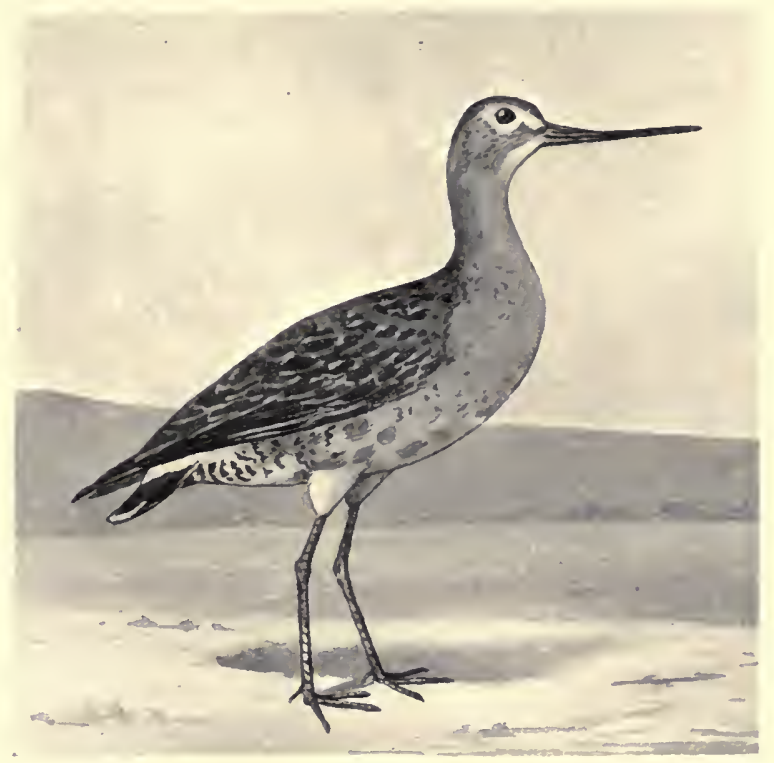

Hudsonian Godwit.

Axillars, dark gray, or sooty gray; belly, grayish white; first primary, dark slaty brown, with white shaft; bill, curved upward; upper tail coverts mostly white.

Limosa homastica. Hudsonian Godwit.

See No. I23.

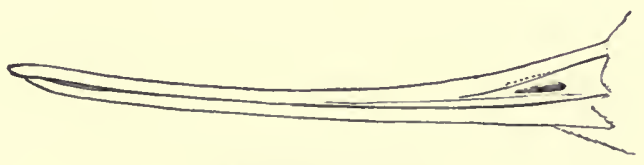

Marbled Godwit.

Axillars, rufous brown; upper tail coverts, not white; belly, buff, sometimes barred with dark brown; primaries, pale rufous brown, with numerous dark dots; shaft of primaries, white; bill, curved upward.

Limosa fedoa. Marbled Godwit. See No. I 22. 
io8 Field Museum of Natural History-Zoölogy, Vol. IX.

SECTION 2. Toes, four (with small web); bill, slightly curved upward or straight; bill, under 2.60 and over 1.50. .

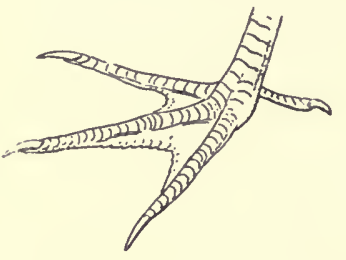

Axillars, smoky black; belly, white; outer primary terminal third, black, rest white; rump, gray; upper tail coverts, white.

Catoptrophorus semipalmatus.

Willet.

Catoptrophorus semipalmatus inornatus.

Western Willet.

See No. I 27 or I 27 a.

Axillars, white, banded with brown; belly, white; outer primary, black; shaft, white; rump, grayish brown; feathers, tipped with white; upper tail coverts, white, more or less barred with dark brown; legs, bright yellow.

Totanus melanoleucus.

Greater Yellow-legs. Winter Yellow-legs.

See No. I 24.

SECTION 3. Toes, four, with small web; bill, nearly straight; bill, under 1.50 .

Axillars, white, banded with brown; first primary, brown, with white bars on inner web; tip, dark.

Bartramia longicauda.

Bartramian Sandpiper. Upland Plover. See No. I 28.

SECTION 4. Toes, four, with small web; bill, curved downward; bill, over 2 inches long.
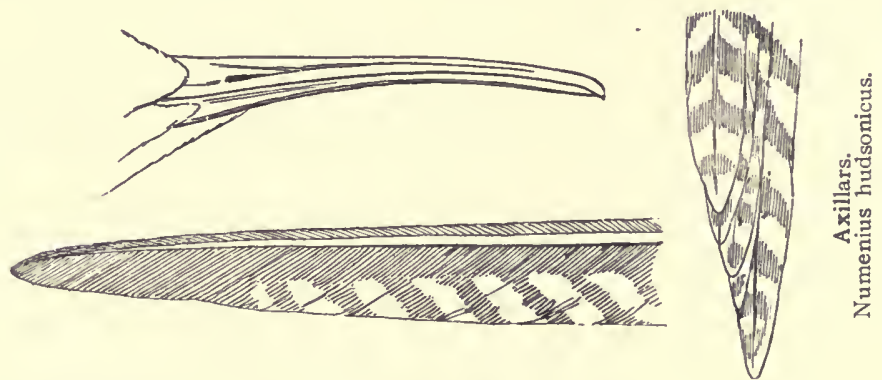

First primary.

Primaries, barred; axillars barred.

Numenius hudsonicus.

Hudsonian Curlew. Jack Curlew.

See No. I32. 
Jan., I909. Birds of Illinois and Wisconsin-Cory.
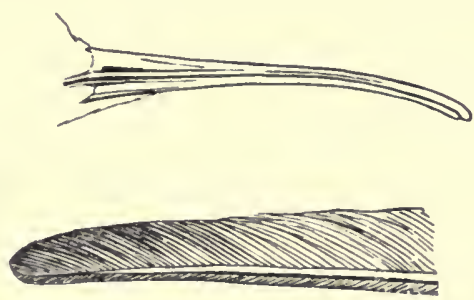

First primary

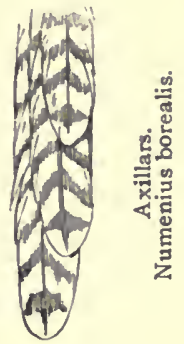

Numenius borealis. Eskimo Curlew. Dough Bird. See No. 133 .

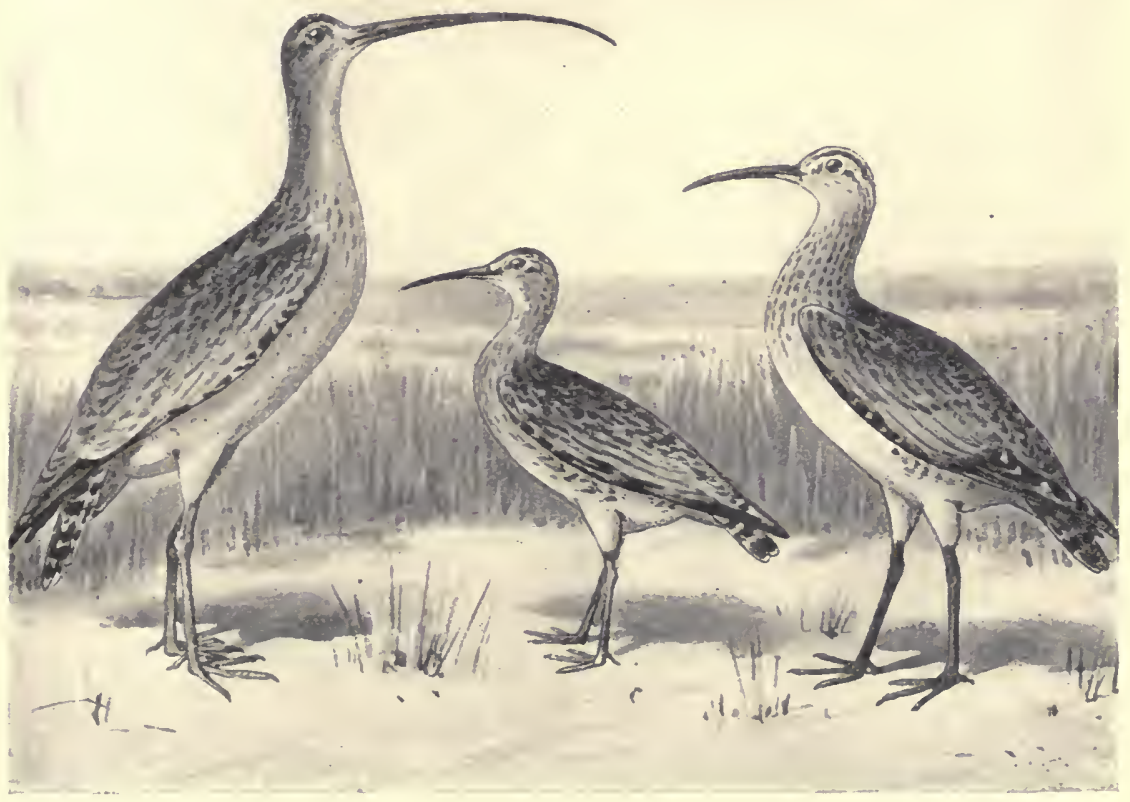

Long-billed Curlew. Eskimo Curlew. Hudsonian Curlew 
ito Field Museum of Natural History-Zoölogy, Vol. IX.

* GROUP 6. Wing, 9 to I 2 inches long. SECTION 1. Toes, four; bill, curved downward.

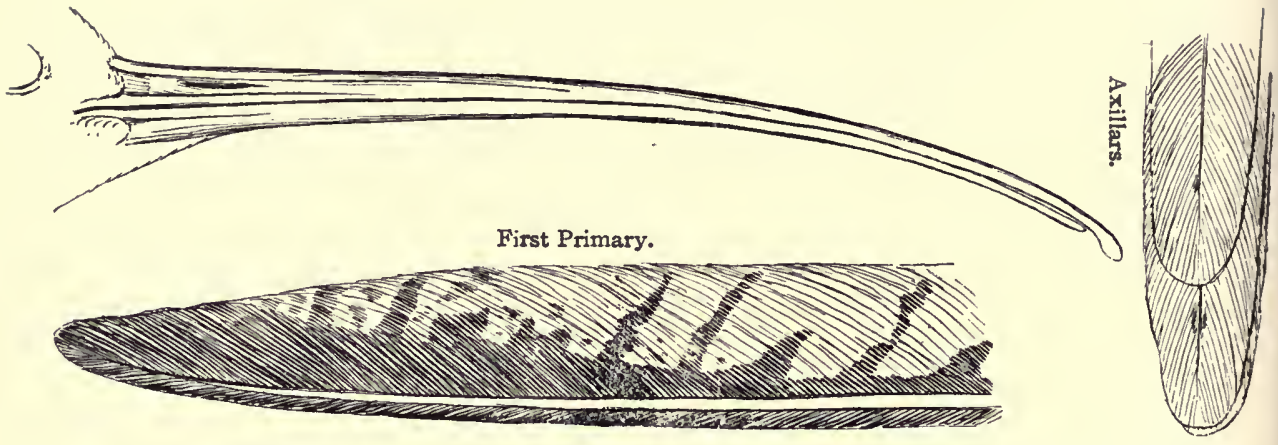

Axillars, reddish brown, with narrow black marks; belly, buff; bill, usually over four inches. Numenius americanus. Long-billed Curlew. Sickle-bill Curlew. See No. I3r.
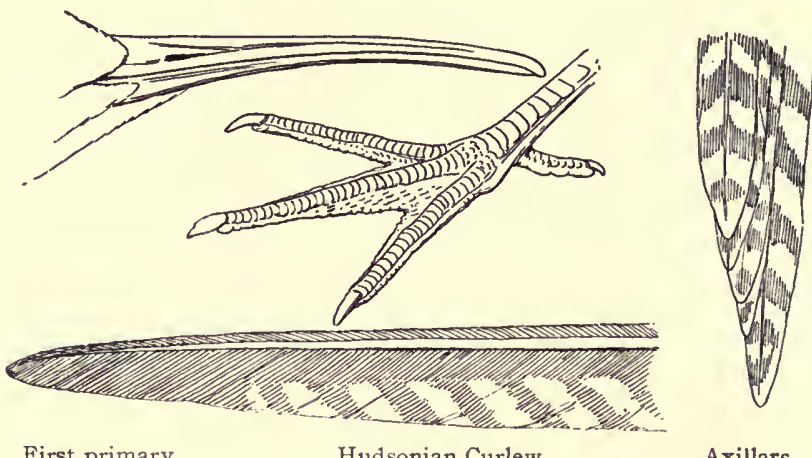

First primary.

Hudsonian Curlew.

Axillars.

Axillars, banded with slaty brown and dull white; belly, whitish; bill, under four inches.

Numenius hudsonicus. Hudsonian Curlew. Jack Curlew. See No. I32.

* For directions for measurement, see page $2 \mathrm{r}$. 
SECTION 2. Toes, four; bill, curved upward or nearly straight.

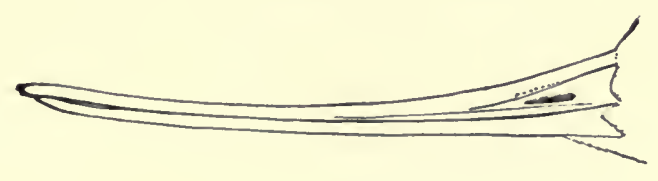

Axillars, rufous; primaries, rufous, dotted with black.

Limosa fedoa. Marbled Godwit. See No. 122.

\section{Family CHARADRIIDÆ.}

\section{PLOVERS.}

Toes, three, no hind toe; bill, comparatively short and soft; front of tarsus, with small rounded scales.

The Plovers are a cosmopolitan family, numbering something less than one hundred species, fifteen of which occur in North America, including exotic stragglers. As a rule they have but three toes, although two genera, Squatarola and Vanellus, have four. The tarsus is reticulate and the toes are partly webbed.

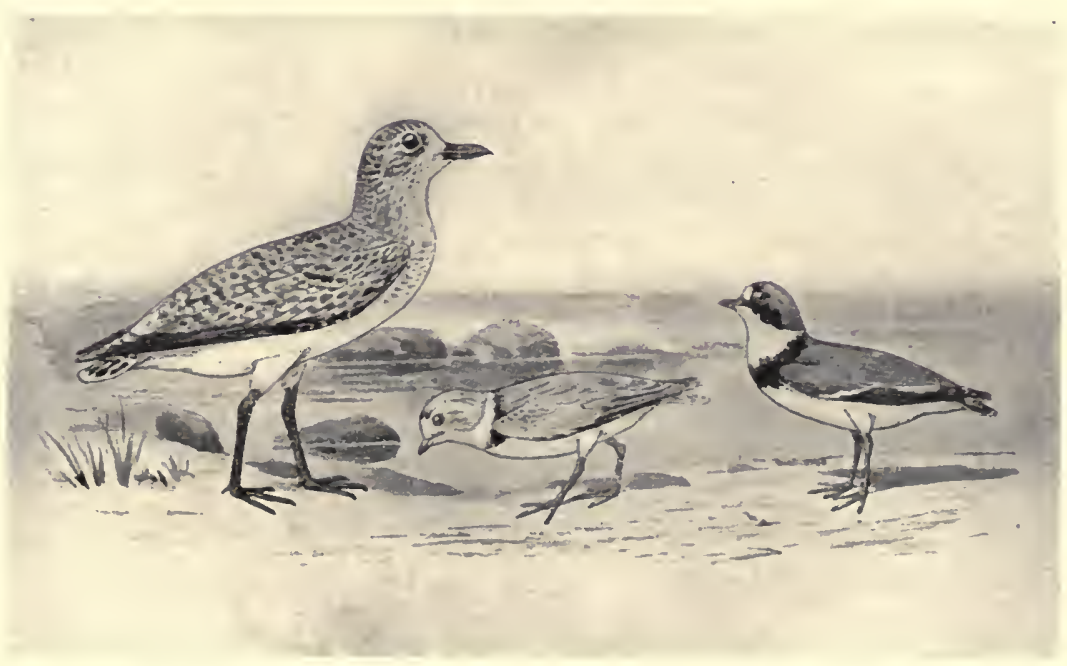

Black-bellied Plover (Winter). Piping Plover. Semipalmated Plover. 
i 2 Field Museum of Natural History-Zoölogy, Vol. IX.

* GROUP 1. Wing, 3.75 to 4.50 inches long. SECTION 1. Bill, under.60.

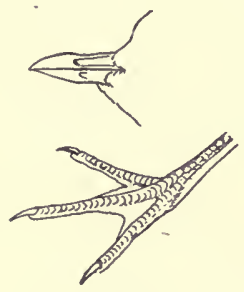

Bill, orange at base, the tip, black; legs, dull flesh color; a black stripe from bill passing under each eye. Egialitis semipalmata. Semipalmated Plover. See No. I 37 .

Egialitis

semipalmata.

Bill, orange at base, the tip, black; legs, orange yellow; two middle tail feathers, tipped with white; no black stripe from bill to eye; more or less of a black breast band.

Egialitis meloda.

Piping Plover.

See No. ${ }_{3} 8$.

* GROUP 2. Wing, 4.50 to 5.50 inches long; toes, three, no hind toe.

SECTION 1. Bill, under .60 inch long.

Bill, orange at base, the tip, black; legs, dull flesh color; a black stripe from bill passing under eye.

Egialitis semipalmata.

Semipalmated Plover. Ring Neck.

See No. I 37 .

Bill, orange at base, the tip, black; legs, orange yellow; no black stripe from bill to eye; black breast band, not confluent; two middle tail feathers, tipped with white. Eastern species not found west of Rocky Mountains.

Egialitis meloda.

Piping Plover.

See No. ${ }_{3} 8$.

* GROUP 3. Wing, 5.50 to 6.75 inches long; toes, three, no hind toe.

Breast, with two black bands; under parts, white; rump and tail coverts, orange brown.

Oxyechus vociferus.

Killdeer Plover.

See No. I36.

* For directions for measurement, see page 2 r. 
* GROUP 4. Wing, over 6.75 inches long.

SECTION 1. Toes, three.

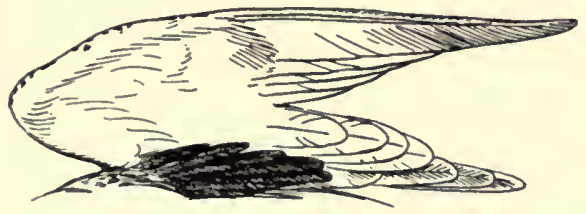

Black axillars of Black-bellied Plover.

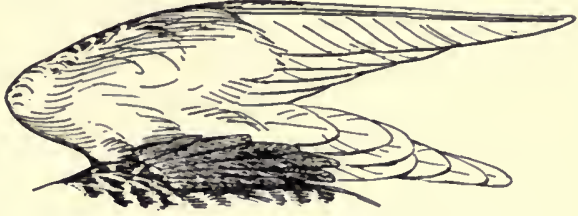

Gray axillars of Golden Plover.

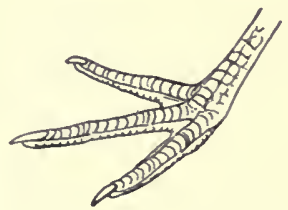

Axillars, gray; rump, not orange brown. Charadrius dominicus. Golden Plover. See No. I35.

Charadrius dominicus.

Axillars, smoky black; rump and upper tail coverts, not orange brown.

Squatarola squatarola. Black-bellied Plover.

See No. I34.

The Black-bellied Plover has four toes (the hind toe being so small that it often escapes notice), and properly belongs in Section 2, but owing to the fact that it is constantly looked for among the three-toed species it is included in both sections.

Rump, orange brown; under parts, white, with two black bands on the breast; axillars, pure white.

Oxyechus vociferus. Killdeer Plover. See No. 136 .

\section{SECTION 2. Toes, four.}

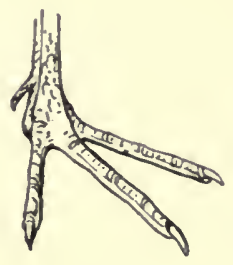

Axillars, smoky black; tarsus, over I.70; hind toe, very small.

Squatarola squatarola.

Black-bellied Plover.

See No. 134.

* For directions for measurement, see page 21 . 
i 4 Field Museum of Natural History-Zoölogy, Vol. IX.

\title{
Family APHRIZIDÆ.
}

\author{
SURF BIRDS AND TURNSTONES.
}

Subfamily ARENARIINÆ. Turnstones.

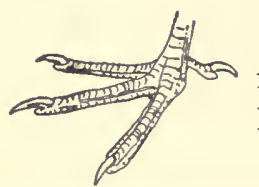

Bill, shorter than head and horny at tip; toes, four; lower back and rump, white, with black band; legs, comparatively short and stout.

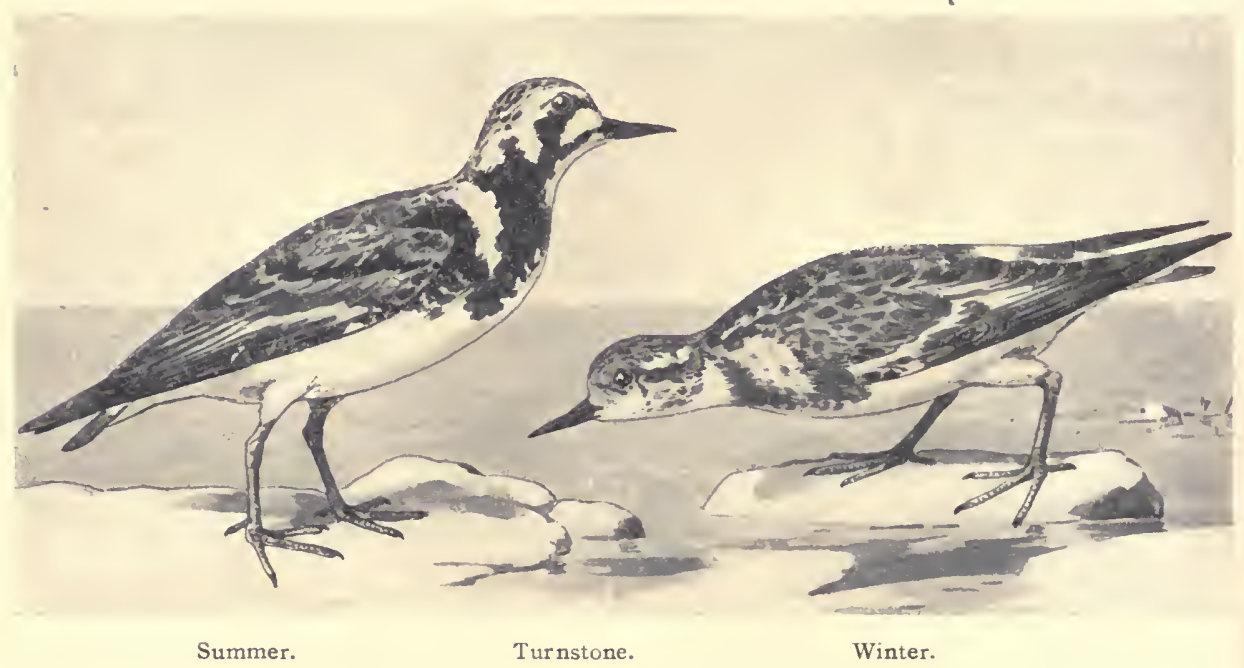

Adult in summer: General upper parts, mottled and variegated with black, white, rufous, and tawny; throat and breast, black and white; rest of under parts, white; tail, with subterminal band of black, tipped with white.

Adult in winter: Above, light, streaked and dashed with dark brown; an imperfect band of dark brown on the jugulum; chin and upper part of the throat, white; sides of breast, like the back; rest of under parts, white; a distinct white band on the wing; rump, white, with a broad patch of black on the upper tail coverts; tail, dark brown, the tips and basal half of the inner feathers, and nearly two thirds of the outer feathers, white; legs, reddish orange; bill, black.

Length, 8.65; wing, 5.70; tail, 2.60; tarsus, 1 ; bill, .95.

Arenaria interpres morinella.

Turnstone.

See No. r 39 . 


\section{INDEX TO KEY TO FAMILIES.}

\section{LAND BIRDS.}

Group I. Birds having wings less than I.75 inches long. See page II 7 .

Group 2. Birds having wings from $\mathrm{I} .75$ to 2.75 inches long. See page II 7 .

Section r. First primary less than half as long as third. See page $\operatorname{Ir} 7$.

Part I. Tip of upper mandible with small but distinct hook or notch. See page ir 7 .

Part 2. Upper mandible without notch or hook at tip. See page i 8.

Section 2. First primary more than half as long as third. See page Irg.

Part I. Tip of upper mandible with small but distinct hook or notch. See page irg.

Part 2. Tip of upper mandible, not notched or hooked. See page 120 .

Group 3. Birds having wings measuring from 2.75 to 3.25 inches long. See page I $2 \mathrm{I}$.

Section 1. First primary less than half as long as third. See page $\mathrm{I} 2 \mathrm{I}$.

Part I. A small but distinct hook or notch at tip of upper mandible. See page I $2 \mathrm{I}$.

Part 2. Tip of upper mandible not notched or hooked. See page $\mathrm{r} 2 \mathrm{r}$.

Section 2. First primary not short, always more than half as long as third. See page 122.

Part I. Tip of upper mandible with small but distinct hook or notch. See page $\mathbf{2} 2$.

Part 2. Tip of upper mandible not notched or hooked. See page $\mathbf{r} 22$.

Group 4. Birds having wings measuring from 3.25 to 9.50 inches long. See page $\mathrm{r} 24$.

Section I. Bill with strong hook, toes armed with talons. See page 124 . 
it6 Field Museum of Natural History-Zoölogy, Vol. IX.

Section 2. Upper mandible with more or less hook, but toes not armed with talons. See page I 25.

Section 3. Tip of upper mandible not notched or hooked. See page 126.

Part I. First primary less than half as long as third, sometimes very small. See page 126 .

Part 2. First primary more than half as long as third. See page $\mathbf{2} 28$.

Group 5. Birds having wings over 9.50 inches long. See page 133 . 


\section{LAND BIRDS. KEY TO FAMILIES.}

* GROUP 1. Birds having wings less than 1.75 inches long.
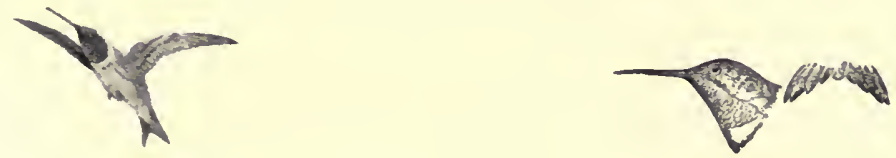

Smallest of our birds; bill, very slender; primaries, Io; rectices, ro; feet, very small and weak.

Family TROCHILIDÆ. Humming Birds. See page 169 .

Tail, rounded; the outer feathers, shorter than middle ones; first primary, less than two thirds as long as third; second primary, much shorter than third; tarsus, scutellate.

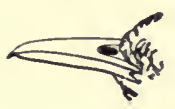

Family TROGLODYTIDÆ. Wrens.

See page 262 .

* GROUP 2. Birds having wings from 1.75 to 2.75 inches long.

SECTION 1. First primary, less than half as long as third.

PART 1. Tip of upper mandible, with small but distinct hook or notch.

Toes, joined at base. Plain colored birds, usually greenish or grayish, but often show a faint wash of yellow on under parts; tail, always without white spots.

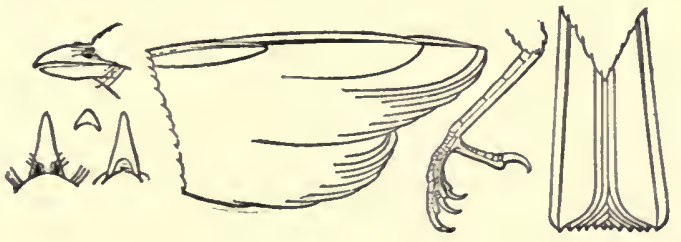

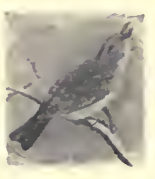

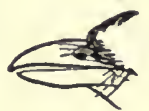

Family VIREONIDE. Vireos.

See page 227 .

* For directions for measurement, see page 2 r. 
i 8 Field Museum of Natural History-Zoölogy, Vol. IX.

PART 2. Upper mandible without notch or hook at tip.

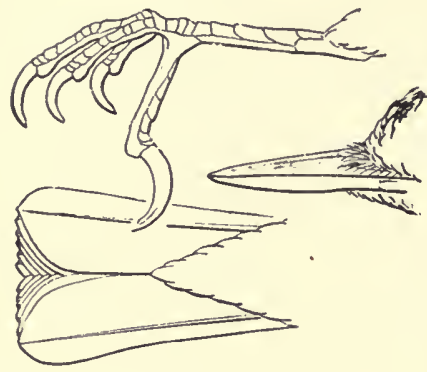

Bill, as illustrated; back, gray or bluish gray; bill, over .50 ; nostrils, concealed by bristly tufts; tarsus, scutellate; tail feathers, not stiff or pointed.

Family SITTID $\notin$. Nuthatches. See page 267 .

Bill, as illustrated; back, bluish gray; bill, less than .50; size, small; length, less than $5.5^{\circ}$; first primary, very short.

Family SYLVIID E. Subfamily POLIOPTILINÆ. Gnatcatchers.

See page 270 .

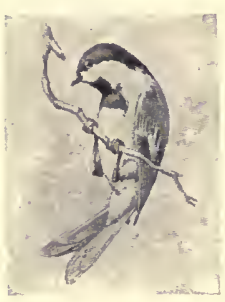

Bill, as illustrated; throat, black; nostrils, concealed by tufts of bristly feathers.

Family PARIDE. Titmice, Chickadees.

See page 268 .

Bill, as illustrated; back, brown or brown streaked; tail feathers, not sharp pointed; outer tail feathers, shortest; tarsus, scutellate; first primary, short.
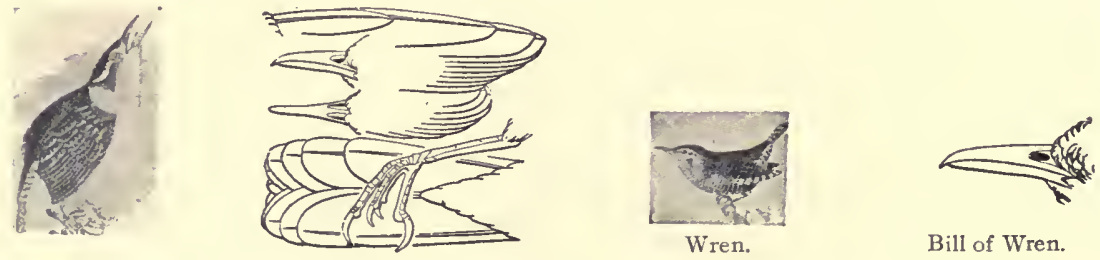

Family TROGLODYTIDÆ. Wrens. See page $26_{2}$. 


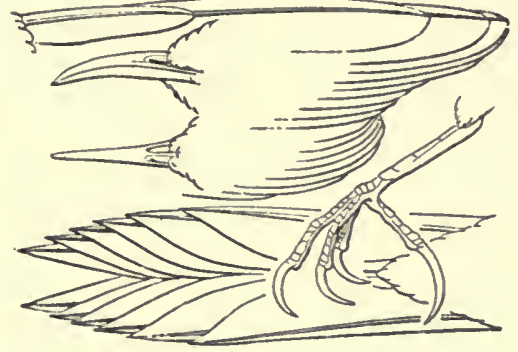

Bill, as illustrated; back, streaked; 'tail feathers, stiffened and sharply pointed.

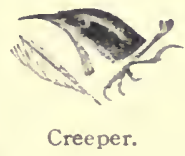

Family CERTHIIDE. Creepers.

See page 266.

Bill, as illustrated; back, olive green;

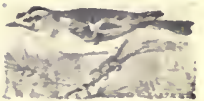
bill, less than .50 inch long. Two species: both males and one of the females have brilliant red or yellow crown patch; the other female has crown, dull green, like back.

Family SYLVIID E. Subfamily REGULIN $Æ$. Kinglets. See page 260 .

SECTION 2. First primary, more than half as long as third. PART 1. Tip of upper mandible, with small but distinct hook or notch.

Bill, flattened, wide at base; tip, with small hook; numerous black bristles at base of bill; back of tarsus, rounded; wings, longer than tail; first primary, never very short.

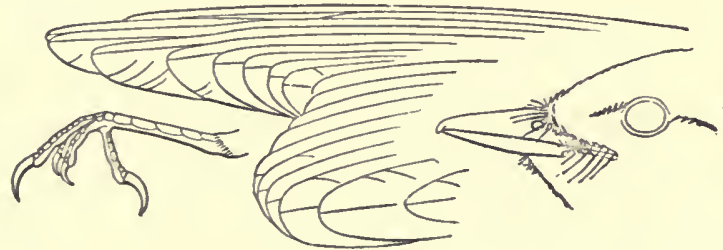

Flycatcher.

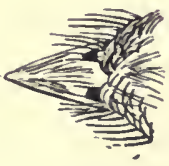

Top of bill. Side of bill. Flycatcher.

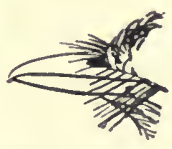

Family TYRANNIDÆ. Flycatchers.

See page r 70 .

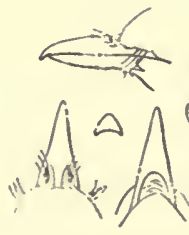

Bill of Vireo.

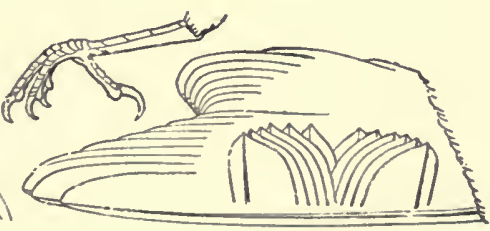

Vireo. 
i 20 Field Museum of Natural History-Zoölogy, Vol. IX.

Bill, very slightly hooked, not wide and flat at base, as in the Flycatchers; toes, joined together at base. Plain colored birds, usually greenish or grayish, but often show a faint wash of yellow on under parts; tail, always without white spots; first primary, variable. very short in some species, in others nearly as long as second.

Family VIREONID E. Vireos.

See page 227 .

PART 2. Tip of upper mandible, not notched or hooked.

First primary, not short, never less than two thirds as long as second or third; bill, stout and conical; nostrils, high near the culmen; primaries, 9; tarsus, flattened behind.
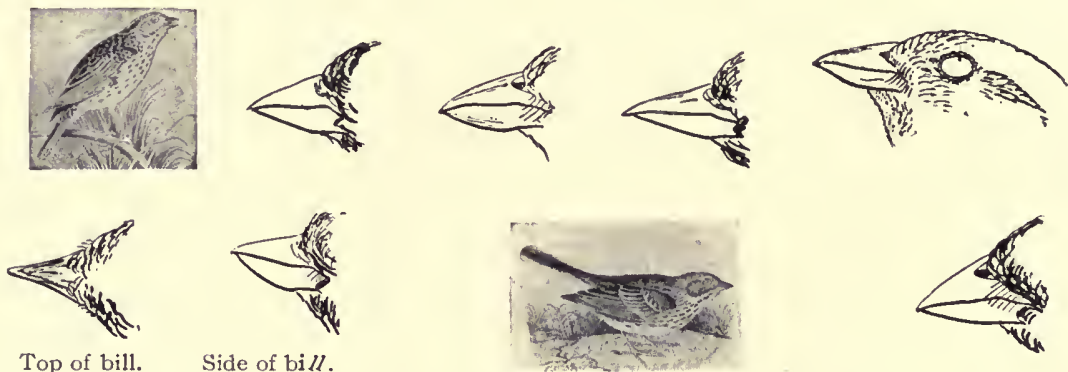

Top of bill. Side of bi $l l$.

Family FRINGILLIDÆ. Sparrows, Finches, Buntings, etc. See page 190 .

First primary, not short, never less than

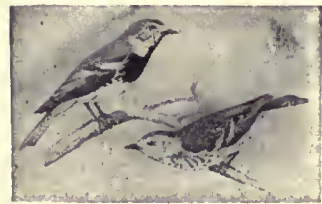
two thirds as long as third, and often nearly the same length; bill, slender and pointed; back of tarsus, thin and sharp, not rounded as in front; hind toe and claw, not longer than middle toe and claw.
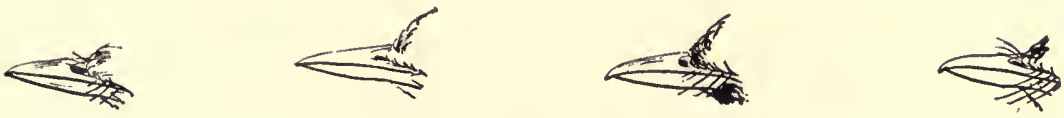

Family MNIOTILTID E. Warblers. See page 23 I. 
* GROUP 3. Birds having wings measuring from 2.75 to 3.25 inches long.

SECTION 1. First primary less than half as long as third.

PART 1. A small but distinct hook or notch at tip of upper mandible.

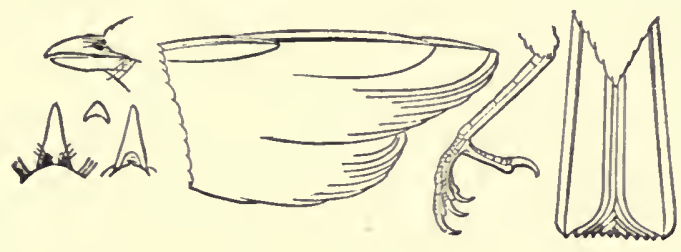

Bill, very slightly hooked; primaries, Io, the first often very short; toes, joined together at base. Plain colored birds, usually greenish or grayish, but often show a faint wash of yellow on underparts; tail, always without white spots.

Family VIREONIDA. Vireos.

See page 227 .

PART 2. Tip of upper mandible, not notched or hooked.

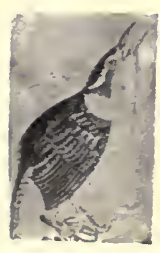

Bill, as illustrated; back, brown; rump, with concealed white spots; outer tail feathers, shortest; tarsus. scutellate.

Family TROGLODYTIDÆ. Wrens. See page 262 .

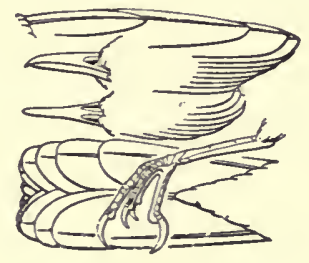

Bill, as illustrated; back, gray or bluish gray; nostrils, concealed by tufts of bristly feathers.

Family SITTID $\&$. Nuthatches. See page 267 .

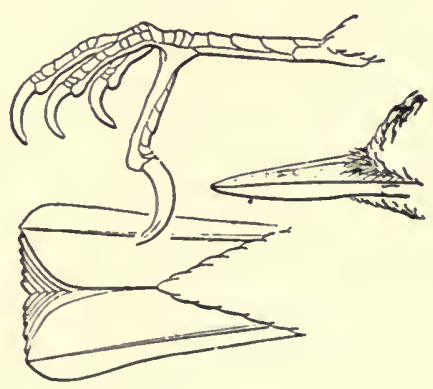

* For directions for measurement, see page 2 r. 
i22 Field Museum of Natural History - Zoölogy, Vol. IX.

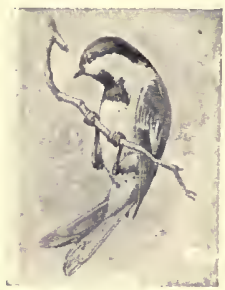

Bill, as illustrated; throat, black ; crown, black and no rufous brown on sides (Chickadee), or forehead, black; sides, with rufous brown (Titmouse).

\section{Family PARIDÆ. Titmice and Chickadees. See page 268 .}

SECTION 2. First primary, not short, always more than half as long as third.

PART 1. Tip of upper mandible, with small but distinct hook or notch.

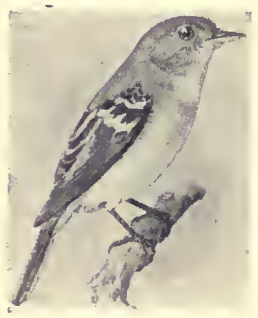

Bill, flattened and wide at base; numerous black bristles at base of bill; back of tarsus, rounded; wing, longer than tail.

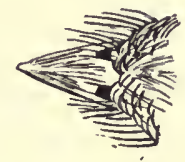

Top of bill.

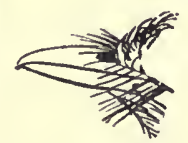

Side of bill.

Family TYRANNID $Æ$. Flycatchers. See page r 70.

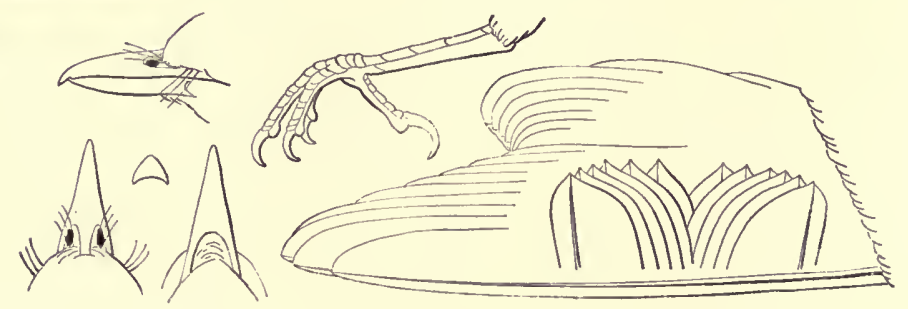

Bill, very slightly hooked or notched at tip; not flattened at base, as in the Flycatchers; toes, joined at base. Plain colored birds, usually greenish or grayish, at times, with wash of yellow on under parts; no white on tail.

Family VIREONIDÆE. Vireos. See page 227 .

PART 2. Tip of upper mandible not notched or hooked.

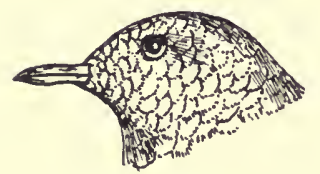

Toes, 4 ; nostrils, opening into a soft, fleshy membrane; tarsus, usually shorter than toes.

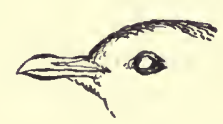

Family COLUMBIDA.

Pigeons and Doves.

See page 139 . 
Bill, pointed; first primary, not short; base of bill, extending upon and dividing the feathers of the forehead; nostrils, exposed; outer tail feathers, shorter than middle feathers. Family ICTERIDE. Orioles.
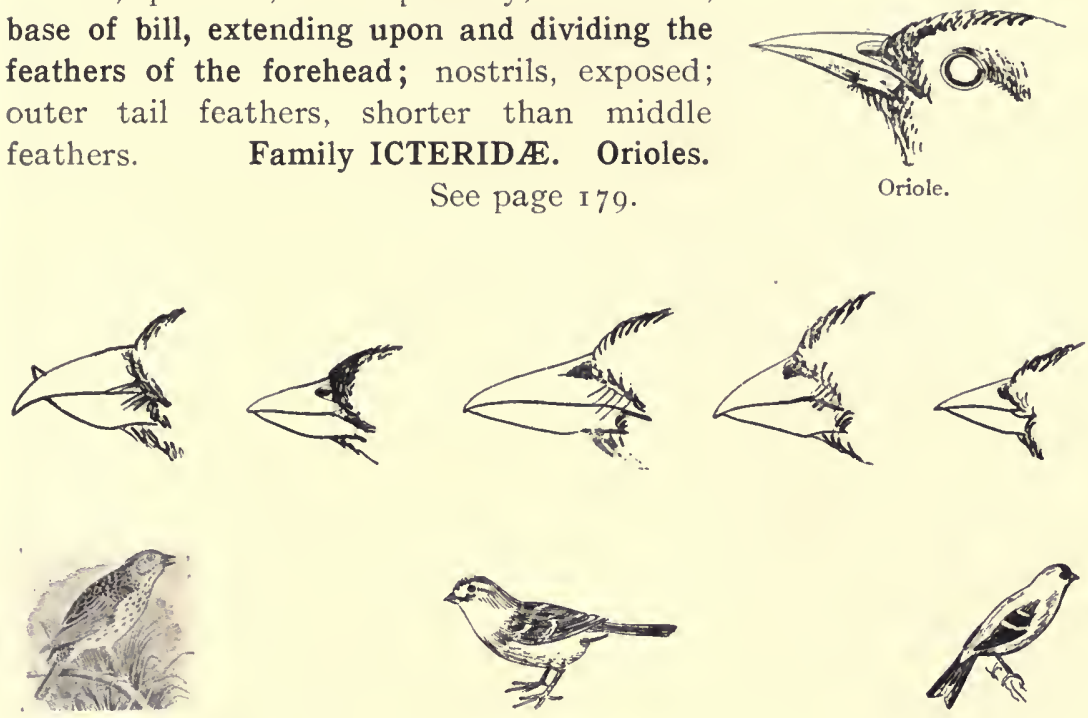

First primary, not short, never less than two thirds as long as second or third; bill, stout and conical; nostrils, near the culmen; primaries, 9; tarsus, flattened behind.

Family FRINGILLIDE. Sparrows, Finches, Crossbills, and Buntings.

See page 190 .
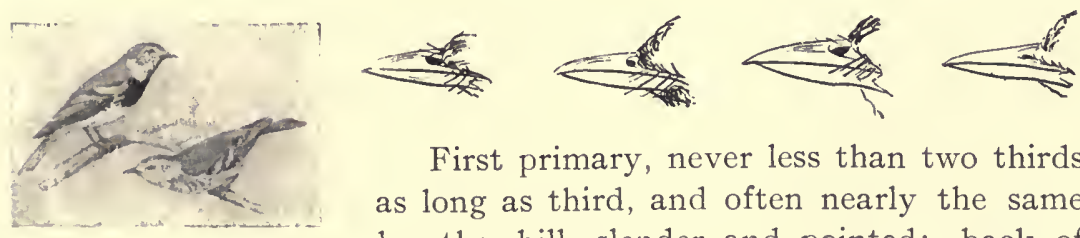

First primary, never less than two thirds as long as third, and often nearly the same length; bill, slender and pointed; back of tarsus, thin and sharp, not rounded, as in front; hind toe and claw, not longer than middle toe and claw.

Family MNIOTILTIDE. Warblers.

See page $23 \mathrm{I}$.

Bill, slender; first primary, not short, the first, second and third being about equal in length; hind toe and claw, longer than middle toe and claw; hind toe nail, long, in this somewhat resembling Larks, 
i 24 Field Museum of Natural History-Zoölogy, Vol. IX.

but no tufts of hair-like feathers over nostrils. Usually observed in small flocks on the ground in open places.

Family MOTACILLIDÆ. Wagtails, Pipits, Titlarks, etc. See page $26 r$.

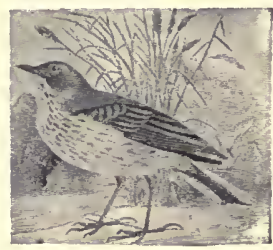

Titlark.

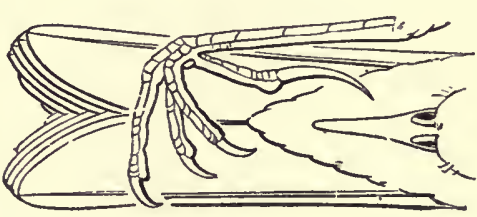

Titlark.

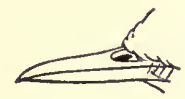

* GROUP 4. Birds having wings from 3.25 to 9.50 inches long. SECTION 1. Bill, with strong hook; toes armed with talons.
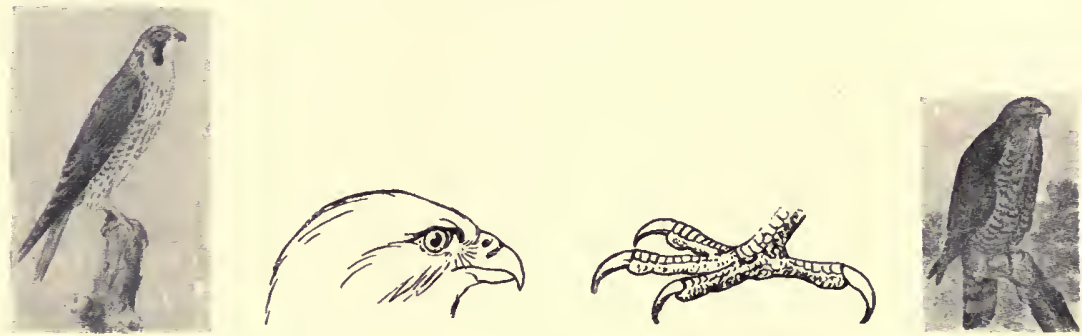

Eyes, not surrounded by radial disk of feathers, as in the Owls; toes, armed with talons; head, not bare.

Family FALCONID E. Hawks, Falcons, Eagles, etc. See page 143 .

Eyes, surrounded by radiated disk of feathers; plumage, soft; bill, hooked; toes, armed with talons.
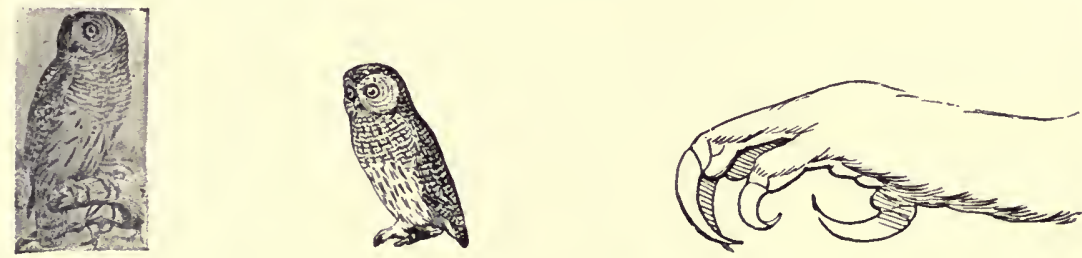

Family STRIGIDE. Horned Owls, Hoot Owls. See page i 55 .

* For directions for measurement. see page $2 \mathrm{r}$. 
SECTION 2. Upper mandible, with distinct notch and hook at tip, but feet, not armed with talons.
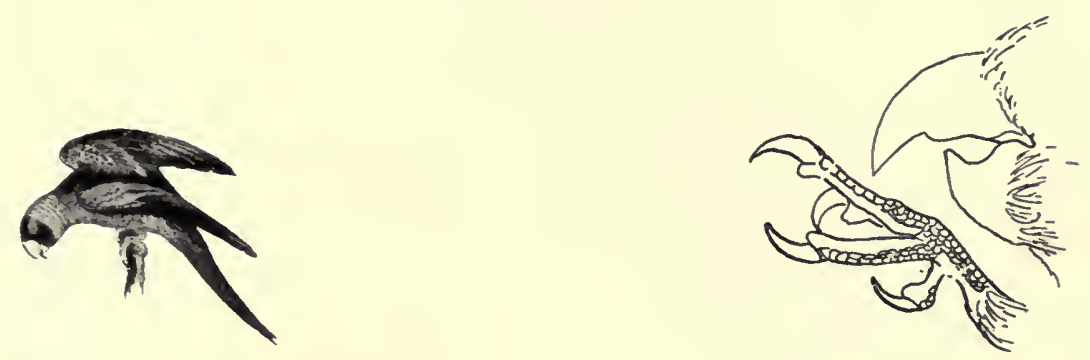

Toes, four, zygodactyle (two in front, two behind); bill, with cere (skin-like covering over base of bill).

Family PSITTACID瓜. Parrots and Paroquets. See page 160.

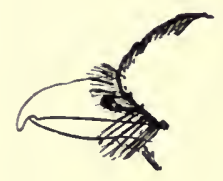

Bill, strong, notched near the end, and decidedly hooked; tarsus, scutellate; tail, rounded. But two species occur with us, both grayish birds with blackish wings and tail, and a dark stripe through the eye.

Family LANIID E. Shrikes. See page 226.

Bill, flattened and wide at base; tip, with small hook; numerous black bristles at base of bill; back of tarsus, rounded; wings, longer than tail; first primary, not very short, usually longer than the sixth.

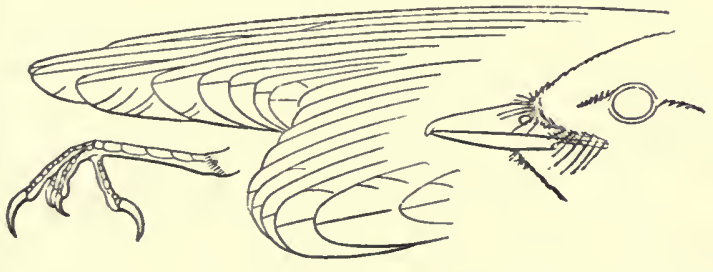

Flycatcher.
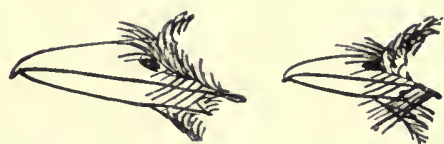

Family TYRANNID E. Flycatchers. See page I 70 . 
i26 Field Museum of Natural History-Zoölogy, Vol. IX.

SECTION 3. Upper mandible, not notched and hooked at tip.

PART 1. First primary, less than one-half as long as third.
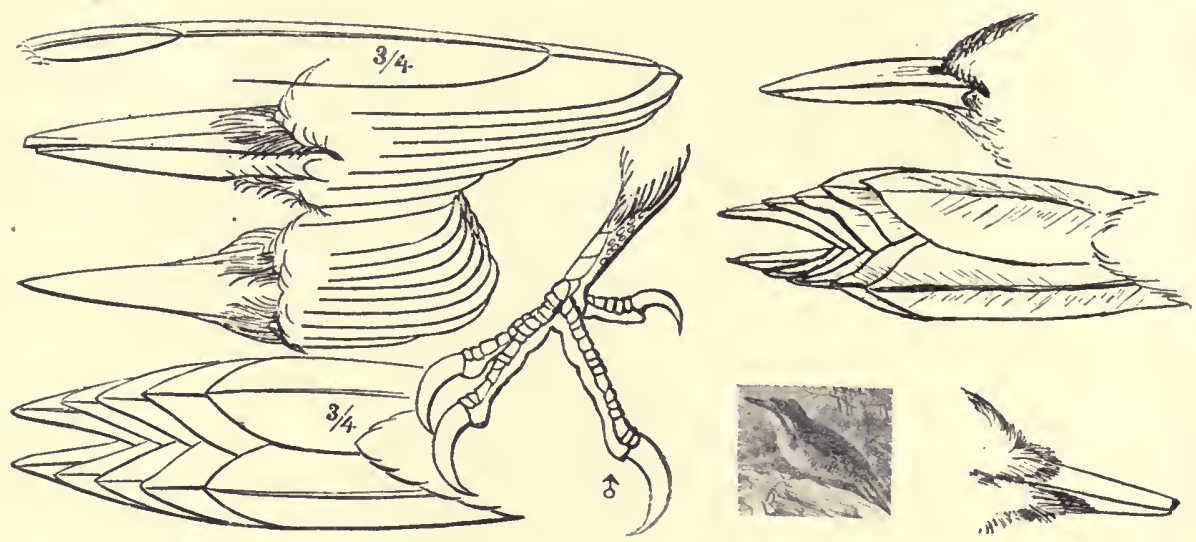

Toes, four, two in front and two behind; or toes, three, two in front and one behind; tail feathers, stiff and pointed. (If tail feathers are not stiff and pointed, see Nuthatches, next family.)

Order PICI. Woodpeckers. Family PICID E. Woodpeckers. See page 163 .

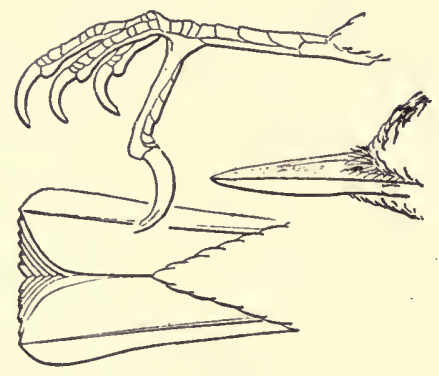

Bill, as illustrated; nostrils, concealed by bristly tufts; tarsus, scutellate; first primary, very short; tail feathers, not stiff and pointed. (If tail feathers are stiff and pointed, look for the bird under Family Picidæ.)

Family SITTID $Æ$. Nuthatches. See page 267 .

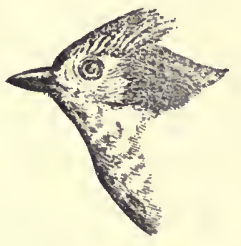

Bill, as illustrated; nostrils, concealed by bristly tufts of hair-like feathers; first primary, short; forehead, black; back, gray; head, with more or less crest; sides of body, washed with brown (Tufted Titmouse).

Family PARID $\approx$. Chickadees and Titmice. See page 268 . 
First primary, about onehalf as long as third; feet, zygodactyle (toes, two in front, two behind); outer tail feathers, very much shorter than middle feathers.

Family CUCULID $Æ$. Cuckoos.

See page r6r.

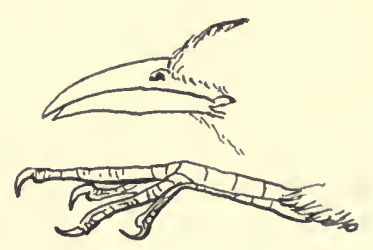

Bill, stout and strong; the nostrils concealed by coarse hair-like feathers; outer tail feathers, shorter than middle feathers;

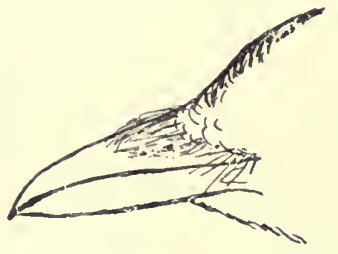
first primary, decidedly less than half as long as third; tail, over seven inches long (Magpies); first primary, about half as long as third; tail, less than seven inches long (Jays).

Family CORVID瓜. Subfamily GARRULINÆ. Magpies and Jays.

See page 176 .

Tail, rounded; the outer feathers, shorter than middle ones; first primary, less than two-thirds as long as third; second primary, much shorter than third; tarsus, scutellate.
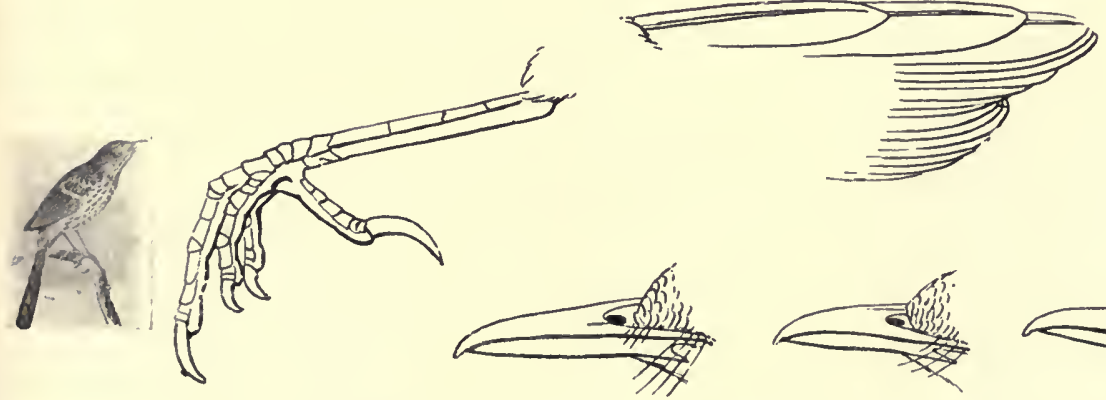

Family MIMIDÆ. Thrashers, Mocking-birds, Cat-birds, etc.

See page 265 .

First primary, very short; tarsus, booted (no scales showing, except near the toes ); bill, shorter than head; wing, over 3.50 inches long. 
i28 Field Museum of Natural History-Zoölogy, Vol. IX.

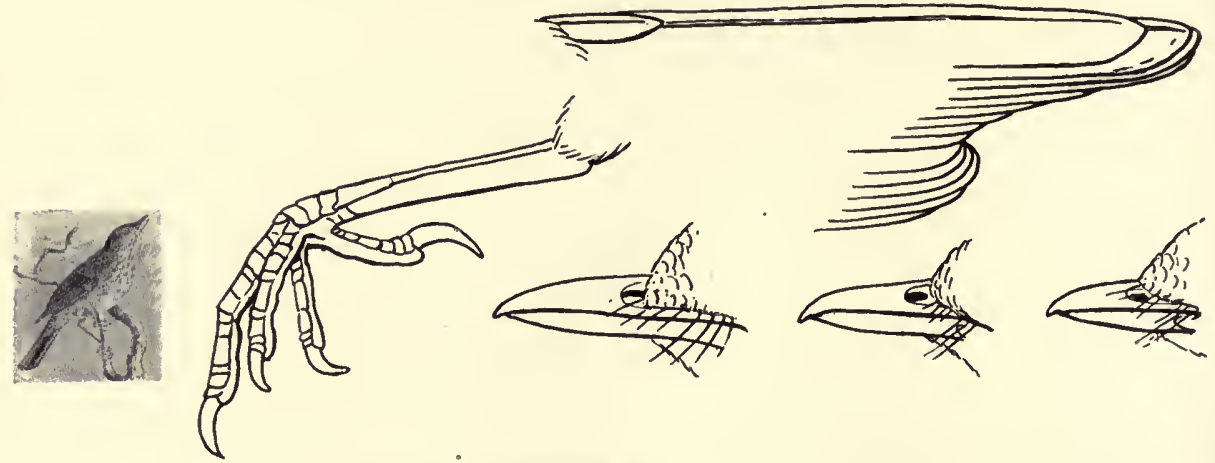

Family TURDID $Æ$. Thrushes, Robins, Bluebirds. See page 27 I.

PART 2. First primary, more than half as long as third.
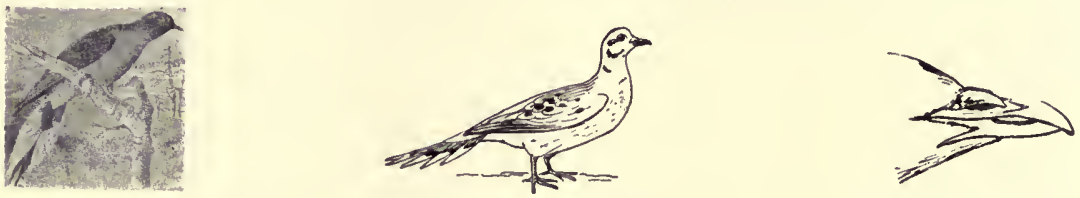

Toes, four, hind toe not elevated above the rest; nostril, opening into a soft fleshy membrane; tarsus, usually shorter than the toes.

- Family COLUMBIDÆ. Pigeons and Doves.

See page r 39 .

Toes, four, the hind toe elevated above the rest; bill, rather short and stout; wing, short and somewhat rounded, the outer primaries curved.
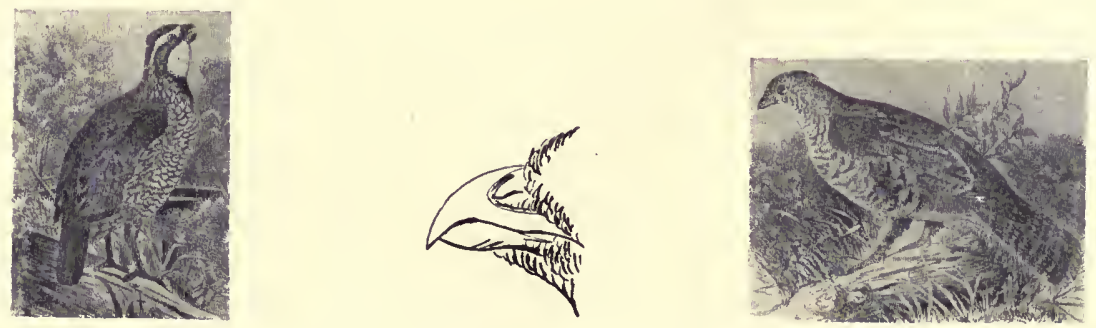

Family TETRAONIDÆ. Grouse and Quail.

(a) Tarsus, feathered; wing, over 5.50 inches long.

Subfamily TETRAONINÆ. Grouse.

See page 136 . 
Jan., 1909. Birds of Illinois and Wisconsin-Cory.

(b) Tarsus, bare; wing, less than 5.50 inches long.

Subfamily PERDICINÆ. Quail. Partridges. See page 136 .

Feet, small and weak; front toes, sometimes webbed at base; primaries, ten; mouth, large; bill, very small in comparison with size of bird; middle toe nail, with comb-like edge.

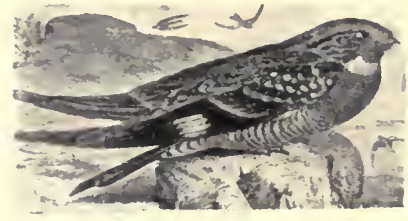

Family CAPRIMULGIDÆ. Whip-poor-wills, Nighthawks, etc. See page 168 .

Bill, small, flattened, and somewhat triangular in shape, the gape very wide; wings, very long, usually extending beyond the tail.

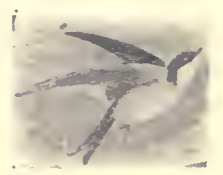

Swallow.

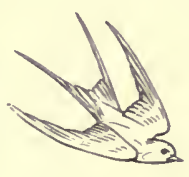

Swallow:

(Chimney Swifts, which belong to a very different family, are often mistaken for Swallows when seen flying about; they are smoky black and the shafts of the tail feathers extend in spines beyond the webs. See next Family.)

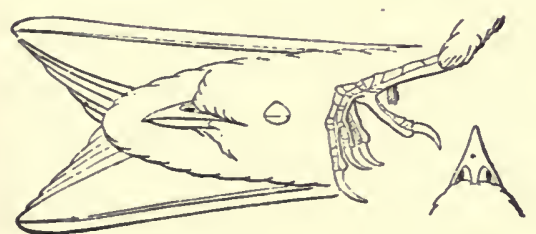

Swallow.

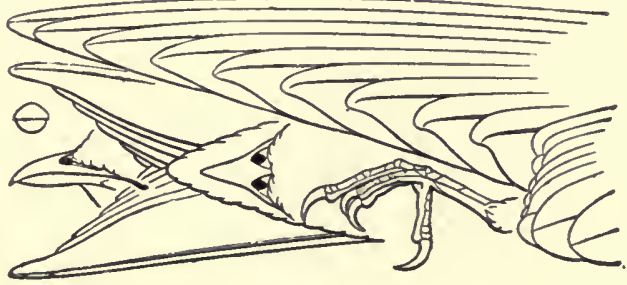

Martin.

Family HIRUNDINIDÆ. Swallows and Martins.

See page 222.

Plumage, smoky black; shafts of tail feathers, extending beyond the web in sharp spines. Sometimes mistaken for Swallows by persons unfamiliar with birds. 
izo Field Museum of Natural History - Zoölogy, Vol. iX.
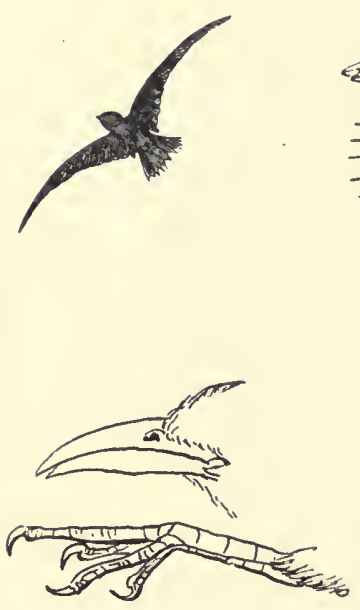

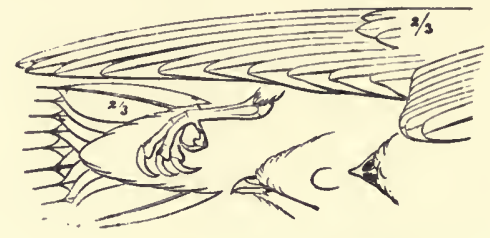

Family MICROPODIDÆ. Swifts.

See page 169 .

First primary, about half as long as third; feet, zygodactyle (toes, two in front, two behind); outer tail feathers, very much shorter than middle feathers.

Family CUCULIDÆ. Cuckoos.

See page I6r.

Feet, syndactyle; toes, four, the middle and outer ones joined, being fastened together for more than half their length.
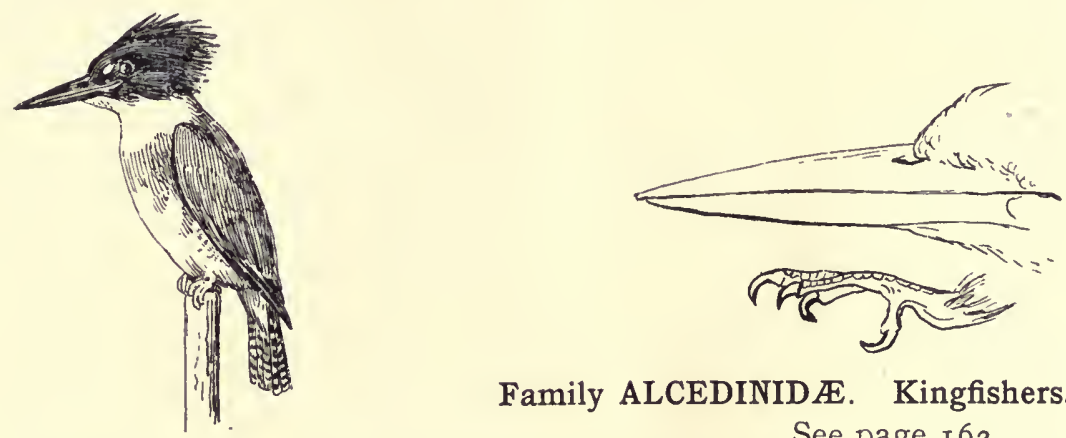

Family ALCEDINID $Æ$. Kingfishers. See page 162 .

First primary, much shorter than second, always less than threefourths as long as third; fourth, or fifth primary, longest; bill, stout and strong; the nostrils, concealed by coarse, hair-like feathers; outer tail feathers, shorter than middle feathers.
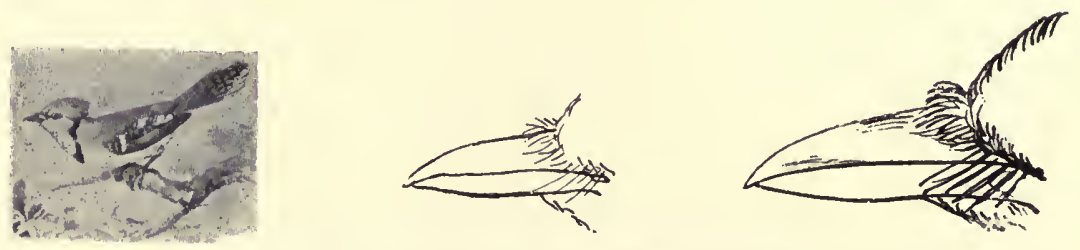

Family CORVIDÆ. Subfamily GARRULIN $Æ$. Jays. See page 176 . 
i32 Field Museum of Natural History-Zoölogy, Vol. IX.

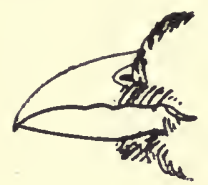

Bill, somewhat fringilline, but having a small " tooth," near the middle of the edge of upper mandible; primaries, nine; tarsus, scutellate. But two species (a third accidental): Males, bright red, one with black wings; one female is olive green above, and yellowish green below; the other is olive green above, and the under parts, dull orange yellow or buff yellow. (If bird does not agree with above description, see Fringillidæ.)

Family TANGARID $Æ$. Tanagers.

See page 220 .

Bill, without notch; head, with crest; primaries, ten; tarsus, shorter than middle toe and claw; a black stripe from forehead through the eye; inner primaries and tail feathers, often tipped with little hard red bits, like minute drops of sealing wax; general plumage, vinaceous gray brown; tail, tipped with yellow.

Family BOMBYCILLIDÆ. Waxwings, Cedar Birds. See page 225 .

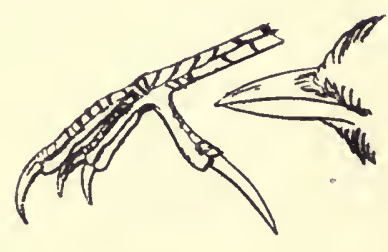

Bill, pointed, and somewhat rounded; back of tarsus, rounded; hind toe nail, elongated, equal or longer than the toe; nostrils, nearly or quite concealed by tufts of hair-like feathers; wing, over 4 inches long.

Family ALAUDID $Æ$. Larks.

See page 175 .
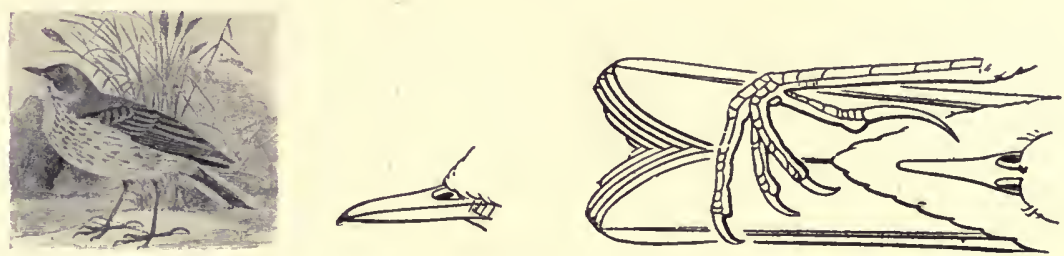

Bill, slender; first primary, not short, the first, second, and third, being about equal in length; hind toe nail, long, in this somewhat resembling the larks, but no tufts of hair-like feathers over nostrils; wing, less than 4 inches long.

Family MOTACILLID $Æ$. Wagtails, Pipits, Titlarks, etc.

See page $26 \mathrm{I}$. 
Small birds, wing, less than 3.75 inches long; first primary, not short, never less than two-thirds as long as third, and often nearly the same length; bill, slender and pointed; back of tarsus, thin and sharp, not rounded as in front; hind toe and claw, not longer than middle toe and claw.
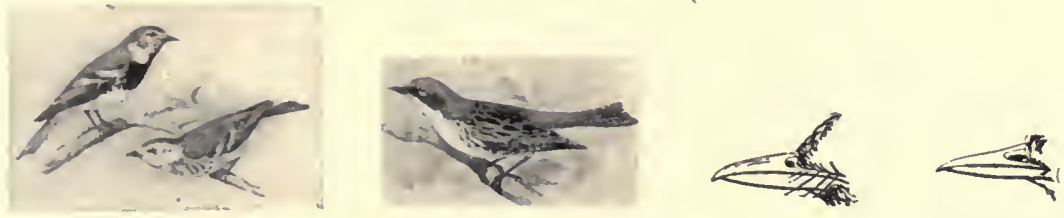

Family MNIOTILTIDE. Warblers. See page $23 \mathrm{I}$.

* GROUP 5. Birds having wings over 9.50 inches long.

IVing, less than 12 inches long; toes, four; hind toe, elevated above the rest; bill, stout; wing, rounded, the outer primaries curved, body feathers, double.

Family TETRAONIDE. Grouse. See page 136 .

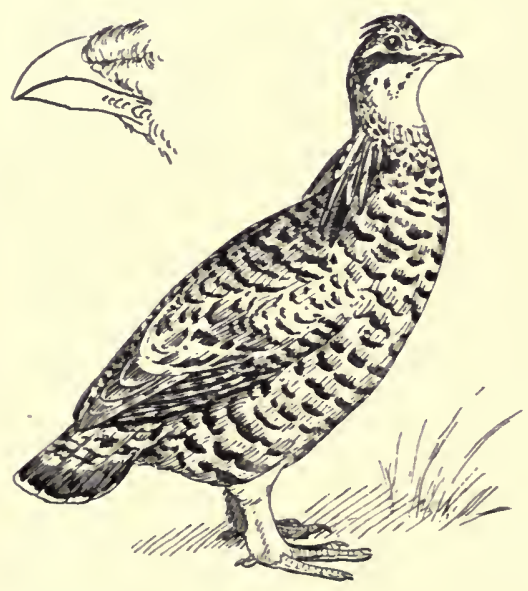

Grouse.

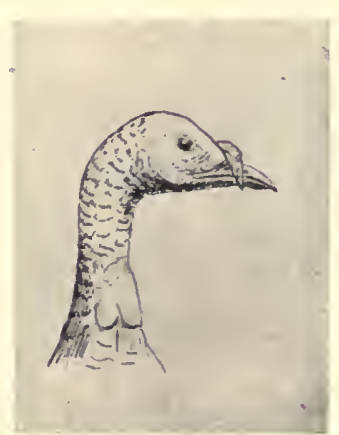

Turkey.

Wing, over I 2 inches long; toes, four, the hind toe elevated above the rest; bill, rather short and stout; wing, short and somewhat rounded, the outer primaries curved.

Family PHASIANIDEE. Subfamily MELEAGRINÆ. Turkeys. See page I39.

* Fol directions for measurement. see page 21 . 
i34 Field Museum of Natural History-Zoölogy, Vol. IX.
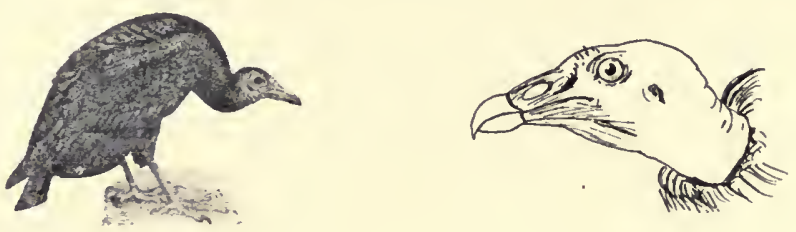

Size, large; eyes, not surrounded by radiated disk of feathers; plumage, black or dark brown; hind toe, short; claws, not sharp; head, bare in adult.

Family CATHARTIDE. Vultures. See page 14 I.
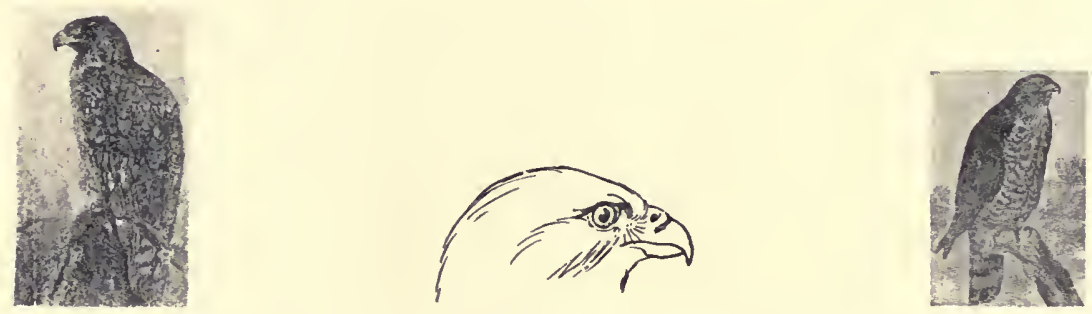

Eyes, not surrounded by radiated disk of feathers, as in the Owls; toes, armed with talons; head, not bare.

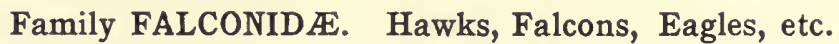
See page 143 .
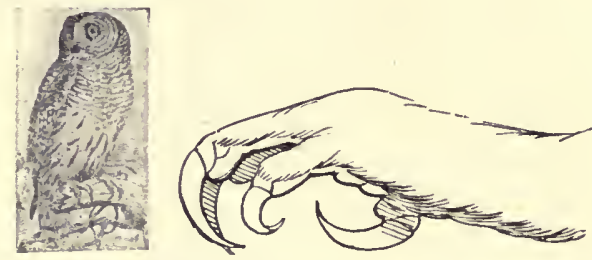

Eyes, surrounded by radiated disk of feathers; plumage, soft; bill, hooked; toes, armed with talons.

(a) Middle toe nail with comb-like edge.

FAMILY ALUCONIDE. Barn Owls. See page 157 .

(b) Middle toe nail without. comb-like edge.

Family STRIGIDÆ. Horned Owls, Hoot Owls. See page 155 . 
Toes, four, two in front and two behind (zygodactyle); tail feathers, stiff and pointed.

Family PICIDÆ. Woodpeckers.

See page 163 .
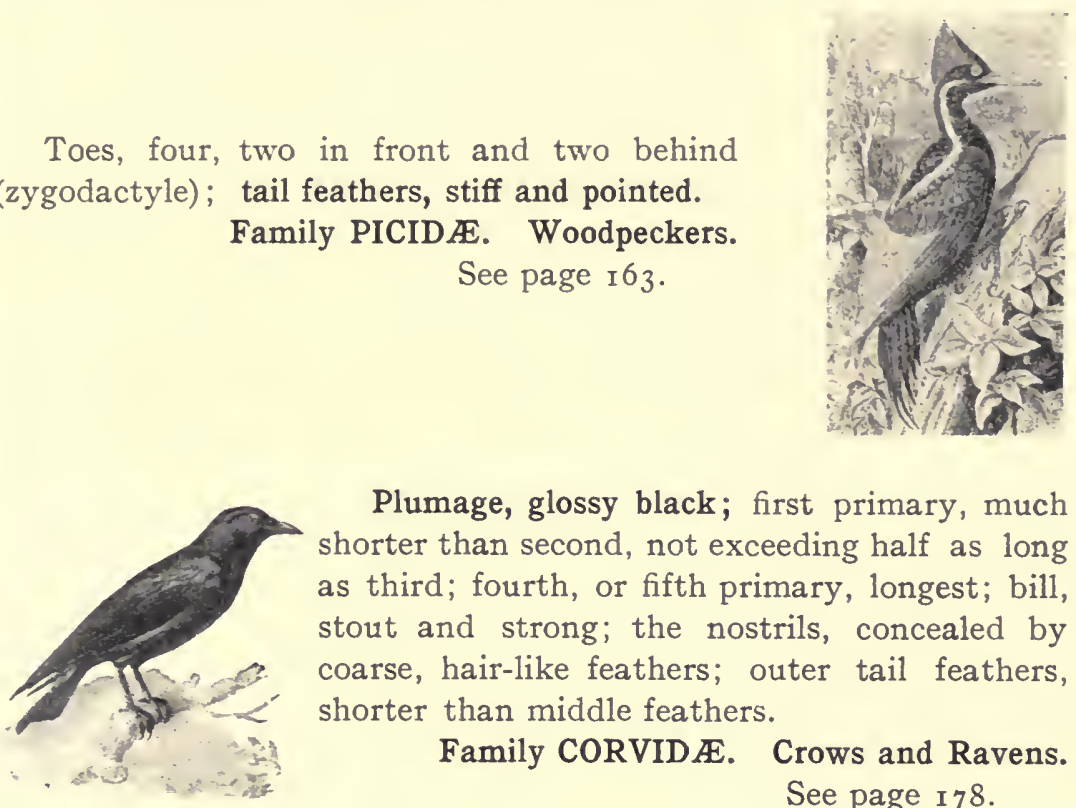

Plumage, glossy black; first primary, much shorter than second, not exceeding half as long as third; fourth, or fifth primary, longest; bill, stout and strong; the nostrils, concealed by coarse, hair-like feathers; outer tail feathers, shorter than middle feathers.

Family CORVID $Æ$. Crows and Ravens. See page 178 . 


\section{LAND BIRDS. \\ KEY TO THE SPECIES.}

\section{Family TETRAONIDÆ. Grouse, Partridges, Quails, etc.}

Toes, four, the hind toe elevated above the rest; bill, rather short and stout; wing, short and somewhat rounded, the outer primaries curved; wing, less than $\mathrm{I} 2$ inches long; body feathers, double. In Eastern North America divided into two subfamilies, which may be recognized as follows:

(a) Tarsus, not feathered; wing, less than 6 inches long (carpus to tip). Subfamily PERDICINÆ. "Quail" and Partridges.

(b) Tarsus, more or less feathered; wing, more than 6 , but less than $\mathrm{I}_{2}$ inches long.

Subfamily TETRAONINÆ. Grouse, Ptarmigan,"etc.

GROUP 1. Wing, less than 5 inches long.

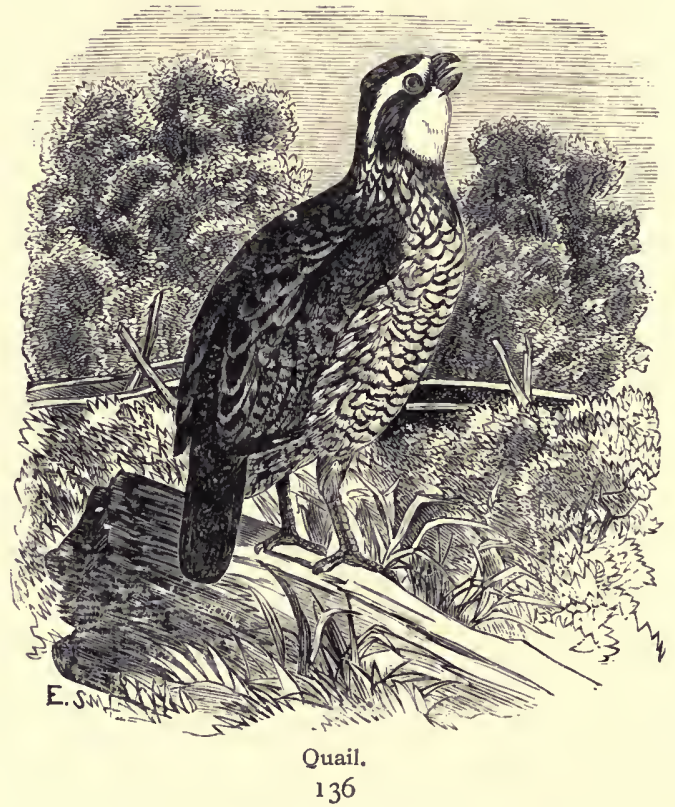


Jan., Ig09. Birds of Illinois and Wisconsin-Cory.

Under parts, white, black, and rufous; throat, white (male); throat, buff brown (female).

Colinus virginianus, and races.

Quail. Bob-white.

See No. I 40.

* GROUP 2. Wing, more than 5 inches long.

SECTION 1. The following species do not have the greater portion of the primaries white:-

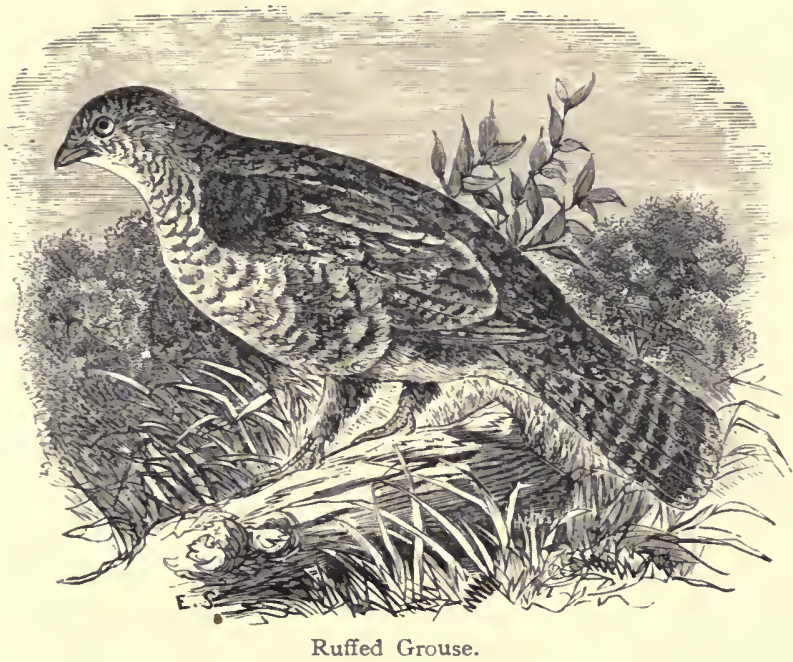

A tuft of black feathers on sides of the neck; tarsus, not entirely feathered; axillary plumes, white, barred with brown.

Bonasa umbellus, and races. Ruffed Grouse. "Partridge." See Nos. I 42, I $42 \mathrm{a}$.

Tarsus, entirely feathered; axillary plumes, entirely white; no elongated tufts of feathers on sides of neck; tail, pointed.

Pedicecetes phasianellus campestris.

Prairie Sharp-tailed Grouse.

See No. I45.

Tarsus, entirely feathered; axillary plumes, white; sometimes with faint bars near tip; a tuft of ten or more elongated feathers on each side of the neck; tail, not pointed. Tympanuchus americanus.

Prairie Hen. Pinnated Grouse.

See No. I 44 .

\footnotetext{
* For directions for measurement, see page $2 \mathrm{r}$.
} 
i38 Field Museum of Natural History - Zoölogy, Vol. IX.

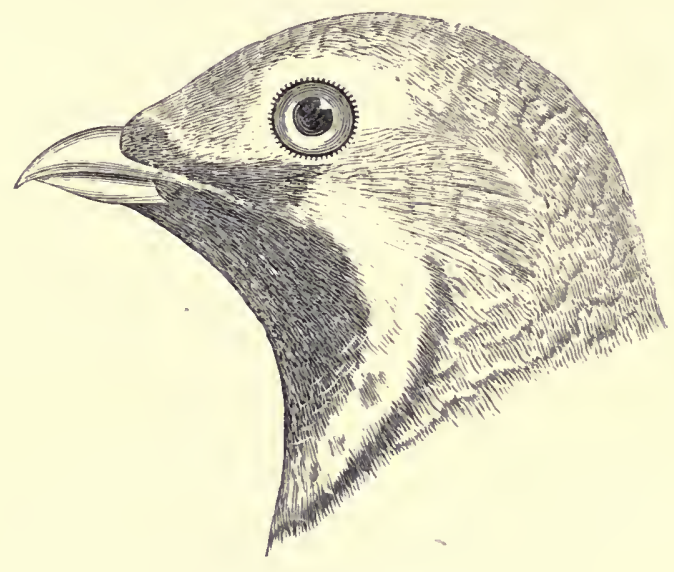

Canada Grouse (Male).

Tarsus, entirely feathered; axillary plumes, smoky gray, with white shafts, and tipped with white; the male has the breast black; the female has the breast tawny brown, black, and white.

Canachites canadensis.

Canada Grouse. Spruce Partridge. See No. I4I.

SECTION 2. The following species have the greater portion of the primaries white :-

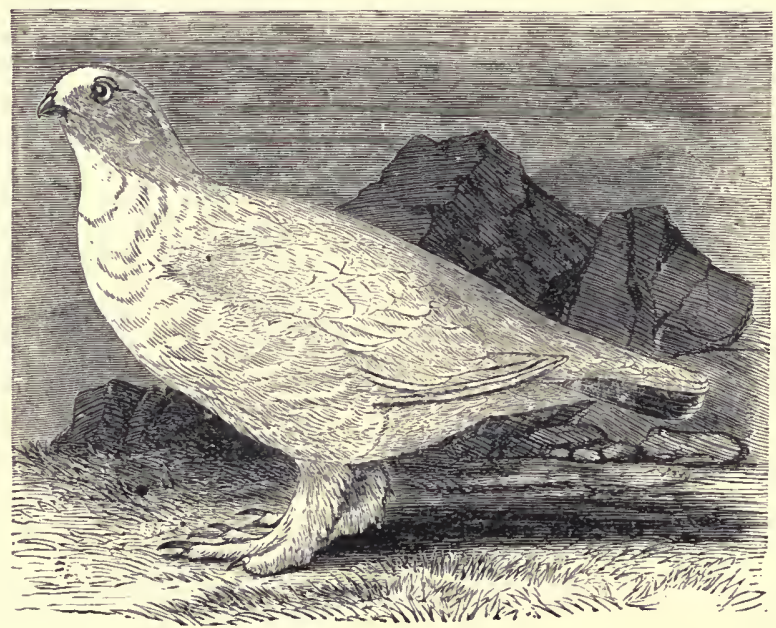

Willow Ptarmigan. 
Winter plumage, mostly white; no black on lores or shafts of secondaries; summer plumage, a mixture of black, rufous, tawny, and buffy white; depth of bill, at base .40 or more.

Lagopus lagopus. Willow Ptarmigan. See No. 443 .

\section{Family PHASIANIDÆ. Pheasants, Turkeys, etc.}

Subfamily MELEAGRINÆ. Turkeys.

Toes, four, the hind toe elevated above the rest; bill, rather short and stout; wing, short and somewhat rounded, the outer primaries curved; wing, more than 12 inches long.

Resembles domestic Turkey, but legs usually pink red; primaries, broadly barred with white; upper tail coverts and tail, tipped with chestnut brown.

Meleagris gallopavo silvestris.

Wild Turkey.

See No. 146 .

\section{Family COLUMBID瓜. Pigeons and Doves.}

Toes, four, hind toe not elevated above the rest; nostril, opening into a soft fleshy membrane; tarsus, usually shorter than the toes; wings, rather long and flat.

GROUP 1. Wing, less than 6.50 inches long.

SECTION 1. Primaries, dark slaty brown or blackish.

Upper parts, grayish olive; rump, grayish olive; crown, tinged with slate color; sides of neck, with purplish metallic reflections; a bluish black spot on lower edge of ear coverts; tail, pointed; middle tail feathers, much longer than outer feathers; length, less than I 3 inches.

Zenaidura macroura carolinensis.

Mourning Dove.

See No. I 48 . 
i 40 Field Museum of Natural History-Zoölogy, Vol. IX.
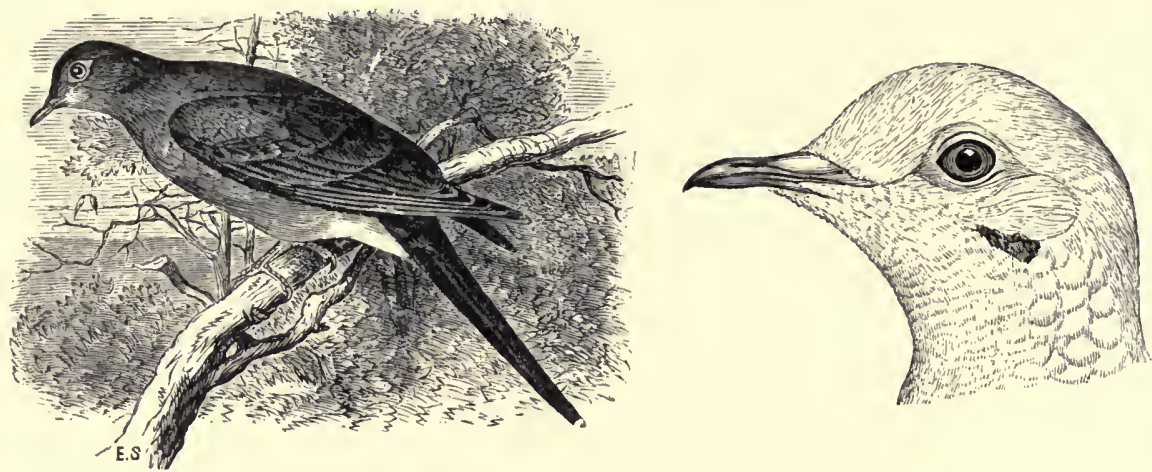

Mourning Dove.

* GROUP 2. Wing, over 6.50 inches long.

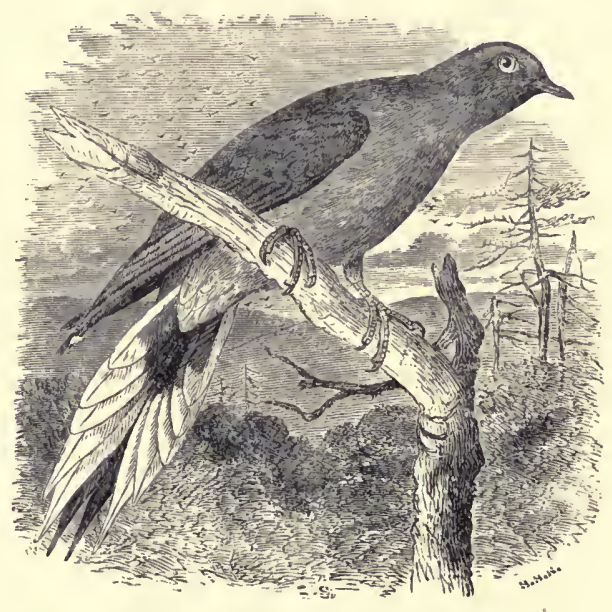

Passenger Pigeon.

Decidedly larger than the Mourning Dove; length, over I 4 inches; wing, over 7 inches; most of back and rump, bluish slate color; tail, pointed and rather long; under tail coverts, white; under parts vinaceous, shading into white on the lower belly (male). Female, similar, but duller; breast, pale grayish brown; immature birds have the primaries marked with rufous.

Ectopistes migratorius. Passenger Pigeon. See No. 147 .

* For directions for measurement, see page $2 \mathrm{r}$. 


\section{Family CATHARTIDÆ. American Vultures.}

Size, large; plumage, black or dark brown; hind toe, short; claws, not sharp; head, bare in adult; nostrils, large.

GROUP 1. Wing, from 14 to $2 \mathrm{I}$ inches long. SECTION 1. Wing, less than 17 inches long.

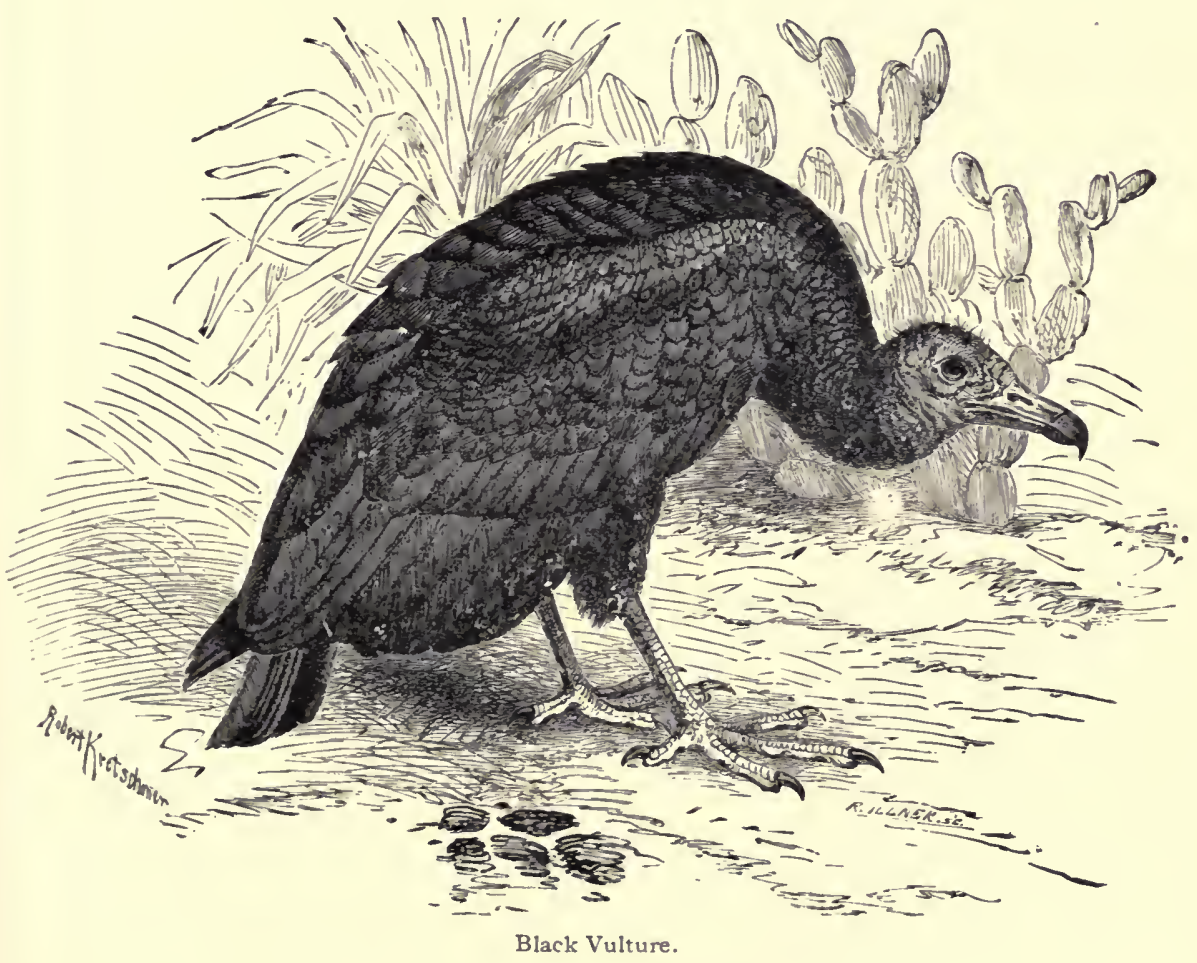

Head and fore-neck, bare; skin of head, blackish; general plumage, black; primaries, hoary white beneath. Catharista urubu. Black Vulture. Carrion Crow. See No. I 50. 
i 42 Field Museum of Natural History-Zoölogy, Vol. IX.

SECTION 2. Wing, over 17 inches long.

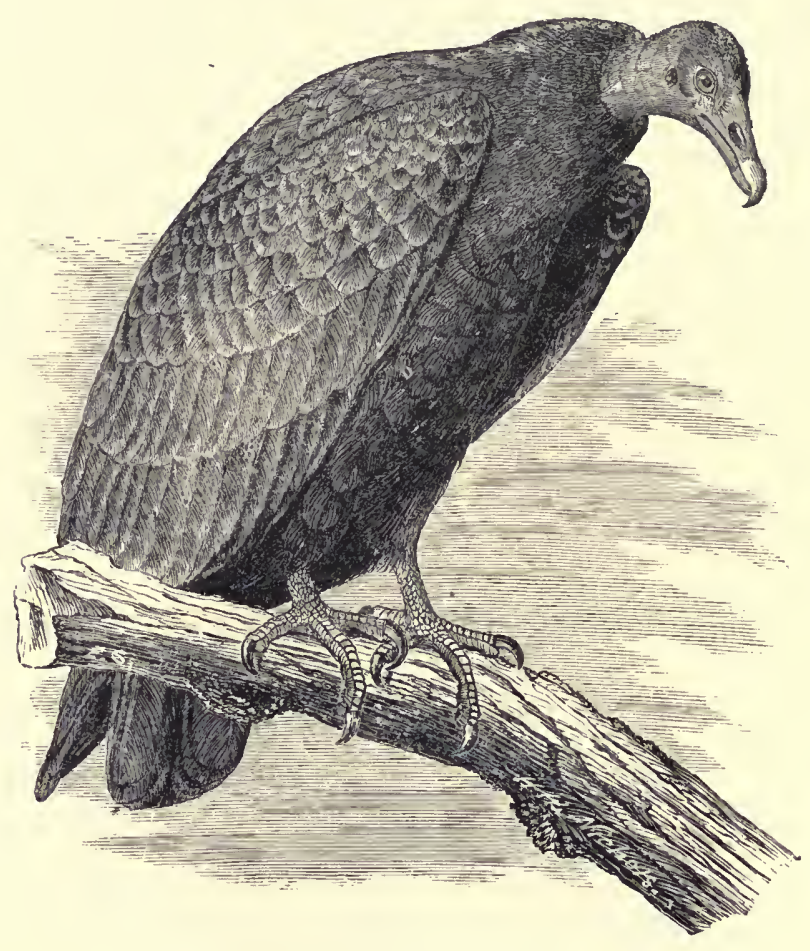

Turkey Vulture.

Head and fore-neck, bare; skin of head, red; general plumage, brownish black or dark brown; bill, whitish; immature birds have the head feathered.

Cathartes aura septentrionalis. Turkey Vulture. Turkey Buzzard. See No. I49. 


\section{INDEX TO KEY.}

\section{Family FALCONIDÆ. Hawks, Falcons, Eagles, Kites, etc.}

Group r. Wing, less than 8.50 inches long. See page 145 .

Group 2. Wing, 8.50 to 9.50 inches long. See page $\mathrm{r}_{4} 6$.

Group 3. Wing, 9.50 to $\mathrm{I}_{3}$ inches long. See page 147 .

Section r. Species having second primary longest. See page I 47.

Section 2. Species having third primary longest. See page $x_{47}$.

Section 3. Species having fourth primary longest. See page 147 .

Group 4. Wing, $\mathrm{I}_{3}$ to $\mathrm{I}_{5}$ inches long. See page $\mathrm{I}_{4} 8$.

Section r. Second primary, longest; first and second primaries, emarginate or notched. See page 148 .

Section 2. Third primary, longest; face, bare. See page I 49.

Section 3. Fourth primary, longest; upper tail coverts, white. See page 149.

Section 4. Fourth primary, longest; upper tail coverts, not white. See page 149 .

Group 5. Wing, $I_{5}$ to $I_{7}$ inches long. See page $r_{5} 0$.

Section 1. Second primary, longest; only first primary, notched. See page 150 .

Section 2. Second primary, longest; first and second primary, notched. See page ${ }_{15} \mathrm{r}$.

Section 3. Third primary, longest. See page $\mathrm{I}_{5} \mathrm{I}$.

Section 4. Fourth primary, longest; four or five outer primaries, notched; upper tail coverts, white. See page $5_{52}$.

Section 5. Fourth primary longest; four or five outer primaries, notched; upper tail coverts, not white; tarsus, partly feathered. See page $\mathbf{r}_{5}{ }^{2}$.

Section 6. Fourth primary, longest; four or five outer primaries, notched; tarsus, entirely feathered. See page 152 .

Section 7. Fourth primary, longest; three outer primaries, notched. See page 153 .

Group 6. Wing, 17 to $2 \mathrm{I}$ inches long. See page $\mathrm{I}_{53}$.

Section 1. Third primary, longest; tarsus, wholly feathered. See page 153 .

Section 2. Third primary longest; tarsus, not wholly feathered. See page 153.

Section 3. Fourth primary, longest; tarsus, partly feathered. See page 154.

Section 4. Fourth primary, longest; tarsus, entirely feathered. See page 154.

Group 7. Wing, over $2 \mathrm{I}$ inches long. See page 155 . 


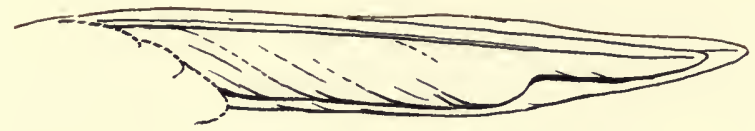

First primary, emarginate or notched. Duck Hawk, etc.

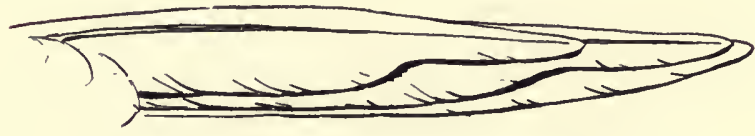

First two primaries, emarginate. Swallow-tailed Kite, etc.

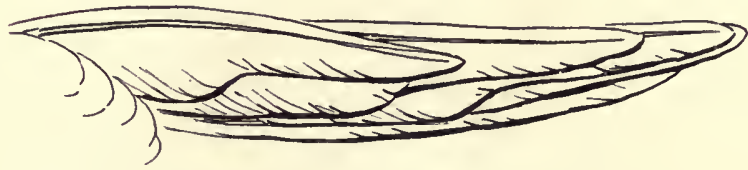

First three primaries. emarginate. Swainson's Hawk, etc.

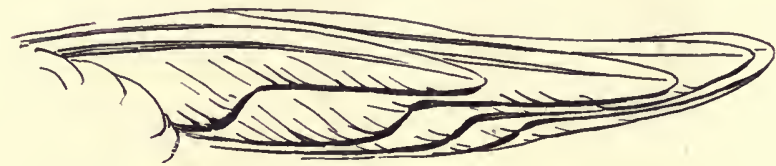

First four primaries, emarginate. Rough-legged Hawk, etc.

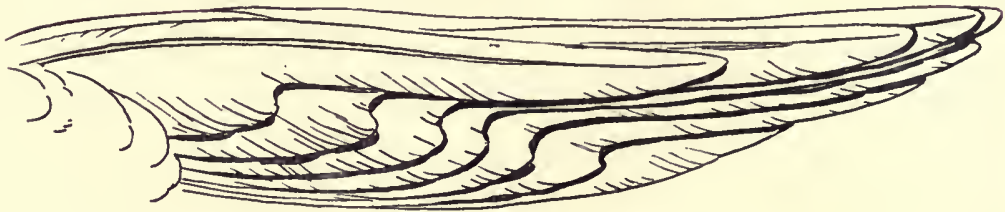

First five primaries, emarginate. Bald Eagle, etc.

Types of emarginate or "notched" primaries. 


\section{Family FALCONIDÆ. Hawks, Falcons, Eagles, Kites, etc. .}

Toes, four, three in front, one behind; toes, with strong, curved talons or claws; bill, with cere (hard skin-like covering at the base of upper mandible through which the nostrils open); bill, hooked.

\section{*GROUP 1. Wing, less than 8.50 inches long.}

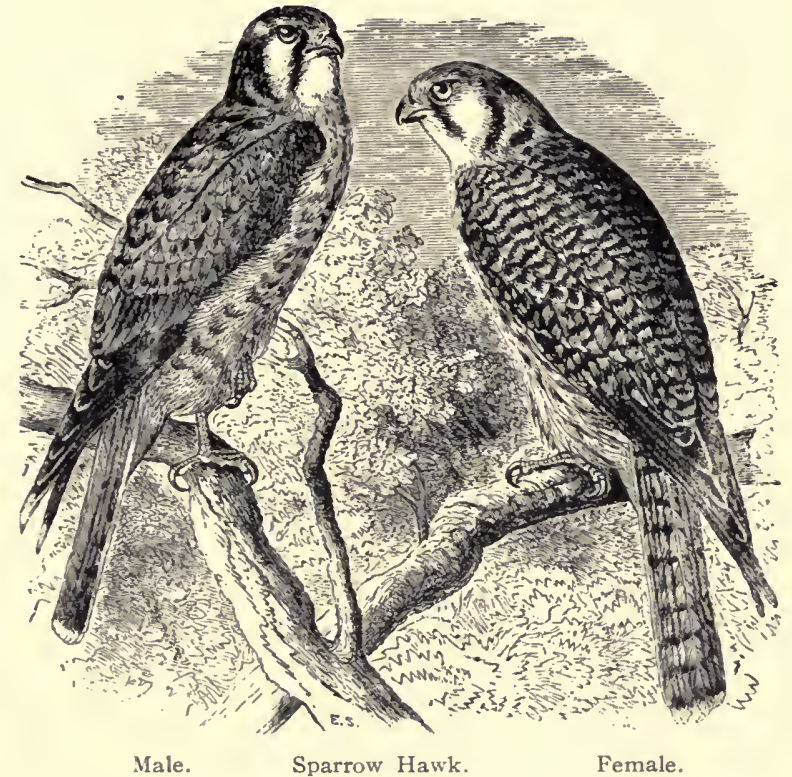

Rump and upper tail coverts, rufous brown; tail, more or less marked with rufous brown; tarsus, less than I.50; second primary, longest.

Falco sparverius. American Sparrow Hawk. See No. I 7 .

Rump and upper tail coverts, slaty brown; tarsus, over 1.50 ; fourth primary, longest.

Accipiter velox. Sharp-shinned Hawk. See No. 155 .

* For directions for measurement, see page 21 . 
i 46 Field Museum of Natural History-Zoölogy, Vol. IX.

Rump and upper tail coverts, dark brown; breast, streaked with dark brown; no rufous brown on tail; second primary, longest (immature); back and rump, slate color (adult).

Falco columbarius, and races.

Pigeon Hawk.

See Nos. I70, I70a.

GROUP 2. Wing, 8.50 to 9.50 inches long.

Second primary, longest.

Falco columbarius, and races.

Pigeon Hawk.

See Nos. I70, I70a.

Fourth primary, longest; outer tail feather, three-quarters inch or more shorter than middle feather; tail, usually more than 7.25 long.

Accipiter cooperii. Cooper's Hawk. See No. 156 .

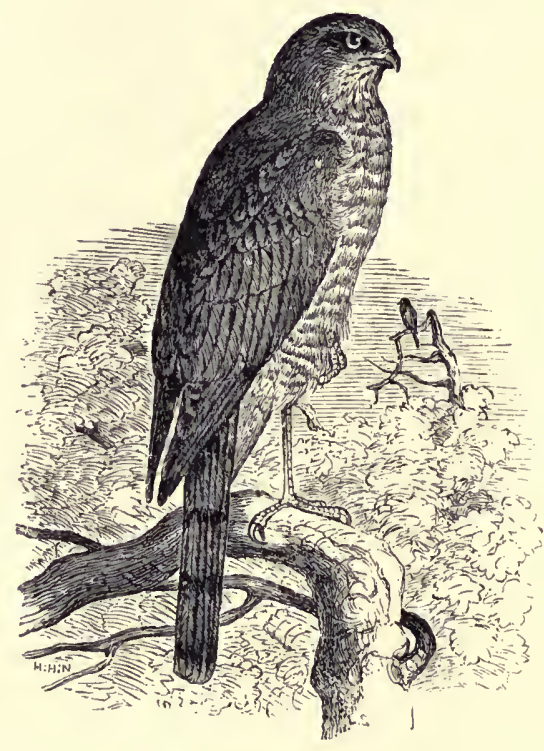

Sharp-shinned Hawk.

Fourth primary, longest; outer tail feather, less than three-quarter inch shorter than middle feather; tail, usually less than 7.25 long. Accipiter velox. Sharp-shinned Hawk. See No. I55. 
GROUP 3. Wing, 9.50 to 13 inches long. SECTION 1. The following species have the second primary longest :-

Upper parts, ash gray; head, nearly white; shoulder, black; iris, red; upper surface of inner web of first primary, without bars; breast and belly, white.

Elanus leucurus. White-tailed Kite. See No. 152 .

Upper surface of inner web of first primary, barred with white; breast and belly, streaked.

Falco mexicanus.

Prairie Falcon. See No. 168.

Upper surface of inner web of first primary, barred with pale rufous brown; breast and belly, streaked. Falco peregrinus anatum. Duck Hawk. Peregrine Falcon. See No. I69.

SECTION 2. The following species have the third primary longest:-

Belly, slaty gray (adult), or buffy streaked more or less with pale brown (immature); upper tail coverts, not white; no white band on tail.

Ictinia mississippiensis.

Mississippi Kite.

See No. I 53 .

Third and fourth primaries, about equal length; upper plumage, slaty gray; tail, black, banded with white (adult); wing, always less than 12 inches long.

Asturina plagiata. Mexican Goshawk. See No. I62.

Third and fourth primaries, about equal length; upper plumage, dark brown; tail, grayish brown, banded with black (immature); wing, always less than 12 inches long.

Asturina plagiata. Mexican Goshawk. See No. I62.

SECTION 3. The following species have the fourth primary longest :-

Upper tail coverts, white; wing, less than 12 inches long; tail, less than 8.25 ; a Mexican species; accidental in Illinois (only one record). 
i 48 Field Museum of Natural History-Zoölogy, Vol. IX.

Upper tail coverts, white; tarsus, over 2.25; wing, over 12 inches long; third and fourth primary, nearly the same length; a common species in Illinois.

Circus hudsonius. Marsh Hawk. See No. I 54 .

Fourth outer primary, not decidedly notched; no white on upper surface of outer webs of primaries; under surface of primaries, not strongly barred with dark brown and white; tail, less than 9.50; upper tail coverts, not white.

Buteo platypterus. Broad-winged Hawk. See No. r6r.

Fourth outer primary, decidedly notched; under surface of outer primaries, not heavily barred with dark brown and white; tail, 9.50, or over; wing, over II.5०. Astur atricapillus, and races. American Goshawk. See Nos. I 57, I 57 a.

Fourth outer primary, decidedly notched; under surface of outer primaries, not heavily barred with dark brown and white; tail, less than 9.50; upper surface of tail, with distinct white bars.

Buteo lineatus. Red-shouldered Hawk. See No. I 59 .

Under surface of primaries, heavily barred with dark brown and white; wing, under I $\mathrm{x} .50$.

Accipiter cooperii.

Cooper's Hawk.

See No. I 56 .

GROUP 4. Wing, I 3 to I 5 inches long.

SECTION 1. Second primary, longest; first and second primaries, emarginate, or notched.

Length, always under I9; primaries, hoary gray, without bands; breast and belly, white; a patch of black on the shoulder.

Elanus leucurus. White-tailed Kite.

See No. I 52. 
First primary, pale brown, with numerous bands on inner web; length, usually under 19 (some females are longer); upper plumage, grayish brown.

Falco mexicanus. Prairie Falcon. See No. I 68.

Length, always over I9; under tail coverts, spotted, or washed with dusky; upper parts, grayish, barred and marked with white; under parts, white, streaked and spotted with blackish.

Falco rusticolus. Gray Gyrfalcon. See No. i 67 .

SECTION 2. Third primary, longest; face, bare.

Throat, white or buff; upper surface of tail, grayish brown, with numerous bars; three outer primaries, emarginate, or notched.

Buteo swainsoni. Swainson's Hawk. See No. I60.

SECTION 3. Fourth primary, longest; upper tail coverts, white.

Upper tail coverts, white; under surface of tail, white or pale rufous, with several bands of dark brown.

Circus hudsonius. Marsh Hawk. See No. I 54 .

SECTION 4. Fourth primary, longest; upper tail coverts, not white. Upper surface of tail, bright rufous brown, with or without bands (adult).

Buteo borealis, and races. Red-tailed Hawk.

See Nos. I $58,158 \mathrm{a}$, I $58 \mathrm{~b},{ }_{5} 8 \mathrm{c}$.

Upper surface of inner webs of outer tail feathers, barred with brown and white; tail feathers, more or less tinged with pale rufous; primaries, not tinged with rufous (immature).

Buteo borealis, and races. Red-tailed Hawk.

See Nos. I 58, i $58 \mathrm{a}, 158 \mathrm{~b}$, i $58 \mathrm{c}$.

Upper surface of inner web of outer tail feathers, barred with brown and white; tail feathers, more or less tinged with pale rufous; primaries, more or less tinged with rufous (immature). 
i5o Field Museum of Natural History-Zoölogy, Vol. IX.

Upper surface of tail, dark brown, barred with white (adult).

Buteo lineatus.

Red-shouldered Hawk.

See No. I 59 .

Throat, white; breast, dull brown; thighs, barred rufous brown and white; three outer primaries, emarginate, or notched (adult).

Buteo swainsoni.

Swainson's Hawk.

See No. I60.

Throat, buff or buff white; breast, heavily marked with dark brown; thighs, pale rufous or buff with or without bars; three outer primaries, emarginate, or notched (immature).

Buteo swainsoni.

Swainson's Hawk.

See No. r6o.

Throat and under parts finely barred with gray and dull white, the feathers with dark shafts; thighs, barred and mottled with gray and white; tail, 9.50 or over; wing, over II.50 (adult).

Astur atricapillus, and races.

American Goshawk.

See Nos. I 57 , I $57 \mathrm{a}$.

Throat and under parts and thighs, white, or tawny white, streaked with dark brown; tail, strongly barred (immature).

Astur atricapillus.

American Goshawk.

See No. I 57 .

GROUP 5. Wing, I5 to I 7 inches long.

SEC'TION 1. Second primary, longest; only first primary, emarginate, or notched.

Length, under I9; primaries, dark brown, banded on inner web with pale rufous.

Falco peregrinus anatum.

Duck Hawk.

See No. I69.

Length, over I9; under tail coverts, marked with dusky or spotted; general plumage, gray and white, with more or less black marking; primaries, not dark brown.

Falco rusticolus.

Gray Gyrfalcon.

See No. 167 . 
SECTION 2. Second primary, longest; first and second primaries, emarginate, or notched.

Back, entirely brown; belly, white, without streaks; under tail coverts, pure white; tarsus, nearly bare.

Pandion haliaëtus carolinensis. American Osprey. Fish Hawk. See No. I 72.

Back, slaty brown and white; under tail coverts, spotted or marked with dusky.

Falco rusticolus, Gray Gyrfalcon. See No. I67.

SECTION 3. Third primary, longest.

Four outer primaries, notched; basal portion of inner webs of primaries, largely white, without bars; thighs, tawny or buff, more or less barred; tarsus, thickly feathered.

Archibuteo lagopus sancti-johannis.

American Rough-legged Hawk. See No. I64.

Four outer primaries, notched; basal portion of inner webs of primaries, largely white, without bars; thighs, tinged with deep rufous, heavily barred; tarsus, thickly feathered.

Archibuteo ferrugineus.

Ferruginous Rough-legged Hawk. See No. I63.

General plumage, entirely sooty brown, or black; four outer primaries, notched; primaries and tail, with more or less white, or gray; tarsus, thickly feathered. Archibuteo lagopus sancti-johannis. American Rough-legged Hawk (black plumage). See No. I64.

Three outer primaries, notched; belly and thighs, not white. Buteo swainsoni. Swainson's Hawk. See No. $x 60$.

Three outer primaries, notched; a part of inner web of outer primaries, white, showing numerous imperfect bars; belly and thighs, pure white; back, dark brown.

Pandion haliaëtus carolinensis. American Osprey. Fish Hawk. See No. I 72. 
152 Field Museum of Naţural History-Zoölogy, Vol. IX.

- Two outer primaries, notched; primaries, dark slaty blue, showing greenish tinge when held in the light; tail, long and forked; under parts and thighs; white.

Elanoides forficatus. Swallow-tailed Kite. See No. I 5 I.

SECTION 4. Fourth primary, longest; four or five outer primaries, emarginate, or notched; upper tail coverts, white.

Upper tail coverts, white; under surface of tail, white or pale rufous, with several bands of dark brown.

Circus hudsonius.

Marsh Hawk. See No. I 54 .

SECTION 5. Fourth primary, longest; four or five outer primaries, emarginate, or notched; upper tail coverts, not white; tarsus, partly (but not entirely) feathered.

Tail, bright rufous brown (adult); tail, whitish or grayish, with numerous brown bars (immature.)

Buteo borealis, and races.

Red-tailed Hawk.

See Nos. I 58, I $58 \mathrm{a}, 158 \mathrm{~b}$, I $58 \mathrm{c}$.

General plumage, dark sooty brown, sometimes with under parts pale, more or less streaked and spotted.

Buteo borealis harlani. Harlan's Hawk. See No. I 58 c.

SECTION 6. Fourth primary, longest; four or five outer primaries, emarginate, or notched; tarsus, entirely feathered; upper tail coverts, not white.

Thighs, tawny, more or less streaked or barred.

Archibuteo lagopus sancti-johannis.

American Rough-legged Hawk.

See No. I64.

General plumage, sooty brown or black (black plumage). Archibuteo lagopus sancti-johannis. American Rough-legged Hawk. See No. 164 . 
Thighs, tinged with deep rufous, with numerous bars.

Archibuteo ferrugineus.

Ferruginous Rough-legged Hawk.

See No. I63.

SECTION 7. Fourth-primary, longest; three outer primaries, emarginate, or notched.

Tarsus, partly feathered; throat, white (adult); throat,-tawny or buff (immature).

Buteo swainsoni.

Swainson's Hawk.

See No. 160.

GROUP 6. Wing, 17 to 21 inches long.

SECTION 1. Third primary, longest; tarsus, wholly feathered.

Basal portion of inner web of primaries, largely white, without bars; thighs, tawny or buff, more or less barred; tarsus, thickly feathered.

Archibuteo lagopus sancti-johannis. American Rough-legged Hawk. See No. 164 .

Basal portion of inner web of primaries, largely white, without bars; thighs, tinged with deep rufous, heavily barred.

Archibuteo ferrugineus. Ferruginous Rough-legged Hawk.

See. No. 163 .

General plumage, entirely sooty brown or black; primaries and tail, with more or less white or gray.

Archibuteo lagopus sancti-johannis. American Rough-legged Hawk (black plumage). See No. 164.

SECTION 2. Third primary, longest; tarsus, not wholly feathered.

Wing, from 16.90 to $2 \mathrm{I}$; a part of inner web of outer primaries, white, showing numerous imperfect bars; three outer primaries, notched; belly and thighs, pure white; back, dark brown.

Pandion haliaëtus carolinensis. American Osprey. Fish Hawk.

See No. 172. 
i 54 Field Museum of Natural History-Zoölogy, Vol. IX.

Head, neck and entire under parts, pure white; rest of plumage, glossy bluish black; wing, less than I9; primaries, dark slaty, showing greenish tinge when held in the light; two outer primaries, notched; tail, long and forked.

Elanoides forficatus. Swallow-tailed Kite. See No. I 5 I.

Wing, always over 18.50 ; belly and thighs, never white; only adult birds have the hood and tail white. Haliceetus leucocephalus. Bald Eagle. See No. I66.

SECTION 3. Fourth primary, longest; tarsus, partly (not entirely) feathered.

Tail, rufous brown (adult); tail, whitish or grayish, with numerous brown bars (immature).

Buteo borealis, and races.

Red-tailed Hawk.

See Nos. I 58, I $58 \mathrm{a}$, I $58 \mathrm{~b}$, I $58 \mathrm{c}$.

General plumage, dark sooty brown, sometimes with pale under parts, more or less streaked and spotted. Buteo borealis harlani.

Harlan's Hawk. See No. r $58 \mathrm{c}$.

Wing, always over I8.50; only adults have head and tail white. Haliceetus leucocephalus.

Bald Eagle. See No. I66.

SECTION 4. Fourth primary, longest; tarsus, entirely feathered. Thighs, tawny, more or less streaked or barred.

Archibuteo lagopus sancti-johannis. American Rough-legged Hawk. See No. I64.

General plumage, sooty brown or black (black plumage). Archibuteo lagopus sancti-johannis.

American Rough-legged Hawk. See No. I64. 
Jan., I909. Birds of Illinois and Wisconsin-Cory.

Thighs, tinged with deep rufous, with numerous bars.

Archibuteo ferrugineus.

Ferruginous Rough-legged Hawk.

See No. r63.

GROUP 7. Wing, over $2 \mathrm{I}$ inches long. (Eagles.)

General plumage, fuscous brown; tarsus, entirely feathered; head and terminal portion of tail, never white. Immature birds have the basal half or more of the tail feathers white.

Aquila chrysaëtos.

Golden Eagle.

See No. 165 .

Tarsus, not entirely feathered; head and tail, more or less white in old birds; younger birds have no white on head, and very little on the tail, but the partly bare tarsus will always distinguish immature birds of this species from the Golden Eagle; fully adult birds have the head, neck, and tail entirely white and the bill yellow.

Halicetus leucocephalus.

Bald Eagle.

See No. I66.

\section{Family STRIGIDÆ. Owls.}

Radiated disk of feathers surrounding the eye; plumage, soft; toes, armed with strong curved talons; bill, hooked.

* GROUP 1. Wing, less than 8.50 inches long.

SECTION 1. Toes, thickly feathered.

Wing, less than 6.10; upper plumage, dark cinnamon brown, more or less marked with white; under parts, whitish, streaked with brown; adult birds have much white about the face; immature birds have the face dusky, but the eyebrows white.

Glaux acadicus.

Saw-whet Owl. Acadian Owl.

See No. I79.

* For directions for measurement, see page $2 \mathrm{r}$. 
i 56 Field Museum of Natural History-Zoölogy, Vol. IX.

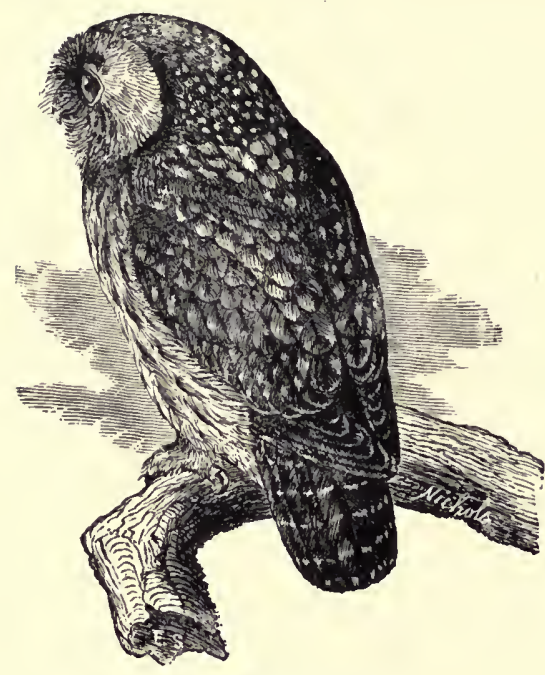

Richardson's Owl.

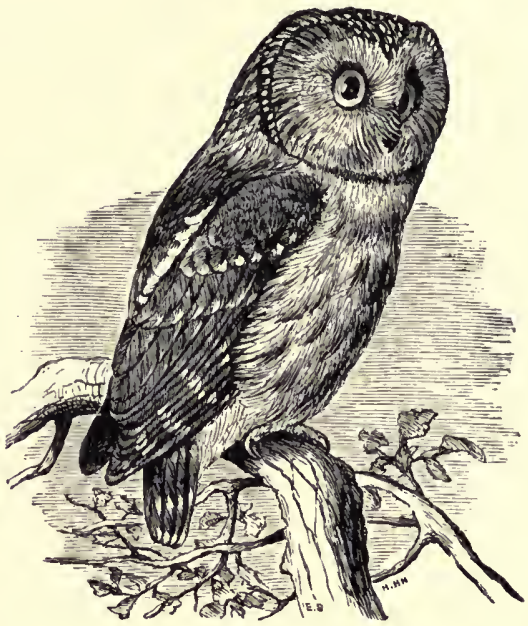

Saw-whet Ow1.

Wing, over 6.10; upper plumage, dark cinnamon brown, more or less spotted with white; under parts, brown and white.

Glaux funerea richardsoni.

Richardson's Owl.

See No. I 78 .

SECTION 2. Toes, nearly bare, or but thinly feathered.

Tarsus, thickly feathered; head with two horn-like tufts of feathers; general plumage, sometimes gray, sometimes rufous brown, more or less streaked and spotted.

Otus asio.

Screech Owl.

See No. I 80 .

GROUP 2. Wing, 8.50 to I I inches long.

Primaries, dark brown, more or less marked with tawny brown; head with ear tufts an inch or more long.

Asio wilsonianus.

American Long-eared Owl.

See No. I 74 .

Primaries, dark brown, more or less marked with pure white; no horn-like tufts of feathers on head.

Surnia ulula caparoch. American Hawk Owl.

See No. 183 . 
GROUP 3. Wing, I I to 13 inches long.

Back, not heavily barred or mottled with whitish; first and second primaries, "notched" or emarginate; ear tufts, very small, hardly noticeable.

Asio flammeus.

Short-eared Owl.

See No. 175 .

Back, finely mottled with whitish (not heavily barred); head, with ear tufts an inch or more long; first primary only, "notched."

Asio wilsonianus.

American Long-eared Owl.

See No. I74.

General plumage, umber brown, mottled and barred with whitish; belly, streaked dark with brown and whitish; toes, feathered; no ear tufts.

Strix varia. Barred Owl. See No. 176 .

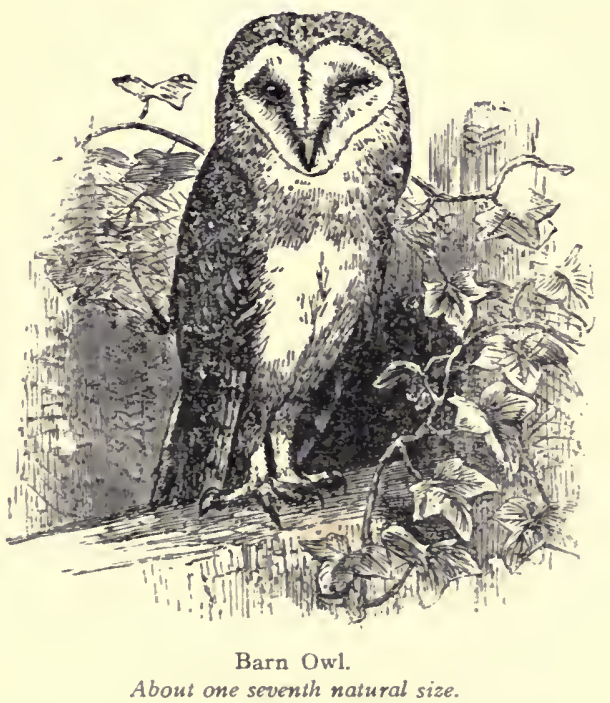

Under parts, white, or tawny white, with more or less small spots of brown; middle toe nail, with comb-like edge. (This species belongs in Family Aluconidæ, the Barn Owls having been separated from the Strigidæ.)

Aluco pratincola. Barn Owl.

See No. 173 . 
i58 Field Museum of Natural History-Zoölogy, Vol. IX.

\section{GROUP 4. Wing, I 3 to I 5 inches long.}

SECTION 1. Second primary, decidedly shorter than fourth.

Under parts, white, barred and streaked with brown; toes, more or less feathered.

Strix varia. Barred Owl. See No. 176.

SECTION 2. Second primary, about equal in length to fourth. Two large, ear-like tufts of feathers above the eyes.

Bubo virginianus, and races. Great Horned Owl. See Nos. I8I, I8Ia.

SECTION 3. Second primary, decidedly longer than fourth.

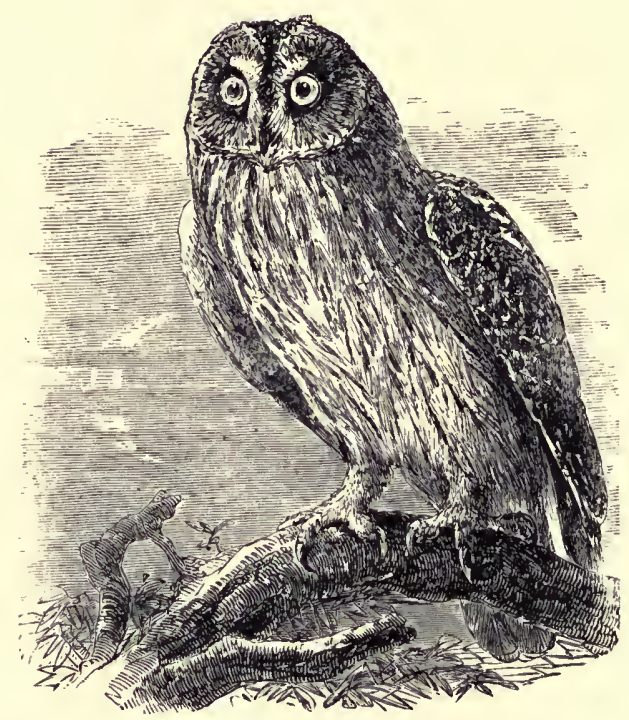

Short-eared Owl.

Under parts, streaked; feet, thickly feathered.

Asio flammeus. Short-eared Owl. See No. I75.

Under parts, white or buff white, more or less spotted; feet, nearly bare; middle toe nail, with comb-like edge.

Aluco pratincola. Barn Owl. 
GROUP 5. Wing, over I 5 inches long.

Bill, black; general plumage, tawny, black and white; horn-like tufts of feathers over the eyes.

Bubo virginianus, and races.

Great Horned Owl. See Nos. I8r, I8ra.

Bill, black; general plumage, white, usually more or less marked with slate brown, or dark brown; no horn-like tufts of feathers over the eyes.

Nyctea nyctea. Snowy Owl.

See No. I82.

Bill, yellowish; no horn-like tufts of feathers over eyes; general plumage, gray mixed with white and dark brown.

Scotiaptex nebulosa. Great Gray Owl. See No. I77.

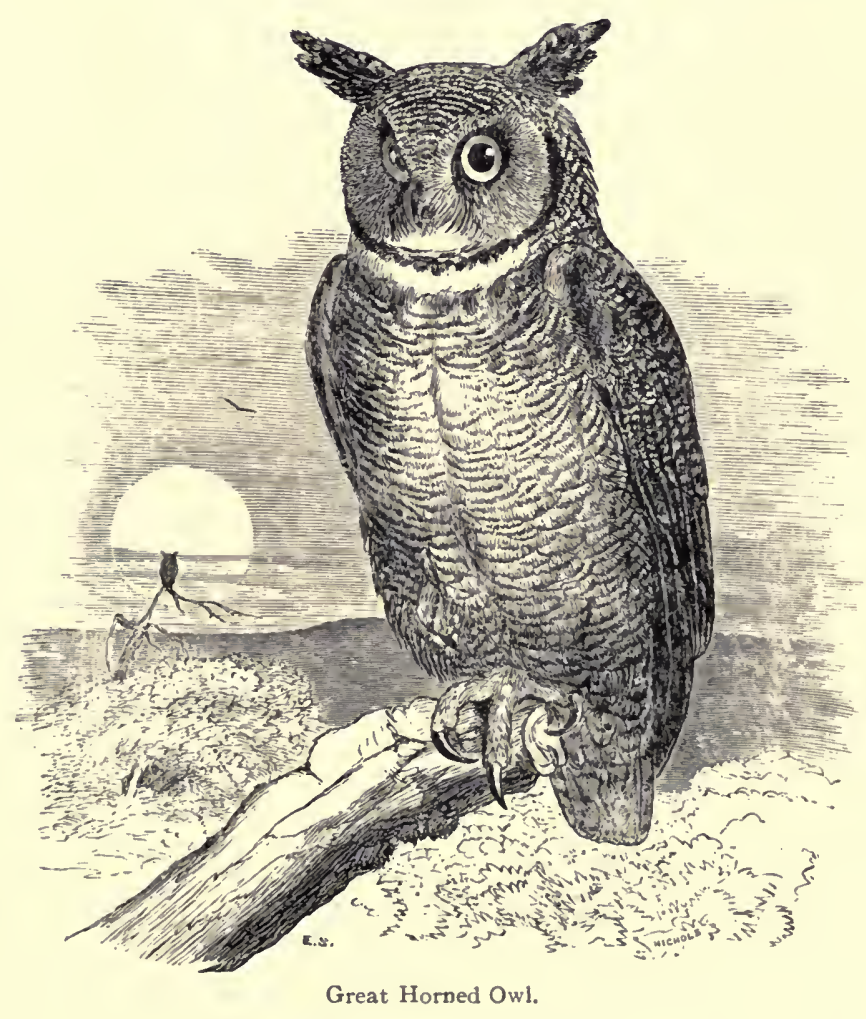


r6o Field Museum of Natural History-Zoölogy, Vol. IX.

\section{Family PSITTACIDÆ. Parrots and Paroquets.}

Toes, four, two in front and two behind (zygodactyle); bill, with cere (a skin-like covering over base of mandible).

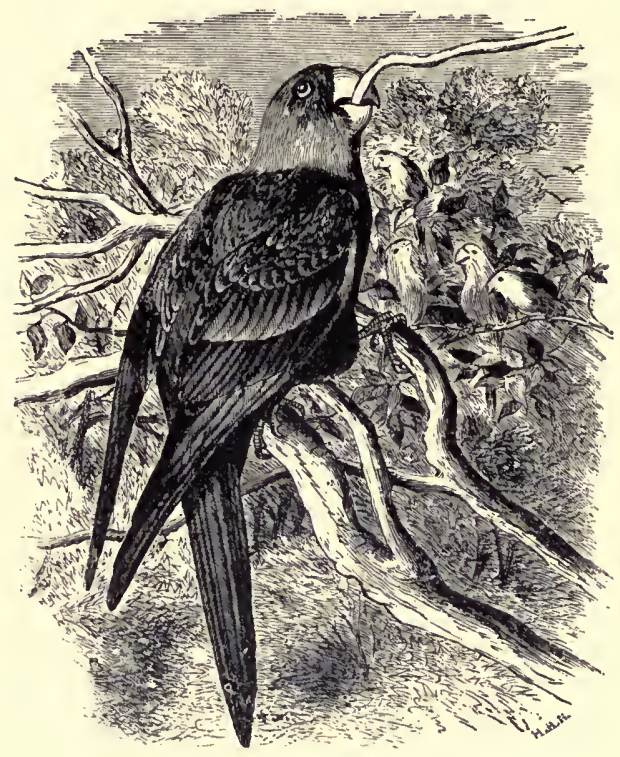

General plumage, green; head and neck, yellow, becoming orange on the forehead and cheeks; bend of wing, yellow. Immature birds have but little yellow on the head.

Conuropsis carolinensis. Carolina Paroquet. See No. 184 .

Once common in Southern States and as far north as Illinois; apparently now restricted to Florida and Indian Territory. 


\section{Family CUCULIDÆ. Cuckoos.}

Feet, zygodactyle (two toes in front, two behind); first primary, about half as long as third; outer tail feathers, much shorter than middle ones.

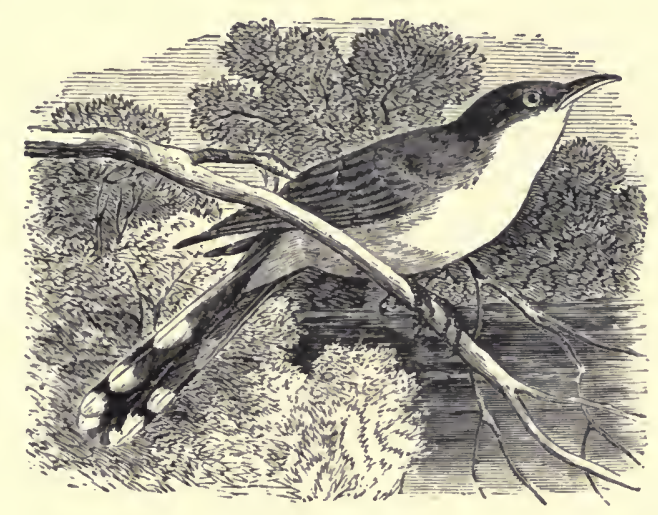

Yellow-billed Cuckoo.

Upper parts, brownish gray, with faint gloss of greenish; under mandible, mostly yellow; greater portion of primaries, rufous brown, tipped with grayish olive; under parts, dull white; outer tail feathers, black, tipped with white.

Coccyzus americanius. Yellow-billed cuckoo. See No. 185 .

Upper parts, grayish brown, with faint gloss of green; bill, black; no rufous brown on primaries; under parts, dull white; outer tail feathers, like back in color. Coccyzus erythrophthalmus.

Black-billed Cuckoo.

See No. r 86. 
i62 Field Museum of Natural History - Zoölogy, Vol. IX.

\section{Family ALCEDINIDÆ. Kingfishers.}

Bill, long and straight; feet, syndactyle; toes, four, the middle and outer ones joined, being fastened together for more than half their length; tarsus, very short and reticulate (scales rounded) in front.
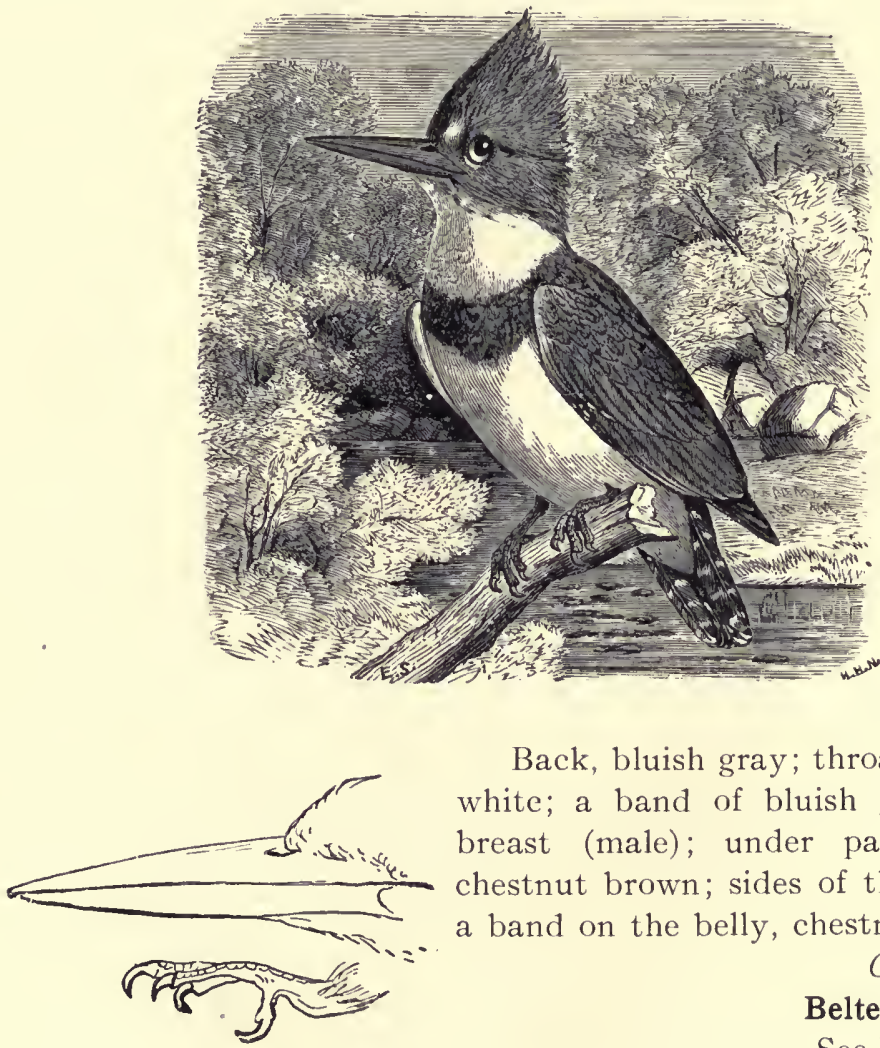

Back, bluish gray; throat and belly, white; a band of bluish gray on the breast (male); under parts, without chestnut brown; sides of the body and a band on the belly, chestnut (female).

Ceryle alcyon. Belted Kingfisher. See No, i 87 . 


\section{Family PICIDÆ. Woodpeckers.}

Bill, strong and sharp; toes, four or three, never more than two in front; nostrils, partly concealed by small bristly feathers; tail feathers, stiff and pointed. Woodpeckers are commonly seen climbing about on trunks of trees.

*GROUP 1. Wing, less than 4.25 inches long.

Back, black, streaked with

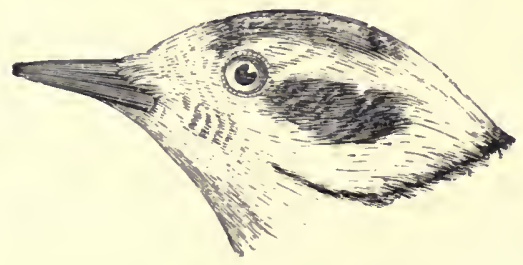
white; crown, with red nuchal patch (male); without red nuchal patch (female); tail feathers, stiff and pointed; toes, four, two in front, two behind.

Dryobates pubescens medianus. Downy Woodpecker. See No. I 90 .

GROUP 2. Wing, 4.25 to 5.50 inches long. SECTION 1. The following species have three toes; no trace of red on the crown or nape:-

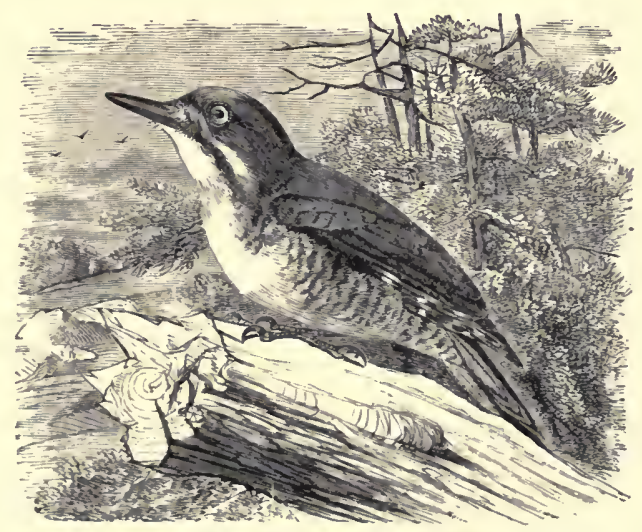

Toes, three; crown, with patch of yellow; back, black, without white (male). 
i64 Field Museum of Natural History-Zoölogy, Vol. IX.

Toes, three; crown, black; back, black, without white.

Picoides arcticus (female). Arctic Three-toed Woodpecker. See No. I9r.

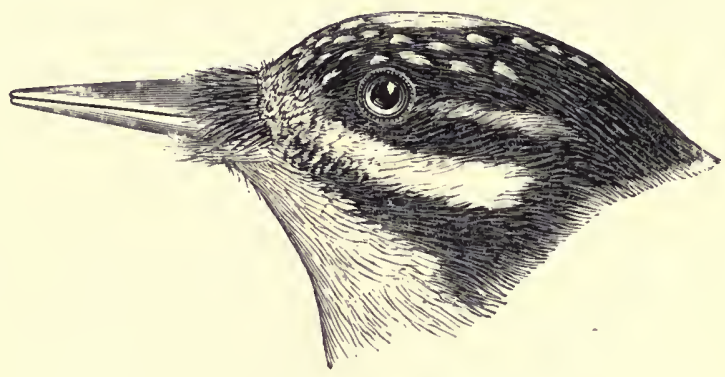

Picoides americanus.

Toes, three; crown, yellow; back, black and white.

Picoides americanus (male).

American Three-toed Woodpecker. Banded-backed Woodpecker. See No. 192.

Toes, three; crown, black, marked with white; back, black and white.

Picoides americanus (female).

American Three-toed Woodpecker. Banded-backed Woodpecker. See No. I 92 .

SECTION 2. The following species have four toes; no trace of red on crown or nape:-

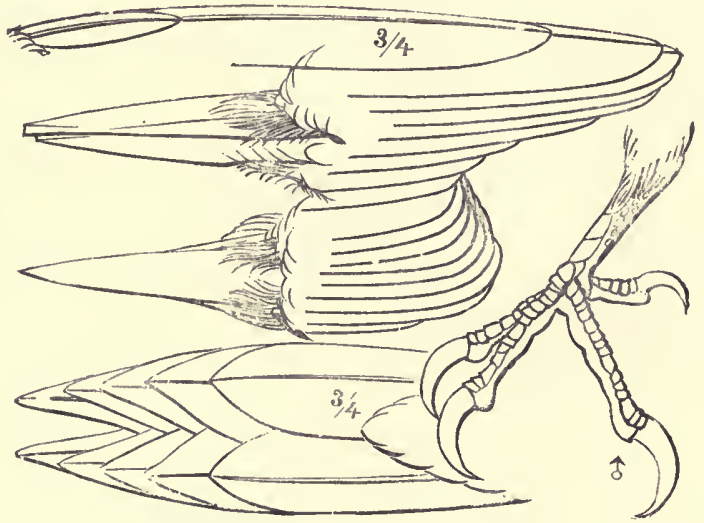

Ear coverts, black; no white on inner web of two middle tail feathers; middle of back, more or less white, but not heavily banded as in borealis; lower rump and upper tail coverts, black.

Dryobates villosus ( $f e$ male).

Hairy Woodpecker. See No. I 89. 
Rump and upper tail coverts, pure white; greater portion of tertials and secondaries, white; the shafts, black; inner webs of two middle tail feathers, not marked with white. Adult birds of both sexes have the head red; immature birds have the head dark brownish gray.

Melanerpes erythrocephalus (immature). Red-headed Woodpecker. See No. I95.

Inner webs of two middle tail feathers, heavily marked with white; belly, usually tinged with pale yellow.

Sphyrapicus varius (immature). Yellow-bellied Woodpecker. See No. I93.

SECTION 3. The following species have four toes, and more or less red on crown or nape :-

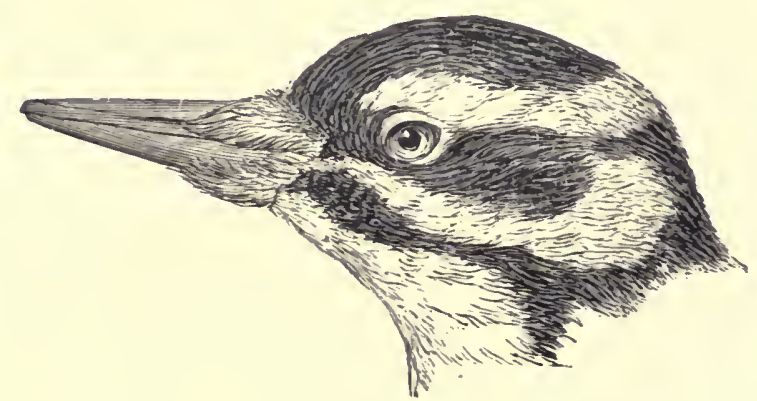

Crown, black; a patch of red on the occiput (back of the head); ear coverts, black; no white on inner webs of two middle tail feathers; back, black, with white patch in middle, but not heavily banded with black and white; wings, with round white spots; upper tail coverts, black.

Dryobates villosus (male). Hairy Woodpecker. See No. 189 .

Crown, red; throat, red (male); crown, red; throat, white (female); belly, tinged with yellow; two middle tail feathers, heavily marked with white on the inner webs; a patch of black on the breast, varying in size, according to age and season.

Sphyrapicus varius (adult). Yellow-bellied Woodpecker. See No. I 93 . 
Crown, red (male); crown, ashy gray, nape, red (female); throat and under parts, pale ash gray, the belly tinged with red or buff, according to season.

Centurus carolinus. Red-bellied Woodpecker. See No. I 96.

Rump and upper tail coverts, pure white; greater part of secondaries and tertials, white, with black shafts (sometimes with one brown band near tip); entire head and throat, red (adults); immature birds have the head brownish gray, speckled and marked with dull black, but usually showing more or less red in places.

Melanerpes erythrocephalus.

Red-headed Woodpecker. See No. I95.

\section{GROUP 3. Wing, 5.50 to 8.00.}

Under surface of wings and tail, yellow; a band of red on the nape, and a black molar stripe (male); similar but without the black molar stripe (female).

Colaptes auratus luteus. Northern Flicker. Golden-winged Woodpecker. See No. 197.

Rump and upper tail coverts, pure white; greater portion of tertials, white, the shafts, black; middle tail feathers, not marked with white; belly, white. Adult birds of both sexes have the entire head red; immature birds have the head dark brownish gray.

Melanerpes erythrocephalus.

Red-headed Woodpecker.

See No. I95.

Middle tail feathers, marked with white; under parts, ashy, tinged with red or buff on the belly; back barred with black and white; whole top of head, red (male); top of head, ash gray, nape red (female).

Centurus carolinus. Red-bellied Woodpecker. See No. I 96 .

Throat, red (male) or white (female), not gray; belly, tinged with yellow; wing coverts, mostly white.

Sphyrapicus varius.

Yellow-bellied Woodpecker.

See No. I93. 


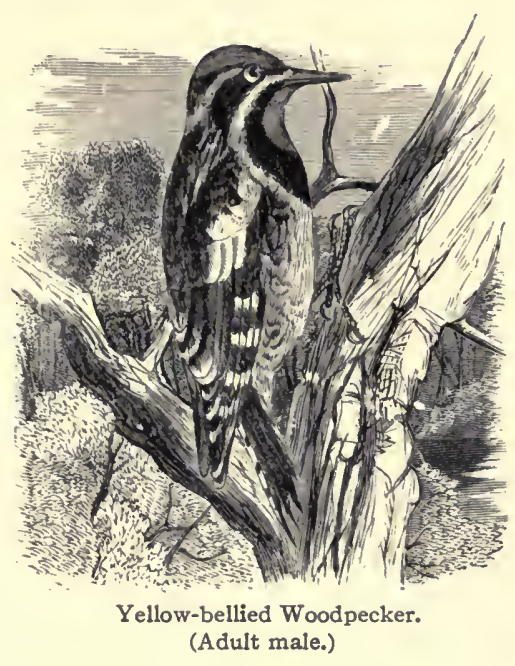

\section{GROUP 4. Wing, over 8.00.}

Bill, dark slaty, or blackish; upper plumage, blackish; basal half of wing feathers, white; whole crown, scarlet red (male); front of crown, not red (female); size, large, length over I 5 inches.

Phlcootomus pileatus albieticola. Northern Pileated Woodpecker. See No. I 94 .

Bill, yellowish white; greater portion of plumage, black; greater portion of secondaries, and tips of inner primaries, white; a white stripe extends down sides of the neck to the back; crest, bright red (male); crest, black (female). Formerly found in Illinois, but now occurs only in Florida, and a few localities along the Gulf coast; very rare.

Campephilus principalis. Ivory-billed Woodpecker.

See No. 188 . 


\section{Family CAPRIMULGIDÆ. Nighthawks, Whip-poor-wills, etc.}

Feet, small and weak; mouth, very large; bill, small; middle toe nail, with fine comb-like edge; front toes, connected at base.

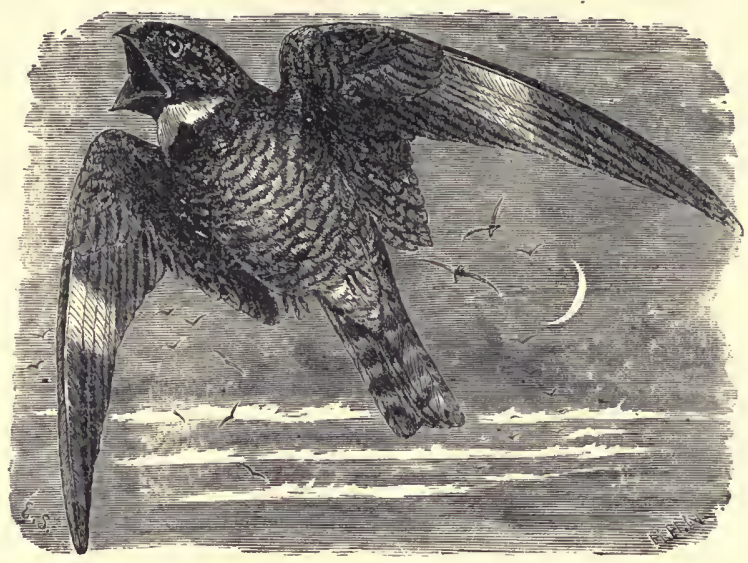

A band of white on the wing; tail feathers, not tipped with white.

Chordeiles virginianus, and races.

Nighthawk.

See Nos. 200, 200a.

No white on the wing; primaries, banded with rufous brown and black; wing, over 7.50 in. long.

Antrostomus carolinensis. Chuck-will's-widow. See No. 198.

No white on wing; outer tail feathers, broadly tipped with white; wing, under 7.50 in. long. Antrostomus vociferus.

Whip-poor-will. See No. I99.

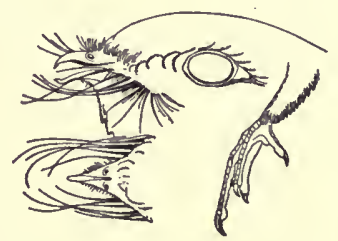




\section{Family MICROPODIDÆ. Swifts.}

Bill, small and weak; mouth, large; feet, small; tail feathers, with sharp spines extending beyond the tips.
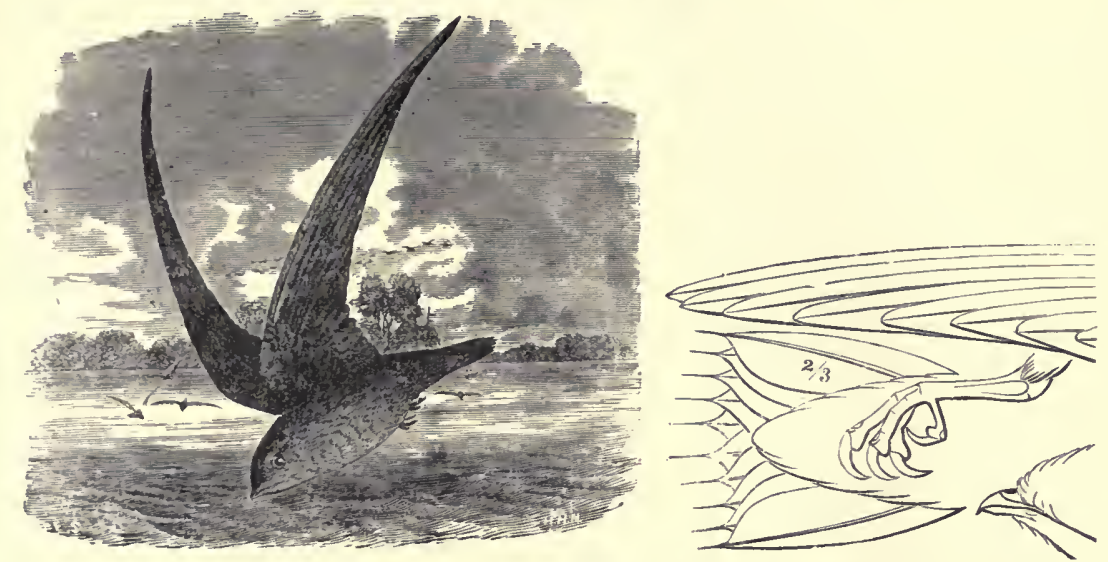

General plumage, sooty brown, showing a faint greenish tinge on the upper parts; throat, ashy white; tail feathers, with sharp spines, or points formed by the shafts of the feathers, extending beyond the webs. The Swifts are widely separated generically from the Swallows; but persons unfamiliar with birds might look for them under the same family.

Chatura pelagica. Chimney Swift. See No. 201 .

\section{Family TROCHILIDÆ. Hummingbirds.}

Smallest of Birds. Wing less than I.75 inches long (carpus to tip).

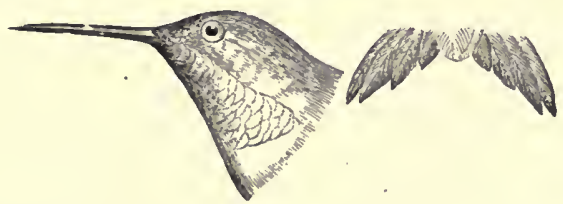

Throat, ruby red; back, golden green (male); no red on throat (female and young male).

Trochilus colubris. Ruby-throated Hummingbird.

See No. 202 . 


\title{
Family TYRANNIDÆ. Flycatchers.
}

\author{
$\because$ GROUP 1. Wing, 2.I 3 to 2.37 inches long.
}

Bill, broad and flattened, with numerous small black bristles at base of upper mandible; tip, with small but distinct hook; tarsus, rounded, not flattened and sharp at the back as in the Vireos.
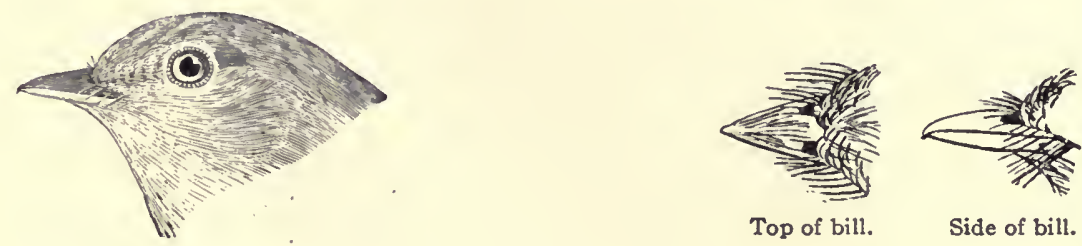

First primary shorter than fifth; bill, with small hook at tip, flat and wide at base; back, olive green; belly, not yellow, or only faintly tinged with yellow; eye ring, whitish. Empidonax minimus. Least Flycatcher. See No. 2 I 5 .

Back, olive green; belly, clear yellow. Empidonax flaviventris. Yellow-bellied Flycatcher.

See No. 2 I 2.

GROUP 2. Wing, 2.37 to 2.75 inches long.

First primary, about as long as fifth; under mandible yellowish white; throat, dull white; breast and belly, dull white, tinged with pale yellow; back, olive green.

Empidonax virescens. Green-crested Flycatcher. Acadian Flycatcher. See No. 2 I 3 .

Under mandible, yellowish white; throat and under parts, yellow or greenish yellow; back, olive green.

Empidonax flaviventris. Yellow-bellied Flycatcher. See No. 2 I 2.

* For directions for measurement, see page $2 \mathrm{r}$. 


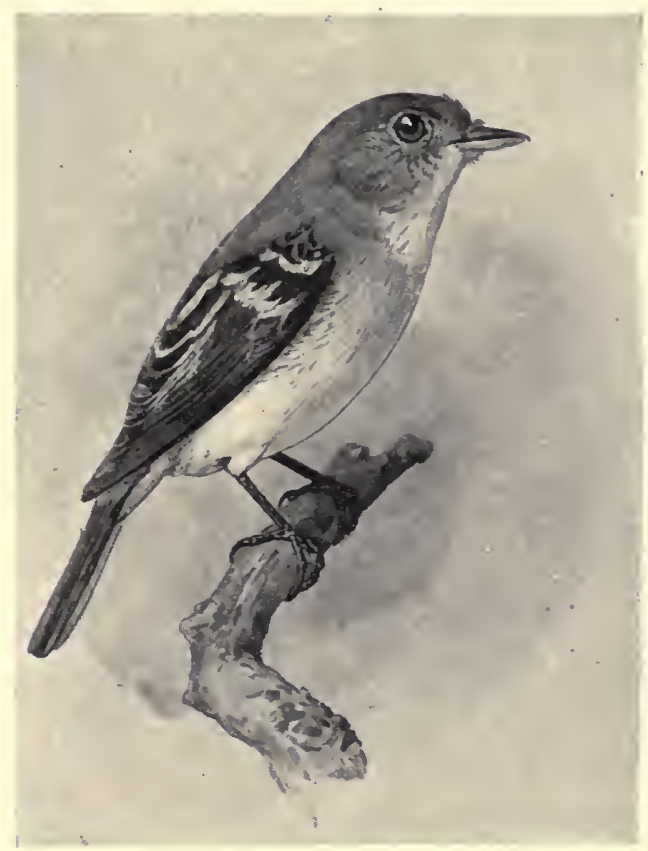

Flycatcher.

First primary, shorter than fifth; under mandible, pale yellowish white, or brownish white; back, tinged with olive brown; wing, over 2.60; eye ring and wing bars, whitish. Empidonax traillii, and races. Traill's Flycatcher. See Nos. $214,2142$.

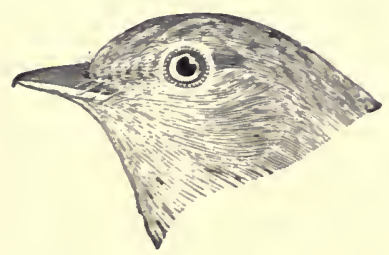

Eye ring, whitish; first primary, shorter than fifth; under mandible, usually pale brown or brownish white; wing, under 2.60 .

Empidonax minimus. Least Flycatcher. See No. 2 I 5 .

GROUP 3. Wing, 2.75 to 3.25 inches long.
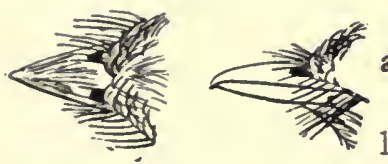

Bill, flat and wide, with small hook at tip, and black bristles at base.

Wing, under 3.05; under mandible, yellowish white; throat and under parts, pale greenish yellow; back, olive green.

Empidonax flaviventris. Yellow-bellied Flycatcher. See No. 2 I 2. 
i72 Field Museum of Natural History-Zoölogy, Vol. IX.

Wing, usually under 3.05; under mandible, straw color or yellowish white; throat, white; belly, whitish, faintly tinged with yellow; back, olive green; first primary, about as long as fifth.

Empidonax virescens.

Green-crested or Acadian Flycatcher.

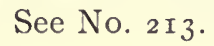

Wing, under 3.05 ; upper parts, tinged with olive brown; throat, white; under mandible, yellowish white; eye-ring and wing bars, pale tawny; first primary, shorter than fifth. Empidonax traillii, and races.

Traill's Flycatcher. See Nos. 2 I 4,2 I 4 a.

GROUP 4. Wing, 3.25 to 3.75 inches long.

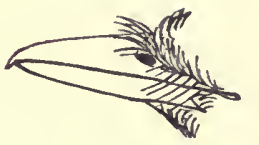

Both mandibles, blackish; back brownish olive, under tail coverts, pale yellowish white.

Sayornis pheebe. Phœbe Flycatcher. See No. 207.

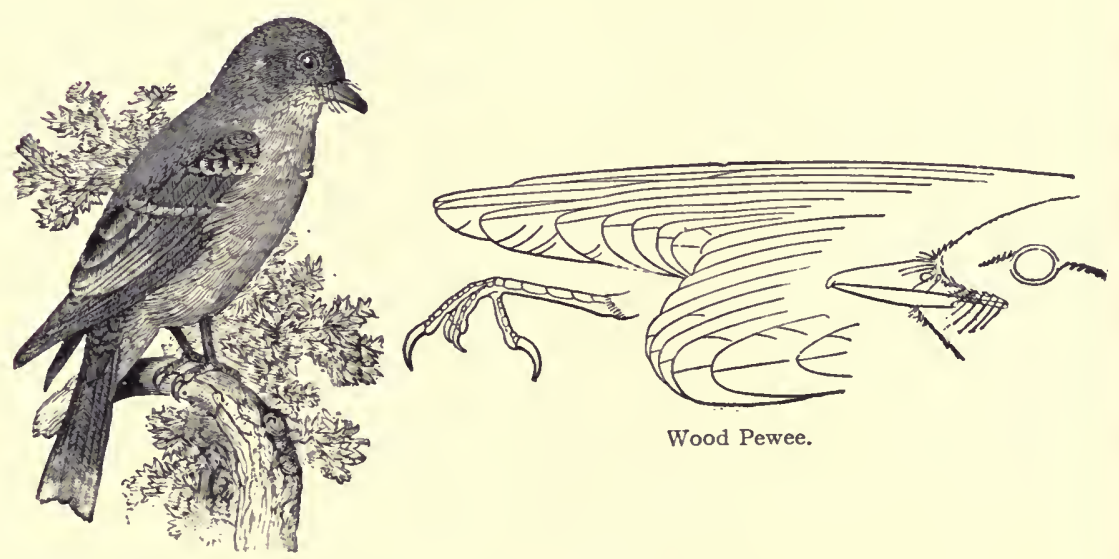

Wing, longer than the tail; under mandible, pale, usually yellowish, or yellowish brown; back, dull olive; breast and sides, olive gray.

Myiochanes virens.

Wood Pewee.

See No. 2 Io. 
GROUP 5. Wing, 3.75 to 4.25 inches long.

Bill, with small hook at tip, and black bristles at base; back of tarsus, rounded.

Throat, grayish; belly, yellow; back, dull olive; more or less rufous brown on the tail feathers.

Myiarchus crinitus. Crested Flycatcher. See No. 206.

Throat, grayish olive; belly, pale rufous brown; upper parts, olive gray.

Sayornis saya. Say's Phœbe Flycatcher.

See No. 208.

Wing, longer than tail; throat and middle of belly, white, sometimes tinged with yellow; under mandible, pale at base; upper parts, brownish olive; greater portion of breast, and sides of the body, brownish olive; upper mandible, black; a tuft of whitish fluffy feathers on the flanks.

Nuttallornis borealis. Olive-sided Flycatcher.

See No. 209.

GROUP 6. Wing, 4.25 to 4.75 inches long.

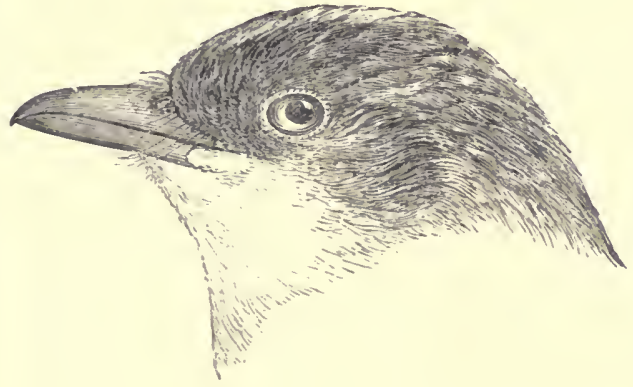

Back, blackish; a concealed patch of fiery red on crown; tail, tipped with white; belly, white.

Tyrannus tyrannus.

Kingbird.

See No. 204.

Kingbird.

Crown and back, dull olive; throat, gray; belly and under tail coverts, yellow; tail feathers, heavily marked with rufous.

Myiarchus crinitus.

Crested Flycatcher.

See No. 206. 
i74 Field Museum of Natural History-Zoölogy, Vol. IX.

Crown, dull olive gray; throat, olive gray; belly, rufous brown; tail, black.

Sayornis saya.

Say's Phœbe Flycatcher.

See No. 208.

Upper plumage, brownish olive, or dull, grayish olive; throat and middle of belly, white, sometimes tinged with pale yellow; breast (except middle) and sides of body, dull grayish olive; under mandible, pale.

Nuttallornis borealis. Olive-sided Flycatcher. See No. 209.

Crown and back, ashy; throat and breast, ashy white; sides of breast and body, orange red; tail, forked, very long, rarely less than four and one half inches.

Muscivora forficata. Scissor-tailed Flycatcher. See No. 203.

GROUP 7. Wing, 4.75 to 5.50 inches long.

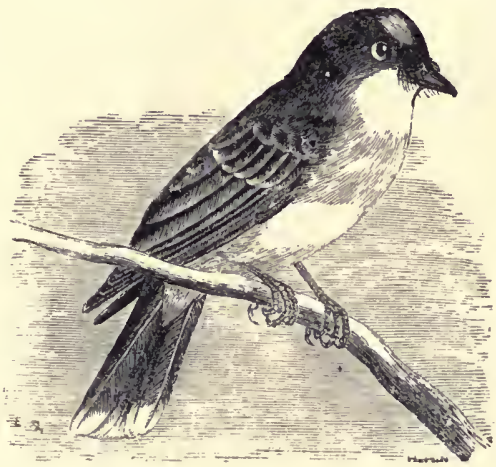

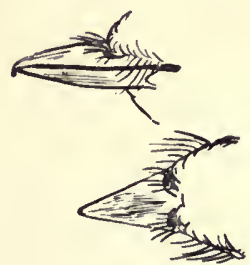

Top of bill.

Back, blackish; a concealed patch of fiery red on the crown; tail, black, tipped with white; belly, white.

Tyrannus tyrannus. Kingbird.

See No. 204.

Back, olive gray; a concealed orange patch on the crown; throat, gray; belly, yellow; outer web of outer tail feather, white; a western species which has occasionally been taken east of the Mississippi.

Tyrannus verticalis.

Arkansas Kingbird.

See No. 205. 
Crown and back, ashy; throat and breast, ashy white; sides of breast and body, orange red; tail, very long, rarely less than four and one half inches. A southwestern species, several examples of which have been taken in eastern North America, from Ontario to Florida.

Muscivora forficata.

Scissor-tailed Flycatcher.

See No. 203.

\section{Family ALAUDIDÆ. Larks.}

Bill, pointed, and somewhat rounded; back of tarsus, rounded; hind toe nail, elongated, equal or longer than the toe; nostrils, more or less concealed by tufts of hair-like feathers; wing, 3.75 to 4.50 .

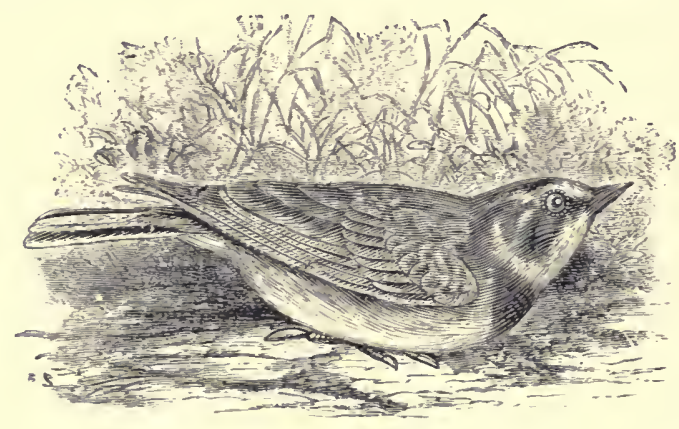

Horned Lark.
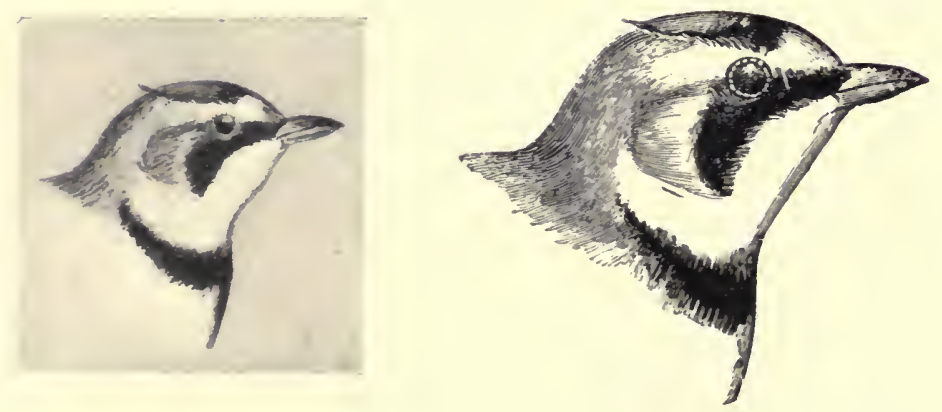

Upper throat and line over the eye, yellow, or yellowish white; a stripe from bill below the eye, and a patch on breast, black, or blackish; belly, white; upper parts, brownish, more or less streaked; hind toe nail long, and nearly straight; greater portion of outer web 
i 76 Field Museum of Natural History - Zoölogy, Vol. IX.

of outer tail feather, white. In immature and winter birds, the hornlike tuft of feathers is lacking, or indistinct.

Otocoris alpestris, and races.

Horned Lark.

See Nos. 2 I6, 2 I6a, and 2 I6b.

\section{Family CORVIDÆ. Crows, Jays, etc.}

Subfamily GARRULINÆ. Magpies and Jays.

First primary, much shorter than second, always less than three fourths as long as third; fourth or fifth primary, longest; bill, stout and strong; the nostrils, concealed by coarse hair-like feathers; outer tail feathers, shorter than middle feathers.

* GROUP 1. Wing, less than 5.50 inches long

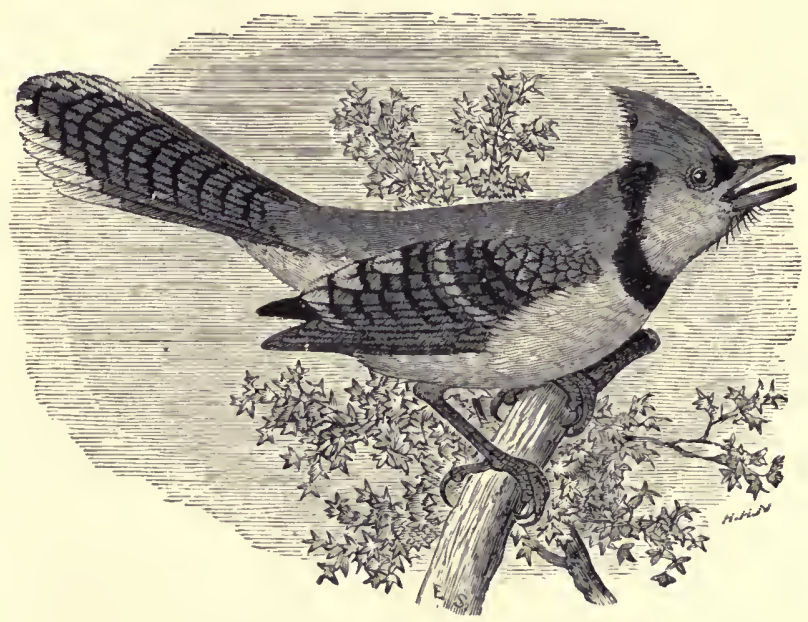

Upper parts, pale blue or purplish blue; tail,

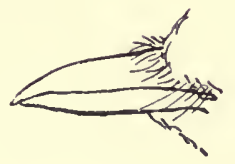
bright blue, barred with black and (except middle feathers) tipped with white; wings, blue, marked with white; under parts, ashy white; breast with black band.

Cyanocitta cristata. Blue Jay. See No., 2 I 8.

* For directions for measurement, see page $2 \mathrm{I}$. 


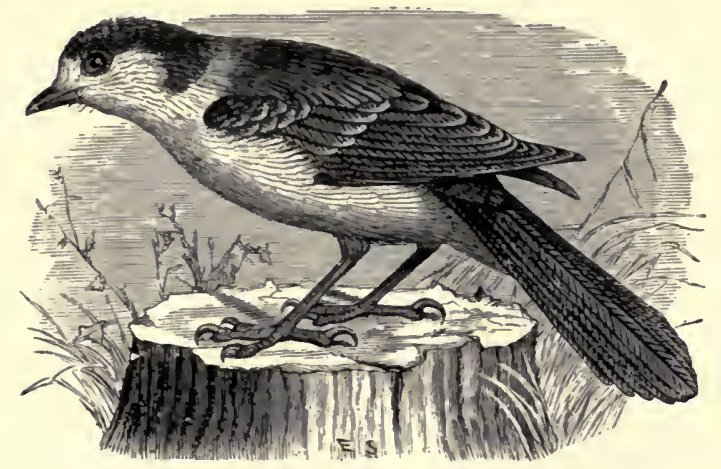

Canada Jay.

No blue on plumage anywhere; greater part of crown, dusky; breast and belly, gray; throat, lighter.

Perisoreus canadensis.

Canada Jay.

See No. 2 I 9.

\section{GROUP 2. Wing, 5.50 to 6.50 inches long.}

Upper parts, pale blue, or purplish blue; tail; bright blue, barred with black and (except middle feathers) tipped with white; wings, blue, marked with white; under parts, ashy white; breast, with black band.

Cyanocitta cristata. Blue Jay.

See No. 2 I 8.

Forehead, throat, and sides of head, dull white; back of crown and nape, blackish; back, gray; under parts, ashy, palest on the throat.

Perisoreus canadensis.

Canada Jay.

See No. 219.

GROUP 3. Wing, 6.50 to 8.50 inches long.

Head and breast, black; tail, long, showing more or less green and purple reflections.

Pica pica hudsonica.

American Magpie.

See No. 217 .

General plumage, ash gray, becoming white on front of head; most of tail, white except the two middle feathers which are black; 
i78 Field Museum of Natural History-Zoölogy, Vol. IX.

wings, black; wing, from 7.20 to 8 ; tail, about 5.25 ; belongs to the subfamily Corvinæ.

Nucifraga columbiana.

Clarke's Nutcracker.

See No. 222.

\section{Subfamily CORVIN代. Crows and Ravens.}

* GROUP 4. Wing, 9.50 to I 5 inches long.

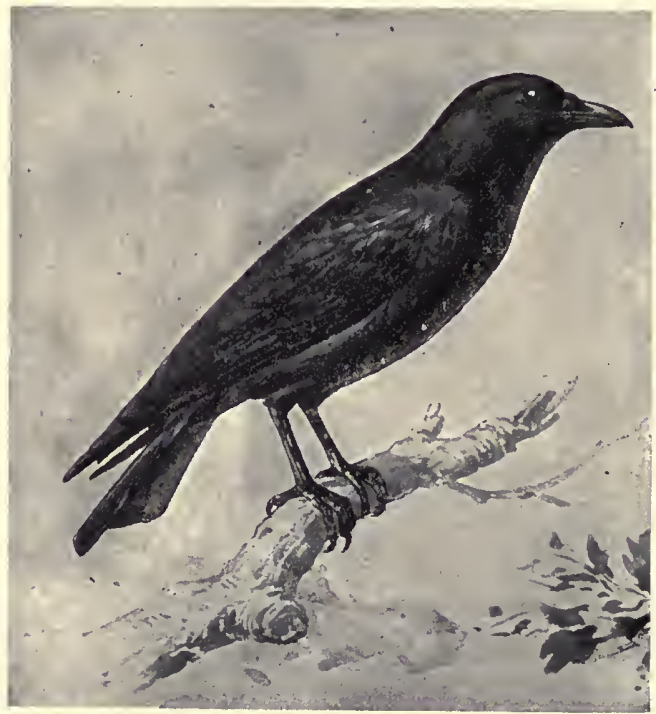

Crow.

Plumage, black; wing, over I1.50; tarsus, over 2.I0; bill, over I.80.

Corvus brachyrhynchos.

American Crow.

See No. 22 I.

GROUP 5. Wing, over 15 inches long.

General plumage, black; feathers on throat, narrow and pointed, size alone will distinguish it from the Crow.

Corvus corax principalis.

Northern Raven.

See No. 220.

* For directions for measurement see page $2 \mathrm{I}$. 


\section{Family ICTERIDÆ. Blackbirds, Orioles, Meadowlarks, etc.}

Bill, usually acute; first primary, not short, about the same length as second; base of bill slightly dividing the feathers of the forehead; nostrils exposed; outer tail feathers, shorter than middle feathers.

* GROUP 1. Wing, less than 3.75 inches long.

SECTION 1. The following species have the under parts more or less marked with either yellow, orange, or chestnut brown:-

Head and throat, black; under parts, orange yellow; back, black. Icterus galbula (male). Baltimore Oriole. See No. 230.

Head, more or less marked with black; back, blackish; under parts, orange, paler than the male.

Icterus galbula (female).

Baltimore Oriole.

See No. 230.

Crown and back, dull olive, faintly tinged with yellow on rump; under parts, pale yellow, usually with faint orange tinge; wing, over 3.45 .

Icterus galbula (immature).

Baltimore Oriole.

See No. 230.

Head and back, black; rest of under parts, chestnut brown.

Icterus spurius (male).

Orchard Oriole.

See No. 229.

Crown and back, greenish, without stripes; under parts, yellow (not orange); wing, under 3.45 .

Icterus spurius (female).

Orchard Oriole.

See No. 229.

* For directions for measurement, see page $2 \mathrm{I}$. 
i 80 Field Museum of Natural History-Zoölogy, Vol. IX.

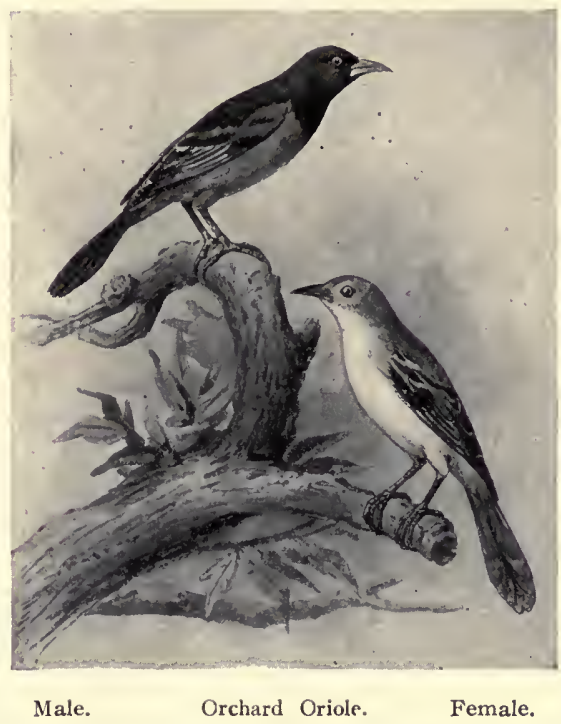

Crown, with yellow buff in center, bordered by black; back, streaked with black; under parts, pale yellow, tinged with buff; tail feathers, pointed.

Dolichonyx oryzivorus (female). Bobolink. Rice Bird. See No. 223.

SECTION 2. The following species have the under parts black, or heavily streaked with black or dark brown:-

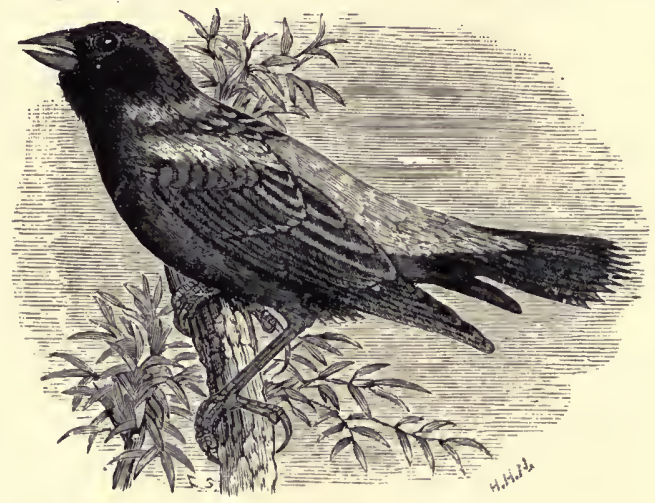

Bobolink.

Under parts, black, often showing more or less whitish on tips of feathers; head, black; back of neck, tawny, or tawny white; back, 
Jan., 1909. Birds of Illinois and Wisconsin-Cory.

I 8 I black, shading into gray and white on rump and upper tail coverts.

Dolichonyx oryzivorus (male.)

Bobolink. Rice Bird. See No. 223.

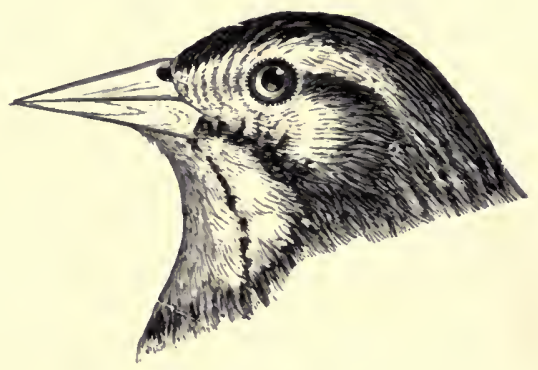

Red-winged Blackbird (female.)

Under parts, whitish or buffy, streaked with black.

Agelaius phreniceus (female), and races.

Red-winged Blackbird.

See Nos. 226, 226 a.

GROUP 2. Wing, 3.75 to 4.25 inches long.

First primary, never less than three fourths as long as third.

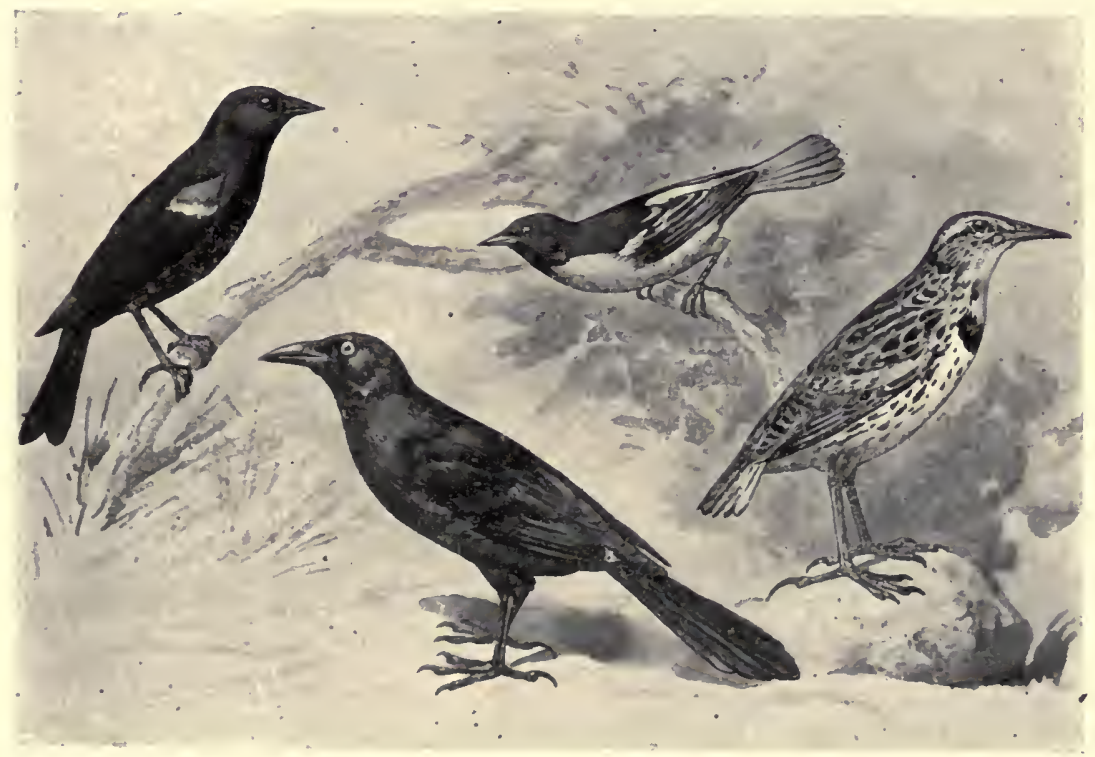

Blackbird.

Grackle, or Crow Blackbird. Oriole.

Meadowlark. 
i82 Field Museum of Natural History-Zoölogy, Vol. IX.

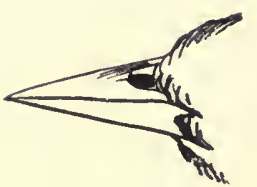

Oriole.

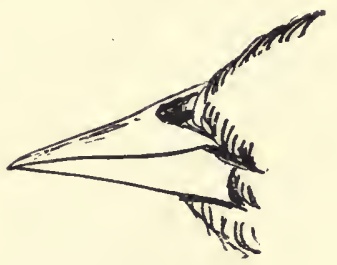

Blackbird.

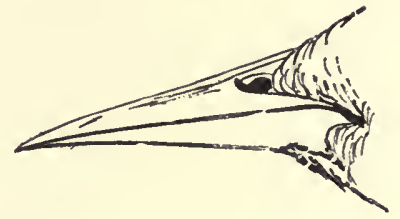

Meadowlark.

SECTION 1. The following species have under parts with more or less yellow :-

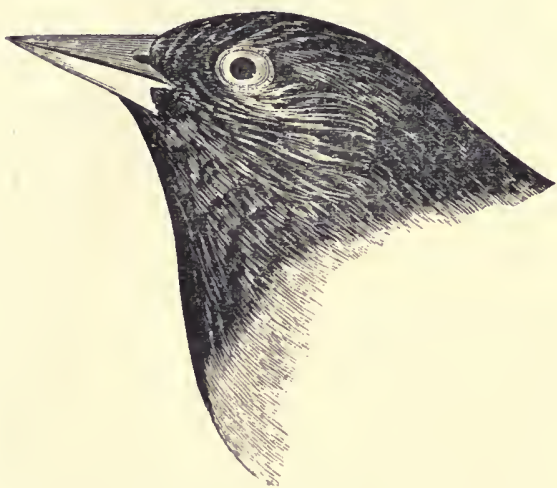

Baltimore Oriole (male).

Head and back, black; throat, black; rest of 'under parts, orange. Icterus galbula (male). Baltimore Oriole. See No. 230.

Head and back, brownish black; throat, black; rest of under parts, paler than the male.

Icterus galbula (female).

Baltimore Oriole.

See No. 230.

Upper plumage, dull brownish olive; rump, yellowish olive; entire under parts, yellowish white or pale buffy yellow, faintly tinged with orange. 
Under parts, pale buff yellow or tawny yellow; whitish on chin; sides, streaked with black; crown, blackish, with tawny stripe in center; back, streaked; tail feathers, very pointed.

Dolichonyx oryzivorus (female). Bobolink. Rice Bird. See No. 223 .

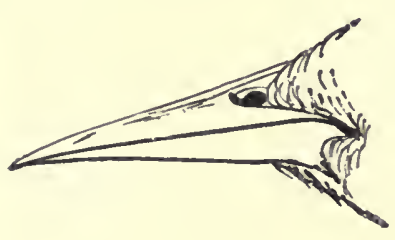

Throat and under parts, yellow; breast, with more or less black; crown brownish black, with buff white stripe in center.

Sturnella magna, and races. Meadowlark.

See Nos. 227,227 a, and 228 .

SECTION 2. The following species have no yellow on the under parts :-

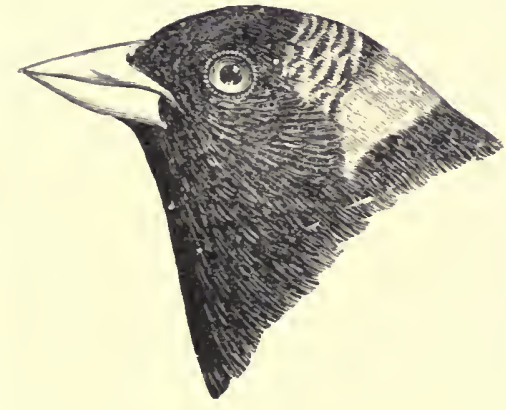

Bobolink (male).

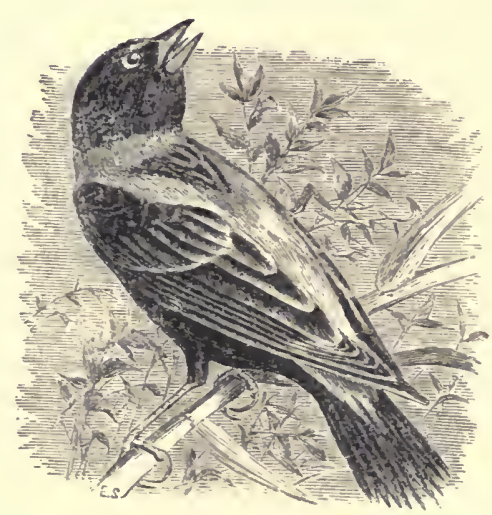

Bobolink (male).

Under parts, black, generally with more or less feathers tipped with dull white; crown, black; back of the neck, tawny; tail feathers, very pointed.

Dolichonyx oryzivorus. Bobolink. Rice Bird. See No. 223. 
i 84 Field Museum of Natural History-Zoölogy, Vol. IX.

Under parts, heavily streaked with black; throat, tinged with tawny.

Agelaius phoniceus (female).

Red-winged Blackbird. See No. 226.

Head and throat, brown; rest of plumage, glossy greenish black. Molothrus ater (male).

Cowbird.

See No. 224.

Under parts, brownish gray; upper parts, pale grayish brown.

Molothrus ater (female). Cowbird.

See No. 224 .

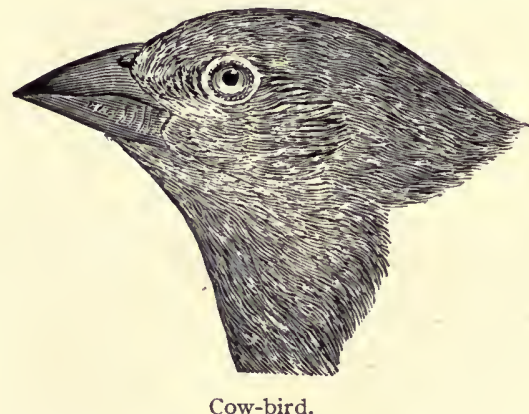

GROUP 3. Wing, 4.25 to 4.75 inches long.

First primary, never less than three fourths as long as]third.

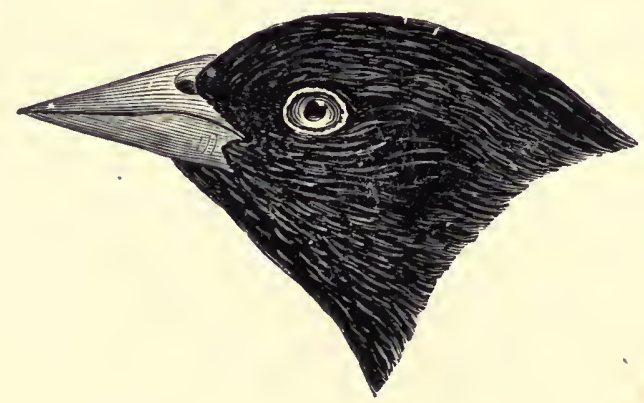




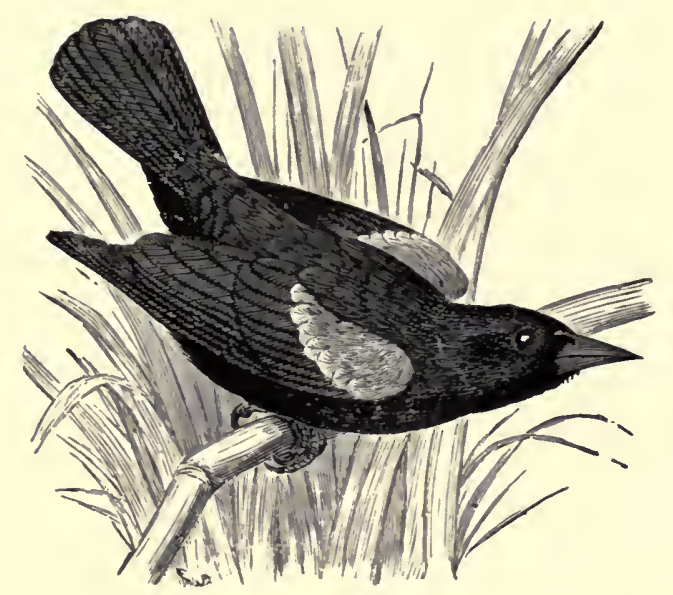

General plumage, black; a patch of scarlet on the shoulder. Agelaius phoniceus (male), and races. Red-winged Blackbird.

See Nos. 226, 226 a.

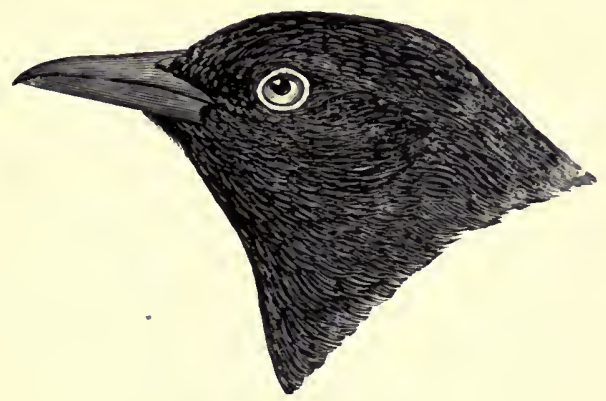

Rusty Blackbird.

General plumage, black; no red shoulder patch; head, not tinged with purple.

Euphagus carolinus (male).

Rusty Blackbird.

See No. 23 I.

General plumage, black, glossed on the head with purplish or violet black, and back and under parts, tinged with metallic green; no red on shoulder; wing, rarely less than 5 inches long.

Euphagus cyanocephalus (male). Brewer's Blackbird.

See Nu. 232. 
186 Field Museum of Natural History-Zoölogy, Vol. IX.

General plumage, black, tinged with rusty brown on the crown and back; the feathers on the under parts, tipped with rusty brown; under parts, not streaked; no red on shoulder.

Euphagus carolinus (female and immature in fall).

Rusty Blackbird.

See No. 231 .

General plumage, black, more or less streaked and marked with brown, buff, and dull white; lesser wing coverts (shoulder), dull red. Agelaius phoniceus (young male).

Red-winged Blackbird.

See No. 226 .

Upper parts, blackish, streaked with brownish buff; under parts, streaked with black; no red patch on shoulder.

Agelaius phoniceus (female), and races.

Red-winged Blackbird.

See Nos. 226,226 a.

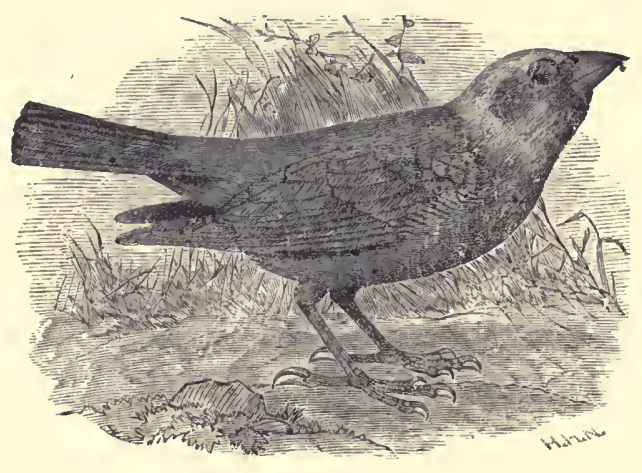

Cowbird.

Head and breast, chocolate brown; rest of plumage, glossy black. Molothrus ater (male).

Cowbird.

See No. 224 .

General plumage, gray; palest on the throat.

Molothrus ater (female).

Cowbird.

See No. 224 . 
Jan., ig09. Birds of Illinois and Wisconsin-Cory.

Throat, yellow; belly, black; adult males have the entire head yellow; females and immature birds have the crown often blackish. Xanthocephalus xanthocephalus (female).

Yellow-headed Blackbird. See No. 225 .

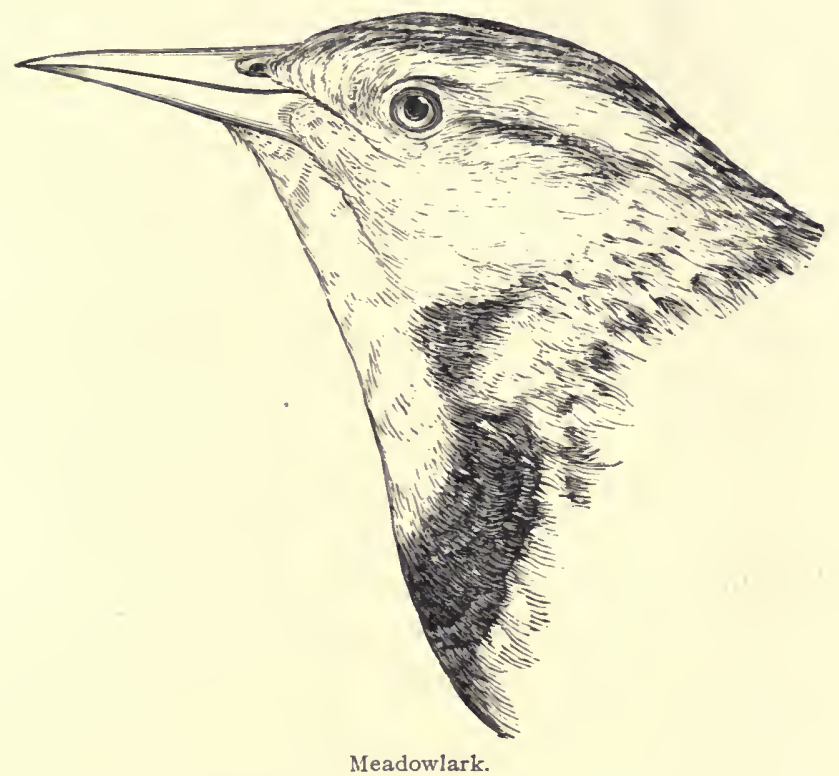

Throat and belly, yellow; breast, with more or less black.

Sturnella magna, and races. Meadowlark.

See Nos. 227,227 a, and 228 .

General plumage, dark slate or brownish slate color; under parts, inclining to plumbeous.

Euphagus carolinus (female) (adult in summer). Rusty Blackbird. See No. 23 I.

GROUP 4. Wing, 4.75 to 5.50 inches long.

First primary, not short; base of bill, dividing the feathers of the forehead; nostrils, exposed; outer tail feathers, shorter than middle feathers. 
i 88 Field Museum of Natural History-Zoölogy, Vol. IX.

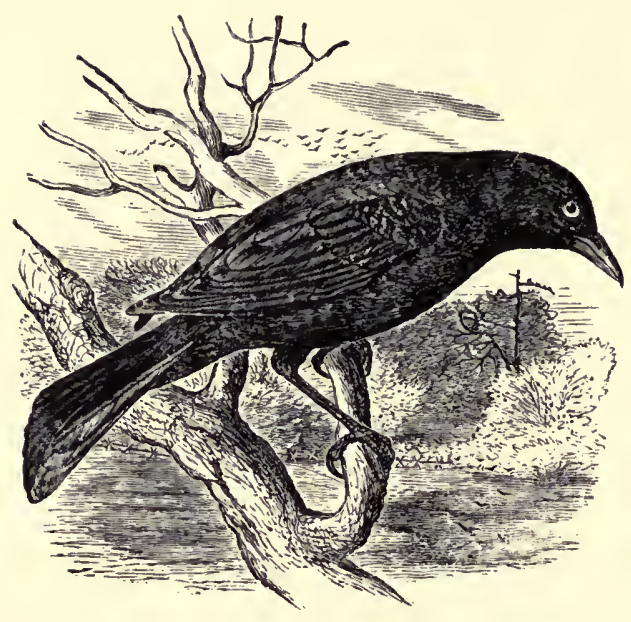

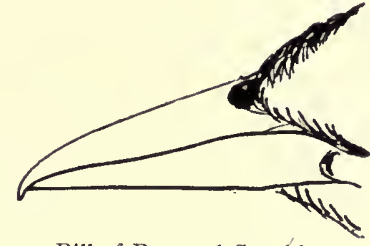

Bill of Bronzed Grackle.

General plumage, metallic green, purple, and bronze.

Quiscalus quiscula aneus.

Bronzed Grackle.

See No. 233.

General plumage, black; a patch of scarlet red on the shoulder. Agelaius phoniceus (adult male).

Red-winged Blackbird.

See No. 226.

General plumage, black, more or less streaked and marked with buff, brown, and dull white; traces of more or less red on the shoulder (lesser wing coverts).

Agelaius phoniceus, and races (immature). Red-winged Blackbird. See Nos. 226,226 a.

Adult birds entirely lustrous black; no red

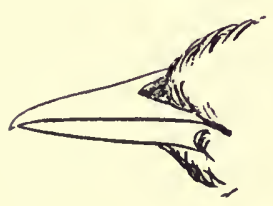
shoulder patch. Immature birds have the upper parts more or less rusty brown and the feathers on the under parts, tipped with brown.

Euphagus carolinus (male, and immature). Rusty Blackbird. See No. 23r.

General plumage, dark slate or brownish slate color; under parts, plumbeous slate color.
Euphagus carolinus (female, in summer).

Rusty Blackbird.

See No. 23 r. 
Jan., 1909. Birds of Illinois and Wisconsin-Cory.

General plumage, black, glossed on the head with purplish or violet black; the back and under parts, tinged with metallic green; no red on shoulder. Western species rare in Eastern United States. Euphagus cyanocephalus (male). Brewer's Blackbird. See No. 232.

Throat, yellow; belly, black; amount of yellow on head varies according to age and season.

Xanthocephalus xanthocephalus (female). Yellow-headed Blackbird. See No. 225 .

Throat and belly, yellow; breast, with more or less black.

Sturnella magna, and races.

Meadowlark. Marsh Quail. See No. 227,227 a, and 228 .

GROUP 5. Wing, 5.50 to 6.50 inches long.

General plumage, black, showing metallic, reflections of green, purple, and bronze, when held in the light.

Quiscalus quiscula aneus.

Bronzed Grackle.

See No. 233 .

Head and throat, yellow, belly, black (male); throat, yellow, belly, grayish brown (female).

Xanthocephalus xanthocephalus.

Yellow-headed Blackbird.

See No. 225 .

Throat, yellow; belly, yellow; a black crescent on the breast.

Sturnella magna, and races.

Meadowlark.

See No. 227,227 a, and 228 . 


\section{INDEX TO KEY.}

\section{Family FRINGILLIDÆ. Sparrows, Finches, Crossbills, Buntings, etc.}

GRoUP I. Wing, I.75 to 2.13 inches long. See page I 92.

Group 2. Wing, 2.13 to 2.37 inches long. See page I93.

Part I. Breast, more or less streaked; carpal joint, edged with yellow. See page r 93 .

Part 2. Breast, more or less streaked; carpal joint, not yellow. See page I93.

Part 3. Breast, not streaked; carpal joint, edged with yellow. See page 193 .

Part 4. Breast, not streaked; carpal joint, not edged with yellow. See page 194 .

Group 3. Wing, 2.37 to 2.75 inches long. See page r 94.

Part I. Throat or under parts, more or less blue, red, dull green, or bright yellow. See page r 94 .

Part 2. Throat or under parts, not marked with red, blue, yellow, or green, breast, distinctly streaked; carpal joint, edged with yellow. See page I95.

Part 3. Under parts, not marked with red, blue, yellow, or green; breast distinctly streaked; carpal joint, not edged with yellow. See page I96.

Part 4. Under parts, not marked with red, blue, yellow, or green; breast; not streaked; bend of wing (carpal joint), edged with yellow. See page 197 .

Part 5. Under parts, not marked with red, blue, yellow, or green; the breast, not distinctly streaked, and no yellow on bend of wing. See page 198 .

GRoUP 4. Wing, 2.75 to 3.25 inches long. See page I 99.

Part I. Throat or under parts, more or less red, blue, green, or yellow See page r 99 .

Part 2. No blue, red, green, or yellow on the under parts; more or less of throat, black (sometimes only the chin); breast and sides, not distinctly streaked. See page 202 .

Part 3. No blue, red, green, or yellow on the under parts; throat or chin, not black; breast or sides, not distinctly streaked; tail feathers, marked with more or less white. See page 203 .

Part 4. No blue, red, green, or yellow on the under parts; throat or chin, not black; breast or sides, not distinctly streaked; no white on tail feathers. See page 204 .

Part 5. No red, blue, green, or yellow on the under parts; throat, more or less (sometimes only the chin) black; breast or sides, distinctly streaked. See page 206 . 
Jan., I909. Birds of Illinois and Wisconsin-Cory.

Part 6. No red, blue, green, or yellow on the under parts; throat or chin, not black; breast, distinctly streaked or spotted. See page 207 .

Group 5. Wing, 3.25 to 3.75 inches long. See page 209.

Part I. More or less of either red, blue, yellow, or green on the under parts. See page 209 .

Part 2. No red, blue, yellow, or green on the under parts. See page 2 I 1 . Group 6. Wing, 3.75 to 4.25 inches long. See page 2 I 5 .

Part $x$. More or less red on the under parts. See page 2 I 5.

Part 2. More or less yellow, orange, or green on the under parts. See page 2 I 6 .

Part 3. No red, yellow, orange, or green on the under parts. See page $2 \mathrm{r} 7$. Group 7. Wing, 4.25 to 4.75 inches long. See page 2 I9. 


\section{Family FRINGILLIDÆ. Sparrows, Finches, Crossbills, etc.}

Primaries, consisting of 9 feathers; first primary, not short, never less than two-thirds as long as second or third; bill, stout and conical; nostrils, high, near the culmen; tarsus, flattened behind.

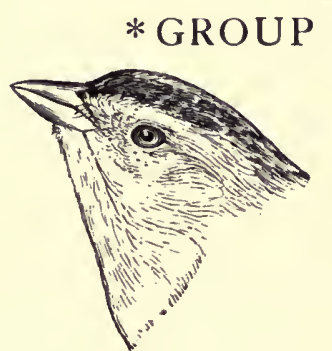

Coturniculus leconteii.

Top of head, blackish, with tawny stripe in middle, and tawny stripe over each eye; tail usually longer than wings.

Coturniculus leconteii.

Leconte's Sparrow. See No. $25^{2}$.

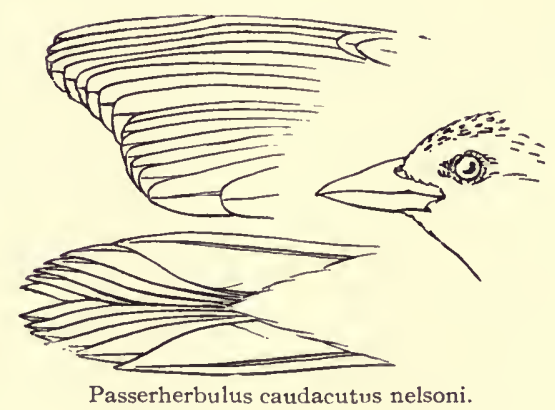

Top of head, brownish and slate color; a tawny stripe over each eye; no tawny stripe on middle of crown.

Passerherbulus caudacutus nelsoni. Nelson's Sharp-tailed Sparrow.

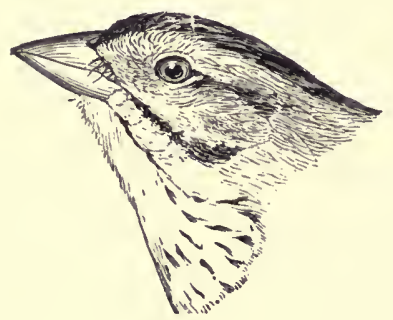
See No. 253.

Top of head and nape, pale olive green, mixed with black; no tawny stripe over eye.

Coturniculus henslowii.

Henslow's Sparrow. See No. 25 r.

* For directions for measurement, see page 21 . 
GROUP 2. Wing, 2.I 5 to 2.37 inches long.

PART 1. The following species have the breast more or less streaked; carpal joint (bend of wing), edged with yellow:-

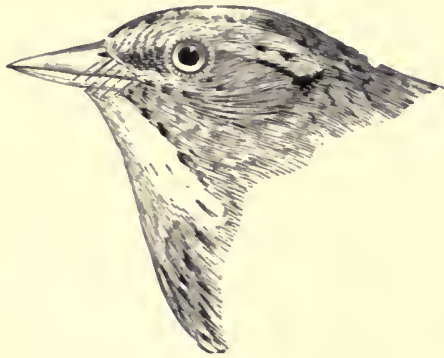

Bill, dark; sides of head, tawny buff enclosing a patch of gray behind the eye; heavy tawny buff superciliary stripe. Passerherbulus caudacutus nelsoni.

Nelson's Sharp-tailed Sparrow. See No. 253.

Bill, pale horn color; sides of head and nape, tinged with olive green.

Coturniculus henslowii.

Henslow's Sparrow. See No. $25 x$.

PART 2. The following species have the breast more or less streaked; carpal joint (bend of wing), not yellow:-

Breast, very faintly streaked; middle tail feathers, rufous brown. with black stripe in middle, including the shaft; wing coverts and secondaries, edged with rufous brown.

Melospiza georgiana.

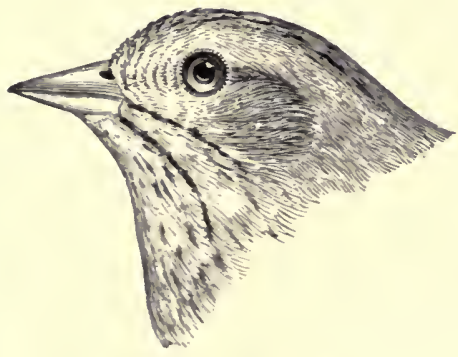

Swamp Sparrow.

See No. 269.

Melospiza lincolnij.

PART 3. The following species have the breast not streaked (in the adult*); carpal joint (bend of wing), edged with yellow:-

Top of head, black with tawny stripe in center; an orange brown spot over, and somewhat in front of, the eye; bend of wing, yellow.

Coturniculus savannarum australis.

Grasshopper Sparrow. Yellow-winged Sparrow.

See No. 250.

* In several species, very young birds in first plumage have the breast streaked. 
ig4 Field Museum of Natural History-Zoölogy, Vol. IX.

Top of head and back, rufous brown with more or less gray on feathers; sides, without spots; tail feathers, narrow; tail much rounded, the outer feathers being half an inch or more shorter than the middle feathers.

Aimophila cestivalis bachmanii.

Bachman's Sparrow.

See No. 266.

PART 4. The following species have the breast not streaked (in the adult); carpal joint (bend of wing), not edged with yellow:-

Wing coverts and secondaries, edged with rufous brown; flanks, brownish olive.

Melospiza georgiana.

Swamp Sparrow.

See No. 269.

Wing coverts and secondaries, edged with pale tawny buff; tail feathers, brown, narrowly edged with brownish white; flanks, pale buffy white.

Spizella pallida. Clay-colored Sparrow.

See No. 26 I.

GROUP 3. Wing, 2.37 to 2.75 inches long.
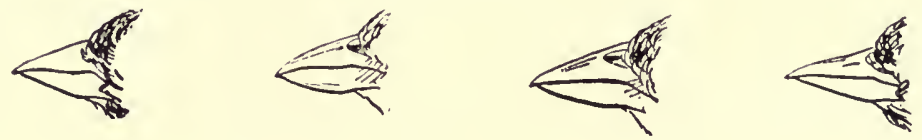

PART 1. The following species have the throat or under parts more or less marked with either blue, red, dull green, or bright yellow :-

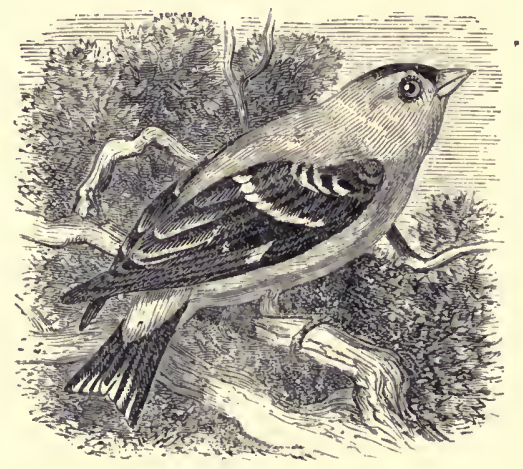


Jan., 1909. Birds of Illinois and Wisconsin-Cory.

Under parts, entirely yellow (male), or throat, yellow; under parts, dull olive gray (female); wings and tail, black, marked with white; yellow on under parts varies much, according to age and season.

Astragalinus tristis.

American Goldfinch. Yellowbird.

See No. 242.

Under parts, bright red, or tinged with red; back, green; crown, blue.

Passerina ciris (male).

Painted Bunting. Nonpareil.

See No. 277 .

Under parts, greenish; back, green.

Passerina ciris (female).

Painted Bunting.

See No. 277.

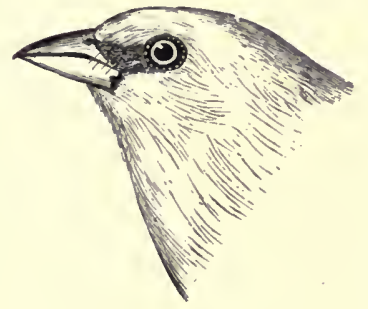

Under parts, blue; general plumage, blue; wings and tail, black, edged with blue.

Passerina cyanea (male).

Indigo Bird. Indigo Bunting. See No. 276 .

Under parts, more or less blotched with blue.

\section{Passerina cyanea (immature). \\ Indigo Bird. \\ See No. 276 .}

PART 2. The following species have the under parts not marked with red, blue, yellow, or green; breast, distinctly streaked; carpa joint (bend of wing), edged with yellow: -

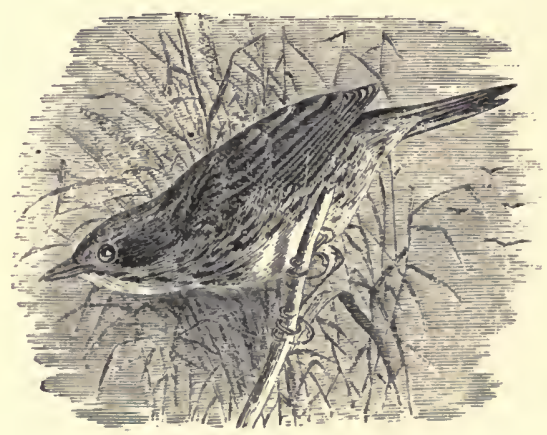

Sharp tailed Sparrow. 
ig6 Field Museum of Natural History-Zoölogy, Vol. IX.

Breast and flanks, tawny; a tawny stripe over the eye; outer tail feathers, decidedly shorter than middle ones.

Passerherbulus caudacutus nelsoni. Nelson's Sharp-tailed Sparrow. See No. 253.

Breast and flanks, white streaked with brown; a yellow spot in front of eye (absent in some plumages); rump, pale brown, marked with dark brown; outer tail feathers, not shorter than middle ones; under tail coverts, white.

Passerculus sandwichensis savanna.

Savanna Sparrow.

See No. 249.

PART 3. The following species have the under parts not marked with red, blue, yellow, or green; breast, distinctly streaked; carpal joint (bend of wing), not edged with yellow :-

Forehead, reddish brown; crown, brown, with imperfect gray streak in middle, and blackish dots; no yellow in front of eye; breast, white, heavily streaked with dark brown; outer tail feathers, shortest.

Melospiza melodia.

Song Sparrow. See No. 267.

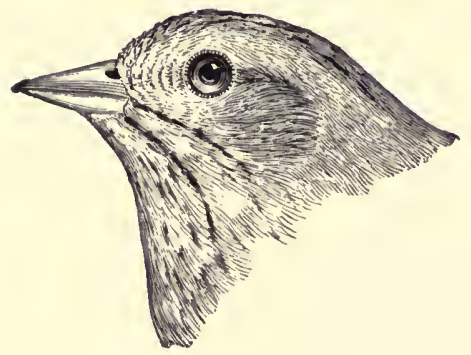

Crown, brown, streaked with black; breast, buff, streaked with black; back, streaked; outer tail feathers, shortest.

Melospiza lincolnii.

Lincoln's Sparrow.

See No. 268.

Crown, black, streaked with pale brown; a yellow spot in front of eye (wanting in some plumages); breast, white, streaked with dark brown; back, streaked; outer tail feathers, not shorter than middle ones.

Passerculus sandwichensis savanna.

Savanna Sparrow.

See No. 249. 


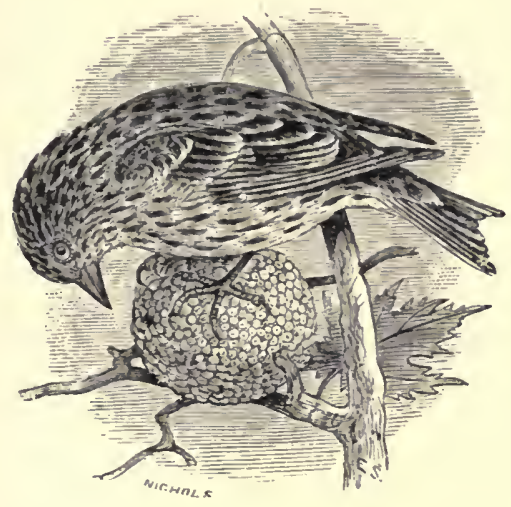

Wings and tail, dark brown, more or less margined with yellow; the bases of the feathers, pale yellow; under parts, heavily streaked with brownish black; crown and back, brownish olive, heavily streaked with black.

Spinus pinus.

Pine Siskin.

See No. 243.

Crown and back, brown, without streaks; under parts, pale buff brown, faintly streaked on breast and sides.

Passerina cyanea (female). Indigo Bunting. See No. 276.

PART 4. The following species have the under parts not marked with red, blue, yellow, or green, and the breast not distinctly streaked, but have the carpal joint (bend of wing) edged with yellow :-

Crown, black, with pale tawny buff stripe on middle; ear coverts, tawny buff; middle back, blackish; feathers, edged with buff; tail feathers, very pointed; tail, less than 2.25 long.

Coturniculus savannarum australis.

Grasshopper Sparrow. Yellow-winged Sparrow. See No. 250.

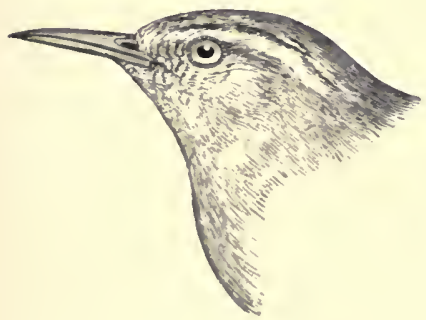

Crown, grayish, without tawny stripe in middle; ear coverts, gray; back, olive and gray; a distinct superciliary stripe of buff or yellowish.

Passerherbulns caudacutus nelsoni.

Nelson's Sharp-tailed Sparrow.

See No. 253.

Crown and back, rufous brown, the feathers, more or less marked with black, and edged with gray; no tawny stripe on middle of crown; 
i98 Field Museum of Natural History-Zoölogy, Vol. IX.

tail feathers, not pointed; tail, over 2.25 long, and much rounded, the outer feathers half an inch or more shorter than the middle feathers.

Aimophila cestivalis bachmanii.

Bachman's Sparrow.

See No. 266.

PART 5. The following species have the under parts not marked with red, blue, yellow, or green; the breast, not distinctly streaked, and no yellow on the carpus (bend of the wing):-

Crown and back, the same color, brown without streaks.

Passerina cyanea (female). Indigo Bunting. See No. 276 .

Crown and back, bright olive green, without streaks.

Passerina ciris (female). Painted Bunting. Nonpareil. See No. 277.

Back, streaked with black; rump, olive brown, streaked with black; wing coverts and secondaries, broadly edged with rufous brown; sides of body, clear olive brown; middle of belly, whitish.

Melospiza georgiana. Swamp Sparrow. See No. 269.

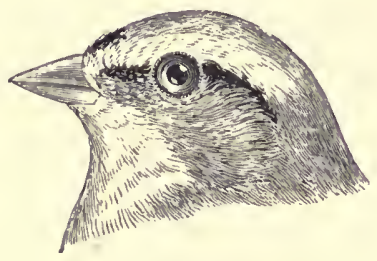

Bill, black or dark brown; back, streaked with black; rump, slate gray; adult birds have the crown rufous.

Spizella passerina. Chipping Sparrow. See No. 260.

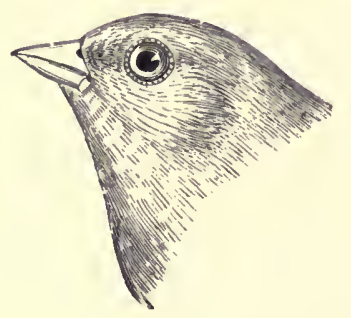

Bill, reddish brown; crown and back, rufous brown; back, streaked with black; rump, pale grayish brown.

Spizella pusilla. Field Sparrow. See No. 262. 


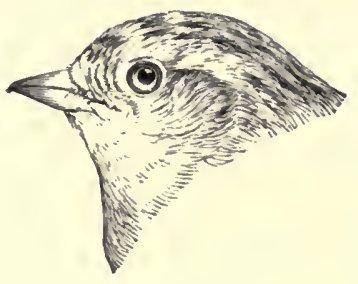

Bill, pale brown (not reddish brown); under parts, dull white (not grayish on sides as in the Chipping Sparrow); crown and back, pale grayish brown, streaked with black; rump, grayish brown (not slate gray as in the Chipping Sparrow).

Spizella pallida. Clay-colored Sparrow. See No. 261.

* GROUP 4. Wing, 2.75 to 3.25 inches long.

PART 1. The following species have the throat, or under parts, more or less red, blue, green, or yellow:-

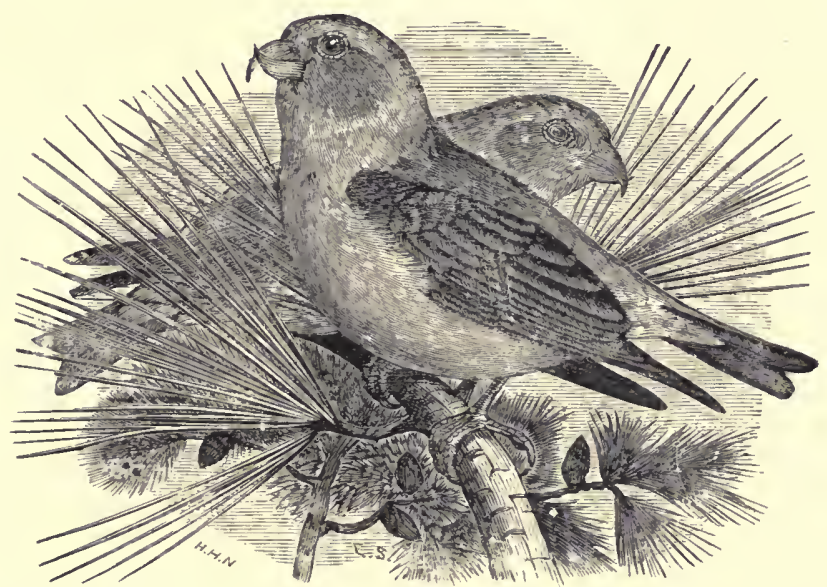

Mandibles, crossed; general plumage, dull red; wings, brownish; no white on wings (male).

Loxia curvirostra minor.

American Crossbill.

See No. 238.

Mandibles, crossed; no white on wings; under parts, greenish.

Loxia curvirostra minor (female).

American Crossbill.

See No. 238.

Mandibles, crossed; more or less red on under parts, head, and back; wing bars, white.

Loxia leucoptera (male). White-winged Crossbill. See No. 239.

* For directions for measurement, see page $2 \mathrm{x}$. 
200 Field Museum of Natural History-Zoölogy, Vol. IX.

Mandibles, crossed; wing bars, white; under parts, greenish.

Loxia leucoptera (female). White-winged Crossbill. See No. 239.

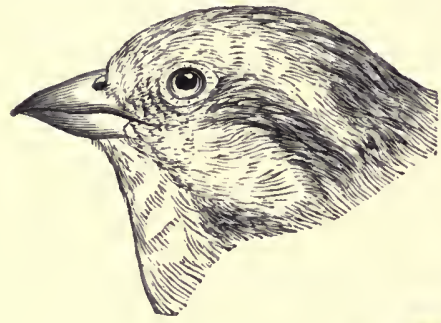

Mandibles, not crossed; breast and crown, rose red; back, brown, tinged with red; chin, not black.

Carpodacus purpureus (male). Purple Finch. See No. 236.

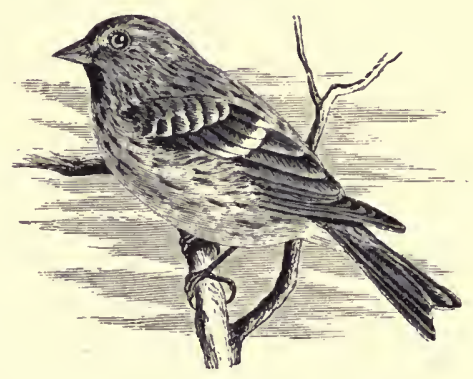

Redpoll.

Mandibles, not crossed; chin, blackish; breast, rose red; front crown, metallic red; rump, streaked. Acanthis linaria, and races.

Redpoll.

See Nos. 24I, 24 Ia.

Mandibles, not crossed; chin, blackish; under part, whitish, with faint tinge of pink on breast; rump, white, without streaks, sometimes tinged with rose color. Acanthis hornemannii exilipes.

Hoary Redpoll. See No. 240.

Mandibles, not crossed; under parts, yellow; back, yellow; wings and tail, black, marked with white. Astragalinus tristis (male). American Goldfinch. Yellowbird. See No. 242.

Mandibles, not crossed; throat, yellow; rest of under parts, grayish olive; tail and wings, black, marked with white.

Astragalinus tristis (female). American Goldfinch. Yellowbird.

See No. 242. 


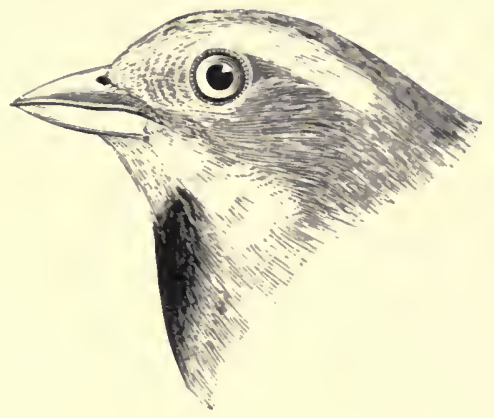

Mandibles, not crossed; chin, white; throat, black; breast, yellow; belly, white; back, streaked with black; shoulder, chestnut.

Spiza americana.

Dickcissel. Black-throated Bunting. See No. 278 .

Mandibles, not crossed; under parts, red; crown and sides of head, blue; back, green.

Passerina ciris (male).

Painted Bunting. Nonpareil.

See No. 277 .

Mandibles, not crossed; under parts, tinged with red; upper parts, bright olive green; no white on wings or tail.

Passerina ciris (young male).

Painted Bunting.

See No. 277 .

Mandibles, not crossed; under parts, greenish yellow; upper plumage, bright olive green; no white on wings or tail.

Passerina ciris (female).

Painted Bunting.

See No. 277 .

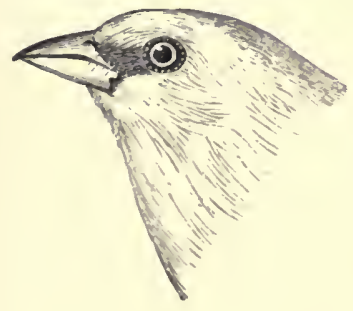

Mandibles, not crossed; general plumage, blue, with black wings and tail, edged with blue. Passerina cyanea (adult male). Indigo Bunting. Indigo Bird. See No. 276 . 
202 Field Museum of Nátural History-Zoölogy, Vol. IX.

Mandibles, not crossed; general plumage, brownish, blotched with blue.

Passerina cyanea (young male).

Indigo Bunting. Indigo Bird.

See No. 276 .

PART 2. The following species have no red, blue, green, or yellow on the under parts; more or less of the throat, black (sometimes only the chin); breast and sides, not distinctly streaked :-

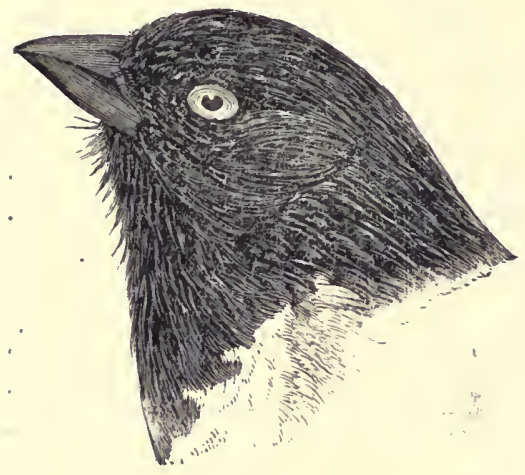

Head, back, throat, and upper breast, black; sides of body, rufous brown; wings and tail, black, marked with white; bill, dark.

Pipilo erythrophthalmus (male). Towhee Bunting. See No. 27 r.

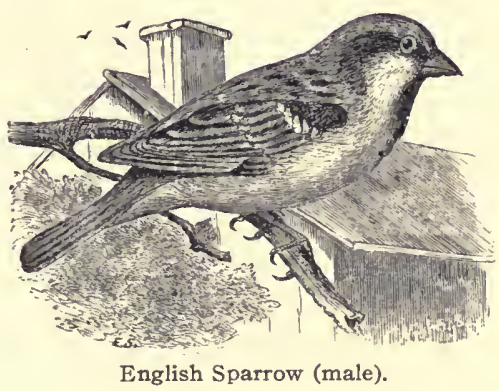

Throat, black; crown, gray; malar region, white; occiput, chestnut brown; rump, olive gray; bill, black. Passer domesticus (male). English Sparrow. House Sparrow. See No. 237.

Chin, black; throat, white, slightly tinged with tawny; rest of under parts, white; crown, fiery red; rump, white, not streaked.

Acanthis hornemannii exilipes.

Hoary Redpoll.

See No. 240. 
Head, face, and throat, black; tail, grayish brown; bill, pale red; back, brown, streaked with black; wing, over three inches long.

Zonotrichia querula.

Harris's Sparrow.

See No. 255 .

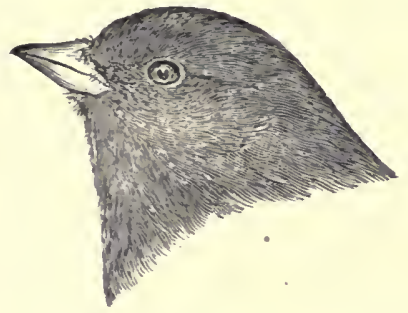

Head and throat, slaty gray; belly, white; back and rump, grayish brown; bill, pale; outer tail feather, entirely white.

Junco hyemalis. Slate-colored Junco. Snowbird. See No. 263 .

PAR'T 3. The following species have no red, blue, green, or yellow, on the under parts; throat or chin, not black; and the breast or sides, not distinctly streaked; tail feathers, marked with more or less white :-

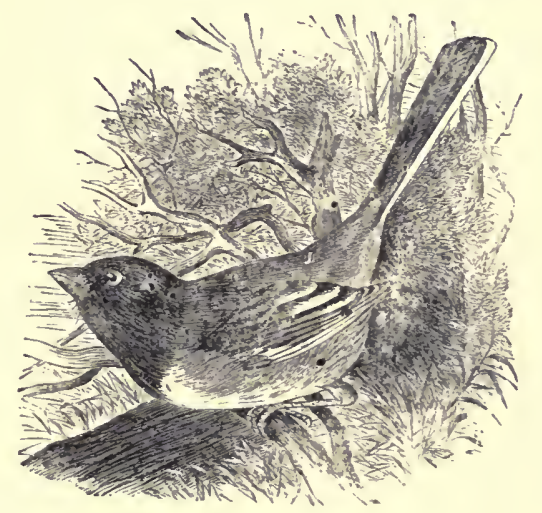

Throat, grayish brown; sides of body, deep rufous brown; back, not streaked; belly, white; bill, black. Pipilo erythrophthalmus. Towhee. Towhee Bunting. See No. 27 I.

Head and throat slate gray, belly, white; back and rump, grayish brown; back, not streaked; bill, pinkish white.

Junco hyemalis, and races. Slate-colored Junco. Snowbird. See No. 263 . 
204 Field Museum of Natural History-Zoölogy, Vol. IX.

Resembles common Junco, but sides, pinkish brown; head, neck, and chest, slate gray.

Junco hyemalis montanus.

Montana Junco.

See No. 264 .

Similar to last, but has head, neck, and chest, black or blackish; sides, pinkish brown.

Junco oregonus shufeldti.

Shufeldt's Junco.

See No. 265 .

Throat, white; crown, brown, with whitish stripe through middle; back, streaked; tail feathers, broadly tipped with white.

Chondestes grammacus.

Lark Sparrow.

See No. 254.

Throat, ashy white; belly, white, tinged with pale buff on sides; crown, bright rufous; tail feathers, very narrowly edged with white; upper mandible, blackish; lower mandible, pale yellowish white, with dark tip; back, streaked.

Spizella monticola.

Tree Sparrow.

See No. 259.

Throat and under parts, pale buffy white or ashy white; crown and back, dull brown; back, streaked with blackish; tail, very narrowly edged with buffy white; bill, reddish brown; rump, brownish.

Spizella pusilla.

Field Sparrow.

See No. 262.

Throat, white; crown, rufous; a white stripe over the eye; outer tail feather, very narrowly edged with whitish on inner web; bill, black; back, streaked; rump, slaty gray.

Spizella passerina.

Chipping Sparrow.

See No. 260.

PART 4. The following species have no red, blue, green, or yellow on the under parts; throat or chin, not black, and the breast or sides, not distinctly streaked; no white on breast or the tail feathers:-

Crown, green, like back; throat and under parts, pale buff; back, green, without streaks.

Passerina ciris (immature).

Painted Bunting. Nonpareil. See No. 277 . 
Crown, brown, like back; throat and under parts, pale brown; whitish on belly; breast, usually with indistinct streaks; back, brown, without streaks.

Passerina cyanea (female).

Indigo Bird. Indigo Bunting. See No. 276 .

Crown, black, with white stripe in center; stripe over eye, white; usually more or less yellow in front of eye; throat, white; breast, grayish; carpal joint (bend of wing), pale yellow; back, streaked. Zonotrichia albicollis. White-throated Sparrow. See No. 258.

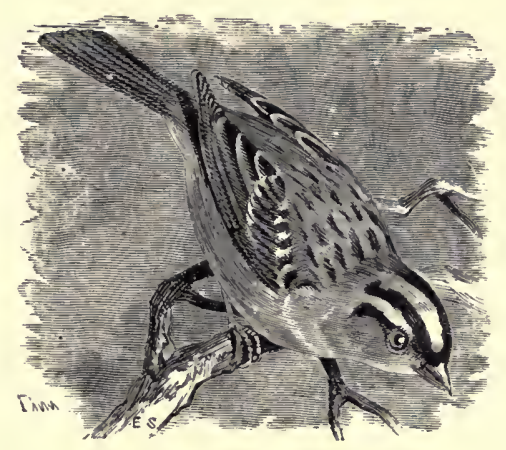

White-crowned Sparrow.

Crown, black, with white stripe in center; no yellow in front of eye; no distinct white patch on throat; carpal joint (bend of wing), not yellow; back, streaked.

Zonotrichia leucophrys. White-crowned Sparrow. See No. 256.

Crown, brown, with grayish brown center; no yellow in front of eye; nape, gray; bill, reddish brown; back, streaked; wing coverts, tipped with white.

Zonotrichia leucophrys (immature). White-crowned Sparrow. See No. $25^{6}$.

Crown, light chestnut brown (streaked with black in young birds); rump, slaty gray; bill, black; back, streaked. Young birds in fall have the bill brownish.

Spizella passerina. Chipping Sparrow. See No. 260. 
206 Field Museum of Natural History-Zoölogy, Vol. IX.

Crown, rufous brown; rump, pale olive brown; upper mandible, black; under mandible, pale, with dark tip; back, streaked.

Spizella monticola.

Tree Sparrow.

See No. 259.

Crown, black and white; no yellow on crown or in front of the eye; lores, gray; throat, ash gray; edge of wing, yellow. Western species of possible accidental occurrence within our limits.

Zonotrichia leucophrys gambelii.

Gambel's Sparrow.

See No. 256 a.

Crown, pale chestnut brown; rump, olive brown; bill, reddish brown; back, streaked.

Spizella pusilla.

Field Sparrow.

See No. 262.

PART 5. The following species have no red, blue, green, or yellow on the under parts; thruat, more or less (sometimes only chin) black, and the breast or sides distinctly streaked:-

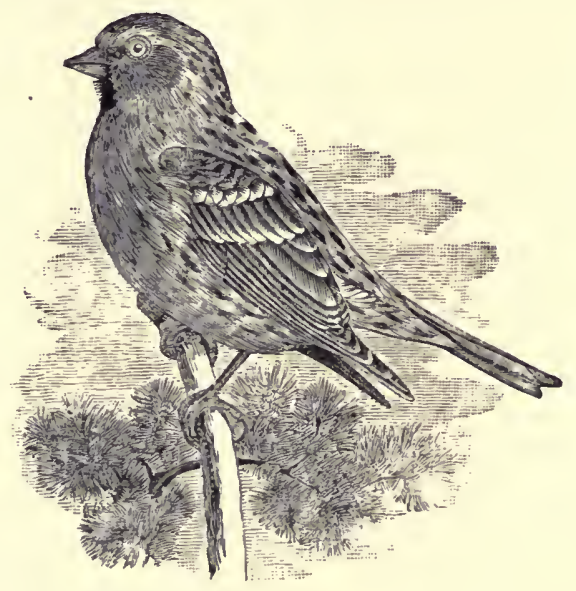

A black spot on the chin; crown, with more or less metallic red; rump, streaked; bill, yellowish, with dark tip. Common on Atlantic coast. Acanthis linaria, and races.

Redpoll.

See Nos. 24I, 24 Ia. 
A black spot on the chin; crown, with more or less metallic red; rump, white, usually without streaks; bill, yellowish, with dark tip; plumage, much whiter than linaria. Rarely occurs south of Labrador. Acanthis hornemannii exilipes.

Hoary Redpoll. See No. 240.

PART 6. The following species have no red, blue, green, or yellow on the under parts; throat or chin, not black, and the breast, distinctly streaked or spotted:--

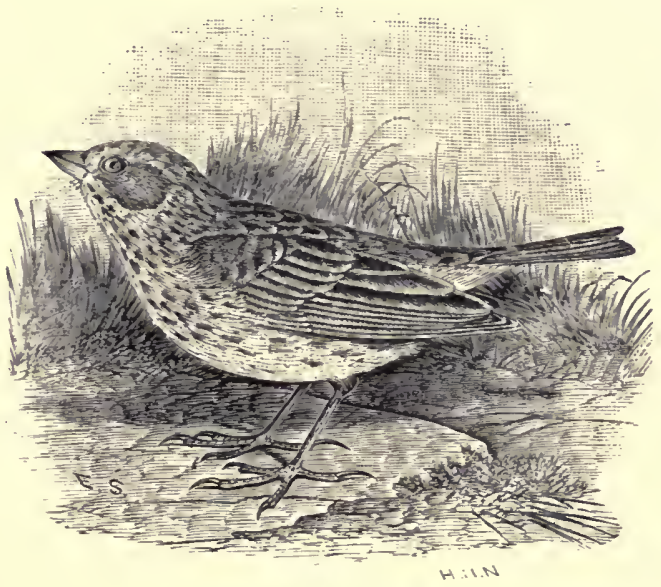

Savanna Sparrow.

Crown feathers, blackish, narrowly edged with light brown; an imperfect buff white line through center of crown; tail, usually under 2.20; wing, usually under 2.90 (more or less yellow over and in front of eye in some plumages); outer tail feathers, not shorter than middle ones; a black streak on sides of upper throat; back, streaked; breast, streaked with dark brown; outer web of outer tail feather, edged with dull white.

Passerculus sandwichensis savanna.

Savanna Sparrow.

See No. 249.

Rump and upper surface of tail feathers, rufous brown.

Passerella iliaca.

Fox Sparrow.

See No. 270. 

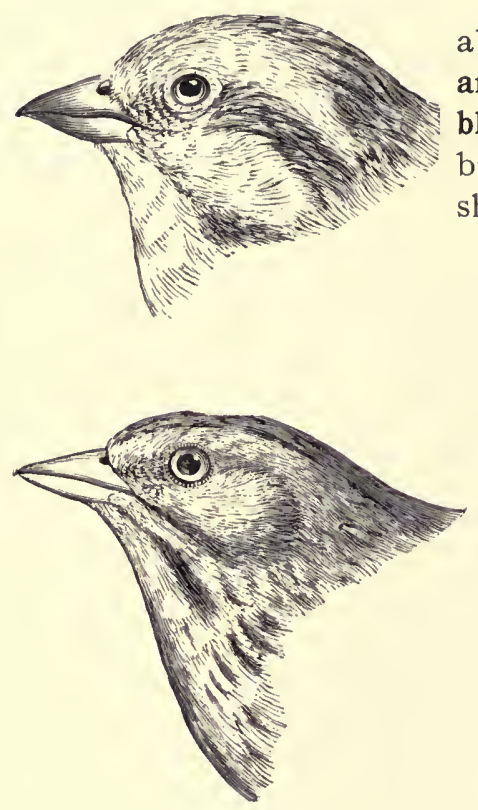

with more or less rufous brown); back, streaked.

Bill, large; depth of bill at base, about equal to length of culmen; crown and back, brownish olive, streaked with blackish; throat, streaked dark olive brown, not black; middle tail feathers, shorter than outer feathers.

Carpodacus purpureus (female). Purple Finch. See No. 236 .

Outer tail feathers, decidedly shorter than middle ones; crown, dull rufous brown, streaked with black and showing a grayish stripe in the center; under parts, white; the breast, heavily streaked with black; carpal joint, not edged with yellow; outer tail feathers, not half white (the breast and sides, often faintly tinged with tawny and black striping on breast, often mixed Melospiza melodia.

Song Sparrow. See No. 267.

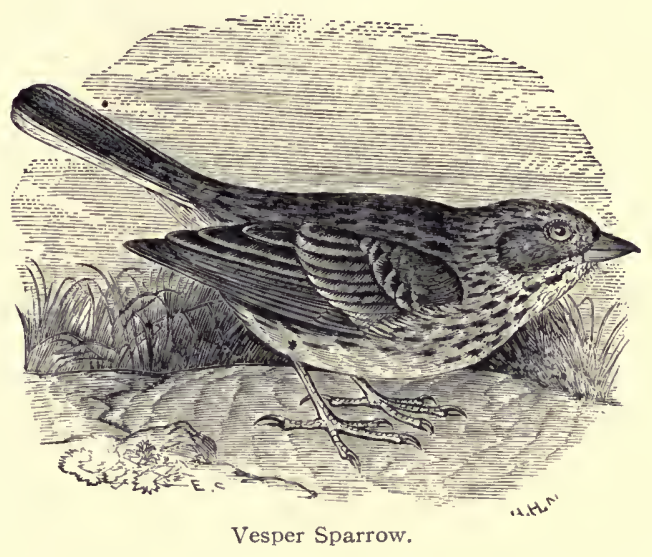

Shoulder (lesser wing coverts), rufous brown; at least half of outer tail feathers, white; back, streaked.

Pocecetes gramineus. Vesper Sparrow. See No. 248. 


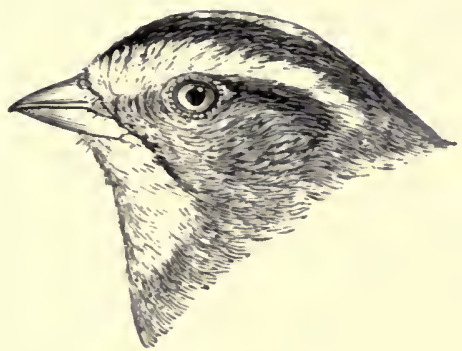

Back, tinged with rufous brown, and streaked with black; carpal joint (bend of wing), edged with pale yellow; tail, over 2.50; usually an indication of yellow in front of the eye; no white on tail feathers.

Zonotrichia albicollis. White-throated Sparrow. See No. 258.

Bill, sharp; tail, under 2 inches; entire upper plumage, olive buff, streaked with black; under plumage, buffy white, or ashy white, heavily streaked with black; more or less yellow on edge and base of wing feathers, and base of tail feathers.

Spinus pinus. Pine Siskin. Pine Finch. See No. 243.

Crown and back, dull brown, without streaks; under parts, brownish, whitish on belly; breast streaks, not very pronounced, often ndistinct (female).

Passerina cyanea.

Indigo Bird. Indigo Bunting. See No. 276.

GROUP 5. Wing, 3.25 to 3.75 inches long.

PART 1. The following species have more or less of either red, blue, yellow, or green on the under parts*:-

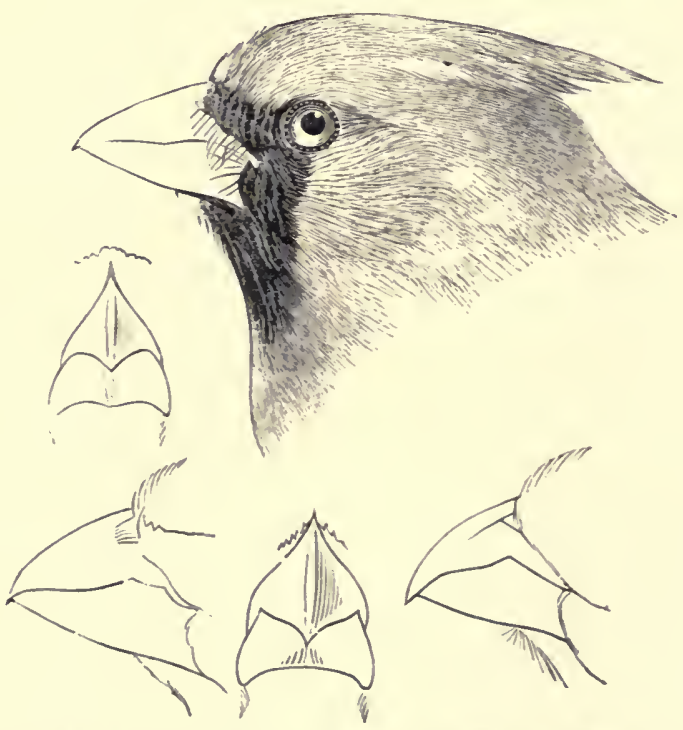

* If a bird is red or olive green, with wing measuring between 3.35 and 4 inches long (carpus to tip) and cannot be found in this section, see Family Tanzaridæ. The bill of a Tanager somewhat resembles that of a Finch. 
2 io Field Museum of Natural History-Zoölogy, Vol. IX.

General plumage, red; crown and under parts, bright red; crown, with crest; throat, black; wings, not black (male).

Cardinalis cardinalis.

Cardinal Grosbeak.

See No. 273.

General plumage, red; back, streaked; belly, whitish (male). Carpodacus purpureus.

Purple Finch.

See No. 236 .

Crown, rump, and under parts, rose red; more or less white on wing; mandibles, crossed.

Loxia leucoptera (male).

White-winged Crossbill.

See No. 239.

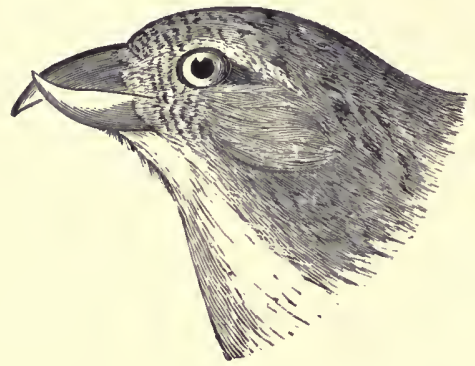

Crown, rump, and greater part of under plumage, dull red; no white on the wing; mandibles, crossed. Loxia curvirostra minor (male). American Crossbill. See No. 238.

Wings, with more or less white; general plumage, grayish olive, or olive green, more or less strongly tinged with yellowish green on rump; mandibles, crossed.

Loxia leucoptera (female). White-winged Crossbill.

See No. 239.

Under parts, tinged with green, or olive green; yellowish green on rump; no white on wings; mandibles, crossed.

Loxia curvirostra minor (female). American Crossbill. See No. 238.

Crown, olive gray; chin, white; throat, black; breast, yellow; belly, white; shoulder (wing coverts), chestnut brown; back, streaked with black; more or less yellow over the eye.

Spiza americana.

Dickcissel. Black-throated Bunting.

See No. 278. 
Under parts, dull buffy yellow; more or less black streaks on sides crown, blackish, with tawny buff stripe through center; back, heavily streaked with black; tail feathers, very pointed. (This bird belongs in Section 8, as it is not a Tanager or a Finch, but the bill might appear Fringilline to beginners.)

Dolichonyx oryzivorus (female). Bobolink.

See No. 223.

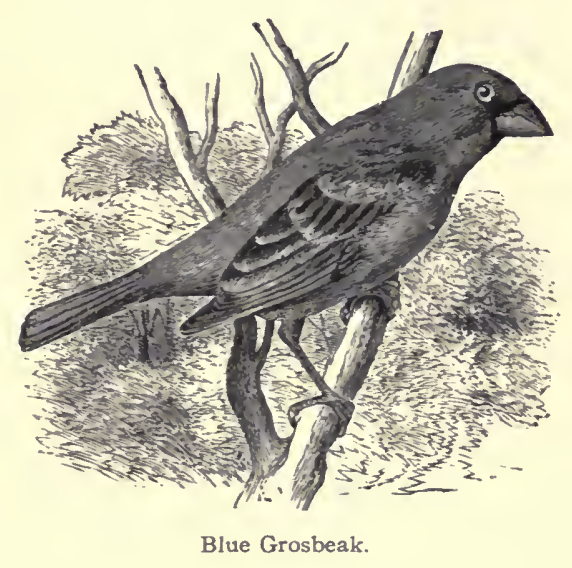

General plumage, more or less blue.

Guiraca cerulea. Blue Grosbeak. See No. 275 .

Under parts, brownish white, tinged with blue on the breast; head, rump, and lesser wing coverts, usually tinged with blue.

Guiraca ccerulea (female.)

Blue Grosbeak.

See No. 275 .

PART 2. The following species have no red, blue, yellow, or green on the under parts:-

Under parts, brownish white; crown and back, brownish gray, usually tinged with more or less blue on the head, rump, and lesser wing coverts; middle wing coverts, edged with rufous brown.

Guiraca carulea (immature). Blue Grosbeak.

See No. 275 . 
2 i 2 Field Museum of Natural History-Zoölogy, Vol. IX.

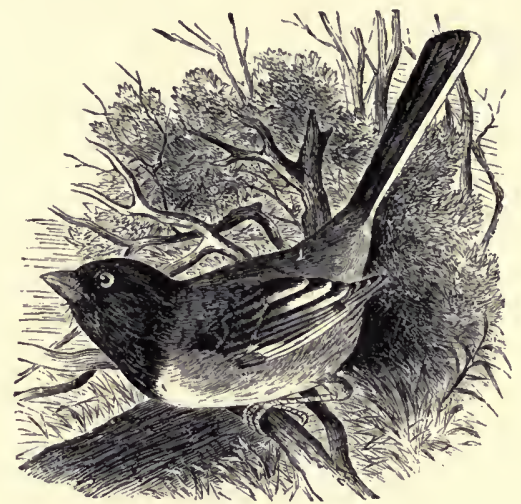

Towhee Bunting.

Crown and back, black; throat, black; sides of body, rufous brown; belly, white.

Pipilo erythrophthalmus (male).

Towhee Bunting.

See No. 27 I.

Head and entire under parts, black; a tawny white patch on the back of the neck; back, black; rump, whitish. (This species belongs in the family Icteridæ (see Section 8), but to the uninitiated the bill has a slight resemblance to birds in this class.) Dolichonyx oryzivorus.

Bobolink.

See No. 223 .

Crown, black, mixed with buffy white; a nuchal collar (back of neck), chestnut; back, streaked; breast, more or less marked with black; belly, white; hind toe nail, long; an oblique white patch on outer tail feather.

Calcarius lapponicus.

Lapland Longspur.

See No. 245.

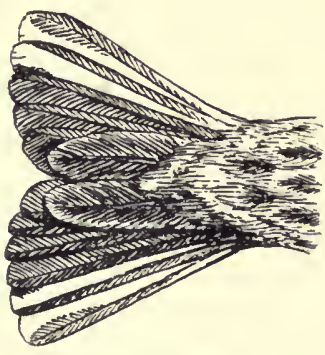

Smith's Longspur.

Top and sides of the head, black (in summer); ear coverts and superciliary stripe, white; back, streaked; under parts, buff; hind toe nail, long; in winter without black head, and markings different, but the tawny buff under parts will distinguish it from the other Longspurs.

Calcarius pictus. Smith's Longspur. See No. 246. 


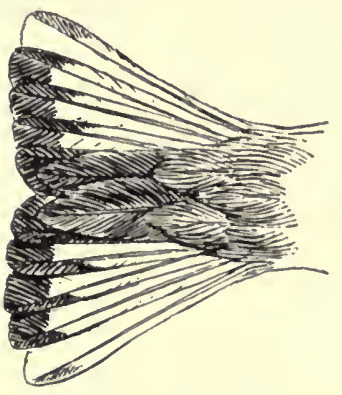

Top of head, black; wing coverts, heavily marked with chestnut; throat and belly, white ; a large patch of black on the breast; most of the tail.feathers, white, tipped with dark brown. .

Rhynchophanes mccownii.

McCown's Longspur.

See No. 247.

McCown's Longspur.

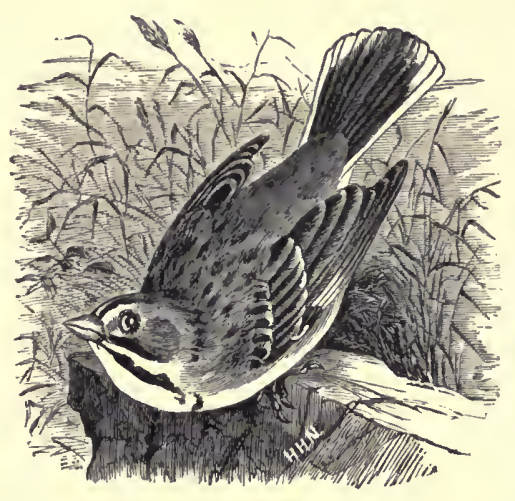

Lark Sparrow.

Crown, chestnut, with stripe of white in center (male), or dull olive, streaked with blackish (female); back, streaked; under parts, white (pale brownish olive on sides of body); a short streak of dark brown or black on each side of white throat; tail feathers, tipped with white.

Chondestes grammacus.

Lark Sparrow. Lark Finch.

See No. 254.

Head, face, and throat, black; tail, grayish brown; bill, pale red; back, brown, streaked with black; wing, about $3 \cdot 35$.

Zonotrichia querula.

Harris's Sparrow.

See No. 255 . 
2 I 4 Feld Museum of Natural History - Zoölogy, Vol. IX.

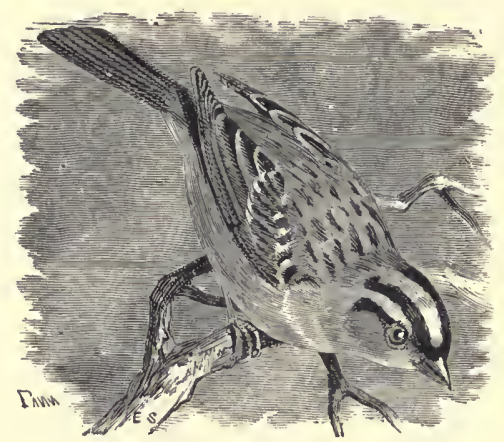

Crown, black, with white stripe in middle; under parts, ashy shading to pale buff on the flanks; no white on tail feathers; no yellow in front of eye, or on bend of wing.

Zonotrichia leucophrys. White-crowned Sparrow.

See No. 256.

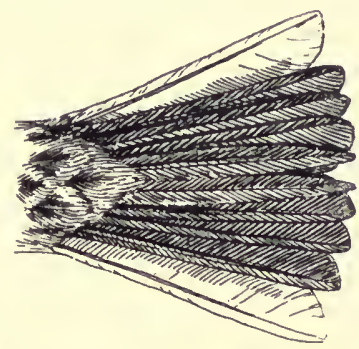

Tail of Vesper Sparrow.

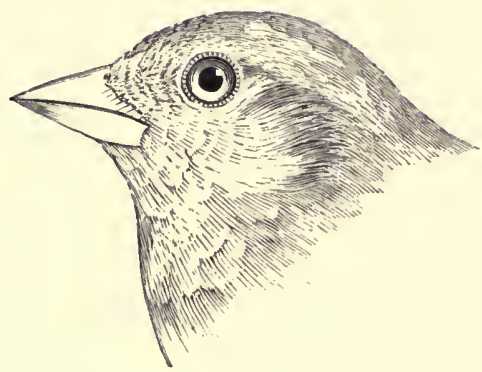
white.
Crown and back, grayish or buffy, streaked with black; shoulder (lesser wing coverts), rufous brown; breast, streaked; greater part of outer tail feather, including outer web,

Poccetes gramineus.

Vesper Sparrow. Bay-winged Bunting.

See No. 248.

Crown and back, slaty brown, or dull rufous brown; rump, and upper surface of tail feathers, light rufous brown; under parts, white, heavily streaked and spotted on breast and sides with rufous brown.

\section{Passerella iliaca.}

Fox Sparrow. See No. 270.

Crown and back, dark brown, with indistinct streaks; no white on tail; under parts, white, with numerous brown spots or streaks (female); middle tail feathers, shorter than outer feathers.

Carpodacus purpureus.

Purple Finch.

See No. 236. 
Crown, with crest of red feathers; back, olive; under parts, tawny, shading to olive on the sides; under surface of wing, red (female).

Cardinalis cardinalis.

Cardinal Grosbeak.

See No. 273.

Crown, with fiery red patch; a black spot on the chin; belly, white; rump, white. Acanthis hornemannii exilipes.

Hoary Redpoll. See No. 240.

GROUP 6. Wing, 3.75 to 4.25 inches long. PART 1. The following species have more or less red on the under parts*:-

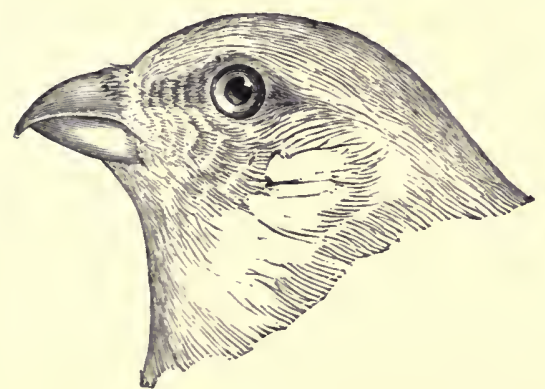

Pine Grosbeak.

General plumage, rose red, usually mixed with more or less gray; wing coverts, edged with pinkish white.

Pinicola enucleator leucura. Pine Grosbeak. See No. 235 .

Throat and base of bill, black; general plumage, red; crown, with more or less of a crest: wings and tail, not black (male).

Cardinalis cardinalis.

Cardinal Grosbeak.

See No. 273 .

* If bird is red or olive green, with wing between 3.35 and 4 inches long (bend of wing to tip), see Family Tanagridæ. The bill of a Tanager somewhat resembles that of a Finch. 
2 i6 Field Museum of Natural History-Zoölogy, Vol. IX.

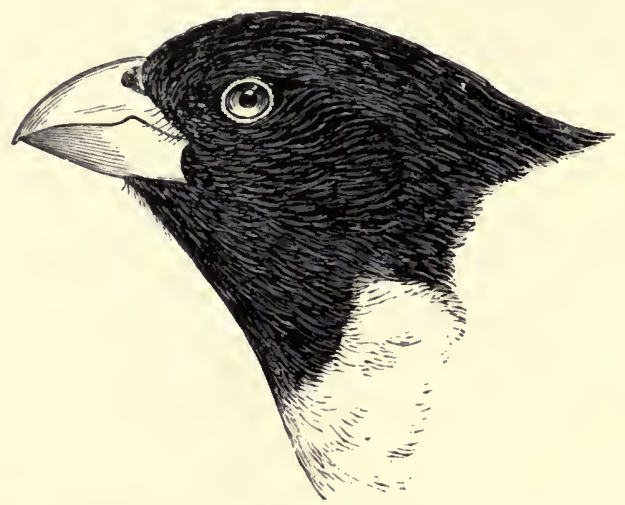

Head and back, black; breast and under wing coverts, rose red; belly, white (male).

Zamelodia ludoviciana.

Rose-breasted Grosbeak.

See No. 274.

PART 2. The following species have more or less yellow, orange, or green on the under parts:-

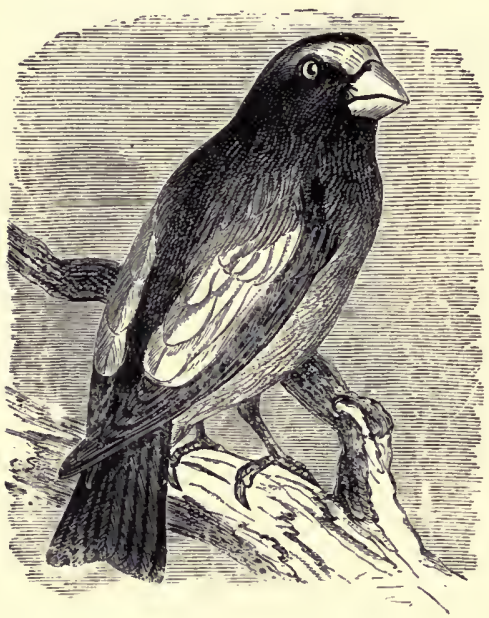

Forehead, yellow; crown, black; rump, greenish yellow; tertials, heavily marked with white; under parts, dark olive yellow on belly.

Hesperiphona vespertina (male).

Evening Grosbeak.

See No. 234.

Under parts, gray, faintly tinged with greenish yellow; back, gray, more or less tinged with green; wings and tail, black, marked with white.

Hesperiphona vespertina (female). Evening Grosbeak.

See No. 234.

Under parts, pale tawny yellow, more or less streaked with black on sides of body; crown, black, with brownish buff stripe in center; tail feathers, sharp pointed. (This species belongs in Family Icteridæ, but might be looked for under this section.)

Dolichonyx oryzivorus (female).

Bobolink.

See No. 223. 
PART 3. The following species have no red, yellow, orange, or green on the under parts :-

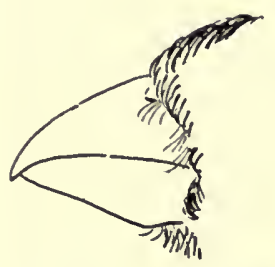

Under parts, gray; upper parts, gray, tinged with green; wings and tail, black, heavily marked with white; bill, yellowish.

Hesperiphona vespertina (female).

Evening Grosbeak.

See No. 234.

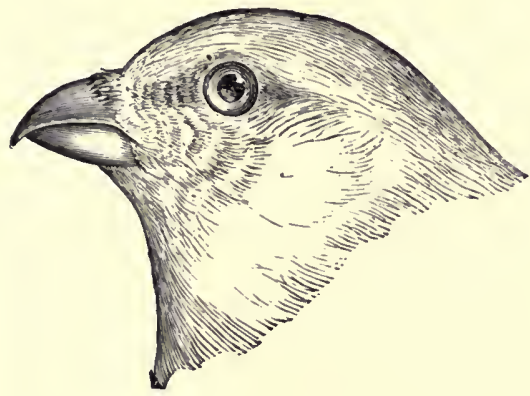

General plumage, gray; crown and rump, tinged with yellowish green; bill, dark; no white on tail feathers; wing coverts and tertials, edged with white.

Pinicola enucleator leucura

(female). Pine Grosbeak. See No. 235 .

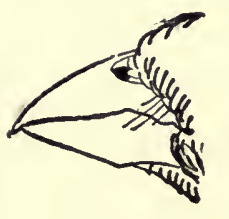

Crown, brownish black, with whitish streak in center; under wing coverts, orange yellow; breast, streaked with dark brown.

Zamelodia ludoviciana (female). Rose-breasted Grosbeak. See No. 274.

Head and entire under parts, black; back of neck, tawny buff; back, black, mixed with buff; rump, gray; tail feathers, very pointed. [This species belongs in Family Icteridæ (Section 9), but might be looked for under this section.]

Dolichonyx oryzivorus (male).

Bobolink.

See No. 223 .

Head and throat, dull chocolate brown; rest of plumage, greenish black; no white on wings or tail. (See Section 9, Family Icteridæ, where it belongs.)

Molothrus ater (male).

Cowbird.

See No. 224. 
218 Field Museum of Natural History-Zoölogy, Vol. IX.

General plumage, brownish gray; no white on wing coverts or tail feathers. (This species belongs in Family Icteridæ, but the bill is somewhat Finch-like in appearance, and the bird might be looked for under this section.)

Molothrus ater (female). Cowbird.

See No. 224 .

Head, with crest; breast, grayish buff or light tawny; back, olive gray, without streaks; rump and upper surface of tail, not rufous brown.

Cardinalis cardinalis (female).

Cardinal Grosbeak. Cardinal.

See No. 273.

Crown, brown, with white stripe in middle; a black stripe on each side of throat; under parts, soiled white; tail feathers, broadly tipped with white; rump and upper surface of tail, not rufous brown.

Chondestes grammacus.

Lark Sparrow. Lark Finch.

See No. 254.

Rump and upper surface of tail feathers, rufous brown; under parts, white, more or less spotted or streaked with brown. Passerella iliacá.

Fox Sparrow.

See No. 270.

Entire head and back, brown (female) or black (male); belly, white; sides of body, bright, rufous brown. Pipilo erythrophthalmus.

Towhee Bunting.

See No. 27 I.

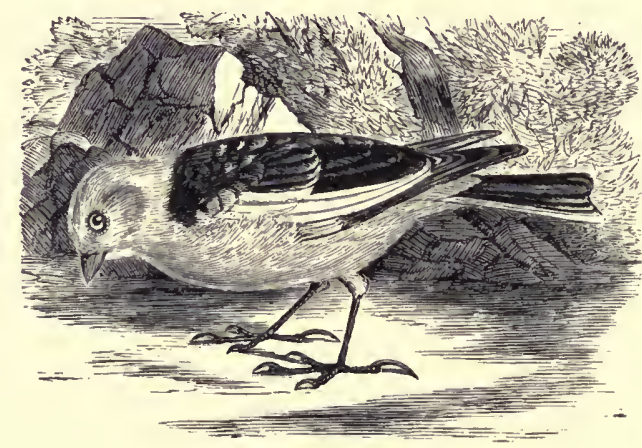

Snow Bunting.

Summer Plumage.

Under parts, white, often tinged with light brown on the breast; greater part of outer tail feathers, white; a large white patch on wing; back rusty brown (not black) in winter.

Plectrophenax nivalis. Snowflake. Snow Bunting. See No. 244. 


\section{GROUP 7. Wing, 4.25 to 4.75 inches long.}

First primary, not short, never less than two-thirds as long as second or third; bill, stout and conical; nostrils, high, near the culmen; primaries, nine; tarsus, flattened behind.

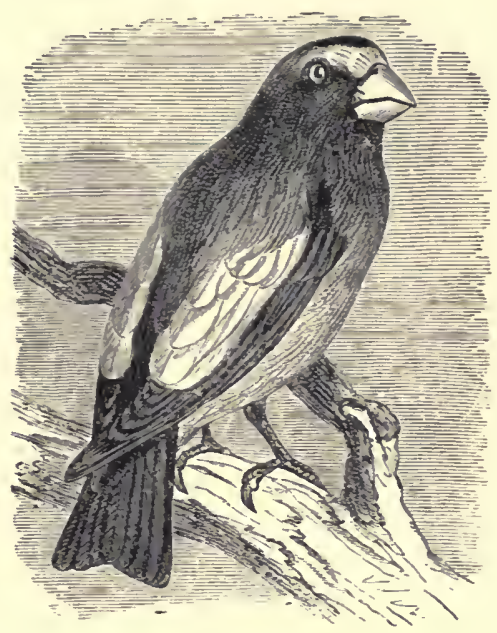

Evening Grosbeak (male).

Throat, brownish olive, shading to yellowish green on the belly; wing, black, with patch of white; bill, yellowish; forehead, yellow; crown, black (male); forehead and crown, grayish (female).

Hesperiphona vespertina.

Evening Grosbeak.

See No. 234.

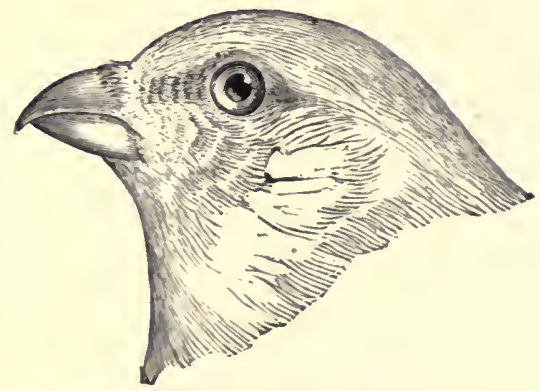

General plumage of body, rose red, more or less mixed with gray; tail, dark brown; wings, brown, the coverts and tertials, edged with white.

Pinicola enucleator leucura (male). Pine Grosbeak. See No. 235 .

General plumage, gray ; the crown and rump, tinged with yellowish olive; wings, dark brown; the coverts and secondaries, edged with white.

Pinicola enucleator leucura (female).

Pine Grosbeak.

See No. 235 . 
220 Field Museum of Natural History - Zoölogy, Vol. IX.

Under parts, white; breast, usually more or less tinged with pale brown in winter; greater part of outer tail feathers, white; back and crown, rusty brown, a large part of the wings white, very conspicuous when flying.

Plectrophenax nivalis. Snowflake. Snow Bunting. See No. 244.

Head, chocolate brown; rest of plumage, greenish black (male); general plumage, gray, palest on the throat; no white on wing coverts; crown and rump, like back (female). (This species belongs in Section ıo, under Family Icteridæ, but might be looked for under this family by mistake.)

Molothrus ater.

Cowbird.

See No. 224.

\section{Family TANGARIDÆ. Tanagers.}

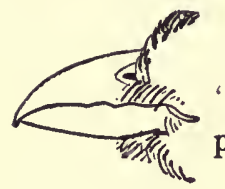

Bill, somewhat fringilline, but having a small "tooth" near the middle of the edge of upper mandible; primaries, 9 ; tarsus, scutellate; males, bright colored.

GROUP 1. Wing, 3.25 to 4.25 inches long.

PART 1. The following species have more or less of either red, blue, yellow, or green on the under parts:-

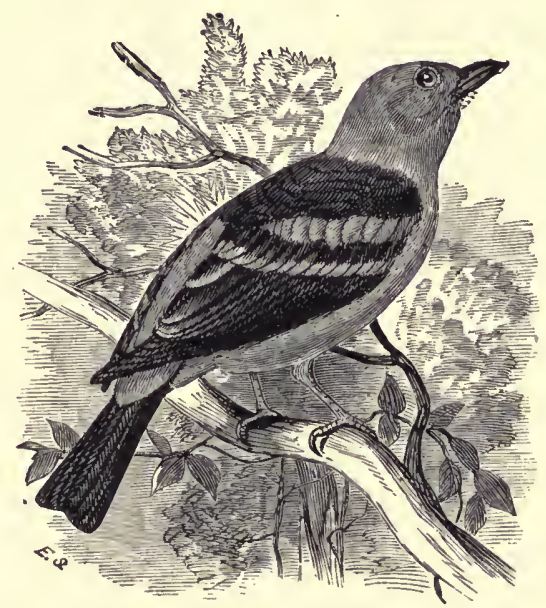

Louisiana Tanager. 
Head and throat, orange red; bright red on crown; rest of under parts, bright yellow; back, wings, and tail, black; rump, yellow (male).

Piranga ludoviciana.

Louisiana Tanager.

See No. 279 .

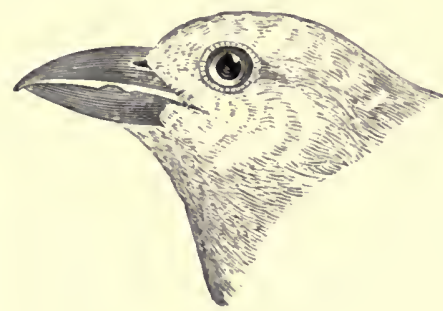

General plumage, scarlet red; wings and tail, black; throat, not black (male).

Piranga erythromelas.

Scarlet Tanager.

See No. 280.

General plumage, red; no black on throat; wings and tail, not black; back, not streaked; belly, not whitish (male). Piranga rubra.

Summer Tanager See No. 28 r.

Under parts, yellowish green, or greenish yellow; back, grayish; greater wing coverts and tertials, edged with dull white, or yellowish white; mandibles, not crossed (female).

Piranga ludoviciana.

Louisiana Tanager. See No. 279.

Under parts, yellowish green, or greenish yellow; back, light olive green; no white on wing coverts; wings and tail, fuscous brown (female); wings and tail, black (young male); inner webs of inner primaries and secondaries, edged with white; mandibles, not crossed (female).

Piranga erythromelas.

Scarlet Tanager.

See No. 280.

No white on wing coverts; under parts, pale orange yellow; upper parts, olive green, with faint tinge of orange; mandibles, not crossed (female).

Piranga rubra.

Summer Tanager.

See No. $28 \mathrm{r}$.

Under parts, bright yellow; throat, reddish orange; crown and sides of head, orange red; back, wings, and tail, black; rump, yellow (male).

Piranga ludoviciana.

Louisiana Tanager.

See No. 279. 
22 Field Museum of Natural History-Zoölogy, Vol. IX.

\section{Family HIRUNDINIDÆ. Swallows.}

Bill, small and flattened, somewhat triangular in shape; gape, very wide; wings, long, usually extending beyond the tail.

* GROUP 1. Wing, 3.25 to 4.75 inches long.

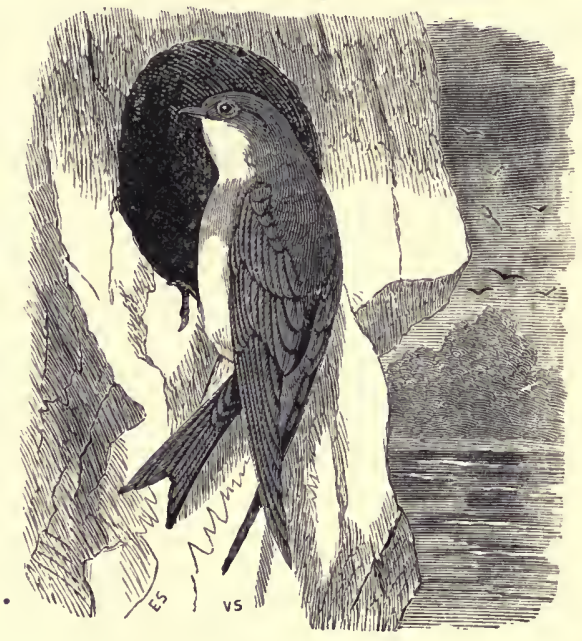

Bank Swallow.

Throat and belly, white; a distinct band of grayish brown on the breast; upper plumage, brownish gray.

Riparia riparia. Bank Swallow. See No. 287 .

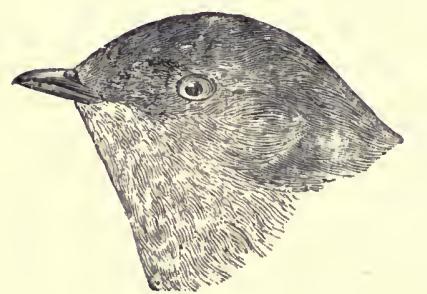

Under parts, brownish gray, gradually shading into whitish on the belly; upper parts, grayish brown; no distinct breast band. Stelgidopteryx serripennis. Rough-winged Swallow. See No. 288.

* For directions for measurement, see page 21 . 
Upper plumage, rich green, showing more or less purple on upper tail coverts; under parts, white; western species, only once taken in Illinois.

Tachycineta thalassina lepida. Northern Violet-green Swallow.

See No. 286.

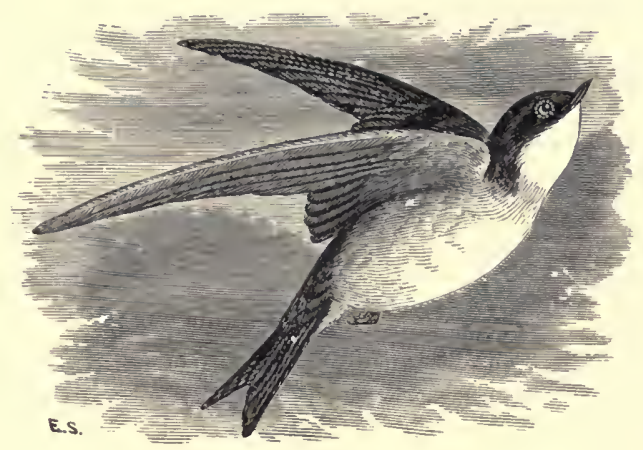

Tree Swallow.

Entire under parts, white; upper plumage, metallic steel blue; young birds have the upper plumage brownish gray, but the under plumage is pure white.

Iridoprocne bicolor.

Tree Swallow. White-bellied Swallow. See No. 285 .

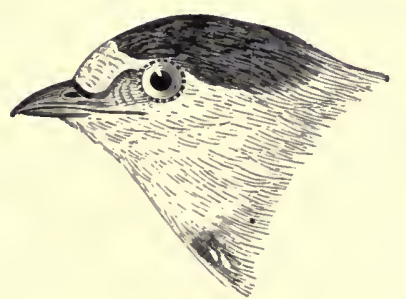

Upper throat and sides of the head, chestnut brown; belly, whitish; forehead, whitish; crown and back, dark steel blue; upper tail coverts, pale rufous brown.

Petrochelidon lunifrons. Cliff Swallow. See No. 283 .

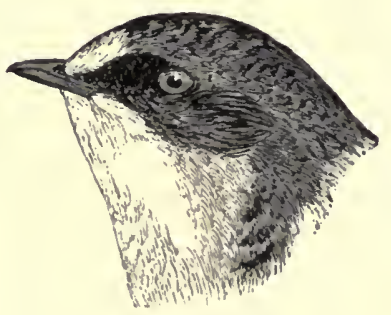

Throat, chestnut; belly, pale brown; entire upper plumage, steel blue; tail forked; upper tail coverts, steel blue.

Hirundo erythrogastra.

Barn Swallow. See No. 284 . 
224 Field Museum of Natural History-Zoölogy, Vol. IX.

GROUP 2. Wing, 4.75 to 5.50 inches long.

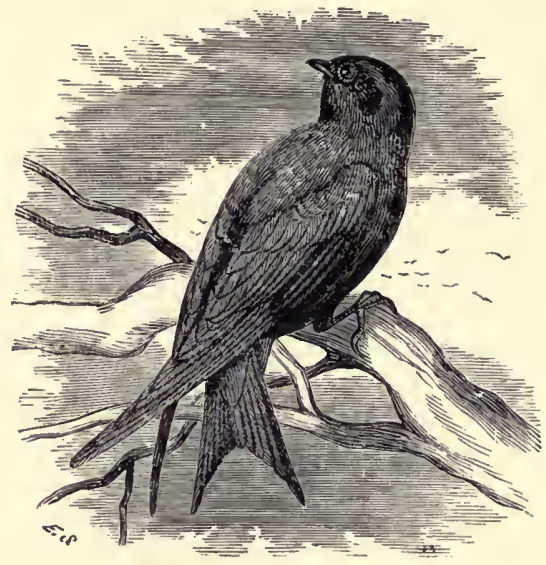

Male: General plumage (including belly), bluish black, or dark steel blue.

Female: Back, like male; under parts, grayish brown, shading into dull white on the belly. Immature birds have the upper plumage, brownish; under parts, brownish on the breast; dull white on the belly.

Progne subis. Purple Martin. See No. 282.

Back, steel blue; belly, white.

Iridoprocne bicolor. Tree Swallow. White-bellied Swallow. See No. 285 .

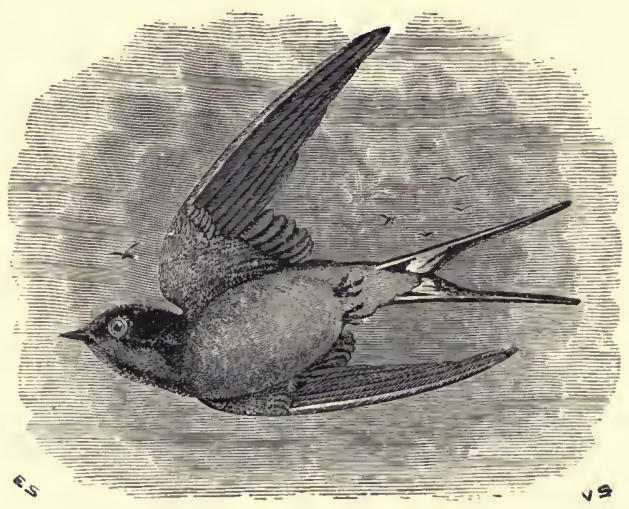

Back, steel blue; under parts, cinnamon brown; tail, very deeply forked.

Hirundo erythrogastra. Barn Swallow. See No. 284. 


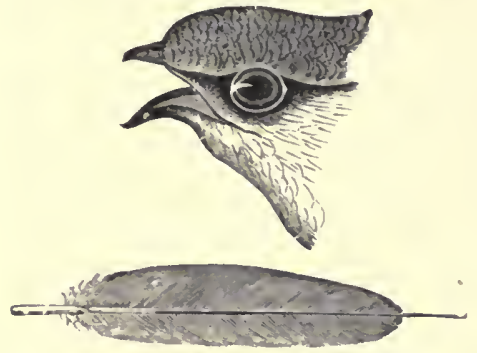
but persons unfamiliar with birds might look for them under the same family.

General plumage, sooty brown, showing a faint greenish tinge on the upper parts; throat, ashy white; tail feathers, with sharp spines, or points formed by the shafts of the feathers, extending beyond the webs. The Swifts belong to the family Micropodidæ and are widely separated generically from the Swallows; Chatura pelagica. Chimney Swift. See No. 201.

\section{Family BOMBYCILLIDÆ. Waxwings and Cedar Birds.}

Bill, without notch; head, with crest; primaries, ten; tarsus, shorter than middle toe and claw; a black stripe from forehead through the eye; inner primaries and tail feathers, often tipped with little hard red bits, like minute drops of sealing wax.

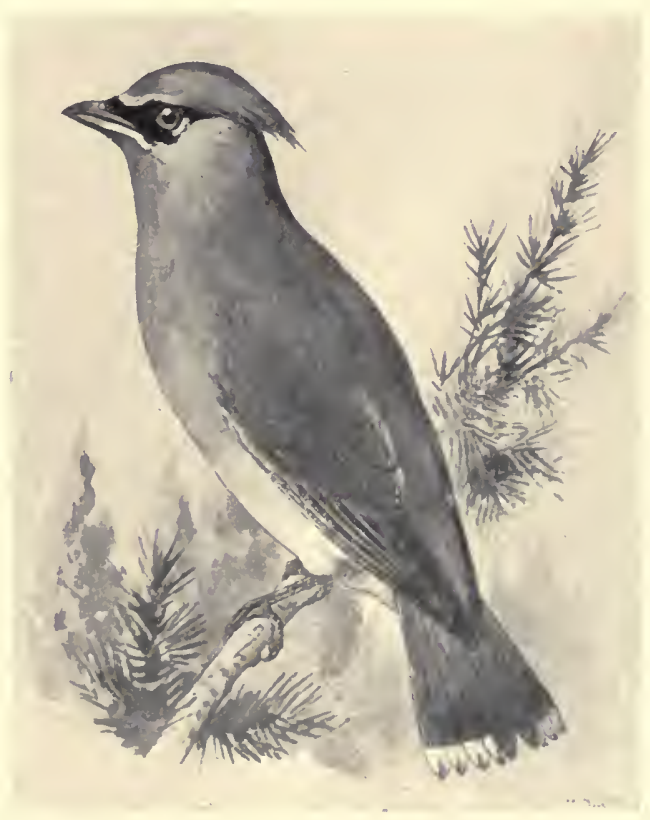

Cedar Bird. 
226 Field Museum of Natural History-Zoölogy, Vol. IX.

Upper parts, grayish brown; crown and breast, pale chocolate brown; a black streak in front of eye; tail, tipped with yellow; belly, yellowish; wing, less than $\mathbf{4 . 2 0}$ inches long; under tail coverts, white.

Bombycilla cedrorum.

Cedar Waxwing. Cedar Bird. Cherry Bird.

See No. 290.

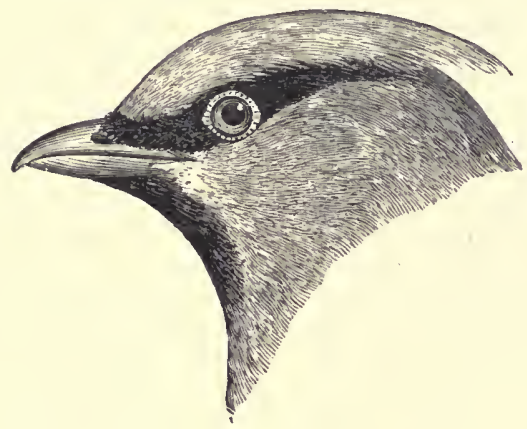

General plumage, pale chocolate brown; forehead, tinged with rufous; chin, black; under tail coverts, rufous; tail, tipped with yellow; wing, over 4.20 inches long.

Bombycilla garrula. Bohemian Waxwing. See No. 289 .

\section{Family LANIIDÆ. Shrikes.}

Bill, strong, notched near the end, and decidedly hooked; tarsus, scutellate; tail rounded. But two species occur with us, both grayish birds with blackish wings and tail and a stripe through the eye.

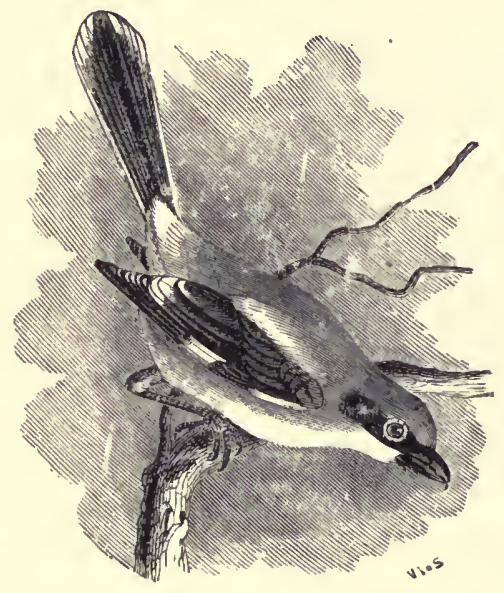

Crown and back, gray; under parts, white; a patch of black on the sides of the head; wing, less than 4.15 inches long.

Lanius Indovicianus.

Loggerhead Shrike. See No. 292. 


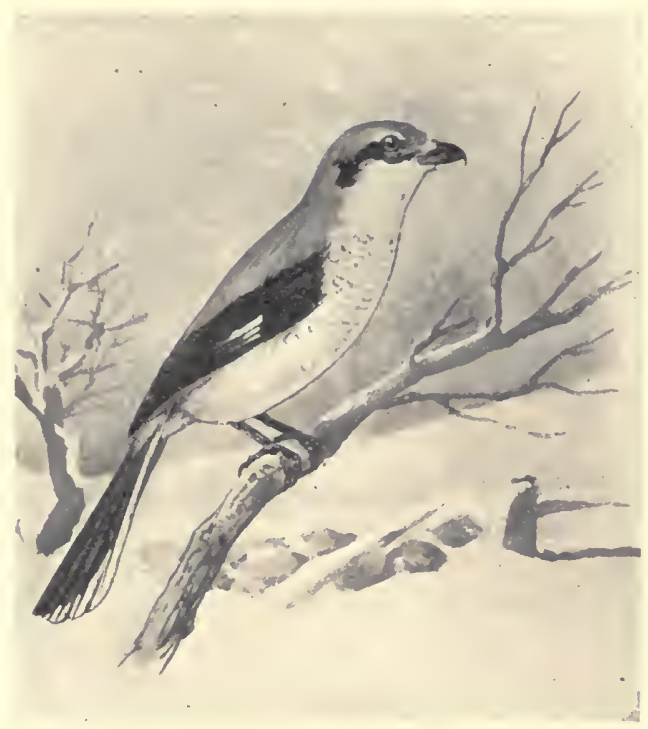

Northern Shrike.

Upper plumage, ash gray or gray tinged with buff; under parts, ashy white, the feathers showing numerous faint narrow black bars; a black streak from bill through the eye; wing, more than 4.15 inches long.

Lanius borealis. Northern Shrike.

See No. 29 r.

\section{Family VIREONIDÆ. Vireos.}

Upper mandible, with very small hook at tip; first primary, very short in some species, in others nearly as long as second; toes, joined at base; tarsus, flattened and sharp behind, not rounded as in front; plain colored birds, usually greenish or grayish, but often showing a faint wash of yellow on under parts; tail, always without white spots.

\section{GROUP 1. Wing, less than 2.37 inches long.}

Crown, grayish; orbital ring, dull white; no yellow in front of eye.

Vireo bellii.

Bell's Vireo.

See No. 299. 
228 Field Museum of Natural History-Zoölogy, Vol. IX.

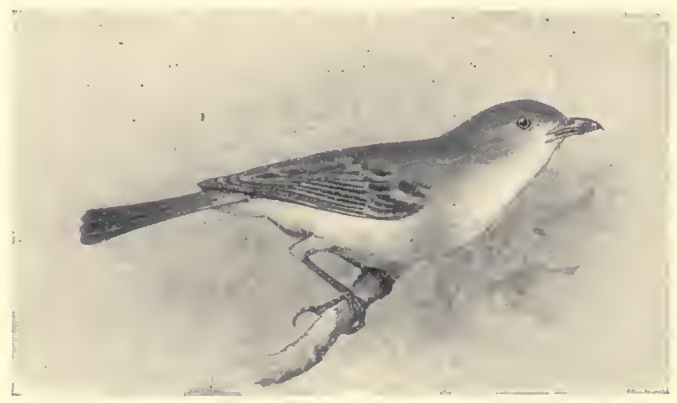

Bell's Vireo.

Crown, grayish, often tinged with olive; orbital ring and lores, yellow.

Vireo griseus. White-eyed Vireo. See No. 298.

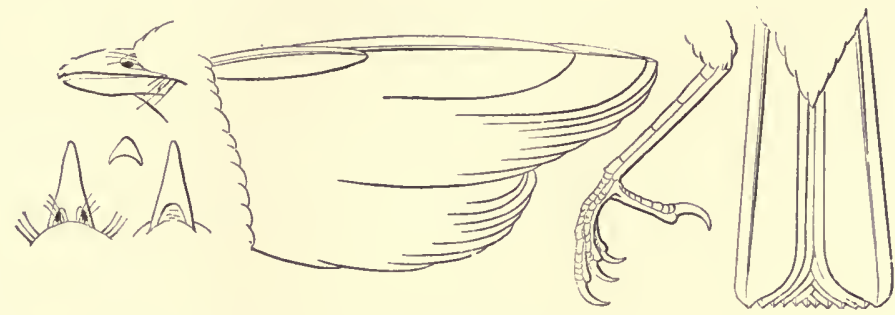

White-eyed Vireo.

GROUP 2. Wing, from 2.37 to 2.75 inches long.

First primary, very short; lores and eye ring, whitish; throat, whitish; breast and sides, faintly tinged with yellow; no wing bars; crown, nearly the same color as back.

Vireosylva gilva. Warbling Vireo. See No. 295 .

First primary, short, but longer than in $V$. gilva; lores and eye ring, yellow; back, olive; wing coverts, edged with white, forming wing bars.

Vireo griseus. White-eyed Vireo. See No. 298. 
First primary, not short (at least as long as fifth); lores and eye ring, dull white; under parts, washed with very pale greenish yellow; no wing bars.

Vireosylva philadelphica.

Philadelphia Vireo.

See No. 294 .

GROUP 3. Wing, from 2.75 to 3.25 inches long.

Bill, with small but distinct hook; no streaks on back or breast; breast or throat, never spotted.
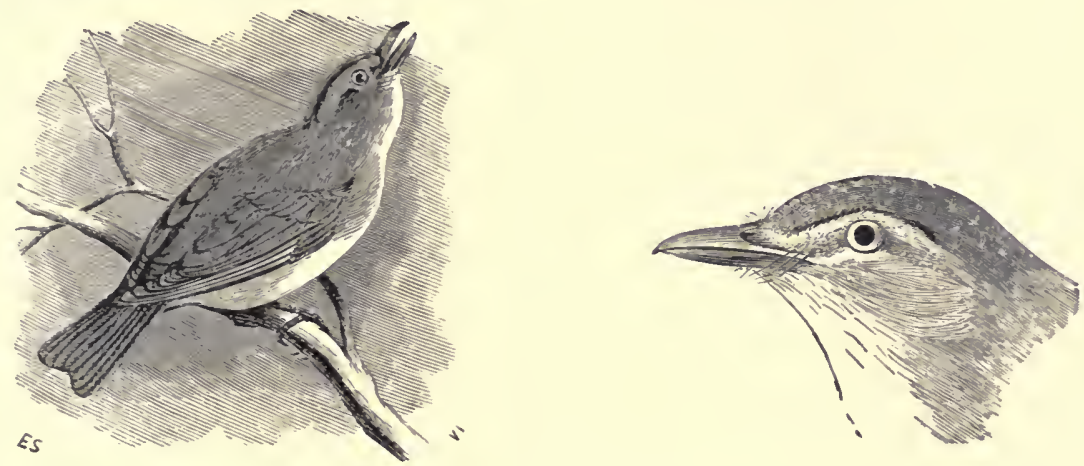

First primary, not shorter than fourth; back and rump, olive; crown, plumbeous gray, or bluish gray; no dusky streak from base of bill on sides of throat; under parts, white, tinged with pale yellowish green on sides of body.

Vireosylva olivacea.

Red-eyed Vireo.

See No. 293.

First primary, very short and narrow; crown and back, grayish olive; under parts, dull white. faintly tinged with olive, or yellowish on sides; no white wing bars.

Vireosylva gilva.

Warbling Vireo. See No. 295 .

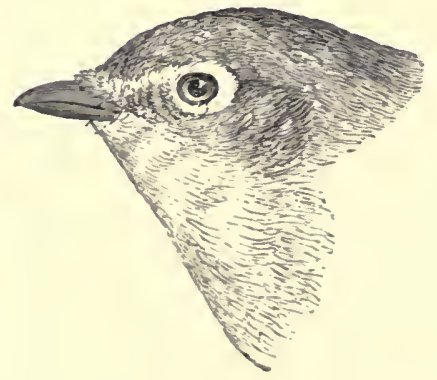

First primary, short; crown, gray; back, olive; rump, olive green; throat and belly, white; sides of body, greenish yellow; lores, white; sides of head. gray; wing bars, white.

Lanivireo solitarius.

Blue-headed Vireo. Solitary Vireo.

See No. 297. 
230 Field Museum of Natural History-Zoölogy, Vol. IX.

First primary, not short; lores and eye ring, yellow; throat and breast, yellow; belly, white; wing bars, white. Lanivireo flavifrons. Yellow-throated Vireo. See No. 296.

First primary, equal to fifth; lores and orbital ring, dull white; upper plumage, light olive, tinged with ashy on the crown; under parts, washed with very pale yellow; no white wing bars.

Vireosylva philadelphica. Philadelphia Vireo.

See No. 294 . 


\section{INDEX TO KEY.}

\section{Family MNIOTILTIDÆ. Warblers.}

Group r. Wing, less than 2.37 inches long. See page 234.

Part I. Throat, breast, and belly, yellow; breast, more or less streaked; some tail feathers, marked with white. See page 234 .

Part 2. Throat, breast, and belly, yellow; breast more or less streaked; no white on tail feathers. See page 235.

Part 3. Throat, breast, and belly, yellow without streaks; some tail feathers, marked with white. See page 235 .

Part 4. Throat, breast, and belly, yellow, without streaks; no white on tail feathers. See page 235 .

Part 5. Throat, yellow; belly, not yellow; tail feathers, marked with more or less white. See page 236 .

Part 6. Throat, yellow; belly, not yellow; no white on tail feathers. See page 237 .

Part 7. Throat, not yellow; belly, yellow; no white on tail feathers. See page 237 .

Part 8. No yellow on throat or belly; no white on tail feathers. See page 237 .

Part 9. No yellow on throat or belly; more or less white on tail feathers. See page 238 .

Group 2. Wing, 2.37 to 2.75 inches long. See page 239.

Part I. Throat, breast, and belly, yellow; breast, more or less streaked; some tail feathers marked with more or less white. See page 239.

Part 2. Throat, breast, and belly, yellow; breast, more or less streaked; no white on tail feathers. See page $24 \mathrm{I}$.

Part 3. Throat, breast, and belly, yellow, without streaks; some tail feathers nuarked with more or less white. See page $24 \mathrm{I}$.

Part 4. Throat, breast, and belly, without streaks; no white on the tail feathers. See page 242 .

Part 5. Throat, yellow; belly, not yellow; tail feathers marked with more or less white. See page 244.

Part 6. Throat, not yellow; belly, yellow; no white on tail feathers. See page 245 .

Part 7. Throat, not yellow; belly, yellow; more or less white on the tail feathers. See page 246 .

Part 8. Throat, not yellow; belly, not yellow; no white on the tail feathers; breast, streaked or spotted with black or dark brown. See page 247 .

Part 9. Throat, not yellow; belly, not yellow; no white on the tail feathers; breast, not streaked or spotted with black or dark brown. See page 247 . 
232 Field Museum of Natural History-Zoölogy, Vol. IX.

Part ro. Throat, not yellow; belly, not yellow; more or less white on the tail feathers; sides of breast and body, with distinct black or blackish streaks. See page 248 .

Part Ir. Throat, not yellow; belly, not yellow; more or less white on the tail feathers; sides of breast and body, not marked with numerous distinct black streaks. See page 250.

Group 3. Wing, 2.75 to 3.25 inches long. See page 253 .

Part I. Throat, breast, and belly, yellow; breast, more or less streaked; some tail feathers, marked with white. See page 253 .

Part 2. Throat, breast, and belly, yellow; breast, more or less streaked; no white on the tail feathers. See page 254 .

Part 3. Throat, breast, and belly, yellow, without streaks; more or less white on the tail feathers. See page 254.

Part 4. Throat, breast, and belly, yellow, without streaks; no white on the tail feathers. See page 255 .

Part 5. Throat, yellow; belly, not yellow; tail feathers, marked with more or less white. See page 255 .

Part 6. Throat, not yellow; belly, yellow; no white on the tail feathers. See page 257 .

Part 7. Throat, not yellow; belly, yellow; more or less white on the tail feathers. See page 257 .

Part 8. Throat, not yellow; belly, not yellow; no white on the tail feathers; breast not streaked or spotted with black or dark brown. See page 257 .

Part 9. Throat, not yellow; belly, not yellow; no white on the tail feathers; breast, streaked or spotted with black or dark brown. See page 258 .

Part ro. Throat, not yellow; belly, not yellow; more or less white on the tail feathers; sides of breast and body, marked with numerous distinct black or blackish streaks. See page $25^{8}$.

Part Ir. Throat, not yellow; belly, not yellow; more or less white on the tail feathers; breast and sides of the body, not marked with distinct black streaks. See page 259 .

Group 4. Wing, 3.25 to 3.75 inches long. See page 260 . 


\section{Family MNIOTILTIDÆ. Warblers.}

First primary, not short, never less than two-thirds as long as third, and often nearly the same length; bill, slender and pointed; back of tarsus, thin and sharp, not rounded as in front; hind toe and claw, not longer than middle toe and claw.

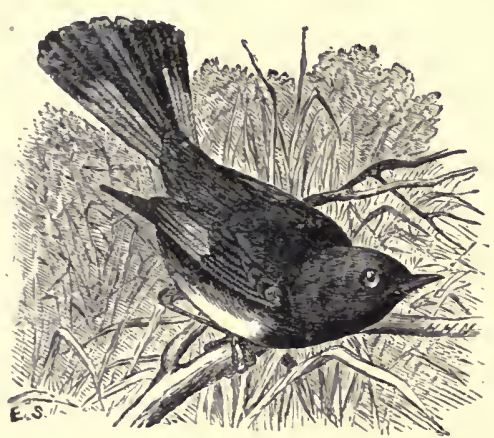

Setophaga ruticilla.

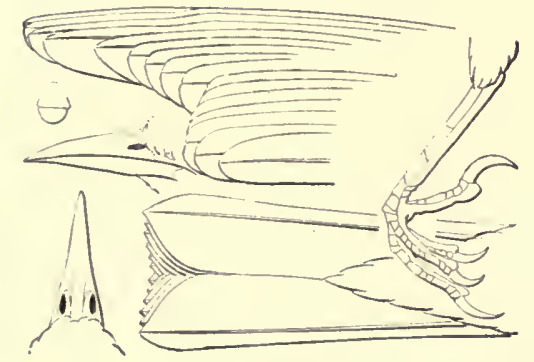

Helmitherus.

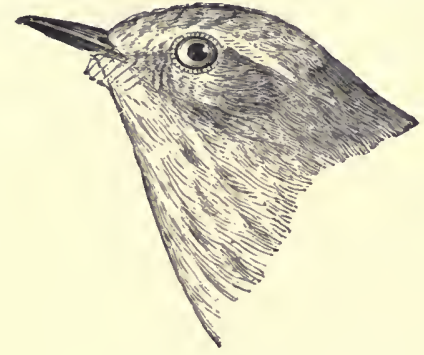

Dendroica.

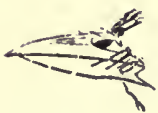

Seiurus.

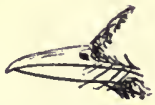

Wilsonia.

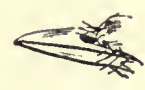

Dendroica.

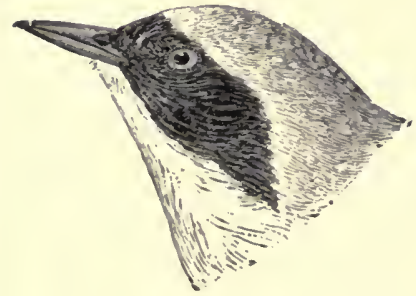

Geothlypis.

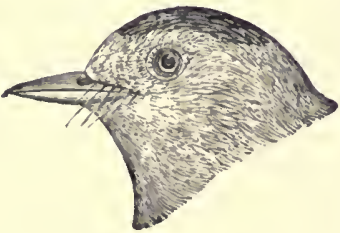

Wilsonia.

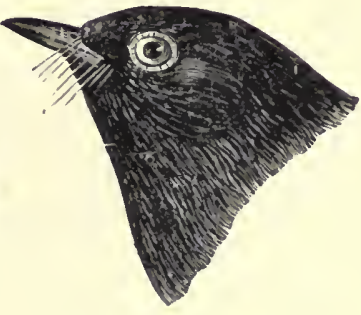

Setophaga. 
234 Field Museum of Natural History-Zoölogy, Vol. IX.

* GROUP 1. Wing, less than 2.37 inches long.

PART 1. The following species have the throat, breast, and belly, yellow; breast, more or less streaked; some tail feathers, marked with white:-

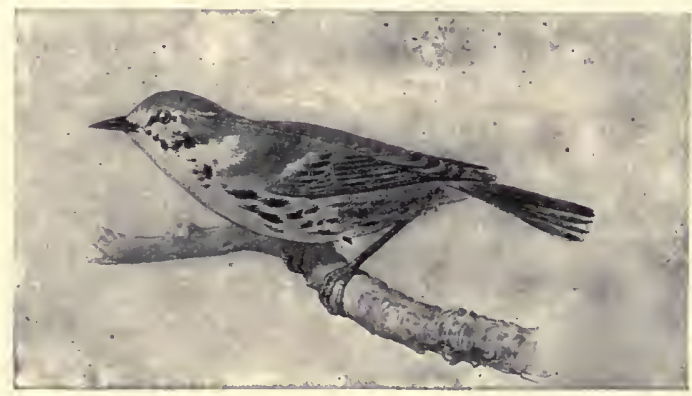

Prairie Warbier.

Wing coverts, broadly bordered with yellow; under surface of wing, yellow; white on tail feathers, extending to tip of inner web; crown, not chestnut brown.

Dendroica discolor. Prairie Warbler. See No. 325.

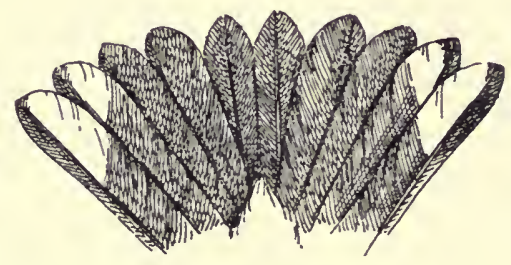

Wing coverts, not bordered with yellow; under tail coverts, yellow.

Dendroica palmarum. Palm Warbler.

Dendroica paimarum.

See No. 324 .

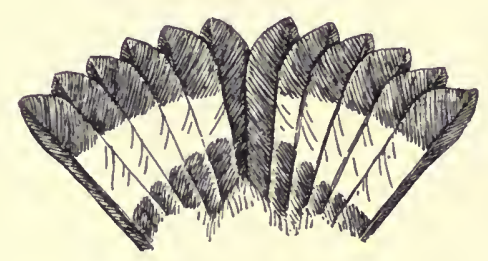

Dendroica magnolia.

Wing coverts, showing much white; under surface of wing, white; tail, with band of white, no white at tip; rump, yellow.

Dendroica magnolia. Magnolia Warbler. See No. 3 I 4 .

* For directions for measurement, see page 2 r. 
PART 2. The following species have the throat, breast and belly, yellow; breast, with more or less streaks; no white on tail feathers -

More or less yellow, on inner webs of primaries and tail feathers.

Dendroica cestiva.

Yellow Warbler.

See No. 3II.

PART 3. The following species have the throat, breast, and belly, yellow without streaks; some tail feathers marked with white:-

Crown and sides of head, grayish or slate color; no yellow on forehead; adult birds have patch of chestnut on crown; some tail feathers, very narrowly edged with white; under wing coverts, yellow; no black streaks on sides of body.

Vermivora rubricapilla.

Nashville Warbler.

See No. 306.

Wing bars, white; under wing coverts, white; some tail feathers with much white on inner webs; adult birds have forehead and more or less of crown yellow; immature birds have crown yellowish green.

Vermivora pinus.

Blue-winged Warbler.

See No. 304.

Wing bars, yellowish; sides of body, more or less streaked with black.

Dendroica discolor.

Prairie Warbler. See No. 325 .

PART 4. The following species have the throat, breast, and belly, yellow without streaks; no white on tail feathers :-

Crown and back, greenish yellow; more or less yellow on inner webs of primaries and tail feathers; crown, yellowish green.

Dendroica cestiva (female or immature).

Yellow Warbler.

See No. 3II.

Crown, slate color, with patch of chestnut in some plumages; sides of head, slate color; wing, longer than tail; lower belly, tinged with white; rump and upper tail coverts, bright yellowish green.

Vermivora rubricapilla.

Nashville Warbler. See No. 306. 
236 Field Museum of Natural History-Zoölogy, Vol. IX.

Crown, dull olive; throat, bright yellow; belly, much paler, ofter whitish; tail, brownish olive, without yellow; wing, not longer than tail; males have black patch on face (forehead and sides of head) which is lacking in females.

Geothlypis trichas.

Maryland Yellow-throat.

See No. 332 .

Throat and belly, nearly the same color; crown, glossy black

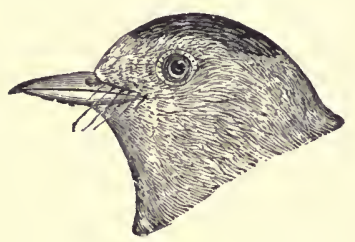
(male), or olive green like back (female); tail feathers, slaty brown faintly washed with olive on outer webs; numerous small black bristles at base of bill. Wilsonia pusilla. Wilson's Warbler. Wilson's Blackcap. See No. 335 .

Entire under parts, yellow; brightest on the belly; wing, longer than tail; crown, grayish; back and rump, dull olive; tail feathers, not marked with yellow.

Oporornis philadelphia (young female).

Mourning Warbler.

See No. 33 I.

PART 5. The following species have the throat, yellow; belly, not yellow; tail feathers, marked with more or less white :-

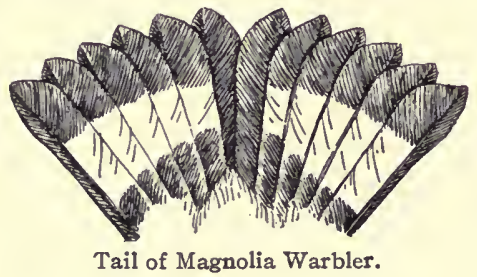

Back, black or dark; tail, black, with broad band of white; rump, yellow.

Dendroica magnolia. Magnolia Warbler. See No. 3 I 4 .

Back, slaty blue, often showing yellowish olive; rump, slate color; sides of head, grayish or slaty blue.

Compsothlypis americana, and races. Parula Warbler. Blue Yellow-backed Warbler. See No. 309 .

Back, dull green; throat, faintly washed with greenish yellow; rump, green; sides, not streaked.

Vermivora peregrina.

Tennessee Warbler.

See No. 308 . 
Jan., ig09. Birds of Illinois and Wisconsin-Cory.

Back, greenish; rump, greenish; cheeks, yellowish; sides, showing more or less dark streaks.

Dendroica virens.

Black-throated Green Warbler.

See No. 321 .

PART 6. The following species have the throat yellow; belly, not yellow; no white on tail feathers :-

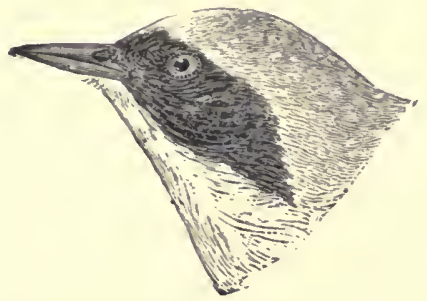

Throat, bright yellow; shading to whitish or olive on belly; forehead and sides of head, black (male); no black on head (female); wing, not longer than tail.

Geothlypis trichas.

Maryland Yellow-throat. See No. 332 .

Throat, showing faint tinge of greenish yellow; throat and sides of body, nearly same color; wing, considerably longer than tail.

Vermivora peregrina.

Tennessee Warbler.

See No. 308.

PART 7 . The following species have the throat, not yellow; belly, yellow; and no white on the tail feathers:-

Head, grayish; back, olive green; belly, bright yellow; throat, blackish (male); throat, grayish (female); legs, pale; tail feathers, olive green; under tail coverts, yellow.

Oporornis philadelphia.

Mourning Warbler. See No. 33I.

Back, grayish brown; belly, faintly tinged with yellow; under tail coverts, yellow.

Dendroica palmarum.

Palm Warbler.

See No. 324 .

PART 8. The following species have no yellow on the throat or belly, and no white on the tail feathers :-

Wing, less than 2.25; under parts, whitish, tinged with olive on sides; throat, with faint wash of yellowish buff, almost white; crown, dull olive; tail, entirely olive green.

Geothlypis trichas (young bird in fall). Maryland Yellow-throat. See No. 332 . 
238 Field Museum of Natural History-Zoölogy, Vol. IX.

Wing, over 2.25; entire under parts, whitish or slightly olive; crown, slaty; back, green; no yellow or orange on tail feathers.

Vermivora peregrina.

Tennessee Warbler.

See No. 308.

Entire under parts, dull olive or olive green; crown, with partially concealed patch of orange brown (sometimes wanting); no yellow or orange on tail feathers.

Vermivora celata.

Orange-crowned Warbler.

See No. 307 .

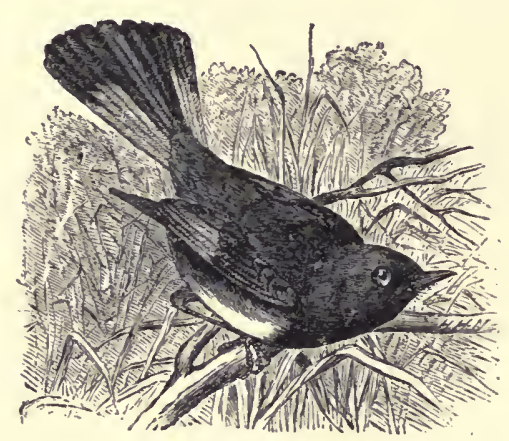

End of tail, brown; basal portion of tail feathers, reddish orange (male), or pale yellow (female); more or less black bristles at base of bill.

Setophaga ruticilla.

Redstart.

See No. 337 .

Redstart.

PART 9. The following species have no yellow on the throat or belly, and more or less white on the tail feathers:-

Wing coverts, broadly edged with yellow; crown, greenish yellow; back, tinged with slate color; tail feathers, marked with white to the tips of inner webs.

Vermivora chrysoptera. Golden-winged Warbler. See No. 305 .

Wing coverts, not yellow; crown, grayish or greenish; back, yellowish green; some tail feathers, narrowly edged with white near tips of inner webs.

Vermivora peregrina.

Tennessee Warbler.

See No. 308. 
GROUP 2. Wing, from 2.37 to 2.75 inches long.

PART 1. The following species have the throat, breast, and belly, ye!low; breast, more or less streaked; some tail feathers, marked with more or less white:-

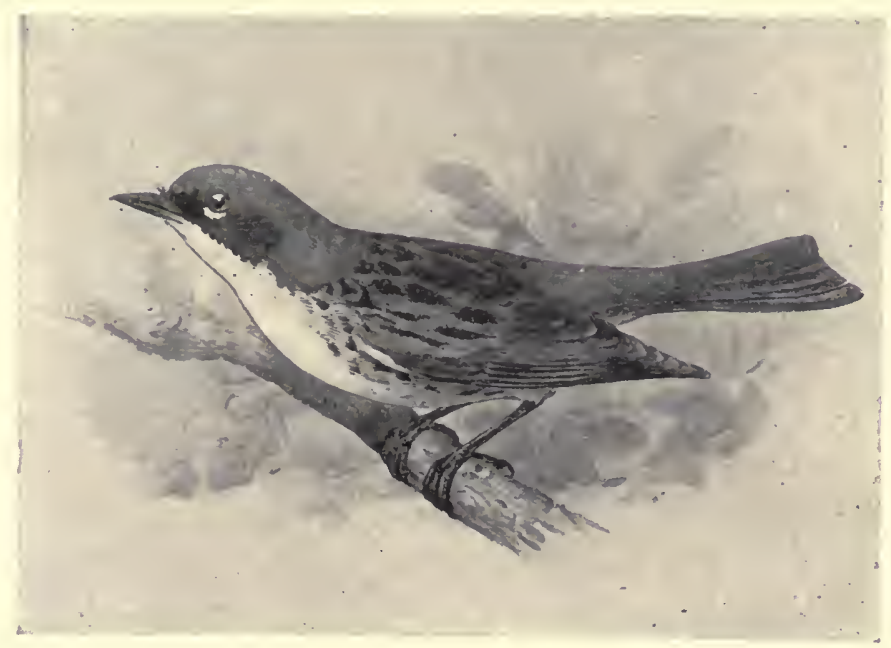

Kirtland's Warbler.

Under parts, pale yellow; sides of breast, streaked with black; under tail coverts, white; crown, grayish; back and rump, ashy, streaked with black.

Dendroica kirtlandii. Kirtland's Warbler. See No. 322.

Under parts, yellow; sides of breast, streaked with olive; under tail coverts, ashy; crown, back, and rump, olive green.

Dendroica vigorsii. Pine Warbler. See No. 323 .
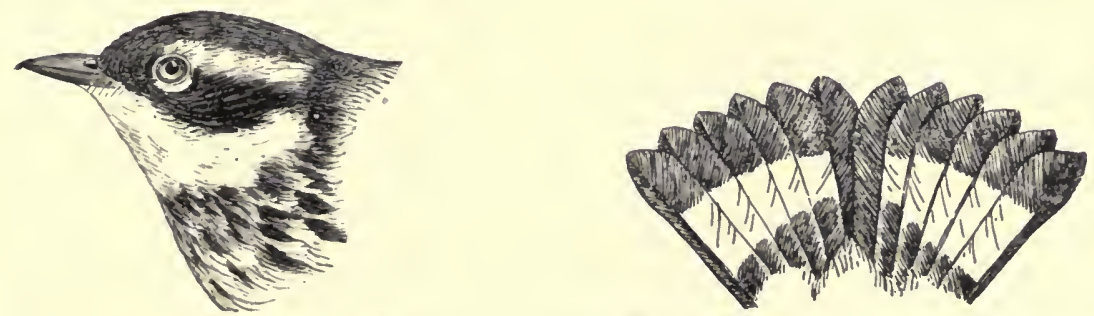

Head and taii of Magnolia Warbler. 
240 Field Museum of Natural History-Zoölogy, Vol. IX.

Under parts, bright yellow; breast, heavily streaked with black; under tail coverts, white; crown, slaty; back, black; rump, yellow.

Dendroica magnolia.

Magnolia Warbler.

See No. 3 I 4 .

Under parts, very pale yellowish, almost yellowish white, faintly streaked with black; under tail coverts, white; crown, back, and rump, olive, streaked with black.

Dendroica striata (female).

Black-poll Warbler. See No. 3 I 8 .
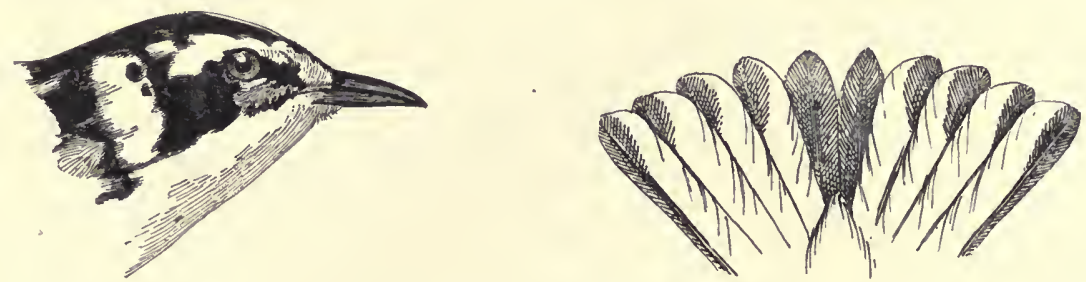

Head and tail of Blackburnian Warbler.

Throat and breast, orange; belly, pale yellow; sides of breast streaked with black; crown, black, streaked with dull white; rump, black; under tail coverts, white.

Dendroica blackburnice.

Blackburnian Warbler.

See No. 3I9.

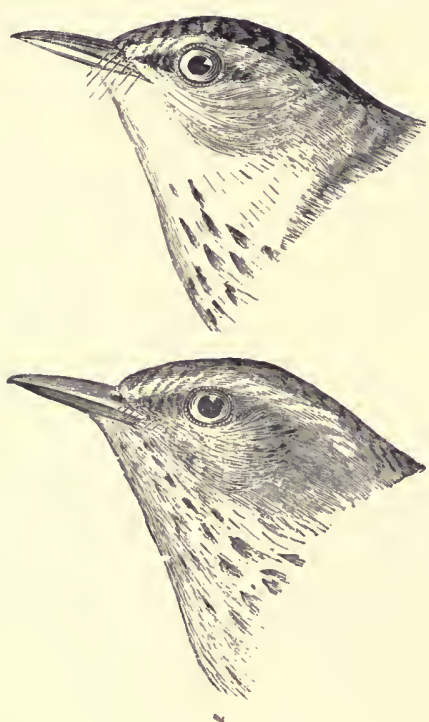

Under parts, yellow; throat, sometimes marked with rufous brown; breast, streaked with black; crown, black or olive gray; back, olive green, marked with black; rump, yellow; under tail coverts, yellowish white.

Dendroica tigrina. Cape May Warbler. See No. 3 ro.

Under parts, very pale yellow, streaked with dark brown; under tail coverts, yellowish white; crown, back, and rump, dark olive.

Seiurus noveboracensis. Water-thrush. Water Warbler. See No. 327 . 
PART 2. The following species have the throat, breast, and belly, yellow; breast, more or less streaked; no white on tail feathers :-

Breast, streaked with rufous brown; major portion of inner webs of tail feathers, yellow.

Dendroica cestiva. Yellow Warbler. See No. 3 I I.

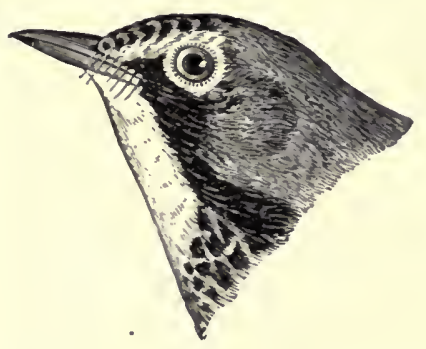

Breast, with black or dusky streaks; tail feathers, entirely dull brown.

Wilsonia canadensis.

Canadian Warbler.

See No. 336 .

PART 3. The following species have the throat, breast, and belly, yellow, without streaks; some tail feathers marked with more or less white:-

Throat and under parts, yellow; under tail coverts, yellow; crown, gray; no yellow about eyes; sides of head, gray; back and rump, olive green; outer tail feathers, very narrowly edged with white (male has a chestnut brown patch on crown).

Vermivora rubricapilla. Nashville Warbler. See No. 306 .

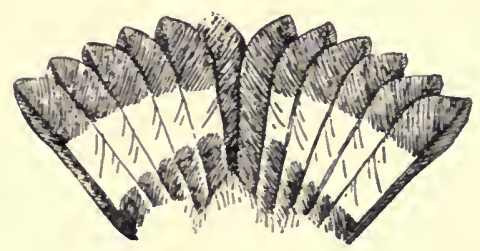

Tail of Magnolia Warbler.

Crown, dull gray; back, olive green; rump and belly, yellow; tail feathers, with white area in the middle (see illustration).

Dendroica magnolia.

Magnolia Warbler.

See No. 3 I 4 .

Under parts, bright yellow; crown, yellow; back and rump, bright olive green; a narrow black streak from bill to eye.

\section{Vermivora pinus (male).}

Blue-winged Warbler.

See No. 304 . 


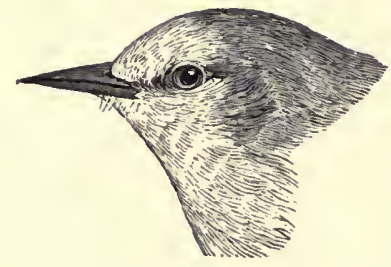

Crown, olive green (sometimes with forehead yellow); under parts, greenish yellow; back and rump, olive green; terminal third of inner webs of outer tail feathers, white.

Vermivora pinus (female and immature).

Blue-winged Warbler. See No. 304 .

Under parts, tinged with greenish yellow; under tail coverts, white; crown, back, and rump, olive green; outer tail feathers very narrowly edged with white (entirely absent in some specimens).

Vermivora peregrina (female in fall and immature).

Tennessee Warbler.

See No. 308 .

Under parts, yellow, washed with olive on sides; sides of head and lores, yellow ; crown, olive green; back and rump, olive green; under tail coverts, pale yellow.

Wilsonia citrina (female in fall and immature).

Hooded Warbler.

See No. 334 .

Under parts, yellow; sides, streaked with black; crown, slaty gray ; back and rump, ashy, streaked with black; lores, black.

Dendroica kirtlandii.

Kirtland's Warbler.

See No. 322 .

Crown, greenish blue; wing coverts, edged with white; back, greenish blue, without streaks; under tail coverts, whitish; under parts, tinged with pale yellow.

Dendroica cerulea (female and immature).

Cerulean Warbler.

See No. 3I 5 .

PAR'T 4. The following species have the throat, breast, and belly, yellow, without streaks, and no white on the tail feathers:-

Crown, slate color, with patch of chestnut (male), or crown, olive gray (female); rump and upper tail coverts, yellowish green; auricular region (sides of head), grayish; under tail coverts, yellow.

Vermivora rubricapilla.

Nashville Warbler. See No. 306. 
Under parts, faintly washed with yellow, or yellowish white; crown, grayish olive; back and rump, olive green; under tail coverts, white; no yellow on tail feathers.

Vermivora peregrina (female in fall).

Tennessee Warbler. See No. 308.

Crown, back, and rump, yellowish green; major part of inner webs of tail feathers, yellow.

Dendroica cestiva (female). Yellow Warbler. See No. 3II.

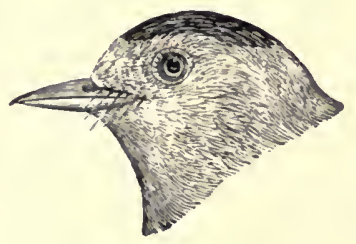

Sides of head, yellowish; crown, glossy black (male); crown, bright olive green, like back (female); back and rump, bright olive green; under tail coverts, yellow.

Wilsonia pusilla. Wilson's Warbler. See No. 335 .

Crown, grayish; back and rump, dull olive green; entire under parts, yellow, palest on throat; no yellow on tail feathers; chin, not whitish; no buff-white stripe over eye.

Oporornis philadelphia (young female).

Mourning Warbler. See No. 33 I.

Crown, grayish; back and rump, green; under parts, pale yellow; chin, whitish; a buff-white stripe over the eye. (This bird belongs in Section 4 , but might be mistaken for a warbler by the novice.)

Vireosylva philadelphica.

Philadelphia Vireo. See No. 294.

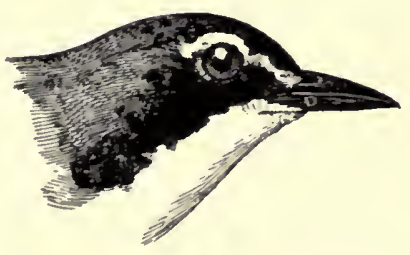

Crown and sides of head, with more or less black; a yellow superciliary stripe; back and rump, olive green.

Oporornis formosa. Kentucky Warbler. See No. 329.

Under parts, yellowish olive; crown, with partly concealed orange brown spot; under tail coverts, greenish yellow. Vermivora celata.

Orange-crowned Warbler. See No. 307. 
PART 5. The following species have the throat, yellow; belly, not yellow ; tail feathers, marked with more or less white :-

Back, green, streaked with black; outer web of outer tail feather, not edged with white; no yellow stripe over eye; chin, whitish; sides of breast and body, streaked.

Dendroica striata (female).

Black-poll Warbler. See No. 3 I 8.

Crown, black, with patch of orange yellow in center; back and rump, black, with more or less white; throat, orange; sides, streaked with black; for illustrations of head and tail, see page 240 .

Dendroica blackburnice (adult male).

Blackburnian Warbler.

See No. 3 I 9 .

Throat, yellow; sides of breast, streaked with blackish; crown, olive, dotted with blackish; back and rump, olive gray, streaked with black; usually a trace of yellow in middle of crown; basal portion of narrow outer web of outer tail feather, edged with white.

Dendroica blackburnice (female, and immature). Blackburnian Warbler. See No. 3 I 9 .

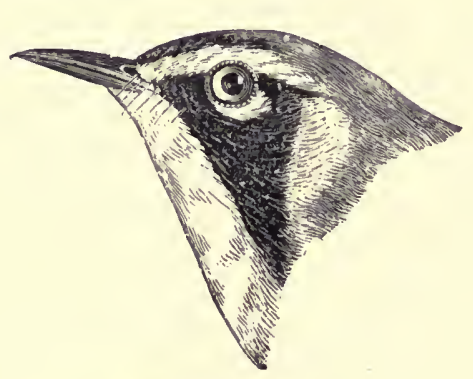

Crown, ash gray; forehead, blackish; throat, yellow; bordered by black; sides of breast, streaked with black; back and rump, slaty gray, not streaked; no white on outer web of outer tail feather.

Dendroica dominica albilora. Sycamore Warbler. See No. 320.

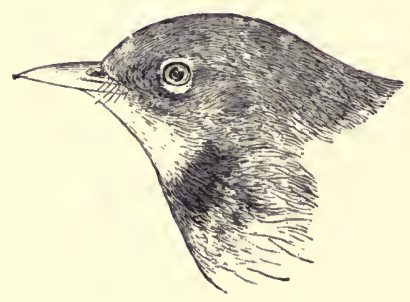

Crown, slaty blue; back, tinged with greenish yellow; rump, like crown; no black streaks on sides of throat, back, or under parts.

Compsothlypis americana, and races.

Parula Warbler.

See No. 309. 
Crown, back, and rump, green (tinged with gray), without streaks; two outer tail feathers with oblique white spots; lores, yellow.

Dendroica vigorsii. Pine Warbler.

See No. 323 .

Crown, back, and rump, green; sides of head, yellowish; at least half of outer web of outer tail feather, edged with white; sides more or less faintly streaked; rump, same color as back.

Dendroica virens (female and fall plumage). Black-throated Green Warbler. See No. 32 I.

Crown, olive; more or less speckled with black; back, olive; rump, yellow or greenish yellow; breast with numerous streaks; no white on outer web of outer tail feathers; sides of head and neck, more or less tinged with yellow.

Dendroica tigrina (female and immature at some seasons).

Cape May Warbler. See No. 3 ro.

PART 6. The following species have the throat not yellow; belly, yeliow, and no white on the tail feathers:-

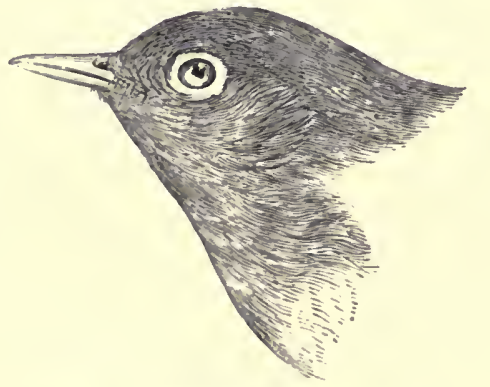

Throat, grayish or brownish; eye ring, white; back, olive green.

Oporornis agilis. Connecticut Warbler. See No. 330.

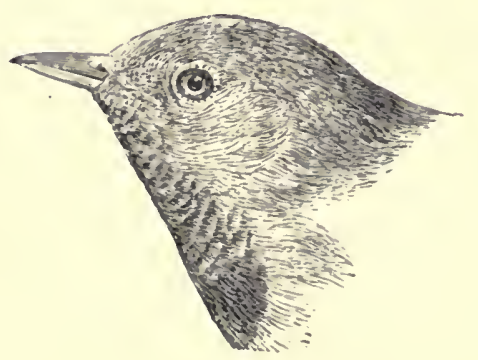

Throat, grayish or ashy, changing to blackish on breast in adult male birds; no white eye ring.

Oporornis philadelphia.

Mourning Warbler.

See No. 33I. 
246 Field Museum of Natural History-Zoölogy, Vol. IX.

PART 7. The following species have the throat not yellow; belly, yellow, and more or less white on tail feathers :-

Crown, blackish; cheeks, chestnut; breast, yellow, streaked with black; back, greenish; rump, yellow; much white on wing coverts.

Dendroica tigrina (adult male).

Cape May Warbler.

See No. 3 Iо.

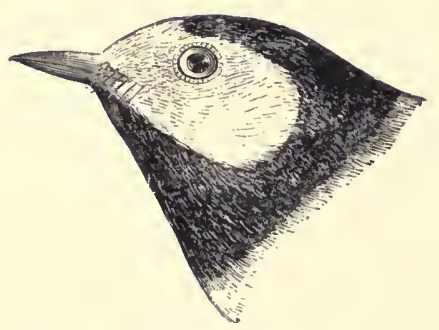

Throat, black; forehead and sides of head, yellow; crown, black.

Wilsonia citrina. Hooded Warbler. See No. 334 .
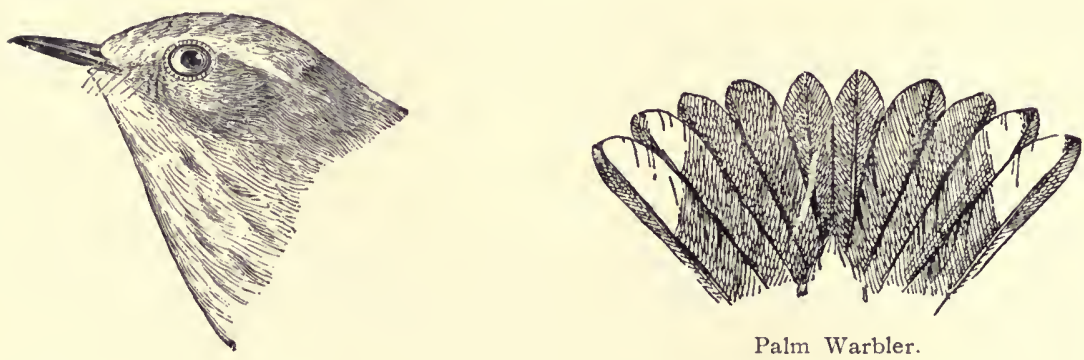

Palm Warbler.

Throat, dull white; breast, faintly streaked; under tail coverts, yellow; wing coverts, tipped with brownish; crown, often marked with more or less rufous brown.

Dendroica palmarum.

Palm Warbler. Red-poll Warbler. See No. 324 .

Crown, bluish green; wing coverts, tipped with white; under tail coverts, whitish; under parts, pale yellowish white.

Dendroica cerulea (female or immature).

Cerulean Warbler.

See No. 3i5. 
PART 8. The following species have the throat, not yellow; belly, not yellow, and no white on the tail feathers; breast, streaked, or spotted with black, or dark brown:-

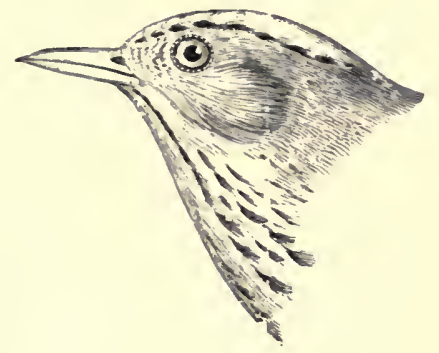

Oven Bird.

Crown, brownish orange; back, olive green; bill, pale. Seiurus aurocapillus.

Oven-bird. Golden-crowned Thrush. See No. 326 .

Crown and back, olive brown; bill, dark.

Seiurus noveboracensis, and races.

Water-thrush.

See No. 327 .

PART 9. The following species have the throat, not yellow; belly, not vellow, and no white on the tail feathers; breast, not streaked, or spotted with black, or dark brown:-

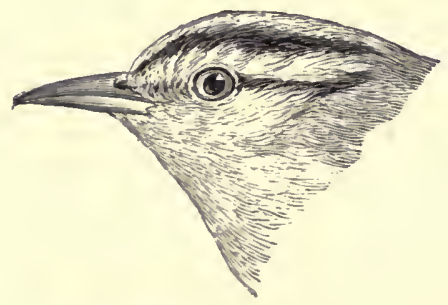

Crown, with stripe of tawny buff, bordered by black stripes; a black stripe through the eye; under parts, buffy white; olive on sides.

Helmitheros vermivorus. Worm-eating Warbler. See No. 303 .

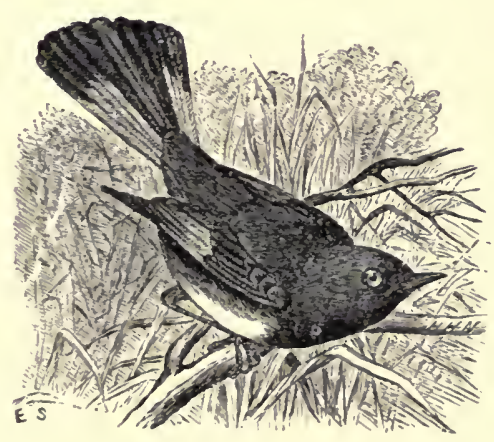

Crown and back, black; throat, black; a patch of orange on sides of breast, and a patch of orange red on wings, and tail.

Setophaga ruticilla (male). Redstart. See No. 337 . 
248 Field Museum of Natural History-Zoölogy, Vol. IX.

Crown, slaty olive; back, dull olive; under parts, white; a patch of yellow on sides of breast; outer tail feathers, yellow, tipped with brown.

Setophaga ruticilla (female).

Redstart.

See No. 337 .

Crown, grayish olive, usually with partly concealed orange brown spot; no yellow on tail feathers; under parts, yellowish green.

Vermivora celata.

Orange-crowned Warbler.

See No. 307.

PART 10. The following species have the throat not yellow; belly, not yellow, and more or less white on tail feathers; sides of breast and body with numerous distinct black or blackish streaks:-

Throat, bright orange; crown, black, streaked with white.

Dendroica blackburnice (adult mate).

Blackburnian Warbler.

See No. 3 I9.

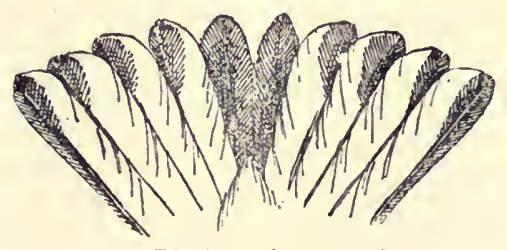

Tail of Blackburnian Warbler.

Crown, back, and rump, bright olive green; sides of head, yellowish ; throat, usually with more or less indications of black in most specimens; inner webs of two outer tail feathers, white.

Dendroica virens (fall and immature). Black-throated Green Warbler. See No. 32 I.

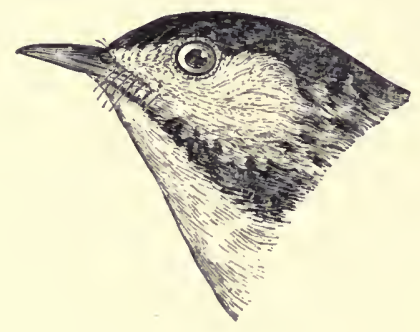

Crown, black; back, grayish olive, streaked with black; rump, like back. Dendroica striata. Black-poll Warbler. See No. 3 I8. 
Crown and back, blue; the back, streaked with black; rump, slaty blue.

Dendroica cerulea. Cerulean Warbler. See No. 315.

Crown, dull olive green, dotted with black; back, grayish olive, streaked with black; rump, like back.

Dendroica striata (fall and immature). Black-poll Warbler. See No. 3 I8.

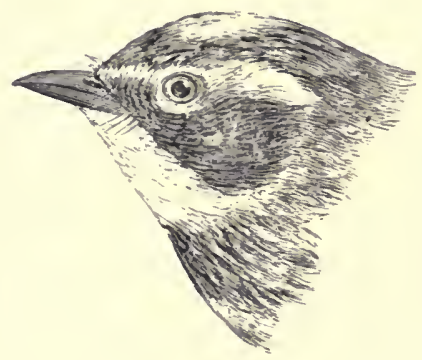

Middle of crown, rump, and sides of the breast, with more or less yellow.

Dendroica coronata. Myrtle Warbler. Yellow-rumped Warbler. See No. 3 I 3 .

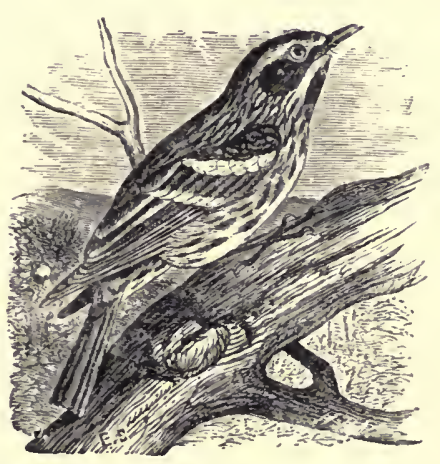

Black and White Warbler.

Crown, black, with white stripe in middle; entire plumage, black and white.

Mniotilta varia. Black and White Warbler. Black and White Creeper. See No. 300 .

Crown and back, grayish olive; rump, yellowish; a patch of white near the tips of outer tail feathers on the inner webs.

Dendroica tigrina (immature female). Cape May Warbler. See No. 3 to. 
250 Field Museum of Natural History-Zoölogy, Vol. IX.

PART 11. The following species have the throat, not yellow; belly, not yellow, and more or less white on the tail feathers; the sides of breast and body, not marked with numerous distinct black streaks:-

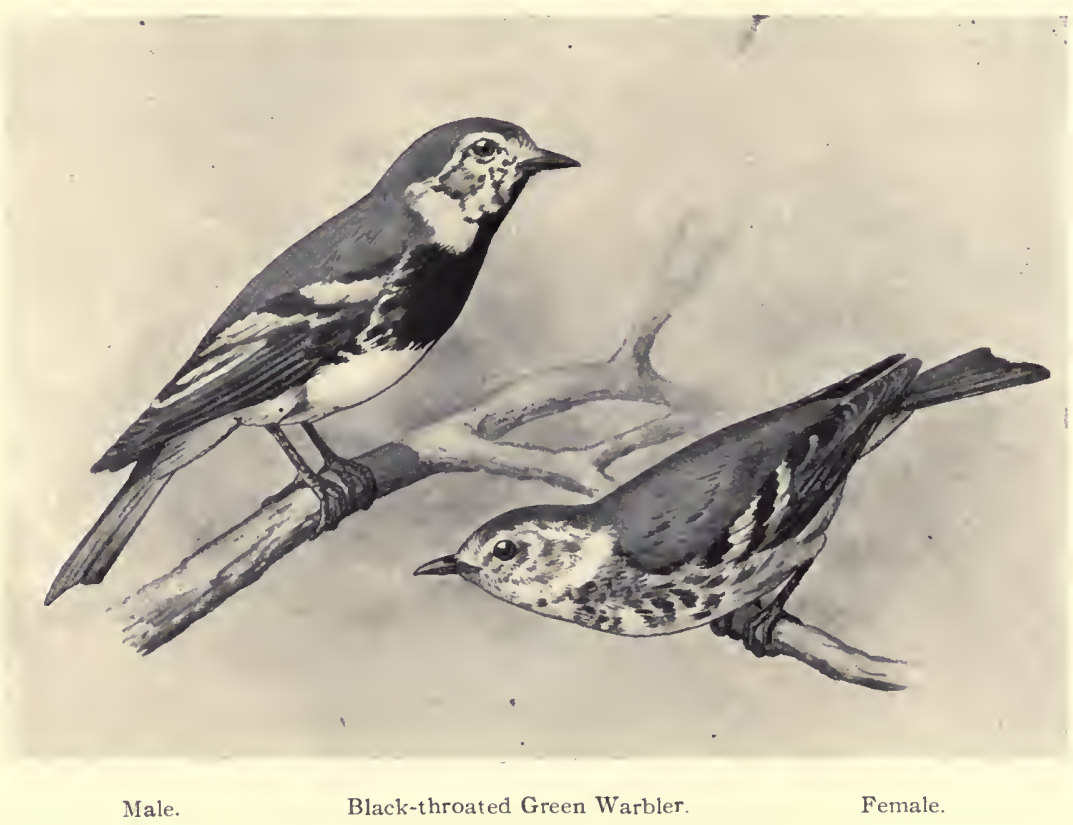

Throat, black; crown, olive green; sides of head, yellow; wing bands, white.

Dendroica virens (adult male). Black-throated Green Warbler.

See No. 32 I.

Throat, black; ear coverts, black; crown, yellowish; wing bands, yellow.

Vermivora chrysoptera (male). Golden-winged Warbler.

See No. 305 .

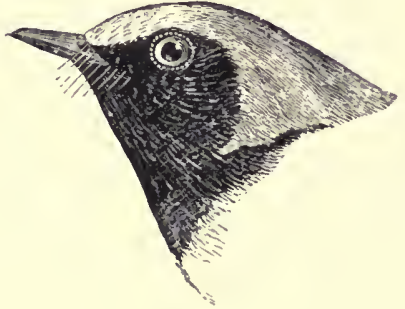

Throat, black; crown, dull blue; sides of breast, bluish black; a patch of white at base of primaries.

Dendroica ccrulescens (adult male). Black-throated Blue Warbler. See No. 312. 


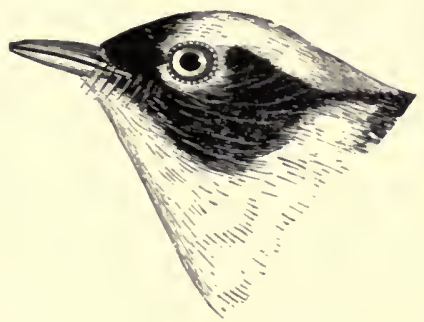

Throat and sides, chestnut; crown, chestnut.

Dendroica castanea (adult male). Bay-breasted Warbler. See No. 3 I 7 .

Throat and sides, more or less marked with chestnut; crown, olive green, streaked with black; back, grayish olive, streaked with black; (crown, with indications of chestnut); belly, cream white.

Dendroica castanea (female).

Bay-breasted Warbler.

See No. 317 .

Throat and under parts, cream white, shading into pale buff; white on flanks; crown and back, green, indistinctly streaked with black; wing bars, white.

Dendroica castanea (immature).

Bay-breasted Warbler.

See No. 3r 7 .

Throat and under parts, pale yellowish white; crown and back, green, indistinctly streaked; wing bars, white; often very difficult to distinguish from immature specimen of $D$. castanea.

Dendroica striata (immature). Black-poll Warbler. See No. 3 I 8 .

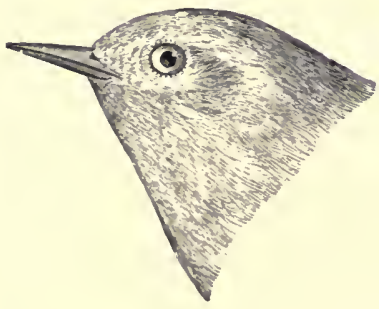

Throat and under parts, white; ashy on the sides; crown, slaty gray; back, green; under tail coverts, white.

Vermivora peregrina (adult male).

Tennessee Warbler. See No. 308.

Throat and under parts, white; wing bars, yellow; crown, and back, bright green.

Dendroica pensylvanica (immature).

Chestnut-sided Warbler.

See No. 316. 
252 Field Museum of Natural History-Zoölogy, Vol. IX.

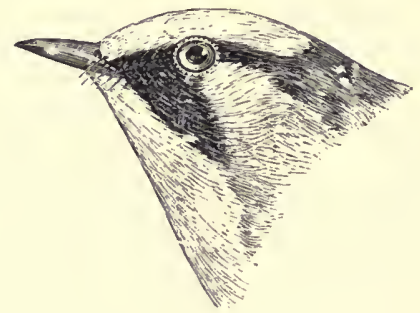

Throat and under parts, white; sides, more or less marked with chestnut; crown, greenish yellow; back, greenish, streaked with black; wing bars, yellowish.

Dendroica pensylvanica. Chestnut-sided Warbler. See No. 3 I6.

Throat and under parts, cream white; crown and back, greenish blue; rump, like back; wing coverts, edged with white; under tail coverts, whitish.

Dendroica cerulea (female).

Cerulean Warbler.

See No. 3i5.

Throat and under parts, dull white; crown and back, grayish olive; wing bars, white; an oblique white spot on inner webs of two outer tail feathers; rest of tail feathers, without white; under tail coverts, whitish.

Dendroica vigorsii (fall and immature).

Pine Warbler.

See No. 323 .

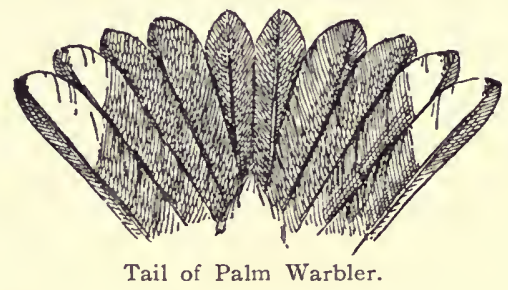

Throat and under parts, whitish, faintly tinged with yellow; breast, with rather indistinct dusky streaks; crown, grayish olive, usually with at least an indication of chestnut; back, grayish olive; rump, olive green; under tail coverts, yellow.

Dendroica palmarum.

Palm Warbler. Red-poll Warbler. See No. 324 .

Throat and under parts, dull yellowish green; crown; green, with partly concealed orange brown patch in center (wanting in young birds); outer tail feathers, narrowly edged with white on inner web; rest of tail feathers, without white; no white spot at base of primaries. .

Vermivora celata.

Orange-crowned Warbler.

See No. 307. 
Throat and under parts, buffy white; crown and back, olive green; bases of primaries, white, forming a small spot on wing (female).

Dendroica ccrulescens. Black-throated Blue Warbler. See No. 3 I 2.

Throat, gray; belly, white (breast, often washed with yellow); crown, yellowish green; wing coverts, broadly tipped with yellow (female).

Vermivora chrysoptera.

Golden-winged Warbler.

See No. 305 .

GROUP 3. Wing, 2.75 to 3.25 inches long.

PART 1. The following species have the throat, breast, and belly, yellow; the breast, more or less streaked; some tail feathers, marked with white :-

Under parts, pale yellow; sides of breast, more or less streaked with black; under tail coverts, white; crown, grayish; back and rump, ashy gray, streaked with black.

Dendroica kirtlandii.

Kirtland's Warbler.

See No. 322 .

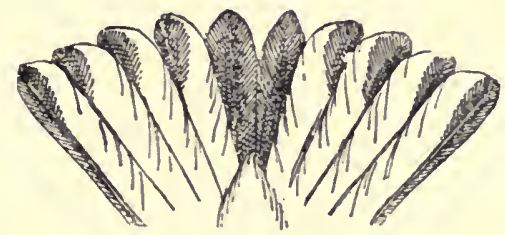

Tail of Blackburnian Warbler.

Throat and breast, orange, belly, pale yellow; sides of breast, streaked with black; crown, black, with orange spot in center; back, black, streaked with whitish; rump, black; under tail coverts, white.

Dendroica blackburnice. Blackburnian Warbler.

See No. 3I9.

Under parts, very pale yellowish, almost yellowish white, faintly streaked with black; under tail coverts, white; crown, back, and rump, olive green, streaked with black. Dendroica striata (female).

Black-poll Warbler.

See No. 3 I8. 
254 Field Museum of Natural History - Zoölogy, Vol. IX.

Under parts, yellow; sides of breast, streaked with olive; under tail coverts, ashy; crown, back, and rump, olive green (not streaked).

Dendroica vigorsii.

Pine Warbler. See No. 323 .

Under parts, yellow; ear coverts, rufous chestnut; breast, streaked with black; crown, black, or olive gray; back, olive green, marked with black; rump, yellow; under tail coverts, yellowish white; a patch of white on wing coverts.

Dendroica tigrina. Cape May Warbler. See No. 3 Io.

Under parts, very pale yellow, streaked with dark brown; under tail coverts, yellowish white; crown, back, and rump, dark olive. Seiurus noveboracensis.

Water-thrush. See No. 327 .

PART 2. The following species has the throat, breast, and belly, yellow ; breast, more or less streaked, and no white on the tail feathers:-

Breast, with black or dusky streaks; tail, dull brown.

Wilsonia canadensis.

Canadian Warbler. See No. 336 .

PART 3. The following species have the throat, breast and belly, yellow, without streaks, and more or less white on the tail feathers:-

Head, neck, and under parts, bright orange yellow; palest on the belly; back, olive green; rump, gray.

Protonotaria citrea. Prothonotary Warbler. See No. 301.

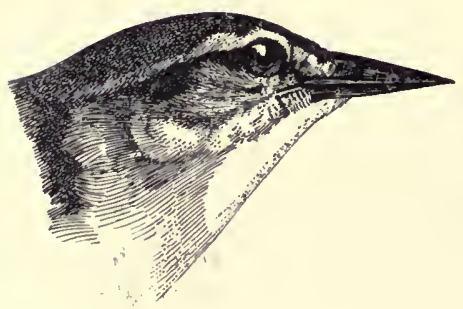

Crown, brownish; under parts, white, faintly tinged with pale yellow; sides, grayish; back and rump, olive brown or grayish brown; a white stripe over the eye.

Helinaia swainsonii. Swainson's Warbler. See No. 302. 
Under parts, yellow; sides, streaked with black; crown, slaty gray; back and rump, ashy, streaked with black; lores, black.

\section{Dendroica kirtlandii.}

Kirtland's Warbler.

See No. 322 .

Under parts, yellow, washed with olive on the sides; sides of head and lores, yellow; crown, olive green; back and rump, olive green; under tail coverts, pale yellow.

Wilsonia citrina.

Hooded Warbler.

See No. 334 .

PART 4. The following species have the throat, breast and belly, yellow, without streaks; no white on the tail feathers:-

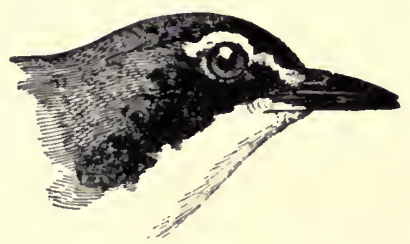

Crown and sides of head, with more or less black; a yellow stripe over the eye; back and rump, olive green.

Oporornis formosa. Kentucky Warbler. See No. 329 .

PART 5. The following species have the throat, yellow; belly, not yellow; tail feathers, marked with more or less white:-

Back, green, streaked with black; outer web of outer tail feather, not edged with white; no yellow stripe over eye; chin, whitish; sides of breast and body, streaked.

Dendroica striata (immature). Black-poll Warbler. See No. 318.

Crown, black, with patch of orange yellow in center; back and rump, black, with more or less white; throat, orange; sides streaked with black.

Dendroica blackburnice (adult male).

Blackburnian Warbler.

See No. 3 I 9 .

Throat, yellow; sides of breast, streaked with blackish; crown, olive, dotted with dull black, and usually showing a trace of yellow in center; back and rump, olive gray, streaked with black; basal portion of narrow outer web of outer tail feather, edged with white.

Dendroica blackburnice (female and immature). Blackburnian Warbler. See No. 3i 9 . 
256 Field Museum of Natural History-Zoölogy, Vol. IX.

Crown, ash gray; forehead, blackish; throat, yellow, bordered by black; sides of breast, streaked with black; back and rump, slaty gray, not streaked; no white on outer web of outer tail feather.

Dendroica dominica albilora.

Sycamore Warbler.

See No. 320.

Crown, back, and rump, green (tinged with gray), without streaks; two outer tail feathers, with oblique white spots; lores, yellow.

Dendroica vigorsii.

Pine Warbler.

See No. 323 .

Crown, olive, more or less speckled with black; back, olive; rump, yellow, or greenish yellow; breast, with numerous streaks; no white on outer web of outer tail feather; sides of head and neck, more or less tinged with yellow. Dendroica tigrina (inmature).

Cape May Warbler.

See No. 3 Iо.

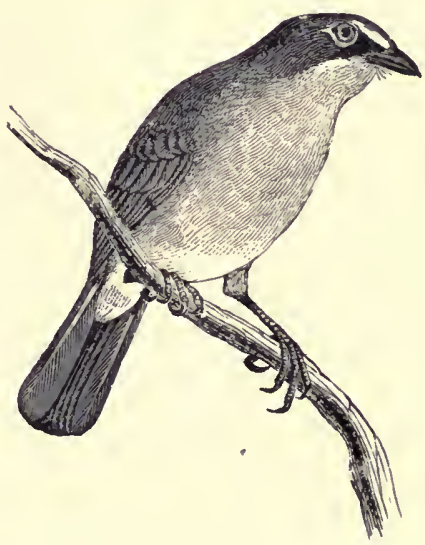

Yellow-breasted Chat.

Throat and breast, bright yellow; lower belly, white; crown and back, olive green; lores and eye ring, white; tail, over 2.50 inches long.

Icteria virens. Yellow-breasted Chat.

See No. 333 . 
PART 6. The following species has the throat, not yellow; belly, yellow, and no white on the tail feathers:-

Throat, grayish or brownish; eye ring, white, or whitish; back, olive green.

Oporornis agilis. Connecticut Warbler. See No. 330.

PART 7. The following species have the throat, not yellow; belly, yellow, and more or less white on the tail feathers :-

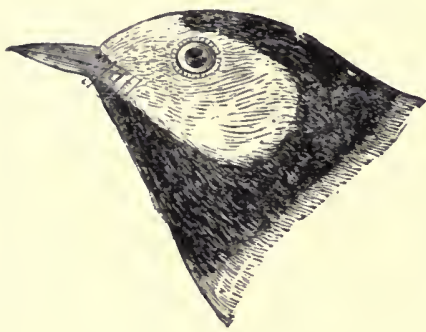

Hooded Warbler.

Throat, black; forehead and sides of head, yellow; crown, black.

Wilsonia citrina. Hooded Warbler. See No. 334 .

Upper throat, tinged with chestnut; breast, streaked with black; back, greenish; rump, yellow; wing coverts, showing much white. Dendroica tigrina (adult male).

Cape May Warbler. See No. 3 Iо.

PART 8. The following species have the throat, not yellow; belly, not yellow, and no white on the tail feathers; breast, not streaked or spotted with black or dark brown:-

Crown, with stripe of tawny buff, bordered by black stripe; a black stripe through the eye.

Helmitheros vermivorus. Worm-eating Warbler.

See No. 303 .

Crown, dull cinnamon brown; a white stripe over the eye; under parts, white, faintly tinged with yellow; sides, tinged with grayish olive.

Helinaia swainsonii. Swainson's Warbler.

See No. 302. 
258 Field Museum of Natural History-Zoölogy, Vol. IX.

PART 9. The following species have the throat, not yellow; belly, not yellow, and no white on the tail feathers; breast, streaked or spotted with black or dark brown :-

Crown and back, olive brown; bill, dark; under parts, white, tinged with yellow, and streaked with black (including throat).

Seiurus noveboracensis, and races.

Water-thrush.

See No. 327 .

Crown and back, olive brown; under parts, white, tinged with buff, and streaked with black; throat, not streaked.

Seiurus motacilla. Louisiana Water-thrush. See No. 328 .

Crown, brownish orange; back, olive green; bill, pale.

Seiurus aurocapillus.

Oven-bird. Golden-crowned Thrush.

See No. 326 .

PART 10. The following species have the throat, not yellow; belly, not yellow; more or less white on the tail feathers; sides of breast, and body, marked with numerous distinct black or blackish streaks: -

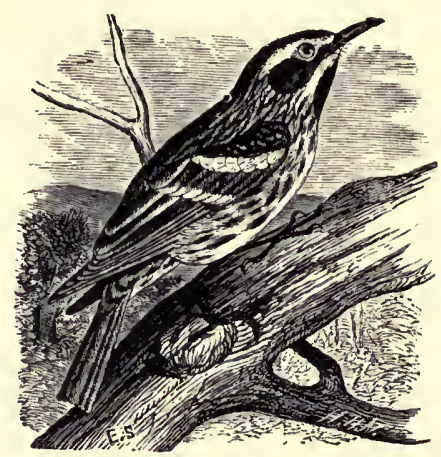

Crown, black, with white stripe in the middle; entire plumage, black and white.

Mniotilta varia. Black and White Warbler. See No. 300 . 
Crown and back, grayish olive; rump, yellowish; a small patch of white near the tips of outer tail feathers on the inner webs.

Dendroica tigrina (immature female). Cape May Warbler. See No. 3 ro.

Middle of crown, rump, and sides of the breast, more or less yellow.

Dendroica coronata. Myrtle Warbler. Yellow-rumped Warbler. See No. 313.

Crown, back, and rump, dull olive or brownish olive; under parts, buffy or grayish, streaked with brown on breast and sides; outer tail feathers, mostly white, including the outer web; hind toe nail, as long as the toe. (This species is not a Warbler, and belongs in Family Motacillidæ, p. $26 \mathrm{r}$, but it might be mistaken for one by the uninitiated.)

Anthus rubescens.

American Pipit. Titlark. See No. 338.

Crown, dull olive green, dotted with black; back, grayish olive, streaked with black; rump, like back; outer tail feather, with patch of white on inner webs.

Dendroica striata (female). Black-poll Warbler. See No. 318.

Throat, bright orange; a patch of orange on the crown.

Dendroica blackburnice (adult male). Blackburnian Warbler. See No. 3 rg.

PART 11. The following species have the throat, not yellow; belly, not yellow; more or less white on the tail feathers; breast and sides of body, not marked with numerous distinct black streaks:Throat and sides, chestnut; crown, chestnut.

Dendroica castanea. Bay-breasted Warbler. See No. 3 I 7 .

Throat and sides, more or less chestnut; crown, olive, streaked with black (usually with trace of chestnut); back, grayish olive, streaked with black.

Dendroica castanea (female). Bay-breasted Warbler. See No. 3r 7 . 
260 Field Museum of Natural History-Zoölogy, Vol. IX.

Throat and under parts, cream white, shading to pale buff on flanks; crown and back, green, indistinctly streaked with black; wing bars, white. (Often difficult to distinguish from female of Black-poll Warbler, D. striata, which resembles it very closely in immature plumage, but has the under parts usually yellowish.)

Dendroica castanea (immature).

Bay-breasted Warbler. See No. 3 I 7 .

Throat and under parts, dull white; crown and back, grayish olive; wing bars, white; an oblique white spot on inner webs of two outer tail feathers, rest of tail feathers, without white; under tail coverts, whitish.

Dendroica vigorsii (fall, and immature).

Pine Warbler. See No. 323 .

Throat and under parts, whitish, faintly tinged with yellow; breast, with rather indistinctly dusky streaks; crown, grayish olive, usually with an indication of chestnut; back, grayish olive; rump, olive green; under tail coverts, yellow. Dendroica palmarum. Palm Warbler. Red-poll Warbler. See No. 324 .

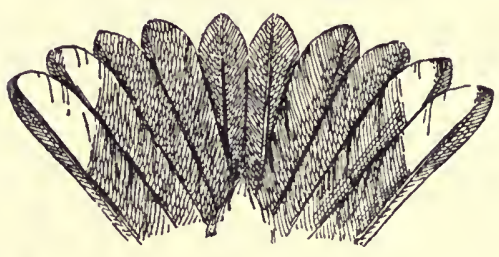

Tail of Palm Warbler.

GROUP 4. Wing, 3.25 to 3.75 inches long.

Under parts, white, faintly yellowish, streaked with brownish black; throat, showing more or less dots or streaks; no white on tail feathers.

Seiurus noveboracensis notabilis.

Grinnell's Water-thrush.

See No. 327 a.

Throat, white; under parts, white, faintly tinged with tawny; breast and sides of body, streaked with dark brown; throat, not streaked; no white on tail feathers.

Seiurus motacilla.

Louisiana Water-thrush.

See No. 328. 
Under parts, grayish white or buffy white, more or less streaked with dark brown; greater portion of outer tail feathers, white; hind toe, with claw longer than middle toe, with claw. (Belongs in Family Motacillidæ, and is very different from a Warbler, but might be mistaken for one by the novice.)

Anthus rubescens.

American Pipit. Titlark. See No. 338.

Throat, faintly yellow; under parts, not streaked; more or less black on cheeks and breast; hind toe nail, straight and long. (This species belongs in Family Alaudidæ, but is included here as well as in its proper place for the benefit of persons unfamiliar with birds, who might look for it under this section.)

Otocoris alpestris praticola. Prairie Horned Lark. See No. 2 r6a.

\section{Family MOTACILLIDÆ. Wagtails, Pipits and Titlarks.}

Bill, slender; first primary, not short, the first, second, and third, being about equal in length; hind toe and claw, longer than middle toe and claw; hind toe nail, long, in this somewhat resembling larks, but no tufts of hair-like feathers over nostrils.

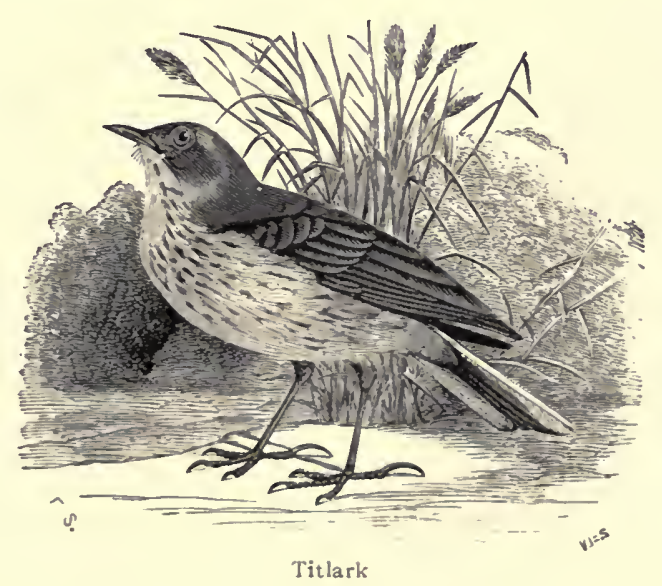


262 Field Museum of Natural History-Zoölogy, Vol. IX.

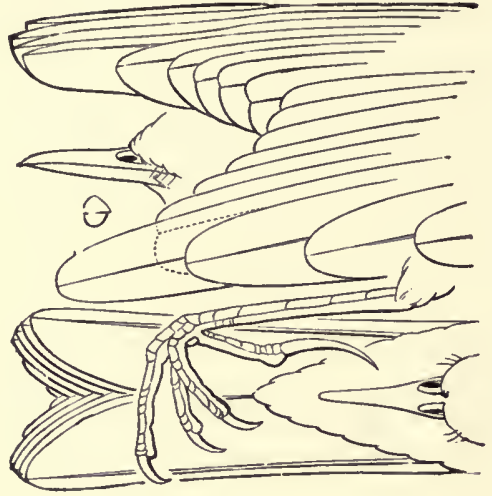

Crown, back, and rump, dull olive, or brownish olive; under parts, buffy, or grayish, streaked with brown on throat and sides; outer tail feather, mostly white, including the outer web; much less white on second feather; hind toe nail, usually as long as the toe.

Anthus rubescens.

American Pipit. Titlark.

See No. $33^{8}$.

\section{Family TROGLODYTIDÆ. Wrens.}

Small, plain-colored birds; first primary, less than two-thirds as long as third; outer tail feathers, decidedly shorter than middle ones, varying from one-eighth to one-half inch or more shorter in different species; toes, not deeply cleft, the inner and middle toes being joined near the base; no noticeable rictal bristles.

* GROUP 1. Wing, less than 3.25 inches long.

PART 1. The following species have the crown or upper back without white streaks or dots :-

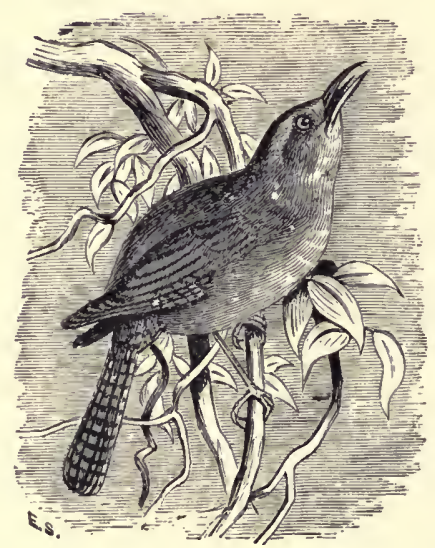

Thryomanes bewickii.

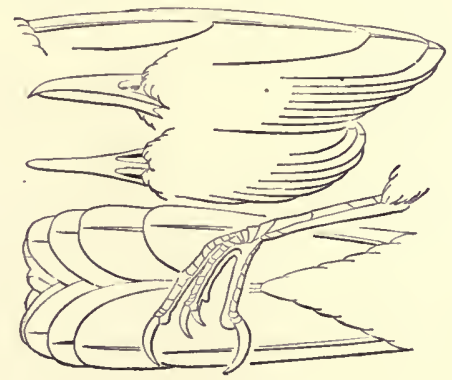

Outer tail feathers, broadly tipped and marked with grayish white.

Thryomanes bewickii.

Bewick's Wren.

See No. 343 .

* For directions for measurement, see page 21 . 


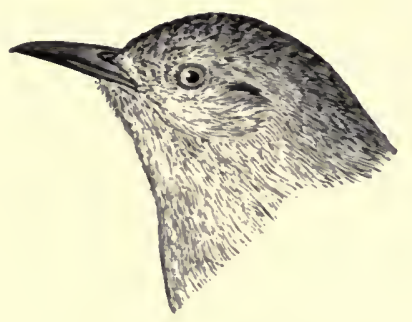

Under parts, grayish; belly, grayish, not speckled; outer tail feathers, not broadly tipped with grayish white; tail, over 1.25 inches long; outer webs of primaries, showing narrow bars.

Troglodytes aëdon, and races.

House Wren.

See No. 344 and 344 a.

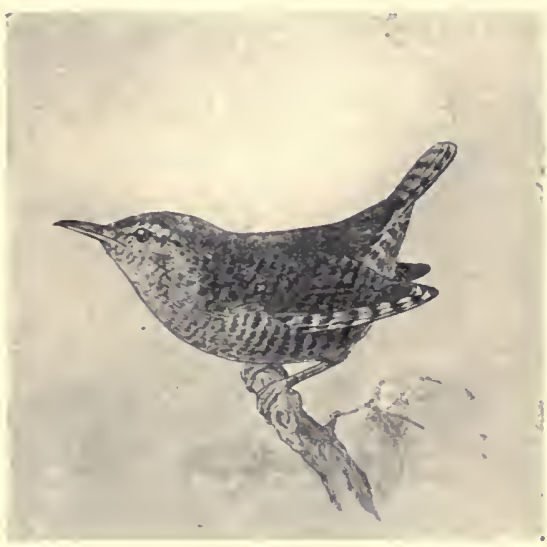

Winter Wren.

Under parts, distinctly brownish, dotted and speckled with brown on flanks and abdomen; tail I.25 or less; outer tail feathers, not broadly tipped and marked with grayish white; outer webs of primaries, with narrow bars.

Nannus hiemalis.

Winter Wren.

See No. 345 .

PART 2. The following species have the crown or upper back showing more or less white streaks or dots:-

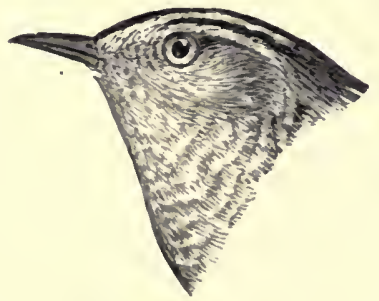

Rump and upper tail coverts, barred with black; bill, shorter than middle toe (without claw).

Cistothorus stellaris. Short-billed Marsh Wren. See No. 346. 
264 Field Museum of Natural History-Zoölogy, Vol. IX.

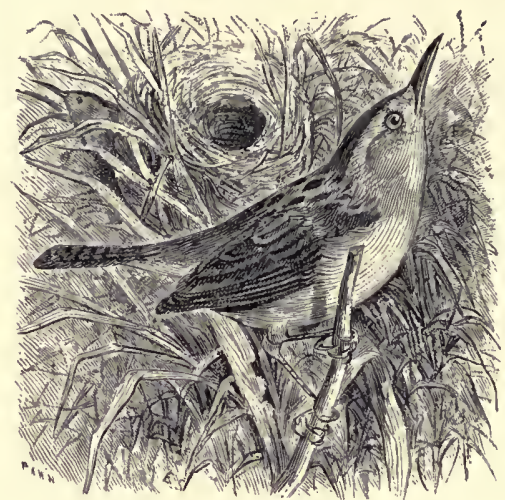

Rump and tail coverts, without black bars; bill, longer than middle toe (without claws). Telmatodytes palustris, and races Long-billed Marsh Wren. See No. 347 .
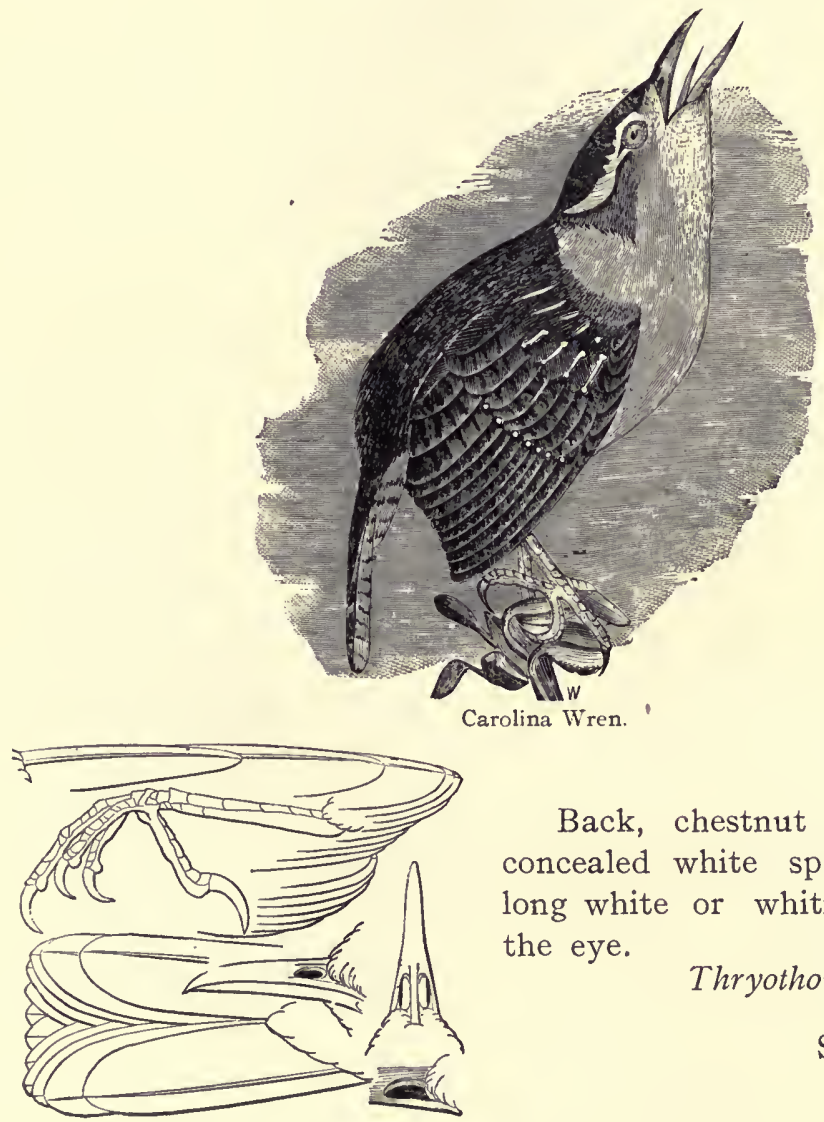

Back, chestnut brown; nearly concealed white spots on rump; a long white or whitish stripe over the eye.

Thryothorus ludovicianus. Carolina Wren. See No. 342 . 
Family MIMIDÆ. Thrashers, Mockingbirds, Catbirds, etc.

Special Characters: Bill, as illustrated; first primary, less than two-thirds as long as third; outer tail feathers, shorter than middle ones; tarsus, scutellate in front; toes, deeply cleft.

* GROUP 1. Wing, from 3.25 to 5.50 inches long.

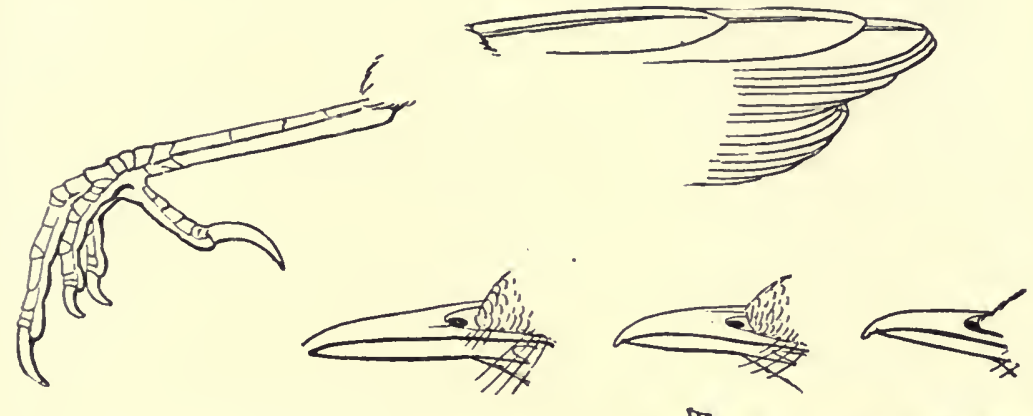

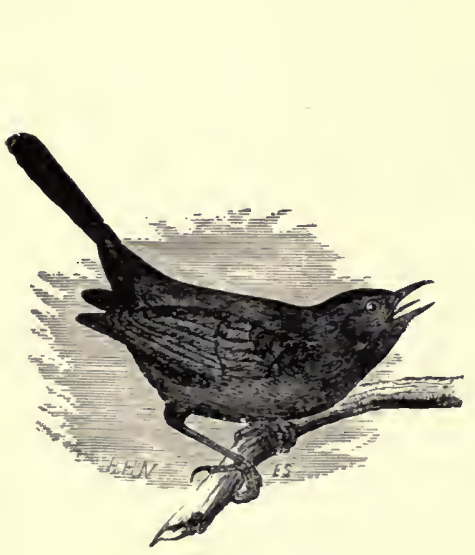

Catbird.

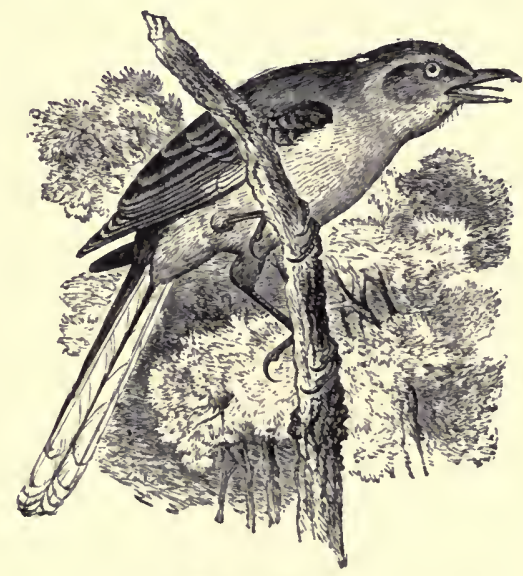

Mockingbird.

General plumage, dark slaty gray; under parts, slaty gray; under tail coverts, dark chestnut brown; crown, blackish; first primary, short.

Dumetella carolinensis. Catbird. See No. 340 .

* For directions for measurement, see page $2 \mathrm{I}$. 
266 Field Museum of Natural History-Zoölogy, Vol. IX.

Upper plumage, ashy gray; basal portion of primaries, white, forming a white wing patch; under parts, ashy white, without streaks.

Mimus polyglottos.

Mockingbird.

See No. 339 .

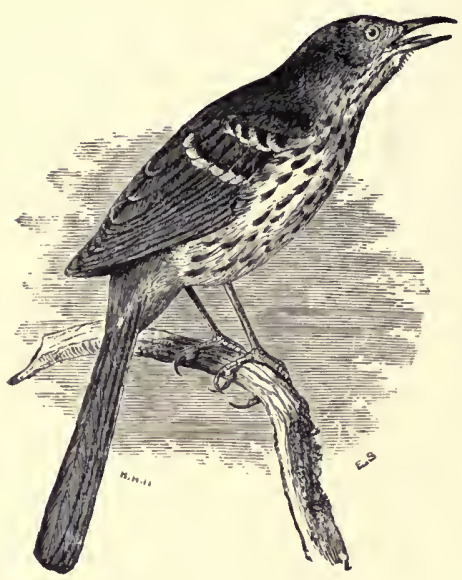

Brown Thrasher.

Entire upper plumage, rufous brown; under parts, buffy white, streaked with dark brown; wing coverts, tipped with white; tail, more than four inches long.

Toxostoma rufum.

Brown Thrasher. Brown Thrush.

See No. 34I.

\section{Family CERTHIIDÆ. Creepers.}

Bill, slender and decurved; tail feathers, stiff and pointed (see cut ); nostrils, exposed; tarsus, scutellate; first primary, very short. But one species occurs in Eastern North America - a small bird; wing, less than three inches; length, less than six inches.

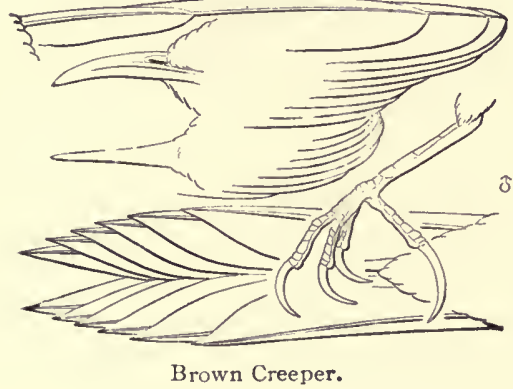

Brown Creeper.

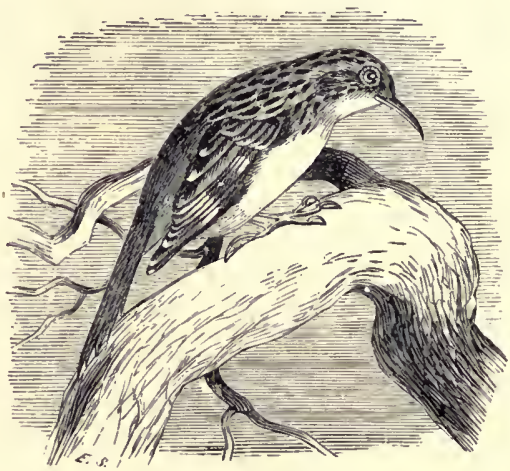

Brown Creeper. 
Jan., 1909. Birds of Illinois and Wisconsin-Cory.

Tail feathers, stiff and pointed; bill, curved; upper parts, streaked; under parts, white; rump, dull rufous brown.

Certhia familiaris americana.

Brown Creeper.

See No. 348.

\section{Family SITTIDÆ. Nuthatches.}
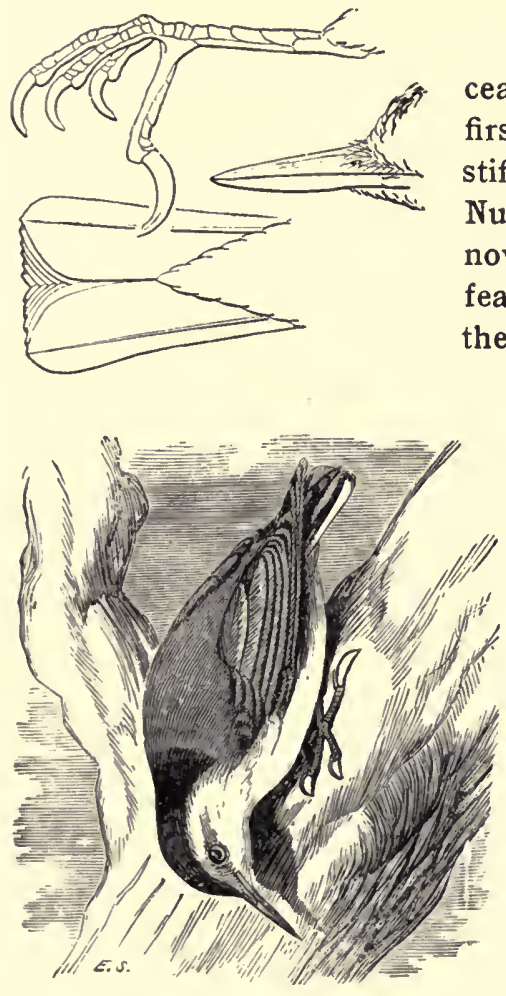

White-breasted Nuthatch.
Bill, as illustrated; nostrils, concealed by bristly tufts; tarsus, scutellate; first primary, very short; tail feathers, not stiff and pointed. The White-breasted Nuthatch is sometimes mistaken by the novice for a small Woodpecker. If tail feathers are stiff and pointed, look for the bird under Family Picidæ.

Crown, black; back, gray, without white; wings, not heavily spotted with white; tail feathers, not stiff or pointed; toes, four, three in front, one behind; wing, 3.50 to 3.75 inches long.

Sitta carolinensis. White-breasted Nuthatch. See No. 349.

Bill, more than three-eighths inch long; under parts, pale rufous brown; crown, black (male); crown, bluish gray (female); wing, 2.60 to 2.85 inches long. Sitta canadensis.

Red-breasted Nuthatch. See No. 350.

Bill, more than three-eighths inch long; crown, grayish brown; under parts, dull grayish white; wing, 2.40 to 2.70 inches long.

Sitta pusilla.

Brown-headed Nuthatch.

See Nos. $35^{\circ}-35^{1}$. 
268 Field Museum of Natural History-Zoölogy, Vol. IX.

\section{Family PARID庄. Titmice and Chickadees.}

Small birds, less than 6.50 inches long; wing, less than 3.50 in the largest; first primary, very short and small; bill, short and stout (as illustrated); nostrils, concealed by bristly feathers; throat, black; crown, black; front toes, joined near the base; wing, less than 3 inches long (Chickadee), or forehead, black; sides, with rufous brown; wing, over 3 inches long (Titmouse).

GROUP 1. Wing, less than 3 inches long.

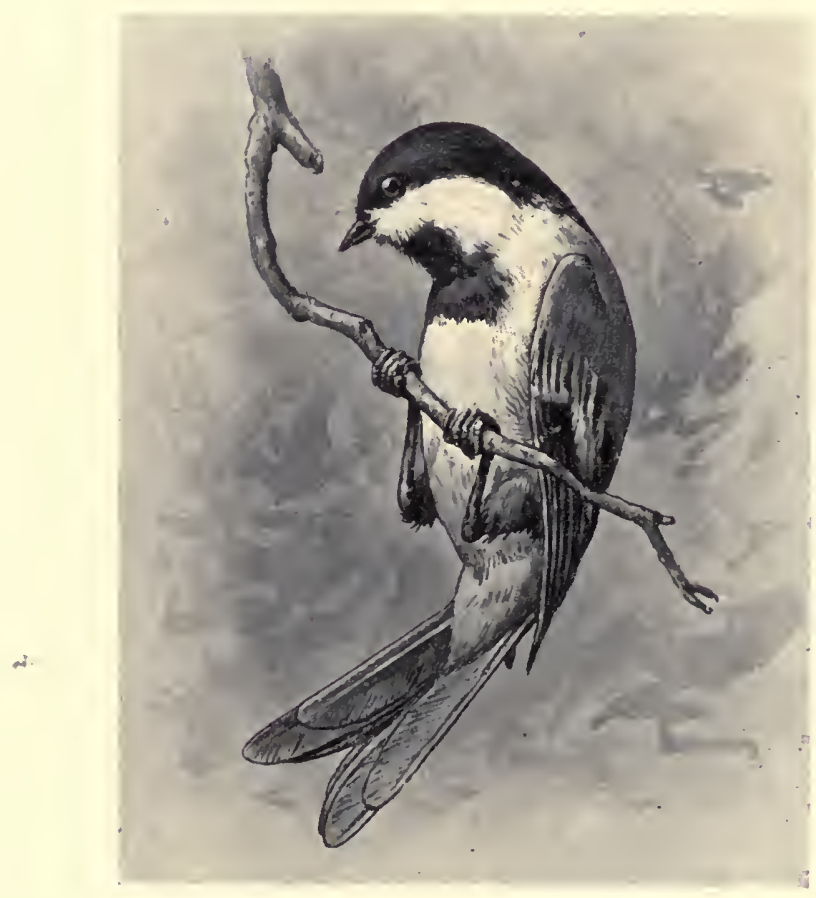

Chickadee.

Bill, less than three-eighths inch long; crown and throat, black; greater wing coverts, edged with white; breast, white; belly and sides, pale buff.

Penthestes atricapillus, and races. Chickadee. Black-capped Titmouse. 
Bill, less than three-eighths inch long; crown and throat, black; greater wing coverts, not edged with white; breast, white; belly and sides, pale buff.

Penthestes carolinensis.

Carolina Chickadee.

See No. 353.

Throat, black; sides of body, chestnut brown.

Penthestes hudsonicus.

Hudsonian Chickadee.

See No. 354 .

GROUP 2. Wing, over 3 inches long.

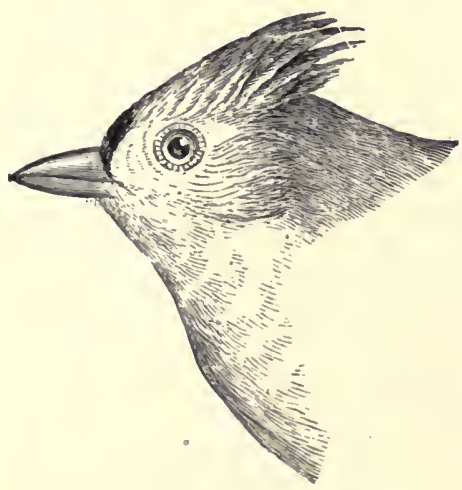

Tufted Titmouse.

Throat and under parts, dull white; sides of body, tinged with rufous brown; crown, gray, with more or less of a crest; forehead, black, in adults.

Bcolophus bicolor.

Tufted Titmouse.

See No. 35 I.

\section{Family SYLVIIDÆ. Kinglets and Gnatcatchers.}

The Sylviidæ are divided into three subfamilies, one of which, the Sylviinæ or Old World Warblers, is not represented in eastern North America. The other two may be summarized as follows:-

\section{Subfamily REGULINÆ. Kinglets.}

Size, small; length, less than 4.75; wing, less than 2.50 inches; tarsus, booted; wings, longer than tail; tail, emarginate; males, with crown of the head showing red or yellow; 8 species, two of which occur in eastern North America. 
270 Field Museum of Natural History-Zoölogy, Vol. IX.

\section{Subfamily POLIOPTILIN $Æ$ Gnatcatchers.}

Size, small; length, less than 4.75 ; wing, less than 2.50 inches; tarsus, not booted; wings, longer than tail; tail, somewhat rounded; color, bluish ash; about 15 species, all American, of which one occurs in eastern North America.
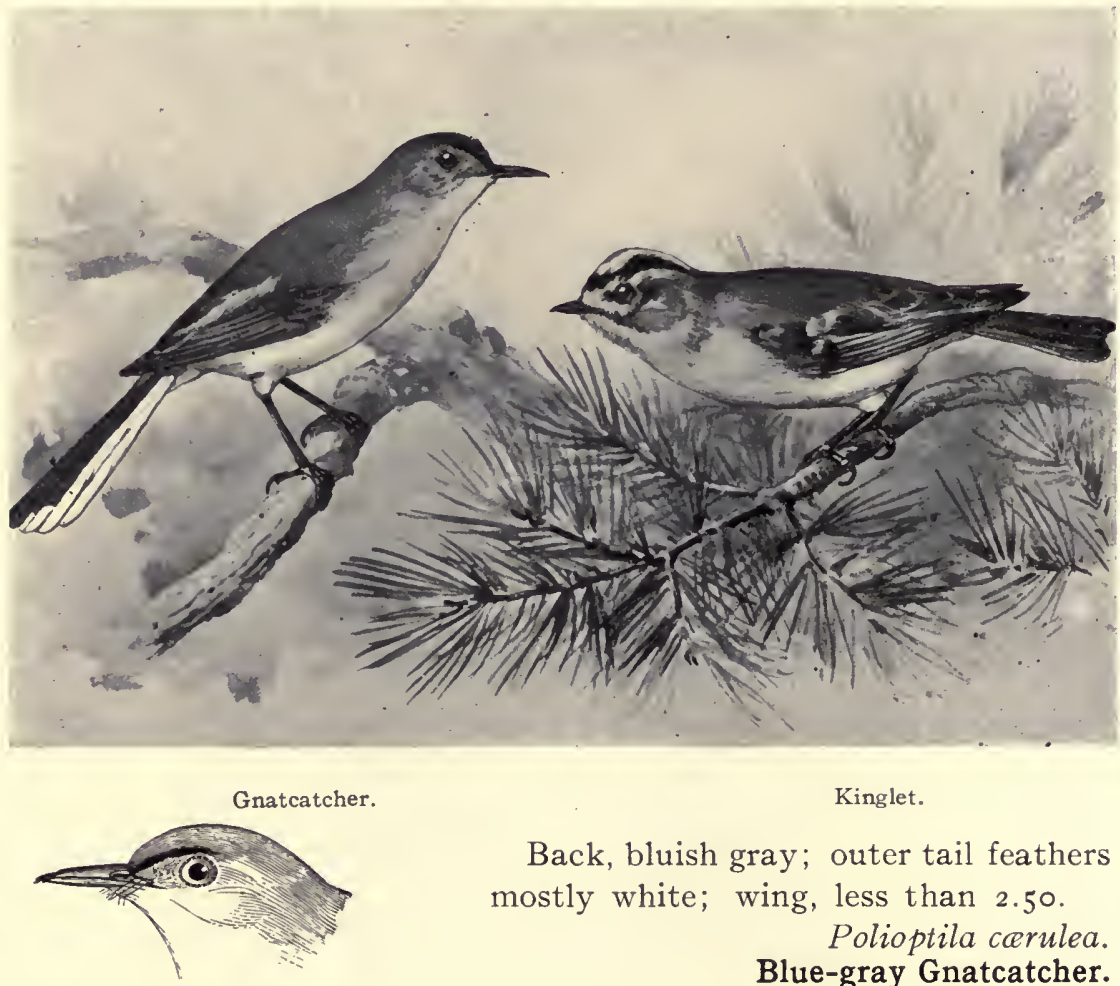

Kinglet.

Back, bluish gray; outer tail feathers mostly white; wing, less than 2.50 .

Polioptila ccerulea. Blue-gray Gnatcatcher. See No. 357 .

Back, olive; no white patch on tail; crown, with patch of bright red (male); crown, olive (female); wing, less than 2.50 .

Regulus calendula. Ruby-crowned Kinglet. See No. 356 .

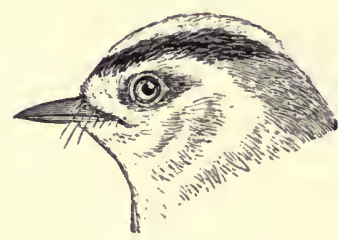

Back, olive; no white patch on tail; crown, with patch of orange edged with yellow and black (male); crown, with yellow patch edged with black (female); wing, less than 2.50 . 
Family TURDIDÆ. Thrushes, Bluebirds, etc.

First primary, very short; tarsus, booted (no scales showing, except near the toes); bill, shorter than head; tip of upper mandible with small notch.

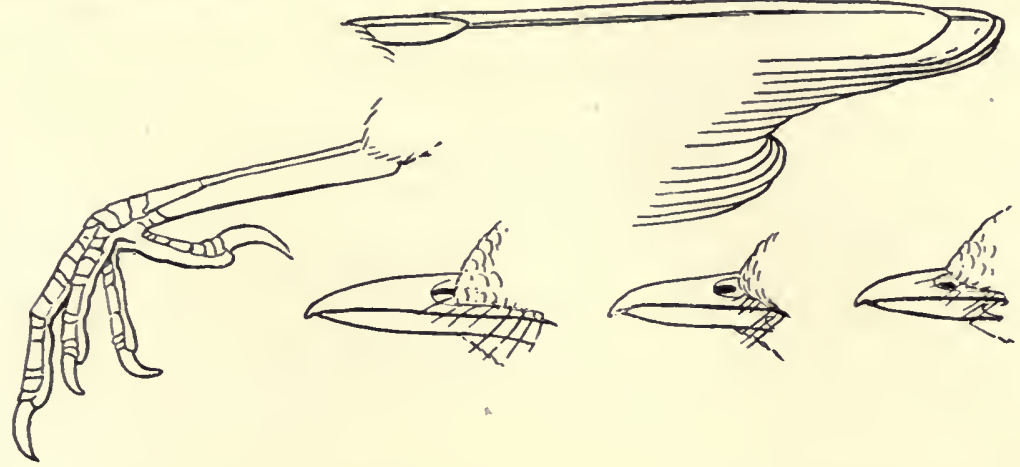

* GROUP 1. Wing, from 3.25 to 4.75 inches long.

PART 1. The following species have the under parts more or less streaked or spotted:-
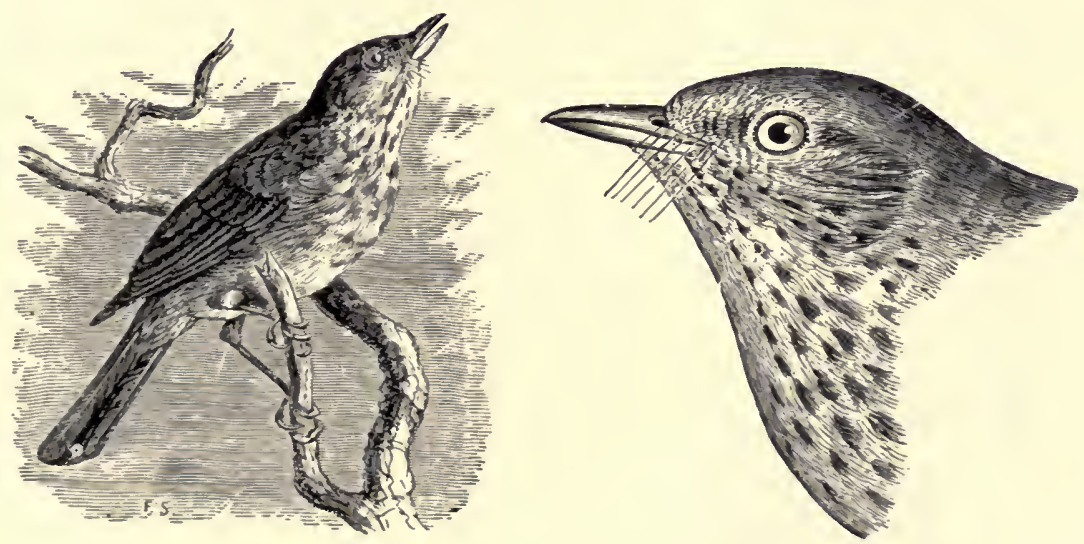

Thrush.

Back, rump, and upper tail coverts, olive, about the same color; eye ring, cheeks, and lores, pale buff; no white on wing coverts.

Hylocichla ustulata swainsonii. Olive-backed Thrush. See No. 362 .

* For directions for measurement, see page $2 \mathrm{r}$. 


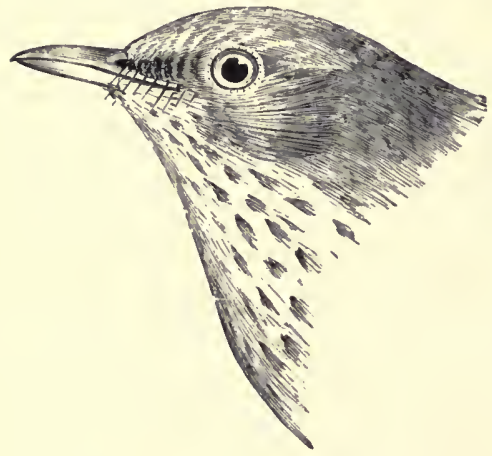

Upper plumage, brownish olive; ends of upper tail coverts and tail, rufous brown, much more rufous than the back; no white on tail; first primary, very small and narrow.

Hylocichla guttata pallasii.

Hermit Thrush.

See No. 363 .

Back, rump, and upper tail coverts, olive, about the same color; eye ring and lores, white, sometimes faintly tinged with buff, but the eye ring never decidedly buff, as in swainsonii; no white on wing coverts.

Hylocichla alicice, and races.

Gray-cheeked Thrush.

See No. 36 I.

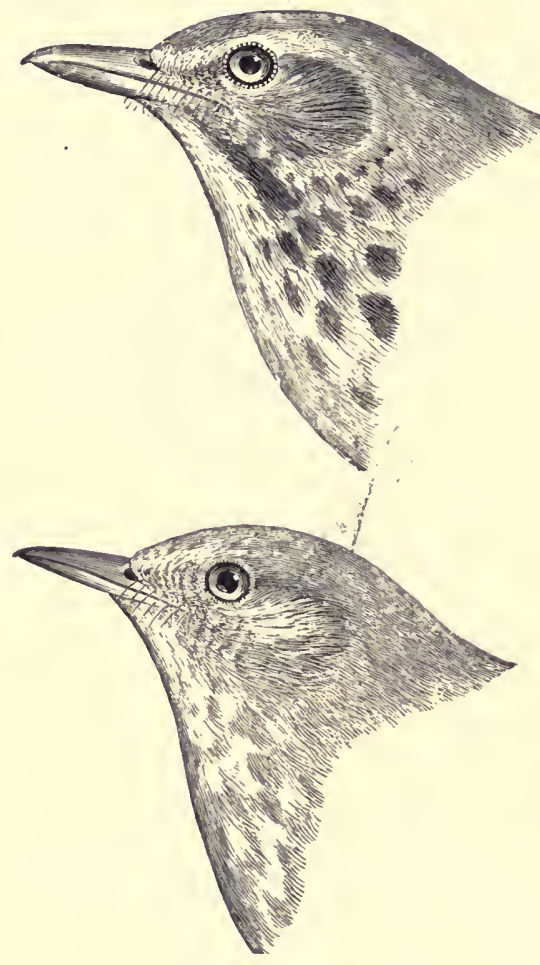

Crown and back, dull cinnamon brown, shading to brownish olive on the upper tail coverts; breast and belly, marked with round brownish black spots; no white on wing coverts.

Hylocichla mustelina.

Wood Thrush. See No. 359.

Crown, back, and upper tail coverts, pale cinnamon brown, nearly uniform in color; breast and sides of throat, tawny brown, marked with small cinnamon brown spots and streaks; belly, whitish, without spots; no white on wing coverts.

Hylocichla fuscescens, and races.

Wilson's Thrush.

See No. 360 . 
Wings and tail, tinged more or less with blue (immature).

Sialia sialis.

Bluebird.

See No. $3_{6}$.

PART 2. The following species have no streaks or spots on the under parts :-

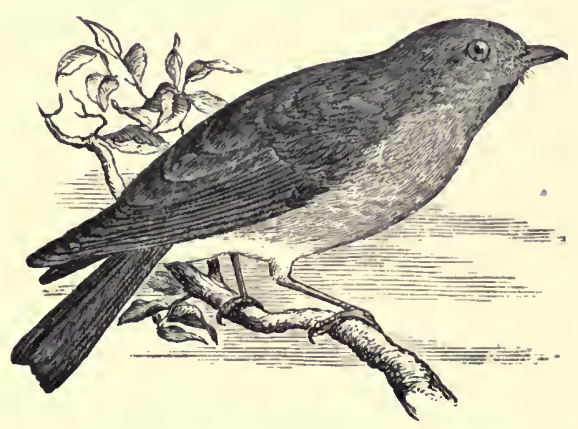

Bluebird.

Upper plumage, blue; breast and sides of body, cinnamon rufous; belly, white (male).

Sialia sialis.

Bluebird.

See No. 365 .

Upper plumage, ashy gray, with bluish tinge, shading to blue on rump, tail, and wings; breast and sides, pale cinnamon brown; belly, white (female).

Sialia sialis.

Bluebird.

See No. 365 .

Entire plumage, gray or brownish gray, palest on the throat; a distinct white ring around the eye; tip and outer web of tail feathers, ashy white; western species; one Illinois record.

Myadestes townsendii.

Townsend's Solitaire.

See No. $35^{8}$. 
274 Field Museum of Natural History-Zoölogy, Vol. IX.

GROUP 2. Wing, from 4.75 to 5.50 inches long.

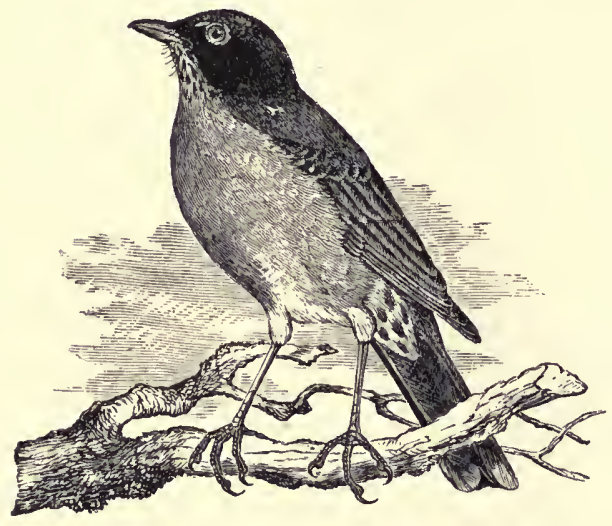

Upper plumage, grayish olive; throat, white, streaked with black; rest of under parts (except lower belly), pale chestnut rufous; young birds have the under parts spotted.

Planesticus migratorius

Robin. American Robin. See No. 364 . 


\section{THE BIRDS OF ILLINOIS AND WISCONSIN.}

\section{WATER BIRDS.}

\section{ORDER PYGOPODES.}

DIVING BIRDS.

Suborder COLYMBI.

\section{Family COLYMBIDÆ. Grebes.}

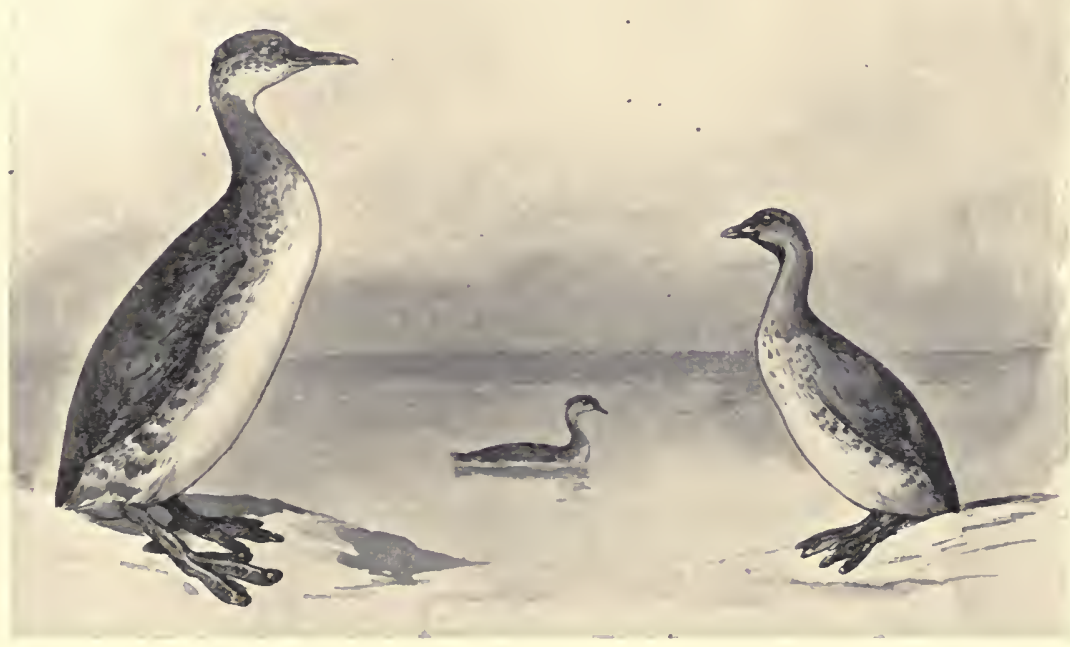

Holbœll's Grebe.

Pied-billed Grebe.

The Grebes comprise a small cosmopolitan family, numbering about 25 species. They are lobe-footed water birds and dive with great dexterity, often remaining under water for a considerable time with only the bill and a small portion of the head protruding above the surface. They feed principally upon small fish. Half a dozen species are found in North America, of which the following are accredited to Illinois and Wisconsin: 
276 Field Museum of Natural History-Zoölogy, Vol. IX.

\section{Genus ÆCHMOPHORUS Coues.}

\section{1. Æchmophorus occidentalis (LAWR.).}

Western Grebe.

Geographical distribution: Western North America, east to Mantoba and south to Mexico; accidental east of Nebraska.

Special characters, adult: Top of head and back of neck, sooty black; rest of upper plumage, slaty gray; forehead and lores, ashy white; primaries, dark chocolate, showing white at the bases; neck (except the back) and under parts, glossy white.

Length, 23 to 29 ; wing, 7 to 8.40 ; bill, 2.40 to 3 .

According to Kumlien and Hollister, this western species has been taken in Wisconsin. A specimen was killed on Lake Koshkonong, January 4,1878 , by L. Kumlien, and another in the same locality, October, г881. (Bull. Wis. Nat. Hist. Soc., r 903 , p. 5.) As far as we know it has not as yet been observed in Illinois.

\section{Genus COLYMBUS Linn.}

\section{Colymbus holbœllii (Reinh.).}

\section{Holbell's Grebe.}

Distr.: North America in general, breeding chiefly north of the United States.

Adult in summer: Top of head, small crest and back of neck, greenish black, or glossy black; throat and sides of the head, silvery white, or whitish ash; most of neck, rufous brown, shading into silvery white on the lower breast and belly; back, black, some of the feathers with grayish edgings; primaries, chocolate brown, the shafts, black.

Adult in winter: Above, blackish; crest, nearly or quite absent; front and sides of neck tinged with pale brown; throat, white; under parts, white. Immature birds have the upper parts dull black; the throat and under parts, silvery white, and the neck, grayish (not tinged with brown).

Length, I 8 to 20 ; wing, 7.35 to 8 ; bill, 1.75 to 2.30 .

Holbœll's Grebe is rare in Illinois and casual in Wisconsin during late fall and early spring, and a few remain in winter. Mr. E. W. Nelson gives it as a "rather uncommon winter resident upon Lake Michigan." (Birds N. E. Illinois, I876, p. I Iо.) Kumlien and Hollister say, "Holboell's Grebe is found sparingly in March and early April on most of the larger inland lakes and rivers, as well as on Lake Michigan, and again from September, but more often from October, 
until the ice forms. Where there is open water, both on Lake Michigan and in the interior, many remain all winter." (Birds of Wisconsin, I 903, p. 5 .)

\section{Colymbus auritus LinN. \\ Horned Grebe.}

Distr.: Northern Hemisphere, breeding from the northern United States northward.

Adult in summer: Bill, deeper than wide at base; top of head, back of neck and throat, greenish black; lores, pale chestnut brown;

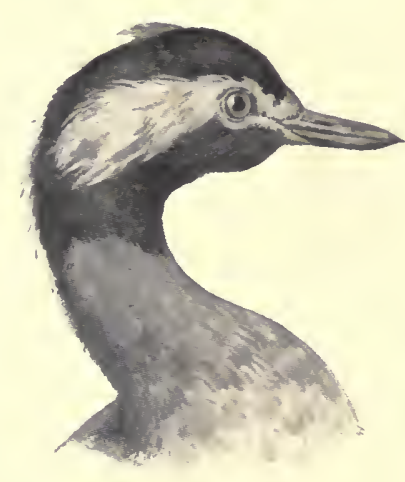

Colymbus auritus. (Breeding plumage.)

a tuft of ochraceous feathers on sides of head behind the eye; front of neck and breast, chestnut brown; sides of body. chestnut brown; belly, white.

Adult in winter, and immature: Upper parts, blackish or grayish black; under parts, silvery white, often tinged with gray on throat and breast; no developed tufts behind the eye.

Length, about I 4 inches ( 2.60 to I 5 ); wing, about 5.70 ; bill, about .90 .

The Horned Grebe is apparently not uncommon at times in Illinois and Wisconsin during the migrations, and a few remain to breed: It arrives from the south in April and breeds in May and Jure.

"Occurs commonly during the migrations - breeds sparingly in the small lakes." (Nelson, Birds N. E. Ill., r 876, p. r 50.) "Still fairly common as a spring and autumn migrant; not infrequently nests in the northern part of the state as it formerly did even in the southern tier of counties. Young, a few days old, were procured at Lake Koshkonong during June, I880." (Kumlien and Hollister, Birds of Wisconsin, 1903, p. 5.)

The nest of the Horned Grebe is a mass of weeds in shallow water, sometimes floating attached to reeds, and again placed on a nearly submerged tussock. The eggs are usually 4 to 7 , dull white, more or less stained with brown. They measure about r.75 x r.1 5 inches.

\section{Colymbus nigricollis californicus (HeERM.).} American Eared Grebe.

Distr.: Northern and western North America, from the Mississippi Valley west to the Pacific, south to Central America (Guatemala). 
278 Field Museum of Natural History-Zoölogy, Vol. IX.

Adult: Very similar to the preceding species in winter plumage (quite different in summer), but the peculiar shape of the bill will distinguish it. The upper mandible is much flattened at the nostril (the width at this point being greater than the depth), and nearly straight from nostril to tip (not decurved as in $C$. auritus); under mandible straight for about three-fourths of its length and then sharply ascending. Size nearly the same as $C$. auritus.

A western species, which is claimed to occur occasionally in Illinois and Wisconsin during the fall and winter. It resembles the Horned Grebe in winter plumage, but the shape of the bill will distinguish it. "Not uncommon in winter upon Lake Michigan." (Nelson, Birds N. E. Illinois, $x 876$, p. I 5 I.)

A. W. Butler states it has twice been taken in Indiana, and W. W. Cooke records it from St. Louis, Mo. Messrs. Kumlien and Hollister say, "Very rare in Wisconsin. We have received two spring specimens from near Iron River, Bayfield County, but have never personally come upon or taken one in Wisconsin. Mr. H. A. Winkenwerder, of Watertown, Wis., has sent us a wing of this species, which is said to have come from a bird shot at that place." (Birds of Wisconsin, r 903 , p. 6.)

Great care should be taken in identifying this species. Several specimens sent to me for examination, which were supposed to be the Eared Grebe, proved to be the Horned Grebe, C. auritus, which it closely resembles in winter plumage.

\section{Genus PODILYMBUS Lesson.}

\section{Podilymbus podiceps (Linn.).}

Pied-billed Grebe.

Distr.: North America in general, from British Provinces south to South America (Chili), including the West Indies and Bermuda; breeds nearly throughout its range.

Adult in summer: Throat, black; a blask band on the bill; no tufts on the sides of the head in any plumage; upper plumage, brownish black; front and sides of the neck and sides of the body tinged with brown; rest of under parts, silvery white.

Adult in winter: Throat, grayish white; no black band on the bill; sides of body, faintly washed with pale brown.

Length, variable, but about I3.50; wing, 4.50 to 5.10; bill, .75; depth of bill at nostril, about .40.

The Pied-billed Grebe is a common summer resident in both Illinois and Wisconsin, breeding in suitable localities throughout both 
states; nidification begins in May. The nest is in a pond, river, or slough, and is usually a mass of floating vegetation among reeds. The eggs are 4 to 8 in number, dull white, usually more or less stained and soiled, and measure about $1.75 \times 1.20$ inches.

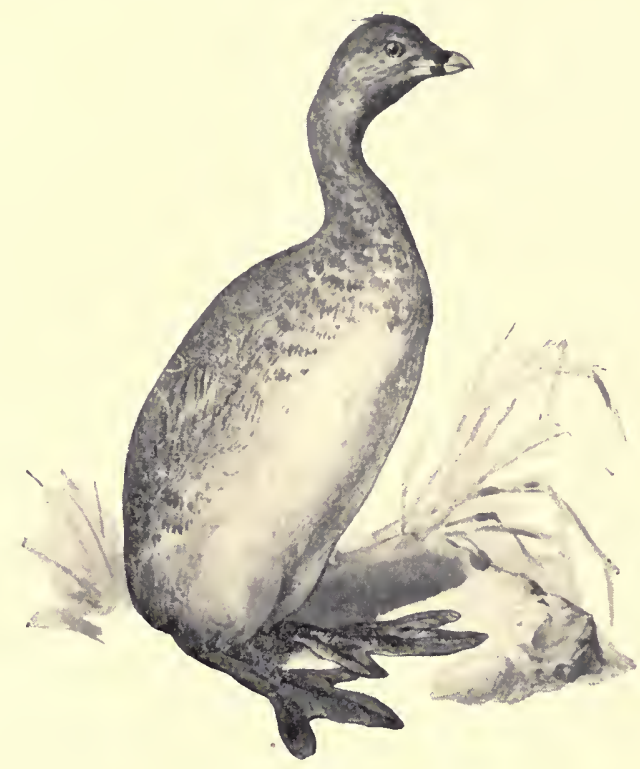

Pied-billed Grebe.

The Field Museum possesses a set of 5 eggs of this species taken in the vicinity of Calumet Lake, Chicago, June 4, I904.

\section{Suborder CEPPHI. Loons and Auks.}

\section{Family ALCIDÆ. Auks, Murres, etc.}

The Auks are confined to the northern hemisphere, many species being found in very high latitudes. They range along the northern coasts of both the Atlantic and Pacific oceans and occasionally wander to temperate regions, but never very far south, as they are "cold weather birds." They are gregarious, especially during the breeding season. One species, the Great Auk, was at one time common along the Atlantic coast from northern New England northward, but owing to its total inability to fly and the destruction of its eggs by fishermen and others, it was entirely exterminated during the last century. 
280 Field Museum of Natural History-Zoölogy, Vol. IX.

\section{Subfamily ÆTHIINÆ. Auklets, Guillemots, etc.}

\section{Genus SYNTHLIBORAMPHUS Brandt.}

\section{Synthliboramphus antiquus (GmeL.).}

\section{Ancient Murrelet.}

Adult in summer: Size, small; depth of bill, more than half its length; sides of neck and stripe on side of occiput and through the eye, white; rest of head, black; back, plumbeous, with lateral streaks of white; under parts, white.

Adult in winter: Head, dusky; back, plumbeous; throat and under parts, white.

Length, about ro inches; wing, 5.40; bill, .65.

Mr. Geo. B. Sennett states that he examined an adult mounted specimen of this species at "Koshkonong Place," which was killed late in October, 1882 , on Lake Koshkonong, Wisconsin, by Rev. G. E. Gordon (Auk, I 884, p. 98 ). The occurrence of a bird of this species in Wisconsin is, of course, most extraordinary. Its true habitat is the North Pacific ocean, from Vancouver Island northward.

\section{Subfamily ALLINÆ. Dovekies.}

Genus ALLE Link.

6-I. Alle alle (Linn.).

Dovekie. Little Auk.

Distr.: Coasts of north Atlantic and eastern Arctic oceans; casual in winter on the Atlantic coast as far south as New Jersey; accidental in Michigan and Wisconsin.

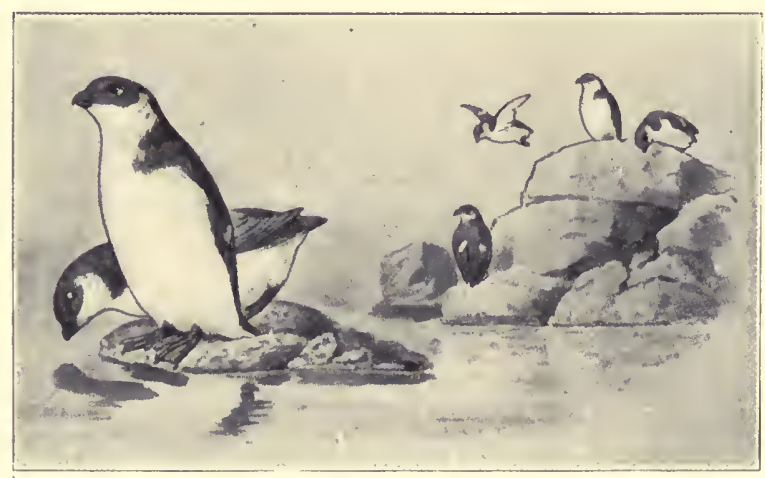

Dovekies 
Winter plumage, adult: Upper parts, black or blackish; under parts, white; smaller than the preceding species.

Length, about 8 ; wing, about 4.50 ; bill, .50 .

Prof. Henry L. Ward records the capture of a single specimen of this northern maritime species near Port Washington, Wisconsin, some twenty-five miles north of Milwaukee. It was shot by a boy, January II, I908, on Lake Michigan. The specimen is preserved in the Milwaukee Public Museum. (The Auk, Vol. XXV, I908, p. 2 I5.)

It has also been taken in Michigan, a bird of this species having been killed on the Detroit River, November 30, 1881. (O. and O., Vol. VII, p. iri.)

Brünnich's Murre, Uria lomvia (Limn.). During the winter of I 896-97, a number of Brünnich's Murres were taken in different parts of Indiana, Michigan (Detroit), Ohio, and Iowa. At least ten were recorded from Indiana (one of them from Newton County), although so far as we know none were actually taken in Illinois. As the birds were all observed about the same time, it would seem likely

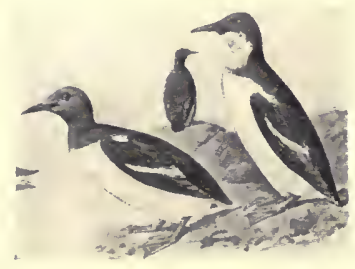

Murres. that they were driven from their usual habitat by stress of weather. It is probable that these birds arrived by way of Lake Erie, but in this connection a statement by Messrs. Kumlien and Hollister is of interest. They say, "We are confident that some species of Guillemot occur on Lake Superior in winter and possibly also on Lake Michigan. There is no positive evidence of a specimen ever having been taken in Wisconsin waters, however." (Birds of Wiscon$\sin , \mathrm{I} 903$, p. I 29. ) Those desiring further information are referred to the following papers: A. W. Butler, Birds of Indiana, 1897, p. 564 ; Ib., The Auk, Vol. XIV, I897, p. I97; F. M. Woodruff, The Auk, 1897, p. 228; Anderson, Birds of Iowa, 1907, p. I 52.

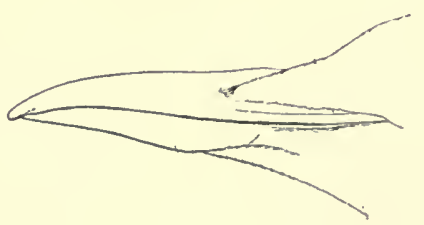

Bill of Murre. 
282 Field Museum of Natural History-Zoölogy, Vol. IX.

\section{Family GAVIIDÆ. Loons.}

The Loons are a small family, consisting of one genus and five species, three of which occur on Lake Michigan. They feed principally upon fish and are expert divers and swimmers, rarely leaving water, except during the nesting season.

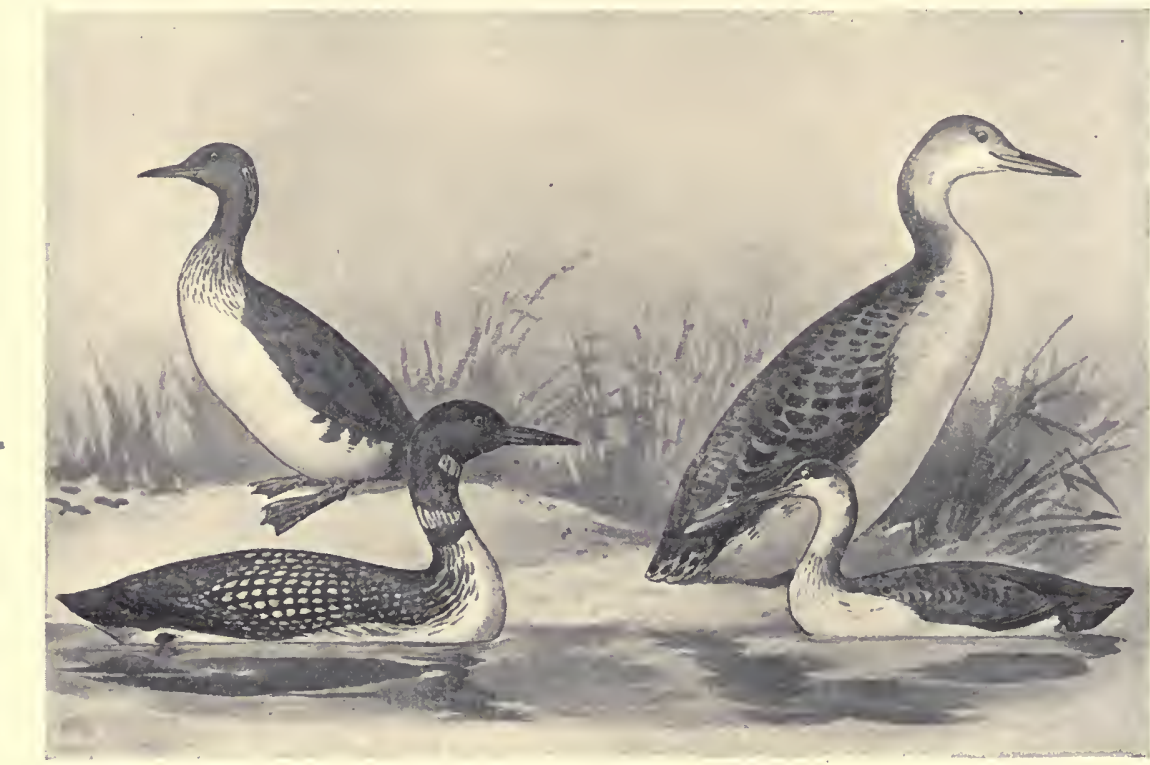

Summer

Loons.

Winter.

\section{Genus GAVIA Forster.}

7. Gavia immer (BRÜNN.).

LoON.

Urinator imber (Gunn.), A. O. U. Check List, r895, p. 3.

Distr.: Ranges throughout the northern part of the northern hemisphere, breeding from the northern United States northward; south in winter to the Gulf of Mexico and Lower California.

Adult in summer: Head and neck, black, showing green in some lights; a patch of white, streaked with black, on the throat and sides of the neck; under parts, white; back, streaked and spotted with white. Adult in winter, and immature: Head, grayish; throat, white or 
Jan., I 909. Birds of Illinois and Wisconsin-Cory.

grayish white; back and wings, blackish, the feathers often with grayish edgings but not spotted or streaked with white.

Its large size will distinguish this species.

Length, about 3 I ; wing, I 3 to I 5 ; bill, 2.80 to 3.40 ; tarsus, about $3 \cdot 35$.

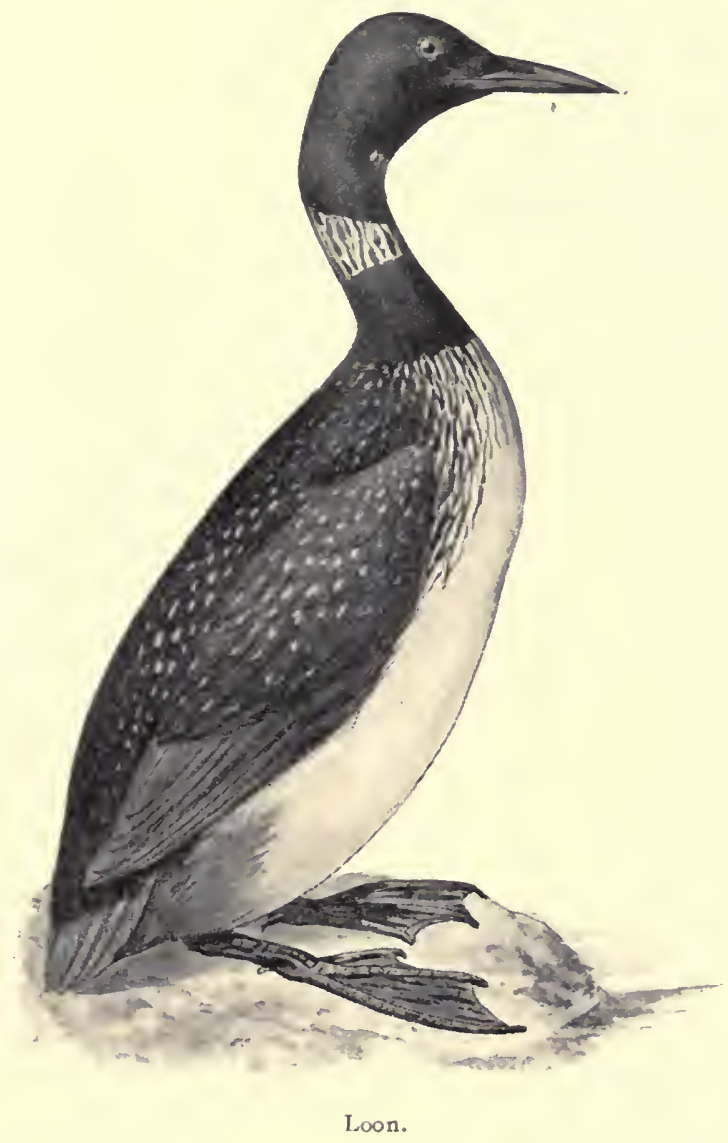

The Loon is a summer resident, and breeds in northern Illinois and Wisconsin. It arrives early in spring and leaves late in the fall; although a few remain on Lake Michigan all winter. It has a peculiar loud, resonant cry, and the "laugh" of the Loon is a familiar sound on pond and lake. It breeds in May and June. The eggs are usually 2, pale olive brown, marked with irregular spots of black. They are deposited on the ground near water, sometimes on a mat of leaves or grass, but usually with little or no attempt at a nest. The eggs measure $3.50 \times 2.25$ inches. 
284 Field Museum of Natural History-Zoölogy, Vol. IX.

\section{Gavia arctica (LINN.).}

Black-throated Loon.

Urinator arcticus (Linn.), A. O. U. Check List, I895, p.4.

Distr.: Northern part of the northern hemisphere; south in winter to the northern United States, east of the Rocky mountains.

Adult in summer: Top of head and nape, gray; throat, black; upper plumage, black, glossed with purplish reflections; sides of neck with longitudinal white streaks; rest of under parts, white.

Adult in winter, and immature: Upper parts, blackish, many feathers with grayish edgings; throat and under parts, white.

Length, about 27 ; wing, I I.50 to I 3.I 5 ; bill, 2.55 to 2.80 ; depth of bill at base, about .78.

The Black-throated Loon is a boreal species which occasionally, but rarely, occurs on Lake Michigan in late fall and winter.

"A very rare winter visitant on Lake Michigan." (Nelson, Birds N. E. Illinois, $\mathrm{I}_{776}$, p. I $\mathrm{I}_{5}$.) "This is certainly a very rare bird in Wisconsin, occurring only as a straggler in late fall or winter. We have access to but three unquestionable records." (Kumlien and Hollister, Birds of Wisconsin, I903, p. 7.) "Exceedingly rare; Lake Michigan; winter." (A. J. Cook, Birds of Michigan, I893, p. 30.)

9. Gavia stellata (PontopPidan).

RED-THROATED LOON.

Urinator lumme (Gunn.), A. O. U. Check List, I 895, p. 4.

Distr.: Northern North America, breeding north of the United States, south in winter occasionally as far as the Gulf of Mexico.

Adult in summer: Back, fuscous, spotted with white; throat and fore neck, plumbeous gray; middle of fore neck with a patch of rich chestnut; back of neck, black, streaked with white; rest of neck and head, plumbeous gray; breast and belly, white.

Adult in winter, and immature: Similar to the winter plumage of the Black-throated Loon, but the back is spotted with white; fore neck and throat, white or grayish white, without chestnut.

Length, 25 ; wing, I0.50 to II.50; bill, 2.30; tarsus, 2.75

While this species varies greatly in size, and size and shape of the bill, it is never as large as G. immer, and may be distinguished from $G$. arctica in the adult by the chestnut red throat and in the immature birds by the white spotting of the upper parts. These spots are most numerous in the upper back and wing coverts and less numerous but larger on the scapulars and tertials. On the middle of the back they are comparatively few and scattered, sometimes almost wanting. 
The Red-throated Loon is not uncommon on Lake Michigan during the late fall and winter. "Very common winter resident on Lake Michigan." (Nelson, Birds N. E. Illinois.) "Not uncommon during winter." (Hoy, Wisconsin.) "A regular and common resident of Lake Michigan in winter." (Kumlien and Hollister, Birds of Wisconsin.) "Dispersed in winter irregularly over the northern half of the Mississippi valley." (W. W. Cooke.) "A rare winter resident." (Butler, Indiana.) "Rather common." (A. J. Cook, Michigan.) Mr. H. K. Coale procured a specimen near Chicago in February, I 885.

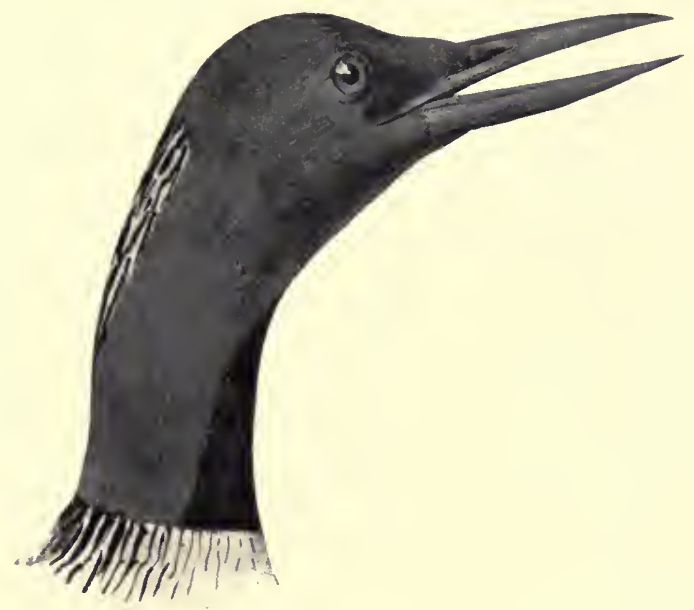

Red-throated Loon.

The patch on the throat is rich chestnut, not black as might be suggested by the illustration. 


\section{ORDER LONGIPENNES.}

LONG.WINGED SWIM.MERS.

\section{Family STERCORARIID瓜. Skuas and Jægers.}

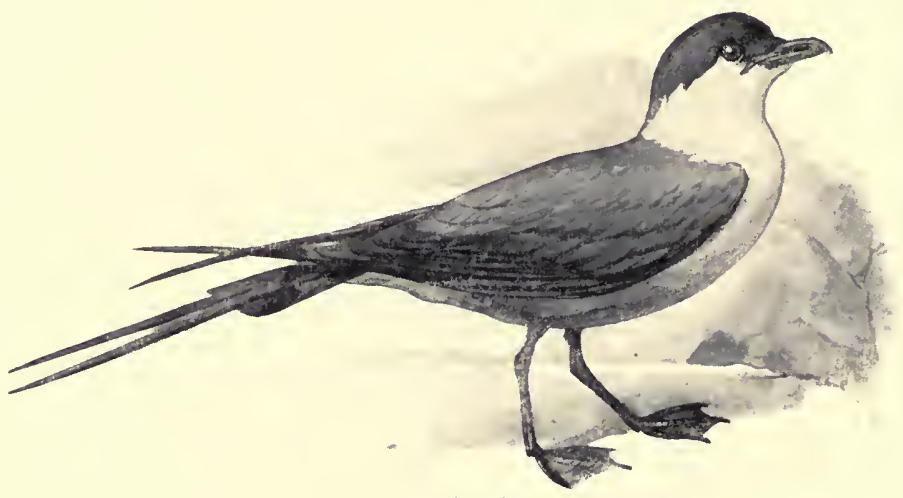

Jæger (adult).

(Immature birds lack the long middle tail feathers.)

The Jægers are pelagic species, although they occasionally occur on the Great Inland Lakes. They feed principally upon fish, much of which they obtain by chasing and robbing the gulls and terns of their prey. Six species are recognized, four of which occur in the northern hemisphere and two in the southern.

\section{Genus STERCORARIUS Brisson.}

\section{Stercorarius pomarinus (ТЕмм.). Pomarine Jeger.}

Distr.: Seas and inland waters of northern part of northern hemisphere; south in winter to Africa and Australia. Its winter range in America is uncertain.

Adult (light phase of plumage): Bill, over 1.35, tarsus, over I.75, upper parts, slaty gray, a tinge of pale yellow on the sides of the head and neck; crown of the head and lores, sooty black; under parts, white, shading into slaty gray on sides and lower belly; ends of two middle tail feathers, rounded.

Adult (dark phase): General plumage, sooty brown, slightly paler below; crown, dark brown.

Immature (light phase): Head and neck streaked with buff or gray; under parts mottled and barred with slaty gray; upper parts, dark gray; some of the feathers edged with buff. 
Immature (dark phase): General color, slaty brown; neck marked with white; feathers on the belly barred with dull white. The two middle tail feathers are rounded at tip, and project more or less beyond the others and the tarsus is black in freshly killed specimens.

Length, 20 to 22 ; wing, 13.25 to 14 ; bill, 1.40 to 1.65 ; tarsus, I. 40 to 1.50 .

The records for Illinois are not very satisfactory and at most it is a rare straggler on Lake Michigan. Nelson saw one near Chicago in 1876 , and was told of another having been seen. (Bull. Essex Inst., Vol. VIII, p. 145, 1877.) For Wisconsin, Kumlien and Hollister state that three were seen on Green Bay in October, 1879, and L. Kumlien secured one on Lake Koshkonong about the same time.

\section{Stercorarius longicaudus Vieill.}

LONG-TAILED JÆGER.

Distr.: Northern part of northern hemisphere, breeding in high latitudes; south to Gulf of Mexico in winter.

Adult: Bill, less than I.35; cere (the hard skin-like covering on base of upper mandible), shorter than the distance from its anterior end to. tip of bill; tarsus, blue in freshly killed specimens; feet, black; above slaty gray; top of head and lores, dull black; sides of the head and neck, pale yellow; under parts, dark slate color; chest and upper belly, whitish; middle tail feathers pointed.

Immature: Resembles the preceding species in color; but differs in. length of bill and having the middle tail feathers pointed.

Length, I 9 to 23; wing, I2.50; tail (adult), I2.50, (immature), 6; tarsus, 1.65; bill, r.10.

Long-tailed Jæger has but a slight claim to be included in the avifauna of Illinois and Wisconsin, although the occurrence of occasional stragglers of this species on Lake Michigan is not unlikely. A specimen identified as the Long-tailed Jæger was picked up dead on the shore of the Mississippi River near Cairo, Ill., by Mr. W. H. Ballou, in November, 1876 . It was badly decomposed and after being examined by Mr. Ballou and another gentleman, was thrown away. (Ridgway, Orn. of Ill., Vol. II, p. 2I8.) This seems to be the only record for either Illinois or Wisconsin, but Mr. Rudolph M. Anderson records a specimen captured near Lone Tree, Johnson County, Iowa, in June, I907. (The Auk, Vol. XXV, 1908, p. 215.)

Parasitic Jæger, Stercorarius parasiticus (Linn.). While there is no actual record of the occurrence of this species within our limits, according to Prof. Ridgway, it is of "occasional occurrence on Lake 
Michigan during winter." (Ornithology of Illinois, I895, p. 2 I7.) A bird of this species was shot on the Mississippi River near Keokuk, Iowa, October 6, I896; and the specimen is preserved in the collection of Mr. William G. Praeger. (Anderson, Birds of Iowa, I 9o8, p. I 53.)

The Parasitic Jæger may be distinguished from the Pomarine Jæger by its shorter bill (less than 1.35) and having the middle tail feathers pointed, not rounded at the ends as in S.pomarinus, and from the Long-tailed Jæger by having the cere longer than the distance from its end to tip of bill.

Skua, Megalestris skua (Brïn.). Mr. Ridgway included this species in his Ornithology of Illinois ( 1895, p. 2 I 2 ), but I find no record of its occurrence in Illinois. It is a north Atlantic species, which is rare on the Atlantic coast of North America.

\section{Family LARIDÆ. Gulls and Terns.}

The Gulls and Terns are a cosmopolitan family, numbering about seventy species. They are true water birds, being rarely found away from its vicinity. Many species occur both along the coasts and on the lakes of the interior. They usually breed in colonies, making their nests upon the ground or on ledges of rocks and cliffs (rarely in trees). They feed principally upon fish, but at times some species eat the young and eggs of other birds, and occasionally small mammals. The Gulls are in most cases larger than the Terns and much less graceful.

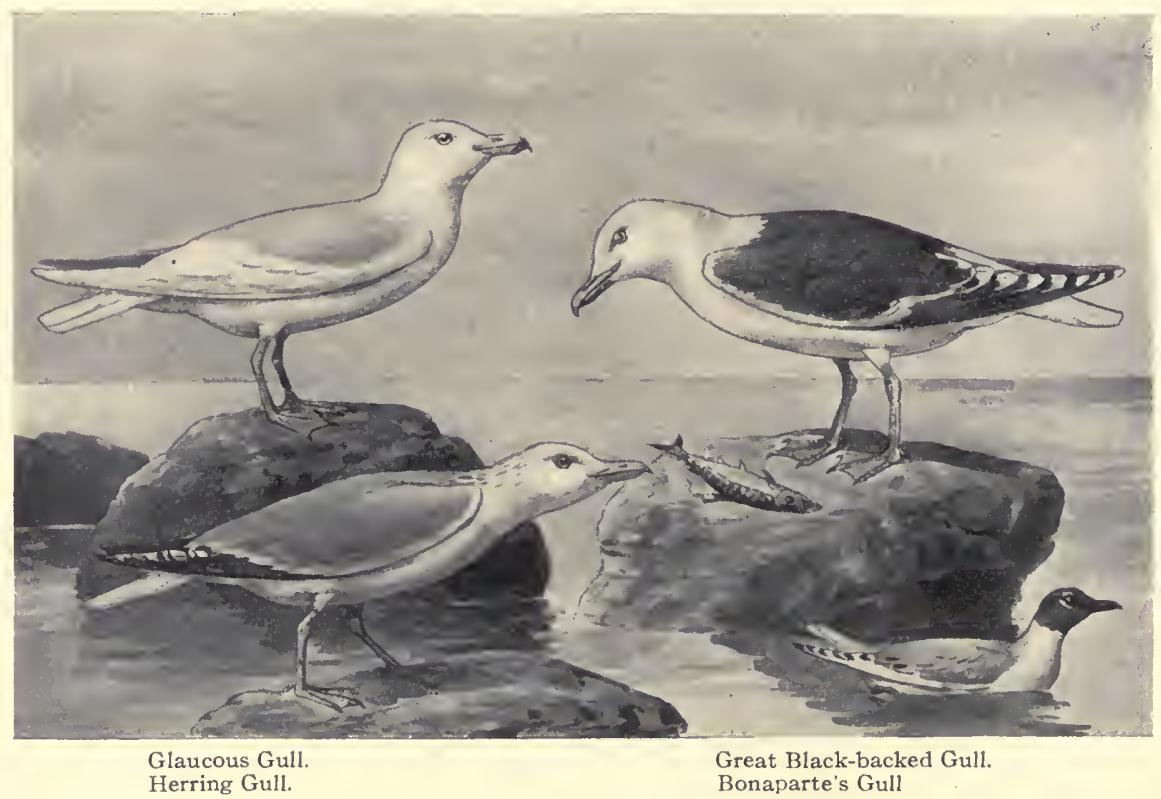




\section{Subfamily LARINÆ. Gulls.}

Genus RISSA Stephens.

12. Rissa tridactyla (LinN.).

KitTiwake Gull.

Distr.: Arctic regions, south in winter to the middle states, accidental on Lake Michigan.

Adult in summer: Hind toe, very small, without nail; head, neck, and tail, white, rest of upper plumage, pearl gray; under parts, white; outer web of first primary, black; second and third primaries, tipped with black; ends of third, fourth, and fifth, black, tipped with white.

Adult in winter: Differs in having the crown and nape pearl gray, and a sooty plumbeous mark on side of the head in front of and behind the eye.

Immature birds somewhat resemble the winter plumage of the adult, but differ in having a patch of dusky or black on the lower part of the back of the neck, more or less black on the lesser wing coverts, and a broad black band at the tip of the tail.

The rudimentary hind toe will distinguish this species.

Length, about I $6.5^{\circ}$; wing, about I 2.20 ; bill, about I.45; tarsus, I.32.

The Kittiwake Gull must be considered a rare straggler on Lake Michigan. Mr. J. Grafton Parker informs me that he has a specimen in his collection, which he killed near Meredosia, Morgan Co., Illinois, on November 25, I898. Mr. Frank M. Woodruff writes, "An adult male of this species was taken by Mr. Christopher Wagner, who was shooting from a boat on Lake Michigan near what is known as Jackknife Bridge in Lincoln Park. The bird was purchased for the collection of the Chicago Academy of Sciences by Mr. Chas. M. Higginson." (The Auk, 1897, p. 228.) Nelson (in his Birds of Northeastern Illinois, I876, p. 46) states, "A rare winter visitant to Lake Michigan. Dr. Hoy writes that in the winter of 1870 a single specimen of this species kept about the harbor for several days, but was too shy to be shot. $\mathrm{He}$ is quite certain of his identification, as he examined the bird carefully with a large field glass while it was standing upon a piece of ice just out of gun shot." Mr. W. W. Cooke says, "A northern species coming south in winter to the Great Lakes. It has been noted from Minnesota (Hatch) and Illinois (Nelson) and March 17 , 
290 Field Museum of Natural History-Zoölogy, Vol. IX.

I 884 , one was seen by Dr. P. R. Hoy, at Racine, Wisconsin." (Bird Migr. Miss. Valley, I 888 , p. 55.)

\section{Genus LARUS Linn.}

\section{Larus hyperboreus GunN.}

Glaucous Gull.

Larus glaucus Brünn., A. O. U. Check List, r895, p. I6.

Distr.: Arctic regions, south in winter to New England, New York, and the Great Lakes.

Adult in summer: General plumage, except back and wings, white; back, pale pearl gray; wings, pearl gray; primaries, pearl gray, shading into white on the edges of the inner webs and at the tips.

Adult in winter: Similar, but having the head and neck streaked with pale gray.

Immature birds have the upper plumage pale gray or whitish, heavily marked and barred with pale brown and gray; under parts ash gray or grayish white, often marked with buff.

Length, about 27 to 32 ; wing, I 7 to 18.70 ; bill, about 2.50 .

The Glaucous Gull is a rare winter visitant on Lake Michigan. Both this and the Iceland Gull have the primaries white, pearl white, or pale ash color, never marked with dark brown or black.

"A rather rare winter visitant to Lake Michigan." (Nelson.) "Occasionally visits Lake Michigan in winter." (Ridgway.) Mr. Frank M. Woodruff states that he killed a bird of this species on Lake Michigan near Millers, Indiana, on August 8, I 897, describing it as "in the pure white plumage of the young of the second year." (The Auk, Vol., XV, I898, p. 6r.) "In the Milwaukee Public Museum are three specimens procured at Milwaukee, January 8, I2, and I4, I895." (Kumlien and Hollister, Birds of Wisconsin, r 903, p. 9.)

\section{Larus leucopterus FABER.}

\section{ICELANd Gull.}

Distr.: Arctic regions, south in winter to New England and the Great Lakes, and occasionally further south.

Adult: Similar to Glaucous Gull, but smaller.

Length, 24 to 26 ; wing, I 5 to 16.60 ; bill, I.60 to I.75.

Apparently a rare winter visitant to Lake Michigan.

"Rare." (A. J. Cook, Birds of Michigan.) "An occasional winter 
visitor to the northern part of the state." (A. W. Butler, Birds of Indiana, 1897, p. 57 I.) "A regular and not uncommon winter resident on Lake Michigan." (Nelson, Birds N. E. Ill., I 876, p. I45.) "A regular winter visitant on Lake Michigan, but by no means common, although occurring more frequently than glaucus." (Kumlien and Hollister, Birds of Wisconsin, r 903, p. 9.)

\section{Larus marinus LisN. \\ Great Black-Backed Gull.}

Distr.: North Atlantic ocean, south in winter to the middle states and the Great Lakes, and occasionally much further south (accidental in Florida ).

Adult in summer: Whole back, dark slate color; outer primaries, black (slaty black when held in the light), tipped with white; head, tail, and under parts, white; bill, chrome yellow, with red spot on lower mandible.

Adult in winter: Similar, but with head and neck streaked with pale brownish gray.

Immature: General plumage mottled and streaked with gray and pale brown, many feathers with pale edges; primaries, brownish black, the inner ones narrowly tipped with white; bill, blackish.

Length, 28 to 3 1.50; wing, 17.50 to 19.50 ; bill, 2.42 to 2.55 ; greatest depth of bill, .92 to 1.05 .

Although apparently not very common, this species occurs on Lake Michigan in the late fall and winter. "Not an uncommon winter resident upon Lake Michigan. The immature young are greatly in excess of the adult." (Nelson, Birds N. E. Ill., 1876, p. 145.) "We have seen this well marked species on Lake Michigan at the Milwaukee Light House, midwinter, I880-8I, and on at least two occasions, out on the Lake. It is, however, rare." (Kumlien and Hollister, Birds of Wisconsin, I903, p. 9.)

\section{Larus argentatus Poxtoppidax.}

Herrixg Gull.

Larus argentatus Brünn., A. O. U. Check List, I 895 , p. I 8.

Distr.: Nearly the whole of North America, south to Cuba in winter; breeds from the latitude of Maine and Wisconsin northward.

Adult in summer: Back, pale bluish gray, or pearl gray; primaries, brownish black, more or less marked with white; rest of plumage, white; bill, yellow, a red spot on lower mandible at the angle. 
292 Field Museum of Natural History-Zoölogy, Vol. IX.

Adult in winter: Similar, but with head and neck streaked and spotted with brownish gray; tail feathers marked with more or less dusky; bill, yellowish.

Immature: Bill, dull flesh color, the terminal third, black; general plumage mottled and streaked with gray and pale brown, the feathers on the back margined with gray; primaries, dark brown.

Length, 22 to 25.50 ; wing, $x 6.20$ to I7.50; bill, I.90 to 2.50 ; greatest depth of bill, .70 to .85 .

The Herring Gull is common on Lake Michigan in winter and during the migrations and is often seen on the Lake near Chicago. It breeds in Wisconsin.

"Very abundant winter resident upon Lake Michigan and occurs throughout the state." (Nelson.) "As a rule it is found in winter throughout Illinois and thence southward to the Gulf of Mexico." (W. W. Cooke.) "Very common on Lake Michigan at almost all seasons and a common migrant on all suitable waters of the state of Wisconsin. Nests commonly on different islands of Green Bay and on the north shore of Lake Michigan." (Kumlien and Hollister, Birds of Wisconsin, I903, p. 9.)

It breeds in May or early in June. The nest is composed of grass and moss on the ground or rocks (very rarely in trees). The eggs are from 2 to 3 , pale olive brown, blotched and lined with chocolate brown, and measure about $2.80 \times 1.90$ inches.

\section{Larus delawarensis ORD. Ring-Billed Gull.}

Distr.: Nearly the whole of North America, south in winter to Mexico and Cuba.

Adult in summer: Back and wing coverts, pearl gray; terminal portion of inner primaries, black, tipped with white; terminal portion of first primary, black, with large white spot near the tip; head, tail, and under parts, white; bill, greenish yellow, with a black band.

Adult in winter: Similar, but having the head and neck streaked with gray; black band on the bill much less distinct.

Immature: General plumage, whitish, more or less mottled and streaked with gray and brownish gray; tail feathers marked with more or less brownish black, forming a broad, irregular black band with narrow white tips; primaries, blackish, only the inner ones tipped with white; bill with basal portion, brownish yellow and the entire end from the nostril, black. 


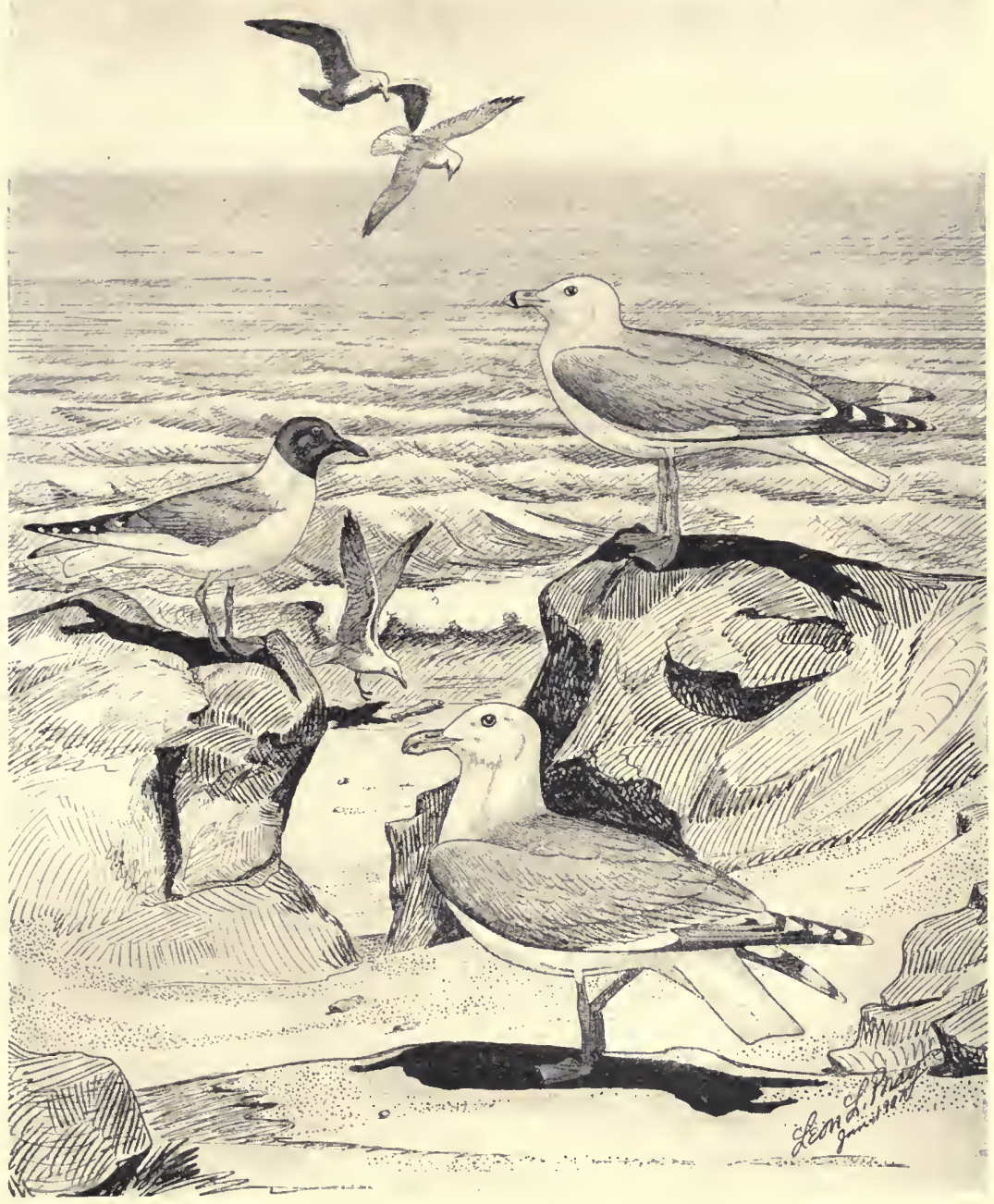

Bonaparte's Gull.

Herring Gull.

Ring-billed Gull.

Length, I8.10 to 20.25 ; wing, I 3.50 to I 5.75 ; bill, I.5O to I.70; greatest depth of bill, $.5^{2}$ to .68 .

The Ring-billed Gull is a common species in Illinois and Wisconsin during the migrations and occasionally a few remain on Lake Michigan all winter. A few pairs occasionally breed in Wisconsin, but the great majority of them go much farther north. 
294 Field Museum of Natural History-Zoölogy, Vol. IX.

"Common migrant along the Lake, very rarely remains through winter." (Nelson, Birds N. E. I11., I876, p. I46.) A common migrant, spring and fall. Formerly bred on Spider and Strawberry Islands, Green Bay, from which localities we have eggs." (Kumlien and Hollister, Birds of Wisconsin, I903, p. Io.)

\section{Larus atricilla LiNN.}

\section{LAUGHING GULL.}

Distr.: Atlantic and Gulf coasts of United States, occasionally north to Maine and even Nova Scotia; south in winter to West Indies, Mexico, Central America, and northern South America.

Adult in summer: Bill, dark red; head and throat, dusky black; a white spot on each eyelid; outer primaries, brownish black; back, slaty gray; under parts, white; tail, white.

Adult in winter: Similar, but has the head and throat white, and at times the crown and back of the neck streaked with gray.

Immature: Bill, blackish; upper plumage and most of head and neck, gray, mixed with pale buff; forehead, whitish; tail feathers, gray, with broad, subterminal band of dark brown, and narrowly tipped with white.

The color and markings of the primaries and larger size will distinguish this species from Franklin's Gull.

Length, I 4.75 to I7; wing, I2.IO to I3.I 5 ; bill, I.45 to I.75.

While rarely found in the interior, the Laughing Gull has been given a place in the avifauna of both Illinois and $\mathrm{W}$ isconsin. If it occurs at all it must be considered an accidental straggler within our limits. When not actually taken, its resemblance to Franklin's Gull might lead to error in identification.

"Very abundant on the Great Lakes." (Dr. Morris Gibbs, List of Birds of Michigan, Bull. U. S. G. and G. Survey, No. 3, 1879.) This is undoubtedly an error. "Summer visitant." (Ridgway, An. N. Y. Lyceum Nat. Hist., I874, p. 39I.) "Probably only an irregular or casual visitor to the Mississippi Valley." (Ridgway, Orn. of Illinois, Vol. II, I895, p. 234.) "A few pass up the Mississippi during the summer as far as southern Illinois." (Cooke.) "The only known Wisconsin record for this species is that of Thure Kumlien, who shot a single specimen on Lake Koshkonong in July, I860." (Kumlien and Hollister, Birds of Wisconsin, I803, p. го.) 


\section{Larus franklinii Sw. \& Rich.}

Franklin's Gull.

Distr.: Interior of North America, chiefly west of the Mississippi River; breeding from Manitoba, western Minnesota, and Dakota northward; south in winter to Central and South America to Peru. Rare on the Atlantic coast. This species occurs on Lake Michigan and in the interior during the migrations.

Adult in summer: Bill, red; head and upper throat, plumbeous black; a white spot on each eyelid; under parts, white, usually tinged with rose color; back and wings, pearl gray; tail, white; first primary, pale grayish white, almost white; the outer web, black, except near the tip; a patch of black on the inner web about an inch and a half from the tip; the second, third, fourth, and fifth primaries with white tips and a subterminal band of black.

Adult in winter: General plumage and markings similar, but has the head and neck white marked with more or less dusky gray on the top and sides of the head; bill, blackish.

Immature: Bill, dark brown or blackish; under parts, white; crown and sides of head, dusky; the gray of back and wings mixed with pale brown; primaries, grayish dusky, darkest on outer webs; all primaries tipped with white, but at times so narrowly on the first and second as to be hardly noticeable.

Length, I3.40 to I 4.75 ; wing, ro.80 to Ir.30; bill, r.I5 to 1.25 .

Franklin's Gull must be considered a rare bird in Illinois. Mr. Chas. K. Worthen, of Warsaw, Illinois, writes, "There is a beautiful adult male of this species mounted in the State Museum at Springfield, which I took in May, I875. It was flying over a pond in the Mississippi bottom three miles below here." (Ridgway, Bull. Nutt. Orn. Club, I880, p. 32.) “A rare visitant to Lake Michigan." (Nelson, Birds N. E. Ill., I 876 , p. 1 46.) "Not common but of regular occurrence in the eastern part of the state as a fall migrant. * * * On Lake Michigan it is less common than anywhere in the interior. * * * It seems remarkable that so few spring specimens are obtained in eastern Wisconsin." (Kumlien and Hollister, Birds of Wisconsin, I903, p. Iо.)

This species should be looked for along the Mississippi River, as it is a not uncommon summer resident and breeds in Minnesota. 
296 Field Museum of Natural History-Zoölogy, Vol. IX.

20. Larus philadelphia (ORD).

Bonaparte's Gull.

Distr.: North America, breeding chiefly north of the United States; south in winter to the Gulf coast.

Adult in summer: Bill, black; whole head, including throat, dark sooty plumbeous; a white spot on the eyelids; back, pearl gray,

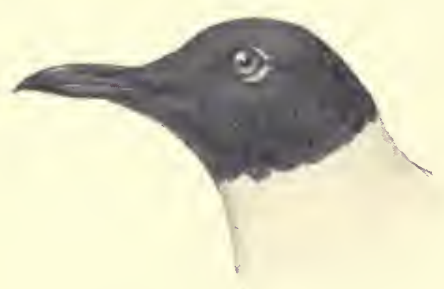

Bonaparte's Gull. Summer. Bonaparte's Gull loses the black head in winter. shading into white at the base of the neck; under parts, white; feet, orange red; tail, white; first primary, white, with outer web and tip, black; second primary, white, tipped with black; rest of primaries with subterminal band of black tipped with white.

Adult in winter: Similar, but having the head and throat white, and the crown and sides of the head showing more or less gray.

Immature: Upper plumage mixed with more or less gray and pale brown; under parts, white; tail with black band narrowly tipped with white.

Length I2.IO to I 4 ; wing, about I0.25; bill, about I.I5.

This species is abundant at times on Lake Michigan and in the interior during the migrations in spring and fall. The majority arrive from the south early in April.

"Exceedingly abundant migrant. * * * In very mild winters a few remain during the season." (Nelson.) "A transient migrant in Illinois, occasionally wintering in the southern part of the state." Ridgway.) "Winters along the Gulf of Mexico and southward and sometimes in Illinois." (Cooke.) "The systematic slaughter of this beautiful gull for millinery purposes has so reduced its numbers that we can no longer claim it as our most abundant species." (Kumlien and Hollister, Birds of Wisconsin, I903, p. I I.)

\section{Genus XEMA Leach.}

\section{2l. Xema sabinii ( $\mathrm{S}_{\mathrm{AB}}$.). \\ Sabine's Gull.}

Distr.: Arctic regions, south in winter occasionally to New York, the Great Lakes, and Great Salt Lake. Stragglers have been taken in Kansas, Iowa*, Bahama Islands, and Peru, S. A.

* Dr. Paul Bartsch records two immature specimens taken near Burlington, Iowa. (The Auk, Vol. xvi, r899, p. 86.) 
Adult in summer: Bill, shorter than tarsus; tail, somewhat forked; legs and feet, black; head and upper neck, plumbeous, bordered

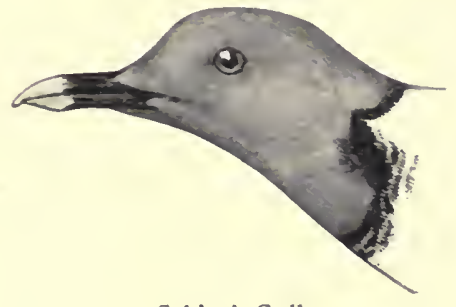

Sabine's Gull. around the neck by a black collar; outer primaries, black; rest of plumage, white; bill, black, tipped with dull yellow; inner web of first primary, about half white; shaft of feathers, dark brown on upper surface.

Adult in winter: Similar, but having the head and neck white; marked on back of head, neck, and ear coverts with dusky.

Length, I 2.75 to I 4 ; wing, Io to Ir.20; bill, about I; tarsus, I.20.

Sabine's Gull is an Arctic species, accidental or very rare on Lake Michigan. Mr. E. W. Nelson states, "Exceedingly rare visitant to Lake Michigan. While collecting on the lake shore near Chicago the first of April, I873, I saw a specimen of this bird in a small pool of water on the beach. At first I supposed it was a Bonaparte Gull and was about passing it when it arose and as it passed towards the Lake I saw it was something new to me and fired. It flew a few rods and fell into the Lake about 30 yards from shore. It was in perfect breeding dress, as was shown by the black markings of the head each time it was raised while struggling in the water. A gale from off shore soon drifted it from sight." (Birds N. E. Ill., I876, p. I47.) According to Kumlien and Hollister: "A young male was shot on Delavan Lake, Walworth Co., October 7 , 1900, by Mr. H. P. Hare, and is now preserved in the collection of $\mathrm{N}$. Hollister. This is probably the only authenticated Wisconsin specimen extant. * * * * In April, 1897 , we examined and identified two fresh wings of this species brought by a taxidermist in Janesville to be prepared for a hat. The bird was killed on Rock River near that city." (Birds of Wis., I 903 , p. I 2.)

\section{Subfamily STERNIN庄. Terns.}

The Terns have the upper mandible nearly straight, not hooked or rounded at the tip as in the Gulls. The outer tail feathers are usually decidedly longer than the middle ones. With few exceptions the North American Terns are smaller than the Gulls. 
298 Field Museum of Natural History - Zoölogy, Vol. IX.

\section{Genus GELOCHELIDON Brehm.}

22. Gelochelidon nilotica (HASSELQ.).

Gull-billed Tern.

Distr.: Nearly cosmopolitan; occurs in North America chiefly along Gulf of Mexico and Atlantic coast as far north as New Jersey (accidental in Massachusetts); winters from the West Indies and Mexico south to Brazil.

Adult in summer: Top of head and nape, black; upper part, including rump and tail, pearl gray; under parts, white; bill and feet, black, the former comparatively short

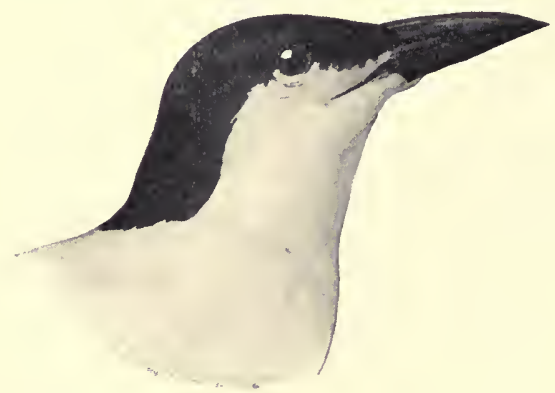
and stout.

Adult in winter: Similar, but having the head and neck white, the nape, ashy, and a dusky patch in front of the eye.

Length, I 4; wing, I 2; tail, 5.50; bill, r.40; tarsus, r.30.

It is far easier to establish a record than it is to reject one, because we must assume that an author who makes the statement that a bird occurs in a certain locality must have a satisfactory reason for so doing. It is not given on hearsay evidence, but is a plain statement of fact, or must be accepted as such until we have good reason to doubt it. Therefore, although I have never seen a specimen of this Tern taken either in Illinois or Wisconsin, and can find no record of its actual capture in either state, I include it upon the authority of the following published statements.

"An exceedingly rare visitant during summer." (Nelson, Birds N. E. I11., r876, p. r47.) "Rare summer visitor." (Ridgway, Cat. Birds Illinois, I88ז, p. 202.) "Rather common." (A. J. Cook, Birds Michigan, 1893 , p. 34.) Also included in Prof. Ridgway's Ornithology of Illinois, probably on some other authority, as he makes no remarks whatever concerning it. It was included by Dr. Hoy in his list of Wisconsin Birds of $x 8_{52}$. Kumlien and Hollister say: "We know of no actual record for Wisconsin and have never seen the bird in the north." (Birds of Wisconsin, I903, p. r 30 .) 


\section{Genus STERNA Linn.}

\section{Sterna caspia Pallas.}

CASPIAN TERN.

Sterna tschegrava (Lepech), A. O. U. Check List, I895, p. 23.

Distr.: A nearly cosmopolitan species; in North America breeding along the midḍle Atlantic and Pacific coasts and in parts of the interior.

Adult in spring: Entire top of head, black, the black extending below the eye; the occipital feathers, lengthened, extending to the

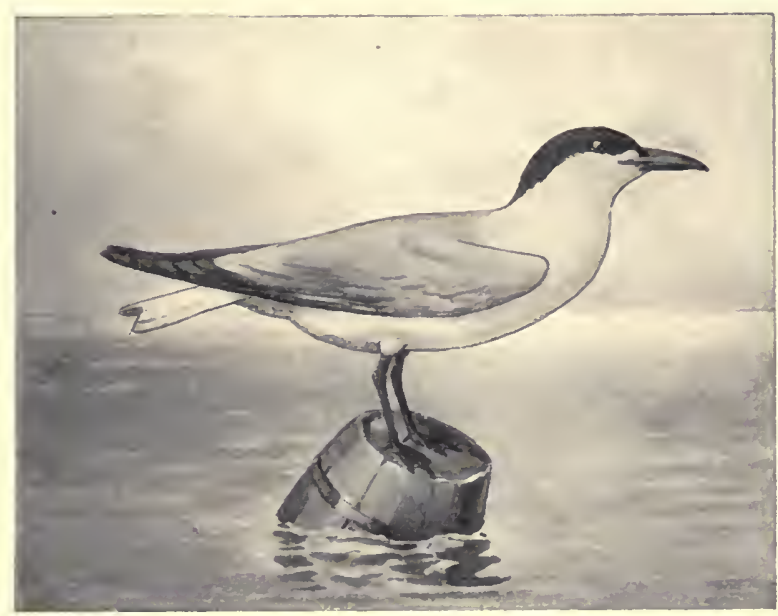

Caspian Tern.

nape; back and wings, pale pearl gray; rest of plumage, white; primaries, ash gray; no white on inner webs; bill, red; feet, black.

Adult in winter, and in summer after the breeding season: Similar, but has the head streaked with black and white.

Immature: Differs in having the head spotted and streaked with black and white, the upper parts more or less marked with brown and dusky; tail with irregular bars of black.

Length, about 20 to 23.50 ; wing, 15.25 to 17 ; tail, 5 to 6.25 ; tarsus, I.50 to r.60; bill, 2.60 to 2.90 ; depth of bill at base, about .90.

The Caspian Tern occurs casually on Lake Michigan in summer and occasionally in winter, and has been found breeding on islands in Green Bay, Wisconsin. The nest is merely a depression in the sand with little or no lining. The eggs are 2 , dull white or whitish with 
300 Field Museum of Natural History-Zoölogy, Vol. IX.

small spots or marks of chocolate brown, and measure about $2.75 \mathrm{x}$ r. 80 inches.

"An irregular but not uncommon visitant during the migrations and in winter upon Lake Michigan." (Nelson.) "Not common, except perhaps on northern Lake Michigan and Green Bay. Breeds, or did in $\mathrm{I} 879-80-8 \mathrm{I}-84$ and $\mathrm{I} 893$, on different islands in Green Bay and on the north shore. Frequently found on Lake Michigan in winter." (Kumlien and Hollister, Birds of Wisconsin, I 903, p. I2.)

Prof. Henry L. Ward found this species breeding in company with Herring Gulls on Gravel Island, Dove County, Michigan, in July, 1905. (Bull. Wisconsin Nat. Hist. Soc., Vol. IV, No. 4, I 906, p. I I3.)

\section{Sterna maxima Bodd.}

Royal Tern.

Distr.: Tropical America and warmer parts of North America, casually as far north as Massachusetts and perhaps the Great Lakes.

Adult in spring: Entire top of head, black, including but not extending below the eye; the black occipital feathers lengthened like

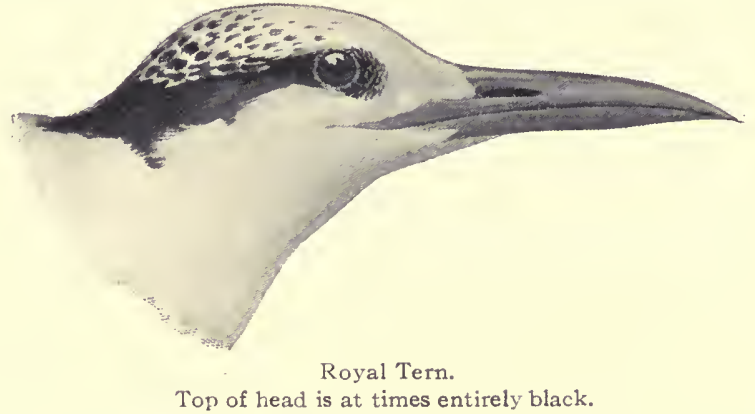

a crest; back and wings, pale pearl gray; rest of plumage, white; greater portion of the inner web of the outer primaries, white; bill, orange red; feet, blackish, becoming dull yellow on the soles.

Adult in winter, and in summer after the breeding season: Similar, but the top of the head streaked with black and white.

Immature: Head spotted and streaked black and white; the gray upper parts marked with buff, pale brown, and blackish.

Aside from the difference in size, the white markings on the outer primaries will distinguish this species from the Caspian Tern in any plumage.

Length, I 8 to 20 ; wing, I 3.75 to I 5 ; tail, 6 to 8 ; bill, 2.45 to 2.70 ; depth of bill at base, about .70; tarsus, I.30 to I.35. 
If the Royal Tern occurs in Illinois or Wisconsin or even on Lake Michigan, it is a very rare bird. We have no positive evidence of its having been taken in either state.

"A summer visitant in Illinois." (W. W. Cooke, Bird Migration Mississippi Valley, I 888, p. 57.) "Although accredited to Illinois as an irregular or casual summer visitor, it is possible that individuals of the Caspian Tern have been mistaken for it." (Ridgway.) "An exceedingly rare summer visitant to Lake Michigan. A specimen was taken at Milwaukee many years since and preserved in a museum there (Hoy)." (Nelson, Birds N. E. Illinois, I876, p. 147.) "The only reference to this species as a bird of Wisconsin that we know of is that of Dr. Hoy. *** Dr. Hoy does not mention caspia, which makes us suspicious that the specimen referred to was of that species. Furthermore, we carefully went through the Natural History Society's collection at Milwaukee a number of times between I 873 and 1875 , and although there used to be an old specimen of caspia there, we never saw or heard of a specimen of maxima." (Kumlien and Hollister, Birds of Wisconsin, I903, p. I30.) "Rare spring and summer; Lake Michigan." (A. J. Cook, Birds of Michigan, I 893, p. 34.)

\section{Sterna forsteri NutT. \\ Forster's TERn.}

Distr.: North America in general, migrating to the West Indies and South America in winter; breeds on the Atlantic coast as far north as Virginia and in the interior from Texas to Manitoba.

Adult in summer: Crown, black; upper parts, pearl gray; under parts, white; inner web of outer tail feather darker than outer web; bill,

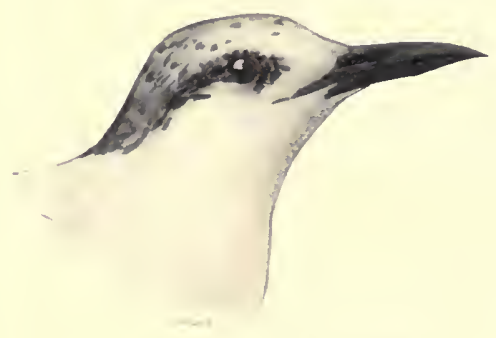

Forster's Tern. Fall plumage. reddish orange, tipped with black; feet, yellowish.

Adult in fall and winter: Bill, dark brown; feet, brown; head, grayish; a dusky black patch on sides of the head, enclosing the eye.

Immature in winter: Upper parts, mottled with pale brown or buff.

Length, I5; wing, ro.25; tail, 6.60 ; tarsus, .90; bill, 1.50 .

Forster's Tern is a common summer resident in both Illinois and Wisconsin, its numbers being augmented during the migrations in spring and fall. Those that remain to breed generally build their nests in the small interior ponds and lakes. The nest is composed of 
302 Field Museum of Natural History-Zoölogy, Vol. IX.

weeds and grass, usually in a marsh. The eggs are three (rarely 4) in number, pale olive gray (sometimes buffy white), marked and blotched with chocolate brown, and measure about $1.85 \times \mathrm{x} .3 \circ$ inches.

"Rather common summer resident in this portion of the state, breeds in the numerous small reedy lakes." (Nèlson, Birds N. E. Ill., I 876, p. I 47.) "Although the larger part are migratory, a good many still nest within the state." (Kumlien and Hollister, Birds of Wisconsin, I903, p. I 2.)

\section{Sterna hirundo LiNN. \\ Common Tern.}

Distr.: Ranges throughout eastern North America, breeding nearly throughout its range from Florida to the Arctic ocean; winters from Virginia southward.

Adult in summer: Bill, red, broadly tipped with black; feet, red; crown, black; upper parts, pearl gray; under parts, pale ashy gray; feet, orange red.

Adult in winter: Forehead and crown, white or grayish white; under parts, white; bill, blackish. Immature specimens have the upper parts mottled with buff or pale brown. The outer web of outer tail feather is darker than the inner web at all seasons.

Length, about I5; wing, about 10.30; tail, 5.50; tarsus, about 75 ; bill, r.45.

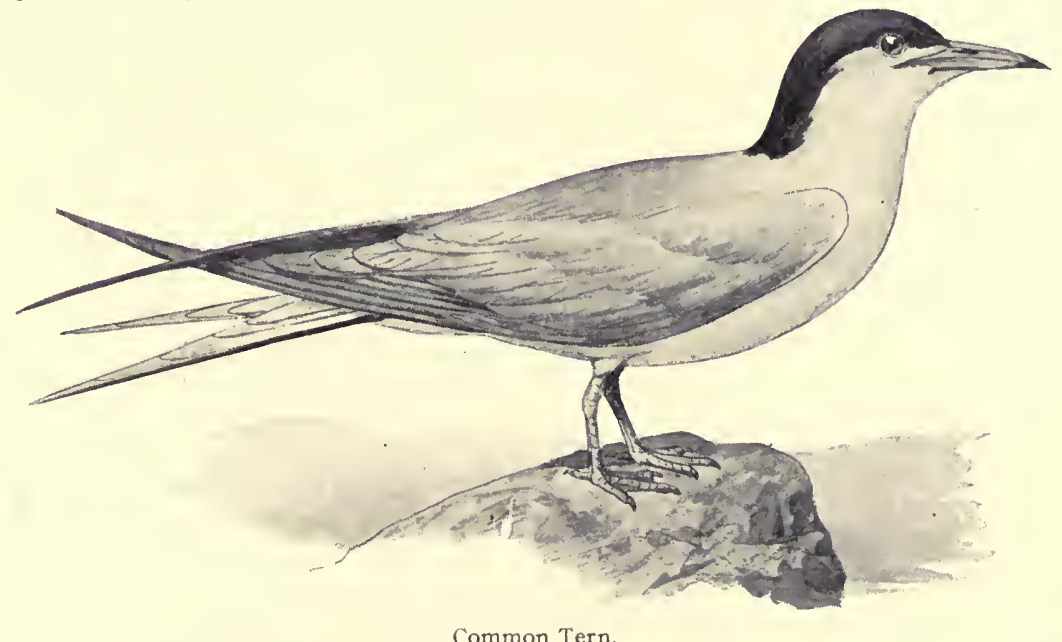

The present species is not uncommon at timess on Lake Michigan during the migrations, and a few remain to breed in Wisconsin. The 
eggs are 3 or 4 , pale gray or buff white (sometimes faintly greenish), marked and blotched with chocolate brown similar to forsteri, but at times showing a more greenish tinge than those of that species. They measure $\mathrm{r} .82 \times \mathrm{r} .30$ inches. "Very abundant migrant. * * * A few still breed on small islands at the northern end of the Lake." (Nelson.) "More common on Lake Michigan than forsteri and more abundant here than in the interior of the state, preferring the gravelly or sandy islands of the Lake and Green Bay for nesting places rather than the smaller inland lakes." (Kumlien and Hollister, Birds of Wisconsin, I903, p. I 3 .)

\section{Sterna paradisæa BRƯNN.}

Arctic Tern.

Distr.: Northern hemisphere, breeding in North America from Massachusetts northward to the Arctic regions, south in winter to the middle Atlantic states and California.

Adult in summer: "Similar to the Common Tern, but differs in having the tarsi shorter and the bill usually entirely red, not broadly tipped with black. The white on the inner webs of the first and second primaries extends considerably nearer to the tip of the feathers than in S. hirundo.

Length, about I5.25; wing, 10.25; bill, I.25 to I.35; tarsus, about .65 (less than .70).

This species has not apparently been observed in Illinois. Kumlien and Hollister (Birds of Wisconsin, I 903, p. I3) state, "A somewhat irregular migrant, at times fairly common and again quite the opposite. We have taken it nesting in Green Bay, I879; and in June, I89I, procured a set of eggs (the parent shot on the nest) at Lake Koshkonong. These nesting records are, however, to be considered exceptional. $* * * *$ Less common in the fall than in the spring, less often met inland in the fall than the two preceding, and not as abundant as either at any time or place in the state."

\section{Subgenus STERNULA Boie.}

\section{Sterna antillarum (Less.).}

\section{LEAST TERN.}

Distr.: Ranges from Labrador to northern South America, and in the interior west to Dakota and Mississippi Valley, breeding nearly throughout its range. 
Adult in summer: Bill, yellow, tipped with black; forehead, white; crown and lores, black; upper parts, pearl gray; under parts, white; outer primaries, brownish black on outer

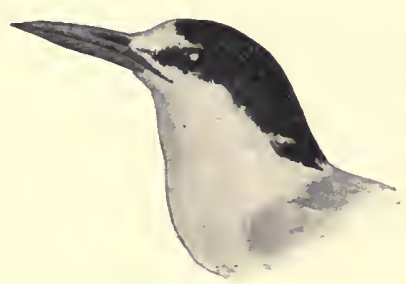

Least Tern. webs and inner half of inner webs; tail, white; feet orange, yellow.

Adult in winter: Forepart of crown, white, marked with black; occiput, black. Immature birds have the upper parts mottled with buff and the bill dark brown.

Length, 9.50; wing, 7; tail, 3.50; tarsus, .6o; bill, I.20.

Although this species occurs on Lake Michigan, and occasionally on the inland waters of Illinois and Wisconsin, it is apparently by no means common. "Occurs in summer, nearly throughout the Mississippi Valley." (Ridgway.) "A very rare summer visitant in this vicinity. $* * * *$ A fine male specimen is in the collection of the Chicago Academy of Sciences, obtained June I I, I876, upon the Calumet marshes." (Nelson, Birds of N. E. Ill., 1876, p. 149.) "Chiefly coastwise but passes up the Mississippi Valley to Dakota and Minnesota; breeds abundantly along the Gulf coast in Louisiana and Texas, also in the interior; known to breed in Kansas and Dakota." (W. W. Cooke, Bird Migration Mississippi Valley, r888, p. 58.) Kumlien and Hollister say, "This species can be considered only as a very rare summer visitor from the south." They mention half a dozen specimens taken in Wisconsin, three of which were shot by L. Kumlien on Lake Koshkonong in June, I893. (Birds of Wisconsin, I903, p. I3.)

\section{Genus HYDROCHELIDON Boie.}

\section{Hydrochelidon nigra surinamensis (GMEL.).}

\section{Black Tern. Marsh Tern.}

Distr.: Temperate and tropical America, from Alaska to the Fur Countries south to South America; breeding from the middle United States west of the Alleghanies, northward.

Adult in spring: Head and under parts (except under tail coverts), black; back, wings and tail, slaty gray; under tail coverts, white; primaries, dusky slate color, palest on the inner webs, the shafts of the feathers, brownish white; bill and feet, black.

Adult in fall and winter: Forehead, back of the neck, and under parts, white or whitish; back of the head, black, mixed with white; wings and back, gray. 


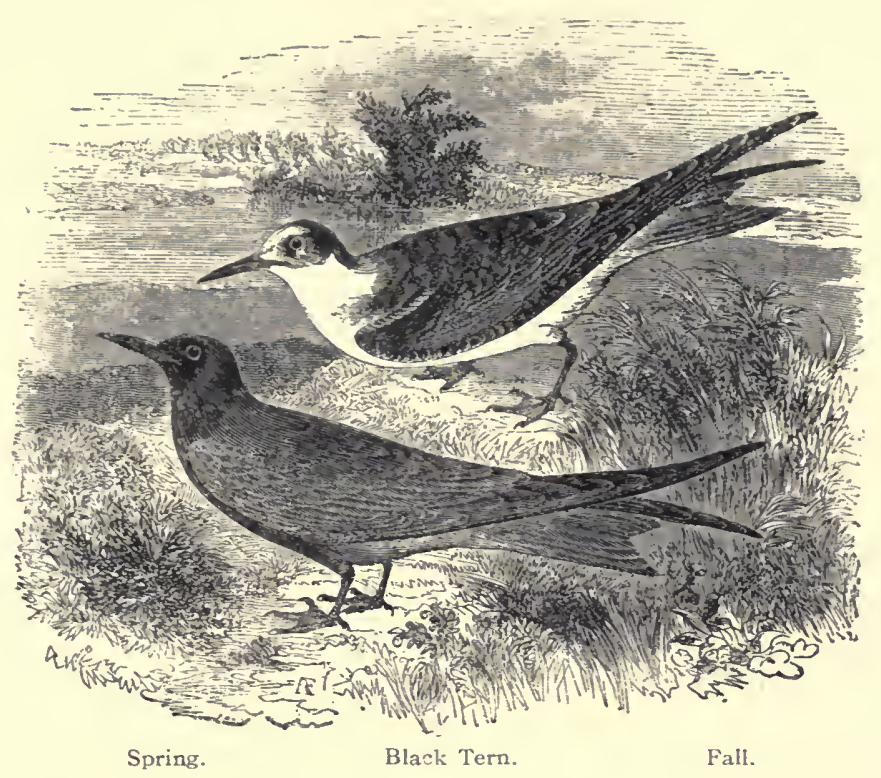

Immature: Upper plumage more or less mixed with buff and pale brown; under parts, white; the sides, gray; usually more or less black about the eye; shafts of the primaries, brown.

During changes of plumage the head and under parts show mixed black and white markings.

Length, about 9.30; wing, about 8.25; tail, 3.80 ; bill, I to 1.20 ; tarsus .50 .

Immature birds are smaller.

The Black Tern is a common summer resident in Illinois and Wisconsin and breeds in both states, in May and June, usually preferring the smaller inland lakes. While it does occasionally eat small fish, the greater portion of its food consists of insects such as dragon flies and beetles, which it pursues and captures while on the wing with great dexterity, turning and twisting in a manner suggesting the flight of a swallow. The nest is built in a marsh or on the edge of some grassy pond, and is composed of grass and reeds, sometimes a mass of floating vegetation. The eggs are 2 or 3 , pale olive brown, heavily marked with chocolate. They measure about $1.40 \mathrm{x}$ I inches. There are several sets of eggs in the Field Museum collection taken at Fox Lake, Lake County, Ill., June 6, I903.

Regarding its occurrence in Wisconsin, Kumlien and Hollister say: "A very common summer resident in all the inland ponds, 
306 Field Museum of Natural History-Zoölogy, Vol. IX.

sloughs, wet marshes and lakes, but seldom found on Lake Michigan, and probably only during migrations; arrives in Wisconsin, of an average year, the first few days of May - dates of arrival for a number of years at Lake Koshkonong range from April r6 to May ir and departs early, few being seen after the middle of September. When they arrive in the spring all are in the black, full breeding plumage; and all are in the white winter plumage before they leave; in fact, a great many begin to assume their winter plumage before they are through nesting." (Birds of Wisconsin, I903, p. I4.)

30. Hydrochelidon leucoptera (Meisn. \& Schinz).

White-winged Black Tern.

Distr.: Eastern hemisphere, accidental in North America (one record, Wisconsin ).

Special characters, adult: Head, neck, and under parts, black; upper parts, plumbeous; entire tail and upper and lower tail coverts, white; anterior lesser wing coverts, white; legs and feet, red.

Length, about 9; wing, about 8 ; bill, about .90.

"The only known instance of the occurrence of this European species on the Western Continent is that of a breeding female shot by L. Kumlien in a large marsh near Black Hawk Island, Lake Koshkonong, July 5, I 873 . The specimen was sent freshly skinned to Dr. Brewer, and was presented by him to the National Museum." (Kumlien and Hollister, Birds of Wisconsin, Bull. Wisconsin Nat. Hist. Soc., I 903 , p. I4.) 


\section{ORDER STEGANOPODES.}

TOTIPALMATE SWIMMERS. ANHINGAS, CORMORANTS, PELICANS, ETC.

\section{Family ANHINGIDÆ. Darters, Snake Birds.}

Of the four known species of this family, only one occurs in the United States. It was at one time not uncommon in southern Illinois and is still to be found in the extreme southern portion of the state. They are fish eaters and expert divers, often remaining for a considerable time under water with the head and perhaps a portion of the neck exposed above the surface.

Genus ANHINGA Briss.

31. Anhinga anhinga (Livn.).

Anhinga.

Local names: Water Turkey. Snake Bird.

Distr.: Tropical and subtropical America, north in the United States to the Carolinas, southern Kansas, and southern Illinois.

Adult male in breeding plumage: Head and neck, black, showing a greenish gloss; back of the head and neck showing lengthened hairlike feathers of dull white; back mottled and streaked with white; upper mandible, olive, edged with yellow; lower mandible, yellow, shading into green at the tip; gular sac, yellow. In winter the male loses the white hair-like feathers on the neck; middle tail feathers showing transverse fluting.

Adult female: Head, neck, and breast, buff color, darker on the nape.

Length, 33.50; wing, I3.50; tail, x0.50; tarsus, I.35; bill, 3.25 .

The Anhinga, commonly called Water Turkey or Snake Bird, occurs more or less commonly in summer in the extreme southern portion of Illinois and may breed there, although I find no actual record of its having done so.

"In summer it passes north regularly to southern Illinois." (Cooke.) "The Anhinga appears to be a regular summer resident in the extreme southern portion of Illinois, since Mr. Kennicott found 
308 Field Museum of Natural History-Zoölogy, Vol. IX.

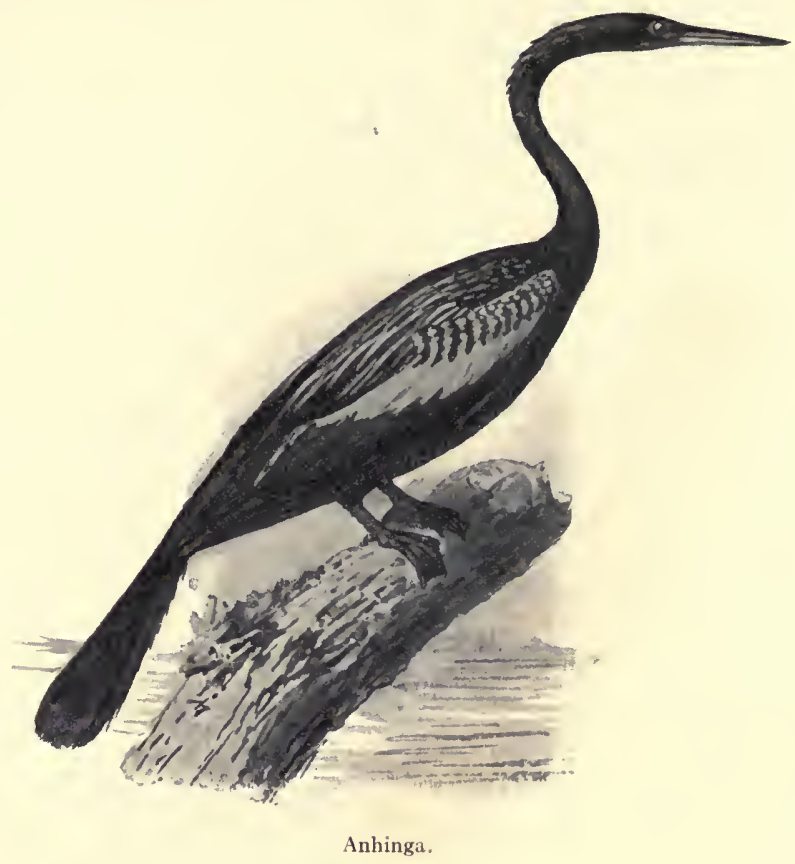

it to be common in the vicinity of Cairo in 1865 , while Mr. Nelson observed it in the same locality twenty years later." (Ridgway, Orn. of Illinois, I895, p. 209.) "Common in summer near Cairo, and seen by Mr. Ridgway near Mt. Carmel." (Nelson, Birds N. E. Ill., I 876 , p. г 5 I.) There is apparently no satisfactory record of its occurrence in northern Illinois or Wisconsin. A bird was described to Mr. W. E. Snyder as having been shot in Dodge Co., Wisconsin, which he believed to be this species. (Bull. Wis. Nat. Hist. Soc., April, I 892.)

\section{Family PHALACROCORACIDÆ. Cormorants.}

Cormorants are maritime birds, but often occur in numbers on some of the larger inland lakes and rivers. They feed principally upon fish and are usually found in colonies. About thirty species are recognized, of which ten occur in North America. 


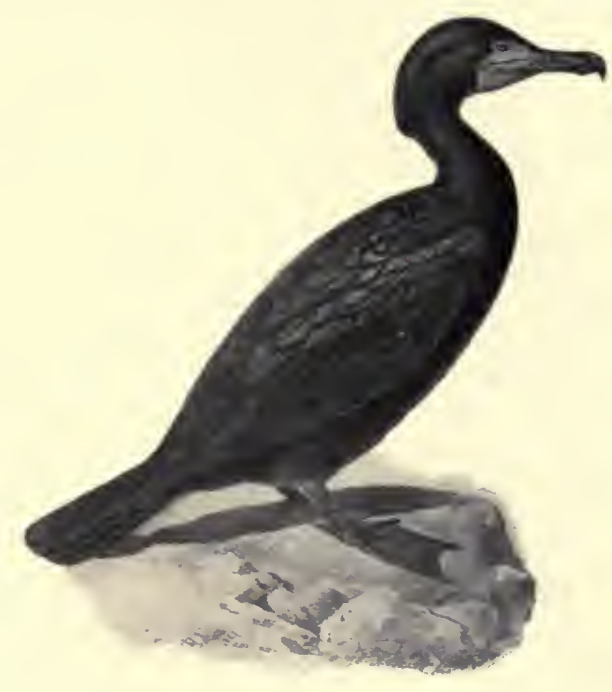

Double-crested Cormorant.

Genus PHALACROCORAX Brisson.

32. Phalacrocorax auritus (LEsson).

Double-crested Cormorant.

Phalacrocorax dilophus (Swain.), A. O. U. Check List, I895, p. 42. Local name: Nigger Goose.

Distr.: Eastern North America, breeding from the latitude of Minnesota, Dakota, and the Bay of Fundy northward; south in winter to the Gulf of Mexico.

Adult in spring: Head, neck, and under parts, glossy black; scapulars and wing coverts, brownish gray, edged with black; tail, black, having I 2 feathers; a tuft of black feathers over the eyes; gular sac and lores, orange yellow.

Adult in fall and winter: Similar, but lacking the tufts of feathers on sides of head, and the gular sac varies in color.

Immature: General plumage, grayish brown, becoming pale on the breast, sometimes whitish; many of the back feathers and scapulars with dark edges; no tufts of feathers on sides of head.

Length, about 30 ; wing, I 2 to I 3.20 ; bill, 2 . IO to 2.50 .

This species occurs in both Illinois and Wisconsin during the migrations. It is not improbable that a few pairs may breed in northern Wisconsin. Mr. Chas. F. Carr (Wisconsin Naturalist, Sept. 
3 io Field Museum of Natural History - Zoölogy, Vol. IX.

I, I890) says, "They breed about some of the larger isolated lakes in the northern and central part of the state."

32a. Phalacrocorax auritus floridanus (AUD.).

Florida Cormorant.

Phalacrocorax dilophus floridanus (Aud.), A. O. U. Check List, I895, p. 42.

Distr.: South Atlantic and Gulf states, northward along the Mississippi Valley to southern Illinois.

The Florida Cormorant is merely a rather small, southern form of the preceding species; the plumage is similar.

Length, less than 30 inches; tarsus, 2 inches or less.

"In summer, north to Illinois, sometimes winters in southern Illinois." (Cooke.) "Common in early spring on the Wabash River as far north as Mt. Carmel." (Ridgway, Orn. of Ill., I 895, p. 205.) "A regular summer resident in southern Illinois, occasionally straying to the northern part of the state." (Nelson, Birds N. E. I11., I876, p. I45.) It has not been observed in Wisconsin.

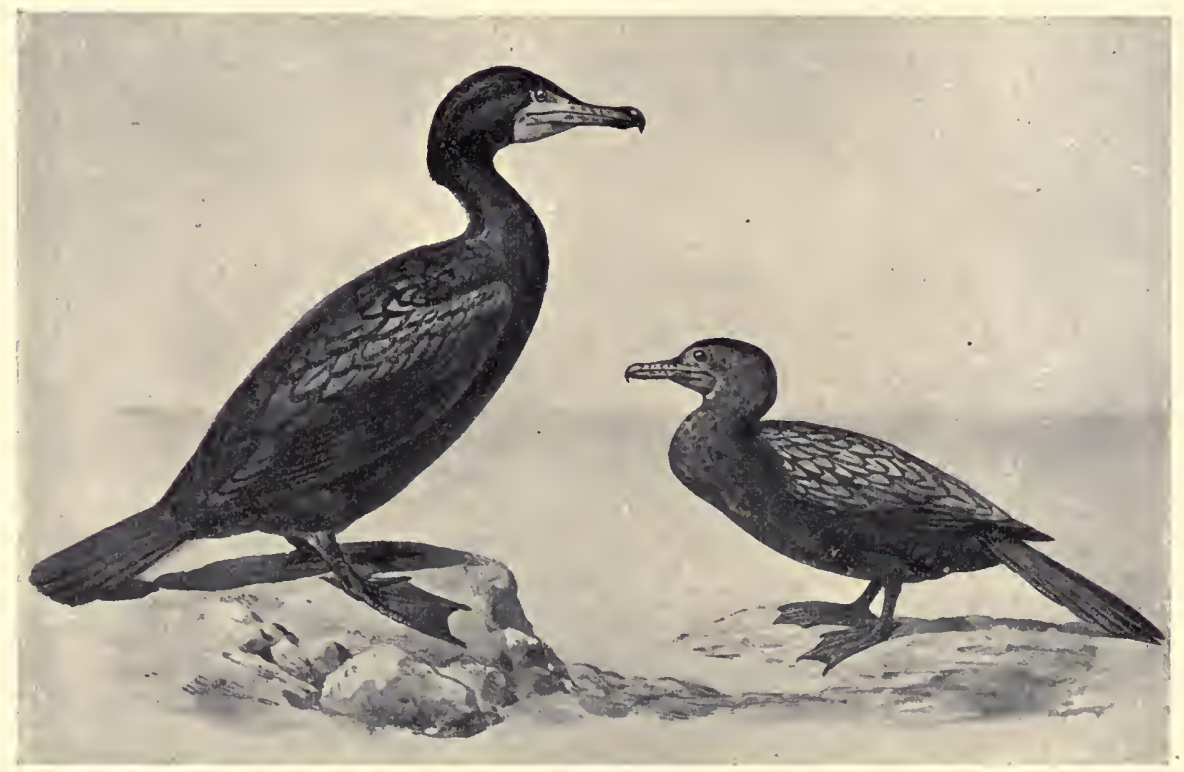


33. Phalacrocorax vigua mexicanus (BRANDT).

Mexican Cormorant.

Phalacrocorax mexicanus (Brandt), A. O. U. Check List, I895, p. 43 .

Distr.: Central America and the West Indies to southern United States, casual or accidental north to Kansas and southern Illinois.

Special characters, adult: Smaller than the preceding species. In the adult breeding plumage the Mexican Cormorant may be distinguished by the narrow edging of white feathers bordering the brownish yellow gular sac, and also by the lack of any definite tufts on the head, which are replaced by long, filamentous white feathers, and in winter by its small size.

Length, about 25; wing, ro to ro.60; bill, I.70 to 2.

The Mexican Cormorant is probably of accidental occurrence in. the extreme southern portion of Illinois. It is easily recognized by its small size (the wing being always less than 10.50 inches) and the white line bordering the base of the gular pouch.

"A very common resident along the coast of Texas, occurs in the Mississippi Valley as far north as southern Illinois and Kansas." (W. W. Cooke, p. 59.) "Mr. Worthen reports that last spring he received a skin of this species labelled 'Near Cairo, Illinois.' It was in summer (not adult) plumage. He was not able to trace the specimen, so there is room for doubt as to the locality." (Ridgway, Bull. Nutt. Orn. Club, Jan., r88o, p. r3.)

\section{Family PELECANIDÆ. Pelicans.}

Pelicans are large birds, frequenting the warmer portions of the world. Of the twelve known species, three occur in North America and two of these in eastern United States.

They are gregarious, usually nesting in large colonies. Their food consists almost entirely of fish, which they capture with great dexterity. The White Pelicans scoop up their food while swimming, but the Brown Pelican will often dive headlong into the water, while on the wing, sometimes disappearing entirely beneath the surface. 
3 i 2 Field Museum of Natural History-Zoölogy, Vol. IX.

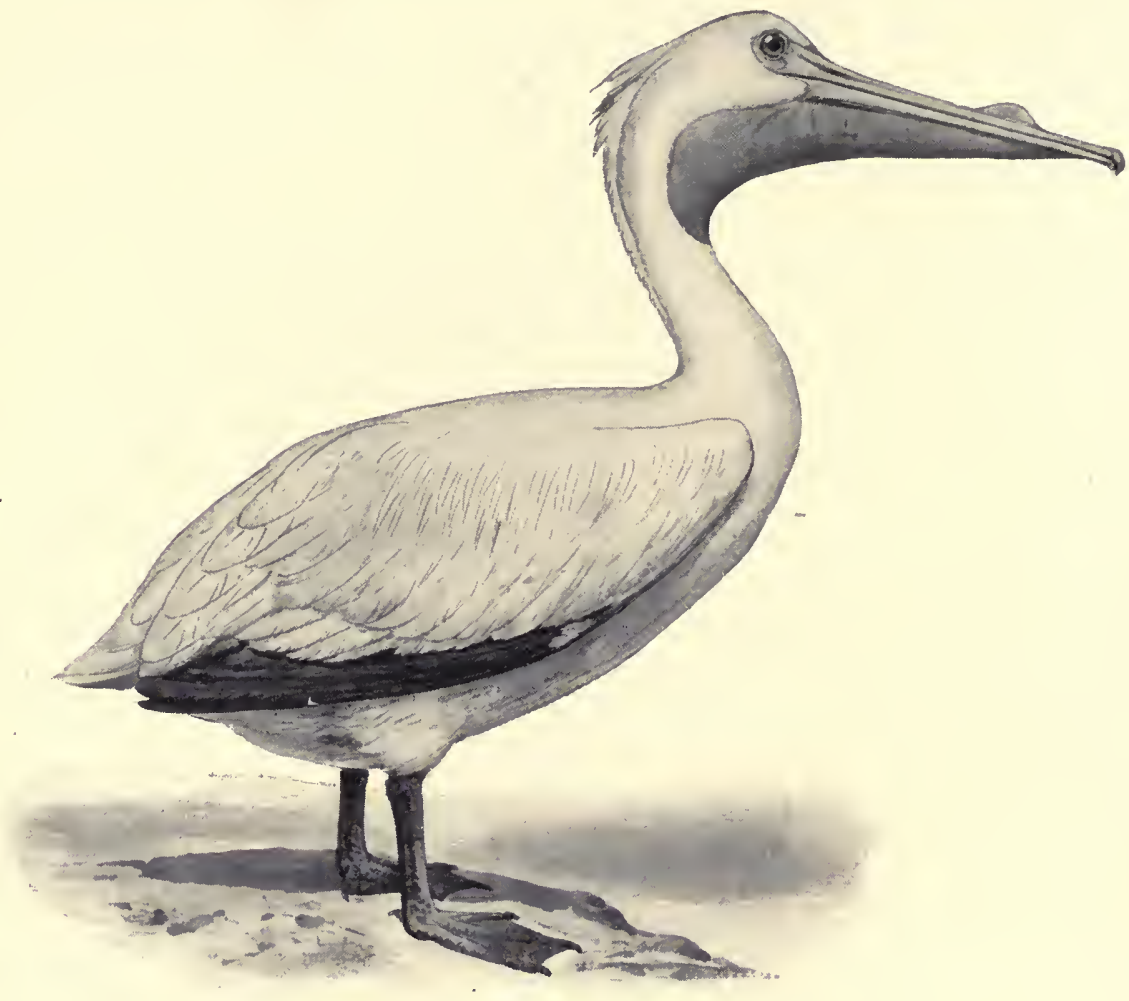

White Pelican.

Genus PELECANUS Linn.

34. Pelecanus erythrorhynchos Gmel.

American White Pelican.

Distr.: Temperate North America, north in the interior to about latitude $6 \mathrm{r}^{\circ}$, breeding chiefly from about the latitude of Minnesota northward; south in winter to Mexico and Central America. It is still abundant in many parts of the interior and along the Gulf coast to Florida and on the coast of California; very rare on the Atlantic coast north of Florida.

Adult in breeding plumage: General plumage, white; bill, yellowish, with horny protuberance on the top (this is lacking in winter); primaries, black; pouch is lemon yellow and the legs, pale yellow; iris, straw color.

Length, 60; wing, 24.50; tarsus, 4.45; bill, I 2. 
This species occurs in Illinois and Wisconsin during the migrations, usually in April, September, and October. It is not improbable that a few pairs may still breed in the northern part of Wisconsin.

"At present an exceedingly rare visitant during the migrations. Formerly they were regular and rather common migrants. Still migrate along the Mississippi River." (Nelson, Birds N. E. 111., I 876 , p. I44.) According to Kumlien and Hollister, White Pelicans nested in Wisconsin as late as 1883 and $\mathrm{r} 884$, but they believe that "probably few, if any, nest in the state at the present time." (Birds of Wisconsin, 1903 , p. 15 .)

\section{Pelecanus occidentalis Linn.}

Brown Pelican.

Pelecanus fuscus (Linn.), A. O. U. Check List, r895, p. 46.

Distr.: Atlantic coast of tropical and subtropical America; abundant in Florida and along the Gulf coast, casual north to the Carolinas and accidental in southern Illinois.

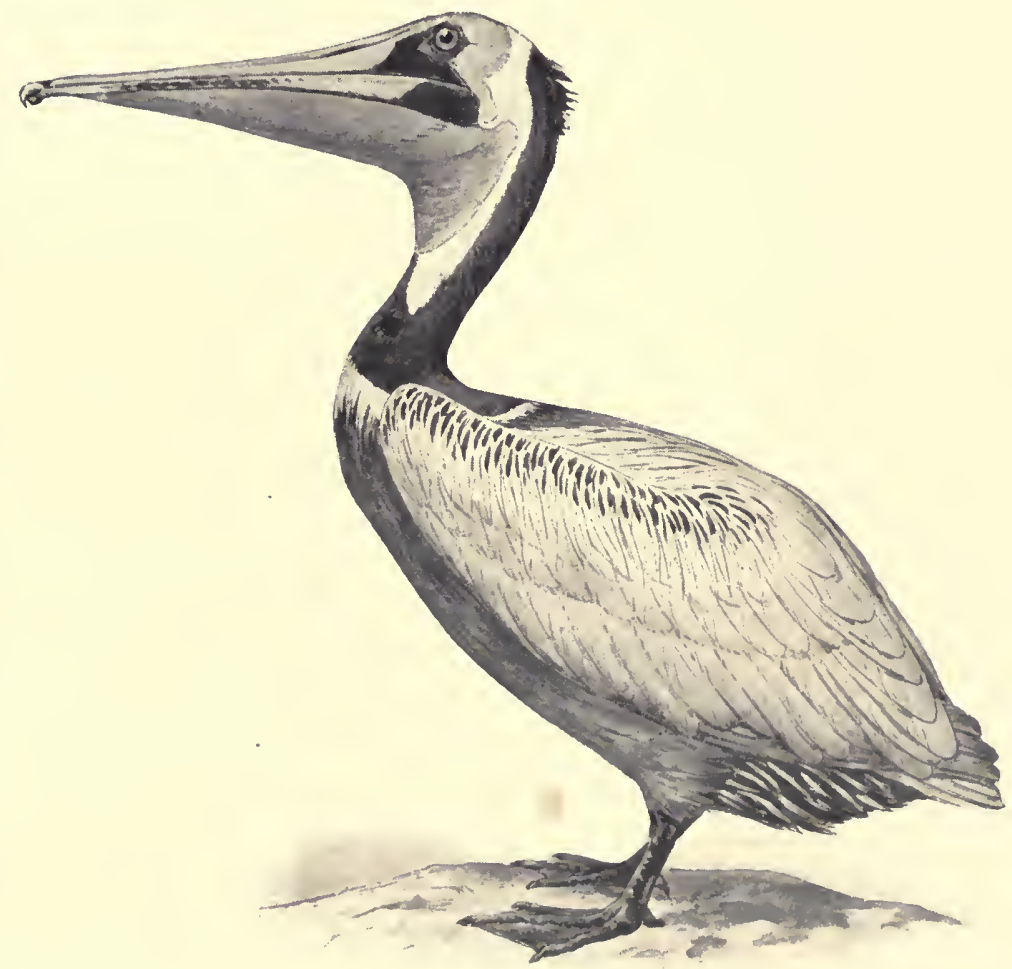

Brown Pelican. 
3 it Field Museum of Natural History-Zoölogy, Vol. IX.

Adult in breeding plumage: Neck, chestnut brown; head and line at the base of the pouch, yellowish white; upper parts, ashy gray, some of the feathers edged with brownish; bill, brownish white, marked with red in spots; pouch, dark greenish black; bare space in front of the eye, bluish; tail, consists of twenty-two feathers. The immature bird has the head and neck brownish gray.

Length, 50; wing, 20; tarsus, 2.90; bill, II.

"The Brown Pelican has a somewhat doubtful claim to be included among the birds of Illinois. Apparently the only record is that given by Mr. Chas. K. Worthen in a letter to Prof. Ridgway, who writes: "Saw a specimen of this bird flying over Lima Lake, a large, shallow body of water ten miles below here (Warsaw, Illinois), in October, 1873 . The bird was not over a hundred yards from myself and two or three others and we watched it for several minutes. $* * *$ It had the color, bill, and size of that species." (Ridgway, Bull. Nutt. Orn. Club, i 880 , p. 3r.)

\section{Family FREGATIDÆ. Man-of-war Birds.}

The Fregatidæ are a family of maritime and pelagic birds, comprising one genus and only two known species, inhabiting the warmer portions of the globe.

\section{Genus FREGATA Lacépède.}

\section{Fregata aquila (LiNN.). MAN-OF-WAR Bird.}

Distr.: Tropical and subtropical coasts and islands. In America north to Florida and Texas, and casually to Nova Scotia, Wisconsin, Indiana, etc.

Adult male: Entire plumage, brownish black, showing a greenish reflection on the head, and purplish upon the back; tail, forked and composed of twelve feathers; gular sac, pale orange; iris, brown.

Adult female: Differs from the male by having a white patch on the breast, which extends along the sides of the neck and around it near the middle.

Length, 43; wing, 25; tail, I9; tarsus, I; bill, 6 .

Stragglers of this strictly maritime species have been recorded from various localities in the interior. Specimens have been taken in Kansas, Ohio, and Indiana (2). 
Jan., I909. Birds of Illinois and Wisconsin-Cory.

It has not been observed in Illinois, but Kumlien and Hollister state that a bird of this species "was shot in the Milwaukee River at Humbold, near the city of Milwaukee, in August, I880. ***** The specimen is now mounted in the Milwaukee Public Museum." (Bull. Wisconsin Nat. Hist. Soc., I903, p. I6.)

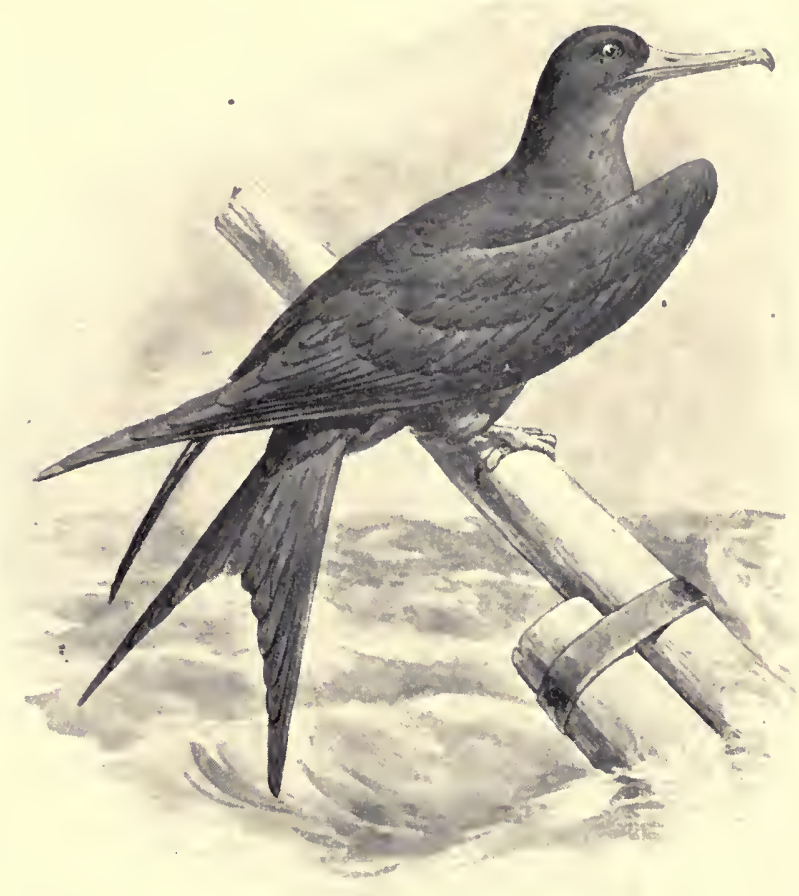

Man-of-war Bird. 


\section{ORDER ANSERES.}

LAMELLIROSTRAL SWIMMERS.

\section{Family ANATIDÆ. Ducks, Geese, and Swans.}

This large family contains nearly 200 species, distributed throughout the world. They are subdivided into several well marked groups or subfamilies.

\section{Subfamily MERGINÆ. The Mergansers or Sheldrakes.}

The Mergansers or Sheldrakes are fish eaters, and the flesh of the adults of most species is strong and unpalatable. The Hooded Merganser is an exception, however, and it is an excellent table bird when properly prepared. Three species occur in Illinois and Wisconsin. They are easily recognized by their long narrow bills edged with small tooth-like serrations.

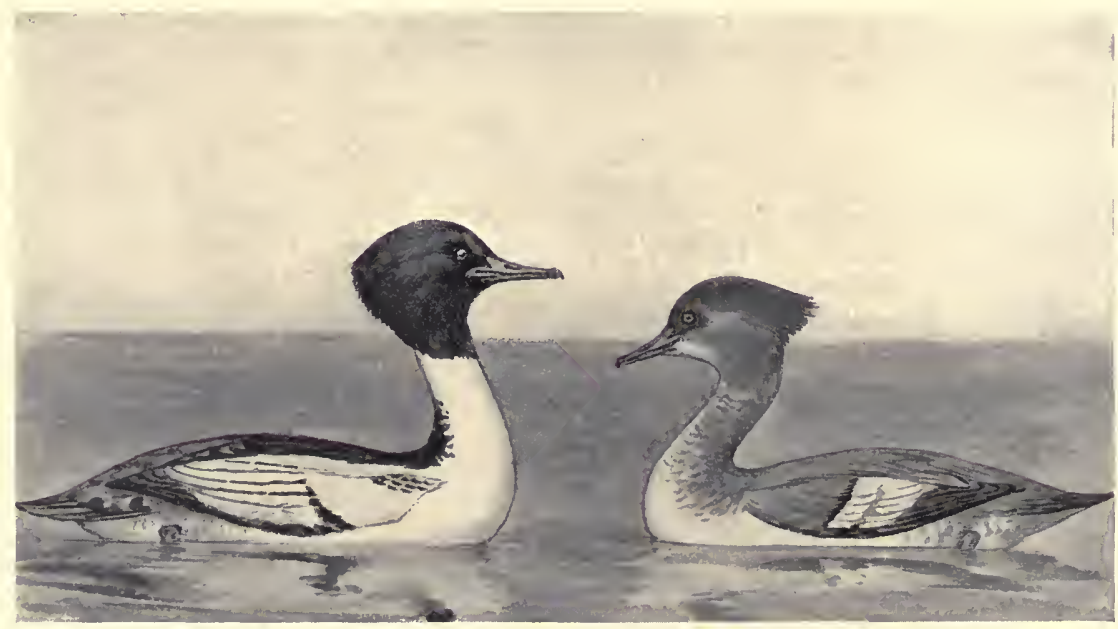

Male.

American Merganser.

Female. 


\section{Genus MERGUS Linn.}

\section{Mergus americanus CAss.}

American Merganser. Sheldrake.

Merganser americanus (Cass.), A. O. U. Check List, I 895, p. 47.

Distr.: General North America, breeds from northern Wisconsin and Pennsylvania northward. It ranges in winter as far south as Florida, the Gulf of Mexico, northern Mexico, and Lower California.

Adult male: Bill, red, long and narrow, with tooth-like serrations on edges; head and neck, greenish black; under parts, creamy white, tinged with salmon color; tail, gray; feet, red; distance from anterior end of nostril to the tip of the bill, less than I.5O inches.

Length, 26; wing, about II; tarsus, 2 ; bill, 2.10.

Adult female: Upper throat, white; breast and head, rufous brown; belly, white; speculum, white; feet, reddish orange; distance from the anterior end of nostril to tip of bill, less than I.50 inches.

Length, about 24.50; wing, about 9.75; tarsus, I.90; bill, 2.

Immature males resemble the female.

The distance from the anterior end of nostril to the tip of the bill is less than 1.50 inches in this species, and the female may be distinguished from the Red-breasted Merganser by this character, as in that species the distance from the anterior end of nostril to tip of bill is more than 1.50 inches.

This species is common in Illinois and Wisconsin, during the migrations, and at times a number remain during the winter. It does not breed in Illinois, and I find no satisfactory record of its having done so in Wisconsin, although Kumlien and Hollister say: "Said to nest in the extreme northern end of Door County." (Bull. Wisconsin Nat. Hist. Soc., p. 16.) Both this and the next species are known to the local gunners by the name of "Sheldrake."

\section{Mergus serrator LiN.}

\section{Red-breasted Merganser. Sheldrake.}

Merganser serrator (Linn.), A. O. U. Check List, I895, p. 47.

Distr.: Northern portions of the northern hemisphere, breeding from northern Illinois northward; winters throughout the United States from Lake Michigan and New England to the Gulf coast, Cuba, and Lower California.

Adult male: Head and upper throat, black, tinged with greenish; a white ring around the neck, not always well defined; breast, rufous, 


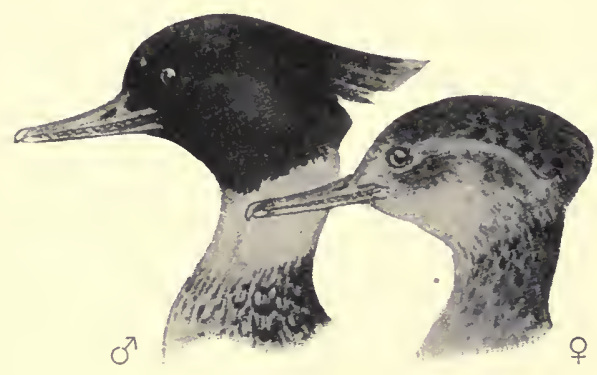

streaked with black; lower breast and belly, white; the sides and rump, delicately pencilled black; distance from nostril to tip of bill, more than I. $5^{\circ}$.

Length, 23; wing, 9; tarsus, $1.90 ;$ bill, 2.30 .

Female and young male: Head, brownish; throat, pale buff; back, gray; under parts of the body are white, and speculum is white.

Length, 2I; wing, 8.80; tarsus, I.90; bill, 2.50 .

Although not abundant, the Red-breasted Merganser is not uncommon at times on Lake Michigan and the inland waters of Illinois and Wisconsin during the migrations. A few remain to breed in northern Illinois and it breeds regularly in Wisconsin. The nest is on the ground, composed of moss and grass lined with down and carefully concealed. The eggs are from 7 to 12 , pale buff color, and measure about $2.50 \times 1.75$ inches.

"Winter resident throughout Illinois and breeds from the northern portion of the state northward." (Ridgway, Orn. I11., I895, p. I 9o.) "The rarest species of the genus in this vicinity. Frequents small reedy lakes where it is a summer resident. Nests upon old muskrat houses. $* * * *$ A very rare winter resident. During the height of the migrations it is rather common upon Lake Michigan, in small flocks." (Nelson, Birds N. E. I11., I 876, p. 44.) "Common during migrations, but not in as great numbers as the preceding. A regular breeder about Green Bay and Lake Superior." (Kumlien and Hollister, Birds Wisconsin, I903, p. I 7.)

\section{Genus LOPHODYTES Reich.}

39. Lophodytes cucullatus (LINN.).

Hooded Merganser.

Distr.: North America in general, south to Cuba and central Mexico, breeding nearly throughout its range.

Adult male: Head with large black and white crest; upper parts, black; under parts, white, having the sides brownish, delicately barred with black.

Length, 19.50; wing, 7.75; tarsus, 1.30 ; bill, I.5०. 

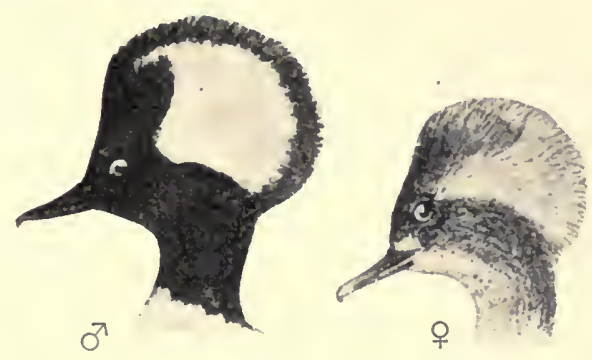

Adult female: Head and neck, brownish, showing a slight crest, but not nearly as large as in the male; under parts, white.

Length, I8.50; wing, 7.75; tarsus, I.30; bill, I.5०.

The young bird resembles. the female, but has no crest.

Length, 18.50; wing, 7.70; tarsus, I.25; bill, I.50.

The Hooded Merganser is an abundant migrant and a not uncommon summer resident in both Illinois and Wisconsin. It frequents the ponds and streams during the breeding season and builds its nest in a hollow tree near water. The eggs are 7 to ro, buff white, and measure about $2.05 \times 1.75$ inches. Its food consists: of roots, seeds, small fish, and occasionally insects. The young are taken from the nest in the bill of the mother. Nidification begins in May.

"Very abundant migrant; common winter resident upon Lake Michigan; breeds sparingly throughout the state." (Nelson, Birds. N. E. Ill., I 876 , p. 44.) "Very common. **** Breeds sparingly in suitable localities." (Kumlien and Hollister, Birds Wisconsin, I 903 , p. I 7.)

\section{Subfamily ANATINÆ. River and Pond Ducks.}

These ducks, while often found in numbers on salt water, seem to. prefer (with few exceptions) the lakes, rivers, and ponds. The food consists of mollusks, small crustaceans, fish, and insects, as well as the roots of aquatic plants and seeds. The members of this subfamily have the bill broad (not narrow as in the Mergansers), and no flap. or web on the hind toe. 
320 Field Museum of Natural History-Zoölogy, Vol. IX.

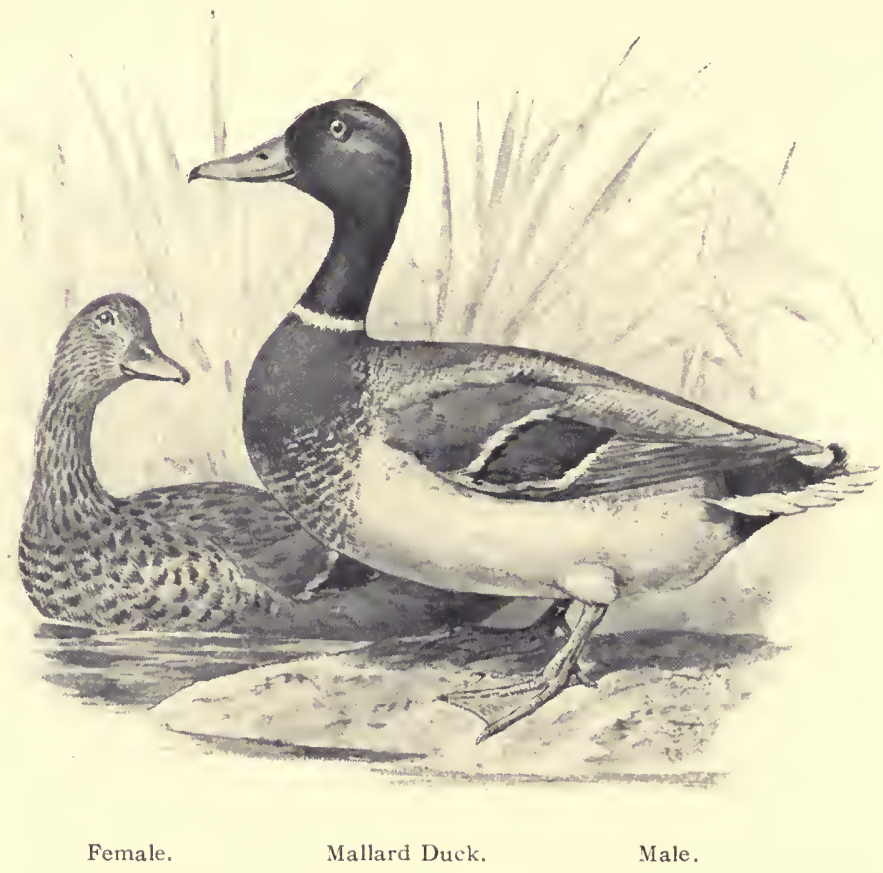

Genus ANAS Linn.

40. Anas platyrhynchos LinN.

Mallard Duck.

Anas boschas Linn., A. O. U. Check List, r 895, p. 48.

Distr.: Northern hemisphere, breeding nearly throughout the temperate zone; south in winter to Cuba, Lower California, Mexico, and Central America to Panama.

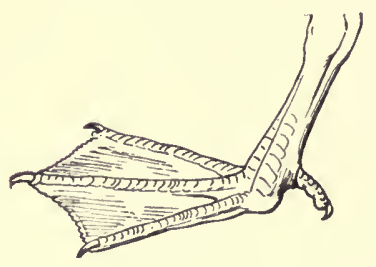

Adult male: Head and neck, dark green, with a white ring on the neck; under parts, whitish or ashy white; breast, rich chestnut brown; under tail coverts, black; upper tail coverts are also black with central feathers elongated and curved upwards; speculum, purple, bordered with black and white; feet, orange red; bill, yellowish olive.

Adult female: Speculum, purple, bordered with black and white; head, brownish buff; belly, buffy brown, usually mottled; feet, orange red. 
Length, 23; wing, 10.50; bill, 2.20 .

An abundant species in Illinois and Wisconsin during the migrations, and a number remain to breed in suitable localities in both states. The nest is usually placed on the ground near water, and is composar of grass and weeds and lined (not always) with down for nu.cro. The eggs are 7 to ro, pale greenish white, and measure about 2.25 X I.70 inches.

Ridgway states: "It has been known, in rare instances, to nest in a tree, in such cases occupying the deserted nest of a hawk, crow, or other large bird." (Orn. of Illinois, 1895, p. r29.)

\section{Anas rubripes Brewster.}

Red-Legged Black Dúck.

Distr.: Eastern North America, north to Ungava and Hudson. Bay, and west to the Manitoba region and the Mississippi Valley; winters from Massachusetts and Illinois southward.

Adult: Head and neck, pale brown, finely dotted and streaked with dark brown; top of the head darker than the cheeks; yeneral plumage, dark brown; feathers, edged with pale

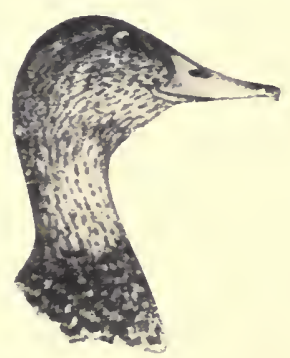
buff; speculum, purple, edged with black; bill, yellowish green, with dark nail, no black at the base; legs and feet, olive, with dusky webs.

Length, 22; wing, II; bill, 2.10; tarsus, 1.75 .

This species may always be distinguished from the female of the Mallard by the absence of white on the speculum.

The Red-legged Black Duck is not uncommon in Illinois and Wisconsin during migrations. Kumlien and Hollister consider it the common for $m$ in the latter state, and the writer has examined a number of specimens offered for sale at different times in the Chicago markets.

\section{1a. Anas rubripes tristis BREWSTER. Black Duck.}

Anas obscura Gmel., A. O. U. Check List, 1895, p. 48.

Distr.: Eastern North America, north to Labrador, and west to Minnesota and Mississippi Valley, Breeds from Maryland and Illinois northward; winters from southern Illinois and Massachusetts to the South Atlantic and eastern Gulf States to the West Indies. 
322 Field Museum of Natural History-Zoölogy, Vol. IX.

The Black Duck differs from the red-legged form in its being somewhat smaller, and having the legs olive, and bill, not so yellow. The sexes are similar.

Length, about 2 I; wing, about I0.75; bill, 2.10.

This species is at times fairly common during the migrations in both Illinois and Wisconsin and a few remain to breed in both states: The nest is on the ground. The eggs are 8 to $\mathrm{I} 2$, pale greenish white or bluish white, and measure $2.45 \times \mathrm{x} .80$ inches. The note of the male is something like "Drake, drake, drake, drake," and also "Shwipe," in a husky voice; the female, "quacks."

"An uncommon migrant with the preceding and a very rare summer resident. **** One or two pairs nest each year on the Calumet marshes." (Nelson, Birds N. E. Ill., I 876, p. I 39.)

\section{Genus CHAULELASMUS Bonap.}

\section{Chaulelasmus streperus (LiNn.).}

GADWALL.

Anas strepera Linn., A. O. U. Check List, I 895, p. 49.

Local names: Gray Duck. Creek Duck.

Distr.: Nearly cosmopolitan. In North America it breeds chiefly from the northern United States (Nebraska, northern Wisconsin, etc.) to Hudson Bay and Manitoba. Ranges from Hudson Bay and Lesser Slave Lake to the Gulf coast, Lower California, and southern Mexico, Florida, and Cuba.

Adult male: Top of head, brownish, finely streaked and mottled with black and dark brown; neck and breast, mottled (black and white), the feathers being black, having a central white mark; under parts, white (sometimes grayish white); under tail coverts, black; upper tail coverts and rump, black; speculum, black and white; the lesser wing coverts, chestnut; bill, black; feet, orange; axillars, white, with white shafts.

Length, 19.50; wing, Io; bill, x.60.

Adult female: Somewhat resembles the male, but has the under wing coverts pure white, and usually little or no chestnut on the lesser wing coverts.

Length, I9; wing, I0.15; bill, I.55.

This species is common in Illinois and Wisconsin during the migrations. It apparently does not breed in Illinois, but it still does so in northern Wisconsin. The nest is placed on the ground and is composed mostly of feathers and down. The eggs are 9 to I 2 , uni- 


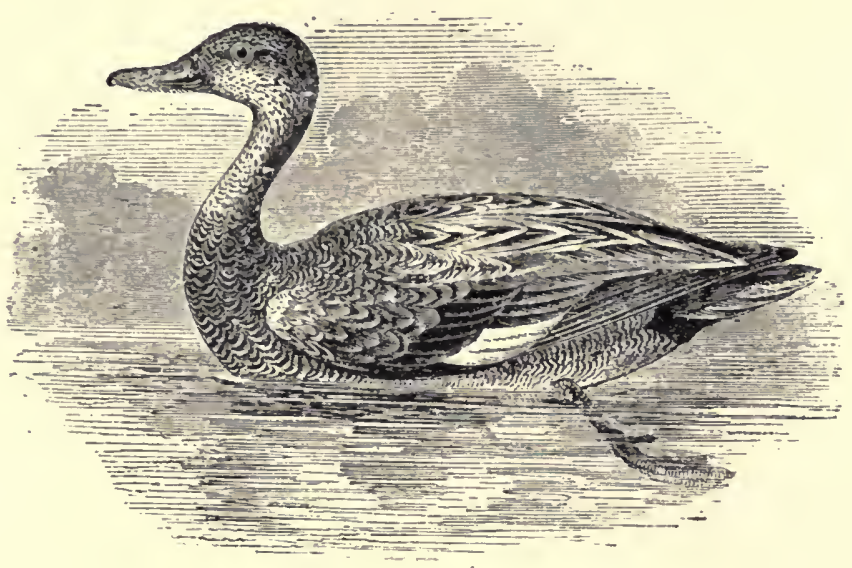

Gadwall Duck.

form cream color or pale buffy white, and measure about $2.10 \times 1.50$ inches.

The Gadwall is known to gunners as Gray Widgeon and Creek Duck. "Very common during the migrations from the middle of October to the last of November and from the first to the last of April." (Nelson, Birds N. E. Ill., I876, p. I39.) "Found principally as a migrant during April and October. Not nearly as common as formerly, in fact at the present time not at all common. Known to nest sparingly near Lake Koshkonong, twenty-five or more years ago. Capt. Goss found it breeding in Horicon Lake (now Horicon marsh). Mr. C. F. Carr records it as breeding in the extreme northern part of the state." (Kumlien and Hollister, Birds of Wisconsin, I903, p. I 8.)

\section{Genus MARECA Stephens.}

\section{Mareca penelope (LinN.).}

EUROPEAN WidGEON.

Anas penelope Linn., A. O. U. Check List, r 895, p. 49.

Distr.: Old World species, accidental in the United States. Numerous records from widely separated localities; Alaska, British Columbia, Wisconsin, Illinois, Ohio, Indiana, Massachusetts, Nova Scotia, Florida, etc., etc.

Adult male: Somewhat resembles the American Widgeon, but has the crown buff cream color and the rest of the head and neck rufous 


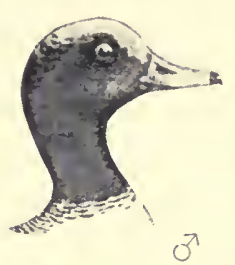

brown, except the throat, which is dusky; back marked with fine wavy lines.

Adult female: Whole head and throat, rusty brown, finely marked with black; greater wing coverts, grayish brown, tipped with black.

Length, about I9; wing, I0.50; bill, I.40.

At least three specimens of the European Widgeon have been taken in Illinois and several in Wisconsin, two of which, according to Kumlien and Hollister, were killed at Lake Koshkonong.

$\mathrm{Mr}$. Ruthven Deane records 20 birds of this species having been killed in interior states, many of them in Indiana. (See Auk, I899, p. $270 ; I b .$, I 903, p. $303 ; I b .$, I 905, p. $76 ; I b .$, I905, p. 206.)

\section{Mareca americana (GMEL.).}

American Widgeon. Baldpate.

Anas americana Gmel., A. O. U. Check List, I895, p. 49.

Distr.: North America generally; breeds chiefly north of the United States; south in winter to the Gulf coast, West Indies, Mexico, and Guatemala.

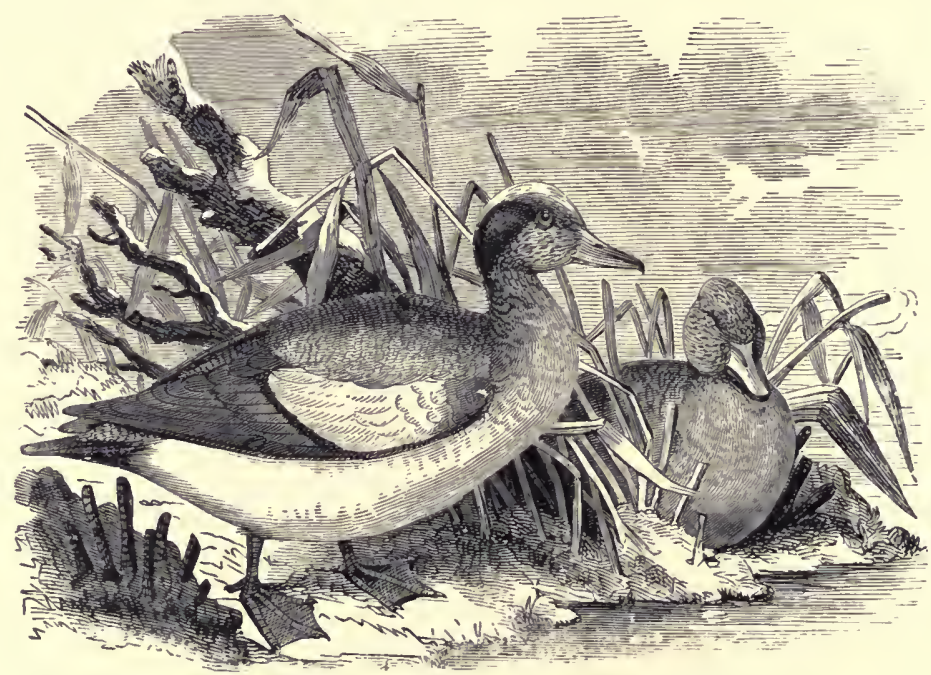

Adult male: Head, speckled black and white; top of head, white; a broad stripe of greenish from eye to the occiput; chin, blackish; upper breast, pale ashy lilac or vinaceous; rest of under parts, pure white; crissum and under tail coverts, black; back, ashy vinaceous, 
finely pencilled with black; a broad patch of white on the wing; most of the secondaries have the outer web black, edged with white; the inner webs are grayish towards the tip; speculum, black and green; axillary plumes, white, with dark shafts.

Adult female: Head and throat, whitish or buffy white, streaked and mottled with black; back, grayish brown; tertials, dusky, edged with whitish.

Length, I9; wing, 10.5०; tarsus, r.60; bill, r.40.

This species is common in Illinois and Wisconsin during the migrations. It is barely possible a few may still breed in northern Illinois, and, according to Kumlien and Hollister, it formerly bred in Wisconsin as far south as Lake Koshkonong and still does so in the less settled portions of the state. The nest is placed on the ground and is mostly composed of feathers and down. The eggs are buffy white, 8 to $\mathrm{I} 2$ in number and measure about $2 . \mathrm{I} 5 \mathrm{X} \mathrm{I.45}$ inches.

"A very abundant species during the migrations and not very rare summer resident." (Nelson, Birds N. E. Ill., r876, p. r40.) W. W. Cooke states it has been known to breed in Illinois. (Report of Bird Migration in Mississippi Valley, I888, p. 66.)

\title{
Genus NETTION Kaup.
}

\section{Nettion carolinensis (GMEL.).}

\author{
Green-winged Teal.
}

Anas carolinensis Gme1., A. O. U. Check List, r 895. p. 50.

Distr.: North America in general, breeding chiefly north of the United States; south in winter to Mexico, Central America and the West Indies.

Adult male: Head and neck, chestnut brown; a patch of green behind the eye extending to the nape; crown feathers are somewhat

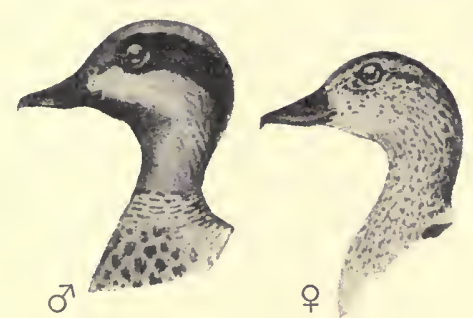
elongated, forming a small crest; sides and back, pale, marked with narrow fine lines of black; under parts, white, shading into pale brown or buff on the breast, which is also spotted with black; speculum, green, bordered with black and chestnut.

Adult female: Top of head, brownish, margined with reddish brown; throat and side of neck, white, spotted with black; breast, brownish, with black spots; rest of under parts, white, sometimes showing black spots on the under tail coverts. 
Length, I 4.50; - wing, 7.20; tarsus, I.20; b1ll, I.45.

The Green-winged Teal is common in Illinois and Wisconsin during the migrations and is claimed to breed sparingly in both states.

The nest is placed on the ground and is thickly lined with down. The eggs are 6 to 12 , usually 9 or ז 0 , pale buff or cream buff in color, and measure about $1.80 \times 1.20$ inches.

In Illinois it has been found breeding in the northern portion of the state, "Rockwood, Lacon, and Fernwood." (Cooke, Bull. Biological Survey, I906, p. 3г.) "Breeds sparingly." (Nelson, Birds N. E. Illinois, I 876 , p. I40.) "Formerly bred sparingly even in southern Wisconsin, eggs having been taken on Black Hawk Island, Lake Koshkonong, by L. Kumlien, in May, I870. At least two other authentic nesting records at this place are known. Further north they breed more plentifully, but the larger number pass beyond our border." (Kumlien and Hollister, Birds of Wisconsin, I903, p. r9.)

\section{Genus QUERQUEDULA Oken.}

\section{Querquedula discors (LinN.). \\ Blue-winged Teal.}

Anas discors Linn., A. O. U. Check List, I895, p. 50.

Distr.: North America in general, but chiefly eastward, breeding northward from Kansas and southern Illinois to Alaska; south in winter to the West Indies, Central and South America as far as Chili.

Adult male: Head, gray, with purplish gloss, darkest on top; a white patch resembling a crescent in front of the eye; greater and
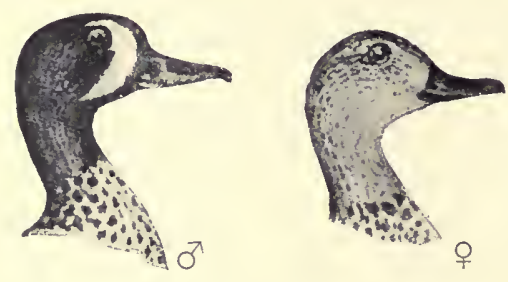
middle wing coverts, pale grayish blue, forming a grayish blue patch on the wing; speculum, rich green; under parts, purplish gray, spotted on the breast with black; the flanks are narrowly barred with black; bill, black; feet, yellow. Adult female: Showing a blue patch on the shoulder which distinguishes it from other teals, except the female of $Q$. cyanoptera, which has the chin dusky; and the upper throat often tinged with rufous. The locality where it is taken should also be considered.

Length, about 15.75 , wing, 7.25 ; tarsus, I.20; bill, I.60.

The Blue-winged Teal is a common summer resident in Illinois and Wisconsin, and breeds in May and June in suitable localities 
throughout the states. The nest is a mass of feathers thickly lined with down, placed on the ground, usually more or less concealed. The eggs are from 7 to 12 , pale buff or cream buff in color, and measure about $\mathrm{I} .80 \mathrm{x}$ I. 30 inches.

\section{Querquedula cyanoptera (VIEILl.). \\ Cinnamon Teal.}

Anas cyanoptera Vieill., A. O. U. Check List, I895, p. 50.

Distr.: Western America from the Rocky mountains and Texas to the Pacific, and from British Columbia south through Middle America and South America to Patagonia and Falkland Islands; casual in the Mississippi Valley and Florida.

Adult male: Head, neck, and upper parts, chestmut brown, the crown somewhat darker than the sides of the head; under parts,

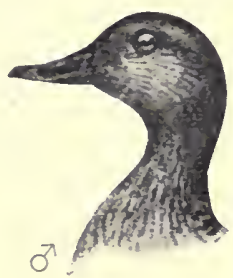
brownish, showing dusky on the belly; rump, olive brown, feathers becoming lighter on the edges; wing coverts, blue gray; speculum, green, the general coloration of the wing being similar to the Blue-winged Teal, but the coloration of the body is so different that it should never be confounded with that species.

Adult female: Resembles the female of the Bluewinged Teal, although somewhat larger; the bill is larger, and the under parts usually show at least a trace of the chestnut marking of the male; the throat, more speckled; chin, dusky and often with rufous tinge, otherwise apparently similar to $Q$. discors.

Length, I6; wing, 7.50; bill, I.75; tarsus, I.30.

Ridgway says: "It is of irregular and uncertain occurrence, having been only once or twice taken in Illinois." "An occasional visitant in Manitoba, Minnesota, Nebraska, Illinois, and Louisiana." (W. W. Cooke, Bird Migr. Miss. Val., I888, p. 68.)

For Wisconsin Kumlien and Hollister record two specimens taken at Lake Koshkonong and add: "There are several more or less authentic records among well-informed sportsmen in different parts of the state and at the Club House on Lake Koshkonong." (Birds of Wisconsin, 1903, p. 20.) 
Genus SPATULA Boie.

48. Spatula clypeata (Linn.).

Shoveller Duck.

Local names: Spoon-bill. Broad Bill.

Distr.: Northern hemisphere, breeding chiefly (in North America) from the Canadian border to the Saskatchewan region, although it breeds more or less commonly much farther north and south. It has been known to nest in Alaska and also as far south as Texas. It winters from southern Illinois and the Carolinas southward. Very abundant in Florida and along the Gulf coast, while a great many continue their migration as far south as South America (Bogata). It also occurs in more or less numbers in the West Indies, Mexico, and Central America.

Adult male: Bill, very much broadened; head and neck, dark green; breast, pure white, shading into purplish chestnut on the belly;
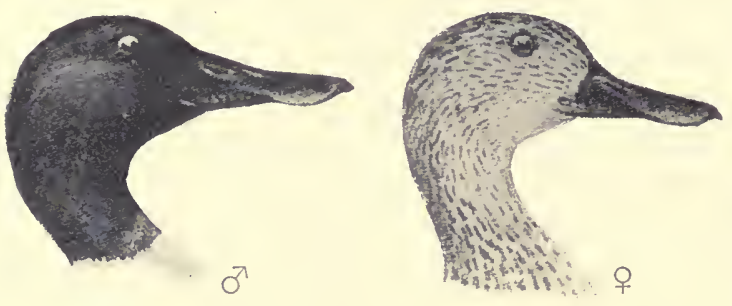
wing coverts, blue; speculum, green, edged with white; feet, orange red.

Length, 20 ; wing, 9.50 ; bill, 2.70 ; tarsus, r.50. Adult female: Head and neck, mottled and streaked with pale brown and dark brown or black; under parts, brownish, mottled and spotted with fuscous, scarcely showing on the middle of the belly; speculum and wing coverts as in the male.

Immature male: Intermediate in plumage between the adult male and female, but the speculum shows but little green, and the wing coverts are slaty gray; the head is often blotched and mottled when changing to adult plumage.

Length, I9.50; wing, 9.50; bill, 2.60 ; tarsus, 1.50.

The Shoveller Duck is abundant during the migrations and a few may still breed in Illinois. It is a not uncommon summer resident in Wisconsin.

The nest is composed of feathers and down placed on the ground. The eggs are 7 to ro, pale buff white, and measure about 2.10 X 1.45 inches.

"An abundant migrant and rather common summer resident. 
Breeds in much the same localities as the preceding ( $Q$. discors). Its eggs are deposited early in May. Arrives the last of March and the larger number pass north before April zoth." (Nelson, Birds N. E. Illinois, 1876 , p. I 40.) “It is still a common duck but can hardly be called abundant. *** Essentially a duck of the large marshes and shallow lakes in these localities. Considerable numbers still nest within the state, even in the most southern counties." (Kumlien and Hollister, Birds of Wisconsin, 1903, p. 20.)

\section{Genus DAFILA Steph. \\ 49. Dafila acuta (LINN.). Pintail Duck.}

Local names: Sprig-tail. Pheasant Duck.

Distr.: A cosmopolitan species, inhabiting the Northern hemisphere, breeding (in North America) from the northern United States northward and ranging south in winter to the Gulf coast, the West Indies, Mexico, and Central America to Panama; abundant in Florida.

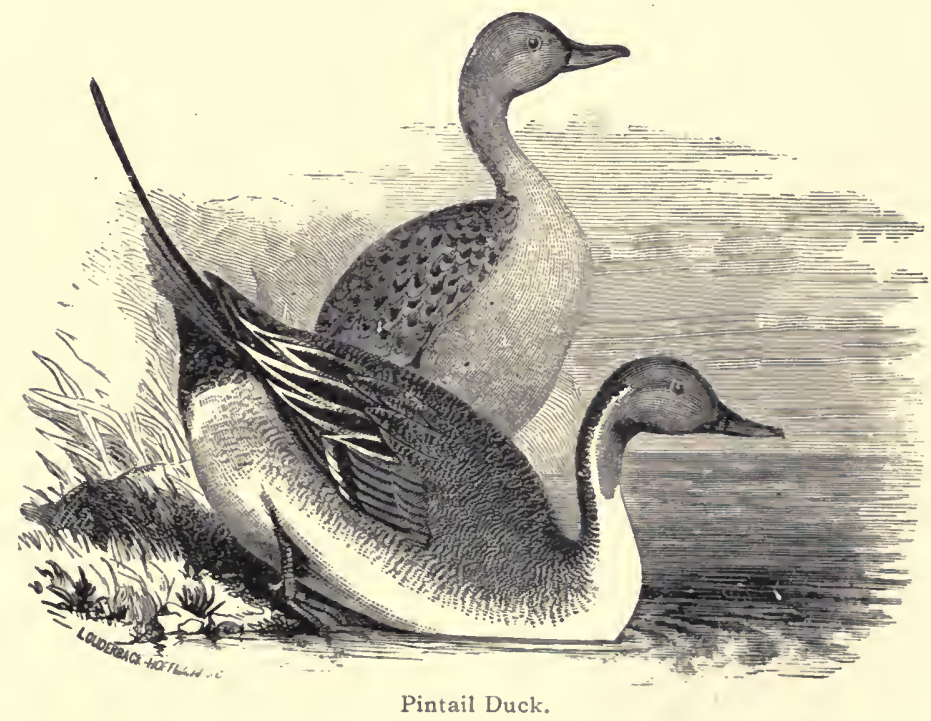

Adult male: Bill, lead color, the base and a stripe along the culmen, black; head and neck, rich brown, sometimes showing a faint gloss of green on the feathers; sides of the neck showing a stripe of white, and a stripe of black extending down the back of the neck; under parts, white, showing faint, wavy, fine lines of dusky on the 
sides; crissum, black, edged with white; central tail feathers, very much elongated in the male; feet, lead color.

Length, 28; wing, 9.50; tail, 7; bill, 2 .

Adult female: Tail feathers, not so much elongated as in the male, but broad and pointed; crown and sides of the head, streaked with dusky and pale brown; breast, spotted with dark brown or black; under parts, white; abdomen and sides showing faint lines of dusky; under wing coverts, fuscous, edged with white; axillary plumes, white, barred with dark brown; speculum, grayish brown, edged with white. The immature male shows considerable variation in plumage, the under parts being usually more streaked or spotted than the adult female, which it otherwise somewhat resembles.

Length, 22; wing, 9.25; tail, 3.5०; bill, 2 .

This species is abundant during the migrations in Illinois and Wisconsin, and is claimed to breed casually in Wisconsin and occasionally in northern Illinois. The nest is of grass and sedge, sometimes lined with feathers and down and often without. The eggs are 8 to I2, pale buff white (sometimes showing a faint bluish tinge), and measure about $2.25 \times 1.50$ inches.

"Very abundant migrant and rare summer resident. **** Every year a few pairs breed upon the marshes in this vicinity. $* * * *$ In the spring of 1875 , several pairs of these birds nested in the prairie sloughs near the Calumet River, and on the 2 th of May I found a nest containing three freshly laid eggs." (Nelsons, Birds N. E. Illinois, I 876 , p. I39.) "An abundant migrant. A few still nest within the state, but they are being gradually pushed further and further north for the summer season." (Kumlien and Hollister, Birds of Wisconsin, 1903, p. 20.)

\section{Genus AIX Boie.}

\section{Aix sponsa (Linn.).}

\section{Wood Duck.}

\section{Local name: Summer Duck.}

Distr.: Temperate North America, breeding throughout its range from Nova Scotia and southern British Columbia south to Cuba and southern California (Mexico, one record from Mazatlan).

Adult male: Bill, red, marked with rose-white, and a black stripe on the middle of the upper mandible and tip; under mandible, black; head, with decided crest which shows white, metallic green, and purple; a narrow superciliary line from the bill to the occiput and 


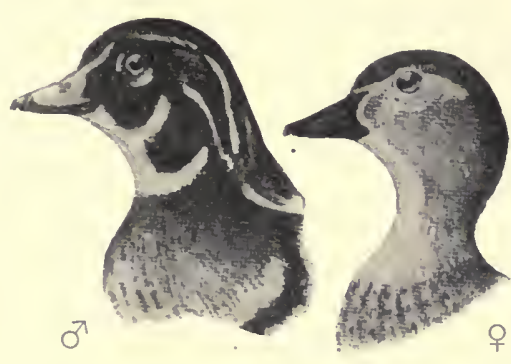

another stripe of white behind the eye, extending to the nape; chin and throat, white, extending upwards in a streak on sides of the head to the ear coverts; sides and front of the lower neck and under breast, purplish chestnut, dotted with white spots; under parts, white, sides sometimes grayish, showing faint pencilling of dusky

lines; upper parts showing bronze-green and purple; speculum, bluish green, edged with black and white.

Length, I8.50; wing, 9.50; bill, 1.40.

Adult female: Crest, small, but the feathers somewhat lengthened; head and neck, grayish, whitening on the chin and front of the eyes; front of the neck and breast, pale brown, mottled with grayish; the breast showing numerous brown spots, which fade away on the lower breast; belly, white.

Length, I8; wing, 9.30; bill, 1.35.

The Wood Duck is a common summer resident in parts of Illinois and Wisconsin, but like most other species it is decreasing in numbers. It breeds in both states in suitable localities, preferring wooded streams and ponds to the larger lakes. The nest is placed in a hole in a tree or large stump, from which the female carries the young in her bill down to the water. The eggs are from 8 to I 2 , sometimes $\mathrm{I}_{4}$, pale buff white, and measure about $2.05 \times 1.50$ inches.

"Common migrant and rather common summer resident in secluded localities and is especially abundant in the 'bottoms' along the rivers in the southern part of the state." (Nelson, Birds N. E. Illinois, 1876 , p. 1 40.) "Formerly a very common summer resident in all heavily wooded regions about streams; at the present time more common during the migrations, spring and fall. **** Considerable numbers still nest in favorable localities in the central and northern parts of the state and in a few places in southern Wisconsin, as about Delavan Lake." (Kumlien and Hollister, Birds Wisconsin, r $9 \circ 3$, p. 20.)

\section{Subfamily FULIGULINÆ. The Sea Ducks.}

The members of this subfamily have the bill broad, and a flap or membranous lobe on the hind toe. Although classed as "sea ducks" 


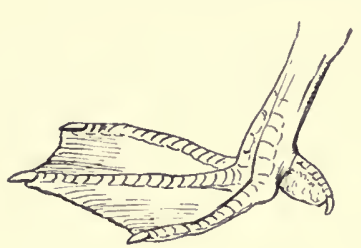

because they are partial to salt water, many of the species occur in large numbers on the interior lakes, rivers, and marshes. Their food consists of mollusks, small fish, and crustaceans, as well as the roots of aquatic plants and seeds. Their nests are usually placed on the ground or among rocks, although a few species, such as the Golden-eye, Buffle Head, etc., lay their eggs in hollow trees.

\section{Genus MARILA Oken.}

\section{Marila americana (EyTON).}

REDHEAD.

Aythya americana (Eyt.), A. O. U. Check List, I895, p. 52 .

Local name: Redhead Duck.

Distr.: North America, breeding from Maine, northern Michigan, Wisconsin, and California northward. Winters in numbers from Chesapeake Bay to Florida and along the Gulf coast to Texas, casual as far south as Mexico and Jamaica.

Adult male: Head and neck, brownish chestnut; lower neck and upper breast, blackish; back, apparently grayish, being white pencilled
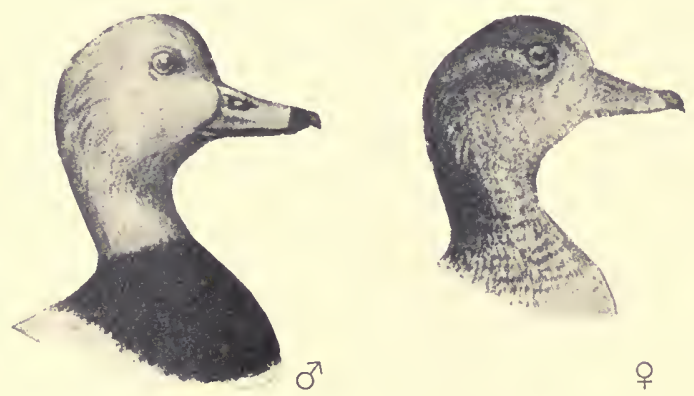
with fine, wavy lines of black; speculum, grayish; upper feathers edged with black, the rest narrowly tipped with white.

Length, 2I; wing, 8.40; tarsus, r.6o; bill, 2.20 .

Adult female: Bill, bluish, showing an indistinct bar near the end; head and neck, reddish brown, palest on the sides of the head, becoming ashy on the sides of the head; upper throat, white; breast and sides, brownish; belly, white; under tail coverts and lower belly, sometimes washed with pale brownish.

Length, 20.50; wing, 8.30; tarsus, r.60; bill, 2.20.

A common species in Illinois and Wisconsin during the migrations and, according to Kumlien and Hollister, a few pairs still breed in Wisconsin in the marshes about Lake Koshkonong.

The nest is in a marsh, made loosely of grass and usually lined 
with feathers and down. The eggs are cream white or grayish white, and measure about $2.35 \times$ I.40 inches.

\section{Marila vallisneria (WILs.).}

Canvas-Back DUCK.

Aythya vallisneria (Wils.), A. O. U. Check List, I895, p. 53.

Distr.: North America, breeding chiefly from North Dakota. Alberta, and southern Canada, and northwest to Alaska, migrating south in winter to the southern and southeastern United States from Chesapeake Bay and the Carolinas along the Gulf coast to Texas and Mexico; accidental in Cuba.

Adult male: Head and neck, rufous brown, becoming dusky on the crown and chin; the breast and upper portion of the back,

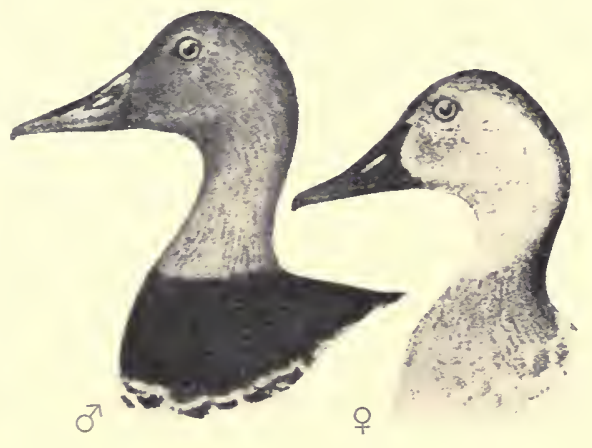
blackish; rest of upper parts and wing coverts showing fine, wavy lines of black, general appearance being grayish; belly, white, the lower portion faintly lined with dusky; sides, white, showing the delicate lines as on the back, but very much fainter and sometimes wanting.

Adult female. Head and neck, cinnamon brown, paler

on the throat; belly, white or grayish white.

Length, 20 to 22 ; wing, 8.75 to 9.25 ; bill, .75 to .80 ; tarsus, 1.70 .

The peculiar form of the bill will always distinguish the Canvasback from the Redhead, which is the only species with which it could be confounded. This species is still common during the migrations in both Illinois and Wisconsin. Although it may have formerly bred occasionally in Wisconsin, it is doubtful if it does so at the present time. Messrs. Kumlien and Hollister write: "We know of three instances of females being seen with nestlings but incline to the opinion that the birds were winged and could not continue the journey northward." (Birds of Wisconsin, I903, p. 22.)

53. Marila marila (Lins.).

Scaup Duck.

Aythya marila nearctica Stejn., A. O. U. Check List, I 895, p. 53.

Local names: Bluebill or Blackhead. 
334 Field Museum of Natural History-Zoölogy, Vol. IX.

Distr.: Northern hemisphere, breeding chiefly (in North America) from North Dakota to Alaska and casually to the Gulf of St. Lawrence. The greater number go south in winter to the Gulf states, Mexico, and the West Indies.

Adult male: Head and neck and upper breast, black, showing greenish reflections; back, grayish white, delicately lined with fine, wavy lines of black, giving it a grayish appearance;

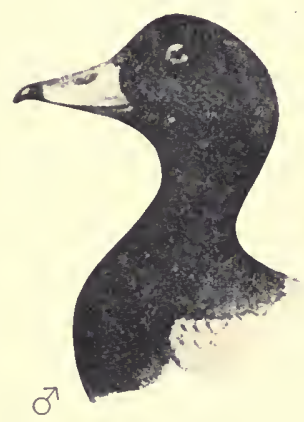
speculum, white; under parts, white, the lower belly showing grayish tinge. Length, I9; wing, 8.50; tarsus, $1.5^{\circ}$, bill, 2 .

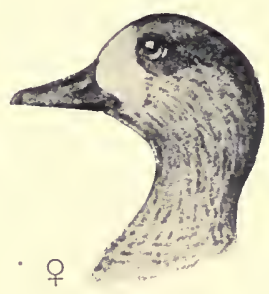

Adult female: Patch at the base of the bill, white or grayish white; rest of the head and neck, breast, and upper back, brownish; belly, white; speculum, white.

Length, 17.75 ; wing, 8.25 ; tarsus, I.30; bill, I.60.

The Scaup Duck occurs on Lake Michigan and waters in the interior of Illinois and Wisconsin during the migrations. More or less. common, varying in different seasons, but rare in comparison with next species.

\section{Marila affinis (EутоN). \\ Lesser Scaup Duck.}

Aythya affinis (Eyt.), A. O. U. Check List, r 895, p. 53.

Local name: Bluebill.

Distr.: North America in general, breeding chiefly north of the United States; south in winter to the Gulf coast and West Indies, Mexico, and Central America to Panama.

Adult male: Resembles the male of the preceding species, but is somewhat smaller in size; the head generally shows a faint gloss

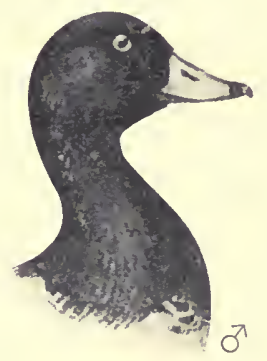
of purplish, which in the Scaup Duck is usually greenish, and the wavy black bars on the flanks. are more distinct and heavier; speculum, white.

Length, about I7; wing, about 8.10; tarsus, I.5०; bill, I.75.

Adult female: Similar to the female of the preceding species, except that it is smaller.

The white speculum (band on the wing) will always distinguish this species in any plumage from the Ring-necked Duck, which has the speculum gray . Length, about $\mathrm{I} 6.25$; wing, about 7.75 ; bill, about $\mathbf{I} .55$. 
The Lesser Scaup Duck is abundant on Lake Michigan and in the interior waters of Illinois and Wisconsin during the migrations. It may occasionally breed in Illinois, and, according to Kumlien and Hollister, it breeds in Wisconsin. The nest is on the ground, usually composed of grass and lined with down. The eggs are 7 to ro, grayish buff or olive buff, and measure about $2.25 \times$ r.6o inches.

"An exceedingly abundant migrant, and in years when the Lake does not become frozen over, is a resident through the year. $* * * *$ About the time they leave for more northern breeding grounds, they congregate in very large flocks on rivers or small lakes and soon all have disappeared from these haunts, and none, except the comparatively few which remain to breed, are found there again until they return in Autumn, about the 5th to Ioth of October." (Nelson, Birds of N. E. Illinois, I876, p. I4I.) "An exceedingly abundant migrant both spring and fall. **** To a limited extent, a breeding species even in southern Wisconsin, having been known to nest anywhere from the southern counties northward." (Kumlien and Hollister, Birds of Wisconsin, 1903, p. 23.)

\section{Marila collaris (Donov.). Ring-NECKED DUCK.}

Aythya collaris (Donov.), A. O. U. Check List, I895, p. 53.

Distr.: North America, breeding chiefly from North Dakota to the Athabaska region and migrating south in winter to the Gulf coast, the Greater Antilles, Lower California, and Mexico.

Adult male: Head and neck, upper breast, and upper back, black, usually showing faint bluish reflections when held in the light. In

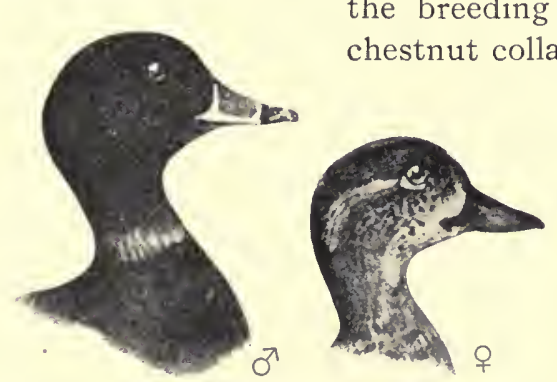
the breeding season the male has an orange $r$, which is usually lacking later in the season; belly, white, with the lower belly finely lined with blackish; speculum, gray; bill, dusky, showing a faint bluish gray band near the end.

Adult female: Head, brownish, the sides mixed with grayish brown shading into whitish on face about base of the bill; belly, whitish, becoming grayish on the lower portion; bill, as in the male. Resembles the female Redhead Duck, but is smaller.

Length, I 7 ; wing, 8; bill, 2.

The Ring-necked Duck is common in Illinois and Wisconsin 
336 Field Museum of Natural History-Zoölogy, Vol. IX.

during the migrations. It breeds more or less commonly in Wisconsin and also does so (or did) in northern Illinois. The nest is built on the ground, usually in marshes or at least near water. The eggs are from 8 to I 2, pale buff or olive buff in color, and measure $2.25 \times 1.65$ inches.

"It often passes the winter in the southern portions of Illinois." (Ridgway.) "This species also breeds about the marshes in northeastern Illinois." (Nelson.) "Very common during spring and fall and to some extent a summer resident. *** Even at the present day some few nest regularly as far south as Rock County and more in the less settled regions." (Kumlien and Hollister, Birds of Wisconsin, r 903 , p. 23.)

\section{Genus CLANGULA Oken.}

56. Clangula clangula americana (BonAp.).

American Golden-eye.

Glaucionetta clangula americana (Bonap.), A. O. U. Check List, I 895 , p. 54 .

Local names: Whistler. Golden-eye Duck.

Distr.: North America, breeding chiefly from Maine and North Dakota northward and westward to Alaska; winters from the Great Lakes and New England coast south as far as Cuba, Lower California and Mexico.

Adult male: Head and throat, glossy dark green; a patch of white on cheeks at the base of the bill, rather round in form; lower throat and under parts, white, encir-
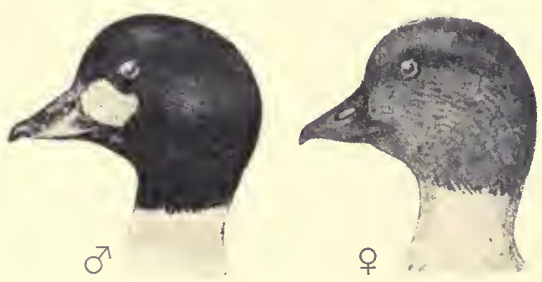
cling the neck and extending slightly upon the upper back; back, black; wings, black; many of the secondaries, white, and the wing coverts, heavily marked with white, giving the appearance of a very broad white patch on the wing.

Length, I9.50; wing, 9; bill, r.50; side of bill, r.90; tarsus, r.70; tail, 3.80 .

Adult female: Head and throat, hair-brown; neck, whitish; upper breast and sides of the body, strongly tinged with gray, the ends of the feathers being whitish; rest of the under parts, white; back, brownish black; wings, black; secondaries, mostly white, forming a broad, white wing band; wing coverts, tipped with gray. 
Length, I6.50; wing, 8.25; bill, I.30; side of bill, I.80; tarsus, I. 25 ; tail, 3.75 .

This species is common on Lake Michigan during the migrations and in winter. It occurs both in Illinois and Wisconsin and is claimed to breed in the latter state. The Golden-eye Duck usually builds its nest in a hollow tree. The eggs are 7 to 10 , pale grayish green or grayish blue in color, and measure about $2.30 \times 1.70$ inches.

"Common migrant throughout the state and abundant on Lake Michigan, where it is usually a winter resident." (Nelson, Birds of N. E. Illinois, I876, p. I $4 \mathrm{I}$.) "Common migrant and winter resident wherever there is open water. There are several breeding records for northern Wisconsin and we have ourselves seen adult males at various northern points during the summer, but found no actual evidence of nesting." (Kumlien and Hollister, Birds of Wisconsin, I 903, p. 24.)

\section{Clangula islandica (GMEL.).}

Barrow's Golden-eye.

Glaucionetta islandica (Gmel.), A. O. U. Check List, I895, p. 54.

Distr.: Iceland, Greenland and northern North America, breeding from the Gulf of St. Lawrence northward; south in winter to New York, Utah, and California.

Adult male: Head and neck, dark bluish purple; rest of under parts, white; a crescent-shaped spot of white on the cheeks at base of

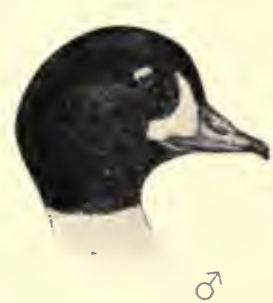
bill; a band of white about two inches wide passes round the neck and joins the white of the sides and breast; rest of upper parts, black; wings, black; and wing coverts, heavily marked with white, and many of the secondaries, white; tail, black.

Wing, 9.20 (male), 8.70 (female); bill, 1.25 , on side, 2 ; tail, 4 ; tarsus, I.50.

Adult female: Resembles the female American Golden-eye, but is somewhat larger; head, dark cimnamon-brown; lower throat and under parts, white, tinged with gray on the upper breast and sides of the body; back, gray, slightly mottled with brown, shading into brown on the rump; wings, black; many of the secondaries, white, and the greater and lesser wing coverts, tipped with grayish white; bill shorter and narrower at tip than in C. c. americana.

Barrow's Golden-eye is a rare winter visitant to Lake Michigan. Mr. Frank M. Woodruff procured two specimens on Lake Michigan near the Daily News Sanitarium, Dec. I I, 1896. (The Auk, I897, 
338 Field Museum of Natural History-Zoölogy, Vol. IX.

p. 227-288.) "It is a rare winter visitant, reaching here about the southern limit of its distribution." (Ridgway, Ornithology of Illinois, r895, p. I70.) "A winter resident upon Lake Michigan and found irregularly throwghout the state at that season. A specimen was obtained at Mt. Carmel on the Wabash River, in December, 1874 , by Prof. F. Stein, and I have observed it at Chicago." (Nelson, Birds N. E. Illinois, I876, p. I42.) Mr. J. G. Parker, Jr. has a specimen taken at Fox Lake, Illinois, January 2, I889. (Butler, Birds of Indiana, 1897 , p. 622.) "Actual records for the state are not many. Reported from Racine in 1860 by Dr. Hoy. One specimen was sent to Thure Kumlien from Edgerton in 1877 , and one was shot by L. Kumlien, Nov. I4, I896, on Lake Koshkonong." (Kumlien and Hollister, Birds of Wisconsin, I903, p. 24.)

\section{Genus CHARITONETTA Stejneger.}

\section{Charitonetta albeola (LINN.).}

\section{BUFFLE-HEAD.}

Local names: Butter-ball. Dipper. Buffle-headed Duck.

Distr.: North America, breeding from Maine and Montana northward to Labrador and Alaska; south in winter to the United States, and occasionally as far as Cuba (one record) and Mexico.

Adult male: A very small duck; head, upper neck, and throat, greenish purple. showing various reflections of bluish and greenish; a large white patch on the head, from the eye backwards; back, black;

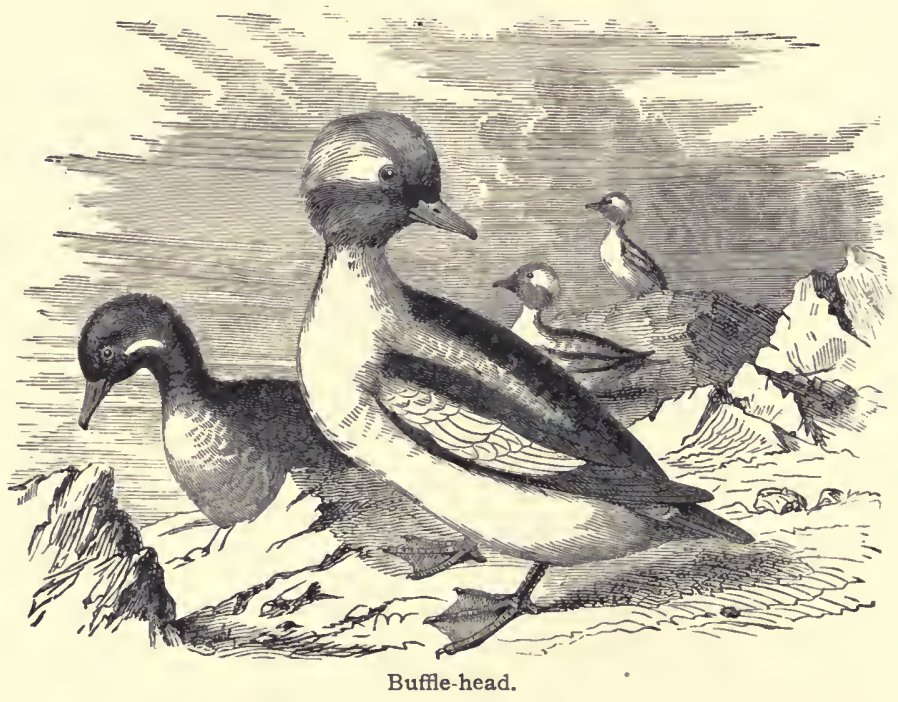


under parts, white; bill, lead color; feet, flesh color; wing coverts, and some of the secondaries, heavily marked with white, forming a broad, white wing patch.

Length, I2.75; wing, 6; tarsus, r.20; bill, r.

Adult female: Head and upper parts, brownish, showing a grayish white patch on the side of the head; under parts, white; speculum, white.

Length, I2.50; wing, 5.75; tarsus, 1.20 ; bill, 1 .

This species, like the Golden-eye, builds its nest in a hollow tree or stump. It is common in Illinois and Wisconsin during the migrations and in winter. There is no authentic record of its nest having been found in either state, although according to Kumlien and Hollister: "Young still unable to fly have been shot on Pewaukee Lake by B. F. Goss." (Birds of Wisconsin, I903, p. 25.)

Genus HARELDA Stephens.

59. Harelda hyemalis (LINN.). Old-SQUAW.

Clangula hyemalis (Linn.), A. O. U. Check List, I895, p. 55.

Local names: Old Wife. Long-tailed Duck.

Distr.: Northern hemisphere, breeding from Hudson Bay and northern Labrador north to about latitude 82 ; winters in eastern United States from New England to the middle states and casually to Florida, on the Pacific side to California and Texas.

Adult male in winter: Central tail feathers, black, much elongated; outer tail feathers, white; top of the head and back of the neck to
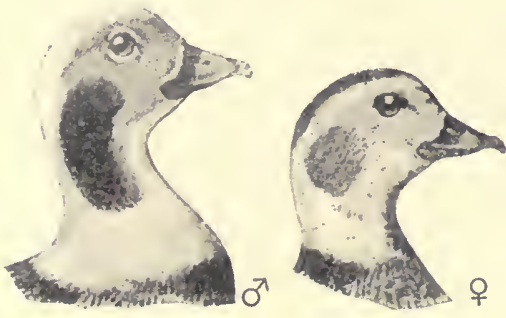
back; white; a patch of grayish on the sides of the head, including the eye, which is succeeded by a patch of black on the sides of the neck, bordered on the lower throat by an indication of brown; throat and upper breast, pure white; breast and upper belly, black, the black continuing over the back in a band;

lower belly and under tail coverts, white; wing coverts, black; quills, brown; a pale yellowish band across the end of the bill.

Adult male in spring: Head, smoky brown or black; crown, black; a white patch on the face including the eyes; entire neck and breast, smoky brown or black; rest of under parts, dull white; feathers of the upper back and scapulars edged with rufous. 
340 Field Museum of Natural History - Zoölogy, Vol. IX.

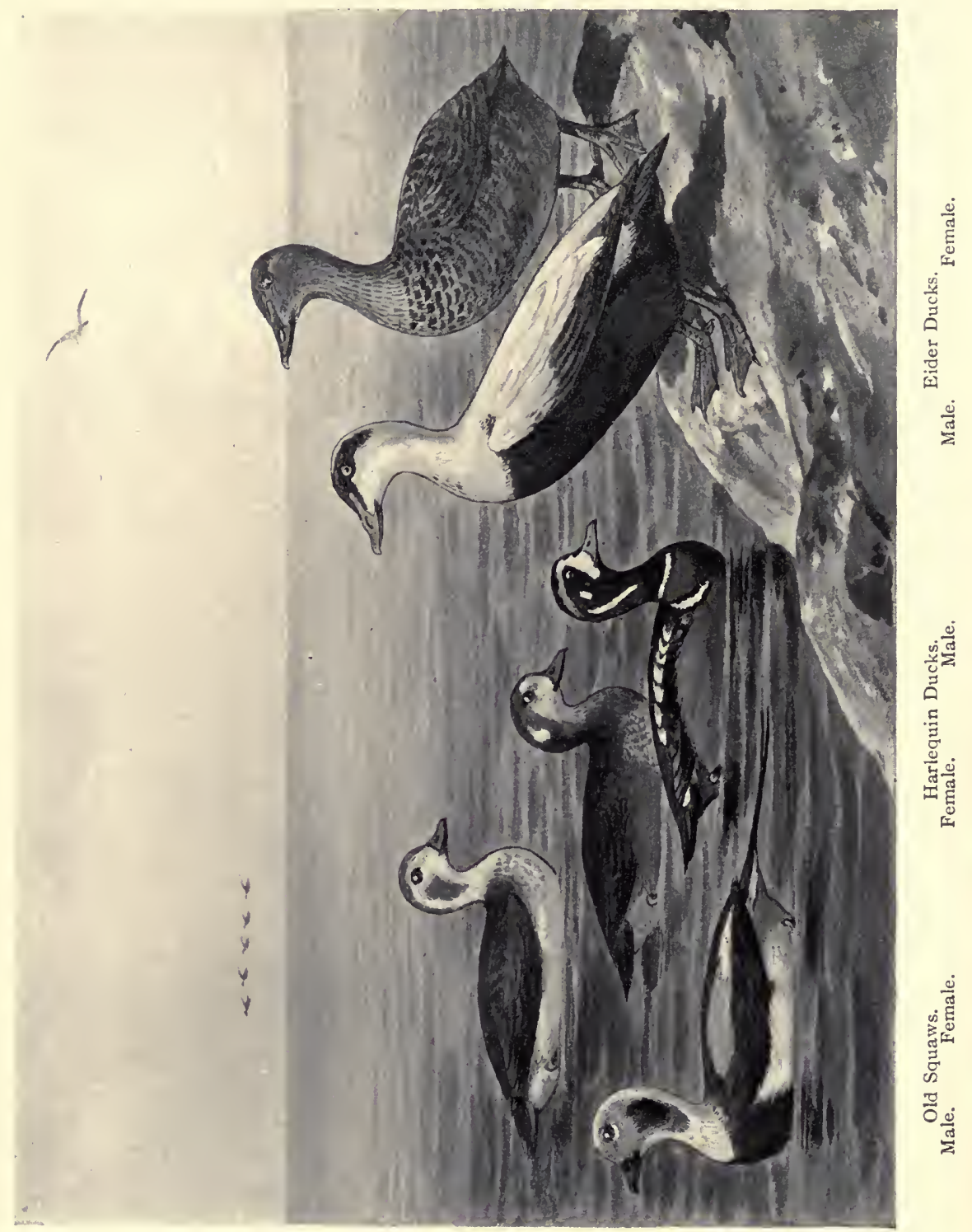

Adult female in winter: Head, dull white on the crown, and a patch on the side of the back of the head, smoky black or brownish black; under parts, fuscous; breast, grayish; belly, white; tail feathers, pointed, but not elongated as in the male.

Length (including tail), $2 \mathrm{I}$; wing, 8.5०; bill, I.Iо.

Abundant on Lake Michigan in the late fall and winter and occurs 
occasionally on inland waters in both Illinois and Wisconsin. Nelson records it from Mt. Carmel. "Small flocks are occasionally seen during the fall migration at St. Louis, Mo." (Cooke.)

\section{Genus HISTRIONICUS Less.}

\section{Histrionicus histrionicus (LINN.).}

\section{Harlequin Duck.}

Distr.: Northern North America and eastern Asia; south to middle Atlantic states, California and Japan in winter; breeds in Labrador, Greenland, Great Bear Lake, and intermediate localities about latitude $65^{\circ}$. Nests in hollow stumps and trees.

Adult male: Head, variously marked with gray, white, rufous brown, and black; a collar of white edged with black passes around the neck; a broad band of white edged with

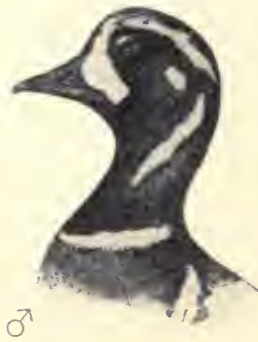
black commences on the sides of the breast and extends upwards; under parts, grayish brown; sides

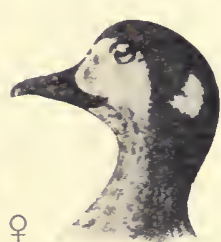

heavily marked with rufous brown; back, dark slate; the scapularies and tertials marked with white; speculum, very dark blue; under tail coverts, bluish black, showing a spot of white on the sides; tail, pointed.

Wing, 7.50; bill, I; sides of bill, I.35; tail, 4.50; tarsus, I.25.

Adult female: Head, grayish brown; face, whitish; spot of white on the ear coverts; entire upper plumage, dull brown; some of the feathers slightly washed with grayish; breast, grayish brown; rest of under parts, mottled grayish brown; wings and tail, brown, without white.

The Harlequin Duck is a rare winter visitant on Lake Michigan. "Rather rare winter resident upon Lake Michigan." (Nelson, Birds N. E. Ill., I876, p. I42.) "The Harlequin Duck is a winter visitant or resident in Illinois, but is probably not at any time a commion species." (Ridgway, Orn. of Illinois, I895, p. I73.) "Rare winter straggler to Lake Michigan. Dr. Hoy obtained at least four specimens at Racine." (Kumlien and Hollister, Birds of Wisconsin, I 903, p. 25.) "Very rare; admitted in Gibbs' Birds of Michigan. **** Prof. Ludwig Kumlien writes me that he has taken two specimens in Jefferson Co., Wisconsin." (A. J. Cook, Birds of Michigan, I893, p. 44.) A bird of this species was killed in 1880 on a small lake in Marion Co., Illinois, about seven miles from St. Louis, and recorded 
342 Field Museum of Natural History-Zoölogy, Vol. IX.

by Mr. Julius Hurter. (Bull. Nutt. Orn. Club, r88I, p. I 24.) "It is found throughout Illinois in winter and has been taken at St. Louis, Mo." (W. W. Cooke, Bd. Migr. Miss. Val., I888, p. 73.)

\section{Genus SOMATERIA Leach.}

\section{Somateria dresseri SHARPE. AMERICAN EIDER Duck.}

Distr.: Atlantic coast of North America, from Maine to Labrador, south to Delaware and west to the Great Lakes in winter.

Adult male: Top of head, black, with a stripe of white on the middle of the crown; occiput, pale green, the color extending on the
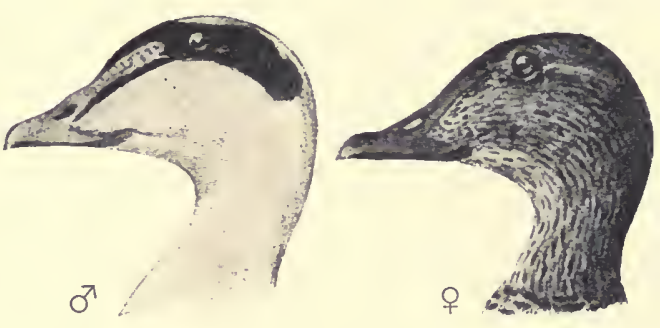
sides of the neck; rest of head, breast and back, white, faintly tinged with dull pinkish on the breast; rest of the under parts, black; tail, black; point of the divided culmen extending upon the forehead, blunt and rounded.

Adult female: General color, pale rufous brown, mottled and banded with black; head, tawny brown, faintly lined and dotted with black; some of the secondaries tipped with white.

Length, about 23; wing, about Ir; tarsus, I.75; bill, 2.ro.

The American Eider Duck closely resembles the Northern Eider, the principle difference being in the shape of the divided culmen, the points of which are broad and rounded, and not pointed as in the latter species. The Northern Eider, however, has not as yet been recorded from the Lake Michigan region, although it occurs commonly in Hudson Bay.

A rare resident on Lake Michigan in winter. A young male bird of this species was shot by a fisherman on the Lake front in Chicago, Dec. I, r9o8. The specimen was purchased by Mr. J. L. DeVine who kindly loaned it to me for examination.

"Not a very rare winter resident upon Lake Michigan and probably occurs in suitable places throughout the state. In my collection is an immature specimen obtained near Chicago, in December, $1874 . "$ (Nelson, Birds N. E. I11., I876, p. 142.) "Jake Michigan in winter, rare. Recorded at Racine in winter, I87.5, by Dr. Hoy. Two specimens were also taken at Milwaukee and were preserved in the Public Museum. The only positive record for the interior that we are aware 
of is one specimen, a female, shot on Lake Koshkonong in November, 189 I." (Kumlien and Hollister, Birds of Wisconsin, I903, p. 25.)

Subgenus ERIONETT TA Coues.

62. Somateria spectabilis (LINN.).

King Eider Duck.

Distr.: Arctic regions, south in winter occasionally as far as the Great Lakes and Virginia. It is found on the Pacific side among the Aleutian and Kadiak Islands, accidental as far south as San Francisco.

Special characters, adult male: Top and back of the head and nape, pale bluish gray; a black $\mathrm{V}$ on the upper throat; feathers

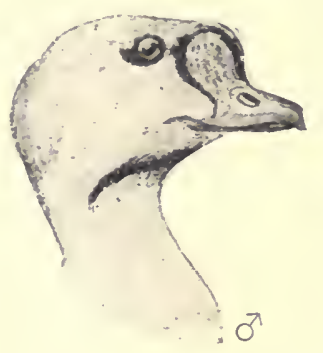
bordering the upper mandible and a spot below the eye, black; sides of head below the eye, whitish, more or less tinged with green; throat, white; breast and upper back, pale buff; rest of under parts, black; middle and greater wing coverts, white; rest of wings, tail and lower back, black; upper back, white; axillars, white. Length, 24; wing, II.25; tarsus, I.90; bill, I.30.

Special characters, adult female: Resembles in general coloration the Northern and American Eiders but may always be known by the peculiar shape of the upper mandible.

Length, 2 I to 24 ; wing, 10.50 to Ir.30; tarsus, r.80; bill, I.25.

The King Eider is a rare winter resident on Lake Michigan. "Rare winter visitant, perhaps winter resident to Lake Michigan and other parts of the state. An adult female obtained at Chillicothe on the Illinois River in the winter of 1874 has been sent to the National Museum by W. H. Collins, Esq., of Detroit, Mich. (Ridgway.)" (Nelson, Birds N. E. I11., I876, p. I 43.) Mr. Wm. E. Praeger records a male specimen of this species shot in the Mississippi River near Keokuk, Iowa, in November, I894. (The Auk, r895, p. 86.) Kumlien and Hollister (Birds of Wisconsin, p. 26) mention 6 specimens as having been taken in Wisconsin: Racine I, Milwaukee 4, Lake Sheboygan I, and others were observed.

\section{Genus OIDEMIA Fleming.}

63. Oidemia americana Sw. \& Rich.

American Scoter Duck.

Local name: Butter-bill Coot.

Distr.: Northern North America, breeding from latitude $52^{\circ}$ north- 
344 Field Museum of Natural History - Zoölogy, Vol. IX.

ward; winters from New Foundland to North Carolina and casually to Florida; on the Pacific side from Aleutian Islands to California.

Adult male: General plumage, entirely black; bill, black, the upper mandible being yellowish orange at the base; jeathers on the bill more
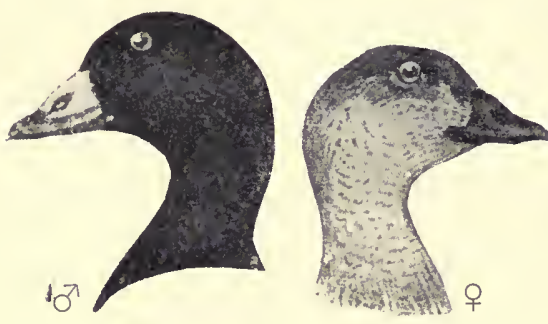
than one-half inch from the nostril; no white on the wing.

Adult female: Brownish, or sooty brown; paler on the under parts, becoming grayish white on the belly; sides of the head, whitish; feathers on the bill more than one-half inch from nostril: no white on the wing. The

female is smaller than the male.

Length, I 9; wing, 9.ro; tarsus, I.65; bill, I.80.

The American Scoter Duck is a common winter resident on Lake Michigan, its numbers varying with different seasons. Arrives in November and leaves early in April.

\section{Subgenus MELANITTA Boie.}

\section{Oidemia deglandi Bonap.}

\section{White-Winged Scoter.}

Local names: White-winged Coot. Velvet Duck.

Distr.: Northern North America, breeding from North Dakota and Labrador north to Hudson Bay and the Arctic coast; winters from the Gulf of St. Lawrence to South Carolina and casually to Florida, and on the Pacific side from Alaska to Lower California.

Adult male: General plumage, black; upper mandible, orange, blackish at the base; a white spot under the eye and a broad patch
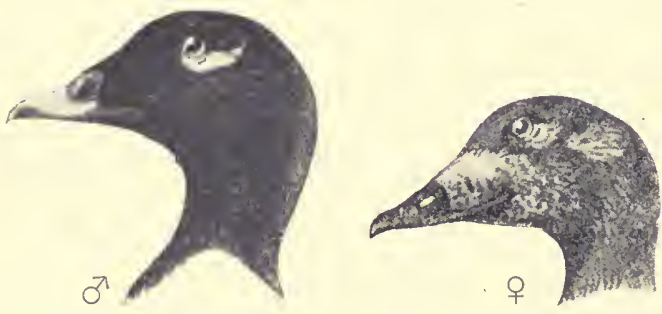
of white on the wing; feathers on the bill less than one-half incli from the nostril.

Adult female: Is grayish brown, showing a wash of grayish white at the base of the bill and behind the ears; the speculum is white, which is a good distinguishing character.

Length, 2I; wing, II.I5; tarsus, 2; bill (culmen), I.75; side measure, 2.75 . 
A common winter resident on Lake Michigan and on the larger waters in the interior of Illinois and Wisconsin and abundant during migrations.

\section{Subgenus PELIONETTA Kaup.}

\section{Oidemia perspicillata (Lisx.).}

\section{Surf Scoter.}

Local names: Skunk-head Coot. Goggle-nose.

Distr.: Northern North America, breeding from Newfoundland west to Alaska; winters from the Gulf of St. Lawrence to South Carolina and casually to Florida, and on the west coast from the Aleutian Islands to Lower California.

Adult male: General plumage, black, no white on the wing; head, black, with a white patch on the forehead and nape; feathers on the
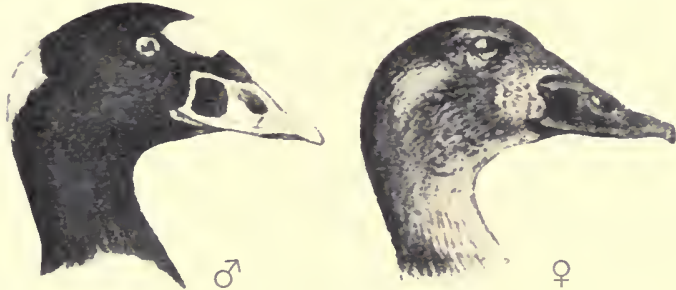
bill, less than one-half inch from the nostril.

A peculiar highly colored bill is one of the distinguishing marks of the male of this species, it being orange, yellow, black, and white, the feathers

on the top of the bill extending much farther forward than on the sides.

Female and immature: Brownish, showing a whitish spot at the base of the bill, and back of the eyes; the female having the upper parts, brownish; under parts, ashy gray, shading into whitish on the belly.

Length, 20.50; wing, 9.60; tarsus, 1.65; bill (culmen), 1.50; side measure, 2.35 .

This species may always be distinguished from $O$. americana by the forward extension of the feathers on the top of the bill, and from $O$. deglandi by the absence of the white wing patch.

Abundant on Lake Michigan in fall and winter, and in many of the interior waters of Wisconsin and Illinois until ice forms. Leaves for the north the last of March. 


\title{
Genus ERISMATURA Bonap.
}

66. Erismatura jamaicensis (GMEL.).

\author{
RUdDY DUCK.
}

Erismatura rubida (Wils.), A. O. U. Check List, I 895, p. 59.

Distr.: North America in general, from Hudson Bay, British Columbia and Great Slave Lake to the West Indies, Mexico, Lower California, and Central America; breeds nearly throughout its range.

Adult male in breeding plumage: Top of head and nape, black; sides of head, white; chin, whitish; throat, breast, and sides of body,
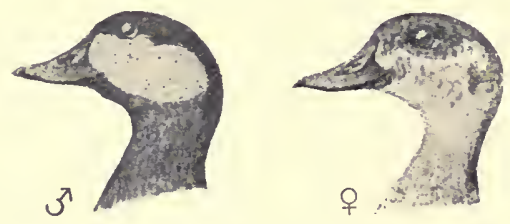

flanks and rest of upper parts, deep rufous brown; wings, brown, without white patch; axillars, grayish white, with pale brown or grayish brown shafts; tail, black, the feathers stiff and pointed.

Adult female: The general color

of the upper parts is brownish gray; sides of the head and throat, whitish, shading into gray on the lower throat and upper breast; under parts, silver white, as in the male.

Length, r5.30; wing, 6; tarsus, r.20; bill, r.50.

The Ruddy Duck may easily be distinguished from other species by its small size, and stiff, pointed tail feathers. It is common during the migrations in spring and fall, and a few remain in summer, and breed in both Illinois and Wisconsin.

Nelson mentions young birds of this species having been seen in northern Illinois, and Cooke states that it is known to breed casually in Ohio and Illinois. (Bull. Biol. Survey, No. 26, I906, p. 63.) It breeds regularly in southern Minnesota and casually in Wisconsin. Kumlien and Hollister state: "A few breed in the state, as about Lake Koshkonong, Pewaukee Lake, Lake Horicon, etc., but sparingly of late." (Birds of Wisconsin, 1903, p. 27.)

\section{Genus NOMONYX Ridgway.}

67. Nomonyx dominicus (LiNN.).

Masked Duck.

Distr.: Tropical America in general, including West Indies, ranging north as far as southern Texas, accidental in eastern North America. Stragglers have been taken in Massachusetts, New York, and Wisconsin. 
Special characters, adult male: Front of head and face, black; back of head and neck, rich rufous brown, shading into pale chest-
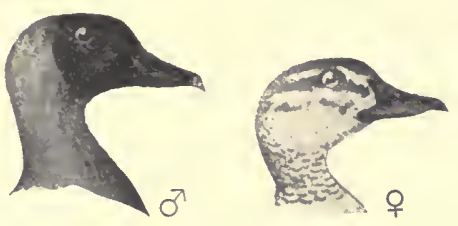
nut, or tawny brown on the under parts; basal portion of wing coverts, white, forming a white patch on the wing; primaries, brown; feathers of the back, black, edged with rufous brown; tail, black, the feathers stiff and pointed; axillars, white; upper mandible, light blue in life, showing a narrow middle stripe of black; feet, gray.

Adult female: Top of the head, and a stripe through the eye, and a cheek stripe, black, or brownish black; rest of the head, and upper throat, pale buff color, whitish on the chin; breast, tawny, mottled with black; rest of under parts, washed with tawny brown, shading into grayish on the abdomen; back, dark brown, the feathers tipped with pale brown, or tawny brown; wings and tail, as in the male; axillars, white.

This tropical species has been taken in Wisconsin; the record is as follows: "A single female was procured by Thure Kumlien, on Rock River near Newville, November, I870, and is now preserved in the collection of the Boston Society of Natural History." . (Kumlien and Hollister, Birds of Wisconsin, I903, p. 27.)

\section{Subfamily ANSERINÆ. Geese.}

Geese are gregarious, especially during migrations. When flying the flock assumes a V-shaped form and is led (it is claimed) by an old gander. They feed principally upon roots, seeds of aquatic plants, and grain and are often found in the grain fields in large numbers. The sexes are similar.

\section{Genus CHEN Boie.}

\section{Chen hyperborea (PALL.).}

Lesser Snow Goose.

Local name: White Brant.

Distr.: North America, breeds from Melville Peninsula to Victoria Land and probably north to latitude $74^{\circ}$; winters from southern Illinois, lower Mississippi Valley, Louisiana, and Texas to Mexico and Guatemala, casually to New England. 
348 Field Museum of Natural History-Zoölogy, Vol. IX.

Adult: General plumage, white; primaries, black; and primary coverts, pale ash. The immature bird has the head, neck, and upper parts, mottled gray and white; the rump and tail are white; under parts, white.

Length, 23 to 28 ; wing, 14 to 17 ; bill, 2 to 2.35 ; tarsus, 2.90 to $3: 20$.

The Lesser Snow Goose is more or less common in Illinois and Wisconsin during the migrations, apparently much more numerous along the Mississippi Valley than on Lake Michigan.

68a. Chen hyperborea nivalis (Forst.).

Greater Snow Goose.

Local name: White Brant.

Distr.: Northeastern North America, breeds in the far North. It is known to winter in numbers in the lower Mississippi Valley and on the coast of North Carolina and Chesapeake Bay. Casual or accidental as far south as Cuba and Jamaica.

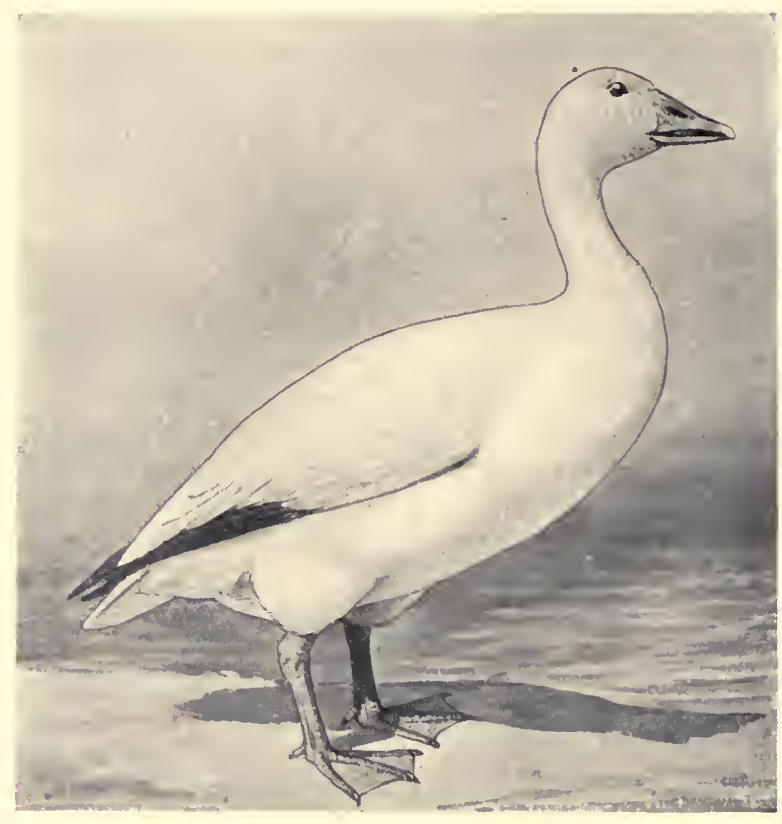

Snow Goose.

Adult: Resembles the Lesser Snow Goose, but is larger. Wing, I 7 to 17.75 ; bill, 2.50 to 2.70 ; tarsus, 3.10 to .3 .50 . Not uncommon 
Jan., igo9. Birds of Illinois and Wisconsin-Cory.

in Illinois and Wisconsin during the migrations. More common along the Mississippi Valley.

\section{Chen cærulescens (LINN.).}

Blue Goose.

Local name: Bald Brant. Blue Brant.

Distr.: Northeastern interior of North America, probably breeding north and east of Hudson Bay; nest and eggs as yet unknown. Winters from southern Illinois throughout the lower Mississippi Valley, Louisiana, and Texas; accidental in California, Cuba, and the Bahamas.

Adult: Head and neck, white or white, tinged with orange brown, or white tinged with grayish; back and breast, dark slaty brown;

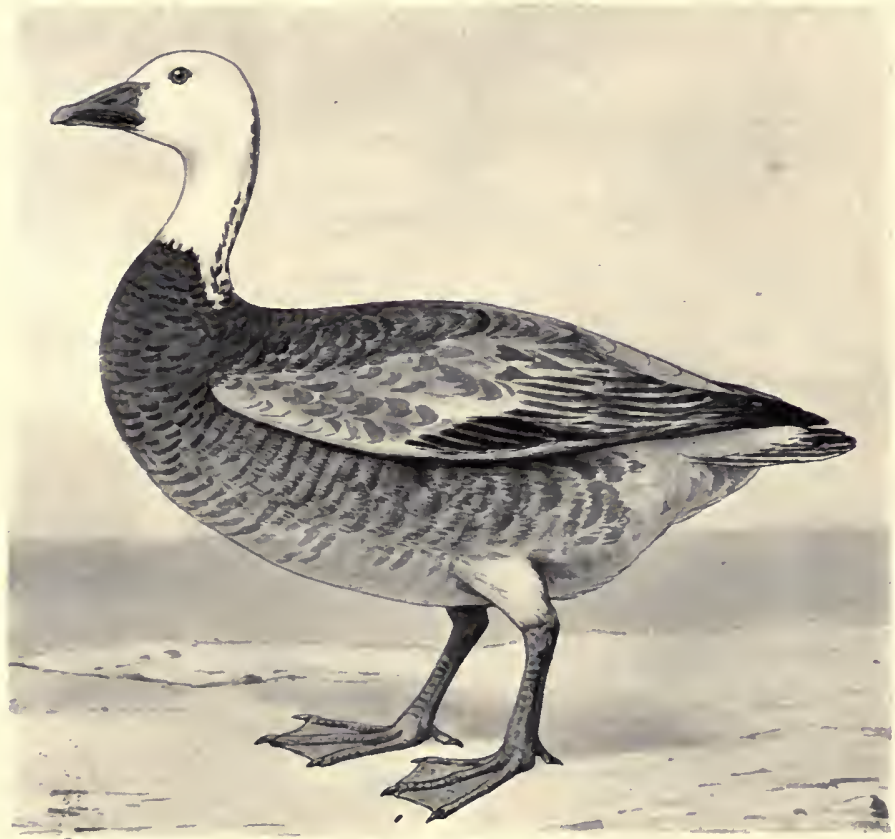

Blue Goose.

the feathers margined with lighter brown; wing coverts and concealed portion of primaries and secondaries, slaty gray; exposed portion of primaries and secondaries, brownish black; greater portion of the shafts, white; lower back and rump, slaty gray; under parts, dull slaty gray, the feathers margined with pale brown or rusty brown; axillars, hoary gray, with grayish brown shafts. 
$35^{\circ}$ Field Museum of Natural History-Zoölogy, Vol. IX.

Wing, I6.25; tail, 5.75 ; tarsus, 2.75 ; bill (culmen), 2.37 ; bill, (nostril to tip), I.37.

The Blue Goose is not uncommon along the Mississippi Valley during the migrations and occurs both in Illinois and Wisconsin, usually associated with White-fronted Geese or Snow Geese.

\section{Genus ANSER Brisson.}

\section{Anser albifrons gambeli (HARTL.).}

American White-fronted Goose.

Local names: Brant. Speckle-belly. Yellow-legged Goose.

Distr.: Northern North America, rare on the Atlantic coast; breeds in Alaska and winters in southern United States from southern Illinois southward and west to Texas, Mexico, and Lower California.

Adult: Forehead and base of bill, white; the rest of the head, brownish; neck, grayish brown, shading into dull white in front;

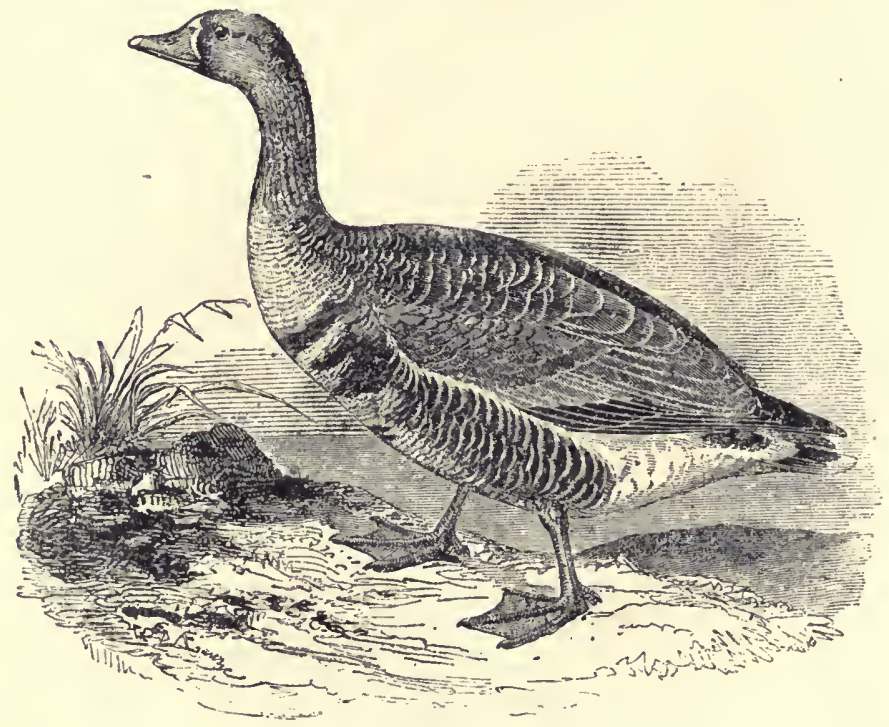

White-fronted Goose.

under parts, whitish, the breast showing black markings; back, ashy gray, the feathers edged with brown on the upper part; shafts of quills, white; bill, pinkish or reddish or pale white; feet, yellow.

The immature bird is similar, but shows no white on the base of the bill, or black markings on the breast.

Length, 28; wing, 16; bill, 2; tarsus, 2.90. 
Jan., I909. Birds of Illinois and Wisconsin-Cory.

This species is much less common than formerly, but still occurs in more or less numbers in Illinois and Wisconsin during the migrations.

\section{Genus BRANTA Scopoli.}

\section{7l. Branta canadensis (LINN.).}

\section{Canada Goose.}

Distr.: Temperate North America, breeding chiefly from the Saskatchewan and Alberta, Minnesota and North Dakota northward; south in winter from the middle Atlantic coast and. Gulf states as far as Jamaica and on the west side from British Columbia to Mexico.

Adult: Head and neck, black; a patch of white on the side of the head behind the eye extending to the chin; back and wings, grayish

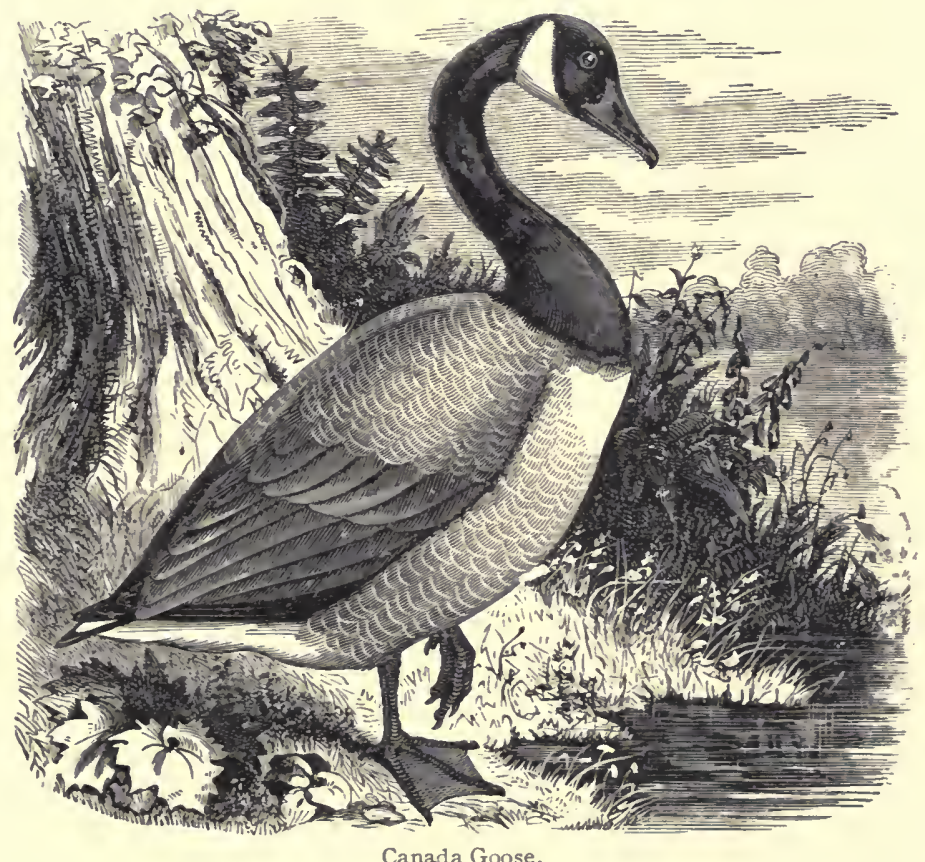

brown; breast and under parts, dull grayish white, becoming white on the belly; tail, black.

The immature bird is similar, but has the throat and cheeks sometimes mottled.

Size, large; length, 35 to 44 ; wing, I 5.75 to $2 \mathrm{I}$; tarsus, 2.50 to 3.75 ; bill, I.50 to 2.75 . 
The Canada Goose is common during the migrations in Illinois and Wisconsin, and once bred in numbers along the upper Mississippi Valley, but at the present time a few pairs make their nest occasionally in Michigan and Wisconsin, and possibly a very few in Illinois. The nest is a mass of sticks on the ground (very rarely in trees). The eggs are usually 4 to 5 , cream white or ivory white in color, and measure about $3.20 \times 2.25$.

The following varieties or subspecies are recognized. There are apparently no well marked differences to separate them, except that of size, and, while the extremes are easily recognized, intermediate specimens are numerous.

\section{7la. Branta canadensis hutchinsii (Sw. \& RICH.).}

Hutchins's Goose.

Distr.: Arctic America, south to Virginia, the Mississippi Valley, Lower California, and Mexico in winter; breeds in the far north from Melville Peninsula to Alaska.

Adult: Plumage, similar to $B$. canadensis; size, medium; length, 25 to 34 ; wing, I 4.75 to I 7 ; tarsus, 2.30 to 3.20 ; bill, I.20 to I.90.

The Hutchins's Goose is merely a small form of the Canada Goose, intermediate in size between it and the Cackling Goose. Common in winter from southern Illinois, Louisiana, and Texas, and at times abundant in Illinois and Wisconsin during the migrations.

\section{7lb. Branta canadensis minima RIDGW.}

CACKLING Goose.

Distr.: Northwest coast of Alaska and Lower Yukon, where it breeds. Winters from southern British Columbia to California; stragglers occur in the Mississippi Valley and Wisconsin.

Adult: Breast and upper belly often darker, being brownish instead of gray; size, small; length, 2 I to 25 inches; wing, I3.60 to I 4.50 ; tarsus, 2.30 to 2.75 ; bill, .95 to I.I 5 .

If this form occurs in Wisconsin or Illinois, it must be considered as accidental.

"Occasional migrant to Mississippi Valley, Wisconsin, Michigan, Illinois (mentions specimen from Andalusia, Illinois)." (Ridgway, Orn. of Illinois, r895, p. I 23.) "Sometimes reaches the Mississippi Valley; has been killed as far east as Wisconsin." (W. W. Cooke, Bird Migration Mississippi Valley, I888, p. 78.) Messrs. Kumlien and Hollister say: "Credited to the fauna of Wisconsin in Ridgway's 
Manual of North American Birds, The A. O. U. Check List, and other works, as a straggling migrant. A small goose with short neck, minimum amount of black, dark under parts, and distinct white crescent at the forward lower part of black neck marking, is of frequent occurrence in Wisconsin, sometimes in large flocks made up of this kind entirely, and again in company with geese of every varying degree of size and marking.

"Specimens of this character have been examined of barely six pounds weight, and in the collection of Mr. Skavlem is a specimen weighing five and one-half pounds, which we think could be called typical minima. These birds are locally known as 'bull necks' by the sportsmen. As with the case of hutchinsii compared with canadensis, there are also intermediates of every varying degree between this form and both the others. There are occasionally large geese with dark under parts, slender necks, and a distinct collar of white on lower neck. The cheek patches appear to be indifferently separated by black on throat or unbroken among geese of all sizes, shape, and coloration. We have examined carefully many dozens of fresh specimens killed at all times from early fall until late spring and frankly admit our inability to satisfactorily unravel the 'goose question ' in Wisconsin." (Birds of Wisconsin, 1903, p. 29.)

\section{Branta bernicla glaucogastra (ВRенM).}

BRANT.

Branta bernicla (Linn.), A. O. U. Check List, r895, p. 63 .

Distr.: Arctic regions, breeding in the far north; south in winter along the Atlantic coast to the Carolinas, casual in Florida and accidental in the West Indies. Stragglers have been recorded from Indiana, Wisconsin, and Nebraska.

Adult: Whole of the head, neck, and upper breast, black, except the sides of the neck, which are speckled with white; back, grayish brown; longer tail coverts, white; lower breast, grayish, shading into white on the belly.

Length, 25; wing, I3; tarsus, 2.25; bill, 1.30.

The Brant must be included upon the authority of various writers, but if it occurs at all so far in the interior, it is merely an accidental straggler. Hearsay evidence is of little or no value as regards this species, as many of the smaller geese are called Brant by the "gunners."

Prof. Ridgway includes it in his Ornithology of Illinois on the authority of Prof. Cooke. "During the winter of $188_{3}-8_{4}$, this species was represented from Illinois southward by a few rare visitants. 


\section{Field Museum of Natural History-Zoölogy, Vol. IX.}

There is much uncertainty in using the records concerning this species, because it is so commonly confounded with the Snow Goose, which is locally known as Brant all through the West." (W. W. Cooke, Report on Bird Migration in the Mississippi Valley, I 888, p. 78. ) "Probably a rare visitant, but the only instance known to me of its capture in this portion of the country is a specimen taken by Dr. Hoy from a flock of three upon the Lake shore near Racine." (Nelson, Bds. N. E. Illinois, I876, p. I38.) "The Brant has been listed as a bird of Wisconsin for a great many years, but when all records are sifted we have left as authentic only the one of Dr. Hoy, a single specimen taken at Racine many years ago. This was one of three from the shore of Lake Michigan. For the past 30 years we have run down 'Brant' records innumerable to find that in every case it proved to be something else, varying from the common Canada Goose to a female Eider Duck." (Kumlien and Hollister, Birds of Wisconsin, I903, p. 30.) There are several supposed Michigan records (A. J. Cook, Birds of Michigan, I893, p. 47), and it has also been given from Indiana (A. W. Butler, Birds of Indiana, I897, p. 639), but these authorities do not record it from personal observation.

\section{Subfamily CYGNINÆ. Swans.}

During the migrations, swans are found in Illinois and Wisconsin. They are easily recognized by their large size and long necks. The adults (in the two species which occur in Illinois) are white and the immature birds, gray. When migrating the flocks assume a V shaped form like the geese. Their food consists of aquatic plants and roots and occasionally small mollusks.

\section{Genus OLOR Wagler.}

\section{Olor columbianus (ORD).}

Whistling Swan.

Distr.: North America, breeding in high latitudes; south in winter to the Carolinas and occasionally to Florida. It is common on the Gulf coast of Louisiana and Texas and a few occasionally winter in southern Illinois. On the Pacific side it winters from British Columbia to southern California, accidental in northern Mexico.

Adult: General plumage, white; bill and feet, black; a small yellow spot (which is not always present) on bare loral skin at the base of 


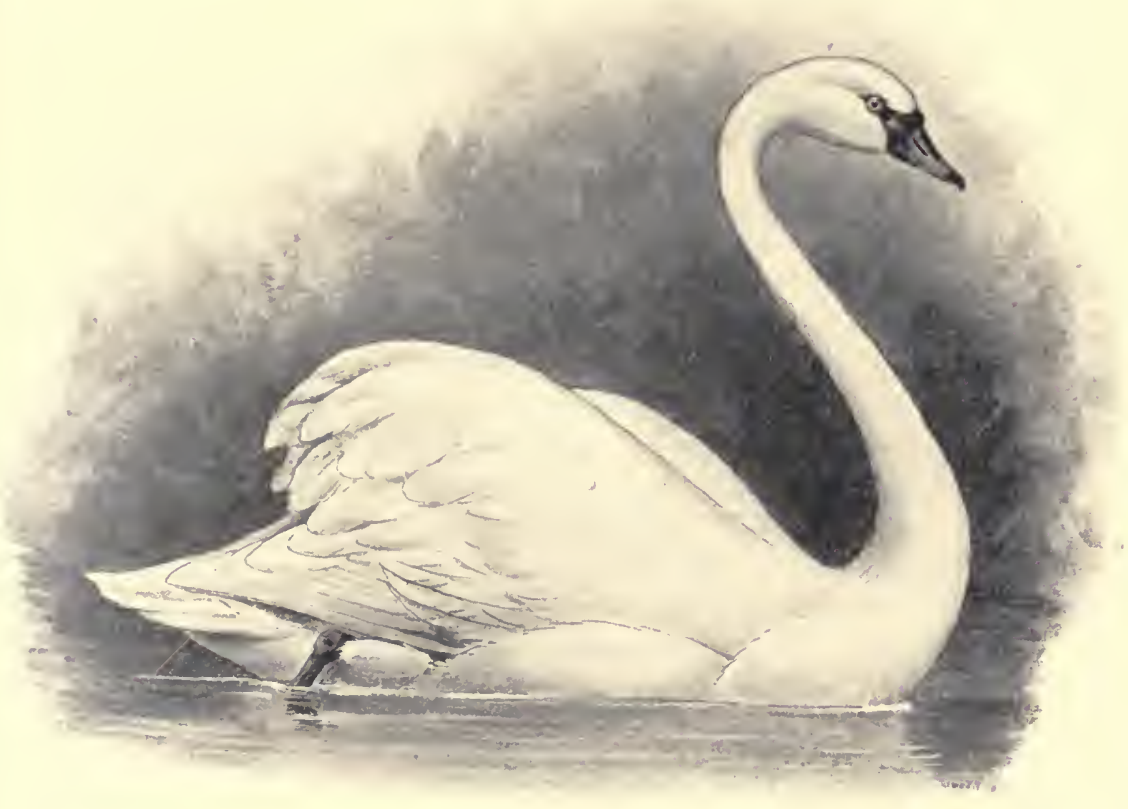

Whistling Swan.

the bill in front of the eye; the distance from the front angle of the eye to the back edge of the nostril is more than the distance from the back edge of the nostril to the end of the bill; this is one of the characters by which it may be distinguished from the Trumpeter Swan, which also . averages larger; bill, and feet, black.

The immature birds are usually pale, plumbeous gray, with a brownish wash on the head and upper neck; feet, pale yellowish, sometimes pale flesh color or grayish.

Length, 53; wing, 21.50; bill, 4; tarsus, 4.20.

This species is not uncommon in Illinois and Wisconsin during the migrations, being more often observed on the inland waters than on Lake Michigan. It grows to a large size, a weight of twenty-five pounds being not uncommon, and the flesh of the immature birds is excellent. Its flight is very rapid, much faster than the Wild Goose and it is claimed a speed of one hundred miles an hour is not unusual. When flying the flocks assume a V-shaped form.

Baird, Brewer and Ridgway state: "The age of this swan may be known by the color of the feathers, the yearling being of a deep leaden tint, with a delicate red bill. In the second year it has a 
$35^{6}$ Field Museum of Natural History - Zoölogy, Vol. IX.

lighter color and a white bill. In the third season the bill has become jet black and about one-third of its plumage is still tipped with gray; and until it is fully five years old an occasional feather will present this tint."

\section{Olor buccinator (RICH.). Trumpeter Swan.}

Distr.: Chiefly interior of North America. In early days it bred commonly, at least as far south as Dakota. At present its nesting range appears to be from southern British Columbia northward; winters on the Gulf coast of Louisiana and Texas and from western British Columbia to southern California. In mild winters a few may remain as far north as southern Illinois.

Adult: General plumage, white; bare loral skin in front of eye, not yellow; bill and feet, black; the distance from the front angle of the eye to the back edge of the nostril is equal or less than the distance from the back edge of the nostril to the end of the bill.

Immature birds are ashy gray, often tinged with brownish on the head and neck; bill and feet, dull yellowish brown, tinged with olive.

Length, about 63 ; wing, 2 I to 26 ; bill, about 4.50 .

The Trumpeter Swan occurs sparingly in Illinois and $\mathrm{W}$ isconsin during the migrations. It is fast becoming a very rare bird, at least east of the Mississippi. 


\section{ORDER HERODIONES.}

HERONS, IBISES, SPOONBILLS, ETC.

\section{Suborder IBIDES. Spoonbills and Ibises.}

\section{Family PLATALEIDÆ. Spoonbills.}

A peculiar family comprising half a dozen species and having representatives in both the Old and New World. They resemble Ibises in habits and structure, except the flattened bill curiously paddleshaped or spoon-shaped at the end, which is characteristic and from which their name is derived. One species occurs in North America.

\section{Genus AJAIA Reichenbach.}

\section{Ajaia ajaia (LinN.). Roseate Spoonbill.}

Ajaja ajaja (Linn.), A. O. U. Check List, I895, p. 67.

Distr.: South Atlantic and Gulf states southward through South America to Patagonia and Falkland Islands.

Adult: Back and wings, a delicate rose white; under parts showing rose color; bare skin of the head, greenish and yellow; bill, widened at the tip, somewhat spoon-shaped but flat, tinted with greenish and yellowish; legs, dull red. Very old birds have the lesser wing coverts and upper tail coverts brilliant carmine red.

The immature bird has general plumage pale pinkish white, with no red on the lesser wing coverts.

Length, 31 ; wing, 15 ; tarsus, 4.10 ; bill, 6.30.

Although there are no recent records of the occurrence of the Roseate Spoonbill in Illinois, it was apparently not uncommon fifty years ago in the southern part of the state.

Ridgway states he was informed that several specimens were killed in the Mississippi bottoms near St. Louis, about I859. Nelson states that it "used to occur in the bottoms opposite St. Louis." "It has been recorded in early days in Indiana." (Butler.) In A. C. Barry's list (Wisconsin, I 854 ) he states that it was "found along the Mississippi within the bounds of our state and occasionally about 


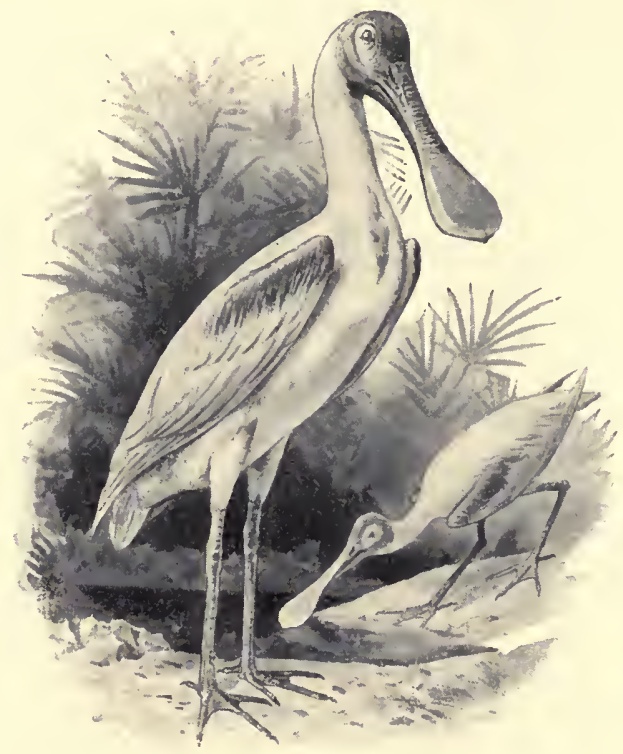

Roseate Spoonbill.

our small lakes in the interior:" Kumlien and Hollister (Birds of Wisconsin, I903, p. 32) state: "The sole, actual and positively authentic record, however, entitling the Spoonbill to a place in the present list is from the fragments, head, wing, and leg of a specimen procured by Indians at Indian Ford on Rock River, near Janesville, in August, 1845 , and preserved by Thure Kumlien. These remains are still extant in the Kumlien collection."

\section{Family IBIDID艮. Ibises.}

Ibises are restricted to the warmer parts of the world. Of the 30 or more known species, three occur in North America. They are gregarious, usually being found in colonies. They frequent the salt water marshes and lagoons as well as inland swamps, rivers, and ponds, being rarely found away from the vicinity of water. Their food consists of fish, frogs, lizards, and small crustaceans. They nest both in trees and marshes. 


\section{Genus GUARA Reich.}

76. Guara alba (LiNN.).

White Ibis.

Distr.: South Atlantic Gulf states and West Indies, Lower California and southward to northern South America.

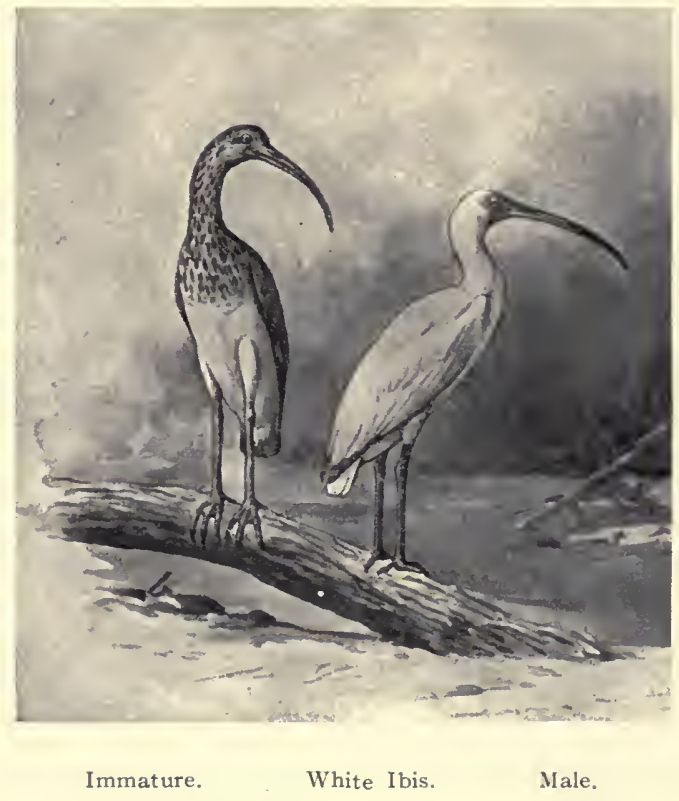

Adult: General plumage, white; the four outer primaries, black; bare skin at base of bill, orange red in life.

Immature: Head and neck, dull white, or brownish white, streaked with grayish brown; wings and back, grayish brown; rump, white; under parts, white.

Length, about 25 ; wing, IO.50 to II.50; tarsus, $3.5^{\circ}$; bill, 5 to 7 .

Casual or rare in summer in the extreme southern portion of Illinois. Mr. Ridgway states (Orn. of Illinois, 1895, p. Io9) that while in company with Mr. William Brewster, he observed a flock of seven or eight examples flying along the Wabash River near Mt. Carmel in May, 1878 . It has not been observed in Wisconsin. 
360 Field Museum of Natural History-Zoölogy, Vol. IX.

\section{Genus PLEGADIS Kaup.}

77. Plegadis autumnalis (HASSELQ.).

Glossy Ibis.

Distr.: Warmer portions of eastern hemisphere. In America found casually in southeastern United States and the West Indies. Stragglers have been taken as far north as New England, Illinois, and Wisconsin.

Adult: General plumage, chestnut; wing coverts, back and front of head showing greenish and sometimes bronzy reflections.

The immature birds have the plumage more brownish and the front of the head slightly mottled; the back, greenish; under parts, dusky brown.

Length, 25; wing, II.25; bill, 5.40 .

Mr. Julius Hurter (Bull. Nutt. Orn. Club, I88I, p. I 24) records an immature specimen taken in Marion Co., Ill., near St. Louis, in February, I880, which was identified by Prof. Ridgway as this species, but later Mr. Ridgway (Ornithology of I11., I 895, p. II 2 ) suggests the possibility of its being an immature specimen of guarauna on account of the coloring of the legs and bare skin in front of the eye in life, as described to him in a letter from Mr. Hurter. Nelson writes: "A very rare visitant. I know of but two or three instances of its occurrence." In Wisconsin, according to Kumlien and Hollister, seven specimens have been observed and one shot on Lake Koshkonong in 1872 , and another was killed on Horicon Marsh, in I879. It has also been recorded from Michigan (Cook), and Iowa (Anderson).

Suborder CICONIÆ. Storks.

\section{Family CICONIIDÆ. Storks and Wood Ibises.}

Two species of this family occur in North America and one of these, the Wood Ibis, has been taken in Illinois and Wisconsin. They are gregarious, nesting in colonies usually (but not always) in high trees. They frequent heavily timbered swamps, wooded rivers, and lagoons 


\section{Subfamily MYCTERIINÆ. Wood Ibises. \\ Genus MYCTERIA Linn.}

78. Mycteria americana LiNN.

Wood IBIs.

Tantalus loculator Linn., A. O. U. Check List, r 895, p. 69.

Distr.: Southern United States, California to the Carolinas and southward, Middle America to the Argentine Republic; common in Florida and some of the Gulf states; casual north to Pennsylvania, New York, and Illinois; accidental in Wisconsin.

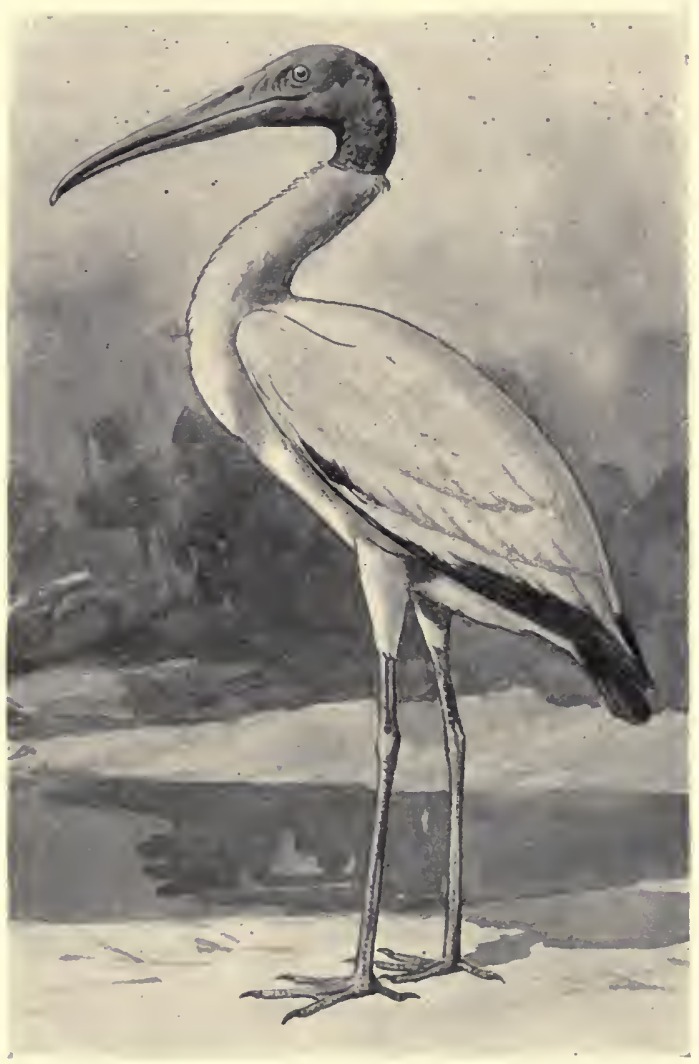

Wood Ibis.

Adult: Head and neck, bare (bluish in life, black in dried skins); bill, brownish yellow; legs, bluish; toes, black, the webs, yellowish; general plumage, white; primaries, primary coverts and tail, black. 
362 Field Museum of Natural History-Zoölogy, Vol. IX.

Young birds have the head and neck covered with downy feathers and the general plumage, dark gray; wings and tail, blackish; sexes similar.

Length, about 48 inches; wing, about I 8 ; bill, about 8.50 ; tarsus, 8 .

The Wood Ibis is apparently not uncommon in late summer in southern Illinois, where it was frequently observed by Prof. Ridgway, near Mt. Carmel, and Mr. J. Hurter (Bull. Nutt. Orn. Club, i 88 I, p. I 24 ) found it numerous in August, I 888, in Madison Co., Ill., near St. Louis. Dr. Hoy ( 1853 ) records a specimen in the Museum of the Wisconsin State Historical Society at Madison, which was shot near Milwaukee, in September, I 852. Kumlien and Hollister consider it a very rare midsummer straggler in Wisconsin and say that in a letter to L. Kumlien, Dr. Hoy stated he had procured a specimen at Racine in September, I868. They also record a third specimen killed on Rock River between Janesville and Edgerton. (Birds of Wisconsin, I 903, p. 33.)

Suborder HERODII. Herons, Egrets, Bitterns, etc. Family ARDEIDÆ. Herons and Bitterns.

About 70 known species belong to this family distributed throughout the world. Many of the true herons are gregarious, while others

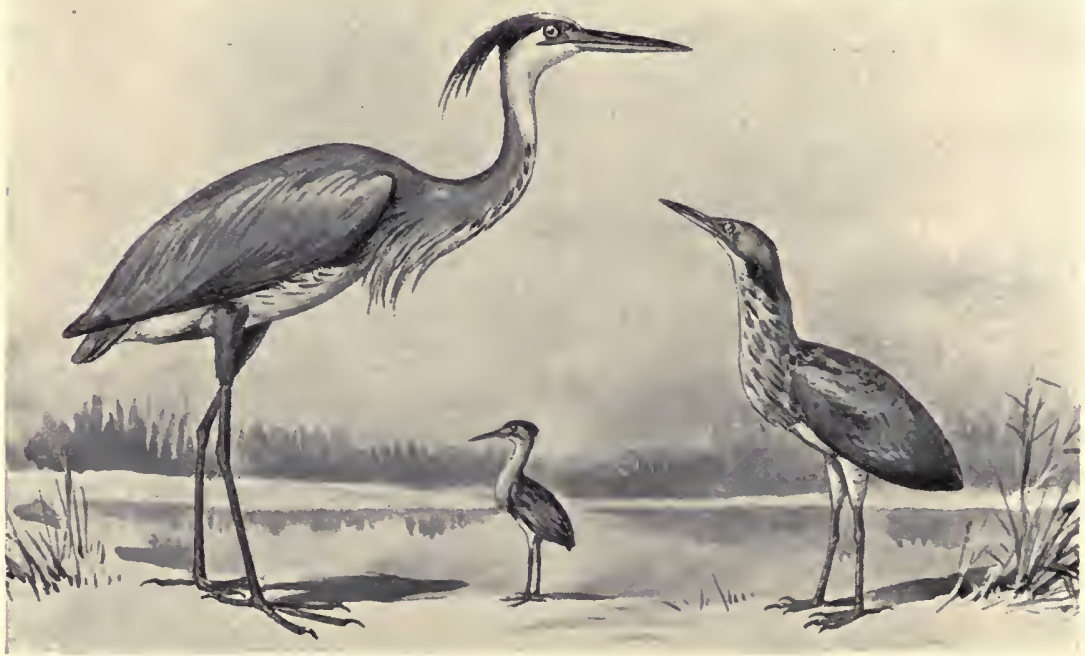

Great Blue Heron.

Least Bittern.

American Bittern. 
are only occasionally so, if at all. When undisturbed they usually nest in colonies or "rookeries," as their breeding places are sometimes called, three or four species often occupying the same tree.

The Bitterns are not gregarious in the true sense of the word, although during the breeding season numbers of nosts of the smaller species may often be found in close proximity to each other: The American Bittern is more solitary in its habits. When feeding they frequent the shores of rivers and ponds as well as marshes and lagoons. The food consists largely of fish, frogs, and small reptiles, which they catch with great dexterity.

\section{Subfamily BOTAURINÆ. Bitterns.}

\section{Genus BOTAURUS Stephens.}

\section{Botaurus lentiginosus (MontAG.).}

American Bittern.

Local names: Stake-driver. Thunder-pump.

Distr.: Temperate North America, south to Guatemala, Cuba, and Jamaica.

Adult: Upper parts, brown; wing coverts, edged and mottled with tawny and buff and washed with ashy; top of the head and nape, slaty, with black streak on sides of the upper neck; neck and under parts, tawny white; feathers, edged with dusky and dull brown; legs, greenish yellow; a loral stripe of dark brown; bill, yellowish, with a dark streak at the top.

Length, 27; wing, II.50; bill, 3 ; tarsus, 3.40 .

The female is smaller than the male and the bird varies in size.

A common summer resident in Illinois and Wisconsin and breeds in suitable localities, building its nest in marshes. The nest is a mass of grass, loosely put together. The eggs are 4 or 5 , pale olive buff color, and measure about I.95 × I.45 inches.

The peculiar "booming" notes made by this species, on account of which it has acquired such local names as Stake-driver, Thunderpump, etc., are admirably described by Mr. Bradford Torrey. (The Auk, I889, p. I.) In the same article he prints an interesting letter from Mr. William Brewster, from which I quote the following: "The bird was well out in the open meadow among short, green grass, growing in perhaps two inches of surface water. I got within less than thirty yards of him before he took alarm and crouched. Previous to this he favored me with several performances in plain sight. 
He would extend his neck, then drawing in his head suddenly, would throw it out with a jerk as if he were affected with violent nausea or were trying to get rid of some obstruction in his throat, at the same time uttering the peculiar pump-er-lunk. After repeating the movement and its accompanying vocal notes several times in rather quick succession, he would stand nearly erect for a few moments before beginning again. As he stood with his back partly towards me, I could not see his breast or throat distinctly, but I am sure he did not fill the latter with water while I was watching him, for not once did his bill descend low enough to get even a hurried sip."

The writer has on one occasion had the pleasure of observing this interesting performance, and can add his testimony to the effect that the bird in question did not at any time lower his bill below the level of the body, certainly not low enough to reach the water, which at that place, upon later investigation, proved to be about two inches deep.

\section{Genus IXOBRYCHUS Billberg.}

\section{Ixobrychus exilis (GMEL.).}

Least Bittern.

Ardetta exilis (Gmel.), A. O. U. Check List, I895, p. 70.

Distr.: Temperate North America, from British Provinces south to West Indies and South America; less common on the Pacific coast.

Adult male: Crown of the head, black, extending into a small crest; back and tail, black, with a greenish tinge back of the neck; wing coverts, chestnut brown; some of the wing coverts, tawny yellow; front and sides of the neck and under parts, yellowish brown, showing white on throat; a patch of brownish black on the sides of the breast; bill, yellowish, dusky on the top; legs, green, yellow on the back; toes, yellow.

Adult female: Having the back and crown purplish chestnut instead of black.

Length, I2.50; wing, 4.50; bill, 2 ; tarsus, 2.10.

The Least Bittern is a common summer resident in Illinois and Wisconsin, breeding throughout both states in suitable localities. The nest is usually built in rushes and reeds in ponds or marshy places, rarely in bushes. The eggs are bluish white, from 4 to 7 in number, and measure $1.20 \times .95$ inches. The Field Museum possesses several sets of eggs of this species taken in the vicinity of Calumet Lake, Chicago, between June I 5 th and June 29 th. 
JaN., igo9. Birds of Illixois AND WiscoNsix-CORY.

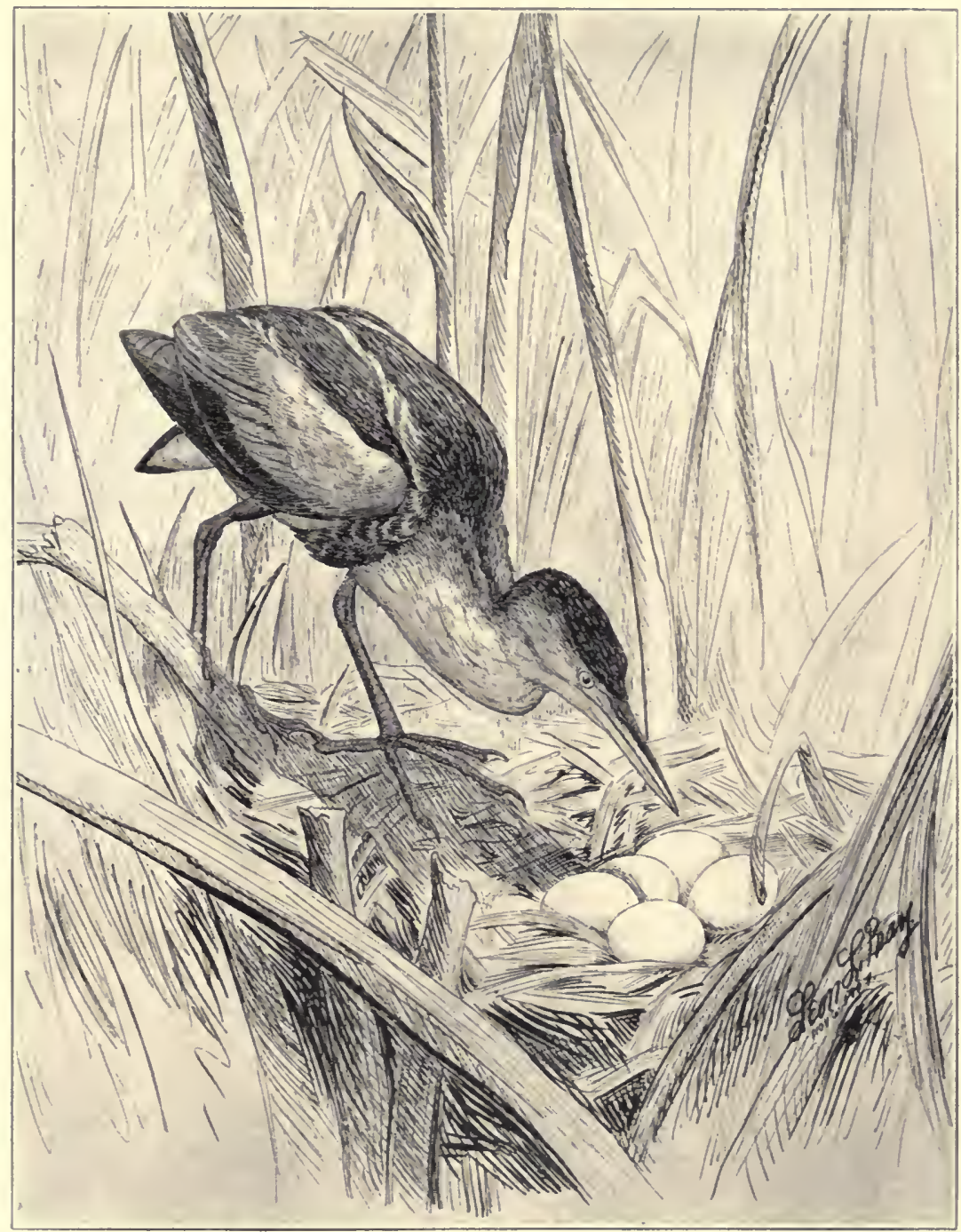

Least Bittern.

\section{Ixobrychus neoxenus (CORY).}

CORY'S LEAST BITTERN.*

Ardetta neoxena Cory, A. O. U. Check List, i 895, p. 70.

The type of this species was taken in the marshes southwest of

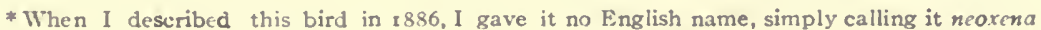
(new and strange). The committee of the American Ornithologists' Union have since honored me by giving it my name. 
Lake Okeechobee, in I886, and since then half a dozen specimens have been killed in that locality and several in Canada, Michigan, and elsewhere, including two in Wisconsin. It has not as yet been observed in Illinois.

Adult: Top of the head, back, and tail, dark greenish black, showing a green gloss when held in the light. Sides of the head and throat, rufous chestnut, the feathers on the back of the neck showing greenish black tips; breast and under parts, nearly uniform chestnut, shading into dull black on the sides; wing coverts, dark rufous chestnut; all the remiges, entirely slaty plumbeous; under tail coverts, dull black.

Wing, 4.30; tarsus, 1.40; bill, I.80.

An adult male was killed at Lake Koshkonong, Wisconsin, May 22, I 893 , by C. E. Akeley. (No. 204I, Field Museum of Natural History.) What is supposed to have been a bird of this species is given by Kumlien and Hollister (Birds of Wisconsin, I 903, p. 34) who write: "In June, 1845 , Thure Kumlien found some Indian children playing with a small headless heron, using it as a target for bow and arrow practice. This was on an Indian encampment on Black Hawk Island, Lake Koshkonong. The bird was new to him and he secured it and later sent a color sketch to Dr. T. M. Brewer. Brewer pronounced it some southern species or a different plumage of the Least Bittern. A copy, or in fact the original sketch, is still in our possession and it plainly shows the specimen to have heen a typical Ardetta neoxena."

\section{Subfamily ARDEINÆE. Herons and Egrets.}

Genus ARDEA Linn.

\section{Ardea herodias LiNN.}

Great Blue Heron.

Distr.: North America, from the Arctic regions south to the West Indies and northern South America; also recorded from Bermuda and the Galapagos Islands.

Adult: Crest, lengthened; bill, yellow, dark brown on top; legs and feet, dark brown; soles of the feet, yellow; a streak from the forehead to the middle of the crown, white; sides of the crown and crest feathers, black; neck, grayish purple mixed with black and white; chin and part of the cheeks, whitish, extending in a tawny line on the throat; neck plumes; belly, black, streaked with white; back and 


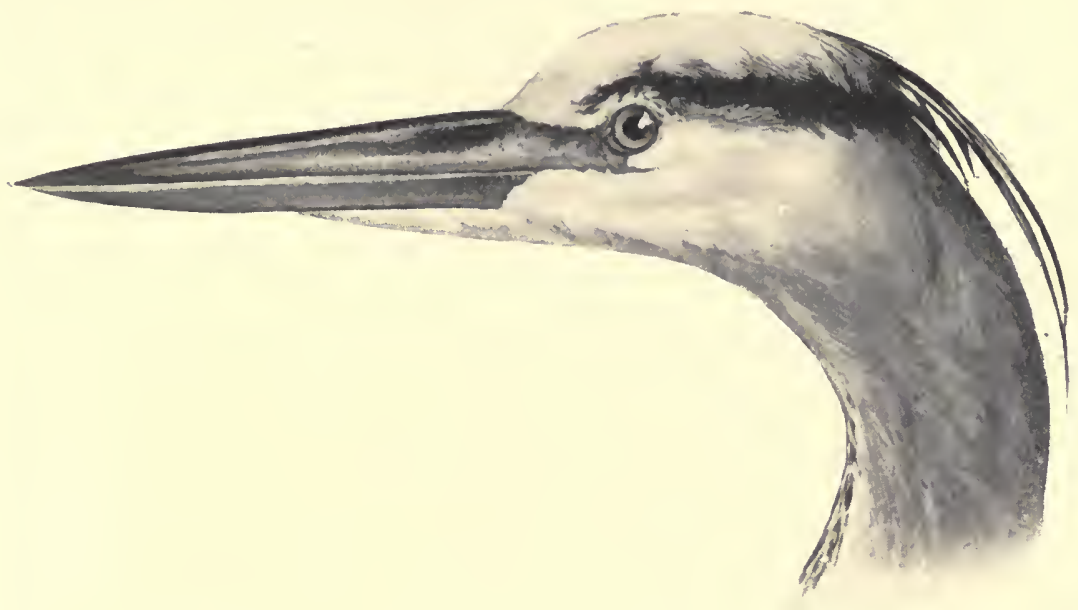

Great Blue Heron.

upper parts, bluish slate or gray. The immature birds show a great variety of color in the plumage.

Length, 48; wing, 20; tail, 7 ; tarsus, 6.50; bill, 5.50.

The Great Blue Heron is a common summer resident in Illinois and Wisconsin, breeding throughout both states. It usually arrives from the south in March or early in April. It breeds in May. The nest is a mass of sticks, usually in large trees. The eggs are three or four, pale blue in color, and measure about $2.50 \mathrm{x} \mathrm{I} .50$ inches.

\section{Genus HERODIAS Boie.}

\section{Herodias egretta (GMel.).}

American Egret.

Ardea egretta Gmel., A. O. U. Check List, I 895, p. 7 I.

Distr.: Temperate and tropical America, from New Jersey, Illinois, and Oregon south to Patagonia; accidental as far north as Minnesota and Nova Scotia.

Adult: Entire plumage, white, having in the breeding season long graceful plumes on the back, which extend beyond the tail; bill, yellow; legs and feet, black; lores, pale orange, edged with greenish.

Length, 38; wing, r6; tarsus, 5.80; bill, 4.80 .

The American Egret was at one time a common summer resident in Illinois and not uncommon in Wisconsin, but it is now rare.

"A rather common summer visitant throughout northern Illinois. ****** Breeds in southern Illinois and perhaps in other parts of 
368 Field Museum of Natural History-Zoölogy, Vol. IX.

the state." (Nelson, Birds of N. E. Illinois, г876, p. г 3 r.) "Twentyfive to fifty years ago the egret was a common bird on the larger marshes and swamps bordering the inland lakes and rivers. $* * * *$ * * A few single birds or small flocks rarely visit Delavan Lake during early fall. $* * * * * *$ Young unable to fly were taken from a colony in a tamarack swamp near Jefferson in July, $\mathrm{x} 86_{3}$. It was found breeding with a large colony of great blue herons to the westward of Two Rivers in June, r880. Also reported as nesting near Waukesha in I866." (Kumlien and Hollister, Birds of Wisconsin, r903, p. 35.)

\section{Genus EGRETTA Forst.}

\section{Egretta candidissima (GMel.).}

SNOWy Heron.

Ardea candidissima Gmel., A. O. U. Check List, I895, p. 72.

Distr.: Temperate and tropical North America, from Long Island and Oregon south to Argentine Republic and Chili. Formerly abundant in parts of the Gulf coast and Florida; accidental as far north as Nova Scotia and southern British Columbia.

Adult: Entire plumage, pure white, having in the breeding season extended plumes on the back and also feathers on the crest lengthened;

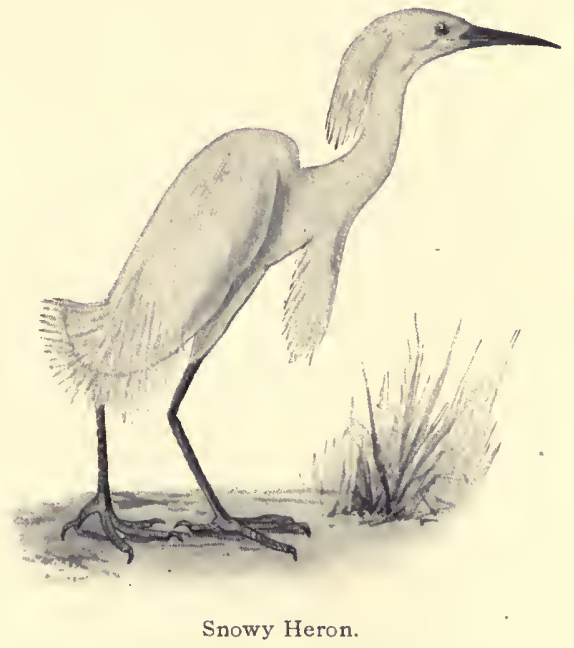

bill, black, becoming yellowish at the base; lores, yellow; legs, black; feet, yellow.

Length, 22 ; wing, $x \mathrm{I}$; tarsus, 3.50 ; bill, 3 . 
The Snowy Heron is of accidental occurrence in Illinois and Wisconsin, although at one time it was apparently not uncommon in southern Illinois. The species is now rase, having been nearly exterminated in the southern states.

Nelson states that it was much less common in Illinois than egretta and occurred about the same time (late summer). Kumlien and Hollister say: "A rare and irregular visitor from the south during August and September. $* * * * *$ In August, I 886, Mr. H. L. Skavlem shot six of these birds from a flock of egrets also on Lake Koshkonong. This is the last authentic record of any numbers that we know of. Of late years very rare." (Birds of Wisconsin, 1903, p. 35.)

\section{Genus DICHROMANASSA Ridgw.}

85. Dichromanassa rufescens (GMEL.).

REDDISH EGRET.

Ardea rufescens Gmel., A. O. U. Check List, I895, p. 72.

Distr.: Ranges from the Gulf states, north to southern Illinois, west to Lower California, south to Mexico (both coasts) and Guatemala. also Cuba, Jamaica, and the Bahama Islands.

Adult in colored phase: Head and neck, lilac brown; rest of plumage, dark slate color. This species has the long plumes extending from the scapular region of the back during the breeding season; legs and feet, bluish, showing dusky on the scales of the tarsus; bill, black on the terminal third, the balance, flesh color; lores, flesh color.

White phase: Entire plumage, white; bill, black on the terminal third; balance, flesh color; legs, greenish.

Length, 29; wing, I4; tail, 4; tarsus,5.30; bill, 3.90.

At one time the white and colored birds of this species were considered distinct, but in June, 1879 , while in the Bahama Islands, the writer took both white and gray, young birds from the same nest.

This southern species was given by Nelson as: "Quite common in the vicinity of Cairo during the last week in August, 1875." (Bull. Nutt. Orn. Club, 1876, p. 40.) It has not been observed in northern Illinois or Wisconsin and there is apparently no record of its occurrence in Illinois since that given by Mr. Nelson. 
Field Museum of Natural History-Zoölogy, Vol. IX.

\section{Genus FLORIDA Baird.}

\section{Florida cærulea (LinN.).}

Little Blue Heron.

Ardea carulea Linn., A. O. U. Check List, I 895, p. 73.

Distr.: Eastern United States, from New Jersey, Illinois, and Kansas, southward through Mexico and Central America to northern South America, also West Indies; accidental as far north as Maine and Wisconsin.

Adult: Head and neck, purplish red or maroon, rest of plumage, grayish blue; bill, black at the end; basal portion and loral space, blue; legs and feet, black.

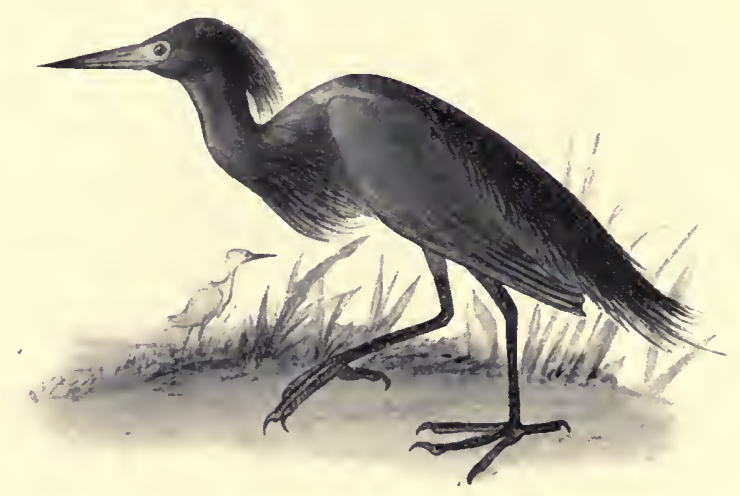

Little Blue Heron.

Immature birds are pure white, except a faint wash of grayish blue near the tips of the primaries; legs, olive or yellowish, and the basal half of the bill, greenish.

Young birds of this species are sometimes confounded with the Snowy Egret, but may easily be distinguished from that species by the slight wash of blue on the ends of the primaries and by the color of the legs and bill.

Length, about 23; wing, II; tarsus, 3.60 .

The Little Blue Heron is not uncommon in late summer in southern Illinois. Accidental stragglers have also been taken in Wisconsin. "A common bird during the latter part of summer, particularly during August, when (in I 875 ) Mr. E. W. Nelson found it exceedingly abundant near Cairo. Considerable numbers make their appearance along the Wabash River, at least as far north as Mt. Carmel and doubtless it occurs generally throughout the state." (Ridgway, 
Orn. Illinois, I895, p. I30.) "Rare accidental straggler. A single individual was shot on Root River, Racine Co. (Wisconsin), August 28 , I 848 , by Dr. P. R. Hoy. A single wing of a decomposed specimen was preserved by Thure Kumlien. This was found on the shores of Lake Koshkonong in the early fifties." (Kumlien and Hollister, Birds of Wisconsin, 1903 , p. 35.)

\section{Genus BUTORIDES Blyth.}

\section{Butorides virescens (LIN.). Green Heron.}

Ardea virescens Linn., A. O. U. Check List, I895, p. 73.

Distr.: Temperate North America, from Ontario and Oregon south to the West Indies, Middle America, and northern South America. In the United States, breeding throughout the greater part of its range.

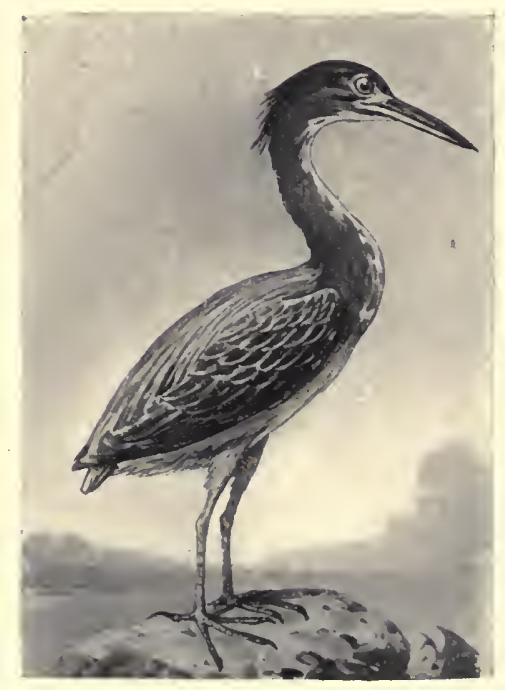

Green Heron.

Adult: Feathers on top of the head extending in a small crest, dark green; neck, chestnut; throat, marked heavily with white; under parts, pale purplish or ashy, marked with white; back, greenish, showing tinge of slate color; wing coverts, green, feathers edged with buffy white; bend of wing, whitish; tail, greenish, upper mandible, black; lower mandible, mostly yellow, dark on the top; legs, yellowish green. 
372 Field Museum of Natural History - Zoölogy, Vol. IX.

Length, 16 inches; wing, 6.50; tail, 2.40 ; tarsus, r.85; bill, 2.30 .

The Green Heron is a common summer resident in Illinois and Wisconsin and breeds throughout both states in suitable localities. Nidification commences in May. The nest is a mass of small twigs placed in a bush or low tree near water. The eggs are 4 to 6 , pale blue or greenish blue, and measure I.50 x.I5 inches. An admirable article on the breeding of this species in Wisconsin is given by Mrs. Irene G. Wheelock in The Auk, Vol. XXIII, I906, p. 432, to which those interested are referred.

\section{Genus NYCTICORAX Forster.}

\section{Nycticorax nycticorax nævius (BODD.).}

Black-crowned Night Heron.

Local name: Quawk.

Distr.: Whole of America, from Ontario and Manitoba south to the West Indies and South America to the Falkland Islands.

Adult: Crown, head, back, and scapulars, greenish black; forehead, lores, most of the neck and under parts, white or ashy white; wings and tail, gray; legs and feet, yellow; two or three very long occipital plumes, white in the breeding season.

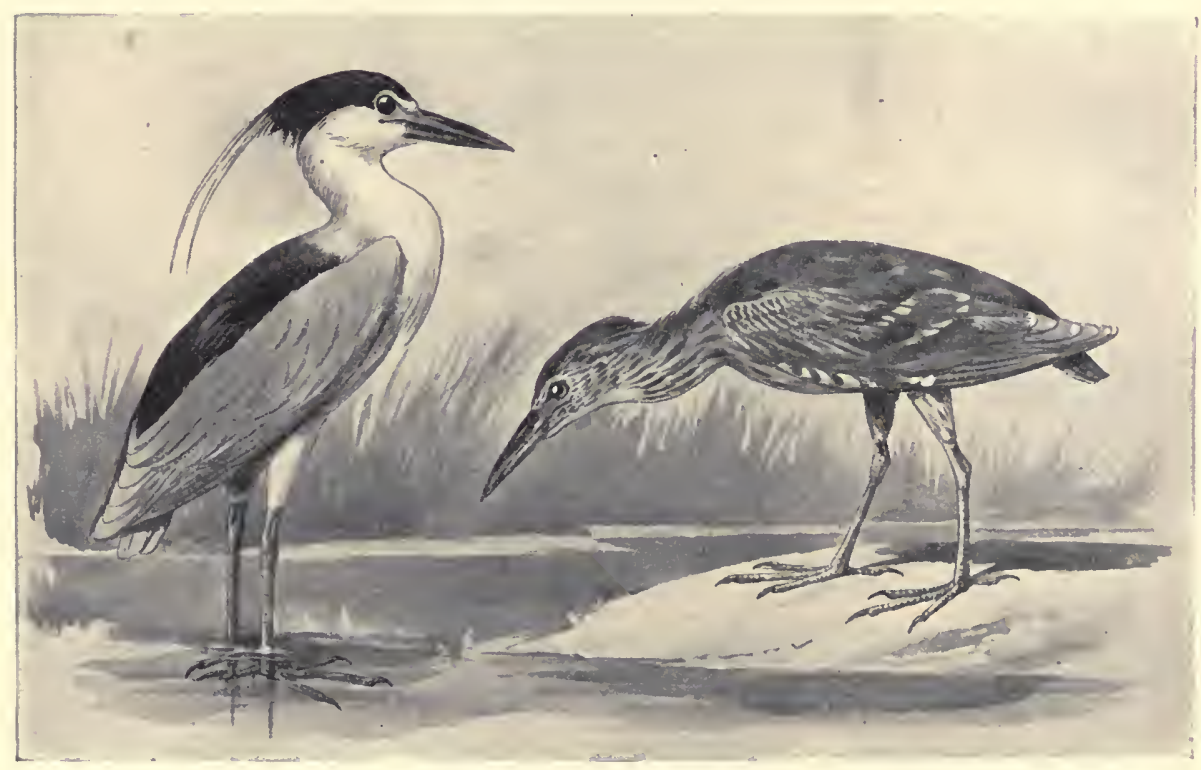

Adult. 
Length, 24 to 26 ; wing, II ; tarsus, 3.10 to 3.40 ; tail, 4.20 to 5.30 .

The immature bird has the general plumage mottled dark brown and gray, the feathers marked and streaked with pointed blotches of grayish or buff; outer web of primaries, buff color; under parts, streaked with black and white.

A common summer resident in Illinois and Wisconsin, breeding in colonies, usually in trees but at times in swampy places among reeds. Nelson states he found them nesting in a dense growth of wild rice. The eggs are 4 or 5 , sometimes 6 in number, pale blue, and measure about $2 \times 1.45$ inches. It arrives from the south late in April and the eggs are laid in May and early in June.

\section{Genus NYCTANASSA Stejneger.}

\section{Nyctanassa violacea (Linv.).}

Yellow-Crowned Night Heron.

Nycticorax violaceus (Linn.), A. O. U. Check List, r 895, p. 74.

Distr.: Tropical and subtropical America, from the Carolinas, southern Illinois, the lower Ohio Valley, and Lower California south to Brazil; accidental or casual north to Massachusetts and Colorado.

Adult: Top of the head, whitish buff, extending into a crest; sides of the head, black; throat, black; breast and under parts, grayish plumbeous; back, plumbeous; two or three very long feathers extending as long plumes from the crest; legs, greenish.

Length, about 23; wing, r3.20; tail, 4; tarsus, 3.70; bill, 2.60 .

Immature birds have the crown dusky, streaked with white or buffy white, the rest of the plumage heavily mottled, blotched with pointed marks of brown; also marked with buff and dull white; primaries, slate color, showing no rufous. The immature birds of this species somewhat resemble those of the Black-crowned Night Heron, but differ from it, having the head darker and no rufous on the primaries.

The Yellow-crowned Night Heron seems to be of regular occurrence in southern Illinois, where it is claimed to breed. The nest is a mass of sticks usually in a tree near water. The eggs are 4 or 5 , pale blue in color, and measure about $1.95 \times 1.40$ inches. As far as known it has not been observed as far north as Wisconsin.

Ridgway states (Ornithology of Illinois, p. 136): "The Yellowcrowned Night Heron occurs during summer throughout at least the southern third of Illinois, though of course only in such localities as are suited to it. These consist of timbered swamps, where the princi- 
374 Field Museum of Natural History-Zoölogy, Vol. IX.

pal food of the species, consisting of crawfish, frogs, and the smaller reptiles, is to be found in abundance. It first became known to the writer as an Illinois bird through Mr. Samuel Turner of Mt. Carmel, who obtained specimens of the bird and its eggs in the coffee flats a few miles south of that place." According to Nelson it breeds at least as far north as Wabash County, Illinois." (Birds of N.E. Illinois, 1876 , p. г 5 r.)

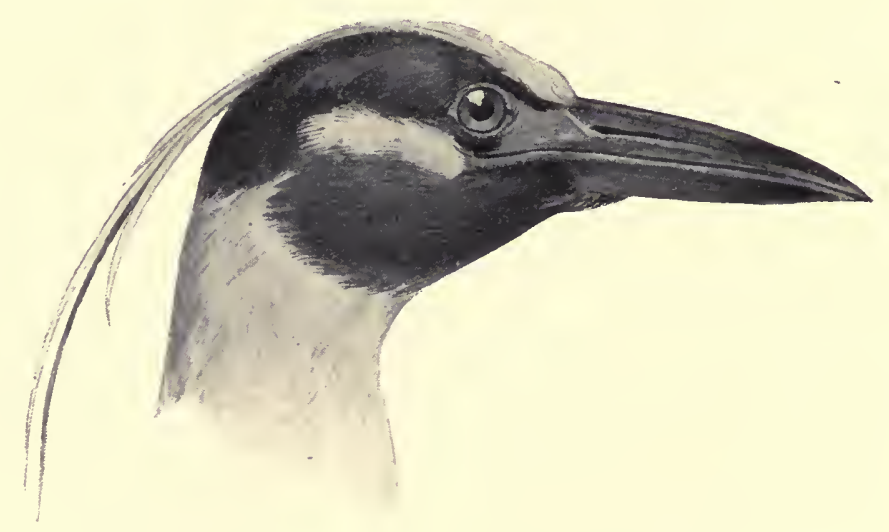

Yellow-crowned Night Heron (adult). 


\section{ORDER PALUDICOLA.}

CRANES, RAILS, ETC.

Suborder GRUES. Cranes.

\section{Family GRUIDÆ. Cranes.}

Three species of Cranes (not Herons, which are sometimes wrongly called by that name) occur in North America. During the migrations they are more or less gregarious, but at other times are usually found

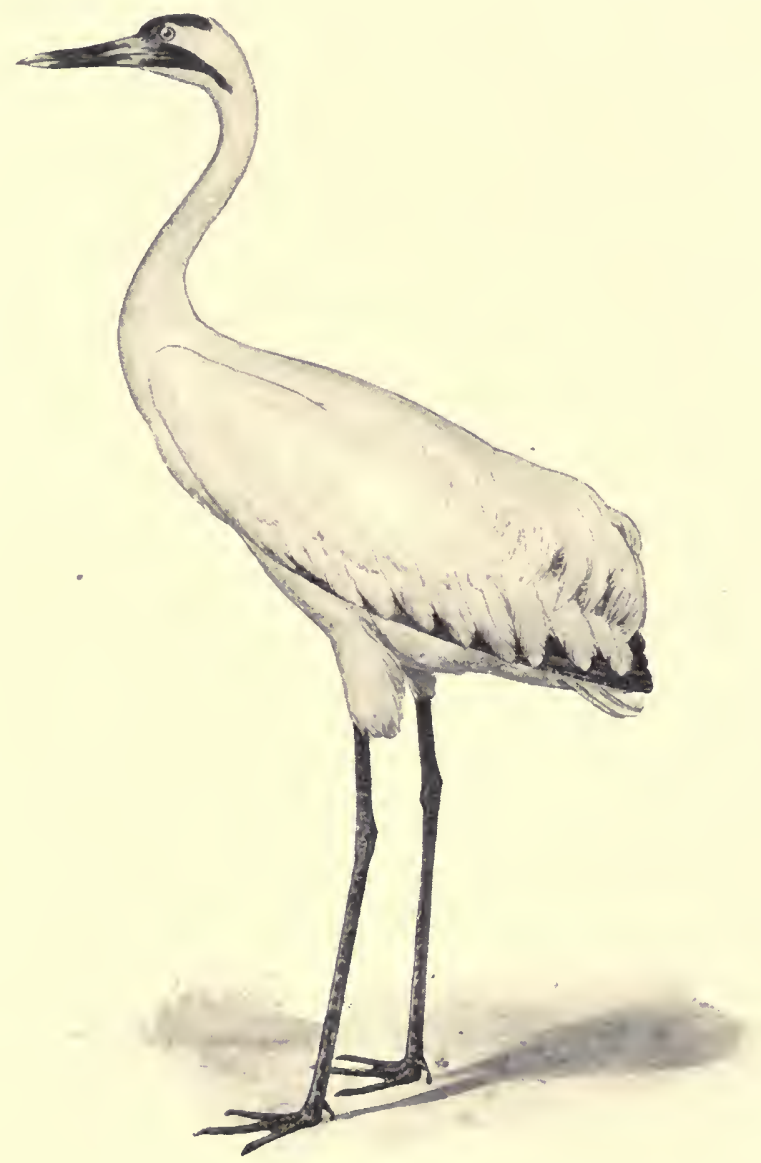

Whooping Crane. 


\section{Field Museum of Natural History - Zoölogy, Vol. IX.}

in pairs. They frequent both plains and marshes, but are more commonly found in the open woods and prairies. Their food consists of small animals, such as lizards, frogs, mice, and snakes, as well as seeds and grain. The loud note of the Sandhill Crane is peculiar, somewhat resembling the sounds made by a block when hoisting a sail. The nest is large, built on the ground. The eggs are two in number.

\section{Genus GRUS Pallas.}

\section{Grus americana (LINN.).}

\section{Whooping Crane.}

Distr.: Interior of North America, from the Fur Countries to Florida, Texas, and Mexico and from the Mississippi Valley to Colorado. Apparently no longer found on the Atlantic coast, except possibly in Florida, where it has become very rare.

Adult: Bare part of the head, hairy; plumage, white; primaries, black; bill, greenish; legs, black; bare skin on the head, carmine red: The immature birds have the head feathered and the general plumage tinged with pale tawny.

Length, 52; wing, 23.50; tail, 8.40; bill, 6.10; tarsus, I 2.

The Whooping Crane was formerly an abundant species in Illinois and Wisconsin, but is now rare. Even in 1876 , according to Nelson, it was no longer common. He writes: "Once an abundant migrant, but is now of rare occurrence in this vicinity. Along the Illinois River and more thinly settled portions of the state, it is still common during the migrations and a few pairs breed upon the large marshes in Central Illinois." (Birds N. E. Illinois, 1876 , p. I33.) In Wisconsin, Kumlien and Hollister consider it a rare bird at the present time. They say: "Formerly of regular occurrence in the southern and western part of the state during migrations, unquestionably breeding to some extent. Thirty or forty years ago it was not rare to see a few among the enormous flocks of Sand Hill Cranes during the October migrations, and even flocks composed entirely of this species. Of late years adults are exceedingly rare and the last record we have of a Wisconsin capture was in October, 1878 , when a fine old bird was shot in Green Co., and sent to Thure Kumlien. ****** Among the flights of the common crane that often remain upon the larger dry marshes for two weeks or more in October, there are noticed a few large 'yellowish' specimens that are presumably the young of the year of the Whooping Crane, but they are so shy that approach is practically impossible." (Birds of Wisconsin, I903, p. 36.) 


\section{Grus canadensis (LinN.).}

Little Brown Crane.

Distr.: Arctic and subarctic America, breeding from the Fur Countries northward; south in winter into western United States.

Adult: Resembles the next species, but may be recognized by its small size, the wing (carpus to tip) being less than 19 inches, and the bill less than 4 inches.

While there is no record of the occurrence of this species in Illinois, it has twice been taken in Wisconsin. Kumlien and Hollister state (Birds of Wisconsin, I 903, p. 37): "Rare straggler during spring and late fall. During the latter part of March and the first part of April, I894, a lone crane kept with a flock of Canada Geese on Rock Prairie, near Johnstown, Rock County, for some days, and appeared to act as chief sentinel while the geese fed in the fields, always flying away with the geese when alarmed. This bird was killed on April 4, (I904) by L. Kumlien and proved to be a fine plumaged male of this species and very small. It is now preserved in the Museum of the Whitewater Normal School. At least one other that we are positive of was shot in Dane Co., late in the fall of 1879 , and came into the possession of Thure Kumlien, frozen stiff. This specimen was formerly in the Museum of Albion Academy."

\section{Grus mexicana (MüLL.).}

Sandhill Crane.

Distr.: Southern half of North America; now rare on the Atlantic coast, except in Georgia and Florida. Occurs in Wisconsin and Illinois during the migrations but much less common than formerly.

Adult: Front of head, bare, the skin, red; general plumage, brownish gray, showing more or less buffy gray on the back. The sexes are similar.

Immature birds have the head feathered and general plumage, buff gray.

Length, 40 to 47 ; wing, 2 I to 24 ; bill, 5 to 6 ; tarsus, 9 to 10 .

Its large size will distinguish it from the Little Brown Crane which it resembles in color, the wing (carpal joint to tip) being always more than $\mathrm{I} 9$ inches and the bill over 4.50 inches.

Ridgway states (Orn. of Illinois, I895, p. I00): "Sandhill Cranes usually arrive in Illinois on their way northward during the latter half of March, and return in October or November. Formerly large numbers remained within the state to breed, but so thickly has the 


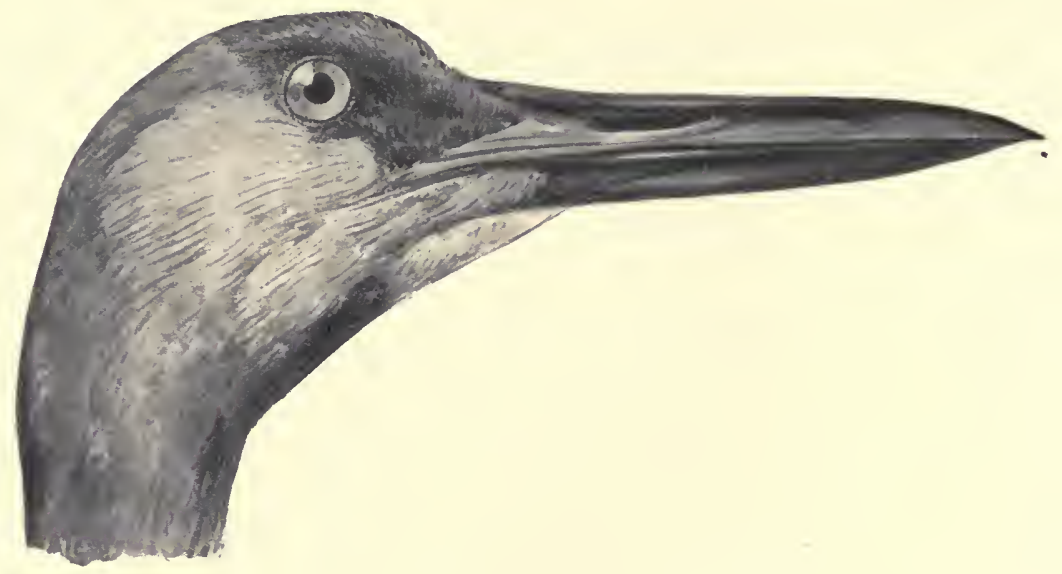

Sandhill Crane.

country become settled that those which now do so are very few indeed, at least in comparison with former years. As long ago as I $876 \mathrm{Mr}$. Nelson stated that while formerly nesting abundantly on all the large marshes, but few then bred except on one or two large marshes in the central part of the state, where he was informed they were still quite numerous. Just where the large marshes in question are located, Mr. Nelson has not told us." Regarding its occurrence in Wisconsin, Kumlien and Hollister say: "Although at the present time entirely absent from most thickly settled portions of the state, there are still many localities, even in southern Wisconsin where it occurs regularly in good numbers. On the "Big Marsh" near Delavan cranes occur every spring and fall in numbers from one hundred to two hundred and fifty, remaining for nearly three weeks at a time. A nest of two eggs was procured on this marsh, May 30,1883 . ***** They were reported as nesting on the immense marsh near Palmyra in 1898 and a few certainly bred near Mauston in 1896 . The last authentic record for nesting in southeastern Wisconsin was of two pair which bred near Jefferson in I900." (Birds of Wisconsin, 1903, p. 37.)

The nest is a large affair, composed of weeds, rushes, and small sticks, built on the ground, usually in marshy places. The eggs are two, grayish olive, spotted and blotched with brown. They measure about $3.85 \times 2.40$ inches. 
Jan., igo9. Birds of Illinois and Wisconsin-Cory.

Suborder RALLI. Rails, Gallinules, Coots, etc.

\section{Family ARAMIDÆ. Courlans or Limpkins.}

- The Limpkins are closely allied to the Cranes osteologically, but differ widely in habits, in the latter resembling both the Rails and Herons. They frequent swamps and streams and like herons are perfectly at home in trees. Their cry is a mournful wailing note, from which it is called "crying bird" in some parts of the south, especially in Florida, where it is also known as Limpkin, from its peculiar style of walking. They eat large numbers of land snails (Ampullaria). The tip of the lower mandible is bent sideways, caused, it is claimed, by forcing the bill into the spiral shell to extract the animal. The single genus belonging to this family comprises but two known species.

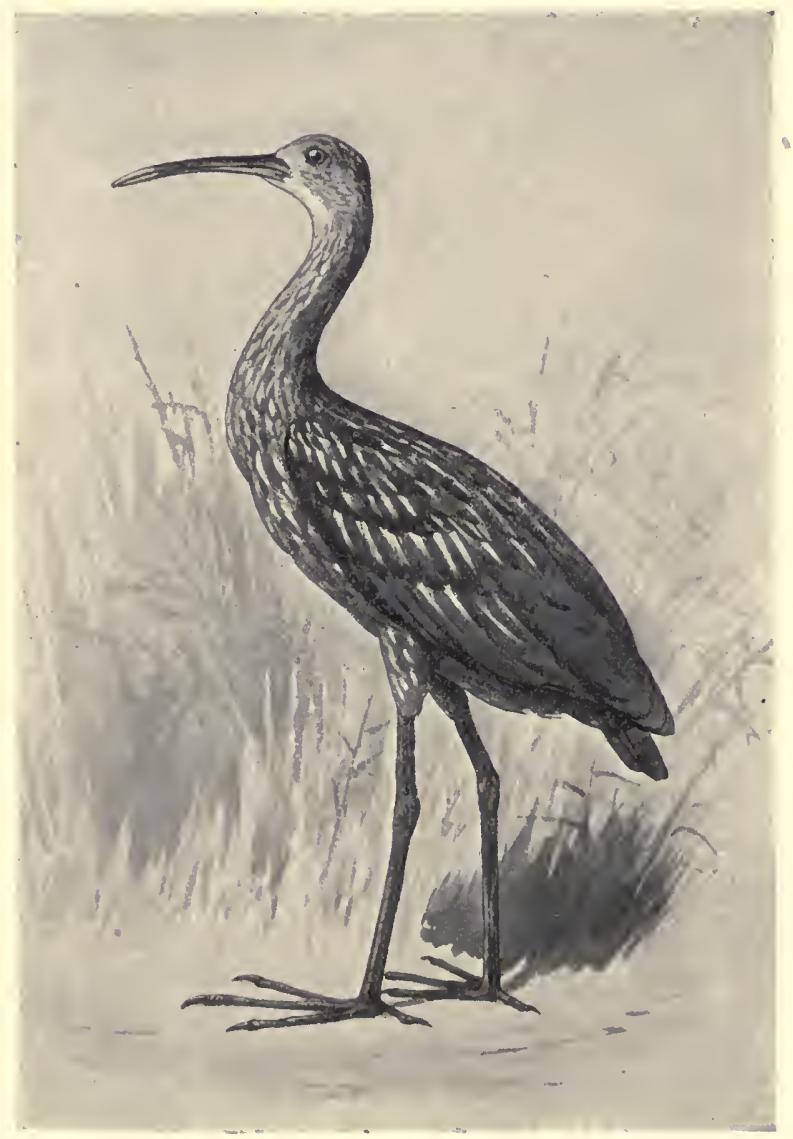

Limpkin. 
380 Field Museum of Natural History-Zoölogy, Vol. IX.

\author{
Genus ARAMUS Vieill. \\ 93. Aramus vociferus (Latham). \\ LIMPKIN.
}

Aramus giganteus (Bonap.), A. O. U. Check List, I895, p. 76.

Distr.: Both coasts of Central America and Mexico to the Rio Grande, also the Greater Antilles; common in Florida.

Adult: General plumage, dark olive brown, striped with white, the stripes on the body being much heavier than those on the head and neck; wing and tail showing bronzy reflections when held in the light; under mandible, slightly twisted near the tip.

Length, 27.50; wing, I3; tarsus, 4.35 ; bill, 4.50 .

$\mathrm{I}$ include this species upon the authority of Mr. Isaac E. Hess who writes me: "A limpkin was taken here (Philo, Champaign Co., I11.) in $\mathrm{r} 896$. I have the wings of this bird yet." This is apparently the only record for Illinois and far north of its usual range. It must of course, "be considered an accidental straggler within our limits.

\title{
Family RALLIDÆ. Rails, Gallinules, Coots, etc.
}

A large family, nearly 200 species, being known throughout the world, 17 of which occur in North America. They frequent the marshes and grassy edges of ponds and rivers. Their food consists principally of aquatic animals and vegetable substances, seeds, etc. Among the true rails, the power of flight is not strong and they rarely take wing unless forced to do so, preferring to run and hide in the grass and weeds to escape danger.

The Coots, belonging to the subfamily Fulicine, although anatomically allied to the true rails, are very different in appearance and habits. They often gather in large flocks and swim about in open water, at a distance resembling flocks of ducks. 
Subfamily RALLINÆ. Rails.

\section{Genus RALLUS Linn.}

94. Rallus elegans Aud.

KING RaIL.

Distr.: Fresh water marshes of eastern United States, north to the Middle states and Wisconsin, Illinois, Indiana, Kansas, etc., casual to Massachusetts and Ontario.

Adult: Upper parts, dark brown; throat, white; breast, reddish brown; sides, darker, barred with white; back and scapulars, brownish,

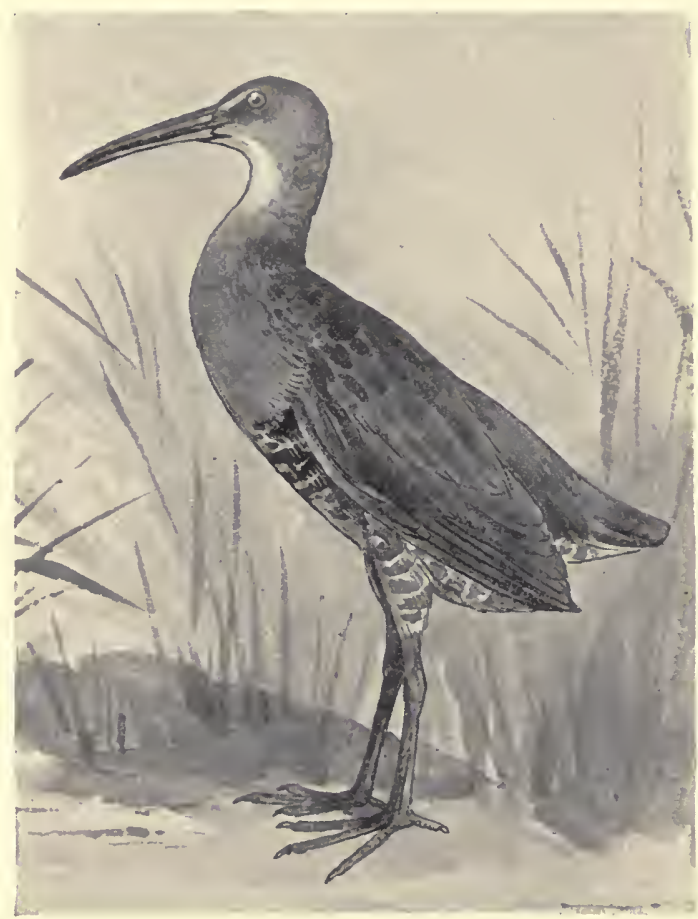

King Rail.

margined with olive gray; wings and tail, dull brown or olive brown; wing coverts, rufous brown.

Length, I 5.40; wing, 6.55; tarsus, 2.25 ; bill, 2.50 .

The King Rail is a summer resident in Wisconsin and Illinois and breeds in both states in suitable localities. Nests in fresh water marshes. The eggs are 8 to I 2 , buffy white, spotted and speckled with rufous brown, and measure about I.70 X 1.20 inches. 
382 Field Museum of Natural History-Zoölogy, Vol. IX.

95. Rallus virginianus LiNN.

Virginia RaIL.

Distr.: North America in general, from the British Provinces south to Guatemala and Cuba.

Adult: Having somewhat the appearance of a very small King Rail; upper parts, dusky or blackish; feathers, edged with grayish

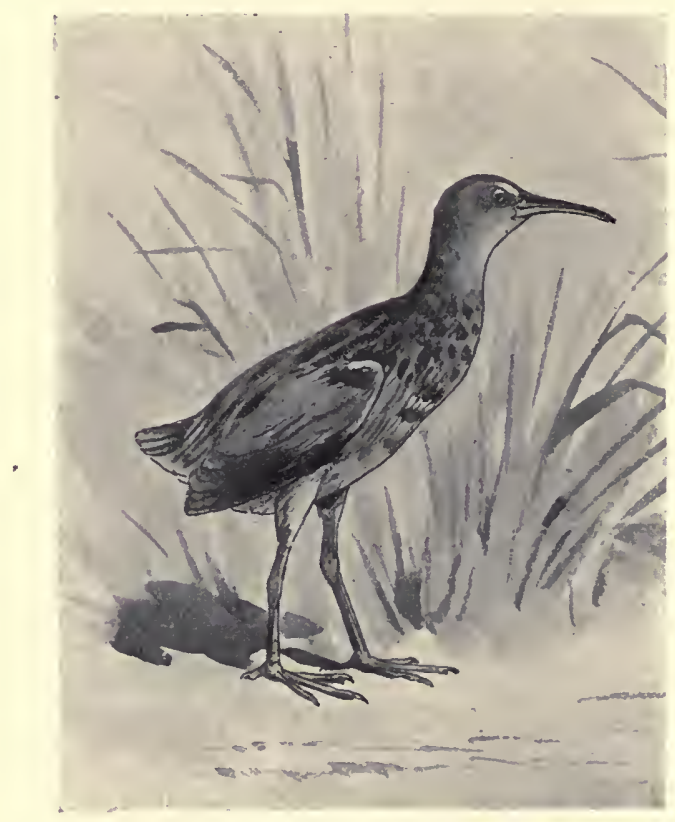

Virginia Rail.

brown; wings, brownish; under parts, dark rufous brown; throat, white; lores, ashy white, shading into gray on the cheeks; flanks and under tail coverts, barred and spotted with white and black.

Length, 9.40; wing, 4.25; tarsus, I.35; bill, I.55.

A common summer resident in Illinois and Wisconsin, breeding throughout both states. Inhabits swamps and marshes. Nests on the ground. The number of eggs varies from 7 to 12 . They are pale buff color, spotted and speckled with rufous brown, and measure about $1.25 \times .95$ inches. In northern Illinois the eggs are laid late in May or early in June. 


\section{Genus PORZANA Vieill.}

\section{Porzana carolina (Linn.).}

Sora or Carolina Rail.

Distr.: Temperate North America, south to West Indies, Central America, and northern South 'America.

Adult: Above, reddish brown, streaked with black and some of the feathers edged with white; flanks and linings of the wings, barred

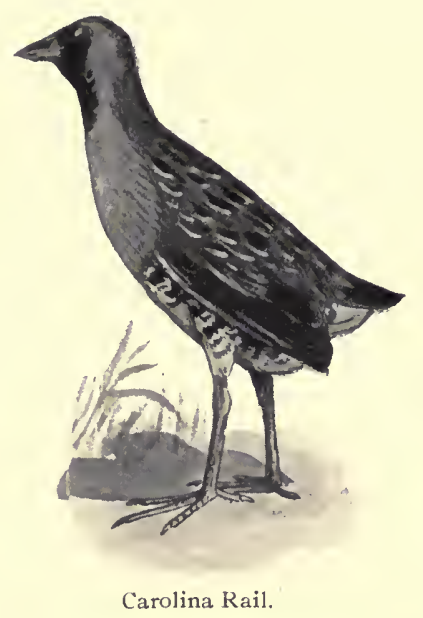

with white and black; abdomen, dull white; a stripe of black passing from the bill down the center of the throat but not reaching the breast; whole of the breast, a cheek patch and superciliary line, slate color; crown, chestnut, with a black stripe through the center; carpus, edged with white; crissum, rufous, shading into whitish.

Length, 7.75 ; wing, 4.20 ; tail, 2 ; tarsus, 1.38 ; bill, .75.

The Carolina Rail is an abundant summer resident in Illinois and Wisconsin, breeding everywhere in suitable localities. The nest is of grass in swampy places. The eggs are from 8 to I4, pale buffy white, spotted and marked with rufous brown, and measure about $1.20 \mathrm{X} .90$ inches. In northern Illinois incubation begins early in May, but is somewhat later in Wisconsin. There is a set of eggs in the Field Museum collection, taken at Goose Lake, Waseca Co., Minnesota, June 3,1892 . 


\title{
Genus COTURNICOPS Bonap.
}

\section{Coturnicops noveboracensis (GMEL.).}

\author{
Yellow RaIL.
}

Porzana noveboracensis (Gme1.), A. O. U. Check List, I 895, p. 79.

Distr.: Chiefly eastern North America, north to Nova Scotia and Hudson Bay, casually west to Nevada and California; accidental in Cuba and Bermuda.

Adult: Above, streaked with blackish and yellowish brown; feathers, barred and mottled with white; under parts, yellowish

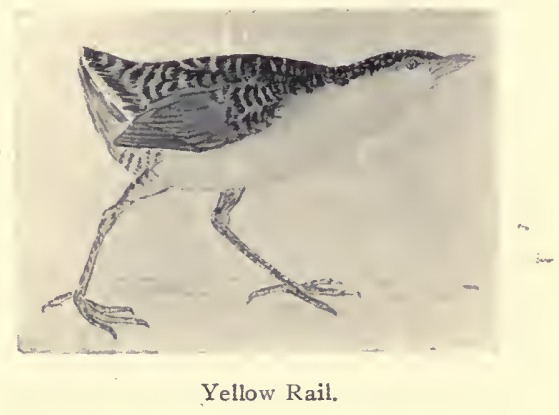

brown, palest on the belly; feathers of the breast, tipped with dark brown; under surface of wings, white; a pale yellowish brown superciliary stripe.

Length, 6; wing, 3 to 3.50 ; tarsus, .90 to r.oo.

The Yellow Rail is a summer resident in both Illinois and Wisconsin. It is not uncommon but is seldom seen in comparison with other species, if we except the Little Black Rail. It breeds in Wisconsin and at least in the northern part of Illinois.

Mr. Nelson gives it as "not very rare" and states that a set of six eggs were taken with the bird, May I 7 , by Mr. J. W. Tolman at Winnebago, Ill., and are now in the possession of the Smithsonian Institution. Kumlien and Hollister give it as a summer resident in Wisconsin. They say: "Not nearly so rare as generally supposed, though by no means common. We have authentic records from Racine, Milwaukee, Elm Grove, Delavan, Janesville, Milton, etc:, and even breeding records as far north as Brown Co." (Birds of Wisconsin, I903, p. 39.)

This species builds its nest in a well-covered marsh. The eggs are six or more, buffy white, spotted heavily on the larger end with brown. They measure about I.IO X .85 inches. 


\section{Genus CRECISCUS Caban.}

98. Creciscus jamaicensis (Gmel.).

BLACK RaIL.

Porzana jamaicensis (Gmel.), A. O. U. Check List, I895, p. 79.

Distr.: Temperate North America, from Massachusetts, Illinois, and Oregon south to the West Indies and Guatemala.

Adult: Top of the head, dusky; nape and upper back, brownish chestnut; rest of back and upper tail feathers, dusky or smoky brown,

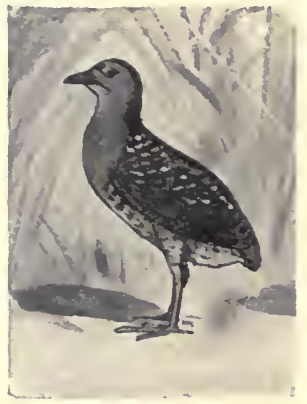

Black Rail. finely barred with white; throat, gray or ash gray; belly, gray; flanks and lower belly and undertail covers, banded with white; bill, black.

Length, 5 ; wing, 2.50 to 3.20 ; tarsus .85 to .90 .

The Black Rail is a regular summer resident in Illinois and perhaps in southern Wisconsin, but on account of its small size and retiring habits it is rarely seen.

According to Nelson, it is not very rare in northern Illinois and breeds. He records the finding of a set of ten eggs of this species by Mr. Frank Dewitt, near the Calumet River, June I 9, I875. (Birds N. E. Illinois, 1876 , p. I 34.) Kumlien and Hollister say: "The only record we are aware of is the following: August 20, 1877 , a Marsh Hawk was killed by Frithiof Kumlien from a muskrat house on the border of Lake Koshkonong. When noted first it was eating something and this proved to be a little black rail. We are quite sure of having seen it on one occasion, but the above is probably the only authentic record for the state as yet." (Birds of Wisconsin, r 903 , p. 39.)

The nest is of grass, built on the ground. The eggs are 8 to io, creamy white or dull white, and measure about $\mathrm{I} \times .80$ inches. An admirable account of the breeding and distribution of this species is given by Dr. J. A. Allen in the Auk, Vol. XVII, I900, p. I. 


\section{Subfamily GALLINULINÆ. Gallinules.}

\section{Genus IONORNIS Reich.}

99. Ionornis martinica (LINN.).

Purple Gallinule.

Distr.: Southern United States, West Indies, Middle America, and northern South America, casual as far north as Maine and Wisconsin.

Adult male: Head, neck, and under parts, bluish purple, grading into black on the belly; above, olive; wing coverts, bluish; back, olive; crissum, white; frontal plate of the bill, blue; bill, red, tipped with yellow; legs, yellow.

Length, I I ; wing, 6.50; tail, 2.65 ; tarsus, 2.30.

The Purple Gallinule is of rare occurrence in Illinois in summer, and a straggler in Wisconsin. Butler (Birds of Indiana, I897) states that it "breeds northward to southern Illinois," but I find no record of the eggs having been taken there. Nelson (Birds N. E. I11., I876, p. I35) mentions a specimen taken near Chicago, by Mr. C. N. Holden, Jr., in May, I866; and Mr. Ruthven Deane records a second Illinois specimen killed by Mr. T. G. Windlass, near Coal City, Grundy Co., on April 24, I900. (The Auk, Vol. XIX, I902, p. 77.) Kumlien and Hollister give three records for Wisconsin, including one by Dr. Hoy, Janesville, Milwaukee and Racine. It has also been taken in Missouri, Iowa and Ohio.

\section{Genus GALLINULA Brisson.}

100. Gallinula galeata (Lichт.).

Florida Gallinule.

Distr.: Temperate and tropical America, from Canada to Brazil and Chili, including the West Indies.

Adult: Head, blackish; bill, tipped with green, rest of bill and frontal plate, deep red; upper back, slaty; lower back and wings, olive brown; under parts, dark slate color; lower belly, grayish; feathers, faintly tipped with white; some of the feathers on the sides have the inner webs white near the tip, giving the appearance of white stripes; under tail coverts, black; tail, white and black; legs, olive green, reddish near the body.

Length, I3; wing, 6.60; tail, 3.10; tarsus, 2; bill, including frontal shield, I.75; bill, from gape, I.25. 


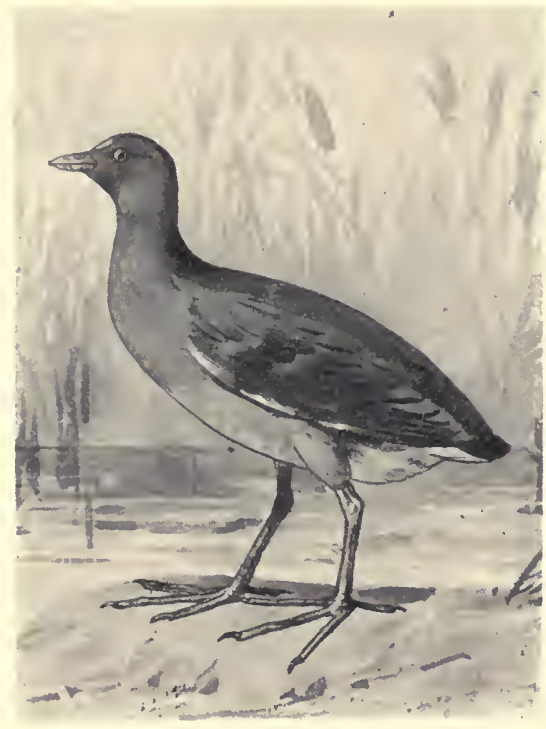

Florida Gallinule.

This species is a common summer resident in Illinois and the greater part of Wisconsin, and breeds in both states. The majority of them arrive early in May and the eggs are laid in June. The nest is a mass of reeds and weeds in a swamp or marsh. The eggs are 8 to I 2 in number, buff white, spotted and speckled with brown, and measure I.80 X I.25 inches. The Field Museum possesses a set of I I eggs taken June 6, 1903 , at Fox Lake, Ill., and another set taken in a marsh near Chicago, May 30, 1888.

\section{Subfamily FULICINÆ. Coots. \\ Genus FULICA Linn.}

\section{I0I. Fulica americana GMeL.}

American Coot.

Distr.: North America, from Greenland and Alaska south to the West Indies and Veragua, in winter.

Adult: General plumage, dark slate color; head and neck, blackish; bill, whitish, marked with reddish black on the upper mandible; frontal plate, brownish white; legs and feet, dark olive, the toes having peculiar semicircular flaps or webs; abdomen, grayish; edge of wing and ends of secondaries, white. 
388 Field Museum of Natural History-Zoölogy, Vol. IX.

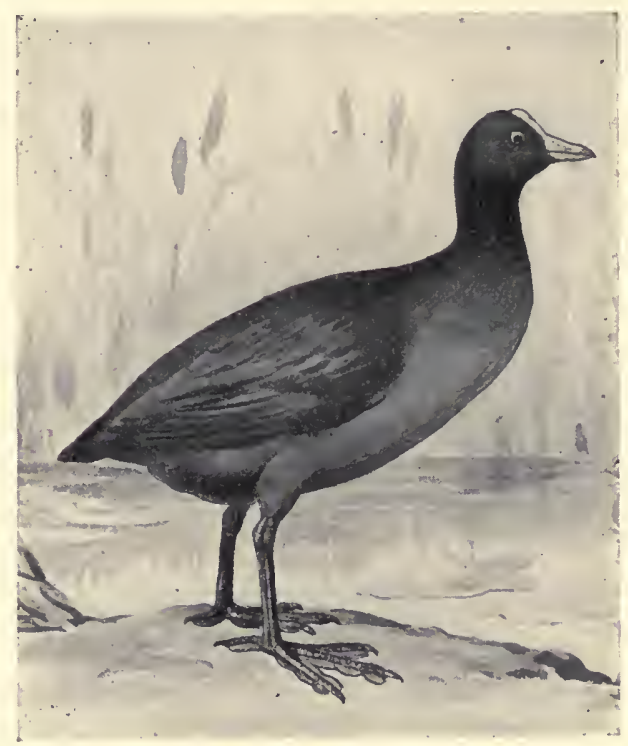

American Coot.

Length, 14.75 ; wing, 7.45 ; tail, 2.30 ; bill, from front edge of frontal plate, r.40.

The Coot or Mud-hen, as it is often called, is a common summer resident in Wisconsin and Illinois, breeding in suitable localities. It may always be distinguished from the Gallinule by the peculiar lobate or scalloped webs on the toes. It breeds in May and early June. The nest is built in a marsh or swampy place in the vicinity of ponds and small lakes and is composed of reeds and grass. The eggs vary in number from 9 to. I 4. They are pale buff or buffy white, finely speckled with dark brown, and measure about $\mathrm{r} .85 \times \mathrm{x} .28$ inches. 


\section{ORDER LIMICOLÆ}

SHORE BIRDS AND MARSH BIRDS.

\section{Family PHALAROPODIDÆ. Phalaropes.}

Phalaropes somewhat resemble sandpipers in appearance, but unlike them, are fond of swimming about on the water like miniature ducks. One species is often seen in flocks far out at sea. The inland forms frequent the ponds, lakes, and rivers. The female, contrary to the usual rule (in birds), is more highly colored than the male and is larger. All of the three species comprising this small family occur in North America. The marginal webs on the toes will distinguish them from the sandpipers.

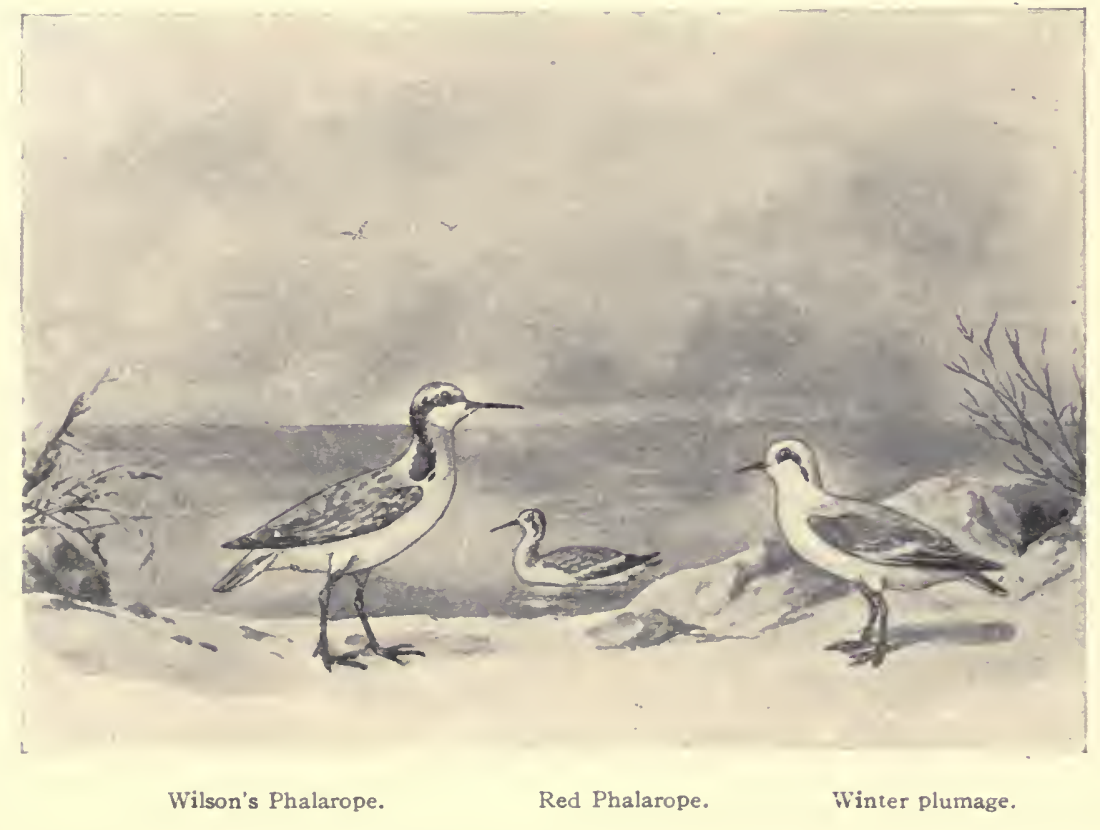


390 Field Museum of Natural History-Zoölogy, Vol. IX.

\section{Genus PHALAROPUS Brisson.}

102. Phalaropus fulicarius (LINN.).

Red Phalarope.

Crymophilus fulicarius (Linn.), A. O. U. Check List, r 895, p. 82.

Distr.: Arctic regions, south in winter, chiefly along the coast, to the Middle states in eastern North America and Lower California in the West.

Adult male in summer: General under parts and sides of the neck, purplish brown; upper tail coverts, purplish brown, slightly darker than the under parts; crown of the head and base of the bill, smoky black; sides of the head,

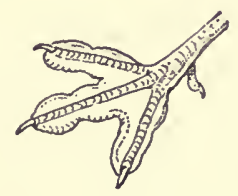

Phalaropus fulicarius. white, extending to the nape; rump, white; back, black; feathers, edged with tawny brown; primaries, dusky, the shafts being white, and the base of the feathers, white; some of the secondaries, white; bill, yellowish brown, dark on the tip; feet, dull yellow.

Adult in winter: Head and under parts, white; a small patch around the eye and a nuchal crest, dusky; the under parts of the body are tinged with ashy gray on the sides; upper parts, grayish ash color; wings, showing a distinct white bar; bill, dusky; feet, brownish.

Length, 7.70; wing, 5.10; tail, 2.50 bill, .94; tarsus, .80.

The Red Phalarope is a comparatively rare bird in Illinois and Wisconsin. Small flocks occasionally occur on Lake Michigan and some of the inland waters during the migrations.

Ridgway includes it as a rare migrant. Nelson in his Birds of Northeastern Illinois (I 876 , p. I 25) says: "Exceedingly rare, occurs only during the migrations." Kumlien and Hollister (Birds of Wisconsin, I903, p. 4I) state that small flocks may be met on Lake Michigan and Lake Superior in autumn and occasionally straggling individuals wander to the inland lakes. They also give several records of specimens killed in the state.

\section{Genus LOBIPES Cuvier.}

103. Lobipes lobatus (LinN.).

Northern Phalarope.

Phalaropus lobatus (Linn.), A. O. U. Check List, r895, p. 82.

Distr.: North portion of northern hemisphere, breeding in Arctic latitudes; south in winter to the tropics. 


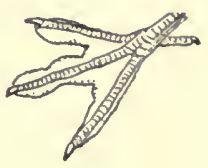

Lobipes lobatus.

Adult female in summer: Upper plumage, dark plumbeous; the back, streaked with buff; sides and front of the neck, rufous brown; greater wing coverts, tipped with white; belly, white.

Adult male in summer: Similar to the female but paler; little, if any, rufous on the front of the neck.

Winter plumage: Upper plumage, grayish; forehead, sides of the neck, cheeks, and under parts, white; top of the head, dull gray; the feathers edged with dull white; a dusky spot on side of head and in front of the eye; breast, tinged with gray.

Length, 7.50; wing, 4.25; tarsus, .80; tail, 2 ; bill, .80 to .90.

The Northern Phalarope occurs in Illinois and Wisconsin during the migrations, and although there are numerous records of its capture in both states, it is by no means common. Kumlien and Hollister state that it is frequently taken on Lake Koshkonong in August. Mr. G. A. Abbott informs me that he killed a specimen on Lake Calumet near Chicago, in September, I903.

\section{Genus STEGANOPUS Vieill.}

\section{Steganopus tricolor VIEILL.}

Wilson's Phalarope.

Phalaropus tricolor (Vieill.), A. O. U. Check List, I895, p. 83.

Distr.: Chiefly interior of North America, breeding from northern Illinois northward; south in winter to South America. Common along Mississippi Valley during migrations, rare or casual on the Atlantic coast.

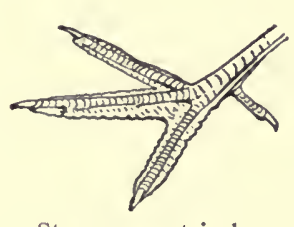

Steganopus tricolor.

Adult female in summer: Crown and middle of back, pearl gray; nape, white; superciliary stripe, white; a dusky or black streak from the eye to the sides of the neck; sides of upper back, chestnut, bordering the gray; middle throat and breast tinged with pale rufous brown; chin, white; belly, white.

Adult male in summer: General resemblance to the female, but smaller and much paler in coloration; the crown and back, more brownish.

Adult in winter: Upper plumage, the feathers more or less edged with white; wings, fuscous, or gray brown; coverts, edged narrowly with white; under parts, white. 
392 Field Museum of Natural History-Zoölogy, Vol. IX.

Female: Length, 9.10 to I0.05; wing, 5.20. to 5.40 ; tarsus, I.25 to I.4O; bill, I. 25 to I.40.

Male: Length, 8.40 to 9.10 ; wing, 4.60 to 4.90 ; tarsus, $\mathrm{x} .20$ to I.3O; bill, I.20 to I.3O.

Wilson's Phalarope is a rather common summer resident and breeds in northern Illinois and Wisconsin. The male of this species, as in the other Phalaropes, is smaller than the female and not so highly colored; he also takes upon himself many domestic duties usually assumed by the female; he sits on the nest, contrary to the usual custom, and devotes himself to the young chicks. The nest is merely a slight depression in the ground, more or less lined with grass. The eggs are usually four, cream white, heavily blotched with dark brown, and measure about $1.25 \times .95$ inches.

\section{Family RECURVIROSTRIDÆ. Avocets and Stilts.}

A small family characterized by long slender legs and extreme slenderness of bill. Two species occur in eastern United States. They are usually seen in flocks wading about in shallow water, but. they are expert swimmers as well as waders.

\section{Genus RECURVIROSTRA Linn.}

105. Recurvirostra americana GmeL.

American Avocet.

Distr.: Temperate North America, north of the Saskatchewan and Great Slave Lake, south to Guatemala and the West Indies in winter; rare in eastern United States.

Adult in summer: Bill, very slender and curved upwards; feet, partly webbed; general plumage, white, becoming cinnamon brown on the head and neck, but remaining whitish at the base of the bill; primaries, black; most of the secondaries, white, forming a broad white patch on the wing; tail, ashy gray; legs, bluish; bill, black.

Adult in winter: Head and most of the neck, ashy gray; tail, ashy gray; rest as in summer plumage.

Length, I 8 to 20 ; wing, 7.50 to 9 ; tail, 3.50 ; bill, 3.25 to 3.75 ; tarsus, 3.60 . 


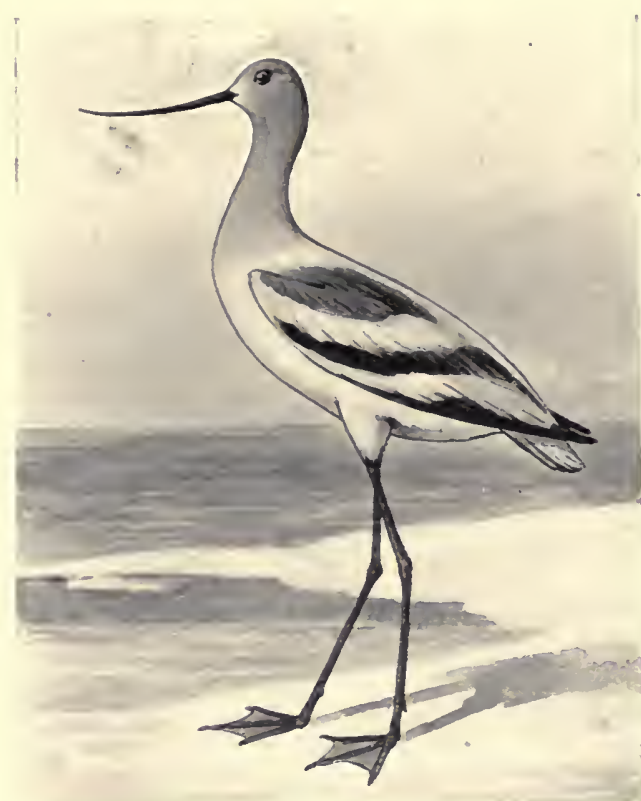

Avocet.

The Avocet is of occasional occurrence in Illinois and Wisconsin. Nelson says (Birds N. E. Ill., I876, p. 124): "A rare migrant, generally occurs in small parties the last of April and the first or May and during September and the first of October. Frequents the borders of marshy pools." Regarding its occurrence in Wisconsin, Kumlien and Hollister say: "Specimens of this peculiar wader were taken by Thure Kumlien at different times from I 844 to 1875 . Three were shot on Lake Koshkonong, September, 1873. Bred in Green Bay in 1879 , where downy young were seen in the possession of a taxidermist, by L. Kumlien. Those taken by Thure Kumlien were more often taken in September and October and were principally young birds. A specimen in the Milwaukee Public Museum is labelled 'Wis.' At the present time it must be considered as exceptionally rare." (Birds of Wisconsin, I g०3, p. 42.) "East of the Mississippi it breeds from Illinois northward." (W. W. Cooke, Bird Migr. Miss. Val., I888, p. go.)

The nest is merely a depression in the ground in marshy places. The eggs are three or four, olive clay color, marked and spotted with chocolate brown, and measure about 2 X I.40 inches. 
394 Field Museum of Natural History-Zoölogy, Vol. IX.

\section{Genus HIMANTOPUS Brisson.}

\section{Himantopus mexicanus (MÜLL.). \\ BlaCK-NECKED Stilt.}

Distr.: Temperate North America, from northern United States southward to the West Indies, northern Brazil and Peru; rare in eastern United States, except in Florida, where it breeds.

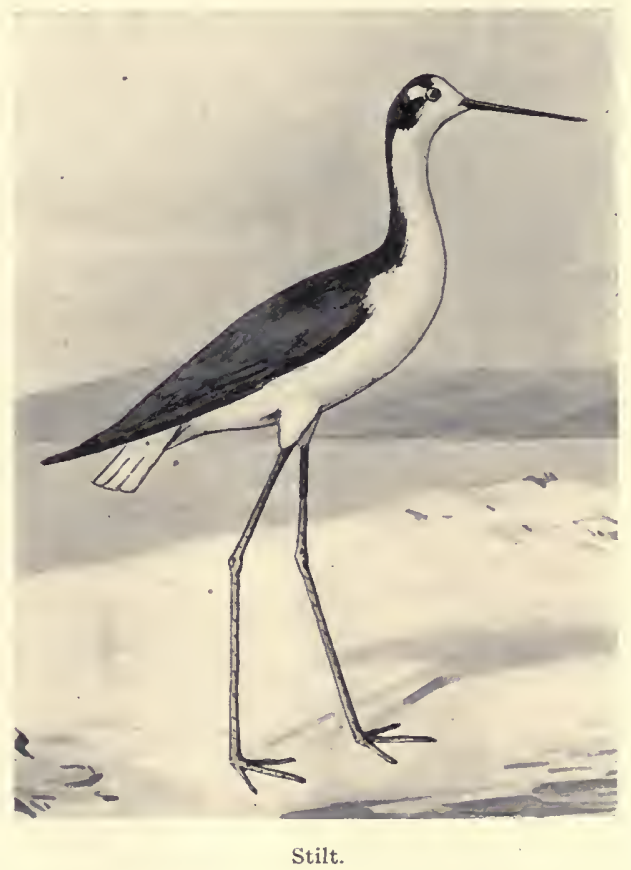

Adult: Top and sides of the head and back of the neck and back, black; under eyelid and a spot above and behind the eye, forehead, and sides of the head under the eye, white; rest of under parts, with the rump and upper tail coverts, white; tail, ash gray or pearl gray; bill, black; legs, red in life.

The immature bird has the upper parts brownish; feathers, edged with whitish; wings, blackish, some of the feathers, tipped with white; wing coverts, edged with buff or tawny brown; under parts, white, mottled with black and tawny brown.

Length, I 5.50; wing, 9; tail, 3 ; tarsus, 4.25 ; bill, 2.70 .

The Black-necked Stilt is of casual occurrence in southern Illinois, although probably rare at the present time. Nelson considered it an exceedingly rare visitant in northern Illinois and states there is a 
fine specimen taken in McLean County, Illinois, in the collection of the Illinois Natural History Society at Normal, Ill. Ridgway says (Orn. of Ill., r 895, p. 76): "While on record only as a summer visitant, the Stilt undoubtedly breeds in some portions of the state." In Wisconsin, it is a very rare straggler, the only known record being that of Dr. Hoy (Transactions of the Wisconsin Agri. Soc., Vol. II, 1852, p. 355) who says: "Met a small flock of these singular birds near Racine, in $1847 . "$

This species is given in Gibbs's Birds of Michigan as a "rare transient."

\section{Family SCOLOPACIDÆ. Snipes, Sandpipers, etc.}

The Scolopacidæ comprise a large family, a hundred or more species being known from various parts of the world. Nearly 50 species occur in North America. The greater portion of these birds frequent the beaches and marshes, some, however, are partial to open fields. The majority of them procure their food by probing with their sensitive bills in mud or sand. Their flesh is excellent and they are much sought after by sportsmen during the migrations.

\section{Genus PHILOHELA Gray. \\ 107. Philohela minor (GMel.). \\ WoODCOCK.}

Distr.: Eastern North America, from British Provinces westward to North Dakota and Kansas and south to the Gulf of Mexico.

Adult: Bill, long, corrugated near the end; upper parts variegated with tawny rufous, brown and black; head, rufous brown, banded on the occiput with alternate bands of black and tawny brown; a line of black from the eye to the bill; a narrow patch on the sides of the lower head, blackish; throat, pale rufous or rufous white; under parts of the body, pale rufous; quills, brownish; three outer primaries, very narrow; tail feathers, dusky, tipped with ash; bill, pale brown, yellowish at the base; legs, reddish; bill, light brown, paler and yellowish at base.

Length, Ir.50; wing, 5.45; tarsus, r.30; bill, 2.90 to 3.05 . 


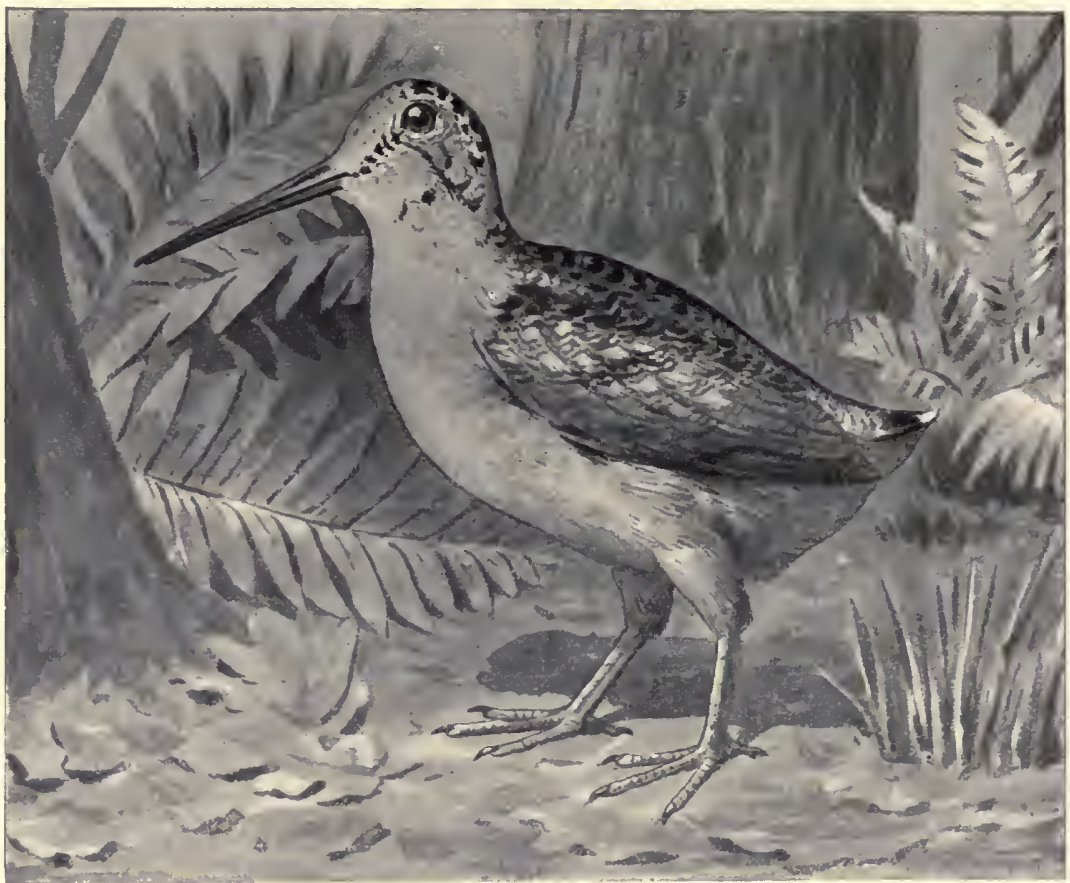

Wood cock.

A common summer resident in Illinois and Wisconsin, breeding in timbered swamps and in the bottom lands along rivers and streams. Its presence is often indicated by numerous holes in the soft ground made by its bill when probing for its food. Arrives from the south late in March or early in April. The whistling sound made by this bird when suddenly "flushed" is caused by the rapid movement through the air of the stiff, narrow outer primaries and is not vocal as some suppose.

Mrs. Irene G. Wheelock writes me regarding the unusual occurrence of a bird of this species in Wisconsin in winter, stating that on January 3, 1908, a Woodcock was flushed in a clump of spruce trees on the grounds of Mr. Charles L. Hutchinson at Lake Geneva. The mud in the sun warmed hollow showed numerous "borings."

The nest is usually a mat of leaves placed on the ground. The eggs are four, pale buff color with more or less distinct markings of rufous brown. They measure about r.60 x r.25 inches. The Field Museum collection contains a set of four eggs taken by Mr. G. A. Abbott in Cook County, Ilinois, April I2, I903. 


\section{Genus GALLINAGO Koch.}

108. Gallinago delicata (ORD).

WiLSON'S SNIPE.

Local names: English Snipe. Jack Snipe.

Distr.: North America, breeding from northern United States northward; south to the West Indies, Middle America, and northern South America, in winter.

Adult: Bill, long and straight, being slightly enlarged near the tip and showing numerous small pits; no web between outer and mid-

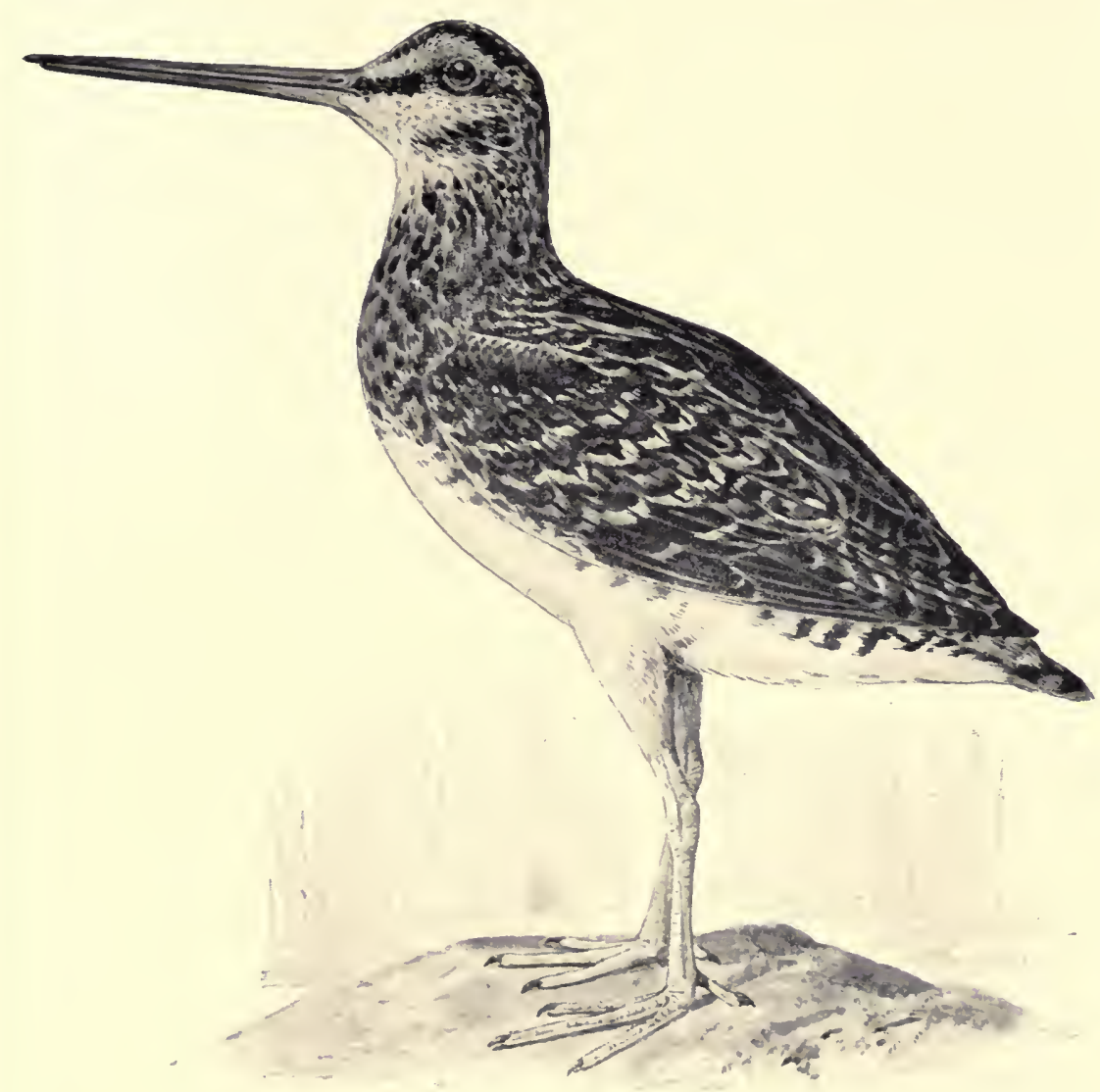

Wilson's Snipe.

dle toes; general upper parts, dark brown, tawny brown, pale yellow, dull white; top of the head, black, with middle stripe of tawny brown; 
outer web of first primary, white; greater wing coverts, brownish or dusky, with white tips; axillars and under surface of wings, barred with black; upper tail coverts, tawny brown, barred with black; tail feathers, chestnut brown, with subterminal black bar; tips, white, and feathers marked with black at the base; under parts, white; breast and throat, speckled and lined with brown; sides of the body, brownish, barred with dull black.

Length, II; wing, 5 ; tail, 2.20; tarsus, 1.25 ; bill, 2.40 to 2.60 .

This species is abundant in Illinois and Wisconsin during the migrations, and some remain to breed in both states, but more commonly in Wisconsin than in Illinois.

The nest is on the ground. The eggs are usually four, grayish or brownish olive, heavily blotched with chocolate brown mostly at the larger end. They measure $1.65 \times 1.20$ inches.

An interesting account of the breeding of this species in Illinois and Indiana is given by Mr. Ruthven Deane (The Auk, Vol. XVI, I 899, p. 270). He states that it must breed more commonly in Illinois and Indiana than is generally supposed, as he found them very numerous at English Lake, Indiana, in the latter part of July and early in August and refers to numbers of specimens having been taken near Davis Station, Ind., and near Waukegan, Ill.

In some localities in the Southern States, during the winter months, thousands of these birds are killed on the marshes where they collect on some especially good feeding ground. When first disturbed they utter a peculiar cheep as they rise from the ground, often repeated during their flight, which is very irregular, making them one of the most difficult birds to shoot.

\section{Genus MACRORHAMPHUS Forster.}

\section{Macrorhamphus griseus (GMEL.).}

Dowitcher. Red-breasted Snipe.

Distr.: Eastern North America, breeding far north; south to the West Indies and Brazil; in winter.

Adult in summer: A small web between the outer and middle toes; upper parts, blackish; feathers, edged with tawny brown; top of head, blackish, mottled with tawny brown; under parts, red brown, banded on the sides; throat and breast only, slightly spotted, entirely without spots in some plumages; tail and upper tail coverts, barred with black; bill, dark olive,

Adult in winter: Upper parts, grayish, the feathers showing 

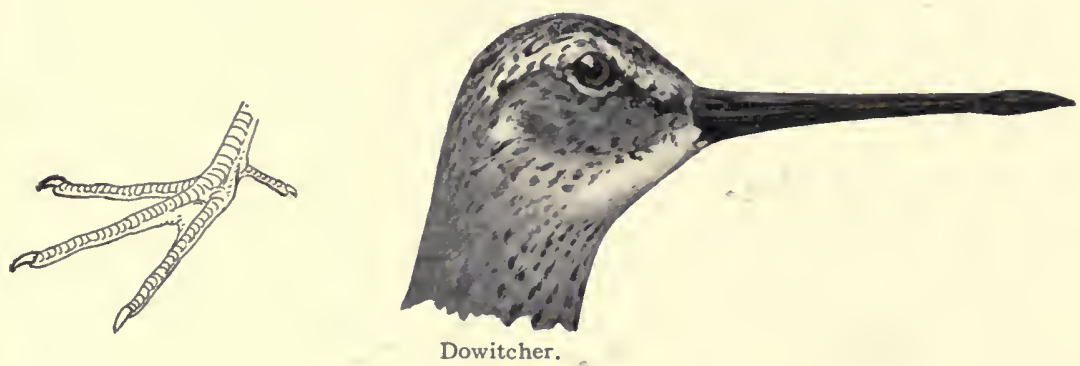

faint edges of buff on the back; chin and superciliary stripe, dull grayish white; breast, gray, showing slight-traces of tawny (often entirely absent); rest of under part, dirty white, mottled on the crissum; tail, banded dark brown or black and white.

Length, 10.30; wing, 5.70; tarsus, 1.30; bill, 2.20 to 2.50 .

The Dowitcher was at one time common, but now occurs only as a rather rare migrant in Illinois and Wisconsin. It is difficult to determine the relative abundance of this species in comparison with the next, from the fact that the ordinary sportsmen, as a rule, do not recognize them as different.

\section{II0. Macrorhamphus scolopaceus ( $\mathrm{SAY})$. \\ LONG-BILled Dowitcher.}

Distr.: Western North America, breeding from Alaska to the Arctic coast; south from the United States and Mexico in winter; casual on the Atlantic coast.

Adult: Resembles the preceding species, but the bill is longer, and in breeding plumage, the sides of the body are more distinctly barred with black; the throat and breast more rufous, and the general plumage more highly colored.

In winter the principal difference is one of size.

Length, II; wing, 6.05 ; tarsus, I.55; bill, 2.20 to 2.60 .

This species is still more or less common in Illinois and Wisconsin during the migrations. It is (or was) a well-known bird to sportsmen, and its long, snipe-like bill will always distinguish it from other species of shore birds, except the Wilson's Snipe, from which it may be known at a glance by the small web between the outer and middle toes, and by its differently marked tail and tail coverts. It occurs in flocks, and where it has not been persecuted by gunners, is very tame and unsuspicious. It was formerly very abundant, but being easy to kill, great 
400 Field Museum of Natural History-Zoölogy, Vol. IX.

numbers of them were shot by market hunters, until now it is almost a rare bird in localities where it was once exceedingly numerous.

Kumlien and Hollister state (Birds of Wisconsin, I903, p. 44): "Young still unable or barely able to fly were taken on several occasions. There is positively no question that considerable numbers bred in Wisconsin from $x 865$ to 1875 and in $\mathrm{r} 872$ and $\mathrm{r} 873$, as far south as Lake Koshkonong. In August the fully fledged young return from the north in great flocks." This is out of its usual breeding range and apparently its eggs were not actually found. It is well to note, however, that Cook in his Birds of Michigan ( 1893, p. $5^{8}$ ) says: "Prof. Ludwig Kumlien writes me that it breeds in the Northern Peninsula. Davie, page III, states that this species breeds on the border of Lake Superior and north."

Genus MICROPALAMA Baird.

III. Micropalama himantopus (BonAP.).

Stilt SANDPiper.

Distr.: Northeastern North America, breeding from the southern shores of Hudson Bay to the Mackenzie region and northward; south in winter to the West Indies, Central and South America.

Adult in summer: Legs, dull olive green; entire plumage, dull white and dark brown, being banded on the under parts with dark brown, and the upper parts, streaked with dark brown; a stripe of chestnut brown above and below the eye, the former extending backwards and joining at the occiput; secondaries, edged with tawny brown.

Adult in winter: Upper plumage, gray; feathers on the back, edged with white; breast, pale buff, slightly mottled, shading into dull white on the upper throat; belly, dull white; bill, black.

Length, 8.20; wing, 5; tarsus, 1.65 ; bill, r.60.

The Stilt Sandpiper can not be considered a common species either in Illinois or Wisconsin, but it occurs regularly in both states during the migrations and is apparently more numerous in late summer than in spring.

Nelson (Birds N. E. Illinois, 1876 , p. I 26) considers it "of rare occurrence" and says: "On the 8th of August, I873, I saw a single specimen on the Lake shore near Chicago, and the roth of September, the same year, R. P. Clark obtained a specimen at the same place."

Mr. Frank M. Woodruff writes: "I have observed a large number 
of this species, and can positively say that they are a rare spring migrant, and a common fall visitant. It is very hard to distinguish them in the fall plumage from the young of Totanus flavipes. I have one in the breeding plumage taken at South Chicago on the Calumet River in April, I890; also one in the light plumage taken at Mud Lake, September 23, I893. Mr. J. G. Parker, Jr., has a bright female taken from a flock of four at Mud Lake, July 25, I893; also a young bird from the same locality. . On August 24, 1895, Mr. J. F. Ferry of Lake Forest, I1l., and myself shot four Stilt Sandpipers from a flock of fifty or more at Libertyville, Ill." (The Auk, Vol. XIII, r896, p. I80.)

Kumlien and Hollister say (Birds of Wisconsin, I903,p. 44): "It is a migrant and doubtless a former summer breeder to a limited extent. $* * * *$ During the seventies they were rather common about Koshkonong, especially during the latter part of July, August, and well into September. We have taken young barely able to fly, readily running them down. These had the head and upper neck still in the natal down, and if they were not hatched at Lake Koshkonong, certainly they could have come but a short distance." This is interesting from the fact that the limit of its supposed breeding range is very much farther north. It will be noted, however, that there is no record of the nest and eggs having been taken in the state.

\section{Genus TRINGA Linn.}

\section{Tringa canutus Lins.}

KNoT.

Distr.: A cosmopolitan species, breeding in high latitudes, migrating south to the southern hemisphere in winter.

Adult in summer: Top of the head, buffy white, mixed with blackish; upper plumage, variegated with black, white, and buff; upper tail coverts, barred with black and white, often marked with buff; entire under parts, except the lower abdomen, rufous brown; lower abdomen, white; axillars, white, with long, arrow-shaped markings of dark gray.

Adult in winter: Entire upper plumage, ashy gray, the feathers having pale, brownish shafts, showing indistinct fine lines; upper tail coverts, white, banded with brown; under parts, white; the breast and sides with indistinct, irregular dots and bands of brownish gray; belly, and under tail coverts, pure white; axillars, white, with irregular, arrow-shaped, brownish gray marking. 


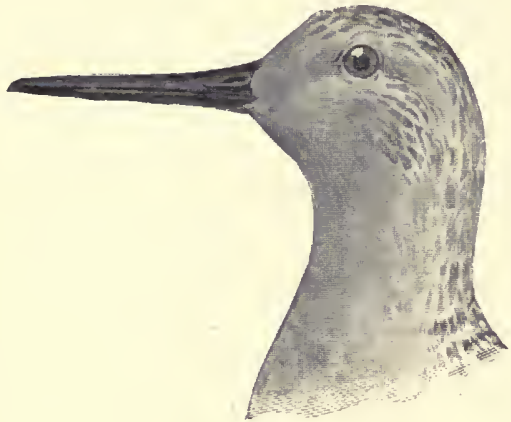

Knot.

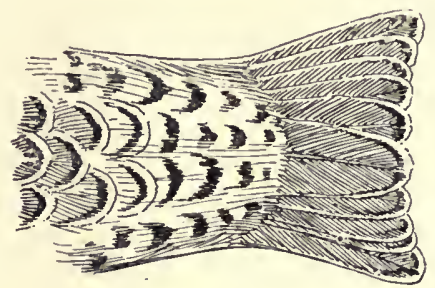

Upper tail coverts.

Length, I0.60; wing, 6.70; tarsus, I.25; bill, I.30.

The Knot occurs sparingly in Illinois and Wisconsin during the migrations. Nelson gives it as a regular migrant, but not common. Kumlien and Hollister say: "Thirty years ago a rather common migrant in May and June and more sparing in Autumn. Of late years decidedly rare at any season." (Birds of Wisconsin, I903, p. 45.)

\section{Genus ARQUATELLA Baird.}

\section{Arquatella maritima (BRÜNN.).}

\section{Purple Sandpiper.}

Tringa maritima Brünn., A. O. U. Check List, I 895 , p. 87.

Distr.: Northern portions of northern hemisphere; in North America chiefly in the northeastern portion, breeding in high latitudes and migrating south in winter to the middle Atlantic states and the Great Lakes; accidental in Florida.

Adult in summer: Top of head, dark gray; back, blackish, the feathers edged with grayish white; rump and upper tail coverts, black or brownish black; a small black spot in front of the eye; breast, grayish, having the appearance of being spotted with black, which black spotting also appears on the sides of the body. This is caused by the feathers of the breast being dark at the base, tipped with white, and on the sides of the body the feathers are white with black spots near the tips; axillars, white.

Adult in winter: Similar, but lacking the black spots on the breast and sides, which are replaced by pale gray; bill, yellowish at base.

Length, 9.25; wing, 5 ; tarsus, .92; bill, I.30.

This species is a rare straggler in Illinois and Wisconsin.

Nelson records a specimen taken on the Lake shore near Chicago, 


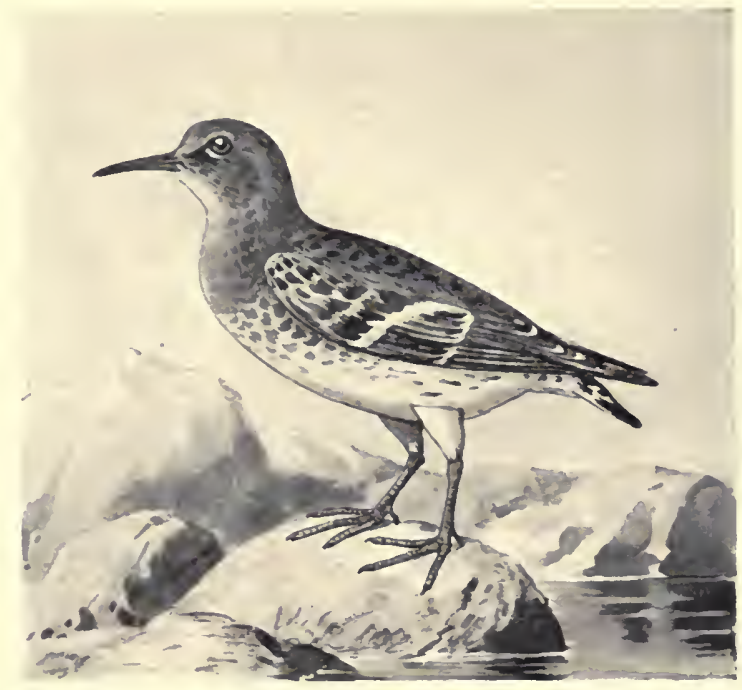

Purple Sandpiper.

November $7,187 \mathrm{I}$, which he states is preserved in the collection of Dr. J. W. Velie. Mr. Frank M. Woodruff writes: "I have a specimen of this bird taken at South Chicago, in June, I 895. This with Dr. J. W. Velie's specimen taken November 7, I 89 I ( I can find of the Purple Sandpiper in Cook County." (The Auk, Vol. XIII, I 896, p. r80.) Kumlien and Hollister (Birds of Wisconsin, I 903 , p. 45) state: "In the collection of the Oshkosh Normal School is a specimen which is said to have been taken at Bay View (Door County), in May, I88r." Dr. Hoy gives it in his list of Wisconsin birds ( 1853 ) as "greatly abundant from $15^{\text {th }}$ of April to 20 th of May." This would seem very unlikely.

\section{Genus PISOBIA Billberg.}

\section{Pisobi-a maculata (Vieill.).}

Pectoral Sandpiper.

Tringa maculata Vieill., A. O. U. Check List, 1895, p. 88.

Local names: Grass-snipe. Grass Bird.

Distr.: The whole of North America, breeding in the Arctic regions; south in winter to West Indies and South America.

Adult in summer: Head and upper parts, dark brown, the feathers edged with tawny; throat and belly, white; breast, pale brown, the 


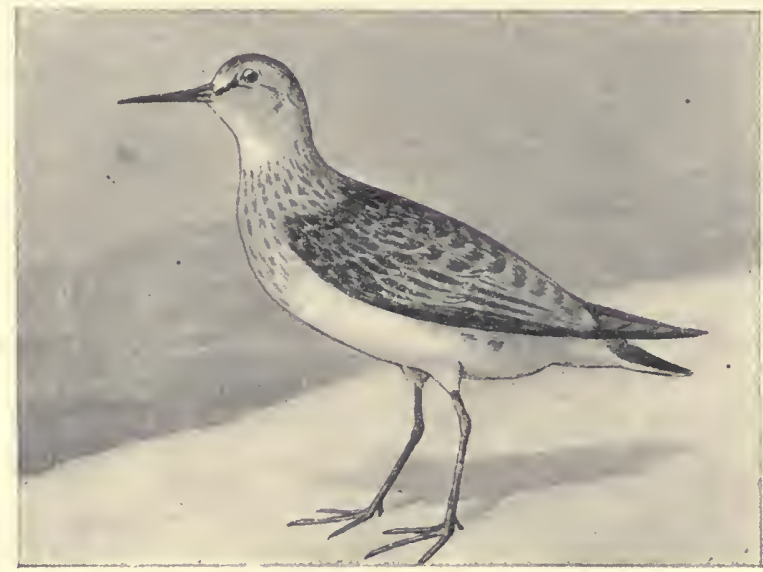

Pectoral Sandpiper.

feathers narrowly streaked with dark brown or blackish; upper tail coverts, black; two middle tail feathers longer than the others; basal half of bill, dull greenish yellow.

Winter plumage: Breast, brownish buff, and upper parts, more brownish.

Length, 9; wing, 5.25; tarsus, I.05; bill, I.I 5 .

Common in Illinois and Wisconsin during the migrations, but not nearly as abundant as formerly. A few remain during the summer. but they are probably sterile birds, as none have been found breeding.

\section{II5. Pisobia fuscicollis (VieIll.). White-RUMPed SANDPiper.}

Tringa fuscicollis Vieill., A. O. U. Check List, r 895 , p. 88.

Distr.: Eastern North America, breeding in the far north; south to the West Indies, Middle America and South America (to Falkland Islands ) in winter.

Adult in summer: Top of the head and back, mottled with black, dull white, and buff; throat, white; breast, finely lined with dark brown; belly, white; an imperfect superciliary line of dull white; rump, dusky gray, and most of upper tail coverts, white.

Adult in winter: Top of the head and back, grayish, some of the feathers marked with dark brown, giving it a slightly mottled appearance on the back and top of the head; upper throat, white; breast, ashy gray, the shafts of the feathers showing brown; belly, white; forehead, whitish, extending in an imperfect superciliary line. 
Length, 6.85 ; wing, 4.95 ; tarsus, .95; bill, .95.

This species is not common, occurring irrregularly in Wisconsin and Illinois during the migrations.

Mr. T. M. Woodruff considers it "a very rare migrant" in the Chicago area and states he has taken it at Meredosia, Illinois. (Birds of Chicago Area, I907, p. 69.) Nelson procured a specimen and saw a number of others on the Lake shore near Waukegan, Ill., on June 9, I876; he also states that Mr. R. P. Clarke had taken it late in the autumn near Chicago. (Birds of N. E. Illinois, I 876, p. I 27.)

Messrs. Kumlien and Hollister give it as occuring regularly in Wisconsin but by no means abundant. They say: "Small flocks of a dozen or less are sometimes found about Lake Koshkonong until the middle of June, and they are back again with barely full-fledged young by August I." (Birds of Wisconsin, 1903, p. 46.)

\section{I6. Pisobia bairdii (Coues).}

BAIRD'S SANDPIPER.

Tringa bairdii (Coues), A. O. U. Check List, I 895 , p. 88.

Distr.: Arctic interior of North America where it breeds; migrating south through the interior to southern South America (Patagonia); rare on the Atlantic coast, and not recorded from the Pacific coast of the United States.

Adult in summer: Crown, dark brown, mixed with buff; nape and upper back, narrowly streaked with buff and dark brown; the

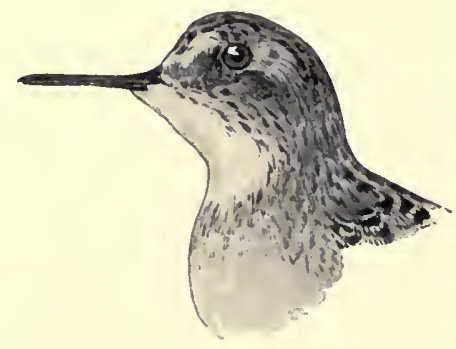

Baird's Sandpiper.

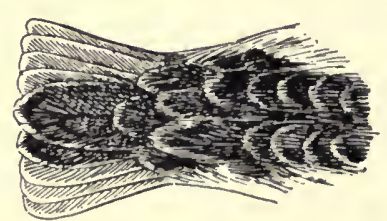

Tail and upper tail coverts.

feathers of the back, dark brown, narrowly edged with white; upper tail coverts, blackish, the feathers usually narrowly tipped with buff; two central tail feathers, very slightly longer than the others (not decidedly longer, as in Pisobia maculata); chin, white; breast, brownish buff, showing very faint and narrow streaks of brown; under parts, buffy white, with a faint tinge of buff, sometimes entirely white. 
406 Field Museum of Natural History-Zoölogy, Vol. IX.

Adult in winter: Similar, but paler.

Immature: Resembles the adult, but has the feathers of the back and wing coverts tipped with white.

Length, 7.40; wing, 4.50 to 4.90 ; tarsus, I; bill, I.

Baird's Sandpiper occurs regularly in small numbers in Illinois and Wisconsin during the migrations in spring and fall, usually in May, August and September.

\section{Pisobia minutilla (Vieill.). Least Sandpiper.}

Tringa minutilla Vieill., A. O. U. Check List, I 895, p. 89.

Local name: Peep.

Distr.: North America; south throughout South America in winter, breeding chiefly north of the United States.

Adult in summer: Very small; upper parts, marked with tawny black and pale buff; under parts, whitish on the throat, shading into ashy gray, and showing faint brownish lines on the breast; rest of the under parts, white; bill, dull black; no web between toes.

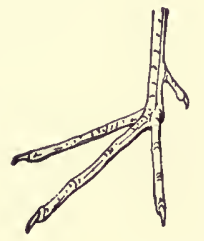

Adult in winter: Similar to the above, but grayer in color.

Length, $5.5^{\circ}$, to 6.50 ; wing, 3.60 ; tarsus, $.75 ;$ bill, .85 .

This species is common during the migrations in May and August in Illinois and Wisconsin, and occasionally birds remain during the summer and may have bred. We have no published record of the eggs actually having been taken in either state.

On June 5, I 875, Mr. Nelson observed a bird of this species building a nest near the Calumet River. It was not completed but "The birds were noticed several times in the vicinity and they probably had a nest in some safer spot." (Birds N. E. Illinois, I 876 , p. I 27.) Kumlien and Hollister say: "We have known of at least two instances of this bird nesting within the state and from specimens seen in various parts of the north and central portions of the state, suspect that at least twenty years ago it bred in some numbers." (Birds of Wisconsin, I903, $\mathrm{p}, 47$.) 
Genus PELIDNA Cuvier.

118. Pelidna alpina sakhalina (Vierll.).

Red-backed Sandpiper.

Tringa alpina pacifica (Coues), A. O. U. Check List, i 895, p. 89.

Distr.: North America and eastern Asia, breeding in the Arctic regions; south to Mexico and Central America, in winter.

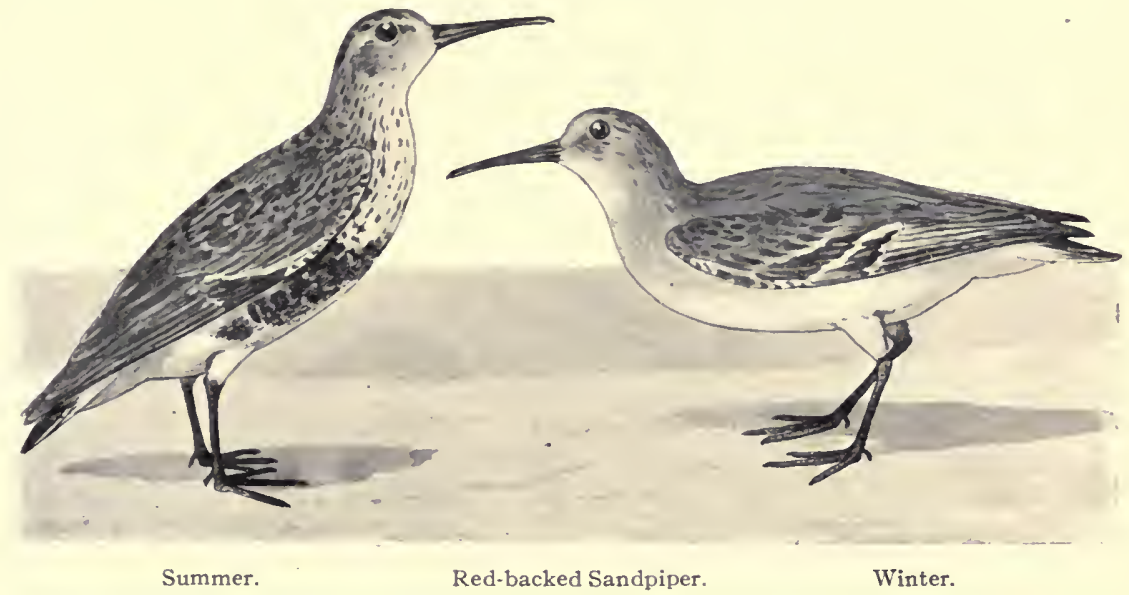

Adult in summer: Bill, slightly bent down near the tip; the feathers on the top of the head and back, bright rufous brown, heavily blotched with black on the central part of each feather; throat, whitish; breast streaked with black; belly, black on the upper part; lower belly and crissum, white; bill, black.

Adult in winter: Upper parts, gray, slightly

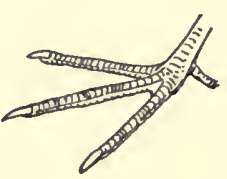
mottled; throat, white; breast, gray, the shafts of the feathers dark brown; belly and under tail coverts, pure white; a faint, dull white superciliary line.

Length, 8 ; wing, 4.75; tarsus, I.10; bill, 1.65.

The Red-backed Sandpiper is abundant in May and common in late August and September, during the migrations in Illinois and Wisconsin. 
408 Field Museum of Natural History-Zoölogy, Vol. IX.

\section{Genus EREUNETES Illiger.}

\section{Ereunetes pusillus (Livn.). Semipalmated Sandpiper.}

Local name: Peep.

Distr.: Eastern North America, breeding north of the United States; south in winter to the West Indies and South America.

Adult in summer: Heavily marked with dark brown and tawny on the top of the head and back; forehead, whitish; under parts and

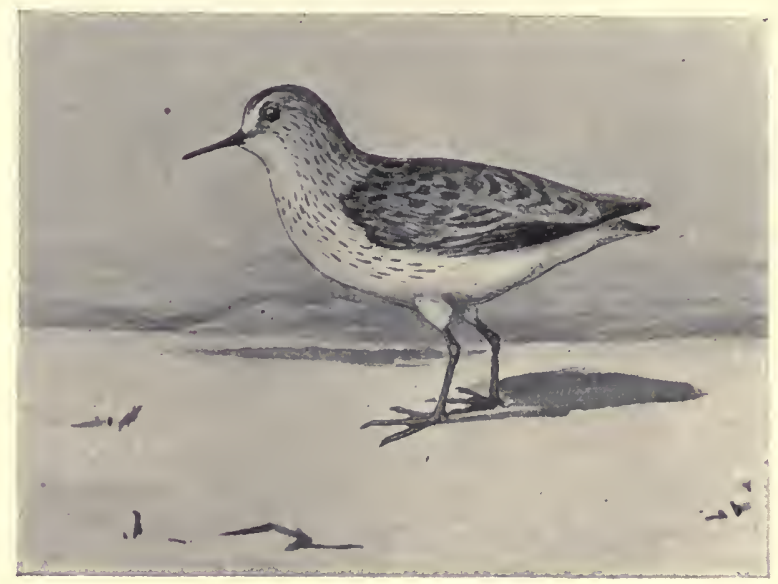

Semipalmated Sandpiper.

throat, white; breast, mottled with grayish; belly, white; toes, with small web.

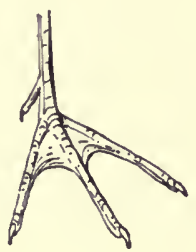

Adult in winter: Upper parts, grayish, mottled with brown on the head, and the feathers showing dark brown, edged with white on the back; throat, white; breast, very faintly washed with gray, which is sometimes very indistinct; belly and under tail coverts, white; toes, with small web.

Length, 6; wing, 3.75; tarsus, .75; bill, .80 .

Abundant in Illinois and Wisconsin in May and September during the migrations. Occasionally birds remain during the summer, but there is not the slightest evidence that these ever breed. 


\section{Ereunetes mauri CABANIs.}

Western Sandpiper.

Ereunetes occudentalis Lawr., A. O. U. Check List, r895, p. 9 I.

Distr.: Chiefly western North America, breeding in high latitudes; not uncommon on the Atlantic coast; south in winter to Middle and South America.

Adult: In summer plumage this species may be distinguished from E. pusillus by its longer bill (which is oftentimes 1.25 inches in length, while E. pusillus rarely, if ever, has the bill one inch), by its decidedly streaked breast, and the feathers of the back being margined with rufous. The winter plumages, however, differ but little, if any, and occasionally specimens of the Western Sandpiper occur which have the bill less than one inch, and in such cases it is almost impossible to. distinguish them from winter examples of E. pusillus; therefore it is perhaps as well to consider all of those birds having bills less than .90 in length to be E. pusillus, and if it is important to have the identification absolutely accurate, they could easily obtain the opinion of some professional ornithologist to decide such a fine point.

Length, 6 ; wing, 3.85 ; tarsus, .82; bill, .90 to I.I 5 .

Common in Illinois and Wisconsin during the migrations, but much less numerous than the preceding species.

Genus CALIDRIS Illiger.

121. Calidris leucophæa (Pallas').

SANDERLING.

Calidris arenaria Linn., A. O. U. Check List, 1895, p. 9 1.

Distr.: Northern hemisphere; in America breeding in the Arctic and subarctic regions; south in winter as far as southern South America (Patagonia), also India and South Africa.

Adult in summer: Head, throat, and upper parts, except rump, reddish brown, black, and white; throat and breast, pale rufous brown, with more or less dark spots; belly, and under parts, pure white; bill and feet, black; toes, three.

Adult in winter: Top of the head and back, ash gray, the shafts of the feathers being brown; forehead and entire under parts white; bill, black.

Length, 8.10; wing, 5.05; tarsus, I; bill, I. 


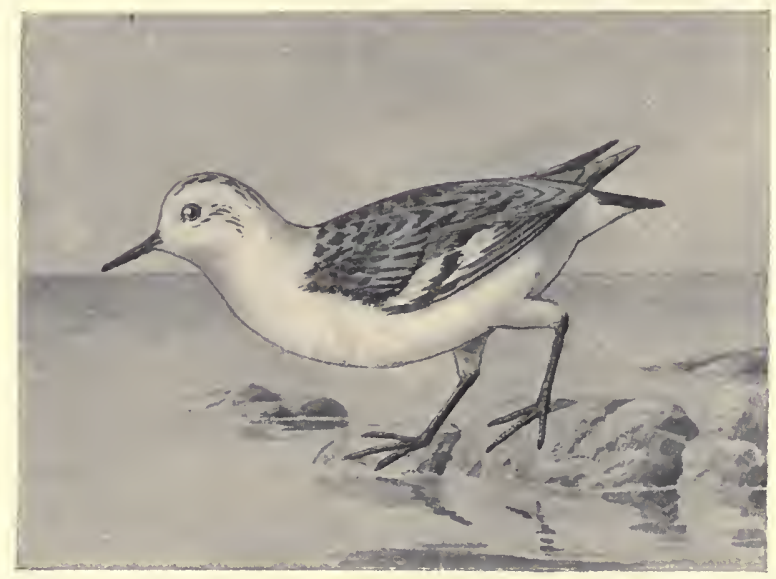

Sanderling.

The Sanderling occurs more or less commonly in Illinois and Wisconsin during the migrations in May, and again from August to October.

\section{Genus LIMOSA Brisson.}

\section{Limosa fedoa (LiNN.).}

Marbled Godwit.

Distr.: Chiefly interior of North America, breeding from Iowa north to the Saskatchewan; south in winter to Cuba and Central America.

Adult in summer: Bill, curved slightly upward; upper parts, mottled with black and tawny; upper throat, white, rest of throat finely streaked with brown; breast, pale tawny, the feathers banded irregularly with brown; belly, tawny, sometimes without bands; bill, dull flesh color in its basal half, the rest blackish; inner webs of outer primaries, speckled with black; tail, barred with black; axillars, irregularly banded with dark slaty brown, in some instances merely showing an indication of bands but always with more or less irregular marks or dots where the bands are not perfect.

Adult in winter: Top of the head, brown, streaked with pale brown; feathers of the back, dark brown, edged with tawny; chin, white; throat, pale buff, faintly barred with brown; inner webs of outer primaries, speckled with black.

Length, I9; wing, 8.80; tarsus, 2.80 ; bill, 3.50 to $4.5^{\circ}$.

The Marbled Godwit was once a common species in Illinois and 


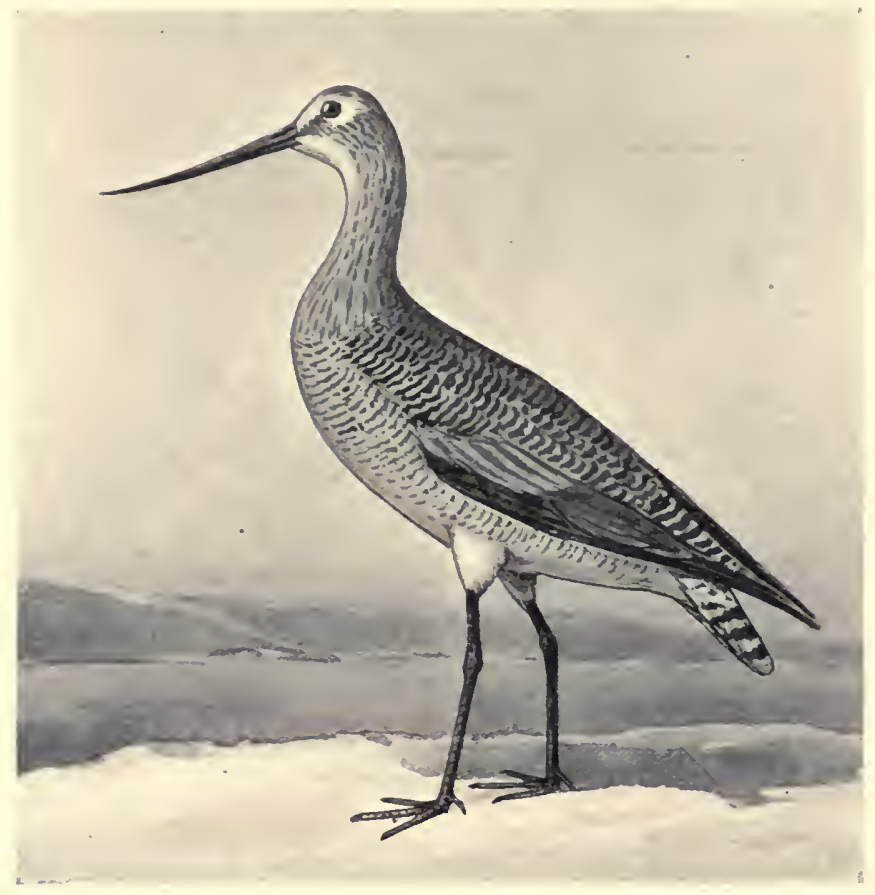

Marbled Godwit.

Wisconsin during the migrations, but is now rare. At the present time the few which occur within our limits are practically restricted to the region along the Mississippi River. According to Kumlien and Hollister it was known to nest on two occasions in Wisconsin, some fifty years ago, once near Stoughton and once near Lake Koshkonong. They also state: "Mr. H. Nehrling gives it as breeding in the northern peninsula of Michigan and it used to nest in Iron County, Wisconsin, and almost certainly along Green Bay." (Birds of Wisconsin, 1903, p. 48 .)

\section{Limosa hæmastica (LINN.).}

Hudsonian Godwit.

Distr.: Northeastern North America; south in winter throughout Middle and South America; breeds in high latitudes.

Adult in summer: Upper parts, dark brown, the feathers showing spots of pale rufous brown on the edges; rump, white; tail, black, tipped with whitish; chin, whitish, with pale rufous; rest of under 


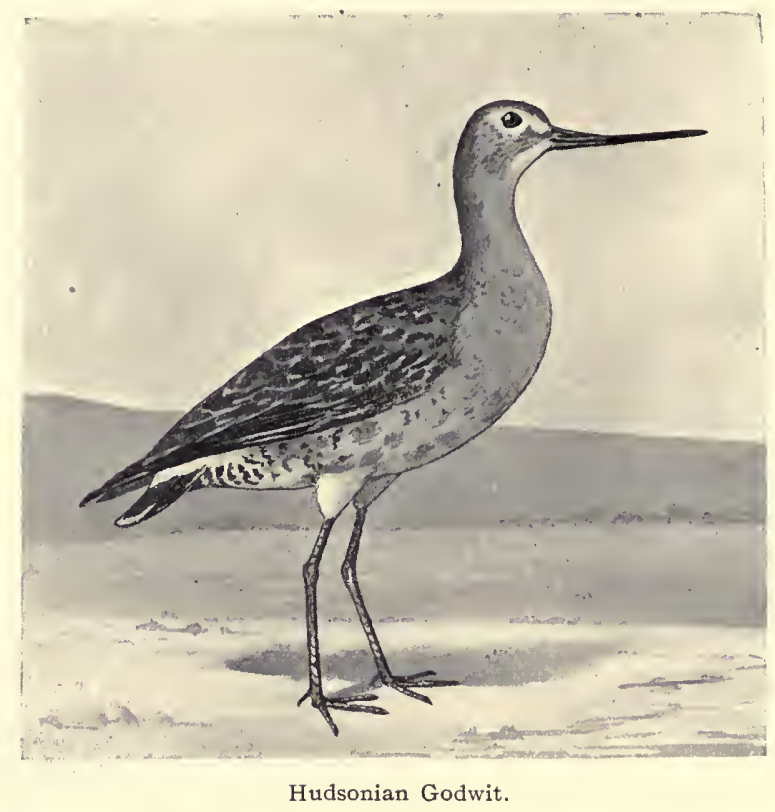

parts, dark rufous brown; the feathers of the throat, more or less streaked with black, and the feathers of the breast and belly, faintly edged with black; axillars, very dark slate color, almost black.

Adult in winter: Upper plumage, dull gray; feathers of the back, more or less edged with dark brown; chin, whitish; breast, pale gray; shafts of the feathers on the sides of the breast, brownish; belly, grayish buff, sometimes buffy white; under tail coverts, whitish; axillars, dark, smoky gray.

Length, I 5 ; wing, 8 to 8.60 ; tarsus, 2.40 ; bill, 2.80 to 3.40 .

In former years the Hudsonian Godwit was not uncommon in Illinois and Wisconsin during the migrations, but at the present time it is a rare bird, at least east of the $95^{\text {th }}$ meridian. It is still moderately common in Dakota, Nebraska, and Texas during the migrations, but. its numbers are fast decreasing. Mr. F. M. Woodruff states he killed a pair of these birds at Grass Lake, Illinois, in June, I892 (Bull. Chicago Acad. Sciences, No. 6, r907, p. 72 ). 


\section{Genus TOTANUS Bechstein.}

\section{Totanus melanoleucus (GMEL.). Greater Yellow-legs.}

Local names: Winter Yellow-leg. Stone Snipe. Telltale.

Distr.: Greater portion of America, breeding from Wisconsin and, perhaps northern Illinois, northward, and migrating south in winter to Middle and South America as far as Chili and Argentine Republic and the West Indies.

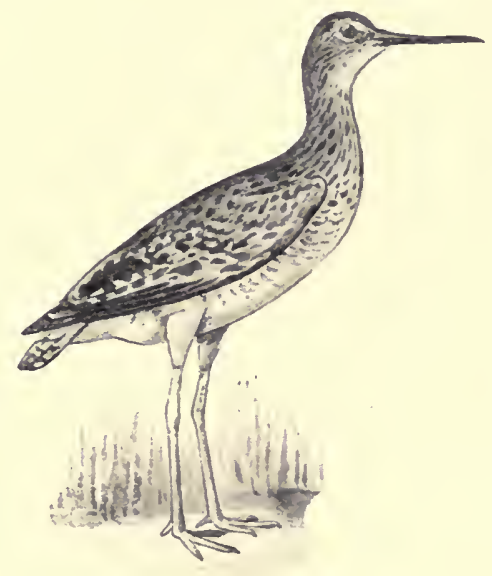

Greater Yellow-legs.

Adult in summer: Bill, nearly straight; upper plumage, mottled with white and black; upper tail coverts, white, barred with black; throat, white, streaked with black; chin, whitish; breast, white, heavily streaked with black; rest of under parts, white, irregularly marked with black; middle of belly, nearly always pure white; bill, black, and legs, yellow.

Adult in winter: Top of the head and neck, streaked white and dark brown; back, brown, the feathers narrowly edged with whitish; chin, white; breast, white, narrowly lined with dark brown; rest of under parts, white; bill, black, and legs, yellow.

Length, I4; wing, 7.75; tarsus, 2.45 ; bill, 2.30 :

This species is a common migrant and casual summer resident in Illinois and Wisconsin. It may breed in northern Illinois and there is little doubt that it does so in Wisconsin. The clear, sharp, whistling note, repeated rapidly four or five times, descending in semi-tones 
4 i 4 Field Museum of Natural History-Zoölogy, Vol. IX.

down the scale, is known to "gunners" throughout the land. Although not as abundant as in former years, it is still numerous in many locations during the migrations.

Mr. E. W. Nelson writes: "A common migrant and regular summer resident. Breeds. Arrives about the middle of April, the larger portion passing north early in May. **** In June, I 875, I found several pairs of these birds about the Calumet marshes, where from their actions I was certain they were breeding, but was not fortunate enough to find their nests. The roth of June, r876, Mr. Rice observed a pair about a prairie slough near Evanston. A few days later a set of four eggs were brought him from a similar situation a few miles northwest of that place and from the description of the parent bird - driven from the nest - he decided they must belong to this species." (Birds N. E. Illinois, I 876, p. I 28.) Regarding its occurrence in Wisconsin, Kumlien and Hollister say: "A common migrant, spring and fall, and also a summer resident. **** At Lake Koshkonong it bred at considerable distance from the lake far out in the miry marshes and did not often visit the lake shore until the young were nearly full grown." (Birds of Wisconsin, I903, p. 49.) They also state that downy young were procured by L. Kumlien near Minnesota Junction in 1882 .

The nest is composed of grass on the ground. The eggs are four, pale brown or buff color, spotted and marked with dark brown. They measure about $1.45 \times 1.20$ inches.

\section{Totanus flavipes (GMEL.).}

\section{YELLOW-LEGS.}

Local names: Summer Yellow-legs. Little Telltale.

Distr.: North America, south in winter to South America, breeds chiefly north of the United States; more common in eastern than in western North America.

Adult: Upper parts, grayish brown, mottled with whitish on the back; chin, white; throat, white, streaked with pale grayish brown; breast, mottled; belly, white; tail feathers, banded brown and white; upper tail coverts, white, more or less barred with black; axillars, white, barred with brown; bill, black; legs, yellow.

Resembles the Greater Yellow-legs, but is smaller.

Length, I0.80; wing, 6.45; tarsus, 2.10; bill, I.45.

This species is still common during the migrations in Illinois and $W$ isconsin, and a few remain during the summer; but non-breeding or wounded birds of many species are found far south of their usual 
range during the summer months and the fact that they are in breeding plumage is not sufficient evidence that they are nesting. That a few may do so, however, is shown by Nelson's statement in his Birds of N. E. Illinois (Bull. Essex Inst., VIII, I876, p. I 28 ) where he says: "A few breed. I obtained the young barely able to fly near a prairie slough the first of July, I 874, a few miles from Chicago, and have since observed several pairs during the breeding season about the Calumet marshes." Kumlien and Hollister state: "Formerly bred at Lake Koshkonong, Horicon Lake, about Lake Pacana, and presumably in other localities. ******* Young still unable to fly are yet obtainable about Lake Koshkonong in July, but of late years not commonly." (Birds of Wisconsin, 1903, p. 49.)

The eggs are three or four, pale brown or buff, irregularly marked with dark brown, and measure about $1.70 \mathrm{x}$ I.I 5 .

\section{Genus HELODROMAS Kaup.}

\section{Helodromas solitarius (WILs.). Solitary Sandpiper.}

Totanus solitarius (Wils.), A. O. U. Check List, I895, p. 94.

Distr.: North America, chiefly east of the Rocky Mountains; south in winter to Argentine Republic and Peru; breeds from northern United States northward.

Adult in summer: Top of head and back, and upper tail coverts, bronzy green, dotted with white; under parts, white; the breast, thickly streaked

Axillars. and dotted brown; bill, greenish brown (in life), dusky, terminally; axillars, white, heavily barred with smoky black.

Adult in winter: Upper parts, including upper tail coverts, olive brown, showing a faint, greenish gloss when held in the light, the feathers faintly dotted with dull white; throat, white; breast, streaked with brown; rest of under parts, white; axillars, heavily barred.

Length, 8.50; wing, 5.30; tarsus, I.20; bill, I.30.

The Solitary Sandpiper is a rather common migrant in Illinois and Wisconsin and a casual summer resident in both states, frequenting the shores of the rivers and ponds. Although the eggs have never been taken within our limits it undoubtedly breeds.

Nelson writes (Birds of N. E. Illinois, i 876 , p. I 29): "Common migrant. Arrives about the first of May and remains until about the 
25 th, when the majority go further north. I have several times taken young of this species just able to fly and I have observed the adults throughout the breeding season. I do not think there is the slightest doubt of its breeding in this vicinity." Kumlien and Hollister say: "There is no Wisconsin bird of which we have so diligently and systematically sought the eggs and without success as this Sandpiper. Numbers of times we have found the young just hatched and judging from the actions of the parents, have often been near the eggs." (Birds of Wisconsin, I 903 , p. 50.)

\section{Genus CATOPTROPHORUS Bonap.}

\section{Catoptrophorus semipalmatus (GMEL.).}

\section{Willet.}

Symphemia semipalmata (Gme1.), A. O. U. Check List, I 895, p. 94. Distr.: Eastern North America, from New Jersey (rarely Maine) to Florida; south in winter to West Indies and eastern South America to Brazil.

Adult in summer: Upper plumage, gray, streaked on the head with dark brown, and the central portion of many of the feathers has the back blotched with brown; chin, white; throat, white, dotted

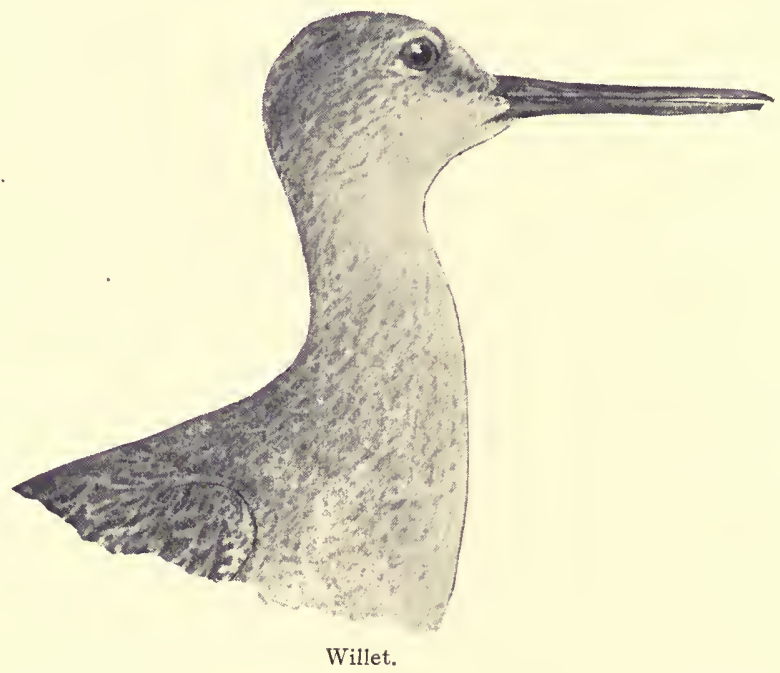

with brown; under parts, dull white, the feathers on the sides barred with brown and washed with tawny; axillars, black; bill, bluish, dusky toward end; blackish. 
Adult in winter: Bill, nearly straight; upper plumage, gray, showing indications of grayish white on the tips of some of the feathers on the back; chin, whitish; throat, ashy gray; the rest of under parts, white, showing ashy on the sides of the body; axillars, smoky black. The broad, white band on the wings is a distinguishing character of this bird when flying.

Length, I5.00; wing, 8.10; tarsus, 2.30; bill, 2 to 2.30 .

This species has been given by various authors as occurring in Illinois and Wisconsin, but we have very little definite information concerning it, on account of the comparative rarity of Willets in this region together with the fact that both forms are considered the same by the average sportsman. All specimens taken within our limits which I have examined proved to be inornatus.

Ridgway writes that he is unable to state whether or not semipalmatus occurs in Illinois. Nelson, of course, considered them all semipalmatus, as at that time $(1876)$ the two forms had not been separated. A. J. Cook (Birds of Michigan, I893, p. 61) includes this species as a "rare summer resident" and does not mention inornatus. A. W. Butler (Birds of Indiana, 1897) gives both semipalmatus and inornatus as rare migrants, possibly rare summer residents. W. W. Cooke (Bird Migration Mississippi Valley, r888, p. 96) does not mention semipalmatus, but gives inornatus. Kumlien and Hollister (Birds of Wisconsin, I903, p. 50) include this species as "A rare wader in Wisconsin," but suggest that inornatus might occur in the state "if only as a rare straggler during migrations."

127a. Catoptrophorus semipalmatus inornatus (BREWST.).

IVESTERN WILLET.

Symphemia semipalmata inornata Brewst., A. O. U. Check List, I 895 , p. 95.

Distr.: Western North America, east to Mississippi Valley and Gulf states and casual on southern Atlantic coast; south in winter to Mexico; breeds from Texas to Manitoba.

Adult: The Western Willet is very similar to the eastern form, but may be distinguished from it in summer plumage by the absence of the bars on the middle tail feathers. Size, slightly larger; wing, about $8.5^{\circ}$; tarsus, about $2.5^{\circ}$ inches; middle tail feathers, without bars. In winter plumage, the two forms can not be distinguished with any certainty.

This form occurs in Illinois and probably Wisconsin, but is by no 
4r8 Field Museum of Natural History-Zoölogy, Vol. IX.

means common. There are numerous records for Illinois. Butler (Birds of Indiana, r897) states that Mr. F. M. Woodruff obtained five from a flock of eight at Millers (Ind.), August I 4, r897. W. W. Cooke (Bird Migration Mississippi Valley, I888, p. 96) gives this form and does not mention semipalmatus. He says: "Occurs during migration throughout the Mississippi Valley. $* * * *$ It breeds throughout Illinois. **** It was seen at Chicago, Ill., May $\mathrm{r}_{3}$ th, though of course this record must not be considered that of first arrival."

The eggs are deposited in a depression in the sand. They are from 3 to 4 in number, pale yellowish brown or buff color, marked with chocolate brown chiefly at the larger end, and measure about 2.10 X 1.56 inches.

\section{Genus BARTRAMIA Lesson.}

128. Bartramia longicauda (BECHST.).

Bartramian Sandpiper.

Local names: Upland Plover. Field Plover.

Distr.: North America, mainly east of the Rocky Mountains, north to Nova Scotia and Alaska, breeding throughout most of its North American range; south in winter to Brazil and Peru.

Adult in summer: Upper plumage, dark brown, or brownish black, the feathers edged with pale buff; upper throat, white; lower throat,

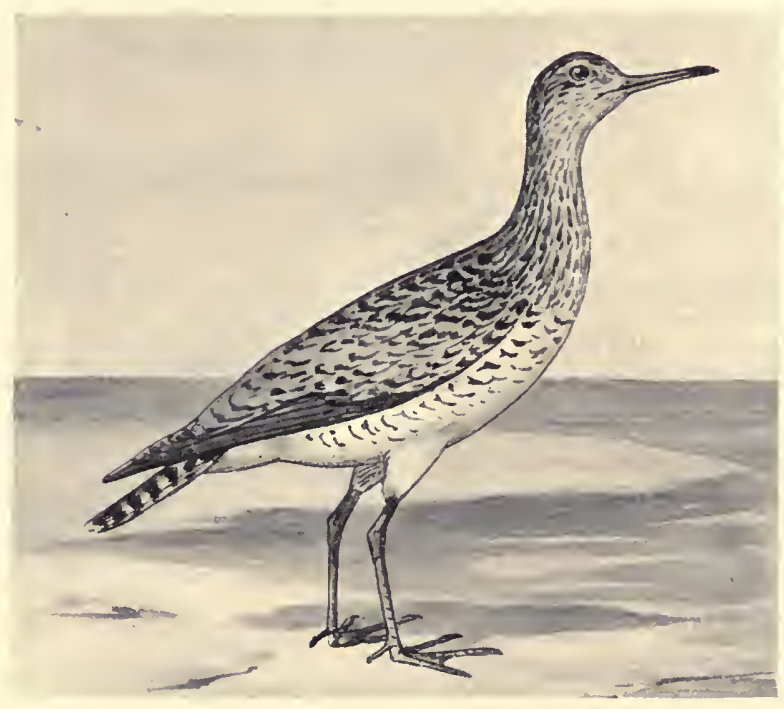

Bartramian Sandpiper. 
pale buff, lined with dark brown; breast, pale buff, with arrow-shaped markings of dark brown; belly, pale buff; axillars, banded with dark slaty brown and white; outer primaries, white, banded with brown on the inner webs.

Adult in winter: Similar, but paler.

Length, II.75; wing, 6.60; tarsus, I.90; bill, I.20.

A summer resident in Illinois and Wisconsin, formerly very abundant, but now only moderately common and becoming less so every year.

The nest is placed on the ground usually in a field or pasture. The eggs are 4 or 5 , buff white, spotted with reddish brown, the markings heavier and more numerous at the larger end. They measure r.80 $\mathrm{X} \quad \mathrm{I} .25$ inches.

Genus TRYNGITES Cabanis.

\section{Tryngites subruficollis (VIEILL.).}

Buff-breasted Sandpiper.

Distr.: General North America, more common in the interior; breeds from Alaska and British America northward; south in winter to South America as far as Peru and Uraguay; not common in eastern United States.

Adult in summer: Upper plumage, buff, mottled with black; the feathers on the back, black, edged with buff; under parts have a mottled buff and white appearance, caused by the exposed portion of the feathers being buff, narrowly tipped with white; the

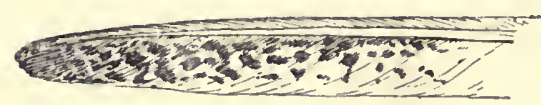

First primary. feathers are dark slate-color at base, but the slate-color is entirely concealed; inner web of first primary, white, speckled with dark brown; the inner primaries and secondaries, narrowly tipped with white, showing a sub-terminal band of black; axillars, white.

Adult in winter: Similar, but paler.

Length, 8 ; wing, 5.30; tarsus,'I.25; bill, .85.

The Buff-breasted Sandpiper is usually a rather rare migrant in Illinois and Wisconsin, although in one instance at least, it was abundant in one locality.

W. W. Cook writes: "Dr. A. K. Fisher tells me that in August, 1874 , he saw hundreds of Buff-breasted Sandpipers on the dry prairie at Maywood, Cook County, I11., only ten miles from Chicago and that he shot numbers of them." (Report Bird Migration Mississippi Valley, 1888, p. 97.) Mr. Wm. A. Bryan mentions a specimen taken near 
420 Field Museum of Natural History-Zoölogy, Vol. IX.

Calumet Lake, Cook Co., I11., Sept. I898. (The Auk, Vol. XVI, I899, p. 276 .) It has occasionally been taken in Wisconsin, but Kumlien and Hollister consider it a "rare migrant."

\section{Genus ACTITIS Illiger.}

130. Actitis macularia (LiNN.).

Spotted Sandpiper.

Distr.: North and South America, from Alaska to the West Indies, Middle America and Brazil; breeds throughout temperate North America.

Adult in summer: Top of the head and back, olive green, showing bronzy reflections when held in the light; some of the feathers on the back irregularly marked with brown; under parts, white, marked with large, round black spots.

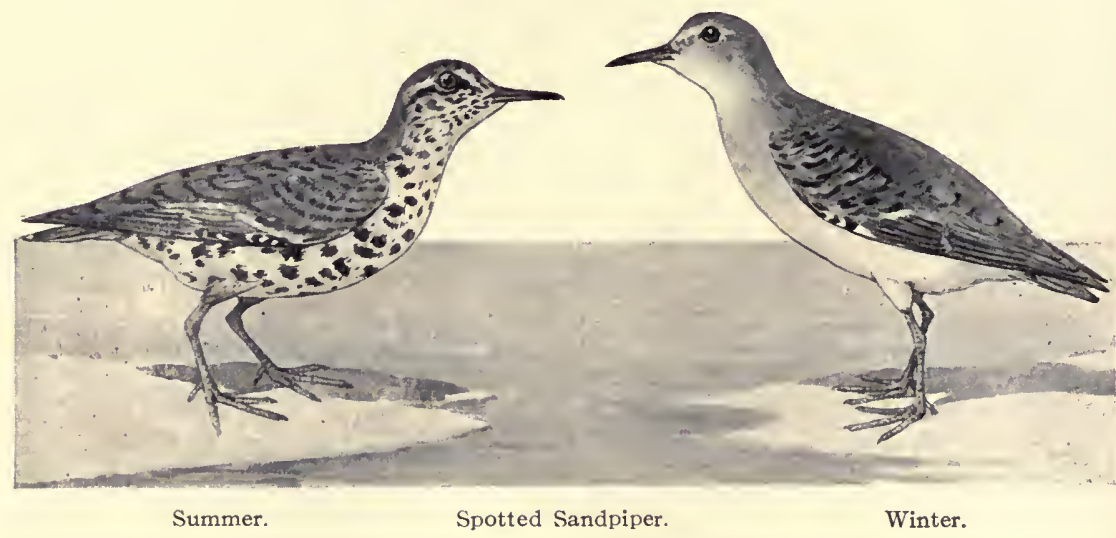

Adult in winter: Above, olive, showing a faint bronzy luster when held in the light; feathers on the back, faintly tipped with dusky; wing coverts, narrowly banded with tawny; throat, white; breast, faintly tinged with ashy; under parts, including belly and under tail coverts, white; mandible and edge of the maxilla, pale wax yellow (in life), rest of bill, black.

Length, 8; wing, 4.20; tarsus, I; bill, I.

This well known species is a very common summer resident in Illinois and Wisconsin and breeds in suitable localities. It is often seen along the banks of rivers and ponds. The nest is at times a slight structure of grass, while at others it is a mere depression in the ground with a little loose grass and leaves. 
Jan., I909. Birds of Illinois and Wisconsin-Cory.

The eggs are four, buff white or cream white, spotted with chocolate brown more pronounced at the larger end. They measure about r. $30 \times .95$ inches. There are several sets in the Field Museum collection taken in northern Illinois between June 8th and I6th, and a set from Oconto County, Wisconsin, taken June I I, I889.

\section{Genus NUMENIUS Brisson.}

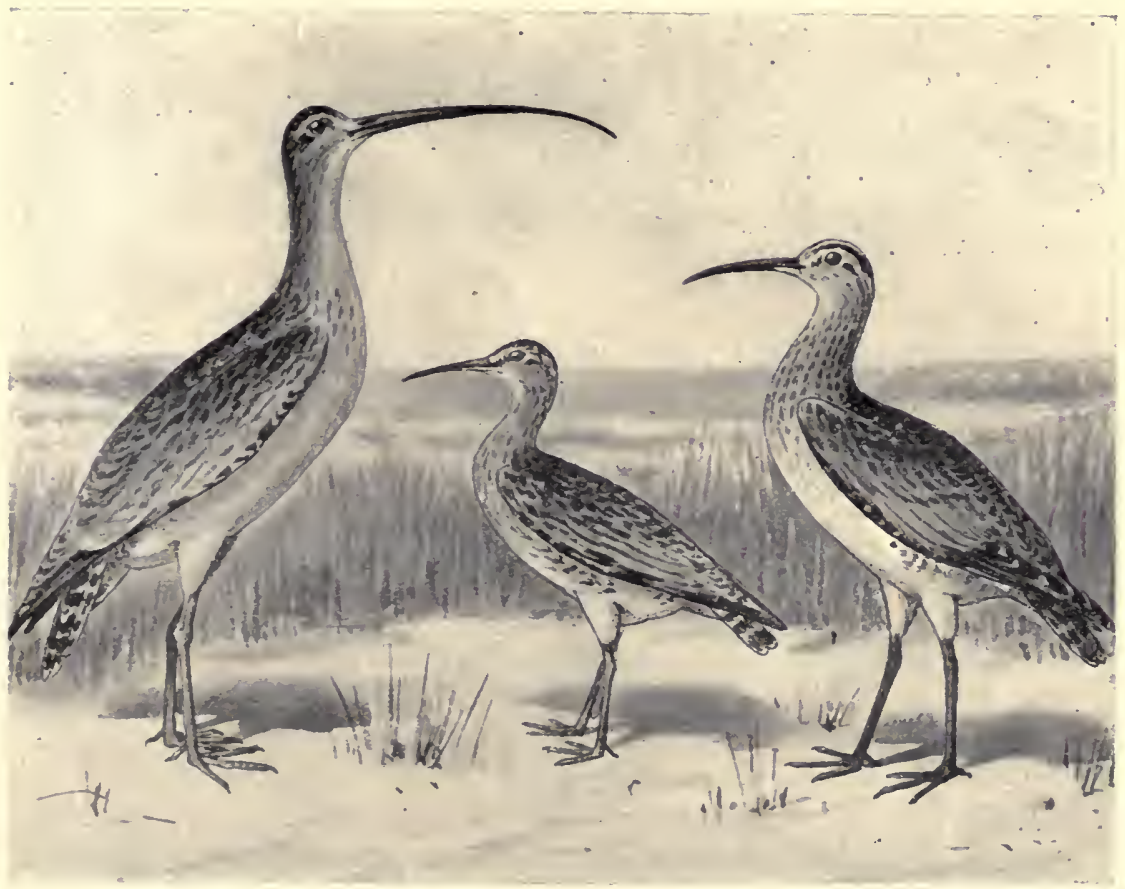

Long-billed Curlew.

Eskimo Curlew.

Hudsonian Curlew.

13I. Numenius americanus Bechstein.

LoNg-Billed Curlew.

Numenius longirostris Wils., A. O. U. Check List, 1895, p. 97. Local name: Sickle-bill.

Distr.: Temperate North America, migrating south as far as Jamaica and Guatemala, in winter; breeds in the south Atlantic states and in the interior throughout most of its North American range.

Adult in summer: Upper parts, marked with buff and black; tail feathers, alternately banded with tawny buff and brown; throat, 
422 Field Museum of Natural History-Zoölogy, Vol. IX.

whitish; rest of under parts, pale reddish brown, becoming very light on the belly; breast, narrowly striped with brown on the middle of the feathers; bill, very long; axillars, rufous brown.

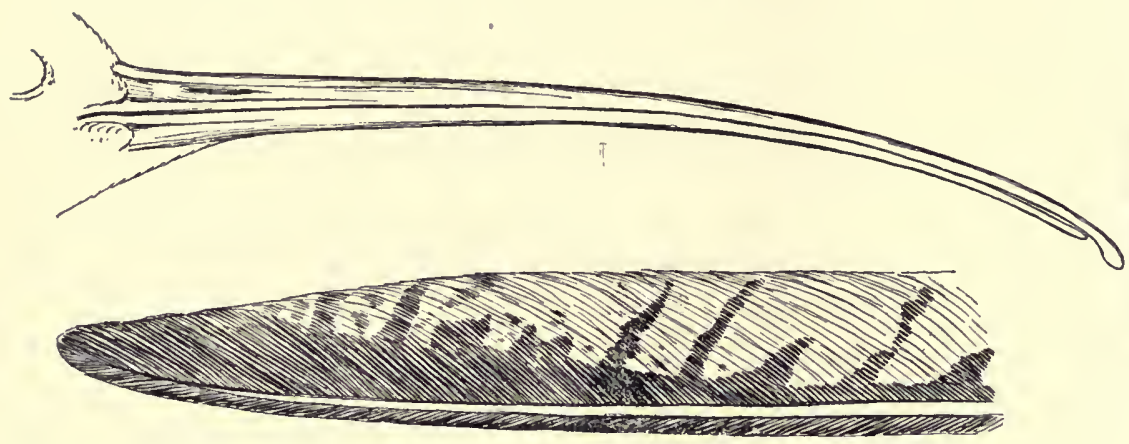

Axillars and first primary of Long-billed Curlew.

Adult in winter: General plumage, tawny brown; the back, blackish, mottled with buff; top of the head, dark brown; the feathers edged with tawny; throat, white; under parts, pale buff brown; feathers on the lower throat and upper breast, finely lined with dark brown; bill, very long and curved downward; bill, black, becoming dull lilac brown on basal half of the mandible; axillars, rufous brown.

Length, 26; wing, I0.50; tarsus, 2.30; bill, very variable, measuring from 2.3 to 9 .

The immature of this species has the bill nearly straight, but quite short, sometimes not exceeding two inches in length.

The Long-billed Curlew was once a common migrant in Illinois and $\mathrm{Wisconsin}$, but is now rather rare.

Mr. Nelson states that a pair nested on the Calumet Marshes, near Chicago, in 1873 . It arrives about the last of April and leaves for the south early in October. According to Kumlien and Hollister, it was once very abundant in Wisconsin and bred in numbers. They say: "As an illustration of the former numbers of the curlew, Mr. Skavlem tells of his boyhood experiences in the early fifties when he was set to following the plows when breaking up the virgin prairie sod and gathering up the eggs for the house." (Birds of Wisconsin, I 903, p. 52.)

The eggs of the Long-billed Curlew are three or four in number, grayish green or pale olive buff, blotched and marked with chocolate brown, and measure about $2.55 \times$ r.85 inches. 


\section{Numenius hudsonicus Lath. Hudsonian Curlew.}

Local name: Jack Curlew.

Distr.: All of North and South America, including the West Indies; breeds in the far north; winters chiefly south of the United States.

Adult in summer: Bill, curved downward, top of the head, brown, with a stripe of buffy white through the middle; rest of upper parts, dark brown; feathers, pale on the edges, giving a slightly mottled appearance to the back; chin, white; throat and breast, streaked and faintly barred with brown and white; belly, dull white; an imperfect superciliary stripe; axillars, pale buff, barred with slaty brown; first primary, barred on inner web.

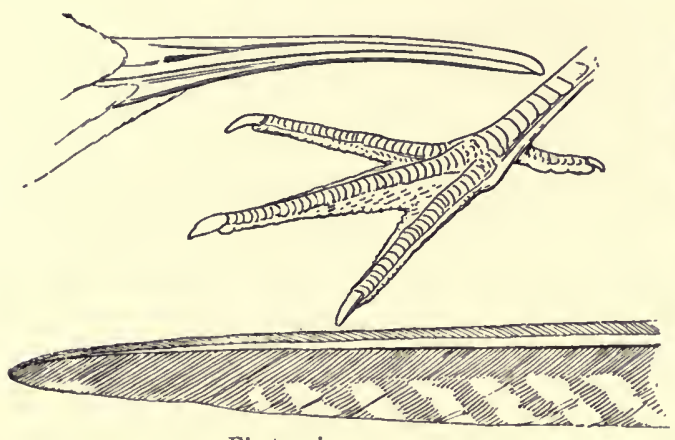

First primary.

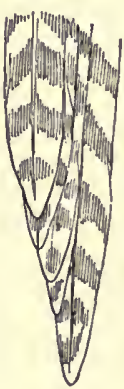

Axillars.

Adult in winter: Similar to the last, but showing much more tawny, mottled on the upper parts, and the under parts, paler; a superciliary stripe of dull white; axillars, pale buff, barred with slaty brown; first primary, barred on inner web.

Length, I7.50; wing, 9.20; tarsus, 2.30 ; bill, 3 to 3.75 .

Although once common, the Hudsonian Curlew is now a rare bird in Illinois and Wisconsin during the migrations.

\section{Numenius borealis (Forst.).}

Eskimo Curlew.

Local name: Dough Bird.

Distr.: Eastern North America, breeding in high arctic latitudes; south in winter to southern South America.

Adult in summer: Bill, curved downward; general plumage above, 
424 Field Museum of Natural History-Zoölogy, Vol. IX.

mottled black and tawny; chin, whitish; throat and under parts, tawny buff, marked on the throat with dark brown, and on the breast with arrow-like brown markings; flank and sides of the body, tawny, the arrow-like marks being much heavier and larger; top of the head showing no central stripe of buffy white; inner web of first primary, without bars; axillars, barred with slaty brown.

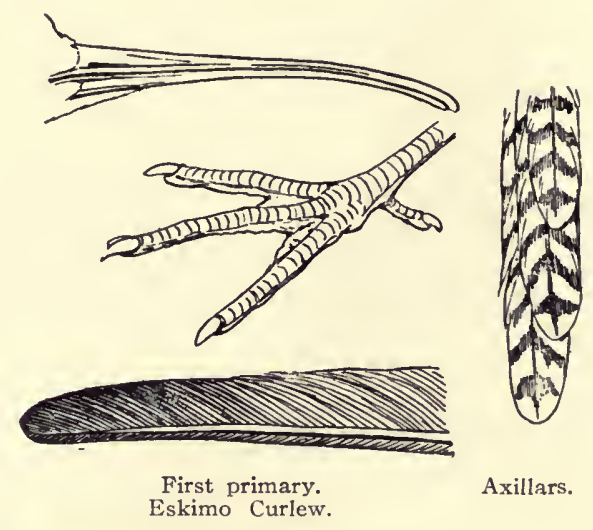

Adult in winter: Lacking the tawny color of the summer plumage; more whitish on the under parts, otherwise the markings being similar.

Length, I3; wing, 8.10; tarsus, 2 ; bill, 2.75 to $3.5^{\circ}$.

The Eskimo Curlew may still occur during the migrations in Wisconsin and Illinois, but is becoming very rare and the species is apparently fast disappearing. Prefers the fields and highlands to the marshes. Formerly abundant and as late as 1895 it was not uncommon in some localities. 


\section{Family CHARADRIIDÆ. Plovers.}

Most Plovers are gregarious. They vary considerably in their habits in different species; some prefer the beaches and marshes while others frequent the fields and plains. Of the hundred or more known species, ${ }_{5}$ occur in North America and 9 in the eastern United States. Their flesh is excellent, especially in the fall, when they are usually very fat.

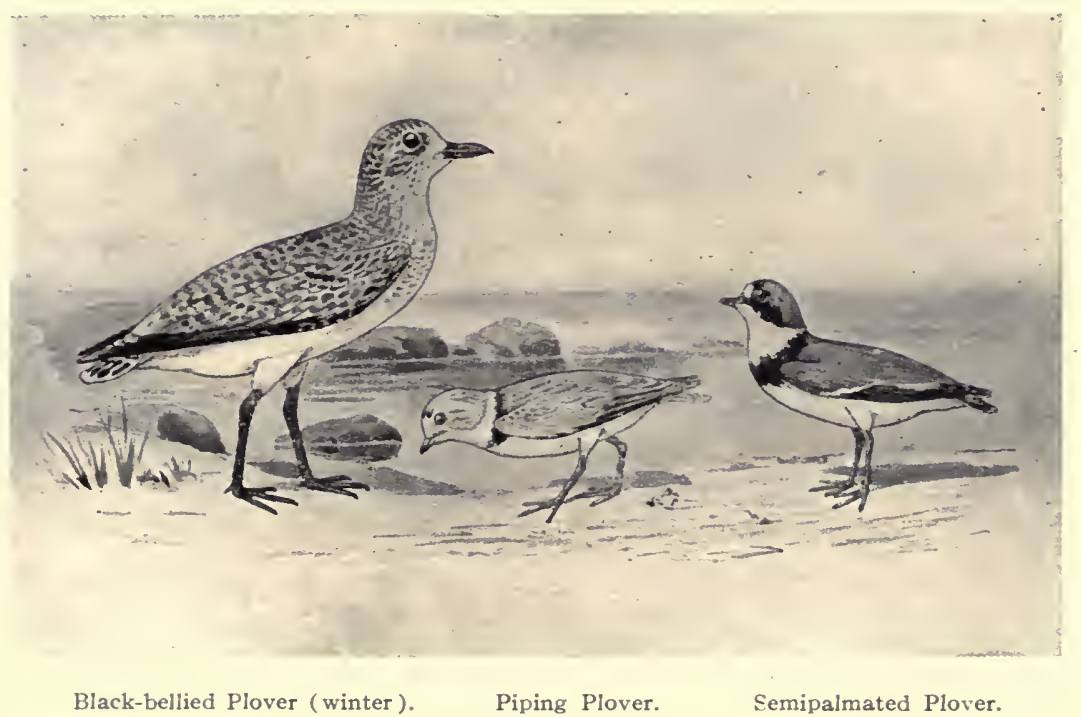

Genus SQUATAROLA Cuvier.

134. Squatarola squatarola (LiNx.).

Black-Bellied Plover.

Charadrius squatarola (Linn.), A. O. U. Check List, r895, p. 99.

Local names: Beetle-head. Black-breast.

Distr.: Nearly cosmopolitan, chiefly in northern hemisphere; breeds in the far north; south in winter to the West Indies, Brazil, and Colombia.

Adult male in summer: Upper parts, smoky black; feathers, edged with dull white; breast and most of belly, black in highest 


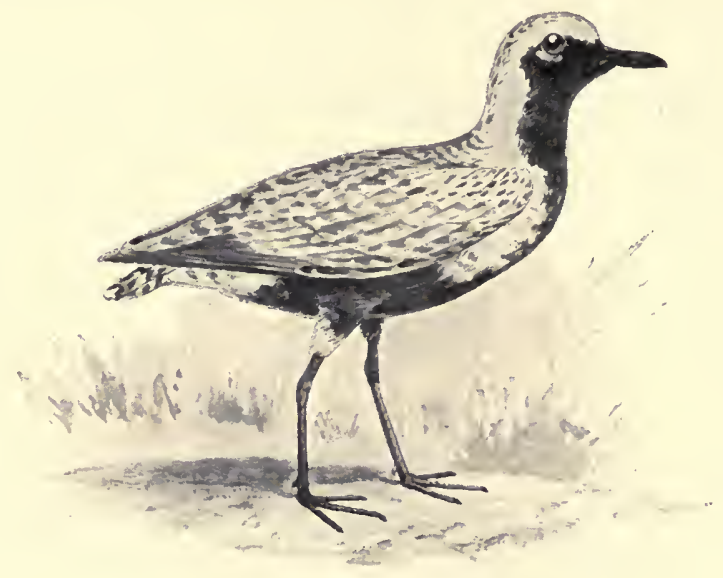

Black-bellied Plover (summer plumage).

plumage, but usually showing traces of whitish on the feathers; abdomen and under tail coverts, white; forehead, white; axillars, smoky black.

Adult in winter: Throat and breast, not black; upper plumage, brownish, mottled with gray; under parts, white; breast and sides, streaked with ashy brown; bill, black; under parts sometimes showing traces of blackish, but not black; as in the breeding plumage. Unlike our other Plover this species has a rudimentary hind toe.

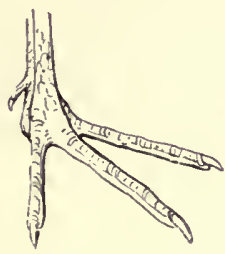

Black-bellied Plover.

Length, Ir.25; wing, 7.45 ; tarsus, 1.85; bill, r.ro.

The Black-bellied Plover is more or less common in Illinois and Wisconsin during the migrations. As is the case with a number of species, a few non-breeding birds remain throughout the summer. The black axillary plumes and rudimentary hind toe are good distinguishing characters in any plumage.

\section{Genus CHARADRIUS Linn.}

135. Charadrius dominicus MüLL.

American Golden Plover.

Local names: Green Plover. Frairie Pigeon.

Distr.: Arctic America (except the shores of Bering Sea), migrating through North America to southern South America, in winter; breeds in the far north. 
Adult in summer: Back and upper parts, smoky black, feathers marked and edged with yellow and brown; sides of the breast, whitish; rest of under parts, throat, and sides of the head, including eye, black; forehead, whitish, a white stripe extending backwards over the eye and down the sides of the neck; bill, black; axillars, gray.

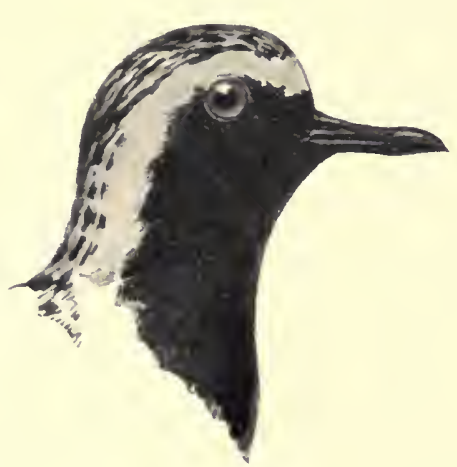

Breeding plumage.

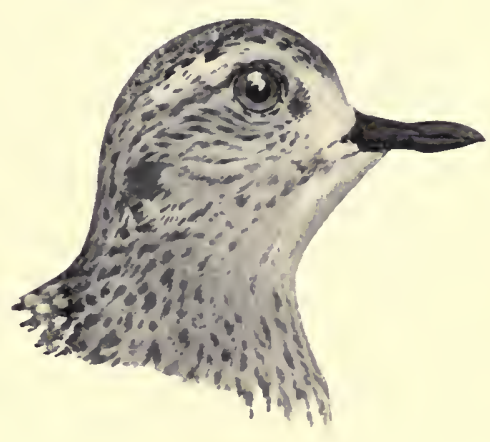

Fall and winter plumage.

Adult in winter: Upper parts, brownish, feathers marked with dull tawny yellow or buff; under parts are dull white, streaked with ashy brown or gray on the breast and sides.

Length, 10.25; wing, 7 ; tarsus, 1.55 ; bill, .92.

This species may be distinguished from the Black-bellied Plover in any plumage by its gray axillars and the absence of the rudimentary hind toe.

The Golden Plover was at one time abundant and is still more or less common in Illinois and Wisconsin during the migrations. Arrives from the south the latter part of April and from the north in September. As is the case with others of its family, its numbers are decreasing year by year.

\section{Genus OXYECHUS Reich.}

136. Oxyechus vociferus (Lins.).

Killdeer Plover.

Egialitis vocifera (Linn.), A. O. U. Check List, I895, p. 100.

Distr.: Temperate North America; south in winter to the West Indies, Middle America, and South America; breeding throughout its North American range as far north as Newfoundland and Manitoba. 
428 Field Museum of Natural History-Zoölogy, Vol. IX.

Adult: Crown and back, brownish gray, feathers tipped with rufous; a ring around the neck, lores, and a patch on the breast,

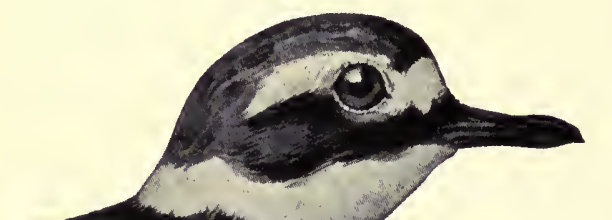
black; forehead, white; throat and spot behind the eye and a band around the neck, white; lower breast and belly, white; tail coverts and rump, bright rufous; tail, rufous and

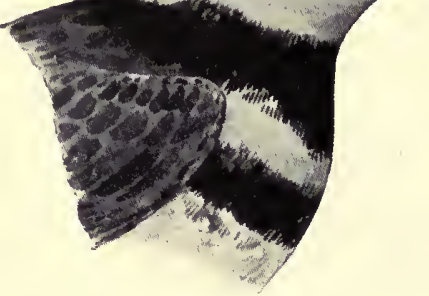

Killdeer Plover. gray, tipped with black and white; bill, black.

Length, I0.65; wing, 6.55; tarsus, I.40; bill, .75.

This species is a common summer resident in Wisconsin and Illinois, breeding in suitable localities. It arrives in March and remains until cold weather sets in. It breeds in April and May.

The nest is merely a depression in the ground with, at times, a slight lining of grass. The eggs are usually four, pyriform in shape, dull white, blotched and spotted with chocolate brown, more numerous at the larger end, and measure 1.65 x I.1 5 inches.

\section{Genus ÆGIALITIS Boie.}

\section{Egialitis semipalmata Bonap. \\ Semipalmated Plover.}

Local name: Ring-neck.

Distr.: Arctic and subarctic America, breeding from Labrador northward, migrating south to the West Indies, Brazil, Peru, and the Galapagos Islands, in winter.

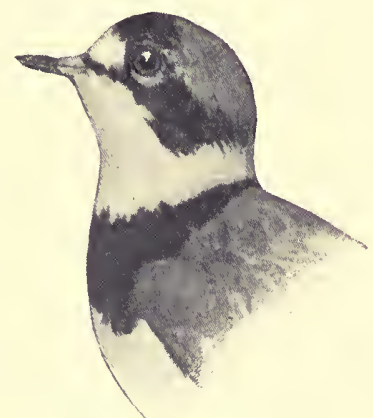

Semipalmated Plover.

Adult in summer: Forehead, white, s:cceeded by a band of black; rest of head, back, and wings, ashy gray; a dull stripe of blackish passing from the bill under the eye to the sides of the neck; a small patch of white back of the eye; a broad band of black on the breast; rest of under parts, white; throat, white, extending around the neck and joining at the back in a very narrow stripe; secondaries, tipped with white; bill, black, orange at the base; a bright orange ring around the eye; toes webbed at base. 
Adult in winter: Similar, but the black marking replaced by brownish or gray.

Length, 6.80; wing, 4.75; tarsus, .93; bill, .50.

The Semipalmated Plover or "Ring-neck" is common in Illinois and Wisconsin during migrations and a few birds remain during the summer. Mr. Nelson obtained specimens near Chicago, July ist.

Kumlien and Hollister state: "Numbers remain about the larger lakes and Lake Michigan during the summer. We procured the young still unable to fly at Lake Koshkonong on one occasion." (Birds of Wisconsin, 1903, p. 54.) It will be noted that the nest and eggs have not actually been found.

\section{8. Ægialitis meloda (ORD). Piping Plover.}

Local name: White Ring-neck.

Distr.: Eastern North America, breeding from northern Illinois and Virginia northward to Labrador, Newfoundland, Lake Winnipeg, and Assiniboia.

Adult in summer: Upper parts, ashy; forehead, white, separated from the ash color of the head by a narrow patch of black; a band on the side of the breast, black; under

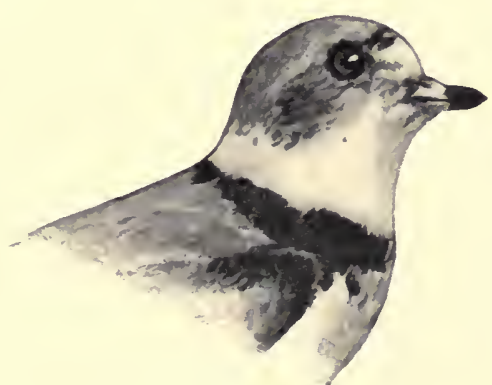

Piping Plover. parts and a ring around the neck, white.

Adult in winter: Similar to the summer plumage, but the black marking replaced by grayish buff, or ashy gray, instead of black; bill, orange at base, tipped with black.

Length, 7.20 ; wing, 4.80 ; tarsus, .90; bill, .50

The Piping Plover occurs more or less commonly during the migrations in Illinois and Wisconsin, and a few remain as summer residents and breed.

Nelson found it breeding commonly. on the flat, pebbly beach between the sand dunes and the shore of Lake Michigan. Mr. John F. Ferry procured young birds unable to fly at Beach, Lake County, Illinois, in June, I906, and Mr. F M. Woodruff found it breeding and took a set of eggs at Millers, Indiana, June I3, r 902 (Birds of the Chicago Area, 1907, p. 8I). Kumlien and Hollister state that it formerly bred in Wisconsin, about Lake Koshkonong and near She- 
430 Field Museum of Natural History-Zoölogy, Vol. IX.

boygan on the Lake shore, but is now almost entirely absent, except a limited number during migrations (Birds of Wisconsin, I 903, p. 54).

The nest is merely a depression in the sand. The eggs are three or four in number, cream white, speckled with chocolate brown. They measure about $1.25 \times 1.96$ inches. The subspecies $A$. m. circumcincta is no longer recognized as separable.

\section{Family APHRIZIDÆ. Surf Birds and Turnstones.}

Three of the four known species are found in North America, but only one is known to occur in Illinois. They are plover-like in appearance, frequenting the beaches and sand flats in company with other waders. The name Turnstone is supposed to be derived from the habit of turning over small stones while searching for food.

\section{Subfamily ARENARIINÆ. Turnstones.}

Genus ARENARIA Brisson.

139. Arenaria interpres morinella (LINN.).

TURNSTONE.

Arenaria interpres (Linn.), A. O. U. Check List, I895, p. I०3.

Local names: Calico-back. Brant Bird.

Dist.: Northern North America, chiefly east of the Mackenzie River basin, breeding in high latitudes; south to Patagonia in winter; rare on the Pacific coast.

Adult in summer: General upper parts, mottled and variegated with black, white, rufous and tawny; throat and breast, black and white; rest of under parts, white; tail, with subterminal band of black, tipped with white.

Adult in winter: Above, light, streaked and dashed with dark brown; an imperfect band of dark brown on the jugulum; chin and upper part of the throat, white; sides of breast, like the back; rest of the under parts, white; a distinct white band on the wing; rump, white, but with a broad patch of black on the

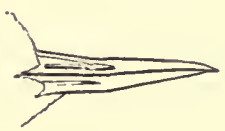
upper tail coverts; tail, dark brown, the tips and basal half of the inner feathers, and nearly two-thirds of the outer feathers, white; legs, reddish orange; bill, black. 


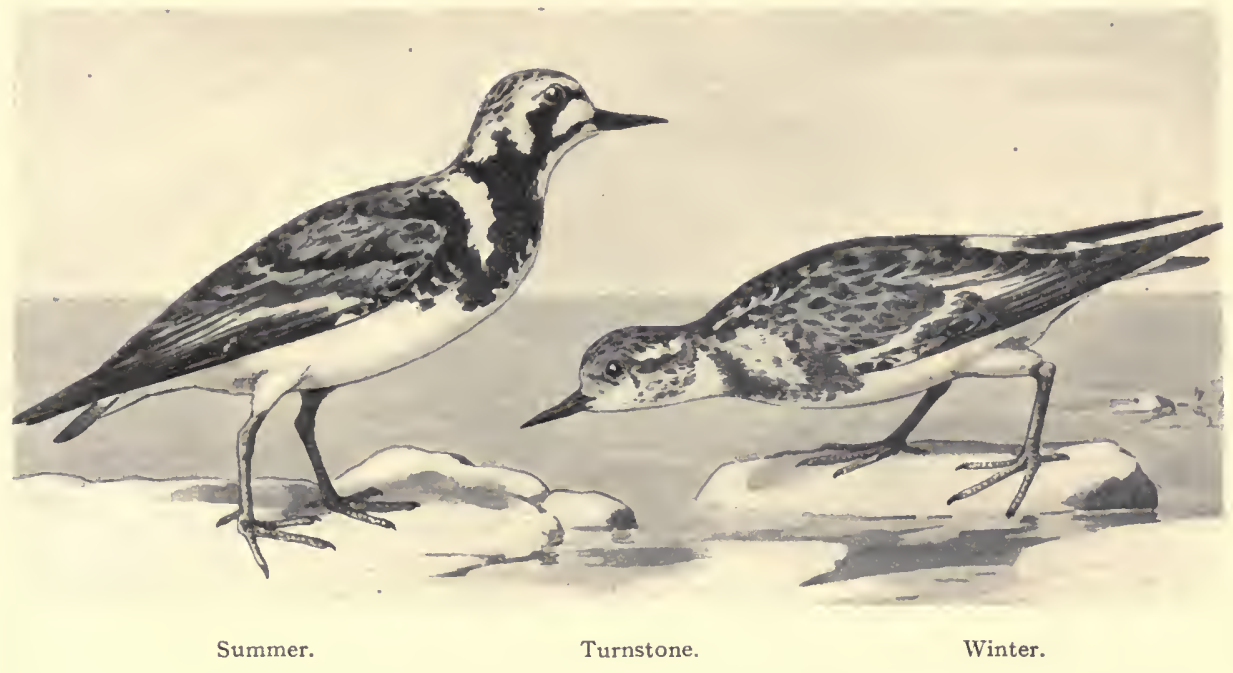

Length, 8.65; wing, 5.70; tail, 2.60; tarsus, I; bill, .95.

The Turnstone is not uncommon in Illinois and Wisconsin during the migrations, principally on the shores of Lake Michigan. It has received its name from the manner in which it turns over small pebbles and shells while searching for the small crustaceans and insects upon which it feeds. 


\section{LAND BIRDS.}

\section{ORDER GALLIN Æ.}

GALLINACEOUS BIRDS.

Suborder PHASIANI. Pheasants, Grouse, Partridges, etc. Family TETRAONIDÆ. Grouse, Partridges, etc.

This large family contains nearly two hundred species, represented in eastern North America by two subfamilies; the Perdicince or "Quail" and Partridges, and the Tetraonine, the Grouse, Ptarmigan, etc. Some, like the Prairie Hen, frequent open, plains and fields, while others, like the Ruffed Grouse, prefer the woods. With few exceptions they are not migratory. After the nesting season they are found in flocks or "covies."

\section{Subfamily PERDICINÆ. Quail and Partridges. \\ Genus COLINUS Lesson.}

140. Colinus virginianus (LinN.).

QuaIl * or Bob-white.

Distr.: Eastern United States, from southern Maine and southern Ontario to the Gulf states. Has been introduced in a number of western states, California, New Mexico, Oregon, etc.

Adult male: Throat, white, bordered by black mixed with chestnut and white on sides of the neck; a stripe of white from the forehead over the eye; a streak of black below the eye, separating it from the white throat; under parts, dull white, the feathers with narrow bands of black; sides of the body streaked with chestnut; feathers of the upper back, pale chestnut brown, bordered with gray, showing

* Although birds belonging to the genus Colinus are not true "Quail" from a scientific standpoint. they are so widely known an 1 generally recognize 1 by that name it seems undesirable to change it. 


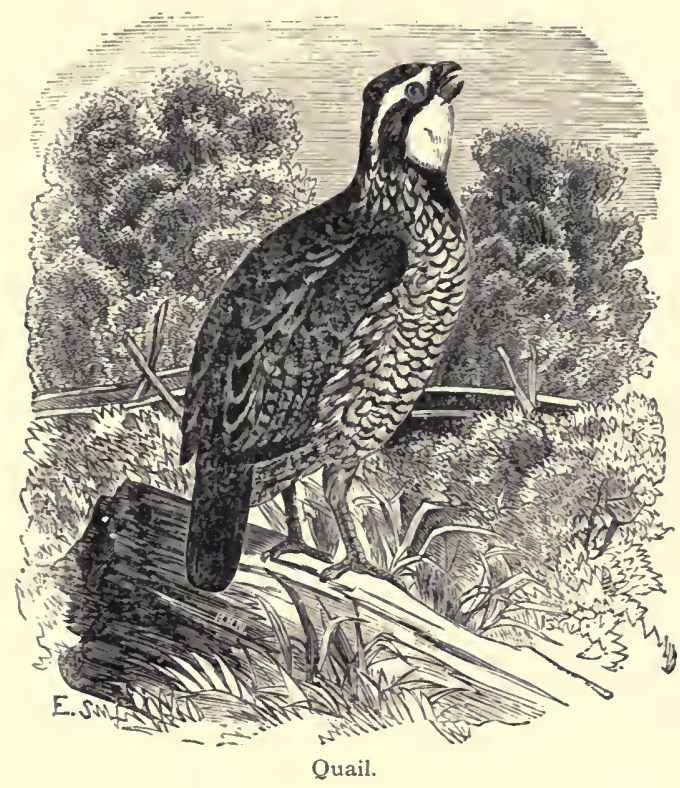

narrow dusky bars; primaries, grayish brown; crown showing more or less black mixed with chestnut brown; bill, black.

Adult female: Similar, but has the throat and the line over the eye tawny buff instead of white, and little or no black on the breast.

Length, about Io; wing, about $4.5^{\circ}$; bill, about .45; tarsus, I.

This species is a common resident throughout Illinois and Wisconsin, except in the northern part of the latter state. It is found in small flocks and is terrestrial, although when frightened will occasionally alight in trees. The note is a clear loud whistle, crudely described as hu-hui or hu-huit, which by a slight effort of the imagination is supposed to sound like the words Bob-white. The loud notes are often preceded by a short low one, which can only be heard at a comparatively short distance.

It breeds throughout its range, nidification commencing about the first of May. The nest is on the ground, usually in open places, such as grassy fields. The eggs are white or creamy white, and number from Io to 15 (occasionally more); they measure about $1.20 \times .95$ inches.

Specimens are often taken in southern Illinois, which are somewhat dark and small and which are apparently intermediate between $C$. virginianus and the Florida form $C$. v. floridanus. 
434 Field Museum of Natural History-Zoölogy, Vol. IX.

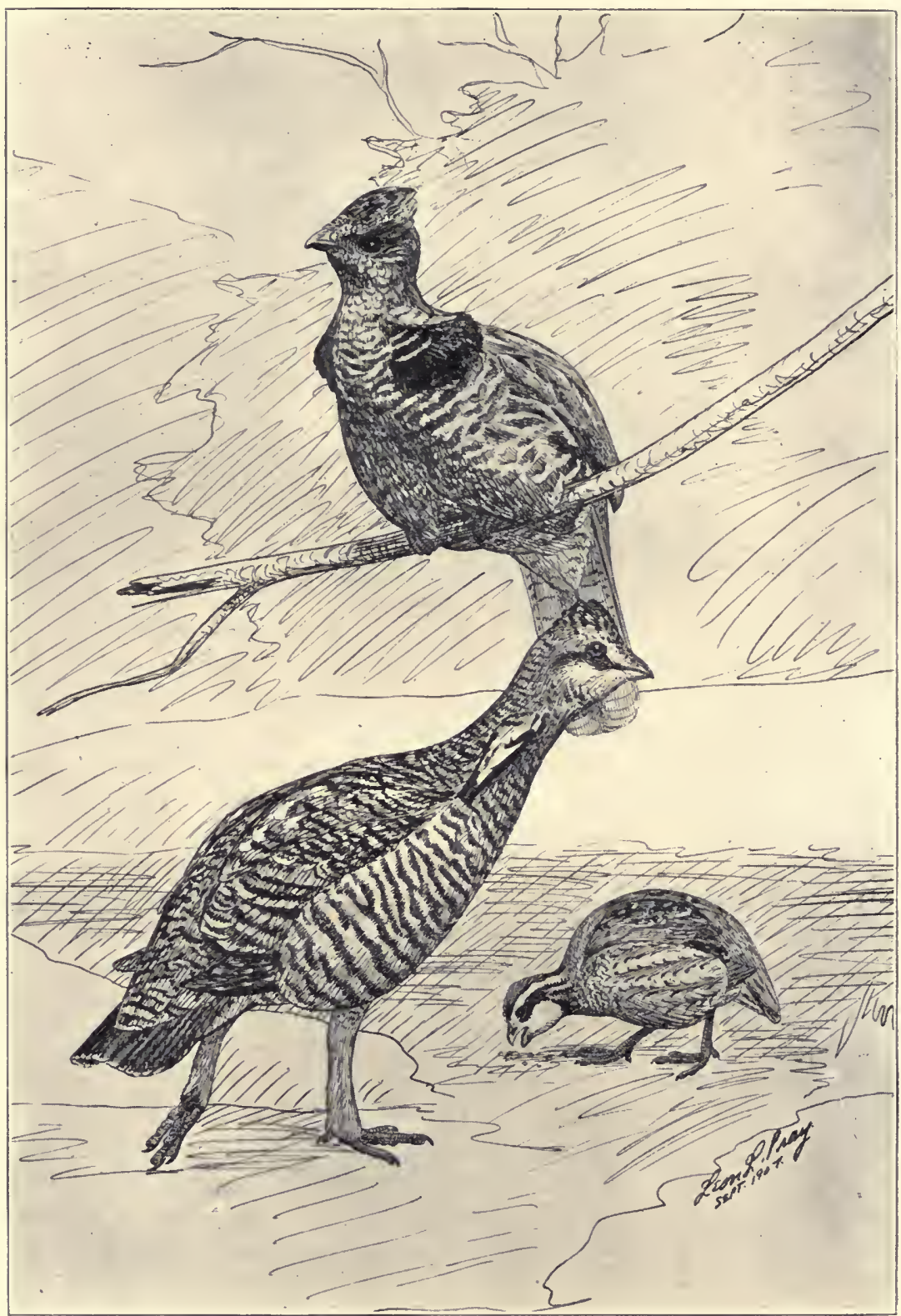

Prairie Hen.

Ruffed Grouse.

Quail.

(Illustrating comparative difference in size.) 
Subfamily TETRAONINÆ. Grouse, Ptarmigan, etc.

Genus CANACHITES Stejneger.

141. Canachites canadensis canace (LinN.).

Canada Grouse. Spruce Partridge.

Dendragapus canadensis (Linn.), A. O. U. Check List, I 895, p. I I I. Distr.: New Brunswick and northern New York and southern Canada, west to northern Minnesota; accidental or casual in northern Wisconsin.

Adult male: Bare skin above the eye, red (in life); upper plumage, gray, barred with black; top of head, gray, mottled with ;black; throat, black, mixed with white; feathers on base of bill, black, a nar-

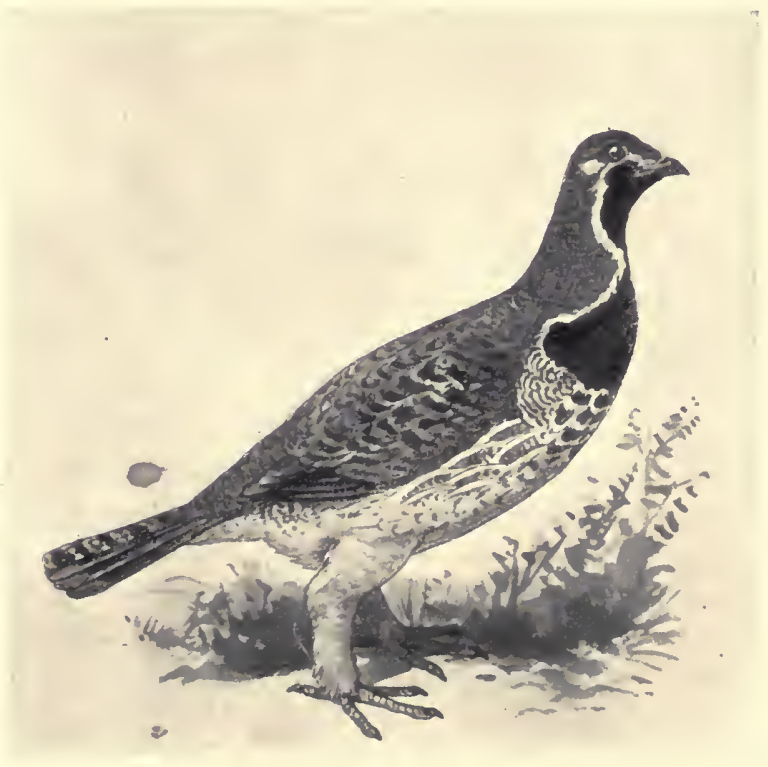

Canada Grouse (male).

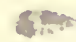

row white line extending back of the eye; breast, black; rest of under parts barred with black and white; axillars, slaty gray, the shafts of the feathers and the tips, white; first primary, grayish brown, the rest, grayish brown with outer webs mottled with pale buff; tail, brownish black. tipped with rufous.

Adult female: Head and upper back, marked with rufous, gray and black; lower back and rump, gray, with narrow black bars on the 
436 Field Museum of Natural History-Zoölogy, Vol. IX.

feathers; throat and breast, rufous, mottled and barred with black; feathers of the under parts barred with pale rufous, black and white; tail, brownish black, mottled and barred with pale rufous brown, the outer feathers, broadly tipped with pale rufous; axillars, as in the male.

Length, about 15.25; wing, 6.60; bill (from end of nostril), .40.

This species is not uncommon in northern Wisconsin, but does not occur in Illinois.

"A very common resident in the coniferous forests of northern Wisconsin, where it is partial to swamps." (F. H. King, Geology of Wisconsin, Vol. I, r883, p. 59r.) "Fairly common resident in the pine regions of the state, but so far as we can learn has never been found south of the pine belt. *** In some sections of our extreme northern counties many still remain." (Kumlien and Hollister, Birds of Wisconsin, r903, p. 56.)

The nest is built on the ground. The eggs are ro to 16 in number, buff color, speckled and spotted with dark brown, and measure about $1.70 \times 1.20$ inches.

\section{Genus BONASA Stephens.}

\section{Bonasa umbellus (Linn.).}

Ruffed Grouse. Partridge.

Distr.: Eastern United States and southern Canada, west to Minnesota; also mountainous regions of Georgia, Mississippi, and Arkansas.

Adult male: Upper plumage, mixed gray tawny brown and ck some scapulary feathers, broadly marked with buffy white; mroat, pale tawny brown, sometimes with narrow indistinct bars of black; feathers on the lower breast and belly, broadly tipped with white and barred with black or brown; inner webs of primaries, grayish brown; outer webs, barred with buff white or dull white; tail, pale brown, irregularly barred with gray and blak, and with a broad subterminal band of black or brown, the feathers tipped with gray; a tuf black feathers on the side of the neck, edged with iridescent green; axillars, barred with brown and white. Plumage very variable, often with a rufous brown tinge to the feathers; some specimens have the ruffle or tufts of feathers on the sides of the neck chestnut brown, with iridescent edges instead of black, and the bands on the tail, brown.

Adult female: Similar, but slightly smaller and has the tufts of feathers on the neck smaller and browner. 


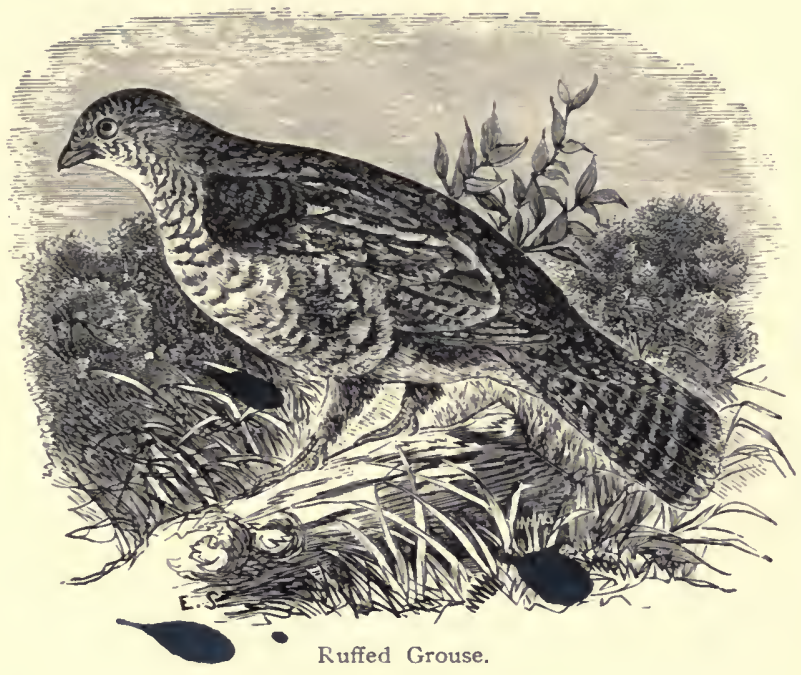

Length, about $\times 6.50$; wing, about 7.50 ; bill (end of nostril to tip), .50 ; tarsus, $\mathrm{x.55}$.

The Ruffed Grouse is a common resident in wooded portions of Illinois and Wisconsin, and abundant in northern Wisconsin. The nest is built on the ground, usually in woods. Nidification commences in Illinois the latter part of May (sets of eggs taken May 27th and June I.). The eggs are brownish buff, from nine to thirteen or fourteen in number, and measure about $\mathrm{x} .50 \mathrm{x}$ x.I 2 inches.

The peculiar drumming sounds made by the male are produced by rapidly beating his wings against his body.

\section{2a. Bonasa umbellus togata (Linv.).}

Canadian Ruffed Grouse.

Distr.: Northern New England and New York, throughout British Provinces, west to the Pacific; casual in extreme northern United States.

The Canadian Ruffed Grouse may be distinguished from B. umbellus by the under parts being gray, instead of rufous brown, the breast and belly being distinctly barred, and the throat usually "barred with dusky.

This form is included by Kumlien and Hollister in their Birds of Wisconsin, but they appear somewhat doubtful as to its occurrence, as they write: "Typical togata is rare in Wisconsin. A number of 
438 Field Museum of Natural History-Zoölogy, Vol. iX.

grouse supposed to be of this form appear to be only intermediates, and typical umbellus occurs in the most northern counties." (p. 56.)

I have never seen a typical specimen of togata from Wisconsin, all specimens examined being nearer to umbellus than to the northern form.

\section{Genus LAGOPUS Brisson.}

\section{Lagopus lagopus (LinN.). Willow Ptarmigan}

Distr.: British Provinces to Arctic regions; accidental in northern New England and probably in other parts of the northern boundary of the United States.

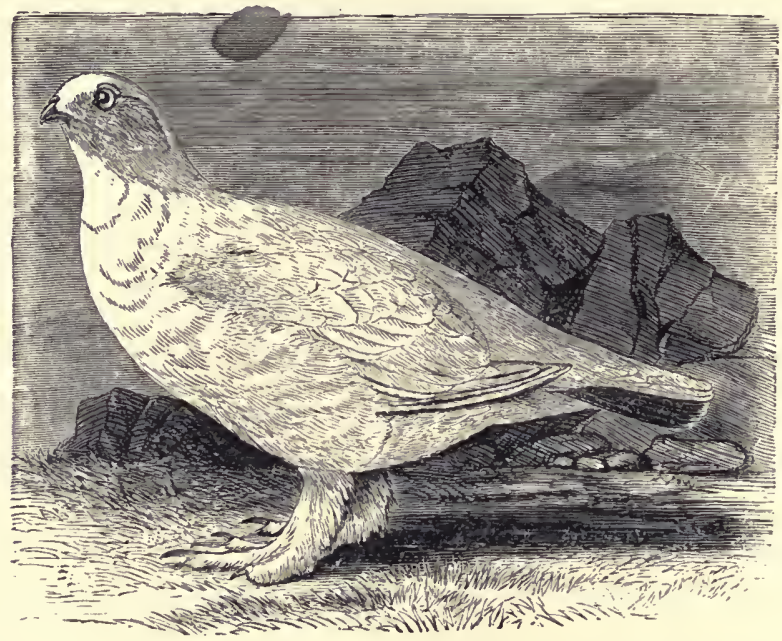

Willow Ptarmigan.

Winter plumage, male and female: General plumage, pure white; primaries, white, the shafts, blackish; most of the tail feathers, black. tipped with white; feet, entirely feathered.

In summer both sexes assume a barred and mottled plumage of rufous brown, black, and buffy white.

Length, I 5 to I 7.25 ; wing, 7.10 to 7.60 ; bill (nostril), .40.

The Willow Ptarmigan must be considered a rare bird in extreme northern Wisconsin in winter and it may have occurred in Illinois during the past century, as Robert Kennicott states:* "Sometimes found in the timber along Lake Michigan." Dr. R. P. Hoy procured

\footnotetext{
* Catalogue of the Animals observed in Cook Co., Illinois. Trans. Ill. State Agricultural Soc.,
} Vol. I, I 853, p. 586 . 
two specimens near Racine, Wisconsin, in December, 1846 . (Trans. Wisconsin State Agri. Soc., Vol. II, r852, p. 34r.) Kumlien and Hollister give two additional records from northern Wisconsin and say: "It is certain, however, that the ptarmigan occurs as a rare winter visitor in the northern peninsula of Michigan and formerly at least reached Wisconsin during the severest weather." (Birds of Wisconsin, I 903 , p. 57 .)

\section{Genus TYMPANUCHUS Gloger.}

144. Tympanuchus americanus (REICH.).

Prairie Hen. Pinnated Grouse.

Distr.: Prairies of United States, from Texas, Nebraska, and Kansas, east to Indiana, Ohio, Illinois, and Michigan, and from Ontario and Michigan to Missouri and Louisiana.

Adult male: Sides of neck with tufts of ten or more stiffened feathers marked with rufous and buffy white, the greater portion of the longer feathers, brownish black, and showing bare skin beneath; upper plumage, mixed pale brown, black and buffy white, the feathers broadly barred; throat, pale buff or buffy white; under parts barred with brown and white; most of the tail feathers, plain slaty brown, tipped with white, the middle feathers marked with more or less pale brown; middle tail feathers, not decidedly longer than the others.

Adult female: Similar, but having the tail barred with black and tawny buff, and the neck tufts, smaller.

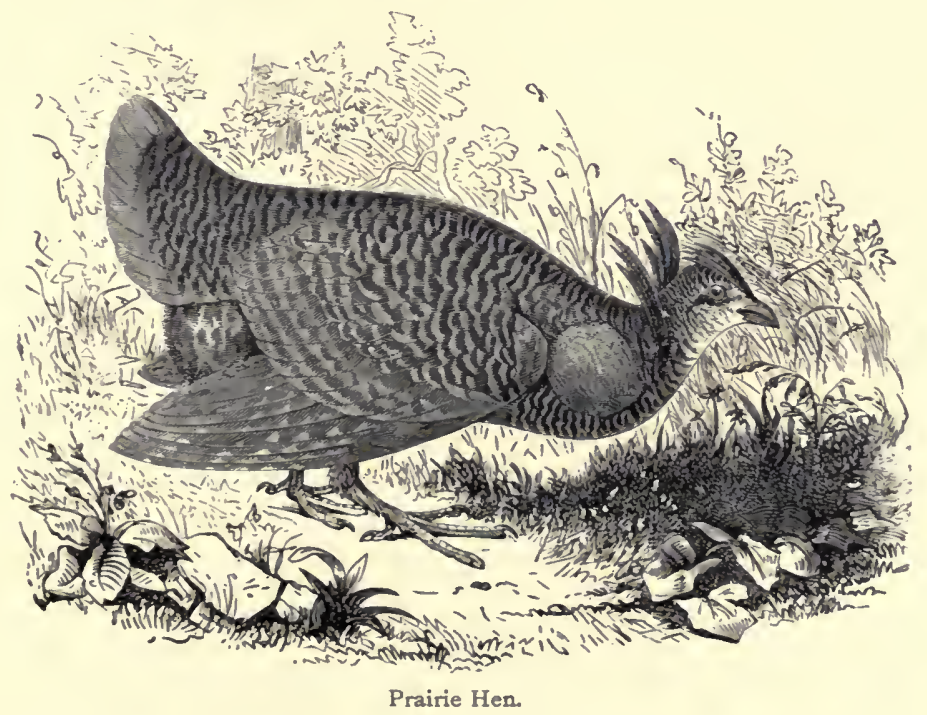


440 Field Museum of Natural History-Zoölogy, Vol. IX.

Length, about $x 7$; wing, 8 to 9 ; bill (end of nostril to tip), .5०.

The Prairie Hen was formerly very abundant in Illinois and Wisconsin and is still not uncommon in prairie lands of the less settled portions. Breeds in May in open prairies and fields. The eggs are ten to fourteen, olive buff or greenish gray in color, usually unmarked but occasionally finely specked with brown. They measure about I.65 X 1.22 inches.

Regarding the curious "booming" sounds made by the cock bird and its strange antics during the mating season, Mr. Frank M. Chapman writes as follows: "At short range the bird's note suggested the mellow resonant tone of a kettledrum. $* * * *$

"As a rule each bird had its own stand separated by about ten yards from that of his neighbor. The boom is apparently a challenge. It is preceded by a little dance in which the bird's feet pat the ground so rapidly as to produce a rolling sound. This cannot be heard at a greater distance than thirty yards. It is immediately followed by the inflation of the great orange air sacks at the side of the neck, which puff out as quickly as a child's toy balloon whistle; the tail is erected and widely spread, the wings drooped, the neck-tufts are raised straight upward, giving the bird a singularly devilish look, then with a convulsive movement of the lowered head the boom is jerked out and at its conclusion the air sacks have become deflated.

"One might imagine that after so violent a performance the bird would feel a certain sense of exhaustion or at least quiescent relief, but his excess of vitality seeks still other outlets. Uttering hen-like calls and cracks he suddenly springs a foot or more straight into the air, whirling about as though he were suffering from a combined attack of epilepsy and St. Vitus's dance.

"But all this activity is only a prelude to the grand finale of actual combat. Like a strutting turkey cock, the neighboring birds go toward each other by short little runs, head down, the orange eyebrow expanded and evident, pouches inflated, neck tufts and tail straight up, and looking like headless birds with two tails. Their meeting is followed by no make-believe duel, but an actual clash of wings. Uttering a low, whining note they fight as viciously as game-cocks, and the number of feathers left on the ground testifies to effective use of bills and claws." (The Outing Magazine, November, I908, p. 224.) 


\section{Genus PEDICECETES Baird.}

\section{Pediœcetes phasianellus campestris (RIDGw.). \\ Prairie Sharp-tailed Grouse.}

Distr.: Prairies east of Rocky Mountains, to Illinois and Wisconsin, and from Manitoba south to New Mexico.

Adult male: No noticeable tufts of feathers on sides of the neck, as in the Prairie Hen; middle tail feathers, about an inch longer than the others; back and upper parts, marked with tawny buff and black, the feathers, irregularly barred; wing coverts, spotted with white; outer webs of primaries, barred with white, the first with buffy white; throat, pale buff; feathers on the breast marked with white, centres and edges with arrow shaped markings of dark brown; belly, white, with a few brown marks; sides of body, rufous, black and white; axillars, white.

Adult female: Similar, but smaller and somewhat lighter.

Length, about I 7 ; wing, 8 to 9 ; bill (from end of nostril), .50.

The Prairie Sharp-tailed Grouse was formerly not uncommon in northern Illinois and Wisconsin. It still occurs in northwestern Wisconsin, but none have been observed in Illinois for many years.

Mr. E. W. Nelson writes (Birds N. E. Illinois, $18 ; 6$, p. I 2 I): "The last record of its occurrence in this vicinity is furnished by my friend, Mr. L. H. Douglass, who informs me that in the fall of 1863 or I 864, while two gentlemen were shooting Prairie Chickens near Waukegan, they found and secured a covey of these birds numbering fourteen individuals. They had in all probability been raised in the immediate vicinity." Kennicott gives it as formerly not uncommon in Cook Co., I11.

In Wisconsin, according to F. H. King (Geology of Wisconsin, I883, p. 59I), it was "Resident from Berlin northward and was abundant in the vicinity of Lake Flambeau, in October, I877." According to Kumlien and Hollister: "A few sharp-tails were found about Stevens Point in 1898 and scattered records have been received from Markesan and other points in the north central part of the state." (Birds of Wisconsin, I903, p. 58.)

The nest is placed on the ground. The eggs are from I 2 to I 4 in number, pale olive buff or pale buff in color, and measure about r.70 $\mathrm{X} 1.20$ inches. 


\section{Family PHASIANIDÆ. Pheasants, Turkeys, etc.}

The family Phasianidæ contains nearly one hundred species and includes the Jungle Fowl, the Asiatic Pheasants, some of them of gorgeous plumage, and the well known Peacock; also in America the splendid Ocellated Turkey of Yucatan and the Wild Turkey, from which our domestic race is supposed to have descended. In the United States the Wild Turkey is becoming less and less common every year and is fast becoming rare or has entirely disappeared in many localities where it was once abundant. Several subspecies are recognized.

\section{Subfamily MELEAGRINÆ. Turkeys.}

Genus MELEAGRIS Linn.

\section{Meleagris gallopavo silvestris (VIEILl.).}

\section{Wild TURKEY.}

Distr.: Eastern United States (except southern Florida, where it is replaced by the Florida Wild Turkey), north to Virginia, Wisconsin, Michigan, and Kansas.

The Wild Turkey resembles the domestic turkey, but differs in having the upper tail coverts and tail tipped with chestnut, the primaries more broadly barred with white, and the legs decidedly pink red; bare skin of head, pale blue, the excrescences, purplish red.

Length, 40 to 50 inches; wing, 20 to 22 ; tail, about I 8.

Wild Turkeys were formerly abundant in Wisconsin and Illinois, but for many years none have been observed in the former state. Kumlien and Hollister (Birds of Wisconsin, p. 58) say: "Residents of the extreme southwestern counties claim that a few were found among the bluffs near the river as late as I $894 . "$

It has apparently disappeared from northern Illinois, but is still to be found in the heavily wooded districts in the southern portion of the state*. Mr. Ferry reports a flock having been seen near Olive Branch in February, I907.

Regarding the occurrence of Wild Turkeys in the vicinity of Chicago, Mr. H. K. Coale having kindly placed his journal at my disposal, I quote the following: "March 23, I878, met several hunters

*Mr. A. H. Felger states that five Wild Turkeys were killed in Clinton Co., southern Illinois, in October, 1903. (The Auk, Vol. xxvi, r909, p. 78.) 
who came over from the Ten Mile House and Englewood in search of Wild Turkeys. They had shot eight in the vicinity of the Ten Mile House; and had seen nearly a hundred, probably driven in by the severe snow storms out west. The balance of the flock scattered off in the direction of South Chicago; and although the hunters had been looking for them all day, they had not seen any more. One shot two Wild Pigeons and a Crow."

The nest is built on the ground. The eggs are pale buff color, finely speckled with brown. They number from ten to thirteen or fourteen, and measure about $2.50 \times 1.95$ inches.

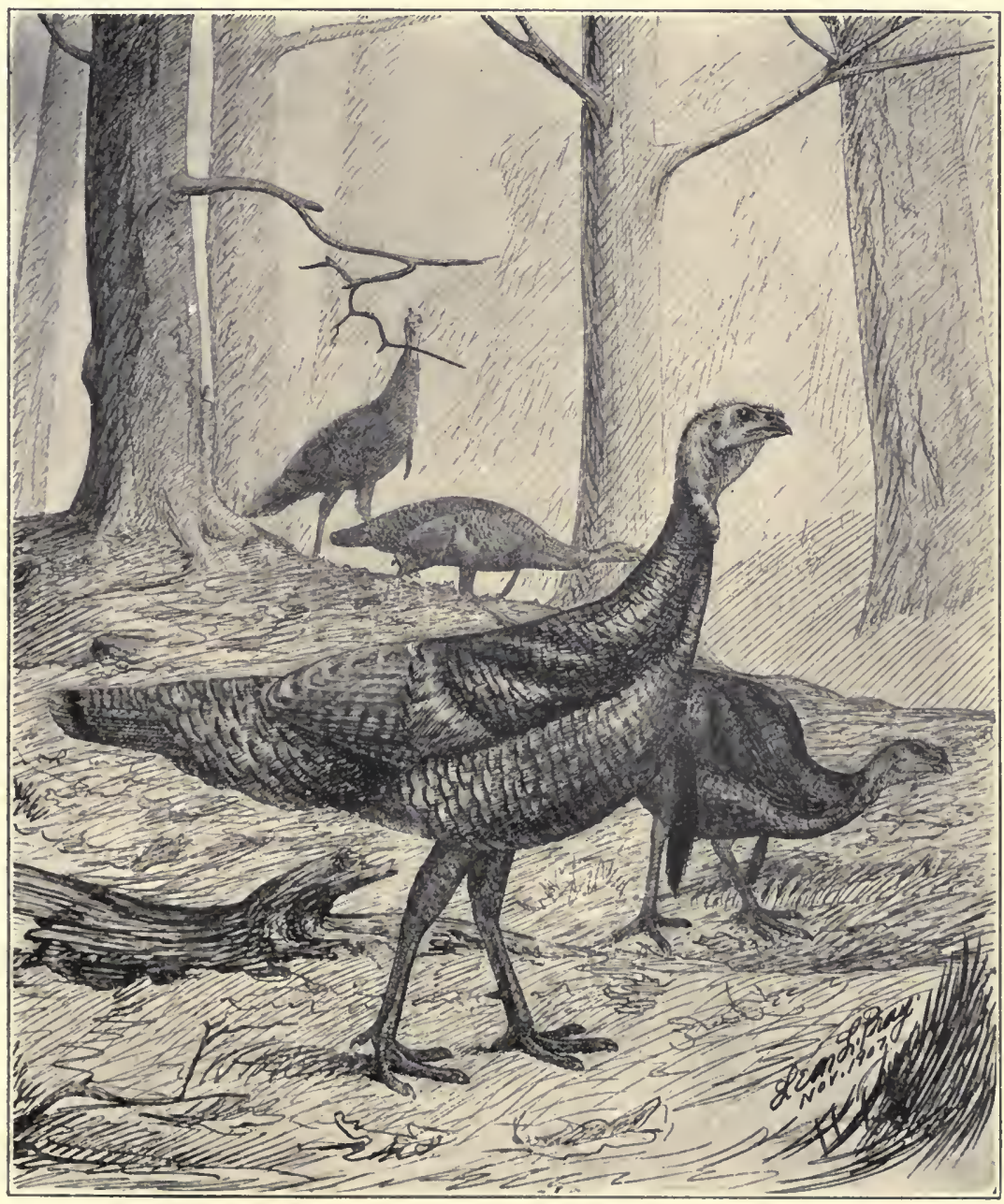

Wild Turkeys. 


\section{ORDER COLUMBA.}

\section{PIGEONS.}

\section{Family COLUMBIDÆ. Pigeons.}

The Pigeons are a very large family, numbering about 300 species, distributed in different parts of the world, about a dozen of which are found in North America. Their habits vary with different species, but they are all decidedly monogamous. In feeding the nestlings the macerated food is mixed with a milky fluid secreted in the gullet and is given to the young birds by regurgitation. When first hatched the young are naked. At one time flocks numbering tens of thousands of Wild Pigeons passed through Illinois, but they have now disappeared and the species is on the verge of extinction.

\section{Genus ECTOPISTES Swains.}

\section{Ectopistes migratorius (Linv.).}

\section{Passenger Pigeon. Wild Pigeon.}

Distr.: Eastern North America, north to Hudson Bay, west to the plains; breeds in Canada and northern border of United States; now very rare or extinct in localities where it was once very abundant.

Adult male: Upper plumage, including head, slaty blue; rump, bluish slate color; back and wings tinged with grayish olive; wing

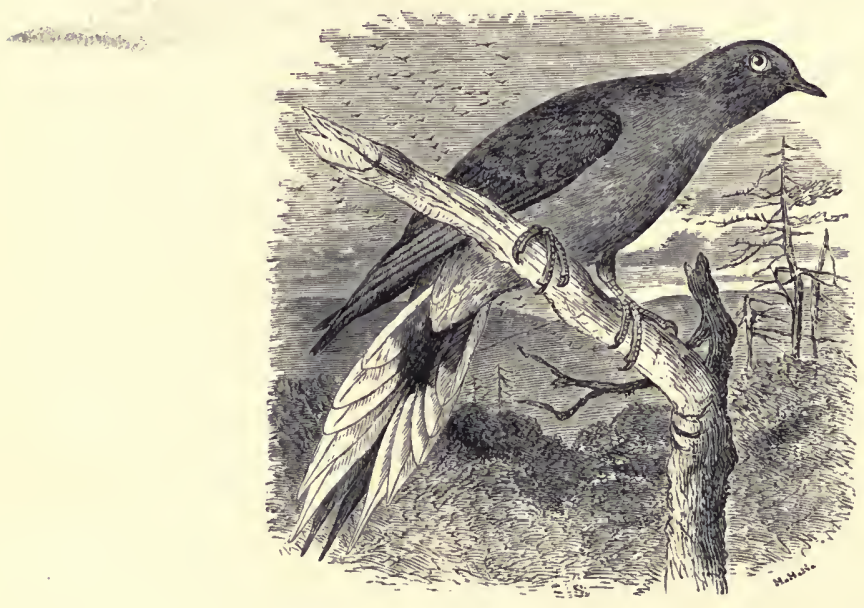

Passenger Pigeon. 
coverts with numerous black spots; sides of neck with metallic reflections of gold and violet; throat and breast, pale purplish chestnut, shading into white on the lower belly; sides of body, grayish slate color; primaries, blackish, edged with brownish white; two middle tail feathers, dusky, the rest shading from bluish gray to white at the tips, but marked with more or less chestnut and dusky at the extreme bases; bill, black; feet, red; skin about the eye, red.

Adult female: Somewhat smaller, the metallic reflections on the neck, paler, and the forehead and breast tinged with grayish brown.

Immature birds have the primaries marked with rufous brown.

Length, I 6 to I 8 ; wing, 8 to 8.60 ; bill, .75; tarsus, I.

The size and bluish gray rump will always distinguish this species from the Mourning Dove.

As late as the year 1882 , Wild Pigeons were very abundant in Illinois and Wisconsin; but about that time their numbers began to decrease very rapidly. Besides the thousands which were shot, immense numbers were caught in nets on their breeding grounds, with the result that in 1895 it had become a rare bird. At the present time the species is practically extinct.

To appreciate the slaughter of these birds in early days, I quote a statement by Prof. H. B. Roney (Chicago Field, Vol. X, p. 345): "The number of dead birds sent by rail was estimated at r 2,500 daily. or $1,500,000$ for the summer, besides $80,35^{2}$ live birds and an equal number was sent by water."

Kumlien and Hollister (Birds of Wisconsin, p. 59) say: "Mr. J. M. Blackford, now residing at Delavan, states that the last large catch of the netters was in 1882 . The following spring but one hundred and thirty-eight dozen were taken in the best pigeon grounds in the state, and this was practically the end."

Mr. Ruthven Deane (Auk, I898, p. I84) states that Mr. A. Fugleberg, of Oshkosh, Wisconsin, observed a number of flocks of Wild Pigeons near Lake Winnebago, Wisconsin, on August 16, r897. He estimated that six or more flocks contained from 35 to 80 pigeons each. He also records a flock of from 75 to roo birds observed by Mr. W. F. Rightmire near Cook, Johnson Co., Nebraska, on August I 7 , r 897 *

Mr. John F. Ferry informs me that Mr. F. C. Farwell killed a Wild Pigeon and observed two others near the Desplaines River in Lake Co.,

\footnotetext{
* Those who desire further information regarding the history and destruction of this species are referred to Mr. Ruthven Deane's valuable papers in The Auk, Vol. XII, 1895. p. 298, and Vol. XV, I898, p. 184; also to one by Mr. William Brewster, The Auk, Vol. VI, 1889, pp. 285291 , entitled "The present status of the Wild Pigeon (Ectopistes migratorius) as a bird of the United States, with some notes on its habits."
} 
Illinois, early in September, I 89,3, and Mr. Ferry has a female specimen in his collection killed at Lake Forest, Illinois, August 7, I 895 .

The following are among the late records given by $\mathrm{Mr}$. Otto Widmann of its occurrence in Missouri.

"I 894, April I 5. Mr. E. S. Currier sent ten pigeons to Keokuk, his first since $\mathrm{I} 888$.

x 896 , May 19 . The same sees one among doves, and again one October 18 , of the same year.

i 896, September I 7. Mr. W. Praeger shoots a male near Keokuk.

x 896, December 17 . Out of a flock of fifty near Attick, Oregon Co., Mo., Mr. Chas. U. Holden, Jr., kills a pair and sends them in the flesh to Mr. R. Deane of Chicago.

I 897, August r7. A flock of 75-roo is seen twenty-five miles west of our state line in Johnson Co., Neb.

I 902 , September 26. Last seen at New Haven by Dr. Eimbech." (Birds of Missouri, I907, p. 84.)

The nest is composed of sticks and twigs built in a tree. The eggs are white, one or two in number (often only one), and measure about $\mathrm{I} .45 \times \mathrm{I} .05$ inches.

\section{Genus ZENAIDURA Bonap.}

\section{Zenaidura macroura carolinensis (LINN.).}

Mourning Dove.

Zenaidura macroura (Linn.), A. O. U. Check List, I895, p. I 2 I

Distr.: United States and southern Canada, Central America and West Indies; breeds throughout its range.

Adult male: Upper plumage, grayish brownish"olive; crown, slate color, shading into vinaceous on the forehead, a purplish black spot
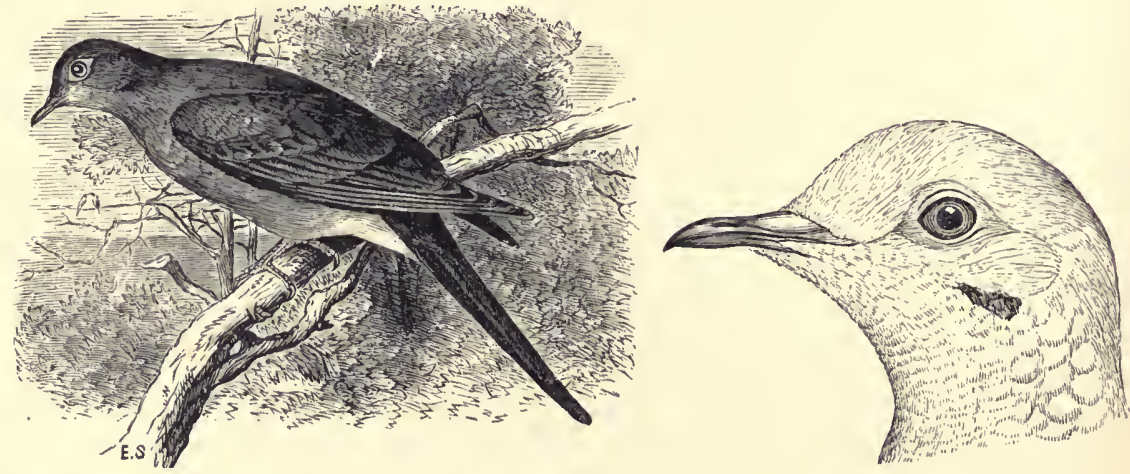

Mourning Dove. 
above the ear; sides of neck showing metallic reflections; breast, vinaceous, shading into pale buff on the belly; outer tail feathers tipped with dull white and barred with black; bare skin around the eye, bluish; feet, red.

Adult female: Similar, but paler and somewhat smaller; the purplish tinge of the breast replaced by grayish brown.

Length, about I 2 ; wing, 5.75 ; bill, .52 ; tarsus, .80; tail, 5.40 . The Mourning Dove is a common summer resident in northern Illinois and Wisconsin and a few remain during the winter. In southern Illinois it is a permanent resident. The mournful note of the male suggests its name.

The nest is a mat of twigs usually in a tree, occasionally on the ground. The eggs are white, two in number, and measure about 1.05 $\mathrm{x} .85$ inches. The Field Museum collection contains a series of sets of eggs ot this species taken in northern Illinois, between May roth and June 29 th. 


\title{
ORDER RAPTORES.
}

\author{
BIRDS OF PREY.
}

Suborder SARCORHAMPHI. American Vultures.

\section{Family CATHARTIDÆ. American Vultures.}

The Vultures are scavengers. The presence of a dead animal is often indicated by numbers of them roosting in trees or circling slowly about in its vicinity. Except during the nesting season, they are usually found in flocks. Their sense of sight is very keen, enabling them to distinguish objects at great distances.

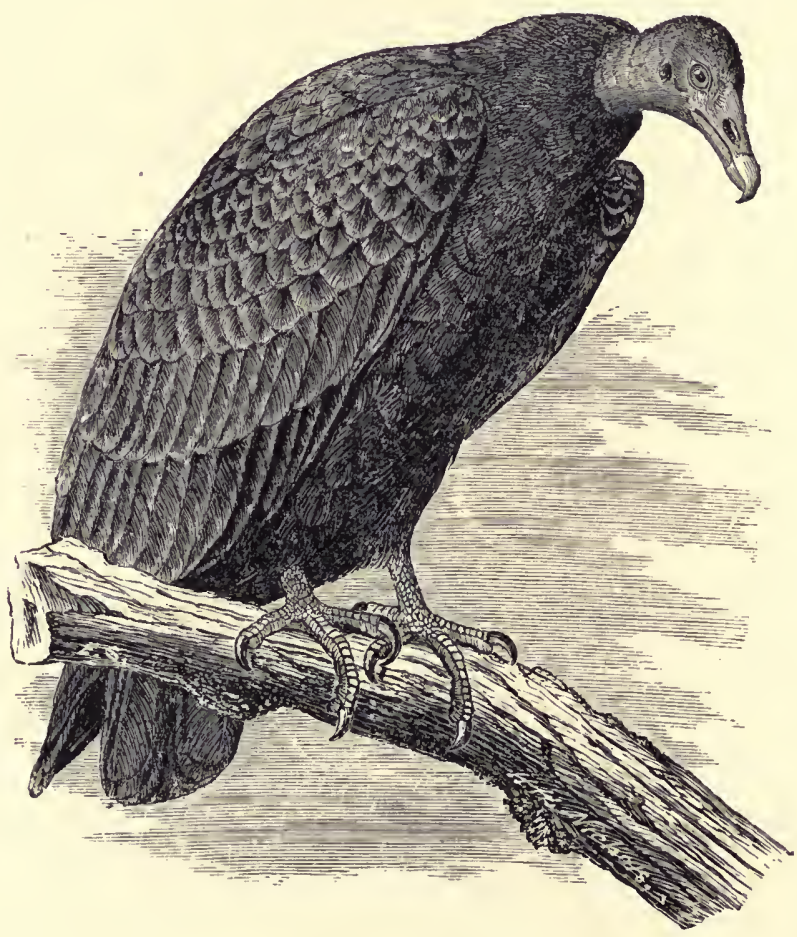

Turkey Vulture. 


\section{Genus CATHARTES Illiger.}

\section{Cathartes aura septentrionalis (WIED).}

Turkey Vulture. Turkey Buzzard.

Distr.: Greater part of North, Central and South Anıerica, from New Jersey and British Columbia to Patagonia; accidental in New England.

Adult: General plumage, sooty brown, the feathers being black, edged with dark grayish brown; head and neck, bare, the skin, red; bill, brownish white; tail, black, with light brown shafts.

Inmature birds have the head and neck covered with grayish brown, downy feathers.

Length, 28 to 30 ; wing, 22 to 24 ; bill, 2.35 .

The Turkey Buzzard is an abundant resident in southern Illinois. It is rather rare in the northern part of the state, but has been observed on several occasions in the vicinity of Chicago. * Mr. Ruthven Deane informs me he observed a bird of this species at Highland Park. Illinois, on June 28, I908. It occurs more or less regularly in Wisconsin, and according to Kumlien and Hollister: "Undoubtedly breeds sparingly in the southwestern part of the state." Mr. Isaac E. Hess informs me he has taken eleven sets of eggs of this species in May and June near Philo, Champaign Co., Illinois.

In southern Illinois it nests on the ground or on partly hollow logs (some writers claim in stumps of trees). The eggs are usually two, dull white, blotched and spotted with chocolate brown. They measure about $2.75 \times 1.90$ inches.

\section{Genus CATHARISTA Vieill.}

\section{Catharista urubu (Vieill.).}

\section{Black Vulture. Carrion Crow.}

Catharista atrata (Bartr.), A. O. U. Check List, I895, p. I25.

Distr.: Southern portion of North America, West Indies, Central and greater portion of South America; breeds in eastern United States from North Carolina and Illinois to the Gulf; accidental in New England.

Adult: General plumage, black; head and neck, bare, the skin black; under surface of wings tinged with hoary white; shafts of primaries, white; bill, blackish.

* Dunn, The Auk, I895, p. 394: Gault, Wilson Bull., No. 9, r896, p. 3, etc. 
450 Field Museum of Natural History--Zoölogy, Vol. IX.

Sexes similar.

Length, 23 to 26 ; wing, I 6 to 17.50 ; bill, 2.20 .

The Black Vulture is not uncommon in southern Illinois, and according to Prof. Ridgway (Orn. of Illinois, Vol. I, r 889, p. 492) occurs at least as far north as Mt. Carmel. It has apparently not been taken in Wisconsin.

Kumlien and Hollister (Birds of Wisconsin, I903, p. I3I.) write: "We do not consider the records of this species for Wisconsin sufficiently authentic to warrant us in giving it a place at the present time."

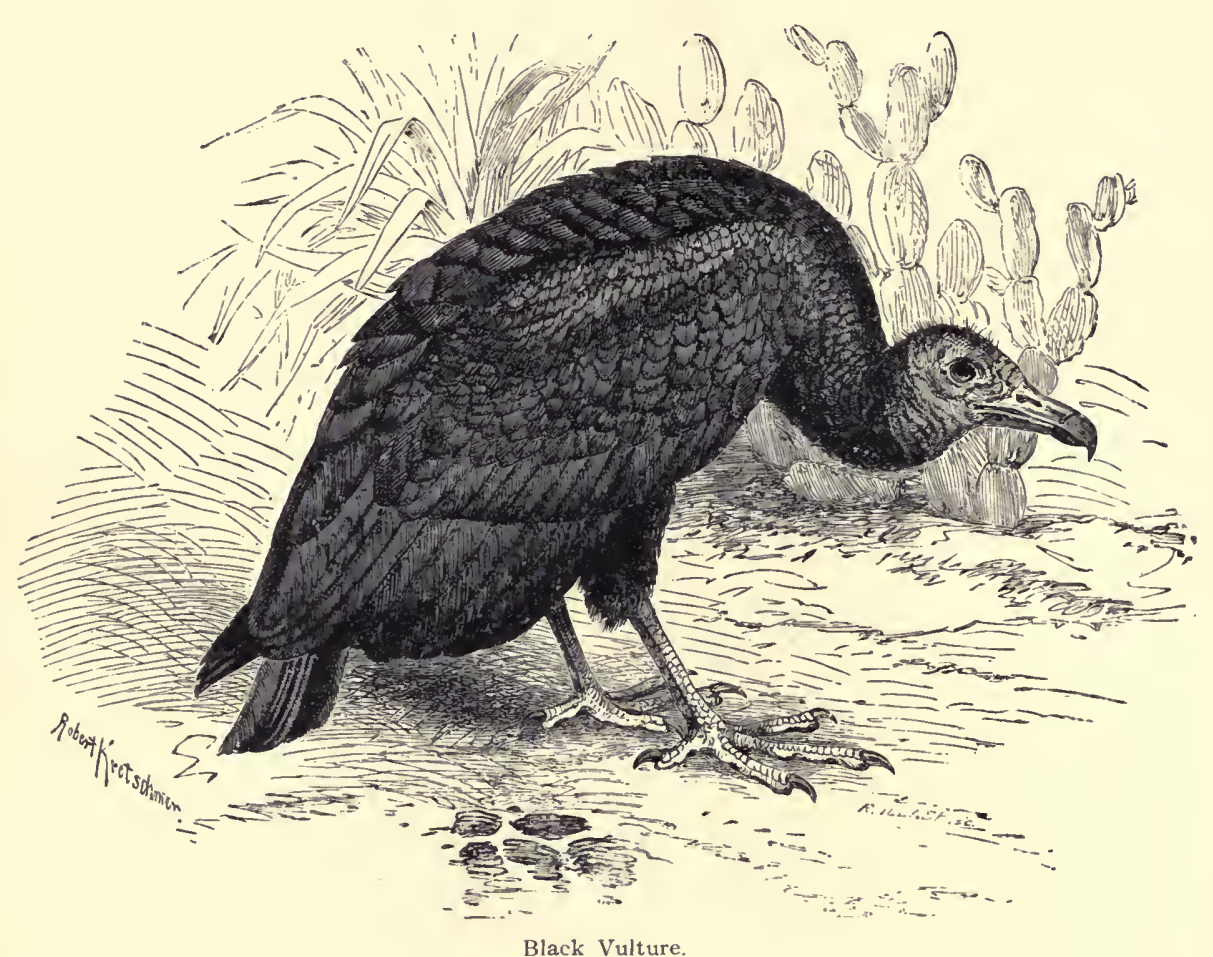

Black Vulture. 
Suborder FALCONES. Hawks, Falcons, Eagles, Kites, etc.

\section{Family FALCONIDÆ. Hawks, Falcons, Eagles, Kites, etc.}

About $35^{\circ}$ species belong to this family, widely distributed throughout the world. As a rule they do not feed on dead animals unless forced by hunger to do so, but delight in the pursuit and capture of their prey. Their choice of food differs with various species, but the majority of them kill birds, mammals and small reptiles. The Bald Eagle has a partiality for fish, which he occasionally catches for himself or finds dead on the shore, but a large portion of his larder is supplied by the Fish Hawks or Ospreys, which are forced after catching their prey to give it up to their more powerful rival. While hawks may occasionally kill a few chickens and song birds, the greater portion of them are a decided benefit to the agriculturist. They are not gregarious, but a few species associate in flocks during the migrations. As a rule the females are larger than the males.

\section{Subfamily BUTEONINÆ. Hawks, Kites, Eagles, etc.}

Genus ELANOIDES Vieill.

15I. Elanoides forficatus (LiNN.).

Swallow-tailed Kite.

Distr.: Central and South America and southern United States; casual as far north as Carolina and Minnesota; accidental in New England; breeds in southern United States southward, and casually as far north as Wisconsin and Illinois.

Adult: Back, tail, and wings (except some of the tertials), bluish black, glossed with purple; head, neck, rump, and under parts, pure white; tail, forked and usually over $\mathrm{I} 2$ inches long.

Immature birds have the head streaked with dusky and the primaries and tail feathers narrowly tipped with white.

Length, 20 to 25 ; wing, about 16 to 17 ; outer tail feathers, about 12.50 to 14 ; bill, .75. 


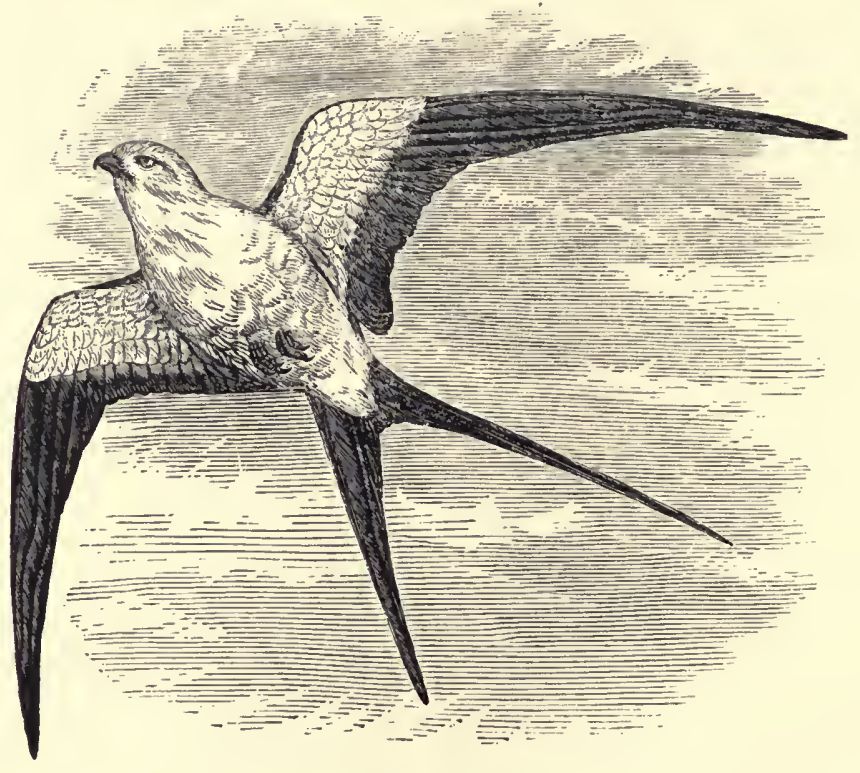

Swallow-tailed Kite.

The Swallow-tailed Kite is more or less common in Illinois and casual in Wisconsin, where according to Kumlien and Hollister it was found breeding near Fort Atkinson in the summer of 1854 . Dr. Hoy gives it as nesting near Racine in 1848 . A specimen is preserved in the Milwaukee Public Museum, shot in Milwaukee County, May I 5 , I 888 .

There are numerous records of its occurrence in Illinois. "Prof. Ridgway shot one near Mt. Carmel and states that in former years it was common throughout the state. (Orn. of I11., Vol. I, I889, p. 445.) Mr. Frank M. Woodruff writes (Birds of Chicago Area, I907, p. 9r.): "Mr. J. Grafton Parker, Jr., shot one at Lake Villa, a few miles from Chicago, on June 5, I895. Mr. Henry K. Coale reports the taking of three adult specimens at Highland Park in April, r 905:"

The nest is a mass of sticks and grass placed in a tree, usually at a considerable distance from the ground. The eggs are 4 to 6 , dull white, speckled and blotched with chocolate brown, and measure about $1.90 \times 1.50$ inches. 


\section{Genus ELANUS Savig.}

\section{Elanus leucurus (Vieill.). \\ White-tailed Kite.}

Distr.: Southern United States, from South Carolina and southern Illinois to Central and South America. Breeds in southern United States southward.

Adult: Upper parts, ashy gray; primaries, ashy gray; head, mostly white; a large black patch on the shoulder (wing coverts);

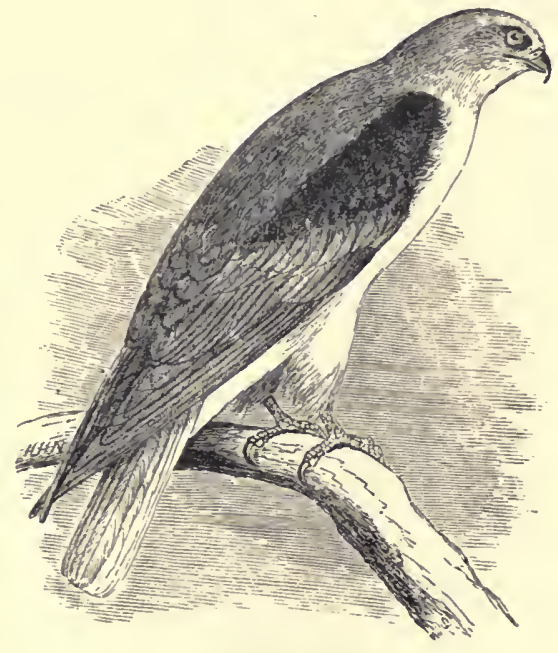

White-tailed Kite.

tail and under parts, white; a black spot in front of the eye; iris, red; bill, black; cere, yellowish; feet, yellow.

The sexes are similar, but the female is slightly larger than the male.

Immature birds show more or less rusty brown; wing feathers tipped with white and the breast is marked with pale rusty brown; middle tail feathers, grayish, varying with age.

Length, I 5 to 16.50 ; wing, II.75 to $13.5^{\circ}$; tail, about $6.5^{\circ}$; bill, .70 ; tarsus, I.30.

This beautiful species is included on the authority of Prof. Ridgway, who states that a pair was "observed near the river at Mt. Carmel, during the summer of 1863 or 1864 " and he considers it, "very likely of not uncommon occurrence during the summer in suitable places in the extreme southern counties of the state." (Orn. of Ill., Vol. I, i 889 , p. 447.) 
454 Field Museum of Natural History - Zoölogy, Vol. IX.

153. Ictinia mississippiensis (WiLs.).

Mississippi Kite.

Distr.: Southern United States, east of the Rocky Mountains from South Carolina and Illinois to Central America.

Adult: General plumage, plumbeous gray, palest on the head and darkest on the wings and tail; inner webs of primaries marked with rufous; no white on tail.

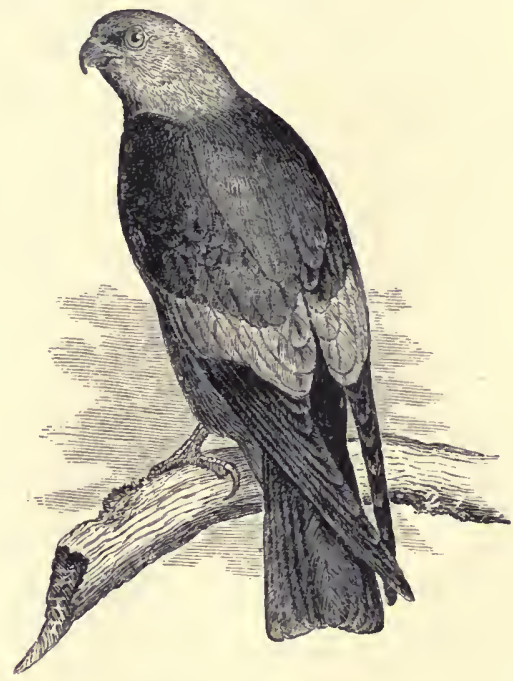

Mississippi Kite.

Immature birds have the head, neck, and under parts, whitish or buffy white, striped and spotted with dusky brown; upper plumage, dusky brown, the feathers marked with buffy white or whitish; tail, dusky, narrowly barred with dark gray (outer webs) and grayish white (inner webs); under wing coverts marked with reddish brown.

Length, $\mathrm{r}_{3} .50$ to $\mathrm{I}_{5}$; wing, 10.50 to $\mathrm{I} 2$; tail, 6.50 .

The Mississippi Kite is not uncommon in southern Illinois in summer.

Nelson gives it as an "abundant summer resident in the southern portion of the state, probably occurs in northern Illinois." Ridgway states (Orn. of Illinois, I889, p. 449): "In August, I87 I, it was very plentiful on Fox Prairie." In Wisconsin Kumlien and Hollister do not include it as having been taken, although a number of the older 
writers mention it as having been seen. If it occurs at all it is an accidental straggler in Wisconsin.

The nest is built in a tree. The eggs are three or four in number, brownish white or whitish overlaid and mottled with madder brown, and measure about $1.65 \times 1.30$ inches.

\section{Genus CIRCUS Lacépède.}

\section{Circus hudsonius (LinN.).}

MaRSH Hawk.

Distr.: North America, from Fur Countries to the Gulf, breeding throughout its range; south in winter to $\mathrm{Cuba}$ and Central America.

Special characters, adult male: General plumage, ashy gray; upper tail coverts, white; belly and flanks, white, spotted with pale tawny brown; wing, I 3 to 15 inches; tail, over 8.25 inches.

Female and immature male: Upper parts, brown, showing more or less tawny rufous; upper tail coverts, white; under parts, tawny;

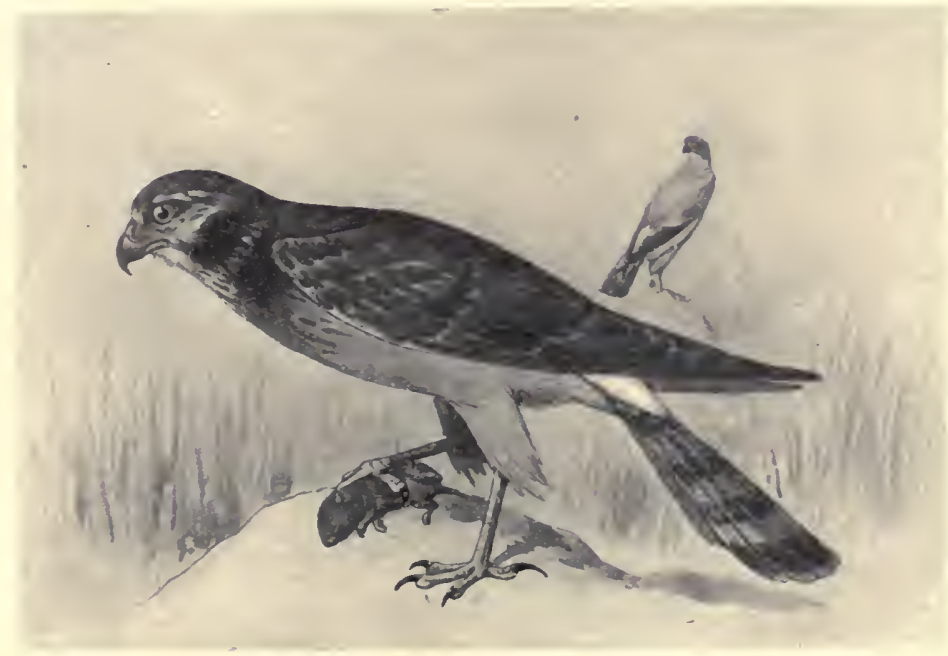

Marsh Hawk.

the belly and flanks, without bars or spots; wing, I. 3 to I 6 inches; tail, more than 8.25 inches long.

The Marsh Hawk is a common summer resident in Illinois and Wisconsin. It frequents the fields and open marshes and may be recognized by its conspicuous white upper tail coverts. 
$45^{6}$ Field Museum of Natural History-Zoölogx, Vol. IX.

In southern Illinois it occurs more or less commonly in winter. W. W. Cooke says: "During the winter of $188_{4}-85$ the Marsh Hawk was plentiful at Paris, I11." (Bird Migr. Miss. Val., I888, p. x I3.)

The nest is placed on the ground in grassy marshes. The eggs are usually 4 or 5 , dull white or faintly tinged bluish or greenish, and measure about $\mathrm{x} .85 \times \mathrm{x} .45$ inches. The Field Museum collection contains sets of eggs of this species taken between May $\mathrm{r}_{4}$ and June I5. Although the majority breed in May and June, eggs have been taken in northern Illinois during the latter part of April.

\section{Genus ACCIPITER Briss.}

\section{Accipiter velox (WILS.).}

Sharp-shinned Hawk.

Distr.: North America, breeding nearly throughout its range; in winter south to Mexico and Central America.

Special characters: Fourth primary, longest; tail, nearly square, the outer tail feather being less than three-quarters of an inch shorter than the middle feathers; under surface of primaries, dull white, barred with grayish brown.

Adult male and female: Upper plumage, slaty gray; tail with broad alternate bars of light ash gray and dark slaty gray, tipped with

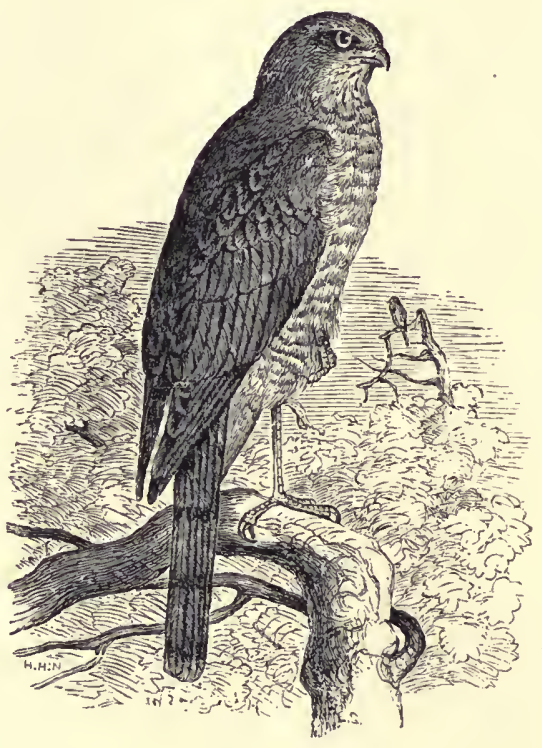

Sharp-shinned Hawk. 
white; throat, whitish, narrowly streaked with dusky; rest of under parts, barred with pale rufous brown and white, the shafts of the feathers dusky, showing fine hair-like lines; under tail coverts, white.

Male: Length, $\mathrm{r} 1$; wing, 6.70 ; tail, 5.60 ; tarsus, 1.90 .

Female: Larger; length, 12.50 to 13.50 ; wing, 6.50 ; tarsus, 2.05 .

Immature: Upper plumage, fuscous brown, the feathers often edged with rufous; wings and tail marked as in the adult, but of a more brownish tinge; under parts, whitish, streaked with brown, the shafts of the feathers dusky, showing hair-like lines.

The "square" tail and smaller size will always distinguish this species from the Cooper's Hawk.

A common species during the migrations in Apr1, May, September and October. The majority of them go farther north, although a few are summer residents in Illinois and probably breed. In Wisconsin it is more common in summer. Kumlien and Hollister have found it nesting at Milton in two instances and have breeding records from many localities throughout the state.

The nest is built in a tree (sometimes on a ledge of rocks) and is composed of sticks, moss, and grass. The eggs are usually four or five, pale bluish white or buffy white, blotched and washed with various shades of brown. They measure about $1.50 \times 1.20$ inches. The nesting season lasts from April until June.

\section{Accipiter cooperii (Bonap.). \\ COOPER'S HAWK.}

Distr.: North America and Mexico, breeding throughout its range.

Special characters: Fourth primary, longest; tail, rounded, the outer tail feather being three-quarters of an inch or more shorter than the middle feather.

Adult and immature birds of this species resemble the Sharpshinned Hawk, but may easily be distinguished by the larger size and more rounded tail. In the adult the crown is usually darker.

Male: Length, 14.25 to 16.75 ; wing, 8.90 to 9.40 ; tail, 7.75 to 8.25 ; tarsus, 2.30 to 2.50 .

Female: Length, r7.50 to 19.50 ; wing, ro to Ir; tail, 9 to ro.30; tarsus, 2.60 to 2.80 .

The Cooper's Hawk is a common summer resident in Illinois and Wisconsin. It is commonly known as Hen Hawk or Chicken Hawk, and undoubtedly deserves the name more than several other species to which it is applied. Dr. A. K. Fisher states that "of I 33 stomachs examined, 34 contained poultry or game birds; 52 , other birds; I I, mammals; I, frog; 3 , lizards; 2 , insects; and 39 were empty." 


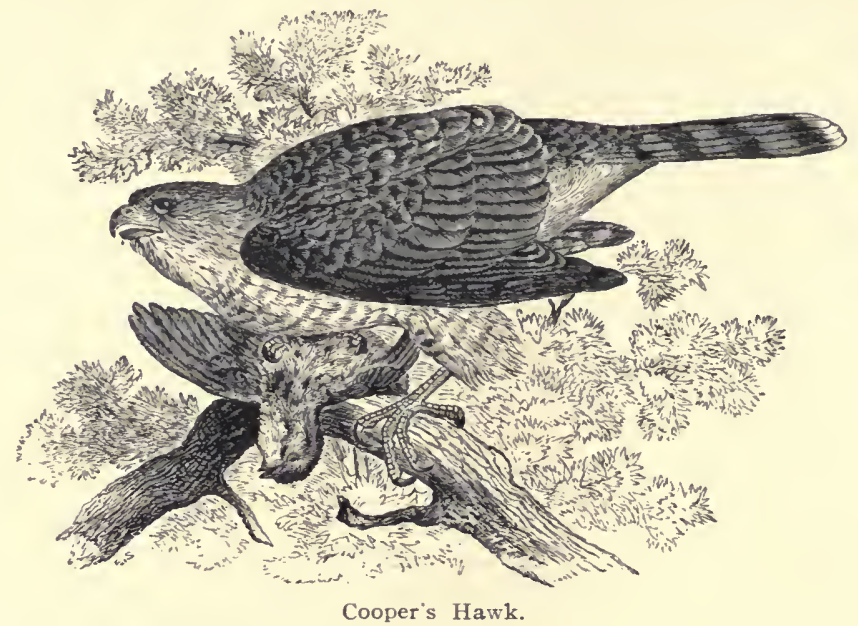

The nest is built in a tree, usually at a considerable distance from the ground (from 30 to 60 feet). The eggs are usually 3 or 4 in number, and measure about $1.95 \times 1.50$ inches. They are grayish white, sometimes pale bluish white, as a rule without markings, although occasionally showing a few pale brown spots.

The following sets of eggs are contained in the Field Museum collection: 5 eggs, Chicago, Ill., May I8, I 904; I egg, Lake Forest, Ill., May I8, Ig03; 4 eggs, Grinnell, Iowa, May 4, I893; 4 eggs, Lake Forest, I11., May I6, I907.

\section{Genus AS'TUR Lacépède.}

\section{Astur atricapillus (WILS.). \\ American Goshawk.}

Accipiter atricapillus (Wils.), A. O. U. Check List, I895, p. I 29.

Distr.: Greater portion of North America north of the Middle states; breeds from northern border of United States northward.

Adult male and female: Back and wings, slaty gray, the shafts of the feathers on the back darker; entire under parts, thickly barred with gray and white, the shafts of the feathers, dusky, showing fine lines; upper surface of primaries showing faint, indistinct, grayish brown dark bars, and marked with more or less white on the inner webs; top and sides of head, dusky, a whitish streak extending backwards from above the eye; tail feathers with imperfect, indistinct, dusky bars and narrowly tipped with whitish; bill, lead color: feet, yellowish. 


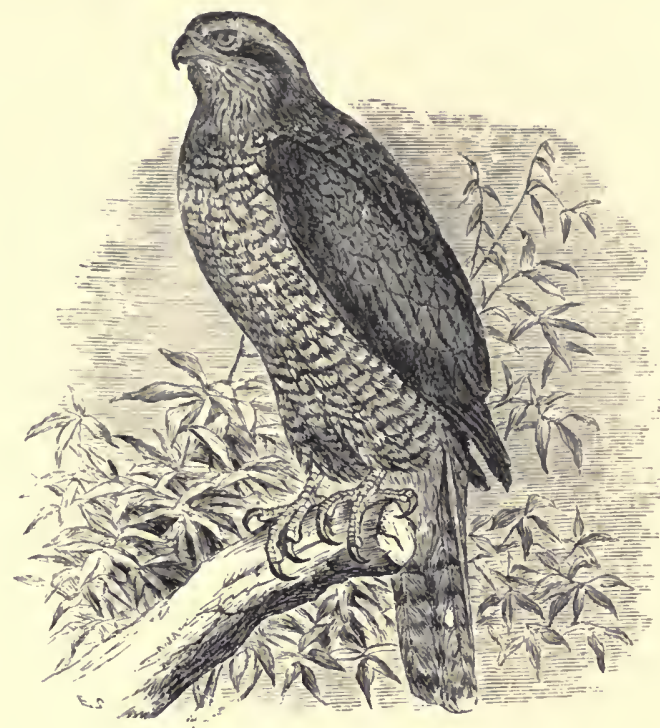

Goshawk (adult).

Immature: Upper plumage, brown, the feathers narrowly margined with buff and buffy white; crown, tawny, streaked with brown; under parts, buffy white, streaked with dark brown; upper surface of primaries barred with darker brown; under surface of primaries barred with brown and brownish white; tail with broad bars of brownish gray and dark brown, usually with white tips.

Male: Length, 20 to 23 ; wing, 12 to 13.40 ; tail, 9.60 to 10.50 ; tarsus, 2.65 to 3 .

Female: Length, 22 to 25 ; wing, r.3.25 to I 4.25 ; tail, I I to I 2.25 ; tarsus, 2.70 to 3.10 .

The large size of this hawk will distinguish it from others which somewhat resemble it in immature plumage.

This fine, large Hawk is a rather rare winter visitant or resident in Illinois and Wisconsin, although apparently more common in the latter state. There are numerous records of its occurrence and capture and the writer saw an adult bird of this species in Jackson Park, Chicago, in February, 1907. According to the older writers it was formerly more common. Barry states that in the early fifties a friend of his shot twenty in one season.

Mr. E. W. Nelson took a specimen at Waukegan, May 3, I876, and states that Dr. A. L. Marcy found it quite plentiful near Evanston during the winter of $1870-187 \mathrm{r}$. Mr. Frank M. Woodruff took an adult male at Beverly Hills, March $30, \mathrm{r} 880$ (Birds of the Chicago Area, 
460 Field Museum of Natural History-Zoölogy, Vol. IX.

I907, p. 93). While it may possibly breed in northern Wisconsin, there is no record of its having done so. Messrs. Kumlien and Hollister and Mr. Clark give it as a regular but by no means a common winter resident in Wisconsin.

\section{7a. Astur atricapillus striatulus RIDGW. Western Goshawk.}

Distr.: Western North America, from Idaho and Nebraska to California and Alaska; accidental as far east as Mississippi Valley.

Special characters: The Western Goshawk may be distinguished from the eastern bird by its sooty back and generally darker upper plumage. In the immature bird, the black stripes on the under parts are decidedly broader than in A. atricapillus and the thighs are marked with large black spots.

Mr. Chas. K. Worthen writes me he has taken this bird near Warsaw. Its occurrence in Illinois must be considered as accidental.

\section{Genus BUTEO Cuvier.}

I58. Buteo borealis (GMel.).

Red-Tailed Hawk.

Distr.: Eastern North America and Canada, south to Mexico; breeds nearly throughout its range.

Adult male and female: Size, large; four outer primaries, notched; upper surface of tail, rich rufous brown, with or without one or more black bars, and tipped with white; some specimens have the tail without bars, others with several (the latter seem more commonly to be females); upper plumage, dark brown, mixed with whitish and pale rufous brown; under parts, white; the feathers marked with pale rufous brown on sides of neck, breast, and body; upper surface of primaries, brown, faintly barred with dusky and becoming white on the basal portion of the inner webs.

Immature: General markings similar to adult, but differs in color; the rufous brown replaced by cinnamon brown on the sides of throat, breast, and body, and the under parts with more or less brown markings on the belly; the breast, usually plain white; tail quite different from the adult, grayish brown, mixed with tawny and banded with dark brown, the feathers tipped with white, and usually with more or less white on the inner webs of the outer feathers, varying according to age. 


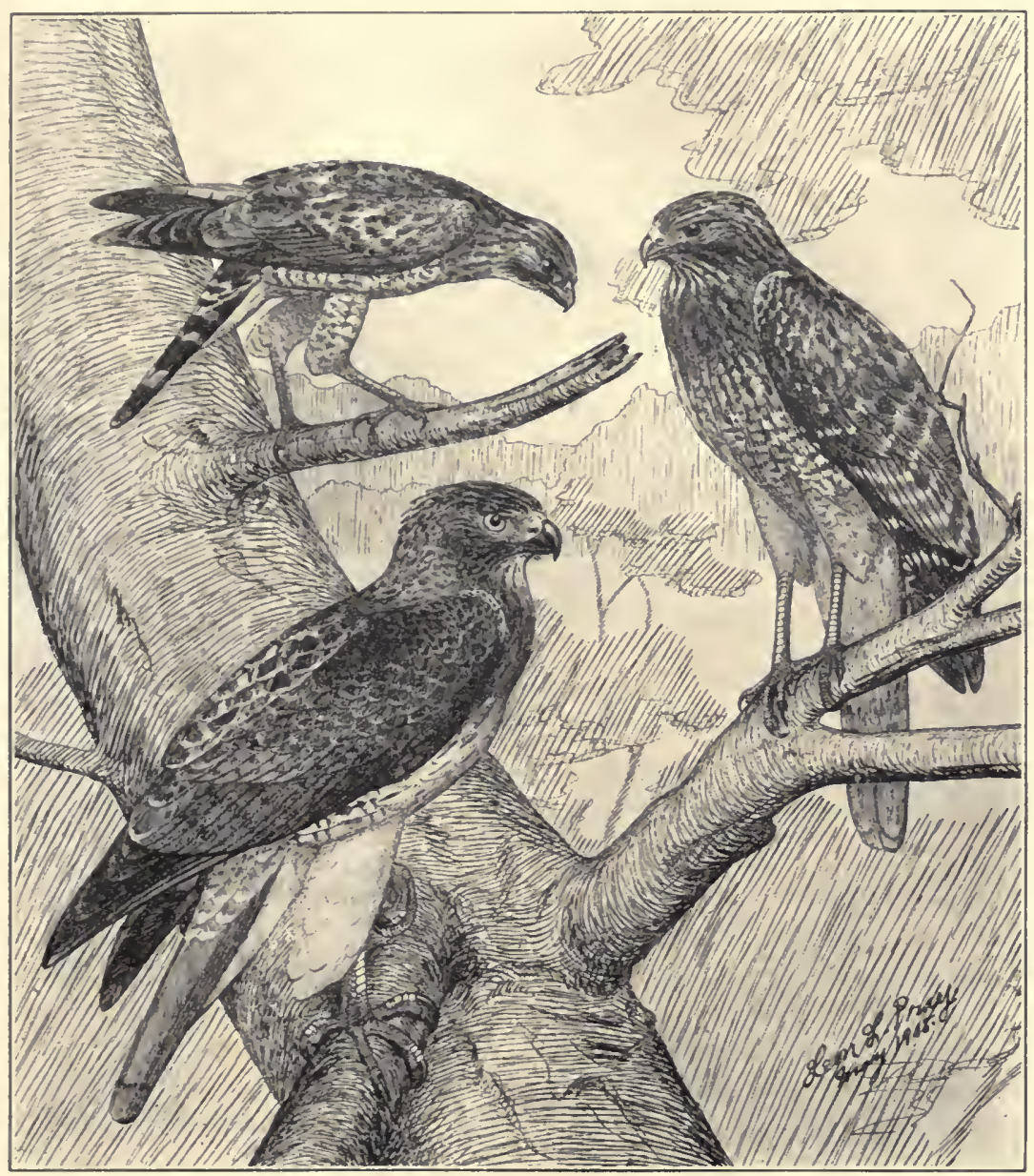

Cooper's Hawk.

Red-shouldered Hawk.

Red-tailed Hawk.

Illustrating comparative difference in size.

Male: Length, I9 to 22.50 ; wing, I3.50 to I6; tail, 8.60 to Io; tarsus, 2.50 to 3 .

Female: Length, 20.50 to 24 ; wing, I 4.75 to I 7.50 ; tail, 9 to I0.50; tarsus, 2.75 to 3.10 .

This is the common form of Red-tailed Hawk in Illinois and Wisconsin and breeds in both states. The adult may be easily recognized by its size and rufous red tail. The immature bird has the tail brownish gray with numerous bars. The large size and stout 


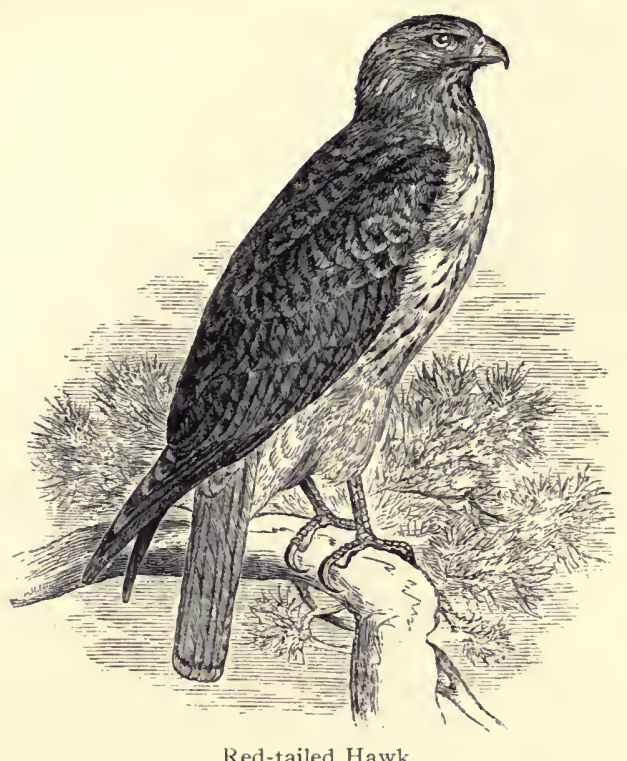

Red-tailed Hawk.

tarsus partly covered by feathers and the entire absence of any tinge of red on the shoulder or upper wing coverts should aid in distinguishing it from other eastern species.

The nest is large, built in a tree, and composed of sticks, twigs, moss, and leaves. The eggs are usually three, dull white, sometimes with a faint wash of pale brown and occasionally blotched and marked with cinnamon brown. They measure about $2.40 \times 1.95$ inches.

Nidification usually commences in March in this latitude, although nests are found in April. There is a set of 3 eggs in the Field Museum collection taken at Grinnell, Iowa, May 3, I893. Mr. Isaac E. Hess informs me he has in his collection seven sets of two eggs and one of three eggs taken near Philo, Champaign Co., Illinois.

According to Dr. H. K. Fisher, in 562 stomachs of this species examined by him, 54 contained poultry or game birds ; $5^{\mathrm{r}}$, other birds; 278 , mice; I 31 , other mammals; 37 , batrachians or reptiles; 47 , insects ; 8 , crawfish; I, centipede; 13 , offal, and 89 were empty.

\section{8a. Buteo borealis kriderii Hoopes.}

Krider's Red-tailed Hawk.

Distr.: Ranges from Wyoming, Dakota, and Minnesota to Texas; casual in Iowa and Illinois.

Differs from $B$. borealis in being much paler, and showing more 
white on the plumage; the head, sometimes almost white; under parts, white; tail, pale rufous, sometimes but not always showing the dark subterminal bar. Size of $B$, borealis.

This western form is casual or accidental in Illinois and Wisconsin. Mr. H. K. Coale records a specimen taken near Halfday, Illinois (Auk, I885, p. 109), and states that it was shot near the Desplaines River, thirty miles northwest of Chicago, July 25, r876. Kumlien and Hollister (Birds of Wisconsin, 1903, p. 63) record a specimen shot by Mr. J. N. Clark at Meridian, Dunn Co., Wisconsin, Oct. 22 , I 892 , and state that three others have been taken at Lake Koshkonong during the past few years.

\section{8b. Buteo borealis calurus (CASs.). \\ Western Red-tailed Hawk.}

Distr.: "Western North America, from the Rocky Mountains to the Pacific, south into Mexico; casual east to Illinois." (A. O. U.)

Adult birds differ in having the plumage very dark, sometimes sooty, except the tail which is rufous. Some specimens have the general plumage dark and the whole breast rufous brown, the tail showing one or more black bars. Measurements the same as $B$. borealis.

Stragglers occasionally occur in both Illinois and Wisconsin. Mr. Nelson states: "In my collection is a fine adult specimen of this variety obtained near Chicago in April, 1873 , by my friend, Mr. C. H. Smith." (Birds of N. E. Illinois, 1876 , p. Ir9.) Mr. Charles K. Worthen writes me it has been taken near Warsaw, Illinois. Kumlien and Hollister consider it rare, "but of regular occurrence in Wisconsin in the late fall. Six or eight specimens were procured about Lake Koshkonong by Thure and L. Kumlien." They also record a specimen from Delavan killed Oct. I9, r9or, and another taken by Mr. J. N. Clark at Meridian, Oct. 23, r893.

\section{8c. Buteo borealis harlani (AUD.). \\ Harlan's Hawk.}

Distr.: Ranges from Gulf states north to Iowa, Kansas, and Mississippi Valley; casual east to Pennsylvania; south in winter to Central America.

Special characters: A very dark form. Adult birds have the head and neck sooty brown, often streaked with whitish; the general plumage above is dark sooty, sometimes almost black, but showing 
more or less streaks, the concealed portion of the feathers being white; under parts, more or less white with various markings. The tail, instead of being rufous, is thickly mottled with gray, dusky, and white, and tipped with whitish, at times showing a tinge of rufous, but often without. The immature bird has the tail banded with grayish and dusky brown.

Adult male: Length, about I9; wing, about 15.50 .

Adult female: Length, about 20.50; wing, about 16.50 .

Harlan's Hawk is of casual or accidental occurrence in Illinois. Mr. Chas. K. Worthen shot an adult male bird of this species near Warsaw, Ill., March I8, I879 (Ridgway, Bull. Nutt. Orn. Club, Vol. $\mathrm{V}, \mathrm{I} 880, \mathrm{p} .3 \mathrm{I}$ ). Mr. Worthen records a second specimen, which had been caught in a trap by a farmer near Warsaw, January I9, 1899 (The Osprey, Vol. III, r899, p. 94). A third specimen was secured by Mr. Frank M. Woodruff, who purchased it from a hunter who had shot it near Calumet Lake, Chicago, Oct. $x, 1895$ (Birds of the Chicago Area, I 907, p. 95).

It does not appear to have been observed in Wisconsin.

\section{Buteo lineatus (GMEL.).}

Red-Shouldered Hawk.

Distr.: Throughout eastern North America, north to Manitoba, breeding throughout its range; south to the Gulf states, Texas, and Mexico.

Adult: Four outer primaries notched, a rufous brown patch on the "shoulder" formed by the lesser wing coverts; upper plumage, dark brown, mixed with rufous and showing more or less white on the wing coverts; primaries, dark brown, with large broken bars of white edged with pale rufous; most of under parts, rufous brown, with numerous pale bars; the shafts of the feathers, dark, forming narrow, longitudinal, dusky streaks; tail, slaty brown, banded with white; feet and cere, greenish yellow.

Immature: Above, dark brown, mixed with rufous and dull white; under parts, buffy white, streaked with dark brown; thighs, pale rufous, spotted with brown; terminal portion of primaries, dark brown, the basal portion, pale rufous shading into white on the inner webs, and with imperfect bars of dark brown; tail, with rather faint bars of slaty brown, dark brown and pale rufous; the inner webs of most of the feathers marked with more or less white; rufous "shoulder patch" of the adult broken and not pronounced, but usually more or less indicated. 


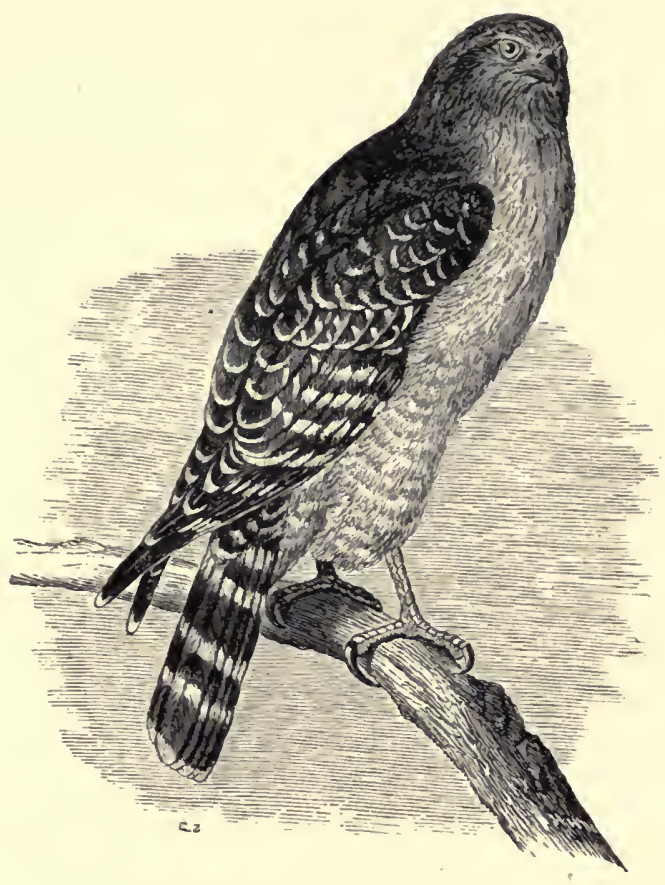

Red-shouldered Hawk (adult).

Male: Length, I 8 to 20.50 ; wing, I I.60 to 3.25 ; tail, 7 to 8.50 ; tarsus, 2.75 to 3.10 .

Female: Length, I9.50 to $22.5^{\circ}$; wing, I 2 to 14.25 ; tail, 8.25 to 9.25 ; tarsus, 3.00 to 3.25 .

The Red-shouldered Hawk is a common summer resident in Illinois and not uncommon in Wisconsin. The immature birds somewhat resemble those of $B$. borealis, but besides other differences they are smaller and the tarsus more slender and less feathered than in that species.

Usually nests in a large tree. The eggs are 3 to 5 , rarely six, dull white, spotted and marked various shades of brown. They measure about $2.10 \mathrm{x}$ 1.70 inches. Incubation usually commences in late April or May in this latitude.

\section{Buteo swainsoni BonaP.}

Swainson's Hawk.

Distr.: Ranges from Wisconsin, Illinois and Mississippi Valley west to the Pacific Ocean, and from the Fur Countries south to South 
466 Field Museum of Natural History-Zoölogy, Vol. IX.

America (Argentine Republic). Breeds nearly throughout its North American range.

Adult male: Three outer primaries, notched; upper plumage, dark brown, mixed with rufous brown and buff; primaries, dark

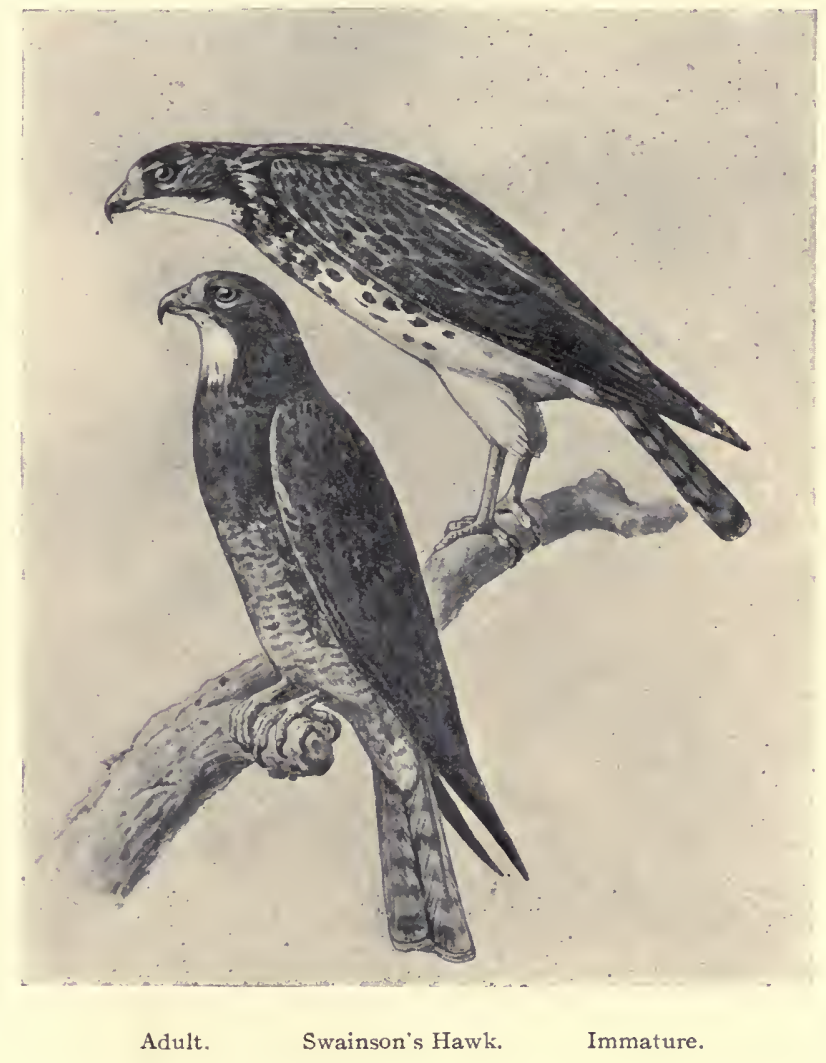

brown, without bars; throat, white; a large rufous brown patch on the breast; belly, buff white or whitish, marked with dusky and rufous brown; tail, grayish brown, with indistinct dark bands.

Adult female: Similar, but has the under marking darker and the breast about the same color as the back.

Melanistic plumage, male and female: Very dark or blackish; specimens of this species are often taken in which the whole plumage is sooty brown; usually the under tail shows pale rufous or whitish markings, but specimens are common representing innumerable different phases of plumage between the light and dark forms. 
Immature: Upper parts, dark brown, mixed with rufous brown and buff; head, neck, and under parts, pale buff; the head, streaked, and the under parts more or less spotted with dusky.

Male: Length, about 20; wing, I 4.50 to 16 ; tail, 8 to 9; tarsus, about 2.50 .

Female: Length, 20 to 22 ; wing, I4.60 to 17 ; tail, 8.50 to 10; tarsus, 2.50 to 2.85 .

While the various color differences in this Hawk may be confusing, it may be distinguished from other Hawks except the Broad-winged Hawk, which is much smaller, by having only the three outer primaries notched.

Swainson's Hawk is of casual accurrence during migrations in Illinois, and according to Mr. Nelson it breeds in southern Illinois and probably does so occasionally in other parts of the state. Ridgway states (Orn. of Illinois, p. 475): "Mr. Nelson found it breeding on Fox Prairie, in Richland Co., during the summer of 1875 , and obtained specimens." Mr. Charles K. Worthen has taken it at Warsaw, Ill. Mr. Isaac E. Hess informs me that a set of three eggs of this species was taken by Mr. Jessee, at Lynn Grove, near Philo, Champaign Co., Ill., in 1902 .

In Wisconsin it is not common, but can hardly be called rare, especially during the fall migrations. I have been unable to find any record of its breeding in Wisconsin, although it probably occasionally does so, as it is a common summer resident in Minnesota and breeds regularly in that state.

In wooded countries the nest is usually built in large trees, but it also nests on the ground and on cliffs. The nest is a mass of sticks, leaves, and grass or moss, according to locality. 'The eggs are usually two, rarely three; dull white, sometimes washed (rarely spotted) with brown. They measure about 2.25 × I.75 inches.

\section{Subgenus TACHYTRIORCHIS Kaup.}

\section{Buteo platypterus (VIEILl.).}

BROAD-WINGED HAWK.

Buteo latissimus (Wils.), A. O. U. Check List, r895, p. r33.

Distr.: Throughout eastern North America, breeding from Canada to the Gulf states; south in winter to West Indies, Middle America, and South America.

Adult male and female: Three outer primaries, notched; primaries, dark brown, having the greater portion of the inner webs white, with 
a few imperfect brown bars, the upper surface of outer webs, entirely without white; upper parts, dark brown, the feathers margined with pale brown and pale rufous brown; tail, dark brown, with two grayish white bars and tipped with whitish; feathers of the under parts heavily barred with reddish brown and dull white.

Immature: Differs from the adult in having more buff about the head; under parts, buffy white, streaked with dark brown; tail, grayish brown, with several rather obscure and irregular bands of dark brown, the tips, whitish.

The size, combined with having only the three outer primaries notched, will distinguish this species.

Male: Length, I3.30 to I 5.00; wing, ro.00 to II; tail, 6.25 to 7 ; tarsus, 2.40 .

Female:Dength, I $5.5^{\circ}$ to 17.50 ; wing, I to Ir.50; tail, about $7.5^{\circ}$; tarsus, $2.5^{\circ}$.

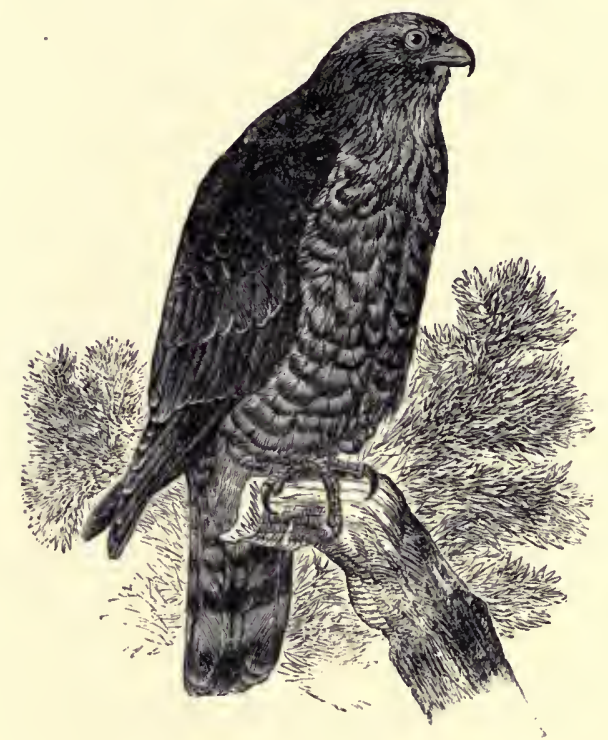

Broad-winged Hawk (adult).

The Broad-winged Hawk is common during the migrations and a more or less common summer resident in Illinois and Wisconsin, and breeds in many localities. Nests in trees, usually at a considerable height from the ground. The eggs are three to five, dull white or pale buff, blotched and washed with different shades of brown. They measure about $2.05 \times 1.60$ inches. Incubation usually begins in May in "this latitude. There is a set of three eggs in the Field Museum collection taken at Joliet, I11., May го, I906. 


\section{Genus ASTURINA Vieill.}

162. Asturina plagiata Schlegel.

Mexican Goshawk.

Distr.: Mexican species, ranging from southwestern United States throughout Mexico and Central America to Panama. Casual or accidental as far east as Illinois.

Special characters, adult: Upper plumage, slaty gray; upper tail coverts, white; under parts, gray, the feathers banded with white, giving a barred appearance to the entire under parts; a broad white band on the tail and also a second white band narrower and more imperfect; wing, 9.40 to II.75, always less than I2.25; tail, less than 8.25 inches long.

Immature: Upper plumage, brown; upper tail coverts, white; tail, grayish brown, with numerous dark brown bands; under parts white, the feathers of the breast and belly marked with large dark brown spots; flanks barred with dark brown; wing, 9.40 to Ix.75, always less than 12.25 inches long; tail, less than 8.25 inches long. usually about 7.50 inches.

The only known record of the occurrence of this species in Illinois is that of Prof. Ridgway (Orn. of Illinois, p. 463), which is as follows:

"A specimen of this tropical species was seen by the writer on Fox Prairie, in Richland Co., on the r gth of August, r87r. It several times came so near that its peculiar markings could be seen with perfect distinctness and, the writer having previously handled many stuffed specimens, there cannot be the slightest doubt as to the correctness of its identification." Mr. R. M. Anderson records a pair of these birds taken by Mr. Walter G. Savage in Van Buren County, Iowa, May 25, I895. (Birds of Iowa, I907, p. 251.)

\section{Genus ARCHIBUTEO Brehm.}

\section{Archibuteo ferrugineus (Licht.).}

Ferruginous Rough-legged Hawk.

Distr.: North America, chiefly west of Mississippi Valley, breeding from Utah northward; south in winter to Mexico; casually as far east as Illinois.

Special characters: Entire front of tarsus thickly feathered. This species occurs in both light and dark phases of plumage, the former the more common; but the feathering of the tarsus and its size are good diagnostic characters. 
470 Field Museum of Natural History-Zoölogy, Vol. IX.

Adult, light phase: Upper parts, bright rufous brown, mixed with dark brown, the centers of the feathers being the latter color; crown

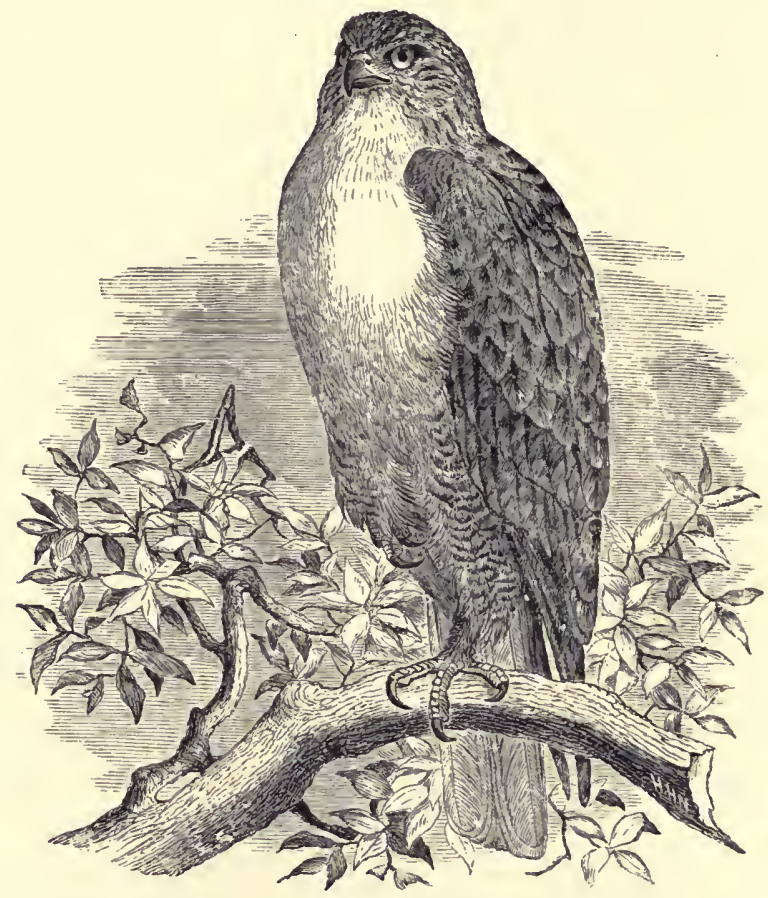

Ferruginous Rough-legged Hawk.

and upper back mixed with more or less white; primaries, dark slaty brown, the basal portion of the inner webs, white; under parts, white or buffy white, sometimes almost unmarked but usually showing streaks of rufous brown on the breast; belly heavily barred with dark brown and rufous; thighs, deep rufous brown, barred with black or dark brown; tail, ashy white below, above pale ashy, shading into white at the base and tip, and more or less edged with rufous brown.

Adult, dark phase: General plumage, dark brown; wings and tail similar in marking to the light phase but darker.

Immature: Upper parts, dark brown, mixed with tawny and buff; under parts, white, streaked and spotted with dark brown; tail, without bars, the color variable, the greater portion, usually ash gray becoming white at the base.

Male: Length, about 22; wing, 16.50; tail, 9.20; tarsus, 2.70.

Female: Length, about 23 ; wing, 16.75 to 17.75 ; tail, 9.50 ; tarsus, 2.90 . 
This fine Hawk appears to be of accidental occurrence in Illinois. Dr. Coues saw one in Illinois a few miles east of the Mississippi River (Bull. Nutt. Orn. Club, 1877 , p. 26). Kumlien and Hollister record three specimens taken in Wisconsin, two at Lake Koshkonong on November I0, I893, and another in October, I894. Nelson (Birds N. E. I11., r 876, p. I 5 I) gives it as having been observed by Dr. Coues on the Illinois side of the Mississippi River near Rock Island, in the autumn of 1876 , and undoubtedly refers to the single specimen observed by Dr. Coues mentioned in his note in Bull. Nutt: Orn. Club, I 877 , previously mentioned. W. W. Cooke records a specimen taken by Mr. Bolmer at Paris, I1l., on January I9, I886, and states that it "has been found nesting at Vermillion. Dakota, and Grinnell, Iowa." (Bird Migr. Miss.Va1., ı 888, p. I I 7.)

\section{Archibuteo lagopus sancti-johannis (GMEL.). \\ American Rough-Legged Hawk.}

Distr.: North America, from Gulf states northward; breeds chiefly north of the United States.

Light phase, adult: Four outer primaries, notched; entire front of tarsus, thickly feathered; upper plumage, dark brown, the feathers margined with tawny buff and buffy white; primaries, grayish brown,

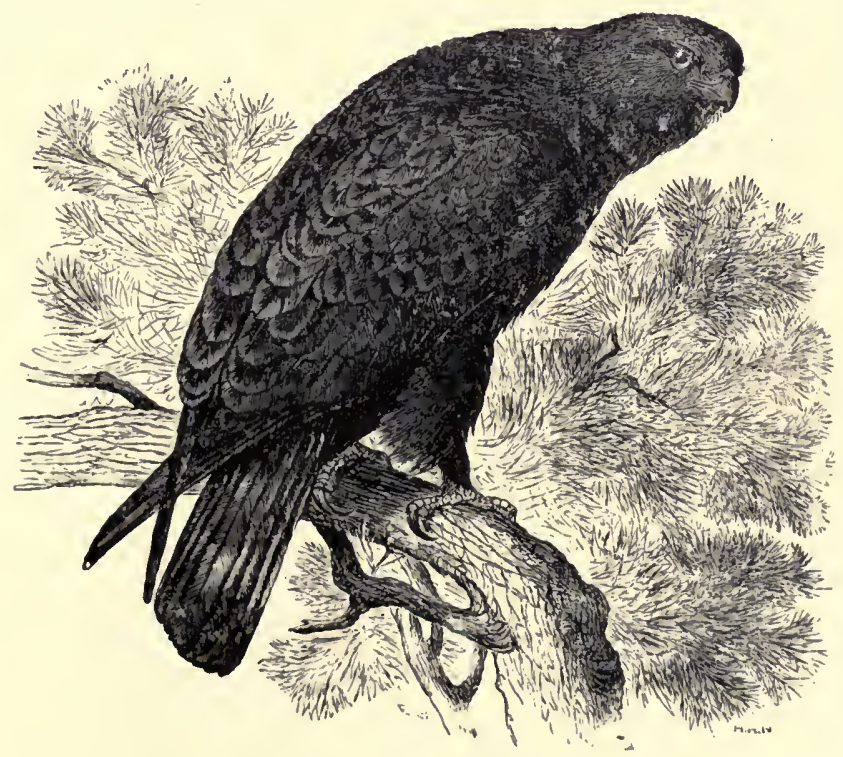

American Rough-lezged Hawk.

(Dark phase.) 
472 Field Museum of Natural History-Zoölogy, Vol. IX.

the basal portion of inner webs white; upper portion of tail, whitish, lower portion, dark, with whitish bars; under parts, white or buff, more or less streaked and spotted; belly, heavily marked with blackish and buff, forming an irregular dark band; thighs, tawny or brownish buff, more or less barred with black, but not ferruginous or deep rufous brown, as in A. ferrugineus.

Immature: Resembles the normal adult, but the terminal portion of tail not barred; the under parts more heavily marked and the blackish band on the belly broader and more perfect.

Dark phase, adult and immature: General plumage, blackish, or dark brown, with the exception of forehead and inner webs of anterior portion of primaries; primaries and tail, with pale bars.

Various intermediate plumages, too varied to be described, occur between the light and dark forms.

Adult male: Length, about 20; wing, I6 to i 8 ; tail, 9 to I0.75.

Adult female: Length, about 22.50; wing, I6.25 to I8.25; tail, 9.25 to I I.

The American Rough-legged Hawk is not uncommon in Illinois in spring and fall during the migrations, and a few remain during the winter. Although the majority go farther north it has been known to breed in Wisconsin.

Kumlien and Hollister (Birds of Wisconsin, I903, p. 64) state: "In May, I872, a pair of these hawks was found nesting in the eastern part of Dane County, by L. Kumlien. The nest was placed in a low burr oak, about eight feet from the ground, and contained three eggs well incubated."

\section{Genus AQUILA Brisson.}

\section{Aquila chrysaëtos (LinN.). \\ Golden Eagle.}

Distr.: North America and part of Mexico (also parts of Europe, Asia, and Africa); breeding nearly throughout its range, usually in the mountainous parts of unsettled localities.

Adult: Tarsus, entirely feathered; general plumage, dark brown, lighter brown on the wing and tail coverts; feathers on back of head and nape, golden brown; primaries, dark brown; tail feathers, dark brown, more or less variegated with lighter brown and grayish at the bases.

Immature: Similar to the adult, but somewhat darker and the basal two thirds or less, of the tail feathers, white; feathers of the tarsi, pale brown or whitish. 


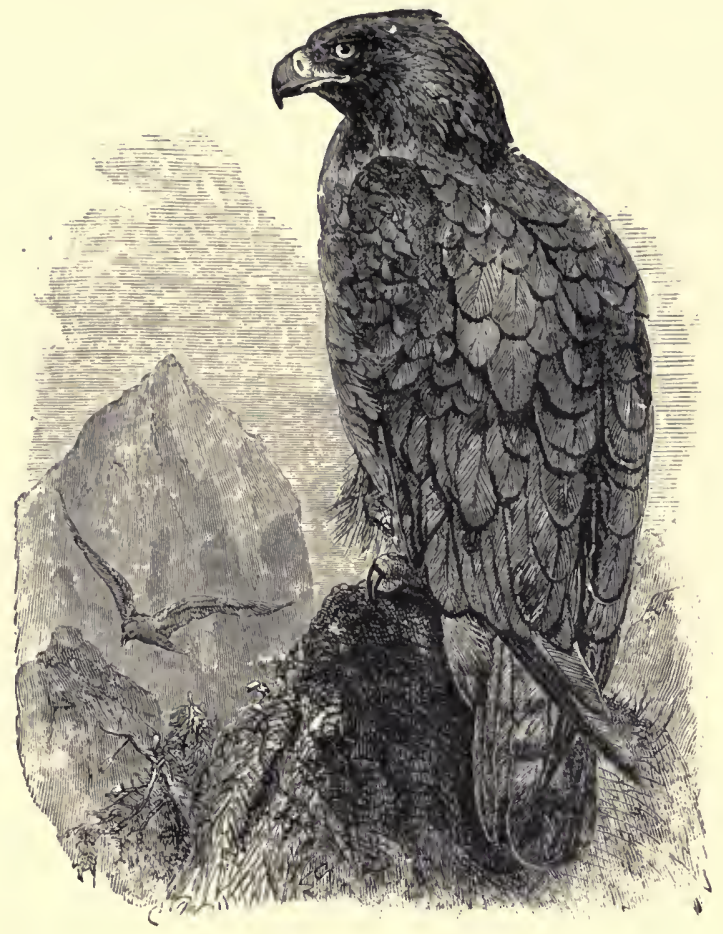

Golden Eagle.

Male: Length, 30 to 36 ; wing, 22.50 to 25 ; tail, 14.50 ; tarsus, 3.60 to 3.75 .

Female: Length, 35 to 39 ; wing, 24 to 26.50 ; tail, I 5 ; tarsus, 4.05 to 4.25 .

The Golden Eagle was formerly not uncommon in winter in Illinois and Wisconsin, but is now rare.

Mr. Isaac E. Hess informs me he has a Golden Eagle in his collection taken near Philo, Champaign Co., Illinois, May I 3, I899; he also states that two others have been taken in that vicinity during the last seven years. Mr. E. W. Nelson writes (Birds N. E. Illinois, I 876 . p. I 20): "Not very uncommon during winter. Arrives in November and departs early in spring. Formerly nested throughout the state."

I can find no record of the eggs having been actually taken in Illinois and only one for Wisconsin, that of Dr. Hoy, (Trans. Wisconsin Agricultural Society, Vol. I, I 852) who describes the nesting of a pair in a large oak tree near Racine, in $185 \mathrm{I}$.

The nest is a very large structure, sometimes in the top of a tall 
474 Field Museum of Natural History-Zoölogy, Vol. IX.

tree, but more commonly on a rocky cliff. The eggs are from two to four, dull white or washed and marked with brown. They measure about $3 \times 2.35$ inches.

\section{Genus HALIÆETUS Savigny.}

\section{Haliæetus leucocephalus (LinN.). Bald Eagle.}

Distr.: North America from northern Mexico to British Columbia and Ungava (a subspecies occurs in Alaska), breeding throughout its range.

Adult: Tarsus, not entirely feathered as in the Golden Eagle; head, neck and tail, white; general plumage, dark brown; primaries,

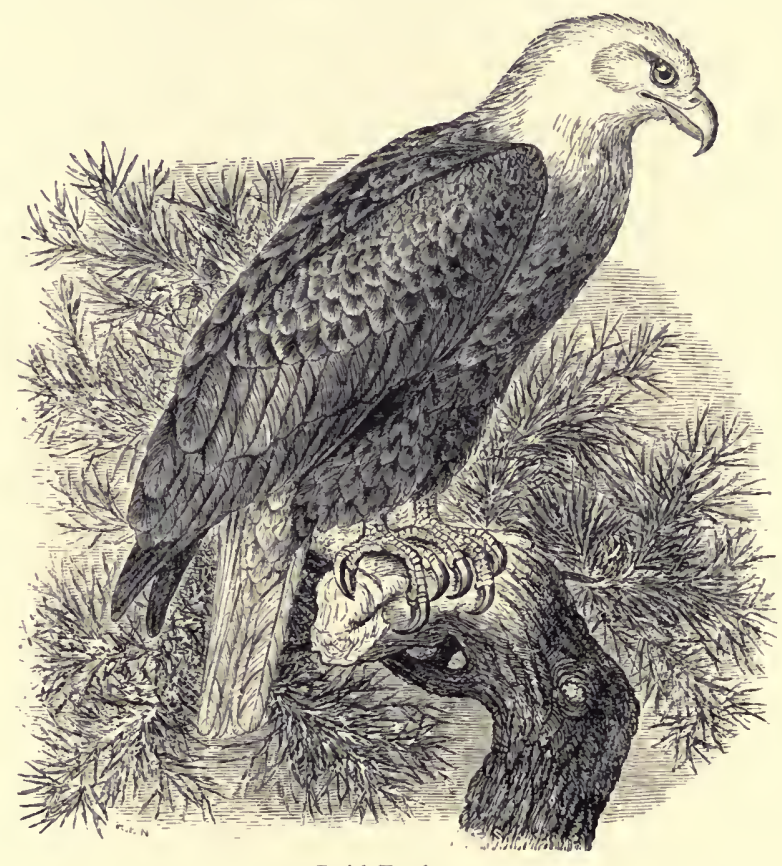

Bald Eagle.

black or blackish; bill and feet, yellow; iris, yellow. The sexes are similar but the female is larger than the male. The adult does not assume the perfect white head and tail until the third year.

Immature (first year): Very dark brown, the bases of the feathers, white, and showing more or less in the plumage; bill, black; iris, brown; feet, yellowish. 
Immature (second year): General plumage, dark grayish brown, the concealed bases of the feathers, white, and more or less exposed in places; feathers on back of head, tipped with light brown; tail, brownish black, the feathers more or less blotched and speckled with white on the inner webs; bill, blackish; feet, yellowish.

Male: Length, 37 to $38.5^{\circ}$; wing, 22.50 to $24.5^{\circ}$; bill, 2.50 .

Female: Length, 38 to 42.50 ; wing, 24 to 26.50 ; bill, 2.50 to 2.80 .

The Bald Eagle occurs more or less commonly throughout Illinois and Wisconsin in the more unsettled localities, and breeds throughout its range. Numerous nesting records.

The location of the nest varies with different localities, either in large trees or on rocky cliffs and even on the ground, according to $\mathrm{Mr}$. Harry C. Oberholser, who writes (Bull. U. S. Dept. of Agriculture, I 906, p. 9): "Where there are no trees, a rock or a niche in a cliff serves the purpose, while along the coast of Texas nests have been found even on the ground of low islands."

The eggs are usually two, dull white, and measure about $3 \times 2.5^{\circ}$ inches. Nidification commences late in February or in March in this latitude.

\title{
Subfamily FALCONINÆ. Falcons, etc.
}

\section{Genus FALCO Linn.}

\author{
Subgenus HIEROFALCO Cuvier.
}

\section{Falco rusticolus Lins.}

Gray Gyrfalcon.

Distr.: Arctic America, accidental or casual in winter to northern border of United States.

Adult: Size, large; length, over 20 inches; wing, over I3; tarsus, feathered, at least half way down on front and sides; second primary, longest; first primary, shorter than third; upper plumage, mixed slaty brown and white, the feathers being barred and edged with grayish white or buffy white; under parts, white, streaked and marked with dusky; under tail coverts, spotted and barred with dusky; tail with numerous bands.

Male: Length, about $2 \mathrm{I}$; wing, I3.50 to i 5 ; tail, 8 to 9 ; bill, about .95 ; tarsus, about 2.35 .

Female: Length, 23; wing, I 5 to I 7 ; tail, 9 to ro; bill, about I; tarsus, about 2.50 . 
470 Field Museum of Natural History-Zoölogy, Vol. IX.

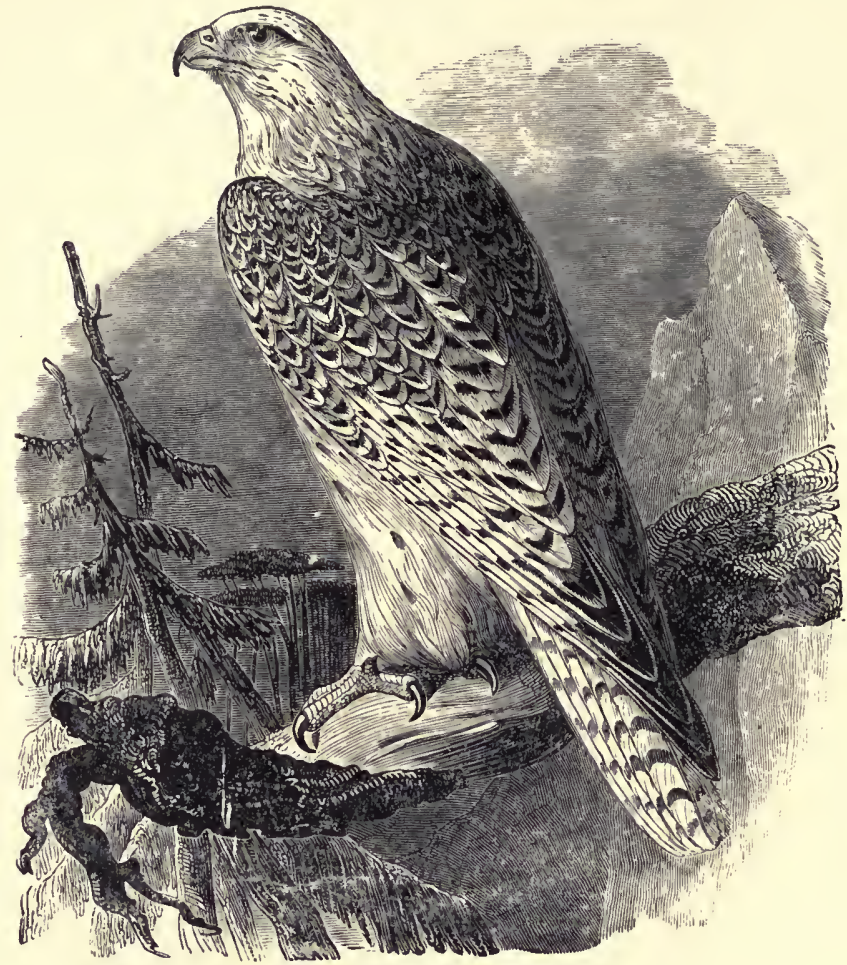

Gray Gyrfalcon.

Mr. W. E. Snyder records the capture of a bird of this species (Auk, Vol. 22, I905, p. 4I3) in Wisconsin by Mr. Fred Dean, near "Skunk Island," on Nov. 27, I904, and states that the specimen was examined by Prof. Robert Ridgway of the Smithsonian Institution, who identified it as an immature Falco rusticolus.

The above seems to be the only authentic record of the occurrence of a Gyrfalcon in Wisconsin, although Kumlien and Hollister write (Birds of Wisconsin, I903, p. I32): "Some species of gyrfalcon has been credited to the fauna of Wisconsin in an early day, a thing by no means impossible or unlikely, but there is no actual record obtainable at present."

It has not been observed in Illinois. W. W. Cooke records a specimen taken at Manhattan, Kansas, December I, I880 (Bird Migr. Miss. Val., I888, p. I 18 ).

Although, so far as known, the Gray Gyrfalcon is the only one which has been observed within our limits, it is not unlikely that other forms may occur, as the Gyrfalcon and Black Gyrfalcon have been 
recorded from Dakota and Minnesota (W. W. Cooke, Bird Migration Miss. Val., I 888 , p. I 18 ).

The following brief synopsis of the two forms may be useful:

Gyrfalcos. Falco rusticolus gyrfalco (Linn.).

Size of Gray Gyrfalcon; back, grayish, the barring irregular, sometimes wanting; tail, like back, showing imperfect pale bars; head, streaked; under parts, heavily streaked with whitish and brownish gray.

Specimen taken at Vermillion, Dakota, Oct. 21, r880, by Dr. Agersborg (Cooke).

Black Gyrfalcon. Falco rusticolus obsoletus (Gmel.).

Size about the same as preceding; general color above and below, dusky or dusky slate color, without bars; the dark under parts more or less marked, with buff.

"Has been taken in Minnesota a few times as a rare winter visitant. A specimen has been examined by Mr. Ridgway." (Cooke.)

\section{Falco mexicanus Schleg.}

Prairie Falcon.

Distr.: Western species, ranging from the plains to the Pacific, south to Mexico; accidental as far east as Illinois.

Adult: First primary, notched; second primary, slightly notched about one and a quarter inches from tip; second primary, very slightly longer than third; upper plumage, grayish brown, the feathers edged and more or less barred with buff or pale rusty brown; tail, pale brownish gray, most of the feathers barred with brownish white; primaries, grayish brown, with numerous white bars on the inner webs which do not reach the shaft of the feathers and the inner portion of these white marks tinged with pale brown; under parts, dull white, streaked and spotted with dark brown, heaviest on sides; a brown stripe on sides of throat.

Immature: Upper plumage, grayish brown, the feathers edged with rusty brown; under parts, buffy white or pale buff, streaked with dusky; axillars, plain dusky, without bars.

Male: Length, I6.75 to I8; wing, II.5० to I 2.50 ; tail, 7 ; tarsus, about 2 .

Female: Length, I 8 to I9.50; wing, I 2.50 to I4; tail, 8.50; tarsus, 2.25 .

This species is of accidental occurrence in Illinois. Ridgway writes (Orn. of Illinois, p. 43I): “A specimen was obtained at Rock Island by Mr. I. D. Sargent of Philadelphia, and by him presented to 
478 Field Museum of Natural History-Zoölogy, Vol. IX.

the Academy of Natural Sciences in that city; while it has been observed on two occasions by the writer, once near Mount Carmel and once in Lawrence County (near the town of Bridgeport), both during the month of September, i 87 I."

There is no satisfactory record for Wisconsin. According to Kumlien and Hollister (Birds of Wisconsin, I903, p. 132) a bird came into the possession of Thure Kumlien in a badly decomposed state sometime in the early sixties, "which was never satisfactorily identified otherwise than as a young prairie falcon."

\section{Subgenus RHYNCHODON Nitzsch.}

\section{Falco peregrinus anatum (Bonap.).}

Duck Hawk. Peregrine Falcon.

Distr.: North America, breeding in many parts of the United States; south in winter as far as Chile, South America.

Adult. Crown, blackish, rest of upper plumage, slaty plumbeous, or dark bluish ash color, the edges of the feathers, paler; under parts, varying from white to buff, barred and spotted with blackish, except on the throat and breast, which are usually free from markings; sides of face below the eye, black; primaries, blackish, barred on inner webs with buffy white; upper surface of tail, faintly barred with gray, the tips, whitish; under surface of tail feathers, grayish brown; barred with whitish; most of bill, black, the cere and base of bill, yellow; feet, dull yellow.

Immature: Crown, tawny, streaked with dark brown, rest of upper parts, dark slate color, mixed with rusty brown and rufous; under parts, tawny or ochraceous buff, streaked (not barred) and marked with dark brown, except on the throat which is usually immaculate or at most marked with a few hair-like lines; a black streak below the eye, extending down sides of throat; inner webs of primaries, barred with buff; tail, grayish brown, with irregular bars of pale rufous, the tips, white.

Male: Length, I6.50; wing, I 2 to I3; tail, 6.50; tarsus, I.70.

Female: Length, I8.50; wing, $\mathrm{I} 3$ to $\mathrm{I} 4.75$; tail, 7 to 8 ; tarsus, 1.80.

Although by no means common, the Duck Hawk occurs in Illinois and $W$ isconsin during the migrations in spring and fall and a few remain during the summer. Prof. Ridgway found several pairs nesting in the neighborhood of Mt. Carmel, Ill. (Orn. of Illinois, p. I889, p. 433). Kumlien and Hollister state that it formerly bred at Racine, Wisconsin. 


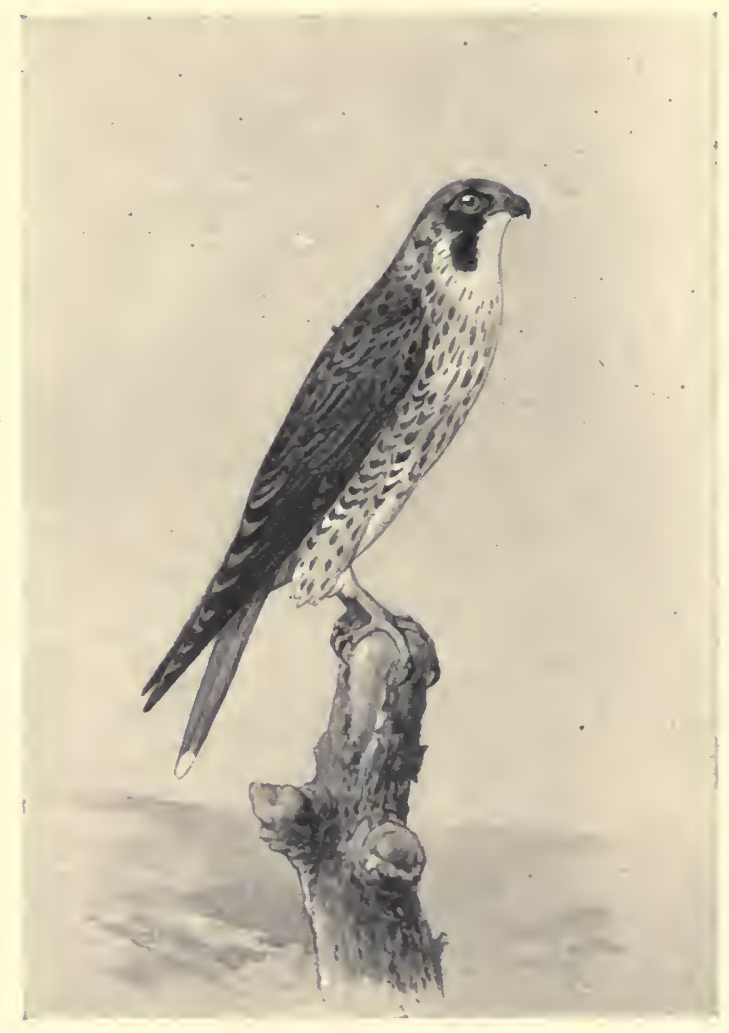

Duck Hawk.

The nest is placed on cliffs or in hollows in branches of large trees. It has also been known to nest on the ground. The nests found near Mt. Carmel were placed in cavities in the tops of very large sycamore trees. The eggs are two to four, rarely five. They are dull white, washed and blotched with different shades of brown, and measure about $2.20 \times \mathrm{r} .70$ inches.

\section{Subgenus TINNUNCUI.US V'ieill.}

\section{Falco columbarius Lins. \\ Pigeon Hawk.}

Distr.: North America, West Indies, south to northern South America; breeds from the northern border of United States northward.

Adult: Second primary but slightly longer than the third; upper plumage, slate color; back and sides of neck, marked with tawny 
480 Field Museum of Natural History-Zoölogy, Vol. IX.

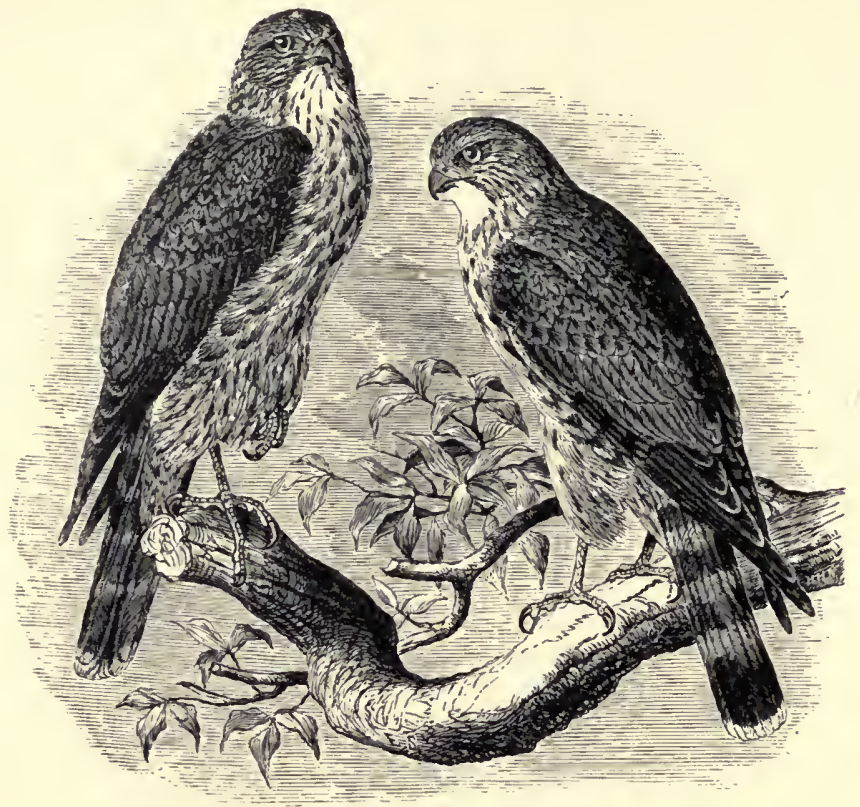

Pigeon Hawk.

and buff; primaries, slaty brown, barred with white; on inner. webs, brownish black, barred and tipped with grayish white; under parts, tawny buff, thickly streaked with brown except on the throat.

Immature: Upper plumage, dark grayish brown; crown with narrow dark streaks; throat, whitish; under parts, tawny or buffy white, streaked with brown; primaries, barred with pale rufous buff; tail, barred with pale buff and tipped with dull white.

Male: Length, I0.25 to II.25; wing, 7.45 to 7.80 ; tail, about 5 ; tarsus, I.35.

Female: Length, I 2 to I3; wing, 8.25 to 8.50 ; tail, about 5.40 ; tarsus, I.55.

The Pigeon Hawk is not uncommon during the migrations in spring and fall in Illinois and Wisconsin and it has occasionally been observed in summer. Kumlien and Hollister consider it "A rare summer resident in southern Wisconsin, but it not infrequently remains in the central and northern parts of the state. Dr. Hoy speaks of its nesting near Racine in I 852." (Birds of Wisconsin, I903, p. 66.)

Nests on cliffs or in hollows in large trees. The eggs are four or five, very variable in color, ranging from dull white, faintly spotted, to brown, either washed or heavily blotched with different shades of reddish brown or dark brown. They measure about $1.60 \times 1.25$ inches. 


\section{0a. Falco columbarius richardsonii (RIDGW.).}

Richardson's Pigeon Hawk. Richardson's Merlin.

Falco richardsonii Ridgw., A. O. U. Check List, x 895, p. I39.

Distr.: North America, west of the Mississippi Valley, from the Saskatchewan to Arizona and west to the Pacific coast; accidental in Wisconsin.

This western form may be distinguished from $F$. columbarius by its lighter color, the tail banded by six pale and five darker bands; and outer webs of primaries, distinctly spotted.

Mr. Charles K. Worthen writes me he has killed a bird of this species at Warsaw, Ill., and according to Kumlien and Hollister a number of specimens have been taken in Wisconsin. They write: "We have two specimens from Stevens Point and have taken it several times during the past ten years at Lake Koshkonong. **** A fine specimen in Mr. Skavlem's collection was shot near Janesville in the fall of 1886 ." (Birds of Wisconsin, I903, p. 67.) It has also been recorded from Michigan, Minnesota, South Dakota, and Iowa.

\section{Subgenus CERCHNEIS Boile.}

\section{Falco sparverius LinN.}

American Sparrow Hawk.

Distr.: "North America, east of the Rocky Mountains, and from Great Slave Lake south to northern South America." (A. O. U.)

Adult male: Top of head, bluish slate color, with a spot of rufous brown on back of crown; back, rufous brown, banded with black; rump and tail, rufous brown, irregularly marked with more or less black and having a broad subterminal band of black tipped with white; wing coverts, slate color, marked with black; primaries, dark grayish brown, banded with white on the inner webs; a stripe of black extending from beneath the eye down the side of the throat; throat, whitish; breast, brownish buff; sides of belly, buffy white, spotted with black.

Adult female: Crown, rufous; the nape, slate color; rest of upper parts, rufous brown, banded with black; upper surface of tail, bright rufous brown, with numerous narrow bands of black, and narrowly tipped with buffy white; primaries, banded with brown and white and with more or less rufous bordering the shafts; under parts, dull white or buffy white, streaked with pale brown. 


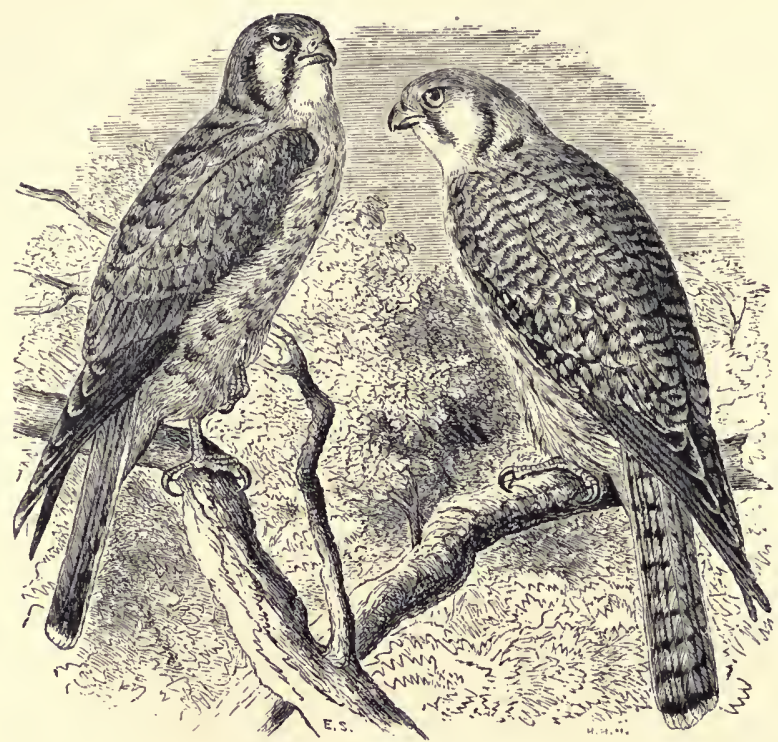

Male. American Sparrow Hawk. Female.

Male: Length, 8.60; wing, 6.60 to 8; tail, 4.40; tạrsus, I.35.

Female: Length, ro to I 2 ; wing, 7 to 8.20 ; tail, about 4.50 ; tarsus, I.40.

The Sparrow Hawk is a common summer resident in Illinois and Wisconsin, arriving from the south in late March or early in April, and leaving in October. The birds build no nest, the eggs being deposited in hollow trees (sometimes deserted woodpeckers' holes) or occasionally on a ledge of rocks.

The eggs are five to seven, pale brownish or cream buff, blotched and spotted with dark brown, varying from this to buff white or dull white and showing a few faint spots of pale brown. They measure about I.30 X I.I 5 inches.

The following sets of eggs from northern Illinois are contained in the Field Museum collection: 4, Joliet, I11., May I6, I 906; 5, Lake Forest, I11., May 23, 1906; 4, Joliet, I11., June r 9, I9з6. 
Subfamily PANDIONINÆ. Ospreys, Fish Hawks.

\section{Genus PANDION Savig.}

\section{Pandion haliaëtus carolinensis (GMEL.).}

American Osprey. Fish Hawk.

Distr.: Greater portion of North America, the West Indies and northern South America; common in the eastern United States; breeds nearly throughout its range.

Adult: Head and neck, white, the crown streaked with dusky, and a blackish stripe from the eye to the nape; upper plumage,

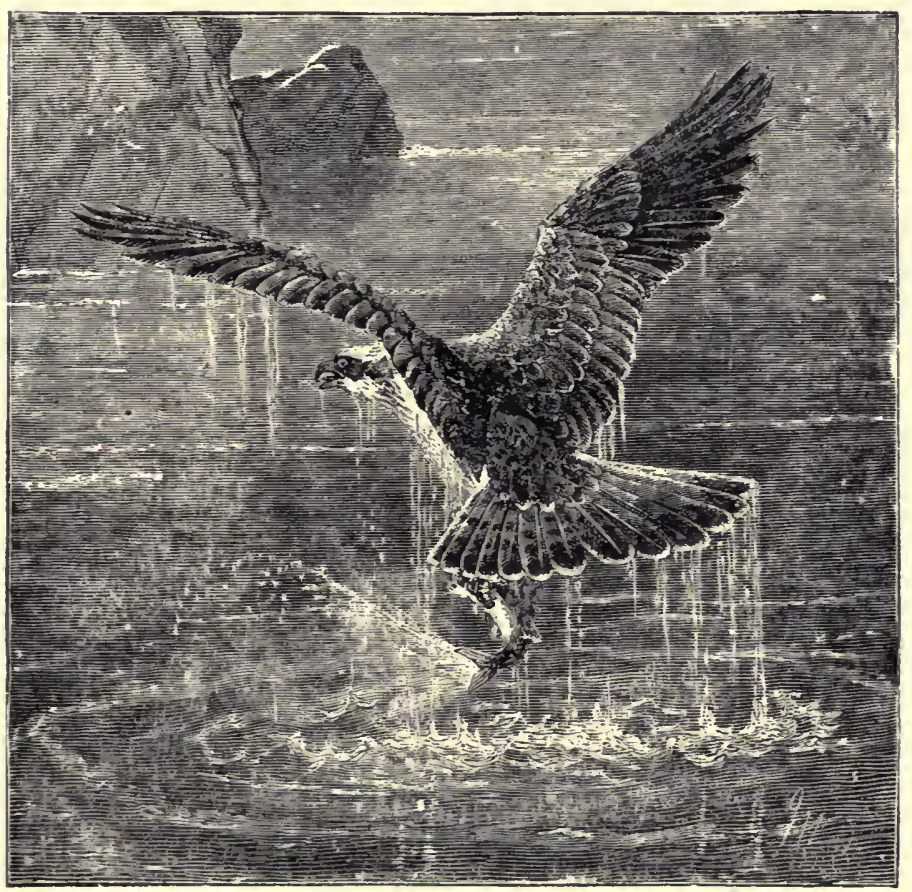

American Osprey.

fuscous brown, the feathers more or less edged with white; tail, dark brown, barred with dusky and tipped with white, and all but the middle feathers barred with white on the inner webs; under parts, white; bill, dark; feet, grayish blue.

Immature birds are darker on the upper parts and show less white. 
484 Field Museum of Natural History-Zoölogy, Vol. IX.

Length, 2 I to 26 ; wing, I7.50 to 20.50 ; tail, 7.25 to Io; tarsus, r. 90 to 2.30 .

The Osprey, or "Fish Hawk" as it is often called, is a summer resident in Illinois and Wisconsin. While not rare it can not be considered as common. Its food consists of fish which it captures with great dexterity.

The nest is a large mass of sticks mixed with weeds, usually in a tree or on the top of a dead stump, rarely on rocks or ground. The eggs are from two to four, dull white or buff white, washed and blotched with chocolate and other shades of brown. They measure about $2.45 \times 1.80$ inches. In Illinois nidification commences the latter part of March, the breeding season lasting until May and occasionally later. Birds of this species when not disturbed return to the same nesting ground year after year.

\section{Suborder. STRIGES. Owls.}

Owls are nocturnal birds of prey. There are about 200 species of cosmopolitan distribution, of which some 20 or more occur in North America. Their food consists principally of mammals, but they also kill birds. Some species nest in holes in trees, while others build a rough nest of sticks. The Burrowing Owl deposits its eggs in holes in the ground and the Short-eared Owl chooses a grassy marsh for its breeding place. The eggs of all species are usually two and always white. .

\section{Family ALUC.ONIDÆ. Barn Owls.}

Genus ALUCO Fleming.

173. Aluco pratincola (Bonap.).

BARN OWL.

Strix pratincola Bonap., A. O. U. Check List, I895, p. I 42.

Distr.: Throughout United States, Mexico, and northern West Indies, more common in southern states, rarely as far north as southern Canada; breeds casually as far north as latitude $.40^{\circ}$.

Adult: Upper plumage, tawny or tawny buff, the feathers beautifully variegated with gray and spotted with brown and white; upper 


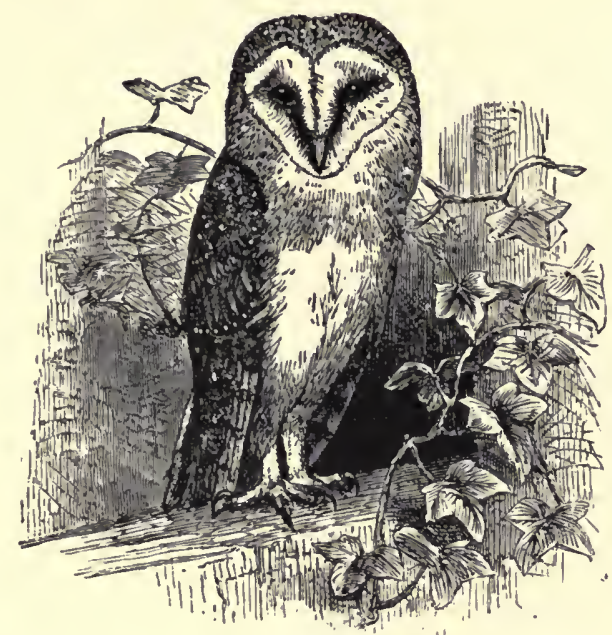

Barn Owl.

parts ranging in different specimens from pure white to buff, marked with scattered spots of brown; facial disks varying from white to tawny and bordered with buff, or in some cases dark brown; a brown spot in front of the eye; primaries, tawny, shading to white on the inner webs and banded with dark brown; tail, varying from white to tawny, usually mottled and banded with brown; iris, black.

Length, I 5 to 20 ; wing, 12.25 to I 3.75 ; bill, .95; tarsus, about 2.60 .

The Barn Owl is of casual occurrence in northern Illinois and has been taken several times in Wisconsin. It probably breeds regularly in southern Illinois. There are a number of records of its having been taken in the state, among which is that of an adult male killed in Jackson Park, Chicago, August I5, I 896. The specimen is now in the collection of the Field Museum of Natural History. Mr. Charles W. Douglass of Waukegan, I11., has a mounted specimen in his collection, taken near that city.

Although rather rare in Wisconsin, according to Kumlien and Hollister, specimens have been taken near Racine (Hoy) and in Jefferson County, Janesville, La Crosse, and Ripon. "The only authentic breeding record we have for the state (Wisconsin) is furnished us by Mr. H. H. T. Jackson of Milton, who saw in Green County, in April, I899, a live female with three eggs, which had been taken from a hollow burr oak tree." (Birds of Wisconsin, r903, p. 68.) 
Nests in a hollow tree or bank, sometimes in buildings. The eggs are usually six to nine, dull white or yellowish white, and measure about $1.75 \times 1.25$ inches.

\section{Family STRIGIDÆ. Horned Owls, Screech Owls, etc.}

Genus ASIO Brisson.

174. Asio wilsonianus (Pall.).
American Long-Eared OWl.

Distr.: Temperate North America to Mexico; breeds throughout its range.

Adult: Ear tufts, very noticeable, usually an inch or more long; first primary only, notched or emarginate; upper plumage, dark

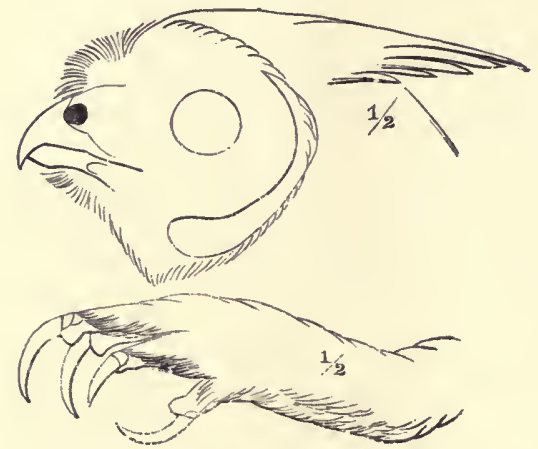
brown, finely mottled with grayish white; bases of the feathers, tawny; under parts, buff and dull white, streaked with dark brown on the breast; belly and sides, barred with dark brown; facial disk, pale brown, edged with blackish; tail, with numerous dark brown bars.

Sexes similar.

Length, about I4.50; wing, I r.80; tail, 6.

This species is a not uncommon summer resident in Illinois and Wisconsin, and breeds in suitable localities in both states.

It nests in various places, sometimes in a hollow tree or among the branches, at others on rocks or even on the ground. It often uses an old deserted nest of a crow or hawk. The eggs are white, five to seven in number, and measure about $1.55 \mathrm{x} \mathrm{I} .35$ inches. The breeding season lasts from late March until May. There is a set of 5 eggs in the Field Museum collection taken at Grinnell, Iowa, May I, I 893. 


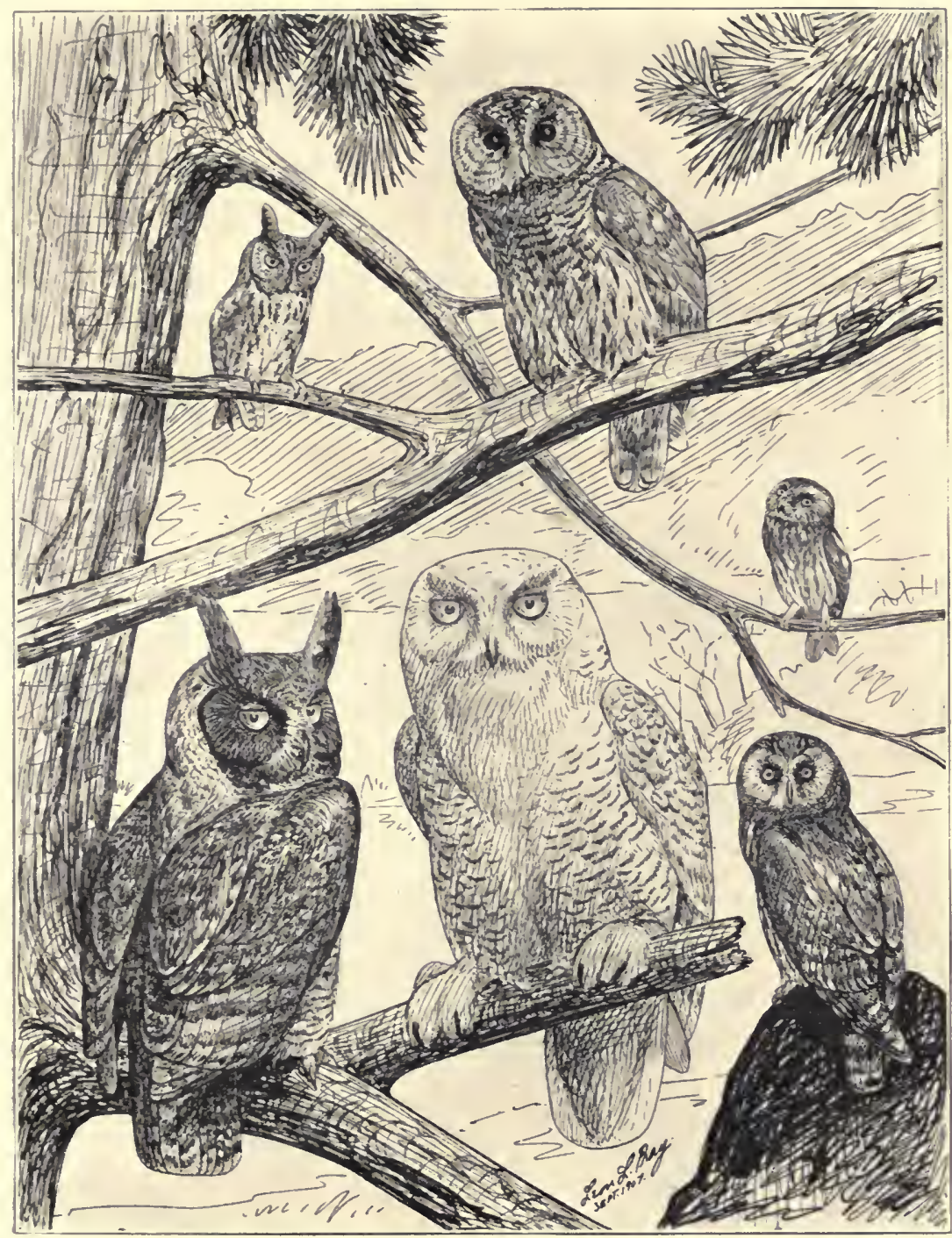

Screech Ow:

Great-horned Owl.
Barred Owl.

Sno.vy Owl.
Saw-whet Owl.

Short-eared Owl.

Illustrating comparative difference in size. 
488 Field Museum of Natural History-Zoölogy, Vol. IX.

175. Asio flammeus (Pontoppidan).

Short-eared Owl.

Asio accipitrinus (Pall.), A. O. U. Check List, I895, p. I42.

Distr.: North America; breeds from about latitude $39^{\circ}$ northward.

Adult: Ear tufts, very short, hardly noticeable in some specimens; first and second primaries, notched; general plumage, streaked and

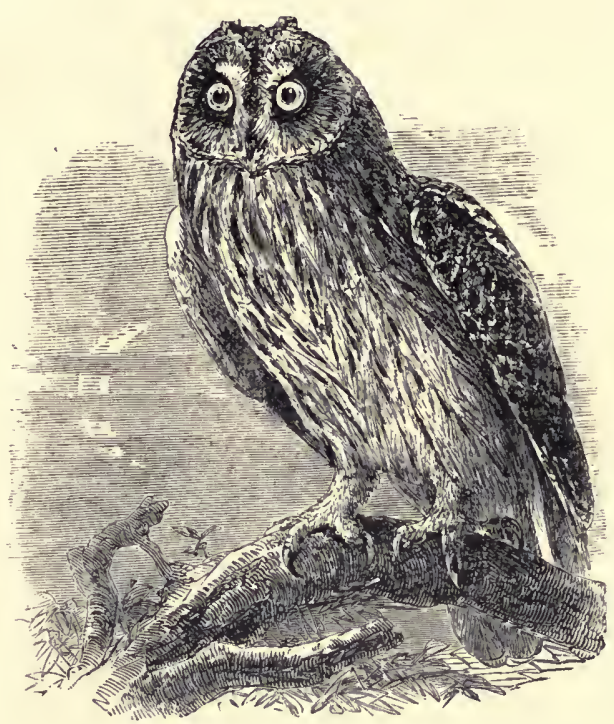

Short-eared Owl.

marked with dark brown and tawny; belly, streaked; primaries and tail, barred with dark brown and tawny; facial disk, whitish, more or less speckled and marked with black around the eye; iris, yellow.

Sexes, similar.

Length, about I 4.75 ; wing, I 2 to I 3 ; tail, 6.

This species is common in spring and fall in Illinois and Wisconsin during the migrations, and a not uncommon resident throughout the year. It frequents the prairies and marshes. It has been found nesting in Cook County, Illinois (Kennicott), and Mr. F. M. Woodruff found it breeding "a few miles south of Chicago, at Lowell, Indiana." (Bull. Chicago Acad. of Sciences, No. VI, I907, p. I02.)

The nest is usually built on the ground and consists of a little grass 
Jan., igo9. Birds of Illinois and Wisconsin-Cory.

and feathers. The eggs are white, four to seven in number, and measure about $\mathrm{I} .55 \times \mathrm{x} .25$ inches. Breeds late in April or in May.

\section{Genus STRIX Linnæus.}

\section{Strix varia BARTON.}

BARRED OWL.

Syrnium nebulosum (Forst.), A. O. U. Check List, I 895, p. I 43.

Distr.: Southern and eastern United States, north to Nova Scotia and Canada; breeds throughout its range.

Adult: No ear tufts; toes, feathered; tail, rounded; upper plumage, umber brown,thickly barred with buff and whitish; breast, the same;

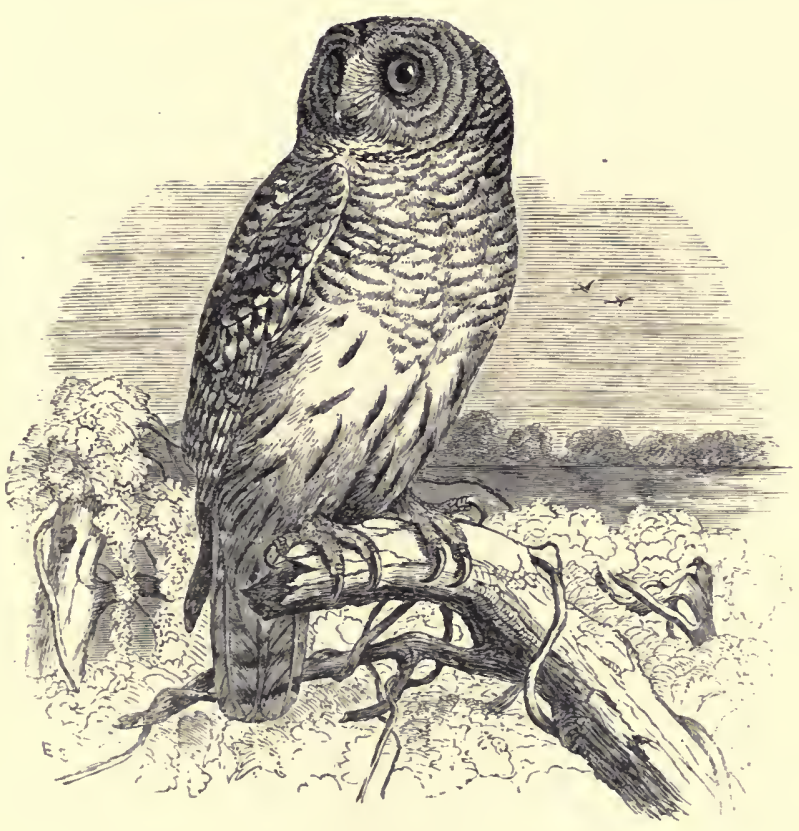

Barred Owl.

belly, whitish, heavily streaked (not barred) with dark brown; wings and tail barred with gray and pale brown, many of the bars edged with whitish; facial disk with circles of brown around eyes; iris, brownish black.

Length, I 7.50 to 20 ; wing, 12.75 to $\mathrm{r} 3.50$; tail, 9 to 10.25 .

The Barred Owl is a common resident in wooded localities in Illinois and Wisconsin. The nest is in a hollow tree, or sometimes a 
490. Field Museum of Natural History-Zoölogy, Vol. IX.

deserted crow's or hawk's nest is used. The eggs are white, two to four in number, and measure about $2 \times 1.75$ inches. Breeds in March and April and farther south somewhat earlier. There is a set of 3 eggs in the Field Museum collection taken in Clark Co., Missouri, March I, I 896 .

The "hoot" of the Barred Owl may be described as hoo-hoo, $h$-hoo-hoo, ho-hoo-o-o. The notes are as a rule several tones higher than those of the Great Horned Owl and the hoot is longer. It also litters a wild scream.

Genus SCOTIAPTEX Swainson.

177. Scotiaptex nebulosa (Forster).

Great Gray OWL.

Scotiaptex cinerea (Gmel.), A. O. U. Check List, I 895, p. I 44.

Distr.: Arctic species which occurs in winter as far south as New England and Illinois.

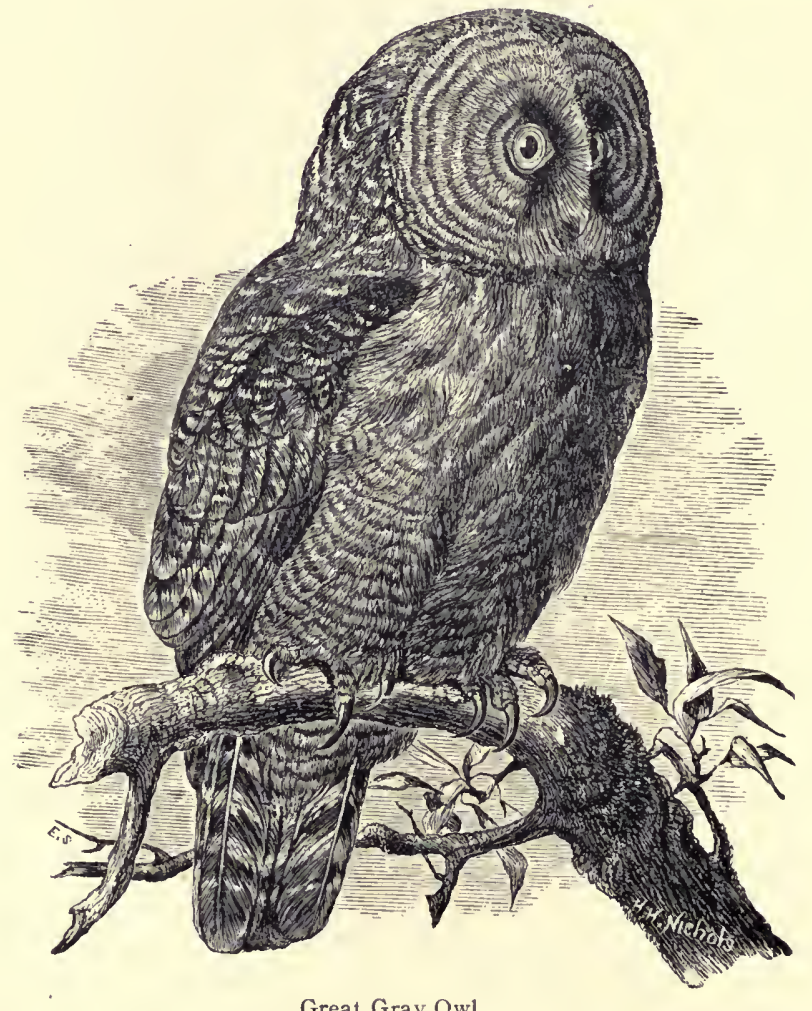

Great Gray Owl. 
Adult: The largest of our owls; no ear tufts; feet. thickly feathered; general plumage, dark brown, mottled and marked with grayish white; facial disk, gray, marked with fine dark brown rings concentric with each eye; under parts, more heavily streaked on the breast; iris and bill, yellow.

Length, about 25 to 29 ; wing, 16.25 to I8.25; tail, about I 2 ; bill, I.

The Great Gray Owl is of rare occurrence in Illinois. Kennicott (I 854 ) records it from Cook County, and Mr. E. W. Nelson (Birds N. E. Illinois, p. I 6 ) gives it as "a very rare winter visitant."

In Wisconsin Dr. Hoy gives it as having been taken near Racine in 1848 . Kumlien and Hollister (Birds of Wisconsin, p. 70) write: "Two specimens were sent Thure Kumlien from Bark River woods, Jefferson County, about the same time ( 1848 ). We have received two specimens from Iron River, taken in November, 1891. ***** If we could trust reports from hunters and residents in the Lake Superior region, we would say that it is not rare in winter in that section, particularly during severe weather." King (Geology of Wisconsin, $188_{3}$, p. 580 ) gives it as a winter resident.

\section{Genus GLAUX Morris.}

\section{Glaux funerea richardsoni (BONAP.).}

\section{Richardson's OWL.}

Nyctala tengmalmi richardsoni (Bonap.), A. O. U. Check List, I 895, p. I 44 .

Distr.: Arctic America; casual in winter in northern United States as far south as New England and Illinois; breeds north of the United States.

Adult: Upper plumage, dark cinnamon brown, more or less marked with white; under parts, streaked with white; top of head with white spots; a black spot in front of the eye; more or less white on the face; primaries, brown, marked with pure white irregular spots; tail, brown, with imperfect bands of white; toes, thickly feathered; legs and feet, more or less marked with dark brown.

Length, 9.50 to I 2 ; wing, 6.50 to 7.50 ; tail, about 4.40 .

Richardson's Owl must be considered a rare bird within our limits. Mr. J. E. Deckinson records the capture of a bird of this species in Rockford, Winnebago County, Illinois (Ornithologist and Oologist, March, 1885 p. 47) as follows: "Captured one Richardson's Owl, October 15, 1884. He flew against a store window and was slightly 


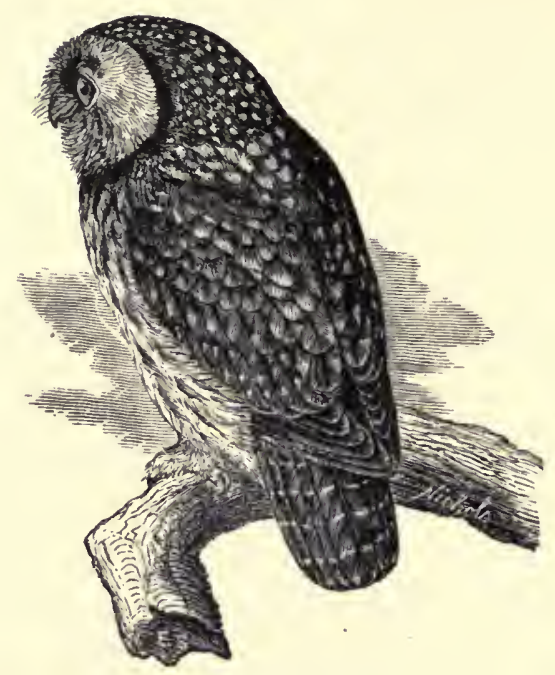

Richardson's Owl.

stunned." Mr. Ruthven Deane states (Auk, I903, p. 305): "I am indebted to Mr. Robert H. Van Schaack for the following information: 'The Richardson's Owl was shot by my son, Louis F. Van Schaack, Dec. 26, r902, in Kenilworth, Ill. He found the bird along a small ditch that drains from the Skokie Swamp. He shot the owl with a toy air-gun. I examined the specimen while in the possession of the taxidermist who mounted it, who informed me that he had mounted another specimen of this species about the same time, which was said to have been shot not far from Chicago.'"

In a later article Mr. Deane writes (Auk, I903, p. 443): "In recording the second capture of this owl from the state, I mentioned that another specimen had been reported, but that I was then unable to get any definite information as to locality and date. Through the kindness of Mr. Frederick C. Pierce of Chicago, I am now enabled to record a third specimen which was taken in Cicero, in December, I 902, and is now in his possession."

In Wisconsin Dr. Hoy and Mr. King include it in their lists of Wisconsin birds. Kumlien and Hollister state (Birds of Wisconsin, I903, p. 70): "A very rare visitant in southern Wisconsin during winter. Probably occurs more frequently in the northern part of the state. Dr. Hoy records a single specimen taken at Racine, Nov. 30, I $85^{\circ}$. Thure Kumlien procured three or four specimens in Dane and Jefferson Counties during nearly fifty year's residence in those parts. L. Kumlien has taken two, one in Dane County, r 869, and one 
at Fort Atkinson, August, I872. Mr. J. N. Clark, of Meridian, Dunn County, took one specimen, February $24, \mathrm{I} 893$, capturing it in his hands from the side of a straw stack. One specimen (no record) is preserved in the Milwaukee Public Museum.'

\section{Glaux acadicus (GmeL.).}

Saw-whet Owl. Acadian Owl.

Nyctala acadica (Gmel.), A. O. U. Check List, I895, p. I 45.

Distr.: Throughout North America, breeding from the middle states northward; occurs in mountainous districts in the West as far south as Mexico.

Adult: Decidedly smaller than Richardson's Owl, which is the only species with which it might be confounded; top of head, streaked

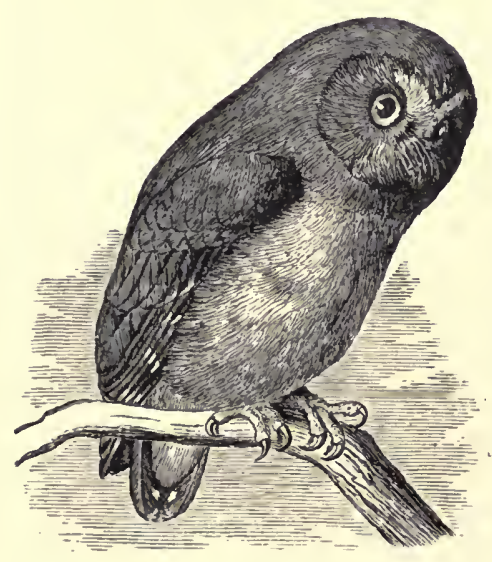

Immature.

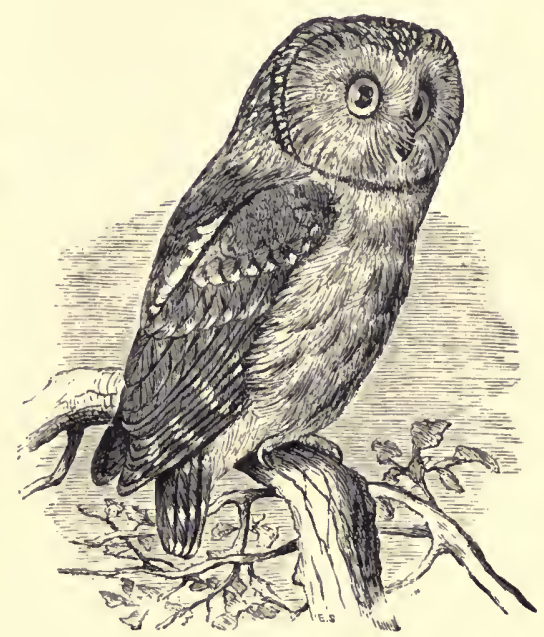

Adult

(not spotted); upper plumage, dark cinnamon brown, more or less marked with white, but mostly on the nape and upper back; tail and wings, cinnamon brown, marked with white; legs and feet, plain buff or buffy white, without dark spots or marks.

Immature birds have the face dusky and a white streak over the eye:

Length, 7.20 to 8.50 ; wing, 5.20 to 5.85 ; tail, about 3 .

This interesting little species is not uncommon in Illinois and Wisconsin. Numerous specimens have been taken in and about Chicago, more commonly in winter. While it has occasionally been observed in summer, there are no records of its breeding in Illinois. 
494 Field Museum of Natural History-Zoölogy, Vol. IX.

It is known to breed in Wisconsin, where it is not uncommon, and is resident throughout the year.

Dr. Hoy states that its eggs have been taken near Racine. Kumlien and Hollister write: "It certainly used to breed in Jefferson County and Thure Kumlien took specimens in May and at least once in August." S. E. Willard states that it breeds in Brown and Outagamie Counties (Trans. Wis. Acad. Sciences, Vol. VI, I883, p. I 88).

Nidification usually begins in April. The nest is placed in a hole in some tree or stump, occasionally a deserted woodpecker's nest being used. The eggs are white, from three to five in number, and measure about I.20 X I inches.

\section{Genus OTUS Pennant.}

180. Otus asio (LinN.).

SCREECH Owl.

Megascops asio (Linn.), A. O. U. Check List, 1895, p. I45.

Distr.: Eastern North America, Canada to Georgia; breeds nearly throughout its range.

Adult (gray plumage): Toes with small, scattered, bristly feathers; not thickly feathered; well developed ear tufts, sometimes an inch long, differing in this from the other small owls; upper plumage, brownish gray, mottled with buff and streaked with black; under parts, gray on the breast and dull white on the belly, streaked with black and finely barred with buff and dusky; under surface of primaries, brown, barred with brownish white.

Adult (rufescent plumage): Upper plumage, bright rufous brown, with a few small black streaks, mostly on the crown and wing coverts; under parts, whitish, mixed with rufous brown and streaked with black; ear tufts, like back; face showing more or less white.

Length, about 8.25 to 10; wing, 6 to 7 ; tail, 2.90 .

The Screech Owl is a common resident in Illinois and Wisconsin, and is a familiar bird in wooded districts where, from its partiality to mice and English sparrows, it is a decided benefit to the agriculturist. While the majority of birds of this species appear to be gray, it is dichromatic, having two distinct phases of plumage, one grayish and the other bright rufous brown, which apparently have no relation to age or sex, both red and gray birds being found occasionally in the same nest.

It utters a soft, trilling note, and again a harsh screech, varying 


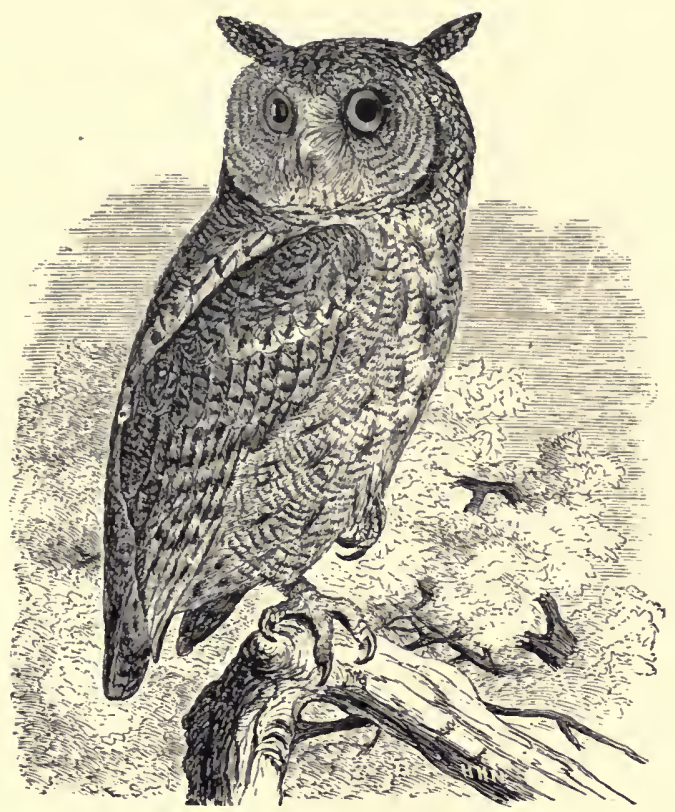

Screech Owl.

About one-quarter natural size.

in intensity and at times somewhat resembling the cry made by a cat when expressing his disapprobation of a rival. Taken when young they are easily tamed and made amusing pets.

The eggs are deposited in holes in trees. They are pure white, four to six in number, and measure about I.40 X I.20 inches. Nidification usually commences in April.

\section{Genus BUBO Duméril.}

\section{I. Bubo virginianus (GMEL.). Great Horned Owl.}

Distr.: Eastern North America, north to Labrador; breeds throughout its range.

Adult: Ear tufts, large; general plumage, mixed tawny black and white, the tawny color predominating; a white patch on the throat.

The Conspicuous ear tufts and coloration will always distinguish it from our other large owls, and its size from the smaller species.

Length, about 23; wing, I 4.20 to 16 ; tail, about 9 . 
496 Field Museum of Natural History-Zoölogy, Vol. IX.

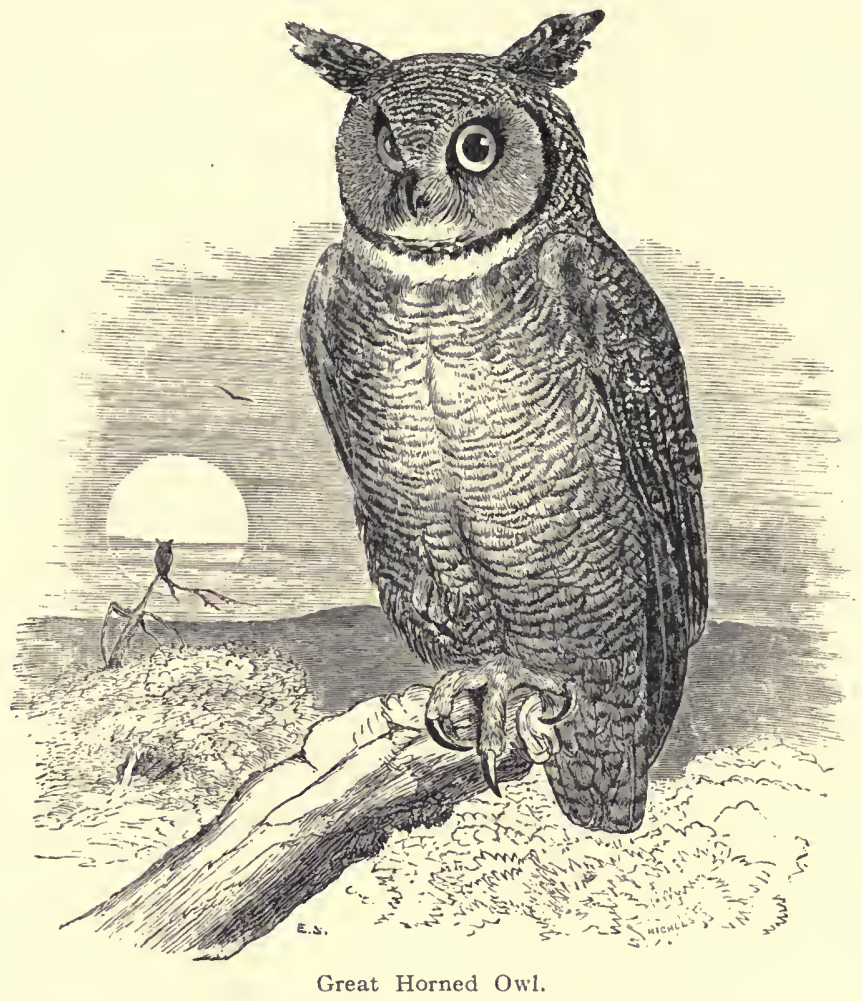

The Great Horned Owl is rather common throughout heavily wooded portions of Illinois and Wisconsin. Formerly quite common in the vicinity of Chicago, but now rare. It breeds in suitable localities in both states. The "hoot" is usually a loud hoo-hoo, hoo-hoo, hoo, shorter and deeper toned than that of the Barred Owl. It also utters a variety of unearthly screams.

Mr. Woodruff (Birds of the Chicago Area) states that "in I 890 Mr. Ned Pratt collected several sets of the eggs of this owl near Lake Forest, a short distance north of Chicago."

Kumlien and Hollister (Birds of Wisconsin) state that it "breeds as early as the middle of February" and is "usually more plenty in the hardwood timber of bottom lands along streams."

Nests in a hollow tree or in an old hawk's, crow's, or squirrel's nest. The eggs are white, from two to three in number, and measure about $2.20 \times 1.82$ inches. Nidification begins in February or early in March. Eggs have been taken as early as February first. The Field Museum collection contains a set of 3 eggs taken at Grinnell, Iowa, February 29, I 893 . 
181a. Bubo virginianus subarcticus (Hoy).

Arctic Horned OwL.

Distr.: Interior of northern British America, Hudson Bay to the Mackensie River region, south to the northern United States in winter.

This northern form differs from our common species, B. virginianus, in being much paler, the general coloration more gray and white, with decidedly less brownish or ochrąceous buff.

It must be considered as merely an accidental straggler in Illinois and a rare winter visitant in Wisconsin.

Nelson includes it in his Birds of N. E. Illinois as a rare winter visitant and says: "Have a fine specimen in my collection taken the last of December, I874. It was given by Dr. Hoy as having been taken at Racine, Wisconsin." Kumlien and Hollister state: "Taken by Hoy at Racine and by Kumlien at Lake Koshkonong, both at an early day, a fine specimen preserved in the Milwaukee Public Museum was procured at Ashland, January, I886."

It is not improbable that the Western Horned Ow1, B. v. pallescens, may occur within our limits, as it has been recorded from North Dakota, Minnesota, and Iowa. It is darker than virginianus and the under parts are more heavily barred.

There has been more or less confusion as to name of this subspecies. Swainson's name arcticus, as has been shown by Dr. Richmond, is preoccupied and untenable and he has revived subarcticus of Hoy for the northern form.

\section{Genus NYCTEA Stephens.}

182. Nyctea nyctea (LiNn.).

SNowy OwL.

Distr.: Arctic regions; south in winter in North America to middle states; accidental as far south as Carolina, Texas, and California; breeds north of the United States.

Adult: Varying from pure white to white, spotted and barred with grayish brown or dusky; no ear tufts; feet, thickly feathered; bill, black; iris, yellow. Pure white specimens are rare.

Length, abo11t 24 ; wing, I6 to I 7.50 ; tail, about $9.5^{\circ}$.

The Snowy Owl is a winter visitant, varying in numbers in different years; at times not uncommon.

Mr. E. W. Nelson gives the Snowy Owl as a regular winter resident 
498 Field Museum of Natural History-Zoölogy, Vol. IX.

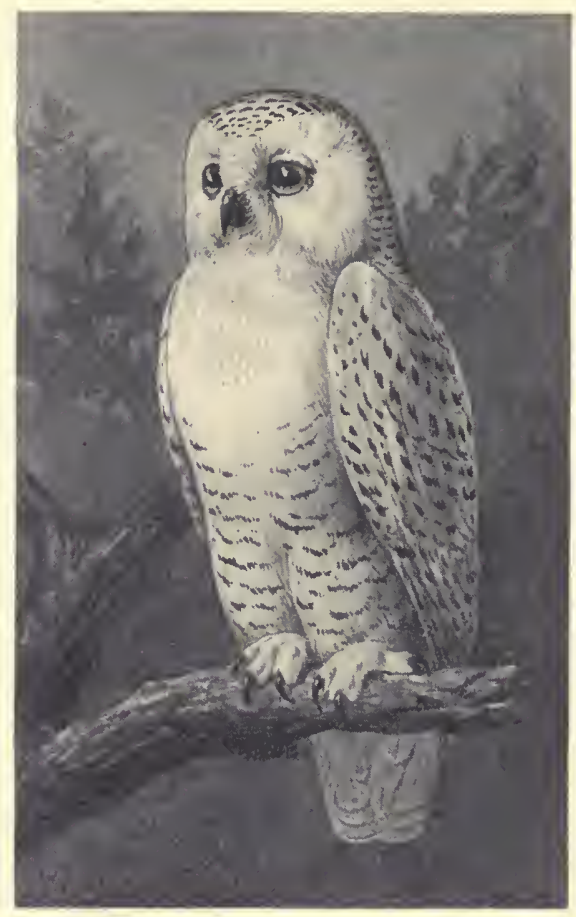

Snowy Owl.

in Illinois, "more numerous in the vicinity of the lake. Arrives in November and a few remain as late as the first of May." (Birds N. E. I11., I 876.) Mr. Frank M. Woodruff writes (Birds of the Chicago Area, r 907, p. 107): "Mr. J. Grafton Parker, Jr., informs me that on Nov. 3, I 885 , he observed two Snowy Owls perched on the chimney tops of a residence in Grand Boulevard near 35th St." According to Robert Kennicott* in early days it was common in Cook Co., Illinois, in winter. He writes, "Common in winter. Last winter during the very cold and stormy weather, I frequently saw them capture prairie hens."

In Wisconsin Kumlien and Hollister give it as a "Winter resident of irregular occurrence. Some winters the snowy owl is quite common. **** When these owls reach Lake Koshkonong during open water, they persistently hunt along the edge of the rushes for wounded ducks and at times, apparently from choice, as other food is plenty, will catch fish." (Birds of Wisconsin, r903, p. 72.) p. $58 \mathrm{r}$.

*Catalogue of Animals observed in Cook Co., Ill. Trans. Ill. State Agri. Soc., r853-54, 


\section{Genus SURNIA Duméril.}

\section{Surnia ulula caparoch (MüLL.).}

American Hawk Owl.

Distr.: Arctic North America; south in winter to northern border of United States and casually as far as Illinois and New England; breeds north of United States.

Adult: No ear tufts; upper plumage, dark brown (brownish black on the head), finely spotted with white on the head, and blotched and barred with white on the back; primaries with white spots on both

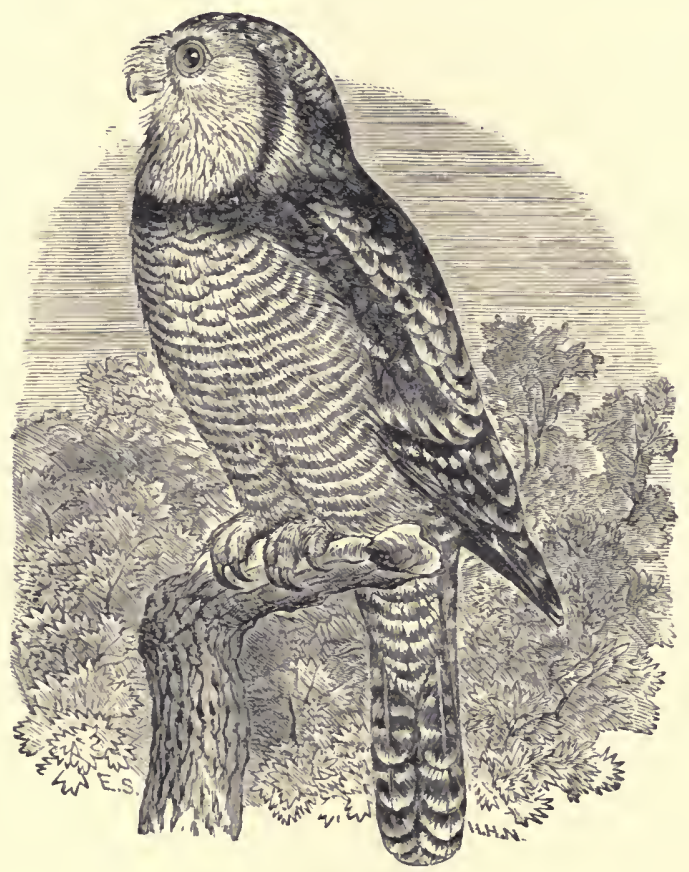

Hawk Owl.

webs; tail, unevenly barred with whitish; face, grayish white, bordered by a streak of black behind the ear; a dusky patch on chin and middle throat, rest of under parts, barred with white and dark brown; tail, rounded, the outer feathers being decidedly shorter than the middle feathers; eyes and bill, yellow.

Length, about I $_{5}$; wing, about 9 ; tail, about 7 .

A very rare winter visitant in both Illinois and Wisconsin.

Robert Kennicott included it in his list of the birds of Cook County, 
500 Field Museum of Natural History-Zoölogy, Vol. IX.

I11., (1853-54). Nelson gives it as " a rare winter resident" and writes: "Dr. J. W. Velie tells me that he obtained a specimen in Kane County, Ill., the first of September, I869." (Birds. N. E. Ill., I876, p. II 7.)

Kumlien and Hollister (Birds of Wisconsin, p. 72) give it as "A very rare winter visitant in southern Wisconsin, more frequent in the northern part, especially of late years. Recorded from Racine by Dr. Hoy and from the same place by Thure Kumlien, who received a specimen from there killed in the winter of 1869 . Several were also taken about Lake Koshkonong at an early day. Mr. J. N. Clark has taken the Hawk Owl twice at Meridian, in April, 1885 , and in December, I900. In the winter of $189^{2}$, we received three specimens from Bayfield County. A specimen in the Milwaukee Public Museum is labelled, Fox Point, Milwaukee, Wisconsin."

Unlike our other owls, the Hawk Owl is diurnal in its habits, and in its home in the far north it may be observed in the daytime, perched after the manner of a hawk on some commanding stump, watching for its pray. Dr. C. Hart Merriam in writing of the species says: "In the vicinity of Hudson Bay during the winter season, the White Ptarmigan (Lagopus albus) constitutes its chief article of diet; and it is said to follow the hunter, pouncing upon his game before he has time to reach it." (Review of Birds of Conn., I877, p. 73.) 


\section{ORDER PSITTACI.}

\section{PARROTS, PAROQUETS, ETC. \\ Family PSITTACIDÆ. Parrots and Paroquets.}

A very large family numbering some 360 species, the majority being distributed throughout the tropical parts of the world. But one species properly belongs in the United States, the Carolina Paroquet. This beautiful bird was at one time abundant throughout southeastern North America, but has now disappeared except in a few localities in Florida and the Indian Territory.

\section{Genus CONUROPSIS Salvadori.}

184. Conuropsis carolinensis (Linn.).

Carolina Paroquet.

Conurus carolinensis (Linn.), A. O. U. Check List, I895, p. I 52.

Distr.: Formerly southeastern United States, as far west as Texas and Colorado and north to New York; now occurs only regularly in parts of Florida and Indian Territory, although stragglers are occasionally taken in southern Missouri and Kansas; apparently fast becoming extinct.

Adult: Forehead and cheeks, deep reddish orainge, rest of head and neck, yellow; bend of wing and tibia, yellow, tinged with orange; rest of plumage, green; lighter green on under parts; outer webs of primaries, green, yellowish at bases; inner webs, dark brown; upper surface of tail feathers, green, with brown shafts.

Immature birds have the orange on the face and forehead the same, but the rest of the head is green, instead of yellow, and there is no yellow or orange on the bend of the wing or tibia.

Length, about I 2; wing, 7.30; tail, 6.40; bill (straight line), .87; tarsus, .65.

During the early part of the last century, Paroquets were not uncommon in Illinois and southern Wisconsin. Wilson found them abundant in the neighborhood of the Ohio River and lower Mississippi, and Audubon, in I8 3 I (Ornithological Biography, p. I38) writes: 


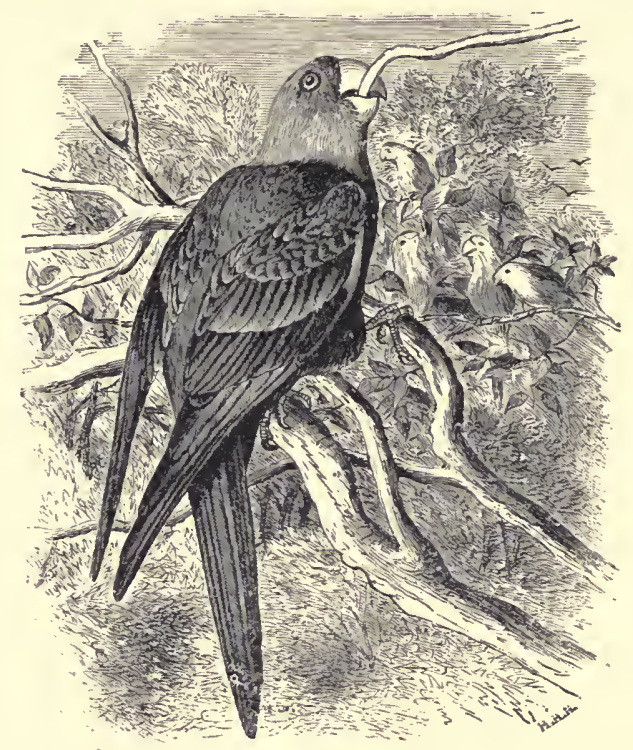

Carolina Paroquet.

"Our paroquets are very rapidly diminishing in number and in some districts where twenty-five years ago they were plentiful, scarcely any are now to be seen. At that period they could be procured as far up the tributary waters of the Ohio as the Great Kenhawa, the Scioto, the heads of the Miami, the mouth of the Manimee at its junction with Lake Erie, on the Illinois River, and sometimes, as far east as Lake Ontario and along the eastern districts as far as the boundary line between Virginia and Maryland. At the present day very few are to be found higher than Cincinnati. nor is it until you reach the mouth of the Ohio that paroquets are met with in considerable numbers. I should think that along the Mississippi there is not now half the number that existed fifteen years ago."

Ridgway writes (Birds of Illinois, I889, p. 397): “The avifauna of Illinois has lost no finer or more interesting member than the present species which is probably now everywhere extinct within our borders, though fifty years ago it was of more or less common occurrence throughout the state. The National Museum possesses a fine adult example from Illinois (Cat. No. I $27_{2}$ ), another from Michigan, and several from the Platte River in Nebraska. Now, however, it appears to be quite exterminated except in isolated and rapidly contracting areas in Florida and thence westward to the lower Mississippi Valley. Its present northern limit in the interior is uncertain, but 
so far as known, is the eastern part of Indian Territory and portions of Arkansas."

The latest record of its occurrence in any northern locality seems to be that given by Dr. Eliot Coues in his Birds of the Northwest (1874, p. 296). He writes: "In Iowa, according to Mr. Trippe, the Parrot still occurs. A resident of Decatur County told me that he had several times seen a flock of Parrots in the southern part of the county on a tall, dead cottonwood tree, known to the neighboring inhabitants as the "parrot tree" from its having been frequented at intervals by the same flock for several years." In a previous article (Proc. Boston Soc. Nat. Hist., Vol. XV, I 872 , p. 237), he quotes the same authority and adds "he had shot one of them on one occasion."

In 1863 Dr. F. V. Hayden (Trans. Am. Philos. Soc., XII, I 863, p. I54) states that Paroquets were "very abundant in the Mississippi Valley along the thickly wooded bottoms as far up the Missouri as Fort Leavenworth.'

Mr. Rudolph M. Anderson in his Birds of Iowa (Proc. Davenport Acad. of Sci., Vol. XI, I907, p. 27 I) writes: "A series of about a dozen specimens in the University Museum were taken by $\mathrm{D}, \mathrm{H}$. Talbot's collectors at the mouth of the Arkansas River in $1882 . "$

Mr. A. W. Butler (Birds of Indiana, I897, p. 8rg) gives an interesting account of the history and distribution of Paroquets in Indiana and states that it "bred at least north to the vicinity of Indianapolis."

Mr. Otto Widmann states that as late as July i 8, I 905, a Paroquet was seen at Notch, Stone Co., Missouri, and another killed in August, the previous year, near Potter, Kansas, opposite Platte Co., Missouri. (Birds of Missouri, 1907, p. ri6.) 


\section{ORDER COCCYGES.}

CUCKOOS, KJNGFISHERS, TROGONS, ETC.

Suborder CUCULI. Cuckoos.

\section{Family CUCULID瓜. Cuckoos, Anis, etc.}

The family Cuculidæ contains about $\mathrm{I} 80$ species from different parts of the world, and of these 9 (including subspecies) occur in North America. They are rather solitary birds and are rarely found away from trees. Unlike the European species, the American Cuckoos build their own nests, although occasionally their eggs are found in the nests of other birds. Its peculiar note suggests its name, and is a familiar sound to those who wander in the woods and fields. They are of great value to the agriculturist, as besides other insects they destroy immense numbers of caterpillars, including the Canker Worm, and the Tent Caterpillar, Clisiocampa americana.

\section{Subfamily COCCYGINÆ. American Cuckoos.}

\section{Genus COCCYZUS Vieill.}

\section{Coccyzus americanus (LinN.).}

Yellow-Billed Cuckoo.

Distr.: Eastern North America, from the plains to the coast and Canada to the Gulf of Mexico, breeding throughout its range. Occurs in winter in West Indies and Central America.

Adult: Under mandible, mostly yellow; upper mandible, dark; upper parts, brownish gray, with a faint gloss of greenish; under parts, dull white; greater portion of primaries, rufous brown, tipped with grayish olive; outer tail feathers, black, tipped with white.

Length, II to I 2; wing, 5.60 to 6; tail, about 6; bill, about I.

A common summer resident in Illinois and Wisconsin. Arrives from the south in May and remains until October. Apparently less common in northern Wisconsin.

The nest is a mat of twigs and small sticks, built in a bush or the lower branches of a tree, rarely more than six or eight feet from the 


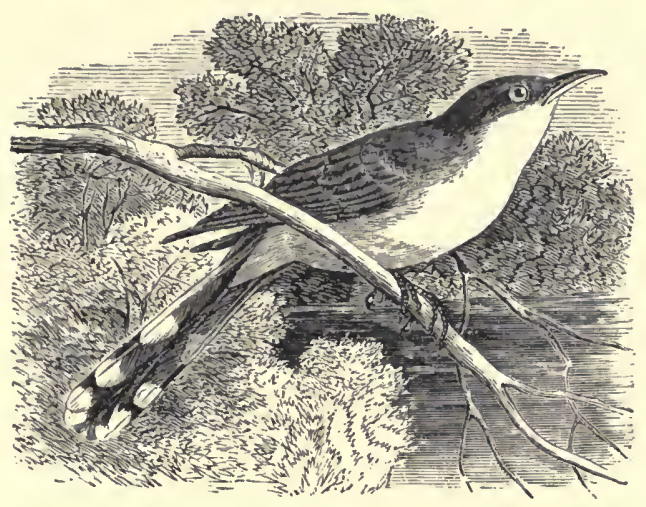

Yellow-billed Cuckoo.

ground. The eggs are 3 to 5 , pale greenish blue or bluish white, and measure about I.20 X. 90 inches. Mr. H. S. Swarth found it breeding at Joliet, Illinois, June I, Igo6.

The notes of the Cuckoo are pleasing, but rather monotonous and not particularly musical. They vary somewhat but the most characteristic is the familiar $c u-c u, c u-c u$, repeated several times, from which it has derived its name.

\section{Coccyzus erythropthalmus (Wils.). Black-billed Cuckoo.}

Distr.: Eastern North America, from Rocky Mountains to the coast; breeds in eastern United States and north to Labrador; south in winter to West Indies and northern South America.

Adult: Bill, brownish black (occasionally with a tinge of yellow at base of lower mandible); upper plumage, grayish brown, with a faint gloss of green; under parts, dull white; tail feathers, color of back, tipped with white; primaries, pale olive brown, shading into whitish at bases of inner webs; eyelids, red.

Length, II to I 2 ; wing, about 5.25 ; tail, 6.25 ; bill, .75.

Easily distinguished from the Yellow-billed Cuckoo by the black lower mandible, absence of rufous on primaries, and the color of the tail.

The Black-billed Cuckoo is a common summer resident in Illinois and Wisconsin. Arrives from the south in May and remains until October. Kumlien and Hollister consider it more common than the 
yellow-billed species in Wisconsin, while the opposite seems to be the case in Illinois.

The nest is a mat of small sticks and twigs built in low trees or bushes. The eggs are pale greenish blue, three or four in number, and measure about I.I5 $\times .85$ inches.

The Field Museum collection contains several sets of eggs of this species taken near Joliet, Ill., between June 8 and I I, I 906.

\section{Suborder ALCYONES. Kingfishers.}

\section{Family ALCEDINIDÆ. Kingfishers.}

But one species of this large family occurs in eastern North America. It is a familiar bird, being common wherever there is water. They are solitary birds, being usually found singly or in pairs. The nest is built in a hole in some bank near a stream or pond. There are about I 25 known species, those found in America being fish eaters, while many of the Australian and Indian forms are insectivorous and live in forests, nesting in holes in trees.

\section{Genus CERYLE - Boie.}

\section{Ceryle alcyon (Linn.).}

Belted Kingfisher.

Distr.: The whole of North America and south to the West Indies and Mexico, and Central America to Panama.

Adult male: Upper parts, bluish gray, the elongated feathers of the crown, blackish; wing coverts with small spots of white; terminal third of primaries, black; the rest, heavily marked with white, and rest of feathers narrowly edged with bluish gray, the centers of the feathers, black, spotted and banded with white; a white spot in front of the eye; throat, white; a band on the breast and sides of body, bluish gray (tinged with rufous brown in immature specimens), rest of under parts, white.

Adult female: Similar to the male, but having the sides of the body and $a$ band on the upper belly rufous brown.

Length, I 2 ; wing, 6 to 6.40 ; bill, r.90; tail, 3.50

The Kingfisher is a common summer resident in Illinois and Wisconsin. It arrives in April and remains with us until October, and 


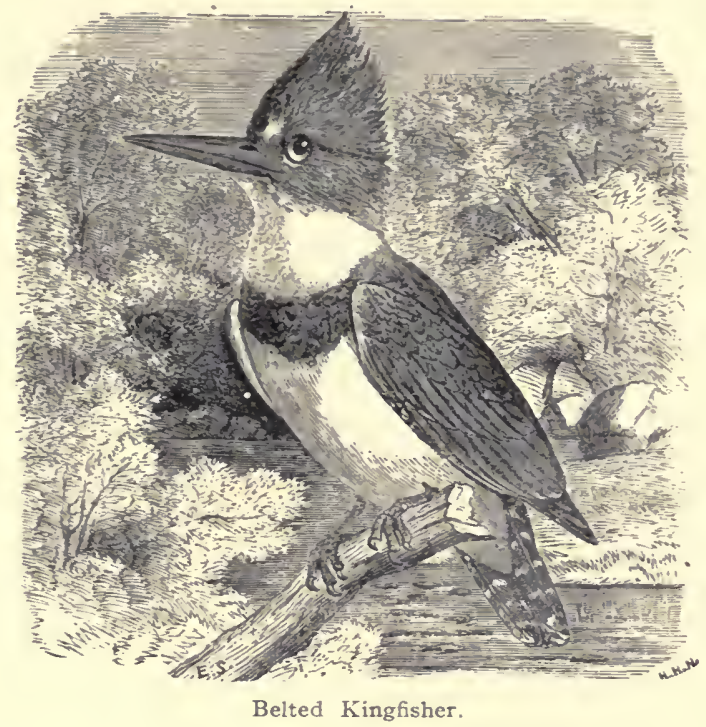

is a familiar bird with us wherever there is water. The note is harsh and loud-a peculiar sound not unlike the noise made by a watchman's rattle. The nest is in a deep hole in a bank, usually about six or more feet from the entrance. The eggs are from six to eight in number, pure white, and measure about $\mathrm{I}: 35 \times \mathrm{x} .05$ inches. 


\section{ORDER PICI.}

WOODPECKERS, WRYNECKS, ETC.

\section{Family PICIDÆ. Woodpeckers.}

Of the three hundred and fifty or more known species of woodpeckers, some 35 (including subspecies) occur in North America. They are wood birds and may often be seen climbing about the trunks of trees in search of their food, and their stiff tail feathers pressed against the bark greatly assists in supporting them. Woodpeckers are of decided benefit to the agriculturist, for while they occasionally destroy a little fruit, they eat great quantities of injurious insects and larvæ. The tongue is eminently adapted for extracting larvæ from the crevices in the bark, being very long and slender and tipped with a sharp, hard point edged with minute bristle-like hooks. Their presence in the woods is often indicated by their loud rapid tapping on trees. Their eggs are laid in holes in trees. $?_{0}$ : -

\section{Subfamily PICINÆ.}

\section{Genus CAMPEPHILUS Gray.}

188. Campephilus principalis (LinN.).

IVORY-BILLED WOODPECKER.

Distr.: Formerly south Atlantic and Gulf states, from Texas to the Carolinas and north to southern Illinois and Indiana; now occurs only in isolated localities in some of the Gulf states and Florida.

Adult male: Greater portion of plumage, black; a brilliant scarlet crest covered on top by the elongated black feathers of the crown, a white stripe extending down each side of the neck to the middle off the back; terminal half, or more, of secondaries and tips of inner primaries, white; under wing coverts, white; entire under parts, black; nostril bristles, white; bill, dull white.

Adult female: Similar, but without the scarlet crest.

Length, about 19.50; wing, Io; bill, 2.50; tail, 7. 


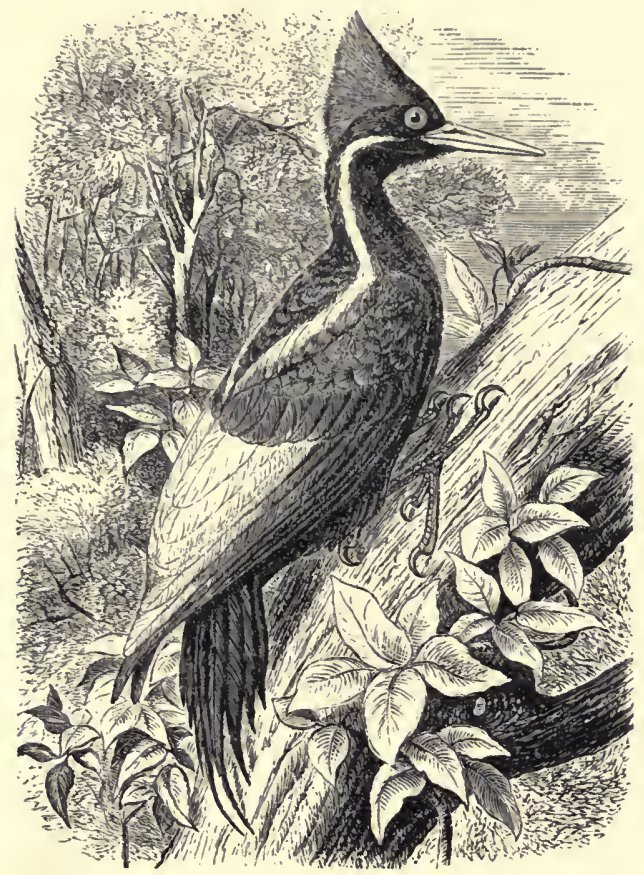

Ivory-billed Woodpecker.

While it is probable that the Ivory-billed Woodpecker does not occur in Illinois at the present time, it was once not uncommon in the heavily timbered regions of the southern part of the state. Audubon found it along the Ohio River near its junction with the Mississippi, during the early part of the last century and mentions its breeding in Indiana and Kentucky.

Prof. Ridgway states (Birds of Illinois, I 889, p. 375): "The writer has a distinct recollection of what he believes to have been this species in White County, some 40 miles south of Mount Carmel,(I11.), but never observed it in the vicinity of the latter place." Mr. Otto Widmann states that a male bird of this species was killed near Morley, Scott Co., Missouri, Nov. 8, I895. (Birds of Missouri, I907, p. II9.) 


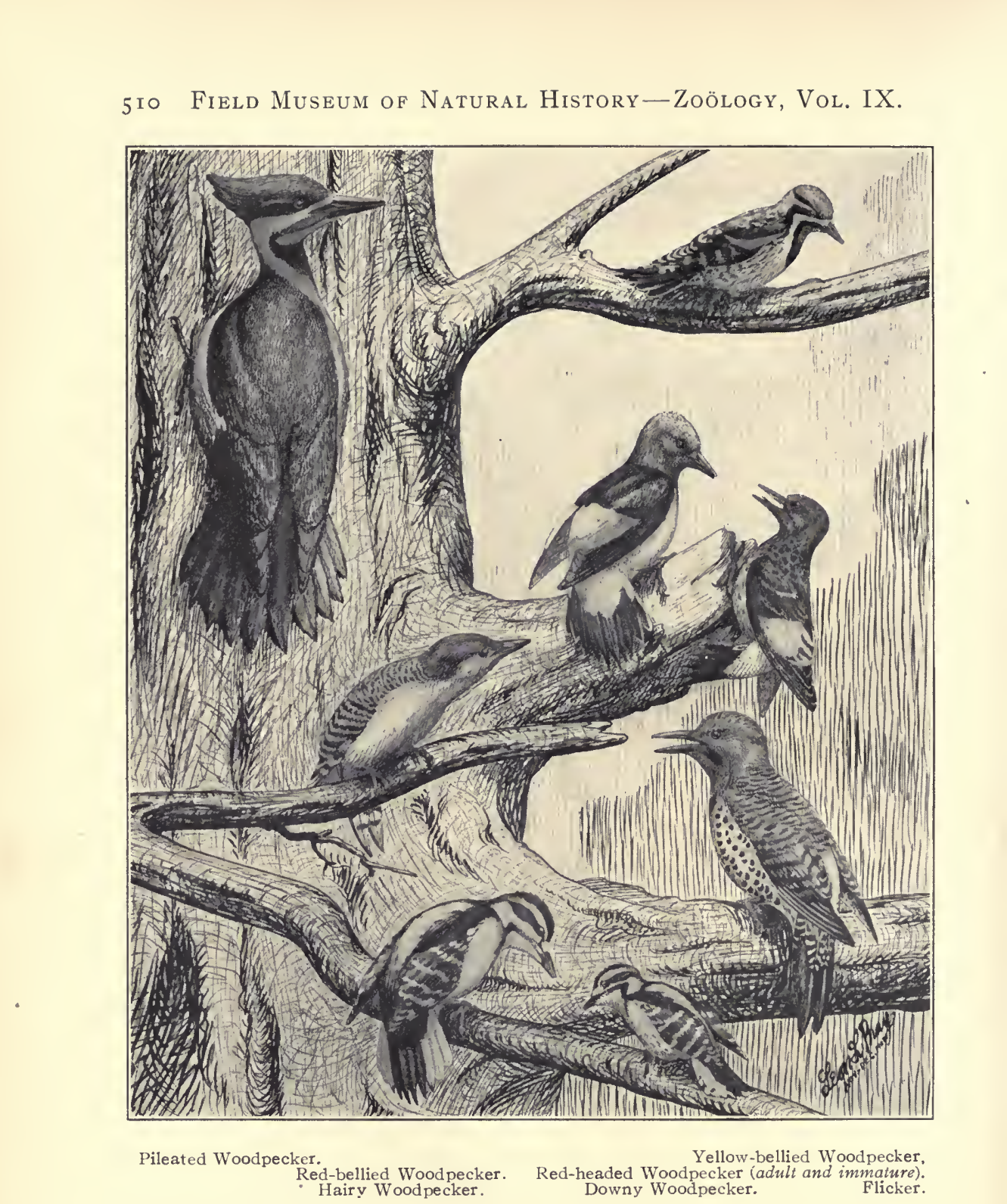




\section{Genus DRYOBATES Boie.}

189. Dryobates villosus (LinN.).

HAIRY WOODPECKER.

Distr.: Atlantic coast from North Carolina to Nova Scotia, west to Kansas and Nebraska.

Adult male: Crown and greater portion of upper plumage, black; a scarlet nuchal band; a white stripe over the eye, bordered below

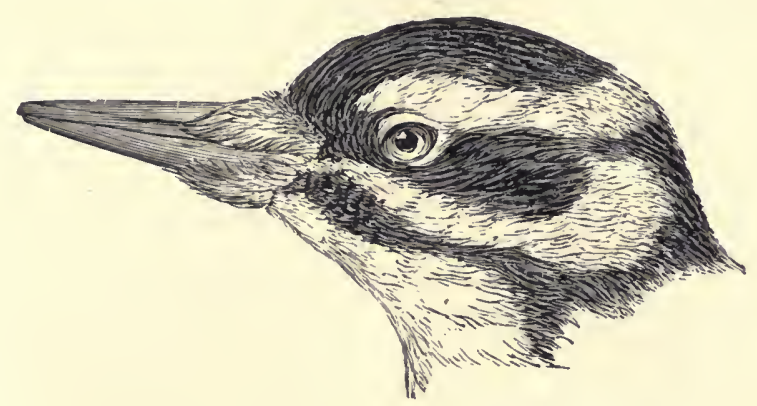

Hairy Woodpecker.

by a black stripe through the eye, then another white stripe bordered below by a black one on the sides of the throat; a patch on side of neck and middle of back, white; wings, heavily spotted with white; under parts, white; middle tail feathers, black; outer tail feathers, white.

Adult female: Similar, but without scarlet on back of the head.

Young birds have the crown more or less tinged with red, and occasionally dull yellow.

Length, about 9.45 ; wing, 4.50 to 5 ; tail, 3.25 ; bill, 1.25 .

The Hairy Woodpecker resembles the Downy Woodpecker in plumage, but is much larger, and the outer tail feathers are white, not irregularly barred with black, as in the latter species.

It is a common species in Illinois and Wisconsin, being a resident in both states throughout the year. A number of specimens in the Field Museum collection, taken in northern Wisconsin in winter, proved to be this form.

The nest is generally in a hole in a dead tree. The eggs are from 4 to 6 , pure white, and measure about .96 $\times .76$ inches. Nidification usually commences in Illinois the latter part of April. 
5 2 Field Museum of Natural History-Zoölogy, Vol. IX.

189a. Dryobates villosus leucomelas (BoDd.).

Northern Hairy Woodpecker.

Distr.: "Northern North America, south to about the northern border of the United States." (A. O. U.)

Special characters: Similar to D. villosus, but larger and showing more hoary white in the plumage; wing, 5.02 to 5.45 , not less than 5 ; bill, I.40 to I.60, not less than I.40.

The Northern Hairy Woodpecker is said to occur occasionally in northern Wisconsin in winter. Kumlien and Hollister state that "up to I 875 it was a regular visitor in winter in the tamarack swamps in north Jefferson County. During the past ten or fifteen years not a specimen has been taken and Hairy Woodpeckers collected in winter and late fall in northern Wisconsin have all proved to be typical villosus." (Birds of Wisconsin, 1903, p. 74.)

\section{Dryobates pubescens medianus (Swains.). \\ DOWNY WOODPECKER.}

Distr.: Eastern and northern United States, from the Rocky Mountains to the Atlantic, and from about the latitude of South Carolina north to Newfoundland and southern Canada.

Adult male: Resembles the Hairy Woodpecker, except that it is much smaller, and has the white outer tail feathers marked with more or less imperfect bars or spots of blackish.

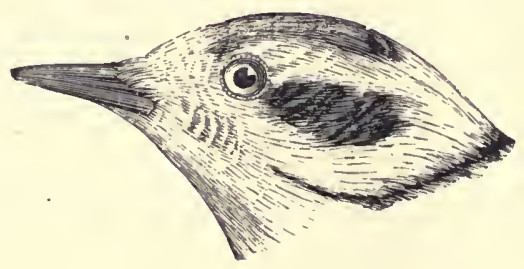

Downy Woodpecker.

Adult female: Similar, but without the scarlet nuchal patch.

Length, 5.90 to 7 ; wing, 3.45 to 4 ; tail, 2.70 ; bill, about .62 .

The Downy Woodpecker is a common resident in Illinois and Wisconsin. Specimens taken in extreme southern Illinois average smaller than northern birds.

The majority breed in May. The nest is in a hole in a tree, usually a dead stump. The eggs are white, from 4 to 6 in number, and measure about $.75 \times .60$ inches. 


\section{Genus PICOIDES Lacépède.}

191. Picoides arcticus (Swains.).

Arctic Three-toed Woodpecker.

Distr.: Northern North America, from the Arctic regions south to the northern United States; New England, Michigan, Wisconsin, etc.

Adult male: Toes, three; upper plumage, glossy bluish black; a patch of yellow on the crown; front of forehead, white, extending

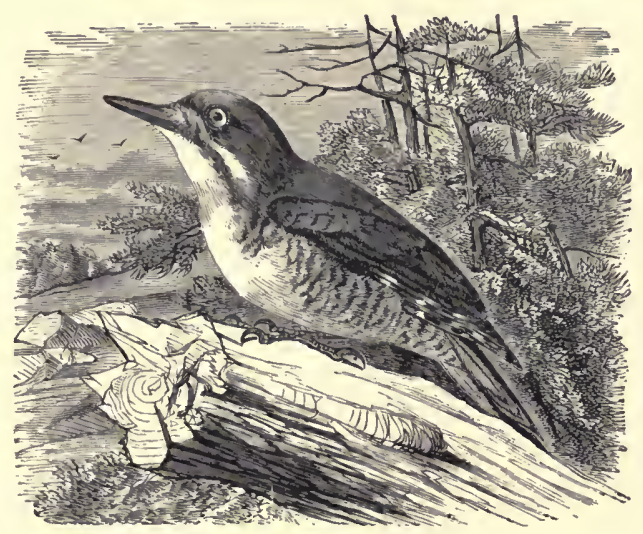

in a white stripe below the eye to side of neck; throat, breast, and middle of belly, white; sides of body, black, barred with white; middle tail feathers, black; outer tail feathers, white, except at the base.

Adult female: Similar, but without yellow on the crown.

Length, 9.45; wing, 5.25; tail, 4.05; bill, I.20.

The Arctic Three-toed Woodpecker is a rare winter visitant in Illinois. Mr. Isaac E. Hess writes me he has taken a specimen near Philo, Illinois. Mr. Nelson writes (Birds N. E. Illinois, I876, p. I I5): "A specimen was shot from a telegraph pole in Chicago a few years since by Dr. Velie. It is a common species in northern Wisconsin, and before the pines along the Lake were destroyed, was probably a regular winter visitant in this state." Mr. Woodruff (Birds of the Chicago Area, r907, p. Iro) records the occurrence of a bird of this species on the authority of Mr. Eliot Blackwelder at Morgan Park, Illinois, Dec. 29, 1894 .

It is more or less common in northern Wisconsin in winter and may be resident, as Kumlien and Hollister state (Birds of Wisconsin, I903, p. 75): "This species undoubtedly breeds in the northern part 


\section{Field Museum of Natural History-Zoölogy, Vol. IX.}

of the state, as there are several records of specimens taken during summer months. We have seen it at Merrill and near Wausau in June, and near Oconto (several specimens) in early August."

Mr. John F. Ferry procured three adult birds and three young not long out of the nest, near Woodruff, Vilas County, Wisconsin, during the last week in June; rgo8.

\section{Picoides americanus BREHM.}

\section{American Three-toed Woodpecker.}

Distr.: Northern North America east of the Rocky Mountains, from the northern border of the United States to the Arctic regions; accidental as far south as Massachusetts and New York.

Adult male: Toes, three; upper plumage, black, a patch of yellow on the crown; back, banded with white; under parts, white; the sides,

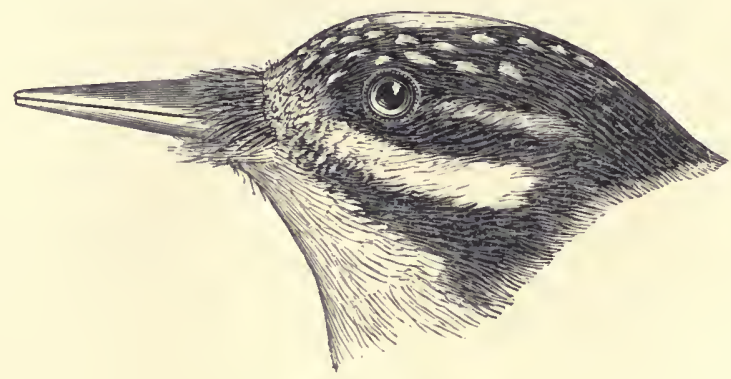

American Three-toed Woodpecker.

banded with black; primaries, spotted with white, middle tail feathers, black, outer ones, marked with black at the bases, but the the tips, broadly white.

Adult female: Similar, but no yellow on the head; crown, black, finely spotted with white.

Length, 8 to 9 ; wing, 4.50 to 5 ; tail, 3.30 ; bill, .95.

Not recorded from Illinois, and apparently a rare winter visitant in Wisconsin. Kumlien and Hollister state (Birds of Wisconsin, I 903, p. 75): "Records of this woodpecker for Wisconsin are very few. From I 860 to 1870 several specimens; about a dozen all told, were taken by Thure and L. Kumlien in the large tamarack wood near Jefferson. Dr. H. V. Ogden and Dr. E. Copeland have taken two specimens in Iron County, a male and a female, taken respectively Sept. 30 and Sept. 25, I 898, and preserved in the collection of E. Copeland and $\mathrm{H}$. Russel at Milwaukee; and it has been reported from the upper peninsula of Michigan by Mr. H. Nehrling." 


\section{Genus SPHYRAPICUS Baird.}

\section{Sphyrapicus varius (LINN.).}

\section{YELLOW-BELLIED WOODPECKER.}

Distr.: Eastern North America; south in winter to West Indies, Mexico and Central America; breeds from Massachusetts and northern border of eastern United States northward.

Adult male: Toes, four; top of head and throat, red; a white stripe over, and another below the eye; a black stripe through the

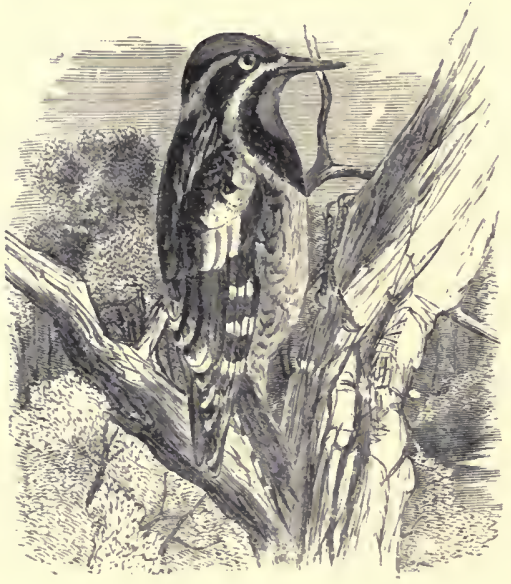

Yellow-bellied Woodperker. eye, extending to the sides of the neck; breast, with large black patch, bordered with yellow and white; belly, pale yellow; sides, marked with white and dusky; back, irregularly marked with black and dingy yellowish white; wing coverts, heavily marked with white, forming a conspicuous wing bar; primaries, black, spotted with white; tail feathers, black, the outer ones edged with white, and the inner webs of middle feathers broadly barred with white.

Adult female: Similar, but the throat white, instead of red, and

the red on the crown less extended.

Immature birds have the crown dusky, the throat whitish or grayish, and breast, gray, mottled with dusky.

The white wing bar and the yellowish tinge of the plumage will distinguish this species.

Length, about 8.50 ; wing, about 5 ; tail, 3.15 ; bill, .90.

The Yellow-bellied Woodpecker is a common spring and fall migrant in Illinois and Wisconsin, and an occasional summer resident in northern Illinois and Indiana. It is a common summer resident in Wisconsin, where according to Kumlien and Hollister, it breeds in considerable numbers as far south as Lake Koshkonong (Birds of Wisconsin, I903, p. 76). Mr. John F. Ferry procured a nest of young birds at Woodruff, Wisconsin, June 25,1908 . It occurs more or less commonly as a winter resident in southern Illinois.

The nest is a hole in some large tree or stump, usually 30 or more feet from the ground. The eggs are white, six or seven in number. and measure about $.85 \times .66$ inches. 
5i6 Field Museum of Natural History-Zoölogy, Vol. iX.

\section{Genus PHLOEOTOMUS Cabanis.}

194. Phlœotomus pileatus albieticola (BANGs).

Northern Pileated Woodpecker.

Distr.: Heavily wooded regions of North America, from the Alleghanies and middle United States northward.

Adult male: General color, dull black; top of head and a cheek patch beginning at base of lower mandible, bright scarlet; throat, a

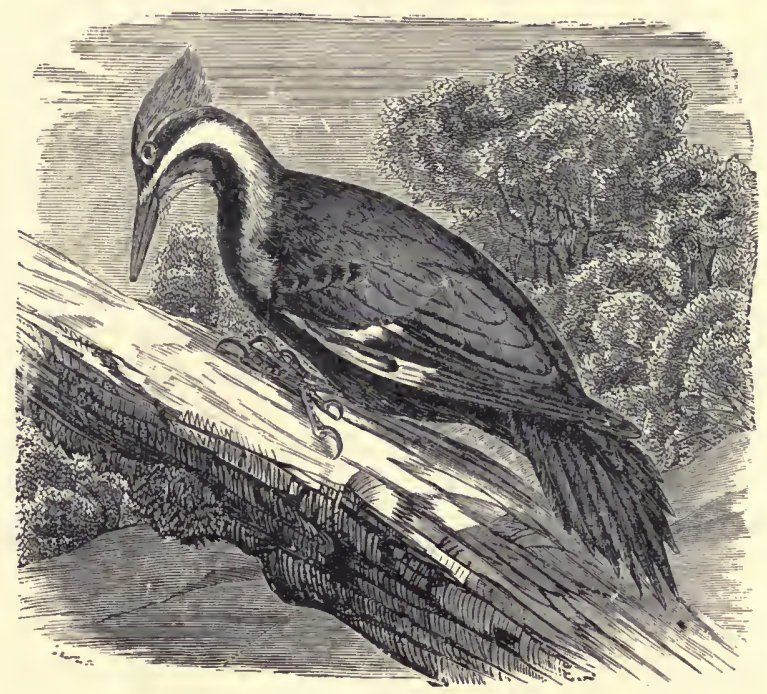

Northern Pileated Woodpecker.

stripe behind the eye, and a larger one extending from the nostril along side of head and neck, and breast, white; terminal half of primaries, brownish black, the basal half, white (at times tinged with pale yellow), forming a conspicuous white wing patch when flying; tail, black; bill, brownish black, paler below.

Adult female: Similar, but only back of head scarlet, the front crown, brownish black, and without scarlet red patch at base of under mandible.

Length, about $\mathrm{r}_{7.50}$; wing, about 9; tail, 6.60; bill, r.90.

This species is resident and not uncommon in southern Illinois, and occurs sparingly in wooded districts of northern Illinois and Wisconsin. Mr. E. W. Nelson gives it in his Birds of Northeastern Illinois as "A rare winter visitant. Two specimens were taken near Chicago during the winter of 1873 ." Mr. Frank M. Woodruff writes: "Mr. George 
Clingman reports the taking of a specimen at Half Day, Illinois, on Dec. 30, I893." (Birds of the Chicago Area, 1907, p. III.)

Regarding its occurrence in Wisconsin, Kumlien and Hollister write: "Going back to 1870 and earlier, it was not at all an uncommon bird in Bark River Woods in Jefferson County, where it bred regularly as late as $I 872$, and sparingly even later. $* * * *$ One was shot in Jefferson County in 1877 in late fall, the last record for the section. One was seen in Walworth County in May, r889. In the central and northern part of the state it is still fairly common, especially in the heavily timbered hardwood districts. $* * * *$ We received a specimen in October, 1898, which had been killed by a boy with a sling shot in Lincoln Park, Chicago."

Nests in a hole in a tree, usually fifty or more feet from the ground. The eggs are white, five or six in number, and measure about $1.30 \mathrm{x}$ .95 inches.

\section{Genus MELANERPES Swainson.}

195. Melanerpes erythrocephalus (LINN.).

RED-HEAded Woodpecker.

Distr.: Eastern United States, from Rocky Mountains to Florida and north to about latitude $50^{\circ}$; casual east of the Hudson River.

Adult male and female: Back, tail and most of wing, bluish black; whole of head and throat, including upper breast, crimson red;

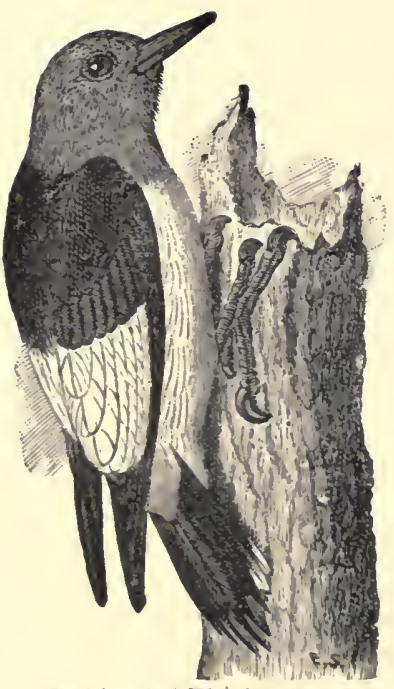

Red-headed Woodpecker. greater portion of secondaries and wing coverts, pure white; under parts, white, more or less tinged with buff; tail, black, the outer feathers more or less margined with white; bill, slaty brown or horn color. The sexes are similar.

Immature: Head and neck, brownish gray, streaked with dusky; feathers of the back, blackish, faintly tipped with grayish white; primaries, brownish black; secondaries, broadly but irregularly barred with black and white; tail, black, most of the feathers tipped with white; under parts, whitish, streaked with dusky, most heavily on the throat and breast.

Length, 9; wing, 5.25; tail, 3.40; bill, I.

The Red-headed Woodpecker is an abundant summer resident in Illinois and 
5i 8 Field Museum of Natural History-Zoölogy, Vol. IX.

Wisconsin and a regular winter resident in southern Illinois. A few remain during the winter in southern Wisconsin and northern Illinois, but the great majority go south.

Nests in a hole in a dead tree or stump. The eggs are white, five or six in number, and measure about .98 x.75 inches. Breeds in May and June.

\section{Genus CENTURUS Swainson.}

\section{Centurus carolinus (Linn.). \\ Red-Bellied WoOdPeCKer.}

Melanerpes carolinus (Linn.), A. O. U. Check List, I895, p. I66.

Distr.: Eastern and southern United States, from New York, Michigan, and Ontario to the Gulf states; west to Nebraska, Kansas, and Texas; not numerous in northern part of its range.

Adult male: Top of head and nape, scarlet red, becoming pale on the forehead; back and wings barred with black and white; under

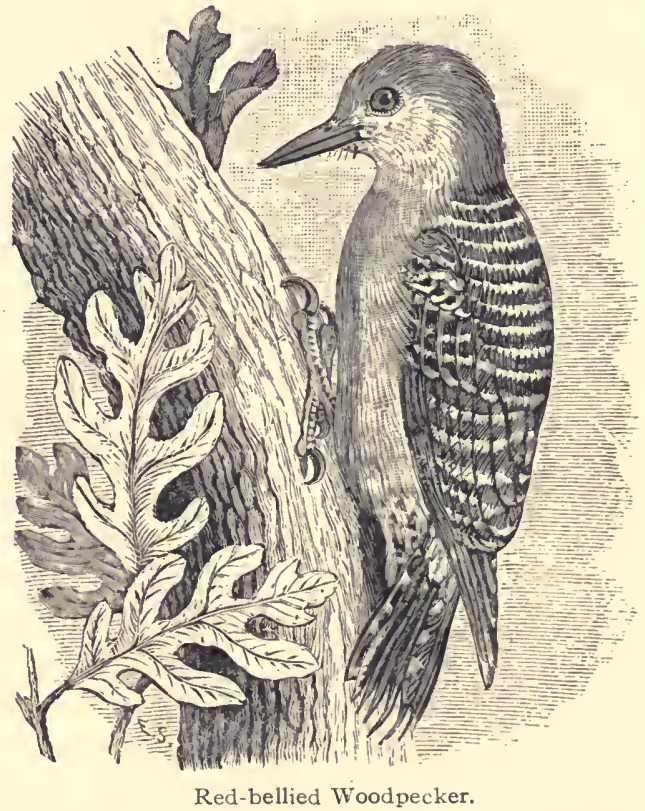

parts, ashy gray, more or less tinged with olive gray on the sides; middle of belly, red, and breast sometimes tinged with red; tail, black, the outer feathers and inner webs of middle feathers irregularly barred with white; basal half of primaries, white, marked with black; terminal half, dark brown. 
Adult female: Similar, but only the nape and feathers about the nostrils, red; the crown, ashy gray.

Immature birds have the belly tinged with buff.

Length, 9.40; wing, 5.10; tail, 3.25; bill, r.ro.

The Red-bellied Woodpecker is a rather uncommon resident in northern Illinois and Wisconsin, but common in southern Illinois, Mr. H. K. Coale observed a pair in Lincoln Park in July, and a few are observed every year in and about Chicago.

According to Kumlien and Hollister it has been found breeding several times in Jefferson County, Wisconsin. "The nesting sites were always in large, dead trees overhanging water and generally at a considerable height and very hard to reach. Mr. W. E. Snyder records three specimens from Dodge County in June, October, and November. We took a single specimen in Milwaukee County in May, I882, but in no part of the state have we found it as plenty as along the bottom lands of Koshkonong Creek, Jefferson County." (Birds of Wisconsin, 1903, p. 77.)

Breeds from April I 5 to June $\mathrm{I}$; nests in holes in trees and stumps. The eggs are white, four to six in number, and measure about $1.05 \mathrm{x}$ .75 inches.

The Field Museum collection contains a set of 3 eggs taken at Joliet, Illinois, May 26, I 906.

\section{Genus COLAPTES Swainson.}

197. Colaptes auratus luteus BAngs.

Northern Flicker.

Distr.: "Eastern and northern North America, south to North Carolina, west to the eastern base of the Rocky Mountains; occasional on Pacific slope from California northward." (A. O. U.)

Adult male: Top of head and sides of neck, ashy gray; a band of scarlet on back of the head (nuchal band); sides of head, whole throat and upper breast, lilac brown; a broad black band on the breast; a black submaxillary stripe (on the cheeks extending to base of the bill); back and exposed wing coverts, olive brown, with bars of black; under parts, whitish, shading to buffy white on the sides and marked with numerous round, black spots; upper surface of primaries, dark brown; the shafts of the feathers bright yellow; under surface of primaries, golden yellow; upper surface of tail feathers, blackish, some of them edged with buffy white spots, the shafts, yellow; under surface of tail, golden yellow, tipped with black; rump, pure white (conspicuous when flying); bill, horn color. 


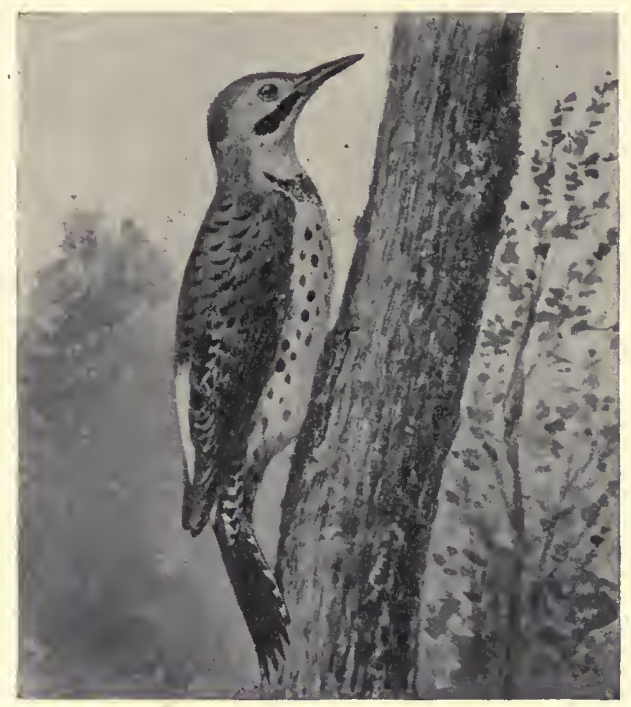

Northern Flicker.

Adult female: Similar, but lacking the black streaks on the cheeks. Immature birds are similar, but often show more red on the head.

Length, I2.50; wing, 6.10; tail, 4.50; bill, I.40.

An abundant summer resident in Illinois and Wisconsin, the majority arriving early in April and remaining with us until October. A few remain in northern Illinois all winter, and it is common in winter in the southern part of the state. Specimens are occasionally taken having the yellow on the tail feathers replaced by orange red, possibly due to reversion or hybridization of the eastern form with the red-shafted western species.

It breeds in May and early June. The nest is usually built in a hole in a tree, but occasionally in such places as hollow piazza posts or holes in roofs of summer houses. The eggs are usually from six to nine in number, pure white, and measure about $1.08 \times .85$ inches.

This species is known by various local names, such as High-hole, Yellow-hammer, Golden-winged Woodpecker, etc. The cry is loud and piercing, and it has a curious song or call which may be poorly described as wick-er-wick-er-wick-er-wick-er-wick-er. 


\section{ORDER MACROCHIRES.}

GOATSUCKERS, SWIFTS, ETC.

Suborder CAPRIMULGI. Goatsuckers, etc.

\section{Family CAPRIMULGIDÆ. Nighthawks, Whip-poor-wills, etc.}

Between 85 and 90 known species belonging to this family are distributed throughout the warmer parts of the globe. They are nocturnal in their habits, being rarely seen in the day time except when frightened from their hiding places in some wood or thicket.

Our species are strictly insectivorous, and they capture their food while on the wing. Their notes are characteristic and varied, some like the Whip-poor-will being well known. On account of their small and comparatively weak feet they rest lengthwise on a branch and do not perch in the manner of other birds.

\section{Genus ANTROSTOMUS Bonap.}

\section{Antrostomus carolinensis (GMEL.).}

CHUCK-WILL's-WIDOW.

Distr.: Southern United States, north to Virginia, southern Illinois, and Kansas; south to Cuba, Central America, and Colombia in winter.

Adult male: Plumage, soft; mouth, large; bill, small; lateral filaments to the bristles of the mouth; general color, pale rufous, or tawny brown, mottled with black, buff and dull white; crown, streaked with black feathers; throat, with a bar of buffy white; breast, darker than belly, but the entire under parts variegated with tawny, black and buff white, the prevailing color being tawny; primaries, black, heavily marked with rufous brown; tail feathers (except the four middle ones), with large spaces of plain white on upper surfaces.

Adult female: Similar, but no white on tail, the feathers being tawny rufous irregularly mottled and barred with black; breast band, tawny buff instead of whitish. 
522 Field Museum of Natural History-Zoölogy, Vol. IX.

Length, about I2; wing, 8.25; tail, 5.50; bill, .45.

The Chuck-will's-widow is a southern species which occurs casually in southern Illinois. Ridgway found it not uncommon as far north as Mount Carmel. (Orn. of Illinois, r889, p. 367.)

Mr. Otto Widmann states it is a fairly common summer resident in Missouri "from Perry County southwestward along the southern slope of the Ozark Mountains, from the latter part of April to the end of September" (Birds of Missouri, I907, p. I 28). It has not been observed in Wisconsin.

199. Antrostomus vociferus (WILs.).

-WHIP-POOR-WILL.

Distr.: Eastern North America, from Great Plains to the Atiantic, and from southern Canada to Mexico, Central America, and northern West Indies.

Adult male: Smaller than the preceding species, bristles of the mouth, without lateral filaments; plumage, soft; bill, small; mouth,

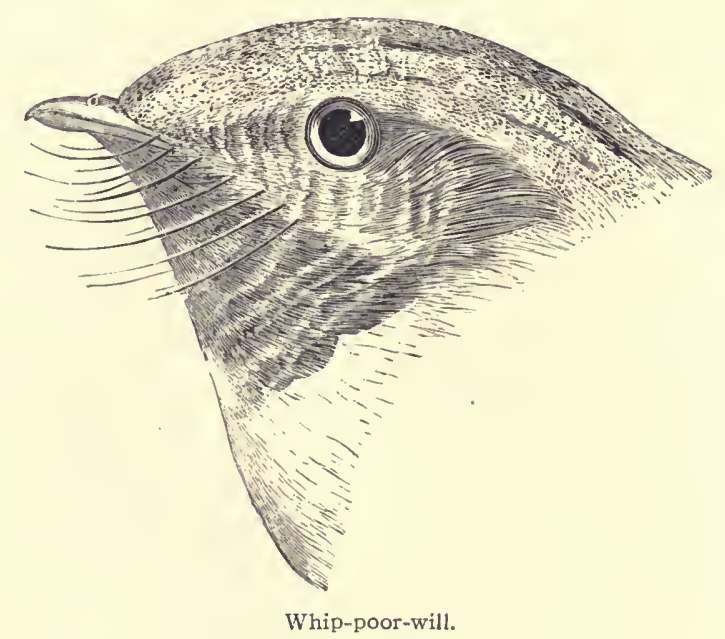

large; general plumage, mixed gray, tawny and black; the crown, streaked with black; throat, blackish, mixed with tawny; a narrow white band on the breast; belly, tawny buff, irregularly marked with black; primaries, dark brown, marked with imperfect rufous bars; tail, grayish, mottled with black and buffy white; the three outer feathers broadly tipped with white (the second and third for about two inches). 
Adult female: Similar, but outer tail feathers narrowly tipped with tawny, and throat band, pale buff instead of white.

Length, 9.50; wing, 6.10; bill, .35; tail, 4.75 .

The Whip-poor-will is a summer resident in Illinois and Wisconsin, where its familiar note is often heard, although the bird itself is rarely seen on account of its nocturnal habits. It usually arrives from the south late in April and nidification commences early in May.

The eggs are two in number, deposited on the ground. They are grayish white, faintly washed in places with pale lilac and showing a few pale brown spots. They measure about $1.20 \times .85$ inches.

\section{Genus CHORDEILES Swainson.}

\section{Chordeiles virginianus (Gmel.).}

NighthaWK.

Distr.: Eastern North America, west to the Great Plains, and from Labrador to the Gulf of Mexico; south to Argentine Republic in winter.

Adult male: Upper plumage, black, mottled more or less on the back with pale rufous, and on the wing coverts with gray and buffy

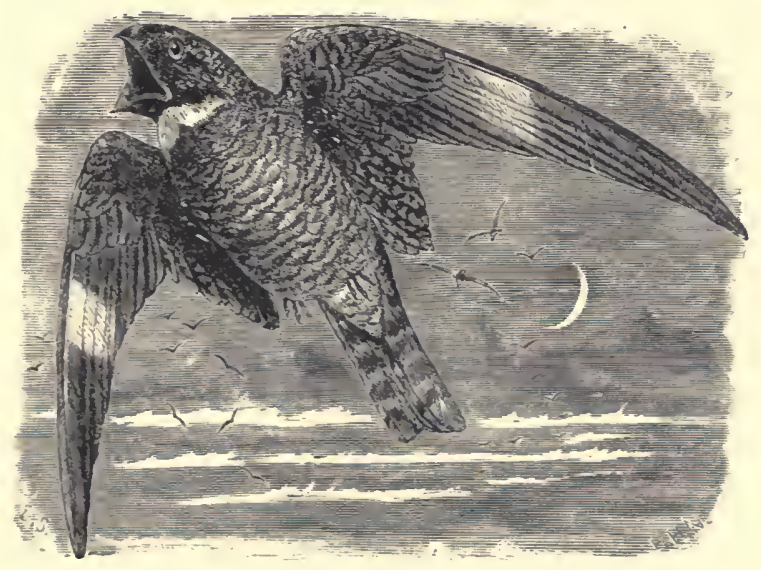

Nighthawk.

white; throat, white; breast, blackish, marked with pale rufous; belly, barred with black and white, and tinged with buff; primaries, blackish, with a single broad white bar (forming a conspicuous wing band when flying); tail, brownish black, more or less marked with buff and, with a broad subterminal, imperfect band of white. 
524 Field Museum of Natural History-Zoölogy, Vol. IX.

Adult female: Similar, but without white tail band, and the throat, tawny instead of white.

Length, about 9; wing, 8; tail, 4.55; bill, .25.

The Nighthawk is a common summer resident throughout Illinois and Wisconsin, arriving in May and leaving again in September. As soon as the sun goes down, it may be observed flying about in pursuit of insects, uttering at frequent intervals a loud, harsh " peet," the cry being immediately preceded by two or three hurried strokes of the wings. During the mating season the male makes a peculiar "booming" sound preceded by a downward rush or drop from a considerable height.

The majority breed in June and July. The eggs are two in number and are deposited on the ground or flat rock, occasionally on the roof of a house, without any attempt at a nest. They are dull white, speckled and marked with pale brownish gray, and measure about I.I $8 \times .85$ inches.

\section{0a. Chordeiles virginianus sennetti (Coves).}

\section{Sennett's Nighthawk.}

Distr.: Great Plains region, from Texas to the Saskatchewan.

Sennett's Nighthawk differs from the eastern form in having the upper parts paler and the under parts showing more white. Most of the specimens of the Western Nighthawk, C. v. henryi, which have been recorded as taken in Illinois and Wisconsin, are probably sennetti, although the variation in plumage is such that individuals occur which might be referable to either form. The range of the Western Nighthawk, $C . v$. henryi, is supposed to be from the Rocky Mountains to the Pacific Ocean, but prior to the year 1888 its range extended to Illinois, as the "plains" form, now known as sennetti, had not been recognized as separable from it.

In 1875 Nelson found what he considered to be $C$. $V$. henryi breeding in considerable numbers among the sand hills near Waukegan (I11.), but Ridgway (Cat. Bds. I11. I88I) states they were "merely somewhat pale examples of the eastern bird."

The late Captain Charles Bendire gives henryi as the prevailing form throughout the prairie regions of northern and central Illinois (Life Hist. Am. Bds., 1895 , p. 168) but as he does not recognize sennetti, the statement is open to question.

Kumlien and Hollister give henryi as occurring in Wisconsin, stating that there were three specimens in the Kumlien collection, one of which was sent to Dr. Coues for identification and pronounced typical henryi, but at that time sennetti was not recognized. 
A specimen labelled henryi in the Field Museum collection from Mr. C. K. Worthen taken at Fox Island, Missouri, is much nearer sennetti, and judging from specimens available for examination, the occurance of henryi, at least in Illinois, requires further confirmation.

Sennett's Nighthawk has been recorded from Iowa (Bartsch, Auk, I899, p. 86), Minnesota (Lano, Auk, I 898, p. 54), and has been found not uncommon in North Dakota (Bishop, Auk, r896, p. r 34 ).

The three forms may generally be recognized by the following characters, although there is often much variation in plumage:

C. virginianus: General plumage, dark, the black predominating on upper parts; under parts, barred with black and white in about equal amounts; very little rufous shown anywhere.

C. $v$. sennetti: Much paler; grayish white and brown, on upper parts; under parts, white, barred with narrow imperfect dark bars, the white predominating; very little or no rufous noticeable anywhere.

C. v. henryi: Upper plumage showing considerable tawny rufous marking; under parts, marked with tawny white and dusky black.

\section{Suborder CYPSELI. Swifts.}

\section{Family MICROPODIDÆ. Swifts.}

Swifts are often mistaken for swallows by those unfamiliar with birds, but are widely separated from them both in habits and structure. The sharp spines extending from the tail feathers and sooty brown plumage will readily distinguish the species which occurs in eastern North America.

A peculiar feature of this family is the wonderful development of the salivary gland, enabling the birds to salivate the material of which the nest is formed, not only sufficiently to glue it together but to attach it to a rock or brick wall, often-times a chimney. The young are fed by regurgitation. The edible birds' nests of China are made by birds of this family. About 50 species are known from various parts of the world. 


\section{Subfamily CHÆTURINÆ. Sharp-tailed Swifts.}

Genus CHæTURA Stephens.

201. Chætura pelagica (LinN.).

Chimney Swift.

Distr.: Eastern North America, north to Labrador, and the Fur Countries, west to the Great Plains and south to Central America in winter.

Adult: General plumage, sooty brown, showing a faint greenish tinge on the upper parts; throat, grayish or pale ashy; a black spot

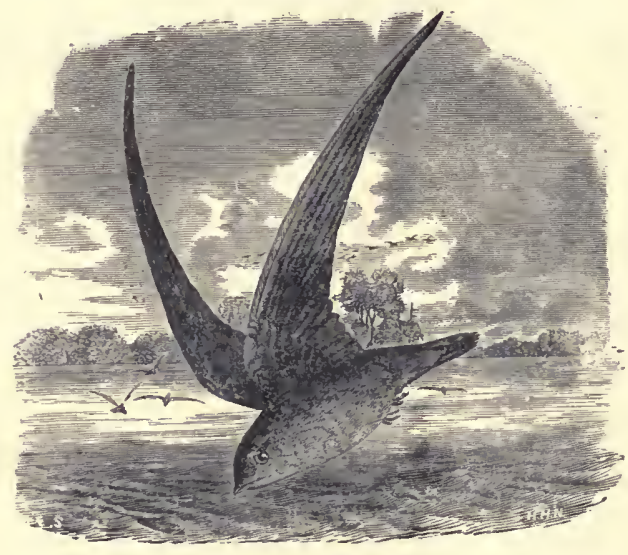

Chimney Swift.

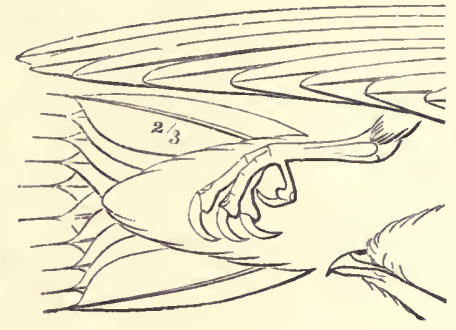

in front of the eye; tail feathers with sharp spines at the ends, formed by the shafts of the feathers extending beyond the webs.

Length, about 5.50 ; wing, 4.90 ; tail, r.85; bill, .I 8 .

The Chimney Swift is a common summer resident in Illinois and Wisconsin, usually arriving in April and leaving for the south in September or early in October.

Nests in chimneys and hollow trees. The nest is made of twigs glued together and fastened to the side of the chimney or tree by secretion from the bird's salivary glands. The eggs are white, usually five or six, and measure about $.85 \times .50$ inches. Nidification usually commences in May. 
Suborder TROCHILI. Hummingbirds.

\section{Family TROCHILIDÆ. Hummingbirds.}

Hummingbirds are peculiar to America, ranging from Alaska to southern South America. More than 400 species are recognized, most of which are restricted to tropical parts of South and Central America. Some I8 species occur in North America, but only one is found in eastern United States. When flying the rapid movements of the wings produce a distinct humming sound. The food consists largely of insects, but they also eat the juices of flowers.

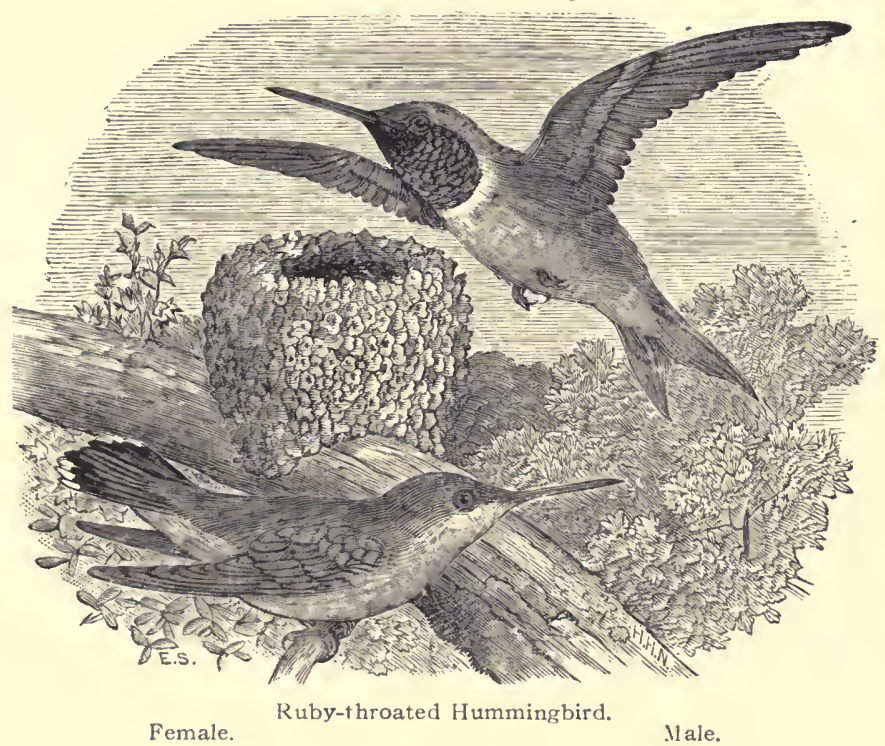

Genus TROCHILUS Linn.

202. Trochilus colubris LINN.

Ruby-throated Hummingbird.

Distr.: Eastern North America, from the Great Plains to the Atlantic coast, breeding from Labrador to Florida; south in winter to Cuba and Mexico.

Adult male: Upper plumage, golden green; wings and tail, dusky brown, tinged with purple when held in the light; throat, metallic 
528 Field Museum of Natural History-Zoölogy, Vol. iX.

ruby red, bordered with whitish on the breast; rest of under parts, dusky gray, tinged with green on the sides; tail, forked.

Adult female: Similar, but no red on throat; throat and under parts, whitish; tail with more or less black bars, the outer feathers tipped with white.

Immature males have the throat white, streaked with dusky, and the feathers of the upper parts more or less tipped with buff.

Length, 3.20; wing, r.65; bill, .65; tail, r.20.

This beautiful little species is a common summer resident in both Illinois and Wisconsin, arriving in May and the majority leaving for the south early in September. During the summer months they are often seen darting from flower to flower, thrusting their bills into the blossoms, extracting the honey and feeding upon the minute insects found therein. They show a partiality for the trumpet-shaped kinds such as the honeysuckle and begonia. They also catch very small insects with great dexterity while on the wing, and from time to time will perch to rest on some slender twig of bush or tree. The note is a faint cheep.

It breeds in late May and June. The nest is a dainty, little structure composed of plant down and lichens and built on a limb, usually from ten to twenty feet from the ground. The eggs are two, pure white, and measure about $.48 \times .35$ inches. The young are fed by regurgitation. 


\section{ORDER PASSERES.}

PERCHING BIRDS.

Suborder CLAMATORES. Songless Perching Birds.

\section{Family TYRANNIDÆ. Flycatchers.}

Some 350 species of Flycatchers are known belonging to this family and between 35 and 40 of these occur in North America. They frequent wooded localities, being rarely found away from trees or bushes. They are insectivorous, catching their prey while on the wing with great dexterity. They are pugnacious, especially during the breeding season, fighting among themselves and fearlessly attacking much larger birds which approach too closely the vicinity of their nests. The Kingbird seems to have an especial antipathy for the Crow, which it often pursues for a considerable distance.

\section{Genus MUSCIVORA Lacépède.}

\section{Muscivora forficata (GMel.).}

Scissor-tailed Flycatcher.

Milvulus forficatus (Gmel.), A. O. U. Check List, 1895, p. I80.

Distr.: "Texas, Oklahoma, Indian Territory, southern Kansas, and southwestern Missouri, south through eastern Mexico to Costa Rica; accidental in southern Florida (Key West), New Jersey, New England and at York Factory, Hudson Bay." (A. O. U.)

Adult: Tail, very long and forked: concealed crown patch, orange scarlet; head and back, pale gray; rump, grayish brown; throat and breast, white, shading into pink on the belly and sides; a patch of bright scarlet on the sides; wings, blackish brown, with pale edges to inner webs; the long outer tail feathers, pinkish white for twothirds of their length, the ends, dark brown; first primary, emarginate near the tip.

Length, 9.50; wing, 4.60; tail, 6 to ro (length very variable); bill, .65.

The Scissor-tailed Flycatcher must be considered an accidental straggler in Wisconsin. Not recorded from Illinois. 


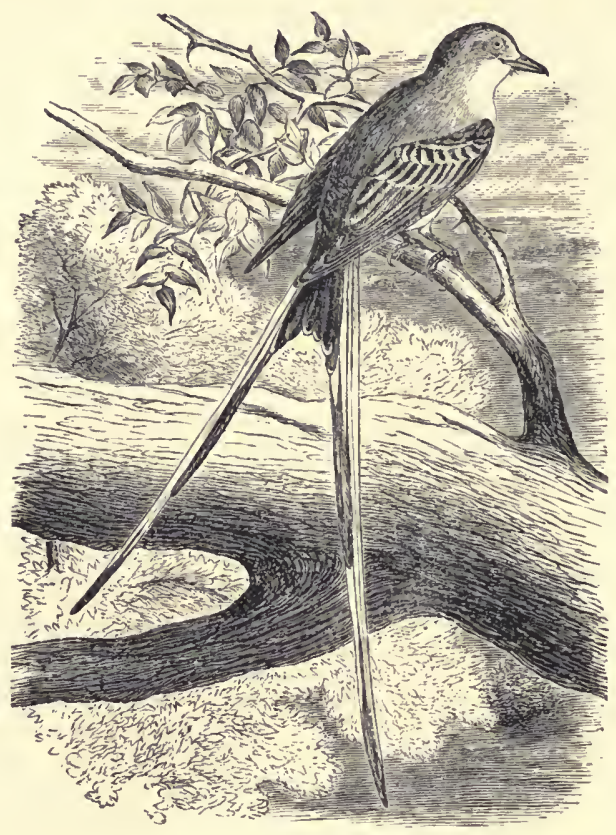

Scissor-tailed Flycatcher.

Kumlien and Hollister state: "The only record of the occurrence of this bird in Wisconsin is that of the single adult male taken by $L$. Kumlien, near Milton, Rock County, October I, I905. The bird was perched on a fence by the roadside and was shot as it flew away. Although a cold, blustering day, it seemed entirely at ease and was in perfect condition, being very fat. The specimen is preserved at Milton." (Birds of Wisconsin, I903, p. 80.)

\section{Genus TYRANNUS Cuvier.}

204. Tyrannus tyrannus (LinN.).

KINGBIRD.

Distr.: "North America, from the British Provinces south, in winter, through eastern Mexico, Central and South America. Less common west of the Rocky Mountains." (A. O. U.)

Adult: Top and sides of head, blackish, shading into dusky slate on the back; a concealed crown patch of fiery orange red; throat, white; breast, ashy, rest of under parts, white; first and second pri- 


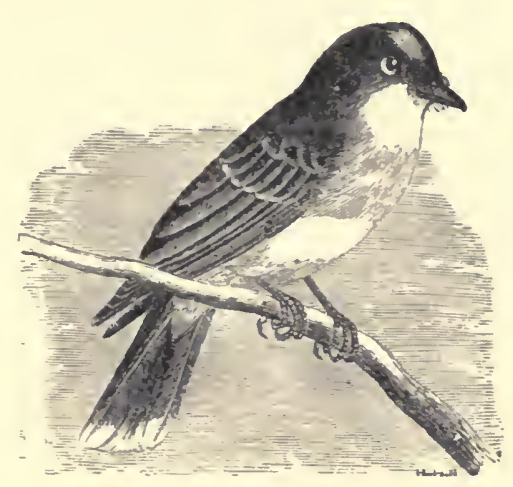

Kingbird.

maries, emarginate or "notched" near the ends; primaries, dark brown; tail, black, tipped with white. The sexes are similar.

Immature birds are without the orange red crown patch, and the outer primaries, not emarginate.

Length, 8; wing, 4.50; tail, 3.50 ; bill, .60.

The Kingbird is a common summer resident in Illinois and Wisconsin, arriving from the South late in April. It may often be observed perched upon a dead twig, watching for insects which it dashes after and catches with great dexterity while on the wing, when it will usually return to the same post of observation. The notes are a series of loud sharp twitters.

It breeds in May and June. The nest is composed of dry weeds, grass and moss, built on a limb, usually from ten to twenty feet from the ground. The eggs are four or five, dull white, spotted with dark brown, and measure about $\mathrm{r} .00 \mathrm{x} .75$ inches. There are contained in the collection of the Museum several sets of eggs taken at Joliet and about Chicago between June $\mathrm{I} 2$ and $\mathrm{r} 6$.

\section{Tyrannus verticalis $S_{A Y}$.}

Arkansas Kingbird.

Distr.: Western United States, from British Columbia to Mexico and Guatemala; accidental in Massachusetts, Wisconsin, Maryland, New Jersey, New York, and Maine.

Adult: Top and sides of head, gray, a concealed patch of fiery orange red; chin, whitish, rest of throat, gray; back, grayish olive; 
532 Field Museum of Natural History-Zoölogy, Vol. IX.

belly, yellow; primaries, dark brown, the first very much attenuated, the others gradually less so; outer web of outer tail feather, entirely white, rest of tail, dull black; bill, dark brown.

Immature birds lack the orange red patch on the head, and the primaries are not attenuated.

Length, 9.00; wing, 4.45; tail, 4 ; bill, .70.

The single specimen of this western species which has been taken within our limits is recorded by Messrs. Kumlien and Hollister: "An adult female was shot near Albion, Dane County, Wisconsin, June $x \mathrm{x}, \mathrm{I} 877$. The specimen is preserved in the Museum of Milton College." (Birds of Wisconsin, r903, p. 80.)

\section{Genus MYIARCHUS Cabanis.}

\section{Myiarchus crinitus (LinN.).}

Crested Flycatcher.

Distr.: "Eastern United States and southern Canada, west to Manitoba and the Plains, south through eastern Mexico to Costa Rica, Panama, and Colombia. Breeds from Florida northward." (A. O. U.)

Adult: Crown and back, dull olive; throat and upper breast, gray; belly and under tail coverts, yellow; primaries, brown, edged with

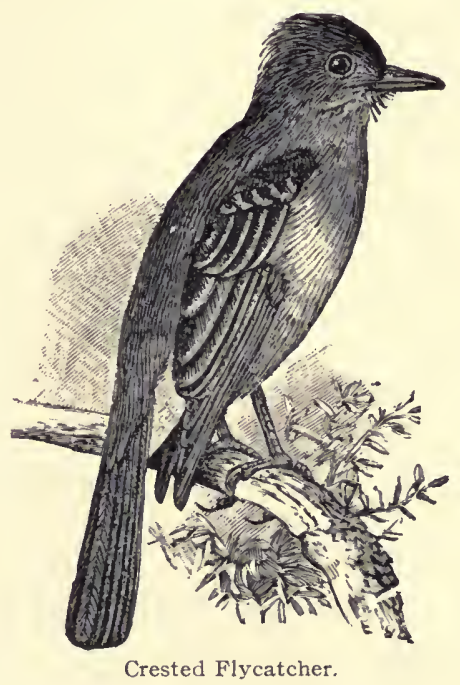

pale rufous; middle tail feathers, brown, rest of tail feathers have the inner webs rufous, the outer webs, brown. 
Length, about 8.50 ; wing, 4 ; tail, 4 ; bill, .75.

The Crested Flycatcher is a regular although not a common summer resident in northern Illinois and Wisconsin; more numerous in southern Illinois. The nest is placed in a hole in a tree, sometimes a deserted woodpecker's nest is used. The eggs are from four to six in number, dull white or cream white, streaked with chocolate brown. They measure about $.90 \times 1.70$ inches.

The Field Museum collection contains a nest and egg taken at Joliet,Ill., June I 2, I 906, and a set of five eggs at New Lenox (Chicago), Ill., June 27,1905 .

\section{Genus SAYORNIS Gray.}

\section{Sayornis phœbe (LAтH.).}

\section{Phebe Flycatcher}

Distr.: Eastern North America, west to Colorado and Texas, and from the British Provinces south to Mexico and Cuba in winter. Breeds from about the latitude of South Carolina northward.

Adult: Both mandibles, blackish; upper plumage, olive brown; the top and sides of the head, decidedly darker than the back; under parts, dull whitish, faintly tinged with very pale yellow, at times hardly noticeable; sides of breast, grayish brown; wings and tail dusky brown, the secondaries and outer tail feathers narrowly edged with white; a somewhat obscure whitish ring around the eye; primaries, not emarginate.

Length, about 7 ; wing, 3.25; tail, 3.15; bill, .50.

The Phœbe Flycatcher, or Phœbe as it is usually called, is an abundant summer resident in Illinois and Wisconsin, breeding throughout both states. In connection with its size, the dark brown or blackish lower mandible and the white outer vane of the outer tail feather will easily distinguish it from other local species.

It arrives from the south early in April and at once begins mating. The nest is rather large, composed of moss, grass and mud, and lined with hair and feathers. It is built on rocks, beams of old buildings, bridges, etc. The eggs are 5 or 6 , usually pure white, but sometimes showing a few dots or spots of brown. Size about $.82 \times .56$ inches.

The Field Museum collection contains the following sets of eggs from northern Illinois. I egg, Joliet, Ill., May 8, I906; 5 eggs, Chicago, Ill., May I I, I904; 5 eggs, Joliet, Ill., June I7, I905; 5 eggs, Joliet, I11., June 17, I906; 2 eggs, Chicago, Ill., June 27, I905. 
534 Field Museum of Natural History-Zoölogy, Vol. IX.

\section{Sayornis saya (Bonap.). \\ Say's PhєBe Flycatcher.}

Distr.: Western United States, from Dakota and Nebraska to the Pacific, and from Arctic Alaska south to southern California and Mexico; accidental in Illinois, Wisconsin, Iowa, and Massachusetts.

Adult: Upper parts, grayish olive brown; the head, darker, the feathers on the crown with dark centers; throat and breast, olive gray, shading into cinnamon brown on the belly; wings, brownish black, edged with whitish on the coverts and inner feathers; under wing coverts, buffy white; tail, entirely black; bill, black.

Length, about 7 ; wing, 3.75 to 4.30 ; bill, .55 .

An accidental straggler in Illinois and Wisconsin. Mr. E. W. Nelson records two specimens in the Northwestern University at Evanston from West Northfield, Ill., (Birds N. E. Illinois, I876, p. I 2 ); and Dr. T. M. Brewer states (Baird, Brewer, and Ridgway, N. A. Birds, Vol. II, I 874 , p. 349): “This species has been observed as far to the east as Racine, Wisconsin, where it was taken by Dr. P. R. Hoy. This specimen was sent to Mr. Cassin and its identity fully established."

\section{Genus NUTTALLORNIS Ridgw.}

\section{Nuttallornis borealis (Swarns.). Olive-sided Flycatcher.}

Contopus borealis (Swains.), A. O. U. Check List, I 895, p. I85.

Distr.: Distributed throughout North America, breeding from the mountainous regions of the United States to British Columbia, and accidental to Alaska and Greenland; in winter south to Central and South America as far as Peru.

Adult: Wing, longer than tail; upper parts, brownish olive; throat and middle of belly, whitish, usually faintly tinged with yellow; greater portion of breast and sides of body, brownish olive, the breast faintly streaked; primaries, dark brown; the secondaries and tertials, narrow, tipped or edged with whitish; tail, brownish black; upper mandible, brownish black; under mandible, mostly dull yellowish; a tuft of fluffy whitish feathers on the flanks, the last being a good character by which this species may be distinguished.

Length, about 7 ; wing, 3.85 to 4.30 ; tail, 3 ; bill .70.

The Olive-sided Flycatcher occurs as a rather uncommon migrant in Illinois and southern Wisconsin; and a casual summer resident in northern Wisconsin, where it breeds in the coniferous forests. 
The nest is composed of twigs and moss placed in a tree, usually near the extremity of a limb. The eggs are from four to five, pale lavender white, spotted at the larger end with rusty brown and lilac gray, and measure about $.84 \times .62$ inches.

\section{Genus MYIOCHANES Cabanis \& Heine.}

210. Myiochanes virens (Linn.).

Wood PEWEe.

Contopus virens (Linn.), A. O. U. Check List, I895, p. I86.

Distr.: Eastern North America, from the Plains to the Atlantic and from southern Canada to the Gulf; south in winter to Mexico, Central America, and northern South America. Breeds in eastern North America from Florida to Newfoundland.

Adult: Wing, longer than tail; under mandible, pale yellowish brown; upper mandible, brownish black; back, brownish olive; crown, dark olive brown, shading into the lighter color of the back; throat and belly, dull yellowish white; breast and sides of body, gray or olive gray; wings and tail, dark brown, the wing coverts narrowly edged with whitish.

Immature birds have the wing coverts edged with pale buff.

Length, 6.60; wing, 3.30; tail, 2.60; bill, .50.

The Wood Pewee Flycatcher is a common summer resident in Illinois and Wisconsin, usually arriving about the first of May.

It breeds in June. The nest is on a limb of a tree, usually from 20 to 30 feet from the ground, and is composed of grass, twigs, and moss, covered with green and gray lichens. The eggs are 3 to 4 in number, cream white or buff white, spotted at the larger end with umber brown and lilac gray, and measure about .70 x .54 inches. The Field Museum collection contains several sets of eggs taken in northern Illinois between June 2 and June 23. The notes of the Wood Pewee are very varied, but the most characteristic is the oftrepeated, high, plaintive whistle, $P e e-e-w e e$, from which it has derived its name.

\section{Myiochanes richardsonii (Swarns.). \\ Western Wood Pewee.}

Contopus richardsonii (Swains.), A. O. U. Check List, I895, p. I86.

Distr.: "Western United States, from the Plains to the Pacific, north to British Columbia and the interior of British America, south through Central America to Colombia." (A. O. U.) 
536 Field Museum of Natural. History-Zoölogy, Vol. IX.

The Western Wood Pewee differs from M. virens in being darker and less olivaceous above, and having the wings and tail averaging longer." While generally recognized as distinct, the differences between this and the preceding species are very slight.

Wing, 3.20 to 3.50 ; tail, 2.55 to 2.95 .

This species, if it occurs at all, can only be considered as an accidental straggler within our limits. It has apparently not been observed in Iowa or Illinois, although it is known to occur in western Nebraska and western Kansas.

It is included by Kumlien and Hollister who state: "Several typical western wood pewees have been taken at Lake Koshkonong. One pair with nest and eggs were identified by Dr. Coues as unquestionably of this species. Not reported by other observers at any point in the state and we can add nothing to the above bare facts.' (Birds of Wisconsin, I903, p. 82.)

\section{Genus EMPIDONAX Cabanis.}

212. Empidonax flaviventris BAIRD.

Yellow-Bellied Flycatcher.

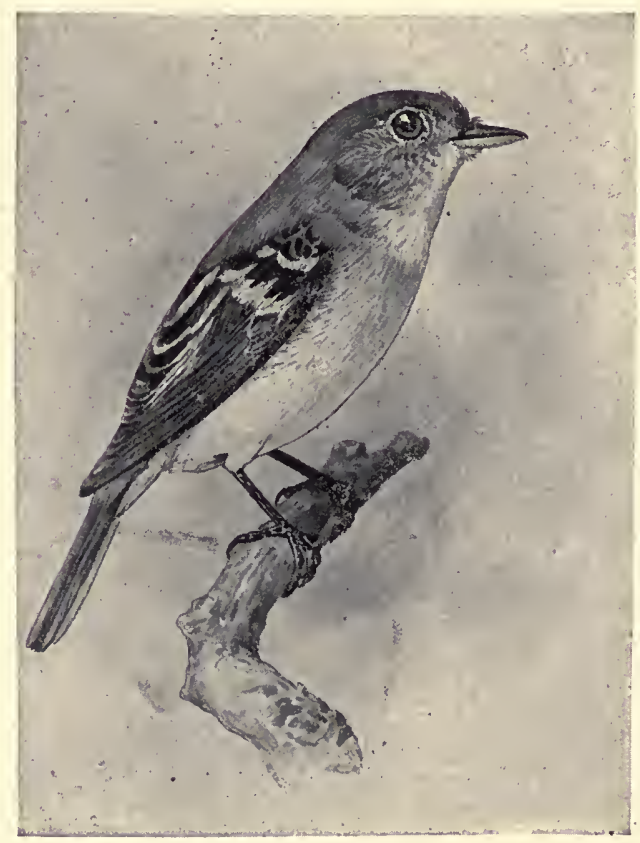

Yellow-bellied Flycatcher. 
Distr.: "Eastern North America, west to the Plains, and from southern Labrador south through eastern Mexico to Panama, breeding from the Northern States northward. Casual in Greenland." (A. O. U.)

Adult: Upper mandible, brownish black; under mandible, yellowish white; upper parts, olive green; throat and under parts, greenish yellow, tinged with olive on the breast and sides; wing coverts, tipped with yellowish white (buff in immature birds), forming distinct bands; eye ring, pale yellow.

Length, 5.60; wing, 2.60; tail, 2.18; bill, .37.

A not uncommon migrant in Illinois and Wisconsin and an occasional summer resident in the latter state, where it is known to breed. Thure Kumlien is recorded as having taken three nests and eggs from $\mathrm{I} 860$ to $\mathrm{I} 864$, and L. Kumlien procured a nest in a tamarack swamp near Albion, June 25, 1891.

The nest of this species is composed of moss and grass placed on an old log or mossy bank. The eggs are usually four, dull white, marked with cinnamon brown more heavily at the larger end. They measure about $.72 \times .52$ inches.

\section{I3. Empidonax virescens (VIEILl.).}

Green-crested Flycatcher. Acadian Flycatcher.

Distr.: "Eastern United States, north to southern New York and southern Michigan, west to the Plains, south to Cuba and Costa Rica. Rare or casual in southern New England (Hyde Park, Mass.)." (A. O. U.)

Adult: First primary, about as long as fifth; upper mandible, dark brown; under mandible, dull whitish or pale flesh color in life; upper plumage, clear olive green; under parts, whitish, washed with olive on sides of body and on the breast; throat, whitish; belly, generally tinged with pale yellow; eye ring and wing bars, buffy white or pale tawny white. Fall birds have the yellow somewhat brighter.

Length, 5.75 to 6.20 ; wing, 2.80 to 3 ; tail, 2.50 to 2.75 ; bill, .50 .

The Green-crested Flycatcher is a rather common summer resident throughout Illinois, where it breeds. Kumlien and Hollister do not include this species in their Birds of Wisconsin, but this Museum possesses a nest and eggs taken by Mr. John F. Ferry near Lake Forest, Illinois, and several specimens have been taken so near the Wisconsin line that there is little doubt of its occurrence, at least in the extreme southern portion of that state.

The majority breed in June in this latitude. The nest is a flat 
structure, usually placed near the end of a branch. The eggs are three to four (usually three) in number, cream white, speckled or spotted chiefly at the larger end with rusty brown, and measure about $.72 \times .52$ inches.

The Field Museum collection contains the following sets of eggs from northern Illinois: 3 eggs, Joliet, Ill., June 6, 1906; 3 eggs, Joliet, Ill., June 8, r9o6; 3 eggs, Joliet, Ill., June 9, r 906; 3 eggs, Joliet, Ill., June I6, I 906; 3 eggs, Joliet, Ill., June 24, r907; 3 eggs, Lake Forest, Ill., June 27, 1906.

Length, 5,50 to 6.10 ; wing, 2.70 to 2.85 ; tail, about 2.35 to 2.50 ; bill, about .45 .

\section{Empidonax traillii (AUD.).}

Traill's Flycatcher.

Distr.: "Western North America, from the Mississippi Valley (Ohio, Illinois, and Michigan) to the Pacific, and from the Fur Countries south into Mexico." (A. O. U.)

Adult: First primary, decidedly shorter than fifth; eye ring, and wing bars (formed by the pale tips of the greater and lesser wing coverts), ashy white; upper mandible, brownish black; under mandible, pale brown or horn color; upper plumage, olive brown, darker on the head; throat, whitish; breast and sides of body, washed with olive gray; belly, whitish, faintly tinged with pale yellow.

Length, 5.50 to 6.10 ; wing, 2.70 to 2.85 ; tail, about 2.35 to 2.50 ; bill, about .45 .

Traill's Flycatcher differs from the eastern race (E. t.' alnorum) in having the upper parts brownish olive (instead of greenish olive). There are other slight characters which are apparently inconstant, such as somewhat larger bill and browner wing bands.

A regular, but by no means common summer resident in Illinois and of casual occurrence in Wisconsin. Mr. F. M. Woodruff records a brood of young birds observed near Calumet Lake, Chicago, June ro, r896. Mr. Robert Ridgway found it breeding near Mt. Carmel, Ill., and Mr. B. T. Gault procured a nest and four eggs in Dupage Co., Ill. Kumlien and Hollister state (Birds of Wisconsin, r903, p. 83): "A specimen taken at Delavan (Wisconsin), August I, 1907, has been identified by Mr. Brewster as typical traillii. Perhaps occurs as a regular summer resident in parts of southern and southwestern Wisconsin; but more specimens will be necessary to satisfactorily determine its range and abundance."

The nest is cup shaped and is usually built in forks of upright branches of bushes or small trees. The eggs are from 3 to 4 , cream 
white, spotted and marked with rusty brown chiefly at the larger end, and measure about $.7 \mathrm{I} \times .52$ inches.

\section{I4a. Empidonax traillii alnorum BREWSTER.}

Alder Flycatcher.

Distr.: Eastern North America, from the Maritime Provinces and New England westward at least to Michigan, Wisconsin, and Illinois, breeding from the southern edge of the Canadian fauna (and probably northern Wisconsin) northward; south in winter to Central America.

Similar to Traill's Flycatcher, E. traillii, but differs in being more greenish olive above (instead of brownish olive as in traillii), the hind neck rather more gray and having the bill averaging smaller. The differences are slight and specimens occur which might be difficult to determine with certainty. Such specimens should be sent to a specialist for identification.

The Alder Flycatcher, while not common, occurs regularly in Illinois and Wisconsin during the migrations, and probably breeds in the northern portion of the latter state. Kumlien and Hollister state they have taken specimens in Wisconsin (identified by Mr. Brewster) in late May and June. In Illinois it seems to be more common in spring and fall than traillii. The Museum collection contains a number of specimens of this form taken in Illinois.

\section{Empidonax minimus BAIRD.}

Least Flycatcher.

Distr.: "Chiefly eastern North America, west to eastern Colorado and central Montana, south in winter, to Central America. Breeds from the Northern States northward." (A. O. U.)

Adult: Very similar to E. traillii, but smaller; wing less than 2.60 inches long (averaging about 2.45); first primary, shorter than fifth; eye ring and wing bars (ends of greater and lesser wing coverts), ashy white; upper mandible, brownish black; under mandible, pale brownish or horn color; upper plumage, olive brown; throat and belly, dull white, the latter with a trace of pale yellow; breast and sides of body, more or less tinged with brownish olive; primaries, dark brown, the edges of the inner webs, pale; tail, dark brown, but slightly lighter than the wings.

Length, about 5 to 5.50 ; wings, 2.30 to 2.58 ; tail, 2.05 to 2.40 ; bill, about $\cdot 37$. 
An abundant migrant in Illinois and a rather common summer resident in the northern part of the state. It is a common summer resident in Wisconsin, usually arriving early in May and leaving for the south in September.

It breeds in May or early in June. The nest is cup shaped, placed in the fork of a branch in bushes or low trees. The eggs are usually four, dull white, unmarked but sometimes showing a faint tinge of buff. They measure about $.62 \times .50$ inches.

\section{Suborder OSCINES. Song Birds. Family ALAUDIDÆ. Larks.}

The Larks form a comparatively small family of terrestrial birds frequenting the open plains and fields. They are gregarious except during the nesting season and have a pleasing song, although some species are much more gifted vocalists than others. The famous Europèan Skylark belongs to this family.

\section{Genus OTOCORIS Bonap.}

216. Otocoris alpestris (LINN.).

Horned Lark. Shore Lark.

Distr.: Northeastern North America, Greenland, and northern Europe, south in North America to Missouri and the Carolinas in winter.

Adult male: Forehead, throat, and line over the eye, yellow; front of crown, a stripe from bill below the eye and a shield-shaped patch on the breast, black; a small tuft of elongated feathers on each side of the head (hence the name,

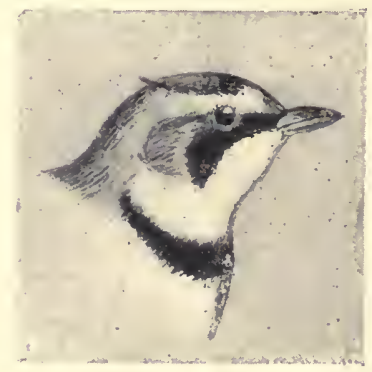
Horned Lark); back of crown, nape and rump, dull vinaceous; back, dull vinaceous, mixed with gray and more or less streaked with dark brown; lesser wing coverts, deep vinaceous or pinkish brown, forming a "shoulder" patch of that color; tail feathers, except the middle pair, black, the outer feather edged with whitish; outer primaries, fuscous brown, the outer web of the first primary, whitish. 
Female: Slightly smaller and plumage slightly duller. In fall plumage the black feathers on the breast are tipped with yellowish white.

Length, 6.80 to 7.50 ; wing, about 4.40 ; tail, 2.80 ; bill, .45.

The Horned Lark may usually be distinguished from the prairie form, $O$. a. praticola, by its larger size, the yellow stripe over the eye, and somewhat browner coloration.

It occurs as a winter visitant in Illinois and Wisconsin, but carn not be considered common. Nelson states that "it arrives in large numbers with the Longspurs in October and disperses over the prairies"; but Mr. Woodruff considers it a rare winter visitant in northeastern Illinois, which agrees with my experience, as the Museum does not possess a specimen of this species taken in the state.

In Wisconsin Kumlien and Hollister state that it is "found on the prairies during winter, ofttimes in considerable numbers."

In a series of eastern specimens the wing measurements are as follows:

Males, wing (carpus to tip), 4.25 to 4.50 inches.

Females, wing (carpus to tip), 4.05 to 4.40 inches.

\section{I6a. Otocoris alpestris praticola Hensh.}

Prairie Horned Lark.

Distr.: Upper Mississippi Valley and the Great Lakes region, breeding eastward to New England, south in winter to South Carolina, Texas, etc.

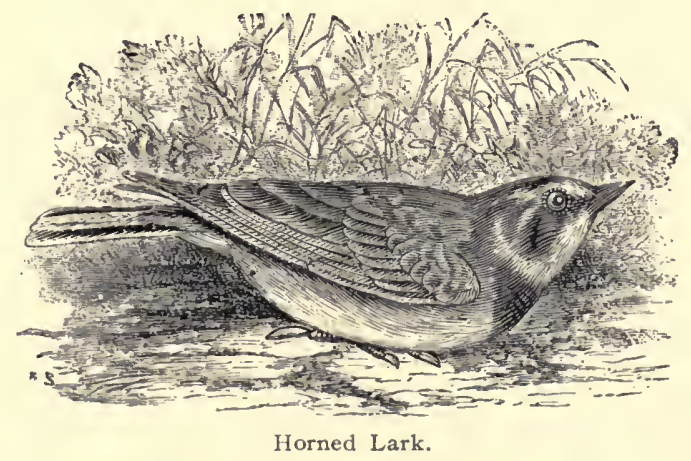

The Prairie Horned Lark differs from the eastern form, O. alpestris, in having the line over the eye whitish (not yellow), the throat but faintly tinged with yellow and in being somewhat smaller and paler. Wing, (carpus to tip) males, 4 to 4.25 inches; females, 3.75 to 4.20 inches. 
It is a common resident throughout the year in Illinois and Wisconsin, and is one of the few birds which may be observed in flocks on the open fields and prairies during the winter. It breeds in Illinois from March to May, more commonly in April, although the late Captain Charles Bendire states that it has been found breeding near Milwaukee, Wisconsin, as early as February 23. The nest is composed of grass placed on the ground. The eggs are 3 to 5 , pale olive or olive white, speckled and finely marked with pale olive brown, rarely with cinnamon brown. They measure about $.85 \times .60$ inches.

\section{2/6b. Otocoris alpestris hoyti Bishop.} HOYT'S HORNED LARK.

Distr.: British America, from Hudson Bay to Mackenzie River and from Athabaska Lake to the Arctic coast; south in winter to Kansas, Michigan, Ohio, and Wisconsin.

This form differs from the Prairie Horned Lark, O. a. praticola, in being larger and the vinaceous markings darker. The line over the eye (superciliary stripe) is whitish as in praticola, not yellow as in alpestris. Wing (males), 4.25 to 4.50 inches. The females are smaller and are often difficult to distinguish from the prairie form.

Hoyt's Horned Lark has not been taken in Illinois, but may occur as a straggler in winter, as it has been recorded from Michigan, Wisconsin, and Iowa.

Kumlien and Hollister state (Birds of Wisconsin, I903, p. 84): "Have carefully gone over our series from many parts of the state. We find, as a consequence, no less than three perfectly typical specimens of $O$. a. hoyti, all procured in winter in Rock County, from large flocks of alpestris. The birds are doubtless of rare but regular occurrence as late fall stragglers in many open prairie sections of the state."

\section{Family CORVIDÆ. Crows, Jays, Magpies.}

The Corvidæ are a large family numbering about 200 species distributed throughout the world. In North America they are represented by two subfamilies: Garruline, containing the Magpies and Jays, and the Corvine, or Crows and Ravens. The latter, although constantly persecuted by man, seem to be abundantly able to take care of themselves, as their numbers apparently do not materially decrease. 
The members of the family which occur within our limits prefer wooded parts of the country. They are omnivorous, eating grain, seeds, insects, and fruit, as well as eggs and young birds, etc.

\title{
Subfamily GARRULINÆ. Magpies and Jays.
}

\author{
Genus PICA Brisson.
}

\section{Pica pica hudsonica ( $\mathrm{S}_{\mathrm{AB}}$.).}

American Magpie.

Distr.: Greater portion of western North America, principally in sparsely wooded districts, from southern Arizona and. New Mexico to northwestern Alaska, east to Lake Winnipeg and the western portion of the Great Plains; accidental in Michigan, wisconsin, Illinois, Nebraska, and Iowa.

Adult male: Whole head, neck, breast and back, black, tinged with purple and gold when held in the light; belly, white; lower belly and crissum, black; a large white shoulder patch; outer primaries, mostly white, rest of quills, steel blue and greenish on outer webs; tail, very long, showing iridescent blue, green and purple; bill, black.

Not to be confounded with any other species except the western yellow-billed species, from which it differs in the color of bill.

Wing, about 8 ; tail, I I to I 2 inches long; bill, I.I 5 .

The American Magpie is of accidental occurrence in northern Illinois and Wisconsin. Kennicott* in 1854 considered it "not uncommon in winter" in Cook Co., Illinois. Mr. James O. Dunn in the Auk (Vol. XII, I 895, p. 395) states: "On the morning of Oct. I 7,1892 , Mr. Wallace Craig observed a magpie (Pica pica hudsonica) in a small grove not far from the World's Fair (Chicago). It was rather shy and was followed from tree to tree by some Blue Jays and House Sparrows. It may have been an escaped cage bird."

According to Kumlien and Hollister it is a rare winter visitant in Wisconsin. They write:

"The Magpie was doubtless formerly of more frequent occurrence in Wisconsin than during recent years. Dr. Hoy states that two were shot at Caledonia in December, I848, and one was obtained at Bailey's Harbor on Lake Michigan, November I 5, I 849 , by a gentleman from Racine. Mr. J. N. Clark of Meridian writes us that one was captured in a trap in Dunn County in 1870 and that he himself saw one in the same locality, at close gun range, in February, 1884.

* Trans. Ill. State Agr. Soc. for 1853-54-55, p. 585 . 
In the winter of $1859-60$, Thure Kumlien made a number of ineffectual attempts to shoot a specimen that came daily to feed on some hog offal that had been hung upon a neighbor's fence when butchering. $\mathrm{He}$ saw the bird plainly on two or three occasions when he did not have a gun. This was in Jefferson County. A specimen was also taken near Ashland in I880. Deer hunters from northern Wisconsin report seeing specimens, but very rarely. During severe winters they are 'sometimes seen about lumber camps. A pine-land hunter with whom we were acquainted, said he had seen perhaps half a dozen in all his experience of many years in northern Wisconsin." (Birds of Wisconsin, 1903, p. 84.)

\section{Genus CYANOCITTA Strick.}

218. Cyanocitta cristata (Linn.).

\section{Blue Jay.}

Distr.: Eastern North America to the Plains and from the Fur Countries south to eastern Texas, the Gulf coast and northern Florida.

Adult: Crown, bluish purple, the feathers elongated in the form of a crest and tipped with black; forehead and spot in front of the eye, black; back, bluish purple; throat, whitish; a stripe of black from

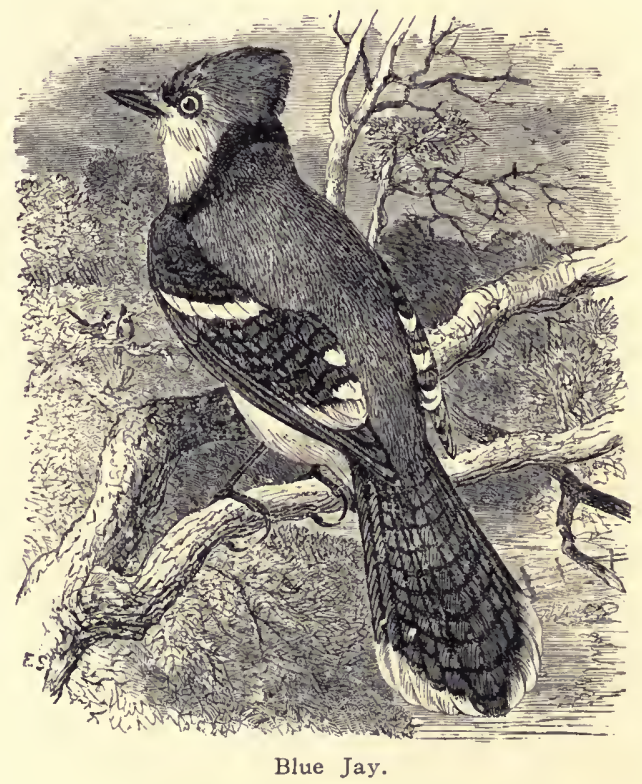


the head down sides of neck and joining, on the breast forming a black band; rest of under parts, buffy white, or grayish white; under tail coverts, white; wings, blue, banded with black, and the tips of the coverts and secondaries. white; tail, blue, middle feathers strongly banded with black; rest of tail feathers showing more or less black bands and broadly tipped with white; bill, black.

Length, I I to I 2 ; wing, 5 to 6 ; tail, about 5.30 ; bill, I.05.

The Blue Jay is a common resident throughout the year in Illinois and Wisconsin, being one of our most familiar birds. In addition to its harsh cry it has a peculiar bell like note, and on rather rare occasions, a delightful warbling song. The nest is usually built in the crotch of a tree and is composed of small interwoven twigs. The eggs are from 3 to 6 in number, pale olive or pale buff color with scattered markings and speckles of brown. They measure about $1.10 \times .82$ inches.

The Field Museum collection contains a number of sets of eggs taken in northern Illinois between May 8 and June 10.

\section{Genus PERISOREUS Bonap.}

\section{Perisoreus canadensis (Linn.).}

Caxada Jay.

Distr.: Northern border of the United States, from Wisconsin to the Atlantic Ocean northward to Arctic America.

Adult: Plumage, soft; back, dusky gray; forehead, sides of head and neck, and throat, whitish; back of head and nape, sooty black; lower breast and belly, ashy or ashy buff; primaries, dark brown; the

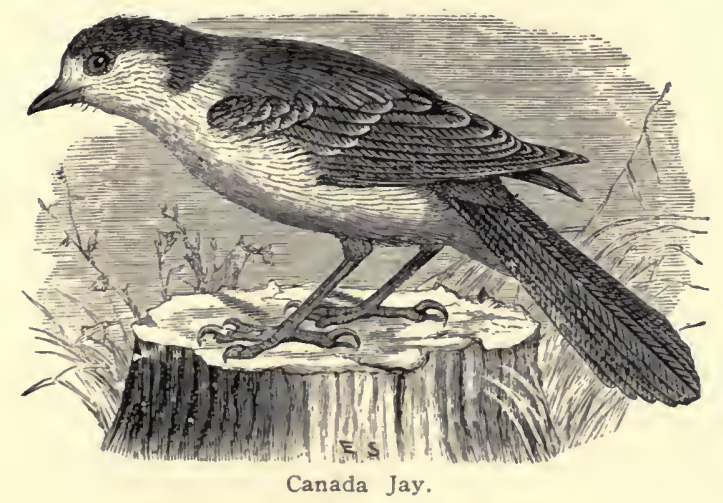


546 Field Museum of Natural History-Zoölogy, Vol. IX.

outer webs, slate gray and narrowly tipped with white; tail, ashy gray; tipped with white.

Length, about I0.5०; wing, 5.50 to 5.80 ; tail, 6 ; bill, .72.

The Canada Jay, while it is not known to range as far south as Illinois, is a common winter visitant in the pine regions of northern Wisconsin and accidental as far south as Racine. It may breed in northern Wisconsin as it has been found nesting near Mahoning, northern Michigan, by Mr. O. B. Warren (Auk, Vol. XVI, p. I 2), and in northern Minnesota (Cook, Bird Migr. Miss. Val., I888, p. I 58).

This is a familiar bird about logging camps in the north woods, where it is known by the name of "Camp-robber" and "Whiskey Jack."

\section{Subfamily CORVINÆE.}

Genus CORVUS Linn.

\section{Corvus corax principalis RIDGW.}

\section{Northern Raven.}

Distr.: Northern North America, south to British Columbia Michigan, Wisconsin, New Brunswick, and Maine, casual in Illinois. Replaced by the American Raven (C. c. simuatus) in the western United States, from Missouri, southern Illinois, and central Mississippi Valley west to California and south to Mexico and Guatemala.

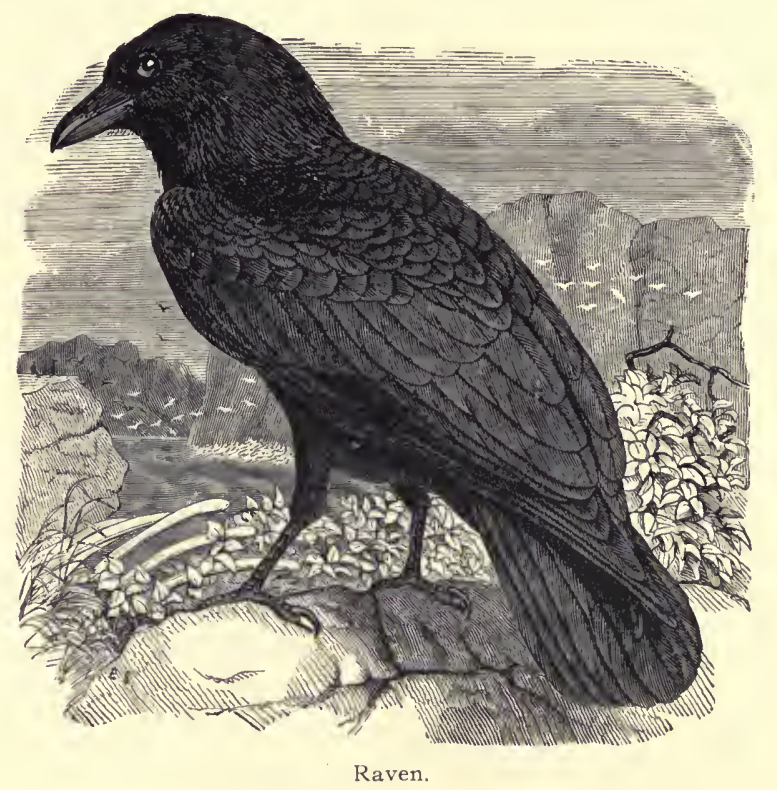


Adult: Entire plumage, blue black; throat feathers, elongated and attenuated; sexes, similar.

Length, 2 I to 25 or more; wing, I 6 to 18 ; tail, about ro; bill, 2.50 .

The difference between the Northern and American Ravens is mainly one of size, the northern form being larger and the bill relatively larger and broader; but intermediate specimens occur which are apparently indistinguishable. Under the circumstances, for the present at least, until a series of specimens can be obtained from the different localities, it may be well to consider Wisconsin and northern Illinois specimens as principalis and those from southern Illinois as simuatus.

According to Mr. Nelson (Birds N. E. Ill., I876, p. I I 2) the Raven was "formerly a not uncommon resident, now only occurs in winter and is rare. Frequents the sand hills along the lake shore from the last of October until spring. The first of November, I875, I saw several specimens near Waukegan, where they were repeatedly seen flying along the lake shore and also eating the dead fish found there." Mr. Frank M. Woodruff procured a bird of this species at Meredosia, I11., on Oct. 23,1892 . The specimen was examined by Prof. Ridgway and pronounced principalis (Auk, $\mathrm{r} 896, \mathrm{p} .83$ ). The form which occurs in Missouri, however, is apparently the American Raven (C. c. sinuatus), as Mr. Otto Widman gives it as formerly a permanent resident in that state and records a set of five eggs having been taken by Mr. Philo W. Smith, Jr., at Hahatonka, Camden Co., Missouri, on April 5, r 90 r (Trans. Acad. Sci. of St. Louis, 1907, p. 147), so that it is not unlikely that both forms may still occur in Illinois.

Mr. Ridgway states (Birds of Illinois, r889, p. 331): “The Raven is a very local and nowhere abundant bird in Illinois. The writer has seen it only in the bottoms of Big Creek and about the borders of Fox Prairie, in Richmond Co., where up to 187 I at least one or two pairs might be seen at almost any time, usually soaring in circles over the timber." Mr. H. K. Coale writes me he observed a Raven at Highland Park, Ill., in the spring of 1908.

In Wisconsin according to Kumlien and Hollister, the Northern Raven (C.c.principalis) is not uncommon. They write (Birds of Wisconsin, I903, p. 85): "Steadily decreasing in numbers, but yet rather a common species in the less settled portions of northern Wisconsin. Dr. Hoy, in $185^{2}$, gave it as more numerous than the next at Racine. It has always been considered as more common along Lake Michigan than in the interior, except in the northern part of the state. $* * *$ King gives it as 'common the whole length of the Flambeau River, October and November, 1877 , several seen daily.' Willard reports 
but one specimen from Brown County, and Grundtvig, one from Outagamie County, in I882. Grundtvig, on the authority of residents, states that it was formerly common in that county. Thirty to forty years ago the raven was not a rare winter visitant to southern Wisconsin, but of late years it is rarely seen. A single specimen shot at Lake Koshkonong, November, I89r, by L. Kumlien and mounted for Albion Academy, is the last real record we have, although others have been 'seen.' We have met it at several points in northern Wisconsin in late fall and winter, but more often along Lake Michigan and Lake Superior than elsewhere. It is really common at several points along Lake Superior, where it seems to replace the Crow entirely. It is commonly found around the lake fishing stations." Mr. J. B. Mann of Woodruff, Vilas County, Wisconsin, who is well acquainted with the Raven, informs me that a few are seen every winter in that vicinity.

The nest is large and bulky, composed of sticks and weeds, usually built on trees or rocky cliffs. The eggs are from 3 to 7 , greenish or pale olive, thickly marked with brownish and olive. They measure about $2.03 \times \mathrm{I} .37$ inches.

\section{Corvus brachyrhynchos BREHM.}

AMERICAN CROW.

Corvus americanus Aud., A. O. U. Check List, I 895, p. 200.

Distr.: North America, from British America to the Gulf of Mexico.

Adult: General plumage, shiny black, the head, rather dull black; the female is similar to the male, but smaller.

Length, I 7 to I 9 ; wing, I 2 to $13.5 \circ$; tail, 6.50 to 8 ; bill, I.70 to 2 .

This well known species is an abundant resident in Illinois and Wisconsin. In spite of his reputation as an undesirable citizen and although every man's hand is against him, the Crow seems eminently able to take care of himself, and his numbers do not appear to materially lessen.

They seem to entertain an intense dislike to certain animals, especially an owl. Often the peaceful quiet of the woods is suddenly broken by the harsh excited "cawing" of a flock of crows, who have discovered a bird of that species quietly enjoying his diurnal siesta, and the din rarely ceases until the hated bird has been driven from his concealment and forced to seek other quarters.

It breeds in April and early in May. The nest is a bulky structure, composed of sticks and grass, placed in a tree, usually at some distance from the ground. The eggs are 4 to 6 , usually bluish green or 


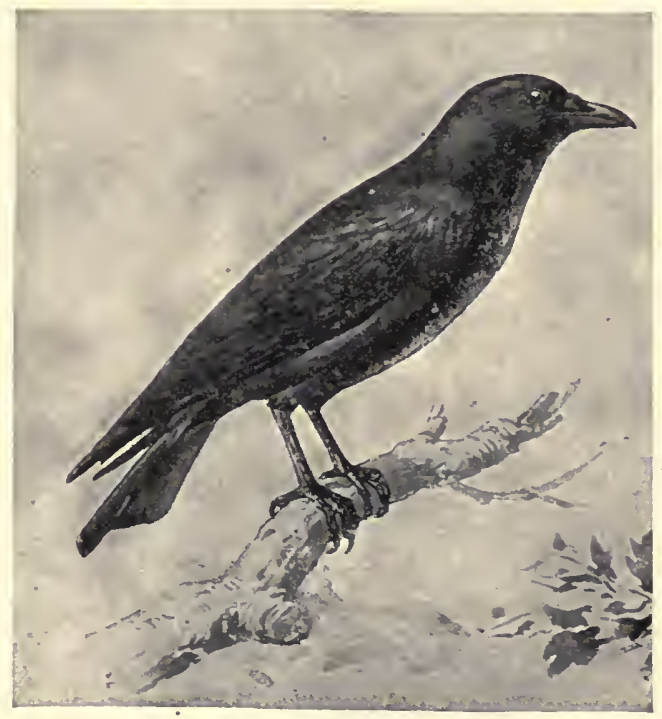

American Crow.

grayish green, thickly marked with different shades of dull brown, and measure about $1.64 \times 1.20$ inches. The Field Museum collection contains a number of sets of eggs taken in northern Illinois between April 17 and May 19.

\section{Genus NUCIFRAGA Brisson.}

Subgenus PICICORVUS Bonap.

222. Nucifraga columbiana (Wils.).

Clarke's Nutcracker.

Distr.: "Higher coniferous forests of western North America, from the eastern slope of the Rocky Mountains to the Pacific, and from Putnam River, Alaska, south to Arizona and northern Lower California. Accidental in Kansas, Missouri and Arkansas," (A. O. U.) Wisconsin.

Adult: General plumage, pale ashy gray; dull white on forehead, chin and about the eyes; primaries and middle tail feathers, black, more or less tinged with blue black; tips of secondaries and outer tail feathers, white; bill, black.

Length, about I 2.50; wing, 7.50; tail, 5.20; bill, I.40. 
$55^{\circ}$ Field Museum of Natural History-Zoölogy, Vol. IX.

This western species is included in our list upon the authority of Messrs. Kumlien and Hollister, who state: "A specimen of Clarke's crow was shot by Mr. Hawley, in the western outskirts of Milwaukee (Wisconsin) in the late fall of 1875 . The bird was too badly shot to make a good skin and it came into the possession of Dr. G. W. Peckham, who made a skeleton of it himself. The specimen, with the exact date, etc., was later destroyed by the disastrous high school fire in that city." It has not been observed in Illinois.

\section{Family ICTERIDÆ. Blackbirds, Orioles, etc.}

The Icteridæ are an American family, comprising about I 50 species, varying much in appearance and habits. The Blackbirds, Meadowlarks, etc., are more or less gregarious, while the Orioles are rather solitary. Some species (the Orioles) build a pensile nest attached to branches; others, like the Marsh Blackbirds prefer swamps, while the Meadowlark makes its nest on the ground in open fields and plains.

All are vocalists of more or less excellence. Their food consists of seeds and insects, although at times they eat fruit. One species, the Bobolink, becomes very fat while in the south, where it is known as Rice Bird and Reed Bird, and is there considered a great delicacy.

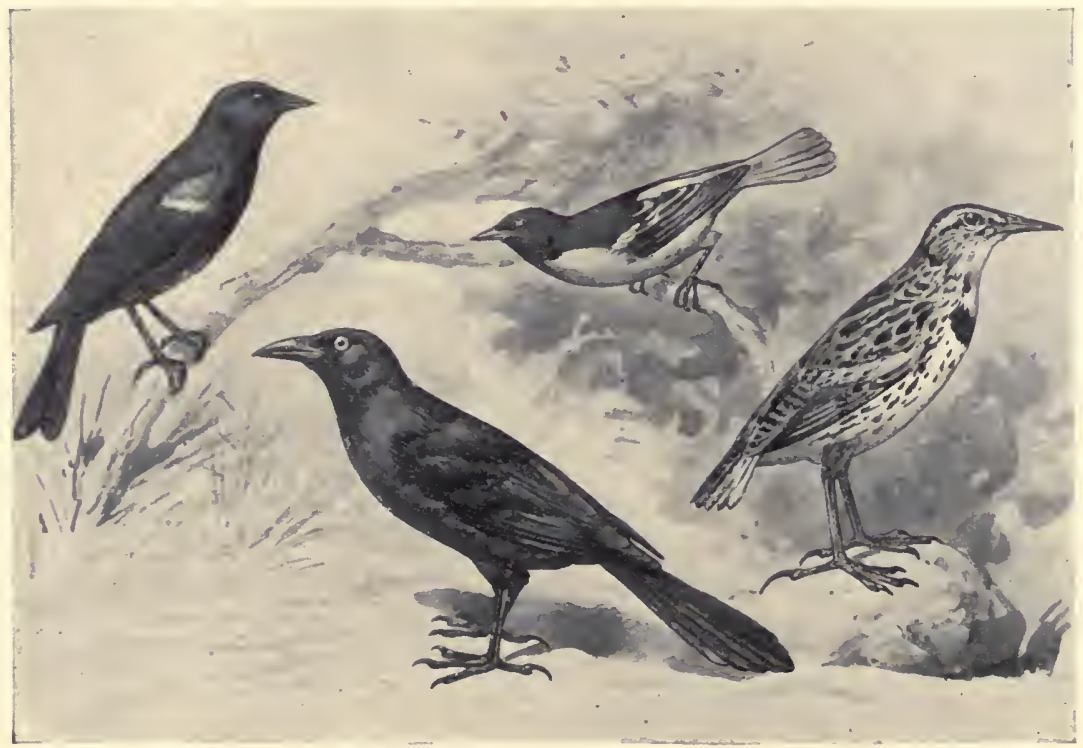

Red-winged Blackbird.

Grackle.

Oriole.

Meadowlark. 


\section{Genus DOLICHONYX Swainson.}

\section{Dolichonyx oryzivorus (LiNN.).}

\section{BOBOLINK.}

Distr.: Ranges in North America from the Atlantic coast west to Utah and Montana, north to Ontario, south to Florida and the Gulf coast; winters in South America.

Adult male in spring: Head, throat and under parts, black; the feathers of under parts, either edged with pale buff or entirely black,

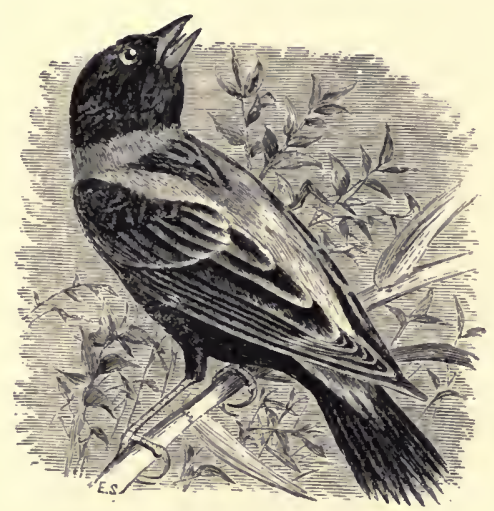

Bobolink.

according to season; a patch of pale tawny or tawny buff on back of neck; upper back, black, with tawny streaks down into the middle; most of scapulars, lower back and rump, whitish; primaries and tail feathers, black, the latter narrowly tipped with gray and the middle feathers sharply pointed.

Adult female in spring: Upper parts, olive buff, streaked with black; a streak of olive buff on middle of crown; under parts, yellowish buff; the throat, pale; sides of body, streaked with black. Somewhat smaller than the male.

Adult male in fall: Plumage similar to the spring female, but rather more buffy.

Male: Length, 7 to 7.40 ; wing, 3.60 to 3.80 ; tail, 2.75 to 3 ; bill, .50.

Female: Length, 6.60 to 7.10 ; wing, 3.30 to 3.60 ; tail, 2.80 ; bill, .45.

The Bobolink is an abundant migrant in southern Illinois, and 
a common summer resident in northern Illinois and Wisconsin, breeding in open meadows. It arrives from the south about the first of May and nidification commences the latter part of May or early in June. The song of the Bobolink is a delightful medley impossible to describe and is often uttered while the bird is poised high in the air or slowly descending to the ground.

The nest is of grass, built on the ground or in a tussock of grass in fields and meadows. The eggs are 4 to 7 , dull white or buffy white, thickly blotched and spotted with dark brown and a few lines and spots of blackish, and measure about $.82 \times .62$ inches.

The Field Museum collection contains a number of sets of eggs of this species taken in the vicinity of Joliet and Chicago, I1l., between May 28 and June 8.

\section{Genus MOLOTHRUS Swainson.}

\section{Molothrus ater (BODD.).}

COWBIRD.

Distr.: Whole of the United States, and north to southern British America; south to Mexico in winter.

Adult male: Head, neck, and breast, seal brown; rest of plumage, bluish black, with purplish and greenish reflections; bill and feet, black.

Adult female: General plumage, brownish gray, darker above than below; throat, pale ashy gray, decidedly lighter than rest of under parts; wings and tail, dark brown.

Length, 7.85 ; wing, 4.28 ; tail, 3 ; bill, .62.

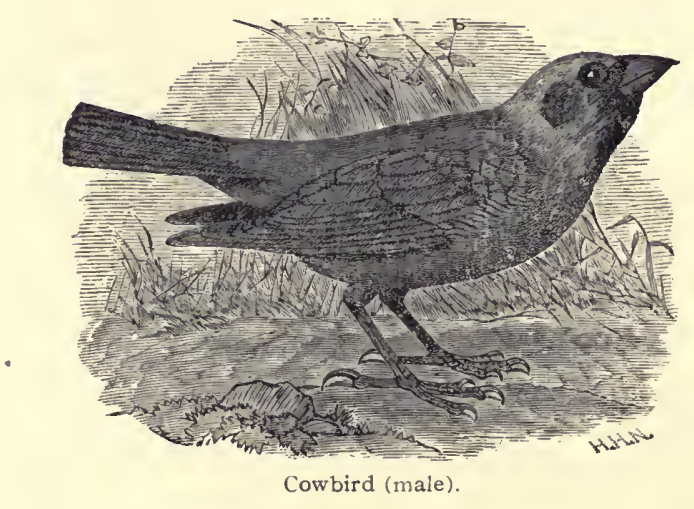


The Cowbird is a common summer resident throughout Illinois and Wisconsin. The female builds no nest of her own, but deposits her eggs in the nests of other birds, usually selecting that of some bird smaller than herself.

The Yellow Warbler, which is included in the list of desirable species by the Cowbird mother to relieve her of domestic cares, often gets the better of her undesirable visitor by building a second story to her nést, thereby covering the despised egg. Instances are known where the rightful owner, to avoid being forced to start an avian eleemosynary institution, was compelled to build a third and even a fourth story to her nest before she was left in peace to attend to her own family duties. Usually one, sometimes two, and rarely three or four eggs are left to be incubated and the young reared by the foster mother. A nest of the Scarlet Tanager, taken by Dr. N. Dearborn at Fox Lake, Ill., on June I 4 , I903, contained the remarkable number of six, well incubated Cowbird's eggs and none of the rightful owner. When found, the female Tanager was on the nest. The eggs are dull white, or pale buff, irregularly and thickly marked with brown, and measure about $.87 \times .66$ inches.

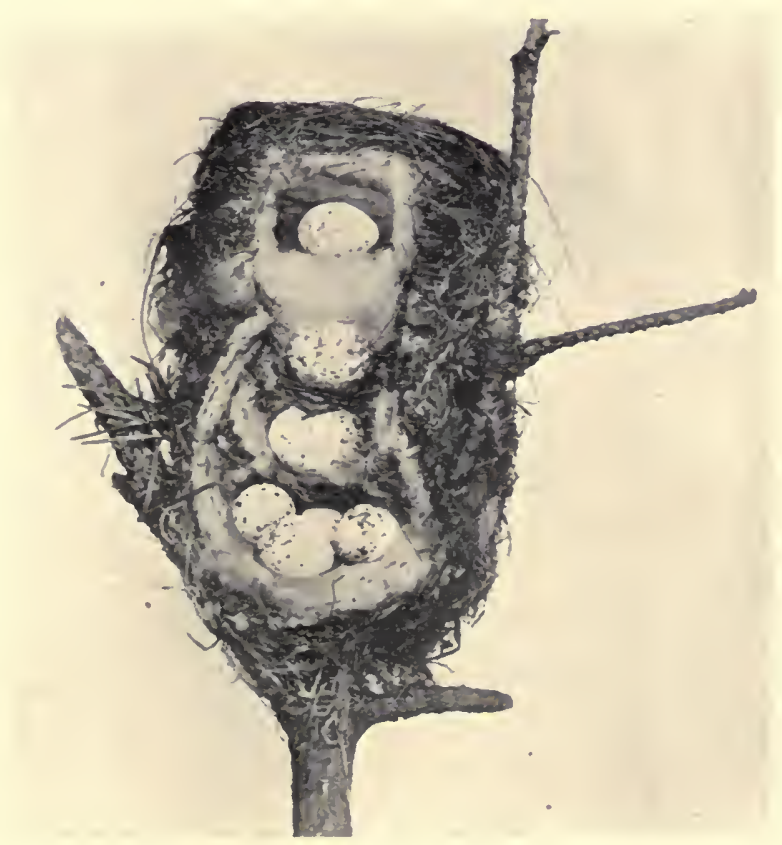

Section of four-story nest of Yellow Warbler in which Cowbird's eggs have been deposited. 
554 Field Museum of Natural History-Zoölogy, Vol. IX.

The Field Museum collection contain nests and eggs of the following species in which one or more eggs of the Cowbird have been deposited:

Scarlet Tanager (2 nests), Song Sparrow (5 nests), Yellow Warbler (3 nests), Bobolink, Bell's Vireo, Red-eyed Vireo, and Maryland Yellow-throat. The late Captain Charles Bendire in his Life Histories of North American Birds gives a list of 9I different species in whose nests Cowbird's eggs have been found, including among them Mourning Dove, Yellow-headed Blackbird, Kingbird, and, strange to say, Red-headed Woodpecker.

\section{Genus XANTHOCEPHALUS Bonap.}

\section{Xanthocephalus xanthocephalus (BonAP.).}

YELLOW-HEADED BLACKBIRD.

Distr.: Western North America, from Indiana, Illinois, and Wisconsin west to the Pacific coast, north to British Columbia and south to Mexico; accidental on the Atlantic coast.

Adult male: Whole head, neck, and breast, orange yellow; chin, and around the eye, black; primary and greater secondary coverts, white, forming a white wing patch; rest of plumage, black.

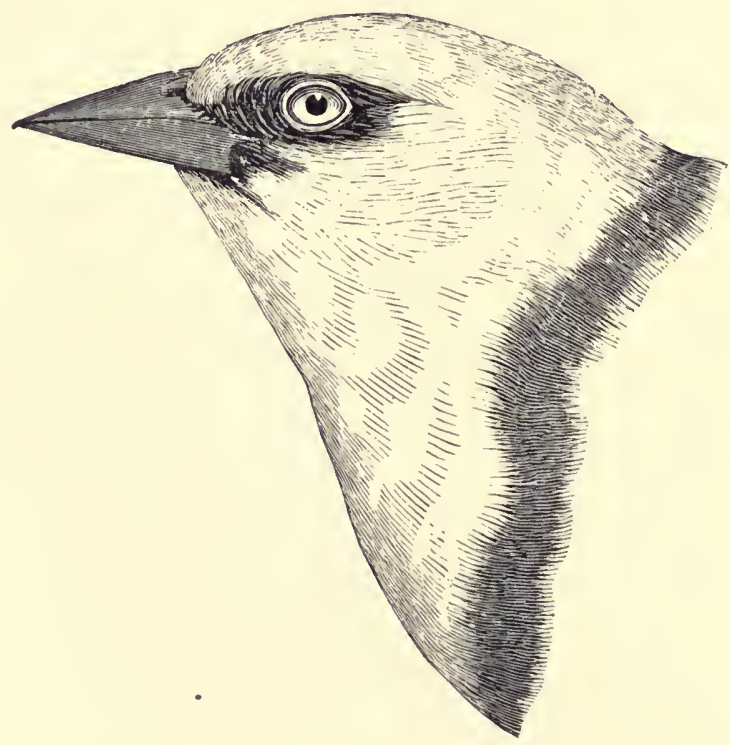

Yellow-headed Blackbird (male). 
Adult female: Smaller than the male; general plumage, dark brown; a line over the eye; cheek patch and throat, including upper breast, washed with dull yellow; wing and tail, dark brown; lower breast usually with more or less dull white streaks; no white on the wing.

Male: Length, about ro; wing, 5.60; tail, 4.50 ; bill, .78.

Female: Length, about 8 ; wing, 4.90 ; tail, 4 ; bill, .66.

The Yellow-headed Blackbird is a summer resident in northern Illinois and Wisconsin, breeding in open swampy places. It seems to be somewhat local in its distribution, being common in some localities and rare or absent in other and intermediate points, where the conditions are apparently the same. This species was once abundant in the vicinity of Chicago about Calumet Lake and is still not uncommon in that locality. Numerous colonies were found breeding near Fox Lake in 1907 and 1908.

Kumlien and Hollister state that it breeds abundantly in Wiscon$\sin$ in some sections of the State, while in others it seems to be totally absent.

The nest is composed of grass and weeds attached to reeds or in low bushes in swamps or marshes. The eggs are from 3 to 6 , grayish or grayish white, speckled with pale cinnamon brown and occasionally with a few fine irregular lines of black, and measure about I.०० $\mathrm{x} .7 \mathrm{I}$ inchẹs.

\section{Genus AGELAIUS Vieill.}

\section{Agelaius phœniceus (LINN.).}

Red-winged BlackBIRd.

Distr.: Eastern United States and southern British provinces, except the Gulf coast and Florida; west to the great plains.

Adult male: General plumage, glossy black; lesser wing coverts, scarlet red, bordered with buffy white, forming a brilliant red "shoulder" patch; bill and legs, black.

Adult female: Upper plumage, rusty brown and black; the exposed portion of the feathers of the back being black edged with rusty; a buffy stripe over the eye; under parts, dull white or buffy white, streaked with black; wing, dark brown, edged with buff; tail, dark brown.

Male: Length, about 8.25 ; wing, 4.50 to 4.80 ; tail, 3.60 ; bill, .80 to .92 .

Female: Length, about 8 ; wing, 3.84 to 4.05 ; tail, 3.50 ; bill, .68 to .80 . 


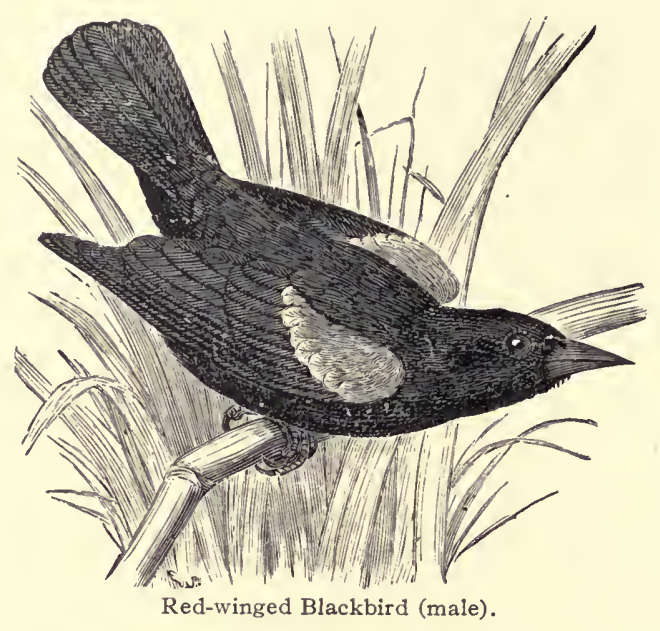

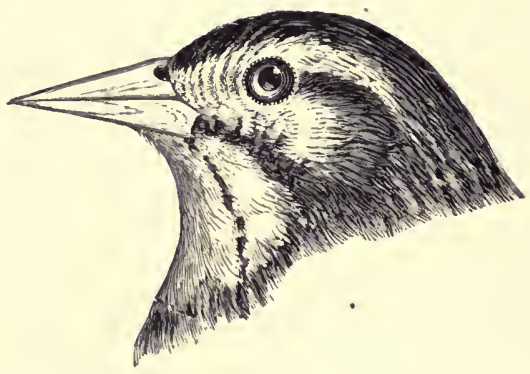

Female.

The Red-winged Blackbird is an abundant summer resident in Illinois and Wisconsin, frequenting swampy places and breeding throughout both states. It arrives from the south in March and leaves in October. The note is a loud chuck, while its song is a medley of metallic vocal sounds beyond description.

The nest is of dry grass, built in reeds or on branches of bushes and low trees bordering marshes or ponds. The eggs are from 3 to 5 in number, pale blue or grayish marked and scrawled with black, dark brown, and purplish gray. They measure about .98 x .70 inches.

The Field Museum collection contains a number of sets of eggs of this species taken near Joliet, Illinois, between May $2 \mathrm{r}$ and June I4.

226a. Agelaius phœniceus arctolegus Oberholser.

Arctic Red-winged Blackird.

Distr.: "Montana, North Dakota, Minnesota, and northern Michigan; north to Kewatin, Athabaska, and Mackenzie; in migration south to Colorado, Texas, Illinois, and probably Ohio." (Oberholser, Auk, r907, p. 332.) 
Mr. Oberholser has lately described this geographical race of the Red-winged Blackbird, which is apparently indistinguishable from the eastern form, except by size. According to Mr. Oberholser, A. p. fortis Ridgway occupies the plains from northwestern Texas to Colorado, Nebraska, and Wyoming, and the large form which has been recorded from Illinois is arctolegus. In a series of specimens representing the two forms the measurements are as follows:

Agelaius phoniceus, $0^{\top}$, wing, 4.50 to 4.80 ; culmen, .81 to .92 .

Agelaius phceniceus, of, wing, 3.84 to 4.05 ; culmen, .68 to .80 .

Agelaius p. arctolegus, $0^{7}$, wing, 4.78 to 5.12 ; culmen, .90 to 1.02 .

Agelaius p. arctolegus, + , wing, 3.82 to $4.2 \mathrm{I}$; culmen, .67 to $.8 \mathrm{r}$.

Such geographical races are only of value to the specialist; but for that reason great care should be taken in their identification. The student should bear in mind that while the northern form arctolegus averages larger than phoniceus, individual variation is considerable and it does not necessarily follow that a large New England specimen should be recognized as arctolegus merely because its measurements agree with one of medium size taken in Alberta. It is far better to err on the side of conservatism than to burden Ornithological literature with questionable records.

Mr. Oberholser gives arctolegus as having been taken in Illinois near Jacksonville and Bloomington, and the Museum possesses a male specimen (No. 30358) taken near Chicago, Oct. I 5, I 903, which might be referred to this subspecies. The measurements are as follows:

Wing, 5.08; culmen, .96; depth of bill at base, .48.

\section{Genus STURNELLA Vieill.}

\section{Sturnella magna (LiNN.).}

MEADOWLARK.

Distr.: "Eastern United States and southern Canada to the Plains. Breeds from the Gulf of Mexico northward." (A. O. U.)

Special characters: Upper plumage, black, bordered and tipped with buff and rufous brown; crown with buff line through the center; breast and upper portion of belly, bright yellow; yellow of throat not extending over malar region; greater portion of under parts, gamboge yellow; throat and breast separated by a crescent shaped patch of black; flanks and under tail coverts, tinged with buff; middle tail feathers and tertials with imperfect brown bars, which run together along the shaft, not clearly separated; distinct bars extending across the feather as in the Western Meadowlark.

Male: Wing, 4.50 to 5.10 inches; bill, 1.22 to 1.42 inches. 


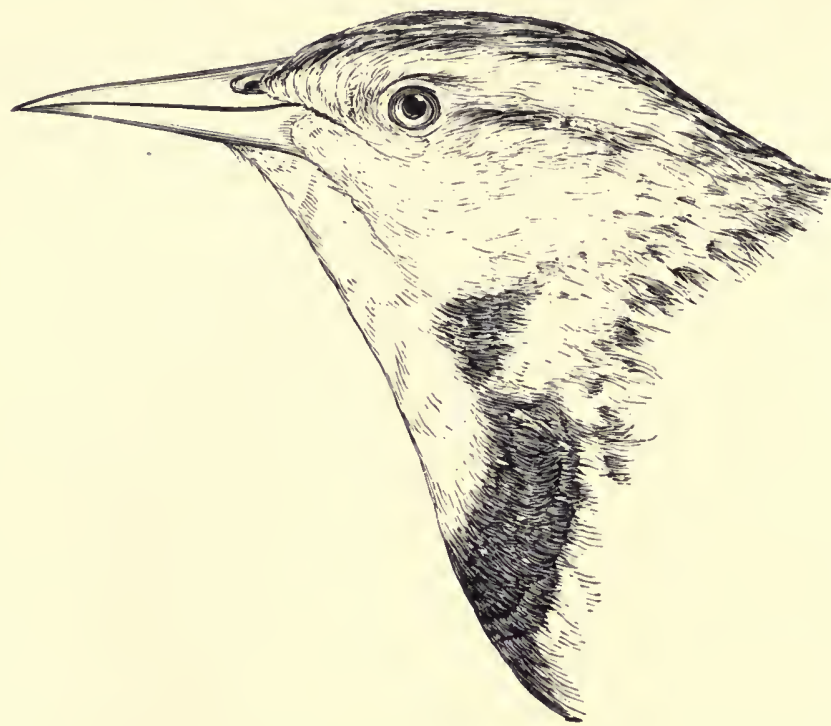

Female: Wing, 4.I 4 to 4.50 inches; bill, I.05 to 1.26 inches.

The Meadowlark is a common summer resident throughout Illinois and Wisconsin, frequenting the open fields and prairies. A few remain during the winter, but the majority arrive in March and leave for the south again late in the fall. Its song is clear and rather plaintive, and is subject to considerable variation.

It breeds in May. The nest is built on the ground and is composed of dry grass. The eggs are white, sparsely marked and speckled with brown and lilac gray. They are from 4 to 6 in number, and measure about I.I $2 \times .80$ inches.

\section{7a. Sturnella magna argutula (BANGS.).}

\section{Southern Meadowlark.}

Distr.: Southeastern United States, from Florida to Louisiana and north through the lower Mississippi Valley to southern Illinois and western Indiana.

Special characters: Similar to S. magna, but smaller and somewhat darker, the back generally showing more black; the imperfect barring of middle tail feathers and tertials as in magna.

Male: Wing, 4.25 to 4.65 ; bill, I.22 to I. 40 .

Female: Wing, 3.75 to 4.05 ; bill, r.10 to I.20.

Specimens of this southern race contained in the Field Museum collection were taken at Grand Chain, Pulaski County, southern Illi- 
nois, in April, 1897. Others from the same locality are apparently intermediate in size and coloration between this and S. magna.

The measurements of four selected specimens are as follows:

No. 5737 , male, April r6, r897; wing, 4.44; bill, r.25.

No. 5735 , male, April 14 , 1897 ; wing, 4.54 ; bill, $\mathrm{r} .27$.

No. 5733 , male, April r6, r897; wing, 4.63; bill, r.24.

No. 5734, male, April x7, x897; wing, 4.65; bill, x.25.

\section{Sturnella neglecta Aud.}

Western Meadowlark.

Distr.: "Western United States, southwestern British Provinces and northwestern Mexico; east to prairie districts of Mississippi Valley in Minnesota, Iowa, Missouri, Indian Territory, and Texas; occasionally to Illinois, Wisconsin, and southern Michigan." (Ridgway.)

Special characters: General plumage, grayer and paler than in S. magna; yellow of the under parts, paler, the yellow of throat usually extending laterally more or less upon the malar region; middle tail feathers and tertails with distinct and separate bars extending across the feather and not broken at the shaft. General upper plumage, paler and grayer; the rufous and black markings of S. magna replaced by gray and dark brown; flanks and under tail coverts, whitish.

Male: Wing, 4.60 to 5.09 ; bill, 1.20 to I.44.

Female: Wing, 4.12 to 4.55 ; bill, I.08 to $\mathrm{r} .26$.

The Western Meadowlark is apparently of rather rare occurrence in Illinois, but more common in Wisconsin. Nelson records a specimen taken near Chicago the last of May, 1876 . Ridgway states that he has heard its unmistakable song on the prairies of Richland Co., (Ill.), but was unable to obtain a specimen (Orn. of Ill., Vol. I, r889, p. $3{ }^{1}$ 7). In Wisconsin Kumlien and Hollister cite numerous records and state: "In many parts of the state the western meadowlark breeds more or less commonly." (Birds of Wisconsin, I 903, p. 88.)

The song of the Western Meadowlark is quite different and readily distinguishable from that of the eastern bird. 


\section{Genus ICTERUS Brisson.}

\section{Icterus spurius ( $\operatorname{LiNN}$ ).}

Orchard Oriole.

Distr.: Whole of eastern United States, west to the plains and southwest through Texas, Mexico, and Central America to Panama.

Adult male: Whole head, throat, upper breast, and móst of back, black; rest of under parts, and rump and upper tail coverts, chestnut; wings and tail, dark brown, more or less tipped with brownish white.

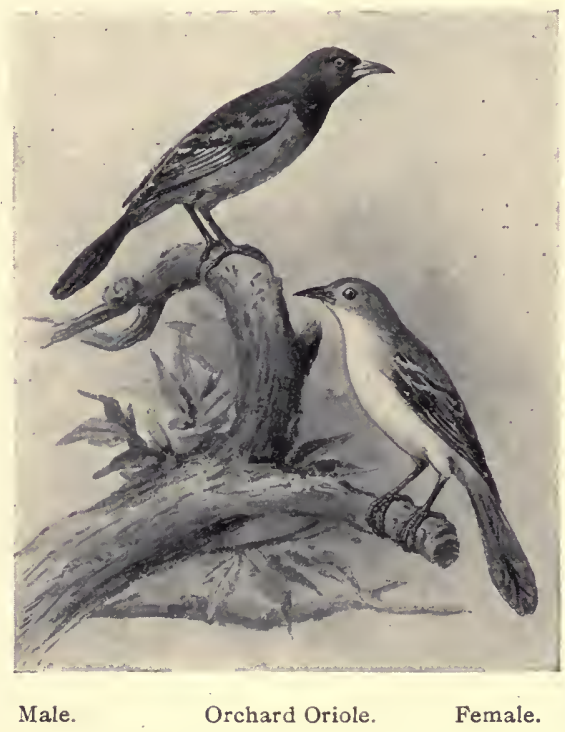

Adult female: Upper plumage, dull olive yellow, faintly tinged with grayish olive on the back; under parts, yellow; wing coverts, edged and tipped with dull white; tail, olive yellow.

Immature male, first year: Resembles adult female, but back more grayish brown.

Immature male, second year: Similar to adult female, but throat, black, and with or without patches of chestnut on the under parts.

Length, about 6.75 ; wing, 3.20 ; tail, 2.80 ; bill, .62.

The Orchard Oriole is a common summer resident in Illinois and southern Wisconsin at least as far as Dunn Co., and according to Kumlien and Hollister it occasionally occurs as far north as the shores of Lake Superior. Its delightful whistling notes are uttered more rapidly than those of the Baltimore Oriole and are somewhat sharper. 
It breeds in May and June; the nest, which is built in a tree, is composed of grass, occasionally more or less pendulous, but usually supported in a crotch near the extremity of a branch. The eggs are 3 to 5 , bluish white or dull white, scrawled and marked with dark brown and lilac gray, and measure about $.80 \times .5^{8}$ inches.

\section{Subgenus YPHANTES Vieill.}

\section{Icterus galbula (LINN.).}

Baltimore Oriole.

Distr.: Eastern United States and southern Canada, from the Atlantic coast west to the eastern border of the Rocky Mountains, south to Central America and northern South America; breeds from Texas, Kansas, Mississippi, and the Carolinas northward.

Adult male: Whole head, neck and back, black; rump and under parts, except throat, bright orange; middle tail feathers, black, rest of tail feathers, orange yellow; wings, black, the middle and greater coverts more or less edged with white; bill, lead color.

Adult males in full plumage sometimes show a tinge of red on the breast.

Adult female: Upper plumage, dull olive yellow, more or less mixed with dusky; under parts, dull orange; throat, more or less marked with dull black; tail and upper tail coverts, dull yellowish orange, the middle tail feathers, darker.

Immature males resemble the female, but have no black on the throat, and are more highly colored.

Length, 7.50 ; wing, 3.60 ; tail, 3 ; bill, .63.

The Baltimore Oriole is a common summer resident in Illinois and Wisconsin, arriving from the south in May (earliest Chicago record, April 26). Wherever there are woods and orchards his loud clear whistle, consisting of two or three notes, may be heard.

The nest is usually suspended from twigs near the end of a branch of a tree, usually at a considerable distance from the ground. This pensile basket like structure is finely woven of grass, plant fibre, hair, etc. The eggs are dull white, sparsely scrawled and marked with dark brown or blackish. They are from 4 to 6 in number and measure about $.92 \times .6 \mathrm{I}$ inches. 
562 Field Museum of Natural History-Zoölogy, Vol. IX.

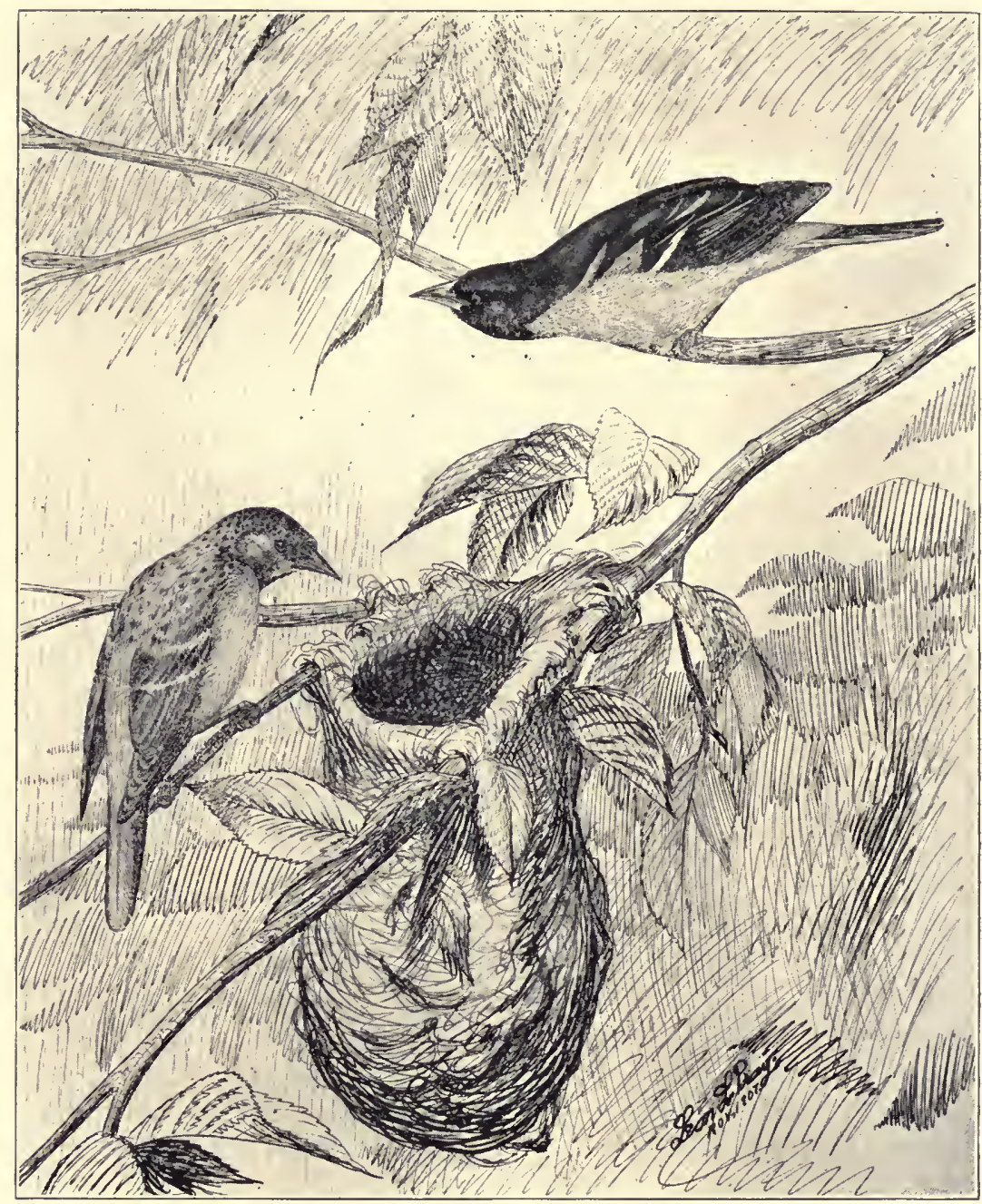

Female.

Baltimore Oriole.

Male.

Genus EUPHAGUS Cassin.

231. Euphagus carolinus (MÜLL.).

Rusty BlackBird.

Scolecophagus carolinus (Mü11.), A. O. U. Check List, I895, p. 209. Distr.: Eastern North America from the Atlantic coast to the Great Plains and from the Gulf of Mexico to Ungava and the Arctic 
coast; breeds from the northern border of the United States northward. (Northern Michigan, New York, Maine, etc.)

Adult male in summer: Entirely lustrous black, with greenish reflections; head nearly or quite the same color (never purplish blue);

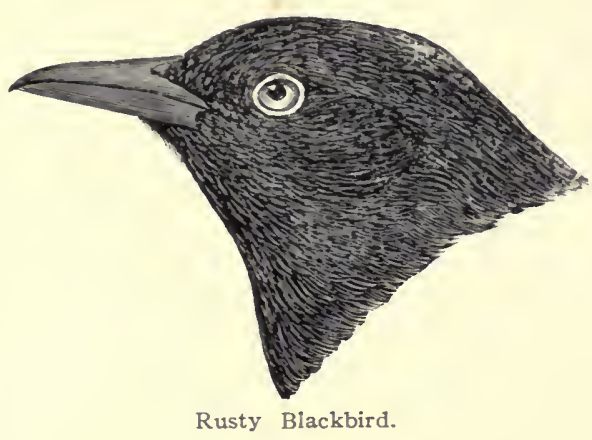

feathers of under parts, tipped with buff brown.

Adult female in fall: Feathers of the upper parts, broadly tipped with ferrugineous or rusty, often almost entirely concealing the gray bases of the feathers on the head and upper back; a buffy superciliary line; feathers of under parts, tipped with pale tawny brown.

The females are smaller than the males.

Male: Length, 9; wing, 4.75 ; tail, 3.50 ; bill, .75.

Female: Length, 8.50 ; wing, 4.45 ; tail, 3.40 ; bill, .65.

This species is an abundant migrant in spring and fall in Illinois and Wisconsin. Kumlien and Hollister state that formerly it occured as a.summer resident in Wisconsin, but only a single instance of its breeding within our limits is on record: "A set, nest and eggs taken at Storrs' Lake near Milton, June, I86I, is now in the Kumlien collection." (Birds of Wisconsin, I903, p. 89.)

\section{Euphagus cyanocephalus (WAGL.).}

\section{BREWER'S BLACKBIRD.}

Scolecophagus cyanocephalus (Wag1.), A. O. U. Check List, 1895, p. 209 .

Distr.: Western United States, from the British Provinces to Central America; accidental as far east as Illinois and Wisconsin. Breeds from southern Texas northward to Alberta, Manitoba and the Saskatchewan and east to Minnesota and Nebraska.

Adult male in summer: Bill, stouter than E. carolinus; general plumage, lustrous greenish black; whole head and throat, steel bluish 
564 Field Museum of Natural History-Zoölogy, Vol. IX.

or purplish; bill, black; iris, pale yellow; wing over 5 inches long (measured from carpus to tip).

Adult female in summer: Dark grayish brown, tinged with greenish on the back, wings, and tail; under parts, grayish brown, becoming dusky brown on the belly.

Adult female in fall: Similar, but feathers more or less inconspicuously edged with light grayish brown.

The females are smaller than the males, approaching in size the female Rusty Blackbird, but the difference in shape of the bill and the grayish brown (not rusty brown) edgings to the feathers, and absence of pale superciliary stripe will distinguish it in fall plumage.

Male: Length, 9.50; wing, 5.05 to 5.25; tail, 4.00; bill, .75.

Female: Length, 9; wing, 4.50 to 4.95 ; tail, 3.70; bill, .75.

Brewer's Blackbird must be considered an accidental straggler within our limits. Nelson considered it "a very rare visitant" in Illinois. Ridgway records a female shot at Mount Carmel, Ill., in December, 1866.

In Wisconsin Mr. F. H. King records a specimen from Green Lake County: "A single mature male obtained in July, on the large marsh just east of Princeton." (Natural History of Wisconsin, I883, p. 551.) Kumlien and Hollister state: "The only known instance of its nesting in the state was at Lake Koshkonong, June I4, I862. Two or three specimens besides these have been taken at the same locality in the past sixty years." (Birds of Wisconsin, I903, p. 89.)

\section{Genus QUISCALUS Vieill.}

\section{Quiscalus quiscula æneus (RIDGw.).}

Bronzed Grackle. Crow-Blackbird.

Distr.: United States, from the eastern border of the Rocky Mountains to the New England coast. Apparently absent from the southeastern coast states from New Jersey to Florida; breeds from Pennsylvania, northern Mississippi, and Louisiana northward to Newfoundland, southern Labrador, and the Great Slave Lake region.

Adult male: Whole head, neck, and upper breast, iridescent bluish purple; back and under parts, bronze green; wings and tail, blackish, tinged with purple; bill and feet, black; iris, pale yellow.

Adult female: General plumage, black, much duller than the male and showing comparatively little iridescence.

Length, I1.25 to I3; wing, 5.60; tail, 5.10; bill, I.15.

The Bronzed Grackle is a common summer resident in Illinois 


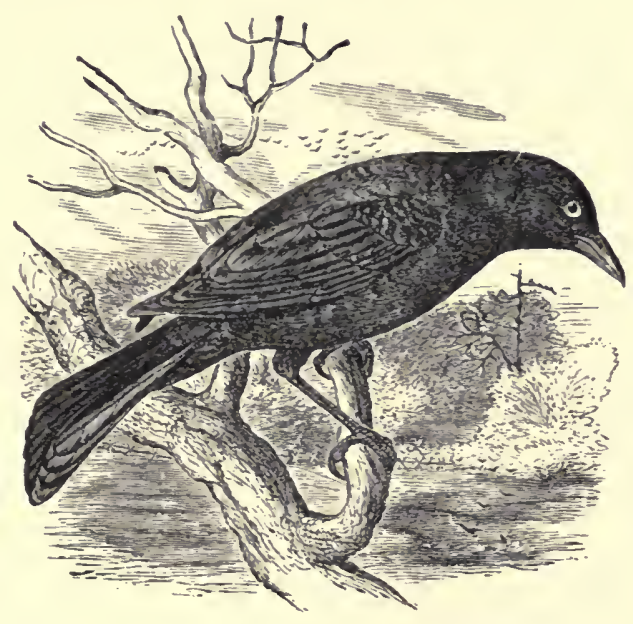

Bronzed Grackle.

and Wisconsin. The majority arrive the first of April and leave again in October (First Chicago record, March I6).

It breeds from April to June. The nest is a rather large structure of coarse grass, usually built in trees, but occasionally in cavities or openings in dead trees and stumps. The eggs are from 3 to 6 in number, pale bluish or greenish, marked and scrawled with dark brown and black, and measure about I.I $6 \times .82$ inches.

\section{Family FRINGILLIDÆ Finches, Sparrows, Crossbills, etc.}

The Fringillidæ comprise the largest known family of birds, containing over 500 species and distributed nearly throughout the world (except Australia). They are granivorous, being principally seed eaters, although they also feed upon buds, fruits, and insects, With few exceptions they are not gregarious, although often seen in flocks. Their nesting habits vary with different species. 


\title{
Genus HESPERIPHONA Bonap.
}

\section{Hesperiphona vespertina (Coop.).}

\author{
Evening Grosbeak.
}

Coccothraustes vespertinus (Coo P.), A. O. U. Check List, I895, p. 2 I I.

Distr.: Interior of eastern North America, from New York and New England west to the Rocky Mountains and north to the British provinces (Saskatchewan); south in winter to Ohio, Kansas, Wisconsin, northern Illinois, and northern Indiana. Breeding range unknown.

Adult male: Bill, very large and thick, pale greenish yellow in color; forehead, yellow, the color extending back in a line over the

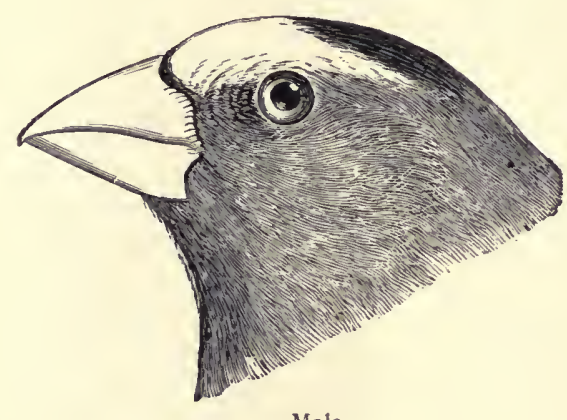

Male. eye; crown, blackish; sides of head, grayish olive brown; upper back, brownish olive; breast, yellowish olive, shading into yellow on the belly and under tail coverts; rump, yellow; wings and tail, black, the terminal half of the secondaries and coverts, pure white.

Adult female: General plumage, grayish brown, darkest

on top and sides of head; upper throat, whitish; sides of body and under wing coverts, more or less tinged with yellow; wings and tail, black, marked with more or less white, the tail feathers being tipped with white on inner webs.

Length, 7.25 to 8.50 ; wing, 4.10 to 4.60 ; tail, 2.75 ; bill, .70.

This fine species is a not uncommon winter visitant in $W$ isconsin and occurs occasionally in winter in northern Illinois. Mr. E. W. Nelson states:" "A winter visitant occurring at irregular intervals. In the winter of $\mathrm{I} 87 \mathrm{I}$ they wer equite common throughout the northern portion of the state." Mr. F. M. Woodruff considers it a very irregular winter visitant to northeastern Illinois. He procured a specimen at River Forest on January I3, I887, and another at Englewood, March, I888. He writes: "Mr. B. T. Gault informs me that on December 25, 1886, he observed five in Garfield Park, Chicago, where they were feeding upon the keys of the box elder. $* * * * * \mathrm{Mr}$. H. K. Coale has furnished me with the following interesting record: "On Febr. II, I887, Mr. E. A. Colby shot twelve Evening Grosbeaks in Chicago, which he presented to me in the flesh; he also saw several flocks during the winter feeding on the buds of trees." (Birds of the 
Jax., igog. Birds of Illinois and Wisconsin-Cory.

Chicago Area, I 907 , p. I 26.) There are numerous other Illinois records, flocks have been seen in northern Illinois late in April, and it has been taken in northern Indiana as late as May I3.

In the more central portions of Illinois it is rare. Specimens have been taken by Mr. Charles $\mathrm{K}$. Worthen at Warsaw, Ill., and Mr. O. P. Hay records taking six birds of this species near Eureka, Woodford Co., in the fall of 1872 . (Bull. Nutt. Orn. Club, July,

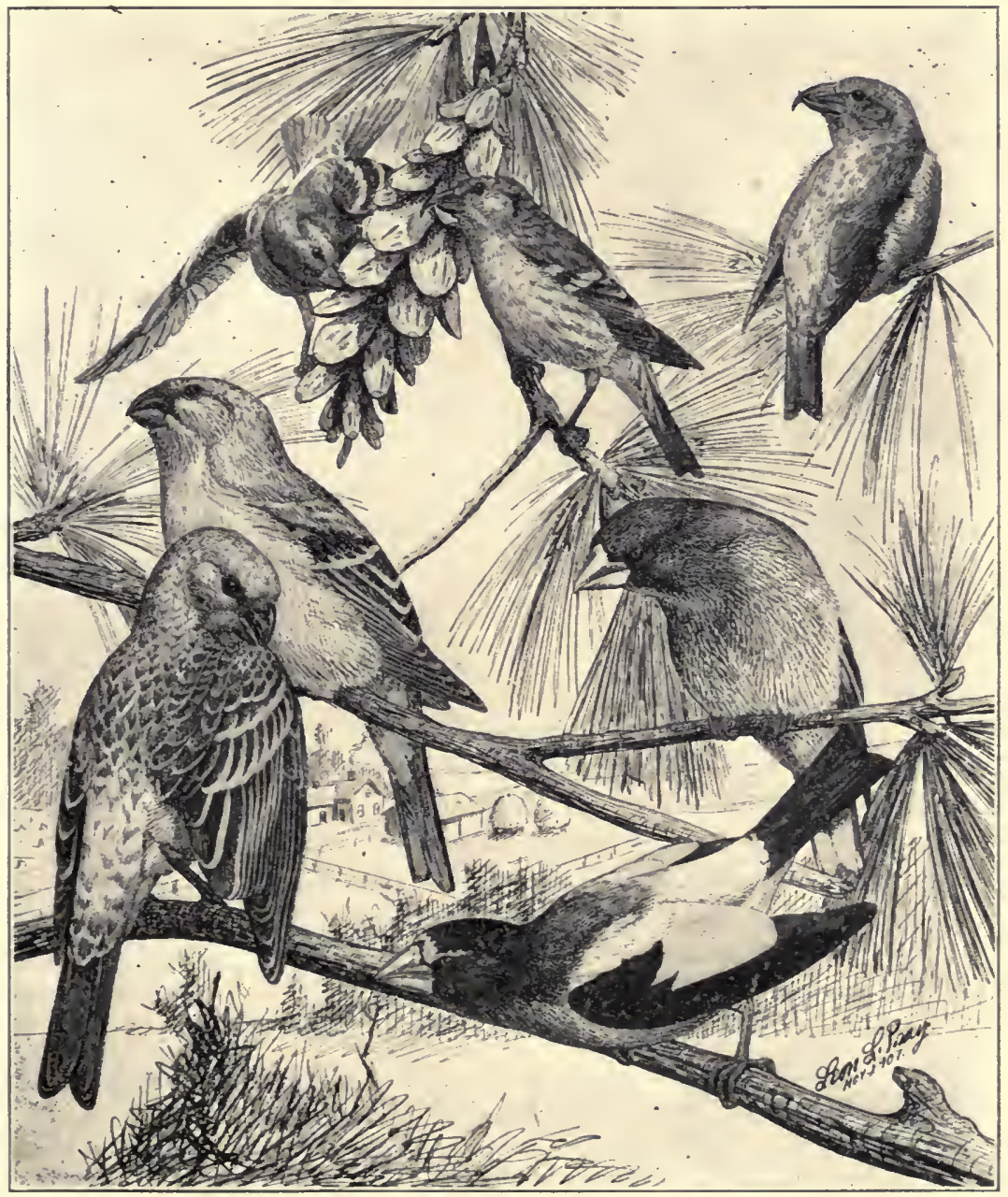

White-winged Crossibill. (Male and female.)

Fine Grosbeak (Male and female.)
American Crossbill. (Male.) Evening Grosbeak. (Male and female.) 
1881, p. r79.). According to Mr. L. O. Pindar a flock was seen at Hickman, Kentucky, on the Mississippi River, between Cairo and New Madrid. Three specimens were taken (Widmann, Birds of Missouri, 1907 , p. I66).

Messrs. Kumlien and Hollister include this species (Birds of Wisconsin, 1903, p. 90) as a "common winter visitant, usually found in good numbers any time from December on."

\section{Genus PINICOLA Vieill.}

\section{Pinicola enucleator leucura (MÜLLER).}

Pine Grosbeak.

Distr.: Northeastern North America, from about longitude $95^{\circ}$ to the coast; breeding from northern Maine and New Hampshire, Quebec and Ontario northward to the limit of coniferous trees; ranges south in winter to northern Illinois, northern Missouri, and Iowa.

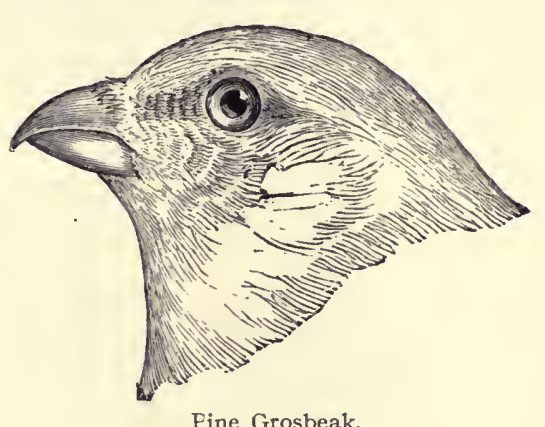

Pine Grosbeak.

Adult male: Bill, stout; general plumage, rosy red, the feathers of back with dusky gray centers; lores, dusky; wings, dark brown, the secondaries and coverts, more or less edged with white; some of the primaries, narrowly edged with white.

Adult female: General plumage, ashy gray; the head, upper back, and rump, dull saffron yellow; breast with faint tinge of same; more or less black in front of eye; wings, as in the male.

Immature birds resemble the female.

Length, about 8 ; wing, 4.55 ; tail, 4 ; bill, .50.

The Pine Grosbeak is an irregular winter visitant to northern Illinois, but is common in winter in Wisconsin, especially in the northern part of the state. Mr. Frank M. Woodruff records a specimen taken by him at River Forest, January, I887. Mr. John F. Ferry procured several specimens from a flock at Lake Forest in the winter of 1895 . The Field Museum collection contains two specimens, a male and a female, taken by Mr. W. Kennicott and Mr. John Dearlove at "The Grove," Cook County, Ill., on Nov. 23, I903, and a male taken by Mr. John F. Ferry at Beach, Lake Co., I11., Nov. I 7 , 1906.

Kumlien and Hollister state that it is a common winter bird in northern Wisconsin. 


\section{Genus CARPODACUS Kaup. \\ 236. Carpodacus purpureus (GMEL.). \\ PURPLE FINCH.}

Distr.: North America, from the Atlantic coast to the Rocky Mountains and from the Gulf of Mexico to British Columbia, northern Quebec, and Labrador. Breeds regularly in coniferous trees from northern Wisconsin northward.

Adult male: Tail, very slightly forked; general plumage, more or less rose red, deeper red on the head, and mixed with brown on the

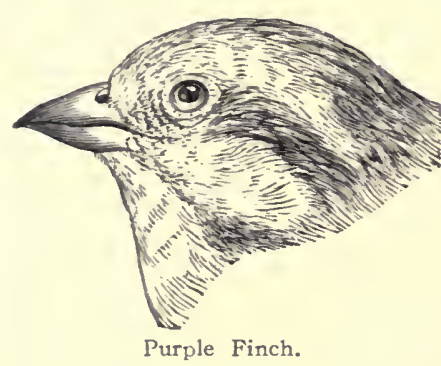
back; throat and breast, rose red, shading to white on the belly; wings and tail, dark brown, with narrow pale edgings.

Adult female: Upper plumage, dark brown, streaked with dusky brown; under parts, white, streaked irregularly with dark brown; rump, more or less tinged with dull olive.

The female of this species may be distinguished from other sparrows and finches by the slightly forked tail and the small tufts of feathers over the nostril.

Length, 5.75 to 6 ; wing, 2.90 to 3.25 ; tail, 2.35 ; bill, .40 .

This handsome species is a common migrant in spring and fall in Illinois and a not uncommon winter resident, especially in the southern part of the state. Authentic breeding records for Illinois are very rare. In 1876 Nelson included it in his Birds of northeastern Illinois as "A common winter resident, a few breed." Mr. Frank M. Woodruff considers it "An irregular migrant and a not uncommon winter resident." Mr. W. W. Cook states: "It breeds regularly from northern Minnesota and Dakota northward, but has also been found breeding in northern Illinois. Mr. Kline has taken one set of eggs at Polo, Illinois." (Bird Migration Mississippi Valley, I 888, p. I 79.) Nehrling states that it has been taken at. Waukegan, Ill., during the breeding season, (Our Native Birds, etc., I 896, p. 29), and there is an egg in the Thomas H. Douglass collection at Waukegan, labelled as having been collected by him in that locality on May I 3,1875 .

In Wisconsin Messrs. Kumlien and Hollister consider it a more or less common migrant in spring and fall and state they have observed it in summer, but give no definite nesting records of their own. Dr. Hoy found it breeding near Racine about i 850 , and F. L. Grundtvig 
found the nests of three pairs near Shiocton in 1883 . It probably breeds regularly in the northern part of the state, as Mr. John F. Ferry found it not uncommon near Woodruff, Vilas County, during the last week in June, Igo8.

The nest is built in trees, usualby at a considerable distance from the ground. It is composed of grass, twigs, and hair. The eggs are from 4 to 6 , clear blue, spotted and marked about the larger end with dark brown, and measure about $.80 \times .56$ inches.

\section{Genus PASSER Brisson.}

237. Passer domesticus (LiNn.).

English Sparrow. House Sparrow.

Adult: Top of head, gray; nape, sides of neck, and stripe from the eye backward, rich chestnut; cheeks and sides of throat, white;

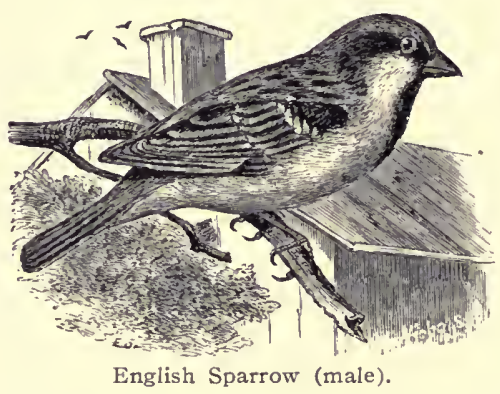

front of eye, throat and breast, black; upper back, chestnut, with black streaks; lower back and rump, gray; belly, white; wing, dark brown, more or less edged with pale rufous brown; tail, brown.

Adult female: Upper plumage, dark grayish brown; the middle of the back, dull tawny brown, streaked with black; under parts, pale, dull whitish on belly and the breast; sides of body, washed with pale grayish brown; middle wing coverts, tipped with whitish; rest of wing feathers, more or less edged with pale brown.

Length, about 6; wing, 3 ; tail, 2.40 ; bill, .42.

The English Sparrow is an Old World species, which was introduced into this country some years ago and has now unfortunately become very numerous throughout the greater portion of the United States.

It destroys but few insects and is most pugnacious, driving away 
our native insectivorous birds, and has proved itself a most undesirable addition to our avifauna.

The nest is a mass of loose grass, leaves, or almost any soft substance easily procured. It builds anywhere, but usually about buildings. The eggs are variable, but the majority are dull white with scattered markings of olive brown (occasionally nearly pure white and again thickly blotched with dark brown). They number from 4 to 7 , and measure about $.84 \times .62$ inches. They are very prolific, the breeding season lasting from February until September or October and several broods are raised in a year.

The European Tree Sparrow, Passer montanus, is not uncommon in the vicinity of St. Louis, Mo., where it was introduced in 1870 . It has increased in its numbers and according to Mr. Otto Widmann: "It has left the thickly settled parts of St. Louis; but is found scatteringly throughout the outskirts and suburbs, spreading to neighboring cities." (Birds of Missouri, I 907, p. I72.) It is probable that it will be observed in Illinois in the near future.

\section{Genus LOXIA Linn.}

\section{Loxia curvirostra minor (BREHM). American Crossbill. Red Crossbill.}

Distr.: Northern North America, in coniferous forests. Breeds from northern Michigan and northern Wisconsin northward. In the Eastern states has been found breeding as far south as Tennessee and the Alleghanies; ranges in winter south to Louisiana and South Carolina, and on the Pacific coast to Lower California.

Adult male: Mandibles, crossed; general plumage, red, brightest on head and rump; feathers of the back, more or less faintly marked with dusky olive; wings and tail, dark brown.

Adult female: Mandibles, crossed; upper plumage, greenish olive, mixed with grayish and dusky, becoming clear olive yellow on the rump; under parts, gray, more or less washed with yellowish olive.

Immature males show various mixed plumages of red and green during the change to the adult stage.

Length, 6; wing, 3.48 ; tail, 2.50; bill, .60 (length of bill very variable).

The Red Crossbill is a regular; but by no means, common winter visitant in Illinois and a common winter resident in Wisconsin. According to Kumlien and Hollister it breeds irregularly in the northern part of the state. Mr. John F. Ferry obtained young birds not long 


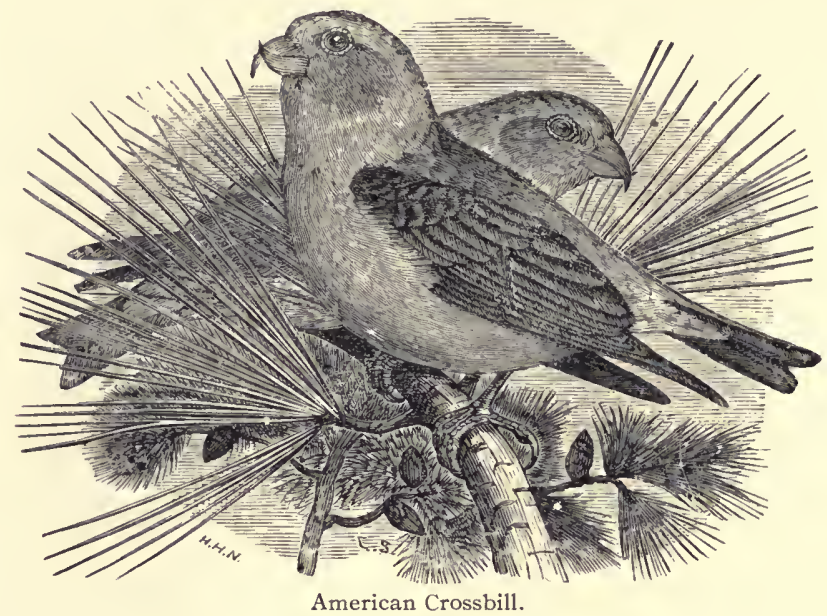

out of the nest near Woodruff, Vilas Co., Wisconsin, during the last week in June, I 908 .

The nest is built in coniferous trees and is composed of grass, rootlets, or small twigs and moss. The eggs are 3 to 4 , pale green or greenish white, marked and dotted chiefly at the larger end with brown and lilac gray, and measure about .76 x .58 inches.

This species is well represented in the collection of the Field Museum of Natural History by a series of specimens taken in northern Illinois in winter and spring, some of them as late as June $\mathbf{I}$.

Loxia curvirostra bendirei Ridgway is no longer considered separable from this species.

\section{Loxia leucoptera GMEL.}

White-Winged Crossbill.

Distr.: Northern North America, breeding from northern New England and northern Michigan (Mackinac Island) northward; south in winter to middle United States (Ohio, Illinois, Missouri, Kansas, etc.).

Adult male: Mandibles, crossed; general plumage, crimson red, or deep rosy red; inner secondaries and greater and middle wing coverts, tipped with white, forming a noticeable white wing patch, rest of wing, black; middle of belly, brownish gray, streaked with dusky; tail, blackish.

Adult female: Mandibles, crossed; upper plumage, grayish olive, streaked with dusky; rump, tawny yellow; under parts, grayish, 
the breast and sides of body more or less washed with pale tawny, and faintly marked with dusky; belly, grayish white; wing markings, as in the male.

Immature males assume various plumages from dusky gray with whitish streaks to the bright red of the adult, including the mixed red and grayish olive stages.

Length, 6; wing, 3.50; tail, 2.40 ; bill, .60.

This species is an irregular winter visitant in Illinois and Wisconsin, varying in numbers from year to year. It was common in northeastern Illinois during the late fall of 1906.

Mr. Frank M. Woodruff states that: "In the year 1904 , from the ninth to the twentieth of November, enormous flocks of these Crossbills passed along the lake shore and many were shot with slingshots by boys." (Birds Chicago Area, I907, p. I30.) It occurs as a winter visitant in Wisconsin but as far as known there is no record of its breeding in the state, although W. A. Oldfield records it nesting September 28, I 888, at Keweenaw Point, Michigan (Orn. and Ool., I 889, p. 43).

\section{Genus ACANTHIS Bechstein.}

\section{Acanthis hornemannii exilipes (Coues).}

HoARY REDPOLL.

Distr.: Arctic America and northeastern Asia, occasionally south in winter to the northern border of the United States; breeds in the far north (Ungava, northern Alaska, etc.).

Male in winter plumage: General plumage, pale, whitish or light gray prevailing; rump, plain white, without streaks, often tinged with rose-pink; under tail coverts, white, occasionally showing a few indistinct streaks; breast, more or less strongly tinged with rose-pink; sides showing a few narrow brownish dusky streaks or at times without streaks; rest of under parts, white; crown, with more or less metallic red; a black spot, on the chin; bill, yellowish with the tip dark.

Female in winter plumage. Similar but smaller and lacks the rose-pink on the breast.

The unstreaked rump will distinguish this from the next species.

Male: Wing, 2.95 to 3.10 ; tail, 2.48 to 2.55 ; culmen, .30; depth of bill, .20 to .25 .

Female: Wing, 2.85 to 3.05 ; tail, 2.35 to 2.55 ; culmen, .30; depth of bill, .20 to .24.

The Hoary Redpoll is a rare winter visitant to Illinois. Prof. Ridgway writes: "I have seen specimens in the collection of Mr. E. 
574 Field Museum of Natural History-Zoölogy, Vol. IX.

W. Nelson that were collected in the vicinity of Chicago, but I am unable to give dates of their capture. The National Museum likewise possesses specimens from Mount Carmel, collected by Dr. H. Skinner." (Orn. of Illinois, I889, p. 232.)

According to Kumlien and Hollister, it is an irregular winter visitor in Wisconsin, usually rare, although they state that: "During January, February, and March, I896, Mr. J. N. Clark found these birds tolerably common in Dunn County," where he procured thirty specimens during the three months. There are numerous other Wisconsin records.

\section{4l. Acanthis linaria (Lin.v.). \\ REDPOLL.}

Distr.: Northern portions of northern hemisphere; breeds in the far north (Ungava, Alaska, etc.); south in winter to South Carolina, northern Alabama, Kansas, Colorado, etc.

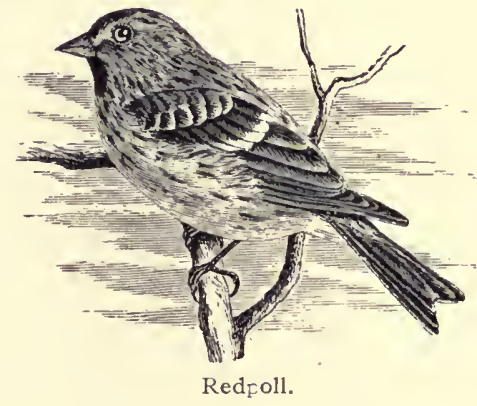

Male in winter plumage: General plumage, streaked, decidedly darker than exilipes and the tail, shorter; upper parts, brownish or grayish brown, streaked with dusky; rump, streaked with dusky, usually more or less tinged with rose or pink; breast and upper belly, rosy or pink; under parts, whitish or white; sides and flanks, broadly streaked with dusky; under tail coverts, streaked; crown, with more or less metallic red; a black spot, on the chin; bill, yellowish, with the tip dark. The female is similar but lacks the pink on the breast and rump; young birds have no red on the crown.

Male: Wing, 2.85 to 3.05 ; tail, 2.20 to 2.50 ; bill, .32 to .37 ; depth of bill, .22 to .26 .

Female: Wing, 2.75 to 2.95 ; tail, 2.20 to 2.44 ; bill, .30 to .36 ; depth of bill, .22 to .25.

The Redpoll is a common winter visitant in Illinois and Wisconsin from November until March. When the snow is on the ground flocks of these little birds may often be seen flying about among the bushes. They are usually very tame and unsuspicious. 


\title{
24la. Acanthis linaria holbœllii (BREHM).
}

\author{
HoLböLL'S REDPOLL.
}

Distr.: Northern parts of northern hemisphere, breeding in the Aretic regions, occasionally south in winter to northern United States (New York, Massachusetts, Illinois).

Similar to A. linaria, but averaging larger, and the bill proportionally longer, the difference being merely one of size and by no means constant; identification is often difficult. It is apparently intermediate between linaria and rostrata.

Male: Wing, 2.85 to 3.05 ; tail, 2.25 to 2.50 ; bill,.. 36 to .42 ; depth of bill, .25 to .30 .

Female: Wing, 2.80 to 3 ; tail, 2.25 to 2.48 ; bill, .35 to .42 ; depth of bill, .25 to .30 .

There has been more or less confusion as to Illinois records of this form. Mr. H. K. Coale records a female (Bull. Nutt. Orn. Club, Vol. VIII, I883, p. 239) shot in Chicago by Mr. Geo. F. Klingman, Nov. 2, 1878 , which was identified by Mr. Ridgway as holbellii.

Mr. W. W. Cooke (Bird Migration Mississippi Valley, I888, p. I 8I) writes: "Mr. Ridgway kindly informs me.that he examined specimens from northern Illinois," and later Mr. A. W. Butler (Birds of Indiana, 1897 , p. 924) mentions a specimen taken by Mr. Coale, Nov. 21,1878 , in Cook Co., Ill., near the Indiana line, which he states was the first Illinais record (sic) and adds that while it was reported as A.l. holbcllii it was evidently rostrata. He does not, however, inform us how he arrived at this conclusion. To further complicate matters the only reference for Illinois given by $\mathrm{Mr}$. Ridgway in his "Birds of North and Middle America" in the synonomy under holballii is that of Mr. W. W. Cooke as cited above, the others being given under rostrata.

Assuming that "the specimens examined by Mr. Ridgway from northern Illinois," were those taken by Mr. Coale and which he now evidently considers to be rostrata, the number of Illinois records for this form becomes decidedly reduced.

According to Kumlien and Hollister, Holböll's Redpoll is a rare winter straggler in Wisconsin. They write: "One specimen was shot at Lake Koshkonong, January 22, I 867 (L. K.), and identified by Prof. Baird in $\mathrm{x} 88 \mathrm{r}$. In a series of redpolls taken during January, February, and March, r896, by Mr. J. N. Clarke at Meridian, are four specimens easily referable to this race. Mr. Clarke has kindly sent 
one of these to us for examination which has been marked as holbcllii by Ridgway and Fisher, who identified a number of redpolls for him at the time." (Birds of Wisconsin, 1903, p. 93.)

\section{4lb. Acanthis linaria rostrata (Coues).}

Greater Redpoll.

Distr.: Greenland (where it breeds) and northeastern North America; accidental or casual in winter in northeastern United States (Illinois, Michigan, New England, etc.).

Winter plumage: Larger than holbcllii or linaria; wing, not less than 3.06; the marking of the plumage, darker and stripes on the under parts, larger; the bill, heavier; rump and under tail coverts streaked distinctly with dusky; sides and flanks streaked; breast, rose-pink; rest of under parts, white or whitish; a black spot on the chin; crown with more or less metallic red; bill, yellowish, with dark tip. Female similar, but lacking the pink tinge on the breast.

Male: Wing, 3.06 to 3.30 ; tail, 2.35 to 2.70 ; bill, .32 to .42 ; depth of bill, .25 to .32 .

Female: Wing, 3 to 3.25 ; tail, 2.40 to 2.60 ; bill, .32 to .42 ; depth of bill, .25 to .30 .

A rare winter straggler to Illinois, although apparently more common in Wisconsin. Mr. W. W. Cooke writes: "The only instance of its capture within the Mississippi Valley is the record of a specimen taken Nov. 2, I 878, at Chicago, by Mr. H. K. Coale." (Bird Migration Mississippi Valley, I888, p. I82.) Mr. Ridgway writes: “Mr. H. K. Coale has taken this bird near Chicago and has kindly sent me for examination the specimens which he secured." (Orn. of Ill., I889, p. 235.) In the catalogue of Birds of the British Museum (Vol. XII, I 888 , p. $25 \mathrm{I}$ ), Dr. Sharpe includes in his list of specimens of this species the following: $\mathrm{O}^{\text {t }}$ ad., Chicago, Ill., Nov. 2, I 873 (sic) (H. K. Coale) (wing 3.3). Mr. F. M. Woodruff states: "There is a specimen in the collection of the Chicago Academy of Sciences taken in the seventies by Mr. C. N. Holden, which is in the plumage of the young male." (Birds Chicago Area, r907, p. г3r.)

Regarding the occurrence of the Greater Redpoll in Wisconsin, Messrs. Kumlien and Hollister state: "Winter visitant. Mr. Clark collected over thirty of these birds in Dunn Co., during the winter of I $895^{-6}$. ***** A series sent us by Mr. Clark at the time, in the flesh, all proved to be of this variety, and specimens of this and the other races were identified for him later by Prof. Robert Ridgway. Specimens have also been received from Stevens Point and Iron 
Co., and others have been taken quite regularly at Lake Koshkonong, especially during winters of heavy snow fall. Here they have never been found except as associated with linaria." (Birds of Wisconsin, r 903 , p. 93.)

\section{Genus ASTRAGALINUS Cabanis.}

\section{Astragalinus tristis (LiNx.).}

Americax Goldfinch. Yellowird.

Spinus tristis (Linn.), A. O. U. Check List, 1895, p. 2 1 8.

Distr.: United States, east of Rocky Mountains to the Atlantic coast, north to Manitoba and northern Canada, south to the Gulf coast, including Florida and Texas (replaced from Rocky Mountains westward by several subspecies). Breeds from middle United States, Tennessee, Missouri, Kansas, etc., northward.

Adult male in spring: General plumage, bright yellow; crown, black; wings, black, the secondaries and coverts, tipped with white;

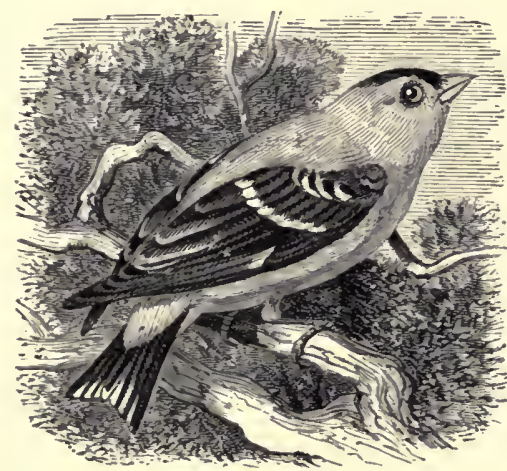

American Goldfinch. tail, black, with more or less white on inner webs; upper tail coverts, white. In fall the black cap is absent, and the general plumage is buffy brown above and pale brownish white on under parts, with more or less yellowish; head, tinged with yellow.

Adult female: Upper parts, pale brownish olive; under parts, dull white, tinged with buff on sides and breast, and showing more or less yellow, especially on the throat; wings and tail, dusky;

the feathers, with whitish edgings.

Very young birds are strongly tinged with buffy and the wing feathers edged with tawny buff.

Length, 4.90 to 5.15 ; wing, 2.70 to 2.85 ; tail, 2 ; bill, .42 .

The American Goldfinch is an abundant summer resident in Illinois and Wisconsin and a few occasionally remain during the winter. The majority arrive from the south about May ist, although a few return much earlier. Adult spring males of this species may be readily recognized by the bright yellow plumage and black wings and tail.

The song of the male is a musical chee-wee or chee-e-wee, and at times a faint whistle and twitter. The flight is a series of undu- 
578 Field Museum of Natural History-Zöology, Vol. iX.

lations, usually accompanied on the downward swing by the familiar chee-e-wee.

Nidification begins in May. The nest is built in large bushes or low trees, and is woven of grass and plant fibre, lined with thistle down. The eggs are from 3 to 6, pale blue or bluish white in color, and measure about $.66 \times .47$ inches.

\section{Genus SPINUS Koch.}

\section{Spinus pinus (WILS.). Pine Siskin.}

Distr.: "North America generally, breeding in the British Provinces, Rocky Mountains, Sierra Nevada, and high mountains of Arizona, south to Lower California and the mountains of Mexico to Orizaba. Also breeds sparingly in northeastern United States." (A. O. U.)

Adult: Upper plumage, streaked with pale brown and dark brown; under parts, grayish white, streaked with dusky; rump, yellow,

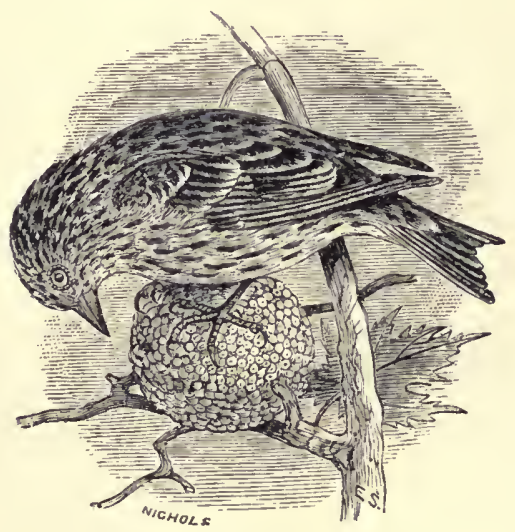

Pine Siskin.

streaked with dusky; at times the whole plumage faintly tinged with yellow and again hardly noticeable; basal portion of quills and tail, yellow.

Sexes, similar.

Length, 4.75; wing, 2.77; tail, 2 ; bill, .35.

The yellow markings at the base of the wing and tail feathers will distinguish this species.

This species is common in Illinois and Wisconsin during the migrations and a more or less common winter resident, especially in 
Illinois. It was not uncommon about Chicago during the latter part of January of the present year, and on February I 4 , the writer saw a large flock in Jackson Park and two others containing from ${ }_{15}$ to 20 individuals at Burnside. The notes are somewhat similar to those of the Goldfinch but are not so loud. It is supposed to breed in Wisconsin, but I find no authentic record of its having done so. Dr. Hoy "supposed" it to breed in the pine regions, but did not apparently find a nest. Kumlien and Hollister have never taken it in Wisconsin in summer. Mr. Norman A. Wood found it common in Ontonagon Co., Michigan, from July ${ }_{5} 5$ to August I4, I904. (The Auk, Vol. XXII, I905, p. I77.)

\section{Genus PLECTROPHENAX Stejneger.}

\section{Plectrophenax nivalis (Linn.).}

\section{Snowflake. Snow Bunting.}

Distr.: Northern parts of northern hemisphere (Arctic Europe, Asia, and North America), south in winter in United States as far as Illinois, Kansas, etc.; breeds in the far north (Ungava, Greenland, etc.).

Adult in winter: Crown and cheeks, dull chestnut brown; back, mixed black, buff, and chestnut; under parts, white; breast, with

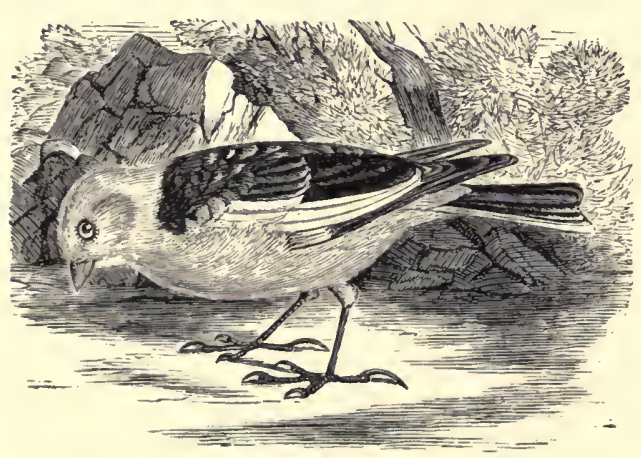

Snow Bunting. more or less of a band of chestnut brown; sides, washed with pale brown; basal portion of primaries and most of secondaries, white; the terminal portion of most of the primaries, black, tipped with white; the inner secondaries, mostly black (when flying, greater portion of wing appears white); three outer tail feathers, mostly white, rest of tail feathers, blackish, tipped with ashy white or buffy white; bill, yellowish.

The summer plumage is black and white, but the species does not occur within our limits at that season.

Length, 6.50; wing, 4.15; tail, 2.75 ; bill, .38.

A common winter resident in Wisconsin and northern Illinois. It is gregarious and frequents open fields and prairies. 
580 Field Museum of Natural History-Zöology, Vol. IX.

Genus CALCARIUS Bechs.

245. Calcarius lapponicus (LinN.).

LAPLAND LONGSPUR.

Distr.: Northern portions of northern hemisphere, south in winter to the Carolinas, Arkansas, and northeastern Texas; breeds in the far north.

Adult male in spring: Hind toe nail, long; head, throat, and breast, black, a streak of buff from the eye backward; a chestnut col-

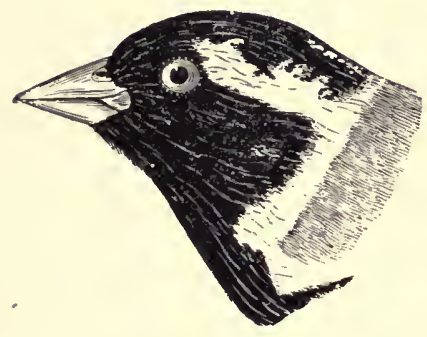

Male. lar around back of neck; upper parts, streaked with black and buff; under parts, white, with more or less black streaks on sides; primaries, dusky brown, the feathers with pale edgings; tail, blackish; outer tail feather, with narrow dusky streak along the shatt near the tip, the rest of the end, white, extending up the feather in an oblique and gradually narrowing patch and separating the black on the inner web from the shaft for a considerable distance.

Adult female in spring: Upper plumage, streaked with buff, black, and pale rufous; a rather faint, buffy chestnut collar on back of neck; head, buffy and black; under parts, white; breast, with more or less black.

Adult male in winter: Crown, black, more or less mixed with buffy, a buffy streak from the eye backwards; throat and breast, mixed black and white; chestnut collar on back of neck, mixed with gray; rest of plumage resembling spring female.

Adult female in winter: Similar to summer plumage, but plumage duller and collar on the nape faintly indicated.

Length, 6.25; wing, 3.60; tail, 2.60; bill, .38.

Abundant during migrations in late fall and spring, and a common winter resident both in Illinois and Wisconsin. It frequents the fields and prairies, usually in flocks. The majority leave for the north in April, although it is not uncommon in Wisconsin in May. 


\section{Calcarius pictus (Swains.).}

SMITH'S LoNGSPUR.

Distr.: Interior of North America; south in winter to Illinois and Texas; breeds from the latitude of the Great Slave Lake northward to the Arctic Ocean.

Adult male in fall and winter: Hind toe nail, long; two outer tail feathers, largely white; under parts, entirely tawny buff, showing more

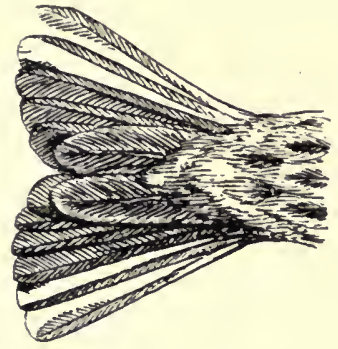
or less small, dusky spots on the breast; upper plumage, including crown, streaked with black and grayish buff; nape with faint indications of a tawny buff collar; most of wing coverts, edged with pale brown and tipped with whitish; sides of head, with more or less dusky; feet, pale.

In summer plumage the male has the crown and sides of the head black.

Adult female in fall and winter: General resemblance to the male in winter, but slightly paler.

Length, 6.50 ; wing, 3.70 ; tail, 2.60 ; bill, . 38 .

Smith's Longspur is an irregular but, at times, a not uncommon migrant in spring and fall in Illinois and probably in southern Wisconsin, frequenting the open plains.

Nelson states he observed a flock of some seventy-five individuals near Lake Calumet. Mr. Frank M. Woodruff found it abundant, May 5, I893, in the vicinity of Worth Township, and states that in the year 1896 they seemed to be quite abundant. Mr. A. W. Butler records flocks being seen in Cook Co., Ill., in April, 1896 , and again in October of that year (Birds of Indiana, 1897, p. 932).

Kumlien and Hollister consider it "as rare and of extremely erratic occurrence in Wisconsin" having "found it but a few times and never in flocks of any size."

Several specimens in the Field Museum.of Natural History collection were taken at Worth, Illinois, May 3, I894.

\section{Genus RHYNCHOPHANES Baird.}

247. Rhynchophanes mccownii (LAwR.).

McCown's Longspur.

Distr.: Interior of North America, from the Saskatchewan to Texas and northern Mexico; breeds from Kansas and Nebraska 
northward through the Dakotas, Wyoming, and Montana to the Saskatchewan; accidental in Illinois.

Adult male in summer: Hind toe nail, long; crown, black; a white line over the eye (superciliary line); sides of head, pale ashy;

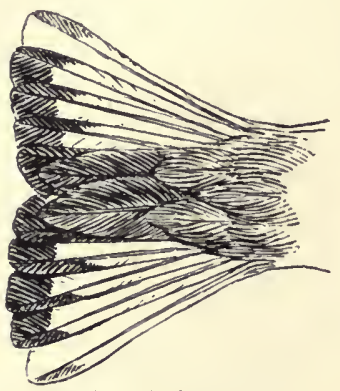

McCown's Longspur. (Tail an 1 upper tail coverts.)

a black malar stripe (extending from lower mandible); throat, white; a large crescent shaped. black patch on the breast; rest of under parts, whitish; back, grayish, streaked with dusky and buff; a conspicuous chestnut patch on the "shoulder" formed by the median coverts; all tail feathers except the two middle ones, mostly white, tipped with dark brown.

Adult male in fall and winter: No black on crown; breast patch, only slightly indicated; head, buffy, the crown streaked with dark brown; belly, whitish or white. It may be recognized by the chestnut "shoulder" patch, and the characteristic marking of the tailfeathers.

Adult female in fall and winter: Upper plumage, mixed buff and dark brown; a rather faint, pale buff streak over the eye; throat, buffy white; breast, pale tawny buff, at times tinged with dusky; sides of body, washed with tawny buff; belly, whitish; chestnut shoulder patch (median coverts) of the male replaced by pale rufous brown; tail markings, as in the male.

Length, about 5.50 to 6 ; wing, 3.50 ; tail, 2.45 ; bill, . 38 .

McCown's Longspur is an accidental straggler in Illinois. The only record I have been able to find of its occurrence in the state is that of Mr. H. K. Coale in the Bulletin of the Nuttall Ornithological Club, 1877 , p. $5^{2}$, in which he states: "While looking over a box of Snow Buntings and Shore Larks in the market, January 15,1877 , I found a specimen of Plectrophanes mccowni shot at Champaign, Illinois. January $\mathrm{I} 7$, another box containing Lapland Longspurs was sent from the same place and among them was a second specimen of P. mccowni, which is now in the collection of C. N. Holden. Jr., Chicago. January I 9 , I obtained a third specimen from the same source, which has been sent to Mr. E. W. Nelson of this city. They were all males, showing plainly the chestnut coloring on the bend of the wing and the peculiar white markings of the tail."

It has not been observed in Wisconsin. 


\section{Genus POCECETES Baird.}

248. Poœcetes gramineus (GMEL.).

Vesper Sparrow.

Distr.: Eastern North America, from Dakota and Nebraska to the Atlantic coast, north to Ontario and Quebec and south to the Gulf coast; breeds from Missouri and Kentucky northward.

Adult: Upper plumage, grayish brown, streaked with black, some of the feathers edged with pale rufous brown; under parts, w'itish;

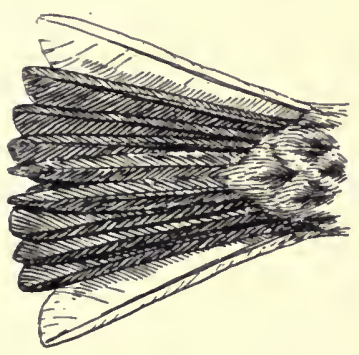

Tail of Vesper Sparrow.

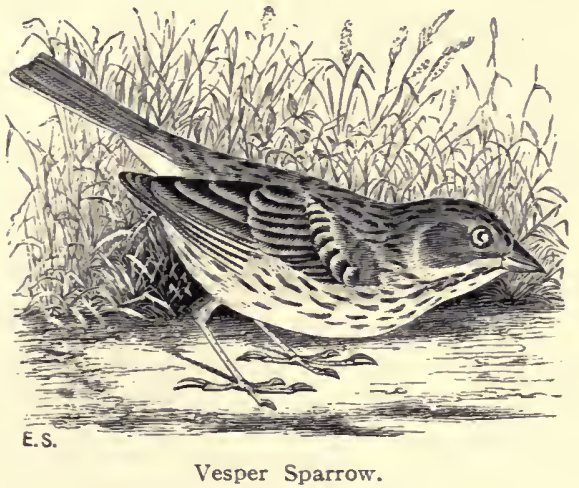

Vesper Sparrow.

the sides of throat, breast, and sides of body streaked with dark brown and pale buff; lesser wing coverts, rufous brown; tail, dark brown, the outer feathers mostly. white (see cut, in Key to Species).

Length, 6 ; wing, 3 ; tail, 2.45 ; bill, .38 .

An abundant summer resident in Illinois and Wisconsin, arriving from the south the latter part of March or early in April. (First Chicago record, March 2o). The song, which is very sweet and plaintive, is often heard after sundown.

The breeding season lasts from May until July. The nest, which is built on the ground in open places, is composed of dry grass and small rootlets. The eggs are from 4 to 6 , usually dull white or pinkish white, marked and scrawled with black and pale purplish brown, and measure about $.82 \times .6 \mathrm{I}$ inches. 
584 Field Museum of Natural History-Zoölogy, Vol. IX.

\section{Genus PASSERCULUS Bonap.}

\section{Passerculus sandwichensis savanna (WILs.).}

Savanna Sparrow.

Ammodramus sandwichensis savanna (Wils.), A. O. U. Check List, I 895 , p. 224.

Distr.: Eastern North America, from Dakota and Nebraska to the Atlantic coast and from Labrador and Ungava south to the Gulf of Mexico, Florida, Cuba, and Yucatan; breeds from Illinois, Wisconsin, and Pennsylvania northward to limit of its range (Cape Eskimo, Ungava, Labrador, etc.).

Adult: A superciliary line and bend of the wing, pale yellow, on the latter so pale at times as to be hardly noticeable; all tail

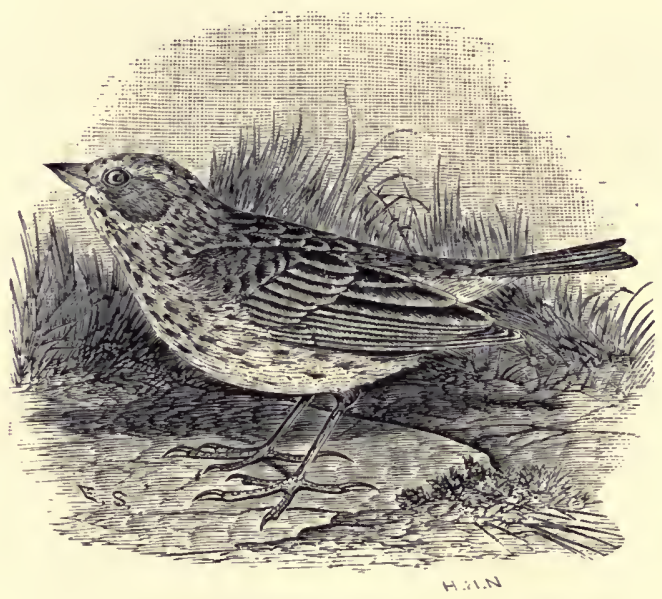

Savanna Sparrow.

feathers, dark grayish brown and rather pointed; upper plumage, streaked, mixed black, ashy and pale rufous brown; under parts, white, streaked on breast and sides with brownish black; belly, generally without streaks; wings, dark slaty brown, the coverts and inner secondaries, brownish black, edged with pale rufous brown.

Length, 5.60; wing, 2.65; tail, 2.15; bill, .38.

The Savanna Sparrow is a common summer resident in northern Illinois and Wisconsin, from April until October. Frequents fields and prairies. A few remain in southern Illinois during the winter.

The note is a faint trill preceded by peculiar rasping sounds somewhat resembling those of the Grasshopper Sparrow. 
It breeds in May and June. The nest, which is placed on the ground, is made of dry grass. The eggs are from four to five, pale bluish or buffy white, speckled and blotched (sometimes washed) with cinnamon brown or dull rufous brown, nearly obscuring the ground color. They measure about $.77 \times .56$ inches.

\section{Genus COTURNICULUS Bonap.}

250. Coturniculus savannarum australis (MAYNARD).

Grasshopper Sparrow.

Ammodramus savannarum passerinus (Wils.), A. O. U. Check List, I 895 , p. 226 .

Local name: Yellow-winged Sparrow.

Distr.: Eastern United States, from the Great Plains to the Atlantic coast, north to southern Canada and south in winter to Cuba, Porto Rico, and Central America; breeds from Missouri and the Carolinas northward.

Adult: Crown, brownish black, with a pale buffy white streak in centre; an orange yellow spot above the eye; bend of wing, clear yellow; feathers on the back, dark brown, edged with rufous and gray; under parts, pale tawny buff, shading into whitish on the belly, usually without streaks; primaries and tail feathers, dusky, with very narrow pale edgings, the outer tail feather, pale, but not white.

Very young birds in August have the breast streaked or spotted with dusky and show no yellow above the eye or on bend of wing.

Length, 5; wing, 2.45; tail, I.80; bill, .40.

A common summer resident in Illinois and Wisconsin, from late in April until September or October.

Breeds from May to July. The nest is built on the ground and is composed of dry grass, sometimes more or less arched over at the top. The eggs are from 3 to 5 in number, pure white, speckled and spotted with reddish brown, chiefly at the larger end, and occasionally showing small markings of black and dull lavender. They measure about $.73 \times .56$ inches.

Mr. Frank M. Chapman says: "Its fine insect-like notes give it the name of Grasshopper Sparrow. They may be written pit-tuck, $z e e-e-e-e-e-e-e-e$. Under favorable circumstances they can be heard by an attentive listener at a distance of two hundred and fifty feet, but the casual observer would pass within ten feet of a singing bird and be none the wiser." (Handtook Bds. Eastern N. A., I 895, p. 294.) 
586 Field Museum of Natural History-Zoölogy, Vol. IX.

\section{I. Coturniculus henslowii (AUD.).}

Henslow's Sparrow.

Ammodramus henslowii (Aud.), A. O. U. Check List, I895, p. 226.

Distr.: Eastern United States, from the Atlantic coast west to the plains, and from southern New England and southern Ontario to the Gulf of Mexico; breeds from Kentucky, Illinois, and Missouri northward.

Adult: - Greater portion of head and nape, dull olive green; crown, black, with olive green stripe in centre; feathers of the back, rufous

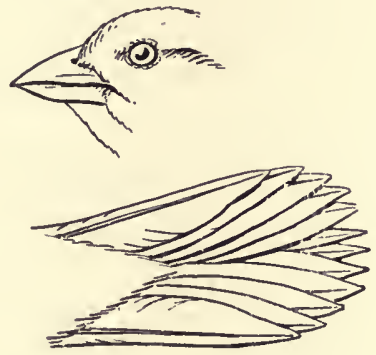

Tail and bill.

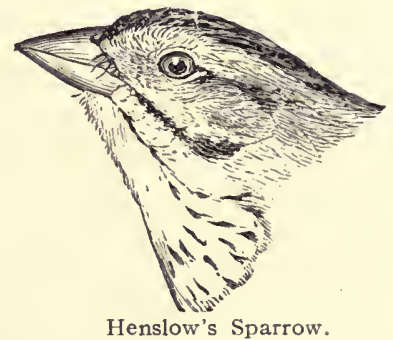

Henslow's Sparrow.

brown, with black centres; and narrowly edged with ashy white; throat, whitish or buffy white; breast, pale buff, streaked with black; belly, dull white; sides of body, buff, streaked with black; tail feathers, narrow and pointed, the two middle feathers, rufous brown, with a dark brown streak in the centre bordering the shafts.

Length, 5, or less; wing, 2.15; tail, 2 ; bill, .36.

This species is a rather common summer resident in suitable localities in Illinois and Wisconsin, arriving the latter part of April and leaving for the south early in October. Frequents open prairies, fields, and marshes.

Breeds in May and June. The nest is placed on the ground, and is composed of dry grass, often lined with fine grass or hair. The eggs are grayish white, thickly spotted and speckled with light rufous brown, from 4 to 5 in number, and measure about $.76 \times .57$ inches.

\section{Coturniculus leconteii (AUD.).}

Leconte's Sparrow.

Ammodramus leconteii (Aud.), A. O. U. Check List, I895, p. 227.

Distr.: From the Great Plains eastward to Illinois, Indiana, and Kentucky, and from Manitoba to the Carolinas, Florida, and Texas 
in winter; breeds from Iowa northward through Minnesota and the Dakotas to Manitoba.

Adult: Top of head, blackish, with a grayish buff streak in the centre; a tawny buff stripe over the eye; feathers of the back, brownish

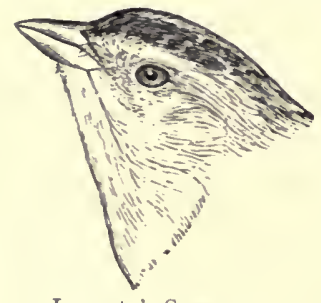

Leconte's Sparrow. black, edged with pale rufous and buff; throat, buffy white; breast and sides, pale buff, streaked with dull black; tail feathers, narrow and pointed, the shafts, dark.

Length, 5 or less; wing, 2.10; tail, 2 ; bill, .33.,

Leconte's Sparrow is a more or less common migrant in Illinois and Wisconsin and some years abundant in some localities. Ridgway considers it an abundant migrant in some localities and states that in the latter part of October, I882, he "found it numerous in meadows on Sugar Creek prairie, Richland Co., in company with $C$. henslowi."

Nelson considered it a rare migrant in northeastern Illinois. Mr. Frank M. Woodruff gives it as a rare migrant in the vicinity of Chicago. Specimens were taken by Mr. Nelson near the Calumet River. It has been observed on several occasions near Worth, Ill., and Mr. H. S. Swarth procured a specimen there on October I 2, I 905.

In a note regarding its occurrence near Warsaw, Ill., Mr. Chas. K. Worthen states: "I have taken in the last two years on the prairies here some twenty specimens; have taken them both in fall and spring as well as during the summer, and am satisfied they breed here, though I have not been able to find their nests or eggs. I have found them on low swampy prairies in the Mississippi bottoms and on dry prairies on the bluffs, but generally in swampy or marshy ground." (Bull. Nutt. Orn. Club, Vol. V, I880, p. 32.)

According to Kumlien and Hollister it is abundant at times in Wisconsin. They state: "This" species was taken at Lake Koshkonong but three or four times, but always in the autumn, from 1842 to 1890 . One specimen was taken near Milwaukee in the fall of 1879 . In September, I 894, numbers were procured at Lake Koshkonong and at the same date in 1895 five hundred could have been taken. In I 896 but few were seen, and in 1897 none were procured: Since 1897 but a few each fall could be found. One was taken at Delavan in September, I900, and others noted. We are at a loss to account for its great numbers in 1895 , when a series of sixty skins were secured in two days, and as many more could easily have been taken. It is also rather remarkable that the closest search has failed to produce a single specimen in spring, none having been noted before August." (Birds of Wisconsin, 1903, p. 96.) 
Genus PASSERHERBULUS Maynard.

253. Passerherbulus caudacutus nelsoni (ALLEN).

Nelson's Sharp-tailed Sparrow.

Ammodramus caudacutus nelsoni Allen, A. O. U. Check List, I 895 , p. 227 .

Distr.: Breeds from northern Illinois and northwestern Indiana northward through the Dakotas and Manitoba to Athabaska; south in winter to Texas. Occurs on Atlantic coast from New England to South Carolina and northern Florida during migrations; frequents fresh water marshes.

Adult: Crown, dark olive brown, with a grayish streak through. the centre; an orange buff streak over the eye; a patch of gray on the

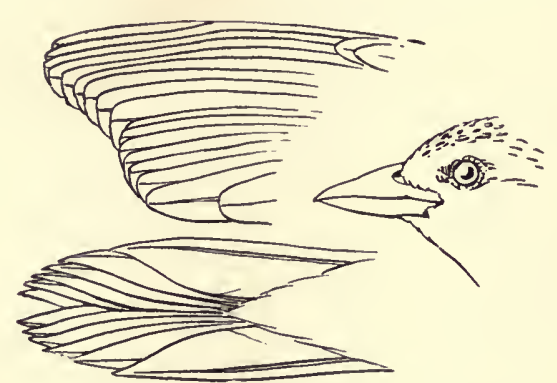

Nelson's Sharp-tailed Sparrow. ear coverts, and cheeks bordered by orange buff below; nape, tinged with grayish olive; feathers of the back, grayish olive, sometimes brownish olive, margined with gray or pale buff; throat, pale buff or buffy white; breast and sides of body, ochraceous buff, faintly streaked with dusky; middle of belly, white or whitish; bend of wing, tinged with yellow; tail feathers, narrow and pointed, dull brown in color; the shafts of tail feathers, dark brown, and usually (but not always) with numerous indistinct narrow dusky bars, giving them a "watered" appearance; primaries, brown; greater coverts and inner secondaries, dark brown, broadly edged with rufous brown and pale buff.

Length, 5.40; wing, 2.20; tail, 2 ; bill, .45.

Nelson's Sharp-tailed Sparrow, or Sharp-tailed Finch as it is often called, is abundant at times in Illinois during the migrations, but apparently much less common in spring than in the fall. A few remain to breed in the state, although the majority go further north.

Nelson states: "The I 2 th of June, I875, I saw several of these birds in the dense grass bordering Lake Calumet, where they were undoubtedly breeding." (Birds N. E. Ill., I876, p. I07.) Mr. Frank M. Woodruff writes, "I have taken the nest and eggs of this species from near Calumet Lake." (Birds of the Chicago Area, 1907, p. I38.) Messrs. Kumlien and Hollister consider this species an 
abundant migrant in Wisconsin in the fall, but have not observed it in spring. They found it "exceedingly abundant about Lake Koshkonong in September and early October." (Birds of Wisconsin, 1903, p. 93.)

Nest in marsh, composed of coarse grass and weeds, usually supported between upright reeds or stalks of coarse grass, but often on the ground and rarely in low bushes. The eggs are from 3 to 5 , dull white, speckled and spotted with brown, and measure about $.76 \times .57$ inches.

\section{Genus CHONDESTES Swainson.}

\section{Chondestes grammacus ( $\mathrm{S}_{\mathrm{AY}}$ ).}

\section{LARK Sparrow.}

Distr.: Central portion of United States, common from Dakota, Nebraska, and Kansas to Michigan and Illinois, but found occasionally as far east as the Atlantic coast; breeds from Texas to northern Wisconsin and North Dakota and casually east to New York and New England; south in winter to Florida and the Gulf states.

Adult: Sides of crown and a patch on the ear coverts, chestnut; forehead, black, with a whitish spot in centre, shading into an ashy

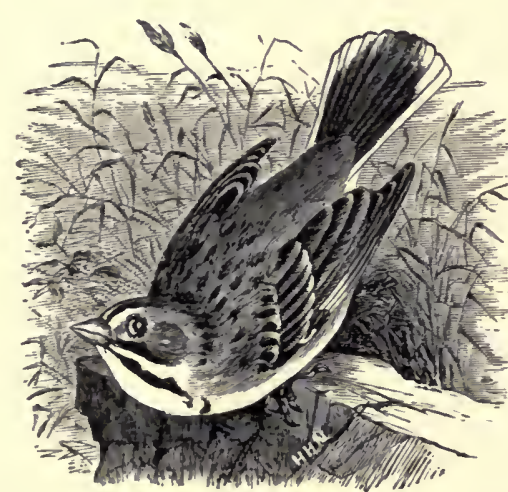

Lark Sparrow.

strip through the middle of the crown; a whitish streak in front of and below the eye; a buffy white stripe behind the eye, extending to the neck; throat, white, with a black line on each side; back, grayish, streaked with black; a black spot on the middle of the breast; rest of under parts, white, faintly tinged with brownish gray; wings, brown; middle tail feathers, dark brown like the wings, the others black, tipped with white; the outer tail feathers, white for at least three-fourths of an inch from the tip, the extent of the white marking decreasing on each succeeding feather.

Length, 6.20; wing, 3.50 ; tail, 2.80 ; bill, .40.

This melodious songster is a more or less common summer resident in Illinois and Wisconsin, being more numerous in the western than in the eastern parts of both states and apparently of rather local distribution. It arrives from the south in April. It is one of our 
most delightful songsters, the notes being strikingly clear and melodious. As Mr. Ridgway describes it "This song is composed of a series of chants, each syllable rich, loud, and clear, interspersed with emotional trills."

It breeds in May and June. The nest is built on the ground or in low trees or bushes, and is composed chiefly of dried grass. The eggs are 3 to 5 , white or faintly bluish white, marked, speckled and lined chiefly at the larger end with black and dark brown; size about . $70 \mathrm{x}$ .50 inches.

The Field Museum collection contains the following sets of eggs of this species taken in northern Illinois: 4 eggs, Joliet, May $2 \mathrm{I}$, I 906; 5 eggs, Chicago, May 20, I 905; 4 eggs, Chicago, May 20, I 905.

\title{
Genus ZONOTRICHIA Swainson.
}

\section{Zonotrichia querula (NutT.).}

\author{
HARRIS's SPARROW.
}

Distr.: Middle United States, from Illinois, Missouri, and Iowa, west to middle Kansas, the Dakotas, and plains east of the Rocky Mountains, and from Texas north to Hudson Bay and Assiniboia; breeds north of the United States.

Adult male: Crown and throat, black; sides of head, grayish buff; back, brown, streaked with dark brown; sides of body, olive buff, streaked with-dusky; belly and lower breast, white; under tail coverts, pale buff; bill, reddish brown.

Female: Similar, but with much less black marking on head and throat, often broken and irregular.

Length, 7.25; wing, 3.40 ; tail, 3.50 ; bill, .45.

Mr. E. W. Nelson considered this species a rare visitant in northeastern Illinois. Prof. Ridgway (Bulletin of the Nuttall Ornithological Club, 1880, p. 30) records two specimens taken by Mr. W. H. Garman in Illinois, one at Bloomington in the spring of 1877 and another at Normal on the i 4 th of November, I879. He also states that according to $\mathrm{Mr}$. H. K. Coale, three specimens were collected at La Crosse, Wisconsin, October 3, I883 (Orn. of Illinois, Vol. I, 1889, p. 267). Mr. James O. Dunn procured a specimen east of Riverdale, Illinois, which he observed in a growth of small willows (Auk, I895, p. 395). Mr. Frank M. Woodruff quotes Mr. Ruthven Deane as having observed a male of this species feeding with a flock of sparrows in the south end of Lincoln Park, May II, 1904 (Birds of the Chicago Area, I907, p. I39). Mr. Otho C. Poling states he procured two 
specimens in Adams County, Illinois (The Auk, Vol. VII, I89o, p. 24r). Mr. Isaac E. Hess writes me he has taken it at Philo, Illinois, and Mr. Frank S. Daggett records a specimen taken by Mr. L. E. Wyman at Beach Lake Co., Illinois, October I3, I907 (The Auk, Vol. XXV, I 908 , p. 82). Mr. Chas. K. Worthen informs me he has taken it near Warsaw, Ill.

Messrs. Kumlien and Hollister give numerous records of the occurrence of this species in different parts of Wisconsin, and state that in their opinion the bird "is becoming more common in Wisconsin than formerly." (Birds of Wisconsin, I903, p. 98.)

\section{Zonotrichia leucophrys (FORST.).}

\section{White-crowned Sparrow.}

Distr.: North America and northern Mexico; breeding in the Rocky Mountains, the Sierra Nevada, and from the extreme northern border of the United States to Ungava, Labrador, and probably Greenland.

Adult male: No yellow anywhere on head or edge of carpus; crown, black, divided in the centre by a broad white stripe, a white

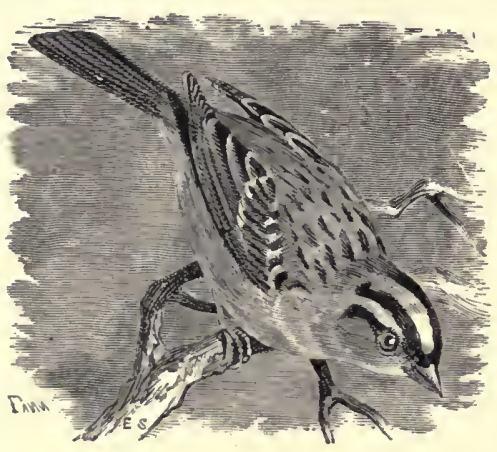

White-crowned Sparrow. line from above and somewhat behind the eye extends backward, bordered below by a black streak; nape, gray; back, grayish, streaked with brown; rump, grayish olive; throat, ashy, shading to grayish on the breast; belly, white; flanks and under tail coverts, pale olive buff; edge of carpal joint, whitish or white; primaries and tail, grayish brown; wing coverts, tipped with white; sexes, similar.

Length, about 6.50 ; wing, 3.15 ; tail, 3.10 ; bill, .38.

A common spring and fall migrant in Illinois and Wisconsin and has been known to breed in Wisconsin. Messrs. Kumlien and Hollister say: "The white-crown is a common migrant, usually in the scattered flocks of white-throats, fox and other hedge and brush-loving sparrows. It also nests very sparingly in the state. Dr. Hoy reported that a few nested near Racine. It was also taken at Cedarburg in June, $\mathrm{I} 882$, when two of the five young barely able to fly were taken. In 1873 it nested on the north shore of Lake Monona, at Mad- 
592 Field Museum of Natural History-Zoölogy, Vol. IX.

ison, and it has been known to remain through the summer a number of times at Lake Koshkonong." (Birds of Wisconsin, r 903, p. 98.)

The nest is placed in low bushes or on the ground. The eggs are from 4 to 5, pale greenish blue or pale brown, spotted and speckled chiefly at the larger end with rufous brown, and measure about $.88 \mathrm{x}$ .62 inches.

\section{6a. Zonotrichia leucophrys gambelii (Nutr.):}

Gambel's Sparrow.

Zonotrichia leucophrys intermedia RIDGw., A. O. U. Check List, I 895 , p. 230.

Distr.: Western North America, breeding from Montana to Alaska; south in winter to northern Texas and northern Mexico; casual or accidental during migrations in Minnesota, Missouri, and Wisconsin.

Gambel's Sparrow is similar to the White-crowned Sparrow, but differs from it in having the lores, grayish (without black), while leucophrys has a black stripe from the front of the eye to the bill. $Z$. l. gambellii also has the edge of the carpal joint yellowish instead of white as in leucophrys.

I can find no satisfactory record of the occurrence of this species in Illinois, but according to Mr. Nelson it has been taken in Wisconsin. He states: "The 20 th of April, I87I, a specimen of this form was obtained near Racine by Dr. Hoy. The specimen has been kindly loaned to me for examination and is without doubt a perfectly authentic example of this variety." (Birds N. E. Ill., I 876 , p. I07.) Messrs. Kumlien and Hollister state that "specimens have been taken a number of times about Lake Koshkonong which were almost, if not quite, typical gambelii." (Birds of Wisconsin, r903, p. 99.)

This form is often referred to as "Intermediate Sparrow."

\section{Zonotrichia coronata (PALL.).}

Golden-crowned Sparrow.

Distr.: Pacific coast region of the United States; breeds in Alas$\mathrm{ka}$; south in winter to southern California; accidental in Wisconsin.

This species somewhat resembles the White-crowned Sparrow, Z. leucophrys, but differs in having the front of the middle crown yellow and the carpal joint tinged with yellow. There are various other differences, but the above should be sufficient to recognize it.

Length, about 7 ; wing, 3 ; tail, 3.25 ; bill, .40.

The Golden-crowned Sparrow has not been recorded from Illinois, 
but is included as a rare straggler in Wisconsin. Dr. Hoy claims to have taken several specimens near Racine from 1853 to 1858 . Mr. E. W. Nelson says: "A beautiful male specimen of this species was obtained the middle of April, I $85^{8}$, by Dr. Hoy in his garden at Racine. The specimen was first identified by Mr. Cassin. This specimen was loaned me with the preceding and upon comparison I find it differs but very slightly from California specimens of the same species in my collection." (Birds N. E. Illinois, I 876 , p. I08.)

\section{Zonotrichia albicollis (GMEL.).}

White-throated Sparrow.

Distr.: North America east of the Rocky Mountains, from the gulf coast to Athabaska. Ungava, and Labrador; accidental or casual on the Pacific coast; breeds from Wisconsin, Michigan, and New York, northward.

Adult: Crown, black, divided by a white stripe through the centre; a yellow streak in front of the eye; a white stripe extending back-

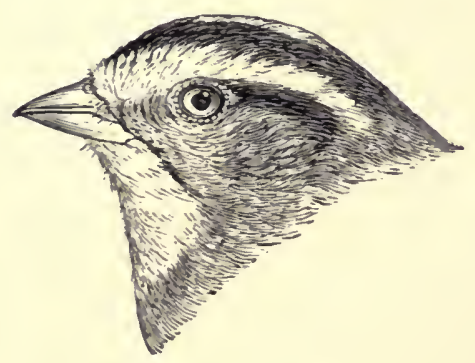

White-throated Sparrow. ward from above the eye to base of the crown, bordered below by a black stripe; chin and upper throat, white; lower throat and upper breast, grayish, shading into white on the lower breast and belly: sides of body, pale olive buff; edge of carpal joint (bend of wing), yellow; back, rufous brown, streaked with black, some of the feathers, edged with ashy; primaries and tail, grayish brown; most of secondaries, dark brown, edged, with rufous; greater and middle wing coverts, dark brown, more or less edged with rufous and tipped with white.

Adult female in fall: Similar, but more or less brown instead of black on the crown.

Immature birds have the black on the crown replaced by brown, the yellow spot in front of the eye paler and smalier, and the yellow on the carpal joint much paler; the breast sometimes with obscure streaks.

Length, 6.70 ; wing, 2.85 to 3.10 ; tail, 3 ; bill, .38; tarsus, .87 .

The White-throated Sparrow is an abundant migrant in Illinois and Wisconsin in spring and fall and, according to Kumlien and Hollister, a not uncommon summer resident in the latter state, breeding 


\section{Field Museum of Natural History-Zoölogy, Vol. IX.}

in favorable localities. Mr. John F. Ferry found four young birds of this species unable to fly near Woodruff, Vilas Co., Wisconsin, on June 20 , I 908.

The song is characteristic and very pleasing, a clear musical whistle, a suggestion of which may be had by playing the following notes on a fife:

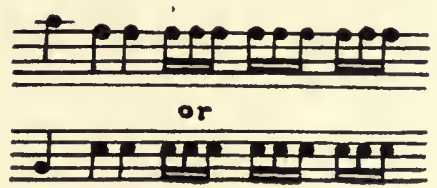

The nest is on the ground or in low trees or bushes. The eggs are 4 to 5 in number, pale brown or greenish blue, spotted and speckled with reddish brown, and measure about $.82 \times .60$ inches.

\section{Genus SPIZELLA Bonap.}

\section{Spizella monticola (Gmé.).}

Tree Sparrow.

Distr.: " Eastern North America, west to the Plains, and from the Arctic Ocean south, in winter, to the Carolinas, Kentucky, and eastern Kansas. Breeds north of the United States, east of the Rocky Mountains." (A. O. U.)

Adult: Top of head, rufous brown, a gray stripe over the eye and a narrow rufous stripe extending from the eye backward; a short

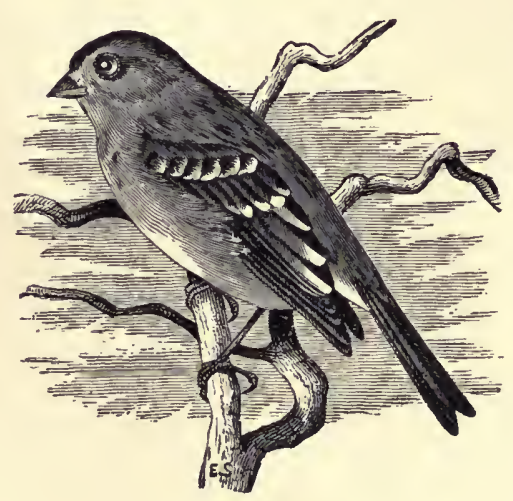

Tree Sparrow.

narrow streak of rufous on side of throat, from base of lower mandible; back, streaked with rufous brown, black and pale buff; rump, brownish gray; breast, grayish white, with an obscure dusky mark or small irregular spot in the middle; belly, dull white; sides of body, pale brownish buff; wing coverts, with black centres broadly edged with rufous and tipped with white, forming a noticeable white wing 
bar; tail feathers, dusky brown, narrowly edged with whitish; upper mandible blackish; lower mandible, mostly yellow; sexes, similar.

Length, about 5.90; wing, 2.90; tail, 2.75 ; bill, .30.

An abundant migrant and common winter resident in both Illinois and Wisconsin, possessing musical ability above the average. Its song is delightful, but difficult to describe. The notes are loud and clear, usually ending with a warble. It arrives in October and leaves for the north in April.

\section{Spizella passerina (BECHST.).}

Chipping Sparrow.

Spizella socialis (Wils.), A. O. U. Check List, I895, p. 232.

Distr.: "Eastern North America, west to the Rocky Mountains, north to Great Slave Lake, and south to eastern Mexico, breeding from the Gulf States northward." (A. O. U.)

Adult: Crown, chestnut rufous; forehead, blackish, with a spot of gray on the centre joining base of culmen; a grayish superciliary stripe and a narrow black line extending from the eye backwards; bill, mostly black; under parts, ashy, shading into whitish on throat and belly; back, streaked with black, dull rufous and grayish brown; greater and middle wing coverts, narrowly tipped with white; rump, ashy or grayish, sometimes streaked; primaries and tail feathers, dusky brown, with very narrow pale edges; sexes, similar.

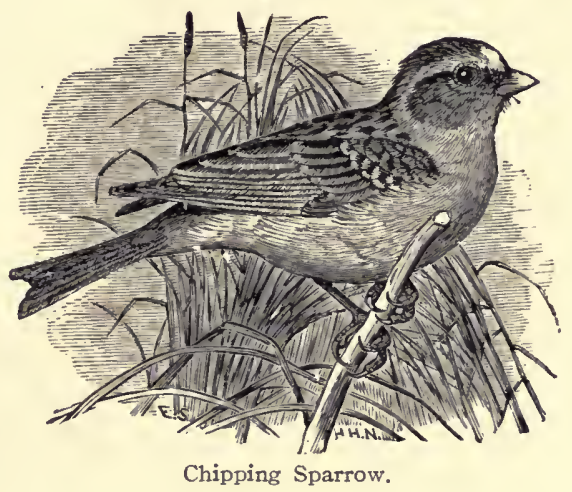

Young birds have the crown streaked like the back (without rufous) and the breast and sides streaked with dusky.

Length, 5.25; wing, 2.75; tail, 2.25; bill, .35.

The Chipping Sparrow or "Chippy," as it is often called, is one of our most familiar birds. It is a common summer resident in Illinois and Wisconsin, arriving in April and leaving for the south in October. It is a cheerful but not a particularly good songster, the usual notes being a rather long trill combined with the familiar and oft repeated chip.

It breeds in May and June. The nest is in a tree or bush, and is composed of grass and plant stems, usually lined with horse hair, 
596 Field Museum of Natural History-Zoölogy, Vol. I X.

when in the vicinity of dwellings. The eggs are from 3 to 5 , pale greenish blue or pale blue, speckled and marked with brown and black, chiefly at the larger end, and measure about $.68 \times .50$ inches.

\section{I. Spizella pallida (SwaIns.). \\ Clay-colored Sparrow.}

Distr.: Interior of North America, from Wisconsin and Illinois west to the Rocky Mountains, north to Saskatchewan and Athabaska region, and south in winter to Mexico and Lower California; breeds from Iowa, Wisconsin, and Nebraska northward.

Adult: Crown, streaked with pale brown and black, and an irregular gray stripe through the centre; a whitish stripe over the eye and a dark stripe from the eye backward; side" of head (loral and auricular region), buffy brown, bordered below with dusky; throat, white, with a narrow dusky maxillary streak; back, clay brown, streaked with black; rump, brownish gray; under parts, white, more or less faintly tinged with pale ashy brown on breast and sides; upper mandible, dark; under mandible, pale; legs and feet, pale.

Length, about 5.10; wing, 2.45; tail, 2.40; bill, .36.

The Clay-colored Sparrow is not uncommon during migrations and may be considered a summer resident in northern Illinois. It is more common in Wisconsin. Nelson considered it "a rare summer resident about the borders of prairies. Specimens are in Mr. Holden's collection taken near Chicago." (Birds N. E. I11., I876, p. го8.) Mr. O. C. Poling met with this species occasionally during migrations near Quincy, I11., and says: "Early in May, r887, I collected a number of specimens and found them quite common in pasture and stubble fields near the city." (The Auk, r89o, p. 242.)

Regarding its occurrence in Wisconsin, Kumlien and Hollister write: "An irregularly distributed summer resident from the southern part of the state northward. $* * * * *$ Has been taken nesting at Lake Koshkonong, where it occurs as a regular summer resident. More common about Stevens Point than any other locality we know of." (Birds of Wisconsin, I903, p. roo.)

The nest is in low bushes or on the ground, and is composed of grass. The eggs are 3 to 5 , pale greenish blue, speckled and marked chiefly at the larger end with dark brown, and measure about .66 $\mathrm{x} \cdot 50$ inches. 


\section{2.' Spizella pusilla (WiLs.).}

Field Sparrow.

Distr.: Whole of eastern United States, from the Dakotas and Kansas to the Atlantic coast, and from the Gulf of Mexico to southern Canada; breeds from northern Florida, Alabama, Louisiana and Texas northward.

Adult: Bill, reddish brown; crown, rufous chestnut; a gray superciliary stripe and post-ocular patch of rufous chestnut; back, rufous chestnut, narrowly streaked with black and the feathers edged

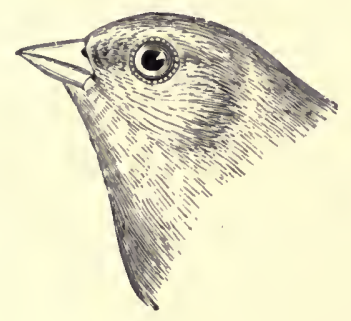
with ashy; rump, brownish gray, sometimes showing a faint olive tinge; under parts, white, without streaks, but washed with pale brown on breast and sides; wing coverts and inner secondaries, brownish black, broadly edged with pale rufous and tipped with white, forming two narrow white bands; tail, grayish brown.

Sexes similar.

Length, 5.55 ; wing, 2.40; tail, 2.50; bill, .35.

The Field Sparrow is a common summer resident in Illinois and Wisconsin, arriving in April (earliest Chicago record, March 22) and leaving for the south in October. It is a pleasing songster, the song consisting of several short notes followed by a musical trill.

It breeds in May and June. The nest is composed of grass, either on or near the ground. The eggs are from 3 to 5 , dull white or greenish or pale buff, marked with brown, chiefly at the larger end, and measure about $.68 \times .50$ inches. The Field Museum collection contains a series of sets of eggs taken in northern Illinois between May 9 and June 18 .

\section{Genus JUNCO Wagler.}

The species and subspecies of Juncos or Snowbirds which occur within our limits may be recognized by the following characters:

Junco hyemalis: General plumage, slate gray; the head darker, sometimes blackish in front and again often tinged with brownish in immature females; belly and outer tail feathers, white; sides (in adult), gray like the chest; bill, pinkish white. Immature birds have the upper part, throat and breast streaked with blackish.

Wing, 2.95 to 3.20 ; tail, 2.70 to 2.90 ; bill, .46 to .52 in. 
598 Field Museum of Natural History-Zoölogy, Vol. IX.

Junco hyemalis montanus: General appearance of $J$. hyemalis, but differs in having the sides distinctly pinkish brown, the color well defined, and the entire head, neck and chest, slate-gray.

Junco oregonus shufeldti: Similar to $J . h$. montanus, but differs in having the head, neck and chest black or blackish; sides, pinkish brown or vinaceous as in montanus.

\section{Junco hyemalis (LiNn.).}

Slate-colored Junco. Snowbird.

Distr.: Occurs nearly throughout the whole of North America, but chiefly east of the Rocky Mountains, south to Florida, the Gulf coast, Texas, and California in winter; breeds from the mountains of New England, northern Wisconsin and Minnesota northward.

The Junco is an abundant migrant and a more or less common winter resident throughout Illinois. Although it does not breed in Illinois, stragglers are occasionally

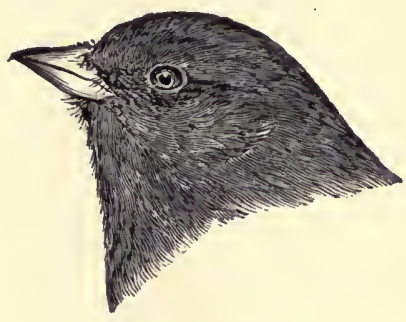
observed late in the spring. Prof. S. A. Forbes procured a specimen near Elizabethtown, Hardin County, in southern Illinois, June 9, r88r (Bull. Nutt. Orn. Club, I88r, p. I80).

In Wisconsin it is an abundant migrant and a common winter resident and also a more or less common summer resident, and breeds in the northern part of the state. Mr. John F. Ferry procured three nests of this species, two containing four eggs and the third containing a young bird and two eggs, near Woodruff, Vilas County, during the last week in June, r9o8.

Kumlien \& Hollister say: "Nests sparingly in northern Wisconsin. Three sets were taken at Oconto in May, r882 (coll. of L. K.). The nests were placed on the ground among spagnum moss. Dr. Hoy mentions its breeding on the shores of Lake Superior. In rare instances the junco breeds in southern Wisconsin. Young barely able to fly have been taken near Jefferson, which is the most southern point for which we have any record, and this must be taken as an exceptional case." (Birds of Wisconsin, r903, p. roo.)

The nest is placed on the ground, composed of grass and often lined with animal hair. The eggs are from 4 to 5 , greenish white and spotted and blotched with brown. Size about $.75 \times .58$ in. 


\section{Junco hyemalis montanus (RIDGWAY). \\ Montana Junco.}

Distr.: Rocky Mountain region, from Alberta to western Texas and northern Mexico, breeding from northern Idaho and northwestern Montana north to Alberta; accidental in Illinois, Wisconsin, Indiana, Michigan, etc.

Similar to Shufeldt's Junco, but the adults with head, neck and chest slate-gray instead of black; the pale pinkish brown or vinaceous color on the sides will distinguish it from the adult Slate-colored Junco.

This species, like the preceding, is an accidental straggler in Illinois and Wisconsin. The records are as follows:

A specimen was killed by Mr. H. K. Coale in Chicago, Oct. I4, I 875; identified by Mr. Nelson as Junco oregonus (Bull. Nutt. Orn. Club, Vol. II, I877, p. 82); now referred to as montanus by Mr. Ridgway (Birds of North and Middle Am., rgor, p. 290).

A specimen was killed by Mr. F. S. Dayton on October $2 \mathrm{I}, \mathrm{I} 898$, west of North Evanston, Ill. The identification was confirmed by Mr. Ridgway (F. M. Woodruff, Birds of the Chicago Area, I907, P. I4I). The bird is now in the collection of the Chicago Academy of Sciences.

Regarding its occurrence in Wisconsin, Kumlien \& Hollister write: "A single female of this species was taken at Delevan, October 23, I 898 , and is now in the Hollister collection. Mr. Wm. Brewster, who has kindly examined the skin, writes: "This bird matches perfectly a specimen in my collection from Illinois identified by $\mathrm{Mr}$. Ridgway as typical montanus.' Doubtless occurs as a straggling migrant anywhere in southern Wisconsin. The various old records of Junco oregonus, $J$. o. shufeldti, J. h. connectens, etc., probably belong here." (Birds Wisconsin, I903, p. гог.)

White-winged Junco, Junco aikeni Ridgw. In the Auk for January, I885, page 32 , Prof. W. W. Cooke recorded a bird of this species taken in Jefferson, Wisconsin, but according to Kumlien \& Hollister (Birds of Wisconsin, I903 p. I33) Mr. Cooke now considers the record untrustworthy.

\section{Junco oregonus shufeldti (COALE).}

Shufeldt's Junco.

Junco hyemalts shufeldti Coale, A. O. U. Check List, I895, p. 235.

Distr.: Ranges from Montana, Wyoming and Colorado west to Nevada and Oregon, north to British Columbia, and south to Texas 
600 Field Museum of Natural History-Zoölogy, Vol. IX.

and northern Mexico; breeds from Idaho and Oregon northward, accidental in Illinois.

Special characters: General appearance of the Slate-colored Junco, $J$. hyemalis, but differs in having the sides pale pinkish brown, the back browner and the head, neck and chest black or blackish, not grayish or slate color.

Shufeldt's Junco must be considered an accidental straggler in Illinois. There is a specimen of this form in the Field Museum collection (No. 4959), an adult male taken by Mr. H. K. Coale at Waukegan, Ill., February 20, I887.

Mr. Wm. E. Praeger states: "On the I6th of December, I892, 1 shot a specimen of Junco hyemalis shufeldti on the Illinois shore just opposite this city (Keokuk, Iowa). It was with several other Juncos, all as far as I could tell of the common variety." (The Auk, I895, p. 85.)

Mr. A.W. Butler (Birds of Indiana, I897, p. 965) records a specimen taken at West Lafayette, Indiana, January 20 , I89I.

Genus AIMOPHILA Swainson.

266. Aimophila æstivalis bachmanii (AUD.).

Bachman's Sparrow.

Peucra cestivalis bachmanii (Aud.), A. O. U. Check List, I895, p. 239.

Distr.: Southeastern United States, from southern. Iowa and central Illinois south to Texas and the Gulf, and east to the Atlantic coast; from Maryland southward; breeds nearly throughout its range, except in Florida.

Adult: Whole of upper plumage, chestnut rufous, the feathers edged with ash gray, forming irregular streaks; a grayish buff superciliary line; edge of wing at carpal joint, yellow; middle of belly, whitish; breast and sides of body, dull brownish ash; no streaks on. under parts except occasionally on sides of breast; tail, much rounded, the outer feathers being half an inch or more shorter than the middle feathers.

Sexes similar.

Length, about 5.85 ; wing, 2.50 ; tail, 2.55 ; bill, .44.

Bachman's Sparrow occurs in Illinois, in the southern and central portion of the state, but has not been recorded from northern Illinois or Wisconsin. Ridgway states: "Bachman's Sparrow first came under my observation early in June, I87 1 , when several were seen and others heard about half way between Mount Carmel and 
Jan., igog. Birds of Illinois and Wisconsin-Cory.

601

Olney, the former in Wabash, the latter in Richland county, Illinois." (Orn. of Ill., r889, p. 28r.) Mr. Nelson gives it as "common locally in Wabash, Richland, and adjoining counties" (Birds N. E. Ill., r876, p. I5I), and Mr. O. C. Poling shot three birds of this species in an apple orchard at Quiricy, Ill., in Mav, I887. (The Auk, I89o, p. 242.)

Mr. Isaac E. Hess found a nest and four eggs of this species at Philo, Ill., Champaign Co., on May 26, I896 (Nidologist, Vol IV, I 897, p. 45).

The nest is made of grass and is built on the ground. The eggs are from 3 to 5 , pure white or pale bluish white, and measure about $.74 \times .60$ inches.

\section{Genus MELOSPIZA Baird.}

267. Melospiza melodia (Wilson).

SONG SPARROW.

Melospiza fasciata (Gmel.), A. O. U. Check List, I895, p. 24 I.

Distr.: United States and British Provinces, east of the Rocky Mountains; breeds from Kansas, southern Illinois and South Carolina northward.

Adult: Crown, dark rufous chestnut, streaked with gray in the centre; a gray superciliary line and a post-ocular line of chestnut;

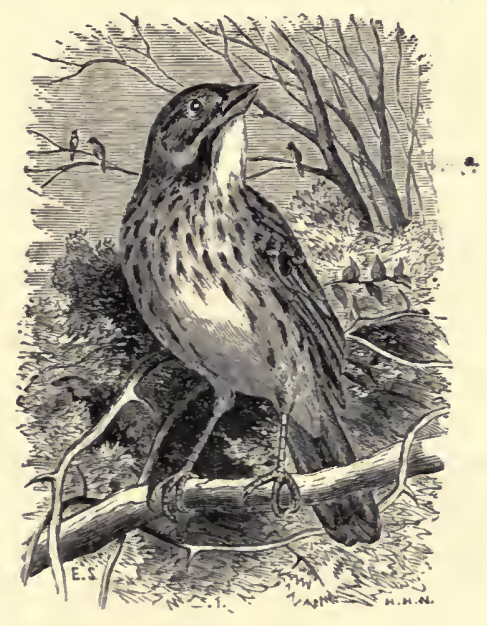

Song Sparrow.

back, streaked with dark brown, dull chestnut and grayish; throat, whitish, heavily streaked with blackish brown on the sides; breast, buffy white or grayish white, streaked with dark brown, often run- 
ning together and forming what appears to be a dark patch (noticeable in the living bird when seen at a short distance); sides of body, streaked with dark brown and pale rufous brown; middle of belly, white; middle tail feathers, tinged with dull rufous brown; rest of tail feathers, grayish brown, more or less faintly edged with rufous.

Length, about 6.10 ; wing, 2.65 ; tail, 3 ; bill, . 38 .

The Song Sparrow is an abundant summer resident in Illinois and Wisconsin, and a not uncommon winter resident in southern Illinois. The majority arrive from the south in March and leave again in October, although specimens have occasionally been taken as far north as southern Wisconsin in mid-winter.

The song is loud and pleasing but two varied to be properly described. The more common form begins with a clear note, repeated three times, and followed by a complicated warbling trill.

The nest is built on the ground or in low bushes and is made of dry grass, shreds of bark, etc. It breeds from May until July. The eggs are 4 to 5 in number, pale bluish white or dull white, thickly marked and spotted with rufous brown; size about . $78 \times .59$ inches. The following records are selected from sets of eggs in the collection of the Field Museum of Natural History: 4 eggs, Joliet. I11., May 3 , I906; 4 eggs, Joliet, Ill., May 7, I906; 4 eggs, Fox Lake, Ill., June 8, I907; 5 eggs, Milton, Wisconsin, July 9, I 895 .

\section{Melospiza lincolnii (Aud.).}

LinCOLN'S SPARROW.

Distr.: "North America at large, breeding chiefly north of the United States (as far north as Fort Yukon) and in the higher parts of the Rocky Mountains and Sierra Nevada; south, in winter, to Panama." (A. O. U.)

Adult: Crown, chestnut brown, streaked with black and with a grayish stripe through the centre, partially obscured by the black

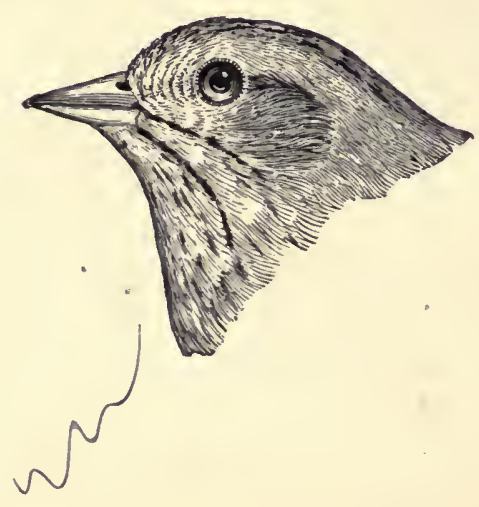
streaks; a gray stripe over the eye; a post-ocular black streak and another black streak from the lower mandible, the latter often not clearly defined; back, grayish olive brown, streaked with black; the inner secondaries and some of the wing coverts edged with pale rufous; primaries, grayish brown, faintly edged with a dull rufous brown; middle of throat, 
white, streaked with black; sides of throat and breast, tawny buff, with narrow black streaks; sides of body pale, brownish buff, streaked with black; belly, white. The amount of buff and white on the under parts is variable. but the tawny buff pectoral band is a good diagnostic character.

Sexes similar.

Length, 5.70; wing, 2.50; tail, 2.45; bill, .37.

Lincoln's Sparrow is a not uncommon migrant in parts of Illinois and Wisconsin, and a winter resident in southern Illinois. It is an occasional summer resident in northern Illinois and Wisconsin, and has been known to breed.

Mr. E. W. Nelson writes: "Common during the migrations from May 8 to 20 and Sept. 20 to Oct. I 5 th. Have seen several specimens during the breeding season, and the last of May, I875, as I was walking through a patch of weeds, a female started from a few feet in advance of me, while my attention was attracted in another direction and ran off with half-spread wings. It was shot and showed unmistakable signs of incubation, but a protracted search failed to reveal the nest. Specimens were taken in July, I875, near Waukegan by Mr. Rice." (Birds of N. E. Ill., I876, p. Iog.)

Mr. Ridgway states: "Instead of being the rare bird that it is commonly supposed to be, Lincoln's Sparrow is at times almost as numerous as the Swamp Sparrow; and the fact that it associates freely with the latter species, which it closely resembles in habits and general appearance, may in a measure account for its supposed scarcity. In the southern part of the State a greater or less number usually pass the winter in company with $M$. georgiana, in the dense brushwood and rank dead herbage of swamps and marshes, in the bottom lands." (Orn. of .HH., "₹889, p. 2.2.5.)"

Mr. Frank M. Woodruff says: "A rare summer resident and a not uncommon spring and fall migrant. Mr. Geo. K. Cherrie obtained a young bird just out of the nest at Worth, Illinois, on June 30, I896, and on July I6, I896, Mr. Cherrie and Mr. J. Grafton Parker, Jr., obtained an adult and a nestling near Lake Calumet." (Birds of the Chicago Area, 1907, p. I43).

Cook (Bird Migration Miss. Valley, r888, p. 209) states: “Breeds but sparingly in the United States. For a long time Racine, Wis., was the southernmost point at which it was known to nest, but recently nests have been found in northern Illinois."

In Wisconsin Dr. Hoy found it nesting near Racine (I852). Kumlien \& Hollister write: "A somewhat irregularly distributed species, even during the migrations. Nowhere very abundant, but 
604 Field Museum of Natural History-Zoölogy, Vol. iX.

occurs more plentifully than generally supposed. Mr. Clark calls it an irregular migrant in small numbers in Dunn County. Dr. Hoy did not consider it rare about Racine and stated that a few nested. Dr. Ogden reports it rather plenty at Milwaukee. A regular migrant at Lake Koshkonong, especially in spring and sometimes a summer resident, though no nests have been found. Appears to be rather rare at Delavan and not noted, as yet, except in spring." (Birds of Wisconsin, I 903 , p. IOI).

The nest is on the ground, composed of grass and shreds of bark and occasionally lined with hair. The eggs are from 4 to 5 , pale greenish or buff white, marked and spotted with rufous brown and lilac brown, and measure about $.78 \times .60$ inches.

\section{Melospiza georgiana (LATH.).}

SWAMP SPARROW.

Distr.: Eastern North America, from the Plains to the Atlantic coast, south in winter to the Gulf of Mexico; breeds from Iowa, northern Illinois and Ohio northward to Athabaska and Labrador, accidental in Utah.

Adult in summer: Crown, bright chestnut, becoming blackish on the forehead, usually with narrow black streaks and an irregular median line of ashy (these streaks occasionally absent), an ashy gray superciliary line and a dusky post-ocular stripe, a dusky maxillary streak often imperfect; nape with more or less ashy; back, streaked with black, buff, and rufous chestnut; primaries, secondaries and coverts, edged with chestnut rufous, giving a general rufous krown appearance to the wing when closed; throat and belly, whitish; breast, ashy; sides of body tinged with olive buff; tail, brown, narrowly edged with rufous brown on outer webs.

Adult and immature in fall and winter: Similar, but differs in having the crown deep chestnut, heavily streaked with black, and the median line dull olive gray; nape showing scarcely any gray; breast and sides tinged with brown, especially on the flanks.

Length, about 5.75 ; wing, 2.40 ; tail, 2.40 ; bill, .40.

The Swamp Sparrow is a common summer resident in Illinois and Wisconsin and a winter resident in southern Illinois. It arrives from the south late in March and leaves again in October. While not as often heard as that of many of our Sparrows, the song is sweet and musical. It has a delightful little trill, most often heard in the spring and occasionally a soft warble.

The nest is built on the ground and is composed of dry grass and 
shreds of bark. The eggs are 4 to 5, dull greenish white or bluish green, thickly and heavily marked with brown, and measure about $.76 \times .56$ inches.

\section{Genus PASSERELLA Swainson.}

270. Passerella iliaca (MERR.).

Fox Sparrow.

Distr.: Eastern North America, from the Plains to the Atlantic coast, south in winter to Texas and the Gulf states, accidental in California; breeds chiefly north of the United States, from northern Manitoba to Alaska and from northern Maine to Labrador.

Adult: General color above, rusty brown, mixed with gray, the back showing imperfect streaks of rusty; tail and tail coverts, rufous

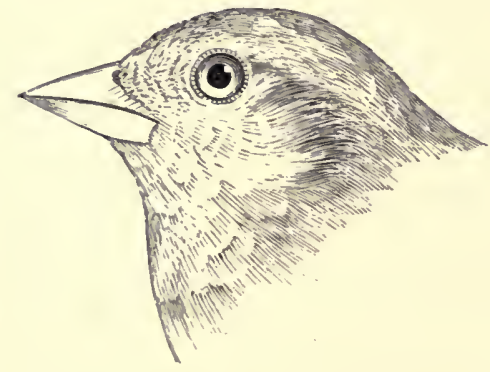
brown, the latter often with narrow pale edgings; under parts, white, more or less heavily and irregularly marked, except on the belly and crissum, with rusty brown; wings appear rufous brown when closed, caused by the slaty brown feathers being heavily margined with that color; greater and middle wing coverts, more or less faintly tipped with white (absent in immature birds); upper mandible, dark; lower mandible, yellow, except at tip.

Sexes similar.

Length, about 7 ; wing, 3.45 ; tail, 3.10 ; bill, .43.

The Fox Sparrow is common during the migrations in Illinois and Wisconsin and is a winter resident in southern Illinois. Frequents thickets and shrubbery, and is rather retiring in its habits. It has a charming song, perhaps, unsurpassed by any of our sparrows. Its loud, clear whistling notes, however, are so varied as to make any attempt at description unsatisfactory.

\section{Genus PIPILÒ Vieill.}

\section{Pipilo erythrophthalmus (Linn.).}

Towhee. Towhee Bunting.

Distr.: "Eastern United States and southern Canada, west to the Plains, breeding from the lower Mississippi Valley and Georgia northward; in winter from the middle districts southward." (A. O. U.) 
606 Field Museum of Natural History-Zoölogy, Vol. IX.

Adult male: Whole head, throat and back, black (occasionally the feathers of the back with narrow rufous brown edgings); belly.

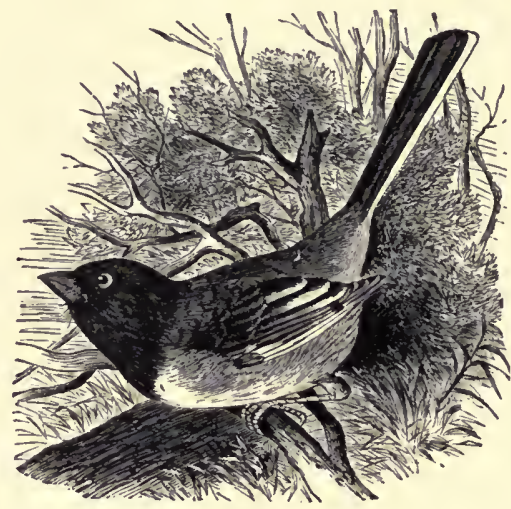

Towhee.

white; sides of body and flanks, rufous chestnut; crissum, tawny brown; primaries and inner secondaries, black, marked with white on outer webs, forming a conspicuous white patch; tail, black, the three outer tail feathers, broadly tipped with white, the outer feather with about the terminal third of inner web, white, the white patch decreasing in size on the second and third; iris, red; bill, black.

Adult female: General markings as in the male, but differs in having the head, throat, back, wings and tail, grayish brown, often with a faint tinge of olive.

Very young birds in first plumage have the back and under parts streaked with dusky.

Length, about 8; wing, 3.30; tail, 3.60; bill, .50.

The Towhee Bunting is a common summer resident in Illinois and Wisconsin, frequenting the hedges and thickets, from April until October (earliest Chicago record, March I6). The characteristic note of this species is a loud, clear chee-we or che-wink.

It breeds from the latter part of April until July. The nest is built on or near the ground and is composed of leaves, strips and shreds of bark, etc., and lined with fine grass. The eggs are from 3 to 5 , white or pinkish white or buff white, speckled all over with brown, occasionally showing a few blotches at the larger end; size about $.95 \times .7 \mathrm{I}$ inches. 


\section{Pipilo maculatus arcticus (Swainson).}

Arctic TowheE.

Distr.: "Plains of the Platte, Upper Missouri, Yellowstone and Saskatchewan Rivers, west to the eastern slope of the Rocky Mountains, south in winter to Kansas, Colorado and Texas." (A. O. U.)

The Arctic Towhee resembles the common Towhee, $P$. erythrophthalmus, but differs from it in having the upper plumage dull black (not clear black), tinged with olive on the rump, and the scapulars and interscapulars marked and streaked with white. The female has the upper plumage dusky brown, more or less tinged with olive and the forehead tinged with gray; feathers of the back (interscapulary region) edged with more or less white.

Length, about 8.15 ; wing, 3.40 ; tail, 3.65 ; bill, .50.

The Arctic Towhee is an accidental straggler in Illinois and Wisconsin. In a foot-note in his Birds of Northeastern Illinois, p. I Io, Mr. Nelson states: "Through Dr. Hoy I learn that two specimens of $P$. arcticus have been taken in Wisconsin, one near Milwaukee, where it is now preserved, and a second opposite Dubuque, Iowa. $\mathrm{He}$ has seen both specimens and is positive of their identity."

Another specimen is recorded by Mr. Frank M. Woodruff, who writes: "The only record that I have found of the taking of the Arctic Towhee within our limits is that of Mr. F. S. Dayton, who shot one of these birds in the woods west of North Evanston, Illinois, on October 24, I898, near the same locality where he obtained specimens of Junco montanus three days before. The specimen is in the collection of the Chicago Academy of Sciences, having been donated by Mr. Dayton. It is the skin of a typical adult male." (Birds of the Chicago Area, I907, p. I44.)

Kumlien \& Hollister state: "One specimen, an adult male, has been shot (by L. K.) in Jefferson County. This specimen was sent to Prof. Sundevall and the record can not be found at present. There was also a specimen - formerly preserved in the old Wisconsin Natural History Society collection - which was taken near Milwaukee about 1867 or 1868 . One was noted by Dr. Hoy in a collection of birds at Dubuque, Iowa, which had been taken on the Wisconsin side of the river." (Birds of Wisconsin, I 903, p. I02). 
608 Field Museum of Natural History-Zoölogy, Vol. IX.

Genus CARDINALIS Bonap.

273. Cardinalis cardinalis (LinN.).

Cardinal. Cardinal Grosbeak.

Distr.: Eastern United States, from the Plains to the Gulf of Mexico and Atlantic coast, north to southern New York, southern Wisconsin and southern Minnesota; breeding throughout its range. Resident in Bermuda; accidental in Maine, New Brunswick and Colorado.

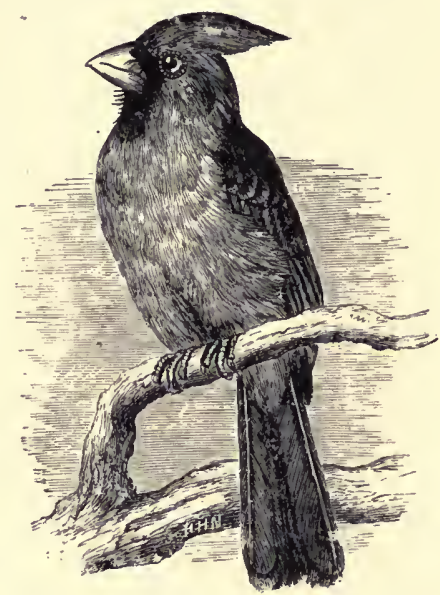

Cardinal (male).

Adult male: General plumage, bright red; head with elongated crown feathers forming a crest; throat and face, including area around the base of the bill, black; feathers of the back, tinged with olive gray; bill, red.

Adult female and immature male: Crest, wings and tail, tinged with dull red; throat and face, dusky; back, ashy olive brown; under parts, pale buff, whitening on the belly; breast, more brownish and often tinged with red; under surface of wing, bright rosy red.

Length, 8.50 ; wing, 3.60 ; tail, 4.25 ; bill, .6o.

The Cardinal is a very common permanent resident in southern Illinois, and a rather uncommon summer resident in northern Illinois and $\mathrm{W}$ isconsin.

Nelson considered it "a rare and irregular summer resident" in northeastern Illinois in 1876 . Mr. Frank M. Woodruff writes: "Some years ago I found a nest of the Cardinal at River Forest, Illinois. Mr. O. M. Schantz informs me that in the year 1904 there were two 
pairs nesting at Riverside, Illinois, and that they arrived in that locality on the I7th of April." (Birds of the Chicago Area, I907, p. I 45.) Mr. Otto C. Poling found it "an abundant resident" in the vicinity of Quincy, Adams County, Illinois. (The Auk, r89o, p. 243).

In Wisconsin it is rare. Dr. Hoy ( $\left.185_{2}\right)$ states that a few specimens formerly nested near Racine. Messrs. Kumlien \& Hollister (Birds of Wisconsin, 1903, p. 102) record three specimens from the vicinity of Milwaukee and one or two others which they suppose might have been escaped cage birds.

The nest is a comparatively small structure of rootlets, shreds of bark, etc., built in a low tree or bush. The eggs are 3 or 4 , variable in color, white or buff white or greenish white, marked, spotted and speckled with various shades of brown and lilac gray, and measure about $\mathrm{x} \times .74$ inches. There is a set of three eggs in the Field Museum collection, taken at Poland, Ohio, May r9, I89r.

\section{Genus ZAMELODIA Coues.}

\section{Zamelodia ludoviciana (Linn.). Rose-breasted Grosbeak.}

Habia ludoviciana (Livv.), A .O. U. Check List, i895, p. 250.

Distr.: Eastern North America, and southern Canada, west to Athabaska and Saskatchewan, south in winter to Central and northern South America; breeds from North Carolina, Ohio, Illinois and Nebraska northward.

Adult male: Whole head, throat and back, black; breast and under wing coverts, brilliant rosy red, rest of under parts, white; wings,

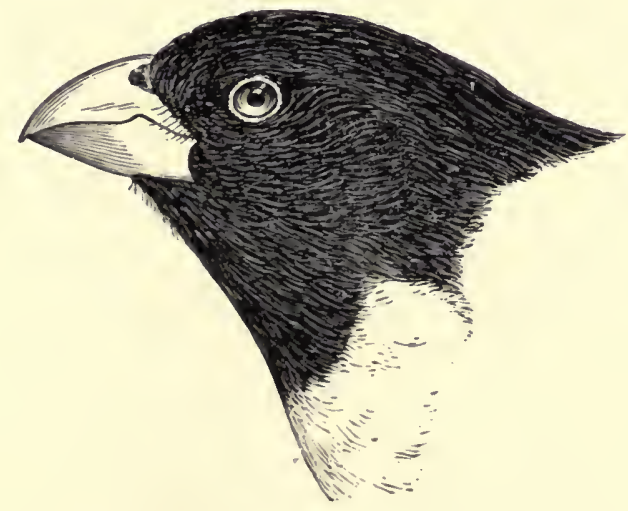

Rose-breasted Grosbeak (male). 
wing coverts and tail; black, more or less marked with white; the primaries and outer tail feathers, heavily marked with white; rump, white; upper tail coverts, black, tipped with white; bill, brownish white.

Adult female: Under wing, coverts, bright saffron-yellow; upper parts, grayish brown, streaked with dusky brown and more or less tinged with olive brown on the rump; crown and sides of head, dark grayish brown, a whitish streak in centre of crown and a white superciliary stripe; wings and tail, grayish brown; wing coverts, tipped with white; throat, breast and sides of body, tinged with pale buff and streaked with dusky; belly, whitish.

Length, about 8 ; wing, 4 ; tail, 3 ; bill, .65 .

This beautiful species is a common summer resident in northern Illinois and Wisconsin, and occurs during migrations in southern Illinois. It is one of the most beautiful of our birds and of special value to the agriculturist as, besides other insects, it eats the potato beetle. The male is one of our most gifted songsters, its delightful warble being varied and very sweet.

It breeds in May and June. The nest is in bushes or low trees and is composed of rootlets and dry stalks of weeds, etc. The eggs are from 3 to 4 , rarely 5 , pale greenish blue or bluish green, marked and speckled with various shades of brown, and measure about .96 $x .67$ inches.

\section{Genus GUIRACA Swainson.}

\section{Guiraca cærulea (LiNN.).}

Blue Grosbeak.

Distr.: Eastern United States, southern Illinois, Nebraska and southern New Jersey to Florida and the Gulf states, south in winter to Cuba and eastern Mexico (Yucatan); breeds throughout its United States range.

Adult male: General plumage, dark blue; chin and region about base of bill, black; wings and tail, blackish brown; middle and greater wing coverts, tipped with chestnut, forming wing bars. (In assuming adult plumage the feathers of the back are edged with chestnut, and the feathers of under parts narrowly edged with whitish).

Adult female: Upper parts, brown, the head, clear brown, shading to grayish brown on the rump; under parts, buffy brown, palest on throat and belly; wing and tail, grayish brown, the greater and middle wing coverts, edged and tipped with tawny brown. 
Immature males at first resemble the female, but later assume a mixed plumage of brown and blue.

Length, 6.60; wing, 3.40; tail, 2.80 ; bill, .63.

The Blue Grosbeak occurs in southern Illinois and is an accidental straggler in Wisconsin. Both Ridgway and Nelson state that it is

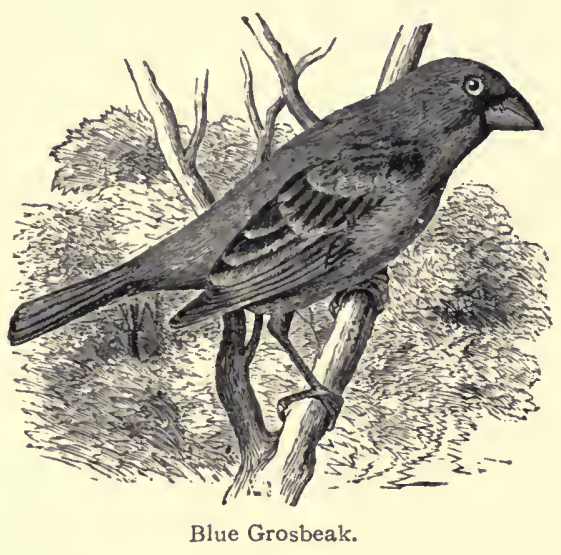

a rare bird in Illinois, even in the southern half of the state, but give no definite records of its capture. W. W. Cooke says: "In its migration it reaches southern Illinois and southern Nebraska." (Bird Migration Miss. Valley, I 888, p. 2 18. .)

Kumlien \& Hollister state: "A rare straggler in Wisconsin. Thure Kumlien captured a pair near Lake Koshkonong in June, I860. It was also taken at least once by Dr. Hoy and there was also a Milwaukee specimen, which seems to have entirely disappeared." (Birds of Wisconsin, 1903, p. 102.)

\section{Genus PASSERINA Vieillot.}

\section{Passerina cyanea (Linn.).}

\section{Indigo Bunting. Indigo Bird.}

Distr.: Eastern United States, from Kansas and Nebraska eastward, north to Minnesota, Ontario and Quebec, and south in winter to Cuba and Central America to Panama; breeds from the Gulf states northward.

Adult male: General plumage, blue; 'clear indigo-blue on head, throat and breast; lighter blue on back and with the blue of the flanks tinged with greenish; lores, black; wings and tail, .blackish, more or less edged with greenish blue. 
6iz Field Museum of Natural History-Zoölogy, Vol. IX.

Adult female: Upper plumage, brown; under parts, grayish brown, indistinctly streaked with darker brown; throat, brownish white or whitish.

Immature male: At first similar to the female, but later mixed blue and brown; the under parts mixed with whitish.

Length, 5.50; wing, 2.70; tail, 2.20; bill, .38.

A common summer resident in Illinois and Wisconsin, being especially noticeable on account of the brilliant blue plumage of the male.

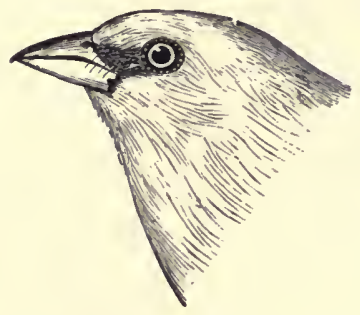

It arrives from the south in May and remains until the latter part of September and sometimes later.

The song is varied and sweet but not loud. Alexander Wilson in describing it, writes: "It mounts to the highest tops of a large tree and chants for half an hour at a time. Its song is not one continuous strain, but a repetition of short notes, commencing loud and rapid, and falling by almost imperceptible gradations for six or eight seconds, till they seem hardly articulate, as if the little minstrel was quite exhausted; and after a pause of half a minute or less, commences again as before $* * *$ His usual note when alarmed by an approach to his nest, is a sharp chip, like that of striking two hard pebbles smartly together." (Am. Orn., 1877 , p. 100.)

The nest is in a bush, composed of grass, leaves and shreds of bark. The eggs are from 3 to 4 , usually pale bluish white in color, but occasinally showing a few brown spots. Size, about $.73 \times .54$ inches.

The Field Museum collection contains a series of sets of eggs taken in northern Illinois between June 4 and June 24 .

\section{Passerina ciris (LinN.).}

\section{Painted Bunting. Nonpareil.}

Distr.: South Atlantic and Gulf states to western Texas, north to North Carolina and casual or accidental to southern Illinois and Kansas; in winter south through Mexico and Central America to Panama.

Adult male: Whole head (except throat) and sides of breast, indigo-blue; back and scapulars, golden green; throat and under parts, vermilion red; wings, dark fuscous brown, more or less glossed with green; tail, fuscous brown, faintly washed with red. 
Adult female: Upper parts, olive green; under parts, pale greenish yellow, without streaks; tail, dark brown, more or less edged with olive green.

Immature males in early stages similar to the female, but later variegated with colors of the male.

Length, 5.35 ; wing, 2.75 ; tail, 2.25 ; bill, .40.

The only record of the occurrence of this bird within our limits is that given by Prof. Ridgway, who states he observed a female bird of this species in Wabash County, Ill., June ro, I87r, "under circumstances which allow of no doubt as to correct identification." (Orn. of Ill., I 889 , p. 302.)

\section{Genus SPIZA Bonap.}

\section{Spiza americana (GMEL.).}

\section{Dickcissel. Black-throated Bunting.}

Distr.: "Eastern United States to the Rocky Mountains, breeding from Texas north to Massachusetts, New York, southern Ontario, Wisconsin, Minnesota, and North Dakota; south in winter through Central America to northern South America; southwest in migrations to Arizona. Now rare or entirely absent east of the Alleghanies." (A. O. U.)

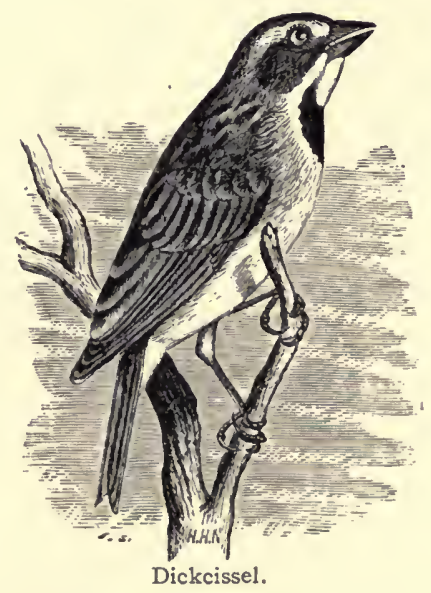

Adult male: Crown, olive yellow, shading to ashy on the nape; sides of head, ash gray; chin, white; throat, black, a yellow superciliary line and maxillary spot; breast and more or less of middle belly, yellow; back and rump, ashy brown, tinged with rufous and streaked with black on the interscapulary region; carpal joint, 
6 i 4 Field Museum of Natural History-Zoölogy, Vol. IX.

edged with bright yellow; wings and tail, fuscous brown; middle and lesser wing coverts, bright chestnut, forming a chestnut "shoulder" patch; belly and crissum, whitish; sides of body, washed with gray.

Adult female: Similar to the male, but smaller and paler, and without the black patch on the throat; breast more or less streaked with blackish.

Length, about 6.60 ; wing, 3.25 ; tail, 2.50 ; bill, .52.

This species is a common summer resident in Illinois and Wisconsin, arriving from the south in May and breeding throughout both states. Wherever it occurs it makes its presence known, as it is a persistent songster. The notes are strong and clear and may be described as see-see, dick-cissel, cissel. Prof. Ridgway says:

"The location of the nest varies much with locality, though probably not more than in the case of many other species. At Mount Carmel, all that I found were in clover fields, and built upon or very close to the ground. In Richland County they were almost invariably built in small clumps of coarse weeds, at a height of about a foot above the ground. In Wisconsin, however, according to Dr. Brewer (Hist. N. Am. B., Vol. II, p. 68), Dr. P. R. Hoy, of Racine, has never found a nest within one foot of the ground, some of them being as elevated as six feet. Of nineteen nests discovered by Dr. Hoy during one season, 'ten were built in gooseberry bushes, four on thorn bushes, three among blackberry bushes, one on a raspberry bush, and one on a wild rose." " (Orn. of Ill., I889, p. 304.)

The nest is composed of leaves and grass, often in meadows and prairies and at times in bushes. The eggs are 4 to 5 , pale blue in color, and measure about .80 x.60 inches.

The Field Museum collection contains the following sets of eggs taken in northern Illinois and Wisconsin: 3 eggs, Joliet, Ill., May 26, I906; I egg, Joliet, I11., May 28, I906; 4 eggs, Joliet, Ill., June 4, I9o6; 4 eggs, Columbus, Wisconsin, May 25, 1892 .

\section{Family TANGARIDÆ. Tanagers.}

The Tanagers number some 300 species, most of which are found in Central and South America. They are arboreal, frequenting wooded localities and are both frugivorus and insectivorous. Most of the males are highly colored. A single genus (Piranga) occurs in eastern North America, two species of which are found in Illinois, 
and a third has been recorded from Wisconsin. As a rule they are fair, but not powerful, songsters. The nest is built in trees.

\section{Genus PIRANGA Vieill.}

\section{Piranga ludoviciana (WILS.). \\ Louisiana Tanager.}

Distr.: Western United States, from western Texas, Kansas, and western Dakota to the Pacific coast, north to Ontario and British Columbia, south in winter to Guatemala; breeds from western Texas, New Mexico, and Arizona northward; accidental in Louisiana, Wisconsin, New York, Maine, etc.

Adult male: Head and throat, red; nape, rump, and under parts, yellow; wings and tail, blackish; back, black; greater and middle wing coverts, broadly tipped with yellow or yellowish.

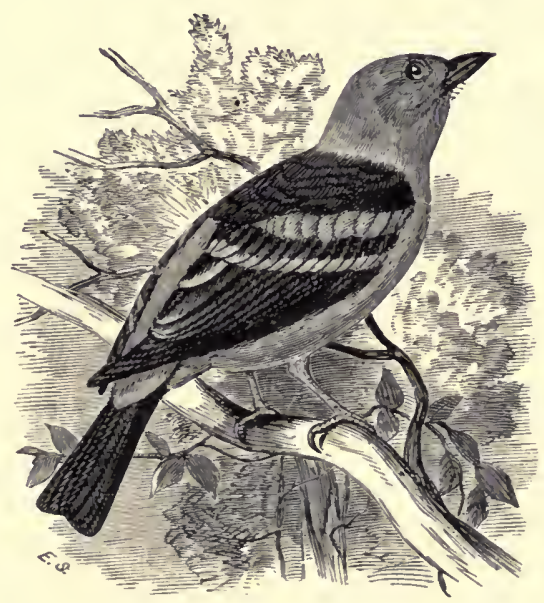

Louisiana Tanager.

Adult female: Above, olive green, brightest on rump and top of head; under parts, olive yellow, palest on belly; under tail coverts, yellow; greater and middle wing coverts, tipped with yellowish white, forming wing bars.

The wing bars will distinguish the female of this species from that of our other Tanagers.

Length, about 7 ; wing, 3.50 to 3.85 ; tail, 2.90 ; bill, .6०.

The only records of the occurrence of this handsome Tanager, either in Illinois or Wisconsin, are the following by Messrs. Kumlien \& Hollister: 
6i6 Field Museum of Natural History-Zoölogy, Vol. IX.

"During the latter part of May, 1877 , Thure Kumlien found this species nesting within a few rods of the Kumlien homestead in Jefferson County. Nest, eggs and parents were secured, and are now preserved in the Museum of the State University at Madison. The nest was not especially different from that of $P$. erythromelas and was placed well out on a horizontal branch of a large white oak. This is without doubt the easternmost breeding record for the species, although stragglers are reported even from New England. A second male was procured the next June (I878); and in July, I89I, another, also an adult male, was shot in the same locality by L. Kumlien." (Birds of Wisconsin, I903, p. 103.)

\section{Piranga erythromelas VieILL.}

Scarlet Tanager.

Distr.: Eastern United States, from the Plains to the Atlantic coast, north to Quebec, Ontario, and Manitoba, south in winter to West Indies, Central America, and South America to Peru; breeds from Kentucky, southern Illinois, and southern Missouri northward.

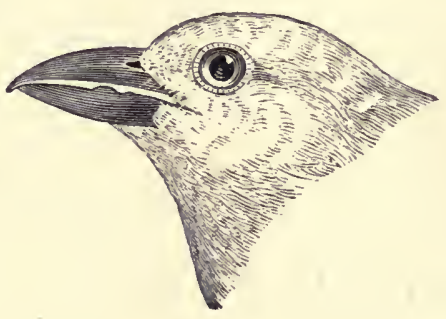

Adult male: General plumage, scarlet; wings and tail, black; under wing coverts, white.

Adult female: Upper plumage, olive green; under parts, greenish yellow; wings and tail, grayish brown, faintly edged with greenish; no wing bars.

Immature male: Resembles the female, but when changing shows irregular blotches of red and green. Adult male not infrequently shows abnormal coloring, such as a different shade of red or even orange.

Length, 6.80 ; wing, 3.75 ; tail, 2.90 ; bill, .5०.

This beautiful species is a common summer resident in Illinois and Wisconsin from about the first of May until September. The song somewhat resembles that of the Robin, but is more shrill. The male does not assume its full perfect red plumage until the spring of the third year.

It breeds in May and June. The nest is on the limb of a tree, and is composed of grass, flower stems, etc. The eggs are 3 to 5, pale bluish or greenish, spotted and speckled with brown, and measure about $.92 \times .66$ inches.

The Field Museum collection contains sets of eggs taken in northern Illinois between May 28 and June I4. 


\section{Piranga rubra (Linv.).}

Summer Tanager.

Distr.: "Eastern United States, to the Plains, north to southern New Jersey and southern Illinois, casually north to Massachusetts and Ontario, and accidentally to Nova Scotia. In winter, Cuba, eastern Mexico, Central America, and northern South America to Peru." (A. O. U.)

Adult male: General plumage, rich rose-red; wings and tail, fuscous brown, edged with rose-red; bill, pale.

Adult female: Upper plumage, brownish olive; under parts, pale brownish orange; no wing bars; under wing coverts, dull buffy yellow.

Length, 7.25; wing, 3.80 ; tail, 3 ; bill, .53.

The Summer Tanager is a common summer resident in southern Illinois, but is a rare summer resident in northern Illinois and Wisconsin.

Kennicott states that about the middle of the last century it nested in Cook County. Prof. Ridgway found it common and breeding at Mt. Carmel, Ill. Mr. Nelson gives it as "A rare summer resident" in northeastern Illinois. Mir. Frank M. Woodruff records a specimen seen by Mr. O. M. Schantz at Morton Park, Illinois, in April, r904. (Birds of the Chicago Area, r907, p. r47.)

Kumlien \& Hollister say: "Rare, but evidently a regular summer visitor in southern Wisconsin. It has been taken near Janesville by Mr. H. L. Skavlem; and near Albion, twice at least, by Thure Kumlien. In the Johnstown woods, between Milton and Johnstown, it appears to occur regularly every summer, we having seen it on a number of occasions, and taken specimens. Reported from Racine by Dr. Hoy, and two specimens taken near Milwaukee, were mounted by local taxidermists and were formerly in the old Natural History Society collection." (Birds of Wisconsin, 1903, p. 204.) 


\section{Family HIRUNDINIDÆ. Swallows.}

Some 85 or 90 species of Swallows are known from different parts of the world. They are insectivorous birds and therefore migratory. Being strong flyers, they are able to travel great distances with surprising swiftness. They usually assemble in large flocks just prior and during the migrations. The nesting habits vary with different species; some nest in holes in trees, others in banks, while still others build their nests on rafters in barns and outbuildings.

\section{Genus PROGNE Boie.}

\section{Progne subis (LiNN.).}

Purple Martin.

Distr.: Breeds throughout whole of United States (except California) and northern Mexico, north to southern Quebec and southern Athabaska region; south in winter to Central America and northern South America.

Adult male: Brilliant dark steel-blue; wings and tail, dark fuscous, tinged with bluish; bill, black.

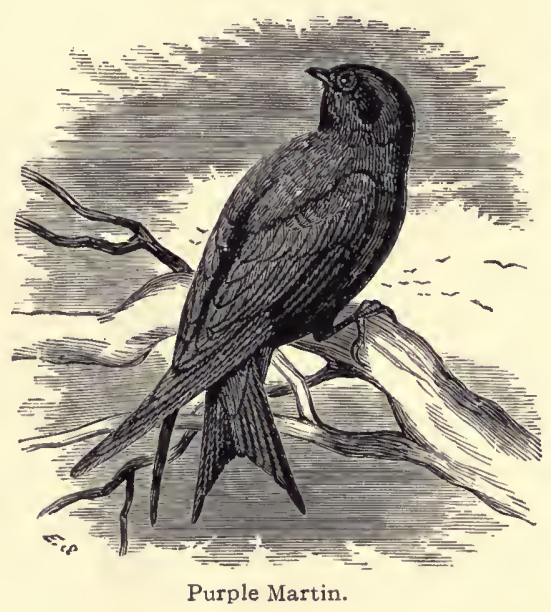

Adult female: Upper plumage, dark steel-blue; forehead, grayish; throat, breast, and sides, brownish gray, the feathers edged with whitish; middle of belly, white. 
Young birds resemble the adult female. In changing to adult plumage the male shows irregular patches of steel-blue.

Length, 7.50; wing, 5.75; tail, 3.60 ; bill, .40.

The Purple Martin is a common summer resident throughout Illinois and Wisconsin, arriving from the south in April.

Breeds in May and June. The nest is in holes in trees or about houses or in boxes. The eggs are pure white, usually from 4 to 5 in number, and measure about $.98 \times .72$ inches.

\section{Genus PETROCHELIDON Cabanis.}

\section{Petrochelidon lunifrons ( $\left.\mathrm{S}_{\mathrm{AY}}\right)$.}

Cliff Swallow.

Distr.: Whole of North America, north to Ungava and Alaska, breeding throughout its North American range; south in winter to Mexico, Central and South America.

Adult: Forehead white or brownish white; crown, back and a small patch on middle of lower throat and upper breast, dark steel-

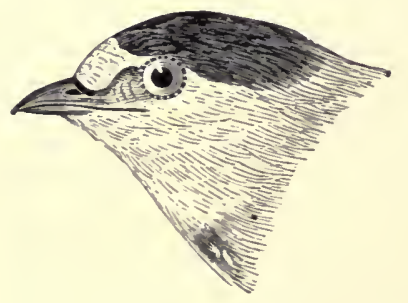
blue; chin, throat, and sides of the head, rufous chestnut; shorter upper tail coverts, dull rufous brown; breast and sides, grayish, tinged with rusty brown, whitening on the belly; under tail coverts, long, extending to within half an inch or less of end of tail feathers.

Sexes similar.

Length, 5.25 ; wing, 4.40 ; tail, 2.50 ; bill, .30.

An abundant migrant and a common summer resident, arriving from the south in April or early in May and leaving again in September.

The nest is gourd-shaped, composed of mud and dry grass and attached underneath overhanging cliffs or the eaves of buildings. The eggs are 4 or 5 in number, pure white, and measure about .8I $\mathrm{x} .54$ inches. 


\section{Genus HIRUNDO Linn.}

\section{Hirundo erythrogastra Bòd.}

Barn Swallow.

Chelidon erythrogastra (Bodd.), A. O. U. Check List, r 895, p. 258.

Distr.: Whole of North America, north to Ungava, Hudson Bay and Alaska, breeding throughout its North American range and in northern Mexico; south in winter throughout Central America, the West Indies, and a considerable portion of South America.

Adult male: Tail, much forked; upper plumage, lustrous dark steel-blue; forehead and throat, rufous chestnut; rest of under parts,

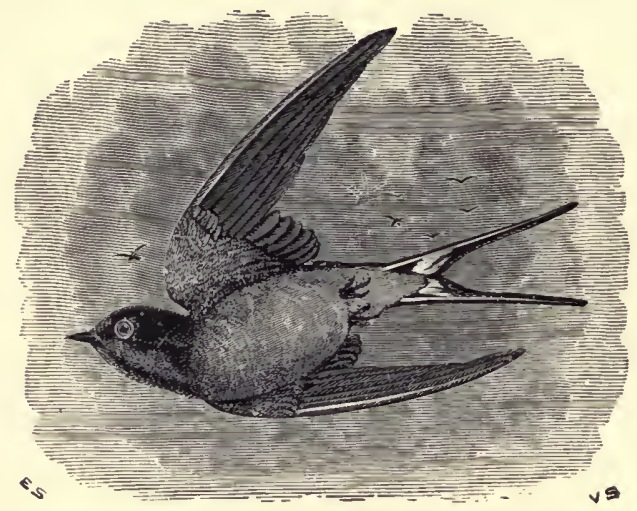

Barn Swallow.

pale brown or buffy brown, varying in intensity; outer tail feathers, much elongated; tail, fuscous, tinged with blue, all but the central feathers with broad white spot on inner web.

Adult female: Similar, but duller.

Immature birds have the tail less forked, the outer tail feathers less elongated, the general plumage duller, and the upper parts tinged with brown.

Length, 6 to 7.10 (varying according to length of tail); wing, 4.50 to 5 10; tail, 2.75 to 4.50 ; bill, . 30 .

The Barn Swallow is a common summer resident in Illinois and Wisconsin, from May until September, breeding throughout both states.

The nest is cup-shaped, composed of mud and straw and lined with feathers. It is usually built on rafters of barns, or when away from buildings, attached to side or in crevices of a cliff or in caves. The eggs are 3 to 5 , white, spotted with various shades of brown and often pale lilac, and measure about $.78 \times .54$ inches. 


\section{Genus IRIDOPROCNE Coues.}

\section{Iridoprocne bicolor (VIEILL.).}

Tree Swallow. White-bellied Swallow.

Tachycineta bicolor (Vieill.), A. O. U. Check List, I895, p. 258.

Distr.: Whole of North America, north to Ungava, Hudson Bay, and Alaska, south in winter to Cuba and Central America; breeds from Alabama and Texas northward throughout its range.

Adult male: Upper plumage, glossy greenish blue or steel-blue, showing a greenish gloss when held in the light; under parts, white;

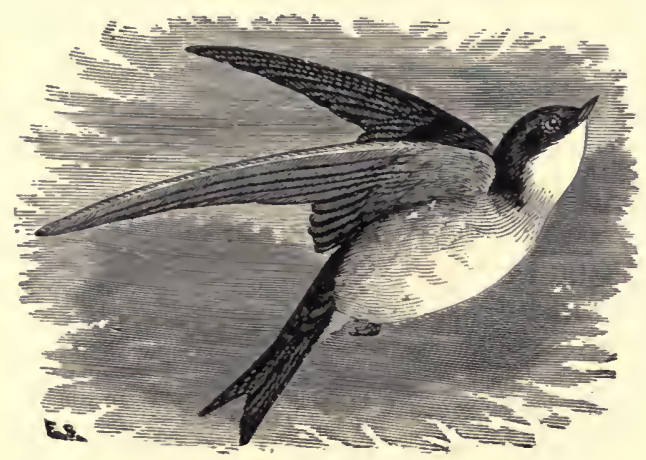

Tree Sivallow.

wings and tail, blackish, with faint greenish gloss; tail, slightly emarginate, the outer feathers being only $3 / 8$ of an inch or less longer than the middle feathers. In fall plumage the inner secondaries are edged and tipped with white.

Adult female: Similar, but duller.

Young birds in first plumage on leaving the nest have the upper parts, including the wings and tail, slaty gray; under parts, white, more or less washed with ashy; feet, yellow.

Length (adult), about 6; wing, 4.50 to 4.90 ; tail, 2.50 ; bill, .28.

The Tree Swallow is a common summer resident throughout Illinois and Wisconsin from the latter part of April until September. Late in August they congregate in large flocks preparatory to the southern migration.

The nest is usually in hollow trees, but sometimes in buildings or on the sides of a cliff. The eggs are from 4 to 6 , pure white, and measure about $.75 \times .54$ inches. 
622 Field Museum of Natural History-Zoölogy, Vol. IX.

\section{Genus TACHYCINETA Cabanis.}

\section{Tachycineta thalassina lepida (MEARns).}

Northern Violet-green Swallow.

Distr.: Western United States, from western Nebraska to the Pacific coast, north to Alaska and south to Central America in winter; breeds from Arizona, New Mexico, and northwestern Texas northward.

Adult male: Upper parts, rich deep green, tinged with purple on the upper tail coverts; under parts, white; a patch of pure white on flanks, extending upon sides of rump.

Adult female: Similar, but duller.

Length, 4.75 to 5.50 ; wing, 4.50 ; tail, 2.20 ; bill, .25.

The Northern Violet-green Swallow must be considered an accidental straggler within our limits. According to Mr. F. M. Woodruff, a male bird of this species was taken by Mr. George Clingman at South Kenwood, Illinois, on May 4, I897, (Birds of the Chicago Area, I907, p. I 49).

There is apparently no other record of its occurrence in Illinois or Wisconsin, but it is known to breed in Nebraska, and has been taken in southeastern Dakota (Cooke) and in Minnesota (Hatch).

\section{Genus RIPARIA Forster.}

287. Riparia riparia (LinN.).

Bank Swallow.

Clivicola riparia (Linn.), A. O U. Check List, I895, p. 259.

Distr.: Whole of North America, south in winter to Central America, the West Indies, and South America; breeds from the Gulf states, Texas, and Arizona north to northern Alaska, Melville Island, northern Labrador, and the far north.

Adult: Upper plumage, grayish brown; a dusky spot in front of the eye; breast with a broad band of grayish brown; rest of under parts, white; a few very small feathers on the tarsus near base of hind toe. In fall plumage the secondaries are tipped with white.

In some cases a few feathers on the middle breast below the pectoral band are grayish brown.

Length, about 5.10; wing, 4; tail, 2 ; bill, .23.

This species may be distinguished from the Rough-winged Swallow by the distinct breast band of grayish brown, the rest of the under parts being white. 


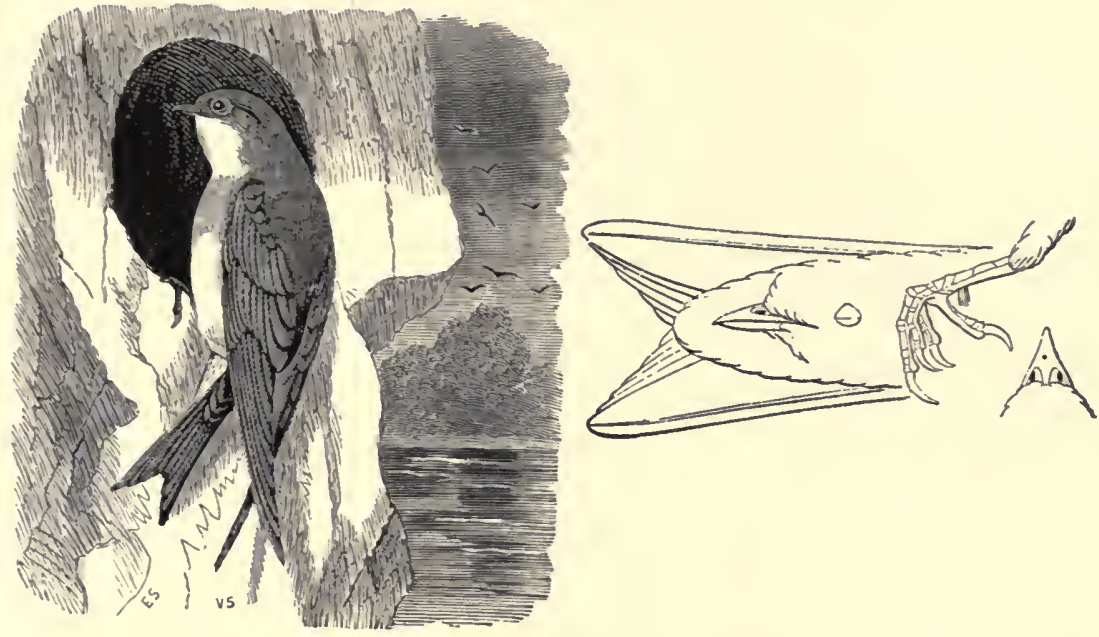

Bank Swallow.

The Bank Swallow is a very common summer resident in Illinois and Wisconsin from May until about the first of September.

The majority breed early in June. The nest is in a hole in the side of a steep bank. Where sand banks are available, they usually breed in colonies. The eggs are from 3 to 6 , pure white, and measure about $.69 \times .48$ inches.

\section{Genus STELGIDOPTERYX Baird.}

\section{Stelgidopteryx serripennis (AUD.).}

Rough-winged Swallow.

Distr.: Breeds throughout whole of United States (except portions of the extreme northern border), northern Mexico and southern British Columbia; south in winter to Mexico and Central America to Costa Rica.

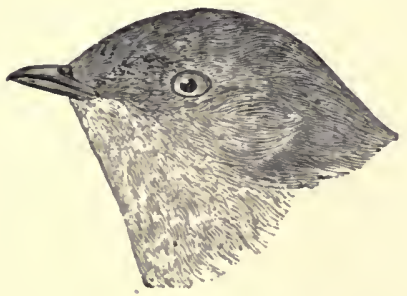

Special characters: Resembles the Bank Swallow, but has no distinct band on the breast, the under parts being brownish gray, gradually shading into white on the lower belly and under tail coverts. In the adult bird, the edge of the outer web of the outer primary is rough, the feathers being recurved and

resembling a series of little hooks.

Length, about 5.60; wing, 4.20; tail, 2.10; bill, .25.

The Rough-winged Swallow is a common summer resident 
624 Field Museum of Natural History-Zoölogy, Vol. IX.

throughout Illinois and southern Wisconsin from May until September. In northeastern Illinois it breeds about Fox Lake, Joliet, and other localities. Often confused by the ordinary observer with the Bank Swallow.

Breeds during the latter part of May and in June. The nest is usually in a hole in a bank, although at times in stone walls or under bridges. The eggs are from 3 to 6 , pure white, and measure about $.72 \mathrm{X} .5 \mathrm{I}$ inches.

\section{Family BOMBYCILLIDÆ. Waxwings, etc.}

This small family contains but two genera and three species. Two of these, comprising the subfamily Ampelince or Waxwings, occur within our limits. They are gregarious during migrations and attract attention by their faint whistle, which appears to be their only note. Their food consists of fruit, berries and insects, and they build their nests in trees.

\section{Genus BOMBYCILLA Vieill.}

\section{Bombycilla garrula (LinN.).}

BoHemian Waxwing.

Ampelis garrulus Linn., A. O. U. Check List, I895, p. 260.

Distr.: Northern parts of northern hemisphere; south in winter to Pennsylvania, Illinois, and Kansas; breeds north of the United States from about the latitude of Hudson Bay northward.

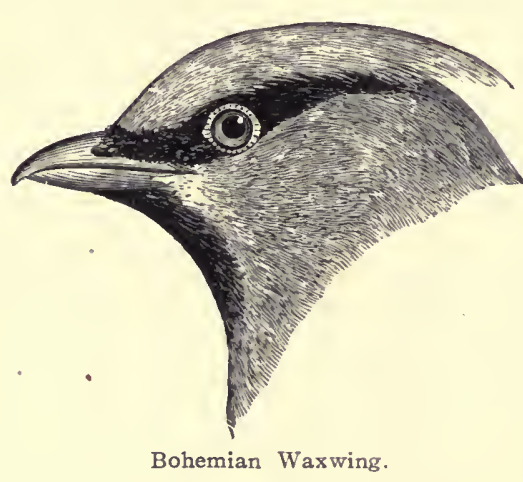

Adult: Crown with crest; chin, throat, and a narrow frontal streak extending backward through the eye, black; forehead nged with rufous chestnut; general color above, rich grayish brown; grayish on the upper tail coverts; breast, grayish brown, shading to grayish on belly; under tail coverts, rufous chestnut; most of the primaries tipped with clear yellow or yellowish white on outer webs, and tipped

with white on inner webs; secondaries with outer webs, tipped with white; primary coverts, tipped with white; tail, with terminal band of yellow; shafts of secondaries and sometimes tail feathers, with 
hard, red elongated tips, resembling bits of sealing-wax; while usually confined to the secondaries, these sometimes appear on some of the primaries or coverts.

Immature birds show pale streaks.

Sexes similar.

Length, 7.50; wing, 4.50; tail, 3.50 ; bill, .38.

This fine species is an irregular but occasionally a not uncommon winter visitant or resident as far south as northern Illinois and accidental in southern Illinois.

Mr. E. W. Nelson states, "Arrives in December and sometimes remains until April. The winter of $1875-76$ they were unusually numerous. In a letter dated March 16 , I876, Mr. Charles Douglass, of Waukegan, describes an immense flock of these birds which he observed the day previous, upon the lake shore near the town." (Birds of N. E. Ill., I876, p. I03.) Mr. Frank M. Woodruff writes: "On January I, I896, I obtained a fine pair at Lake Forest, Illinois, and saw about twenty more." Mr. John F. Ferry has also taken specimens in that locality. Prof. S. A. Forbes procured a specimen in soathern Illinois at Villa Ridge, Pulaski Co., on December I8, I879 (Bull. Nutt. Orn. Club, Vol. V., p. II 8.).

According to Mr. Butler (Birds of Indiana, 1897, p. I002) they were numerous at Whiting, Lake Co., Indiana, on March 30, I880, and "on December 4, I880, Mr. R. A. Turtle shot thirty or forty specimens out of a large flock at Whiting, Indiana."

It is a regular winter visitant in Wisconsin and according to Kumlien \& Hollister "of much more regular occurrence from the central part of the state northward." (Birds of Wisconsin, I903, p. 106.)

\section{Bombycilla cedrorum Vieill.}

\section{Cedar Waxwing.}

Ampelis cedrorum (Vieill.), A. O. U. Check List, r 895, p. 260.

Distr.: Whole of the United States and north to Ontario, Quebec, and Athabaska, breeding from the Carolinas, Kentucky, Missouri and Kansas northward; south in winter to the West Indies and Central America to Costa Rica.

Special characters: Much smaller than the Bohemian Waxwing; belly, tinged with yellow; under tail coverts, white.

Adult: Head, with small crest; upper plumage, rich grayish brown, brightest on the head and shading into gray on the rump and upper tail coverts; a line of black across forehead at base of bill, extending backward in a stripe through the eye; throat and breast, grayish brown, shading into pale yellow on the belly; under tail 


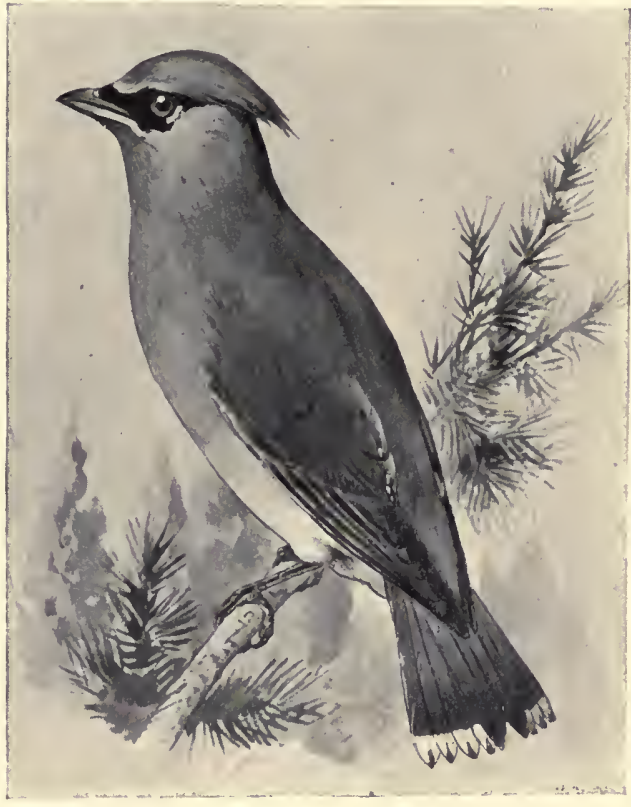

Cedar Waxwing. coverts, white; a short white line from base of under mandible and a very narrow white line separating the black forehead from the grayish brown crown; primaries, slate-gray; tail, siategray, shading to blackish at the ends and tipped with yellow; shafts of secondaries and sometimes tail feathers with hard, red, elongated tips resembling bits of sealingwax; the location of these varies, as in $B$. garrula, and are sometimes entirely lacking in apparently adult birds.

Immature birds show

more or less pale streaks, especially on the breast and sides of body.

Length, 6.25 to 7.25 ; wing, 3.50 to 3.75 ; tail, 2.20 ; bill, .34 .

The Cedar Waxwing or Cedar Bird is a common summer resident in Illinois and Wisconsin and a more or less common winter resident, varying in numbers according to the severity of the season. In the fall they are usually observed in flocks and their peculiar hissing or "wheezy" notes are unmistakable.

It breeds from June until August. The nest is large, built in a tree and composed of twigs, shreds of bark, leaves, moss, etc. The eggs are from 3 to 5 , pale bluish gray, spotted, and marked with dark brown and black, and measure about $.88 \times .6 \mathrm{r}$ inches. 


\section{Family LANIIDÆ. Shrikes.}

The Shrikes are a large family, containing some 200 species mostly exotic. Two species occur in Illinois and Wisconsin, both grayish birds with dark wings and tail, and a noticeable stripe through the eye. They are pugnacious and savage, preying upon animals as well as insects. They have the singular habit of impaling small birds and animals upon sharp twigs and thorns, and it is not uncom-

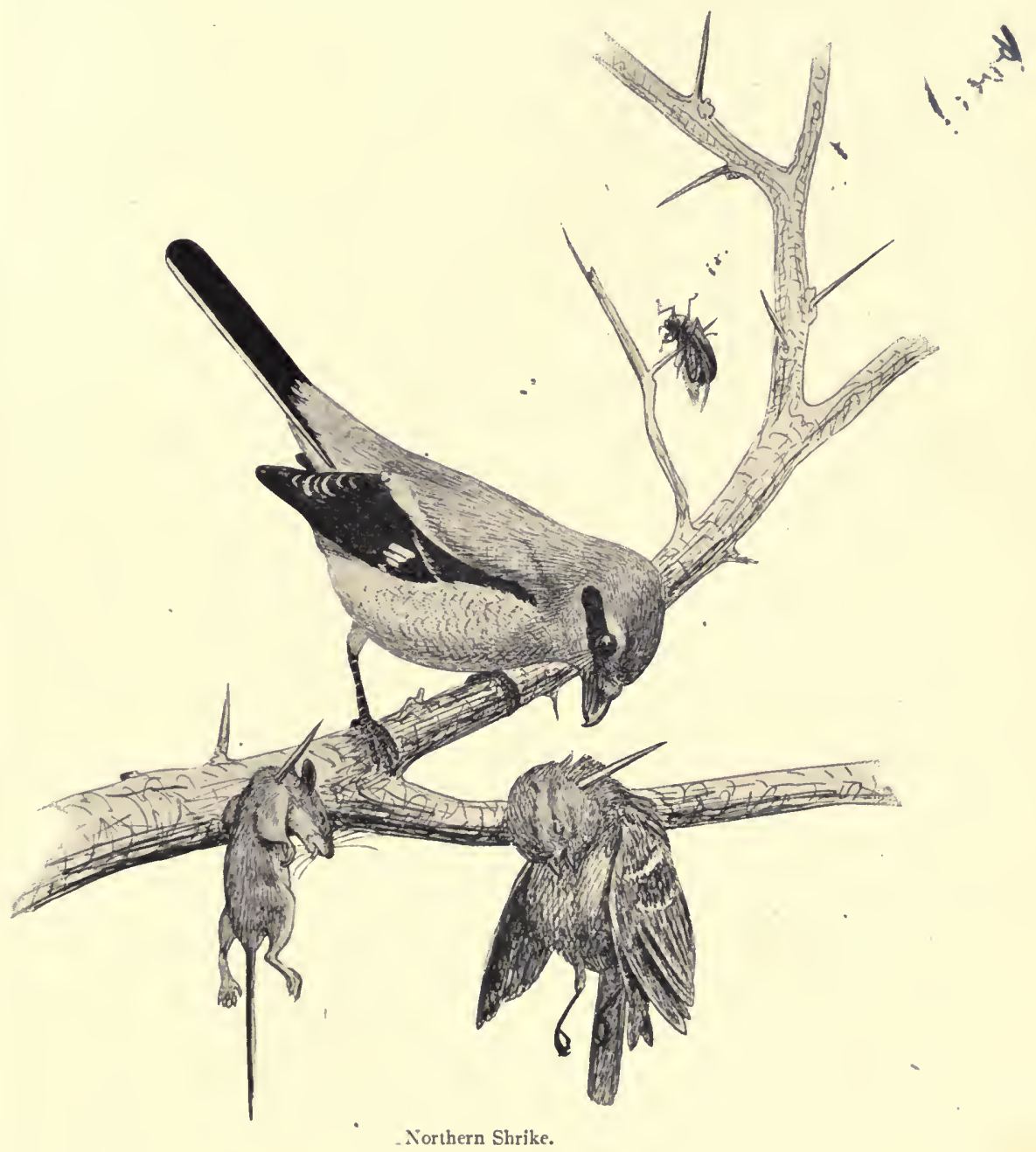


628 Field Museum of Natural History-Zoölogy, Vol. IX.

mon to find bushes ornamented in this manner with the bodies of their victims. The nest is a large rough structure, placed on a crotch or branch of some tree.

\section{Genus LANIUS Linn.}

\section{Lanius borealis Vieill.}

Northern Shrike. Butcher Bird.

Distr.: Northern North America, breeding in the far north (Labrador, Ungava, Alaska, etc.); south in winter to southern Illinois, Kansas, Arizona, etc.

Adult: Upper plumage, clear ash-gray, tinged with whitish on rump and scapulars; under parts, dull white, marked with numerous narrow wavy bars of dusky; a black stripe through the eye on sides of head, and a narrow white mark above the eye; primaries, blackish, with white band; tail, blackish, the four outer feathers, tipped with white, the outer feather having the terminal third and the entire outer web, white.

Sexes similar.

Immature: Markings similar to adult, but upper plumage, brownish gray; black streak on sides of head replaced by dusky.

Length, 9.30 to 10.30 ; wing, 4.50 ; tail, 4.15 ; bill, .6o.

- This species is a common winter resident in northern Illinois and Wisconsin, from the latter part of October until March; and casual or rare in southern Illinois.

It is hawk-like in disposition and well deserves the name of Butcher Bird, as it delights in killing small birds and animals and impaling them upon thorns and sharp twigs.

\section{Lanius ludovicianus LinN. Loggerhead Shrike.}

Distr.: Southern United States, from Texas eastward and north to Arkansas, Tennessee, and Illinois (replaced in the northern states by the Migrant Shrike).

Special characters: Upper parts, slate-color; under parts, almost white, with no decided tinge of gray; bill, stout and large; tail, longer than the wing (carpus to tip).

Adult: Upper plumage, slaty gray; a black stripe on sides of head through the eye and continuing in a very narrow black line across the forehead at base of bill; under parts, white, often faintly 


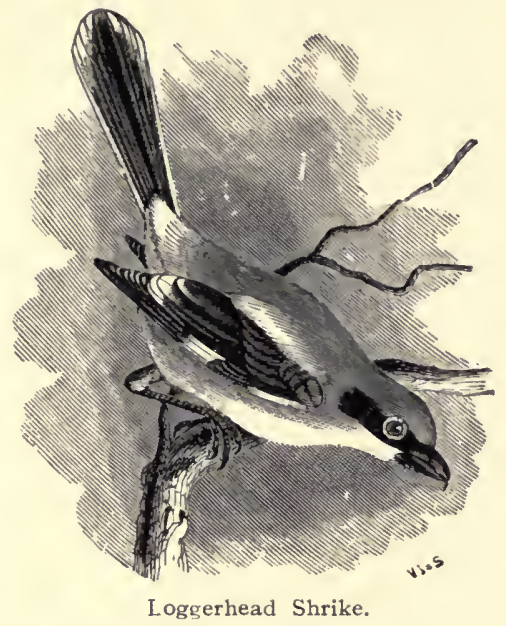

tinged with ashy; inner secondaries, black, tipped with white; primaries, fuscous brown, the bases, white; tail, blackish, the outer feathers with the ends largely white.

Sexes similar.

Immature birds have the under parts marked with wavy, dusky lines, as in L. borealis.

Length, about 8.75 ; wing, about 3.80 ; tail, 3.90 ; bill, . 50 .

The Loggerhead Shrike is a summer resident in southern Illinois and perhaps farther north; but is replaced in northern Illinois and Wisconsin by the form, now recognized as a migrans. In a series of specimens from various localities in Indiana and Illinois, the majority are intermediate between ludovicianus and migrans; but three from southern Illinois may be referred to ludovivianus.

Perched on a stump or a commanding branch, the Loggerhead watches for and swoops down upon his prey. Birds, beetles, grasshoppers, or even small mice are killed and hung in his larder.

It breeds in May and June. The nest is a large rough structure, composed of dry grass, small sticks, and feathers, built in a low tree or hedge. The eggs are from 4 to 6 , dull white, thickly spotted and marked with brown and purplish gray, and measure about . $98 \times .74$ inches. 
630 Field Museum of Natural History-Zoölogy, Vol. IX.

\section{2a. Lanius ludovicianus migrans Palmer.}

\section{Migrant Shrike.}

Distr.: Eastern United States, north of South Carolina, Alabama, and Mississippi, and from Arkansas, Iowa, and Minnesota eastward to the coast.

Special characters: Very similar to the Loggerhead Shrike, but supposed to differ in having the upper parts more bluish gray; under parts washed with slaty gray; bill, more slender; and tail, shorter than the wing (carpus to tip).

A common summer resident in Illinois and Wisconsin. Intermediates occur between ludovicianus and migrans which might be referred to either form. The majority arrive in northern Illinois late in March or early in April (earliest Chicago record, March 8).

Kumlien and Hollister state that it is "Not as common north of the central part of the state as south of it, except toward the northwest, where it appears to be found more or less to the extreme north portion." (Birds of Wisconsin, 1903, p. 107.)

Habits, nest, and eggs are similar to those of the Loggerhead Shrike.

The Field Museum collection contains the following sets of eggs from northern Illinois: 4 eggs, Chicago, April 26; 6 eggs, Joliet, May 3; 5 eggs, Joliet, May I г 2 eggs, Joliet, May r r ; 6 eggs, Joliet, May 26; also a set of eggs taken at Grinnell, Iowa, June $\mathrm{r} 2$. 


\section{Family VIREONIDÆ. Vireos.}

The Vireos number about 60 species confined to the Americas and adjacent islands. They are insectivorous birds, usually dull colored, inhabiting woodland and shrubbery, and build their nests in trees or bushes. The song is a pleasing warble.

\section{Analysis of the Species.}

\section{A. Wing without bars.}

Throat and under parts, more or less pale yellow; first primary, not short, at least as long as fifth.

Philadelphia Vireo.

Throat, breast, and belly, not yellow; crown nearly same color as back; first primary, spurious; 1 less than an inch long.

WARBI.ING VirEo.

Throat, breast, and belly, not yellow; sides of body, olive green; crown very different from back; a blackish streak on sides of crown, and a whitish streak over eye, first primary about as long as fifth.

RED-EYed ViREO.

B. Wing with white or whitish bars.

(Formed by coverts being tipped with white or yellowish white.)

Eye ring, yellow; throat and breast, yellow; rump, grayish.

YELLOW-THROATED VIREO.

Eye ring, yellow; a spot in front of eye, yellow; throat, white or buffy white; sides of body, yellow or greenish yellow.

WHITE-EyED VIREO.

Eye ring, white; crown and sides of head, slaty or plumbeous; wing, over 2.50 inches long, first primary very short.

BLUE-HEAded Vireo.

Eye ring, white or whitish, sometimes indistinct; wing, under 2.50 inches long; first primary, small, about half as long as third; ning bar, narrow.

BELL'S VIREO.

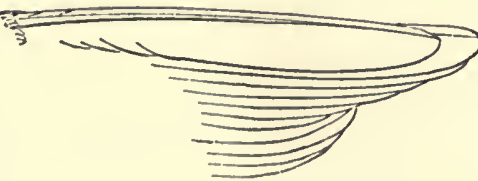

Philadelphia Vireo. (Showing long first primary.)

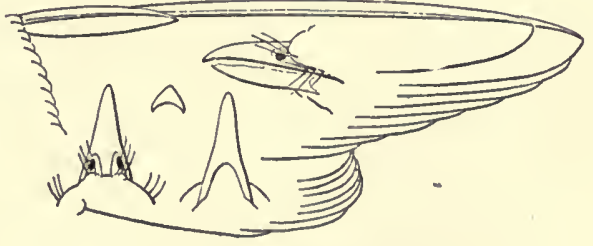

Blue-headed Vireo. (Showing short first primary.) 
632 Field Museum of Natural History-Zoölogy, Vol. IX.

Genus VIREOSYLVA Bonap.

293. Vireosylva olivacea (LinN.).

RED-Eyed Vireo.

Vireo olivaceus (Linn.), A .O. U. Check List, r 895: p. 263 .

Distr.: North America, from Colorado, Utah, western British Columbia and Northwest Territory, eastward to the Atlantic coast; breeds throughout its North American range; south in winter to northern South America.

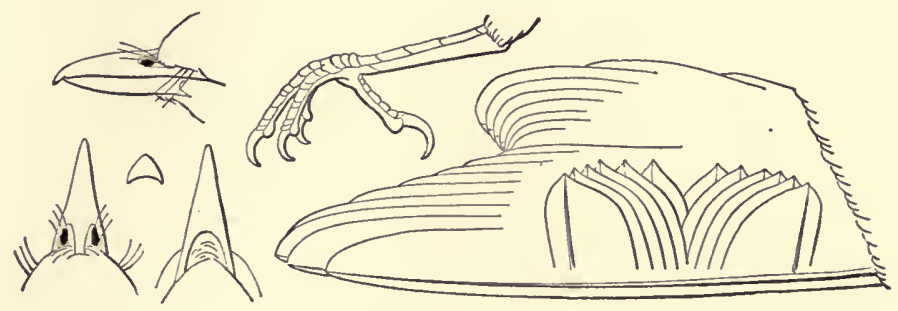

Adult: Crown, gray, bordered by a black line; a whitish stripe over the eye and a dusky stripe through the eye; back, olive green; sides, olive green, rest of under parts, white; wings and tail, slaty brown, edged with greenish; iris, red.

Sexes similar.

Length, about 6; wing, 3.25; tail, 2.I5; bill, .50.
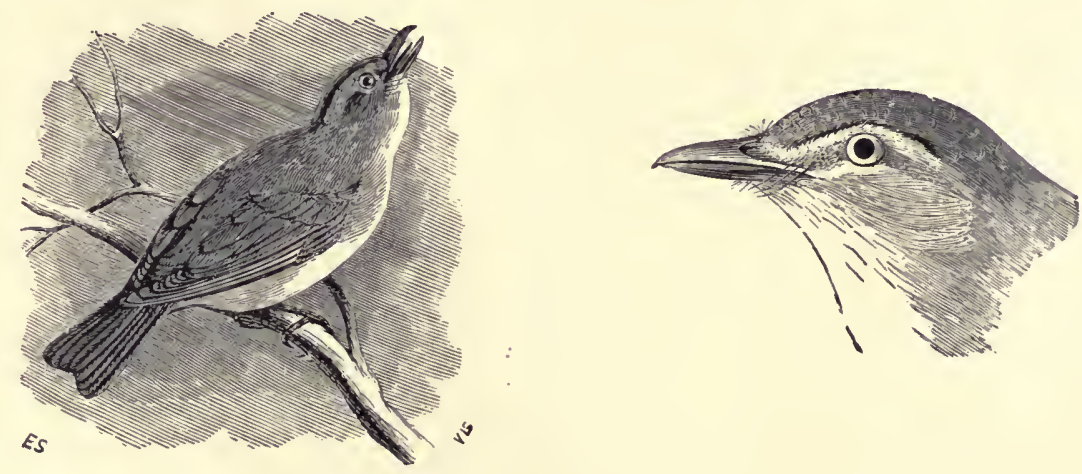

Red-eyed Vireo.

A common summer resident throughout Illinois and Wisconsin from May until October.

It breeds in May and June. The nest is a pensile structure, finely made of shreds of bark, vegetable fiber, and plant down, and is attached to a branch of $a$, tree. The eggs are 3 to 4 , white, 
with a few scattered spots of black or dark brown, and measure about $.82 \times .56$ inches.

The song of the Red-eyed Vireo is a melodious and often-repeated warble.

\section{Vireosylva philadelphica CASS. \\ Philadelphia Vireo.}

Vireo philadelphicus (Cass.), A. O. U. Check List, 1895, p. 203.

Distr.: United States and British Provinces, from Kansas, the Dakotas, and Athabaska eastward, breeding from the northern edge of the United States northward and occasionally farther south.

Adults: Upper parts, grayish olive, the crown, slightly grayer than back; a pale line over the eye; wings and tail, slaty brown, faintly edged with olive green; under parts, pale greenish yellow; chin and belly, often whitish; first primary as long or longer than fifth.

Sexes similar.

Length, 4.70; wing, 2.55; tail, 2 ; bill, .36.

A rather common migrant in Illinois and Wisconsin, but owing to its plain colors often overlooked. It has not as yet been found nesting within our limits, but may do so in northern Wisconsin and perhaps farther south.

Mr. E. W. Nelson found it abundant in the vicinity of Waukegan. He says: "They were so numerous near Waukegan about the twentieth of May, 1876 , that a dozen specimens might have been obtained in an hour. The first of July, I874, I found two pairs of these birds in a dense thicket bordering Mazon Creek about 60 miles south of Chicago. Upon my approach the birds showed great anxiety, uttering a short, complaining cry and coming within a few feet of me. That they had young in the vicinity I was sure, but owing to the character of the covert they were not found." (Birds of N. E. Ill., I 876 , p. I02.)

\section{Vireosylva gilva (VIEILl.). \\ WARBLING Vireo.}

Vireo gilvus (Vieil1.), A. O. U. Check List, 1895, p. 264.

Distr.: United States and British Provinces east of the Rocky Mountains, from Kansas, Wyoming, Montana, and Saskatchewan eastward to the Atlantic coast, breeding throughout its range, except in southern Florida.

Adult: Upper parts, ash-gray, faintly tinged with olive; no white bars on wings; throat, whitish; rest of under parts, whitish, faintly 
634 Field Museum of Natural History-Zoölogy, Vol. IX.

tinged with pale olive yellow, more especially on the sides; wings and tail, slaty brown, more or less faintly edged with olive; first primary, very short, less than an inch long.

Sexes similar.

Length, 5.60; wing, 2.90; tail, 2.20; bill, .40.

The Warbling Vireo is a common summer resident in suitable localities in Illinois and Wisconsin, arriving in May and leaving for the south in September. The song somewhat resembles that of the Red-eyed Vireo but is sweeter and not so loud.

The nest is pensile, usually attached to a forked branch of a tree. The eggs are 3 to 4 , pure white, with a few scattered spots of black and brown chiefly at the larger end, and measure about $.75 \times .54$ inches.

\section{Genus LANIVIREO Baird.}

\section{Lanivireo flavifrons (VIEILL.). \\ Yellow-throated Vireo.}

Vireo flavifrons Vieill., A. O. U. Check List, r895, p. 264.

Distr.: Breeds in United States and southern British Provinces, from Texas, Kansas, the Dakotas, north to southern Manitoba, and eastward to the Atlantic coast; south in winter to Cuba, Mexico, Central America, and Colombia, S. A.

Adult: Wing coverts, tipped with white, forming wing bars; upper parts, olive green, shading to grayish on the rump; eye ring, yellow or yellowish; throat and breast, yellow; belly, white; inner secondaries, edged with white.

Sexes similar.

Length, 5.80; wing, 3 ; tail, 2 ; bill, . 38 .

A common migrant and not uncommon summer resident in wooded districts in Illinois and Wisconsin, although apparently rather rare in the vicinity of Chicago. It arrives from the south late in April, and the majority have gone by October I.

Mr. Frank M. Woodruff records a nest and eggs of this species taken June 8, I885, in Lake County, Illinois, by Mr. B. T. Gault.

The nest is attached to the branch of a tree, usually in woods, and is composed of grass, lichens, shreds of bark, and plant fibers. The eggs are three or four, pure white, with a few scattered spots of black and brown, chiefly at the larger end. Size, about .80 x.59 inches. 


\section{Lanivireo solitarius (WILS.). Blue-headed Vireo.}

Vireo solitarius (Wils.), A. O. U. Check List, 1895, p. 264.

Distr.: United States and British Provinces east of the Rocky Mountains, south in winter to Cuba and Central America; breeds from southern New England, Wisconsin, and Minnesota northward.

Adult: Crown and sides of head, slaty or plumbeous; eye ring, white; back and rump, olive green; throat, breast, and middle of

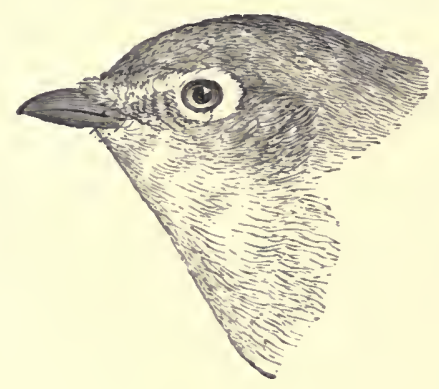
belly, white; sides of body, olive, shading into olive yellow on flanks; greater and middle wing coverts, tipped with white, forming wing bars; inner secondaries, edged with white; first primary, very short and small, less than $3 / 4$ inch long; tail feathers, more or less edged with white. Sexes similar.

Length, 5.50; wing, 2.95; tail, 2.18; bill, .37.

The Blue-headed Vireo is a common migrant in Illinois in May and September and a more or less common summer resident in Wisconsin. The song is a melodious warble, somewhat similar but softer than that of the Red-eyed Vireo.

Kumlien and Hollister say: "A common migrant in May and September and a regular summer resident in limited numbers. Dr. Hoy reported it as nesting at Racine and we have noted it as a summer resident at Madison, Two Rivers, Milwaukee, and Jefferson. We have, however, found but one nest (Bark River woods, Jefferson County) and this contained young almost able to fly." (Birds of Wisconsin, I 903 , p. 108.)

The nest is built in the lower branches of a small tree or in large bushes. The eggs are 3 or 4 , pure white, with a few scattered spots of black and brown, chiefly at the larger end, and measure about $.79 \times .55$ inches. 
636 Field Museum of Natural History-Zoölogy, Vol. IX.

\section{Genus VIREO Vieill. \\ 298. Vireo griseus (BODDAERT). \\ White-eyed Vireo.}

Vireo noveboracensis (Gmel.), A. O. U. Check List, I895, p. 266.

Distr.: United States east of the Rocky Mountains, south in winter to Cuba and Mexico; breeds throughout its United States range.

Adult: Upper plumage, including rump, olive green, more or less tinged with gray; forehead, yellowish green; a line from eye to nos-
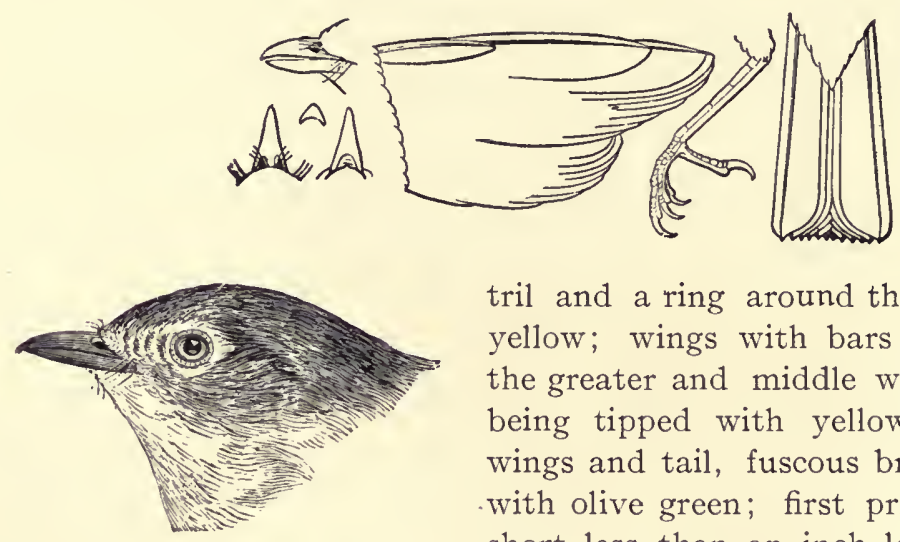

tril and a ring around the eye, clear yellow; wings with bars formed by. the greater and middle wing coverts being tipped with yellowish white; wings and tail, fuscous brown, edged with olive green; first primary, very short, less than an inch long; throat and belly, whitish; breast and sides of body, greenish yellow; iris, whitish.

Sexes similar.

Length, 5.20; wing, 2.45; tail, 2 ; bill, .38.

The White-eyed Vireo is a very common summer resident in southern Illinois, but of only casual occurrence in northern Illinois, and a rare summer resident in southern Wisconsin.

Mr. E. W. Nelson gives it as a rather rare summer resident in northeastern Illinois. Mr. Frank M. Woodruff considers it a rare bird in the "Chicago Area" and records a specimen taken by Mr. B. T. Gault at Glen Ellyn, May 24, I898. Prof. Ridgway found it "an abundant species in suitable localities" in southern Illinois, and Mr. John F. Ferry found it common in the vicinity of Henry, Marshall Co., Illinois. It has been found breeding at Fairbury, Livingston Co., Illinois. (Mundt, Orn. and Oöl., Vol. VIII, I883, p. Io.) And there is an egg in the Thomas H. Douglass collection at Waukegan, Lake Co., Illinois, labeled as having been collected by him in that locality, May I3, 1875 . 
Messrs. Kumlien and Hollister consi der it "A rare summer resident in southern Wisconsin." (Birds of Wiszonsin, 1903, p. I03.)

The nest is pensile, usually suspended from the fork of a branch in bushes or low trees. The eggs are 3 or 4 , white with a few scattered spots of black and brown chiefly at the larger end, and measure about $.75 \times .54$ inches.

\section{Vireo bellii AUD.}

BelL's Vireo.

Distr.: " Upper Mississippi Valley and Great Plains, from Dakota, Minnesota, Illinois, and western Indiana, southwestward to Mexico." (A. O. U.).

Adult: Size, small; back and rump, olive green; crown, olive, tinged with ashy, but slightly different from the color of the back; under

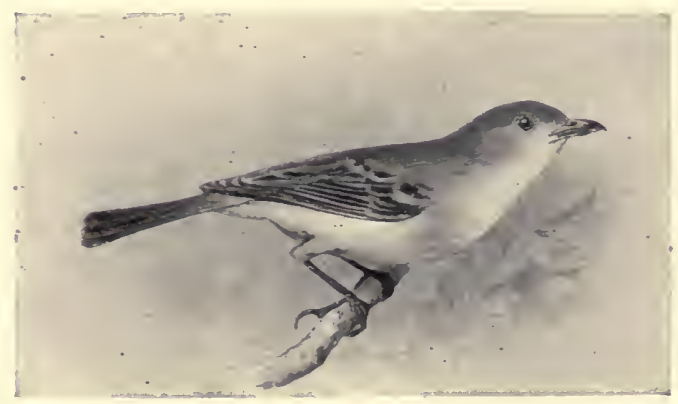

Bell's Vireo.

parts, pale greenish yellow, deepest on the sides and flanks, and shading to whitish on the chin and middle of the belly; inner quills, with pale edges; first primary, about half as long as second; greater and middle wing coverts, narrowly edged with whitish, forming inconspicuous wing bands, one of which is at times hardly noticeable.

Sexes similar.

Length, 4.75; wing, 2.20; tail, I.90; bill, .36.

Bell's Vireo is a not uncommon summer resident in Illinois. Both Prof. Ridgway and Mr. Nelson record specimens taken on Fox Prairie, Richland Co., Illinois.

Mr. H. S. Swarth found it not uncommon and breeding near Joliet, Illinois, in June, rgo6. Several nests were taken, one containing four eggs. Mr. Isaac E. Hess informs me he found a nest with four eggs on July 4, I899, near Philo, Champaign Co., Illinois. Mr. E. W. Nelson procured a specimen near Chicago, June 25, I875, and the same year Mr. H. K. Coale obtained a specimen, which had been shot by a boy in Chicago. 
638 Field Museum of Natural History-Zoölogy, Vol. IX.

There are apparently no satisfactory records of its occurrence in Wisconsin. Messrs. Kumlien and Hollister say (Birds of Wisconsin, I903, p. I33): "This bird has been taken within a few miles of the Wisconsin line in Illinois, and near Chicago, by Nelson. A1though it has been credited to the fauna of Wisconsin the proof is still läcking. A specimen sent to us for the purpose of verifying the record proved to be $V$. noveboracensis. In the early forties Thure Kumlien procured specimens of a vireo which he called belli, of which he had no description, simply to distinguish it from gilvus. This led to some confusion with Lawrence, Baird, and others who had not seen the specimens. The bird referred to was later described by Cassin as $V$. philadelphicus."

The nest is a pensile structure, composed of plant fibers, grass, and shreds of bark finely interwoven and attached to the fork of a branch in bushes or low trees. The eggs are 5 or 6 , white, marked with a few scattered spots of black and brown, chiefly at the larger end, and measure about $.67 \times .49$ inches.

The Field Museum collection contains two nests and sets of eggs of this species taken by Mr. Swarth, June 16 and 26 .

\section{Family MNIOTILTID在. Wood Warblers.}

The Mniotiltidæ or Wood Warblers are an American family, numbering upwards of too species, about 70 of which occur in North America. They frequent woodland and shrubbery and are strictly insectivorous. During migrations they at times assemble in large flocks, several species being often represented. The song is sweet, but not loud, varying with different species.

\section{Genus MNIOTILTA Vieill.}

300. Mniotilta varia (LiNN.).

Black and White Warbler.

Distr.: United States and British Provinces east of the Rocky Mountains; breeds from North Carolina, Illinois, and Kansas north to Quebec, Athabaska, and the Mackenzie region.

Adult male: General plumage, black and white; back, black, streaked with white; crown, black, with a white stripe through the centre and another over the eye; under parts, white, heavily streaked 
with black except on middle of the belly; greater and middle wing coverts, broadly tipped with white, forming two conspicuous wing

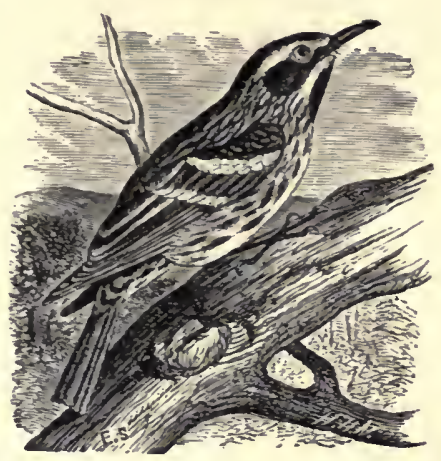
bands; wings, fuscous brown, the inner secondaries edged with white; middle tail feathers, blackish, edged with gray; outer tail feathers, broadly marked with white on terminal portion of inner webs.

Adult female: Similar, but paler and with sides more or less tinged with buffy brown.

Length, 5.20; wing, 2.65; tail, I. 85 ; bill, .40.

The Black and White Warbler is very common during the migrations in Illinois and Wisconsin, and a summer resident in the latter state, and may often be seen climbing about the trunks of trees much in the manner of a Creeper. It is possible it may occasionally nest in northern Illinois, but I find no record of its having done so, although Mr. E. W. Nelson, in his Birds of Northeastern Illinois, gives it as "not an uncommon summer resident."

Regarding its occurrence in Wisconsin, Messrs. Kumlien and Hollister say (Birds of Wisconsin, I903, p. rog): “An abundant migrant, and tolerably common summer resident. This species is one of the first of the warblers to arrive, appearing in the southern part of the state with the myrtle and palm warblers during the latter part of April. It is common from then until close of the breeding season, when its numbers are greatly diminished. On the southern migration it begins to increase in numbers in August and is again abundant until October."

The nest is on the ground and carefully hidden. The eggs are 3 to 5 , cream white, spotted and speckled with brown, chiefly around the larger end, and measure about $.67 \times .56$ inches. The song of this species is a penetrating but rather faint, see, see, see, see. 
640 Field Museum of Natural History-Zoölogy, Vol. IX.

\section{Genus PROTONOTARIA Baird.}

\section{I. Protonotaria citrea (BODD.).}

\section{Prothonotary WARBLER.}

Distr.: Eastern United States, from Kansas and Nebraska to the Atlantic coast, north to southern Michigan and southern Wisconsin; breeding throughout its United States range, except in southern Florida; south in winter to Yucatan, Central America, and northern South America.

Adult male: Crown, olive yellow, shading to yellow on forehead; back, yellowish olive, shading to slaty gray on the rump; under

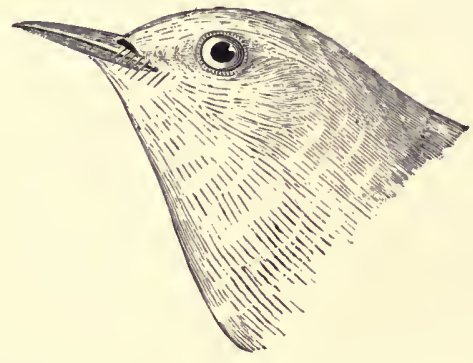
parts, clear orange yellow; primaries, fuscous brown, the outer webs narrowly edged with slaty gray, inner webs, edged with white; greater portion of inner webs of tail feathers (except the middle ones) white, tipped with blackish; outer webs, dark; under tail coverts, mostly white.

Adult female: Similar, but the yellow markings paler.

Length, 5.40; wing, 2.80; tail, I.90; bill, .50.

A common summer resident in Illinois south of the Kankakee River and of irregular occurrence as far north as southern Wisconsin. Mr. Isaac E. Hess informs me he has found this species nesting commonly in Piatt Co., Illinois, and abundantly along the Illinois River in Putnam Co.

Grundtvig records it as far north as Shiocton, Outagamie County (Trans. Wis. Acad. Sci. Arts \& Let., Vol. X, p. I40). Messrs. Kumlien and Hollister say: "In suitable localities in the southern and western parts of the state the prothonotary warbler is not a rare summer resident."

Breeds in May and June. The nest is of moss, usually in a hole in a dead tree or stump. The eggs are 3 to 6 , white or faintly buff, irregularly marked with various shades of brown, and measure about $.69 \times .55$ inches.

The Field Museum collection contains a set of 6 eggs taken at Lima, Ill., May 22, I889, and another of 4 eggs taken at English Lake, Lake Co., Indiana, June 30 , 1907. 
Genus HELINAIA Audubon.

302. Helinaia swainsonii AUD.

SWAINSON'S WARBLER.

Distr.: Southeastern United States, from eastern Texas and Arkansas to the Atlantic coast, north to southern Indiana, breeding throughout its United States range, except in southern Florida; south in winter to southern Florida, Cuba, Jamaica, and eastern Mexico (Vera Cruz).

Adult: Upper plumage, dark olive brown; crown and wings, tinged with cinnamon-brown; tail, dark olive brown, without any

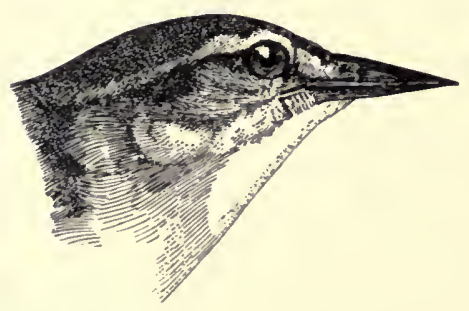
white marking; a dull yellowish white stripe over the eye; under parts, 'yellowish white, tinged with brownish olive on the sides; bill, pale brown.

Sexes similar.

Length, 5.25; wing, 2.60; tail, 2 ; bill, .50.

It is doubtful if this species has ever actually been taken in Illinois, although it undoubtedly occurs in the southern portion of the state. Mr. Ridgway in his Notes on Birds observed at Mt. Carmel, southern Illinois, in the spring of 1878 (Bull. Nutt. Orn. Club, r 878 , p. r63) states: "In the cyprus swamp a bird was several times noticed by Mr. Brewster and myself, which we both agreed must be this species. It was well seen on several occasions and its song heard, while one specimen was shot, but unfortunately could not be found." In the synonomy of his Birds of North and Middle America (1902, p. 438) he refers to this record as from "Knox Co., Indiana," from which it would appear that the birds were observed on the Indiana side of the Wabash River.

Mr. Otto Widmann gives Swainson's Warbler as a summer resident in southeast Missouri (Birds of Missouri, r 907, p. 21 4).

Mr. Alfred O. Gross records having seen a Swainson's Warbler near Du Quoin, Perry County, Illinois, on June 17, 1907. (The Auk, Vol. XXV, r908, p. 225.) 
642 Field Museum of Natural History-Zoölogy, Vol. IX.

\section{Genus HELMITHEROS Rafinesque.}

303. Helmitheros vermivorus (GMEL.).

\section{WORM-EATING WARBLER.}

Distr.: Eastern United States, west to Nebraska and Texas and north to southern New England, Indiana, Illinois, and Nebraska; breeds throughout its United States range; south in winter to the Bahamas, Cuba, Jamaica, Central America, and northern South America.

Adult: Crown, black, divided in centre by a broad tawny buff stripe; a tawny buff stripe over the eye and a black stripe through

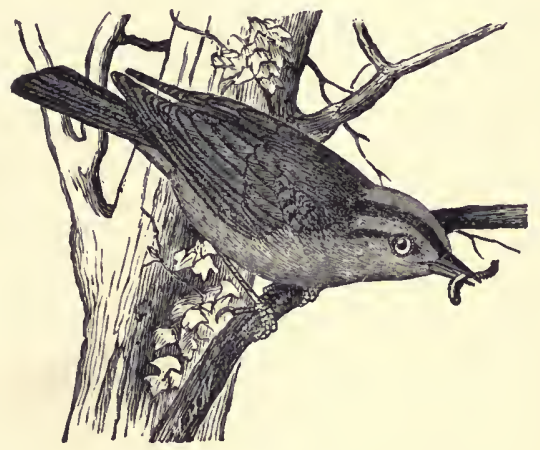
the eye; back and tail, olive green; primaries, fuscous, edged with olive green; no wing bars; under parts, buffy; whitish or buffy white on belly and throat.

Sexes similar.

Length, 5.50; wing, 2.70 ; tail, 2 ; bill, . 48 .

The Worm-eating Warbler is a commion summer resident in southern Illinois and rare in northern Illinois and southern

Wisconsin. Mr. E. W. Nelson procured a specimen at Waukegan on May 2I, I876, and Mr. R. W. Chaney informs me he observed an adult male in Jackson Park, Chicago, on May II, I908.

Dr. Hoy states (Racine, I852): "A few nest in this section." Regarding this statement Messrs. Kumlien and Hollister say: "As we remember it, he (Dr. Hoy) procured but three specimens in all, and knowing it to be a southern species supposed, of course, that it bred, if. it occurred there at all." Thure Kumlien procured two specimens at Lake Koshkonong. (Birds of Wisconsin, I903, p. I09.)

It breeds commonly in southern Illinois. The nest is on the ground among dead leaves and is composed of fern stems, shreds of bark, and leaves. The eggs are 3 to 5 , cream white, finely speckled chiefly at the larger end with brown, and measure about $.69 \times .5 \mathrm{I}$ inches. 


\section{Genus VERMIVORA Swainson.}

\section{Vermivora pinus (Linv.).}

BLUE-WINGED WARBLER.

Helminthophila pinus (Linn.), A. O. U. Check List, r895, p. 270.

Distr.: Eastern United States, from Kansas, Nebraska, and South Dakota eastward and south from southern New England, Wisconsin, and Minnesota; ranges in winter to Central America and northern South America (Colombia); breeds from Georgia, Tennessee, and Oklahoma northward.

Adult male: Crown and under parts, bright yellow; under tail coverts, whitish; back and rump,. clear olive green; a black line

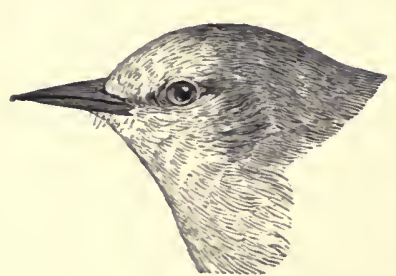
through the eye; primaries, fuscous brown, edged with grayish on outer webs and dull white on inner webs; greater and middle wing coverts, edged with white, forming wing bars; tail, brownish gray, the inner webs of the two outer tail feathers, mostly white.

Adult female: Similar, but paler and the yellow crown patch smaller.

Length, 4.75; wing, 2.45; tail, 2 ; bill, .42.

This species is a rather common summer resident in southern Illinois and a casual summer resident in northern Illinois; rare in southern Wisconsin.

Mr. Ridgway found it breeding at Mt. Carmel, Ill., and Mr. E. W. Nelson in his Birds of N. E. Illinois, gives it as an "abundant migrant," which is not the case at the present time. Mr. Frank M. Woodruff gives half a dozen records of its occurrence in northeastern Illinois (Birds of the Chicago Area, 1907, p. 157 ), and Messrs. Kumlien and Hollister give eight records for southern Wisconsin, including a female with nest and eggs taken near Delavan, May 22, r 899 (Birds of Wisconsin, 1903, p. 100).

The nest is usually on the ground and is composed of leaves and shreds of bark. The eggs are 5 or 6 , pure white, finely and rather irregularly speckled with brown chiefly at the larger end, and measure about $.60 \times .49$ inches. 
644 Field Museum of Natural History-Zoölogy, Vol. IX.

305. Vermivora chrysoptera (LiNN.).

Golden-Winged Warbler.

Helminthophila chrysoptera (Linn.), A. O. U. Check List, I895, p. 270. .

Distr.: Eastern United States, north to southern New England, southern Ontario, and southern Manitoba, and west to Dakota, Nebraska, and Kansas; breeds from New Jersey and northern Indiana northward; south in winter to Central America and northern South America.

Adult male: Crown, yellow; rest of upper plumage, bluish gray, more or less tinged with olive green; greater and middle wing coverts, broadly tipped with yellow, forming a conspicuous yellow wing patch; a broad stripe on side of head and a patch on the chin; throat and breast, black; a narrow white superciliary stripe bordering the yellow crown; a white stripe on side of throat; rest of under parts, white, shading to ashy on the sides; three lateral tail feathers with large white spaces on inner webs.

Adult female: Similar, but duller, yellow of the crown mixed with olive and the black patches on sides of head and throat replaced by dusky gray.

Length, 5 ; wing, 2.45; tail, 2 ; bill, . 38 .

The Golden-winged Warbler is a rather common migrant and a more or less common summer resident in parts of Illinois and Wisconsin. Prof. Ridgway states he found it breeding on the southern edge of Calhoun Prairie in Richland County, Illinois, in June, I885, and that Mr. H. K. Coale found it common and breeding on May I , I884, in the woods on the Kankakee River in Stark County, Indiana (Orn. of Illinois, 1889, p. I 26).

Messrs. Kumlien and Hollister state (Birds of Wisconsin, I903, p. III): "This superb warbler is a regular, though rather rare, migrant and a summer resident from the southern part' of the state northward. Dr. Hoy took several nests at Racine and T. Kumlien procured fledglings in Jefferson County. Grundtvig found it common, in fact, 'extremely numerous' in Outagamie County in $1882-3$. $\mathrm{He}$ found it a common summer resident, but did not find a nest. Recorded by Willard as breeding in Brown County, and by Mr. J. N. Clark from Dunn County. We have found it more common along Lake Michigan than elsewhere and a rather common breeder at Two Rivers in $\mathrm{I} 88 \mathrm{I}$. It is a regular summer resident in Jefferson County, but as elsewhere is restricted to favorite localities."

The nest is on or near the ground, composed of leaves, plant fiber, 
shreds of bark, etc. The eggs are from 4 to 6 , white, finely speckled with brown chiefly at the larger end, and measure about $.63 \times .5^{2}$ inches.

306. Vermivora rubricapilla (WILS.).

Nashville Warbler.

Helminthophila ruficapilla (Wils.), A. O. U. Check List, 1895, p. 27 I.

Distr.: United States and British Provinces east of the Rocky Mountains; breeds from about the latitude of Nebraska and Pennsylvania northward to northern Quebec and Athabaska.

Adult male in summer: Crown and sides of head, ashy gray, with a partially concealed chestnut patch on the crown; back and rump, yellowish olive or light olive green, brightest on upper tail coverts; under parts, including under tail coverts, yellow, shaded with olive on the sides; wings and tail, fuscous brown, edged with olive green.

Adult female in summer: Similar, but paler, the crown patch smaller, and the middle of the belly more or less whitish.

Immature birds usually lack the chestnut crown patch.

Length, 4.65 ; wing, 2.45 ; tail, 1.90 ; bill, .36.

A common migrant in Illinois and Wisconsin and a more or less common summer resident in the latter state. The song somewhat resembles that of the Yellow Warbler.

Regarding its nesting in Wisconsin, Kumlien and Hollister say: "The Nashville Warbler nests regularly in different parts of the state. We have nesting records at different times in Walworth County, at Lake Koshkonong, Dunn County, and northward. It is an especially common migrant along Rock River Valley. A favorite nesting site seems to be in tamarack swamps, the nest being placed on sphagrum, or reindeer moss." (Birds of Wisconsin, I903, p. II I.)

The nest is on the ground and is composed of fine rootlets, moss, and grass. The eggs are 4 or 5, pure white, finely speckled with brown chiefly at the larger end, and measure about.60 x .47 inches.

\section{Vermivora celata $\left(\mathrm{S}_{A Y}\right)$.}

Orange-CROWNED WARBLER.

Helminthophila celata (Say), A. O. U. Check List, I895, p. 272.

Distr.: Greater portion of North America, breeding in the western portion from New Mexico and Utah northward to the Mackenzie region and northern Alaska; rare east of the Alleghany Mountains north of Virginia; winters in the south Atlantic and Gulf states and Mexico. 
646 Field Museum of Natural History-Zoölogy, Vol. IX.

Adult male: Crown with partially concealed patch of orange brown; a rather obscure yellowish orbital ring; rest of upper parts, dull grayish olive, shading to olive green on the rump; under parts, yellowish olive, showing very faint and obscure dusky streaks on the breast; wings and tail, fuscous brown, the former narrowly edged with olive and the latter apparently plain, but the outer feathers with very narrow whitish edgings.

Adult female: Similar, but crown patch less extended.

Young birds lack the orange brown crown patch, and the orbital ring is whitish.

Length, 4.90; wing, 2.40; tail, 1.90; bill, .38.

The Orange-crowned Warbler is common in Illinois and Wisconsin during the migrations in spring and fall. Specimens have been taken in Wisconsin in June and July, and Messrs. Kumlien and Hollister are of the opinion that it breeds, but there is no record of the nest and eggs having been taken in the state.

\section{Vermivora peregrina (WILs.).}

Tennessee Warbler.

Helminthophila peregrina (Wils.), A. O. U. Check List, I895, p. 272 .

Distr.: Eastern North America, west to the Rocky Mountains; breeds from northern New York, northern New England, Manitoba, and the mountains of Colorado north to Ungava and the Mackenzie region; winters in Mexico. Central America, and northern South America.

Adult male: Upper parts, clear olive green, brightest on the rump; crown, ash-gray; eye ring and lores, and occasionally more or less

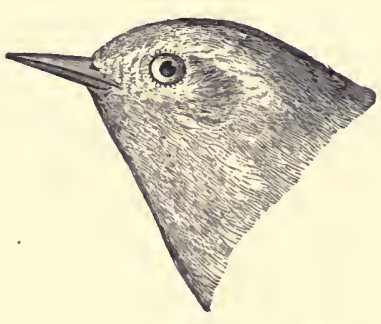
of a superciliary stripe, whitish; under parts, white (sometimes faintly tinged with pale yellow in places); flanks tinged with olive; wings, dark fuscous brown, the feathers edged with the color of the back; inner secondaries, narrowly edged with whitish on inner webs; tail, fuscous, the inner web of the outer tail feather generally with white edge near tip.

Adult female: Similar, but under parts tinged with pale greenish yellow.

Immature: Upper parts, including crown, yellowish olive; under parts, greenish yellow, shading to whitish on belly and crissum. 
Length, 4.90; wing, 2.70; tail, 1.70; bill, .35.

This plain colored little Warbler is an abundant migrant in Illinois and Wisconsin during spring and fall. It arrives on its way north in May and is with us again from the latter part of August until October. Mr. Ernest E. Thompson admirably describes the song as beginning with chipiti, chipiti, repeated a dozen times or more with increasing rapidity, then suddenly changing into a mere twitter.

\title{
Genus COMPSOTHLYPIS Cabanis.
}

\section{Compsothlypis americana (LiNN.).}

\author{
Parula Warbler.
}

Distr.: Eastern United States west to the Plains and north to Canada; south in winter to Central America and the West Indies; breeds in suitable localities nearly throughout its United States range.

Adult male: Upper parts, grayish blue, a broad patch of greenish yellow across middle of back; lores, blackish; a white spot on the

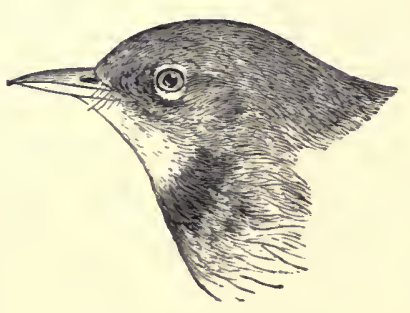

Parula Warbler. eyelids; upper throat and lower breast, yellow, separated by a more or less perfect chest band of black bordered with orange brown; belly, white; sides washed with grayish blue; wings, dark fuscous, narrowly edged with grayish blue; the greater and middle coverts, tipped with white, forming wing bands; tail, dark fuscous, the outer feathers with broad white patches on inner webs.

Adult female: Similar, but paler; the breast band much less distinct and sometimes absent.

Length, 4.65 ; wing, 2.40 ; tail, 1.75 ; bill, .36.

The Parula Warbler is a common summer resident in Illinois and Wisconsin in localities where there are swampy forests, building its nest in the long gray lichens or "gray.moss," which grow on the trees in such places. Away from forests it occurs as a migrant. It arrives early in May and leaves for the south in September.

The eggs are from 3 to 5, dull white or cream white, speckled and marked with rufous brown chiefly at the larger end, and measure about $.65 \times .46$ inches.

Compsothlypis americana ramaline Ridgway is no longer recognized as separable. 


\section{Genus DENDROICA Gray.}

\section{Dendroica tigrina (GMEL.).}

\section{Cape May Warbler.}

Distr.: Eastern North America, north to Lake Winnipeg and Hudson Bay territory, west to the Plains; breeds from northern New England and southern Ontario northward.

Adult male: Crown, black in full breeding plumage, usually mixed with olive; back, light olive green, irregularly marked with black;

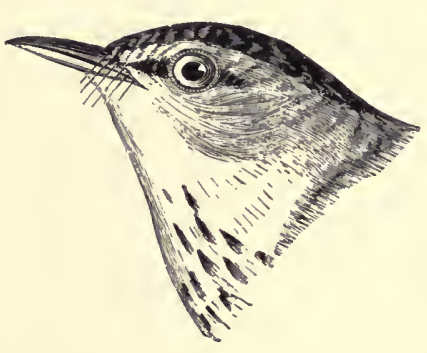
rump, yellow; a brownish yellow superciliary stripe and a black streak through the eye; sides of head around ear coverts, light chestnut brown, bordered below and on sides of neck with clear yellow; under parts, bright yellow (the throat and upper breast usually more or less tinged with brown), heavily streaked with black, the yellow shading to whitish on the belly; wing coverts, broadly tipped with white, forming a white patch; three outer tail feathers with large white patch on inner webs.

Adult female: Above, grayish olive, shading to greenish yellow on rump; head marking not like the male; a faint yellowish line over the eye; white markings on wing coverts and tail much smaller; throat, pale yellow; under parts, yellowish white, streaked with dusky.

Length, about 5 ; wing, 2.70 ; tail, 1.95 ; bill,. .36 .

This species is common during the migrations in Illinois and Wisconsin in May and September.

\section{II. Dendroica æstiva (GMEL.). Yellow WARBLER.}

Distr.: Whole of North America, except British Columbia and Alaska, north to the Mackenzie region, Hudson Bay, and Labrador; breeds nearly throughout its North American range; south in winter to Middle America and porthern South America.

Adult male: Upper plumage, bright olive yellow, more yellowish on crown and rump; under parts, bright yellow, streaked with rufous brown; wings, fuscous brown, edged with greenish yellow; greater portion of inner webs of tail feathers, yellow. 


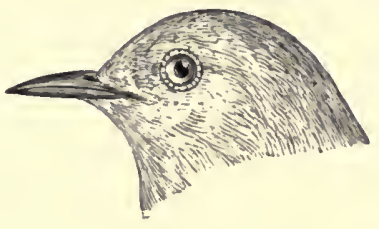

Adult female: Similar, but upper parts slightly deeper olive yellow than the male; under parts, pale yellow, rufous streaks faint or entirely wanting.

Diagnostic character in any plumage: Tail feathers, fuscous brown, with inner webs largely clear yellow.

Length, 4.90; wing, 2.50; tail, 2 ; bill, .38.

The Yellow Warbler is a very common summer resident in Illinois and Wisconsin; noticeable on account of its yellow plumage. The majority arrive from the south the latter part of April or early in May, and leave early in September. Aside from its familiar chirp it has a pleasing song, which may be crudely described as we-chee, we-chee, we-chee-u.

Breeds in May and June; the nest is cup shaped, usually in bushes or low trees, and composed of plant fiber and grass, lined with plant down and feathers. The eggs are from 3 to 6, bluish or greenish white, spotted with light and very dark brown and gray chiefly at the larger end, and measure about $.68 \times .49$ inches.

The Field Museum collection contains a series of sets of eggs of this species taken in northern Illinois between June 8th and I 8th.

\section{Dendroica cærulescens (GMEL.).}

Black-throated Blue Warbler.

Distr.: Eastern North America, west to the Rocky Mountains and north to Labrador, northern Ontario, and Quebec; breeds from northern New England and northern New York northward and in the Alleghany Mountains south to Georgia; winters in the West Indies, Central America, and northern South America.

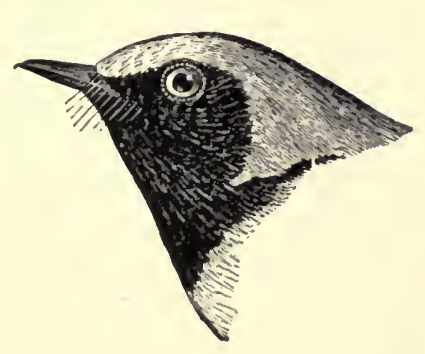

Adult male: Upper plumage, slaty blue (occasionally in full breeding plumage showing more or less black on the back); sides of the head from above the eyes, throat and sides of body, black, the sides more or less mixed with white; rest of under parts, pure white; basal portion of most of quills, white, extending beyond the coverts and forming a white wing spot; wing coverts, black, edged with slaty blue; tail, blackish, the outer feathers with white blotches on inner webs. 
$65^{\circ}$ Field Museum of Natural History-Zoölogy, Vol. IX.

Adult female: Dark greenish olive above; tail feathers, dark fuscous brown, generally faintly edged with grayish blue; under parts dull buffy white.

Diagnostic character in any plumage: Exposed white spot on primaries at end of coverts.

Length, 5.20; wing, 2.50; tail, 2 ; bill, .35.

This species is a common migrant in Illinois and Wisconsin in spring and fall, and undoubtedly breeds in northern Wisconsin, as Mr. John F. Ferry observed a bird of this species feeding young (which were taken) near Woodruff, Vilas County, July 2, I908, and Messrs. Kumlien and Hollister say: " There are several records of summer specimens from different localities."

\section{I3. Dendroica coronata (LiNN.).}

Myrtle Warbler. Yellow-rumped Warbler.

Distr.: Whole of North America, but much more common east of the Rocky Mountains; breeds from northern New York and northern Michigan and in the Alleghany Mountains north to Ungava and Alaska; winters in the West Indies and Central America.

Adult male in spring: Upper plumage, bluish gray, streaked with black; crown, sides of breast and rump, clear yellow; throat, white;

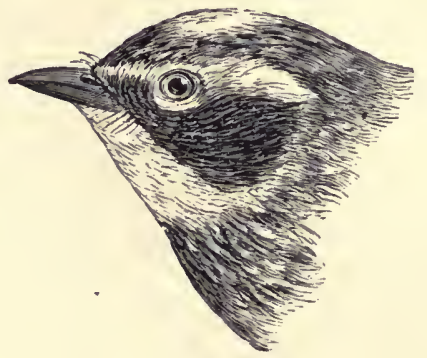
a white superciliary line; sides of head, black; breast, white, streaked with black; sides, the same; wings and tail dark fuscous, the latter with white blotches.

Adult female in spring: Similar, but browner above and with but little black on under parts; yellow patches duller and smaller.

Adult in fall and immature: Yellow on crown more or less concealed; upper parts, grayish brown, streaked with black or dusky.

Diagnostic characters in any plumage: Crown, sides of breast and rump more or less yellow; throat, white or whitish.

Length, about 5.50 ; wing, 2.95 ; tail, 2.30 ; bill, .36.

The yellow patches on the rump and sides of the breast are usually sufficiently noticeable to identify this species in the field.

The Myrtle Warbler is an abundant migrant in spring and fall in Illinois and Wisconsin. Although the eggs have not been taken within our limits, it may breed in northern Wisconsin. Mr. F. H. 
King states (Geol. of Wisconsin, Vol. I, 1883, p. 503): “A few may breed in northern Wisconsin, for I obtained a male at Elk Lake in Chippewa County, July 26 , I 876 ."

\section{Dendroica magnolia (Wrlson).}

\section{Magnolia Warbler.}

Dendroica maculosa (Gmel.), A. O. U. Check List, I895, p. 276.

Distr.: Eastern North America, west to the Rocky Mountains; breeds from Virginia and northern Michigan (Mackinac Island) north throughout Quebee, Ontario, and the British Provinces to the Mackenzie region; south in winter to the West Indies, and Central America to Panama.

Adult male in spring: Crown, ash-gray; back, black; rump, yellow; sides of head, white; a white stripe from above the eye extending

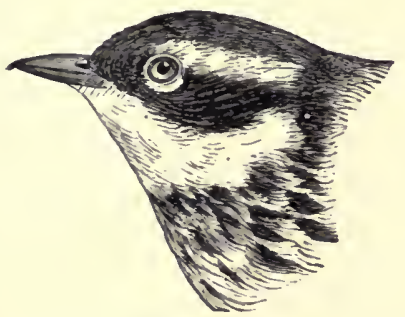

Magnolia Warbler.

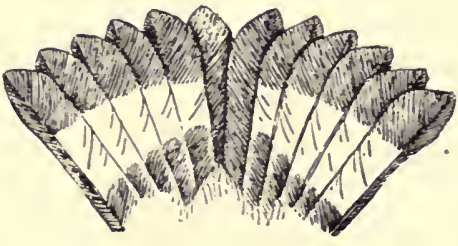

Tail.

backward; lower eyelid white; throat, yellow; under parts, yellow, streaked with black except on middle of belly; under tail coverts, white; primaries edged with white on inner webs; wing coverts, mostly white, forming a white wing patch; tail, blackish, with broad white band across the middle, except the two central feathers.

Adult female in spring: Similar, but duller and back tinged with olive.

Immature: Top and sides of head more or less ashy; back, olive green; under parts, yellow, whitish on belly; tail as in the adult.

Diagnostic characters in any plumage: Tail with broad white band across the middle (except the two central feathers); rump, yellow.

Length, 5; wing, 2.35; tail, 2.10 ; bill, . 36 .

Common during the migrations in spring and fall in Illinois and Wisconsin. It is not improbable that it may breed in northern Wisconsin, as it has been found nesting on Mackinac Island, northern Michigan (White, Auk, Vol. X, 1893, p. 228). 
652 Field Museum of Natural History-Zoölogy, Vol. IX.

\section{I5. Dendroica cerulea (WiLs.). \\ Cerulean Warbler.}

Distr.: Eastern North America and southern Ontario, west to the Dakotas, Nebraska, Kansas, and eastern Texas, rare east of New York; breeds from West Virginia, Tennessee, Alabama, and eastern Texas north to Wisconsin and Minnesota.

Adult male: Upper plumage, light blue, shading to grayish blue on the rump; back streaked with black; crown with more or less black markings; ear coverts, dusky; a white superciliary line; throat, breast, and belly, white; a band of grayish blue or dusky blue across upper breast; sides of body, white, streaked with grayish blue and dark blue; wing coverts tipped with white, forming wing bands; tail, blackish, all the feathers except the middle ones with subterminal white blotches on inner webs.

Adult female: Upper plumage, dull greenish blue or grayish green, with or without faint streaks of dusky; superciliary line, whitish; throat and under parts, whitish, more or less washed with dull, yellowish or pale greenish yellow; no band on breast; tail markings as in the male. The white edgings to the wing coverts and different tail markings will always distinguish the female of this species from that of $D$. ccerulescens.

Length, 4.40; wing, 2.65; tail, r.90; bill, .38.

The Cerulean Warbler is a summer resident in Illinois; common in the southern part of the state, but casual or rare in northern [llinois and in Wisconsin.

Mr. Ridgway considers it "by far the most abundant of the summer resident members of the family in Illinois." Mr. Frank M. Woodruff writes (Birds of the Chicago Area, I907, p. I62): "The Cerulean Warbler is a rare summer resident in the heavy timber of DuPage County, Illinois, and a few probably breed in the woods bordering the Desplaines River at River Forest. Mr. B. T. Gault has observed this species during the summer months in DuPage County and at Lake Forest, Illinois. It arrives from about the tenth to the twentieth of May, and departs early in September. Mr. H. K. Coale informs me that he shot a male Cerulean Warbler at Winnetka, Illinois, on May I 2, 1879, and that he also found them breeding in woods seven miles west of Lake Forest, Illinois, in i 876. ."

Messrs. Kumlien and Hollister state: "A rather rare species in Wisconsin, though of regular occurrence, especially along Lake Michigan. There are many records for Lake Koshkonong, as this section has been closely observed for a long period. There are also 
records for Delavan, Milwaukee, Racine, Two Rivers, etc. Mr. Clark has not found it in Dunn County. Dr. Hoy considered it as a breeding species, which is very probably true. There is one record for Lake Koshkonong, June I4 (I872)." (Birds of Wisconsin, 1903, p. II3.)

Breeds in May and June. The nest is built in a tree, usually from 30 to 50 feet from the groand, and is composed of grass, shreds of bark, plant fiber, and spiders' webs. The eggs are 3 or 4 , cream white or pale greenish white, marked and spotted with brown, and measure about $.63 \times .5 \mathrm{I}$ inches.

\section{Dendroica pensylvanica (Linx.).}

Chestnut-sided Warbler.

Distr.: Eastern North America south of northern Quebec, northern Ontario, and Manitoba, and west to Montana, the Dakotas, and Kansas; breeds from southern Indiana and Illinois and in the Appalachian highlands from South Carolina northward; south in winter in Mexico and Central America to Panama.

Adult male: Crown, yellow; a black stripe over the eye and a black patch in front of and below the eye; sides of head about ear

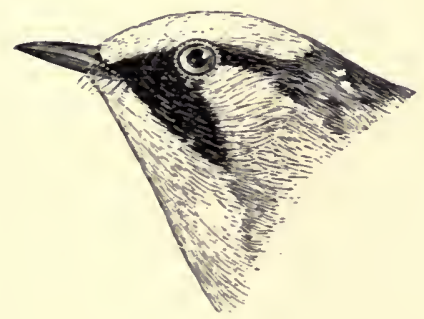
coverts, white; back streaked with black and greenish yellow; wing coverts tipped with whitish yellow, forming pale yellowish wing bars; sides of breast, chestnut; under parts, white.

Adult female: Similar, but duller and the black on the face more restricted and sometimes only slightly indicated.

Immature: Upper parts, clear yellowish olive; under parts, white; sides of head and body, ashy; wing bars as in the adult.

Diagnostic characters in any plumage: Wing bars, yellowish; throat and belly, white.

Length, 5; wing, 2.45; tail, I.95; bill, .37.

The Chestnut-sided Warbler is an abundant migrant throughout Illinois in spring and fall and is claimed to be a more or less common summer resident in northern Illinois and Wisconsin. Its note is a faint, soft tseep and the song resembles wee-see, wee-see, wee-see repeated quickly, and on an ascending scale.

Mr. Robert Kennicott (Trans. Ill. Agri. Soc., Vol. I, I853, p. 583) states that it was known to breed in Cook Co., Illinois. Mr. E. W. 
654 Field Museum of Natural History-Zoölogy, Vol. IX.

Nelson gives it as "an abundant migrant" and states that it "breeds sparingly away from the lake." (Birds N. E. Ill., I 876, p. 99.)

In Wisconsin it is a common summer resident.

The nest is in a bush or small tree, usually less than 6 feet from the ground, and is composed of shreds of bark, rootlets, plant fiber, etc. The eggs are 4 or 5 , white or creamy white, marked and spotted with different shades of brown and gray around the larger end, and measure about $.67 \times .49$ inches.

There is a set of two eggs of this species in the T. H. Douglass collection at Waukegan labelled, "Collected by Thomas H. Douglass, Waukegan, I11., May 13,1874 ."

\section{Dendroica castanea (WILS.).}

\section{BAY-BREASTED WARBLER.}

Distr.: Eastern North America, north to northern Quebec and Hudson Bay; breeds from northern New England and northern Michigan northward; south in winter to eastern Mexico, Central America, and Colombia, S. A.

Adult male: Crown, throat, upper breast and sides of body, chestnut; forehead and sides of head, black; a patch of pale buff on sides

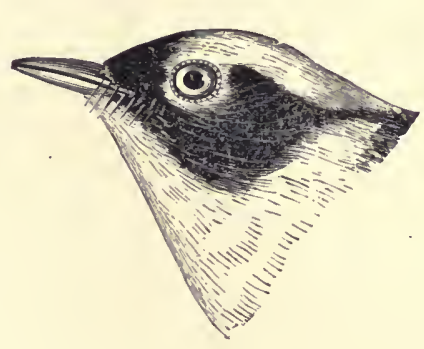
of neck; back streaked with black and dull gray; lower breast and belly, buffy whitish; greater and middle wing coverts tipped with white, forming two white wing bars; inner webs of outer tail feathers with white patches at tips.

Adult female: Crown, olive green, obscurely streaked or spotted with black and usually showing more or less chest-

nut; back similar to the male, but black streaks less pronounced; under parts, buffy white, tinged with pale chestnut on sides of breast and body; wing bars as in the male.

Immature: Upper parts, olive green, with obscure black streaks on back; under parts, dull whitish, often faintly washed with very pale greenish yellow on breast, but with sides of body and flanks tinged with pale buff (not whitish or pale olive yellow as in D. striata); wing and tail markings as in the adult.

Length, 5.50; wing, 2.90 ; tail, 2.10 ; bill, . 38 .

This species is common during the migrations in Illinois and Wisconsin in spring and fall. Although it has not as yet been found nesting in northern Wisconsin, it is not unlikely that it does so, as it has been found breeding in northern Michigan. 


\section{Dendroica striata (Forst.).}

BLACK-POLL WARBLER.

Distr.: Whole of North America, except west of the Rocky Mountains south of British Columbia; breeds from the southern British Provinces and northern New England northward to northern Ungava and northern Alaska; south in winter to West Indies and South America.

Adult male: Crown, black; nape streaked black and white; auricular region, white; back and rump, grayish ashy, streaked with

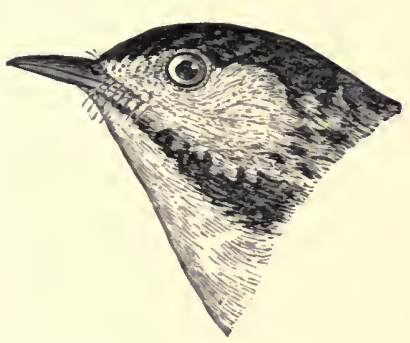
black; under parts, white, the sides of breast and belly streaked with black; two white wing bars formed by the middle and greater wing coverts being tipped with white; inner webs of outer tail feathers with patch of white near the tips.

Adult female: Upper parts, dull olive green, the crown and back streaked with black; under parts, white, more or less faintly washed with pale yellow; sides streaked with black; wings and tail as in the male.

Immature in fall: Upper plumage, dull olive green, the back with obscure black streaks; under parts washed with pale olive yellow, whitening on the belly; the sides of breast usially with obscure streaks; sides of body and flanks tinged with pale olive yellow (not buffy as in castanea); wings and tail as in the adult.

Immature birds of this species and Bay-breasted Warbler are very similar and at times difficult to distinguish with certainty, but the latter usually has a distinct buffy tinge on the flanks, and the obscure streaks on the sides of the breast are absent in that species.

Length, about 5.50; wing, about 2.90; tail, 2.15; bill, .38.

A common migrant in Illinois and Wisconsin in spring and fall, arriving on its northern migration early in May and passing south again in September. The song is a clear trilling whistle, but like several others of our species they often utter a clear and occasionally often repeated chip. 
656 Field Museum of Natural History-Zoölogy, Vol. IX.

\section{Dendroica blackburniæ (GMEL.).}

Blackburnian Warbler.

Distr.: Eastern North America, west to eastern Texas, Kansas, and Manitoba, north to Hudson Bay and Labrador; breeds from the southern Alleghanies, Massachusetts, Michigan, and Wisconsin northward; south in winter to Central America and northwestern South America to Peru.

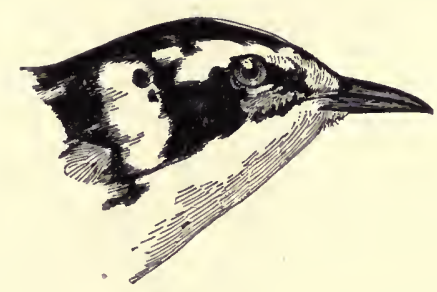

Male.

Blackburnian Warbler.

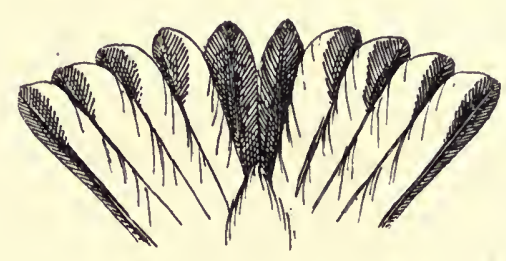

Tail.

Adult male: Crown, black, with an orange patch in the centre; sides of head, black, bordered above by an orange superciliary stripe; throat and breast, bright orange; back, black, more or less streaked with white; belly, pale yellowish; sides streaked with black; greater portion of wing coverts, white, forming a large white wing patch. Tail feathers, except the middle ones, have the inner webs of the inner feathers, and the narrow outer web of the outer feather, white, except near the tips.

Adult female: Upper plumage, grayish olive, streaked with black, some of the feathers edged with whitish; crown with yellow patch in center; superciliary line and throat pale orange yellow, shading into yellowish white on the belly; sides streaked with dusky.

Immature birds resemble the female, but are paler, the back browner, and the yellow crown spot more restricted.

Diagnostic characters in any plumage: Basal portion of outer web of outer tail feather, white; throat, yellow or orange; crown with at least a trace of yellow or orange in the centre.

Length, 5; wing, 2.67; tail, 2 ; bill, .34.

The Blackburnian Warbler is a very common migrant in Illinois and Wisconsin in spring and fall and a summer resident in the latter state. Mr. John F. Ferry procured a female with denuded abdomen and carrying an insect in its bill on July 3, 1908, near Trout Lake, Vilas Co., Wisconsin, and the writer found the species not uncommon in the same locality between July 23 and 30 .

Regarding its nesting in Wisconsin, Messrs. Kumlien and Hollister 
write: "A few nest regularly in the state, even in the southern counties, most often in the tamarack swamps. Eggs have been taken in Jefferson County and young in Manitowoc County (L. K.)." (Birds of Wisconsin, I903, p. II 4 .)

The nest is usually in evergreen trees, composed of plant fiber, moss, grass, and horse-hair. The eggs are 4 , greenish white, spotted and marked with shades of brown chiefly around the larger end, and measure about $.69 \times .50$ inches.

\section{Dendroica dominica albilora (RIDGW.). SYCAMORE WARBLER.}

Distr.: Mississippi Valley region, west to the Plains, north to southern Wisconsin and southern Michigan, east to the Alleghany Mountains, south in winter to Mexico and Central America to Costa Rica; breeds nearly throughout its United States range from Illinois and Ohio southward.

Adult male: Upper parts, ashy gray; throat, bright yellow; rest of under parts, white, streaked with black on the sides; belly, white,

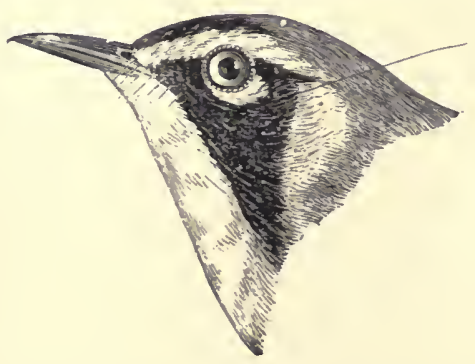
without streaks; forehead (sometimes greater portion of crown also), black; a white superciliary stripe, sometimes tinged with yellow near nostril; a white patch on sides of neck; lores, cheeks, and sides of throat, black; middle and greater wing coverts tipped with white, forming wing bands; terminal portion of inner webs of

three outer tail feathers marked with white.

Adult female: Similar, but the yellow throat somewhat paler.

Immature in fall: Similar to the female, but back tinged with brown, and under parts, brownish white.

Diagnostic characters in any plumage: Throat, yellow; belly, white; back, gray or brownish gray, never green or greenish.

Length, 5; wing, 2.60; tail, 2 ; bill, .50.

The Sycamore Warbler is a common summer resident in southern Illinois, frequenting heavily timbered regions where sycamore trees are found $I t$ is rare in northern Illinois and an accidental straggler in Wisconsin.

Mr. Frank M. Woodruff records an adult male in the collection of Mr. T. H. Douglass, taken at Waukegan, Ill., in the spring of 1876 . (Birds Chicago Area, I907, p. r64.) 
658 Field Museum of Natural History-Zoölogy, Vol. iX.

Dr. Hoy took a specimen at Racine, June 20, I848. Messrs. Kumlien and Hollister record two specimens taken by Thure Kumlien, one at Lake Koshkonong in 1877 , and another in southern Wisconsin "at a very early date, I $842-50 . "$ (Birds of Wisconsin, I903, p. Ir 5.)

The nest is in large trees, usually pines or live-oaks, and at a considerable distance from the ground. It is composed of shreds of bark, plant fiber and plant down, and is often concealed in hanging masses of long "Spanish" moss. The eggs are four or five, dull white or grayish white, spotted and marked chiefly at the larger end with shades of brown, and measure about .7 $\mathrm{I} .5 \mathrm{I}$ in.

\section{Dendroica virens (GMel.).}

\section{Black-throated Green Warbler.}

Distr.: Eastern North America, west to eastern Texas, Nebraska, and the Dakotas and north to northern Quebec, Hudson Bay, and the Saskatchewan region; breeds from northern Ohio and northern Illinois northward; in winter south to Cuba and Central America to Panama.

Adult male: Upper plumage, yellowish olive green; sides of head and extreme forehead, yellow; a yellow superciliary stripe and a

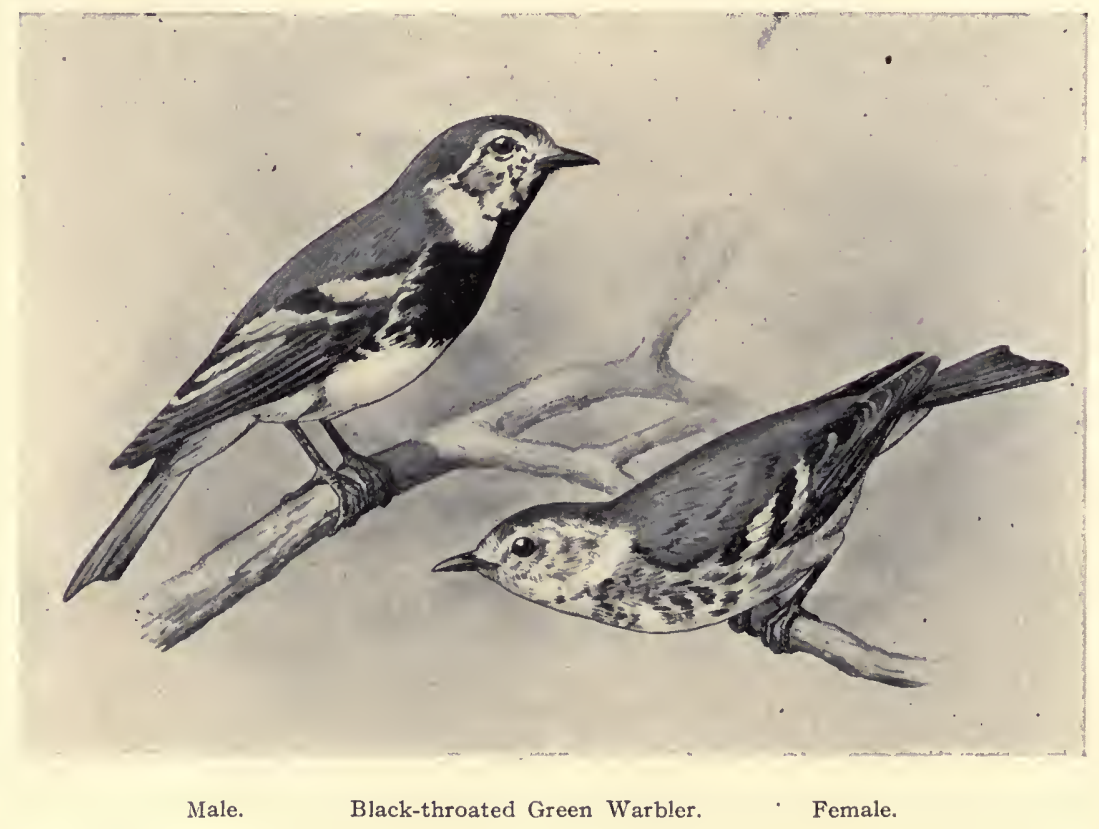


dusky stripe through the eye; throat and upper breast, black; under parts, white, streaked with black on the sides; thighs, pale yellow; wings, fuscous; greater and middle wing coverts, blackish, edged with white at tip, forming two noticeable white wing bars; inner webs of two outer tail feathers, mostly white, the third feather with white spot at end; basal half or more of outer web of outer tail feather, white.

Female: Similar, but the throat more or less yellow and the black on the breast mixed with dull whitish (the feathers being more or less edged and tipped with whitish).

Immature: Similar to the female, but throat tinged with pale yellow, the black marking on throat and breast often absent.

Diagnostic characters in adult plumages: Throat and breast (or breast alone), black, or at least with traces of black; sides of head, yellow; basal half or more of outer web of outer tail feather, white.

Length, 5; wing, 2.45; tail, 2 ; bill, . 38 .

A common migrant in Illinois and Wisconsin in spring and fall. Nelson says, "A few remain to breed." (Birds N. E. Ill., I876, p. Ioo.)

Regarding its occurence in Wisconsin, Messrs. Kumlien and Hollister say: "As is the case with many of the warblers, this one occurs in varying numbers, being sometimes only fairly common, and again greatly abundant, either in spring or fall. Dr. Hoy wrote that a few nest with us, and Mr. Clark suspects that they breed in Dunn County, as he has found them during the summer months. Young just able to fly were taken in Jefferson County in July, r868, and adults are frequently seen in summer as far south as Rock, Dane, and Jefferson Counties. We have known several pairs to remain in the vicinity of Milton all summer, but have never succeeded in finding a nest." (Birds of Wis., I903, p. II 5.)

The nest is is a tree, usually at a considerable height. The eggs are 4 in number, white, spotted with various shades of brown, and measure about $.68 \times .49$ inches.

\section{Dendroica kirtlandii BAIRD.}

Kirtland's Warbler.

Distr.: Eastern United States, recorded from Illinois, Minnesota, Missouri, Indiana, Michigan (breeding), Wisconsin, Ohio, Virginia, South Carolina, Florida, Toronto, and Ontario; winters in the Bahama Islands.

Adult male in spring: Crown, slaty gray, or bluish slate-color, usually finely dotted or narrowly streaked with black; lores and a 
660 . Field Museum of Natural History - Zoölogy, Vol. IX.

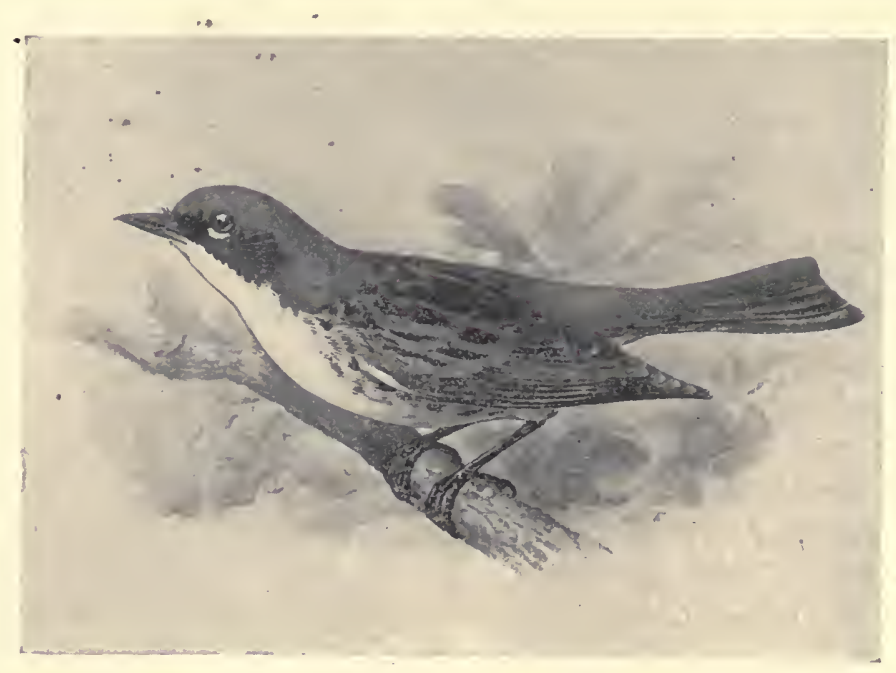

Kirtland's Warbler.

space below the eye, black; a narrow line of black across forehead bordering base of upper mandible; auricular region, slaty gray, an imperfect whitish orbital ring, broken in front; back, grayish buff, streaked with black; upper tail coverts, slaty gray; under parts, pale yellow, usually with small black spots on the breast; sides of body, grayish, streaked with black. (Some male specimens from the Bahama Islands, taken in March, have the breast practically immaculate.) Two outer tail feathers marked with a patch of white on terminal portion of inner webs, the white patch much larger on the outer feather than on the second; under tail coverts, whitish; greater wing coverts, brownish black, narrowly edged with grayish white or whitish.

Adult female in spring: Similar to the male, but back tinged with brownish and the under parts slightly paler yellow, the breast more extensively spotted.

Immature birds in fall and winter resemble the female, but have the crown, like the back, without gray, and the whole breast thickly spotted with blackish.

The yellow under parts, streaked with black on the sides and usually spotted on the breast, combined with the black streaked back and grayish rump, will usually distinguish this species.

Length, 5.45 ; wing, 2.70; tail, 2.35 ; bill, .38.

Three specimens of this rare warbler have been taken in Illinois and one recorded from Wisconsin. The records are as follows: 
Specimen taken by Mr. B. T. Gault at Glen Ellyn, Du Page Co., Illinois, May 7, I894 (Auk., I894, p. 258).

Specimen taken by Mr. J. E. Dickinson in Winnebago Co., I1linois, May 25, I894 (L. Jones, Wilson Orn. Chäpter, Bull. No. 4, Jan., 1895, p. I4).

Male shot by Mr. Eliot Blackwelder in Morgan Park, Chicago, May 22, I899 (Auk, Vol. XVI, 1899, p. 360).

A specimen shot, wounded, and picked up, but which fluttered away and escaped, Lake Koshkonong, Wisconsin (Kumlien.and Hollister, Birds of Wisconsin, I903, p. I33).

Mr. Norman A. Wood found it breeding in Oscoda County, Michigan in July, I903, and procured a nest and egg and fifteen specimens of old and young birds (Bull. Mich. Orn. Club, Vol. V, I905, p. 5).

Mr. Otto Widmann took a male bird of this species near the city limits of St. Louis, on May 8, I885 (The Auk, Vol. II, r885, p. 382).

\section{Dendroica vigorsii (AUD.).}

Pine Warbler.

Distr.: Eastern United States, from the Plains to the Atlantic coast, north to Manitoba and Ontario; breeding from Florida and the Gulf states northward throughout its range; winters in the south Atlantic and Gulf states and the Bahama Islands.

Adult male in summer: Upper parts, yellowish olive green; sides of head and neck, olive green; a somewhat faint and often obscure yellow superciliary stripe; under parts (except belly), yellow; sides of breast, streaked with olive; belly, whitish or grayish white: wings, fuscous brown,edged with grayish white on inner webs; wing coverts, tipped with grayish white or ashy, forming two ashy wing bands (not white); tail, fuscous brown, the outer feather largely white on inner web, the second with patch of white at end of inner web.

Adult female in summer: Similar, but the upper parts, grayish olive; throat and breast, pale olive yellow, shading into dull white or brownish white on the belly.

Immature in fall and winter: Resembles adult female, but upper parts, brownish olive; throat and breast tinged with pale yellow, rest of under parts, grayish white or brownish white, more distinctly brownish on the sides of the body.

Length, 5.35; wing, 2.90; tail, 2,20; bill, .42.

The Pine Warbler is a common migrant throughout Illinois and Wisconsin and a summer resident in suitable localities. Its usual song is a delightful little trilling whistle. 
662 Field Museum of Natural History-Zoölogy, Vol. IX.

"It has been found feeding its young in the heavy timber of the Wabash bottom lands near Mt. Carmel." (Ridgway, Orn. of Ill., r 889, p. r 53). Mr. E. W. Nelson considered it a common migrant in northeastern Illinois and says: "The first of July, I874, I found a large number of these birds with young just old enough to follow their parents in the 'Pinery' and presume they nest there regularly." (Birds N. E. Ill., r876, p. 100.)

According to Kumlien and Hollister it is : "A fairly common summer resident in the pine regions. Migratory in the hardwood districts of southern Wisconsin. Much more common along Lake Michigan than in the interior. A rather early arrival in the spring, generally preceding the majority of the warblers by several days. Although we have never found the nest we have noted this bird at various northern points in June and July. Dr. Hoy gives it as breeding in the northern pine forests." (Birds of Wis., r903, p. Ir 5. .)

The nest is built in a high tree, usually in a pine or cedar. The eggs are four or five, dull white or grayish white, spotted and speckled with brown and lilac-gray chiefly around the larger end, and measure about . $70 \times .53$ inches.

\section{Dendroica palmarum (GMEL.).}

Palm Warbler. Red-poll Warbler.

Distr.: Chiefly interior of North America, breeding in the far north (Hudson Bay and Mackenzie region); south in winter to eastern Mexico and the West Indies; casual in the Atlantic states during migrations.

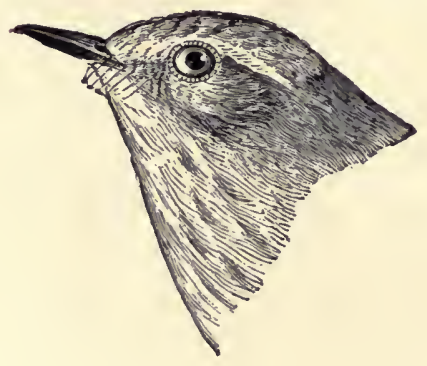

Palm Warbler.

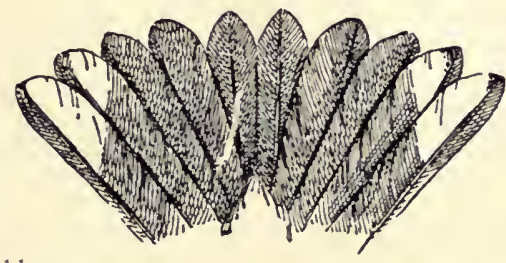

Adult male: Crown, chestnut; back, grayish olive brown; upper tail coverts, yellowish olive; a yellow superciliary stripe; a dusky spot in front of and behind the eye; auricular region, grayish brown; throat and under tail coverts, clear pale yellow; belly, grayish, sometimes tinged with yellow; breast and sides of throat more or less 
streaked with pale chestnut brown; sides and flanks usually with obscure streaks of the same; no noticeable wing bands; inner webs of two outer tail feathers with nearly square cut white spaces at tips.

The sexes are similar.

Immature: Similar to adult, but much more brownish olive above; the markings less distinct, and less yellow on the under parts.

Diagnostic characters in any plumage: Shape of white tail spots on two outer feathers (see cut), combined with pale brownish wing bars (never white), formed by the tips of the wing coverts.

Length, 5.10; wing, 2.55; tail, 2 ; bill, . 38 .

The Palm Warbler is an abundant migrant in spring and fall in Illinois and Wisconsin. Its song is a sweet trill.

\section{Dendroica discolor (VIEILl.).}

Prairie Warbler.

Distr.: Eastern United States, west to Kansas and Nebraska, breeding from Florida to southern New England and Michigan; winters in Florida and the West Indies.

Adult male: Upper plumage, bright olive green, the back marked and spotted with chestnut; a yellow line over the eye and a yellow spot

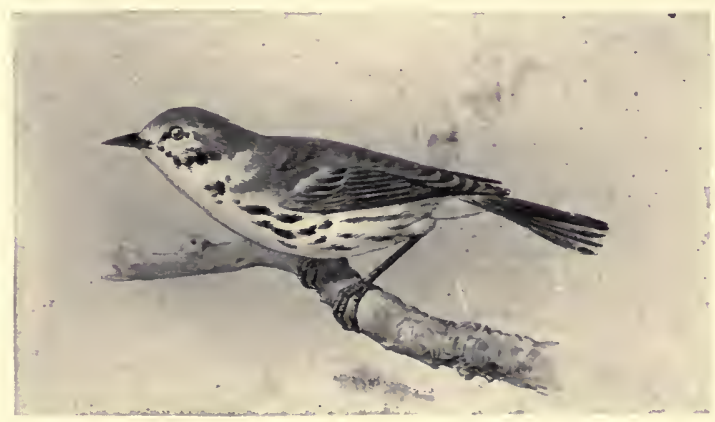

Prairie Warbler.

under the eye, bordered below on side of throat by a short black stripe; throat and under parts, bright yellow, streaked with black on sides of breast and body; wing coverts tipped with yellow, forming pale yellow wing bars; three outer tail feathers with white patch on inner webs; outer web of outer tail feather, white, except near the tip.

Adult female: Similar, but somewhat paler and with but little or no chestnut on the back. 
664 Field Museum of Natural History-Zoölogy, Vol. IX.

Immature: Upper parts more grayish olive; wing bars, absent, or only slightly indicated by dull whitish; sides obscurely streaked with olive instead of black.

Diagnostic characters for adults: Wing bars, yellow, and under parts, including belly, yellow.

Length, 4.65; wing, 2.15; tail, 2 ; bill, .36.

The Prairie Warbler must be considered a rather rare bird in Illinois and a rare straggler in Wisconsin. Mr. Isaac E. Hess writes me he has taken it at Philo, Champaign Co., Illinois, and Mr. Ridgway took a specimen at Mt. Carmel, Ill. Mr. L. E. Wyman shot a male at Riverside, near Chicago, on May 8, I907 (The Auk, Vol. XXV, I908, p. 87), and another specimen, a female, was shot by Mr. John F. Ferry on May 22, 1907, at Lake Forest, Illinois. Nelson considered it "a very rare spring and summer visitant." But few specimens have been taken in the vicinity of Chicago. Mr. Frank M. Woodruff writes: "Mr. George Clingman informs me that he took a pair at Bryn Mawr, Chicago, during the second week of June, 1878. He also took a nest and eggs of this species at Forty-eighth Street and Vincennes Ave., Chicago, on May 22, 1892." (Birds of the Chicago Area, I907, p. I69.)

It has also been recorded as breeding by Mr. D. H. Eaton at Peotone, Will County, Illinois (Forest and Stream, Vol. XI, Aug., I 878 , p. 47); by Mr. A. H. Mundt at Fairbury, Livingston Co., Illinois (Ornithologist and Oologist, Vol. VIII, Feb., I883, p. 9), and by Mr. W. E. Loucks at Peoria, Illinois (Oologist, I89r, p. 224).

Dr. Hoy says: "A few are occasionally seen about the middle of May. Rare in Wisconsin." (Proc. Acad. Nat. Sci. Phila., Vol. IV, I853, p. 3 Ir.) Messrs. Kumlien and Hollister record a specimen taken by Thure Kumlien at an early date at Lake Koshkonong. (Birds of Wisconsin, I903, p. II6.)

The nest is built in a small tree or bush and is composed of plant fiber, shreds of leaves, etc., and lined with plant down and hair. The eggs are 4 or 5 , white or buffy white, spotted with brown chiefly around the larger end, and measure about .64 .47 inches. 


\section{Genus SEIURUS Swainson.}

326. Seiurus aurocapillus (LiNN.).

OVEN-BIRD.

Distr.: Eastern North America, west to the eastern slope of the Rocky Mountains; breeds from northern Mississippi and Kansas northward to northern Quebec, Hudson Bay, and Alaska; south in winter to the West Indies, Central America, and Colombia, S. A.
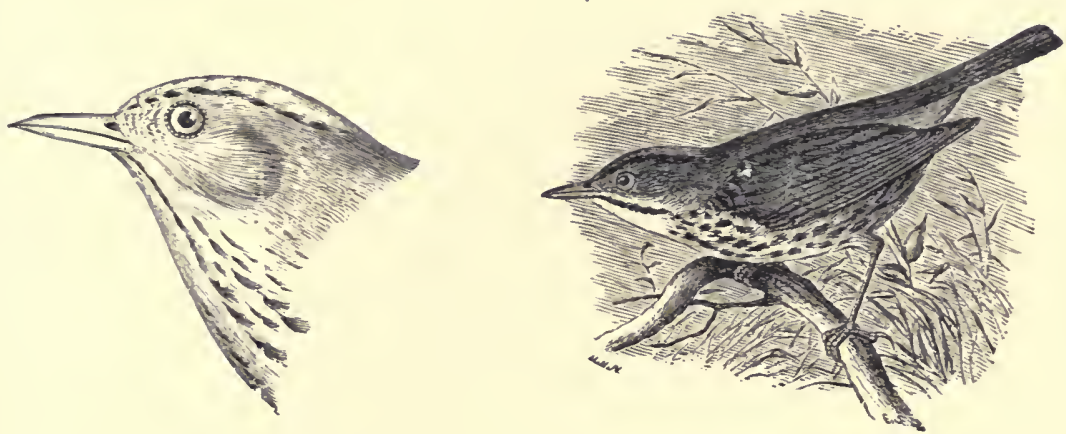

Adult: Crown, with broad stripe of orange brown in the centre, bordered by narrow stripes of black; sides of head, dull olive brown; throat, white, with narrow black stripe; sides, upper parts, wings and tail, brownish olive; wings, without bars; under parts, white, heavily streaked on breast and sides with black; no white on tail.

Sexes, similar.

Length, 6.05; wing, 2.90; tail, 2.25 ; bill, .45; tarsus, .82.

The Oven-bird is a common summer resident in wooded districts of Illinois and Wisconsin from May until the latter part of September. It has a delightful warbling song far different from its usual familiar notes, but which is apparently reserved for'special occasions, as it is not often heard and rarely or never, except after sundown. The more common song may be described as wee-chee, wee-chee, weechee, wee-chee, wee-chee, wee-chee, wee-chee, wee-chee, wee-chee repeated rapidly and with gradually increasing power.

Nidification begins in May. The nest is a covered, oven-like structure on the ground, with the entrance on the side often concealed by vegetation, and composed of grass, weeds, and leaves. The eggs are 4 or 5 , dull white, unevenly spotted and speckled with brown, and measure about $.79 \times .60$ inches. 


\section{Seiurus noveboracensis (GMEL.).}

WATER-THRUSH.*

Distr.: Eastern North America, west to Illinois and north to Hudson Bay and Ungava; breeds from the northern United States northward; winters in the West Indies, Central America, and northern South America.

Adult: Upper parts, including wings and tail, uniform olive brown; no white on wings or tail and no wing bars; a buffy white superciliary

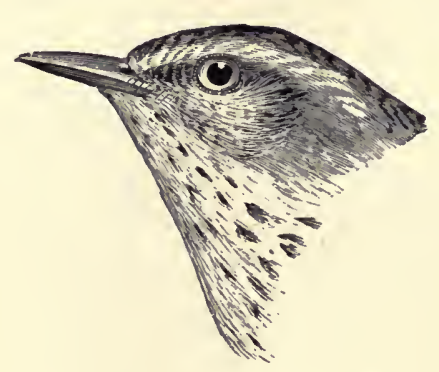

line; throat and under parts, pale sulphur yellow, heavily streaked with blackish, except on the middle of the belly; chin and upper throat speckled.

Sexes similar.

Length, 5.70; wing, 2.95; tail, 2.10; bill, about .50 .

The Mississippi Valley region seems to be the dividing line between the eastern and western forms of this species, and as would be expected, a large number of intermediates occur in Illinois and Wisconsin, in fact, typical examples of S. noveboracensis are by no means common. The Field Museum possesses a well marked specimen of this species (No. 5 IO4) taken by Mr. H. K. Coale at Grand Crossing, Ill., May 2, I887. It occurs as a migrant in southern Illinois, and Ridgway gives it as sometimes common in the latter half of August at Mt. Carmel, Ill. (Orn. of Ill., I889, p. I62.)

Mr. E. W. Nelson (Birds of N. E. Illinois, 1876, p. Ioo) says: "An abundant migrant, April I to May ro and August 25 to October 25. Found everywhere in damp woods or along the banks of streams during the migrations. A few remain to breed in secluded woods."

In Wisconsin Messrs. Kumlien and Hollister consider this species to be more common than its western race (S. $n$. notabilis) and state that: "It breeds sparingly in the southern counties and more commonly and regularly farther north." (Birds of Wisconsin, I903, p. II6.)

The nest is hidden in a mossy bank or on ground in swampy places. The eggs are 4 or 5 , white or cream white, marked with brown chiefly at the larger end, and measure about .75 x. $5^{8}$ inches.

\footnotetext{
* Although called Water-thrush from long usage, the name is unfortunate as likely to be more or less misleading to the student. T he name Wag-tail Warblers as used by Dr. Coues would seem more appropriate for these birds.
} 


\section{7a. Seiurus noveboracensis notabilis (RIDGW.).}

GRINNELL's WATER-THRUSH.

Distr.: Western United States, east to Illinois and Mississippi Valley and casual to the Atlantic coast; breeds chiefly from northern Minnesota and western Nebraska northward to the Mackenzie region and Alaska; in winter from southern border of United States to Central America, the West Indies and northern South America.

Grinnell's Water-thrush differs from the eastern bird, S. noveboracensis, in being larger and having the upper parts darker, more grayish olive than brownish olive, and the superciliary stripe and under parts decidedly whiter.

Wing, 2.90 to 3.20 ; bill, .45 to .55 inches.

An abundant migrant in Illinois and Wisconsin in spring and fall. While numerous intermediates occur, typical examples are not uncommon. Prof. Ridgway says: "Examples collected by me in Richland and Wabash Counties, Illinois, and in Knox County, Indiana (near Wheatland), are very typical of this race." (Orn. Ill., I889, p. I63.)

According to Kumlien and Hollister, it is a regular migrant, even in the southeastern part of the state. They say: "Specimens of this race were identified by Mr. William Brewster among the waterthrushes sent for his inspection." (Birds of Wisconsin, I 903, p. I I 7.)

\section{Seiurus motacilla (VIEILL.).}

Louisiana Water-thrush.

Distr.: Eastern United States and southern Canada, west to Iowa, eastern Kansas and eastern Texas, north to southern New England and southern Michigan, southern Wisconsin and southern Minnesota; breeds throughout its United States range, except southern Florida; winters from southern border of United States southward to the Greater Antilles, Mexico, and Central America to northern South America.

Adult: Resembles somewhat $S$. noveboracensis, but bill larger and the pale yellow of the under parts replaced by white, shading into pale buff on the flanks, abdomen, and under tail coverts; superciliary line, white.

Sexés similar.

Length, 6.15; wing, 3.15 ; tail, 2.25 ; bill, .55.

The Louisiana Water-thrush is a common summer resident in southern Illinois, and of casual occurrence in parts of northern Illinois 
668 Field Museum of Natural History-Zoölogy, Vol. IX.

and southern Wisconsin. Frequents thick woods in the vicinity of water. Its song is delightful, a complicated warble difficult to describe, but which begins loud, and gradually dies away.

Mr. Isaac E. Hess informs me he took a nest with five eggs near Philo, Champaign Co., Illinois, on June 9, I907. Messrs. Kumlien and Hollister record half a dozen specimens taken in Wisconsin during the past 50 years; one in Walworth County, another in Milwaukee County, and the others about Lake Koshkonong. (Birds of Wisconsin, I903, p: II 7.)

The nest is large and is composed of leaves, fine twigs, and grass or moss, hidden in a mossy bank or beneath old logs and roots of dead trees. The eggs are 5 or 6 , dull white, speckled and spotted with brown, and measure about $.74 \times .59$ inches.

\section{Genus OPORORNIS Baird.}

329. Oporornis formosa (Wils.).

KentUCKY WARBLER.

Geothlypis formosa (Wils.), A. O. U. Check List, I895, p. 282.

Distr.: Eastern United States, west to Kansas and Nebraska; breeds from the Gulf states to southern New England, southern Michigan and Iowa; winters in the West Indies, eastern Mexico, and Central America to Panama.

Adult male and female in spring: Crown and sides of head, black, extending in a streak on sides of throat; a yellow superciliary stripe;

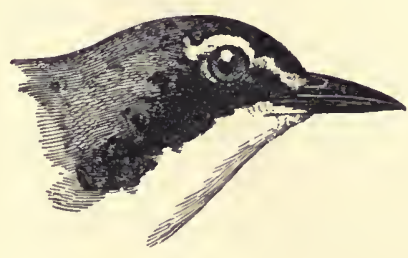
upper parts, wings and tail, olive green; under parts, clear bright yellow, shading to olive on sides; no white on wings or tail.

Adults in fall and winter: Similar, but black feathers on the crown edged with grayish olive.

Immature in fall: Similar, but the black markings replaced by dusky or entirely absent.

Length, 5.50; wing, 2.55; tail, 2 ; bill, .38.

A common summer resident in southern Illinois, but rare in northern Illinois and southern Wisconsin.

Mr. Isaac E. Hess informs me he has taken several sets of eggs of this species in Putnam amd Champaign Counties, Illinois. Mr. H. S. Swarth took 4 specimens and observed several others of both sexes at Joliet, Illinois, between May I3 and 29, I907. Dr. Joseph L. Han- 
cock took a female near Grand Crossing, Chicago, on. May 23, 1887 . (The Auk, r888, p. 2 Iо.) Mr. Frank M. Woodruff records a specimen taken by Mr. George Klingman at Bryn Mawr, Chicago, during the first week in May, 1892 (Birds of the Chicago Area, r907, p. I73), and there are other records.

In Wisconsin Dr. Hoy "shot one near Racine May, Io, I85r." (Proc. Phil. Acad. Sci., I853, p. 3 II) and according to Kumlien and Hollister, there are six other records for the state, all taken at Lake Koshkonong in spring (Birds of Wisconsin, I903, p. II 7 ).

The nest is large, built on the ground in woods and is composed of leaves, small twigs, etc. The eggs are 4 to 5 , white, speckled and marked with rufous and umber brown, and measure about $.73 \times .57$ inches.

\section{Oporornis agilis (WILS.).}

Connecticut Warbler.

Geothlypis agilis (Wils.), A. O. U. Check List, x895, p. 282 .

Distr.: Eastern United States and British Provinces, north to Ontario and Manitoba; breeds chiefly from Minnesota northward; south in winter to the Bahama Islands and northern South America.
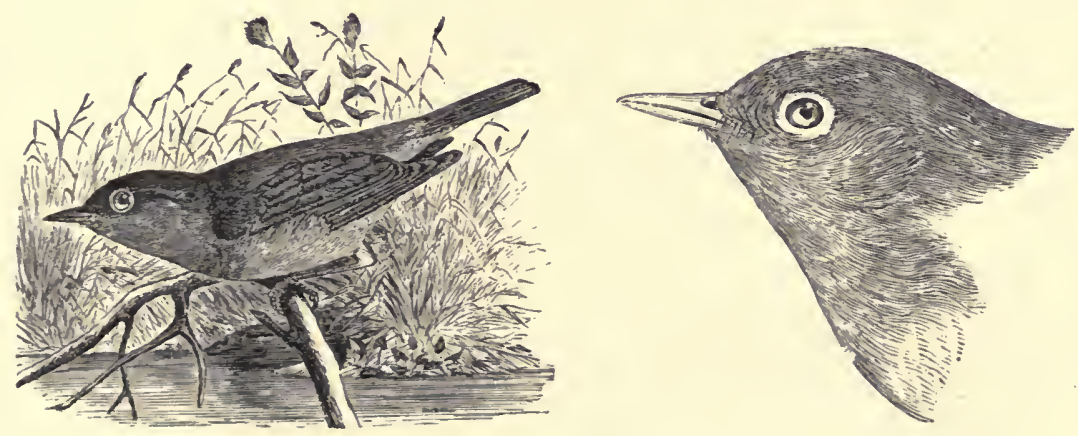

Adult male: Wings decidedly longer than the tail; head, throat, and breast, ashy gray, darkest on the crown and palest on the chin; $a$ white eye ring; rest of upper plumage, olive green; wings and tail, fuscous brown, more or less edged with olive and without white; belly and crissum, yellow; sides tinged with olive green. In full breeding plumage the breast becomes very dark, almost black.

Adult female: Characters as in the male, but slate color of the head replaced by brownish olive or grayish olive; chin and throat, brownish buff, becoming darker on the breast; eye ring, whitish or buffy white. 
670 Field Museum of Natural History-Zoölogy, Vol. IX.

This species somewhat resembles the Mourning Warbler, but the eye ring should distinguish it.

Length, 5.45; wing, 2.90; tail, 2.I5; bill, .42.

The Connecticut Warbler is a not uncommon migrant in spring and fall in Illinois and Wisconsin, and according to Kumlien and Hollister a few breed in the latter state; although the majority go farther north. They say: "In Jefferson County a pair was found, June I6, I 874 (L. K.), putting the finishing touches upon their nest. It was placed on the ground in a dense thicket of hazel, briars, etc. Though the nest was not touched they abandoned it, but bred in the same thicket; the nest, however, could never be found. Has been found in the dense tamarack swamps of Jefferson County in July, on several occasions when it was, without question, nesting, and we have no doubt that a considerable number nest within the state. It is the very last warbler to pass northward in the spring. Many observers fail to find this species. Mr. Clark has not, as yet, taken it in Dunn County, and it was not found in the state by King, Grundtvig, or Willard." (Birds of Wisconsin, I903, p. I1 7 .)

\section{Oporornis philadelphia (WILS.). \\ Mourning Warbler.}

Geothlypis philadelphia (Wils.), A. O. U. Check List, 1895, p. 283.

Distr.: Eastern United States and southern British Provinces, west to Manitoba, the Dakotas, and Kansas; breeds from Pennsylvania, New York, northern Michigan, and northern Wisconsin northward; south in winter to Central America and northern South America.

Adult male in summer: Head and sides of neck, ash-gray; throat, grayish, mixed with black, shading into black on the breast (in full

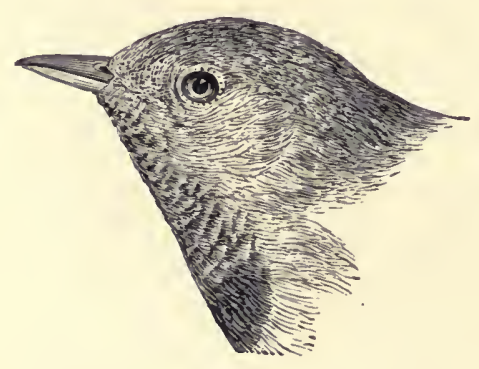
breeding plumage the whole throat and breast, black); no white eye ring; rest of upper parts, clear olive green; under parts (except throat and breast), yellow; wings, slaty brown, edged with olive; tail strongly washed wth olive; no white on wings or tail.

Adult male in fall: Similar, but black feathers on throat and breast edged with gray.

Adult female in summer: Similar to adult male, but throat and breast gray, palest on chin. 
Length, 5.50 ; wing, 2.50; tail, 2.20; bill, .33.

The Mourning Warbler is not uncommon during the migrations in spring and fall in Illinois and Wisconsin, and is a summer resident in the northern part of the latter state. Although I know of no record of the eggs having actually been taken in Wisconsin, Mr. John F. Ferry observed two different parent birds feeding their young in different localities and procured specimens near Woodruff, Vilas County, on July 7 , I908.

Macgillivray's Warbler, Oporornis tolmiei, a western species, is recorded as having been taken by Mr. H. K. Coale at Wolf Lake, Indiana, June $\mathrm{I}, \mathrm{I} 876$, a few hundred yards from the Illinois state line, and, therefore, not strictly within our limits. The specimen is now in the British Museum (Sharpe, Cat. Birds Brit. Mus., Vol. X, I 885, p. 365 ).

\section{Genus GEOTHLYPIS Caban.}

\section{Geothlypis trichas (LivN.).}

Maryland Yellow-throat.

Distr.: North America, from the western portion of the Great Plains eastward, north to Athabaska, Hudson Bay, and southern Labrador; breeds from Virginia and Tennessee northward and perhaps farther south; winters from the Gulf states southward to the Bahamas, Greater Antilles, Mexico, and Central America to Costa Rica.

Adult male in summer: A broad mask-like black band on front and sides of head, bordered behind by pale ash; upper plumage, dull
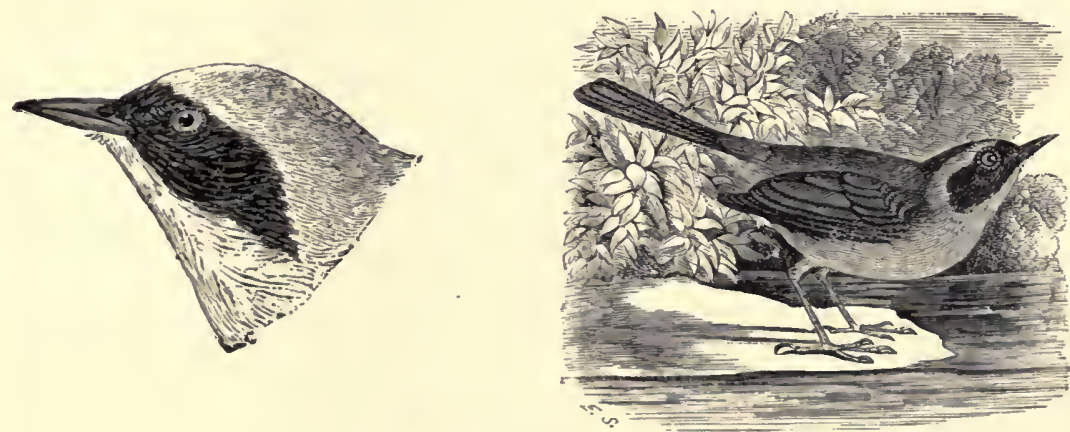

Maryland Yellow-throat.

olive green, often with faint brownish tinge on the crown; throat, breast, and under tail coverts, yellow; belly, whitish; sides of body 


\section{Field Museum of Natural History-Zoölogy, Vol. IX.}

tinged with pale brown; bend of wing, yellow; no wing bars; no white on tail.

Adult male in fall: Similar, but feathers of black mask tipped with gray; back and sides browner.

Adult female in summer: No black mask on head; forehead more or less tinged with brown; sides of head grayish olive; under parts much paler yellow, shading to whitish on belly; otherwise similar to adult male.

Immature in fall: The male has the dark mask only partially developed and often merely indicated by dusky; sides more strongly tinged with buffy brown. The female has the under parts strongly tinged with buff, shading to brownish on the sides and flanks.

Length, 4.85 ; wing, 2.20 ; tail, 2.10 ; bill, .40.

The Maryland Yellow-throat is a very common summer resident in Illinois and Wisconsin, where it frequents thickets and bushes.

Breeds in May and June. The nest is on or near the ground, cupshaped and composed of shreds of bark, leaves, and grass. The eggs are 4 or 5 , pure white, speckled with dull rufous and dark brown chiefly at the larger end, and measure about .7 I X .53 inches.

The note is clear and comparatively loud. Mr. Frank M. Chapman happily suggests that the song of this bird be written " $I$ beseech you, I beseech you, I beseech you, I beseech you." It varies considerably however, and at times resembles we-chee-chu repeated several times with the accent on the first instead of the third syllable.

Geothlypis trichas brachidactyla (Swainson) is no longer recognized as separable from $G$. trichas.

\section{Genus IC'TERIA Vieill.}

\section{Icteria virens (LINN.).}

\section{Yellow-BREasted Chat.}

Distr.: Eastern United States, west to the Dakotas, Kansas, and eastern Texas, north to southern Ontario, southern New England, southern Wisconsin, and southern Minnesota, breeding throughout its United States range; winters in eastern Mexico and Central America to Costa Rica.

Adult: Strikingly different in size and appearance, from all other local species, belonging to this family.* Upper plumage, bright

* Since the monotypic genus Icteria was placed in the family Mniotiltidæ by Professor Baird in I 858 , his view in the matter has been generally accepted by Ornithologists (albeit in some cases with more or less hesitation) as being the best way out of a rather difficult problem. 
olive green; wings and tail, unmarked and glossed with olive green; throat and breast, bright golden yellow; under wing coverts, yellow; belly; white; sides tinged with ashy; lores, black, shading into gray

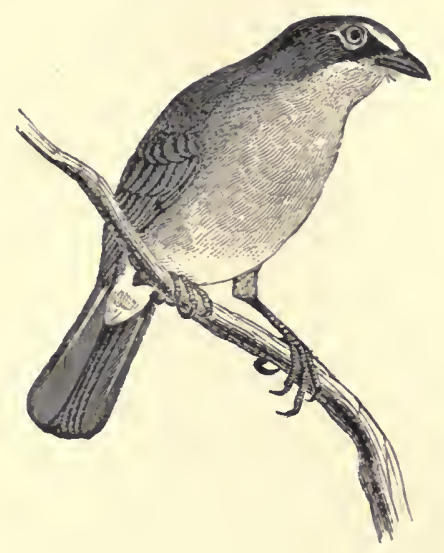

Yellow-breasted Chat.

on the auricular region; a stripe over the eye and lower eyelid, white; a short white maxillary line. Sexes similar.

Length, about 7.10; wing, .3; tail, 3.15 ; bill, .55.

The Yellow-breasted Chat is a common summer resident in suitable localities in Illinois and southern Wisconsin. Frequents thick undergrowth and shrubbery. The majority arrive from the south early in May.

Breeds in May and June. The nest is rather large, built in thick bushes, and composed of shreds of bark, leaves, and coarse grasses, lined with finer grasses. The eggs are from 3 to 5 , white or cream white, spotted and speckled with various shades of brown and purplish gray, and measure about .90 x.65 inches.

In writing of this species Dr. Elliott Coues says: "An exclusive inhabitant of low tangled undergrowth, and oftener heard than seen, except during the mating season, when it performs the extravagant aerrial evolutions for which, as well as for the variety and volubility of its song, it is noted." 
674 Field Museum of Natural History-Zoölogy, Vol: IX.

\section{Genus WILSONIA Bonap.}

334. Wilsonia citrina (BODDAERT).

Hooded Warbler.

Sylvania mitrata (Gmel.), A. O. U. Check List, I895, p. 285.

Distr.: Eastern United States, west to Kansas and Nebraska and north to southern Wisconsin, southern Ontario, New York and southern New England; breeds nearly throughout its United States range; winters in the West Indies, Mexico, and Central America to Panama.

Adult male: A bright yellow mask (gamboge yellow) or hood, including front of crown and sides of head; rest of head and throat,

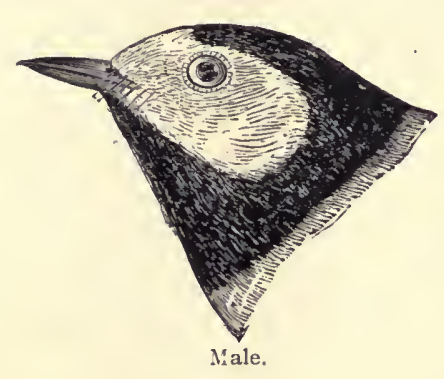
black; rest of upper parts, olive green; rest of under parts, gamboge yellow; wings, slaty brown, edged with olive; tail feathers, slaty brown, edged with olive; three outer tail feathers marked with white, the first and second, white on terminal portion of inner webs for at least half their length, the white patch on the third much smaller.

Adult female: No black on throat, which is entirely yellow; black on head often mixed with olive and restricted to a comparatively narrow area bordering the yellow on forehead and sides of head; otherwise resembles the adult male.

Immature male: Similar to adult male, but black feathers more or less tipped with yellow.

Immature female: Resembles the adult female, but no black whatever on head; entire upper parts, including top of head, olive green.

Adults in fall and winter: Apparently little or no variation from summer plumage.

Length, 5.5०; wing, 2.55; tail, 2.40; bill, .38.

The Hooded Warbler is an abundant summer resident in southern Illinois, but occurs casually in northern Illinois and Wisconsin. According to Mr. F. M. Woodruff a specimen was taken by Mr. B. T. Gault at River Forest, Illinois, May I I, I88I, and another was killed by a boy with a sling shot in Hyde Park, Chicago, April 28, I884 (Birds of the Chicago Area, I907, p. I76).

Mr. Isaac E. Hess informs me he has found it breeding near Philo, Champaign County, Illinois, and took a set of 5 eggs, May 30, I897. 
Mr. W. W. Cooke records specimens taken at Chicago, March 28, I884, and May 3, r895.

Another record for the vicinity of Chicago is that of an adult male taken by Mr. H. K. Coale, Chicago, Ill., May 5 th (Sharpe, Cat. Birds Brit. Ilus., Vol. X, I885, p. 439).

Messrs. Kumlien and Hollister say: "Not an uncommon migrant along Lake Michigan in southern Wisconsin and it undoubtedly breeds to the northward of Milwaukee. Much less common in the interior than along the lake shore. We have seen this species repeatedly at Two Rivers in July, but in Jefferson, Dane, and Rock counties only in the spring migration in May. We have also taken specimens at Milwaukee in the latter part of May." (Birds of Wisconsin, I903, p. II9.)

The nest is in low bushes in swampy woods. The eggs are 3 or 4 , usually 4 , white or buffy white, speckled and marked chiefly at the larger end with dark brown and brownish gray and occasionally a few specks of black. Size, about .70 x .54 inches.

\section{Wilsonia pusilla (Wils.).}

Wilson's WARBLER.

Syliania pusilla (Wils.), A. O. U. Check List, I895, p. 285.

Distr.: Eastern North America, west to the Rocky Mountains, north to Labrador, Hudson Bay, and Alaska; breeds from northern New England and southern British Provinces northward; south in winter to Mexico and Central America.

Adult male: Crown, glossy black; forehead, a line over the eye and under parts, bright yellow; upper parts, olive green; sides tinged
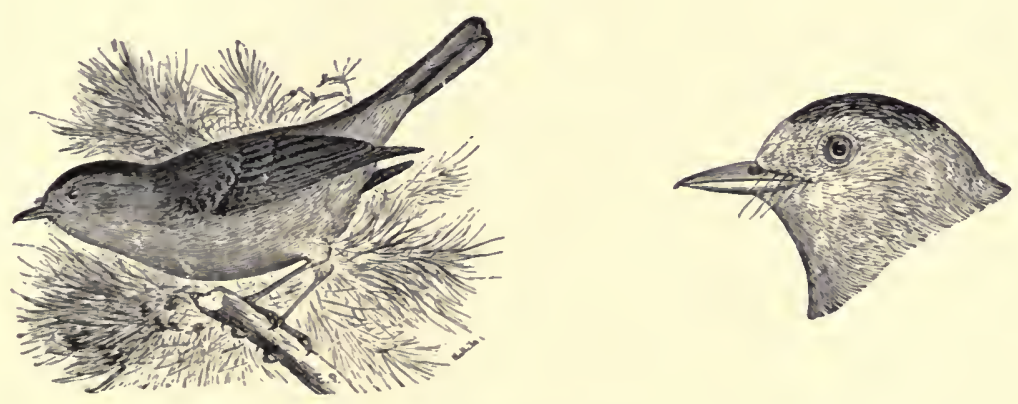

W.1 ion's Warbler.

with olive; wings and tail, slaty brown, edged with olive; no wing bars and no white spots on tail. 
676 Field Museum of Natural History-Zoölogy, Vol. IX.

Adult female: Similar to the adult male, but usually (not always with black cap on crown more restricted and more or less obscured by the feathers being tipped with olive. In some adult females the black is entirely absent, the crown being olive green like the back.

Immature: Similar, but without the black cap.

The plumage of adults in fall and winter apparently varies but little from that of spring.

Length, 4.80; wing, 2.25; tail, 2 ; bill, .32.

Wilson's Warbler occurs more or less commonly as a migrant in spring and fall in Illinois and Wisconsin, and according to Messrs. Kumlien and Hollister, a few remain to breed in the northern part of the latter state. They say: "A common migrant in southern Wisconsin, passing northward late, often as late as the first week of June. Undoubtedly a few nest in Wisconsin, even as far south as Jefferson County, although there is no actual record. Specimens have been taken near Jefferson, June 16 . Young birds are often taken as early as the middle of August in the large tamarack swamps. Principally a frequenter of low lands, and willowy thickets, often in tamarack swamps." (Birds of Wisconsin, I903, p. II9.)

\section{Wilsonia canadensis (LINN.).}

CANADIAN WARBLER.

Sylvania canadensis (Linn.), A. O. U. Check List, I895, p. 286.

Distr.: Eastern North America, west to the Plains and north to southern Labrador, northern Quebec, and Athabaska; breeds from Alleghany Mountains, southern New England, Wisconsin; and Michigan northward; south in winter to Central America and northern South America.

Adult: Upper parts, ash-gray; forehead and crown, black; most of the crown feathers edged with gray, producing a streaked appear-

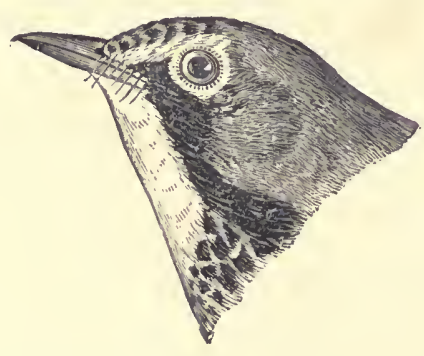

under tail coverts, white. ance; eye ring, yellowish or yellowish white; a short yellow superciliary stripe extending to base of bill; an irregular black streak from below the eye, extending on sides of neck; throat and under parts, yellow, the breast marked with a band of irregular short black streaks or dashes; wings and tail, plain brownish gray, without white spots;

Adult female: Similar, but black on head restricted to a few small 
blackish spots on front of crown; black streaks on breast replaced by dusky.

Immature females show the breast streaks but faintly if at all.

Length, 5.30 ; wing, 2.50; tail, 2.25 ; bill, .37.

A common migrant in Illinois and Wisconsin in spring and fall. According to Messrs. Kumlien and Hollister a few nest in northern Wisconsin. They say: "A common migrant during the latter part of May and again in September. A few nest in central and northern Wisconsin, along the borders of hemlock swamps, but the great majority pass beyond our borders to summer. King mentions taking a fully fledged young bird near Worcester, July. I9, I876 (I), and a pair were seen feeding young, which were flying about on July $\mathrm{r} 2, \mathrm{I} 882$, in Door County, to the northward of Sturgeon Bay (L. K.)." (Birds of Wisconsin, r903, p. I 20.)

\section{Genus SETOPHAGA Swainson.}

\section{Setophaga ruticilla (LiNN.).}

\section{REDSTART.}

Distr.: North America, north to Hudson Bay and the Mackenzie region, breeding from North Carolina and northern Mississippi northward; winters in the West Indies, Central America, and northern South America.

Adult male: Sides of body and a broad band on wings and tail, reddish orange or salmon color, brightest on the sides; middle of

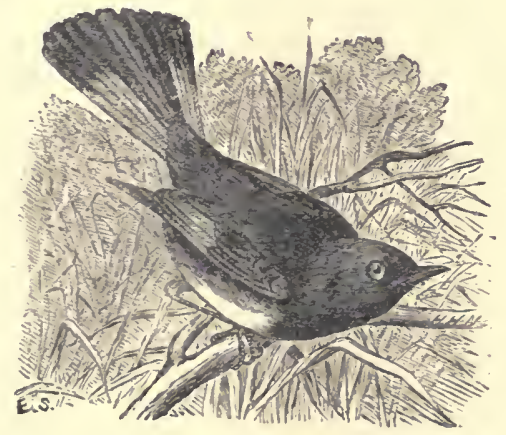

Redstart (male). lower breast, belly and under tail coverts, white; rest of plumage, black; basal half of primaries and most of secondaries, salmon, the ends, brownish black; middle tail feathers, brownish black, the rest salmon color, broadly tipped with brownish black; bill, dark, flattened and wide at base and with numerous rictal bristles approaching that of a Flycatcher.

Adult female: Orange red marking of the male on sides, wings and tail replaced by yellow, no black anywhere; crown, ashy; back, olive gray; throat and under parts, white.

Immature male: Similar to female the first season, and later throat and upper parts mixed black and gráy. 
678 Field Museum of Natural History-Zoölogy, Vol. IX.

There is apparently no seasonal change of plumage in the adults.

Length, 5.30 ; wing, 2.50 ; tail, 2.40 ; bill, .36.

The Redstart is an abundant summer resident in Illinois and Wisconsin, arriving about May I and leaving for the south late in September or the first few days in October. Its song varies considerably but that which is most common may be described as a rather shrill see-wee, see-wee; see-wee, see-wee.

It breeds in May and June. The nest is usually built on the branch of a tree, from 6 to 25 feet from the ground, and is composed of shreds of bark, plant fibers and dried leaf stems, etc. The eggs are 4 or 5 , greenish white or grayish white, spotted and blotched chiefly at the larger end with grayish and dark brown, and measure about $.65 \times .49$ inches. The Field Museum collection contains a series of sets of eggs of this species taken in northern Illinois between June $I$ and June 22.

\section{Family MOTACILLIDÆ. Wagtails, Tit- larks, Pipits, etc.}

This family comprises some sixty or more species, mostly belonging to the Old World. A single species regularly occurs in eastern North America. It frequents open fields and is usually found in flocks. The nest is composed of grass and built on the ground. They are insectivorous and migratory.

\section{Genus ANTHUS Bechs.}

338. Anthus rubescens (Tunstall).

American Pipit. Titlark.

Anthus pensilvanicus (Lath.), A. O. U. Check List, I 89.5, p. 289.

Distr.: North America, breeding north of the Unites States, except in the higher parts of the Rocky Mountains; winters in the Gulf states, Mexico, and Central America.

Adult in summer: Hind toe nail, long, about equal to length of hind toe; upper plumage, brownish gray, some of the feathers with obscure dark centers most noticeable on the back; a buffy superciliary stripe; under parts, pale brownish buff; pale on the chin; the breast and sides with obscure dusky streaks; wings and tail, 

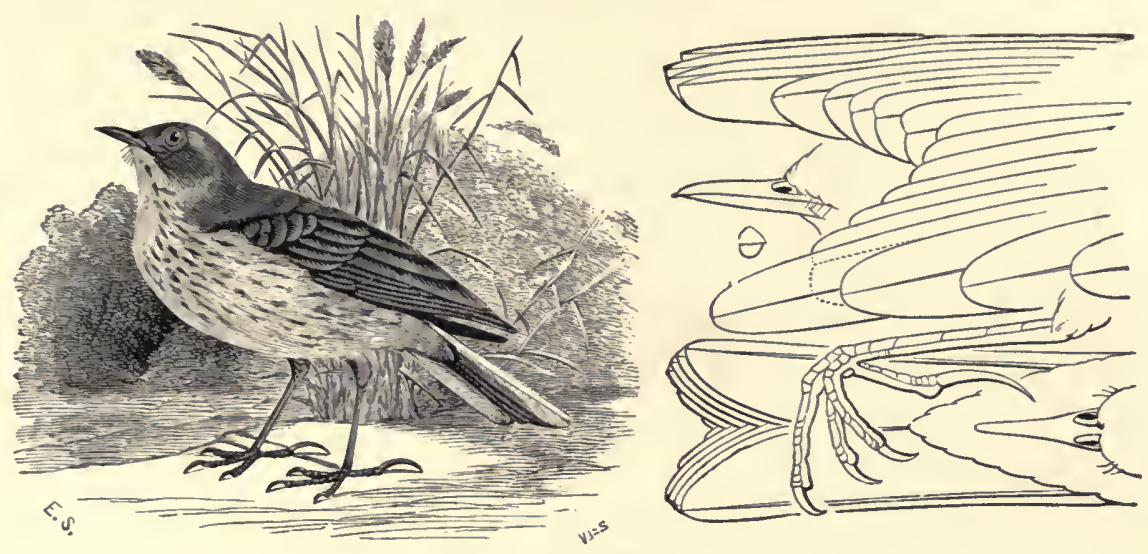

American Pipit.

dusky brown, with grayish edgings to the feathers; two outer tail feathers marked with white; the greater portion of outer tail feather, white, the inner web partly edged with blackish; terminal portion of second feather white, black and white about evenly divided, the portion bordering the shaft being white and the inner half of inner web black for about half an inch from the tip. Sexes similar.

Adult in fall and winter: Upper parts much more brown; under parts whitish or brownish white; breast and sides streaked with brown.

Length, 6.40; wing, 3.45 ; tail, 2.70; bill, .45:

This species is a common migrant in spring and fall in both Illinois and Wisconsin. Frequents open fields and prairies, usually in flocks. A few remain in southern Illinois in winter. 
680 Field Museum of Natural History-Zoölogy, Vol. IX.

\section{Family MIMIDÆ. 'Thrashers, Mocking- birds, etc.}

The members of the family Mimidæ are, as a rule, gifted vocalists, the Mockingbird being perhaps the most prominent on account of its familiarity to most observers. They are wood-loving insectivorous birds, although often seen in the open.

\section{Genus MIMUS Boie.}

339. Mimus polyglottos (Linn.).

MockingBiRd.

Distr.: Southern United States and northern Mexico, from Maryland, Kentucky, southern Illinois, and Kansas southward and casually farther north, breeding throughout its range.

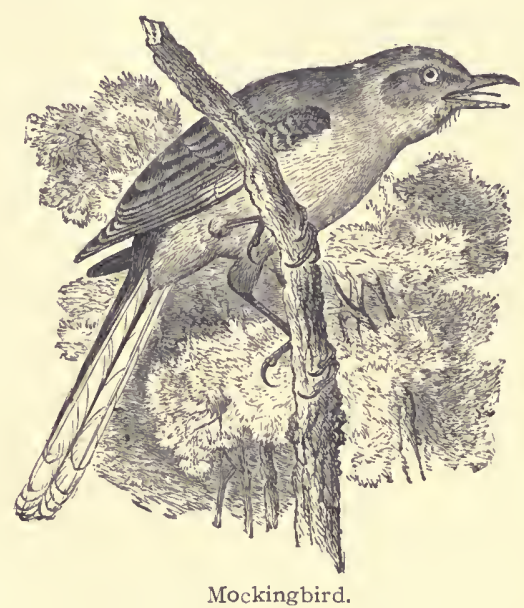

Adult: Upper parts, gray; under parts, white, tinged on breast and sides with pale gray; primary coverts and basal portion of primaries, white, forming a conspicuous white wing patch; middle tail feathers, brownish black; outer tail feathers, mostly white. Sexes similar.

Immature: Upper plumage, grayish brown; under parts, white; breast spotted with dusky; wings and tail as in the adult.

Length, about 9.75 ; wing, 4.45 ; tail, 4.80 ; bill, .65. 
The Mockingbird, so widely celebrated for its vocal accomplishments, is a common summer resident in portions of southern Illinois, but quite rare in northern Illinois and southern Wisconsin, although Mr. E. W. Nelson states: "Dr. Hoy has recorded six nests obtained in the vicinity of Racine, Wisconsin." (Birds of N. E. Ill., I876, p. 94.) Mr. Ridgway found it common in the vicinity of Olney, southern Illinois, and Mr. H. S. Swarth found a pair breeding at Joliet, Will County, Illinois, on May 28, I907, and took the nest and three eggs. It has been observed on several occasions in the parks about Chicago.

Messrs. Kumlien and Hollister consider it a "rare summer visitant" in southern Wisconsin and state: "We have positive records of its nesting on the old Kumlien homestead, in Jefferson County, however, in June, I879, and I880, and of one specimen captured in Milwaukee County in August, I882 (L. K). Hoy reported specimens seen July I6, I85I, between Racine' and Kenosha, and July 26, I846, near the southern state line. Later ( 1885 ), Hoy wrote that mockingbirds nested freely near Racine previous to $185^{6}$, that he obtained three nests and knew of several others that he did not molest, but that none had been seen for fifteen or twenty years. In the Bulletin of the Wisconsin Natural History Society for January, rgoo, Mr. W. J. Bennetts records one seen by himself June 29, I894, near Milwaukee, in the same locality where Mr. John W. Dunlop had reported a pair nesting a few years ago, and also states that Mr. Robert O. Wanvig has a nest and eggs, taken in 1897 , just west of Milwaukee, from a sheltered grove where he has seen the birds for the past few summers." (Birds of Wisconsin, I903, p. I2I.)

The nest is placed in a bush or low tree and is composed of twigs, weed stems, etc. The eggs are 4 or 5 , sometimes 6 , pale bluish white or buffy white, spotted and blotched with brown chiefly at the larger end, and measure about .98 .73 inches.

The Mockingbird, as his name implies, is noted for his power of mimicry and will often imitate the songs of a dozen of our birds in half as many minutes. 
682 Field Museum of Natural History-Zoölogy, Vol. IX.

Genus DUMETELLA S. D. W.

340. Dumetella carolinensis (LinN.).

CATBIRD.

Galeoscoptes carolinensis (Linn.), A. O. U. Check List, r895, p. 292. Distr.: Chiefly eastern United States and British Provinces, north to the Saskatchewan, west to the Rocky Mountains, casual on the Pacific coast; breeds from the Gulf states northward throughout its range; winters in the south Atlantic and Gulf states, the West Indies (to Anguilla) and Central America to Panama.
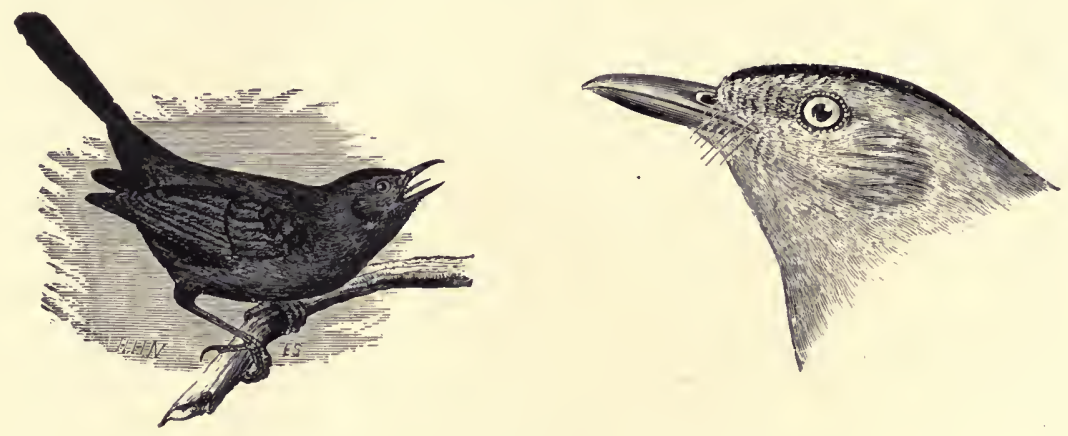

Catbird.

Adult: General plumage, plumbeous slate color; crown and tail, black; under tail coverts, dark chestnut; bill and feet, black. Immature birds have the under tail coverts dull rufous brown. Sexes similar.

Length, 8.50; wing, 3.60 ; tail, 3.65 ; bill, .54.

The Catbird is a very common summer resident in Illinois and Wisconsin. The majority arrive early in May and leave for the south late in September. It is a delightful vocalist and a clever mimic, but its most familiar note is a harsh cry somewhat resembling the "mew" of a cat.

It breeds in May and June. The nest is composed of small twigs, rootlets, and leaves, in a bush, thicket, or low tree. The eggs are 4 or 5 , deep greenish blue, and measure about $.93 \times .68$ inches.

The Field Museum collection contains a series of sets of eggs taken in northern Illinois between May 25 and June $\mathrm{rr}$. 


\section{Genus TOXOSTOMA Wagler.}

341. Toxostoma rufum (Linn.). Brown Thrasher. Brown Thrush.

Harporhynchus rufus (Linn.), A. O. U. Check List, r895, p. 293.

Distr.: Eastern United States, west to the Rocky Mountains, north to southern Maine and the southern British Provinces; breeds from eastern Texas and the Gulf states northward; winters from North Carolina and southeastern Missouri throughout the Gulf states to Texas, accidental in southeastern Arizona.*

Adult: Upper parts, wings and tail, bright rufous brown; wing coverts tipped with white; under parts, white, more or less tinged

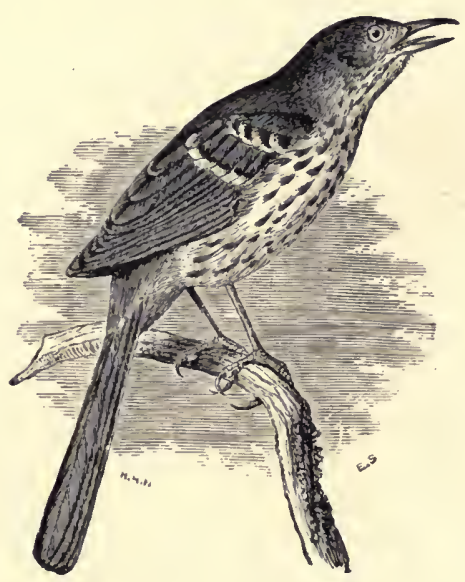

Brown Thrasher.

with pale buff and heavily marked with short streaks or elongated spots of black, except on the throat and belly; under tail coverts, pale buff; primaries and tail, plain, without white. Sexes similar.

Length, about II ; wing, 4 ; tail, 5 ; bill, .92.

The Brown Thrasher is a common summer resident in Illinois and Wisconsin, arriving in April and leaving for the south early in October. It is an accomplished songster, the notes being loud, clear, and continually varied.

It breeds in May and June. The nest, which is comparatively large, is composed of small dried twigs, rootlets, and leaves, usually built in low, thick bushes or on the ground. The eggs are 4 to 6 ,

* Mr. H. S. Swarth informs me he took a male of this species in the Huachuca Mountains, Arizona, in October, 1907. 
684 Field Museum of Natural History-Zoölogy, Vol. IX.

grayish white or buffy white, finely speckled with brown, and measure about $1.06 \times .79$ inches.

The Field Museum collection contains a series of fourteen sets of eggs of this species taken in northern Illinois between May $I 7$ and June $2 \mathrm{I}$.

\section{Family TROGLODYTIDÆ. Wrens.}

The Wrens are a large family numbering upwards of a hundred and fifty species, but only six occur within our limits. Nearly all of them possess more or less vocal ability, some, like the Carolina Wren, being especially gifted. They are thicket loving birds, many of the small species being rarely seen on account of their retiring habits. They are insectivorous and migratory.

\section{Genus THRYOTHORUS Vieill.}

342. Thryothorus ludovicianus (LATH.).

Carolina Wren.

Distr.: Eastern United States, west to the Plains and north to southern Michigan and Nebraska, accidental as far north as Ontario; breeds nearly throughout its range.
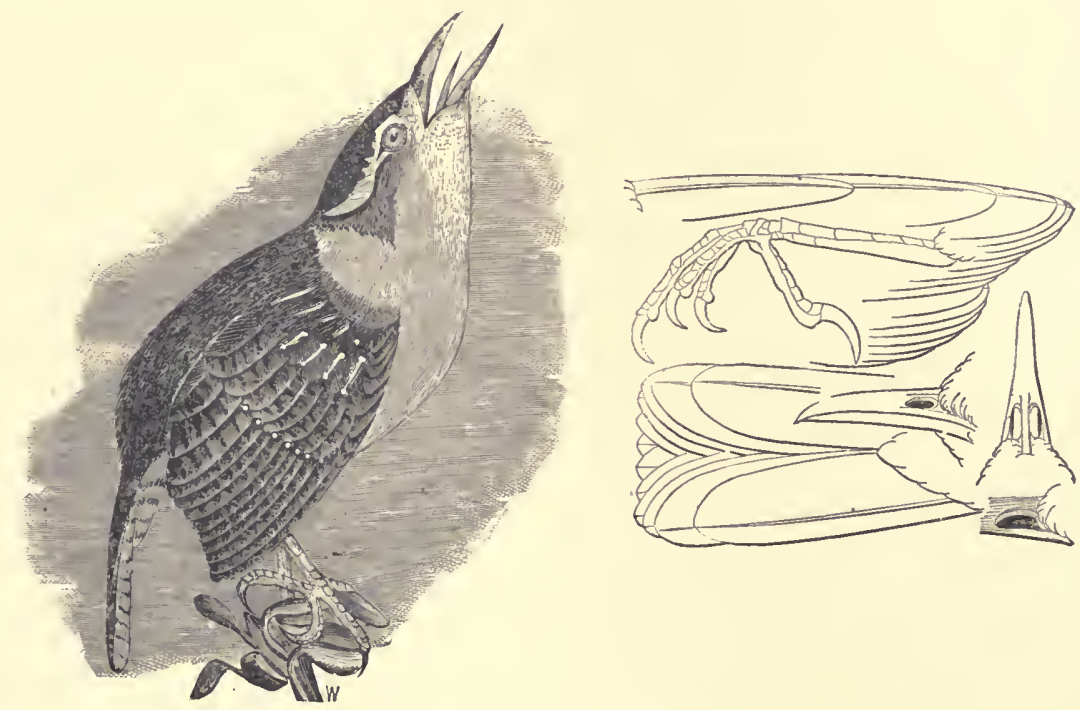

Carolina Wren. 
Adult: Upper parts, rufous brown, the rump with partially concealed white spots; a white superciliary line, bordered above by an indistinct line of blackish (sometimes absent); outer webs of primaries with narrow bars of pale brown; inner webs, grayish brown without bars; exposed feathers on the closed wing with faint, narrow, dusky bars; chin, whitish; rest of under parts, pale tawny buff, varying in intensity, deepest on the flanks; upper surface of tail feathers, rufous brown, narrowly barred with dusky; under tail coverts, barred with blackish. Sexes similar.

Length, 5.30; wing, 2.25; tail, 2.15; bill, .62.

While the Carolina Wren is abundant in southern Illinois, it is uncommon in the northern part of the state and a rare bird in Wisconsin. It is justly noted as a vocalist, but its charming song is too varied to be described.

Mr. Isaac E. Hess informs me it is a not uncommon summer resident, and breeds in the vicinity of Philo, Champaign Co., Illinois. On August I2, I908, Mr. John F. Ferry observed two wrens of this species at Lake Forest, Lake County, Illinois, one of which he shot and which proved to be a female. Mr. H. S. Swarth observed a pair at Joliet, Ill., May II, I907. Mr. F. M. Woodruff says: "Thanks to the protection afforded this bird by Mr. John V. Farwell, Jr., at Lake Forest, Illinois, the species has succeeded in raising several broods in that vicinity." (Birds of the Chicago Area, I907, p. I82.) Mrs. Ellen Drummond Farwell observed two of these birds at Lake Forest, Ill., and has published some interesting notes regarding their habits (The Auk, I902, p. 209).

In Wisconsin Dr. Hoy observed it near Racine. He says: "I met a single wren of this species, July 5, I852." Kumlien and Hollister record a specimen. taken near Janesville, Wis., in 1878 and another at Milwaukee taken in I88I.

The nest is built in holes in stumps or about old buildings. It is a rough affair composed of leaves, feathers, twigs, and coarse grass. The eggs are 4 to 6 , creamy white or pinkish white, speckled and marked with brown chiefly at the larger end, and measure about $.75 \times .58$ inches. 
686 Field Museum of Natural History-Zoölogy, Vol. IX.

Genus THRYOMANES Sclater.

343. Thryomanes bewickii (AUD.).

BEWICK'S WREN.

Thryothorus bewickii (Aud.), A. O. U. Check List, I895, p. 298.

Distr.: Eastern United States, chiefly south of latitude $40^{\circ}$, west to the Plains, casually north to Pennsylvania, southern Ohio, northern Indiana, northern Illinois, and Minnesota.

Adult: Upper parts, dark cinnamon brown; back, without bars; rump with concealed white spots; a whitish or grayish white super-
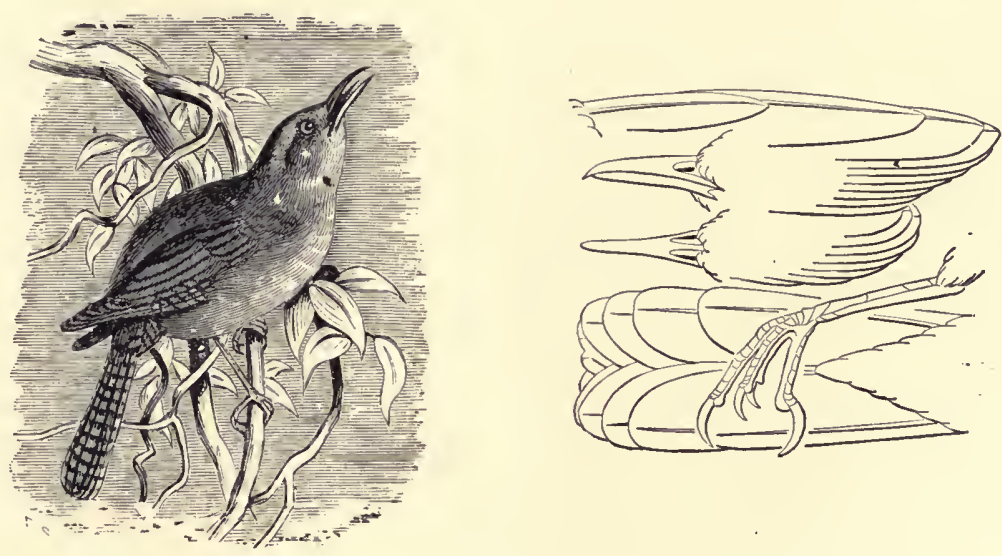

Bewick's Wren.

cilary stripe; outer tail feathers, broadly tipped and marked with grayish white; middle tail feathers, dark brown, with numerous narrow black bars; outer web of first and second primaries, plain, without bars or spots, the others dotted on the edges with pale buff; under parts, grayish white, washed with brown on the flanks. Sexes similar.

Length, 5.I 5 ; wing, 2.I 5 ; tail, 2.I5; bill, .50.

Bewick's Wren is common in southern Illinois, but occurs only as a straggler in the northern portion of the state. Mr. Isaac E. Hess informs me it is rare in the vicinity of Philo, Champaign Co., Illinois, but he has found a pair breeding and took a nest and five eggs on May 27, 1898.

Mr. E. W. Nelson gives it as "A rare summer resident" in northeastern Illinois. He says: "A pair of these birds appeared in a vacant lot in Chicago the first of June, 1876 , and taking possession of a con- 
venient corner in the roof of an arbor proceeded to raise their young. The family suddenly left about the middle of July." (Birds N. E. I11., 1876, p. 96.)

There appears to be no authentic record of its occurrence in Wisconsin.

It breeds commonly in southern Illinois. The nest is in a hole in a stump or crevice in a summer house, arbor, or in a bird box, and is composed of grass, plant stems, etc. The eggs are from 5 to 7 , white or grayish white, finely speckled with rufous brown and lilac-gray, and measure about $.67 \times .5 \mathrm{I}$ inches.

\section{Genus TROGLODYTES Vieill.}

\section{Troglodytes aëdon Vieill.}

House Wren.

Distr.: Eastern United States and southern Canada, west to Kentucky, Indiana, and Illinois; winters in the Gulf states and eastern Mexico.

Adult: Upper parts, dull cinnamon brown, the rump brighter and tinged with rufous brown; back usually with numerous indistinct narrow dark bars; rump with concealed

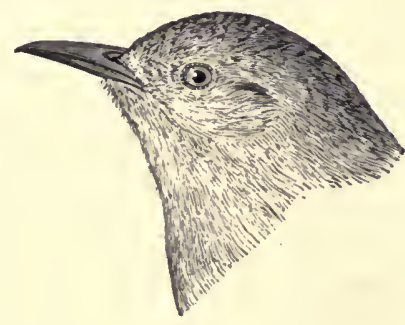
white spots; outer webs of primaries with narrow bars; tail, brown, barred with black (no grayish white patches on tail feathers); under parts, brownish white, brownish on flanks; sides and flanks with numerous narrow dark bars. Sexes similar.

Length, 5.05; wing, 2 ; tail, I.70; bill, .5०.

The House Wren is a not uncommon summer resident in Illinois and Wisconsin and a common migrant in spring and fall. I have examined typical Illinois specimens of this bird. Being retiring in its disposition it is more often heard than seen. It has a charming little song difficult to describe, but usually beginning with several quick, sharp notes followed by a trill.

Messrs. Kumlien and Hollister say: "A common migrant in eastern Wisconsin in almost equal numbers with the next. It breeds sparingly anywhere from the southern border northward. It arrives the last week of April and is common until the middle of May, when all but a few pass northward. It nests late in June in the towns and 
688 Field Museym of Natural History-Zoölogy, Vol. IX.

villages as well as in the more retired woods." (Birds of Wisconsin, T903, p. I 22.)

The nest is in holes in stumps of dead trees or in cavities in old buildings. The eggs are from 5 to 7 , creamy white or pinkish white, finely speckled with rufous brown, with usually a wreath of a darker shade around the larger end, and measure about $.65 \times .50$ inches.

Mr. H. S. Swarth procured a nest and eggs of this species at Joliet, Il1., on June I4, I906.

\section{4a. Troglodytes aëdon parkmanii (AUD.). \\ PARKMAN'S WREN.}

Distr.: Western United States and more southern British Provinces, east to the upper Mississippi Valley, eastern Illinois, and lower Wabash Valley; south in winter to southern Mexico.

Special characters: Differs from the House Wren, T. aëdon, in having the back and rump grayer and barred with dusky.

This form is apparently much more common in Illinois than the preceding species, both as a migrant and summer resident, but Kumlien and Hollister state: "In a series of house wrens from southern and eastern Wisconsin, Mr. William Brewster finds typical examples of both forms, aëdon and aztecus,* the latter slightly predominating in numbers." (Birds of Wisconsin, I903, p. I22.)

The nest and eggs resemble those of the House Wren.

\section{Genus NANNUS Billberg. \\ 345. Nannus hiemalis (Vieill.).}

Winter Wren.

Troglodytes hiemalis Vieill., A. O. U. Check List, I895, p. $30 \mathrm{I}$.

Distr.: Eastern North America, west to the Plains, north to Quebec, Ontario, and Manitoba; breeds from Massachusetts, northern Illinois, and Indiana northward; winters chiefly from Illinois to the Gulf states and Florida.

Adult: Size, small; length rarely over 4.I0 inches, usually less; upper parts, dark cinnamon brown; a narrow buffy stripe over the eye; outer webs of first five or six primaries, blackish, barred with brownish white; rest of primaries and secondaries have outer webs chestnut, barred with blackish; tail, color of rump, all the feathers with narrow black bars; under parts, pale cinnamon brown; sides and

* Now parkmanii. 


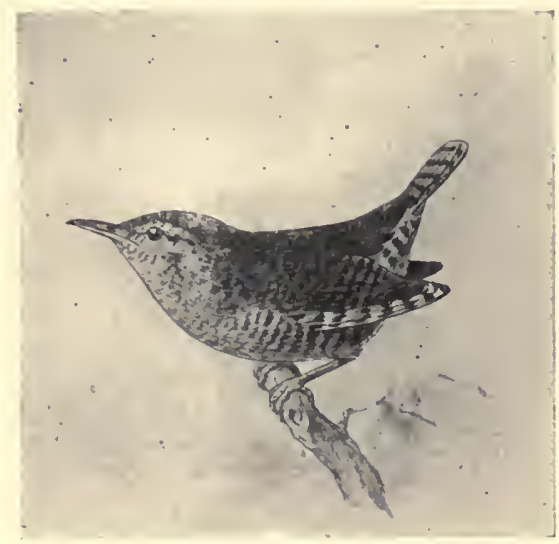

Winter Wren.

belly more or less irregularly barred with black; tail, very short rarely more than $\mathrm{I} .30$ inches long. Sexes similar.

Length, 3.70 to 4.15 ; wing, I.80 to 2 ; tail, I.25; bill, .40.

The Winter Wren is common during the migrations in Illinois and Wisconsin and at least a casual summer resident in the latter state.

Mr. W. W. Cooke states: "Mr. H. A. Kline tells us that it nests in the rubbish along the banks of a stream one mile west of Polo, Illinois." (Bird Migration Mississippi Valley, I888, p. 273.)

In Wisconsin, F. H. King found it common in summer in the northern part of the state (Geol. Wis., 1873-79, p. 491), and Kumlien and Hollister say: "A common migrant throughout the state in early spring and late fall. It unquestionably nests in northern Wisconsin." (Birds of Wisconsin, 1903, p. I 23.)

Mr. John F. Ferry procured a young bird barely able to fly near Woodruff, Vilas County, Wisconsin, on June 24, 1908.

The nest is of plant stems and moss, lined with feathers, under old logs, in crevices, or between roots of trees. The eggs are 5 to 7 , sparingly speckled with rufous brown, and measure about $.68 \times .50$ inches.

\section{Genus CISTOTHORUS Cabanis.}

346. Cistothorus stellaris (Lichit.).

Short-billed Marsh Wren.

Distr.: Eastern United States, north to southern New Hampshire, southern Ontario, Manitoba, and Keewatin, west to Utah; winters in the south Atlantic and Gulf states; breeds chiefly from 
690 Field Museum of Natural History-Zoölogy, Vol. IX.

about the latitude of Ohio northward and occasionally much farther south (Georgia, one record).

Adult: Upper parts, black and tawny brown, streaked with white; crown, streaked; under parts, whitish on throat and belly, washed with tawny brown on breast, sides, and

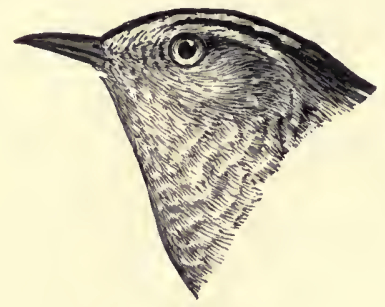
under tail coverts; rump and upper tail coverts barred with black; primaries, dark slaty brown, the outer webs irregularly marked with pale brown; tail, plain brown, banded with black. Sexes similar.

Length, 4.20; wing, I.80; tail, I.50; bill, . 36 .

A common summer resident in suitable localities in Illinois and Wisconsin. The majority arrive early in May and leave for the south in October. Breeds during the latter part of May and June.

The nest is globe shaped, composed of woven grasses, with the entrance on the side, usually attached to reeds in a marsh, but occasionally in a tussock of grass on or near the ground. The eggs are 6 to 8 , pure white, usually unmarked, but occasionally with a few small lilac spots, and measure about $.66 \times .47$ inches.

\section{Genus TELMATODYTES Cabanis:}

\section{Telmatodytes palustris (WILs.).}

Long-billed Marsh Wren.

Cistothorus palustris (Wils.), A. O. U. Check List, I895, p. 302.

Distr.: Northeastern United States, north to New Brunswick, south to South Carolina and casually to western Florida, west to Indiana and Illinois; breeds from about the latitude of Virginia northward.

Adult: Crown, blackish on the sides, usually tinged with brownish in the centre, no streaks on crown; back (interscapular region), black, streaked with white; rump and upper tail coverts, plain cinnamon brown (without black bars); under parts, white or whitish on throat, middle breast and belly; sides tinged with pale cinnamon brown, darkest on the flanks; tail barred with black and tawny brown; edges of outer webs of wing feathers marked with pale tawny brown, giving a barred appearance to the closed wing. Sexes similar.

Length, 5.I 5 ; wing, I.90; tail, I.80; bill, .50. 


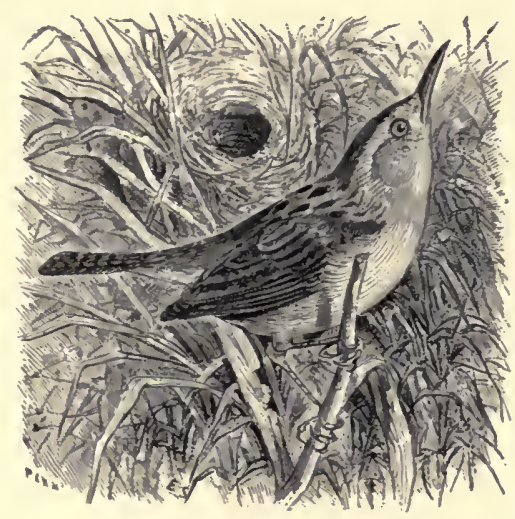

Long-billed Marsh Wren.

The Long-billed Marsh Wren is a common summer resident in suitable marshes, at least in eastern Illinois. I have not seen specimens from the western part of the state and it is probable that in prairie districts it is replaced by $T$. p. iliacus, which also occurs in eastern Illinois. The species is represented in the collection of the Field Museum of Natural History by the following specimens "from eastern Illinois and Indiana:

No. 24451, ㅇ, May 23, 1907, Lake Forest, Ill.

No. I $5446,3^{7}$, June I 4 , I 904 , Chicago, Ill.

No. ${ }_{5447}$, $0^{7}$, June I 4 , I904, Chicago, Ill.

No. I 5448, O7, June I4, I904, Chicago, Ill.

No. 2 I 735 , ठํ, Sept. 10, I906, Beach, Lake Co., Ill.

No. 13732 , ㅇ, Oct. 1o, 1902, Chicago, Ill.

No. 6630, ㅇ, Aug. 9, I896, Chicago, Ill.

No. $6629,0^{7}$, Aug. 2, 1896, Chicago, Ill.

No. $2445^{2}, \sigma^{7}$, June 28 , 1907 , English Lake, Ind.

In Wisconsin, according to Kumlien and Hollister, it is "an abundant summer resident over nearly the entire state, breeding in great numbers about all suitable marshes." (Birds of Wisconsin, I903, p. I 23.)

Breeds in May and June. The nest is attached to reeds in marshes. It is globe shaped with the entrance on the side, and is composed of grasses. The eggs are from 5 to 9 , finely speckled all over with cinnamon brown, and measure about $.65 \times .50$ inches.

The Long-billed Marsh Wren has a pleasant little song, somewhat resembling that of the House Wren, but more broken and not so loud. 
692 Field Museum of Natural History-Zoölogy, Vol. IX.

\section{7a. Telmatodytes palustris iliacus (RIDGWAY). Prairie Long-billed Marsh Wren.}

Distr.: Prairie districts of central United States, east to Illinois and western Indiana and north to the British Provinces; winters chiefly in the Gulf states and Mexico; breeds throughout its summer range.

The Prairie Long-billed Marsh Wren differs from the eastern form in being generally slightly larger, and having the upper parts more russet brown and the flanks clear cinnamon buff, approaching a russet tint more than in $T$. palustris.

The nest and eggs are similar to those of $T$. palustris. By courtesy of the authorities of the United States National Museum, I have been able to examine the type of $T$. p. iliacus * and compare it with specimens in the Field Museum collection. The result shows that both $T$. palustris and T. p. iliacus occur in Illinois. Specimens in the collections of the Field Museum of Natural History from Illinois and Indiana are as follows:

No. 5I50, ㅇ, May 24, r890, Ravinia, Ill.

No. 5I 5 I, ठ․ May 29, r894, Englewood, Ill.

No. 54I5, ठ, May 3 I, I885, Davis, Stark Co., Ind.

No. 30408, $0^{7}$, June 7, 1905, Fox Lake, Ill.

No. 30409, $0^{7}$, June 7, 1905, Fox Lake, Ill.

I have not seen specimens from Wisconsin, but it no doubt occurs there, especially in the western portion of the state.

*U. S. Nat. Mus.. No. 9oI99. Talmatodytes palustris iliacus (type) $\widehat{\odot}$ ad. Wheatland, Indiana, April 30, I 883 . 


\section{Family CERTHIIDÆ. Creepers.}

The Certhiidæ comprise a small group of a dozen species; only one of which (with its various subspecies) occurs in North America. It is an active, graceful little bird, climbing about the trunks of trees and using its stiff tail feathers much after the manner of a woodpecker. It feeds on insects and larvæ, and builds its nest in holes in trees.

\section{Genus CERTHIA Linn.}

\section{Certhia familiaris americana (BONAP.).}

Browy CreEper.

Distr.: Eastern North America, west to the Plains and north to Newfoundland, Ontario, and Manitoba, and probably much farther north, breeding from the mountains of western North Carolina, Missouri, northern Indiana, and Nebraska northward; south in winter to south Atlantic and Gulf states, except southern Florida.

Adult: Tail feathers, stiff and pointed; upper parts, dark brown, thickly streaked with dull white; rump, rusty brown; a conspicuous
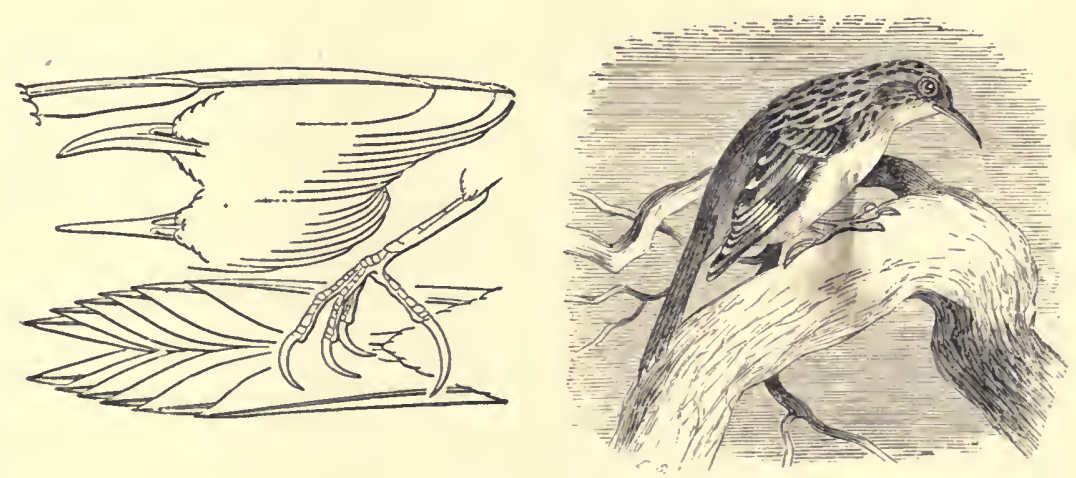

Brown Creeper.

tawny white bar on the middle of primaries (except the first three); under parts, dull white or ashy white, usually faintly tinged with brownish on flanks and under tail coverts. Sexes similar.

Length, 5.50; wing, 2.50; tail, 2.70; bill, . 56 .

The Brown Creeper is a common migrant and more or less common 
694 Field Museum of Natural History-Zoölogy, Vol. IX.

winter resident in Illinois and southern Wisconsin and a regular summer resident in northern Wisconsin.

There is a record of a pair breeding on an island in the Mississippi River a few miles below Davenport, Iowa (Wilson, Wilson Bull., I go6, p. Io), and Mr. John F. Ferry observed a bird of this species at Olive Branch; Alexander County, Illinois, August ro, I907.

Mr. A. W. Butler records two sets of eggs taken in Steuben County, northern Indiana, by Mr. R. W. McBride (Birds of Indiana, r897, p. II 29).

Dr. Hoy gives it as common throughout the year in Wisconsin. Mr. John F. Ferry found a brood of four partly grown birds near Woodruff, Vilas County, June 27, r908. Messrs. Kumlien and Hollister give it as a summer resident in northern Wisconsin and say: "J. N. Clark observed a pair of creepers feeding a young cowbird just from the nest at Meridian in late June, I897." (Birds of Wisconsin, r 903 , p. 124 .)

The nest is of feathers, moss, and plant down, in a crevice usually behind loose bark on a dead tree in woods. The eggs are 6 to 9 , white, speckled and spotted chiefly at the larger end with brown, and measure about $.60 \times .47$ inches.

\section{Family SITTIDÆ. Nuthatches.}

There are about 20 known species belonging to this family, but. only three are found in eastern North America. They are wood birds and may be seen climbing about the trunks of trees, much in the manner of a woodpecker or the little Brown Creeper, but unlike either of them, it climbs equally well down the trunk as up while searching for its food, neither does it use its tail for support like the others. The food consists of insects, larvæ, and nuts, chiefly beech nuts. The nests are built in holes in trees.

\section{Genus SITTA Linnæus.}

\section{Sitta carolinensis LATH.}

White-breasted Nuthatch.

Distr.: Eastern North America, west to the Plains, and from the Gulf coast north to Labrador, northern Quebec, and Keewatin; breeds nearly throughout its range. 
Adult male: Top of head and upper back, glossy black; rest of upper parts, bluish gray; sides of head and under parts, white, more

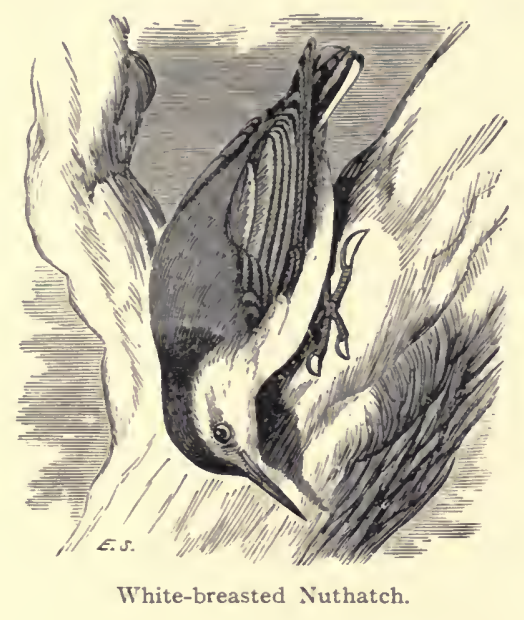

or less marked on flanks and crissum with rusty brown; wings, blackish, the inner feathers edged with gray; middle tail feathers, gray; outer feathers with broad subterminal band of white, the tips, black.

Adult female: Similar, but black of head tinged with bluish gray.

Length, 5.80; wing, 3.50; tail, r.90; bill, .70.

A not uncommon resident in Illinois and Wisconsin and abundant . in spring and fall during the migrations. The note of the Whitebreasted Nuthatch is a strange quenk, quenk, difficult to describe, but which once heard will not easily be forgotten.

The nest is in a hole in a dead stump or tree. The eggs are from 6 to 8 , pure white or creamy white, speckled with rufous brown, and measure about $.73 \times .56$ inches. Mr. H. S. Swarth procured a set of six eggs at Joliet, Ill., May 2 r, 1907.

\section{Sitta canadensis (LINN.). \\ Red-breasted Nuthatch.}

Distr.: Nearly the whole of North America; breeding from northern Indiana, northern Illinois, California, and the mountainous regions of North Carolina and Colorado northward to Labrador, Keewatin, and southern Alaska; winters in the United States.

Adult male: Top of head, black; a black stripe through the eye, extending to sides of neck: a white stripe over the eye; rest of upper 
plumage, bluish gray; throat, white or whitish; rest of under parts, pale rusty brown, deepest on the sides and lower belly; under tail

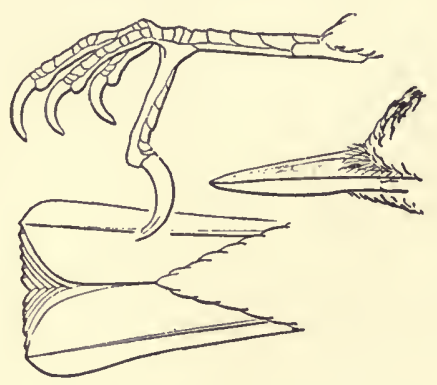
coverts, rusty brown, with pale tips; primaries, dark grayish brown or fuscous; middle tail feathers like back; outer feathers, black, with subterminal white band, the tips, black.

Adult female: Similar, but without black crown; the stripe through the eye dull blackish, not clear black as in the male.

Length, 4.60; wing, 2.60; tail, I.50; bill, .50.

The Red-breasted Nuthatch is a casual summer resident in Wisconsin and has been known to nest in northern Illinois. It is, however, abundant in spring and fall during the migrations in both states and a few remain during the winter. Its note somewhat resembles that of the White-breasted Nuthatch but is much higher and is repeated more hurriedly.

Mr. E. W. Nelson says: "A rare summer resident. I found a pair near Chicago with full grown young the first of July, and Mr. Rice observed a pair feeding unfledged young the last of April, I8.74, near Evanston. The excavation containing the nest was in a tree standing on one of the principal streets of the town." (Birds N. E. Ill., I 876 , p. 96.)

Dr. Hoy writes: "A few nest near Racine and a greater number in the pine regions in the northern part of the state." (Wisconsin.) Kumlien and Hollister say: "A regular spring and fall migrant, but not so common as the white-breast. Mr. Clark has found it in winter in Dunn County, and it occurs as late sometimes as November in Walworth, Jefferson, and Rock Counties, though usually found in April and September. It was found nesting at Pine Lake, near Hartland, July, I888. The nest was about Io feet above the ground in a pine stub, and contained young (L. K.)." (Birds of Wisconsin, I 903 , p. I 24.)

The nest is in a hole in a tree or stump. The eggs are 5 or 6 , white, speckled with brown and purplish gray, and measure about $.6 \mathrm{I} \times .48$ inches.

The Brown-headed Nuthatch, Sitta pusilla Lath., probably occurs as a straggler in southern Illinois. Mr. Otto Widmann observed a specimen within the St. Louis city limits, May 6, I878 (Bull. Nutt. Orn. Club, Vol. V I880, p. I9I); and Mr. J. M. Wheaton states a 
specimen was taken by Dr. H. A. Atkins, near Locke, Ingham County, Michigan, in 1877 . (Geol. Survey of Ohio, Vol. IV, I882, p. 226.)

\section{Family PARIDÆ. Titmice and Chickadees.}

The family Paridæ contains about 75 species, four of which are found in eastern North America. The Chickadees are hardy little birds, migrating only in a moderate degree and enlivening the snow covered silent woods with their peculiar cheery little song. They lay their eggs in holes in trees and stumps, lining the nest with moss, leaves, and feathers.

\section{Genus BÆOLOPHUS Caban.}

\section{I. Bæolophus bicolor (LinN.).}

Tufted Titmouse.

Parus bicolor Linn., A. O. U. Check List, I895, p. 306.

Distr.: Eastern United States, west to the Great Plains and from the Gulf coast regularly north to Ohio, southern Illinois, and Nebraska; casual or accidental to southern Minnesota, southern Wisconsin, and southern New York; breeds nearly throughout its range.

Adult: Crown with crest; forehead, black; rest of upper parts, wings and tail, gray, usually with a faint tinge of olive on the back; under parts, whitish or ashy white,

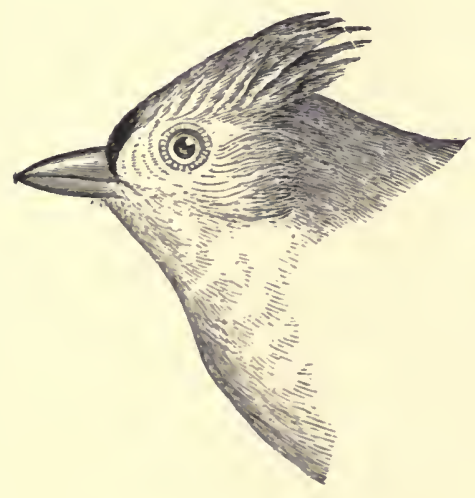
tinged with chestnut brown on the sides and flanks. Sexes similar.

Length, 6.10; wing, 3.10; tail, $2.65 ;$ bill, .40.

The Tufted Titmouse is an abundant resident in southern Illinois, but rather rare in the northern portion of the state. There is a single record of its occurrence in Wisconsin.

Mr. F. M. Woodruff writes: "Mr. J. Grafton Parker, Jr., observed one of these birds at South Chicago on October I5, I 897 , and it is not uncommon during the fall and winter months at Kouts, Indiana, sixty miles southeast of Chicago. Mr. O. MI. Schantz informs me that 
698 Field Museum of Natural History-Zoölogy, Vol. IX.

early in the spring of 1900 , before the trees were in leaf, he saw a large flock of Tufted Titmice in the woods west of Riverside, Illinois." (Birds of the Chicago Area, I907, p. I88.)

There are specimens in the Field Museum collection from the northern half of the state, taken at Henry and Warsaw.

Messrs. Kumlien and Hollister state: "In the Museum of the University of Wisconsin, there is a single specimen of the tufted tit, shot by Mr. N. C. Gilbert, December I 5, I 900 , near Madison. The bird was alone, and this is doubtless the only record for the state." (Birds of Wisconsin, 1903, p. I24.)

The nest is in a hole in a dead tree. The eggs are 5 to 8 in number, pure white or creamy white, speckled with reddish brown, and measure about $.70 \times .55$ inches.

\section{Genus PENTHESTES Reichenbach.}

352. Penthestes atricapillus (Linn.).

ChickadeE.

Parus atricapillus Linn., A. O. U. Check List, I895, p. 307.

Distr.: Eastern United States and British Provinces, north to southern Labrador and southern Keewatin; breeds from Pennsylvania and northern Illinois northward; south in winter to Kentucky, Missouri, and Kansas; also occurs west of the Rocky Mountains in British Columbia, Washington, and Idaho, but not in the intermediate country west of Dakota.

Adult: Crown, nape; and throat, black; sides of head from base of bill, white; back, ashy, with an olive tinge; breast and middle belly, white; sides and lower belly, tinged with pale tawny brown; wings and tail, dark slaty brown, most of the feathers edged with white; greater wing coverts edged with white. Sexes similar.

Length, 5.I5; wing, 2.50; tail, 2.45; bill, .32.

The Chickadee is a common resident in northern Illinois and Wisconsin and a winter visitant in southern Illinois. In addition to the familiar chick-a-dee-dee-dee, from which it has derived its name, the Chickadee has a delightful little pee-wee whistle of two high notes which may be suggested by playing $\mathrm{E} \mathrm{C}$ of the scale softly on the flute.

Breeds in April and May. The nest is in a hole in a dead stump or tree and is composed of moss, feathers, fine grass, plant fiber, etc. The eggs are usually from 6 to 8 in number, pure white, spotted and speckled chiefly at the larger end with shades of brown, and measure about $.60 \times .47$ inches. 


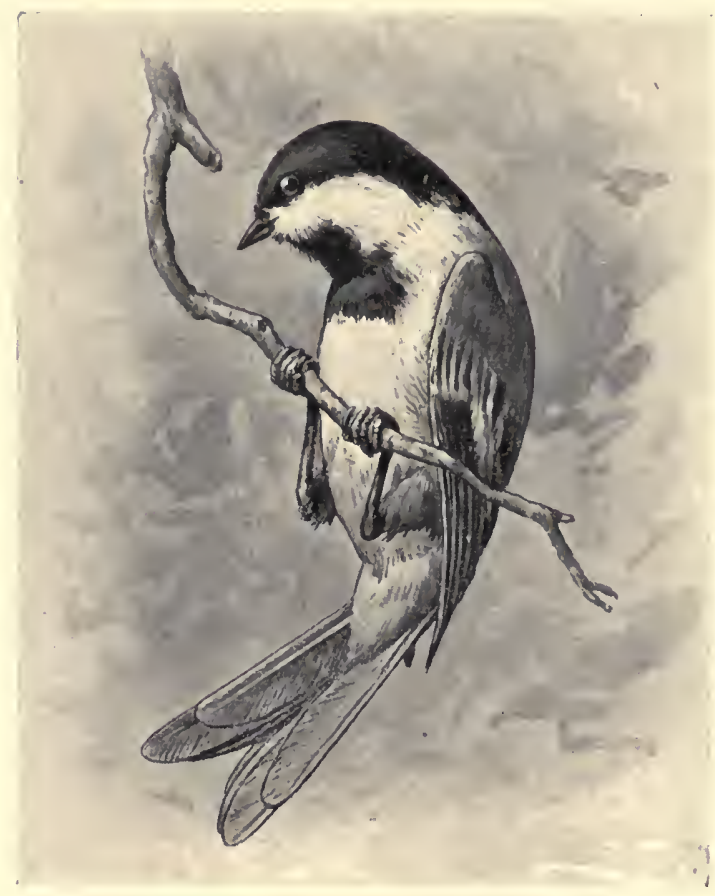

Chickadee.

352a. Penthestes atricapillus septentrionalis (HARRIS).

Long-Tailed Chickadee.

Distr.: Central North America, from the Rocky Mountains and Salt Lake Valley east to Minnesota, Wisconsin, and Iowa, south to Kansas and New Mexico, breeding northward to the Mackenzie region and Alaska (Kenai Peninsula).

Special characters: Resembles $P$. atricapillus, but tail longer than wing (in $P$. atricapillus the wing and tail are about equal in length); tail feathers usually margined with white; the greater wing coverts and tertials broadly edged with white.

While the Long-tailed Chickadee has been taken in Iowa and Wisconsin, it does not appear to have been observed in Illinois and should be looked for in the northwestern part of the state.

Messrs. Kumlien and Hollister say: "In late fall and winter typical specimens of this form are taken in Wisconsin, even in the southern part of the state, but more often in the northwestern portion. A number were taken near Hudson in November. We are unable to say whether they are resident in that district, or merely winter visitors." (Birds of Wisconsin, Ig०3, p. I 24.) 
700 Field Museum of Natural History-Zoölogy, Vol. IX.

\section{Penthestes carolinensis (AUD.). \\ Carolina Chickadee.}

Parus carolinensis Aud., A. O. U. Check List, I895. p. 308.

Distr.: Eastern United States, from the south Atlantic and Gulf states north to Ohio, Indiana, and Illinois; west to Louisiana and eastern Missouri; breeds nearly throughout its range.

Adult: Similar to P. atricapillus, but averaging smaller and the tail shorter; the greater wing coverts not margined witl white; primaries, wings, and tail very slightly edged with white, sometimes entirely absent on tail feathers. Sexes similar.

Length, 4.10 to 4.70 ; wing, 2.20 to 2.55 ; tail, 2.25 ; bill, .32.

The Carolina Chickadee is a common resident in southern Illinois, but rare in the northern portion of the state, the only record being that given by Mr. Nelson who gives it as "a rare summer visitant to the 'Pinery' at the southern end of Lake Michigan." It has not been recorded from Wisconsin. The notes resemble those of $P$. atricapullus but are louder and rather more hurried.

The nest is in a hole in a tree or stump. The eggs are 6 to 8 in number, pure white, spotted and speckled with brown chiefly at the larger end, and measure about $.57 \times .45$ inches.

\section{Penthestes hudsonicus (Forst.). Hudsonian Chickadee.}

Parus hudsonicus Forst., A. O. U. Check List, i 895, p. 309.

Distr.: Northern North America, north to Ungava and Alaska; breeds north of the United States; casually south in winter to northern Michigan, Wisconsin, and northern Illinois (replaced on the Atlantic coast by $P$. h. littoralis Chapman).

Adult: Crown and back, hair-brown or dull grayish brown; sides of head, white; throat, dull black; breast and middle of belly, whitish; sides, flanks, and under tail coverts, chestnut brown; tail, brownish slate-color. Sexes similar.

Length, 5.20; wing, 2.50; tail, 2.50; bill, .32.

The Hudsonian Chickadee is a rare winter visitant in northern Illinois and Wisconsin. Mr. E. W. Nelson gives it as: "A very rare winter visitant" in northeastern Illinois and states that Dr. Velie observed them at Rock Island (Birds N. E. Illinois, I876, p. 95).

Mr. John F. Ferry shot a female bird of this species at Beach, Lake County, I1l., Nov. 5, 1906, and observed another on November 10, I 906, near Lake Forest, I11.; and on Nov. 8, ı 906, Mr. F. M. Woodruff secured two specimens, both females, near Waukegan, Illinois. 
In Wisconsin but few specimens have been taken, although we should expect to find it in winter, especially in the northern portion of the state.

Mrs. Irene G. Wheelock informs me that she observed a bird of this species at Lake Geneva, Wisconsin, on September r 2, I 906.

Dr. Hoy writes: "A small party of this northern species visited Racine during the unusually cold January of $185_{2}$."

Kumlien and Hollister quote Dr. Hoy's record and say: "A single specimen was taken by Thure Kumlien in Jefferson County at this same time. It is recorded from the northern peninsula of Michigan (Nehrling) and Dr. H. V. Ogden of Milwaukee writes us that he saw several, and shot one in Iron County, but unfortunately did not preserve a skin. He also writes: 'I fancy a few could be found every fall in the northern tier of counties.' A single individual was noted in Vilas County, at close range, while waiting on a deer runway, in November, I902, but could not be collected as we were armed only with rifles at the time (N. H.)." (Birds of Wisconsin, I903, p. I25.) 
702 Field Museum of Natural History-Zoölogy, Vol. IX.

\section{Family SYLVIIDÆ. Kinglets, Gnatcatchers, Old World Warblers, etc.}

The members of this family are among the smallest of our birds. They are more or less migratory, although some, like the kinglets, do not object to cold weather and may often be seen in the snow covered woods, especially in early winter. The Gnatcatcher, on the contrary, prefers a warmer climate and spends the winter from Florida southward. The nests are built in the branches of trees, usually some distance from the ground.

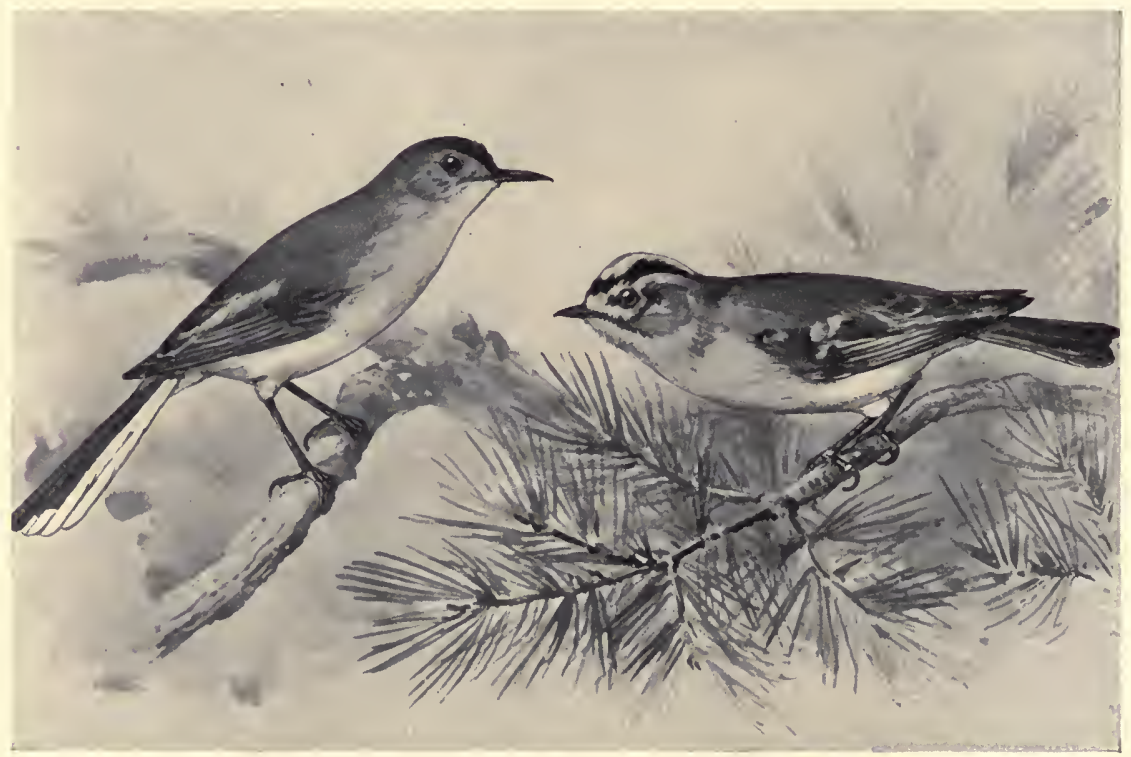

Gnatcatcher.

Kinglet.

Subfamily REGULIN㾁. Kinglets.

Genus REGULUS Cuvier.

355. Regulus satrapa (Licht.).

Golden-crowned Kinglet.

Distr.: North America east of the Rocky Mountains; breeds from New York and northern Michigan northward to Labrador and Keewatin, ranging in winter as far south as Texas and the Gulf states to northern Florida. 
Adult male: A patch of golden orange on middle crown, bordered by yellow; sides of crown, black; an ashy white streak over the eye

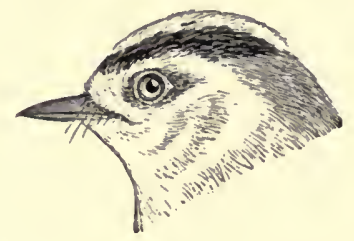
and across front of forehead; a dusky loral streak; upper parts, grayish olive, shading to olive green on the rump; under parts, whitish or buffy white; outer webs of wing feathers edged with pale greenish yellow, broken in the middle by a blackish space, forming a dusky bar on the closed wing; greater and middle wing coverts tipped with yellowish white or whitish; tail, dark slaty brown, narrowly edged with olive green.

Adult female: Similar, but crown patch bright canary yellow (without orange) bordered by black.

Length, about 4; wing, 2.I 2 ; tail, I.70; bill, .26.

This pretty little species is a common migrant in Illinois and Wisconsin in spring and fall, and a more or less common winter resident in Illinois and southern Wisconsin. According to Mr. Kline a few remain all summer in the thick swamps near Polo, Ill., but he has never succeeded in finding their nests (Cooke, Bird Migration Mississippi Valley, I888, p. 279).

Messrs. Kumlien and Hollister state: "Dr. Ogden states that it is sometimes found in mid-winter in Milwaukee County, and the same is true of other sections of the state. The golden-crown breeds along the south shore of Lake Superior, in Ontonagon County, Michigan, and possibly to some extent, therefore, in the pine regions of northern Wisconsin." (Birds of Wisconsin, I903, p. I25.)

While with us it rarely attempts anything more ambitious in the way of a song than a soft, lisping tsee, tsee, tsee.

\section{Regulus calendula (Linn.).}

Ruby-Crowned Kinglet.

Distr.: North America, north to Labrador, the Mackenzie region, and Alaska; winters in the United States, Mexico, and Central America to Guatemala; breeds from Quebec, northern Michigan, and mountains in New Mexico northward.

Adult male: A patch of fiery red on the crown; rest of upper parts, grayish olive, shading to clear olive green on the rump; wing and tail, dusky, edged more or less with yellowish olive; a dusky bar on the closed wing, as in the preceding species; wing coverts tipped with whitish; under parts, ashy white or whitish, more or less tinged with pale olive buff. 
704 Field Museum of Natural History-Zoölogy, Vol. IX.

Adult female: Similar to the male, but top of head like back, without red crown patch.

Length, 4.25; wing, 2.20; tail, I.72; bill, .28.

The Ruby-crowned Kinglet occurs as an abundant migrant in Illinois and Wisconsin in spring and fall, the majority of them being with us in April and October. It has a delightful song, much louder than would be expected from such a little bird. It usually begins with a variety of light whistles followed by a short, sweet warble. Most of them are gone by the first of November, although a few remain much later.

\section{Subfamily POLIOPTILINÆ. Gnatcatchers.}

\section{Genus POLIOPTILA Sclater.}

357. Polioptila cærulea (LinN.).

Blue-gray Gnatcatcher.

Distr.: Eastern United States, west to Nebraska and north to southern Ontario, Michigan, northern Illinois, and southern Wisconsin, breeding from Florida and the Gulf states northward nearly throughout its range; winters in the Gulf states, Florida, the Bahama Islands, Cuba, and the Cayman Islands, and in Middle America to Guatemala.

Adult male: Upper parts, bluish gray; front of forehead, black;

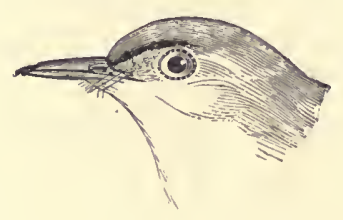
a narrow black line extends backward, bordering the forehead to above the eye; wings, dark slaty brown or fuscous, the secondaries bordered with whitish; tail feathers, black, the two outer feathers entirely white except at the bases, the third feather tipped with

white; under parts, white, usually faintly washed with pale plumbeous on breast and sides.

Adult female: Similar, but grayer above, and without black on head.

Length, 4.40; wing, 2 to 2.15 ; tail, 2.05 ; bill, .40.

The Blue-gray Gnatcatcher is a not uncommon summer resident in Illinois and southern Wisconsin. Butler states on the authority of $\mathrm{Mr}$. Eliot Blackwelder that it breeds in Cook $\mathrm{Co}_{;}$, Illinois (Birds of Indiana, I897, p. II45). Woodruff on the authority of Mr. B. T. Gault records it as breeding in Addison Woods, DuPage Co., Illinois (Birds Chicago Area, I907, p. I9I). 
In southern Wisconsin, Messrs. Kumlien and Hollister consider it a fairly common summer resident. They say: "It arrives early in the spring, in small flocks of half a dozen or more, sometimes by the last week of April. Dr. Ogden has found it breeding in Milwaukee County, and at both Delavan and Milton it nests in reasonable numbers every year. Nest building usually begins by May 20 and by June I incubation has commenced. The young are still in the nest up to June 15 or 20 , and the families remain together the entire summer. Mr. Clark has never taken this species in Dunn County during a great many years of active collecting and observation. It is doubtful if it is common north of the southern tier of counties, except along Lake Michigan, where it is found in fair numbers as far north as Two Rivers." (Birds of Wisconsin, 1903, p. I 25.)

The nest is on a branch of a tree, usually 25 feet or more from the ground and is composed of grass, plant fiber, lichens, etc. The eggs are 4 or 5 , bluish white, thickly spotted and speckled with shades of brown, and measure abont $.55 \times .45$ inches.

\section{Family TURDIDÆ. Thrushes, Bluebirds, Solitaires, etc.}

The family Turdidæ contains about ${ }_{5} 50$ species, a dozen of which (including races) occur in eastern North America. They are migratory and at times gather in flocks, especially in the south and during migrations. Their food consists of insects, berries, and fruit. The location and style of nest varies with different species. They are all good songsters, especially the Wood Thrush, whose notes are particularly sweet and melodious.

\section{Subfamily MYADESTINÆE. Solitaires.}

Genus MYADESTES Swainson.

358. Myadestes townsendii (AUD.).

Townsend's Solitaire.

Distr.: Western United States, from the Great Plains to the Pacific coast and from British Columbia to Lower California; breeds from the mountains of Arizona and New Mexico northward; accidental in Illinois. 
706 Field Museum of Natural History-Zoölogy, Vol. IX.

Special characters: General plumage, uniform brownish gray, paler on throat; a distinct white ring around the eye; tip and outer web of tail feathers, ashy gray.

Length, about 8 inches; wing, 4.40 to 4.80 ; tail, 4.20 to 4.70 .

The only record of the occurrence of this species within our limits is that given by Mr. E. W. Nelson, who states: "A single specimen of this species was obtained Dec. r6, r875, by Mr. Chas. Douglas at Waukegan. The bird was found in a sheltered ravine, extending a short distance into the bluff, bordering the lake shore near the above named place and showed no alarm when approached. Nothing peculiar was observed concerning its habits, except that its movements were very sprightly." (Birds N. E. Ill., I876, p. 94.)

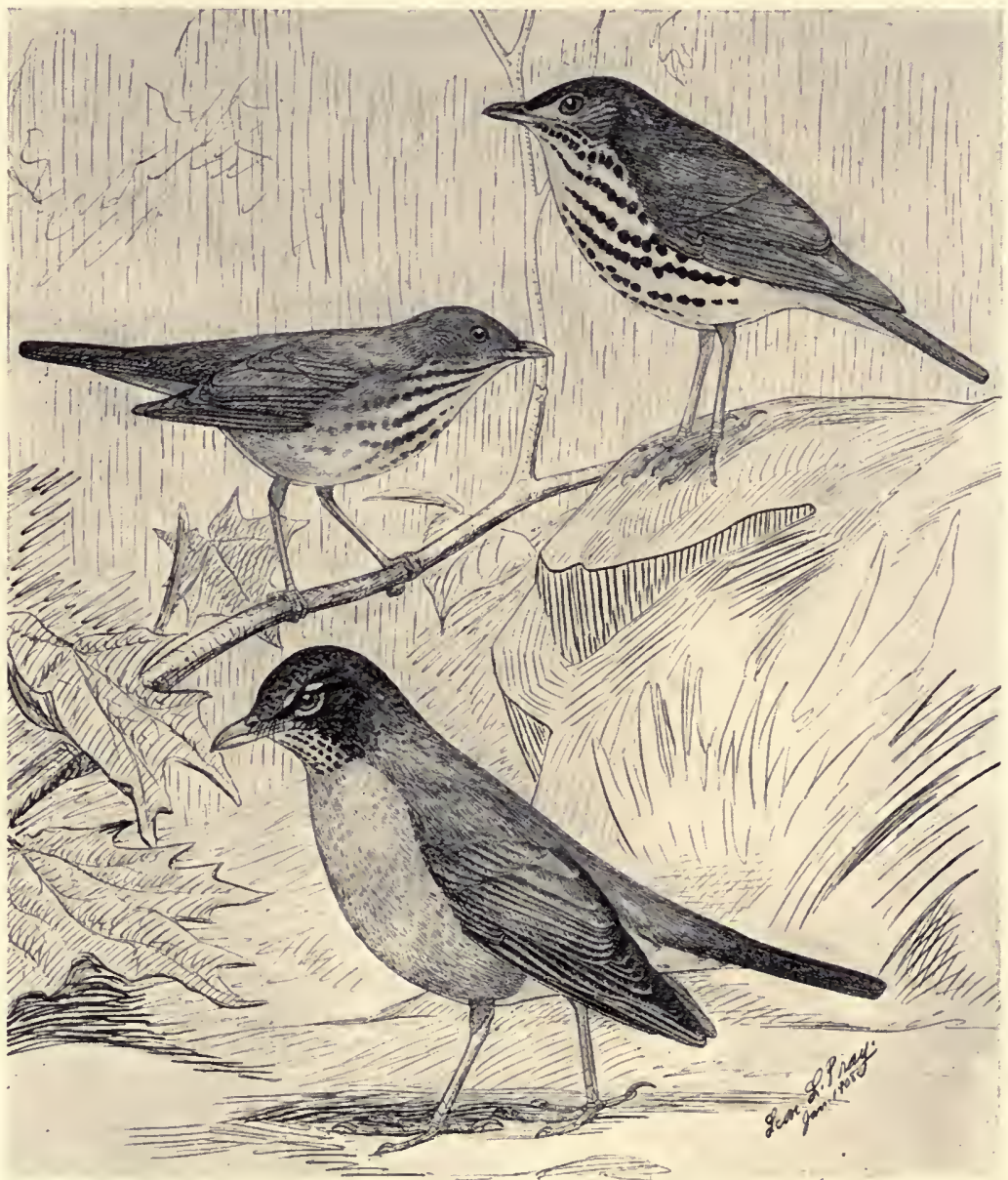




\section{Subfamily TURDINÆE. Thrushes.}

\section{Genus HYLOCICHLA Baird.}

359. Hylocichla mustelina (GMEL.).

WOOD THRUSH.

Turdus mustelinus Gmel., A. O. U. Check List, I895, p. 3 I6.

Distr.: Eastern temperate North America, west to the Great Plains and north to Ontario, Michigan, and Wisconsin; south in winter to Cuba and in Middle America to Guatemala; breeds from northern Florida and the Gulf states northward.

Adult: Top of head, bright tawny cinnamon brown, shading to olive brown on the back and brownish olive on the rump and tail;

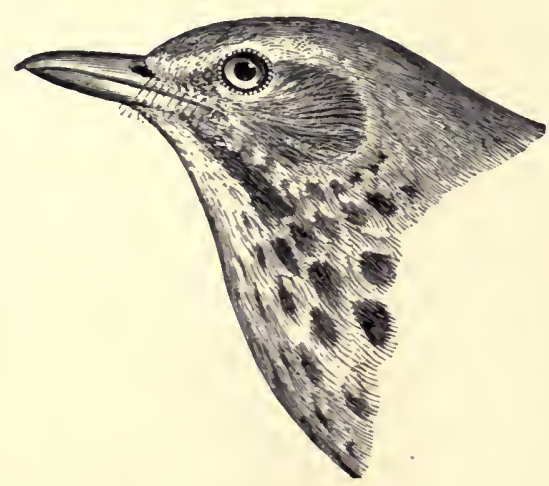
under parts, white, faintly tinged with buff on the breast, and everywhere except on upper throat; middle of belly and under tail coverts marked with large blackish spots (the conspicuous spots on the sides of the body being a good distinguishing character); a distinct white eye ring; auricular region streaked with white and dusky. Sexes similar.

Length, about 7.75; wing, 4.25; tail, 3 ; bill, .64.

The Wood Thrush is a summer resident in Illinois and the greater part of Wisconsin from May until the latter part of September. It is a delightful songster, probably the best of this group of celebrated avian vocalists. It is useless to attempt to describe the song; no adequate idea of it can be conveyed in print, as combined with its peculiar swgetness the peace of the woodland solitude adds 8 its charm and it must be heard to be appreciated.

Breeds in May and June. The nest is in woods, built on the branch of a low tree, rarely more than ro feet from the ground and is made of leaves, small twigs, and mud. The eggs are 3 to 5, plain blue, similar in color to those of the Robin, but slightly lighter. They measure about $1.05 \times .73$ inches.

The Field Museum collection contains a series of sets of eggs of this species taken in northern Illinois between May 26 and June 19. 
708 Field Museum of Natural History-Zoölogy, Vol. IX.

360. Hylocichla fuscescens (STEPH.).

Wilson's Thrush.

Turdus fuscescens Steph., A. O. U. Check List, I895, p. 3 I 7 .

Distr.: Eastern North America, west to the Plains and north to Manitoba, Ontario, and Newfoundland; breeds from northern Ohio, northern Illinois, and Iowa. northward; winters sparingly in the Gulf states and southward to Cuba, Yucatan, and Middle America to northern South America.

Adult: Upper parts, cinnamon brown, nearly uniform, with no decided difference in color between back and tail; no distinct white

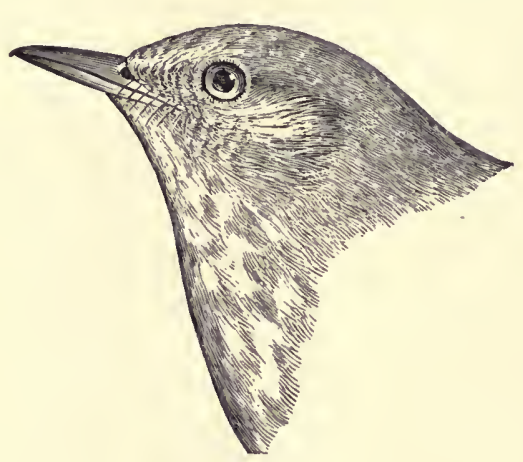

eye ring; throat and belly, white; sides tinged with pale grayish; breast and sides of throat faintly tinged with buff and marked with numerous small, arrow-shaped spots of brownish olive. Sexes similar.

Length, 7.45; wing, 3.80; tail, $2.85 ;$ bill, .50 .

A common migrant throughout Illinois and Wisconsin, and a summer resident from northern Illinois northward. The majority arrive early in May and leave the latter part of September. Its song is delightful but not as fine as that of the Wood Thrush. It may be crudely described as che-re-ry, che-re-ry, che-re-ry, or che-u-ry, che-u-ry, che-u-ry, che-u-ry, beginning high and continuing on a descending scale.

Mr. W. W. Cooke states that Mr. Kline took two sets of eggs at Polo, Illinois, during the season of 1883 .

It breeds regularly in Wisconsin, but is more common in the northern than in the southern portion of the state.

The nest is built on or near the ground and is composed of leaves, shreds of bark, and small twigs. The eggs are 3 to 5 , greenish blue in color, and measure about $.86 \times .66$ inches.

360a. Hylocichla fuscescens salicicola RIDGw.

Willow Thrush.

Turdus fuscescens salicicola Ridgw., A. O. U. Check List, I895, p. 3 I 7 .

Distr.: Interior regions of North America, from the Rocky Mountain region to Illinois and Indiana, north to British Columbia, breeding 
chiefly from North Dakota and Manitoba northward and occasionally farther south; casual as far east as South Carolina during migrations; in winter to Middle America and northern South America.

Special characters: Similar to $H$. fuscescens, but with upper parts darker and more olive brown, and the streaks on throat and upper breast averaging darker.

The Willow Thrush is not uncommon during the migrations in Illinois and probably Wisconsin, but from lack of material I am unable to decide this question. Typical Illinois specimens of both this form and $H$. fuscescens are represented in the Field Museum collection as well as a number of intermediates.

Messrs. Kumlien and Hollister say: "A single specimen taken at Delavan, May 6, I899, and identified by Mr. Wm. Brewster, is the sole claim for introducing this race here. We are of the opinion that a careful examination of the migrating fuscescens will reveal numbers of this form, especially, it would seem, in the western part of the state." (Birds of Wisconsin, 1903, p. I 26.)

Its song is similar to that of the Wilson's Thrush.

\section{I. Hylocichla aliciæ (BAIRD).}

Gray-CheEked Thrush.

Turdus alicice Baird, A. O. U. Check List, I895, p. 3 I 7.

Distr.: Northern and eastern North America, breeding far northward (Newfoundland, Labrador, Mackenzie region, Alaska, etc.), migrating south. east of the Rocky Mountains to the Greater Antilles, Central America, and northern South America.

Adult: Upper parts, uniform olive, with little or no difference between color of the back and tail; lores, grayish; middle of upper throat, middle of belly and under

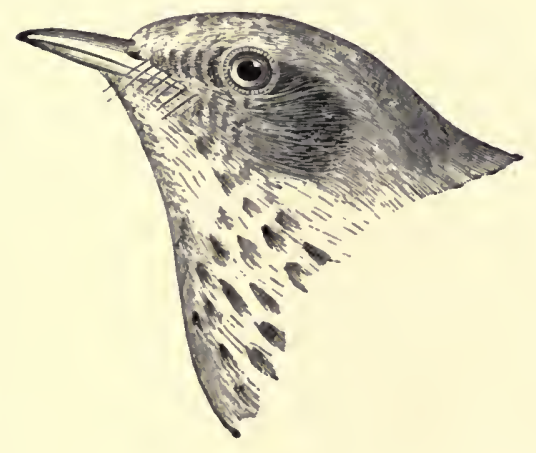
tail coverts, white; sides washed with olive gray; lower throat and breast washed with faint tinge of pale buff and thickly marked with blackish arrowshaped spots. Sexes similar.

Length, 7.45 ; wing, 4 ; tail, 3 ; bill, $.5^{2}$.

The Gray-cheeker Thrush is very common in Illinois and Wisconsin during the migrations in spring and fall. It resembles 
the Olive-backed Thrush but differs in having the breast and sides of the throat only faintly tinged with buff, and in its grayish lores and whitish eye ring.

\section{Ia. Hylocichla aliciæ bicknelli RIDGW.}

\section{BickNell's Thrush.}

Turdus alicice bicknelli (Ridgw.), A. O. U. Check List, I895, p. 317.

Distr.: Eastern United States; breeding on mountains of New England from Massachusetts northward and in Nova Scotia; south in winter to southeastern states and Bahamas; accidental in Illinois.

Special characters: Similar to $H$. alicice but smaller; the tail decidedly shorter and the upper parts averaging browner.

Wing, 3.40 to 3.80 ; tail, 2.60 to 2.88 .

The only record of the occurrence of Bicknell's Thrush within our limits is that given by Ridgway, who states: "A single specimen was obtained at Warsaw, Illinois, on the 24 th of May, I884, by Mr. Chas. K. Worthen, thus considerably extending its known range and adding it to the fauna of this state." (Orn. of Illinois, r889, p. 59.)

The occurrence of this form in Illinois is most unexpected as it is far out of its usual range.

\section{Hylocichla ustulata swainsonii ( $\mathrm{C}_{\mathrm{AB}}$.).}

OLIVE-BACKED THRUSH.

Turdus ustulatus swainsonii (Cab.), A. O. U. Check List, I895, p. 3 I8.

Distr.: North America in general, except Pacific coast of United States, breeding from the northern border of the United States northward to Hudson Bay and Alaska; south in winter to Mexico, Central America, and northern South America.

Adult: Upper parts, uniform olive, showing little or no difference in color of back and tail; eye ring and lores, tawny buff; throat and breast with decided tinge of pale tawny buff, marked on breast and sides of throat with dusky arrow-shaped spots; sides of body washed with grayish olive; belly and under tail coverts, white; a few obscure grayish olive spots on the upper belly. Sexes similar.

Length, about 7.1 5 ; wing, 3.90 ; tail, 2.75 ; bill, .50.

The Olive-backed Thrush is abundant during the migrations in spring and fall in Illinois and Wisconsin. Mr. Nelson records a specimen taken in June and another, July 9 th, in the vicinity of Chicago 


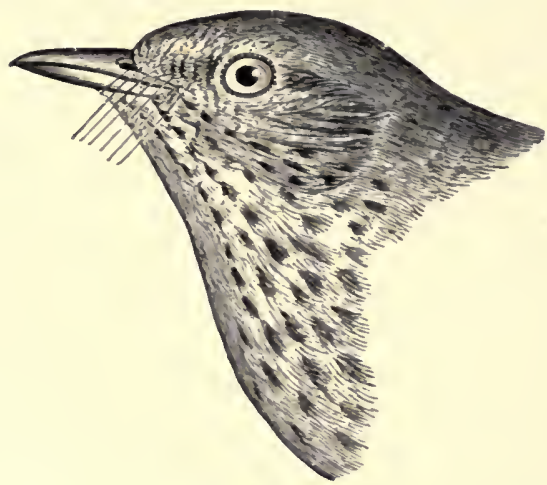

Olive-backed Thrush.

(Birds N. E. Ill., I876, p. 93), but this does not necessarily indicate breeding. Injured or non-breeding birds often remain during the summer far south of their usual habitat.

It is not known to breed in northern Wisconsin, but it is not unlikely that it does so. The song is charming but not as fine or as varied as that of the Wood Thrush, which it. somewhat resembles.

Alma's Thrush, Hylocichla ustulata alme Bishop, recorded from Wisconsin (Kumlien and Hollister, Birds of Wisconsin, I903. p. I 27) is apparently inseparable from $H$. u. swainsonii.

363. Hylocichla guttata pallasii (САB.).

Hermit Thrush.

Turdus aonalaschkce pallasii (Cab.), A. O. U. Check List, I895, p. 3 I9.

Distr.: Eastern North America, breeding from Massachusetts, mountains of Pennsylvania, southern Ontario, and northern Michigan (Mackinac Island) northward to Labrador, Manitoba, Athabaska, and the Mackenzie region; winters from Illinois (about latitude $40^{\circ}$ ) to the Gulf coast; accidental in Greenland, Bermuda, and Europe.

Adult: Upper parts, brownish olive, or dark olive brown, shading into rufous brown on tail coverts and tail, in decided contrast to color

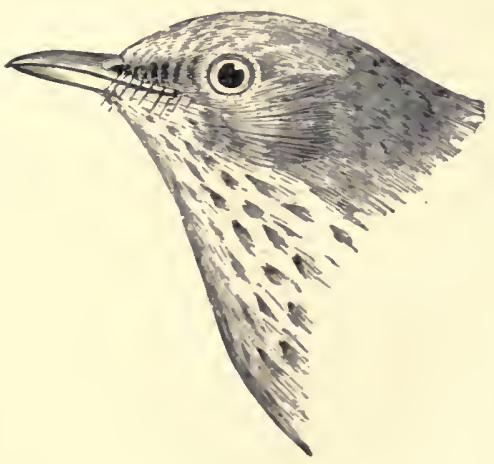

of the back; throat and breast faintly tinged with buff; breast and sides of throat rather heavily marked with blackish arrow-shaped spots; belly, white; sides washed with pale grayish olive. The difference in color of tail and back is a good distinguishing character. Sexes similar.

Length, 7.10; wing, 3.65; tail. $2.85 ;$ bill, . 50 .

This species is common in Illi- 
7 i 2 Field Museum of Natural History-Zoölogy, Vol. IX.

nois and Wisconsin in spring and fall during the migrations, and a not uncommon summer resident in northern Wisconsin. Mr. John F. Ferry found it common near Woodruff, Vilas County, Wisconsin, during the last week in June, I908, and procured partly fledged young birds. Mr. F. H. King records it from Waupaca in July. (Geol. of Wisconsin, I883, p. 475.)

The song, which, is very charming, somewhat resembles that of the Wood Thrush, but is more "metallic" and not so loud.

\section{Genus PLANESTICUS Bonap.}

364. Planesticus migratorius (LinN.).

Robin.

Merula migratoria (Linn.), A. O. U. Check List, 1895 , p. 320.

Distr.: Eastern North America, west to the Rocky Mountains, eastern Mexico, and Alaska; breeds from Virginia, Ohio, northern Indiana, and Illinois northward to Arctic regions (limit of trees); winters chiefly from the northern United States to the Gulf coast and Cuba; acc'dental in Bermuda and Europe.

Adult male in summer: Upper parts, dark slate color, usually with an olive tinge; head, black; the throat, white, streaked with black;

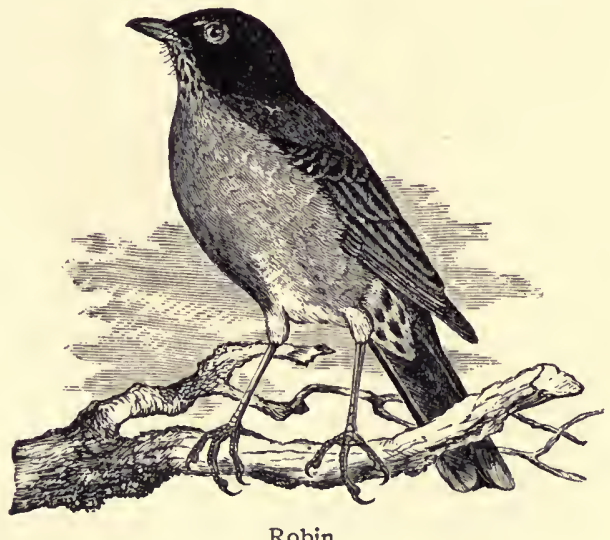

Robin. 
a spot in front of the eye and eyelid, white; primaries, dusky slatecolor, with pale edges; under parts and under wing coverts, rufous chestnut, usually more or less white on lower belly; under tail coverts, white; tail, brownish black, the outer tail feather tipped with white; bill, mostly yellow.

Adult female in summer: Similar but paler, the feathers on back of head tipped with grayish.

Adult male and female in fall and winter: Feathers of under parts, tipped with white; crown feathers, dusky, edged with grayish; bill, dark.

Immature in summer: Plumage paler; under parts spotted with black; back with whitish centres to feathers; a whitish stripe over the eye.

Length, 9.50 to 10.50; wing, 5.10 ; tail, 4 ; bill, .80.

The Robin is an abundant summer resident in Illinois and Wisconsin, and a not uncommon winter resident in the more southern portion of Illinois and casually much farther north.

The majority breed in May and early in June. The nest is rather large, composed of grass, small twigs, leaves, and mud, usually on a branch of a tree. The eggs are from 3 to 5, plain greenish blue, very rarely with a few irregular brown spots, and measure about I.15. $\mathrm{x} .79$ inches.

The song of the Robin is melodious and varied, although he is prone to indulge in a series of loud and somewhat unmusical chirps. $\mathrm{He}$ is among the first to cheer us in the spring and is still to be heard late in the fall when most of our feathered songsters are missing. While he may annoy us by eating our cherries and small fruits, he also destroys many worms and injurious insects, and to quote my esteemer friend, Robert Ridgway, “' 'With all his faults, we love him still.' No American orchard would be complete without its pair of Robins, and his absence would create a void in the ranks of our birds, which would be felt by every one who cherishes memories of his boyhood days." 
7 I 4 Field Museum of Natural History-Zoölogy, Vol. IX.

\section{Subfamily SIALIINÆ. Bluebirds.}

Genus SIALIA Swainson.

365. Sialia sialis (LiNn.).

BLUEBIRD.

Distr.: United States and southern Canada, west to the base of the Rocky Mountains; winters from the middle states to the Gulf coast (casual or accidental in Cuba); breeds nearly throughout its range.

Adult male: Upper parts, bright blue; wings and tail, blue, the former with the ends blackish; throat, breast and sides of body, chest-

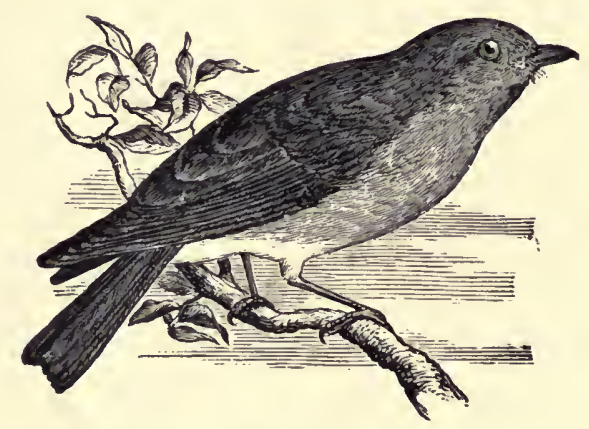

Bluebird.

nut; belly and under tail coverts, white, some of the latter tinged with grayish blue; bill and feet, black.

Adult female: Similar, but blue of upper parts more or less tinged with grayish brown, shading into bright blue on rump and tail, the chestnut on under parts paler.

Immature in first plumage: Upper parts, grayish brown; wings and tail, blue; the back with white streaks (caused by the white shaft lines of the feathers); under parts, white; the feathers of the breast and sides edged with grayish brown, producing an irregular streaked appearance.

Length, 6.80 ; wing, 3.90 ; tail, 2.65 ; bill, .45.

The Bluebird is a very common summer resident in Illinois and Wisconsin, the majority arriving from the south in March (earliest Chicago record, February 22) and leaving again in September. 
Jan., I909. Birds of Illinois and Wisconsin-Cory.

The breeding season lasts from April until the middle of June. The nest is in hollow trees and stumps or about buildings. The eggs are from 4 to 7 , very pale blue or bluish white, rarely white, and measure about $.83 \times .64$ inches.

The Field Museum collection contains a series of sets of eggs taken in northern Illinois between April 25 and June ro. The song of the Bluebird is a pleasing whistle, usually a single note repeated two or three times.

The Mountain Bluebird, Sialia arctica, was included by Mr. Nelson on the authority of Dr. Hoy. He states: "Dr. Hoy informs me that he has seen a specimen of this species in a collection at Dubuque, Iowa, which was taken late in the fall upon the east side of the Mississippi River near that town." (Birds N. E. Ill., I876, p. 95.) But Mr. Ridgway says (Birds North and Middle America, 1907, p. 145, footnote): "I have examined the specimen upon which the above record was based and it proves to be a somewhat discolored example of S. sialis, female." 


\section{INDEX TO KEY TO EGGS.}

GROUP I. White eggs (unmarked) ................ 7 I9

Section I. Nest on branches of trees or bushes............ 7 I9

Part I. Eggs less than .60 inch long............... 7 I9

Part 2. Eggs from .60 to .85 inches long............. 7 I 9

Part 3. Eggs between .90 and 1.25 inches long.......... 7 r 9

Part 4. Eggs more than $\mathrm{r} .50$ inches long.............. 7 I 9

Section 2. Nest in hole in tree, stump, or post ............ 720

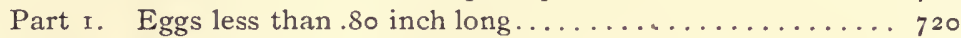

Part 2. Eggs from .80 to .98 inches long.................. 720

Part 3. Eggs from .98 to 1.25 inches long .............. 720

Part 4. Eggs from 1.25 to 1.75 inches long ............ 721

Part 5. Eggs more than I.75 inches long................... 721

Section 3. Nest about dwellings, barns, and out-buildings ...... 72 I

Section 4. Nest in open fields on ground or in bunch of grass..... $7^{2 I}$

Part I. Eggs less than 1.50 inches long................ $7_{21}$

Part 2. Eggs more than 1.50 inches long............. 722

Section 5. Nest in hole in bank ...................... 722

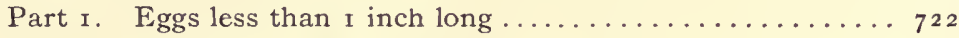

Part 2. Eggs more than $\mathrm{I}$ inch long .................. 722

Section 6. Nest in swampy places, in reeds or grass, on ground, or on floating vegetation..................... 722

Part I. Eggs less than $\mathrm{I}$ inch long .................. 722

Part 2. Eggs between I and I.50 inches long............... 722

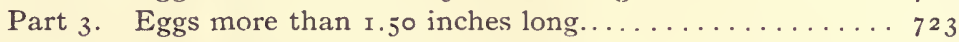

Group 2. Eggs blue or greenish blue (unmarked) ............. 723

Section I. Nest on branches of trees or bushes.............. 723

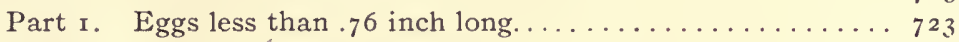

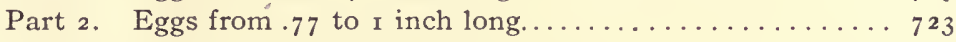

Part 3. Eggs from I 1 nch to $\mathrm{I} .35$ inches long ........... 723

Part 4. Eggs more than 1.35 inches long ................ 724

Section 2. Nest in hole in tree, stump, or post............. 724

Section 3. Nest about dwellings and barns................. 724

Section 4. Nest in open fields, on ground, or in bunch of grass..... 734

Section 5. Nest in swampy places, in reeds, or grass, on ground, or

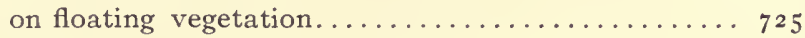

Group 3. Eggs not white or blue (unmarked) ............... 725

Section I: Nest on branches of trees or bushes............... 725

Section 2. Nest in hole in tree, stump, or post ............ 725

Section 3. Nest about dwellings, and barns, and buildings...... 726

Section 4. Nest in open fields, on ground, or in bunch of grass.... 726

Section 5. Nest on ground, in woods, in dry places.......... 726

Section 6. Nest in swampy places, in reeds or grass, on ground, or on floating vegetation.................. 726 
Group 4 Eggs spotted chiefly at larger end .................... 726

Section I. Nest in branches of trees or bushes ............ 726

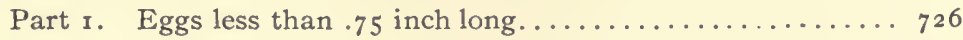

Part 2. Eggs .75 or more inches long .................. 727

Section 2. Nest in hole in tree, stump, or post. ........... 728

Section 3. Nest about dwellings and barns.............. 728

Section 4. Nest in open fields, on ground, or in bunch of grass.... 728

Section 5. Nest in woods, on ground, in dry places.......... 729

Section 6. Nest in swampy places, in reeds or grass, on ground, or

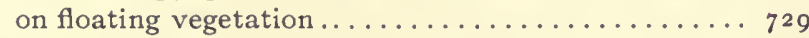

Part I. Eggs less than I.I5 inches long.............. 729

Part 2. Eggs from r.I5 to I.35 inches long............ 729

Part 3. Eggs more than 1.35 inches long ............... 730

Section 7. Nest on sandy shores and beaches............. 730

Group 5. Eggs speckled all over. .............................. 730

Section I. Nest in branches of trees or bushes............. 730

Section 2. Nest in hole in tree, stump, or post........... 73 I

Section 3. Nest about dwellings and barns................ $73^{I}$

Section 4. Nest in open fields, on ground, or in bunch of grass.... $73^{1}$

Part I. Eggs less than $\mathrm{I}$ inch long.................... 73 I

Part 2. Eggs from $I$ to 1.50 inches long............. 73 I

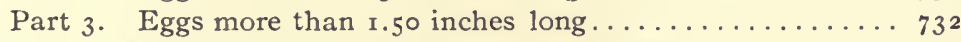

Section 5. Nest on ground, in woods, in dry places.......... $73^{2}$

Section 6. Nest in swampy places, in reed or grass, on ground. or on

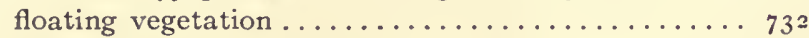

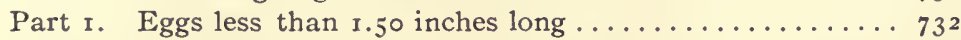

Part 2. Eggs more than 1.50 inches long ............. 732

GRoup 6. Eggs marked all over with irregular blotches, spots, or streaks.. 734

Section I. Nest on branches of trees or bushes ........... 734

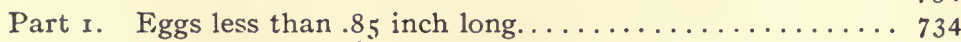

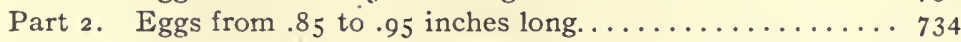

Part 3 . Eggs from .95 to 1.50 inches long.............. 735

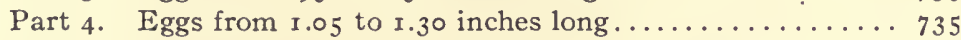

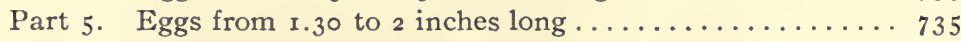

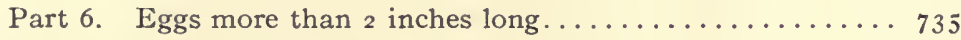

Section 2. Nest in hole in tree, stump, or post ............ 736

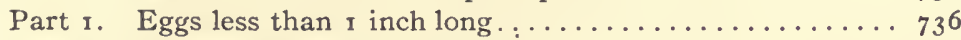

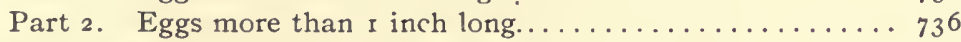

Section 3. Nest about dwellings and barns............. 736

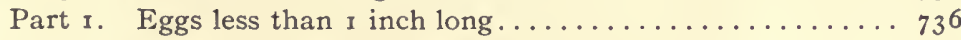

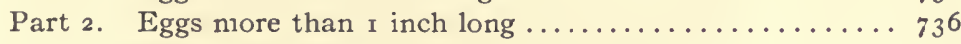

Section 4. Nest in open fields, on ground, or in bunch of grass ... . 737

Section 5. Nest on ground, in woods, in dry places........... 737

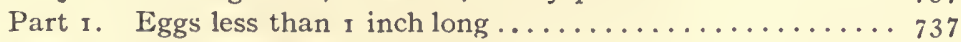

Part 2. Eggs more than 1 inch long ................... $73^{8}$

Section 6. Nest in swampy places, in reeds or grass, on ground, or on

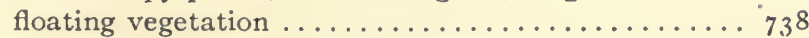

Part $\mathrm{x}$. Eggs less than $\mathrm{I}$ inch long .................. 738

Part 2. Eggs from $I$ to 1.50 inches long $\ldots \ldots \ldots \ldots \ldots \ldots . \ldots \ldots 3^{8}$

Part 3. Eggs more than 1.50 inches long ............... 739 


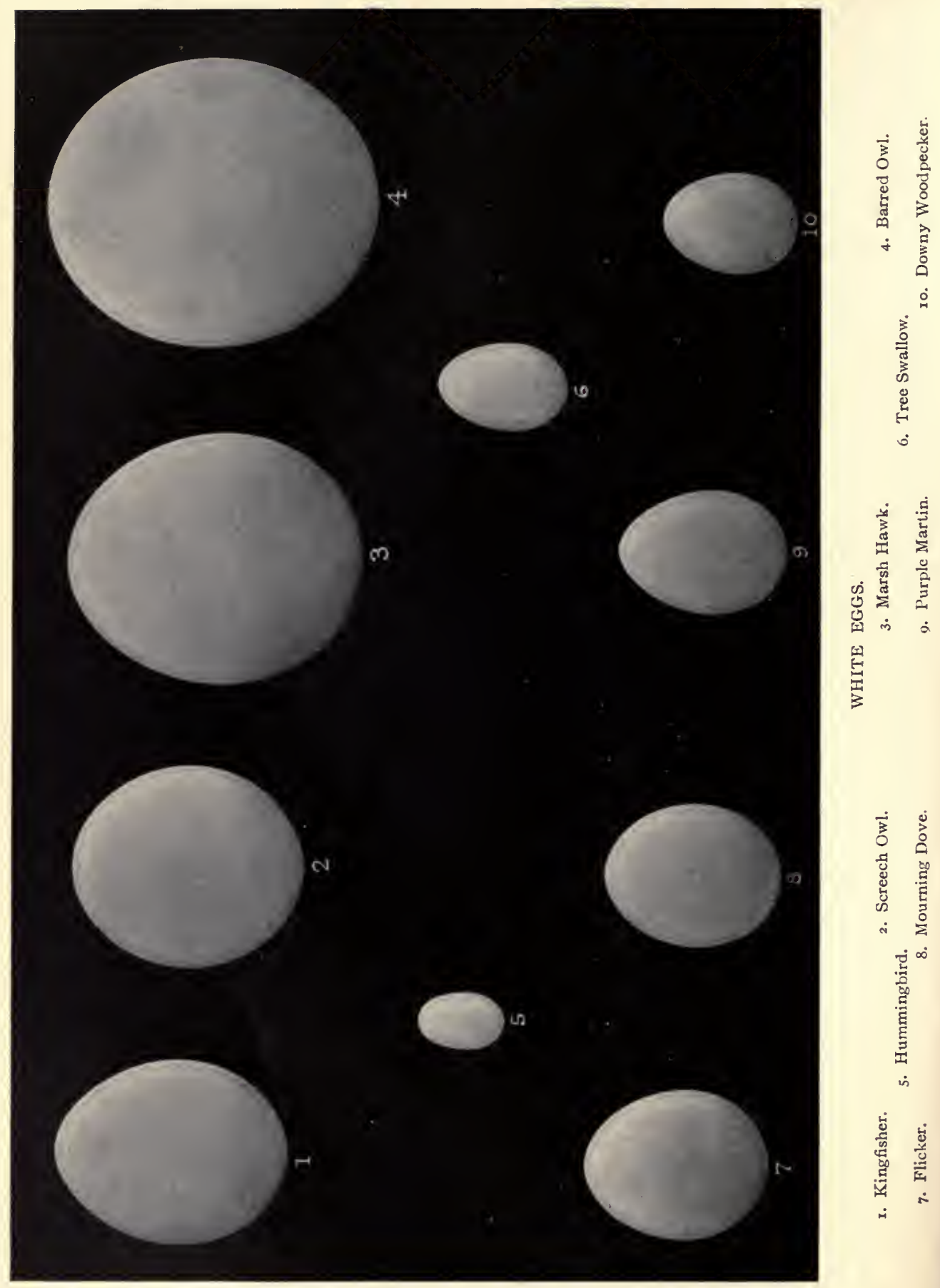




\section{A KEY TO THE EGGS}

OF THE MORE COMMON BIRDS KNOWN TO BREED IN NORTHERN ILLINOIS AND SOUTHERN WISCONSIN.

\section{GROUP 1* WHITE EGGS (UNMARKED).}

\section{SECTION I. NEST ON BRANCHES OF TREES OR BUSHES.}

PART I. EGGS LESS THAN .60 IN. LONG.

Eggs 2. Size, about .50 x.35. Smallest of our birds' eggs.

Trochilus colubris.

Ruby-throated Hummingbird.

PART 2. EGGS FROM .60 TO .85 IN. LONG.

Eggs, 3 to 6 . Size, about $.66 \times .48$. Eggs usually showing faint bluish tinge. Nest lined with thistle down, usually from 6 to 25 feet from ground. Breeds, July and August. Bird: female, wings and tail, dusky; under parts tinged with yellow. Male, bright yellow; crown, wings, and tail, black.

Astragalinus tristis.

American Goldfinch.

Eggs, 3 to 4 . Size, about $.73 \times .55$. Eggs usually showing faint bluish tinge. Nest not lined with thistle down, usually in crotch of bush near ground. Breeds, May and June. Bird: female, grayish; wings, dusky; no yellow on under parts. Male, blue; wing and tail, mostly black.

Passerina cyanea.

Indigo Bunting.

PART 3. EGGS BETWEEN .90 AND I.25 IN. LONG.

Eggs, 2. Size, about $1.08 \times .83$. Nest, a mat of loose twigs.

Zenaidura macroura carolinensis.

Mourning Dove.

PART 4. EGGS MORE THAN r.5० IN. LONG.

Eggs, 3 to 6 . Size, $1.92 \times 1.55$. Eggs, sometimes dull white or pale bluish white, but usually more or less faintly marked with pale brown.

Accipiter cooperii.

Cooper's Hawk.

* Eggs vary more or less in size and as the average measurements are given in this key, they should only be considered as approximate. For example, if in a series of eggs of a certain species the longest was 1.15 in. (measured on a straight line) and the shortest 1.00 , the length here given would be 1.08 in. 
Eggs, 2 to 4 . Size, $1.96 \times$ r.66. Eggs, pure white, not bluish white. Nest in old crow's or hawk's nest, sometimes in hollow tree.

Strix varia.

Barred Owl.

Eggs, 2 to 3. Size, $2.20 \times 1.82$. Eggs, pure white; the size will distinguish them from preceding species. Nest in old crow's or hawk's nest, sometimes in hollow tree.

Bubo virginianus.

Great Horned Owl.

SECTION 2. NEST IN HOLE IN TREE, STUMP, OR POST.

PART I. EGGS LESS THAN .80 IN. LONG.

Eggs, 4 to 7 . Size, $.75 \times .53$; shape, rather long and narrow.

Iridoprocne bicolor.

Tree Swallow.

Eggs, 4 to 6 . Size, .75 ×.60. Eggs rounded; the width will distinguish them from those of preceding species. Bird: if bird is seen, no one can mistake a Woodpecker for a Swallow.

Dryobates pubescens medianus.

Downy Woodpecker.

PART 2. EGGS FROM .80 TO .98 IN. LONG.

Eggs, 5 to 7 . Size, $.88 \times .68$. Bird: female, large; patch of black on breast; top of head, red; no red on throat. A rather rare breeder.

Sphyrapicus varius.

Yellow-bellied Woodpecker.

Eggs, 4 to 6 . Size, $.92 \times .74$. Bird: female, throat and under parts, pure white; crown, black. A common breeder. Dryobates villosus.

Hairy Woodpecker.

\section{PART 3. EGGS FROM .98 TO 1.25 IN. LONG.}

Eggs, 3 to 5 . Size, about $\mathrm{I} .00 \mathrm{x} .70$. The slight but noticeable difference in size will distinguish them from those of the next species. Bird: female, bluish black above (at a distance appears to be black), grayish beneath; no yellow or red in plumage. Male, entire plumage, shiny blue-black.

Progne subis.

Purple Martin.

Eggs, 4 to 6. Size, about $1.00 \times .76$. Shape, more elongated and narrower than next species. Bird, whole head and throat, red; wings showing much white.

Melanerpes erythrocephalus.

Red-headed Woodpecker.

Eggs, 5 to ro. Size, about r.10 x.87. Bird, size, large; black patch on breast; under wings and tail, yellow; no white on wings; top of head and throat, not red. (Female.) Colaptes auratus luteus. 


\section{PART 4. EGGS I.25 TO I.75 IN. LONG.} brown.

Eggs, 4 to 6 . Size, about I. $45 \times$ I.20. Bird, gray, sometimes redOtus asio.

Screech Owl.

PART 5. EGGS OVER I.75 IN. LONG.

Eggs, 8 to I 4 . Size, about $2.05 \times$ I.55. Eggs, buff white, or pale buff, not pure, white.

Aix sponsa. Wood Duck.

Eggs, 2 to 4 . Size, about I.95 x r.65. Eggs, white.

Strix varia.

Barred Owl.

Eggs, 8 to Io. Size, about $2.10 \times 1.75$.

Lophodytes cucullatus.

Eggs, 2 to 3. Size, about $2.20 \times 1.82$ Eggs, pure white.

Hooded Merganser.

Bubo virginianus.

Great Horned Owl.

\section{SECTION 3. NEST ABOUT DWELLINGS AND BARNS.}

Eggs, 4 to 6 . Size, about $.78 \times .5^{8}$. Nest, moss, grass, and mud placed on top of beam or rafter, not attached to side. Sayornis phabe.

Phœbe Flycatcher.

Eggs, 4 to 6 . Size, about $.80 \times \cdot 5^{2}$. Shape, narrower than preceding species. Nest usually in chimney (sometimes in barns), composed of small dead twigs glued to side of bricks or rafter. Bird, smoky black.

Chetura pelagica.

Chimney Swift.

Eggs, 4 to 5 . Size, about $1.00 \times \cdot 70$. Distinguished by size from others in this section.

Progne subis.

Purple Martin.

\section{SECTION 4. NEST IN OPEN FIELDS, ON GROUND OR IN BUNCH OF GRASS.}

\section{PART I. EGGS LESS THAN I.5० IN. LONG.}

Eggs, 2. Size, about I.10 X.82. Nest, a flat mat of twigs, rarely on the ground, usually on a branch. Zenaidura macroura carolinensis.

Mourning Dove.

Eggs, Io to I8. Size, about I.20 x.94. Nest, merely a little grass on ground.

Quail. Bob-white. 
722 Field Museum of Natural History-Zoölogy, Vol. IX.

PART 2. EGGS MORE THAN I.5O IN. LONG.

Eggs, 4 to 7 . Size, about $\times .55 \times$ I.25. Eggs, pure white. Nest on ground in fields and low prairies.

Asio flammeus.

Short-eared Owl.

Eggs, 4 to 7 . Size, about $1.75 \times 1.40$. Eggs, pure white. Nest usually about marshy places.

Circus hudsonius.

Marsh Hawk.

Eggs, 6 to I2. Size, about $1.80 \times$ I.30. Eggs, creamy white, or buffy white, not pure white. Nest, near water. Querquedula discors.

Blue-winged Teal.

\section{SECTION 5. NEST IN HOLE IN BANK.}

PART I. EGGS LESS THAN I IN. LONG.

Eggs, 4 to 6 . Size, about .70 $\times .48$. In size the eggs of this and the next species are hardly distinguishable, although the Rough-wing is slightly the larger. Bird, under parts, white, with conspicuous band of brown on breast. Riparia riparia.

Bank Swallow.

Eggs, 4 to 7 . Size, about $.72 \times \cdot 5^{\text {I. }}$. Bird, under parts brownish gray, no band on breast.

Stelgidopteryx serripennis.

Rough-winged Swallow.

PART 2. EGGS MORE THAN I IN. LONG.

Eggs, 5 to 8 . Size, about I.34 X I.05. Nest, deep hole in bank near water.

Ceryle alcyon.

Belted Kingfisher.

SECTION 6. NEST IN SWAMPY PLACES, IN REEDS OR GRASS, ON GROUND OR ON FLOATING VEGETATION.

PART I. EGGS LESS THAN I IN. LONG.

Eggs, 6 to 8 . Size, about $.66 \times .47$. Nest, on or near ground in grass, made of grasses and globular in shape; entrance on the side.

Cistothorus stellaris.

Short-billed Marsh Wren.

PART 2. EGGS BETWEEN I AND I.5० IN. LONG.

Eggs, 3 to 6 . Size, about $\mathrm{x} .20 \times .92$; white, with faint bluish tinge. Nest in reeds or small bush in swamp or pond. Ixobrychus exilis.

Least Bittern. 
PART 3. EGGS MORE THAN I.5० IN. LONG.

Eggs, 5 to 8. Size, about I.70 $\times 1.19$; dull creamy white or buffy white, more or less soiled. Nest, a mass of floating vegetation in swamp or pond.

Podilymbus podiceps.

Pied-billed Grebe.

Eggs, 3 to 6 . Size, about $1.78 \times 1.40$; pure white. Nest on ground in marshy places. Circus hudsonius. Marsh Hawk.

Eggs, 6 to r2. Size, about $1.84 \times$ r.33; creamy white or buffy white, not pure white. Nest on ground near water.

Querquedula discors.

Blue-winged Teal.

\section{GROUP 2. EGGS BLUE OR GREENISH BLUE (UNMARKED).}

\section{SECTION I. NEST ON BRANCHES OF TREES OR BUSHES.}

PART I. EGGS LESS THAN .76 IN. LONG.

Eggs, 3 to 6 . Size, about $.66 \times .47$; faintly blue or bluish white. Nest lined with thistle down, usually some distance from ground (6 to $25 \mathrm{ft}$.$) .$

Astragalinus tristis.

American Goldfinch.

Eggs, 3 to 4 . Size, about $.73 \times .55$; faintly blue, often apparently white. Nest not lined with thistle down, usually in crotch of bush near ground.

Passerina cyanea.

Indigo Bunting.

PART 2. EGGS FROM .77 TO I IN. LONG.

Eggs, 4 to 5 . Size, about $.80 \times .60$; very pale blue or bluish ashy. Bird, shows more or less yellow on breast.

Spiza americana.

Dickcissel. Black-throated Bunting.

Eggs, 3 to 5. Size, about .93 $\times .68$; deep blue or greenish blue. Bird, general plumage slaty gray. Dumetella carolinensis.

Catbird.

PART 3. EGGS FROM I IN. TO I.35 IN. LONG.

Eggs, 2 to 5 . Size, 1.02 X.74; light blue. Bird, above, rufous brown; under parts, white, with distinct spots. Hylocichla mustelina.

Wood Thrush.

Eggs, 3 to 5 . Size, about I.I 2 × .80; greenish blue, darker and larger than Wood Thrush. Bird, breast and under parts, reddish brown.

Planesticus migratorius.

Robin. 
724 Field Museum of Natural History-Zoölogy, Vol. IX.

Eggs, 2 to 6 . Size, about $1.08 \times .82$. The eggs of this and the next species vary in color and size, those of the Yellow-billed Cuckoo being usually pale greenish blue, somewhat lighter in color than eggs of the black-billed species. . Bird, tail feathers not broadly tipped with white; bill mostly black.

Coccyzus erythrophthalmus.

Black-billed Cuckoo.

Eggs, 2 to 5. Size, about I.I $8 \times .90$. Bird, tail feathers broadly tipped with white; under mandible, mostly yellow.

Coccyzus americanus.

Yellow-billed Cuckoo.

PART 4. EGGS MORE THAN I.35 IN. LONG.

Eggs, 3 to 6 . Size, about I.50 X I.15; pale greenish blue. Nest usually near water.

Butorides virescens.

Green Heron.

Eggs, 4 to 6. Size, about $2.00 \times 1.46$; pale greenish blue. Nest near water.

Nycticorax nycticorax nevius.

Black-crowned Night Heron.

Eggs, 3 to 6 . Size, about 2.55 to $2.70 \times 1.55$ to 1.65 ; pale blue or greenish blue. Nest, a mass of sticks, usually in trees near water.

Ardea herodias.

Great Blue Heron.

\section{SECTION 2. NEST IN HOLE IN TREE, STUMP, OR POST.}

Eggs, 4 to 6 . Size, about $.84 \times .65$. Eggs sometimes almost pure white, usually very pale blue or bluish white.

Sialia sialis.

Bluebird.

\section{SECTION 3. NEST ABOUT DWELLINGS AND BARNS.}

Eggs, 3 to 5. Size, about I.I 2 x .80; color, greenish blue.

Planesticus migratorius.

Robin.

SECTION 4. NEST IN OPEN FIELDS, ON GROUND, OR IN BUNCH OF GRASS.

Eggs, 4 to 5 . Size, about $.80 \times .60$; color, very pale blue.

Spiza americana.

Dickcissel. Black-throated Bunting. 


\section{SECTION 5. NEST IN SWAMPY PLACES IN REEDS OR GRASS, ON GROUND OR ON FLOATING VEGETATION.}

Eggs, 3 to 6 . Size, about $1.20 \times .92$. Color, very pale blue or bluish white. Nest in reeds or small bushes in swamp or pond.

Ixobrychus exilis.

Least Bittern.

Eggs, 4 to 6 . Size, about $2 \times 1.46$. Color, pale greenish blue. Size will distinguish them from preceding species.

Nycticorax nycticorax nevius.

Black-crowned Night Heron.

\section{GROUP 3. EGGS NOT WHITE OR BLUE (UNMARKED).}

\section{SECTION I. NEST ON BRANCHES OF TREES OR BUSHES.}

Eggs, 3 to 6 . Size, about I.16 6.82 ; occasionally pale bluish or brownish without marking, but usually pale bluish or greenish marked and scrawled with dark brown or black.

Quiscalus quiscula ceneus.

Bronzed Grackle.

\section{SECTION 2. NEST IN HOLE IN TREE, STUMP OR POST.}

Eggs, 6 to 8 . Size, about $.64 \times .49$; occasionally pale vinaceous or pinkish without marking, but usually thickly speckled.

Troglodytes aëdon (or parkmanii).

House Wren.

Eggs, 3 to 6 . Size, about I.1 $6 \times .82$; pale bluish or greenish marked and scrawled with dark brown or black.

Quiscalus quiscula ceneus.

Bronzed Grackle.

Eggs, 8 to 14 . Size, about $2.05 \times 1.55$; pale buff or brownish white. 
726 Field Museum of Natural History-Zoölogy, Vol. IX.

\section{SECTION 3. NEST ABOUT DWELLINGS AND BARNS.}

Eggs, 6 to 8 . Size, about $.64 \times .49$; occasionally pale vinaceous or pinkish without marking, but usually thickly speckled.

Troglodytes aëdon (or parkmanii). House Wren.

SECTION 4. NEST IN OPEN FIELDS, ON GROUND OR IN BUNCH OF GRASS.

Eggs, ro to I4. Size, about I.70 X I.26. olive buff.
Color, cream buff or pale Tympanuchus americanus.

Prairie Hen.

\section{SECTION 5. NEST ON GROUND IN WOODS IN DRY PLACES.} white.

Color, pale buff or buffy Bonasa umbellus.

Ruffed Grouse.

SECTION 6. NEST IN SWAMPY PLACES, IN REEDS OR GRASS, ON GROUND OR ON FLOATING VEGETATION.

Eggs, 6 to I 2. Size, about I.85 $8 \times .32$; pale buff or creamy buff.

Querquedula discors.

Blue-winged Teal.

Eggs, 3 to 5. Size, about I.90 X I.44; grayish olive or olive drab.

Botaurus lentiginosus.

American Bittern.

GROUP 4. EGGS SPOTTED OR MARKED CHIEFLY AT LARGER END.

SECTION I. NEST IN BRANCHES OF TREES OR BUSHES.

PART I. EGGS LESS THAN .75 IN. LONG.

Eggs, 4 to 5 . Size, about $.63 \times .50$; dull white, marked with light brown. Bird, sides of body yellow, outer tail feathers pale yellow, broadly tipped with brown. (Female.)

Setophaga ruticilla.

Redstart. 
Eggs, 3 to 6 . Size, about $.66 \times .48$; dull white, marked with light brown. Bird, general plumage, yellow.

Dendroica cestiva.

Yellow Warbler.

Eggs, 4 to 5 . Size, about $.69 \times .50$; dull white, marked with dark slate brown. Bird, above bright greenish yellow; underparts, white, outer tail feathers showing much white.

Dendroica pensylvanica.

Chestnut-sided Warbler.

Eggs, 3 to 5 . Size, about $\cdot 70 \mathrm{X} \cdot 5 \mathrm{I}$; pale bluish white, marked with rufous brown. Bird, crown, brown, no blackish streak through eye.

Spizella pusilla.

Field Sparrow.

Eggs, 4 to 5 . Size, about .70 x.50; pale blue, sparingly marked with dark brown or brownish black. Bird, crown, bright rufous brown, a black streak through the eye.

Spizella passerina.

Chipping Sparrow.

Eggs, 3 to 4 . Size, about $.70 x \cdot 54$; creamy white, marked with dark brown. Bird, upper parts, dark olive; under parts, dusky white.

Myiochanes virens.

Wood Pewee Flycatcher.

Eggs, 2 to 3. Size, about $.73 \times .54$; cream white or buff white, sparingly marked with dark brown. Bird, upper parts, olive; throat, whitish; belly, yellow.

Empidonax virescens.

Green-crested Flycatcher.

Eggs, 3 or 4 . Size, about $.75 \times \cdot 54$; pure white, sparsely speckled or marked with small dots of dark brown. Bird, upper parts, gray; under parts, whitish; sides tinged with pale yellow. Vireosylva gilva.

Warbling Vireo:

\section{PART 2. EGGS .75 OR MORE IN. LONG.}

Eggs, 2 to 3 . Size, about $.75 \times .55$; creamy white or buff white, sparingly marked with dark brown. Bird, upper parts, olive; throat, whitish; belly, yellow.

Empidonax virescens.

Green-crested Flycatcher.

Eggs, 3 to 4 . Size, about $.75 \times .55$; pure white, sparsely speckled or marked with small dots of dark brown. Bird, upper parts, gray; under parts, whitish; sides tinged with pale yellow. Vireosylva gilva.

Warbling Vireo.

Eggs, 3 to 5. Size, about .80 x.58; bluish white or dull white, scrawled and marked with dark brown and lilac-gray. Bird, entire under parts, yellow. (Female.)

Icterus spurius.

Orchard Oriole.

Eggs, 3 to 5 . Size. about .80 x.60; white, more or less dotted or scrawled with dark brown and pale gray brown. Bird, crown, chestnut, with whitish stripe in middle; cheek, chestnut; black stripe on sides of throat; throat and under parts, whitish.

Chondestes grammacus.

Lark Sparrow. Lark Finch.

Eggs, 3 to 4 . Size, about . $80 \times .60$; white, marked sparsely with dots of dark brown. Bird, throat and breast, yellow: belly, white; wings showing white band.

Lanivireo flavifrons. Yellow-throated Vireo. 


\section{Field Museum of Natural History-Zoölogy, Vol. IX.}

Eggs, 3 to 4 . Size, about .81 x.56; white, marked sparsely with dots of dark brown. Bird, throat and under parts, mostly white; crown, slaty; back, olive green.

Vireosylva olivacea.

Red-eyed Vireo.

Eggs, 4 to 6 . Size, about .92 x.6r; dull white, sparsely scrawled and marked with dark brown or blackish. Bird, plumage showing more or less yellow.

Icterus galbula.

\section{Baltimore Oriole.}

Eggs, 3 to 5. Size, about $.95 \times .73$; clear white, marked with dark brown and black. Bird, under parts, white; upper parts, dark.

Tyrannus tyrannus.

Kingbird

Eggs, 3 to 6 . Size, about $1.16 \times .82$; pale bluish or greenish, marked and scrawled with dark brown and black. Quiscalus quiscula ceneus.

Bronzed Grackle.

\section{SECTION 2. NEST IN HOLE IN TREE, STUMP OR POST.}

Eggs, 5 to 8 . Size, about .60 .48 ; white, marked with pale brown.

Penthestes atricapillus.

Chickadee.

Eggs, 6 to 8 . Size, about $.64 \times .49$; vinaceous, speckled with pale brown.

Troglodytes aëdon (or parkmanii).

House Wren.

\section{SECTION 3. NEST ABOUT DWELLINGS AND BARNS.}

Eggs, 6 to 8 . Size, about $.64 \times .49$; vinaceous or pale lilac-brown, speckled all over with pale brown.

Troglodytes aëdon (or parkmanii).

House Wren.

\section{SECTION 4. NEST IN OPEN FIELDS ON GROUND OR IN $\cdot$ BUNCH OF GRASS.}

(Eggs in this section may usually be distinguished by size.)

Eggs, 3 to 5 . Size, about $.70 \times .5^{1}$; pale bluish white, marked with rufous brown.

Spizella pusilla.

Field Sparrow.

Eggs, 4 to 5 . Size, about $.73 \times .56$; speckled and spotted with reddish brown, occasionally showing small markings of black and dull lavender.

Coturniculus savannarum australis.

Grasshopper Sparrow. Yellow-winged Sparrow.

Eggs, 4 to 5. Size, about .78 x 60; white or bluish white, thickly marked with rufous brown. Bird, breast striped with brown.

Melospiza melodia.

Song Sparrow. 
Eggs, 3 to 5 . Size, about $.80 \times .60$; white, more or less dotted or scrawled with dark brown and pale gray brown.

Chondestes grammacus.

Lark Sparrow. Lark Finch.

Eggs, 4 to 6 . Size, about $1.10 \times .78$; white, spotted and speckled with rufous brown and faint lilac-gray.

Sturnella magna.

Meadowlark.

Eggs, 4 to 5 . Size, about I.80 x 1.30; buff, spotted and speckled with various tints of brown.

Bartramia longicauda.

Bartramian Sandpiper. Upland Plover.

\section{SECTION 5. NEST IN WOODS ON GRQUND IN DRY PLACES.}

Eggs, 4 to 5 . Size, about $.80 \times .60$; white, speckled and marked with vinaceous brown or pale brown. Seiurus aurocapillus.

Oven-bird.

Eggs, 4 to 5 . Size, about .95 $\times .7 \mathrm{I}$; pale vinaceous, thickly speckled and tinged all over with pale brown, sometimes blotched at the larger end.

Pipilo erythrophthalmus.

Towhee.

Eggs, 2. Size, about 1.15 $\times .84$; white or creamy white, marked with pale brown and lilac-gray.

Antrostomus vociferus.

Whip-poor-will.

\section{SECTION 6. NEST IN SWAMPY PLACES IN REEDS OR GRASS, ON GROUND OR ON FLOATING VEGETATION.}

\section{PART I. EGGS LESS THAN I.I5 IN. LONG.}

Eggs, 3 to 5 . Size, about $.70 \times .52$; white, marked with pale brown. Geothlypis trichas.

Maryland Yellow-throat.

Eggs, 4 to 5 . Size, about $.78 \times .60$; white or bluish white, thickly marked with rufous brown. Bird, breast striped with brown.

Melospiza melodia.

Song Sparrow.

Eggs, 3 to 5. Size, about $1.00 \times$.70. Eggs, pale blue or pale greenish blue, blotched and scrawled with dark brown or blackish.

Agelaius phaniceus.

Red-winged Blackbird.

PART 2. EGGS FROM I.I5 TO I.35 IN. LONG.

Eggs, 3 to 5 . Size, about $1.25 \times .92$; creamy buff or cream-white, blotched with dark brown

Actitis macularia.

Spotted Sandpiper. 


\section{PART 3. EGGS MORE THAN I.35 IN. LONG.}

Eggs, 3 to 4 . Size, about I. $48 \times 1.08$; pale buff, blotched and scrawled with dark brown. The slight but constant difference in color and size will distinguish the eggs of this species from those of the Wilson's Snipe.

Oxyechus vociferus.

Killdeer Plover.

Eggs, 3 to 4 . Size, about I.55 X I.I 5 ; olive gray or brownish ash, marked with chocolate brown.

Gallinago delicata.

Wilson's Snipe.

Eggs, 4. Size, about I.55 x I.16; buffy or pale brown, spotted with rusty brown and pale purplish gray.

Philohela minor.

Woodcock.

\section{SECTION 7. NEST ON SANDY SHORES AND BEACHES.}

Eggs, 3 to 4 . Size, about $1.25 \times$.94; pale buff or pale olive buff, marked and scrawled with dark brown. Nest, eggs deposited in depression in sand on beach or near shore.

Egialitis meloda.

Piping Plover.

Eggs, 3 to 5 . Size, about $1.25 \times .92$; creamy buff or cream-white, blotched with dark brown.

Actitis macularia.

Spotted Sandpiper.

Eggs, 3 to 4. Size, about $1.48 \times 1.08$; pale buff, blotched and scrawled with dark brown.

Oxyechus vociferus.

Killdeer Plover.

\section{GROUP 5. EGGS SPECKLED ALL OVER.}

\section{SECTION I. NEST IN BRANCHES OF TREES OR BUSHES.}

Eggs, 4 to 5 . Size, about $.56 \times \cdot 54$; bluish white, dotted with brown. Polioptila ccerulea.

Blue-gray Gnatcatcher.

Eggs, usually I or 2. Size, about .87 x.66. Eggs deposited in some other bird's nest. Color, white or pale buff, speckled with brown.

Molothrus ater.

Cowbird.

Eggs, 3 to 6 . Size, about $1.07 \times .79$; ground color, grayish or pale bluish white, thickly speckled with cinnamon-brown or rufous brown. 


\section{SECTION 2. NEST IN HOLE IN TREE, STUMP OR POST.}

Eggs, 5 to 8 . Size, about .60 x.48; white, speckled with pale brown. Penthestes atricapillus.

Chickadee. Eggs, 6 to 8. Size, about $.64 \times .49$; vinaceous, speckled with pale
brown.
Troglodytes aëdon (or parkmanii). House Wren.

\section{SECTION 3. NEST ABOUT DWELLINGS AND BARNS.}

Eggs, 6 to 8 . Size, about $.64 \times .49$; vinaceous, speckled with pale brown.

Troglodytes aëdon (or parkmanii).

House Wren.

Eggs, 2. Size, about $1.20 \times .85$; pale olive buff or grayish white, thickly speckled (usually marked) with brown and washed in places with pale purplish gray. Location, eggs sometimes deposited on roof of house, usually in a field.

Chordeiles virginianus.

Nighthawk.

\section{SECTION 4. NEST IN OPEN FIELDS ON GROUND OR IN BUNCH OF GRASS.}

PART I. EGGS LESS THAN I IN. LONG.

Eggs, 3 to 5 . Size, about $.85 \times .62$; pale olive or dull whitish, thickly speckled and marked with pale brownish olive.

Otocoris alpestris praticola.

Prairie Horned Lark.

Eggs, usually I or 2. 'Size, about $.87 \times .66$; deposite 1 in some other bird's nest. Color, white or pale buff, speckled with brown.

Molothrus ater.

Cowbird.

PART 2. EGGS FROM I TO I.50 IN. LONG.

Eggs, 2. Size, about I.I9 X.86; pale olive buff or grayish white, thickly dotted and speckled with brown, and washed in places with pale purplish gray. Location, eggs deposited on a rock or on the ground, sometimes on flat roofs of houses.

Chordeiles virginianus.

Nighthawk. 
732 Field Museum of Natural History-Zoölogy, Vol. IX.

PART 3. EGGS MORE THAN r.5O IN. LONG.

Eggs, ro to 14 . Size, about $1.70 \times 1.26$; cream buff or pale olive buff, sometimes speckled with brown. Tympanuchus americanus.

Prairie Hen.

\section{SECTION 5. NEST ON GROUND IN WOODS IN DRY PLACES.}

Eggs, usually $\mathrm{r}$ or 2. Size about $.87 \times .66$. Eggs are deposited in some other bird's nest. Color, white or pale buff, speckled with brown.

Molothrus ater.

Cowbird.

Eggs, 4 to 5 . Size, about .95 X.7 r; pale vinaceous, thickly speckled with pale brown.

Pipilo erythrophthalmus.

Towhee.

\section{SECTION 6. NEST IN SWAMPY PLACES, IN REEDS OR GRASS, ON THE GROUND OR ON FLOATING VEGETATION.}

PART I. EGGS LESS THAN I.50 IN. LONG.

Eggs, 5 to 9 . Size, about $.66 \times .48$; thickly speckled with cinnamon or olive brown. Nest, globular; entrance in side; attached to reeds (sometimes small bushes).

Telmatodytes palustris.

Long-billed Marsh Wren.

Eggs, usually I or 2. Size about $.87 \times .66$. Eggs are deposited in some other bird's nest. Color, white or pale buff, speckled with brown.

Molothrus ater.

Cowbird.

Eggs, 4 to 6 . Size, about $1.00 \times .7 \mathrm{I}$; grayish or grayish white, speckled with pale cinnamon-brown. Nest, a mass of grass and reeds.

Xanthocephalus xanthocephalus.

Yellow-headed Blackbird.

PART 2. EGGS MORE THAN I.50 IN. LONG.

Eggs, 8 to 13 . Size, about $1.78 \times 1.20$; pale buff, with irregular marks of rufous brown or clear brown. Gallinula galeata. Florida Gallinule.

Eggs, 7 to 14 . Size, about $1.88 \times 1.28$; pale buffy white, finely speckled and dotted with black. Fulica americana. American Coot. 

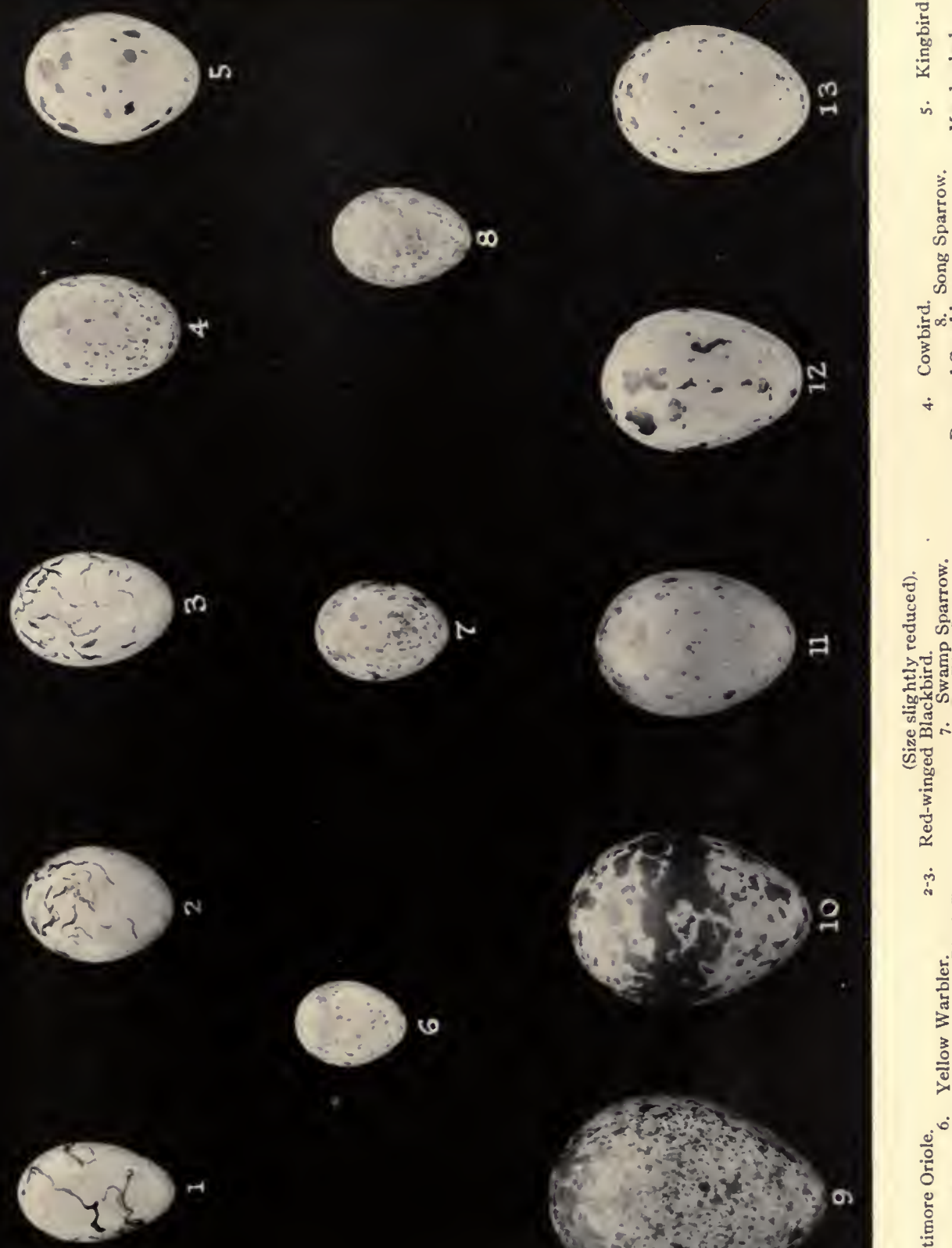

$-7+20$
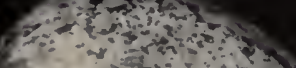

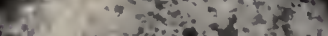




\section{GROUP 6. EGGS MARKED ALL OVER WITH IRREGULAR BLOTCHES, SPOTS OR STREAKS.}

\section{SECTION r. NEST ON BRANCHES OF TREES OR BUSHES.}

PART 1. EGGS LESS THAN .85 IN. LONG.

Eggs, 4 to 5 . Size, about $.56 \times .45$; bluish white or dull white, marked and speckled with brown. Bird, very small; general color, bluish gray.

Polioptila ccrulea.

Blue-gray Gnatcatcher.

Eggs, 4 to 5 . Size, about $.78 \times .60$; bluish white or dull white, irregularly marked with brown. Nest in low bushes or on ground. Bird, under parts, white; breast streaked with brown. Melospiza melodia.

Song Sparrow.

Eggs, 3 to 5 . Size, about $.80 \times .58$; bluish white or dull white, scrawled and marked with dark brown and lilac-gray. Nest, attached to branch, rarely less than Io or ${ }_{5} 5$ feet from ground. Bird, entire under parts, yellow. (Female.)

Icterus spurius.

Orchard Oriole.

Eggs, 3 to 5. Size, about .80 x.60; white or pinkish white, more or less dotted and scrawled with dark brown and pale gray brown. Bird, under parts, whitish; black stripe on side of throat; cheek showing patch of chestnut.

Chondestes grammacus.

Lark Sparrow.

PART 2. EGGS FROM .85 TO .95 IN. LONG.

Eggs, 3 to 5 . Size, about $.87 \times .62$; pale bluish gray, with scattered markings of black or dark brown. Bird, head with crest; general color, soft grayish brown; belly, yellow; tip of tail, yellow. (Female.)

Bombycilla cedrorum.

Cedar Waxwing. Cedar Bird.

Eggs, usually I or 2. Size about $.87 \times .66$; deposited in some other bird's nest. Color, white or pale buff, irregularly and thickly marked with brown.

Molothrus ater.

Cowbird.

Eggs, 3 to 5 . Size, about .90 x.67; white, spotted and finely marked with pale brown or lilac-brown. Bird, throat and breast, bright yellow.

Icteria virens.

Yellow-breasted Chat.

Eggs, 4 to 6 . Size, about $.92 \times .6 \mathrm{I}$; dull white, sparsely scrawled and marked with dark brown or blackish. Nest, pendulous, hanging below the branch. Bird, under parts, orange yellow. (Female.)

Icterus galbula.

Baltimore Oriole. 
Eggs, 3 to 5 . Size, about $.98 \times .67$; pale blue, marked with rufous brown or olive brown. Bird, above, brownish; under parts, dull white, with narrow streaks of brown. (Female.) Zamelodialudoviciana.

Rose-breasted Grosbeak.

\section{PART 3. EGGS BETWEEN .95 AND r.05 IN. LONG.}

Eggs, 4 to 6 . Size, about .95 x.62; dull white, sparsely scrawled and marked with dark brown or blackish. Nest, pendulous, hanging below the branch. Bird, under parts, orange yellow. (Female.)

Icterus galbula.

Baltimore Oriole.

Eggs, 3 to 5 . Size, about $.95 \times .73$; clear white, marked with dark brown or blackish.

Tyrannus tyrannus.

Kingbird.

Eggs, 3 to 5 . Size, about . $98 \times .73$; dull white or ashy white, marked with olive brown.

Lanius ludovicianus.

Loggerhead Shrike.

PART 4. EGGS FROM I.05 TO I.30 IN. LONG.

Eggs, 3 to 6 . Size, about I.Io X .82; pale olive green or pale olive buff, marked and speckled with brown.

Cyanocitta cristata.

Blue Jay.

Eggs, 3 to 6 . Size, about $1.16 \times .82$; pale bluish or greenish, marked and scrawled with dark brown and black. Quiscalus quiscula aneus.

Bronzed Grackle.

PART 5. EGGS FROM I.30 TO 2 IN. LONG.

Eggs, 3 to 5. Size, about I.50 X I.20; dull white or buffy white, blotched with brown.

Accipiter velox.

Sharp-shinned Hawk.

Eggs, 4 to 6 . Size, about $1.66 \times$ x.18; generally pale green (sometimes bluish), marked with olive brown. Corvus brachyrhynchos.

American Crow.

Eggs, 3 to 6 . Size, about $1.92 \times 1,53$; pale bluish white or dull white, showing faint marking of pale brown.

Accipiter cooperii.

Cooper's Hawk.

Eggs, 2 to 4 . Size, about $1.95 \times 1.56$; dull white, spotted and blotched with olive brown or cinnamon-brown. Buteo platypterus.

Broad-winged Hawk.

PART 6. EGGS MORE THAN 2 IN. LONG.

Eggs, 2 to 4 . Size, about $2.05 \times 1.56$; dull white, spotted and blotched with olive brown or cinnamon-brown.

Buteo platypterus.

Broad-winged Hawk.

Eggs, 3 to 6. Size, about 2.15 5 1.70; dull white, marked and blotched with brown. Bird, tail showing white bars. Buteo lineatus.

Red-shouldered Hawk. 
736 Field Museum of Natural History-Zoölogy, Vol. IX.

Eggs, 2 to 4 . Size, about $2.40 \times 1.82$; dull white, scantily marked with olive brown or cinnamon-brown. Bird, tail, rufous brown, no white bars.

Buteo borealis.

Red-tailed Hawk.

SECTION 2. NEST IN HOLE IN TREE, STUMP OR POST.

PART I. EGGS LESS THAN I IN. LONG.

Eggs, 5 to 8 . Size, about $.73 \times .56$; white, marked with pale rufous brown or lavender brown.

Sitta carolinensis.

White-breasted Nuthatch.

Eggs, 3 to 6 . Size, about .90 x.69; pale cream-brown or buff white, marked and streaked longitudinally with chocolate brown.

Myiarchus crinitus.

Crested Flycatcher.

PART 2. EGGS MORE THAN I IN. LONG.

Eggs, 3 to 6 . Size, about $1.16 \times .82$; pale bluish or greenish, marked and scrawled with dark brown and black. Quiscalus quiscula ceneus.

Bronzed Grackle.

Eggs, 3 to 7 . Size, about I.38 x I.14; pale tawny brown or brownish white, marked and speckled with various shades of brown.

Falco sparverius.

Sparrow Hawk.

\section{SECTION 3. NEST ABOUT DWELLINGS AND BARNS.}

\section{PART I. EGGS LESS THAN I IN. LONG.}

Eggs, 4 to 6 . Size, about $.77 \times \cdot 54$; white, marked with cinnamon or olive brown. The slight difference in size will usually distinguish these eggs from those of next species. Bird, tail forked; belly, rufous brown.

Hirundo erythrogastra.

Barn Swallow.

Eggs, 4 to 5 . Size, about .8I x.55; white, marked with cinnamon or rufous brown; usually more pronounced than in preceding species. Bird, tail not forked; belly, white.

Petrochelidon lunifrons.

Cliff Swallow.

PART 2. EGGS MORE THAN I IN. LONG.

Eggs, 3 to 5. Size, about I.I 2 X.80; usually bluish green (unmarked), rarely with irregular spots of reddish brown.

Planesticus migratorius.

Robin.

Eggs, 2. Size, about $1.20 \times .85$; pale olive buff or grayish white, thickly marked and speckled with brown and washed in places with purplish gray. Eggs sometimes deposited on roof of house, usually in fields.

Chordeiles virginianus.

Nighthawk. 


\section{SECTION 4. NEST IN OPEN FIELDS ON GROUND OR IN BUNCH OF GRASS.}

Eggs, 4 to 5 . Size, about $.73 \times .56$; white, speckled and spotted with reddish brown, occasionally showing small markings of black and dull lavender. Bird, no stripes on throat or breast; belly, white.

Coturniculus savannarum australis.

Grasshopper Sparrow. Yellow-winged Sparrow.

Eggs, 4 to 5 . Size, about $.77 \times .56$; dull white or bluish white, thickly marked (somtimes washed) with cinnamon-brown or dull rufous brown, nearly obscuring the ground color. Bird, breast striped. a tinge of yellow over the eye. Passerculus sandwichensis savanna.

Savanna Sparrow.

Eggs, 4 to 5 . Size, about . $78 \times .60$; white or bluish white, irregularly marked with rufous brown. Bird, breast heavily streaked with dark brown.

Melospiza melodia.

Song Sparrow.

Eggs, 4 to 6 . Size, about $.82 \times .6 \mathrm{r}$; white or pinkish white, marked and scrawled with black and pale purplish brown.

Pocecetes gramineus.

Vesper Sparrow. Bay-winged Bunting.

Eggs, 4 to 7 . Size, about $.84 \times .62$; grayish white or dull white, with a few large blotches of vandyke brown and scattered dots of black and dull brown.

Dolichonyx oryzivorus.

Bobolink.

Eggs, usually I or 2. Size, about $.87 \times .66$; deposited in some other bird's nest. Color, white or pale buff, marked all over with irregular spots of brown.

Molothrus ater.

Cowbird.

Eggs, 4 to 6 . Size, about I.I $2 \times .80$; white, sparsely marked and speckled with brown and lilac-gray. The size will distinguish eggs of this species from others in this section. Sturnella magna (or races).

Meadowlark.

Eggs, 2. Size, about $1.20 \times .85$; pale olive buff or grayish white, thickly marked and speckled with brown and washed in places with purplish gray. Eggs deposited on ground or on a rock.

Chordeiles virginianus.

Nighthawk.

\section{SECTION 5. NEST ON GROUND IN WOODS IN DRY PLACES.}

\section{PART I. EGGS LESS THAN I IN. LONG.}

Eggs, 4 to 5 . Size, about $.80 \times .62$; white, speckled and spotted with cinnamon-brown, rufous brown, or lilac-gray markings. Nest, of good size, made of leaves and grasses, usually covered over, with entrance on side.

Seiurus aurocapillus.

Oven-bird. 


\section{Field Museum of Natural History-Zoölogy, Vol. IX.}

Eggs, usually I or 2. Size about $.87 \times .66$; deposited in some other bird's nest. Color, white or pale buff, thickly marked all over with irregular spots of brown.

Molothrus ater.

Cowbird.

\section{PART 2. EGGS MORE THAN I IN. LONG.}

Eggs, 2. Size, about I.I $6 \times .84$; dull white, with a few lilac-gray markings and spots of dull brown. Nest, eggs deposited on ground or a few leaves.

Antrostomus vociferus.

Whip-poor-will.

Eggs, 4. Size, about $1.53 \times 1.15$; pale buff, marked and spotted with light brown and rufous brown. Nest, eggs deposited on leaves on ground.

Philohela minor.

Woodcock.

\section{SECTION 6. NEST IN SWAMPY PLACES IN REEDS OR GRASS, ON GROUND OR ON FLOATING VEGETATION.}

\section{PART I. EGGS LESS THAN I IN. LONG.}

Eggs, 6 to 8 . Size, about $.66 \times .47$; usually pure white, rarely with few pale gray or lavender-spots. Nest, globe-shaped, with entrance on side.

Cistothorus stellaris.

Short-billed Marsh Wren.

Eggs, 4 to 5. Size, about . $76 \times \cdot 56$; whitish or bluish white, irregularly speckled and marked with rufous brown, similar but usually more thickly marked than next species. Bird, breast not streaked with brown.

Melospiza georgiana.

Swamp Sparrow.

Eggs, 4 to 5. Size, about .78 x.59; white or bluish white, irregularly speckled and marked with rufous brown. Bird, breast heavily streaked with brown.

Melospiza melodia.

Song Sparrow.

Eggs, usually I or 2. Size, about $.87 \times .66$; deposited in some other bird's nest. Color, white or pale buff, irregularly marked with brown.

Molothrus ater.

Cowbird.

PART 2. EGGS FROM I TO I.50 IN. LONG.

Eggs, 8 to I4. Size, about I.24 x.90; buff or pale brownish buff, sparsely marked with brown and purplish gray.

Porzana carolina.

Sora Rail. Carolina Rail.

Eggs, 6 to I2. Size, about I.25 X.95; pale buffy white, sparingly spotted and speckled with rufous brown and purplish gray. 
Eggs, 2 to 3 . Size, about $\mathrm{r} .35 \times .98$; brownish olive, heavily marked with dark brown.

Hydrochelidon nigra surinamensis.

Black Tern.

Eggs, 4. Size, about 1.50 x I.I5; pale buff, marked and spotted with light brown and rufous brown. Nest, eggs deposited on leaves on ground.

Philohela minor.

Woodcock.

\section{PART 3. EGGS MORE THAN r.5० IN. LONG.}

Eggs, 4. Size, about I.52 X I.I5; pale buff, marked and spotted with light brown and rufous brown. Nest, eggs deposited on leaves on ground.

Philohela minor.

American Woodcock.

Eggs, 7 to I 2. Size, about I.63 X 1.20; buffy white (rarely dull white), with scattered spots of rufous brown and occasional ones of pale lilac-brown. Nest, a platform of grass and weeds.

Rallus elegans.

King Rail.

Eggs, 3. Size, about I.78 x 1.20; variable; olive gray or pale buff, irregularly marked with dark brown. Nest, a mass of weeds.

Sterna forsteri.

Foster's Tern.

Eggs, 2. Size, about $3.50 \times 2.20$; olive or olive brown, with scattered marks and spots of brownish black.

Gavia immer.

Loon. 


\section{BIBLIOGRAPHY.}

\section{A LIST OF THE PRINCIPAL WORKS AND PAPERS ON THE BIRDS OF ILLINOIS AND WISCONSIN.}

\section{3}

Hoy, P. R. Notes on the Ornithology of Wisconsin. Proc. Acad. Nat. Sci. Phil., Vol. VI, $\times 85^{2-53}$, pp. 304-3r3.

Hoy, P. R. Notes on the Ornithology of Wisconsin, corrected and reprinted from the Proceedings of the Academy of Natural Sciences of Philadelphia. Trans. Wis. State Agri. Soc., Vol. II, I852 (I853), pp. $34 \mathrm{I}-364$.

LEBARon, Dr. WM. Observations upon some of the Birds of Illinois most interesting to the Agriculturist. Trans. I11. State Agri. Soc., Vol. I, r853, pp. $559-5^{6} 5$.

\section{4}

Barry, Rev. A. Ornithological Fauna of Wisconsin. Proc. Bost. Soc. Nat. Hist., Jan., $\times 854$.

\section{5}

Kennicott, R. Catalogue of the Animals observed in Cook County, Illinois. (Birds) Trans. I11. State Agri. Soc., Vol. I, r853-54 (r855), pp. 580-589.

Kennicott, R. Species observed in the middle and southern Portions of the State, which are not given in Mr. Pratten's Catalogue of the Birds of southern Illinois. Trans. I1l. State Agri. Soc., Vol. I, I853-54 (x855), pp. 589-59 r.

Pratten, H. Catalogue of the Birds of (southern) Illinois (Wayne and Edwards Counties). Trans. I11. State Agri. Soc., Vol. I, 1853-54 (1855), pp. 598-60y.

\section{6}

Kennicotr, R. Notes of the Occurrence of Plotus anhinga and Tantalus loculator in southern Illinois. Proc. Bost. Soc. Nat. Hist., I856, p. $39 \mathrm{r}$.

\section{7}

Brendel, F. Vögel der Umgegend Peorias in Illinois. Giebel's Zeitsch. für Naturw., 1857 , p. 420 .

1858

Cassin, J. Remarks on Falco polyagrus. Proc. Acad. Nat. Sci. Phil., r853. p. r,

$$
\text { 1859-60 }
$$

Holder, R. H. Birds of Illinois. Trans. Ill. State. Agri. Soc., Vol. IV, I $859-6 \circ$, pp. $605-6$ r 3 . 
1862

Holder, R. H. Catalogue of the Birds of Illinois (2d ed.). Trans. Ill. Nat. Hist. Soc., Vol. I, I862, p. 77 .

\section{5}

Clifford, E. A. Birds injurious and beneficial to the Horticulturist. Trans. I11. State Agri. Soc., $1861-64$ (1865), pp. 925-927.

\section{8}

Allen, J. A. Some Remarks upon the Birds of Iowa and Illinois. Proc. Bost. Soc. Nat. Hist., Vol. XII, 1868, p. 85 .

Allex, J. A. Notes on Birds observed in northern Illinois in June, 1867. Mem. Bost. Soc. Nat. Hist., Vol. I, 1868, pp. 502-522. 94 species.

\section{0}

Brendel, F. The Fauna of Peoria. Forming chap. XXXIX, pp. 2r7-223, of "The History of Peoria, Illinois," by Chas. Ballance, I870.

1871

Allex, J. A. The Fauna of the Prairies. Amer. Nat., Vol. V, I871, pp. 4-9.

1872

Ridgway, R. New Birds in southern Illinois. Amer. Nat., Vol. VI, July, I 872 , Pp. 430,43 I.

\section{3}

RIDGWAy, R. The Prairie Birds of southern Illinois. Amer. Nat., Vol. VII, April, I873, pp. 197-203.

1874

RIDGway, R. Catalogue of the Birds ascertained to occur in Illinois. Ann. Lyc. Nat. Hist. N. Y., Vol. X, Jan., r 874, pp. 364-394.

RIDGWAY, R. The Lower Wabash Valley considered in its relation to the Faunal Districts of the eastern Region of North America, with a Synopsis of its Avian Fauna. Proc. Bost. Soc. Nat. Hist., Vol. XVI, Feb. 18, r874, pp. 304-332.

Coues, E. Birds of Illinois. Field \& Stream (Chicago), May 2, r874. (A review of Ridgway's "Catalogue of the Birds ascertained to occur in Illinois," in Ann. Lyc. (Nat. Hist.) N. Y., Jan., r874, pp. 364-394).

EditoR's Note. Wild Pigeon very abundant in Michigan, Indiana and Wisconsin in Beech Woods, Sept. ${ }_{5}$, 1874. Forest \& Stream, Vol. III, 1874, p. 107 .

\section{5}

Allen, J. A. Notes on the Sharp-talled Finch. Proc. Bost. Soc. Nat. Hist., Vol. XVII, March, r875, pp. 292-294.

\section{6}

Jones, WM. L. April Birds in Illinois. Forest and Stream Aug. 3, 1876, p. 418 . 
Nelson, E. W. Additions to the Avi-fauna of Illinois, with Notes on other Species of Illinois Birds. Bull. Nutt. Orn. Club, Vol. I, No. 2, July, 1876, pp. 39-44.

Nelson, E. W. Notes upon Birds observed in southern Illinois between July $I_{7}$ and September 4, I875. Bull. Essex Inst., Vol. IX, I875, pp. 32-65.

Nelson, E. W. Birds of Northeastern Illinois. Bull. Essex Inst., Vol. VIII, Dec., I876 (April, I877), pp. 90-r 55 .

Eaton, D. H. Prairie Ornithology. Forest and Stream, Vol. VI, June I5, I 876, p. 301 .

EAton, D. H. Egg collecting in Illinois. Forest and Stream, Vol. VI, June $29, \mathrm{r} 876$, p. 337 .

\section{7}

"W. B." (Brewster, William). Nelson's "Birds of Northeastern Illinois." Bul1. Nutt. Orn. Club., Vol. II, July, I877, pp. 68-69. (Synopsis of Nelson's paper in Bull. Essex Inst., I876.)

Coale, H. K. Junco oregonus in Illinois. Bull. Nutt. Orn. Club, Vol. II, July, r877, p. 82. (Near Chicago, Oct. r4, r 875; one specimen.)

Conle, H. K. MacCown's Longspur in Illinois. Bull. Nutt. Orn. Club, Vol. II, April, 1877 , p. $5^{2}$.

Coale, H. K. Notes on Nyctale acadica. Bull. Nutt. Orn. Club, Vol. II, July, 1877 , pp. $8.3-84$.

Coues, E. Eastward range of the Ferruginous Buzzard (Archibuteo ferrugineus). Bu1l. Nutt. Orn. Club, Vol. II, 1877, p. 26.

Jones, W. L. Arrivals of Birds (at Lebanon, Illinois). Field and Forest, Vol. III, No. r, July, r 877 , pp. r $7 \sim r 8$.

Nelson, E. W. A Contribution to the Biography of Wilson's Phalarope. Bull. Nutt. Orn. Club, Vol. II, April, I877, pp. 38-43.

Nelson, E. W. Notes upon Birds observed in southern Illinois between July I7, and Sept. 4, I875. Bull. Essex Inst., Vol. IX, I877, pp. 32-65.

RoBerts, T. S. Notes on the Breeding of the Black Tern (Hydrochelidon lariformis) in Minnesota. Bull. Nutt. Orn. Club, Vol. II, I877, p. 34. (Contains some notes on the breeding habits in Illinois by E. W. Nelson.)

\section{8}

Brewster, WM. The Prothonotary Warbler (Pratonotaria citrea). Bull. Nutt. Orn. Club, Vol. III, r878, pp. r $53-162$.

Ridgway, R. Notes on Birds observed at Mt. Carmel, Southern Illinois, in the Spring of 1878 . Bull. Nutt. Orn. Club, Vol. III, No. 4, Oct., r878, pp $\mathrm{r} 62-\mathrm{r} 66$.

\section{9}

Gibss, DR. M. Annotated List of Birds, Michigan. Bull. U. S. Geogr. \& Geol. Surv. Terr., Vol. V, No. 3, Article XXIV, pp. 48 r to 497 inclusive. (Refers to occurrence of species in Illinois, p. 496.)

Ridgway, R. On a new Species of Peucca from southern Illinois and central Texas. Bull. Nutt. Orn. Club, October, r879, pp. 2 I8-222.

\section{0}

Allen, J. A. Eastward Range of the Western Meadow Lark. Bull. Nutt. Orn. Club, Vol. V, Jan., I 880 , p. 53. 
Ballou, W. H. Bird Arrivals at Evanston, Illinois. Amer. Nat., Vol. XIV, July, I880, p. 525 .

Deane, R. Destruction of Birds by Drowning. Bull. Nutt. Orn. Club, Vol. V, July, I880, p. 192 .

Nelson, E. W. Coturniculus lecontei. Bull. Nutt. Orn. Club, Vol. V, Jan., I $\$ 80$, p. $5^{\mathrm{I}}$.

Ridgway, R. On six Species of Birds new to the Fauna of Illinois, with Notes on other rare Illinois Birds. Bull. Nutt. Orn. Club, Vol. V, January, I88o, pp. 30-32.

RIDGWAY, R. The Northern Waxwing (Ampelis garrulus) in southern Illinois. Bull. Nutt. Orn. Club, Vol. V, April, r880, p. Ir 8.

Widmann, O. Notes on Birds of St. Louis, Mo. Bull. Nutt. Orn. Club, Vol. V, July, r880, p. r9r.

\section{1}

Forbes, S. A. The Snowbird (Junco hyemalis) in southern Illinois in June. Bull. Nutt. Orn. Club, Vol. VI, i88 I, p. I80.

HAY, O. P. Hesperiphona vespertina in central Illinois. Bull. Nutt. Orn. Club, Vol. VI, July, r88 I, p. I 79.

Hurter, J. The Harlequin Duck and the Glossy and Wood Ibises in southern Illinois. Bull. Nutt. Orn. Club, Vol. VI, April, I88I, p. I 24.

Ridgway, R. A Catalogue of the Birds of Illinois. Bull. No. 4, Ill. State Labr. Nat. Hist., May, I88I, pp. 16 $63^{-208}$.

RIDGWAY, R. An unaccountable Migration of the Red-headed Woodpecker. Bull. Nutt. Orn. Club, Vol. VI, April. I881, pp. I20-I 22.

\section{$1880-85$}

Nehring, H. Beiträge zur Ornis des nordlichen Illinois. Jour. fur Orn., Oct., I880, pp. 408-4I; April, I88I, pp. r96-203; Oct., I88I, pp. 405-4r6; Jan., r883, pp. 84-97; July, r883, pp. 225-257; April, I885, pp. I42-I 5 r.

\section{2}

Hunter, H. Wild Pigeons at Highland Park. Forest and Stream, Vol. XVIII, Feb., I882, p. 7 I.

Wheaton, DR. J. M. Report on Birds of Ohio. Report Geol. Surv. of Ohio, Vol. IV, Zoology and Botany, Part I, Columbus, Ohio, r882, pp.187-628.

\section{3}

Coale, H. K. The Willow Thrush and Holboll's Linnet in Illinois. Bull. Nutt. Orn. Club, Vol. VIII, Oct., I883, p. 239.

Cooxe, W. W. Mississippi Valley Migration. Ornithologist and Oölogist, Vol. VIII, No. I2, Dec., I883, pp. 89-9r.

Forbes, S. A. The Regulative Action of Birds upon Insect Oscillations. Bull. Ill. State Labr. Nat. Hist., Vol. I, No. 6, May, 1883, pp. 3-32.

Hancock, J. L. Parkman's Wren in Illinois. Bull. Nutt. Orn. Club, Vol. VIII, July, $x 883$, p. 179.

Howey, J. M. Bobolinks in northern Illinois. Ornithologist and Ozlogist, Feb., 1883 , p. 15 .

KING, F. H. Economic Relations of Wisconsin Birds. Geol. of Wis., Surv. of I873-1879, Vol. I, I883, pp. 444-610. 


\section{Field Museum of Natural History-Zoölogy, Vol. IX.}

Mundt, A. H. Oölogical and Ornithological. Ornithologist and Oölogist, Vol. VIII, No. 2, Feb., I883, pp. 9-10.

Ridgway, R. On Leconte's Bunting (Coturniculus lecontei) and other Birds observed in southeastern Illinois. Bull. Nutt. Orn. Club, Vol. VIII, Jan., I 883 , p. 58 .

Strumberg, C. W. Notes from Galesburg, I11. Ornithologist and Oölogist, Vol. VIII, No. I, Jan., r883, p. 8.

Willard, S. W. Migration and Distribution of North American Birds in Brown and Outagamie Counties. Trans. Wis. Acad. Sci., Vol. VI, I88 $1-83$, p. $177-196$.

1884

Cооке, W. W. Migration in the Mississippi Valley. Ornithologist and Orlogist, Vol. IX, No. 9, Sept., r884, pp. 105-108.

(W. S. C.) Notes from Peoria, Ill. Young Oölogist, Vol, I, No. 3, July, r884, p. 43 .

Henshaw, H. W. The Shore Larks of the United States and adjacent Territory. The Auk, Vol. I, I884, pp. 254-268. (Description of O. alpestris praticola var. nov: from Richland Co., Illinois, on page 264 .)

\section{5}

Coale, H. K. A new Bird for Illinois. The Auk, Vol. II, Jan., r885, pp. ro9, I ro.

Cooke, W. W. Bird Migration in the Mississippi Valley. Winter birds of southern Illinois. Forest and Stream, Vol. XXIII, No. 23, Jan. I, 1885, pp. 444,445 ; No. 24 , Jan. 8, I 885 , pp. 463,464 .

Dickinson, J. E. Note announcing Capture of a Specimen of Nyctala tengmalmi richardsoni at Rockford, Winnebago Co., Illinois, Oct. I5, I884. Ornithologist and Oölogist, March, r885, p. 47. (Snowy Owls and Northern Waxwings also mentioned.)

“'Kinney." Notes from 'northern Illinois. Young Oölogist, Vol. II, No. 2, June; 1885, p. 27.

Kline, H. A. Ruby-throated Hummingbirds. Ornithologist and Oölogist, Vol. IX, I884, p. Irg.

Sharpe, R. B. Catalogue of the Passeriformes or Perching Birds in the Collection of the British Museum, etc. Vol. X, London, r885, p. 305. (Lists a skin of an adult female bird, Geothlypis macgillivrayi, from Chicago. collected by Henry K. Coale.)

\section{6}

Beal, F. E. L. Some Notes on Bird Migration. Amer. Nat., Vol. XX, Sept., I 886, p. 8 r 7 .

\section{7}

Coale, H. K. Ornithological Curiosities. A Hawk with nine Toes and a Bobolink with Spurs on its Wings. The Auk, Vol. IV, r887, p. 33 r.

RIDGWAY, R. List of Birds found breeding within the corporate Limits of Mt. Carmel, Illinois. Ridgway Ornithological Club, Bulletin No. 2, A pril, I887, pp. 26-35. 


\section{8}

Cooke, W. W. Bird Migration of the Mississipp 1 Valley in the Years $1884-85$. Bull. No. 2, U. S. Dept. of Agri., Div. of Econom. Orn., I888, p. 3 r4.

Deane, R. Destruction in Migration. Forest and Stream, Vol. XXI, Dec., I 888 , p. 385 .

HANcock, J. L. The northern Range of Oporornis formosa in Ill. The Auk., Vol. V, r888, p. 2 ro.

HANcock, J. L. Impeded Migration and Destruction of Birds at Chicago. The Auk, Vol. V, 1888, pp. 432-434.

\section{9}

Brewster, WM. The present Status of the Wild Pigeon (Ectopistes migratorius) as a Bird of the United States, with some Notes on its Habits. The Auk, Vol. V, r 889 , p. $285^{-291 . ~(R e f e r s ~ t o ~ t h e ~ s p e c i e s ~ i n ~ W i s .) ~}$

GAult, B. T. Lapland Longspur at Chicago in June. The Auk, Vol V, I889, p. 278 .

Hough, E. Prairie Chickens in Morgan Park. Chicago and the West, Vol. XXXIII, Aug. 22, I889, p. 86.

Kimball, F. H. Mortality among Eave Swallows. The Auk, Vol. VI, r889, pp. $33^{8}-339$.

Ridgway, R. The Ornithology of Illinois. Nat. Hist. Surv. Ill., State Labr. Nat. Hist., Vol. I, I 889 .

Strode, IV. S. The Food of the Owls. Amer. Nat., Vol. XXIII, I889, pp. $17-24$.

\section{0}

Garman, H. A preliminary Report of the Animals of the Mississippi Bottoms near Quincy, Illinois. Trans. Wis. Acad. Sci., Vol. III, Part I, 1890 (1896), p. I3 1 .

"Korax." Yellow Rail in Chicago. Forest and Stream, Vol. XXXV, Dec., i 890, p. $43 \mathrm{I}$.

Poling, O. C. Notes on the Fringillidæ of Western Illinois. The Auk, Vol. VII, I 890, p. 238.

\section{1}

Butler, A. W. A Catalogue of the Birds of Indiana. Trans. Ind. Hort. Soc., I890, Appendix C, pp. I-I 35 .

Loucks, W. E. List of Birds found breeding in the Vicinity of Peoria, Ili. Oölogist, Vol. VIII, 189r, p. 224.

\section{2}

Butler, A. W. Notes on the Range and Habits of the Carolina Parrakeet. The Auk, Vol. IX, I892, pp. 49-56. (Refers to the species in Illinois.)

Hough, E. Ruffed Grouse at Hinsdale. Chicago and the West, Vol. XXXVIII, Aug., 1892, p. 86.

Hough, E. Bald Eagle killed at Calumet Heights. Chicago and the West, Vol. XXXVIII, Dec. I, I892, p. 469 .

Hатсн, P. L. Notes on the Birds of Minnesota. Geol. and Nat. Hist. Surv. of Minn. First report, June, 1892.

Loucks, W. E. An oölogical Trip to central Illinois. Oölogist, Vol. IX, I892, p. 196. 


\section{3}

Hough, E. Canvasback Ducks in Calumet Lake. Forest and Stream, Vol. XL, March 23, I893, p. 253.

Loucks, W. E. The Illinois River Valley from an Ornithologist's Standpoint. Oölogist, Vol. X, I893, p. I I9.

Murchison, A. C. Distribution of the Long-eared Owl and Cooper's Hawk in Illinois. Ornithologist and Oölogist, Vol. XVIII, I 893.

Murchison, A. C. Distribution of the Mocking Bird in Illinois. Ornithologist and Oölogist, Vol. XVIII, I 893, pp. 67-70.

Murchison, A. C. Distribution of the Black-crowned Night Heron in I1linois. Ornithologist and Oölogist, Vol. XVIII, I893, p. 82.

VAN Winkle. The Caspian or Imperial Tern. Oölogist, Vol. X, No, 4 , April, I 893 , p. II 4 .

White, S. E. Birds observed on Mackinac Island, Michigan, during the Summers of 1889 , I 890 , and I89I. The Auk, Vol X, I893, p. 228.

\section{4}

Clark, E. S. The Last of his Race. Chicago Tribune, Nov. 25, I894. (Passenger Pigeon takes refuge in Lincoln Park.)

Coale, H. K. Willow Thrush in Northeastern Illinois. The Auk, Vol. XI, July, I 894, p. 222.

Dickinson, J. E. Kirtland's Warbler in Illinois. Wilson Ornithological Chapter, Bull. No. 4, Oberlin, Ohio, Jan. I5, 1895.

GAULT, B. T. Kirtland's Warbler in Northeastern Illinois. The Auk, Vol. $\mathrm{XI}, \mathrm{I} 894$, p. 258.

Loucks, W. E. The Life History and Distribution of the Prothonotary Warbler in Illinois. Bull. I11. State Labr. Nat. Hist., Vol. IV, I894, pp. I0-35, with map.

\section{5}

Deane, R. Additional Notes on the Passenger Pigeon in Illinois and Indiana. The Auk, Vol. XII, Jan., I895, p. 98.

Deane, R. Additional Records of the Passenger Pigeon in Illinois and Indiana. The Auk, Vol. XII, July, I 895, pp. 298-300.

Dunn, J. O. Notes on some Birds of Northeastern Illinois. The Auk, Vol. XII, Oct., I 895, pp. 393-395.

Dunn, J. O. The Passenger Pigeon in the Upper Mississippi Valley. The Auk, Vol. XII, I895, p. 389 .

Gault, B. T. The Passenger Pigeon in Northeastern Illinois. The Auk, Vol. XII, I 895 , p. 80.

Gault, B. T. The Willow Thrush. The Auk, Vol. XII, I 895, p. 85.

Grundtvig, F. L. On the Birds of Shiocton in Bovina, Outagamie County, Wisconsin, $188 \mathrm{I}-83$. Trans. Wis. Acad. of Sci., Arts and Letters, Vol. X, I $894^{-1} 895$, pp. $73^{-1} 5^{8}$. (Translated by Chas. E. Faxon.)

Praeger, W. E. Two records from Keokuk, Iowa. The Auk, Vol. XII, I895, p. 85 .

Ridgway, R. The Ornithology of Illinois. Nat. Hist. Surv. I1l., State Labr. Nat. Hist., Vol. II, I 895 , illustrated. 


\section{6}

Cherrie, G. K. Ardetta neoxena from Wisconsin. The Auk, Vol. XIII, I896, p. 79.

Deane, R. Additional Records of the Passenger Pigeon (Ectopistes migratorius) in Wisconsin and Illinois. The Auk, Vol. XIII, r896, p. 8r.

Cory, C. B. A List of the Birds of Eastern North America, Boston, 1896. (Species which occur in Illinois are indicated.)

GaUlT, B. T. Recent Occurrence of the Turkey Vulture and Bald Eagle in Cook County, Illinois. Wilson Bull., No. 9, July 30 , r 896 , p. 3-4.

Hough, E. Acclimating Quail at Calumet Heights. Forest and Stream, Vol. XLVII, Dec., I896, p. 467 .

Woodruff, F .M. The Raven in Illinois. The Auk, Vol. XIII, r 896, pp. $83-84$. WOODRUFF, F. M. On Birds reported as rare in Cook County, Illinois. The Auk, Vol. XIII, I896, pp. I79-I8I.

\section{7}

Blackwelder, E. Notes on Occurrence of Smith's Longspur. The Osprey, Vol. I, I 897 , p. 67 .

Butler, A. W. The unusual Occurrence of Brunnich's Murre (Uria lomvia) far inland, with Notes on other rare Birds. The Auk, Vol. XIV, April, 1897, pp. 197-200.

Gault, B. T. Unusual winter Visitors in DuPage County, Illinois. Wilson Bull., No. I2, Jan., I 897 , p. Io.

Gault, B .T. Short Notes; The Red Crossbill. Wilson Bull., No. I3, March, I 897, p. 20 .

Hess, I. E. Nesting of Bachman's Sparrow. Nidologist, Vol. IV, r 897, p. 93.

Hough, E. Raven and Snowy Owl at Calumet Heights. Forest and Stream, Vol. XLIX, Nov. 20, I897, p. 40 r.

Woodruff, F. M. The Home of the Loggerhead Shrike. The Osprey, Vol. I, No. 8, r 897 , p. I०9.

Woodrupf, F. M. Lake Michigan Bird Notes. The Auk, Vol. XIV, r897, pp. $227-228$.

\section{8}

DeAne, R. The Passenger Pigeon (Ectopistes migratorius) in Wisconsin and Nebraska. The Auk, Vol. XV, I898, p. I84.

FERRY, J.F. Winter Observations at Lake Forest. The Osprey, Vol. II, I 898 , pp. 88-89.

Woodruff, F. M. Lake Michigan Notes. The Auk, Vol. XV, No. r, Jan., I 898 , pp. 6r-62, p. Iо9.

\section{9}

Blackwelder, E. A Note on Kirtland's Warbler (Dendroica kirtlandi). The Auk, Vol. XVI, I899, p. 359.

Bryan, WM. A. Pinicola enucleator canadensis and Tryngites subruficollis in Illinois. The Auk, Vol. XVI, r899, p. 276.

BRYAN, WM. A. Melanerpes erythrocephalus wintering in Chicago. The Auk, Vol. XVI, r 899, p. 272.

Chapman, F. M. Further Notes on Dendroica kirtlandi. The Auk, Vol. XVI, r 899, p. 8 r. 
748 Field Museum of Natural History - Zoölogy, Vol. IX.

Deane, R. Notes on the Breeding of the Wilson's Snipe (Gallinago delicata) in Illinois and Indiana. The Auk, Vol. XVI, r899, pp. 270-272.

Worthen, C. K. Capture of a second Specimen of Harlan's Hawk (Buteo harlani). The Osprey, Vol. IIII, I899, p. 94.

1900

Allen, J. A. The Little Black Rail. The Auk, Vol. XVII, Jan., I900, p. I. (Refers to the nesting of the species in Illinois.)

Bennetts, W. J. Occurrence of the Mocking Bird in Milwaukee County. Bull. Wis. Nat. Hist. Soc., Vol. I, (New series), No. I, r900, p. 6r.

Bennetts, W. J. On the Occurrence of the Evening Grosbeak in Milwaukee in the winter I899-I900. Bull. Wis. Nat. Hist. Soc., Vol. I, (New series), I 900 , P. I 29 .

Bennetts, W. J. Note on the Food of the Canada Jay (Perisoreus canadensis. Bull. Wis. Nat. Hist. Soc., Vol. I, (New series), I90o, p. I33.

Brandon, J. A. Notes on some migratory Birds. Bull. Wis. Nat. Hist. Soc., Vol I, (New series), Igoo, p. I 9 I.

Cory, C. B. Key to the Birds of Eastern North America. Boston, Mass., I 900 .

Gault, B. T. Bird Life at Glen Ellyn. Bird Lore, Vol. II, Dec., I 900, p. i 87.

Gault, B. T. A Correction (note on Empidonax trailli). Wilson Bull., No.32, I 900 , p. 9 .

Hess, I. E. The Prairie Hen in Illinois. Oölogist, Vol. 27 , 1900, p. I 35 .

Hough, E. Canada Goose at Calumet Heights. Forest and Stream, March 3I, I 900, p. 249.

Hough, E. Quail and Ruffed Grouse at Calumet Heights. Forest and Stream, Vol. LV, Nov. 24, I900, p. 405 .

Mead, G. S. The Red-headed Woodpecker near Chicago, Ill. The Auk, Vol. XVII, i900, p. 67.

Woodruff, F. M. The Western Willet. Birds and Nature, Vol. VIII, Nov., 1900, p. 146.

1901

Gault, B. T. The Christmas Bird Census at Glen Ellyn, Illinois. Bird Lore, Vol. III, I90I, p. 32 .

Ridgway, R. The Birds of North and Middle America. Bull. U. S. Nat. Mus., No. 50, part I, I90I.

1902

Deane, R. Second Record of the Purple Gallinule in Illinois. The Auk, Vol. XIX, I902, p. 77.

Farwell, Ellen Drummond. The Carolina Wren at Lake Forest, Illinois. The Auk, Vol. XIX, I902, p. 209.

Gault, B. T. Food Habits of the Wilson's Snipe. Wilson Bull., No. 38, March, I902, p. 7 .

Hess, I. E. An Illinois Heronry. Oslogist, Oct., r902, p. I45.

Ridgway, R. The Birds of North and Middle America. Bull. U. S. Nat. Mus., No. 50, part 2, I902.

SNyder, W. E. Notes on the rarer Birds of Dodge Co., Wisconsin. Bull. Wis. Nat. Hist. Soc., Vol. II, No. 2, 1902, p. 109.

Wheelock, Irene G. Rare Birds seen at Lake Forest. Inter Ocean, March, I 902 . 
Winkenwerder, H. A. The winter Habits of the Red-headed Woodpecker. Bull. Wis. Nat. Hist. Soc., Vol. II, No. I, I 902, p. 69.

Winkenwerder, H. A. Some recent Observations of the Migration of Birds. Bull. Wis. Nat. Hist. Soc., Vol. II, No. 2, 1902, p. 97.

Winkenwerder, H. A. The Migration of Birds, with special Reference to nocturnal Flight. Bull. Wis. Nat. Hist. Soc., Vol. II, No. 4, 1902, pp. I $77-26_{3}$.

\section{3}

Аввотт, G. A. Nesting of the Least Bittern. Birds and Nature, Vol. XIV, No. 2, Sept., I903, p. 7 r.

DeAne, R. Richardson's Owl (Nyctala tengmalmi richardsoni) in Illinois. The Auk, Vol. XX, I903, p. 433.

DeANe, R. Richardson's Owl (Nyctala tengmalmi richardsoni) in Illinois. The Auk, Vol. XX, I903, p. 305.

Kumlien, L. \& Hollister, N. The Birds of Wisconsin. Bull. Wis. Nat. Hist. Soc., Vol. III, Nos. I, 2 and 3, 1903.

\section{4}

Cooke, W. W. On Migration of the Hooded Warbler. Bird Lore, Vol. VI, No. I, Jan.-Feb., I904, p. 22.

Cooke, W. W. Migration of Warblers. Bird Lore, Vol. VI, No. 2, April, I 904, pp. 57-60.

Cooke, W. W. Distribution and Migration of North American Warblers. Bull. No. I8, U. S. Dept. of Agri., Div. Biol. Surv., 1904, p. I42.

Ridgway, R. The Birds of North and Middle America. Bull. U. S. Nat. Mus., No. 50, part 3, I 904 .

Woodruff, F. M. The Loon. Birds and Nature, Vol. XVI, Nov., I 904, pp. I 9 I $-I 9^{2}$.

Woodrupf, F. M. The Sora Rail. Birds and Nature, Vol. XVI, Dec., I904, pp. $201-202$.

\section{5}

Aввотт, G. A. Nesting of the Woodcock. Bull. Mich. Orn. Club, MarchJune, r 905 , p. ro.

Deane, R. Hybridism between the Shoveller and Blue-winged Teal. The Auk, Vol. XXII, 1905, p. 32 I.

Deane, R. Additional record of the European Widgeon. The Auk, Vol. XXII, January, I 905 , p. 76 .

SNyder, W. E. The Gray Gerfalcon in Wisconsin. The Auk, Vol. XXII, I 905 , P. I 43.

Skavlem, H. L. Canvasback Duck Food. The Northwestern Sportsman, I 905 , pp. I6I-164, 236-240

Skavlem, H. L. Canvasback Duc's Food (abstract from preceding paper). Bull. Wis. Nat. Hist. Soc.; Vol. III, No. 4, I 9c5, p. I63.

Thurber, C. The Hermit Thrush. Birds and Nature, Vol. XVIII, No. 2, Sept., r905, p. 50.

Wheelock, Irene G. Regurgitative Feeding of Nestlings. The Auk, Vol. XXII, January, 1905, p. 54. 
1906

Butler, A. W. Some Notes on Indiana Birds. The Auk, Vol. XXIII, I 906 , P. 27 I.

Deane, R. A northern Record for the Swallow-tailed Kite (Elanoides forficatus) in Wisconsin. The Auk, Vol. XXIII, 1906, p. 100.

Deane, R. Unusual Abundance of the Snowy Owl (Nyctea nyctea). The Auk, Vol. XXIII, I 906, pp. 283-298. (Illinois records, pp. 297, 298.)

Norton, A. H. The eastern Distribution of the Prairie Horned Lark, a question of evidence. The Auk, Vol. XXIII, r906, p. 225.

Ward, H. L. Notes on the Herring Gull and the Caspian Tern. Bull. Wis. Nat. Hist. Soc., Vol. IV, No. 4, I 906, pp. II3-I34, 2 plates.

Wheelock, Irene G. Nesting Habits of the Green Heron. The Auk, Vol. XXIII, 1906, p. 432 .

Wilson, B. H. The Birds of Scott County, Iowa. The Wilson Bulletin, Vol. XVIII, March, I906, p. I.

\section{7}

Anderson, R. M. The Birds of Iowa. Proc. Dav. Acad. Sci., Vol. XI, I907, p. I $25-4$ I 7 .

Daggett, F. S. The Whistling Swan in Northeastern Illinois. The Auk, Vol. XXIV, 1907, p. 337 .

Deane, R. Unusual Abundance of the American Goshawk (Accipiter atricapillus). The Auk, Vol XXIV, I907, p. I82.

Ferry, J. F. Ornithological Conditions in Northeastern Illinois, with Notes on some winter Birds. The Auk, Vol. XXIV, I907, p. I2I.

Ferry, J. F. Winter Bird Notes from extreme southern Illinois. The Auk, Vol. XXIV, 1907, p. 281.

Ferry, J. F. Further Notes from extreme southern Illinois. The Auk, Vol. XXIV, 1907, p. 430.

Forbes, S. A. An Ornithological Cross-section of Illinois in Autumn. Bull. I11. State Labr. Nat. Hist., Vol. VII, I 907, pp. 305-335.

Ridgway, R. The Birds of North and Middle America. Bull. U. S. Nat. Mus., No. 50, part 4 , I907.

Widmans, O. A preliminary Catalogue of the Birds of Missouri. St. Louis, I 907 .

Woodruff, F. M. The Birds of the Chicago Area. Bull. No. VI of the Nat. Hist. Surv. The Chicago Academy of Sciences, April I5, I907.

Woodruff, F. M. Rare northern Birds near Chicago. The Auk, Vol. XXIV, 1907 , p. 107 .

Woodruff, F. M. Malformed Bill of Rose-breasted Grosbeak. The Auk, Vol. XXIV, I 907, p. 220.

\section{8}

DAGgett, F. S. Capture of the American Goshawk and Harris's Sparrow near Chicago, I11. The Auk, Vol. XXV, 1908, p. 82.

Gross, A. O. Swainson's Warbler (Helinaia swainsoni). The Auk, Vol. XXV, 1908, p. 225 .

WARD, H. L. Occurrence of a Dovekie at Port Washington, Wisconsin. The Auk, Vol. XXV, igo8, p. 2 I $5^{\circ}$.

Wyman, L. E. The Prairie Warbler near Chicago. The Auk, Vol. XXV, rgo8, p. 87 


\section{INDEX}

\section{A}

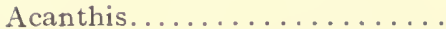

Acanthis hornemannii exilipes.

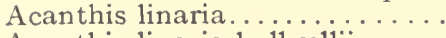

Acanthis linaria holbœllii......

Acanthis linaria rostrata......

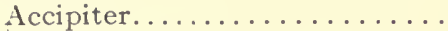

Accipiter atricapillus.........

Accipiter cooperii............

Accipiter velox .............

Actitis.

Actitis macuları...........

Echmophorus ............

Echmophorus occidentalis....

Agialitis meloda............

Agialitis meloda circumcincta. .

Agialitis semipalmata........

Egialitis vocifera...........

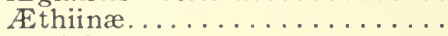

Agelaius................

Agelaius phoeniceus.........

Agelaius phœeniceus arctolegus..

Aimophila

Aimophila æestivalis bachmanii.

Aix.

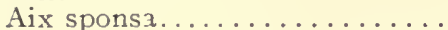

Ajaia.................

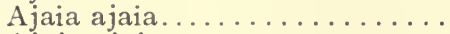

Ajaja ajaja...............

Alaudidæ................

Alcedinidæ...............

Alcidæ.................

Alcyones .................

Alle...................

Alle alle................

Allinæ.................

Aluco ...................

Aluco pratincola............

Aluconidæ................

Ammodramus caudacutus nel-

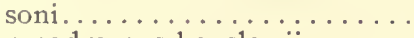

Ammodramus henslowii.......

Ammodramus leconteii........

Ammodramus sandwichensis savanna...............

Ammodramus savannarum pas-

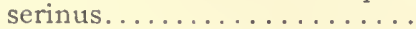

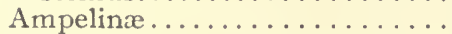

Ampelis cedrorum..........

Ampelis garrulus............

Anas...................

Anas americana............

Anas boschas.
Anas carolinensis ........... 325

Anas cyanoptera........... 327

Anas discors.............. 326

Anas obscura............. 32 I

Anas penelope............. 323

Anas platyrhynchos......... 320

Anas rubripes.................. 32 I

Anas rubripes tristis ........ 322

Anas strepera........... 322

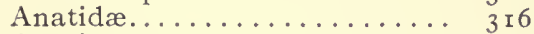

Anatinæ................ 3 I 9

Anhinga.............................. 307

Anhinga anhinga.......... 307

Anhingidæ.............. 307

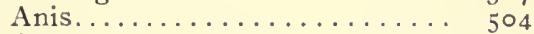

Anser..................... 350

Anser albifrons gambeli...... 350

Anseres............................ 3 I 6

Anserinæ............... 347

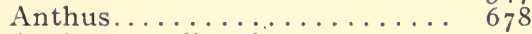

Anthus pensilvanicus............. 678

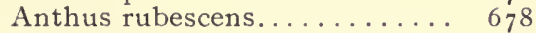

Antrostomus................ 52 I

Antrostomus carolinensis ..... 52 I

Antrostomus vociferus....... 522

Aphrizidæ.............. 430

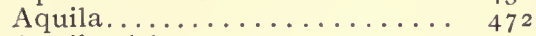

Aquila chrysaëtos.......... 472

Aramidæ................ 379

Aramus................. 380

Aramus giganteus........... 380

Aramus vociferus........... 380

Archibuteo............... 469

Archibuteo ferrugineus....... 469

280 Archibuteo lagopus sancti-jo-

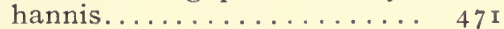

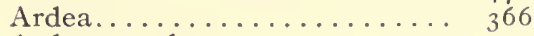

Ardea cærulea.............. 370

Ardea candidissima............... 368

Ardea egretta....................... 367

Ardea herodias............ 366

588 Ardea rufescens............ 369

586 Ardea virescens.......................... 37

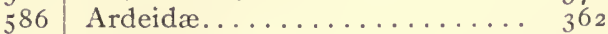

Ardeinæ............... 366

584 Ardetta exilis....................... 364

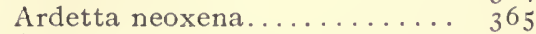

$5^{85}$ Arenaria .............. 43 I

624 Arenaria interpres........... 43 I

625 Arenaria interpres morinella ... 43 I

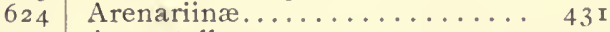

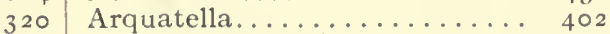

324 Arquatella maritima........ 402

320 As1o................. 486 
Asio accipitrinus.

488

Asio flammeus..............

Asio wilsonianus............

Astragalinus...............

Astragalinus tristis..........

Astur.

Astur atricapillus............

Astur atricapillus striatulus....

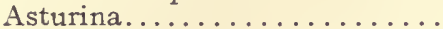

Asturina plagiata...........

Auk, Little................

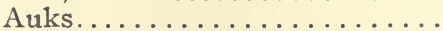

Avocet, American...........

Avocets..................

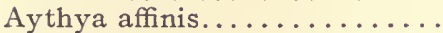

Aythya americana...........

Aythya collaris.

Aythya marila nearctica... . . . .

Aythya vallisneria..........

\section{B}

Bæolophus...............

Bæolophus bicolor...........

Baldpate (Duck).

Bald Brant. . . . . . . . . . . . . . . . . .

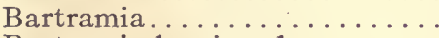

Bartramia longicauda.........

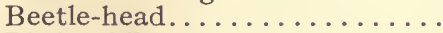

Birds of Prey..............

Bittern, American...........

Bittern, Cory's Least. . . . . . . . . .

Bittern, Least. . . . . . . . . .

Bitterns.................

Blackbird, Arctic Red-winged..

Blackbird, Brewer's..........

Blackbird, Red-winged........

Blackbird, Rusty............

Blackbird, Yellow-headed......

Blackbirds................

Black-breast..............

Blackhead (Duck)............

Bluebill (Duck) .................... 3333

Bluebird................... 7 I 4

Bluebird, Mountain............ 7 I 5

Bluebirds............. 705, 7 I 4

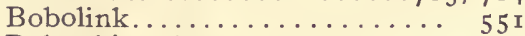

Bob-white............... 432

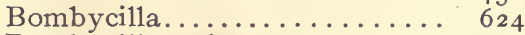

Bombycilla cedrorum........ 625

Bombycilla garrula.......... 624

Bombycillidæ............ 624

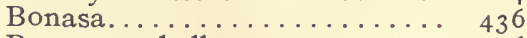

Bonasa umbellus............ 436

Bonasa umbellus togata...... 437

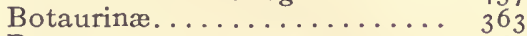

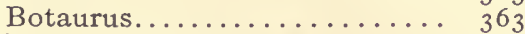

Botaurus lentiginosus........ $3_{3} 6_{3}$

Brant......................... 353

Brant, Bald............. 349

Brant, Blue.............. 349

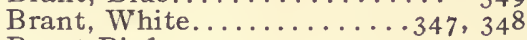

Brant Bird............. 43 I
Branta........................ 35 r

Branta bernicla.......... 353

Branta bernicla glaucogastra... 353

Branta canadensis.......... 35 I

Branta canadensis hutchinsii... $35^{2}$

Branta canadensis minima.... 352

Broadbill (Duck).......... 328

Bubo.................. 495

Bubo virginianus........... 495

Bubo virginianus pallescens.... 497

Bubo virginianus subarcticus... 497

Bunting, Black-throated...... 6 6 3

Bunting, Indigo........... 6 I I

Bunting, Painted........... 6 I 2

Bunting, Snow............ 579

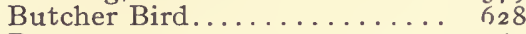

Buteo................. 460

Buteo borealis............. 460

Buteo borealis calurus........ $46_{3}$

Buteo borealis harlani......... $46_{3}$

Buteo borealis kriderii........ 462

Buteo latissimus............ ${ }_{4} 67$

Buteo lineatus.............. 464

Buteo platypterus.......... 467

Buteo swainsoni............ 465

Buteoninæ................... 45 I

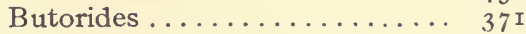

Butorides virescens......... 37 I

Butter-ball (Duck).......... 338

Butter-bill Coot............ 343

Buzzard, Turkey........... 449

\section{C}

Calcarius................. 580

Calcarius lapponicus......... 580

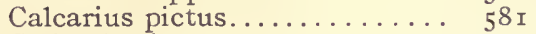

Calico-back.............. 43 I

Calidris................ 409

Calidris arenaria.......... 409

Calidris leucophæa........... 409

Campephilus.............. 508

Campephilus principalis....... 508

Canachites............. 435

Canachites canadensis canace... 435

Caprimulgi................. 52 I

Caprimulgidæ............. 52 I

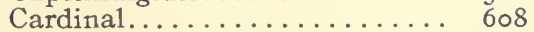

Cardinalis................. 608

Cardinalis cardinalis......... 608

Carpodacus............... $\quad 5_{50}$

Carpodacus purpureus........ 569

Catbird............... 682

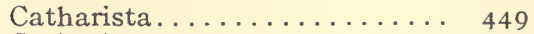

Catharista atrata.......... 449

Catharista urubu............ 449

Cathartes............... 449

Cathartes aura septentrionalis. . 449

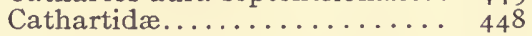

Catoptrophorus............. 4 I 6

Catoptrophorus semipalmatus. . 4 r6

Catoptrophorus semipalmatus inornatus............. 


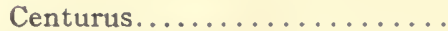

Centurus carolinus...........

Cepphi.................

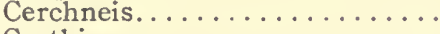

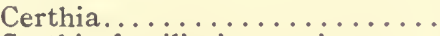

Certhia familiaris americana...

Certhiidæ...............

Ceryle..................

Ceryle alcyon ............

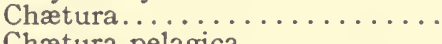

Chætura pelagica............

Chæturinæ...............

Charadriidæ..............

Charadrius...............

Charadrius dominicus.........

Charadrius squatarola.........

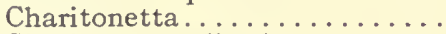

Charitonetta albeola..........

Chat, Yellow-breasted.........

Chaulelasmus..............

Chaulelasmus streperus........

Chelidon erythrogastra........

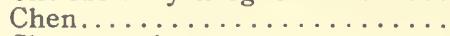

Chen cærulescens..........

Chen hyperborea...........

Chen hyperborea nivalis.......

Chickadee....................

Chickadee, Hudsonian........

Chickadee, Long-tailed........

Chickadees................

Chondestes...............

Chondestes grammacus........

Chordeiles................

Chordeiles virginianus

Chordeiles virginanus....... 523

Chordeiles virginianus henryi... 525

Chordeiles virginianus sennetti.. $\quad 524$

Chuck-will's Widow......... 52 I

Ciconiæ.................. 360

Ciconiidæ............... 360

Circus................ 455

Circus hudsonicus.......... 455

Cistothorus............. 689

Cistothorus palustris......... 690

Cistothorus stellaris.......... 689

Clamatores............. 529

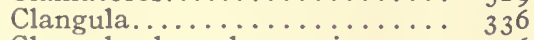

Clangula clangula americana... 336

Clangula hyemalis.......... 340

Clangula islandica.......... 337

Clivicola riparia............ 622

Coccothraustes vespertinus..... 566

Coccyges................. 504

Coccyginæ.............. 504

Coccyzus............... 504

Coccyzus americanus......... 504

Coccyzus erythropthalmus...... 505

Colaptes............... 5 I 9

Colaptes auratus luteus....... 5 I 9

Colinus.............. 432

Colinus virginianus........... $44^{2}$

Columbæ................ 444

Columbidæ............. 444

Colymbi.............. 275

Colymbidæ............. 275

Colymbus............... 276

Colymbus a uritus......... 277

Colymbus holbœllii.......... 276

Colymbus nigricollis californicus. $\quad 277$

Compsothlypis............ 647

Compsothlypis americana..... 647

Compsothlypis americana rama-

linæ................. 647

Contopus borealis......... 534

Contopus richardsonii........ 535

Contopus virens........... 535

Conuropsis............... 501

Conuropsis carolinensis......... 5 01

Conurus carolinensis.......... 501

Coot, American............................. 387

Coot (see Ducks)............ 343

Coot, White-winged (Duck) .... 344

Coots..................... 379, 380

Cormorant, Double-crested .... 309

Cormorant, Florida.......... 3 ro

Cormorant, Mexican........... 3 I I

Cormorants............307, 308

Corvidæ............... 542

Corvinæ................... 546

Corvus.............. 546

Corvus americanus.......... 548

Corvus brachyrhynchos....... 548

Corvus corax principalis....... 546

Corvus corax sinuatus........ 547

Coturnicops.............. 384

Coturnicops noveboracensis..... 384

Coturniculus.............. 585

Coturniculus henslowii........ 586

Coturniculus leconteii.......... 586

Coturniculus savannarum australis............... $5^{85}$

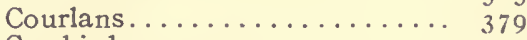

Cowbird............... $55^{2}$

Crane, Little Brown........ 377

Crane, Sandhill............. 377

Crane, Whooping............ 376

Cranes................ 375

Creciscus...................... 385

Creciscus jamaicensis,......... ${ }_{3} \varepsilon_{5}$

Creeper, Black \& White (see

Warbler)............. 638

Creeper, Brown............ 693

Creepers................. 693

Crossbill, American.......... $57 \mathrm{r}$

Crossbill, Red.............. $57 \mathrm{I}$

Crossbill, White-winged...... 572

Crossbills................ 565

Crow, American........... 548

Crow, Carrion............ 449

Crows................ 542

Crow-blackbird.......... 564

Crymophilus fulicarius........ 390

Cuckoo, Black-billed.......... 505

Cuckoo, Yellow-billed.......... 504

Cuckoos................. 504

Cuckoos, American.......... 504 
Cuculi.................. 504

Cuculidæ................ 504

Curlew, Eskimo............. 423

Curlew, Hudsonian........... . 423

Curlew, Jack. ............. 423

Curlew, Long-billed.......... 42 I

Cyanocitta............... 544

Cyanocitta cristata......... 544

Cygninæ................ 354

Cypseli................ 525

D

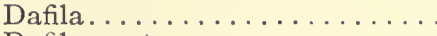

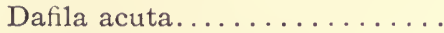

Darters. . . . . . . . . . . . . .

Dendragapus canadensis. . . . .

Dendroica................

Dendroica æstiva...........

Dendroica.blackburniæ........

Dendroica cærulescens........

Dendroica castanea..........

Dendroica cerulea............

Dendroica coronata..........

Dendroica discolor... . . . . . . .

Dendroica dominica albilora....

Dendroica kirtlandii..........

Dendroica maculosa..........

Dendroica magnolia...........

Dendroica palmarum.........

Dendroica pensylvanica........

Dendroica striata...........

Dendroica tigrina............

Dendroica vigorsii............

Dendroica virens.............

Dichromanassa............ .

Dichromanassa rufescens.......

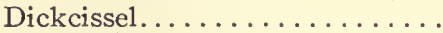

Dipper (Duck).............

Diving Birds...............

Dolichonyx.............

Dolichonyx oryzivorus........

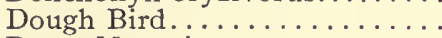

Dove, Mourning.............

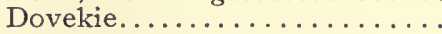

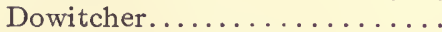

Dowitcher, Long-billed........

Dryobates.................

Dryobates pubescens medianus.

Dryobates villosus............

Dryobates villosus leucomelas...

Duck, American Eider.........

Duck, American Golden-eye....

Duck, American Scoter........

Duck, Barrow's Golden-eye.....

Duck, Black...............

Duck, Buffle-head..............

Duck, Canvas-back ..........

Duck, Creek..................

Duck, Dusky Mallard (see Black Duck)................

Duck, Gadwall ..............

Duck, Gray...............

Duck, Harlequin ...........
Duck, King Eider...........

Duck, Lesser Scaup. . . . . . . . . .

Duck, Long-tailed. . . . . . . . . . .

Duck, Mallard.............

Duck, Masked .............

Duck, Old Squaw...........

Duck, Pheasant............

Duck, Pintail................

Duck, Redhead.............

Duck, Red-legged Black.......

Duck, Ring-necked..........

Duck, Ruddy................

Duck, Scaup...............

Duck, Serf Scoter.............

Duck, Summer . . . . . . . . . . . .

Duck, Velvet...............

Duck, (Widgeon) ............. 324

Duck, Wood............. 330

Ducks.................... 316

Ducks, River and Pond....... 3 I9

Ducks, Sea.............. 33 I

Dumetella.................. 682

Dumetella carolinensis....... 682

\section{E}

Eagle, Bald............. 474

Eagle, Golden............ 472

Eagles.................... $45 \mathrm{r}$

Ectopistes............. 444

Ectopistes migratorius....... 444

Egret, American........... 367

Egret, Reddish............. 369

Egrets............... 362

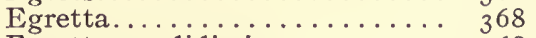

Egretta candidissima......... 368

Elanoides............... $45^{\mathrm{r}}$

Elanoides forficatus.......... $45 \mathrm{I}$

Elanus................ 453

Elanus leucurus........... 453

Empidonax............... ${ }_{536}^{45}$

Empidonax flaviventris....... 536

Empidonax minimus....... 539

Empidonax traillii............. 538

Empidonax traillii alnorum.... 539

Empidonax virescens......... 537

Ereunetes............... 408

Ereunetes mauri.......... 409

Ereunetes occidentalis......... 409

Ereunetes pusillus........... 408

Erionetta................ 343

Erismatura .............. 346

Erismatura jamaicensis........ 346

Erismatura rubida.......... 346

Euphagus.................... ${ }_{562}^{362}$

Euphagus carolinus.......... $5_{562}$

Euphagus cyanocephalus...... $5_{56}$

\section{F}

Falco............... 475

Falco columbarius............ 479

Falco columbarius richardsonii . $48 \mathrm{r}$ 
Falco mexicanus............

Falco peregrinus anatum......

Falco rusticolus..............

Falco sparverius.............

Falcon, Peregrine............

Falcon, Prairie.............

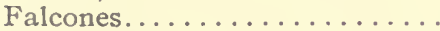

Falconidæ...............

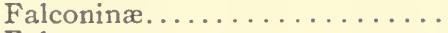

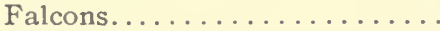

Finch, Purple.............

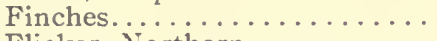

Flicker, Northern. . . . . . . . .

Florida.

Florida cærulea ............

Flycatcher, Acadian..........

Flycatcher, Alder...........

Flycatcher, Crested...........

Flycatcher, Green-crested......

Flycatcher, Least. . . . . . . . . .

Flycatcher, Olive-sided.........

Flycatcher, Phœebe...........

Flycatcher, Say's Phœbe.......

Flycatcher, Scissor-tailed.......

Flycatcher, Traill's...........

Flycatcher, Yellow-bellied .....

Flycatchers...............

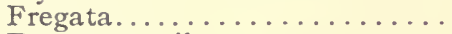

Fregata aquila............

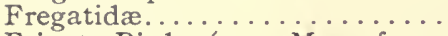

Frigate Bird (see Man-of-war

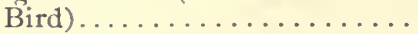

Fringillidæ.............

Fulica.................

Fulica americana...........

Fulicinæ...............

Fuligulinæ.

\section{G}

Gadwall (Duck)

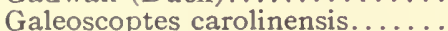

Gallinaceous Birds...........

Gallinæ..................

Gallinago................

Gallinago delicata..........

Gallinula.

Gallinula galeata...........

Gallinule, Florida...........

Gallinule, Purple............

Gallinules................ 379, 380

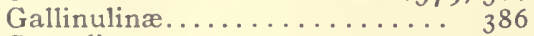

Garrulinæ............... 543

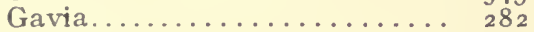

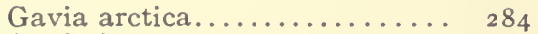

Gavia immer.............. 282

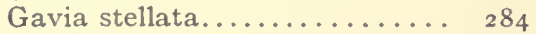

Gaviidæ................. $28{ }_{2}$

Geese..................... 316,347

Gelochelidon............... 298

Gelochelidon nilotica........ 298

Geothlypis ............. 67 I

Geothlypis agilis........... 669
Geothlypis formosa........... 668

Geothlypis philadelphia....... 670

Geothlypis trichas...........6.67

Geothlypis trichas brachidactyla $\quad 672$

Glaucionetta clangula americana.................. 336

Glaucionetta islandica ....... 337

Glaux................. 49

Glaux acadicus........... 493

Glaux funerea richardsoni...... 49 I

Gnatcatcher, Blue-gray....... 704

Gnatcatchers ..........702, 704

Goatsuckers.................... 52 I

Godwit, Hudsonian......... 4 4 I

Godwit, Marbled........... 410

Goggle-nose (Duck)......... 345

Goldfinch, American......... 577

Goose, American White-fronted $35^{\circ}$

Goose, Blue.............. 349

Goose, Brant............... 353

Goose, Cackling............ 352

Goose, Canada............. 35 I

Goose, Greater Snow. . . . . . . . . 348

Goose, Hutchin's. . . . . . . . . 352

Goose, Lesser Snow. . . . . . . . . . . 347

Goose, Yellow-legged......... 350

Goshawk, American......... 458

Goshawk, Mexican.......... 469

Goshawk, Western........... 460

Grackle, Bronzed ........... 564

Grass-bird............... . 403

Grass-snipe............... 403

Grebe, American Eared....... 277

Grebe, Holboll's............ 276

Grebe, Horned............. 277

Grebe, Pied-billed........... 278

Grebe, Western.............. 276

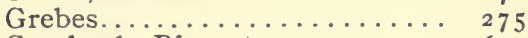

Grosbeak, Blue........... 6 10

Grosbeak, Cardinal.......... 608

Grosbeak, Evening.......... 566

Grosbeak, Pine.............. 568

Grosbeak, Rose-breasted...... 609

Grouse..............4432, 435

Grouse, Canada........... 435

Grouse, Canadian Ruffed...... 437

Grouse, Pinnated........... 439

Grouse, Prairie Sharp-tailed... . 44 I

Grouse, Ruffed............ 436

Grouse, Spruce............. 435

Grues................... 375

Gruidæ................. 375

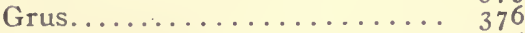

Grus americana ................ 376

Grus canadensis .......... 377

Grus mexicana........... 377

Guara.................. 359

Guara alba............... 359

Guillemot (see Murre)........ 28 I

Guiraca.................. 610

Guiraca cærulea........... 6ro

Gull, Bonaparte's............ 296

Gull, Franklin's............. 295 
Gull, Glaucous .

290

291

Gull, Herring............

Gull, Iceland ..............

Gull, Kittiwake...........

Gull, Laughing............

Gull, Ring-billed...........

Gull, Sabine's..............

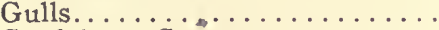

Gyrfalcon, Gray.............

\section{$\mathrm{H}$}

Habia ludoviciana..........

Haliæetus................

Haliæetus leucocephalus.......

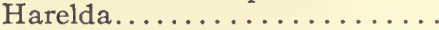

Harelda hyemalis...........

Harporhynchus rufus ........

Hawk, American Rough-legged..

Hawk, American Sparrow..... .

Hawk, Broad-winged.........

Hawk, Cooper's..............

Hawk, Duck................

Hawk, Ferruginous Rough-legged

Hawk, Fish.................

Hawk, Harlan's............ 463

Hawk, Krider's Red-tailed. . . . $44_{42}$

Hawk, Marsh............. 455

Hawk, Pigeon............ 479

Hawk, Red-shouldered........ 464

Hawk, Red-tailed........... 460

Hawk, Richardson's Pigeon,.... 48 I

Hawk, Sharp-shinned......... 456

Hawk, Swainson's.......... 465

Hawk, Western Red-tailed..... 463

Hawks................ 45

Hawks, Fish............... 483

Helinaia.............. 64 I

Helinaia swainsonii.......... 64 I

Helminthophila celata........ 645

Helminthophila chrysoptera... 644

Helminthophila peregrina..... 646

Helminthophila pinus......... 643

Helminthophila ruficapilla...... 645

Helmitheros............. 642

Helmitheros vermivorus....... 642

Helodromas.............. 4 I 5

Helodromas solitarius......... 4 4 5

Hell Diver.............. ${ }_{36} 6$

Herodias................ 367

Herodias egretta.......... 367

Herodii............... 262

Herodiones. $. \ldots \ldots \ldots \ldots \ldots . \quad 357$

Heron, Black-crowned Night... 372

Heron, Great Blue.......... 366

Heron, Green............ $37 \mathrm{I}$

Heron, Little Blue.......... 370

Heron, Snowy........... 368

Heron, Yellow-crowned Night. 373

Herons............357, 362, 366

Hesperiphona............... ${ }_{5} 66$
Hesperiphona vespertina...... 566

Hierofalco.............. 475

Himantopus............. 394

Himantopus mexicanus....... 394

Hirundinidæ.............. 6 r 8

Hirundo............... 620

Hirundo erythrogastra........ 620

Histrionicus............. $34 \mathrm{I}$

Histrionicus histrionicus....... 34 I

Hummingbird, Ruby-throated. . $\quad 527$

Hummingbirds............. 527

Hydrochelidon............. 304

Hydrochelidon leucoptera..... 305

Hydrochelidon nigra surinamensis................. 304

Hylocichla............. 707

Hylocichla aliciæ.......... 709

Hylocichla aliciæ bicknelli...... 7 ro

Hylocichla fuscescens......... 708

Hylocichla fuscescens salicicola.. 708

Hylocichla guttata pallasii.... 7 I I

Hylocichla mustelina........ 707

Hylocichla ustulata almæ...... 7 r I

Hylocichla ustulata swainsonii.. 7 I

\section{I}

Tbides................ 357

Ibididæ................ 358

Ibis, Glossy............. 360

Ibis, White............. 359

Ibis, Wood.................. $36 \mathrm{I}$

Ibises .............. 357, 358

Icteria................ 672

Icteria virens............ 672

Icteridæ.............. 550

Icterus................ 560

Icterus galbula........... $56 \mathrm{I}$

Icterus spurius........... 560

Ictinia............... 454

Ictinia mississippiensis........ 454

Ionornis.............. 386

Ionornis martinica......... 386

Iridoprocne............. $62 \mathrm{I}$

Iridoprocne bicolor......... 621

Ixobrychus exilis........... 364

Ixobrychus neoxenus........ 365

J

Jæger, Long-tailed.......... 287

Jæger, Parasitic............ 287

Jæger, Pomarine............. 286

Jægers................. 286

Jay, Blue.............. 544

Jay, Canada............. 545

Jays............... 542, 543

Junco................. 597

Junco aikeni............. 599

Junco hyemalis......... 597, 598

Junco hyemalis montanus... 598, 599

Junco hyemalis shufeld ti....... 599

Junco oregonus shufeldti.....598, 599 
Junco, Montana

Junco, Shufeldt's.

Junco, Slate-colored...............

\section{K}

Kingbird.

Kingbird, Arkansas.

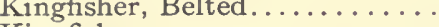

Kingfishers.

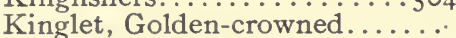

Kinglet, Ruby-crowned........

Kinglets..................

Kite, Mississippi.

Kite, Swallow-tailed..........

Kite, White-tailed.

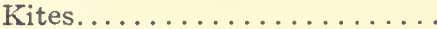

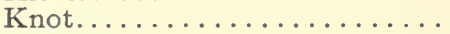

\section{L}

Lagopus................

Lagopus lagopus............

Land Birds................

Laniidæ.................

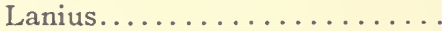

Lanius borealis. ............

Lanius ludovicianus..........

Lanius ludovicianus migrans....

Lanivireo.................

Lanivireo flavifrons..........

Lanivireo solitarius............

Laridæ.

Lark, Horned..............

Lark, Hoyt's Horned. . . . . . . . .

Lark, Prairie Horned..........

Lark, Shore..............

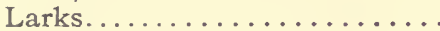

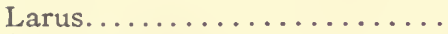

Larus argentatus............

Larus atricilla............

Larus delawarensis..........

Larus franklinii............

Larus glaucus..............

Larv's hyperboreus...........

Larus leucopterus...........

Larus marinus................

Larus.philadelphia...........

Limicolæ.................

Limosa.................

Limosa fedoa..............

Limosa hæmastica...........

Limpkin..................

Limpkins................

Lobipes..................

Lobipes lobatus.............

Longipennes..............

Longspur, Lapland...........

Longspur, McCown's..........

Longspur, Smith's.............

Loon....................

Loon, Black-throated........
530
Loon, Red-throated......... 284

Loons...............279, 282 Lophodytes................ 318

Lophodytes cucullatus ....... 3 I 8

Loxia.................... $57 \mathrm{I}$

Loxia curvirostra bendirei..... 572

Loxia curvirostra minor....... 57 I

Loxia leucoptera.......... 572

\section{M}

Macrochires............. 52 I

Macrorhamphus........... 398

Macrorhamphus griseus....... 398

Macrorhamphus scolopaceus.... 399

Magpie, American.......... 543

Magpies............. 542, 543

Man-of-war Bird............ 3 I4

Mareca............... 323

Mareca americana......... 324

Mareca penelope.......... 323

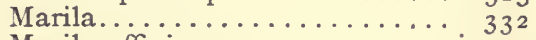

Marila affinis............ 334

Marila americana.......... 332

Marila collaris............. $\quad .335$

Marila marila............ 333

Marila vallisneria........... 333

Marsh Birds.............. 389

Martin, Purple................ 618

Meadowlark............. 557

Meadowlark, Southern........ $55^{8}$

Meadowlark, Western........ 559

Megalestris skua........... 288

Megascops asio........... 494

Melanerpes............... 517

Melanerpes carolinus......... 5 I 8

Melanerpes erythrocephalus..... $5^{\mathrm{I}} 7$

Melanitta.............. 344

Meleagrinæ............. 442

Meleagris.............. 442

Meleagris gallopavo silvestris... 442

Melospiza.............. $60 \mathrm{I}$

Melospiza fasciata........... $60 \mathrm{I}$

Melospiza georgiana......... 604

Melospiza lincolnii........... 602

Melospiza melodia........... 60 I

Merganser americanus........ 3 I 7

Merganser serrator......... 317

Merganser, American.......... 3 I 7

Merganser, Hooded......... 318

Merganser, Redbreasted....... 317

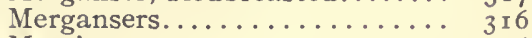

Merginæ.............. 3 1 6

Mergus................ 317

Mergus americanus......... 3I 7

Mergus serrator........... 3 I 7

Merlin, Richardson's......... $48 \mathrm{I}$

Merula migratoria......... 712

Micropalama............. 400

Micropalama himantopus..... 400

Micropodidæ.............. 525

Milvulus forficatus......... 529

Mimidæ..................6 680 


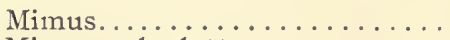

Mimus polyglottos...........

Mniotilta................

Mniotilta varia............

Mniotiltidæ...............

Mockingbird..............

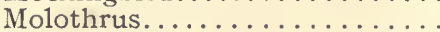

Molothrus ater.............

Motacillidæ...............

Murre, Brünnich's............

Murrelet, Ancient...........

Murres................279,

Muscivora..............

Muscivora forficata..........

Myadestes.................

Myadestes townsendii.........

Myadestinæ.

Mycteria.

Mycteria americana $\ldots \ldots$

Mycteriinæ...............

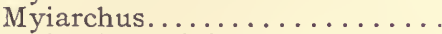

Myiarchus crinitus..........

Myiochanes.

Myiochanes richardsonii........

Myiochanes virens...........

\section{$\mathrm{N}$}

Nannus................

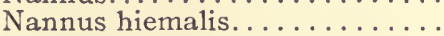

Nettion................

Nettion carolinensis. . . . . . . .

Nigger Goose..............

Nighthawk. .............

Nighthawk, Henry's.........

Nighthawk, Sennett's.........

Nighthawks . . . . . . . . . .

Nomonyx...............

Nomonyx dominicus.........

Nonpareil..............

Nucifraga................

Nucifraga columbiana........

Numenius................

Numenius americanus. . . . . . .

Numenius borealis. . . . . . . . . .

Numenius hudsonicus. . . . . . . .

Numenius longirostris. . . . . . .

Nutcracker, Clarke's..........

Nuthatch, Brown-headed.......

Nuthatch, Red-breasted.......

Nuthatch, White-breasted......

Nuthatches.

Nuttallornis................

Nuttallornis borealis..........

Nyctala acadica............

Nyctala tengmalmi richardsoni..

Nyctanassa...............

Nyctanassa violacea.........

Nyctea ................

Nyctea nyctea............

Nycticorax...............

Nycticorax nycticorax nævius...

Nycticorax violaceus.........
680

680

638

638

638

680

$55^{2}$

552

678

28 I

280

28 I

529

529

705

705

705

$36 \mathrm{I}$

$36 \mathrm{I}$

$36 I$

532

532

535

535

535

688

688

$3^{2} 5$

325

309

523

525

524

521

346

346

6 I 2

549

549

42 I

42 I

423

423

42 I

549

696

695

694

694

534

534

493

49 I

373

373

497

497

372

372

373
$\mathrm{O}$

Oidemia ............... 343

Oidemia americana ......... 343

Oidemia deglandi........... 344

Oidemia perspicillata........ 345

Old-squaw.............. 340

Old Wife............... 340

Olor................... 354

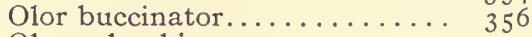

Olor columbianus.......... 354

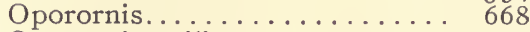

Oporornis agilis........... 669

Oporornis formosa.............668

Oporornis philadelphia........ 670

Oporornis tolmiei...........6. 67 I

Oriole, Baltimore............ 56 I

Oriole, Orchard............. 560

Orioles.................... 550

Oscines................. 540

Osprey, American........... 483

Ospreys.................. 483

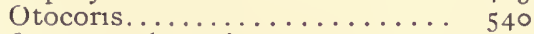

Otocoris alpestris........... 540

Otocoris alpestris hoyti....... 542

Otocoris alpestris praticola.... 54

Otus................... 494

Otus asio................. 494

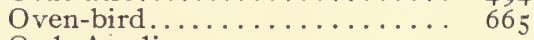

Owl, Acadian.............. 493

Owl, American Hawk......... 499

Owl, American Long-eared..... 486

Owl, Arctic Horned... . . . . . . 497

Owl, Barn................ 484

Owl, Barred.............. 489

Owl, Great Gray............. 490

Ow1, Great Horned... . . . . . . . . 495

Owl, Richardson's........... $49 \mathrm{I}$

Owl, Saw-whet............. 493

Owl, Screech.............. 494

Owl, Short-eared.......... 488

Ow1, Snowy................ 488

Owls..................... 484

Owls, Barn................ 484

Owls, Horned.............. 486

Owls, Screech............. 486

Oxyechus................ 427

Oxyechus vociferus......... 427

\section{$P$}

Paludicolæ............ 375

Pandion............... 483

Pandion haliaëtus carolinensis. . 483

Pandioninæ............. 483

Paridæ................. 697

Paroquet, Carolina.......... 5 or

Paroquets.............. 50

Parrots................ 50I

Partridge............. 436

Partridge, Spruce......... 435

Partridges.............. $43^{2}$

Parus atricapilius. . . . . . . . 698 
Parus bicolor.

Parus carolinensis...........

Parus hudsonicus...........

Passer....................

Passer domesticus............

Passer montanus............

Passerculus..................

Passerculus sandwichensis sa.

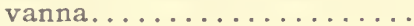

Passerella...............

Passerella iliaca............

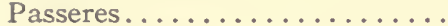

Passerherbulus..............

Passerherbulus caudacutus nelsoni.

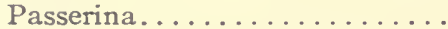

Passerina ciris.............

Passerina cyanea............

Pedicectes................

Pediceetes phasianellus cam-

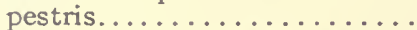

Peep..................... 406, 408

Pelecan, American White..... 3 I 2

Pelecan, Brown............ 3 I 3

Pelecanidx ............ 3 II

Pelecans............. 307, 3 I I

Pelecanus............... 312

Pelecanus erythrorhynchos.... 3 I 2

Pelecanus fuscus............ $3{ }^{\mathrm{I}} 3$

Pelecanus occidentalis....... 313

Pelidna................ 407

Pelidna alpina sakhalina...... 407

Pelionetta............... 345

Penthestes............... 698

Penthestes atricapillus........ 698

Penthestes atricapillus septentrionalis...............

Penthestes carolinensis........

Penthestes hudsonicus.........

Perching Birds.............

Perching Birds, Songless.......

Perdicinæ...............

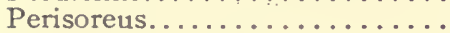

Perisoreus canadensis.........

Petrochelidon.............

Petrochelidon lunifrons........

Peucæa æstivalis bachmanii... .

Pewee, Western Wood.........

Pewee, Wood................

Phalacrocoracidæ...........

Phalacrocorax.............

Phalacrocorax auritus. ........

Phalacrocorax auritus floridanus

Phalacrocorax dilophus........

Phalacrocorax dilophus florida-

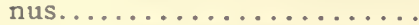

Phalacrocorax mexicanus.....

Phalacrocorax vigua mexicanus.

Phalarope, Northern.........

Phalarope, Red.............

Phalarope, Wilson's. . . . . . . . .

Phalaropes................

Phalaropodidæ.............

697
700

700

570

57
584

584

605

588

588

6 I 2

4 I

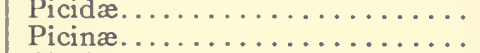

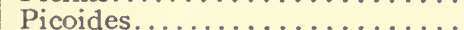

Picoides americanus..........

Picoides arcticus.............

Pigeon, Passenger...............

Pigeon, Wild............. 444

Pigeons............... 444

Pinicola................ 568

Pinicola enucleator leucura.... 568

Pipilo................. 605

Pipilo erythrophthalmus...... 605

Pipilo maculatus arcticus..... 607

Pipit, American............ 678

Pipits................... 678

Piranga................. 6 I $_{5}$

Piranga erythromelas......... 6 I6

Piranga ludoviciana......... 6 I 5

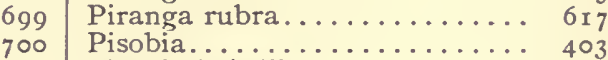

700 Pisobia bairdii.............. 405

529 Pisobia fuscicollis.......... 404

529 Pisobia maculata........... 403

432 Pisobia minutilla........... 406

545 Planesticus............... 7 I2

545 Planesticus migratorius....... 7 I 2

6 I9 Plataleidæ.............. 357

6r9 Plectrophenax............ 579

600 Plectrophenax nivalis........ 579

535 Plegadis............... 360

535 Plegadis autumnalis......... 360

308 Plover, American Golden........ 426

309 Plover, Belted Piping........ 429

309 Plover, Black-bellied......... 425

3 ro Plover, Field............. 4 I 8

309 Plover, Green............. 426

3 ro Plover, Piping........... 429

3 I I Plover, Semipalmated........ 428

3 I I Plover, Upland............ 4 4 I 8

390 Plovers................. 425

390 Podilymbus............. 278

39 I Podilymbus podiceps.......... 278

389 Polioptila............... 704

389 Polioptila cærulea.......... 704 
Polioptilinæ.............

Poøcetes..................

Poœcetes gramineus...........

Porzana.................

Porzana carolina............

Porzana jamaicensis..........

Porzana noveboracensis.......

Prairie Chicken.............

Prairie Hen ..............

Prairie Pigeon (see Golden Plover)................

Progne.....................

Progne subis..............

Protonotaria...............

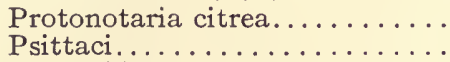

Psittacidæ................

Ptarmigan. . . . . . . .

Ptarmigan, Willow...........

Pygopodes...............

$7 \circ 4$

583

583

383

383

385

384

439

439

426

6 I 8

6 I8

640

640

501

501

435

438

275

\section{Q}

Quail....................

Quawk:....................

Querquedula.................

Querquedula cyanoptera.......

Querquedula discors...........

Quiscalus..................

Quiscalus quiscula æneus......

$\mathrm{R}$

Rail, Black................

Rail, Carolina................

Rail, King ...............

Rail, Sora................

Rail, Virginia...............

Rail, Yellow..................

Rails..................375, 379

Ralli........................ 379,380

Rallidæ................. 380

Rallinæ............... $38 \mathrm{I}$

Rallus.................. $38 \mathrm{I}$

Rallus elegans.............. $38 \mathrm{I}$

Rallus virginianus........... 382

Raptores................... 448

Raven, Northern........... 546

Recurvirostra............. 392

Recurvirostra americana...... 392

Recurvirostridæ............ 392

Redhead (Duck)........... 332

Redpoll.................. 574

Redpoll, Greater........... 576.

Redpoll, Hoary ........... 573

Redpoll, Holböll's............. 575

Redstart................ 677

Regulinæ................. 702

Regulus................ 702

Regulus calendula............ 703

Regulus satrapa..............
Rhynchodon.............. 478

Rhynchopanes............. $58 \mathrm{I}$

Rhynchopanes mccownii...... 58I

Ring-neck (Plover) .......... 428

Ring-neck, White (Plover)..... 429

Riparia................... 622

Riparia riparia................ 622

Rissa.................. $\quad 289$

Rissa tridactyla................. 289

Robin................... $7 \mathbf{1}_{2}$

\section{S}

Sanderling............. 409

Sandpiper, Baird's.............. 405

Sand piper, Bartramian......... 4 48

Sandpiper, Buff-breasted......... 4 r 9

Sandpiper, Least.............. 406

Sandpiper, Pectoral........... 403

Sandpiper, Purple.............. 402

Sandpiper, Red-backed........... 407

Sandpiper, Sanderling........... 409

Sand piper, Semipalmated........ 408

Sandpiper, Solitary........... 4r 5

Sand piper, Spotted........... 420

Sand piper, Stilt............... 400

Sand piper, Western........... 409

Sandpiper, White-rumped...... 404

Sandpipers.................... 395

Sarcorhamphii............. 448

Sayornis................ 533

Sayornis phobe............ 533

Sayornis saya............. 534

Scolecophagus carolinus.......... $\quad 562$

Scolecophagus cyanocephalus... $\quad 563$

Scolopacidæ.............. 395

Scoter, Surf.................. 345

Scoter, White-winged......... 344

Scotiaptex................ 490

Scotiaptex cinerea................. $490^{\circ}$

Scotiaptex nebulosa............ 490

Seiurus.................... 665

Seiurus aurocapillus........... 665

Seiurus motacilla............. 667

Seiurus noveboracensis......... 666

Seiurus noveboracensis notabilis 667

Setophaga................ 677

Setophaga ruticilla............ 677

Sheldrakes.............. 3 I6, 317

Shore Birds................. 389

Shrike, Loggerhead.............. 628

Shrike, Migrant.............. $6_{3}{ }^{\circ}$

Shrike, Northern.............. 628

Shrikes................... 627

Sialia.................. $7^{\mathrm{r}} 4$

Sialia arctica............. $7 \mathrm{rr}^{\mathrm{n}}$

Sialia sialis................. 714

Sialiinæ $\ldots \ldots \ldots \ldots \ldots \ldots, \quad 7 \mathrm{I} 4$

Sickle-bill (Curlew)............. $42 \mathrm{r}$

Siskin, Pine............... 578

Sitta..................... 694

Sitta canadensis................. 695 
Sitta carolinensis...........

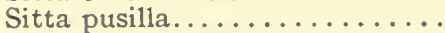

Sittidæ................

Skua.................

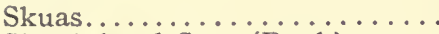

Skunk-head Coot (Duck)......

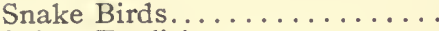

Snipe, English............

Snipe, Jack...............

Snipe, Red-breasted.........

Snipe, Stone...............

Snipe, Western Red-breasted (see I.ong-billed Dowitcher)...

Snipe, Wilson's.............

Snipes...............

Snowbird..................

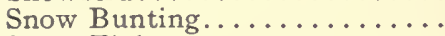

Snow Flake..............

Solitaire, Townsend's.........

Solitaires................

Somateria................

Somateria dresseri...........

Somateria spectabilis.........

Song Birds.................

Sparrow, Bachman's..........

Sparrow, Chipping...........

Sparrow, Clay-colored.........

Sparrow, English............

Sparrow, European Tree.......

Sparrow, Field.............

Sparrow, Fox..............

Sparrow, Gambel's...........

Sparrow, Golden-crowned......

Sparrow, Grasshopper........

Sparrow, Harris's............

Sparrow, Henslow's. . . . . . . .

Sparrow, House..............

Sparrow, Intermediate........

Sparrow, Lark..............

Sparrow, Leconte's...........

Sparrow, Lincoln's. ............

Sparrow, Nelson's Sharp-tailed..

Sparrow, Savanna...........

Sparrow, Song..............

Sparrow, Swamp.............

Sparrow, Tree.............

Sparrow, Vesper.............

Sparrow, White-crowned.......

Sparrow, White-throated.......

Sparrow, Yellow-winged.......

Sparrows.................

Spatula..................

Spatula clypeata............

Speckle-belly..............

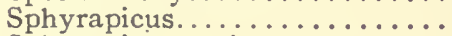

Sphyrapicus varius...........

Spinus.................

Spinus pinus..............

Spinus tristis..............

Spiza..................

Spiza americana............

Spizella................

Spizella monticola............
$694 \mid$ Spizella pallida............

Spizella passerina...........

Spizella pusilla.............. 595

Spizella socialis........... 595

Spoon-bill (Duck)........... 328

Spoonbill, Roseate......... 357

Spoonbills.............. 357

Sprig-tail (Duck)........... 329

Squatarola.............. 425

Squatarola squatarola........ 425

Stake-dnver ............. 363

Steganopodes............ 307

Steganopus............. 391

Steganopus tricolor......... 391

Stelgidopteryx............. 623

Stelgidopteryx serripennis..... 623

Stercorariidæ.............. 286

Stercorarius............ 286

Stercorarius longicaudus...... 287

Stercorarius parasiticus....... 287

Stercorarius pomarinus....... 286

Sterna................. 299

Sterna antillarum......... 303

Sterna caspia............. 299

Sterna forsteri............ 301

Sterna hirundo............. 302

Sterna maxima............ 300

Sterna paradisæa........... 303

Sterna tschegrava............ 299

Sterninæ............... 297

Sternula.............. 303

Stilt, Black-necked........... 394

Stilts................ 392

Storks................. 360

Striges................. 484

Strigidæ.............. 486

Strix................ 489

Strix pratincola........... 484

Strix varia.............. 489

Sturnella.............. 557

Sturnella magna........... 557

Sturnella magna argutula..... $55^{8}$

Sturnella neglecta.......... 559

Surf Birds............... 430

Surf Scoter (Duck).......... 345

Surnia................ 499

Surnia ulula caparoch........ 499

Swallow, Bank............. 622

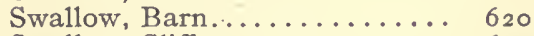

Swallow, Cliff................. 6rg

Swallow, Northern Violet-green 622

Swallow, Rough-winged...... 623

Swallow, Tree................ 62 I

Swallow, White-bellied......... 62 I

Swallows.................. 618

Swan, Trumpeter.......... 356

Swan, Whistling........... 354

Swans................. 16,354

Swift, Chimney............. 526

Swifts................. 52 I, 525

Swifts, Sharp-tailed........... 526

Swimmers, Long-winged....... 286

Swimmers. Totipalmate...... 307 
Swimmers, Lamellirostral..... . Sylvania canadensis......... Sylvania mitrata........... Sylvania pusilla........... Sylviidæ................. Symphemia semipalmata....... Symphemia semipalmata inornata Synthliboramphus........... Synthliboramphus antiquus.... Syrnium nebulosum.........

\section{$\mathrm{T}$}

Tachycineta.

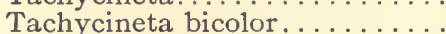
Tachycineta thalassina lepida... Tachytriorchis.... ........ Tanager, Louisiana.......... Tanager, Scarlet........... Tanager, Summer........... Tanagers...............

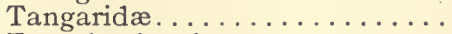
Tantalus loculator...........

Teal, Blue-winged...........

Teal, Cinnamon............

Teal, Green-winged...........

Tell-tale................

Tell-tale, Little. . . . . . . . . . .

Telmatodytes..............

Telmatodytes palustris........

Telmatodytes palustris iliacus...

Tern, Arctic...............

Tern, Black..............

Tern, Caspian..............

Tern, Common.............

Tern, Forster's.............

Tern, Gull-billed. . . . . . . . . . . . .

Tern, Least...............

Tern, Marsh..............

Tern, Royal................

Tern, White-winged Black......

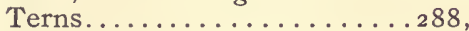

Tetraonidæ..............

Tetraoninæ..............

Thrasher, Brown............

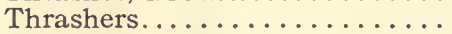

Thrush, Alma's.............

Thrush, Bicknell's............

Thrush, Brown (see Thrasher)..

Thrush, Golden-crowned (see Oven-bird).............

Thrush, Gray-cheeked........

Thrush, Grinnel's Water.......

Thrush, Hermit...........

Thrush, Louisiana Water......

Thrush, Olive-backed.........

Thrush, Water.............

Thrush, Willow............

Thrush, Wilson's...........

Thrush, Wood..............

Thrushes................

Thryomanes................
3 I 6

676

674

675

702

4 I 6

4 I 7

280

280

489

622

62 I

622

467

6 I 5

6 I 6.

6 I 7

6 I 4

6 I 4

$36 \mathrm{I}$

326

327

325

413

4 I 4

690

690

692

$3 \circ 3$

304

299

302

301

298

303

304

300

306

297

432

4.35

683

680

$7 \mathrm{r}$

710
683

665

709

667

$7 \mathrm{r} \mathrm{I}$

667

710

666
708

708

707

705

686
Thryomanes bewickii......... 686

Thryothorus............... 684

Thryothorus bewickii......... 686

Thryothorus ludovicianus...... 684

Thunder-pump............ 363

Tinnunculus.............. 479

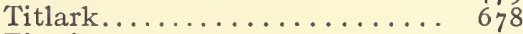

Titmice................ 697

Titmouse, Tufted........... 697

Totanus................ 4 43

Totanus flavipes........... 4 I 4

Totanus melanoleucus........ 4 r 3

Totanus solitarius........... 4 I 5

Towhee................ 605

Towhee, Arctic............ 607

Towhee Bunting............ 605

Toxostoma.............. 683

Toxostoma rufum........... 683

Tringa................. 401

Tringa alpina pacifica....... 407

Tringa bairdii............. 405

Tringa canutus........... 401

Tringa fuscicollis............ 404

Tringa maculata........... 403

Tringa mantima........... 402

Tringa minutilla .......... 406

Trochili................ 527

Trochilidæ.............. 527

Trochilus............... 527

Trochilus colubris.......... 527

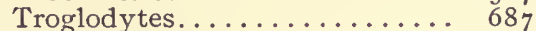

Troglodytes aëdon........... 687

Troglodytes aëdon parkmani.... 688

Troglodytes aztecus........... 688

Troglodytes hiemalis......... 688

Troglodytidæ............. 684

Trogons................ 504

Tryngites................ 4 r 9

Tryngites subruficollis....... 4 r 9

Turdidæ............... 705

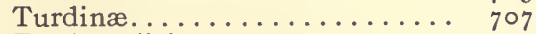

Turdus aliciæ............ 709

Turdus aliciæ bicknelli........ 7 ro

Turdus aonalaschkæ pallasii.... 7 I I

Turdus fuscescens........... 708

Turdus fuscescens salicicola.... 708

Turdus mustelinus.......... 707

Turdus ustulatus swainsonii... 7 ro

Turkey, Wild............. 442

Turkeys................ 442

Turnstone.............. 43 I

Turnstones.............430, 43 I

Tympanuchus............. 439

Tympanuchus americanus.... 439

Tyrannidæ............. 529

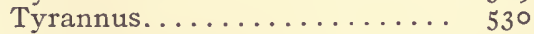

Tyrannus tyrannus......... 530

Tyrannus verticalis.......... $53 \mathrm{I}$

U

Upland Plover........... 4 8

Uria lomvia............. $28 \mathrm{r}$ 
Urinator arcticus............ 284

Urinator imber............ 282

Urinator lumme........... $\quad 284$

\section{V}

Vermivora

Vermivora celata................

Vermivora chrysoptera........

Vermivora peregrina..........

Vermivora pinus.............

Vermivora rubricapilla.........

Vireo.

Vireo bellii...............

Vireo flavifrons.

Vireo gilvus..................

Vireo griseus..............

Vireo noveboracensis.........

Vireo olivaceus.............

Vireo philadelphicus...........

Vireo solitarius............

Vireo, Bell's...............

Vireo, Blue-headed...........

Vireo, Philadelphia............

Vireo, Red-eyed.............

Vireo, Warbling.............

Vireo, White-eyed............

Vireo, Yellow-throated.........

Vireonidæ................

Vireos..................

Vireosylva..............

Vireosylva gilva.

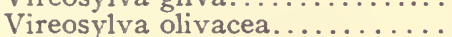

Vireosylva philadelphica.......

Vulture, Black.............

Vulture, Turkey ............

$\begin{array}{lll}\text { Vultures......................... } & 448 \\ \text { Vultures, American....... } & 448\end{array}$

\section{W}

Wagtails.

Warbler, Bay-breasted.....

Warbler, Black and White......

Warbler, Blackburnian..........

Warbler, Black-poll............

Warbler, Black-throated Blue...

Warbler, Black-throated Green.

Warbler, Blue-winged..........

Warbler, Canadian.............

Warbler, Cape May............

Warbler, Cerulean.............

Warbler, Chestnut-sided.......

Warbler, Connecticut..........

Warbler, Golden-winged.......

Warbler, Hooded..............

Warbler, Kentucky..............

Warbler, Kirtland's...........

Warbler, Macgillivray's.........

Warbler, Magnolia...........
Warbler, Maryland Yellow-

throat................ $67 \mathrm{I}$

Warbler, Mourning.......... 670

Warbler, Myrtle............ $65^{\circ}$

Warbler, Nashville.......... 645

Warbler, Orange-crowned..... 645

Warbler, Palm............. 662

Warbler, Parula............ 647

Warbler, Pine............ 66

Warbler, Prairie............ 663

Warbler, Prothonotary........ 640

Warbler, Red-poll........... 662

Warbler, Swainson's......... 64 I

Warbler, Sycamore.......... 657

Warbler, Tennessee.......... 646

Warbler, Wilson's........... 675

Warbler, Worm-eating....... 642

Warbler, Yellow............. 648

Warbler, Yellow-rumped...... $65^{\circ}$

Warblers, Old World........ 702

Warblers, Wood............ 638

Water Birds.............. 275

Water-thrush............. 666

Water-thrush, Grinnell's....... $66_{7}$

Water-thrush, Louisiana...... 667

Water Turkey (see Anhinga)... 307

Waxwing, Bohemian........ 624

Waxwing, Cedar.......... 625

Waxwings.............. 624

Whip-poor-will.......... 522

Whip-poor-wills........... 52 I

Whistler (Duck).......... 336

Widgeon, American......... 324

Widgeon, European......... 323

Willet................ 416

Willet, Western............. 4 r 7

Wilsonia............... 674

Wilsonia canadensis........... 676

Wilsonia citrina........... 674

Wilsonia pusilla............ 675

Woodcock................ 395

Woodpecker, American Threetoed................ $55^{14}$

Woodpecker, Arctic Three-toed 5 I 3

Woodpecker, Downy......... 5 I ?

Wood pecker, Hairy......... 5 II

Wood pecker, Ivory-billed..... 508

Wood pecker, Northern Hairy... $5^{1} 2$

Woodpecker, Northern Pileated 5 r6

Woodpecker, Red-bellied....... 5 18

Wood pecker, Red-headed...... 5 I 7

Wood pecker, Yellow-bellied.... 5 I 5

Woodpeckers............. 508

Wren, Bewick's. . . . . . . . . . 686

Wren, Carolina.............. 684

Wren, House............. 687

Wren, Long-billed Marsh...... 690

Wren, Parkman's. ............ 688

Wren, Prairie Long-billed Marsh 692

Wren, Short-billed Marsh..... 689

Wren, Winter............. 688

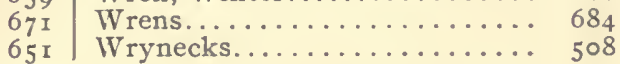


$\mathrm{X}$

Xanthocephalus............ 554

Xanthocephalus xanthocephalus 554

Xema.................. 296

Xema sabinii............. 296

\section{Y}

Yellowbird (see Goldfinch)

Yellow-legs................

Yellow-legs, Greater.......... 4 I 3

Yellow-legs, Summer......... 4 4I4

Yellow-legs, Winter......... 4I 3

Yphantes.............. 56I

\section{Z}

Zamelodia............... 609

Zamelodia ludoviciana........ 609

Zenaidura.............. 446

Zenaidura macroura......... 446

Zenaidura macroura carolinensis 446

Zonotrichia.............. 590

Zonotrichia albicollis......... 593

Zonotrichia coronata......... 592

Zonotrichia leucophrys......... $59 \mathrm{I}$

Zonotrichia leucophrys gambelii 592

Zonotrichia leucophrys inter-

media.............. 592

Zonotrichia querula............ 590 

ILLINOIS COUNTIES

\begin{tabular}{|c|c|c|c|c|c|c|}
\hline Adams. & 40 & Ford. & 26 & Livingston. & 27 & Randolph. \\
\hline Alexander. & 102 & Franklin. & 85 & Logan. & 46 & Richland. \\
\hline Bond. & 68 & Fulton. & 34 & McDonough. & 37 & Rock Island. \\
\hline Boone. & 4 & Gallatin. & 92 & McHenry. & 5 & St. Clair. \\
\hline Brown. & 42 & Greene. & 63 & McLean. & 28 & Saline. \\
\hline Bureau. & I 8 & Grundy. & 22 & Macon. & 56 & Sangamon. \\
\hline Calhoun. & 62 & Hamilton. & $9 \mathrm{I}$ & Macoupin. & 65 & Schuyler. \\
\hline Carroll. & I 3 & Hancock. & 39 & Madison. & 67 & Scott. \\
\hline Cass. & 43 & Hardin. & 99 & Marion. & 78 & Shelby. \\
\hline Champaign. & 49 & Henderson. & $3^{8}$ & Marshall. & 30 & Stark. \\
\hline Christian. & 58 & Henry. & I7 & Mason. & 44 & Stephenson. \\
\hline Clark. & 73 & Iroquois. & 25 & Massac. & 100 & Tazewell. \\
\hline Clay. & 77 & Jackson. & 95 & Menard. & 45 & Union. \\
\hline Clinton. & 79 & Jasper. & $7 \mathrm{I}$ & Mercer. & I6 & Vermilion. \\
\hline Coles. & 53 & Jefferson. & 86 & Monroe. & 82 & Wabash. \\
\hline Cook. & 7 & Jersey. & 64 & Montgomery. & 66 & Warren. \\
\hline Crawford. & 74 & Jo Daviess. & I & Morgan. & 59 & Washington. \\
\hline Cumberland. & 72 & Johnson. & 97 & Moultrie. & 54 & Wayne. \\
\hline Dekalb. & IO & Kane. & 9 & Ogle. & I I & White. \\
\hline Dewitt. & 47 & Kankakee. & 24 & Peoria. & 32 & Whiteside. \\
\hline Douglas. & $5^{2}$ & Kendall. & $2 \mathrm{I}$ & Perry. & 84 & Will. \\
\hline DuPage. & 8 & Knox. & 35 & Piatt. & 48 & Williamson. \\
\hline Edgar. & $5 \mathrm{I}$ & Lake. & 6 & Pike. & 6 I & Winnebago. \\
\hline Edwards. & 88 & La Salle. & 20 & Pope. & 98 & Woodford. \\
\hline Effingham. & 70 & Lawrence. & 75 & Pulaski. & IOI & \\
\hline Fayette. & 69 & Lee. & I 2 & Putnam. & I9 & \\
\hline
\end{tabular}

\section{WISCONSIN COUNTIES}

Adams.

43 Eau Claire.

Apostle Isls.

7 rot

(See Ashland Co.)

Ashland.

Barron.

Bayfield.

Brown.

Buffalo.

Burnett.

Florence.

32 Manitowoc

50

St. Croix.

35

27 Fond du Lac. 47 Marinette. 20

Forest.

2 Marquette.

45

Sawyer.

I 2

Shawano. 25

I 5 Milwaukee. 65

8 Grant.

60 Monroe.

70 Oconto.

3 Green.

$4 \mathrm{I}$

Sheboygan. $\quad 5 \mathrm{I}$

Taylor. I6

I 9

46 Oneida.

Calumet.

Green Lake.

6 I Outagamie.

Trempealeau. 38

Iowa.

49 Iron.

6 Ozaukee.

Chippewa.

Clark.

3 I Iackson.

39 Pepin.

Columbia.

Crawford.

Dane.

Dodge.

Door.

Douglas.

Dunn.

Jefferson.

Juneau.

63 Pierce.

42 Polk.

67 Portage.

22 Price.

40 Racine.

7I Richland.

Vernon.

58

24

52

Vilas.

Walworth. 68

Washburn. II

Washington. 53

I 3 Waukesha. 64

62 Kewaunee.

28

Waupaca. $\quad 26$

54

$2 \mathrm{r}$ Lafayette.

I 8 Rock.

I Rusk.

33 Lincoln. 
ILLINOIS COUNTIES

1. Jo Daviess. 2. Stevenson. 8. Winnebaga, 4. Bone.

b. McHenry.

6. Lake.

7. DuPage.

8. DuPage.

10. Dekalo.

11. Ogle.

12. Lee.

13. Catrolth

14. Whireside.

18. Rock lslami.

16. Mercer.

17. Henry.

18. Bureau.

19. Putnam.

20. Le Salle.

21. Kendall.

22. Grundy.

28. Wint

24. Kankakee

25. troquols.

26. Ford.

27. Livington.

28. Mclean.

29. Woodford.

30. Marshall.

31. Stark.

32. Peoria.

39. Tazewell.

3. Fulton

25. Knox.

36. Warren.

37. McDanousgh.

88. Henderson.

59. Hancoc

40. Adams.

41. Schuyler.

12. Brown.

43. Cass.

44. Mason.

45. Menard.

46. Logan.

47. Dewitt

48. Piate.

48. Champaisn

i0. Vermilion.

51. Edgar.

52. Douglas.

33. Coles.

4. Mouiture.

55. Shelby.

5. Macon.

67. Sangamon

58. Morgan.

0. Scott

61. Pike.

62. Calhoun.

63. Greene.

ab. Jersey.

65. Macoupin.

66. Montgomer

67. Madison

68. Bond.

70. Effingham.

71. Jesper.

72. Cumberland

73. Clark.

7i. Crawford.

73. Luwrence.

76. Richlan

77. Clay.

78. Marion.

79. Clinton.

80. Washington

81. St. Clais.

82. Monroe.

89. Randolph

84. Perry.

85. Franklin.

86. Jefferson.

87. Wayne.

8. Edwards.

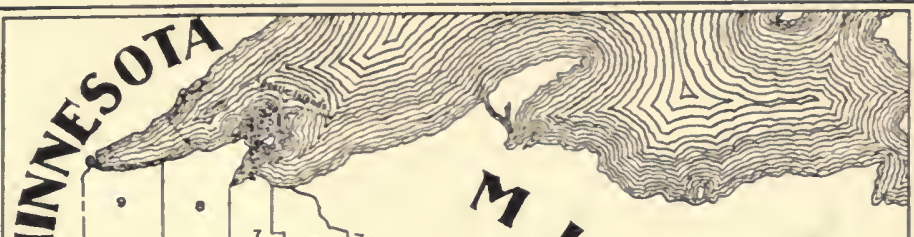

80. Wabash.

90. White

91. Hamilion.

os. Suline.

2. Williamson.

93. Jackson.

96. Union.

97. Johnson.

98. Pope.

D. Hardin.

100. Massac.

II2. Aleander.
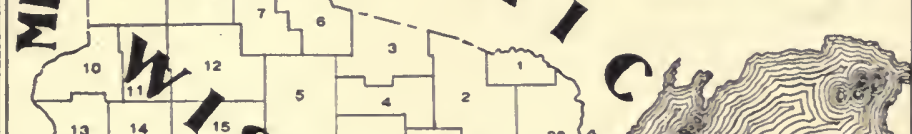

WISCONSIN

COUNTIES.

1. Florence.

2. Forest.

3. Vilas.

5. Price.

6. Iron.

7. Ashland.

(inc. Apostle isls.)

8. Bayfield.

10. Burnet?

11. Washburn.

12. Sawyer.

13. Polk.

14. Barron.

15, Rusk or Gates.

18. Taylor.

17. Lincoln.

18. Langlade.

19. Oconta.

20. Marinette.

21. Door.

(inc. islands)

23. Brown.

24. Outagamie.

24. Outagamie.

26. Whaupaca.

27. Marathon.

I OWA

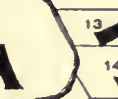

$\int_{12}^{11}$

$\left.10 \begin{array}{lll}9 & 9\end{array}\right]$

28. Rortsge.

30. Charke

31. Chiprew

52. Eu Chire.

33. Dum.

34. Pepin.

38. St. Croia.

36. Pierce

37. Buffalo.

38. Trempealeav.

39. Juckson.

4). La Crosse.

41. Monroe.

42. Juneau.

43. Adams.

4. Waushara.

45. Marquetie.

46. Green Lake.

47. Fond du Laf

48. Winnebego

48. Calumel.

50. Manitowoc.

51. Sheboygan.

52. O

53. Washin

54. Dodge.

B5. Columbi

56. Sauk.

57. Richland.

58. Vernon.

39. Crawlord.

60. Grant.

61. lowa.

O2. Dane.

68. Sefferson.

or. Waukesha.

66. Wilwauke.
66. Racine.

6. Racine.

67. Kenoshia.

69. Rock.

70. Green.

71. Lafayette. 



\title{
Field Museum of Natural Histuky.
}

\section{Puilication izr.}

Zoölogical Series. $\quad$ Vol. IX.

\section{THE BIRDS OF ILLINOIS AND WISCONSIN}

BY

\author{
Charles B. Coky
}

Curator of Department of Zoölogy.

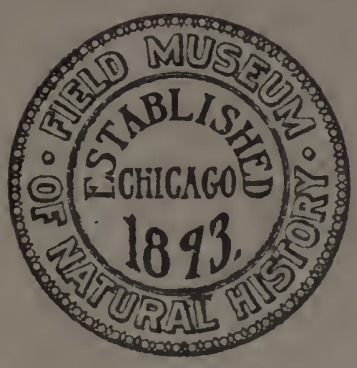

Chicago, U. S. A.

I 909 



